DOC.20041109.0001

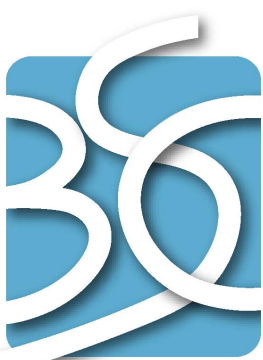

BECHTEL SAIC COMPANYLC
QA: QA

ANL-NBS-HS-000005 REV 03

November 2004

NOTICE OF OPEN CHANGE DOCUMENTS - THIS DOCUMENT IS IMPACTED BY THE LISTED CHANGE DOCUMENTS AND CANNOT BE USED WITHOUT THEM.

1) ACN-001, DATED 10/06/2005

2) ACN-002, DATED 05/04/2006

\title{
In Situ Field Testing of Processes
}

Prepared for:

U.S. Department of Energy

Office of Civilian Radioactive Waste Management

Office of Repository Development

1551 Hillshire Drive

Las Vegas, Nevada 89134-6321

Prepared by:

Bechtel SAIC Company, LLC

1180 Town Center Drive

Las Vegas, Nevada 89144

Under Contract Number

DE-AC28-01RW12101 


\section{DISCLAIMER}

This report was prepared as an account of work sponsored by an agency of the United States Government. Neither the United States Government nor any agency thereof, nor any of their employees, nor any of their contractors, subcontractors or their employees, makes any warranty, express or implied, or assumes any legal liability or responsibility for the accuracy, completeness, or any third party's use or the results of such use of any information, apparatus, product, or process disclosed, or represents that its use would not infringe privately owned rights. Reference herein to any specific commercial product, process, or service by trade name, trademark, manufacturer, or otherwise, does not necessarily constitute or imply its endorsement, recommendation, or favoring by the United States Government or any agency thereof or its contractors or subcontractors. The views and opinions of authors expressed herein do not necessarily state or reflect those of the United States Government or any agency thereof. 
QA: QA

\section{In Situ Field Testing of Processes}

\section{ANL-NBS-HS-000005 REV 03}

November 2004 


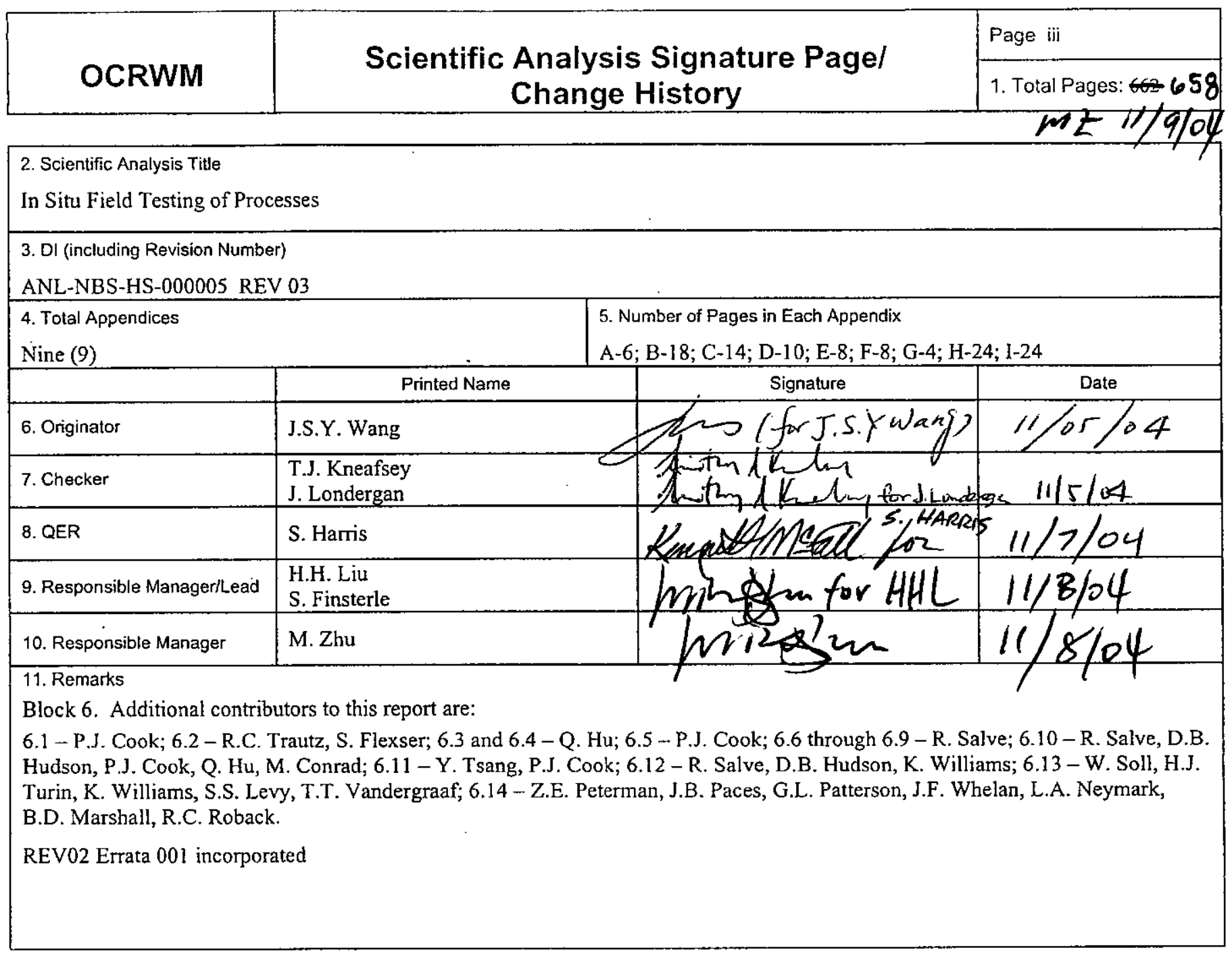




\section{Change History}

\begin{tabular}{|c|c|}
\hline 12. Revision No. & 13. Description of Change \\
\hline REV00 & Initial Issue \\
\hline REV01 & $\begin{array}{l}\text { Complete revision. Numerous changes have been made throughout the document. Table and figure } \\
\text { identifiers have been changed throughout. The main revisions are: } \\
\text { - Section } 4 \text { "Inputs" has been revised to update inputs and to associate subsections with the } \\
\text { various analyses presented in the Section } 6 \text { subsections. } \\
\text { - Section } 5 \text { "Assumptions" has been revised to update assumptions and to associate } \\
\text { subsections with the various analyses presented in the Section } 6 \text { subsections. } \\
\text { - Section } 6.1 \text { is revised (1) to include air-permeability data of Niche CD } 1620 \text { - } \\
\text { - Section } 6.1 .2 .2 \text {, and (2) to analyze the permeability changes - Section } 6.1 .2 .3 \text {. } \\
\text { - Section } 6.2 \text { is revised (1) to present flow path observations at Niche CD } 1620 \text { - } \\
\text { Section } 6.2 .1 .2 \text {, and (2) to present long-term seepage-test data - Section } 6.2 .1 .3 \text {, and (3) to } \\
\text { compare the seepage threshold data from Niche } 4788 \text { with short-term seepage threshold data } \\
\text { from Niche } 3650 \text { - Section } 6.2 .2 \text {. } \\
\text { - Section } 6.3 \text { is revised to present additional tracer distribution data on samples collected from } \\
\text { the ceiling of Niche } 3650 \text { - Section } 6.3 .1 .2 \text {. } \\
\text { - Section } 6.4 \text { is revised to present laser ablation - induced coupled plasma mass spectrometry } \\
\text { data from chemical tracer transport and sorption - Section } 6.4 .3 \text {. } \\
\text { - Sections } 6.5 \text { to Section } 6.9 \text { are not revised. } \\
\text { - Sections } 6.10 \text { is revised (1) to present data of construction water tracer migration below } \\
\text { invert } \\
\text { - Section } 6.10 .1 .3 \text {, and (2) to present observations of non-ventilated Cross Drift - } \\
\text { - Section } 6.10 .2 \text {. } \\
\text { - Section } 6.11 \text { on systematic hydrologic characterization is a new section. } \\
\text { Section } 6.12 \text { on fault test at Alcove } 8 \text { and Niche } 3107 \text { is a new section. } \\
\text { - } 6.13 \text { on Busted Butte unsaturated zone transport test is a new section. }\end{array}$ \\
\hline
\end{tabular}




\begin{tabular}{|c|c|}
\hline REV02 & 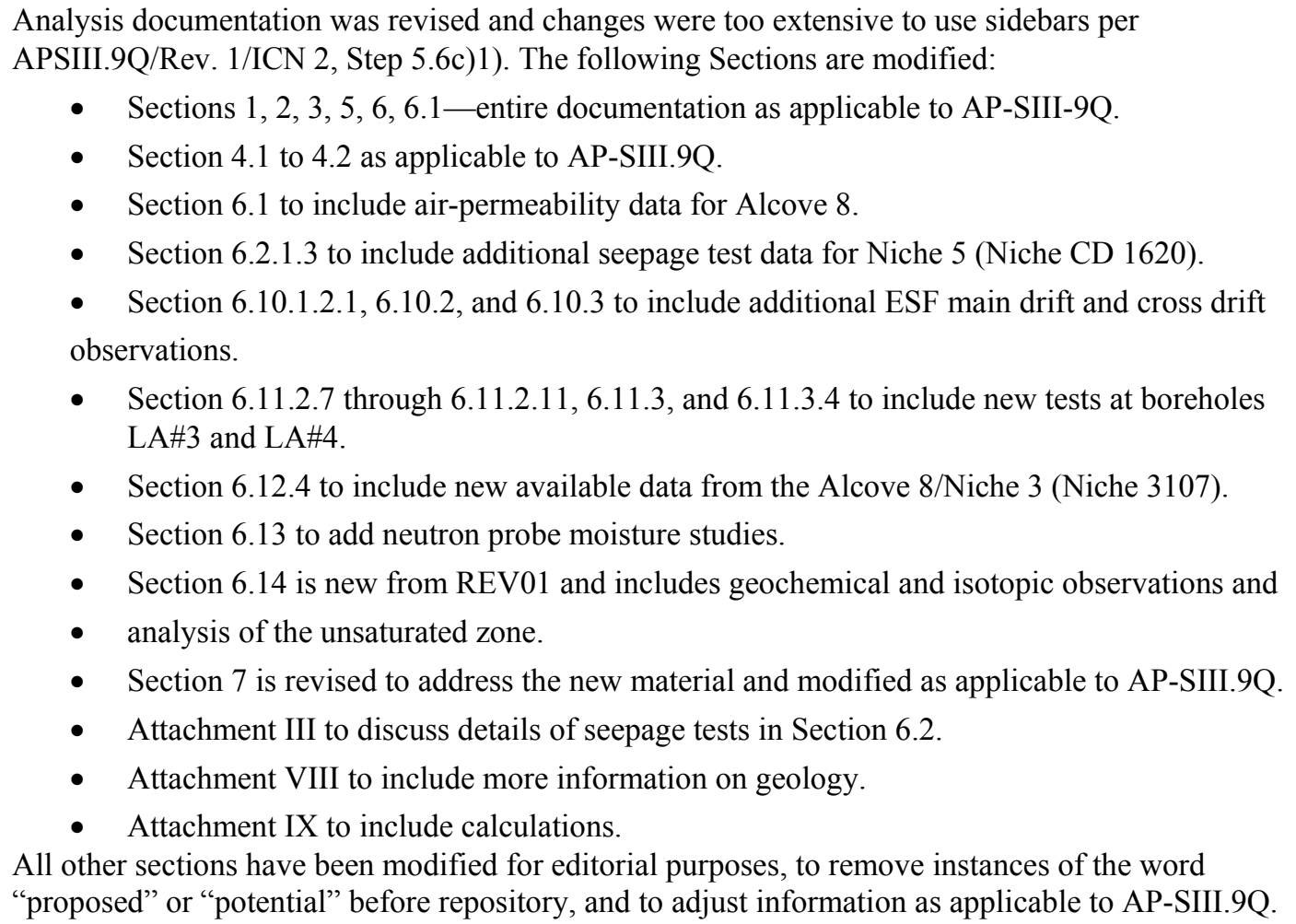 \\
\hline REV02 Errata 001 & Response to CR 1870 \\
\hline REV03 & $\begin{array}{l}\text { Made changes to report in response to recommendations from Regulatory Integration Team/ Natural } \\
\text { Systems Team, and to respond to CRs } 1821 \text { and } 1872 \text {. Entire scientific analysis documentation was } \\
\text { revised. Changes were too extensive to use Step 5.6e)1) per AP-SIII.9Q/Rev.1/ICN } 7 \text {. }\end{array}$ \\
\hline
\end{tabular}




\section{INTENTIONALLY LEFT BLANK}




\section{CONTENTS}

Page

ACRONYMS AND ABBREVIATIONS xxxiii

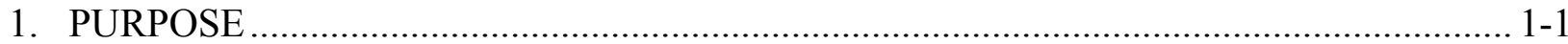

1.1 OBJECTIVES AND PROCESSES ANALYZED BY THE AMBIENT FIELD TESTING ACTIVITIES ..................................................................................... 1-4

1.2 LOCATIONS OF TEST SITES.................................................................... 1-4

1.3 SUPPORT TO FEP ANALYSIS AND TECHNICAL ISSUE RESOLUTION ........ 1-10

1.4 CONSTRAINTS AND LIMITATIONS.............................................................. 1-11

2. QUALITY ASSURANCE ...................................................................................... 2-1

3. USE OF SOFTWARE ....................................................................................... $3-1$

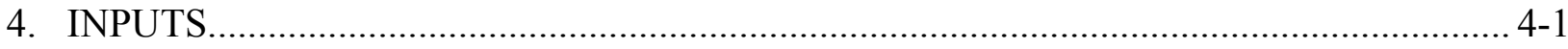

4.1 DIRECT AND INDIRECT INPUTS ....................................................... $4-1$

4.1.1 Data of Air-Permeability Distributions and Excavation-Induced Enhancements ........................................................................................ 4-3

4.1.1.1 Data Used to Illustrate Air-Permeability Distributions and Excavation-Induced Enhancements (Direct Input) ........................ 4-3

4.1.1.2 Data Used to Corroborate Analysis of Air-Permeability Distributions and Excavation-Induced Enhancements (For Reference) ............................................................................ 4-4

4.1.2 Data of Niche Liquid-Release and Seepage-Test Results............................. 4-4

4.1.2.1 Data Used to Illustrate Niche Liquid-Release and Seepage-

Test Results (Direct Input) ........................................................... 4-4

4.1.2.2 Data Used to Corroborate Analysis and Interpretation of

Niche Liquid-Release and Seepage Tests (For Reference) .............4-5

4.1.3 Data Used to Illustrate Tracer-Migration Delineation at Niche 2

(Niche 3650) (Direct Input) .................................................................. 4-6

4.1.4 Data Used to Illustrate Tracer Penetration and Water Imbibition into Welded Tuff Matrix (Direct Input) ................................................................ 4-6

4.1.5 Data Used to Illustrate Crosshole Analysis of Air-Injection Tests (Direct Input)

4.1.6 Data Used to Illustrate Fracture Flow in Fracture-Matrix Test Bed at Alcove 6 (Direct Input) ............................................................................ 4-7

4.1.7 Data of Flow through the Fault and Matrix in the Test Bed at Alcove 4 .........4-7 4.1.7.1 Data Used to Illustrate Flow through the Fault and Matrix in the Test Bed at Alcove 4 (Direct Input) ........................................4-7

4.1.7.2 Data Used to Corroborate Analysis of Flow through the Fault and Matrix in the Test Bed at Alcove 4 (For Reference) ................4-8

4.1.8 Data Used to Compile Water-Potential Measurements in Niches (Direct Input) 


\section{CONTENTS (Continued)}

Page

4.1.9 Data Used to Illustrate Observations of Construction-Water Migration (Direct Input) ................................................................................... 4-8

4.1.10 Data of Moisture Monitoring and Water Analysis in Underground Drifts...... 4-9

4.1.10.1 Data Used to Illustrate Moisture Monitoring and Water Analysis in Underground Drifts (Direct Input) ............................4-9

4.1.10.2 Data on Drift Moisture Monitoring and Water Analysis (For Reference) ................................................................................. 4-10

4.1.10.3 Data on Water Potential and Saturation Measurements (For Reference) ........................................................................... 4-11

4.1.11 Data of Systematic Hydrological Characterization..................................... 4-12

4.1.11.1 Data Used to Illustrate Systematic Hydrological Characterization Results (Direct Input) ...................................... 4-12

4.1.11.2 Data Used to Corroborate Analyses and Interpretations of Systematic Hydrological Characterization (For Reference) ..........4-12

4.1.12 Data of Observations from the Test at Alcove 8/Niche 3107 .......................4-13

4.1.12.1 Data Used to Illustrate Flow and Transport Test Results at Alcove 8/Niche 3 (Niche 3107) (Direct Input) ........................... 4-13

4.1.12.2 Data for Alcove 8 / Niche 3 (Niche 3107) Tests and Summary of the Alcove 1 Tests (For Reference) ...................................... 4-14

4.1.13 Data of Busted Butte Unsaturated Zone Transport Test ............................... 4-15

4.1.13.1 Data Used to Illustrate Busted Butte Unsaturated Zone Transport Test Results (Direct Input)......................................... 4-15

4.1.13.2 Data Used to Corroborate Busted Butte Unsaturated Zone Transport Test (For Reference) .............................................. 4-16

4.1.14 Data of Geochemical Interpretations .................................................. 4-17

4.1.14.1 Data Used to Support Geochemical Interpretations (Direct Input) ................................................................... 4-17

4.1.14.2 Data Used to Corroborate Geochemical Interpretations (For Reference) .............................................................. 4-19

4.2 CRITERIA

4.3 CODES, STANDARDS, AND REGULATIONS .......................................... 4-24

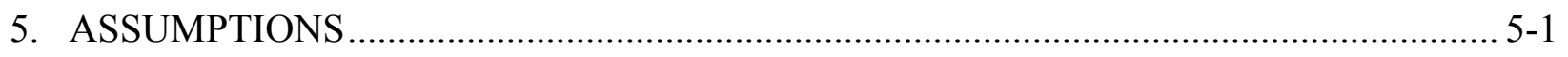

6. SCIENTIFIC ANALYSIS DISCUSSION ........................................................... $6-1$

6.1 AIR-PERMEABILITY DISTRIBUTIONS AND EXCAVATION-INDUCED ENHANCEMENTS .................................................................................. $6-13$

6.1.1 Niche Test Site and Borehole Configuration ......................................... 6-13

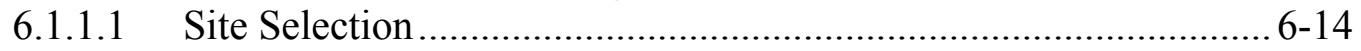

6.1.1.2 Borehole Configuration .......................................................... 6-14

6.1.2 Air-Permeability Testing, Spatial Distribution, and Statistical Analysis ...... 6-20

6.1.2.1 Data Reduction and Air-Permeability Determination ................... 6-21

6.1.2.2 Permeability Profiles ........................................................... 6-23 


\section{CONTENTS (Continued)}

Page

6.1.2.2.1 Pre- and Post-Excavation Permeability Profiles ......... 6-23

6.1.2.2.2 Vertical Permeability Profiles...................................... 6-42

6.1.2.3 Permeability Change as a Function of Initial Permeability............. 6-45

6.1.2.4 Statistical Summary of Air-Permeability Distributions .................. 6-48

6.2 ANALYSIS AND INTERPRETATION OF THE NICHE LIQUID-RELEASE

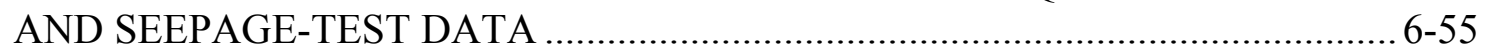

6.2.1 Review of Data Obtained from Liquid-Release and Seepage Tests

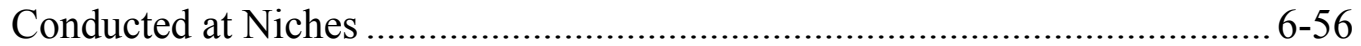

6.2.1.1 Pre-Excavation Liquid-Release Test Data .................................. 6-56

6.2.1.2 Niche Excavation Activities ............................................................ 6-57

6.2.1.3 Post-Excavation Seepage Tests ....................................................6-60

6.2.1.3.1 Niche 2 (Niche 3650) Seepage-Test Data.................... 6-61

6.2.1.3.2 Niche 3 (Niche 3107) Seepage-Test Data.................... 6-63

6.2.1.3.3 Niche 4 (Niche 4788) Seepage-Test Data................... 6-64

6.2.1.3.4 Niche 4 (Niche 4788) Wetting-Area Data .................. 6-66

6.2.1.3.5 Niche 5 (Niche CD 1620) Slot and Seepage-

Threshold Tests .......................................................... 6-67

6.2.2 Niche Seepage Threshold and Fracture Characteristic Curves....................... 6-87

6.2.2.1 Post-Excavation Liquid-Release and Niche Seepage

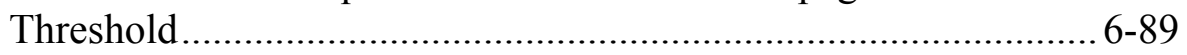

6.2.2.2 Capillary Strength $\left(\alpha^{-1}\right)$ of Fractures ............................................. 6-92

6.2.2.3 Estimated Volumetric Water Content $(\theta)$ of Fractures .................. 6-95

6.2.2.4 Estimated Water Potentials $(\psi)$ of Fractures .................................. 6-97

6.2.2.5 Fracture-Water Characteristic Curves .......................................... 6-99

6.3 ANALYSES OF TRACER-MIGRATION DELINEATION AT NICHE 2

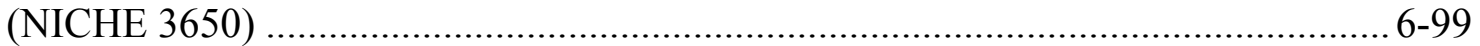

6.3.1 Tracer Distribution from the Tracer-Migration Test .................................. 6-101

6.3.1.1 Field Studies at Niche 2 (Niche 3650) ......................................... 6-101

6.3.1.2 Tracer Migration Test................................................................. 6-101

6.3.2 Delineation of Tracer Distributions from Previous Liquid-Release Tests.... 6-103

6.3.2.1 Detection of Tracers ............................................................... 6-104

6.3.2.2 Distribution of Dyes ..................................................................... 6-107

6.4 ANALYSES OF TRACER PENETRATION AND WATER IMBIBITION

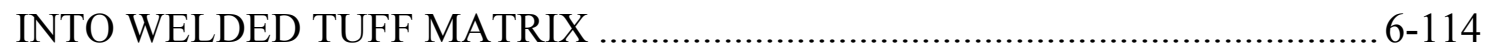

6.4.1 Penetration of Dyes into Rocks from the Niches......................................... 6-114

6.4.1.1 Field Observations................................................................... 6-114

6.4.1.2 Dye Penetrations into Rocks ................................................... 6-116

6.4.1.3 Fast Fracture Flow.................................................................... 6-117

6.4.1.4 Concentration Profiles of Dye Tracer ……………………….... 6-118 


\section{CONTENTS (Continued)}

Page

6.4.2 Retardation and Tracer Front Movement................................................ 6-118

6.4.2.1 Dye Retardation Factor Determined by Front Separation............. 6-123

6.4.2.2 Travel-Front Separation ............................................................. 6-124

6.4.3 Application of LA-ICP-MS to Investigate Chemical Transport and

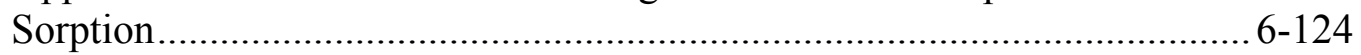

6.5 ANALYSES OF CROSSHOLE AIR-INJECTION TESTS ................................ 6-126

6.5.1 Crosshole Responses in Welded Tuff....................................................... 6-127

6.5.2 Permeability Distributions and Crosshole Responses in Nonwelded Tuff ................................................................................... 6-131

6.6 ANALYSES OF FRACTURE FLOW IN FRACTURE-MATRIX TEST BED

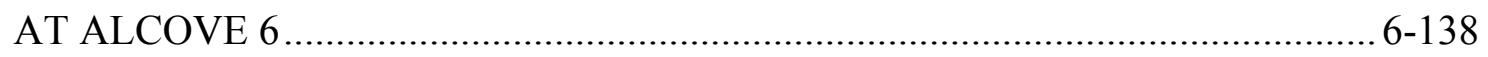

6.6.1 Liquid-Release Tests in Low- and High-Permeability Zones....................... 6-139

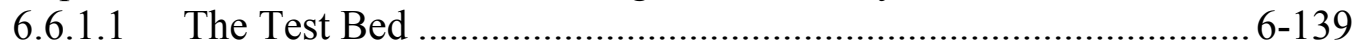

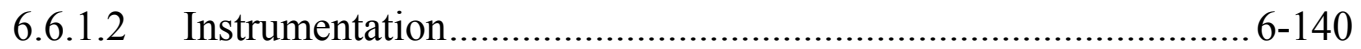

6.6.1.3 Liquid-Release Experiments ................................................... 6-140

6.6.2 Observations of Wetting-Front Migration and Fracture Flow ....................... 6-142

6.6.2.1 Liquid-Release Rates.............................................................. 6-142

6.6.2.2 Formation Wetting and Drying ................................................ 6-144

6.6.2.3 Seepage into the Slot ................................................................ 6-148

6.6.2.4 Tracer Recovery ……………............................................... 6-150

6.7 ANALYSES OF FLOW THROUGH THE FAULT AND MATRIX IN THE

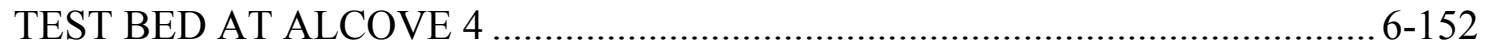

6.7.1 Flow Tests in Paintbrush Tuff Unit Layers and Fault................................... 6-153

6.7.1.1 The Test Bed .......................................................................... 6-153

6.7.1.2 Instrumentation........................................................................ 6-156

6.7.1.2.1 Fluid Injection........................................................ 6-157

6.7.1.2.2 Borehole Monitoring ................................................ 6-157

6.7.1.3 Liquid-Release Experiments ...................................................... 6-157

6.7.2 Observations of Fault Flow and Matrix Flow ........................................... 6-158

6.7.2.1 Fault Responses ..................................................................... 6-158

6.7.2.1.1 Intake Rates......................................................... 6-158

6.7.2.1.2 Water Transport Times in Fault ................................ 6-160

6.7.2.1.3 Dispersion ............................................................ 6-160

6.7.2.2 Matrix Responses ................................................................... 6-162

6.7.2.2.1 Intake Rates........................................................... 6-162

6.7.2.2.2 Wetting Front Migration ............................................ 6-163

6.8 COMPILATION OF WATER-POTENTIAL MEASUREMENTS IN NICHES .... 6-164

6.8.1 Location and Timing of Water-Potential Measurements at Niches.............. 6-165

6.8.2 Observations of Dryout in Niche Boreholes .............................................. 6-168

6.8.2.1 Niche 1 (Niche 3566) Pre-Excavation............................................ 6-169

6.8.2.2 Niche 1 (Niche 3566) Post-Excavation ......................................... 6-170

6.8.2.3 Niche 2 (Niche 3650) Pre-Excavation.......................................... 6-170

6.8.2.4 Niche 3 (Niche 3107) ................................................................ 6-171 


\section{CONTENTS (Continued)}

Page

6.9 OBSERVATIONS OF CONSTRUCTION-WATER MIGRATION .......................6-171

6.9.1 Equipment Setup for Construction-Water Monitoring ................................. 6-172

6.9.1.1 Starter Tunnel Borehole …………………............................... 6-172

6.9.1.2 Electrical Resistance Probes and Psychrometers ......................... 6-172

6.9.1.3 Drift Monitoring at the Crossover Point....................................... 6-173

6.9.2 Wetting-Front Detection and Monitoring below the ECRB Cross-Drift...... 6-175

6.9.2.1 Wetting-Front Detection at the Starter Tunnel............................ 6-175

6.9.2.1.1 Psychrometers ....................................................... 6-178

6.9.2.1.2 Electrical Resistance Probe ...................................... 6-180

6.9.2.1.3 Potential Sensor Comparison.................................... 6-181

6.9.2.2 Wetting-Front Monitoring at the Crossover Point …………….... 6-183

6.10 MOISTURE MONITORING AND WATER ANALYSIS IN

UNDERGROUND DRIFTS ......................................................................... 6-184

6.10.1 Construction (Drift Excavation) Effects on Moisture Conditions ................. 6-184

6.10.1.1 ESF Moisture Monitoring Study ……………........................... 6-184

6.10.1.2 Moisture Conditions and Perturbations Observed in Drifts ......... 6-187

6.10.1.2.1 Observation of Moisture Conditions in Ventilated

ESF Main Drift....................................................... 6-187

6.10.1.2.2 Observation of Moisture Effects in Alcove 3 and Alcove 4 ........................................................... 6-189

6.10.1.2.3 Observation of Moisture Conditions in Ventilated

ECRB Cross-Drift .................................................... 6-190

6.10.1.3 Construction Water Migration below Invert from Excavation .... 6-192

6.10.2 Observation along the Nonventilated Sections of the ECRB Cross-Drift .... 6-192

6.10.2.1 Water-Potential Measurements and Drift Relative Humidity

and Temperature Variations ........................................................ 6-197

6.10.2.1.1 Water-Potential Measurements ................................. 6-197

6.10.2.1.2 Barometric Pressure Variations ................................. 6-199

6.10.2.1.3 Temperature Variations between May 2000 and May 2001 .............................................................. 6-200

6.10.2.1.4 Relative Humidity Variations between May 2000 and May 2001......................................................... 6-201

6.10.2.2 Observations of Wet Zones During Bulkhead Entries .................. 6-202

6.10.2.2.1 Comparison of Observations During

Nonventilated Entries: January 22-25, 2001 and

May 22, 2001 ....................................................... 6-204

6.10.2.2.2 Observations of Entry Made on

October 1-2, 2001 ……............................................ 6-204

6.10.2.2.3 Observations of Entry Made on June 24, 2002 ......... 6-211

6.10.2.3 Estimates of Mass of Vapor in Nonventilated Sections of the ECRB

6.10.3 Chemical and Isotopic Analysis of Water Samples Collected During

Bulkhead Entries. 6-213 


\section{CONTENTS (Continued)}

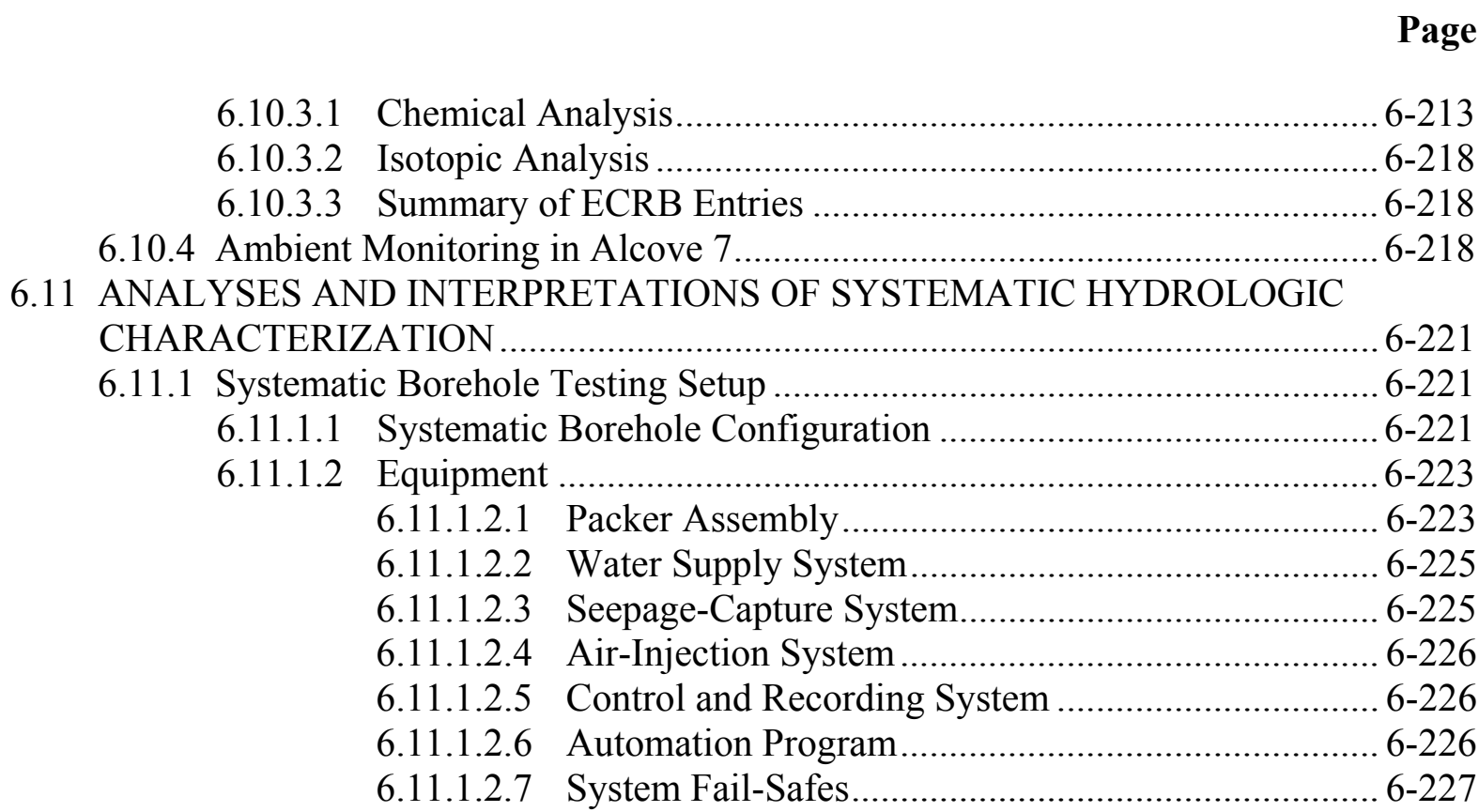

6.11.2 Systematic Testing Results and Observations

6-228

6.11.2.1 Air-Injection Tests and Liquid-Release Tests in LA\#2, Initiated on May 11, 2000 6-228

6.11.2.2 Liquid-Release Test in Zone 1, Zone 2, and Zone 3 in Borehole LA\#2, Initiated on May 17, 2000 6-230

6.11.2.3 Liquid-Release Test in Zone 1, Zone 2, and Zone 3 in Borehole LA\#2, Initiated on May 23, 2000 ................................ 6-232

6.11.2.3.1 Zone 1

6.11.2.3.2 Zone 2

6.11.2.3.3 Zone 3

6.11.2.4 Liquid-Release Test in Zone 2 and Zone 3 in Borehole LA\#2: October 23 to December 1, 2000 $6-237$

6.11.2.5 Liquid-Release Test in Zone 2 of Borehole LA\#1: December 20, 2000, to January 2, 2001

6.11.2.6 Liquid-Release Test in Zone 2 of Borehole LA\#1: February 28 to April 30, 2001

6.11.2.7 Borehole LA\#3 and Liquid-Release Test in Zone 1, Borehole LA\#3: May 10 to June 18, 2001 6-244

6.11.2.8 Liquid-Release Test in Zone 2, Borehole LA\#3: May 10 to July 23, 2001

6.11.2.9 Liquid-Release Test in Zone 3, Borehole LA\#3: May 10 to July 23, 2001

6.11.2.10 Borehole LA\#4 and Liquid-Release Test in Zone 1 of Borehole LA\#4: February 5 to March 11, 2002 6-250

6.11.2.11 Liquid-Release Test in Zone 2, Borehole LA\#4: October 8 to November 18, 2002 


\section{CONTENTS (Continued)}

Page

6.11.2.12 Liquid-Release Test in Zone 3, Borehole LA\#4: February 5 to

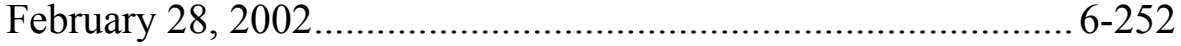

6.11.3 Systematic Testing Discussion and Interpretation .................................. 6-253

6.11.3.1 Participation of Lithophysal Cavities in Storage and Flow Paths $6-253$

6.11.3.2 Estimation of the Steady-State Diversion Flow around the

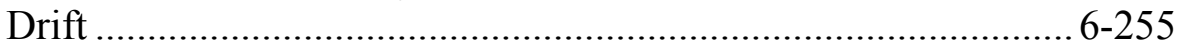

6.11.3.3 Minimum Injection Rate Needed to Induce Seepage .................. 6-257

6.11.3.4 Estimation of Evaporation from within the Fracture System....... 6-257

6.11.3.5 Characteristics and Scale of Flow Heterogeneity along

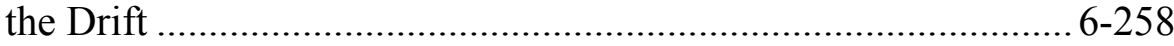

6.11.3.6 Summary of Systematic Hydrologic Testing .............................. 6-259

6.12 DRIFT-TO-DRIFT ALCOVE-8 / NICHE-3 (NICHE 3107) AND SURFACE-

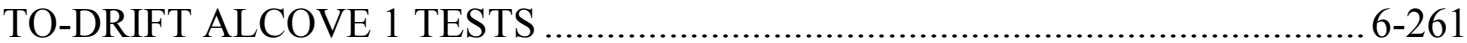

6.12.1 Drift-to-Drift Alcove-8 / Niche-3 (Niche 3107) Tests................................. 6-262

6.12.1.1 Test Sequence of Liquid and Tracer Releases........................... 6-262

6.12.1.2 The Test Bed .................................................................... 6-262

6.12.1.3 Instrumentation................................................................ 6-266

6.12.1.3.1 Fluid and Tracer Injection...................................... 6-266

6.12.1.3.2 Borehole Monitoring........................................... 6-266

6.12.1.3.3 Seepage Collection................................................ 6-267

6.12.1.3.4 Tracer Sampling System ....................................... 6-267

6.12.2 Phase I Observations from the Fault Liquid Test .................................. 6-267

6.12.2.1 Fault Intake Rates ................................................................ 6-267

6.12.2.2 Wetting-Front Migration and Development of the Wetting

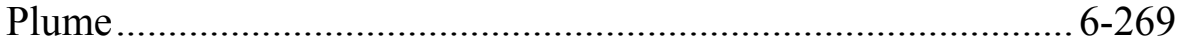

6.12.2.3 Seepage in Niche 3 (Niche 3107) ......................................... 6-271

6.12.2.4 Tracer Recovery in Niche 3 (Niche 3107) ............................... 6-275

6.12.3 Geophysical Imaging of the Drift-to-Drift Test Block .............................. 6-278

6.12.3.1 Background and Ground Penetrating Radar Experimental

Approach .......................................................................... 6-278

6.12.3.2 Results of the Radar Data Acquisition ...................................... 6-279

6.12.3.2.1 Alcove 8 Well Pairs 1-2, 3-4, 1-3, 2-4, and 5-6....... 6-279

6.12.3.2.2 Well Pairs 1 (Alcove 8$)-3$ (Niche 3 ) and 4

(Alcove 8) - 2 (Niche 3) .................................... 6-281

6.12.4 Large Plot Test............................................................................. 6-282

6.12.5 Available Data from Alcove 1 Surface-to-Drift Tests and Implications

for Infiltration Processes .......................................................................... 6-286

6.12.5.1 Alcove 1 Test Data ................................................................ 6-286

6.12.5.2 Alcove 1 and Pagany Wash Infiltration Comparison.................. 6-288

6.13 BUSTED BUTTE UNSATURATED ZONE TRANSPORT TEST ..................... 6-289

6.13.1 Overview of Unsaturated Zone Transport Test ...................................... 6-290

6.13.1.1 Unsaturated Zone Transport Test Location................................ 6-290 


\section{CONTENTS (Continued)}

\section{Page}

6.13.1.2 Unsaturated Zone Transport Test Objectives ............................. 6-290

6.13.1.3 Unsaturated Zone Transport Test Concept.................................. 6-291

6.13.1.4 Test Design ............................................................................. 6-292

6.13.1.5 Site Characterization ............................................................... 6-293

6.13.1.6 Borehole Injection and Sampling Systems................................ 6-294

6.13.1.7 Electrical-Resistance Moisture Sensors ...................................... 6-294

6.13.1.8 Nonreactive and Reactive Tracers and Microspheres .................. 6-295

6.13.1.9 Phase 1 Tracers.................................................................... 6-296

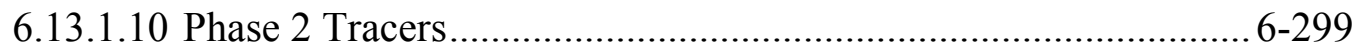

6.13.1.11 Synthetic Pore-Water Recipe ................................................... 6-301

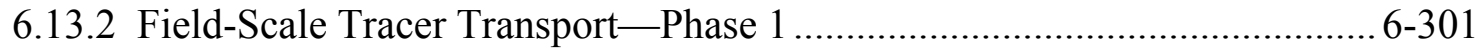

6.13.2.1 Test Phase 1A.................................................................... 6-301

6.13.2.2 Test Phase 1B ....................................................................... 6-304

6.13.3 Field-Scale Tracer Transport-Phase 2 ................................................. 6-309

6.13.3.1 Test Configuration.................................................................. 6-309

6.13.3.2 Additional Coring ..................................................................... 6-310

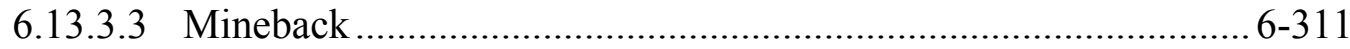

6.13.3.4 Pad Analyses ……………………………............................... 6-311

6.13.3.5 Moisture Movement ............................................................... 6-312

6.13.3.6 Scaling/Travel Distance ............................................................ 6-312

6.13.3.7 Heterogeneity ........................................................................ 6-312

6.13.3.8 Transverse Dispersion .............................................................. 6-314

6.13.3.9 Sorption/Retardation ............................................................... 6-317

6.13.4 Tomographic Studies: Geophysical Techniques at the Busted Butte Unsaturated Zone Test Facility .................................................................... 6-317

6.13.4.1 Busted Butte Ground Penetrating Radar Tomography.................. 6-317

6.13.4.1.1 Background and Experimental Approach ................. 6-319

6.13.4.1.2 Equipment Description, Component Specifications, Operating Principles, and Survey Methodology ………………………........................ 6-319

6.13.4.1.3 Results of the Busted Butte Unsaturated Zone Transport Test Radar Data Acquisition .................... 6-319

6.13.4.1.4 Summary of Ground-Penetrating Radar Tomography ............................................................ 6-327

6.13.4.2 Electrical-Resistance Tomography ............................................. 6-329

6.13.5 Neutron Moisture Measurements................................................................ 6-329

6.13.5.1 Neutron Logging Background and Calibration ........................... 6-329

6.13.5.2 Pre-injection Neutron Logging................................................... 6-330

6.13.5.3 After Beginning Injection........................................................ 6-332

6.13.6 Summary of Laboratory Radionuclide Migration Experiments .................... 6-333

6.14 GEOCHEMICAL AND ISOTOPIC OBSERVATIONS AND ANALYSIS OF THE UNSATURATED ZONE ...................................................................... 6-334

6.14.1 PORE WATER AND ROCK GEOCHEMISTRY ........................................ 6-335 


\section{CONTENTS (Continued)}

\section{Page}

6.14.1.1 Analysis and Interpretation of Pore-Water Data .......................... 6-335

6.14.1.2 Compilation of Rock Chemistry in the ECRB Cross-Drift.......... 6-338

6.14.2 ISOTOPE GEOCHEMISTRY EXAMINATIONS ………….................... 6-343

6.14.2.1 Chlorine-36 Validation Study ................................................... 6-343

6.14.2.2 Tritium Distribution in the ESF and ECRB ................................ 6-346

6.14.2.2.1 Sample Collection and Low-level Analyses of

Tritium Activity ........................................................ 6-347

6.14.2.2.2 Results and Interpretation of Tritium Analyses ........ 6-348

6.14.2.3 Reconstruction of the Paragenetic Sequence and Thermal History of Fracture-Hosted Secondary Mineral Deposits ............ 6-352

6.14.2.3.1 Results ................................................................ 6-353

6.14.3 URANIUM ISOTOPE STUDIES............................................................. 6-357

6.14.3.1 Mineral-Climate Records of UZ Flow ……………………….... 6-357

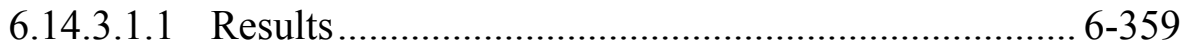

6.14.3.2 Uranium-series Delineation of UZ Flow Zones ........................... 6-367

6.14.3.2.1 Uranium-series "Variations in Fracture Versus

Matrix Samples ....................................................... 6-370

6.14.3.2.2 Uranium-series Variations in Deep UZ Samples ...... 6-371

6.14.3.2.3 Uranium-series Variations in Shallow UZ

Samples ................................................................ 6-373

6.14.3.2.4 Comparisons of Water-rock Environments............... 6-375

6.14.4 FRACTURE MINERAL DISTRIBUTION AND MINERALOGY .............6-375

6.14.4.1 Results ……...................................................................... 6-378

6.14.4.1.1 ESF Line-Survey Results ........................................ 6-378

6.14.4.1.2 Borehole Cutting Results............................................. 6-383

6.14.4.1.3 Interpretation of Results ............................................ 6-385

6.14.4.1.4 Estimates of Past Percolation Volumes ....................... 6-387

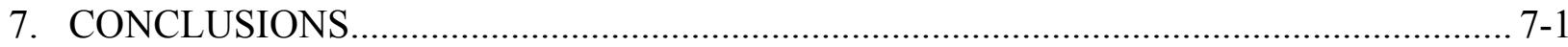

7.1 SUMMARY AND CONCLUSIONS OF AIR-PERMEABILITY

DISTRIBUTION AND EXCAVATION-INDUCED ENHANCEMENT IN

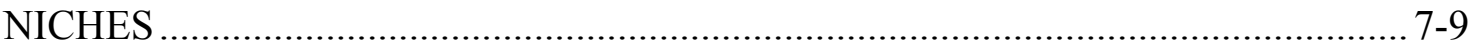

7.2 SUMMARY AND CONCLUSIONS OF LIQUID-RELEASE AND SEEPAGE

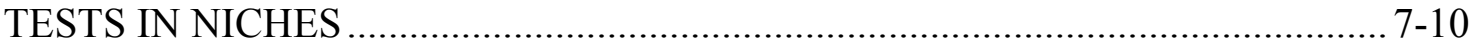

7.2.1 Pre-Excavation Liquid-Release Testing and Niche Excavation Activities..... 7-10

7.2.2 Post-Excavation Seepage Tests at Niche 2 (Niche 3650), Niche 4 (Niche

4788), and Niche 5 (Niche CD 1620) ........................................................ 7-11

7.2.3 Constraints and Limitations of the Niche Seepage Test Results .................... 7-13

7.3 SUMMARY AND CONCLUSIONS OF TRACER-MIGRATION

DELINEATION AT NICHE 2 (NICHE 3650) ...................................................... 7-14

7.4 SUMMARY AND CONCLUSIONS ON TRACER PENETRATION AND

WATER IMBIBITION INTO WELDED TUFF MATRIX..................................... 7-15 


\section{CONTENTS (Continued)}

Page

7.5 SUMMARY AND CONCLUSIONS OF SINGLE-HOLE PERMEABILITY DISTRIBUTIONS AND CROSSHOLE CONNECTIVITY ANALYSES.................7-16

7.6 SUMMARY AND CONCLUSIONS OF FRACTURE FLOW IN THE FRACTURE-MATRIX TEST BED AT ALCOVE $6 \ldots \ldots \ldots \ldots \ldots \ldots \ldots \ldots \ldots \ldots \ldots \ldots \ldots \ldots \ldots \ldots . . . . .17-16$

7.7 SUMMARY AND CONCLUSIONS OF FLOW THROUGH THE FAULT AND MATRIX IN THE TEST BED AT ALCOVE 4 $7-18$

7.8 SUMMARY AND CONCLUSIONS OF WATER-POTENTIAL MEASUREMENTS CONDUCTED IN THREE NICHES WITHIN THE ESF MAIN DRIFT

7.9 SUMMARY AND CONCLUSIONS OF MONITORING CONSTRUCTION-WATER MIGRATION

7.10 SUMMARY AND CONCLUSIONS OF ANALYSES OF CONSTRUCTION EFFECTS

7.11 SUMMARY AND CONCLUSIONS OF SYSTEMATIC HYDROLOGIC CHARACTERIZATION ALONG THE ECRB CROSS-DRIFT

7.12 SUMMARY AND CONCLUSIONS OF DRIFT-TO-DRIFT TESTS BETWEEN ALCOVE 8 AND NICHE 3 (NICHE 3107). $7-23$

7.13 SUMMARY AND CONCLUSIONS OF THE BUSTED BUTTE UNSATURATED ZONE TRANSPORT TEST $7-24$

7.14 SUMMARY AND CONCLUSIONS FOR GEOCHEMICAL AND ISOTOPIC OBSERVATIONS AND ANALYSIS OF THE UNSATURATED ZONE ……....... 7-25

7.14.1 Pore Water and Bulk Repository Rock Unit Geochemistry ........................... 7-26

7.14.2 Isotope Geochemical Studies $7-26$

7.14.2.1 Isotope Geochemical Studies of ${ }^{36} \mathrm{Cl} / \mathrm{Cl}$ Signatures........................ 7-26

7.14.2.2 Tritium in Pore Water.................................................................... 7-26

7.14.2.3 Thermal Regime ………………………............................. $7-27$

7.14.3 Uranium Studies............................................................................... 7-28

7.14.3.1 Uranium-Series Dating ........................................................... 7-28

7.14.3.2 Uranium-series Flow Paths in the UZ ……………………........ 7-29

7.14.4 Fracture Mineralogy .............................................................................. 7-30

7.15 HOW THE ACCEPTANCE CRITERIA ARE ADDRESSED …………………...... 7-30

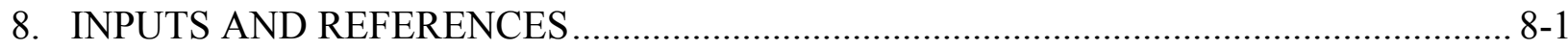

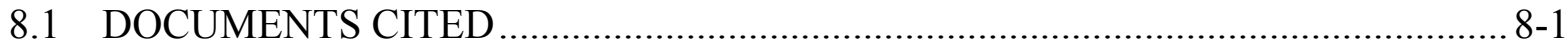

8.2 CODES, STANDARDS, REGULATIONS, AND PROCEDURES ......................... 8-28

8.3 SOURCE DATA, LISTED BY DATA TRACKING NUMBER ……………........... 8-28

8.4 OUTPUT DATA, LISTED BY DATA TRACKING NUMBER ………….............. 8-42

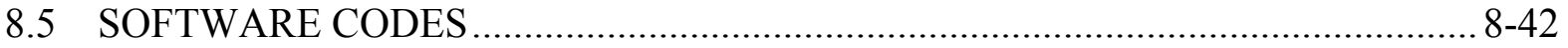




\section{CONTENTS (Continued)}

Page

APPENDIX A - AUTOMATED AIR-INJECTION SYSTEM ……………………............. A-1

APPENDIX B - COMPUTATION TABLES FOR NICHE STUDIES ....................................

APPENDIX C - SUPPLEMENTAL SOURCE OF DATA ON SEEPAGE TESTS AT NICHE 5 (NICHE CD 1620) .....................................................................

APPENDIX D - SEEPAGE PARAMETER EVALUATION ............................................. D-1

APPENDIX E - LABORATORY MEASUREMENTS OF RETARDATION AND FRONT SEPARATION.........................................................................

APPENDIX F - FIELD EQUIPMENT FOR CONTROLLED WATER RELEASE, WETTING-FRONT DETECTION, AND SEEPAGE COLLECTION .........F-1

APPENDIX G - MEASUREMENT OF WATER POTENTIAL USING

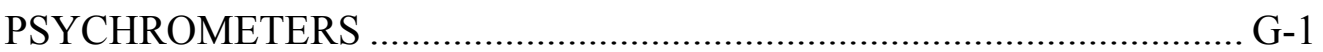

APPENDIX H - GEOLOGY, MINERALOGY, AND HYDROLOGY -BUSTED

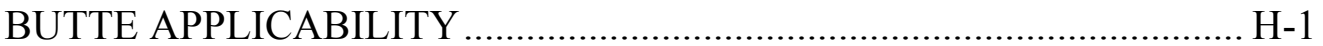

APPENDIX I - CALCULATIONS PERFORMED USING EXCEL SPREADSHEETS AND FUNCTIONS ............................................................................. 


\section{INTENTIONALY LEFT BLANK}




\section{FIGURES}

Page

1-1. Schematic Illustration of Spatial Distribution of Hydrogeologic Units Intersected by the Repository Horizon (Tptpul, Tptpmn, Tptpll, and Tptpln)

1-2. Schematic Illustration of Alcove and Niche Locations in the Exploratory Studies Facility at Yucca Mountain..................................................................................... 1-8

1-3. Schematic Illustration of the ESF and ECRB Cross-Drift........................................... 1-9

1-4. Photo of Yucca Mountain Ridge and Busted Butte, Taken from the Northwest across the Solitario Canyon Fault ................................................................................... 1-10

6-1. Schematic Illustration of Flow Tests in the Exploratory Studies Facility at Yucca Mountain

6-2. Schematic Illustration of the Crossover Point of ECRB Cross-Drift with the Main Drift

6-3. Location Map for Niche 3 (Niche 3107), Niche 1 (Niche 3566), Niche 2 (Niche 3650), Niche 4 (Niche 4788), and Niche 5 (Niche CD 1620)

6-4. Schematic Illustration of the End View of Borehole Clusters at Niche Sites................. 6-16

6-5. Schematic Illustration of the Plan View of Borehole Clusters at Niche Sites ............... 6-17

6-6. Schematic Illustration of the End and Plan Views of Borehole Clusters at Niche 5 (Niche CD 1620).

6-7. Schematic Illustration of the Plan and End Views of Borehole Clusters at Alcove 8 .

6-8. Pre-Excavation Air-Permeability Profiles along Axial Boreholes at Niche 1 (Niche 3566)

6-9. Post-Excavation Air-Permeability Profiles along Radial Boreholes at Niche 1 (Niche 3566)

6-10. Pre- and Post-Excavation Air-Permeability Profiles along Upper Boreholes at Niche 2 (Niche 3650).

6-11. Pre-Excavation Air-Permeability Profiles along Middle and Bottom Boreholes at Niche 2 (Niche 3650)

6-12. Pre- and Post-Excavation Air-Permeability Profiles along Upper Boreholes at Niche 3 (Niche 3107).

6-13. Pre-Excavation Air-Permeability Profiles along Middle and Bottom Boreholes at Niche 3 (Niche 3107)

6-14. Pre- and Post-Excavation Air-Permeability Profiles along Upper Boreholes at Niche 4 (Niche 4788).

6-15. Pre-Excavation Air-Permeability Profiles along Middle and Bottom Boreholes at Niche 4 (Niche 4788).

6-16. Pre- and Post-Excavation Air-Permeability Profiles along Upper Boreholes at Niche 5 (Niche CD 1620)

6-17. Pre- and Post-Excavation Air-Permeability Profiles along AK Side Boreholes at Niche 5 (Niche CD 1620)

6-18. Air-Permeability Profiles along Boreholes Drilled from in Alcove 8 ......................... 6-42

6-18. Air-Permeability Profiles along Boreholes Drilled from in Alcove 8 (Continued)....... 6-43

6-19. Change-Ratio Plot for Niche 5 (Niche CD 1620) Overhead Boreholes ........................ 6-46 


\section{FIGURES (Continued)}

Page

6-20. Change-Ratio Plot for Niche 5 (Niche CD 1620) AK Boreholes................................ 6-46

6-21. Change-Ratio Plot for Niche 2 (Niche 3650) ........................................................ 6-47

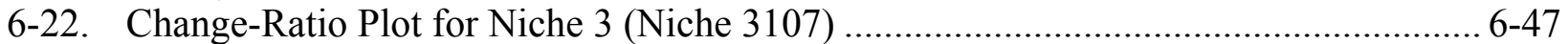

6-23. Change-Ratio Plot for Niche 4 (Niche 4788) ...................................................... 6-48

6-24. Photographic Illustrations of Flow Paths Observed During Niche Excavations .......... 6-59

6-25. Mass of Water Released versus Aspect Ratio............................................................. 6-60

6-26. Schematic Illustration of Seepage Capture System and Test Intervals at Niche 2

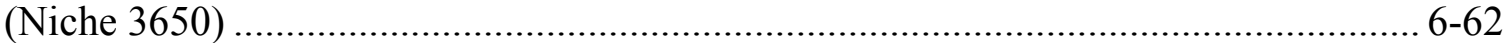

6-27. Relative Humidity and Temperature Inside Niche 3 (Niche 3107) ............................ 6-64

6-28. Relative Humidity and Temperature Inside Niche 4 (Niche 4788) ............................. 6-65

6-29. Stabilized Flow Rates Observed during Test \#1 1-5-00 Conducted on Test Interval UR at Niche 4 (Niche 4788) ................................................................... 6-66

6-30. Wetting-Front Sequences Overlying Fracture Map of Niche 4 (Niche 4788) Ceiling from Seepage Test Begun June 26, 2000

6-31. Wetting-Front Area $\left(\mathrm{m}^{2}\right)$ versus Time (s) for the Seepage Test Shown in

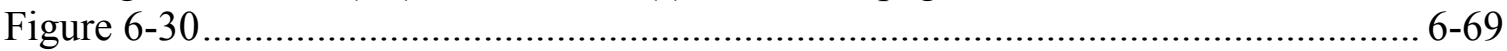

6-32. Square Root of Area (m) Plotted versus Perimeter (m) for Each of the Wetting Fronts in the Niche 4 (Niche 4788) Seepage Test .................................................... 6-69

6-33. Side View of the Boreholes at Niche 5 (Niche CD 1620) ......................................... 6-72

6-34. Plan View of the Boreholes at Niche 5 (Niche CD 1620) ......................................... 6-72

6-35. Schematic Illustration of Front View of Niche 5 (Niche CD 1620) Facing South, Showing Location of Boreholes (\#1-\#7) ................................................................. 6-73

6-36. Schematic Illustration of Front View of Niche 5 (Niche CD 1620) Facing South Showing Profiles 1-6....

6-37. Photograph of Left (East) Rib of Niche 5 (Niche CD 1620) Facing the Opening of a 3.3-m-Long Slot and Showing Ground Support ....

6-38. Photograph of Left (East) Rib of Niche 5 (Niche CD 1620) Showing Ceiling of Slot and Ground Support $6-76$

6-39. General Process Diagram for Seepage Testing at Niche 5 (Niche CD 1620) ............. 6-78

6-40. Capture System Installation Showing Plastic Capture Trays and Tarp in Slot............. 6-80

6-41. Capture System Showing Tarp Installed Next to Slot ........................................... 6-81

6-42. Evaporation Rate Inside and Outside Niche 5 (Niche CD 1620) During Test \#2 9-17-02.....

6-43. Relative Humidity and Temperature of Air Inside and Outside Niche 5 (Niche CD 1620) During Test \#2 9-17-02 ........................................................................... 6-85

6-44. Liquid-Release Rate into Borehole 5 and Seepage of Water into the Capture System of Niche 5 (Niche CD 1620) during Test \#2 9-17-02 ................................. 6-86

6-45. Total Seepage and Seepage into the Tarp Area at the Entrance to the Slot................. 6-87

6-46. Wetted Area Spreading Down the Sidewall in Niche 5 (Niche CD 1620).................. 6-88

6-47. Liquid-Release Flux versus Seepage Percentage.................................................. 6-90

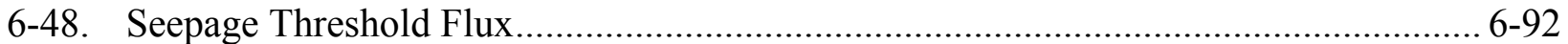

6-49. Water Retention Curves for Fractures ............................................................. 6-100 


\section{FIGURES (Continued)}

Page

6-50. Effect of Wetting History on Water Retention Curves for Test Interval N3650

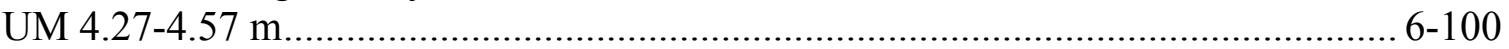

6-51. Schematic of Sampling Borehole Array ……...................................................... 6-102

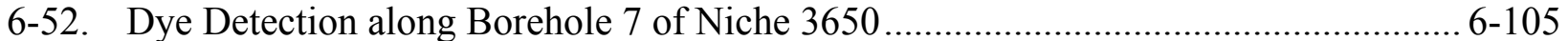

6-53. Dye Detection of (a) Pyranine along Borehole 11 and (b) Acid Yellow 7 along

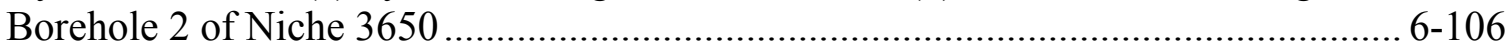

6-54. Three-Dimensional View of FD\&C Blue No. 1 Detection Related to the Release Interval above Niche 2 (Niche 3650) .................................................................... 6-108

6-55. Three-Dimensional View of Sulpho Rhodamine B Detection Related to the Release Interval above Niche 2 (Niche 3650) .......................................................... 6-109

6-56. Three-Dimensional View of Pyranine Detection Related to the Release Interval above Niche 2 (Niche 3650).

6-57. Three-Dimensional View of Acid Yellow 7 Detection Related to the Release Interval above Niche 2 (Niche 3650).

6-58. Three-Dimensional View of Amino G Acid Detection Related to the Release Interval above Niche 2 (Niche 3650).

6-59. Three-Dimensional View of FD\&C Yellow No. 6 Detection Related to the Release Intervals above Niche 2 (Niche 3650).

6-60. Photograph Showing the Wall Face of Niche 4 (Niche 4788) with Fracture Network and Sampling Location of Rock, and Stained Rock Sample

6-61. Sulpho Rhodamine B Penetration Profiles into Rock Matrix from the Fracture

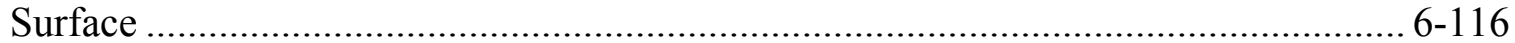

6-62. Tracer Penetration Profile from the Fracture Surface into Rock Matrix .................... 6-119

6-63. Comparison of Tracer Concentration Profiles for Different Tracers in a Core with Low Initial Saturation.....

6-64. Comparison of Tracer Concentration Profiles for Different Traces in a Core with a High Initial Saturation.

6-65. Spatial Distribution along the Tracer Solution Contact Surface of Applied Tracers and the Distribution of Intrinsic Tuff Elements Profiled Using Laser Ablation ICP-MS

6-66. Spatial Distribution Normal to the Tracer Solution Contact Surface (in the Direction of Liquid Imbibition) of Applied Tracers and Distribution of Intrinsic Tuff Elements Profiled Using Laser Ablation ICP-MS

6-67. Crosshole Responses for the Borehole Cluster in Niche 4 .......................................... 6-128

6-68. Air-Permeability Profiles along Boreholes in Alcove 6 …....................................... 6-129

6-69. Crosshole Responses for the Borehole Cluster in Alcove 6 …….............................. 6-131

6-70. Perspective Illustration of Alcove 4 Test Bed ......................................................... 6-132

6-71. Air-Permeability Profiles along Boreholes in Alcove 4 ............................................. 6-133

6-72. Crosshole Responses for the Borehole Cluster at Alcove 4 PTn Test Bed with All Response Pressure (Resp.) Ratios below 0.2 Included

6-73. Crosshole Responses for Borehole Cluster at Alcove 4 PTn Test Bed with Small Response Pressure (Resp.) Ratios Filtered 


\section{FIGURES (Continued)}

Page

6-74. Schematic Illustration of Location and Layout of Alcove 6 in the ESF at Yucca Mountain

6-75. Water Intake Rates Observed in the Low Permeability Zone as a Function of Time.

6-76. Water Intake Rates Observed in the High Permeability Zone 6-143

6-77. Changes in Electrical Resistance and Water Potential Detected during Liquid Release into the Low Permeability Zone.

6-78. Changes in Electrical Resistance and Water Potential Detected during Liquid Release into the High Permeability Zone

6-79. Seepage from High Permeability Zone into Slot in Alcove 6

6-80. Seepage into Collection Trays in the Slot in Alcove 6

6-81. Volume of Water Recovered in the Slot after Liquid Injection at Various Rates into the High Permeability Zone was Stopped

6-82. Tracer Concentrations in Seepage Water Following Injection into the High Permeability Zone

6-83. Geological Sketch and Schematic Illustration for the North Face of Alcove 4 in the ESF at Yucca Mountain

6-84. Perspective Illustration of Three-Dimensional View of the Boreholes, Slot, and Lithological Unit Contacts in the Alcove 4 Test Bed

6-85. Intake Rates along the 0.3-m Zone Located on the Fault in Borehole 12 6-159

6-86. Wetting Front Arrival in Borehole 11 Following Liquid Released into the Fault in Borehole 12 $6-160$

6-87. Changes in Electrical Resistance in Borehole 11 in Response to Liquid Released into the Fault in Borehole 12

6-88. Changes in Electrical Resistance in Borehole 2 in Response to Liquid Released into the Fault in Borehole 12

6-89. Intake Rates along a 0.3-m Zone in the Matrix Located 2.44-2.74 $\mathrm{m}$ from the Collar in Borehole 5

6-90. Changes in Electrical Resistance in Borehole 6 in Response to Liquid Released in Borehole 5

6-91. Schematic Illustration of the Location of Psychrometers in Niche 1 (Niche 3566)

6-92. Schematic Illustration of Location of Psychrometers in Niche 2 (Niche 3650) 6-167

6-93. Schematic Illustration of Location of Psychrometers in Niche 3 (Niche 3107) (Pre Excavation).

6-94. Pre-Excavation Water Potential Measured along Borehole U in Niche 1 (Niche 3566) $6-170$

6-95. Water Potential Measured along Borehole UM in Niche 3 (Niche 3107)..... 6-171

6-96. Schematic Illustration of the Location of Wetting-Monitoring Borehole at the Starter Tunnel of the ECRB Cross-Drift

6-97. Schematic Illustration of the Borehole Wetting Front Monitoring System with Psychrometers and Electrical Resistance Probes

6-98. Schematic Illustration of Sensor Arrays for Wetting Front Monitoring 6-174 


\section{FIGURES (Continued)}

Page

6-99. Changes in Water Potential Observed along the Wetting Front Monitoring Borehole at the Starter Tunnel of the ECRB Cross-Drift .

6-100. Changes in Electrical Resistance Observed along the Wetting-Front Monitoring Borehole at the Starter Tunnel of the ECRB Cross-Drift

6-101. Comparison of Performance of Electrical Resistance Probe and Psychrometer 6-182

6-102. Example of Time Domain Reflectometry Probe Data at the Crossover Point in the ESF Main Drift.

6-103. Relative Humidity Temporal Variations in the ECRB Cross-Drift

6-104. Relative Humidity Spatial Variations along the ECRB Cross-Drift

6-105. Construction Water Distribution below Exploratory Studies Facility Drift 6-193

6-106. Schematic Illustration of Bulkhead Locations in the ECRB Cross-Drift 6-194

6-107. Schematic Illustration Showing Berkeley Lab Monitoring Station in Locations in the ECRB Cross-Drift.

6-108. As-Built Cross Section of the Terminal End of the ECRB Cross-Drift $(23+00 \mathrm{~m}$ to $26+81 \mathrm{~m}$ ) Showing the Bulkhead Locations

6-109. Water-Potential Measurements along the ECRB Cross-Drift 6-198

6-110. Barometric Pressure Measured along the ECRB Cross-Drift.

6-111. Temperature Measured in the Four ECRB Cross-Drift Stations 6-200

6-112. Relative Humidity Measured in the ECRB Cross-Drift Stations. 6-202

6-113. Distribution of Wet Zones during ECRB Bulkhead Entries.... 6-203

6-114. Visibly Different Moisture Levels on Adjoining Rock Surfaces at CD 24+70.... 6-205

6-115. Stalactite-Like Features near First Bulkhead at CD 17+63 $6-206$

6-116. Water Puddle and Condensate on Conveyor at CD 18+25. 6-207

6-117. Water Surrounding Inclusions 6-208

6-118. Condensate on Shotcrete after Second Bulkhead

6-119. Solitario Canyon Fault Left Rib.

6-120. Tarp Discoloration before CD 25+99 Bulkhead

6-121. Relatively Dry Section Inside Bulkhead at CD 25+99 (with TBM).

6-122. Vapor Density at Various Temperatures.

6-123. Mass of Vapor in Sections of ECRB Determined from Temperature and Relative Humidity Measurements at Station CD 21+40 and Station CD 25+52

6-124. Chemical Analyses of Liquid Samples Collected during Bulkhead Entries.

6-125. Comparison of Chemical Signatures

6-126. Plot of the Hydrogen and Oxygen Isotope Compositions of Water Samples Collected from the ECRB Cross-Drift.

6-127. Schematic of Borehole Configuration in the ECRB Cross-Drift for Systematic Characterization of the Lower Lithophysal Unit

6-128. A Schematic of the Equipment System: Packer Assembly, Water Supply and Air-Injection Component, Seepage Collection Component, and Data Acquisition and Control.

6-129. Schematic Illustration of Front Panel for Control Interface on Computer

6-227 


\section{FIGURES (Continued)}

Page

6-130. Pressure Responses (Pink, Orange, and Green) to Constant Mass Flow of Air-Injection (Blue) for Estimation of Fracture Permeability in Borehole ECRB-SYBT-LA\#2

6-131. Cumulative Water Supplied to Zone 1 of Borehole ECRB-SYBT-LA\#2 and Cumulative Seepage into the ECRB Cross-Drift for a Test Performed between May 11 and May 12, 2000.

6-132. Cumulative Water Supplied to Zones 1, 2, and Zone 3 of Borehole ECRB-SYBTLA\#2 and Cumulative Seepage into the ECRB Cross-Drift for Tests Performed between May 17 and May 18, 2000.

6-133. Cumulative Water Supplied to Zone 1 of Borehole ECRB-SYBT-LA\#2 and Cumulative Seepage into the ECRB Cross-Drift for Tests Performed between May 23 and June 1, 2000

6-134. Cumulative Water Supplied to Zone 2 of Borehole ECRB-SYBT-LA\#2 and Cumulative Seepage into ECRB Cross-Drift for Tests Performed between May 23 and June 8, 2000

6-135. Cumulative Water Supplied to Zone 3 of Borehole ECRB-SYBT-LA\#2 and Cumulative Seepage into ECRB Cross-Drift for Tests Performed between May 23 and June 27, 2000

6-136. Cumulative Water Supplied to Zone 2 and Zone 3 of Borehole ECRB-SYBTLA\#2 and Cumulative Seepage into ECRB Cross-Drift for Test Performed between October 23, 2000, and December 1, 2000

6-137. Supply Rate, Seepage Rate and Relative Humidity and Temperature for Liquid-Release Test Performed in Zone 2 of Borehole ECRB-SYBT-LA\#2 between October 23, 2000, and December 1, 2000

6-138. Supply Rate, Seepage Rate, and Relative Humidity and Temperature for Liquid-Release Test Performed in Zone 3 of Borehole ECRB-SYBT-LA\#2 between October 23, 2000, and December 1, 2000

6-139. Cumulative Supply Volume, Relative Humidity, Evaporation, and Temperature Measurements for Zone 2 of Borehole ECRB-SYBT-LA\#1.

6-140. Measurements for Borehole Zone 2 of Borehole ECRB-SYBT-LA\#1

6-141. Cumulative Water Volume and Rate Supplied to Zone 1 of Borehole ECRBSYBT-LA\#3, Related Seepage Rate, and Evaporation with Linear Fit and Slope (mm drop per day) for the Test Performed between May 17 and June 19, 2001

6-142. Cumulative Water Volume and Rate Supplied to and Seeped from Zone 2 of Borehole ECRB-SYBT-LA\#3 and Evaporation with Linear Fit and Slope (millimeter drop per day) for Test Performed from June 20 to July 24, 2001

6-143. Rate Supplied to, Returned from, and Rate of Net Inflow from Zone 3 of Borehole ECRB-SYBT-LA\#3 for Test Performed from May 17, 2001, to July 24, 2001

6-144. Volume and Rate of Water Supplied to, Returned from and Rate of Net Inflow from Zone 1 of Borehole ECRB-SYBT-LA\#4 for Test Conducted from February 6 to March 9, 2002 


\section{FIGURES (Continued)}

Page

6-145. Injection and Seepage Volumes; Injection, Seepage, and Net Rates; and Evaporation Drop for Liquid-Release Test Conducted in Zone 2 of ECRB-SYBT-

LA\#4 2 between October 8 and November 18, 2002

6-146. Volume and Rate of Water Supplied to, Returned from, and Rate of Net Inflow from Zone 3 of Borehole ECRB-SYBT-LA\#4 for Test Conducted from February 6 to February 28, 2002

6-147. Borehole Flow and Path Details

6-148. Summary Plot Showing Injection, Return Flow, Evaporation, and Diversion in All Systematic Hydrologic Tests

6-149. Schematic Illustration of the Test Bed for the Alcove- 8 / Niche-3 Tests $6-263$

6-150. Schematic Illustration of the Infiltration Zones along the Floor of Alcove 8 $6-264$

6-151. Schematic Illustration of the Horizontal Monitoring Boreholes in Niche 3 6-265

6-152. Alcove 8 Trench Infiltration Daily Rates for Saturated and Unsaturated Conditions in the Fault Experiment

6-153. Cumulative Trench Application from March 5, 2001, to August 20, 2002.

6-154. Illustration of Wetting-Front Arrival Detected in Borehole 10 in Niche 3

6-155. Wetting-Front Velocities as Determined from Boreholes 1, 9, and 10 in Niche 3..... 6-270

6-156. Cumulative Seepage (Blue) from All Collection Trays in Niche 3 and the Seepage Rate Observed (Red) along a Section of Fault in Niche 3

6-157. Seepage Rates (L/day) Measured from 10 Trays Located along the Ceiling of Niche 3

6-158. Concentration of Bromide and Seepage Rates Plotted for a Period of 45 Days after First Observations of Drips in Tray 6

6-159. Relative Mass Recovery of Tracers Measured in Seepage in Niche 3 6-277

6-160. Radar Velocity Tomograms between Alcove-8 Well Pairs

6-161. Radar Velocity Tomograms between Alcove 8 and Niche 3 Well Pairs, Baseline Survey 07-19-2000.

6-162. Schematic Illustration of the Infiltration Zones along the Floor of Alcove 8 in Large-Plot Test.

6-163. Infiltration Rates of Individual Plots from August 20, 2002, to November 19, 2002

6-164. Cumulative Application of All Twelve Plots in Alcove 8 Large-Plot Experiment ..... 6-283

6-165. Daily Seepage Rates Measured in Niche 3 Following Release of Water in the Large Infiltration Plot in Alcove 8

6-166. Seepage Rates Measured in Niche 3 Following Release of Water in the Large Plot in Alcove 8

6-167. Schematic Illustration of Alcove 1 Test Site Inside the ESF North Portal 6-287

6-168. Busted Butte Unsaturated Zone Transport Test Site.

6-169. Schematic of Vertical Cross Section of Injection and Collection System Configuration

6-170. Schematic of Phase-1A Borehole Numbers and Relative Locations

6-171. Phase-1B and Phase-2 Borehole Numbers and Relative Locations. 6-297

6-172. Fluorescein Plume at Each of the Four Phase-1A Mineback Faces 6-302 


\section{FIGURES (Continued)}

Page

6-173. Fluorescein Plume at 90-cm Mineback Face at Borehole 3

6-303

6-174. Phase-1B Pad Extraction/Analysis Scheme.

6-305

6-175. Bromide Concentrations in Borehole 6 for Phase 1B

6-306

6-176. 2,6-DFBA Concentrations in Borehole 6 for Phase 1B

6-307

6-177. Fluorescein Concentrations in Borehole 6 for Phase 1B

6-178. Pyridone Concentrations in Borehole 6 for Phase 1B

6-179. Lithium Concentrations in Borehole 6 for Phase 1B

6-180. Borehole Configuration on the Collection Face

6-310

6-181. Schematic Illustration of Locations of Phase 2 Post-Test Overcores

$6-311$

6-182. Moisture Front Precedes Tracer Front

6-183. Influence of Scaling/Travel Distance on Tracer Transport in UZTT for Phase 2 ...... 6-314

6-184. Influence of Rock Heterogeneity on Tracer Transport in UZTT for Phase 2.

6-185. Extent of Transverse Dispersion on Tracer Transport Measured in Borehole 16 of the UZTT for Phase 2 .

6-186. Effect of Sorption/Retardation on Tracer Transport in UZTT for Phase 2

6-187. GPR Tomography Results for Well Pair 46-16 from April 1999, February 2000, and July 2000.

6-188. GPR Tomography Results for Well Pair 46-9 from April 1999, February 2000, and July 2000

6-189. GPR Tomography Results for Well Pair 11-47 from September 1999, February 2000, and November 2000

6-190. GPR Tomography Results for Well Pair 15-13 from April 1999, February 2000, and July 2000.

6-191. Initial Moisture Content at Borehole 16

6-192. Initial Moisture Content at Borehole 46

6-193. Moisture Increase at Borehole 16 at Various Times after Injection

6-194. Moisture Increase at Borehole 46 at Various Times after Injection

6-195. ${ }^{36} \mathrm{Cl} / \mathrm{Cl}$ Ratio Plotted against Sample Location in the Exploratory Studies Facility.

6-196. The Average Homogenization Temperatures $\left(\mathrm{T}_{\mathrm{h}}\right)$ of Two-Phase Fluid Inclusions with Small and Consistent Vapor

6-197. The $\delta^{18} \mathrm{O}$ Values of Calcite from Secondary Mineral Coating Samples in the ESF and ECRB Cross-Drift Tunnels

6-198. Calcite $\delta^{18} \mathrm{O}$ Values Plotted versus Depth Below the Surface in the ESF, Reflecting Separate Trends in the Tiva Canyon and Topopah Spring Welded Tuffs

6-199. Graph of Calcite Depositional Temperatures versus ${ }^{235} \mathrm{U} /{ }^{207} \mathrm{~Pb}$ or ${ }^{230} \mathrm{Th} / \mathrm{U}$ Depositional Ages of Chalcedony or Opal Associated with the Calcite

6-200. Cross Sections of Two Opal Hemispheres Analyzed by Ion Microprobe Shown under Transmitted Light and Reflected Light.

6-201. U/Th Isotope Evolution Plot for Ion-Microprobe Analyses of Opal Hemispheres ..... 6-362

6-202. Depth-Age Relations for Profiles of Opal Hemispheres Analyzed by Ion Microprobe. 


\section{FIGURES (Continued)}

Page

6-203. Depth-Age Relations for Sequential Microdigestions of Opal Hemisphere Subsample HD2074-g2

6-204. Sample Locations and Details of Yucca Mountain, the ESF, and the ECRB 6-370

6-205. Variations in Activity Ratios in Yucca Mountain Whole-Rock Subsamples Plotted against Distance from the Fracture Surface

6-206. Relations between ${ }^{230} \mathrm{Th} /{ }^{238} \mathrm{U}$ and ${ }^{234} \mathrm{U} /{ }^{238} \mathrm{U}$ Activity Ratios (ARs) for Three Samples from the ECRB Cross-Drift

6-207. Map of the Right Rib of the Exploratory Studies Facility Tunnel Showing Uranium-Series Sample Locations

6-208. Uranium-series Isotopic Compositions ( $2 \sigma$ Error Ellipses) for Samples from the Exploratory Studies Facility near the Bow Ridge Fault Zone

6-209. Relations between Calcium Concentration Determined by X-ray Fluorescence and Calcite Concentration Determined by $\mathrm{CO}_{2}$ Evolution for Cuttings of Tiva Canyon and Topopah Spring High-Silica Rhyolite from Boreholes USW SD-6 and USW WT-24

6-210. Hydrogenic Mineral Abundances for 30-m Surveys in the Exploratory Studies Facility Plotted against Distance from the ESF North Portal .

6-211. Calcite Abundances in a Shaded Topographic Map of the Area Overlying the Underground Workings at the Repository Site.

6-212. Histograms Showing Hydrogenic Mineral Abundances in Welded Tuffs in the Exploratory Studies Facility

6-213. Variations with Distance in the Exploratory Studies Facility from the ESF North Portal

6-214. Relation between Hydrogenic Mineral Abundance in Welded Units of the Topopah Spring Tuff and the Number of Faults and Shears Measured in the Corresponding Intervals in the Exploratory Studies Facility

6-215 Summary of Hydrogenic-Mineral Abundances in Welded Tuffs in the Exploratory Studies Facility

6-216. Profiles of Calcite Abundance Calculated from $\mathrm{CO}_{2}$ Determinations on Cuttings from Boreholes USW SD-6 and USW WT-24

6-217. Box and Whisker Plots for Distributions of Calcite Abundance Measurements in Borehole USW SD-6 and the ECRB Cross-Drift (gray boxes) for Three Lithostratigraphic Zones

6-218. Topopah Spring Tuff Details 6-388

A-1. Schematic of Automatic Packer Design ...................................................................... A-1

A-2. Schematic of the Permutation Scheme for Automatic Packers .................................... A-2

C-1. As-Built Profile Niche \#5 Bat-Wing Excavation (Looking in from ECRB) ....................-1

C-2. Process Diagram for the Release and Return Manifolds Used to Control Water Flow to and from the Test Interval ................................................................................

C-3. Process Diagram for the Capture Manifold Used to Measure and Control Seepage Collected inside the Niche 


\section{FIGURES (Continued)}

Page

C-4. Front Panel Display for LabVIEW V.6 Virtual Instrument Showing Example of Equipment Control Parameters …………………………………………………….....

D-1. Comparison of Liquid and Air-Derived Saturated Hydraulic Conductivities ................ D-5

E-1. Comparison of Measured Detection Ratio from the Opposite Drilling Directions

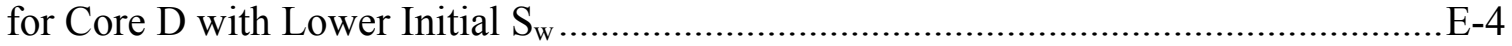

E-2. Comparison of Measured Detection Ratio from the Opposite Drilling Directions

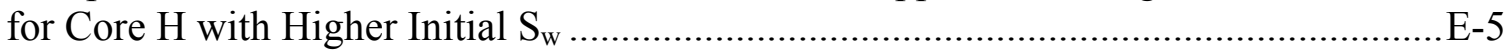

F-1. Schematic Illustration of Liquid Release System for Constant-Head and Constant-

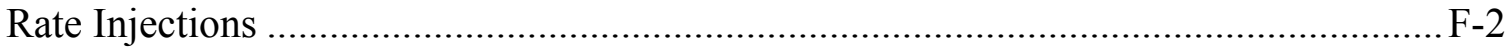

F-2. Schematic Illustration of Borehole Monitoring System ……………………...............F-4

F-3. Schematic Illustration of Water Collection System Installed in Slot …………...............F-5

G-1. Effect of Cooling Current on Psychrometer Output Curve (PSY-732) ………………... G-1

G-2. Effect of Dust Coating on Psychrometer Output Curve (PSY-731) .............................. G-2

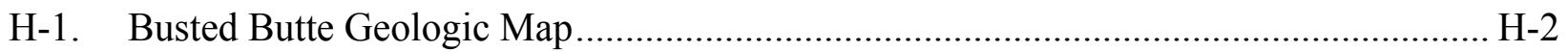

H-2. Stratigraphy and Clay Content of the Phase 2 Test Block ............................................. H-7

I-1. Example of Plotting and Trendline Addition in Excel Based on Figure 6-122 ................ I-4

I-2. Example of Linear Regression in Excel with the $y=m x$ Equation, Where $m$ is the Regression-Slope ……….................................................................................... I-6

I-3. Wetting-Front Velocities for Boreholes 1, 9, and 10 as Presented in Figure 6-155 ........ I-19 


\section{TABLES}

Page

1-1. Approaches and Main Activities in In Situ Field Testing of Processes........................... 1-2

1-2. Underground Tests at Different Locations …......................................................... 1-6

1-3. Features, Events, and Processes Addressed in this Scientific Analysis Report.............. 1-11

3-1. Software and Routines ...................................................................................... 3-1

4-1a. Data Used to Illustrate Air-Permeability Distributions and Excavation-Induced Enhancements (Direct Input) ............................................................................... 4-3

4-1b. Data Used to Corroborate Analysis of Air-Permeability Distributions and

Excavation-Induced Enhancements (For Reference)...................................................... 4-4

4-2a. Data Used to Illustrate Niche Liquid-Release and Seepage-Test Results (Direct Input) ………......................................................................................... 4-4

4-2b. Data Used to Corroborate Analysis and Interpretation of Niche Liquid-Release and Seepage Tests (For Reference) …………………...................................................... 4-5

4-3. Data Used to Illustrate Tracer-Migration Delineation at Niche 2 (Niche 3650) (Direct Input) ………........................................................................................ 4-6

4-4. Data Used to Illustrate Tracer Penetration and Water Imbibition into Welded Tuff Matrix (Direct Input) .......................................................................................... 4-6

4-5. Data Used to Illustrate Crosshole Analysis of Air-Injection Tests (Direct Input)........... 4-7

4-6. Data Used to Illustrate Fracture Flow in Fracture-Matrix Test Bed at Alcove 6 (Direct Input)

4-7a. Data Used to Illustrate Flow through the Fault and Matrix in the Test Bed at Alcove 4 (Direct Input).

4-7b. Data Used to Corroborate Analysis of Flow through the Fault and Matrix in the Test Bed at Alcove 4 (For Reference) ......................................................................... 4-8

4-8. Data Used to Compile Water-Potential Measurements in Niches (Direct Input) ............ 4-8

4-9. Data Used to Illustrate Observations of Construction-Water Migration (Direct Input) ......................................................................................................... 4-8

4-10a. Data Used to Illustrate Moisture Monitoring and Water Analysis in Underground Drifts (Direct Input) ……………………............................................................... 4-9

4-10b. Data on Drift Moisture Monitoring and Water Analysis (For Reference)...................... 4-10

4-10c. Data on Water Potential and Saturation Measurements (For Reference) ....................... 4-11

4-11a. Data Used to Illustrate Systematic Hydrological Characterization Results (Direct Input)

4-11b. Data Used to Corroborate Analyses and Interpretations of Systematic Hydrological Characterization (For Reference).

4-12a. Data Used to Illustrate Flow and Transport Test Results at Alcove 8/Niche 3 (Niche 3107) (Direct Input)

4-12b. Data for Alcove 8 / Niche 3 (Niche 3107) Tests and Summary of the Alcove 1 Tests (For Reference)....................................................................................... 4-14

4-13a. Data Used to Illustrate Busted Butte Unsaturated Zone Transport Test Results (Direct Input) 


\section{TABLES (Continued)}

Page

4-13b. Data Used to Corroborate Busted Butte Unsaturated Zone Transport Test

(For Reference) ................................................................................................ 4-16

4-14a. Data Used to Support Geochemical Interpretations (Direct Input) .............................. 4-17

4-14b. Data Used to Corroborate Geochemical Interpretations (For Reference) ...................... 4-19

4-15. Project Requirements and YMRP Acceptance Criteria Applicable to This Scientific Analysis Report .................................................................................... 4-22

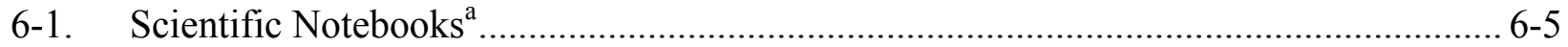

6-2. Summary Statistics of Air Permeability $\left(\mathrm{m}^{2}\right)$ from Boreholes above Niches 2, 3,

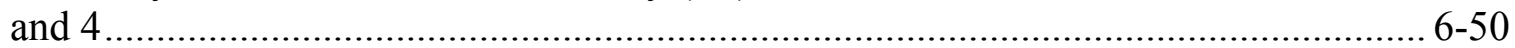

6-3. Summary Statistics of Air Permeability $\left(\mathrm{m}^{2}\right)$ from Boreholes above Niche 5

(Niche CD 1620) …...................................................................................... 6-52

6-4. Summary Statistics of Air Permeability $\left(\mathrm{m}^{2}\right)$ from Boreholes alongside Niche 5 (Niche CD 1620).

6-5. Summary Statistics of Air Permeability $\left(\mathrm{m}^{2}\right)$ from Boreholes under Alcove 8............ 6-54

6-6. Comparison of Geometric Means and Standard Deviations of Niches and Alcoves in the Exploratory Studies Facility at Yucca Mountain................................................. 6-55

6-7. Borehole Depth Summary....................................................................................... 6-77

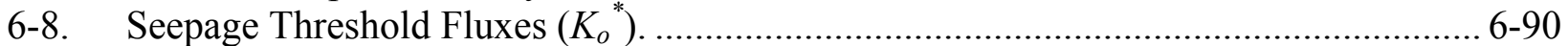

6-9. Alpha $(\alpha)$ Values Estimated for the Fractures .......................................................... 6-94

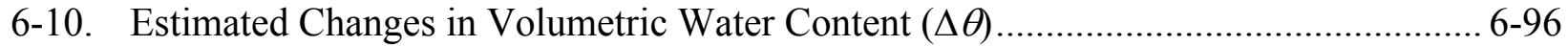

6-11. Estimated Water Potential $(\psi)$ for the Fractures.......................................................... 6-98

6-12. Compilation of Tracer Detection versus Borehole Location ........................................ 6-104

6-13. Liquid-Release Tests and Experimental Conditions .............................................. 6-117

6-14. Post-Excavation Tracer-Release Tests at Niche 2 (Niche 3650) ................................ 6-117

6-15. Measured Properties for Core Samples................................................................... 6-123

6-16. Amount of Water and Types of Tracers Released into the Injection Borehole ........... 6-142

6-17. Summary of Liquid-Injection Tests in the High Permeability Zone ........................... 6-148

6-18. Summary of Liquid Releases into the Fault Zone in Borehole 12 ............................... 6-158

6-19. Water-Potential Measurements in Niche 1 (Niche 3566) .......................................... 6-168

6-20. Water-Potential Measurements in Niche 2 (Niche 3650) .......................................... 6-169

6-21. Water-Potential Measurements in Niche 3 (Niche 3107) ........................................... 6-169

6-22. Psychrometers Response to Excavation at the Starter Tunnel of the ECRB

Cross-Drift ............................................................................................... 6-175

6-23. Electrical Resistance Probe Responses to Excavation at the Starter Tunnel of the ECRB Cross-Drift........................................................................................... 6-176

6-24. Moisture-Monitoring Stations in the Exploratory Studies Facility and in the Enhanced Characterization of the Repository Block Cross-Drift. 6-184

6-25. Water-Potential Measurements in the Exploratory Studies Facility and in the Enhanced Characterization of the Repository Block Cross-Drift. 6-186

6-26. Saturation Measurements in the Exploratory Studies Facility and in the Enhanced Characterization of the Repository Block Cross-Drift. 


\section{TABLES (Continued)}

Page

6-27. Rock Unit Contacts Intersected by the Bulkhead Sections (All within the Topopah Spring Tuff)

6-28. Chemical and Isotopic Data for Liquid Samples Collected in the ECRB Cross-Drift 6-216

6-29. Air-Permeability Values for the Three Zones in Borehole LA\#2 $6-228$

6-30. Alcove 1 Infiltration Test Data 6-288

6-31. Tracer $\mathrm{C}_{\mathrm{o}}$ Values for Phase 1B Injection 6-298

6-32. Summary of Concentrations Used for Phase 1 Injections 6-298

6-33. Summary of Concentrations Used for Phase 2A Injections 6-299

6-34. Summary of Concentrations Used for Phase 2B Injections. 6-300

6-35. Summary of Concentrations Used for Phase $2 \mathrm{C}$ Injections. 6-300

6-36. Phase 1A Samples Taken from the 90-cm Mineback Face at Borehole 3 6-303

6-37. Summary of Statistical Parameters of the Analyses of Pore Water from Topopah Spring Tuff (TSw)

6-38. Mean Composition of the Crystal-Poor Member of the Topopah Spring Tuff in the ECRB Cross-Drift

6-39. Mean Trace Element Concentrations of the Phenocryst-Poor Member of the Topopah Spring Tuff in the ECRB Cross-Drift.

6-40. Mean Normative Mineral Contents of the Phenocryst-Poor Rhyolite Member of the Topopah Spring Tuff in the ECRB Cross-Drift

6-41. Comparison of Chlorine-36 $\left({ }^{36} \mathrm{Cl}\right)$ Validation Study Results with Other ${ }^{36} \mathrm{Cl}$ Results

6-42. Tritium Activities Found in Samples from Locations in the ESF and ECRB

6-43. Microstratigraphic Depth, Date, and Initial ${ }^{234} \mathrm{U} /{ }^{238} \mathrm{U}$ Activity Ratios for Sample HD2074 Opal as Determined by Ion Probe...

6-44. Uranium and Thorium Isotopic Results from Sample HD2074 Opal Hemispheres.... 6-364

6-45. Uranium and Thorium Concentrations and ${ }^{234} \mathrm{U}^{230} \mathrm{Th}^{238} \mathrm{U}^{232} \mathrm{Th}$ Isotopic Compositions for Whole Rock-Samples from the ECRB Cross-Drift and ESF. $6-368$

7-1. Output DTNs from This Report............................................................................. 7-9

B-1. Computation of Aspect Ratio (Depth to Lateral Distance).............................................

B-2. Computation of Distance from Borehole to Niche Ceiling at Niche 4 (Niche 4788) Based on Niche-Study Data

B-3a. Computation of Liquid Release Flux for Post-Excavation Seepage Tests at Niche 3 (Niche 3107) Based on Niche-Study Data.

B-3b. Computation of Liquid Release Flux for Post-Excavation Seepage Tests at Niche 4 (Niche 4788) Based on Niche-Study Data.

B-4. Summary of Regression Equations and Computation of Seepage Threshold Fluxes $\left(\mathrm{K}_{0} *\right)$ and Saturated Hydraulic Conductivities $\left(\mathrm{K}_{1}\right)$ Based on NicheStudy Data.

B-4a. Data Used in Linear Regression Analysis ( $\mathrm{y}^{\prime}$ vs. $\ln \mathrm{q}_{\mathrm{s}}$ ) ...............................................

B-4b. Linear Regression Summary (Output) for Niche 3 (Niche 3107) UM 4.88-5.18.............B-9 


\section{TABLES (Continued)}

Page

B-4c. Linear Regression Summary (Output) for Niche 4 (Niche 4788) UL 7.62-7.93 ..............B-9

B-4d. Linear Regression Summary (Output) for Niche 4 (Niche 4788) UM 6.10-6.40...........B-10

B-4e. Linear Regression Summary (Output) for Niche 4 (Niche 4788) UR 5.18-5.48............B-10

B-5. Computation of $\alpha$-Values Based on Niche-Study Data ............................................. B-11

B-6. Computed Values of Seepage Threshold Values..........................................................

B-7. Computation of Estimated Water Potentials Based on Niche-Study Data .....................B-14

B-8. Computation of Estimated Water Content Change Based on Niche-Study Data ...........B-15

C-1. Source of Data for Post-Excavation Seepage Tests at Niche 5 (Niche CD 1620)............-8

D-1. Time to Steady-State Moisture Conditions …………………………………......... D-7

H-1. Mineralogy of the Busted Butte Phase 2 Test Block (weight percent) .......................... H-10

H-2. Calico Hills Formation Lithostratigraphy ……….................................................... H-15

H-3. Hydrologic Properties of Calico Hills Formation, Busted Butte ................................. H-17

H-4. Porosity Data for the Calico Hills Formation in USW SD-12 ................................... H-18

H-5. Porosity and Permeability Data for the Calico Hills Formation in USW SD-7 7........... H-20

H-6. Hydrogeologic Properties of Busted Butte Units....................................................... H-20

I-1. Calculation Spreadsheet for Permeability (Output) from Input in DTN：LB0011AIRKTEST.001 ...........................................................................

I-2. Calculation Excel Spreadsheet for Output in Table 6-44 and Figure 6-209...................... I-6

I-3. Calculation Excel Spreadsheet for Output in Figure 6-42 …………….......................... I-7

I-4. Calculation Excel Spreadsheet for Output in Figure 6-131(b) ...................................... I-8

I-5. Calculation Excel Spreadsheet for Output in Figure 6-141 ......................................... I-9

I-6. Calculation Excel Spreadsheet for Output in Figure 6-142 …..................................... I-10

I-7. Calculation Excel Spreadsheet for Output in Figure 6-143 ......................................... I-11

I-8. Calculation Excel Spreadsheet for Output in Figure 6-144 ........................................... I-12

I-9. Calculation Excel Spreadsheet for Output in Figure 6-145 ............................................ I-13

I-10. Calculation Excel Spreadsheet for Output in Figure 6-146 ............................................ I-14

I-11a. Date of First Response in Borehole 1 .................................................................. I-15

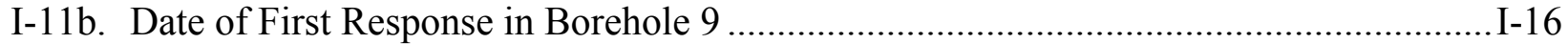

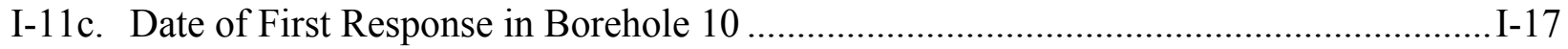

I-12. Wetting-Front Velocity Calculated for Locations along Boreholes 1, 9, and 10 ............ I-18

I-13. Rock Composition Analyses of Duplicated Measurements and Trace Element Conversion 


\section{ACRONYMS AND ABBREVIATIONS}

1-D one-dimensional

2-D two-dimensional

3-D three-dimensional

AMS accelerator mass spectrometry

AR activity ratio

BBTF Busted Butte Test Facility

BST borehole sensor tray

CAMS Center for Accelerator Mass Spectrometry

CHn Calico Hills nonwelded

CHnv Calico Hills nonwelded vitric

CHnz Calico Hills nonwelded zeolitic

CR Condition Report

CS Construction Station (ESF main loop)

CWAT construction water

DFBA Difluorobenzoic Acid

DOE U.S. Department of Energy

DTN data tracking number

ECRB Enhanced Characterization of the Repository Block

ERP electrical resistivity probe

ERT electrical resistivity tomography

ESF Exploratory Studies Facility

FBA fluorobenzoic acid

FD\&C Federal Food, Drug, and Cosmetic Act

FEP feature, event, and process

FI fluid inclusion

FIA Fluid Inclusion Assemblages

FWP Field Work Package

ga geometric average

GPR ground penetrating radar

GUI Graphical User Interface

HPLC high-pressure liquid chromatography

HPZ high-permeability zone

IC Ion Chromatograph/Chromatography

IC P-MS inductively coupled plasma-mass spectrometry

ICP Inductively Coupled Plasma

ICP-AES Inductively Coupled Plasma-Atomic Emission Spectrometry

IMP ion microprobe 


\section{ACRONYMS AND ABBREVIATIONS (Continued)}

ka one thousand years (age)

LA license application

LANL Los Alamos National Laboratory

LBNL Lawrence Berkeley National Laboratory

LLNL Lawrence Livermore National Laboratory

LPZ low-permeability zone

M\&TE measuring and test equipment

$\mathrm{Ma}$ million years ago

MC moisture content

MFC mass flow controller(s)

MS mass spectrometry

NRC U.S. Nuclear Regulatory Commission

NTS Nevada Test Site

PA performance assessment

PC personal computer (specifically IBM compatible)

PFBA pentafluorobenzoic acid

PDWS passive-discrete water sampler

ppm parts per million

PRIME Purdue Rare Isotope Measurement Laboratory

PTn Paintbrush nonwelded Hydrogeologic Unit

PVC polyvinyl chloride

QA quality assurance

SCM Software Configuration Management

SDOM standard deviation of the mean

SITP Site Investigation Test Plan

SMOW standard mean ocean water

SR Site Recommendation

SZ saturated zone

TBM tunnel boring machine

TCw Tiva Canyon welded hydrogeological unit

TDMS Technical Data Management System

TDR time domain reflectrometry

$\mathrm{T}_{\mathrm{h}} \quad$ Homogenization Temperature

TIMS Thermal-Ionization Mass Spectrometry

Tptpll Topopah Spring lower lithophysal unit

Tptpln Topopah Spring lower nonlithophysal unit

Tptpmn Topopah Spring middle nonlithophysal unit

Tptpul Topopah Spring upper lithophysal unit 


\section{ACRONYMS AND ABBREVIATIONS (Continued)}

TSPA Total System Performance Assessment

TSw

Topopah Spring welded hydrogeologic unit

TU tritium unit(s)

TWP technical work plan

USGS U.S. Geological Survey

UV

ultraviolet

$\mathrm{UZ}$

unsaturated zone

UZTT Unsaturated Zone Transport Test

Vis visible

VS Validation Study

YMP Yucca Mountain Project

YMRP Yucca Mountain Review Plan 


\section{INTENTIONALLY LEFT BLANK}




\section{PURPOSE}

The purpose of this scientific analysis report is to update and document the data and subsequent analyses from ambient field-testing activities performed in underground drifts and surface-based boreholes through unsaturated zone (UZ) tuff rock units. In situ testing, monitoring, and associated laboratory studies are conducted to directly assess and evaluate the waste emplacement environment and the natural barriers to radionuclide transport at Yucca Mountain. This scientific analysis report supports and provides data to UZ flow and transport model reports, which in turn contribute to the Total System Performance Assessment (TSPA) of Yucca Mountain, an important document for the license application (LA). The objectives of ambient field-testing activities are described in Section 1.1.

This report is the third revision (REV 03), which supercedes REV 02. The scientific analysis of data for inputs to model calibration and validation as documented in REV 02 were developed in accordance with the Technical Work Plan (TWP) Technical Work Plan for: Performance Assessment Unsaturated Zone (BSC 2004 [DIRS 167969]). This revision was developed in accordance with the Technical Work Plan for: Unsaturated Zone Flow Analysis and Model Report Integration (BSC 2004 [DIRS 169654], Section 1.2.4) for better integrated, consistent, transparent, traceable, and more complete documentation in this scientific analysis report and associated UZ flow and transport model reports. No additional testing or analyses were performed as part of this revision. The list of relevant acceptance criteria is provided by Technical Work Plan for: Unsaturated Zone Flow Analysis and Model Report Integration (BSC 2004 [DIRS 169654]), Table 3-1. Additional deviations from the TWP regarding the features, events, and processes (FEPs) list are discussed in Section 1.3.

Documentation in this report includes descriptions of how, and under what conditions, the tests were conducted. The descriptions and analyses provide data useful for refining and confirming the understanding of flow, drift seepage, and transport processes in the UZ. The UZ testing activities included measurement of permeability distribution, quantification of the seepage of water into the drifts, evaluation of fracture-matrix interaction, study of flow along faults, testing of flow and transport between drifts, characterization of hydrologic heterogeneity along drifts, estimation of drying effects on the rock surrounding the drifts due to ventilation, monitoring of moisture conditions in open and sealed drifts, and determination of the degree of minimum construction water migration below drift. These field tests were conducted in two underground drifts at Yucca Mountain, the Exploratory Studies Facility (ESF) drift, and the cross-drift for Enhanced Characterization of the Repository Block (ECRB), as described in Section 1.2. Samples collected in boreholes and underground drifts have been used for additional hydrochemical and isotopic analyses for additional understanding of the UZ setting. The UZ transport tests conducted at the nearby Busted Butte site (see Figure 1-4) are also described in this scientific analysis report.

In general, the results discussed in this report are from studies conducted using one or a combination of the following three testing approaches: (1) air-injection tests, (2) liquid-release tests, and (3) moisture monitoring. The air-injection tests quantify the spatial variability (heterogeneity) of permeability. The liquid-release tests provide an evaluation of in situ fracture flow and the competing processes of matrix imbibition. In addition to active testing, sensors in boreholes and along drifts are used to monitor the in situ and perturbed conditions, evaluating the 
impact of excavation, ventilation, and construction-water usage on the surrounding rocks. The field studies are supplemented by laboratory testing. Table 1-1 summarizes common testing approaches used in different (main) testing activities. The testing activities are analyzed in Section 6. Table 1-1 provides cross-referencing for comparisons of the same types of data from various tests.

Table 1-1. Approaches and Main Activities in In Situ Field Testing of Processes

\begin{tabular}{|c|c|}
\hline Testing Approaches & Testing Activities \\
\hline Air injection tests along boreholes & $\begin{array}{l}\text { Air-permeability distributions and excavation-induced } \\
\text { enhancements (Section 6.1) } \\
\text { Cross-hole connectivity (Section 6.5) } \\
\text { Systematic hydrologic characterization (Section 6.11) }\end{array}$ \\
\hline Liquid release tests from borehole intervals & $\begin{array}{l}\text { Seepage into drift (Section 6.2) } \\
\text { Tracer-migration delineation (Section 6.3) } \\
\text { Fracture-matrix interaction (Section 6.6) } \\
\text { Fault and matrix flow (Section 6.7) } \\
\text { Systematic hydrologic characterization (Section 6.11) } \\
\text { Drift-to-drift flow and transport (Section 6.12) } \\
\text { Busted Butte transport test (Section 6.13) }\end{array}$ \\
\hline $\begin{array}{l}\text { Moisture monitoring (relative humidity, } \\
\text { temperature) and evaporation measurements }\end{array}$ & $\begin{array}{l}\text { Seepage into drift (Section 6.2) } \\
\text { Moisture monitoring and bulkhead study (Section 6.10) } \\
\text { Systematic hydrologic characterization (Section 6.11) }\end{array}$ \\
\hline $\begin{array}{l}\text { Wetting front monitoring and potential } \\
\text { measurements }\end{array}$ & $\begin{array}{l}\text { Fracture-matrix interaction (Section 6.6) } \\
\text { Fault and matrix flow (Section 6.7) } \\
\text { Construction water migration (Section 6.9) } \\
\text { Drift-to-drift flow and transport (Section 6.12) }\end{array}$ \\
\hline $\begin{array}{l}\text { Laboratory hydrological measurements of rock } \\
\text { and water samples }\end{array}$ & $\begin{array}{l}\text { Tracer penetration and water imbibition (Section 6.4) } \\
\text { Systematic hydrologic characterization (Section 6.11) } \\
\text { Busted Butte transport test (Section 6.13) }\end{array}$ \\
\hline $\begin{array}{l}\text { Laboratory hydrochemical measurements of } \\
\text { rock and water samples }\end{array}$ & $\begin{array}{l}\text { Tracer-migration delineation (Section 6.3) } \\
\text { Tracer penetration and water imbibition (Section 6.4) } \\
\text { Fracture-matrix interaction (Section 6.6) } \\
\text { Construction water migration (Section 6.9) } \\
\text { Moisture monitoring and bulkhead study (Section 6.10) } \\
\text { Busted Butte transport test (Section 6.13) } \\
\text { Geochemical and isotopic observations (Section 6.14) }\end{array}$ \\
\hline $\begin{array}{l}\text { Laboratory isotopic measurements of rock and } \\
\text { water samples }\end{array}$ & $\begin{array}{l}\text { Moisture monitoring and bulkhead study (Section 6.10) } \\
\text { Geochemical and isotopic observations (Section 6.14) }\end{array}$ \\
\hline
\end{tabular}


This scientific analysis report focuses on the results of the tests. For information as documented in the TWP (BSC 2004 [DIRS 167969]), the overall planning documents for field tests and data collection include the following field work packages (FWPs):

- Moisture Studies in the ESF (YMP 2002 [DIRS 160262]), FWP-ESF-96-004

- UZ Transport Test at Busted Butte (YMP 2001 [DIRS 171430]), FWP-ESF-97-002

- Field Test Data Collection System (YMP 2000 [DIRS 161209]), FWP-ESF-96-001.

The specific site investigation test plans (SITPs) include:

- Moisture Monitoring in the ECRB Bulkhead Cross-Drift (BSC 2001 [DIRS 158187]), SITP-02-UZ-001

- Niche 5 Seepage Testing (BSC 2001 [DIRS 158200]), SITP-02-UZ-002

- Alcove 8 Flow and Seepage Testing (BSC 2002 [DIRS 157606]), SITP-02-UZ-003

- Systematic Hydrological Characterization (BSC 2001 [DIRS 158202]), SITP-02-UZ-004

- ${ }^{36} \mathrm{Cl}$ Validation (USGS 2002 [DIRS 158196]), SITP-02-UZ-005

- Busted Butte Transport Testing (BSC 2002 [DIRS 158459]), SITP-02-UZ-006,

- UZ Hydrochemistry Investigations (USGS 2002 [DIRS 158194]), SITP-02-UZ-007

- Moisture Monitoring Investigations and Alcove 7 Studies (BSC 2002 [DIRS 158189]), SITP-02-UZ-010.

The tests are used to enhance understanding of UZ flow, seepage, and transport processes. The observations and measurements in underground drifts contribute to characterization of hydrologic and geochemical features. The support provided (by this report) to the discussion of features, events and processes (FEPs) is summarized in Section 1.3, and discussed in detail in Section 6 . The data collected in UZ tests contribute to model verification and validation.

The following reports provide indirect input to this report:

- Yucca Mountain Site Description (BSC 2004 [DIRS 169734])

- Geologic Framework Model (GFM2000) (BSC 2004 [DIRS 170029]).

The following analysis and model reports use the data collected by ambient field-testing activities summarized in this report (either by direct citation or by use of an output DTN):

- Seepage Calibration Model and Seepage Testing Data

- In-Drift Natural Convection and Condensation

- Conceptual Model and Numerical Approaches for UZ Flow and Transport

- Mountain-Scale Coupled Processes (TH/THC/THM)

- Analysis of Hydrogeologic Properties Data

- Calibrated Properties Model

- Abstraction of Drift Seepage

- Radionuclide Transport Models under Ambient Conditions

- Drift-Scale Coupled Processes (DST and TH Seepage) Models 
- Drift Scale THM Model

- Features, Events, and Processes in UZ Flow and Transport.

The interrelationships of this scientific analysis report with specific model reports beyond direct use of the data are discussed in Section 6 and summarized in Section 7. The output data from this scientific analysis report are also described in Section 7.

\subsection{OBJECTIVES AND PROCESSES ANALYZED BY THE AMBIENT FIELD TESTING ACTIVITIES}

The field-test findings and their implications for drift seepage, fracture flow, matrix imbibition, moisture evolution, and radionuclide transport can be used to address performance assessment (PA) uncertainties and repository design issues. The UZ site-scale models and the drift-scale models require field data for partitioning UZ flux into a fast fracture-flow component and a slow matrix-flow component. This partitioning is controlled by fracture-matrix interaction. The damping of infiltration pulses and diversion by the Paintbrush nonwelded tuff unit (PTn) above the Topopah Spring welded hydrogeologic unit (TSw) are potential mechanisms for infiltration and percolation flux redistribution. In the vicinity of the repository, perturbations by drift excavation, air ventilation, and water usage can change the hydrologic regime in the UZ. Retardation by sorption on the rock matrix and dispersion through fractures are processes affecting the migration of tracers and the dilution of radionuclides in the UZ below the drifts. Some of these processes and related uncertainties, issues, and concerns are addressed by the ambient testing program at underground test sites at Yucca Mountain, and are documented in Section 6. The data uncertainties are integral parts of overall uncertainties in the understanding of processes and in constraining model assessments. Variabilities and uncertainties in both field and laboratory data are presented for cases with sufficient data to be amenable for statistical analyses.

\subsection{LOCATIONS OF TEST SITES}

The repository will be located in the TSw upper lithophysal (Tptpul), the middle nonlithophysal (Tptpmn), the lower lithophysal (Tptpll), and the lower nonlithophysal (Tptpln) units (stratigraphic nomenclature from Proposed Stratigraphic Nomenclature and Macroscopic Identification of Lithostratigraphic Units of the Paintbrush Group Exposed at Yucca Mountain, Nevada) (Buesch et al. 1996 [DIRS 100106], pp. 5-8, Table 2)). The test sites sample all of these hydrogeologic units. As shown in Figure 1-1, the ESF penetrates and provides access to Tptpul, Tptpmn, as well as other units that overlie the repository horizon. The ECRB provides accesses to all four hydrogeologic units to be encountered by the repository. Approximately 80 percent of the repository would be constructed within the Tptpll zone (BSC 2004 [DIRS 168489], Appendix $\mathrm{H}$ for area fractions: Tptpul: 4.5 percent, Tptpmn: 12.4 percent, Tptpll: 80.5 percent, Tptpln: 2.6 percent).

Below the TSw lies the Calico Hills tuff (CHn) unit, which is not accessible by either the ESF main drift or the ECRB cross-drift. The CHn unit is exposed at Busted Butte, $8 \mathrm{~km}$ southeast of the repository area. This Busted Butte outcrop is the site of the Unsaturated Zone Transport Test (UZTT), which is described in Section 6.13. 
Figure 1-2 illustrates the locations of four alcoves (Alcoves 1, 2, 3, and 4) along the north ramp, and three alcoves (Alcoves 5, 6, and 7) and four niches (Niches 3107, 3566, 3650, and 4788) along the main drift of the ESF. The numerical identification for each niche denotes the distance, in meters, from the North Portal. These niches are also referred to as Niches 1, 2, 3, and 4 , in accordance to the time sequence of excavation (so that Niche $1=$ Niche 3566, Niche $2=$ Niche 3650, Niche $3=$ Niche 3107, and Niche $4=$ Niche 4788, along the ESF main drift). The ECRB cross-drift branches out from the ESF north ramp, crosses over the main drift near Niche 3 (Niche 3107), and reaches the western boundary of the repository block, as illustrated in Figure 1-3.

Many emplacement drifts will be in the lower tuff units. The lower units Tptpll and Tptpln have hydrologic characteristics different from Tptpmn, with spatially variable lithophysal cavity and fracture densities affecting the amount of seepage and fracture-matrix flow partition. A systematic study with transient air injection and pulse liquid release along four boreholes drilled into the crown of the ECRB cross-drift has been conducted to evaluate spatial heterogeneity effects. One alcove (Alcove 8) in Tptpul and one niche (Niche CD 1620 or Niche 5, with CD denoting ECRB cross-drift) in Tptpll have been excavated in the ECRB cross-drift. Note that Alcove 8 in the ECRB cross-drift (illustrated in Figure 1-1) is located directly (approximately $20 \mathrm{~m}$ ) above Niche 3 (Niche 3107) in the ESF main drift (illustrated in Figure 1-2).

The ECRB cross-drift penetrates the Yucca Mountain block and crosses the Solitario Canyon fault. The ECRB cross-drift has four bulkheads, as illustrated in Figure 1-1, to hydrologically isolate particular sections of the cross-drift, such as the section that contains the fault. Figure 1-4 provides a panoramic view of the Yucca Mountain ridge, with Solitario Canyon in the foreground and Busted Butte in the background to the southeast of the repository block.

Table 1-2 summarizes the testing activities at different test sites with various measurements. The details of testing techniques are described in Section 6. Table 1-2 is for cross-referencing of similar testing approaches applied to different sites and different sections of this document. 


\begin{tabular}{|c|c|c|c|c|c|c|c|c|c|c|c|c|c|c|c|}
\hline \multirow{4}{*}{$\begin{array}{l}\text { Testing } \\
\text { Activity } \\
\text { Described in } \\
\text { Indicated } \\
\text { Section(s) of } \\
\text { this Report }\end{array}$} & \multicolumn{15}{|c|}{ Section(s) of this Report } \\
\hline & \multirow{2}{*}{\multicolumn{5}{|c|}{ Alcove }} & \multicolumn{5}{|c|}{ Niche } & \multicolumn{5}{|c|}{ Drift } \\
\hline & & & & & & \multirow{2}{*}{$\begin{array}{c}3566 \\
(1) \\
\end{array}$} & \multirow{2}{*}{$\begin{array}{c}3650 \\
(2)\end{array}$} & \multirow{2}{*}{$\begin{array}{c}3107 \\
(3) \\
\end{array}$} & \multirow{2}{*}{$\begin{array}{r}4788 \\
(4)\end{array}$} & \multirow{2}{*}{$\begin{array}{c}\text { CD } 1620 \\
(5) \\
\end{array}$} & \multicolumn{3}{|c|}{ ESF } & \multirow[b]{2}{*}{ ECRB } & \multirow[b]{2}{*}{$\begin{array}{c}\text { Busted } \\
\text { Butte }\end{array}$} \\
\hline & 1 & 4 & 6 & 7 & 8 & & & & & & $\begin{array}{l}\text { North } \\
\text { Ramp }\end{array}$ & $\begin{array}{l}\text { Main } \\
\text { Drift }\end{array}$ & $\begin{array}{l}\text { South } \\
\text { Ramp }\end{array}$ & & \\
\hline $\begin{array}{l}\text { Air- } \\
\text { Permeability }\end{array}$ & 6.12 .5 & 6.5 .2 & \begin{tabular}{l|}
6.5 .2 \\
6.6 .1
\end{tabular} & & 6.1 .2 & 6.1 .2 & 6.1 .2 & 6.1 .2 & $\begin{array}{l}6.1 .2 \\
6.5 .2\end{array}$ & 6.1 .2 & - & - & - & 6.11 .2 & 6.13 .5 \\
\hline $\begin{array}{l}\text { Liquid } \\
\text { Observation }\end{array}$ & - & - & - & - & - & 6.2 .1 & - & - & - & - & - & - & - & 6.10 .2 & - \\
\hline $\begin{array}{l}\text { Dyed Flow } \\
\text { Path }\end{array}$ & - & - & - & - & - & 6.2 .1 & 6.2 .1 & 6.2 .1 & 6.2 .1 & - & - & - & - & - & 6.13 .2 \\
\hline \begin{tabular}{|l|} 
Seepage \\
Threshold \\
\end{tabular} & 6.12 .5 & - & - & - & - & - & 6.2 .1 & 6.2 .1 & 6.2 .1 & 6.2 .1 & - & - & - & 6.11 .2 & - \\
\hline Liquid Release & 6.12 .5 & 6.7 .2 & 6.6 .2 & - & 6.12 .2 & - & $\begin{array}{c}6.2 .1 \\
6.3 \\
\end{array}$ & 6.2 .1 & 6.2 .1 & 6.2 .1 & - & - & - & 6.11 .2 & 6.13 .3 \\
\hline \begin{tabular}{|l} 
Evaporation \\
Measurement
\end{tabular} & - & - & - & - & - & - & - & 6.2 .1 & 6.2 .1 & 6.2 .1 & - & - & - & 6.11 .2 & - \\
\hline \begin{tabular}{|l|} 
Wetting \\
Front/Potential \\
\end{tabular} & - & 6.7 .2 & 6.6 .2 & - & - & 6.8 & - & 6.12 .2 & - & - & 6.10 .1 & 6.9 .2 & 6.10 .1 & $\begin{array}{c}6.9 .2 \\
6.10 .1 \\
\end{array}$ & - \\
\hline \begin{tabular}{|l} 
Moisture \\
Monitoring \\
\end{tabular} & - & - & - & - & - & 6.10 .1 & - & 6.2 .1 & 6.2 .1 & 6.2 .1 & 6.10 .1 & 6.10 .1 & 6.10 .1 & 6.10 .2 & - \\
\hline $\begin{array}{l}\text { Geophysical } \\
\text { Tomography }\end{array}$ & - & - & - & - & 6.12.3. & - & - & 6.12 .3 & - & - & - & - & - & - & 6.13 .4 \\
\hline Lab Hydrology & - & - & 6.10 .1 & 6.10 .1 & - & 6.10 .1 & $\begin{array}{c}6.4 \\
6.10 .1 \\
\end{array}$ & & 6.4 .1 & - & - & - & - & $\begin{array}{l}6.10 .1 \\
6.11 .3 \\
\end{array}$ & 6.13 \\
\hline $\begin{array}{l}\text { Tracer } \\
\text { Analysis }\end{array}$ & - & - & - & - & - & - & $\begin{array}{l}6.3 \\
6.4 \\
\end{array}$ & 6.12 .2 & 6.4 & - & - & - & - & - & 6.13 \\
\hline Geochemistry & - & - & 6.14 .2 & 6.14 .2 & - & - & - & - & - & - & 6.14 & $\begin{array}{c}6.10 .1 \\
6.14 \\
\end{array}$ & $\begin{array}{c}6.10 .1 \\
6.14 \\
\end{array}$ & $\begin{array}{l}6.10 \\
6.14 \\
\end{array}$ & - \\
\hline $\begin{array}{l}\text { Isotopic } \\
\text { Analysis }\end{array}$ & - & - & 6.14 .2 & 6.14 .2 & - & 6.14 .2 & - & - & - & - & 6.14 & 6.14 & 6.14 & $\begin{array}{c}6.10 .3 \\
6.14 \\
\end{array}$ & - \\
\hline
\end{tabular}


(a)

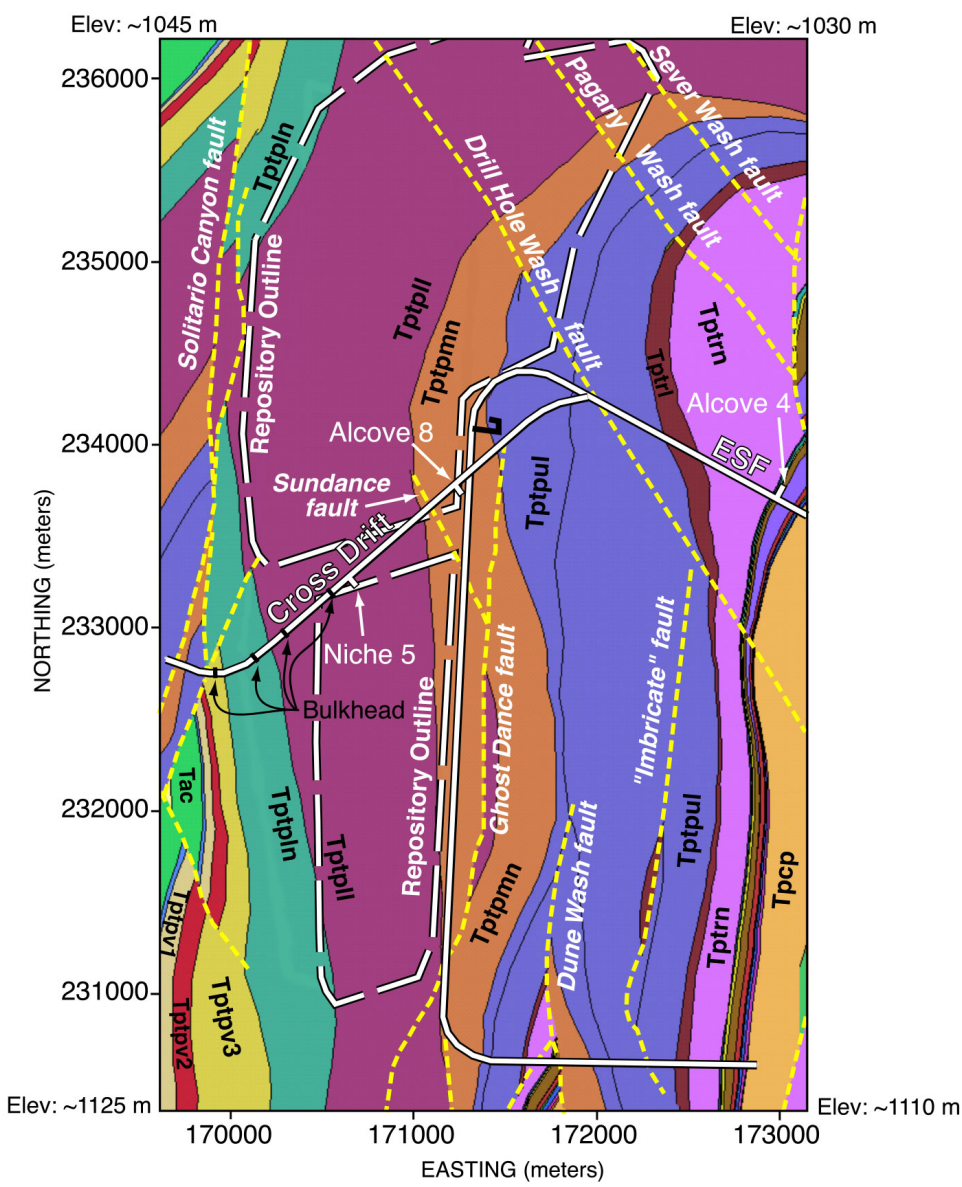

(b)

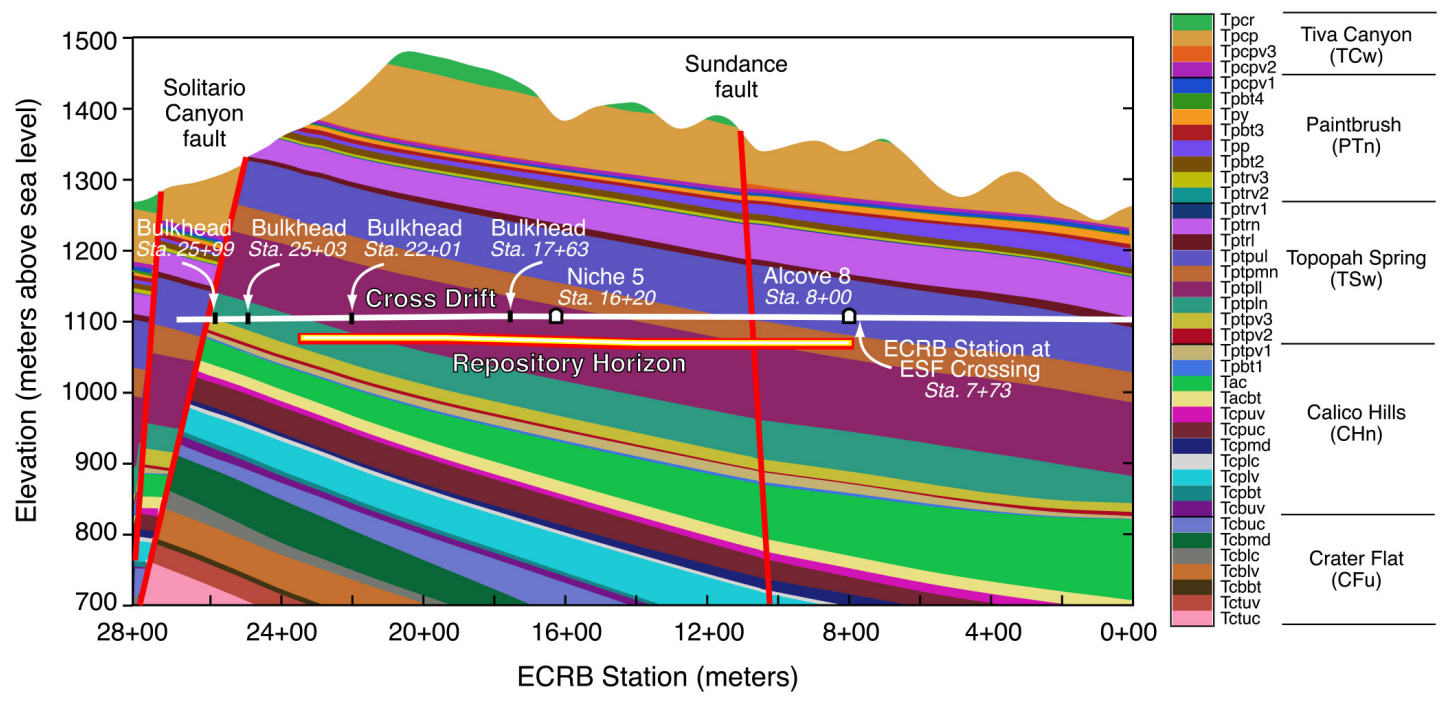

NOTE: The vertical cross section in Panel $b$ of Figure 1-1 is along the ECRB cross-drift in nominally the northeast to southwest direction.

Figure 1-1. Schematic Illustration of Spatial Distribution of Hydrogeologic Units Intersected by the Repository Horizon (Tptpul, Tptpmn, Tptpll, and Tptpln) 


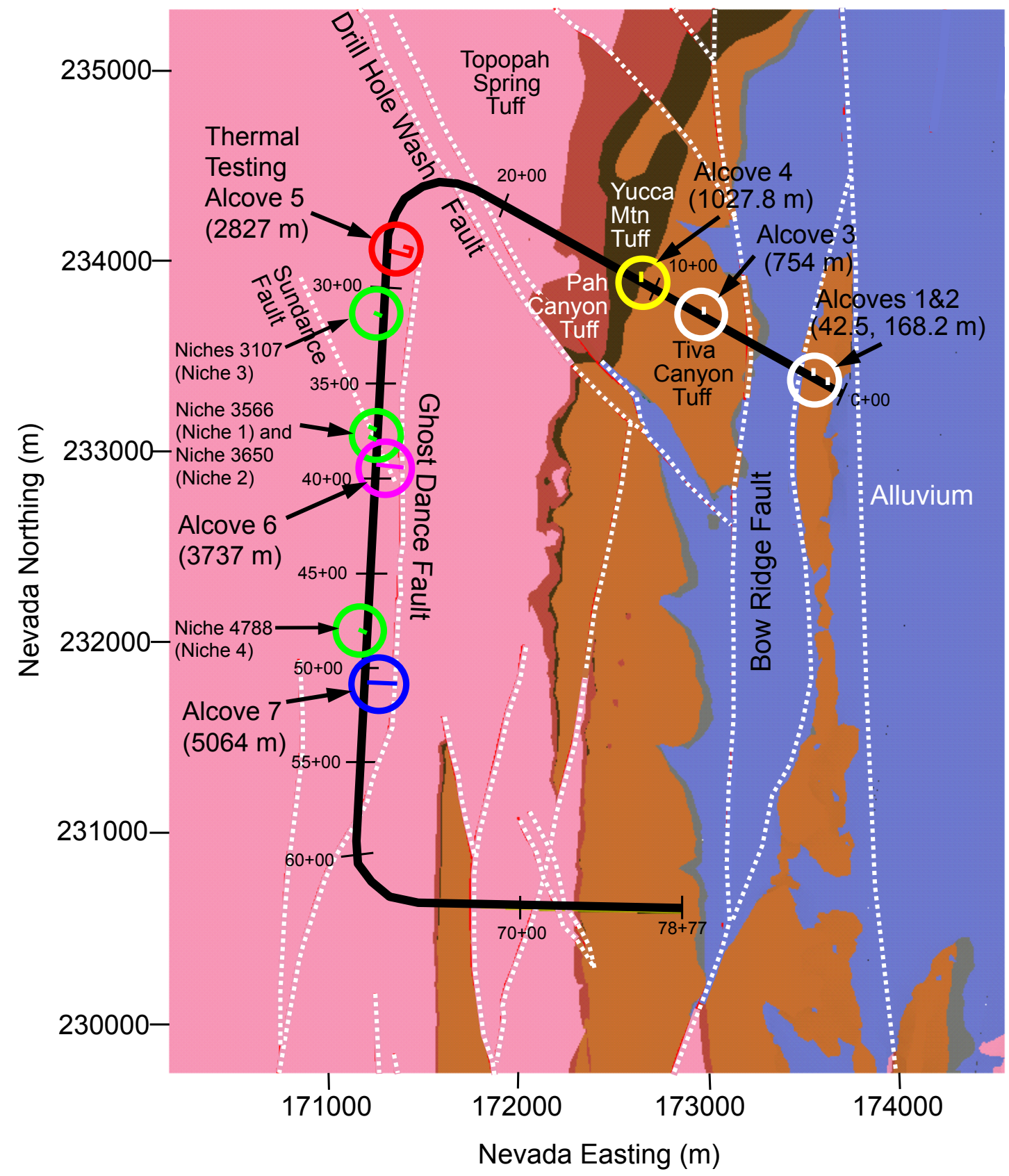

Figure 1-2. Schematic Illustration of Alcove and Niche Locations in the Exploratory Studies Facility at Yucca Mountain 


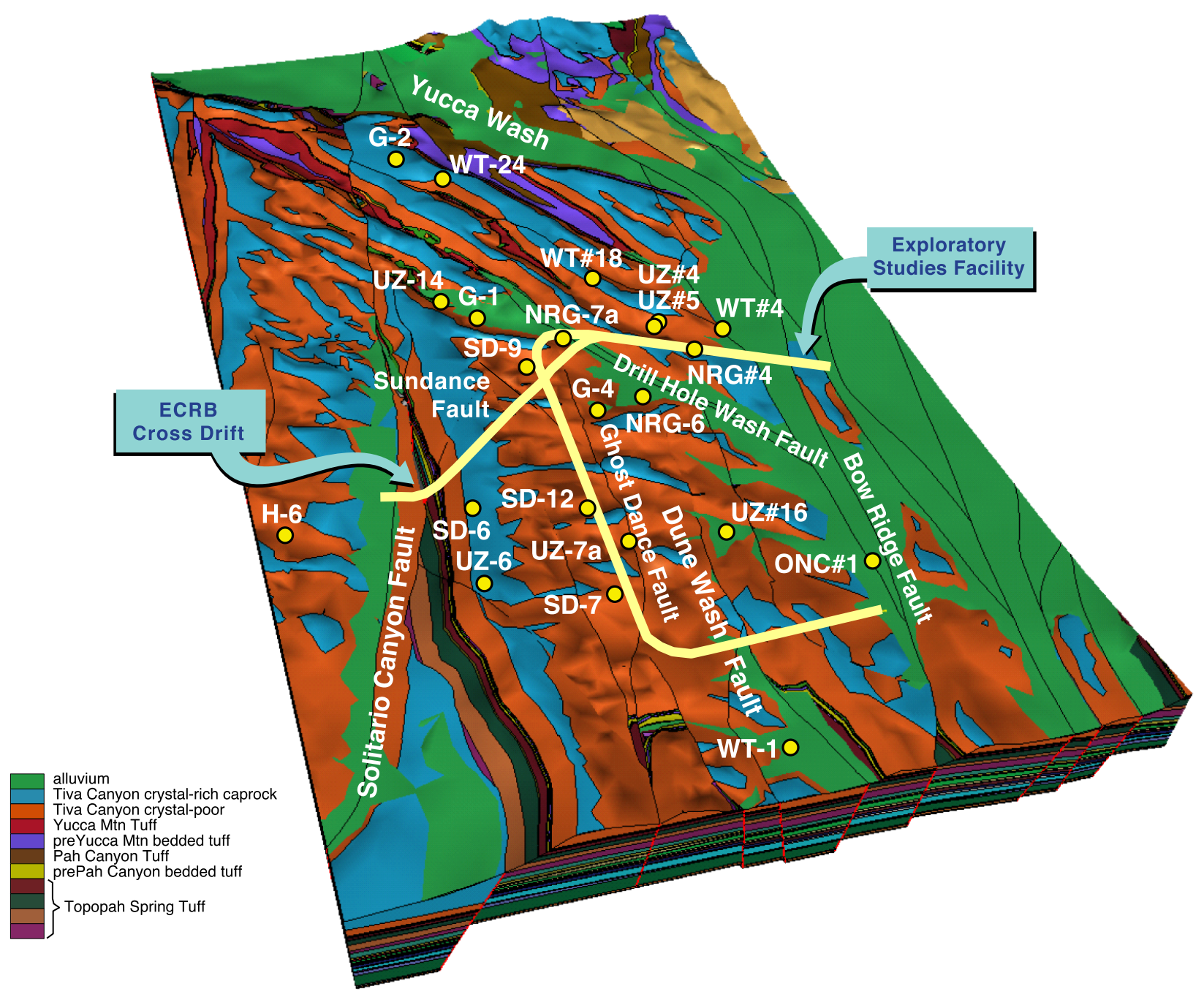

NOTE: The ECRB cross-drift branches out from the north ramp of the ESF, crosses over the main drift, and accesses the western fault boundary of the repository block at Yucca Mountain. Alcoves and niches are illustrated in Figure 1-2 for the ESF and in Figure 1-1 for the ECRB cross-drift.

Figure 1-3. Schematic Illustration of the ESF and ECRB Cross-Drift 


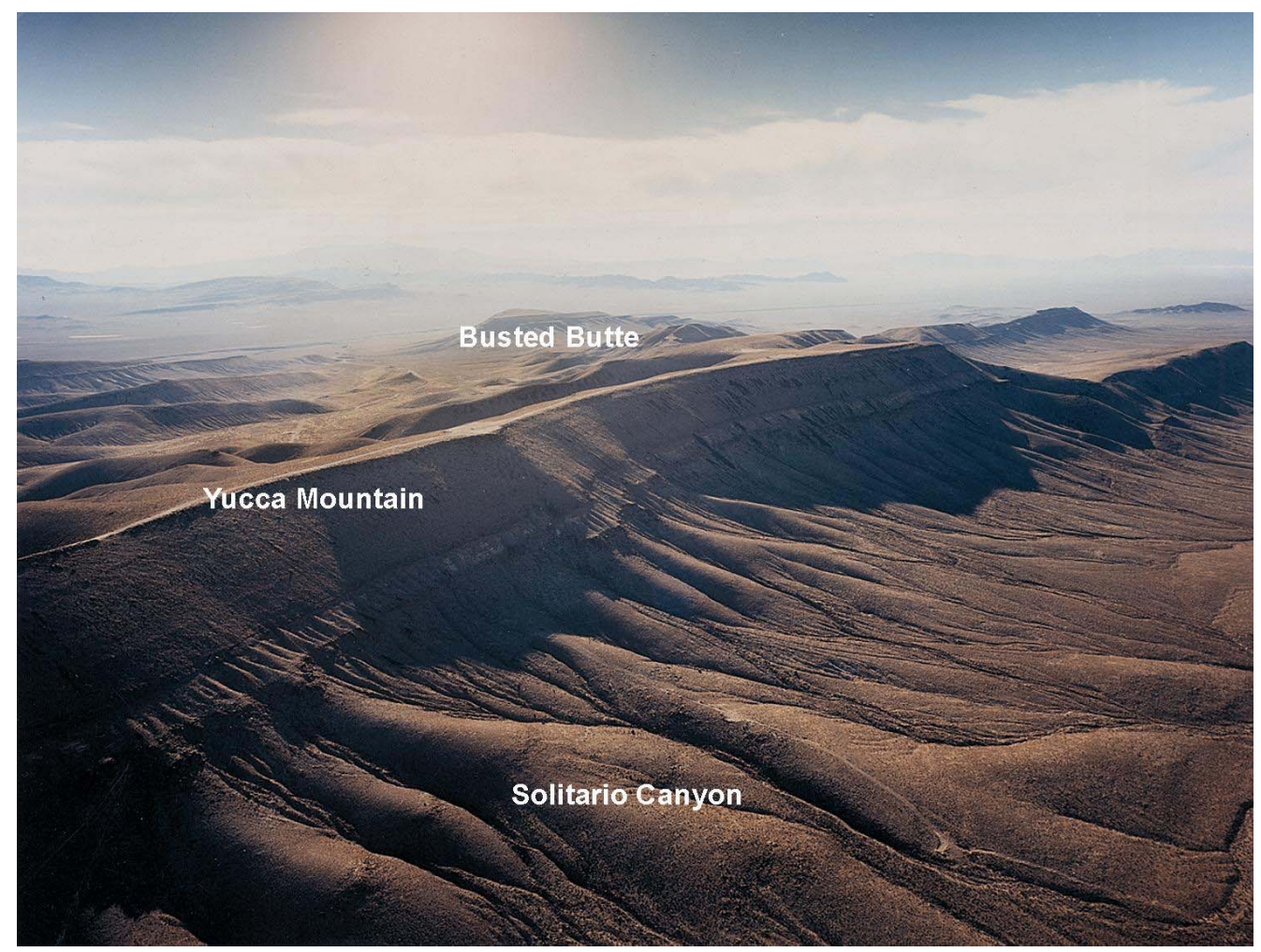

Figure 1-4. Photo of Yucca Mountain Ridge and Busted Butte, Taken from the Northwest across the Solitario Canyon Fault

\subsection{SUPPORT TO FEP ANALYSIS AND TECHNICAL ISSUE RESOLUTION}

This scientific analysis report provides summaries of data, part of which are used in modeling and abstraction reports (as listed in Section 7), and to support the FEPs analysis. Table 1-3 contains a list of selected FEPs taken from the LA FEP List (DTN: MO0407SEPFEPLA.000 [DIRS 170760]) that are associated with the subject matter of this report. This list deviates from the list in the TWP (BSC 2004 [DIRS 169654], Table 2.1.5-1) as follows: FEP 2.2.07.15.0B is an excluded FEP and thus is not discussed in Table 1-3; FEPs 1.2.02.02.0A, 2.2.08.01.0B, 2.2.08.08.0B, 2.2.08.09.0B, 2.2.08.10.0B, and 2.2.09.01.0B are not discussed in Table 1-3 because they do not directly impact the TSPA-LA treatment (i.e., they are included through other analysis or model reports). FEP 2.2.07.02.0A is included in Table 1-3 because the data presented in this analysis report impact the TSPA-LA treatment of this FEP.

This analysis report provides part of the basis for the treatment of FEPs as discussed in the report Features, Events, and Processes in UZ Flow and Transport (BSC 2004 [DIRS 170012]). The UZ FEP report, together with other UZ model reports listed in Section 1, are downstream reports of this scientific analysis report. These downstream reports (rather than this report itself) provide direct inputs to address issues discussed in Total System Performance Assessment-License Application Methods and Approach (BSC 2002 [DIRS 160146], Section 3.2.2). The cross-reference for each FEP to the relevant sections of this report, is given in Table 1-3. 
Table 1-3. Features, Events, and Processes Addressed in this Scientific Analysis Report

\begin{tabular}{|c|l|l|}
\hline LA FEP Number & \multicolumn{1}{|c|}{ FEP Name } & Relevant Section(s) of This Report \\
\hline $1.2 .02 .01 .0 \mathrm{~A}$ & Fractures & Sections 6.1,6.2, 6.6, and 6.9 \\
\hline $2.2 .01 .01 .0 \mathrm{~A}$ & $\begin{array}{l}\text { Mechanical effects of } \\
\text { excavation/construction in the near field }\end{array}$ & Section 6.1 \\
\hline $2.2 .07 .02 .0 \mathrm{~A}$ & $\begin{array}{l}\text { Unsaturated groundwater flow in the } \\
\text { geosphere }\end{array}$ & Sections 6.1 and 6.2 \\
\hline $2.2 .07 .08 .0 \mathrm{~A}$ & Fracture flow in the UZ & Sections $6.2,6.6$, and 6.9 \\
\hline $2.2 .07 .09 .0 \mathrm{~A}$ & Matrix imbibition in the UZ & Sections 6.4 and 6.7 \\
\hline $2.2 .07 .18 .0 \mathrm{~A}$ & Film flow into the repository & Section 6.2 \\
\hline $2.2 .07 .20 .0 \mathrm{~A}$ & Flow diversion around repository drifts & Sections 6.2 and 6.11 .3 \\
\hline $2.3 .11 .03 .0 \mathrm{~A}$ & Infiltration and recharge & Section 6.12 \\
\hline
\end{tabular}

NOTES: FEP = feature, event, and process; LA = license application; UZ = unsaturated zone.

This scientific analysis report also supports the resolutions of Key Technical Issues, including: ECRB moisture monitoring (Section 6.10); Alcove-8/Niche-3 (Niche 3107) testing (Section 6.11); flow through the Calico Hills nonwelded vitric (Section 6.13); and analogue radionuclide data from test blocks at Busted Butte (Section 6.13).

\subsection{CONSTRAINTS AND LIMITATIONS}

The field-testing activities and the associated analyses are subject to the constraints and limitations of spatial locations and temporal durations for tests conducted in the underground drifts. One niche, Niche 5 (Niche CD 1620), has been excavated in the Tptpll unit. Most of the other existing testing alcoves and niches in the ESF (shown in Figure 1-2) are located at or above the horizon of the Tptpmn unit. Test results and analyses from these sites provide data for the upper and middle tuff units. Some of the active flow tests were conducted within a few hours to a few days of each other because of limited accessibility to the test beds in the evenings and on weekends. Depending on system characteristics, the establishment of steady-state conditions can require longer tests. Some tests used automatic data acquisition systems for long-term monitoring and liquid releases, subject to power interruptions and equipment malfunctions. These constraints and limitations are addressed in the analyses of Section 6, if applicable. 
INTENTIONALLY LEFT BLANK 


\section{QUALITY ASSURANCE}

Development of this scientific analysis report has been determined to be subject to the Yucca Mountain Project quality assurance (QA) program as indicated in the Technical Work Plan for: Unsaturated Zone Flow Analysis and Model Report Integration, (BSC 2004 [DIRS 169654], Section 8.1). Approved QA procedures identified in the TWP (BSC 2004 [DIRS 169654], Section 4) have been used to conduct and document the activities described in this scientific analysis report. The governing procedure for the documentation of this report is AP-SIII.9Q, Analyses. The TWP also identifies the methods used to control the electronic management of data (BSC 2004 [DIRS 169654], Section 8.4) during the analysis and documentation activities.

This scientific analysis report provides data for UZ flow, drift seepage, and UZ transport in natural barriers that are classified in the Q-list (BSC 2004 [DIRS 168361]) as Safety Category because they are important to waste isolation, as defined in AP-2.22Q, Classification Analyses and Maintenance of the $Q$-List. The report contributes to the analyses and modeling data used to support PA. The conclusions of this scientific analysis report do not affect the repository design or engineered features important to safety, as defined in $\mathrm{AP}-2.22 \mathrm{Q}$. 
INTENTIONALLY LEFT BLANK 


\section{USE OF SOFTWARE}

The software used in this study is listed in Table 3-1. The qualified software was obtained from Software Configuration Management (SCM), is appropriate for its intended use, and is used only within the range of validation.

For data collection, only acquired software embedded as an integral part of the Measuring and Test Equipment (M\&TE) was utilized. The M\&TE software was controlled by AP-12.1Q, Control of Measuring and Test Equipment and Calibration Standards. Software developed or modified for data collection is discussed in the data document associated with each DTN and associated software management reports; the description and use of M\&TE software is not within the scope of this scientific analysis report.

Table 3-1. Software and Routines

\begin{tabular}{|c|c|c|c|}
\hline $\begin{array}{c}\text { Software Name and } \\
\text { Version }\end{array}$ & $\begin{array}{c}\text { Software Tracking } \\
\text { Number (STN) }\end{array}$ & $\begin{array}{c}\text { DIRS Reference } \\
\text { Number }\end{array}$ & $\begin{array}{c}\text { Platform and } \\
\text { Operating System }\end{array}$ \\
\hline ECRB-XYZ V.03 & $30093-V .03$ & 147402 & PC, Windows 98 \\
\hline
\end{tabular}

The software program ECRB-XYZ V.03 (CRWMS M\&O 1999 [DIRS 147402]) calculates the coordinates of a given ECRB station number; no other software or calculation method was considered because no software alternative is available for this project-specific task. No models were used for the analyses performed in this scientific analysis report.

Microsoft Excel 97, Microsoft Excel Version 7, Microsoft Excel 2002, EARTHVISION V4.0, CorelDRAW v11.633, Adobe Illustrator 10.0.3, Igor Pr 4.08, Photoshop 7.0.1, MacGPS Pro 4.0.3, DataDesk 6.2, and NOeSYS 2.0 were used for visual display or graphic representation of data. Simple calculations (such as the evaluation of mean and standard deviations) are documented in Appendix I of this scientific analysis report. The graphic software is exempt from software qualification per LP-SI.11Q-BSC, Software Management. 
INTENTIONALLY LEFT BLANK 


\section{INPUTS}

Field data collected from underground drifts that characterize ambient and in situ field-testing conditions include the following:

- Pneumatic pressure and air-permeability data (pre- and post-excavation) for ESF niches

- Pneumatic pressure and air-permeability data from Alcove 4, Alcove 6, and Alcove 8

- Seepage and liquid-release data

- Laboratory dye measurements and sorptivity data

- Water-potential data and electrical resistivity probe data from drift walls and boreholes

- In-drift relative humidity and temperature data (under both ventilated and nonventilated conditions)

- Chemical analysis data

- Geologic mapping data

- UZ transport testing data from Busted Butte

- Geochemical data and isotope data from underground drifts and boreholes.

The properties resulting from the analyses of the above field data include air-permeability distributions, fracture network connectivity, fracture flow-path distributions, seepage percentages, seepage thresholds, fracture characteristic curves, formation intake rates, wetting-front travel times, fracture porosities, fracture volumes, fracture flow fractions, tracer distributions, matrix imbibitions, retardation factors, fault and matrix flow rates, water-potential distributions, construction-water migration times, relative humidities, moisture conditions, and hydrochemical distributions.

\subsection{DIRECT AND INDIRECT INPUTS}

The Q-status of all inputs and a description of the data are shown in the Technical Data Management System (TDMS). The direct inputs to the scientific analysis report were obtained from the TDMS. The input data used in this scientific analysis report are summarized in tables, which are organized to correspond to equivalent subsections in Section 6.

Because one of the main objectives of this scientific analysis report is to document the data, both direct inputs and corroborating data are summarized together in this section, using separate tables to clearly distinguish different categories. Direct inputs are key data collected, interpreted, illustrated, or tabulated in this scientific analysis report. All other Data Tracking Numbers (DTNs) identified for corroborative data are tabulated in tables without the "direct input" designation. Where tables that are divided into Part a, Part b, and Part c, Part a is for direct input data, and Parts $b$ and c contain corroborative data. 
With the focus of this scientific analysis on the ambient field-testing activities performed in underground drifts through UZ tuff rock units (Section 1), some data collected from monitoring activities, data from surface-based field activities, and data from laboratory testing activities are not included in the "direct input" tables. These data are potentially important for downstream users for different modeling purposes. The downstream users can make different category selections based on different criteria. If corroborative data are not presented immediately following the direct input data, they are less informative than presentation of the inputs in separated sections.

The direct inputs are presented in the following sections and tables:

- Section 4.1.1.1, Table 4-1a on Data Used to Illustrate Air-Permeability Distributions and Excavation-Induced Enhancements

- Section 4.1.2.1, Table 4-2a on Data Used to Illustrate Niche Liquid-Release and Seepage-Test Results

- Section 4.1.3, Table 4-3 on Data Used to Illustrate Tracer-Migration Delineation at Niche 5 (Niche CD 3650)

- Section 4.1.4, Table 4-4 on Data Used to Illustrate Tracer Penetration and Water Imbibition into Welded Tuff Matrix

- Section 4.1.5, Table 4-5 on Data Used to Illustrate Crosshole Analysis of Air-Injection Tests

- Section 4.1.6, Table 4-6 on Data Used to Illustrate Fracture Flow in Fracture-Matrix Test Bed at Alcove 6

- Section 4.1.7.1, Table 4-7a on Data Used to Illustrate Flow through the Fault and Matrix in the Test Bed at Alcove 4

- Section 4.1.8, Table 4-8 on Data Used to Compile Water-Potential Measurements in Niches

- Section 4.1.9, Table 4-9 on Data Used to Illustrate Observations of Construction-Water Migration

- Section 4.1.10.1, Table 4-10a on Data Used to Illustrate Moisture Monitoring and Water Analysis in Underground Drifts

- Section 4.1.11.1, Table 4-11a on Data Used to Illustrate Systematic Hydrological Characterization Results

- Section 4.1.12.1, Table 4-12a on Data Used to Illustrate Flow and Transport Test Results at Alcove 8/Niche 3 (Niche 3107)

- Section 4.1.13.1, Table 4-13a on Data Used to Illustrate Busted Butte Unsaturated Zone Transport Test Results

- Section 4.1.14.1, Table 4-14a on Data Used to Support Geochemical Interpretations. 
Other associated data are summarized within additional tables of this report.

The uncertainties related to input data and parameters are presented in Section 6 of this scientific analysis report.

\subsubsection{Data of Air-Permeability Distributions and Excavation-Induced Enhancements}

\subsubsection{Data Used to Illustrate Air-Permeability Distributions and Excavation-Induced Enhancements (Direct Input)}

Table 4-1a. Data Used to Illustrate Air-Permeability Distributions and Excavation-Induced Enhancements (Direct Input)

\begin{tabular}{|c|c|c|c|c|}
\hline \multirow[b]{2}{*}{ Inputs } & \multicolumn{3}{|c|}{ Used in } & \multirow[b]{2}{*}{ Description } \\
\hline & Section & Figure(s) & Table(s) & \\
\hline $\begin{array}{l}\text { LB0011AIRKTEST.001 } \\
\text { [DIRS 153155] }\end{array}$ & 13 & $\begin{array}{c}6-8 \\
6-9 \\
6-10 \\
6-11\end{array}$ & $\begin{array}{l}6-2 \\
6-6 \\
1-1\end{array}$ & $\begin{array}{l}\text { Air-permeability measurements in Niche } 1 \\
\text { (Niche 3566) and Niche } 2 \text { (Niche 3650) of the } \\
\text { ESF. }\end{array}$ \\
\hline $\begin{array}{l}\text { LB980901233124.101 } \\
\text { [DIRS 136593] }\end{array}$ & - & $\begin{array}{l}6-12 \\
6-13 \\
6-14 \\
6-15 \\
\end{array}$ & $\begin{array}{l}6-2 \\
6-6\end{array}$ & $\begin{array}{l}\text { Pneumatic-pressure and air-permeability data } \\
\text { from Niche } 3 \text { (Niche } 3107 \text { ) and Niche } 4 \\
\text { (Niche 4788) in the ESF (pre-excavation). }\end{array}$ \\
\hline $\begin{array}{l}\text { LB990601233124.001 } \\
\text { [DIRS 105888] }\end{array}$ & - & $\begin{array}{l}6-12 \\
6-14\end{array}$ & $\begin{array}{l}6-2 \\
6-6\end{array}$ & $\begin{array}{l}\text { Pneumatic-pressure and air-permeability data } \\
\text { from Niche } 3 \text { (Niche } 3107 \text { ) and Niche } 4 \\
\text { (Niche 4788) in the ESF (post-excavation). }\end{array}$ \\
\hline $\begin{array}{l}\text { LB980912332245.001 } \\
\text { [DIRS 110828] }\end{array}$ & - & & $6-6$ & $\begin{array}{l}\text { Air-injection data from Niche } 3 \text { (Niche 3107) of } \\
\text { the ESF (radial boreholes). }\end{array}$ \\
\hline $\begin{array}{l}\text { LB0012AIRKTEST.001 } \\
\text { [DIRS 154586] }\end{array}$ & - & $6-16$ & $\begin{array}{l}6-3 \\
6-6\end{array}$ & $\begin{array}{l}\text { Air-permeability testing in Niche } 5 \text { (Niche CD } \\
1620 \text { upper boreholes, pre-excavation). }\end{array}$ \\
\hline $\begin{array}{l}\text { LB0110AKN5POST.001 } \\
\text { [DIRS 156904] }\end{array}$ & - & $6-16$ & $\begin{array}{l}6-3 \\
6-6\end{array}$ & $\begin{array}{l}\text { Air-permeability measurement in Niche } 5 \\
\text { (Niche CD } 1620 \text { upper boreholes, } \\
\text { post-excavation). }\end{array}$ \\
\hline $\begin{array}{l}\text { LB002181233124.001 } \\
\text { [DIRS 146878] }\end{array}$ & - & $6-17$ & $\begin{array}{l}6-4 \\
6-6\end{array}$ & $\begin{array}{l}\text { Air-permeability and pneumatic-pressure data } \\
\text { collected from Niche } 5 \text { (Niche CD } 1620 \text { side } \\
\text { boreholes, pre-excavation). }\end{array}$ \\
\hline $\begin{array}{l}\text { LB0110AK23POST.001 } \\
\text { [DIRS 156905] }\end{array}$ & - & $6-17$ & $\begin{array}{l}6-4 \\
6-6\end{array}$ & $\begin{array}{l}\text { Air-permeability measurement in Niche } 5 \\
\text { (Niche CD } 1620 \text { side boreholes, } \\
\text { post-excavation). }\end{array}$ \\
\hline $\begin{array}{l}\text { LB980901233124.009 } \\
\text { [DIRS 105856] }\end{array}$ & - & - & $6-6$ & $\begin{array}{l}\text { Pneumatic-pressure and air-permeability data } \\
\text { from Alcove } 4 \text { in the ESF. }\end{array}$ \\
\hline $\begin{array}{l}\text { LB980901233124.004 } \\
\text { [DIRS 105855] }\end{array}$ & - & - & $6-6$ & $\begin{array}{l}\text { Pneumatic pressure and air-permeability data } \\
\text { from Alcove } 6 \text { in the ESF. }\end{array}$ \\
\hline $\begin{array}{l}\text { LB0302ALC8AIRK.001 } \\
\text { [DIRS 164748] }\end{array}$ & - & $6-18$ & $\begin{array}{l}6-5 \\
6-6\end{array}$ & Air-permeability data from Alcove 8. \\
\hline
\end{tabular}

a Input DTN used to generate Output DTN: LB0310AIRK0015.001.

$\mathrm{ESF}=$ Exploratory Studies Facility. 


\subsubsection{Data Used to Corroborate Analysis of Air-Permeability Distributions and Excavation-Induced Enhancements (For Reference)}

Table 4-1b. Data Used to Corroborate Analysis of Air-Permeability Distributions and Excavation-Induced Enhancements (For Reference)

\begin{tabular}{|c|c|c|c|c|}
\hline \multirow[b]{2}{*}{ Inputs } & \multicolumn{3}{|c|}{ Used in } & \multirow[b]{2}{*}{ Description } \\
\hline & Section & Figure & Table & \\
\hline $\begin{array}{l}\text { MO0008GSC00269.000 } \\
\text { [DIRS 166198] }\end{array}$ & 6.1.1.2 & - & - & $\begin{array}{l}\text { As-built ECRB Alcove } 8 \text {, construction observation } \\
\text { alcove boreholes (\#1 through } 7 \text { ). }\end{array}$ \\
\hline $\begin{array}{l}\text { LB990901233124.004 }^{a} \\
\text { [DIRS 123273], Data } \\
\text { Table S00017_002 }\end{array}$ & - & - & $6-6$ & $\begin{array}{l}\text { Statistical analyses of air-permeability data from Niche } 2 \\
\text { (Niche } 3650) \text {, Niche } 3 \text { (Niche } 3107 \text { ), and Niche } 4 \\
\text { (Niche 4788), as well as Alcove } 4 \text { and Alcove } 6 .\end{array}$ \\
\hline
\end{tabular}

${ }^{a}$ Other data tables also used as input in Section 6.5 on crosshole connectivity as shown in Table 4-5.

$\mathrm{ECRB}=$ Enhanced Characterization of Repository Block.

\subsubsection{Data of Niche Liquid-Release and Seepage-Test Results}

\subsubsection{Data Used to Illustrate Niche Liquid-Release and Seepage-Test Results (Direct Input)}

Table 4-2a. Data Used to Illustrate Niche Liquid-Release and Seepage-Test Results (Direct Input)

\begin{tabular}{|c|c|c|c|c|}
\hline \multirow[b]{2}{*}{ Inputs } & \multicolumn{3}{|c|}{ Used in } & \multirow[b]{2}{*}{ Description } \\
\hline & Section(s) & Figure(s) & Table(s) & \\
\hline $\begin{array}{l}\text { LB980001233124.004 } \\
\text { [DIRS 136583] }\end{array}$ & $\begin{array}{c}6.2 .1 .1 \\
6.2 .1 .2 \\
6.2 .1 .3 .1 \\
6.2 .2 .1 \\
6.2 .2 .3 \\
6.2 .2 .4 \\
\text { D2 } \\
\text { D3.2 } \\
\end{array}$ & $\begin{array}{l}6-25 \\
6-48\end{array}$ & $\begin{array}{l}6-11 \\
B-1 \\
B-4 \\
D-1\end{array}$ & $\begin{array}{l}\text { Liquid-release test data from Niche } 1 \\
\text { (Niche 3566) and Niche } 2 \text { (Niche 3650) of } \\
\text { the ESF. }\end{array}$ \\
\hline $\begin{array}{l}\text { LB980901233124.003 }^{a} \\
\text { [DIRS 105592] }\end{array}$ & $\begin{array}{l}6.2 .1 .1 \\
6.2 .1 .2 \\
\text { D2 } \\
\text { D3.2 }\end{array}$ & $\begin{array}{c}6-25 \\
6-47 \\
6-48 \\
6-49 \\
6-50 \\
D-1\end{array}$ & $\begin{array}{c}6-8 \\
6-9 \\
6-10 \\
6-11 \\
\text { B-1 } \\
\text { B-4 } \\
\text { B-5 } \\
\text { B-7 } \\
\text { B-8 } \\
\text { D-1 }\end{array}$ & $\begin{array}{l}\text { Liquid-release and tracer tests in Niche } \\
36501 \text { (Niche 3650), Niche } 2 \text { (Niche } 3650 \text { ), } \\
\text { Niche } 3 \text { (Niche } 3107 \text { ), and Niche } 4 \text { (Niche } \\
4788 \text { ) in the ESF, as well as fracture flow } \\
\text { and seepage testing in the ESF. }\end{array}$ \\
\hline
\end{tabular}


Table 4-2a. Data Used to Illustrate Niche Liquid-Release and Seepage-Test Results (Direct Input) (Continued)

\begin{tabular}{|c|c|c|c|c|}
\hline \multirow[b]{2}{*}{ Inputs } & \multicolumn{3}{|c|}{ Used in } & \multirow[b]{2}{*}{ Description } \\
\hline & Section(s) & Figure(s) & Table(s) & \\
\hline $\begin{array}{l}\text { LB0010NICH4LIQ.001 } \\
\text { ab }[\text { DIRS 153145] }\end{array}$ & 6.2.1.3.3 & $\begin{array}{l}6-28 \\
6-29 \\
6-48\end{array}$ & $\begin{array}{l}B-2 \\
B-3 b \\
B-8\end{array}$ & $\begin{array}{l}\text { Niche } 4 \text { (Niche } 4788 \text { ) seepage tests } \\
\text { measuring injected and captured water } \\
\text { masses over time. Time spans include } \\
\text { considerations for pumping time, wetting-front } \\
\text { arrival time, and dripping duration. }\end{array}$ \\
\hline $\begin{array}{l}\text { LB0102NICH5LIQ.001 } \\
\text { a [DIRS 155681] }\end{array}$ & $\begin{array}{l}6.2 .1 .1 \\
6.2 .1 .2\end{array}$ & $6-25$ & B-1 & $\begin{array}{l}\text { Niche } 5 \text { (Niche CD 1620) seepage } \\
\text { tests-pre-excavation. }\end{array}$ \\
\hline $\begin{array}{l}\text { LB990601233124.001 } \\
{ }^{a} \text { [DIRS 105888] }\end{array}$ & - & - & $\begin{array}{l}6-9 \\
\mathrm{~B}-4\end{array}$ & $\begin{array}{l}\text { Seepage data feed to UZ drift-scale flow } \\
\text { model for TSPA-SR. }\end{array}$ \\
\hline $\begin{array}{l}\text { LB0211NICH5LIQ.001 } \\
\text { [DIRS 160792] }\end{array}$ & $\begin{array}{c}\mathrm{C} 4 \\
\mathrm{~F} 1 \\
\mathrm{I} 6.1\end{array}$ & $\begin{array}{l}6-37 \\
6-38 \\
6-40 \\
6-41 \\
6-42 \\
6-43 \\
6-44 \\
6-45 \\
6-46\end{array}$ & $\begin{array}{l}C-1 \\
\mathrm{I}-3\end{array}$ & $\begin{array}{l}\text { Liquid-release and tracer tests in Niche } 5 \\
\text { (Niche CD 1620) in the ECRB. }\end{array}$ \\
\hline
\end{tabular}

${ }^{a}$ Input DTN for Output DTN: LB0110LIQR0015.001.

b Input DTN for Output DTN: LB0110NICH4LIQ.001.

ECRB = Enhanced Characterization of Repository Block; ESF = Exploratory Studies Facility;

$\mathrm{SR}=$ Site Recommendation; TSPA = Total System Performance Assessment; UZ = unsaturated zone.

\subsubsection{Data Used to Corroborate Analysis and Interpretation of Niche Liquid-Release and Seepage Tests (For Reference)}

Table 4-2b. Data Used to Corroborate Analysis and Interpretation of Niche Liquid-Release and Seepage Tests (For Reference)

\begin{tabular}{|l|c|c|c|l|}
\hline \multirow{2}{*}{\multicolumn{1}{|c|}{ Inputs }} & \multicolumn{3}{|c|}{ Used in } & \multicolumn{1}{c|}{ Description } \\
\cline { 2 - 5 } & Section & Figure & Table & \multicolumn{1}{|c|}{} \\
\hline $\begin{array}{l}\text { MO0107GSC01069.000 } \\
\text { [DIRS 156941] }\end{array}$ & - & - & B-2 & ESF Niche 4 (Niche 4788) borehole as-built data. \\
\hline $\begin{array}{l}\text { MO0107GSC01061.000 } \\
\text { [DIRS 155369] }\end{array}$ & 6.2 .1 .3 .5 .2 & C-1 & - & $\begin{array}{l}\text { As-built profile Niche 5 (Niche CD 1620) bat-wing } \\
\text { excavation. }\end{array}$ \\
\hline $\begin{array}{l}\text { MO0312GSC03176.000 } \\
\text { [DIRS 169532] }\end{array}$ & 6.2 .1 .3 .5 .2 & - & - & $\begin{array}{l}\text { ECRB Niche 5 (Niche CD 1620) borehole as-built } \\
\text { data. }\end{array}$ \\
\hline
\end{tabular}

NOTES: ECRB $=$ Enhanced Characterization of Repository Block; ESF $=$ Exploratory Studies Facility. 


\subsubsection{Data Used to Illustrate Tracer-Migration Delineation at Niche 2 (Niche 3650) (Direct Input)}

Table 4-3. Data Used to Illustrate Tracer-Migration Delineation at Niche 2 (Niche 3650) (Direct Input)

\begin{tabular}{|l|c|c|c|l|}
\hline \multirow{2}{*}{ Inputs } & \multicolumn{3}{|c|}{ Used in } & \multirow{2}{*}{ Description } \\
\cline { 2 - 4 } & Section & Figure(s) & Table & \\
\hline LB990601233124.003 & - & $6-52$ & $6-12$ & Tracer detection data from core samples for \\
[DIRS 106051] & & $6-53$ & & tracers injected in Niche 2 (Niche 3650) in the \\
& & $6-54$ & & \\
& $6-55$ & & \\
& $6-56$ & & \\
& $6-57$ & & \\
& $6-58$ & & \\
& & $6-59$ & & \\
& & & \\
& & & & \\
& & & & \\
\end{tabular}

NOTE: ESF = Exploratory Studies Facility.

\subsubsection{Data Used to Illustrate Tracer Penetration and Water Imbibition into Welded Tuff Matrix (Direct Input)}

Table 4-4. Data Used to Illustrate Tracer Penetration and Water Imbibition into Welded Tuff Matrix (Direct Input)

\begin{tabular}{|c|c|c|c|c|}
\hline \multirow[b]{2}{*}{ Inputs } & \multicolumn{3}{|c|}{ Used in } & \multirow[b]{2}{*}{ Description } \\
\hline & Section & Figure(s) & Table(s) & \\
\hline $\begin{array}{l}\text { LB980001233124.004 } \\
\text { [DIRS 136583] }\end{array}$ & - & - & $\begin{array}{l}6-13 \\
6-14 \\
\end{array}$ & $\begin{array}{l}\text { Liquid-release tests in Niche } 1 \text { (Niche 3566) and } \\
\text { Niche } 2 \text { (Niche 3650). }\end{array}$ \\
\hline $\begin{array}{l}\text { LB980901233124.003 } \\
\text { [DIRS 105592] }\end{array}$ & - & - & $6-13$ & $\begin{array}{l}\text { Liquid-release and tracer tests in Niche } 1 \\
\text { (Niche 3566), Niche } 2 \text { (Niche 3650), Niche } 3 \\
\text { (Niche 3107), and Niche } 4 \text { (Niche 4788) in the } \\
\text { ESF. }\end{array}$ \\
\hline $\begin{array}{l}\text { LB990901233124.003 } \\
\text { [DIRS 155690] }\end{array}$ & 6.4.1.4 & $\begin{array}{c}6-61 \\
6-62 \\
6-63 \\
6-64 \\
E-1 \\
E-2 \\
\end{array}$ & $\begin{array}{l}6-14 \\
6-15\end{array}$ & $\begin{array}{l}\text { Tracer lab analyses of dye penetration in Niche } \\
2 \text { (Niche } 3650 \text { ) and Niche } 4 \text { (Niche } 4788 \text { ) of the } \\
\text { ESF. }\end{array}$ \\
\hline $\begin{array}{l}\text { LB0110TUFTRACR.001 } \\
\text { [DIRS 156979] }\end{array}$ & - & $\begin{array}{l}6-65 \\
6-66\end{array}$ & - & $\begin{array}{l}\text { Spatial distribution of applied tracers and the } \\
\text { distribution of intrinsic tuff elements profiled } \\
\text { using LA-ICP-MS. }\end{array}$ \\
\hline
\end{tabular}

NOTES: ESF=Exploratory Studies Facility; LA-ICP-MS=Laser Ablation Analyzed by Inductively Coupled Plasma-Mass Spectrometry. 


\subsubsection{Data Used to Illustrate Crosshole Analysis of Air-Injection Tests (Direct Input)}

Table 4-5. Data Used to Illustrate Crosshole Analysis of Air-Injection Tests (Direct Input)

\begin{tabular}{|c|c|c|c|c|}
\hline \multirow[b]{2}{*}{ Inputs } & \multicolumn{3}{|c|}{ Used in } & \multirow[b]{2}{*}{ Description } \\
\hline & Section & Figure(s) & Table & \\
\hline $\begin{array}{l}\text { LB980901233124.004 } \\
\text { [DIRS 105855] }\end{array}$ & - & $6-68$ & - & $\begin{array}{l}\text { Pneumatic-pressure and air-permeability data } \\
\text { from Alcove } 6 \text { in the ESF. }\end{array}$ \\
\hline $\begin{array}{l}\text { LB980901233124.009 } \\
\text { [DIRS 105856] }\end{array}$ & - & $6-71$ & - & $\begin{array}{l}\text { Pneumatic-pressure and air-permeability data } \\
\text { from Alcove } 4 \text { in the ESF. }\end{array}$ \\
\hline $\begin{array}{l}\text { LB990901233124.004 } \\
\text { [DIRS 123273] }\end{array}$ & - & $\begin{array}{l}6-67 \\
6-69 \\
6-72 \\
6-73\end{array}$ & - & $\begin{array}{l}\text { Air-permeability crosshole connectivity in } \\
\text { Alcove } 6 \text {, Alcove } 4 \text {, and Niche } 4 \text { (Niche 4788) of } \\
\text { the ESF. }\end{array}$ \\
\hline
\end{tabular}

NOTE: ESF=Exploratory Studies Facility.

\subsubsection{Data Used to Illustrate Fracture Flow in Fracture-Matrix Test Bed at Alcove 6 (Direct Input)}

Table 4-6. Data Used to Illustrate Fracture Flow in Fracture-Matrix Test Bed at Alcove 6 (Direct Input)

\begin{tabular}{|l|c|c|c|l|}
\hline \multirow{2}{*}{ Inputs } & \multicolumn{3}{|c|}{ Used in } & \multicolumn{1}{c}{ Description } \\
\cline { 2 - 4 } & Section & Figure(s) & Table(s) & \multicolumn{1}{c|}{ Alcove 6 flow data, including electrical } \\
[DB990901233124.002 & - & $6-75$ & $6-16$ & resistance, water injection, intake rate, and \\
& & $6-76$ & $6-17$ & water-potential measurements. \\
& & $6-77$ & & \\
& & $6-78$ & & \\
& & $6-80$ & & \\
& & $6-81$ & & \\
\hline LB990901233124.001 & - & $6-82$ & - & Alcove 6 tracer tests: the breakthrough of \\
[DIRS 155694] & & & & tracers, relating to the volume and the measured \\
& & & & tracer concentration of the collected liquid at four \\
& & & & \\
\hline
\end{tabular}

\subsubsection{Data of Flow through the Fault and Matrix in the Test Bed at Alcove 4}

\subsubsection{Data Used to Illustrate Flow through the Fault and Matrix in the Test Bed at Alcove 4 (Direct Input)}

Table 4-7a. Data Used to Illustrate Flow through the Fault and Matrix in the Test Bed at Alcove 4 (Direct Input)

\begin{tabular}{|l|c|c|c|l|}
\hline \multirow{2}{*}{ Inputs } & \multicolumn{3}{|c|}{ Used in } & \multirow{2}{*}{ Description } \\
\cline { 2 - 4 } & Section & Figures & Table & \\
\hline LB990901233124.005 & - & $6-85$ & $6-18$ & Alcove 4 flow data, including electrical resistance, \\
[DIRS 146884] & & $6-86$ & & water injection, and intake rate measurements. \\
& & $6-87$ & & \\
& & $6-88$ & & \\
& & $6-89$ & & \\
& & $6-90$ & & \\
& & & & \\
& &
\end{tabular}




\subsubsection{Data Used to Corroborate Analysis of Flow through the Fault and Matrix in the Test Bed at Alcove 4 (For Reference)}

Table 4-7b. Data Used to Corroborate Analysis of Flow through the Fault and Matrix in the Test Bed at Alcove 4 (For Reference)

\begin{tabular}{|c|c|c|c|c|}
\hline \multirow[b]{2}{*}{ Inputs } & \multicolumn{3}{|c|}{ Used in } & \multirow[b]{2}{*}{ Description } \\
\hline & Section & Figure & Table & \\
\hline $\begin{array}{l}\text { GS960908314224.020 } \\
\text { [DIRS 106059] }\end{array}$ & 6.7.1.1 & - & - & $\begin{array}{l}\text { Analysis report: geology of the north } \\
\text { ramp-stations } 4+00 \text { to } 28+00 \text { data: detailed line } \\
\text { survey and full-periphery geotechnical } \\
\text { map-Alcoves } 3 \text { and } 4 \text {, and comparative } \\
\text { geological cross section-stations } 0+60 \text { to } 28+00 \text {. }\end{array}$ \\
\hline
\end{tabular}

\subsubsection{Data Used to Compile Water-Potential Measurements in Niches (Direct Input)}

Table 4-8. Data Used to Compile Water-Potential Measurements in Niches (Direct Input)

\begin{tabular}{|l|c|c|c|l|}
\hline \multirow{2}{*}{ Inputs } & \multicolumn{3}{|c|}{ Used in } & \multicolumn{1}{c}{ Description } \\
\cline { 2 - 4 } & Section & Figures & Tables & Water-potential measurements in Niche 1 \\
LB0406ESFNH2OP.001 & - & $6-94$ & $6-19$ & Wiche \\
[DIRS 171588] & & $6-95$ & $6-20$ & (Niche 3566), Niche 2 (Niche 3650), and Niche 3 \\
& & G-1 & $6-21$ & (Niche 3107) of the ESF. \\
& & G-2 & & \\
\hline
\end{tabular}

NOTE: $\mathrm{ESF}=$ Exploratory Studies Facility.

\subsubsection{Data Used to Illustrate Observations of Construction-Water Migration (Direct Input)}

Table 4-9. Data Used to Illustrate Observations of Construction-Water Migration (Direct Input)

\begin{tabular}{|l|c|c|c|l|}
\hline \multirow{2}{*}{ Inputs } & \multicolumn{3}{|c|}{ Used in } & \multirow{2}{*}{ Description } \\
\cline { 2 - 4 } & Section & Figures & Tables & Borehole monitoring at the single borehole in the \\
\hline LB980901233124.014 & - & $6-99$ & $6-22$ & Bor \\
[DIRS 105858] & & $6-100$ & $6-23$ & ECRB and ECRB crossover point in the ESF. \\
\hline
\end{tabular}

NOTES: $E C R B=$ Enhanced Characterization of Repository Block; ESF = Exploratory Studies Facility. 


\subsubsection{Data of Moisture Monitoring and Water Analysis in Underground Drifts}

\subsubsection{Data Used to Illustrate Moisture Monitoring and Water Analysis in Underground Drifts (Direct Input)}

Table 4-10a. Data Used to Illustrate Moisture Monitoring and Water Analysis in Underground Drifts (Direct Input)

\begin{tabular}{|c|c|c|c|c|}
\hline \multirow[b]{2}{*}{ Inputs } & \multicolumn{3}{|c|}{ Used in } & \multirow[b]{2}{*}{ Description } \\
\hline & Section(s) & Figure(s) & Table & \\
\hline $\begin{array}{l}\text { LB990901233124.006 } \\
\text { [DIRS 135137] }\end{array}$ & - & $\begin{array}{l}6-103 \\
6-104\end{array}$ & $6-24$ & $\begin{array}{l}\text { Moisture data from the ECRB cross-drift; } \\
\text { relative humidity data from various cross-drift } \\
\text { stations. }\end{array}$ \\
\hline $\begin{array}{l}\text { LAJF831222AQ98.007 } \\
\text { [DIRS 122730] }\end{array}$ & - & $6-105$ & - & $\begin{array}{l}\text { Chloride, bromide, and sulfate analysis of salts } \\
\text { leached from ECRB-CWAT\#1, \#2, and \#3 } \\
\text { drillcore. }\end{array}$ \\
\hline $\begin{array}{l}\text { GS990908314224.010 } \\
\text { [DIRS 152631] }\end{array}$ & - & $6-108$ & - & $\begin{array}{l}\text { Comparative cross section along the ECRB } \\
\text { cross-drift. }\end{array}$ \\
\hline $\begin{array}{l}\text { GS990408314224.006 } \\
\text { [DIRS 108409] }\end{array}$ & - & - & $6-25$ & $\begin{array}{l}\text { Full periphery geological maps for Station } \\
20+00 \text { to } 26+81 \text {, ECRB cross-drift. }\end{array}$ \\
\hline $\begin{array}{l}\text { LB0110ECRBH2OP.001 } \\
\text { [DIRS 156883] }\end{array}$ & - & $6-109$ & - & $\begin{array}{l}\text { Measurements of water potential at three } \\
\text { locations between successive bulkhead doors } \\
\text { in the ECRB. }\end{array}$ \\
\hline $\begin{array}{l}\text { LB0307ECRBRHTB.001 } \\
\text { [DIRS 164843] }\end{array}$ & 6.10 .2 .3 & $\begin{array}{l}6-110 \\
6-111 \\
6-112 \\
6-122 \\
6-123 \\
\end{array}$ & - & $\begin{array}{l}\text { Measurements of relative humidity, } \\
\text { temperature, and barometric pressure at four } \\
\text { locations between successive bulkhead doors } \\
\text { in the ECRB. }\end{array}$ \\
\hline $\begin{array}{l}\text { LB0301ECRBRHTB.001 } \\
\text { [DIRS 164605] }\end{array}$ & $\begin{array}{l}6.10 .2 .2 \\
6.10 .2 .2 .2 \\
6.10 .2 .2 .3\end{array}$ & $\begin{array}{l}6-114 \\
6-115 \\
6-116 \\
6-117 \\
6-118 \\
6-119 \\
6-120 \\
6-121 \\
\end{array}$ & - & $\begin{array}{l}\text { Observations of entries made on } \\
\text { June } 23,2001 \text {, and October 1-2, } 2001 .\end{array}$ \\
\hline $\begin{array}{l}\text { LB0110ECRBH2OA.001 } \\
\text { [DIRS 156886] }\end{array}$ & - & $\begin{array}{l}6-124 \\
6-125\end{array}$ & $6-26$ & $\begin{array}{l}\text { Anion-cation measurements for water samples } \\
\text { from nonventilated sections of the ECRB. }\end{array}$ \\
\hline $\begin{array}{l}\text { LB0110ECRBH2OI.001 } \\
\text { [DIRS 156887] }\end{array}$ & - & $6-126$ & $6-26$ & $\begin{array}{l}\text { Deuterium and DEL O-18 measurements for } \\
\text { water samples from nonventilated sections of } \\
\text { the ECRB. }\end{array}$ \\
\hline
\end{tabular}

NOTES: CWAT $=$ Construction Water; ECRB $=$ Enhanced Characterization of Repository Block. 


\subsubsection{Data on Drift Moisture Monitoring and Water Analysis (For Reference)}

Table 4-10b. Data on Drift Moisture Monitoring and Water Analysis (For Reference)

\begin{tabular}{|c|c|c|c|c|}
\hline \multirow[b]{2}{*}{ Inputs } & \multicolumn{3}{|c|}{ Used in } & \multirow[b]{2}{*}{ Description } \\
\hline & Section & Figure & Table & \\
\hline $\begin{array}{l}\text { LB960800831224.001 } \\
\text { [DIRS 105793] }\end{array}$ & 6.10.1.2.1 & - & $6-24$ & $\begin{array}{l}\text { Relative humidity, temperature, and pressure in } \\
\text { ESF monitoring stations. }\end{array}$ \\
\hline $\begin{array}{l}\text { LB970300831224.001 } \\
\text { [DIRS 105794] }\end{array}$ & - & - & $6-24$ & $\begin{array}{l}\text { Moisture data report from October } 1996 \text { to } \\
\text { January } 1997 .\end{array}$ \\
\hline $\begin{array}{l}\text { LB970801233124.001 } \\
\text { [DIRS 105796] }\end{array}$ & 6.10.1.2.1 & - & $6-24$ & $\begin{array}{l}\text { Moisture monitoring data collected at ESF } \\
\text { sensor stations. }\end{array}$ \\
\hline $\begin{array}{l}\text { LB970901233124.002 } \\
\text { [DIRS 105798] }\end{array}$ & - & - & $6-24$ & $\begin{array}{l}\text { Moisture monitoring data collected at stationary } \\
\text { moisture stations. }\end{array}$ \\
\hline $\begin{array}{l}\text { GS970208312242.001 } \\
\text { [DIRS 135119] }\end{array}$ & - & - & $6-24$ & $\begin{array}{l}\text { Moisture monitoring in the ESF, Oct. 1, 1996, to } \\
\text { Jan. 31, } 1997 .\end{array}$ \\
\hline $\begin{array}{l}\text { GS970708312242.002 } \\
\text { [DIRS 135123] }\end{array}$ & - & - & $6-24$ & $\begin{array}{l}\text { Moisture monitoring in the ESF, Feb. 1, 1997, to } \\
\text { July 31, } 1997 \text {. }\end{array}$ \\
\hline $\begin{array}{l}\text { GS980908312242.024 } \\
\text { [DIRS 135132] }\end{array}$ & - & - & $6-24$ & $\begin{array}{l}\text { Moisture monitoring in the ESF, August 1, 1997, } \\
\text { to July 31, } 1998 .\end{array}$ \\
\hline $\begin{array}{l}\text { GS980908312242.035 } \\
\text { [DIRS 135133] }\end{array}$ & - & - & $6-24$ & Moisture monitoring in the ECRB. \\
\hline $\begin{array}{l}\text { GS021008312242.003 } \\
\text { [DIRS 162178] }\end{array}$ & 6.10.1.2.2 & - & - & $\begin{array}{l}\text { Temperature and water-potential data from } \\
\text { Alcove } 3 \text { and Alcove } 4 \text {. }\end{array}$ \\
\hline $\begin{array}{l}\text { GS030608312231.002 } \\
\text { [DIRS 165547] }\end{array}$ & 6.10.2.2 & - & - & $\begin{array}{l}\text { Digital image data from the moisture monitoring } \\
\text { tests in the ECRB bulkheaded cross-drift from } \\
\text { January } 22,2001, \text { to February } 3,2003 \text {. }\end{array}$ \\
\hline $\begin{array}{l}\text { MO0006J13WTRCM.00 } \\
0 \text { [DIRS 151029] }\end{array}$ & - & $6-125$ & - & J-13 well water composition. \\
\hline $\begin{array}{l}\text { LB0108CO2DST05.001 } \\
\text { [DIRS 156888] }\end{array}$ & - & $6-126$ & - & $\begin{array}{l}\text { Concentration data for } \mathrm{CO}_{2} \text { from gas samples } \\
\text { collected from hydrology holes in drift-scale test. }\end{array}$ \\
\hline $\begin{array}{l}\text { LB0011CO2DST08.001 } \\
\text { [DIRS 153460] }\end{array}$ & - & $6-126$ & - & $\begin{array}{l}\text { Contents of gas samples collected from the } \\
\text { following drift-scale test holes: } 57,58,59,60 \text {, } \\
61,74,75,76,77,78,185 ; \text { and the following } \\
\text { control areas: Heater Drift \#2 and AO drift air. }\end{array}$ \\
\hline
\end{tabular}

NOTES: ECRB=Enhanced Characterization of Repository Block; ESF=Exploratory Studies Facility. 


\subsubsection{Data on Water Potential and Saturation Measurements (For Reference)}

Table 4-10c. Data on Water Potential and Saturation Measurements (For Reference)

\begin{tabular}{|c|c|c|c|c|}
\hline \multirow[b]{2}{*}{ Inputs } & \multicolumn{3}{|c|}{ Used in } & \multirow[b]{2}{*}{ Description } \\
\hline & Section & Figure & Table(s) & \\
\hline $\begin{array}{l}\text { LB0406ESFNH2OP.001 } \\
\text { [DIRS 171588] }\end{array}$ & - & - & $6-25$ & $\begin{array}{l}3 \text { main boreholes, } 5 \text { lateral boreholes in Niche } 1 \\
\text { (Niche } 3566 \text { ) water potential. }\end{array}$ \\
\hline $\begin{array}{l}\text { GS980908312242.022 } \\
\text { [DIRS 135157] }\end{array}$ & - & - & $6-25$ & Heat-dissipation-probe drill holes water potential. \\
\hline $\begin{array}{l}\text { GS980908312242.033 } \\
\text { [DIRS 107168] }\end{array}$ & - & - & $\begin{array}{l}6-25 \\
6-26\end{array}$ & 1 core hole in Alcove 3 water potential and saturation. \\
\hline $\begin{array}{l}\text { GS980908312242.032 } \\
\text { [DIRS 107177] }\end{array}$ & - & - & $\begin{array}{l}6-25 \\
6-26\end{array}$ & $\begin{array}{l}2 \text { core holes in Alcove } 4 \text { water potential and } \\
\text { saturation. }\end{array}$ \\
\hline $\begin{array}{l}\text { GS980308312242.004 } \\
\text { [DIRS 107172] }\end{array}$ & - & - & $6-25$ & $\begin{array}{l}18 \text { north ramp boreholes, } 3 \text { Alcove } 4 \text { boreholes, and } \\
46 \text { south ramp boreholes, HQ, } 2 \text { m length water } \\
\text { potential. }\end{array}$ \\
\hline $\begin{array}{l}\text { GS980308312242.002 } \\
\text { [DIRS 135163] }\end{array}$ & - & - & $6-25$ & Heat-dissipation-probe drill holes water potential. \\
\hline $\begin{array}{l}\text { LB980901233124.014 }{ }^{\mathrm{b}} \\
\text { [DIRS 105858] }\end{array}$ & - & - & $\begin{array}{l}6-25 \\
6-26\end{array}$ & $\begin{array}{l}43 \text { psychrometers on ESF drift walls, } 1 \text { slant borehole } \\
\text { below the invert, } 43 \text { TDR probes on ESF drift walls. }\end{array}$ \\
\hline $\begin{array}{l}\text { GS980908312242.036 } \\
\text { [DIRS 119820] }\end{array}$ & - & - & $6-25$ & 6 heat-dissipation-probe drill holes water potential. \\
\hline $\begin{array}{l}\text { GS970808312232.005 } \\
\text { [DIRS 105978] }\end{array}$ & - & - & $6-25$ & $\begin{array}{l}\text { USW NRG-7a, UE-25 UZ\#4, UE-25 UZ\#5, } \\
\text { USW UZ-7a, and USW SD-12 water potential. }\end{array}$ \\
\hline $\begin{array}{l}\text { GS971108312232.007 } \\
\text { [DIRS 105980] }\end{array}$ & - & - & $6-25$ & $\begin{array}{l}\text { USW NRG-7a, UE-25 UZ\#4, UE-25 UZ\#5, } \\
\text { USW UZ-7a, and USW SD-12 water potential. }\end{array}$ \\
\hline $\begin{array}{l}\text { GS980408312232.001 } \\
\text { [DIRS 105982] }\end{array}$ & - & - & $6-25$ & $\begin{array}{l}\text { USW NRG-7a, UE-25 UZ\#4, UE-25 UZ\#5, } \\
\text { USW UZ-7a, and USW SD-12 water potential. }\end{array}$ \\
\hline $\begin{array}{l}\text { GS031208312232.002 } \\
\text { [DIRS 171748] }\end{array}$ & - & - & $6-25$ & $\begin{array}{l}\text { USW NRG-7a, UE-25 UZ\#4, UE-25 UZ\#5, } \\
\text { USW UZ-7a, and USW SD-12 water potential. }\end{array}$ \\
\hline $\begin{array}{l}\text { GS980908312242.018 } \\
\text { [DIRS 135170] }\end{array}$ & - & - & $6-26$ & $\begin{array}{l}3 \text { main boreholes, } 6 \text { lateral boreholes in Niche } 1 \\
\text { (Niche 3566). }\end{array}$ \\
\hline $\begin{array}{l}\text { GS980908312242.020 } \\
\text { [DIRS 135172] }\end{array}$ & - & - & $6-26$ & 7 main boreholes in Niche 2 (Niche 3650). \\
\hline $\begin{array}{l}\text { GS980908312242.029 } \\
\text { [DIRS 135175] }\end{array}$ & - & - & $6-26$ & 3 boreholes in Alcove 6. \\
\hline $\begin{array}{l}\text { GS980908312242.028 } \\
\text { [DIRS 135176] }\end{array}$ & - & - & $6-26$ & 1 borehole in Alcove 7 saturation. \\
\hline $\begin{array}{l}\text { GS980308312242.005 } \\
\text { [DIRS 107165] }\end{array}$ & - & - & $6-26$ & PTn Borehole core saturation. \\
\hline $\begin{array}{l}\text { GS980308312242.003 } \\
\text { [DIRS 135180] }\end{array}$ & - & - & $6-26$ & South ramp core saturation. \\
\hline $\begin{array}{l}\text { GS980308312242.001 } \\
\text { [DIRS 135181] }\end{array}$ & - & - & $6-26$ & TDR measurements of saturation. \\
\hline $\begin{array}{l}\text { GS980908312242.030 } \\
\text { [DIRS 135224] }\end{array}$ & - & - & $6-26$ & 1 slant borehole core saturation. \\
\hline
\end{tabular}

${ }^{\text {a }}$ Also used as input in Section 6.8 on niche water-potential measurement, as shown in Table 4-8.

${ }^{\mathrm{b}}$ Also used as input in Section 6.9 on construction-water migration, as shown in Table 4-9.

ESF $=$ Exploratory Studies Facility; TDR $=$ time domain reflectrometry. 


\subsubsection{Data of Systematic Hydrological Characterization}

\subsubsection{Data Used to Illustrate Systematic Hydrological Characterization Results (Direct Input)}

Table 4-11a. Data Used to Illustrate Systematic Hydrological Characterization Results (Direct Input)

\begin{tabular}{|c|c|c|c|c|}
\hline \multirow[b]{2}{*}{ Inputs } & \multicolumn{3}{|c|}{ Used in } & \multirow[b]{2}{*}{ Description } \\
\hline & Section & Figure(s) & Table(s) & \\
\hline $\begin{array}{l}\text { LB00090012213U.001 a } \\
\text { [DIRS 153141] }\end{array}$ & 6.11 .2 .1 & $\begin{array}{l}6-130 \\
6-131\end{array}$ & $6-29$ & $\begin{array}{l}\text { Two sets of air-k (pneumatic conductivity) } \\
\text { tests at } 3 \text { intervals in title borehole. Air-k } \\
\text { derived from steady-state pressure response. }\end{array}$ \\
\hline $\begin{array}{l}\text { LB00090012213U.002 a } \\
\text { [DIRS 153154] }\end{array}$ & - & $\begin{array}{l}6-131 \\
6-132 \\
6-133 \\
6-134 \\
6-135 \\
6-148\end{array}$ & - & $\begin{array}{l}\text { Eleven sets of seepage tests. Liquid-release } \\
\text { tests from Borehole SYBT-ECRB-LA\#2 at CS } \\
17+26 \text { in cross-drift. }\end{array}$ \\
\hline $\begin{array}{l}\text { LB0110ECRBLIQR.003 }^{a} \\
\text { [DIRS 156877] }\end{array}$ & - & $\begin{array}{l}6-136 \\
6-137 \\
6-138 \\
6-148\end{array}$ & - & $\begin{array}{l}\text { Measurements of seepage from injection } \\
\text { tests in boreholes located in the drift crown of } \\
\text { the ECRB. }\end{array}$ \\
\hline 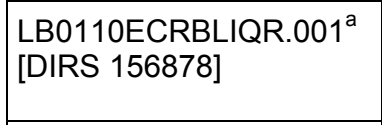 & - & $\begin{array}{l}6-139 \\
6-148\end{array}$ & - & $\begin{array}{l}\text { Measurements of seepage from injection } \\
\text { tests in boreholes located in the drift crown of } \\
\text { the ECRB. }\end{array}$ \\
\hline $\begin{array}{l}\text { LB0110ECRBLIQR.002 }^{\mathrm{a}} \\
\text { [DIRS 156879] }\end{array}$ & 16.2 & $\begin{array}{l}6-140 \\
6-148\end{array}$ & $\mathrm{I}-4$ & $\begin{array}{l}\text { Measurements of seepage from injection } \\
\text { tests in boreholes located in the drift crown of } \\
\text { the ECRB. }\end{array}$ \\
\hline $\begin{array}{l}\text { LB0203ECRBLIQR.001 } \\
\text { [DIRS 158462] }\end{array}$ & 16.3 & $\begin{array}{l}6-141 \\
6-142 \\
6-143 \\
6-148\end{array}$ & $\begin{array}{l}I-3 \\
I-6 \\
I-7\end{array}$ & $\begin{array}{l}\text { Systematic testing in SYBT-ECRB- LA\#3 } \\
\text { (May-July 2001). }\end{array}$ \\
\hline $\begin{array}{l}\text { LB0301SYTSTLA4.001 } \\
\text { [DIRS 165227] }\end{array}$ & 16.4 & $\begin{array}{l}6-144 \\
6-145 \\
6-146 \\
6-148 \\
\end{array}$ & $\begin{array}{l}\mathrm{I}-8 \\
\mathrm{l}-9 \\
\mathrm{l}-10\end{array}$ & $\begin{array}{l}\text { Measurements of seepage from injection } \\
\text { tests in boreholes located in the drift crown of } \\
\text { the SYBT-ECRB-LA\#4. }\end{array}$ \\
\hline
\end{tabular}

${ }^{a}$ Input DTNs used to generate Output DTN: LB0110SYST0015.001.

CS = Construction Station (ESF main loop); ECRB = Enhanced Characterization of Repository Block; ESF = Exploratory Studies Facility.

\subsubsection{Data Used to Corroborate Analyses and Interpretations of Systematic Hydrological Characterization (For Reference)}

Table 4-11b. Data Used to Corroborate Analyses and Interpretations of Systematic Hydrological Characterization (For Reference)

\begin{tabular}{|l|c|c|c|l|}
\hline \multirow{2}{*}{\multicolumn{1}{|c|}{ Inputs }} & \multicolumn{3}{|c|}{ Used in } & \multicolumn{1}{c|}{ Description } \\
\cline { 2 - 4 } & Section & Figure & Table & \\
\hline $\begin{array}{l}\text { LB980912332245.002 } \\
\text { [DIRS 105593] }\end{array}$ & 6.11 .3 .1 & - & - & $\begin{array}{l}\text { Gas tracer data from Niche 3 (Niche 3107) of the } \\
\text { ESF }\end{array}$ \\
\hline $\begin{array}{l}\text { LB0110COREPROP.0 } \\
\text { 01 [DIRS 157169] }\end{array}$ & 6.11 .3 .1 & - & - & $\begin{array}{l}\text { Data measured from cores drilled in the ECRB: } \\
\text { porosity, saturation, bulk density, gravimetric water } \\
\text { content, particle density }\end{array}$ \\
\hline
\end{tabular}

NOTES: $E C R B=$ Enhanced Characterization of the Repository Block; ESF = Exploratory Studies Facility. 


\subsubsection{Data of Observations from the Test at Alcove 8/Niche 3107}

\subsubsection{Data Used to Illustrate Flow and Transport Test Results at Alcove 8/Niche 3 (Niche 3107) (Direct Input)}

Table 4-12a. Data Used to Illustrate Flow and Transport Test Results at Alcove 8/Niche 3 (Niche 3107) (Direct Input)

\begin{tabular}{|c|c|c|c|c|}
\hline \multirow[b]{2}{*}{ Inputs } & \multicolumn{3}{|c|}{ Used in } & \multirow[b]{2}{*}{ Description } \\
\hline & Section & Figure(s) & Table(s) & \\
\hline $\begin{array}{l}\text { GS020508312242.001 } \\
\text { [DIRS 162129] }\end{array}$ & 6.12.2.1 & $\begin{array}{l}6-152 \\
6-153 \\
\end{array}$ & - & $\begin{array}{l}\text { Trenched fault infiltration in Alcove } 8 \text {, } \\
3 / 5 / 2001-6 / 1 / 2001 \text {. }\end{array}$ \\
\hline $\begin{array}{l}\text { GS020908312242.002 } \\
\text { [DIRS 162141] }\end{array}$ & 6.12.2.1 & $\begin{array}{l}6-152 \\
6-153\end{array}$ & - & $\begin{array}{l}\text { Trenched fault infiltration in Alcove } 8 \text {, } \\
6 / 1 / 2001-3 / 26 / 2002 \text {. }\end{array}$ \\
\hline $\begin{array}{l}\text { GS030208312242.003 } \\
\text { [DIRS 165544] }\end{array}$ & 6.12.2.1 & $\begin{array}{l}6-152 \\
6-153\end{array}$ & - & $\begin{array}{l}\text { Trenched fault infiltration in Alcove } 8 \text {, } \\
3 / 26 / 2002-8 / 20 / 2002 \text {. }\end{array}$ \\
\hline $\begin{array}{l}\text { LB0110A8N3LIQR.001 } \\
\text { [DIRS 157001] }\end{array}$ & 16.5 & $\begin{array}{c}6-154 \\
6-155 \\
6-156 \\
6-158 \\
\mathrm{I}-3\end{array}$ & $\begin{array}{l}\mathrm{I}-11 \mathrm{a} \\
\mathrm{I}-11 \mathrm{~b} \\
\mathrm{I}-12\end{array}$ & $\begin{array}{l}\text { Preliminary observations from the fault test at } \\
\text { Alcove } 8 / \text { Niche } 3 \text { (Niche } 3107 \text { ). }\end{array}$ \\
\hline $\begin{array}{l}\text { LB0204NICH3TRC.001 } \\
\text { [DIRS 158478] }\end{array}$ & - & $\begin{array}{l}6-158 \\
6-159 \\
\end{array}$ & - & $\begin{array}{l}\text { Fault infiltration test tracer sampling } \\
\text { April 2001-March } 2002 .\end{array}$ \\
\hline $\begin{array}{l}\text { LB0209A8N3LIQR.001 } \\
\text { [DIRS 165461] }\end{array}$ & 16.5 & $\begin{array}{c}6-155 \\
1-3\end{array}$ & $\begin{array}{l}\mathrm{I}-11 \mathrm{C} \\
\mathrm{I}-12 \\
\end{array}$ & $\begin{array}{l}\text { Resistance measurements from Borehole } 10 \text { in } \\
\text { Niche } 3107 \text { (Niche 3, 5/23/2001-9/3/2002). }\end{array}$ \\
\hline $\begin{array}{l}\text { LB0303A8N3LIQR.001 } \\
\text { [DIRS 162570] }\end{array}$ & - & $\begin{array}{c}6-155 \\
6-157 \\
6-159 \\
\mathrm{I}-3\end{array}$ & - & $\begin{array}{l}\text { Alcove } 8 / \text { Niche } 3 \text { (Niche } 3107 \text { ) seepage data } \\
\text { compilation. }\end{array}$ \\
\hline $\begin{array}{l}\text { LB0110A8N3GPRB.00 } \\
1 \text { [DIRS 156912] }\end{array}$ & - & $\begin{array}{l}6-160 \\
6-161\end{array}$ & - & $\begin{array}{l}\text { Pre-seepage test ground penetrating radar } \\
\text { tomography in radial borehole arrays between } \\
\text { Alcove } 8 \text { (ECRB) and Niche } 3107 \text { (Niche } 3 \text {, } \\
\text { ESF). }\end{array}$ \\
\hline $\begin{array}{l}\text { GS031008312242.007 } \\
\text { [DIRS 166089] }\end{array}$ & 6.12 .4 & $\begin{array}{l}6-163 \\
6-164\end{array}$ & - & $\begin{array}{l}\text { Large plot infiltration in Alcove } 8 \text {, } \\
8 / 20 / 2002-11 / 19 / 2002 \text {. }\end{array}$ \\
\hline $\begin{array}{l}\text { GS030608312242.005 } \\
\text { [DIRS 166200] }\end{array}$ & - & $6-163$ & - & $\begin{array}{l}\text { Surface infiltration in a large plot in Alcove } 8 \\
\text { using permeameters from } 11 / 19 / 2002- \\
03 / 24 / 2003 \text {. }\end{array}$ \\
\hline $\begin{array}{l}\text { LB0306A8N3LIQR.001 } \\
\text { [DIRS 165405] }\end{array}$ & - & $\begin{array}{l}6-165 \\
6-166\end{array}$ & - & $\begin{array}{l}\text { Fault infiltration test from Alcove } 8 \text { to Niche } \\
3107 \text { (Niche 3, 9/18/2002-10/16/2002). }\end{array}$ \\
\hline $\begin{array}{l}\text { LB0308A8N3SEEP.001 } \\
\text { [DIRS 166090] }\end{array}$ & - & $6-166$ & - & $\begin{array}{l}\text { Measurements of seepage at Niche } 3 \text { (Niche } \\
3107 \text { ) from injection tests in an infiltration plot } \\
\text { located at Alcove } 8 \text { of the ECRB, } \\
10 / 16 / 2002-4 / 2 / 2003 \text {. }\end{array}$ \\
\hline
\end{tabular}

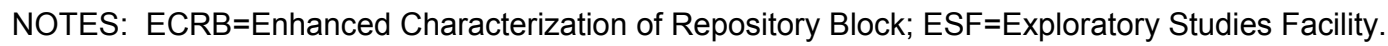




\subsubsection{Data for Alcove 8 / Niche 3 (Niche 3107) Tests and Summary of the Alcove 1 Tests (For Reference)}

Table 4-12b. Data for Alcove 8 / Niche 3 (Niche 3107) Tests and Summary of the Alcove 1 Tests (For Reference)

\begin{tabular}{|c|c|c|c|c|}
\hline \multirow[b]{2}{*}{ Inputs } & \multicolumn{3}{|c|}{ Used in } & \multirow[b]{2}{*}{ Description } \\
\hline & Section & Figure & Table & \\
\hline $\begin{array}{l}\text { GS030508312242.004 } \\
\text { [DIRS 165545] }\end{array}$ & 6.12 .1 .2 & - & - & $\begin{array}{l}\text { Photographs from Niche } 3 \text { (Niche } 3107 \text { ) of the } \\
\text { Alcove } 8 / \text { Niche } 3 \text { (Niche } 3107 \text { ) seepage } \\
\text { experiment during construction showing } \\
\text { construction water in Niche } 3 \text { (Niche } 3107 \text { ), } \\
3 / 6 / 2000\end{array}$ \\
\hline $\begin{array}{l}\text { MO9901MWDGFM31.000 } \\
\text { a }[\text { DIRS 103769] }\end{array}$ & 6.12 .1 .2 & - & - & Geologic framework model, Version GFM 3.1 \\
\hline $\begin{array}{l}\text { GS010608312242.004 } \\
\text { [DIRS 165542] }\end{array}$ & 6.12 .1 .3 .1 & - & - & $\begin{array}{l}\text { Crossover Alcove/Seepage into Niche } 3 \\
\text { (Niche 3107): small plot infiltration using a cylinder } \\
\text { permeameter, } 8 / 9 / 2000-8 / 21 / 2000\end{array}$ \\
\hline $\begin{array}{l}\text { GS010608312242.002 } \\
\text { [DIRS 165543] }\end{array}$ & 6.12 .1 .3 .1 & - & - & $\begin{array}{l}\text { Crossover Alcove/Seepage into Niche } 3 \\
\text { (Niche 3107): small plot infiltration using a box } \\
\text { permeameter, } 8 / 28 / 2000-12 / 14 / 2000\end{array}$ \\
\hline $\begin{array}{l}\text { GS990108312242.006 } \\
\text { [DIRS 162979] }\end{array}$ & - & - & $6-30$ & $\begin{array}{l}\text { Pulse flow meter data for infiltration on surface, } \\
\text { Phase I, May 9, 1998-December 4, } 1998\end{array}$ \\
\hline $\begin{array}{l}\text { GS000308312242.002 } \\
\text { [DIRS 156911] }\end{array}$ & 6.12 .5 .1 & - & $6-30$ & $\begin{array}{l}\text { Seepage data for water collected in Alcove } 1 \text {, } \\
\text { Phase I, 5/5/1998-8/27/1998 }\end{array}$ \\
\hline $\begin{array}{l}\text { GS000808312242.006 } \\
\text { [DIRS 162980] }\end{array}$ & - & - & $6-30$ & $\begin{array}{l}\text { Pulse flow meter data for infiltration on surface, } \\
\text { Phase II, 2/19/1999-6/20/2000 }\end{array}$ \\
\hline $\begin{array}{l}\text { GS000399991221.003 } \\
\text { [DIRS 147024] }\end{array}$ & - & - & $6-30$ & $\begin{array}{l}\text { Preliminary infiltration, seepage, tracer data, } \\
\text { Phase II, 2/19/1999-12/15/1999 }\end{array}$ \\
\hline $\begin{array}{l}\text { GS001108312242.009 } \\
\text { [DIRS 165202] }\end{array}$ & - & - & $6-30$ & $\begin{array}{l}\text { Tracer data for water collected in Alcove } 1 \text {, } \\
\text { Phase II, } 5 / 9 / 1999-7 / 5 / 2000\end{array}$ \\
\hline
\end{tabular}

a The Technical Data Management System shows DTN: MO9901MWDGFM31.000 [DIRS 103769] to be superseded by DTN: MO0012MWDGFM02.002 [DIRS 153777]; however, the new DTN does not include the data used for development of this analysis. The comment section on the Technical Data Information Form for the more recent DTN also states: "GFM2000 does not invalidate GFM3.1." This scientific analysis report maintains the use of the original DTN. 


\subsubsection{Data of Busted Butte Unsaturated Zone Transport Test}

\subsubsection{Data Used to Illustrate Busted Butte Unsaturated Zone Transport Test Results (Direct Input)}

Table 4-13a. Data Used to Illustrate Busted Butte Unsaturated Zone Transport Test Results (Direct Input)

\begin{tabular}{|c|c|c|c|c|}
\hline \multirow[b]{2}{*}{ Inputs } & \multicolumn{3}{|c|}{ Used in } & \multirow[b]{2}{*}{ Description $^{a}$} \\
\hline & Section & Figure(s) & Table & \\
\hline $\begin{array}{l}\text { LA0302WS831372.001 } \\
\text { [DIRS 162765] }\end{array}$ & - & $\begin{array}{l}6-172 \\
6-173\end{array}$ & - & $\begin{array}{l}\text { Fluorescein plumes observed in Phase 1a } \\
\text { mineback. }\end{array}$ \\
\hline $\begin{array}{l}\text { LA9909WS831372.001 } \\
\text { [DIRS 122739] }\end{array}$ & 6.13.2.2 & $\begin{array}{l}6-175 \\
6-176 \\
6-177 \\
6-178 \\
6-179 \\
\end{array}$ & - & $\begin{array}{l}\text { Busted Butte UZ transport test: Phase I } \\
\text { collection pad extract concentrations. }\end{array}$ \\
\hline $\begin{array}{l}\text { LA9909WS831372.002 } \\
\text { [DIRS 122741] }\end{array}$ & 6.13 .2 .2 & $\begin{array}{l}6-175 \\
6-176 \\
6-177 \\
6-178 \\
6-179 \\
\end{array}$ & - & $\begin{array}{l}\text { Busted Butte UZ transport test: Phase I } \\
\text { collection pad tracer loading and tracer } \\
\text { concentrations. }\end{array}$ \\
\hline $\begin{array}{l}\text { LA0112WS831372.001 } \\
\text { [DIRS 157100] }\end{array}$ & - & $\begin{array}{l}6-182 \\
6-183 \\
6-184 \\
6-185 \\
6-186 \\
\end{array}$ & - & $\begin{array}{l}\text { Busted Butte UZ transport test: Phase II } \\
\text { collection pad tracer loading. }\end{array}$ \\
\hline $\begin{array}{l}\text { LA0112WS831372.002 } \\
\text { [DIRS 157115] }\end{array}$ & - & $\begin{array}{l}6-182 \\
6-183 \\
6-184 \\
6-185 \\
6-186 \\
\end{array}$ & - & $\begin{array}{l}\text { Busted Butte UZ transport test: Phase II } \\
\text { collection pad tracer concentrations. }\end{array}$ \\
\hline $\begin{array}{l}\text { LA0112WS831372.003 } \\
\text { [DIRS 157106] }\end{array}$ & - & $\begin{array}{l}6-182 \\
6-183 \\
6-184 \\
6-185 \\
6-186 \\
\end{array}$ & - & $\begin{array}{l}\text { Busted Butte UZ transport test: Phase II } \\
\text { normalized collection pad tracer } \\
\text { concentrations. }\end{array}$ \\
\hline $\begin{array}{l}\text { LB00032412213U.001 } \\
\text { [DIRS 149214] }\end{array}$ & - & $\begin{array}{l}6-187 \\
6-188 \\
6-189 \\
6-190\end{array}$ & - & $\begin{array}{l}\text { Busted Butte ground-penetrating-radar data } \\
\text { collected June } 1998 \text { through February } 2000 \text { at } \\
\text { the Unsaturated Zone Transport Test (UZTT): } \\
\text { GPR velocity data. }\end{array}$ \\
\hline $\begin{array}{l}\text { LB0110BSTBTGPR.001 } \\
\text { [DIRS 156913] }\end{array}$ & - & $6-190$ & - & $\begin{array}{l}\text { Time sequence ground-penetrating-radar } \\
\text { tomography for the Busted Butte tracer } \\
\text { imbibition test. }\end{array}$ \\
\hline $\begin{array}{l}\text { LA0201WS831372.004 } \\
\text { [DIRS 165422] }\end{array}$ & - & $\begin{array}{l}6-191 \\
6-192 \\
\end{array}$ & - & $\begin{array}{l}\text { Calculated moisture content for the Busted } \\
\text { Butte site Phase II collection boreholes. }\end{array}$ \\
\hline $\begin{array}{l}\text { LA0008WS831372.001 } \\
\text { [DIRS 156582] }\end{array}$ & - & $\begin{array}{l}6-193 \\
6-194\end{array}$ & - & $\begin{array}{l}\text { Calculated daily injection rates for the Busted } \\
\text { Butte UZTTs. }\end{array}$ \\
\hline
\end{tabular}

${ }^{a}$ Roman or Arabic numerals are used interchangeably in the designation of test phases; they are consistent with their usage in the supporting DTN.

GPR = Ground Penetrating Radar; UZ = unsaturated zone. 


\subsubsection{Data Used to Corroborate Busted Butte Unsaturated Zone Transport Test (For Reference)}

Table 4-13b. Data Used to Corroborate Busted Butte Unsaturated Zone Transport Test (For Reference)

\begin{tabular}{|c|c|c|c|c|}
\hline \multirow[b]{2}{*}{ Inputs } & \multicolumn{3}{|c|}{ Used in } & \multirow[b]{2}{*}{ Description } \\
\hline & Section & Figure(s) & Table(s) & \\
\hline $\begin{array}{l}\text { LA9909WS831372.016 } \\
\text { [DIRS 140093] }\end{array}$ & 6.13.1.11 & - & - & $\begin{array}{l}\text { lon chromatography pore-water analysis for rock } \\
\text { samples from Busted Butte (used in report as } \\
\text { reference for pore-water composition). }\end{array}$ \\
\hline $\begin{array}{l}\text { LA9909WS831372.017 } \\
\text { [DIRS 140097] }\end{array}$ & 6.13.1.11 & - & - & $\begin{array}{l}\text { pH pore water in rock samples from Busted Butte } \\
\text { (used in report as reference for pore-water } \\
\text { composition). }\end{array}$ \\
\hline $\begin{array}{l}\text { LA9909WS831372.018 } \\
\text { [DIRS 140101] }\end{array}$ & 6.13 .1 .11 & - & - & $\begin{array}{l}\text { Gravimetric moisture content of rock samples } \\
\text { from Busted Butte (used in report as reference for } \\
\text { pore-water composition). }\end{array}$ \\
\hline $\begin{array}{l}\text { LA9910WS831372.008 } \\
\text { [DIRS 147156] }\end{array}$ & 6.13 .2 .1 & - & $6-36$ & $\begin{array}{l}\text { Busted Butte UZTT: gravimetric moisture content } \\
\text { and bromide concentration in selected Phase } 1 \mathrm{~A} \\
\text { rock samples. }\end{array}$ \\
\hline $\begin{array}{l}\text { MO0004GSC00167.000 } \\
\text { [DIRS 150300] }\end{array}$ & & $\begin{array}{l}6-187 \\
6-188\end{array}$ & - & $\begin{array}{l}\text { As-built coordinates of boreholes in the test } \\
\text { alcove and running drift, Busted Butte test facility } \\
\text { (BBTF). }\end{array}$ \\
\hline $\begin{array}{l}\text { LL990612704244.098 } \\
\text { [DIRS 147168] }\end{array}$ & 6.13 .4 .2 & - & - & $\begin{array}{l}\text { ERT data for Busted Butte, electrical properties of } \\
\text { the rock were measured during infiltration. }\end{array}$ \\
\hline $\begin{array}{l}\text { LA0311SD831372.001 } \\
\text { [DIRS 166197] }\end{array}$ & 6.13 .5 .2 & - & - & $\begin{array}{l}\text { In situ air permeability measurements at Busted } \\
\text { Butte. }\end{array}$ \\
\hline $\begin{array}{l}\text { LA0108TV12213U.001 } \\
\text { [DIRS 161525] }\end{array}$ & 6.13 .6 & - & - & $\begin{array}{l}\text { Static batch sorption coefficients and retardation } \\
\text { coefficients. }\end{array}$ \\
\hline $\begin{array}{l}\text { GS990708314224.007 } \\
\text { [DIRS 164604] }\end{array}$ & $\mathrm{H} 6$ & - & - & $\begin{array}{l}\text { Detailed line survey data for Busted Butte access } \\
\text { drift and Busted Butte cross-drift. }\end{array}$ \\
\hline $\begin{array}{l}\text { LA0204SL831372.001 } \\
\text { [DIRS 164749] }\end{array}$ & $\mathrm{H} 7$ & $\mathrm{H}-2$ & $\mathrm{H}-1$ & $\begin{array}{l}\text { Mineralogy of the Busted Butte Phase } 2 \text { test } \\
\text { block. }\end{array}$ \\
\hline $\begin{array}{l}\text { LA0207SL831372.001 } \\
\text { [DIRS 160824] }\end{array}$ & - & - & $\mathrm{H}-3$ & $\begin{array}{l}\text { Lithostratigraphic classification of hydrologic- } \\
\text { property core-sampling depths, Busted Butte } \\
\text { Phase } 2 \text { test block. }\end{array}$ \\
\hline $\begin{array}{l}\text { GS990708312242.008 } \\
\text { [DIRS 109822] }\end{array}$ & - & - & $\begin{array}{l}\mathrm{H}-3 \\
\mathrm{H}-6\end{array}$ & $\begin{array}{l}\text { Physical and hydraulic properties of core samples } \\
\text { from Busted Butte boreholes. }\end{array}$ \\
\hline $\begin{array}{l}\text { GS960808312231.004 } \\
\text { [DIRS 108985] }\end{array}$ & - & - & $\mathrm{H}-4$ & $\begin{array}{l}\text { Physical properties, water content, and water } \\
\text { potential for samples from lower depths in } \\
\text { Boreholes USW SD-7 and USW SD-12. } \\
\text { Submitted: } 08 / 30 / 96 \text {. }\end{array}$ \\
\hline $\begin{array}{l}\text { GS960808312231.005 } \\
\text { [DIRS 108995] }\end{array}$ & - & - & $\mathrm{H}-5$ & Saturated hydraulic conductivity of Busted Butte. \\
\hline $\begin{array}{l}\text { GS951108312231.009 } \\
\text { [DIRS 108984] }\end{array}$ & - & - & $\mathrm{H}-5$ & $\begin{array}{l}\text { Physical properties, water content, and water } \\
\text { potential for Borehole USW SD-7. Submitted: } \\
\text { 09/26/95. }\end{array}$ \\
\hline $\begin{array}{l}\text { GS990308312242.007 } \\
\text { [DIRS 107185] }\end{array}$ & - & - & $\mathrm{H}-6$ & $\begin{array}{l}\text { Laboratory and centrifuge measurements of } \\
\text { physical and hydraulic properties of core samples } \\
\text { from Busted Butte boreholes. }\end{array}$ \\
\hline
\end{tabular}

NOTES: ERT = Electrical Resistance Tomography; UZTT = Unsaturated Zone Transport Test. 


\subsubsection{Data of Geochemical Interpretations}

\subsubsection{Data Used to Support Geochemical Interpretations (Direct Input)}

Table 4-14a. Data Used to Support Geochemical Interpretations (Direct Input)

\begin{tabular}{|c|c|c|c|c|}
\hline \multirow[b]{2}{*}{ Inputs } & \multicolumn{3}{|c|}{ Used in } & \multirow[b]{2}{*}{ Description } \\
\hline & Section(s) & Figure(s) & Table(s) & \\
\hline $\begin{array}{l}\text { GS020408312272.003 } \\
\text { [DIRS 160899] }\end{array}$ & - & - & $6-37$ & $\begin{array}{l}\text { Collection and analysis of pore-water samples } \\
\text { for the period from April } 2001 \text { to February } 2002 . \\
\text { Water chemistry analyses for physical } \\
\text { parameters; common anions and cations from } 15 \\
\text { ECRB-SYS-Series boreholes, USW SD-9 and } \\
\text { USW NRG-7/7A. }\end{array}$ \\
\hline $\begin{array}{l}\text { GS030408312272.002 } \\
\text { [DIRS 165226] }\end{array}$ & - & - & $6-37$ & $\begin{array}{l}\text { Analysis of water-quality samples for the period } \\
\text { from July } 2002 \text { to November } 2002 \text {. Water } \\
\text { chemistry analyses for physical parameters; } \\
\text { common anions and cations; and trace metals. }\end{array}$ \\
\hline $\begin{array}{l}\text { GS000308313211.001 } \\
\text { [DIRS 162015] }\end{array}$ & $\begin{array}{l}6.14 .1 .2 \\
16.6\end{array}$ & - & $\begin{array}{l}6-38 \\
6-39 \\
6-40\end{array}$ & $\begin{array}{l}\text { Geochemistry of repository block-chemical } \\
\text { composition of rock from ECRB cross-drift. }\end{array}$ \\
\hline $\begin{array}{l}\text { LAJF831222AQ98.004 } \\
\text { [DIRS 107364] }\end{array}$ & - & $6-195$ & $6-41$ & $\begin{array}{l}\text { Chloride, bromide, sulfate, and chlorine- } 36 \\
\text { analyses of salts leached from ESF rock } \\
\text { samples. }\end{array}$ \\
\hline $\begin{array}{l}\text { LAJF831222AQ98.009 } \\
\text { [DIRS 145650] }\end{array}$ & - & $6-195$ & - & $\begin{array}{l}\text { Chlorine-36 analyses of salts leached from ESF } \\
\text { Niche } 1 \text { (Niche } 3566 \text { ) drillcore. }\end{array}$ \\
\hline $\begin{array}{l}\text { GS990183122410.001 } \\
\text { [DIRS 146125] }\end{array}$ & - & - & $6-42$ & $\begin{array}{l}\text { Tritium data from pore water from ESF borehole } \\
\text { cores, } 1997 \text { analyses by USGS. Tritium } \\
\text { abundance data from Boreholes ESF- } \\
\text { AL\#3-RBT\#1, ESF-AL\#3-RBT\#4, } \\
\text { ESF-AL\#4-RBT\#1, ESF-NAD-GTB\#1A, } \\
\text { ESF-NDR-MF\#1, ESF-SAD-GTB\#1, } \\
\text { ESF-SR-MOISTSTDY\#1, ESF-SR- } \\
\text { MOISTSTDY\#2 and ESF-SR-MOISTSTDY\#13, } \\
\text { for the period 1/16/97 through 11/6/97. }\end{array}$ \\
\hline $\begin{array}{l}\text { GS020408312272.002 } \\
\text { [DIRS 162342] }\end{array}$ & - & - & $6-42$ & $\begin{array}{l}\text { Tritium abundance data from pore water in core } \\
\text { samples from Yucca Mountain ESF boreholes for } \\
\text { the period of } 4 / 30 / 1998-3 / 21 / 2001 \text {. }\end{array}$ \\
\hline $\begin{array}{l}\text { GS021208312272.005 } \\
\text { [DIRS 162934] }\end{array}$ & - & - & $6-42$ & $\begin{array}{l}\text { Tritium abundance data from pore water in core } \\
\text { samples from Yucca Mountain ESF ECRB. } \\
\text { May } 20,2001 \text { to July 23, } 2002 \text {. }\end{array}$ \\
\hline $\begin{array}{l}\text { GS030208312272.001 } \\
\text { [DIRS 162935] }\end{array}$ & - & - & $6-42$ & $\begin{array}{l}\text { Gas and water vapor chemistry data in Yucca } \\
\text { Mountain ESF ECRB bulkheads. }\end{array}$ \\
\hline $\begin{array}{l}\text { GS010808315215.003 } \\
\text { [DIRS 164844] }\end{array}$ & - & $\begin{array}{l}6-196 \\
6-199\end{array}$ & - & $\begin{array}{l}\text { Fluid inclusion homogenization temperatures } \\
\text { from the ESF and ECRB, } 12 / 99 \text { to } 4 / 01 \text {. }\end{array}$ \\
\hline $\begin{array}{l}\text { GS020908315215.003 } \\
\text { [DIRS 164846] }\end{array}$ & - & $\begin{array}{l}6-196 \\
6-197 \\
6-198 \\
6-199\end{array}$ & - & $\begin{array}{l}\text { Fluid inclusion homogenization temperatures } \\
\text { from ESF and ECRB calcite and fluorite } \\
\text { samples, } 10 / 01 \text { to } 5 / 02 \text {. }\end{array}$ \\
\hline
\end{tabular}

NOTES: $E C R B=$ Enhanced Characterization of Repository Block; ESF = Exploratory Studies Facility; USGS = United States Geological Survey. 
Table 4-14a. Data Used to Support Geochemical Interpretations (Direct Input) (Continued)

\begin{tabular}{|c|c|c|c|c|}
\hline \multirow[b]{2}{*}{ Inputs } & \multicolumn{3}{|c|}{ Used } & \multirow[b]{2}{*}{ Description } \\
\hline & Section(s) & Figure(s) & Table(s) & \\
\hline $\begin{array}{l}\text { GS970208315215.005 } \\
\text { [DIRS 107351] }\end{array}$ & - & $\begin{array}{l}6-197 \\
6-198 \\
6-199\end{array}$ & - & $\begin{array}{l}\text { Carbon and oxygen stable isotope Kiel analyses of } \\
\text { calcite from the ESF and USW G-1, G-2 AND G-4, } \\
\text { UE-25 A\#1, USW NRG-6 and NRG-7/7A, and } \\
\text { UE-25 UZ\#16, April 1996-January 1997. }\end{array}$ \\
\hline $\begin{array}{l}\text { GS970808315215.010 } \\
\text { [DIRS 145920] }\end{array}$ & - & $\begin{array}{l}6-197 \\
6-198 \\
6-199\end{array}$ & - & $\begin{array}{l}\text { Carbon and oxygen stable isotope analyses of } \\
\text { calcite from the ESF and USW G-1, G-2, AND } \\
\text { G-3/GU-3, from } 01 / 16 / 97 \text { to } 07 / 18 / 97 \text {. }\end{array}$ \\
\hline $\begin{array}{l}\text { GS980908315213.002 } \\
\text { [DIRS 146088] }\end{array}$ & - & $\begin{array}{l}6-197 \\
6-198 \\
6-199 \\
\end{array}$ & - & $\begin{array}{l}\text { Carbon and oxygen stable isotopic compositions of } \\
\text { ESF secondary calcite occurrences, } 10 / 1 / 97 \text { to } \\
8 / 15 / 98 \text {. }\end{array}$ \\
\hline $\begin{array}{l}\text { GS990908315213.001 } \\
\text { [DIRS 153379] }\end{array}$ & - & $\begin{array}{l}6-197 \\
6-198 \\
6-199 \\
\end{array}$ & - & $\begin{array}{l}\text { Stable carbon and oxygen isotope macro- and } \\
\text { micro-analysis of calcite from the ESF between } \\
2 / 96 \text { and } 5 / 99 \text {. }\end{array}$ \\
\hline $\begin{array}{l}\text { GS020908315215.004 } \\
\text { [DIRS 164847] }\end{array}$ & - & 6-199 & - & $\begin{array}{l}\text { Stable carbon and oxygen isotope analyses of } \\
\text { ESF/ECRB calcite and USW SD-6 and USW } \\
\text { WT-24 whole rock; 1/1999-6/2002. }\end{array}$ \\
\hline $\begin{array}{l}\text { GS010808315215.004 } \\
\text { [DIRS 164850] }\end{array}$ & - & $6-199$ & - & $\begin{array}{l}\text { Uranium and lead concentrations, lead isotopic } \\
\text { compositions, and U-Pb isotope ages for the ESF } \\
\text { secondary minerals determined at the Royal } \\
\text { Ontario Museum between April 20, 2000, and } \\
\text { April } 19,2001 .\end{array}$ \\
\hline $\begin{array}{l}\text { GS021008315215.005 } \\
\text { [DIRS 164848] }\end{array}$ & - & $6-199$ & - & $\begin{array}{l}\text { Uranium, thorium, and lead concentrations, lead } \\
\text { isotopic compositions, } \mathrm{U}-\mathrm{Pb} \text { isotope ages and } \\
{ }^{234} \mathrm{U} /{ }^{238} \mathrm{U} \text { and }{ }^{230} \mathrm{Th} /{ }^{238} \mathrm{U} \text { activity ratios for the ESF } \\
\text { and ECRB secondary calcite, opal, chalcedony and } \\
\text { fluorite determined at the Royal Ontario Museum } \\
\text { between } 11 / 16 / 01 \text { and } 4 / 7 / 02 \text {. }\end{array}$ \\
\hline $\begin{array}{l}\text { GS021208315215.009 } \\
\text { [DIRS 164750] }\end{array}$ & 15 & $\begin{array}{c}6-203 \\
1-2\end{array}$ & $\begin{array}{c}6-44 \\
1-2\end{array}$ & $\begin{array}{l}\mathrm{U} \text { abundances, }{ }^{238} \mathrm{U}-{ }^{234} \mathrm{U}-{ }^{230} \mathrm{Th}-{ }^{232} \mathrm{Th} \text { activity ratios, } \\
\text { and calculated }{ }^{230} \mathrm{Th} / \mathrm{U} \text { ages, and initial }{ }^{234} \mathrm{U} /{ }^{238} \mathrm{U} \\
\text { activity ratios determined for sequential in situ } \\
\text { microdigestions of opal hemispheres from the ESF } \\
\text { by thermal ionization mass spectrometry. }\end{array}$ \\
\hline $\begin{array}{l}\text { GS021208312272.008 } \\
\text { [DIRS 164609] }\end{array}$ & 6.14.3.2 & $\begin{array}{l}6-204 \\
6-205 \\
6-206 \\
6-207 \\
6-208 \\
\end{array}$ & $6-45$ & $\begin{array}{l}\text { Uranium and thorium concentrations and } \\
{ }^{234} \cup-{ }^{230} \mathrm{Th}^{238} \mathrm{U}-{ }^{232} \mathrm{Th} \text { isotopic compositions from } \\
\text { whole rock samples from the ECRB cross-drift and } \\
\text { ESF collected between December } 5-6,2001 \text {, and } \\
\text { analyzed between February and June } 2002 \text {. }\end{array}$ \\
\hline $\begin{array}{l}\text { GS020608315215.002 } \\
\text { [DIRS 162126] }\end{array}$ & 6.14.1.2 & $\begin{array}{l}6-209 \\
6-216 \\
6-217\end{array}$ & - & $\begin{array}{l}\text { Carbon dioxide abundances, carbon dioxide } \\
\text { concentrations, and normative calcite } \\
\text { concentrations for cuttings from Boreholes USW } \\
\text { SD-6, USW WT-24, and ECRB cross-drift } \\
\text { boreholes, Area 25, Nevada Test Site, determined } \\
\text { by carbon dioxide evolution between May } 25,2000 \text {, } \\
\text { and September } 8,2000 \text {. }\end{array}$ \\
\hline
\end{tabular}

NOTES: $E C R B=E n h a n c e d$ Characterization of Repository Block; ESF=Exploratory Studies Facility. 
Table 4-14a. Data Used to Support Geochemical Interpretations (Direct Input) (Continued)

\begin{tabular}{|c|c|c|c|c|}
\hline \multirow[b]{2}{*}{ Inputs } & \multicolumn{3}{|c|}{ Used in } & \multirow[b]{2}{*}{ Description } \\
\hline & Section(s) & Figure(s) & Table(s) & \\
\hline $\begin{array}{l}\text { GS021008315215.007 } \\
\text { [DIRS 162127] }\end{array}$ & 6.14 .1 .2 & $\begin{array}{l}6-209 \\
6-216\end{array}$ & - & $\begin{array}{l}\text { Carbon dioxide abundance, carbon dioxide } \\
\text { concentration, and normative calcite } \\
\text { concentrations in } 333 \text { powdered cuttings samples } \\
\text { from Borehole USW WT-24 determined by } \mathrm{CO}_{2} \\
\text { evolution between July } 1998 \text { and August } 1999 .\end{array}$ \\
\hline $\begin{array}{l}\text { GS030808315215.001 } \\
\text { [DIRS 165426] }\end{array}$ & - & $\begin{array}{l}6-204 \\
6-210 \\
6-217 \\
6-218\end{array}$ & - & $\begin{array}{l}\text { Calcite and opal mineralization occurrences in } \\
\text { lithophysal cavities, fractures, and breccia zones } \\
\text { from the line survey in the east-west cross-drift. }\end{array}$ \\
\hline $\begin{array}{l}\text { GS030908315215.002 } \\
\text { [DIRS 166097] }\end{array}$ & - & $\begin{array}{l}6-209 \\
6-216 \\
6-217\end{array}$ & - & $\begin{array}{l}\text { XRF fluorescence elemental compositions } \\
\text { determined on cuttings from USW SD-6 and USW } \\
\text { WT-24. }\end{array}$ \\
\hline
\end{tabular}

NOTES: ESF=Exploratory Studies Facility; XRF=X-ray fluorescence.

\subsubsection{Data Used to Corroborate Geochemical Interpretations (For Reference)}

Table 4-14b. Data Used to Corroborate Geochemical Interpretations (For Reference)

\begin{tabular}{|c|c|c|c|c|}
\hline \multirow[b]{2}{*}{ Inputs } & \multicolumn{3}{|c|}{ Used in } & \multirow[b]{2}{*}{ Description } \\
\hline & Section & Figure(s) & Table & \\
\hline $\begin{array}{l}\text { LA0002JF12213U.001 } \\
\text { [DIRS 154760] }\end{array}$ & 6.14.1.1 & - & - & $\begin{array}{l}\text { Chemistry data for pore water extracted from } \\
\text { drillcore from surface-based Boreholes } \\
\text { USW NRG-6, USW NRG-7A, USW UZ-7A, } \\
\text { USW UZ-14, UE-25 UZ\#16, USW UZ-N55, } \\
\text { USW SD-6, USW SD-7, USW SD-9, USW SD- } \\
\text { 12, and USW WT-24. }\end{array}$ \\
\hline $\begin{array}{l}\text { LA0002JF12213U.002 } \\
\text { [DIRS 156281] }\end{array}$ & 6.14 .1 .1 & - & - & $\begin{array}{l}\text { Chemistry data for pore water extracted from } \\
\text { ESF, cross-drift, and Busted Butte drillcore. }\end{array}$ \\
\hline $\begin{array}{l}\text { LAJF831222AQ98.011 } \\
\text { [DIRS 145402] }\end{array}$ & 6.14 .1 .1 & - & - & $\begin{array}{l}\text { Chloride, bromide, sulfate, and chlorine- } 36 \\
\text { analyses of springs, groundwater, perched } \\
\text { water, and surface runoff. }\end{array}$ \\
\hline $\begin{array}{l}\text { LA9909JF831222.012 } \\
\text { [DIRS 122736] }\end{array}$ & 6.14 .1 .1 & - & - & $\begin{array}{l}\text { Chloride, bromide, and sulfate analyses of pore } \\
\text { water extracted from ESF Niche } 1 \text { (Niche 3566) } \\
\text { and Niche } 2 \text { (Niche 3650) drillcore. }\end{array}$ \\
\hline $\begin{array}{l}\text { LL030408023121.027 } \\
\text { [DIRS 162949] }\end{array}$ & - & - & $6-41$ & $\begin{array}{l}\mathrm{Cl} \text { concentrations and } \mathrm{Cl} \text { ratios obtained from } \mathrm{YM} \\
\text { rock samples and analyzed by accelerator mass } \\
\text { spectrometry and ion chromatography. }\end{array}$ \\
\hline $\begin{array}{l}\text { LL031200223121.036 } \\
\text { [DIRS 168531] }\end{array}$ & - & $6-195$ & $6-41$ & $\begin{array}{l}\text { Chlorine concentrations and chlorine ratios } \\
\text { obtained from YM rock samples and analyzed by } \\
\text { accelerator mass spectrometry. }\end{array}$ \\
\hline $\begin{array}{l}\text { LA0305RR831222.001 } \\
\text { [DIRS 163422] }\end{array}$ & - & - & $6-41$ & $\begin{array}{l}\text { Chlorine- } 36 \text { and } \mathrm{Cl} \text { in salts leached from rock } \\
\text { samples for the chloride- } 36 \text { validation study. }\end{array}$ \\
\hline $\begin{array}{l}\text { LA0307RR831222.001 } \\
\text { [DIRS 164091] }\end{array}$ & - & - & $6-41$ & $\begin{array}{l}\text { Chloride, bromide, sulfate, and chlorine-36 } \\
\text { analyses of salts leached from cross-drift } \\
\text { samples in FY99 and FY00. }\end{array}$ \\
\hline
\end{tabular}

NOTES: ESF = Exploratory Studies Facility. 
Table 4-14b. Data Used to Corroborate Geochemical Interpretations (For Reference) (Continued)

\begin{tabular}{|c|c|c|c|c|}
\hline \multirow[b]{2}{*}{ Inputs } & \multicolumn{3}{|c|}{ Used in } & \multirow[b]{2}{*}{ Description } \\
\hline & Section & Figure(s) & Table & \\
\hline $\begin{array}{l}\text { LA0307RR831222.002 } \\
\text { [DIRS 164090] }\end{array}$ & - & - & $6-41$ & $\begin{array}{l}\text { Chloride, bromide, sulfate, and chlorine- } 36 \\
\text { analyses of salts leached from ESF }{ }^{36} \mathrm{Cl} \text { validation } \\
\text { drillcore samples in FY99. }\end{array}$ \\
\hline $\begin{array}{l}\text { GS021208315215.008 } \\
\text { [DIRS 164851] }\end{array}$ & - & $\begin{array}{l}6-200 \\
6-201 \\
6-202\end{array}$ & $6-43$ & $\begin{array}{l}{ }^{238} \mathrm{U}-{ }^{234} \mathrm{U}-{ }^{230} \mathrm{Th}-{ }^{232} \mathrm{Th} \text { isotope ratios and calculated } \\
\text { ages for opal hemispheres from sample hd2074 } \\
\text { (spc00506577) at Station } 30+51 \text { in the ESF } \\
\text { determined using ion-probe mass spectrometry. }\end{array}$ \\
\hline $\begin{array}{l}\text { GS951208312272.002 } \\
\text { [DIRS 151649] }\end{array}$ & 6.14.2.2 & - & - & $\begin{array}{l}\text { Tritium analyses of pore water from USW UZ-14, } \\
\text { USW NRG-6, USW NRG-7A, and UE-25 UZ\#16; } \\
\text { and of perched water from USW SD-7, USW } \\
\text { SD-9, USW UZ-14, and USW NRG-7A from } \\
12 / 09 / 92 \text { to 5/15/95. }\end{array}$ \\
\hline $\begin{array}{l}\text { GS990183122410.004 } \\
\text { [DIRS 146129] }\end{array}$ & 6.14 .2 .2 & - & - & $\begin{array}{l}\text { Tritium data from pore water from ESF borehole } \\
\text { cores, } 1998 \text { analyses by University of Miami. } \\
\text { Tritium abundance data from Boreholes } \\
\text { ESF-NAD-GTB\#1A, ESF-NDR-MF\#1, } \\
\text { ESF-SR-MOISTSTDY\#1, } \\
\text { ESF-SR-MOISTSTDY\#2, ESF-SR- } \\
\text { MOISTSTDY\#4, ESF-SR-MOISTSTDY\#5, } \\
\text { ESF-SR-MOISTSTDY\#6, } \\
\text { ESF-SR-MOISTSTDY\#7, } \\
\text { ESF-SR-MOISTSTDY\#13 and } \\
\text { ESF-SR-MOISTSTDY\#16, for the period 3/31/98 } \\
\text { through 8/20/98. }\end{array}$ \\
\hline $\begin{array}{l}\text { GS990408314224.001 } \\
\text { [DIRS 108396] }\end{array}$ & - & $6-204$ & - & $\begin{array}{l}\text { ESF, ECRB cross-drift, detailed line survey data } \\
\text { collected from stations } 00+00.89 \text { to } 14+95.18 \text {. }\end{array}$ \\
\hline $\begin{array}{l}\text { GS990408314224.002 } \\
\text { [DIRS 105625] }\end{array}$ & - & $6-204$ & - & $\begin{array}{l}\text { ESF, ECRB cross-drift, detailed line survey data } \\
\text { collected from stations } 15+00.85 \text { to } 26+63.85 \text {. }\end{array}$ \\
\hline $\begin{array}{l}\text { GS971108314224.020 } \\
\text { [DIRS 105561] }\end{array}$ & - & $\begin{array}{l}6-204 \\
6-213 \\
6-214 \\
\end{array}$ & - & $\begin{array}{l}\text { Revision } 1 \text { of detailed line survey data, Station } \\
0+60 \text { to Station } 4+00 \text {, north ramp starter tunnel, } \\
\text { ESF. }\end{array}$ \\
\hline $\begin{array}{l}\text { GS971108314224.021 } \\
\text { [DIRS 106007] }\end{array}$ & - & $\begin{array}{l}6-204 \\
6-213 \\
6-214 \\
\end{array}$ & - & $\begin{array}{l}\text { Revision } 1 \text { of detailed line survey data, Station } \\
4+00 \text { to Station } 8+00 \text {, north ramp, ESF. }\end{array}$ \\
\hline $\begin{array}{l}\text { GS950508314224.003 } \\
\text { [DIRS 107488] }\end{array}$ & - & $6-207$ & - & $\begin{array}{l}\text { Provisional results: geotechnical data - full } \\
\text { periphery map data from north ramp of the ESF, } \\
\text { Stations } 0+60 \text { to } 4+00 \text {. }\end{array}$ \\
\hline $\begin{array}{l}\text { GS980308315215.008 } \\
\text { [DIRS 107355] }\end{array}$ & - & $\begin{array}{l}6-210 \\
6-211 \\
6-212 \\
6-213 \\
6-215 \\
6-218 \\
\end{array}$ & - & $\begin{array}{l}\text { Line survey data from the ESF obtained to } \\
\text { estimate secondary mineral abundance. }\end{array}$ \\
\hline $\begin{array}{l}\text { GS960708314224.008 } \\
\text { [DIRS 105617] }\end{array}$ & - & $6-214$ & - & $\begin{array}{l}\text { Provisional results: geotechnical data for Station } \\
30+00 \text { to Station } 35+00, \text { main drift of the ESF. } \\
\text { Detailed line survey data. }\end{array}$ \\
\hline $\begin{array}{l}\text { GS000608314224.004 } \\
\text { [DIRS 152573] }\end{array}$ & - & $6-214$ & - & $\begin{array}{l}\text { Provisional results: geotechnical data for Station } \\
35+00 \text { to Station } 40+00 \text {, main drift of the ESF. }\end{array}$ \\
\hline
\end{tabular}

NOTES: $\quad$ ECRB = Enhanced Characterization of Repository Block; ESF = Exploratory Studies Facility; FY = Fiscal Year; YM = Yucca Mountain. 
Table 4-14b. Data Used to Corroborate Geochemical Interpretations (For Reference) (Continued)

\begin{tabular}{|c|c|c|c|c|}
\hline \multirow[b]{2}{*}{ Inputs } & \multicolumn{3}{|c|}{ Used in } & \multirow[b]{2}{*}{ Description } \\
\hline & Section & Figure(s) & Table & \\
\hline $\begin{array}{l}\text { GS960708314224.010 } \\
\text { [DIRS 106031] }\end{array}$ & - & $6-214$ & - & $\begin{array}{l}\text { Provisional results: geotechnical data for Station } \\
40+00 \text { to Station } 45+00 \text {, main drift of the ESF. } \\
\text { Detailed line survey data. VA supporting data. }\end{array}$ \\
\hline $\begin{array}{l}\text { GS960908314224.014 } \\
\text { [DIRS 106033] }\end{array}$ & - & $\begin{array}{l}6-213 \\
6-214\end{array}$ & - & $\begin{array}{l}\text { Provisional results - ESF main drift, Station } \\
50+00 \text { to Station } 55+00 \text {. Detailed line survey } \\
\text { data. }\end{array}$ \\
\hline $\begin{array}{l}\text { GS970208314224.003 } \\
\text { [DIRS 106048] }\end{array}$ & - & $\begin{array}{l}6-213 \\
6-214\end{array}$ & - & $\begin{array}{l}\text { Geotechnical data for Station } 60+00 \text { to Station } \\
65+00 \text {, south ramp of the ESF. Provisional } \\
\text { results; detailed line survey data. }\end{array}$ \\
\hline $\begin{array}{l}\text { GS971108314224.022 } \\
\text { [DIRS 106009] }\end{array}$ & - & $\begin{array}{l}6-213 \\
6-214 \\
\end{array}$ & - & $\begin{array}{l}\text { Revision } 1 \text { of detailed line survey data, Station } \\
8+00 \text { to Station } 10+00 \text {, north ramp, ESF. }\end{array}$ \\
\hline $\begin{array}{l}\text { GS971108314224.023 } \\
\text { [DIRS 106010] }\end{array}$ & - & $\begin{array}{l}6-213 \\
6-214 \\
\end{array}$ & - & $\begin{array}{l}\text { Revision } 1 \text { of detailed line survey data, Station } \\
10+00 \text { to Station } 18+00 \text {, north ramp, ESF. }\end{array}$ \\
\hline $\begin{array}{l}\text { GS971108314224.024 } \\
\text { [DIRS 106023] }\end{array}$ & - & $\begin{array}{l}6-213 \\
6-214 \\
\end{array}$ & - & $\begin{array}{l}\text { Revision } 1 \text { of detailed line survey data, Station } \\
18+00 \text { to Station } 26+00 \text {, north ramp, ESF. }\end{array}$ \\
\hline $\begin{array}{l}\text { GS971108314224.025 } \\
\text { [DIRS 106025] }\end{array}$ & - & $\begin{array}{l}6-213 \\
6-214\end{array}$ & - & $\begin{array}{l}\text { Revision } 1 \text { of detailed line survey data, Station } \\
26+00 \text { to Station } 30+00 \text {, north ramp and main } \\
\text { drift, ESF. }\end{array}$ \\
\hline $\begin{array}{l}\text { GS971108314224.026 } \\
\text { [DIRS 106032] }\end{array}$ & - & $\begin{array}{l}6-213 \\
6-214 \\
\end{array}$ & - & $\begin{array}{l}\text { Revision } 1 \text { of detailed line survey data, Station } \\
45+00 \text { to Station } 50+00 \text {, main drift, ESF. }\end{array}$ \\
\hline $\begin{array}{l}\text { GS971108314224.028 } \\
\text { [DIRS 106047] }\end{array}$ & - & $\begin{array}{l}6-213 \\
6-214\end{array}$ & - & $\begin{array}{l}\text { Revision } 1 \text { of detailed line survey data, Station } \\
55+00 \text { to Station } 60+00 \text {, main drift and south } \\
\text { ramp, ESF. }\end{array}$ \\
\hline
\end{tabular}

NOTES: ESF = Exploratory Studies Facility.

\subsection{CRITERIA}

The general requirements to be satisfied by the TSPA-LA are stated in 10 CFR 63.114 [DIRS 156605]. Technical requirements to be satisfied by the TSPA-LA are identified in the Yucca Mountain Project Requirements Document (Canori and Leitner 2003 [DIRS 166275]). The acceptance criteria that will be used by the Nuclear Regulatory Commission (NRC) to determine whether the technical requirements have been met are identified in the Yucca Mountain Review Plan, Final Report (NRC 2003 [DIRS 163274]). The pertinent requirements and acceptance criteria for this scientific analysis report are summarized in Table 4-15.

Appropriate criteria for this scientific analysis report are Criteria 2 and 3 from Section 2.2.1.3.3.3 (Quantity and Chemistry of Water Contacting Engineered Barriers and Waste Forms), Section 2.2.1.3.6.3 (Flow Paths in the Unsaturated Zone), and Section 2.2.1.3.7.3 (Radionuclide Transport in the Unsaturated Zone) of the YMRP (NRC 2003 [DIRS 163274]). These criteria are documented in Table 3-1 of the TWP (BSC 2004 [DIRS 169654], and are listed in Table 4-15. 
Table 4-15. Project Requirements and YMRP Acceptance Criteria Applicable to This Scientific Analysis Report

\begin{tabular}{|c|c|c|c|}
\hline $\begin{array}{c}\text { Requirement } \\
\text { Number }^{\mathrm{a}}\end{array}$ & Requirement Title $^{a}$ & 10 CFR 63 Link & YMRP Acceptance Criteria \\
\hline $\begin{array}{l}\text { PRD-002/T- } \\
015\end{array}$ & $\begin{array}{l}\text { Requirements for } \\
\text { Performance } \\
\text { Assessment }\end{array}$ & $\begin{array}{l}10 \text { CFR 63.114(a-c) } \\
\text { [DIRS 156605] }\end{array}$ & $\begin{array}{l}\text { Section 2.2.1.3.3.3, Criteria } 2 \text { and } 3 \text { for } \\
\text { Quantity and Chemistry of Water Contacting } \\
\text { Waste Packages and Waste Forms }{ }^{b} \\
\text { Section 2.2.1.3.6.3, Criteria } 2 \text { and } 3 \text { for Flow } \\
\text { Path in the UZ }{ }^{\mathrm{c}} \\
\text { Section 2.2.1.3.7.3, Criteria } 2 \text { and } 3 \text { for } \\
\text { Radionuclide Transport in the UZ }{ }^{d}\end{array}$ \\
\hline
\end{tabular}

${ }^{a}$ From Canori and Leitner (2003 [DIRS 166275]).

b From NRC (2003 [DIRS 163274], Section 2.2.1.3.3.3).

c From NRC (2003 [DIRS 163274], Section 2.2.1.3.6.3).

${ }^{d}$ From NRC (2003 [DIRS 163274], Section 2.2.1.3.7.3).

$\mathrm{UZ}=$ unsaturated zone; YMRP = Yucca Mountain Review Plan.

The acceptance criteria identified in Sections 2.2.1.3.3.3, 2.2.1.3.6.3, and 2.2.1.3.7.3 of the YMRP (NRC 2003 [DIRS 163274]) are included below. In cases where subsidiary criteria are listed in the YMRP for a given criterion, only the subsidiary criteria addressed by this scientific analysis are listed below. Where a subcriterion includes several components, only some of those components may be addressed. How these components are addressed is summarized in Section 7.15 of this report.

Acceptance Criteria from Section 2.2.1.3.3.3, Quantity and Chemistry of Water Contacting Engineered Barriers and Waste Forms.

\section{Acceptance Criterion 2, Data are Sufficient for Model Justification:}

(1) Geological, hydrological, and geochemical values used in the license application are adequately justified. Adequate description of how the data were used, interpreted, and appropriately synthesized into the parameters is provided;

\section{Acceptance Criterion 3, Data Uncertainty Is Characterized and Propagated through Model Abstraction:}

(2) Parameter values, assumed ranges, probability distributions, and bounding assumptions used in the total system performance assessment calculations of quantity and chemistry of water contacting engineered barriers and waste forms are technically defensible and reasonable, based on data from the Yucca Mountain region (e.g., results from large block and drift-scale heater and niche tests), and a combination of techniques that may include laboratory experiments, field measurements, natural analog research, and process-level modeling studies; 


\section{Acceptance Criteria from Section 2.2.1.3.6, Flow Paths in the Unsaturated Zone}

\section{Acceptance Criterion 2, Data Are Sufficient for Model Justification:}

(1) Hydrological and thermal-hydrological-mechanical-chemical values used in the license application are adequately justified. Adequate descriptions of how the data were used, interpreted, and appropriately synthesized into the parameters are provided;

(2) The data on the geology, hydrology, and geochemistry of the unsaturated zone are collected using acceptable techniques;

(5) Sensitivity or uncertainty analyses are performed to assess data sufficiency, and verify the possible need for additional data;

Acceptance Criterion 3, Data Uncertainty Is Characterized and Propagated through Model Abstraction:

(5) Coupled processes are adequately represented;

(6) Uncertainties in the characteristics of the natural system and engineered materials are considered.

\section{Acceptance Criteria from Section 2.2.1.3.7, Radionuclide Transport in the Unsaturated Zone}

\section{Acceptance Criterion 2, Data Are Sufficient for Model Justification:}

(1) Geological, hydrological, and geochemical values, used in the license application, are adequately justified (e.g., flow-path length, sorption coefficients, retardation factors, colloid concentrations, etc.). Adequate descriptions of how the data were used, interpreted, and appropriately synthesized into the parameters are provided;

(3) Data on the geology, hydrology, and geochemistry of the unsaturated zone, including the influence of structural features, fracture distributions, fracture properties, and stratigraphy, used in the total system performance assessment abstraction are based on appropriate techniques. These techniques may include laboratory experiments, site-specific field measurements, natural analog research, and process-level modeling studies. As appropriate, sensitivity or uncertainty analyses, used to support the U.S. Department of Energy total system performance assessment abstraction, are adequate to determine the possible need for additional data. 


\section{Acceptance Criterion 3, Data Uncertainty Is Characterized and Propagated through Model Abstraction:}

(2) For those radionuclides where the total system performance assessment abstraction indicates that transport in fractures and matrix in the unsaturated zone is important to waste isolation: (i) estimated flow and transport parameters are appropriate and valid, based on techniques that may include laboratory experiments, field measurements, natural analog research, and process-level modeling studies, conducted under conditions relevant to the unsaturated zone at Yucca Mountain; and (ii) models are demonstrated to adequately reproduce field transport test results. For example, if a sorption coefficient approach is used, the assumptions implicit in that approach are verified;

(4) Uncertainty is adequately represented in parameter development for conceptual models, process-level models, and alternative conceptual models, considered in developing the abstraction of radionuclide transport in the unsaturated zone. This may be done either through sensitivity analyses or use of conservative limits.

The following additional criteria are identified in the TWP (BSC 2004 [DIRS 169654], Section 3.4). The work documented in the scientific analysis report will be consistent with the activities performed as part of Technical Work Plan: Regulatory Integration Evaluation of Analysis and Model Reports Supporting the TSPA-LA (BSC 2004 [DIRS 169653]) and will fulfill a portion of the Phase 2 work identified in that plan. It will also satisfy the requirements of AP-16.1Q, Condition Reporting and Resolution to enable closure of condition reports (CRs) generated as a result of the Corrective Action Program. Other requirements related to boundary conditions (BSC 2004 [DIRS 169654], Section 3.5) do not apply to this scientific analysis report.

\subsection{CODES, STANDARDS, AND REGULATIONS}

No codes, standards, or regulations other than those identified in the Project Requirements Documents (Canori and Leitner 2003 [DIRS 166275], Table 2-3) and determined to be applicable in Table 4-15, were used in this analysis report. 


\section{ASSUMPTIONS}

This scientific analysis report on ambient field-testing of processes presents data collected in underground drifts at Yucca Mountain and its vicinity. No assumptions of parameters were used to supplement the measured data. Discussions on issues related to analysis and measurement approximation are included in Section 6. Other than supportable approximations that were necessary in order to use various analytic formulas and established scientific methods, physical assumptions were unnecessary, because no predicted values or simulated results were presented. 
INTENTIONALLY LEFT BLANK 


\section{SCIENTIFIC ANALYSIS DISCUSSION}

This section describes the field-testing results pertaining to UZ processes in underground drifts at Yucca Mountain and its vicinity. The field activities range from decimeter-scale drift-seepage tests above niches, to meter-scale fracture-matrix-interaction tests above slots in alcoves, to decameter-scale flow and transport tests in test blocks or between drifts, to kilometer-scale moisture-monitoring studies along drifts. Niches are room-size excavations, slots are excavations below test beds in alcove walls, and alcoves are side drifts along the ESF Main Loop and ECRB cross-drift.

Specifically, this section contains data and analysis pertaining to the following topics:

- Section 6.1 and Section 6.5 present the test-site characteristics of niches and alcoves from pneumatic air-permeability test results (with Section 6.1 on permeability profiles and Section 6.5 on crosshole connections).

- Section 6.2 shows that drift-seepage thresholds exist and that seepage-threshold data can be interpreted using the capillary barrier theory. It also presents liquid-flow-path data for niche sites.

- Section 6.3 and Section 6.4 present laboratory-measurement results for tracer migration and matrix imbibition for welded tuff samples from the ESF (with Section 6.3 on tracer distribution in the field and Section 6.4 on tracer and fluid penetration into the rock matrix).

- Section 6.6 presents the results of two series of fracture-matrix interaction tests to quantify the partitioning of flux into fast and slow components.

- Section 6.7 presents the results for flow tests in the Paintbrush nonwelded tuff (PTn) test bed.

- Section 6.8 summarizes data collected on ambient water-potential distribution in niches.

- Section 6.9 summarizes observations on construction-water migration.

- Section 6.10 presents data collected on moisture monitoring and water analyses in open drifts under the influence of ventilation and in closed drifts behind bulkheads, including the ECRB cross-drift and Alcove 7.

- Section 6.11 presents the results from systematic hydrological characterization using slanted boreholes along the ECRB cross-drift.

- Section 6.12 presents the results of drift-to-drift tests from liquid releases in Alcove 8 and wetting-front and seepage detection at Niche 3 (Niche 3107). In addition, data from the surface-to-drift tests at Alcove 1 are presented. 
- Section 6.13 presents the results of different phases of transport tests at Busted Butte.

- Section 6.14 summarizes geochemical and isotope data in pore water, rocks, and fracture in-fill minerals collected from test locations in different tuff units.

The list of data supporting these analyses can be found in the tables labeled "b" and "c" of Section 4.1.

The tests performed in niches and alcoves along the ESF are illustrated in Figure 6-1. Seepage into drifts at the repository level is related to water percolating down from the ground surface. Drift-seepage tests at niche sites quantify the seepage from liquid pulses released above the niches. Percolation flux has a fast fracture-flow component and a slow matrix-flow component. This partitioning of flow is evaluated at the fracture-matrix test bed in Alcove 6. The heterogeneous hydrogeologic setting (with alternating tuff layers) determines the percolation distribution throughout the UZ, with input from infiltration at the ground surface boundary. The mechanism of redistributing near-surface fracture flow by the porous PTn, especially the flow-damping process by the PTn unit, is studied in a test bed in Alcove 4. The PTn unit examined at Alcove 4 consists of layered, altered, and bedded tuffs transected by a fault. Wetter climate conditions increase the infiltration, as quantified in an artificial infiltration test in Alcove 1 and in moisture monitoring at depth in Alcove 7. The seepage threshold data from niches and from systematic hydrological characterization are inputs to the model report Seepage Calibration Model and Seepage Testing Data (BSC 2004 [DIRS 171764]).

Figure 6-1 illustrates general issues (DOE 1998 [DIRS 100550], Section 3.1; Figure 3-1) pertaining to UZ flow processes of seepage, percolation, and infiltration. The tests illustrated in Figure 6-1 focus on different issues to quantify the functional relationships among these processes. Seepage is smaller than percolation flux because of capillarity-induced drift diversion (BSC 2004 [DIRS 171764], Section 6), and percolation may be smaller than infiltration because of lateral diversion of percolating water along tuff interfaces to bounding faults. All tests use tracers to assist the characterization of plume migration.

Figure 6-2 illustrates the ECRB cross-drift to ESF main drift seepage collection system to study the migration of water and tracer flow from one drift to another. The crossover point is located in the northern pabrt of the ESF, as illustrated in Figure 1-2 and Figure 1-3. In 1998, the seepage monitoring system was used to monitor the migration of construction water from the ECRB cross-drift. Niche 3 (Niche 3107), originally excavated and used for the drift seepage study, is part of the drift-to-drift study as a seepage collection site. The existing horizontal boreholes at Niche 3 (Niche 3107) are used for wetting-front monitoring for liquid released from Alcove 8, excavated from the ECRB cross-drift and directly above Niche 3 (Niche 3107).

Because neither the ESF main drift nor the ECRB cross-drift reaches the Calico Hills hydrogeologic tuff unit $(\mathrm{CHn})$ below the repository block, a dedicated drift complex was excavated at Busted Butte, $8 \mathrm{~km}$ southeast of Yucca Mountain, to evaluate flow and transport processes in vitric $\mathrm{CHn}$. Early results were first reported in the report Unsaturated Zone and Saturated Zone Transport Properties (CRWMS M\&O 2001 [DIRS 154024]). The different field-testing phases and recent updates are presented in Section 6.13. 
Geochemical and isotope data have been collected from laboratory analyses of samples from various experiments in different test locations. These data have been used to refine the conceptual understanding of the site and for inputs to process models. Results are discussed in the report Yucca Mountain Site Description (BSC 2004 [DIRS 169734]). Section 6.14 presents geochemical and isotope data.

Each testing activity has unique findings to contribute to the assessment of unsaturated flow and transport processes at Yucca Mountain. The progress and analyses of field-test results are presented in the following fourteen subsections for fourteen testing activities. Scientific notebooks (with relevant page numbers) used for recording the ESF Field Testing activities and analyses described in this scientific analysis report are listed in Table 6-1.

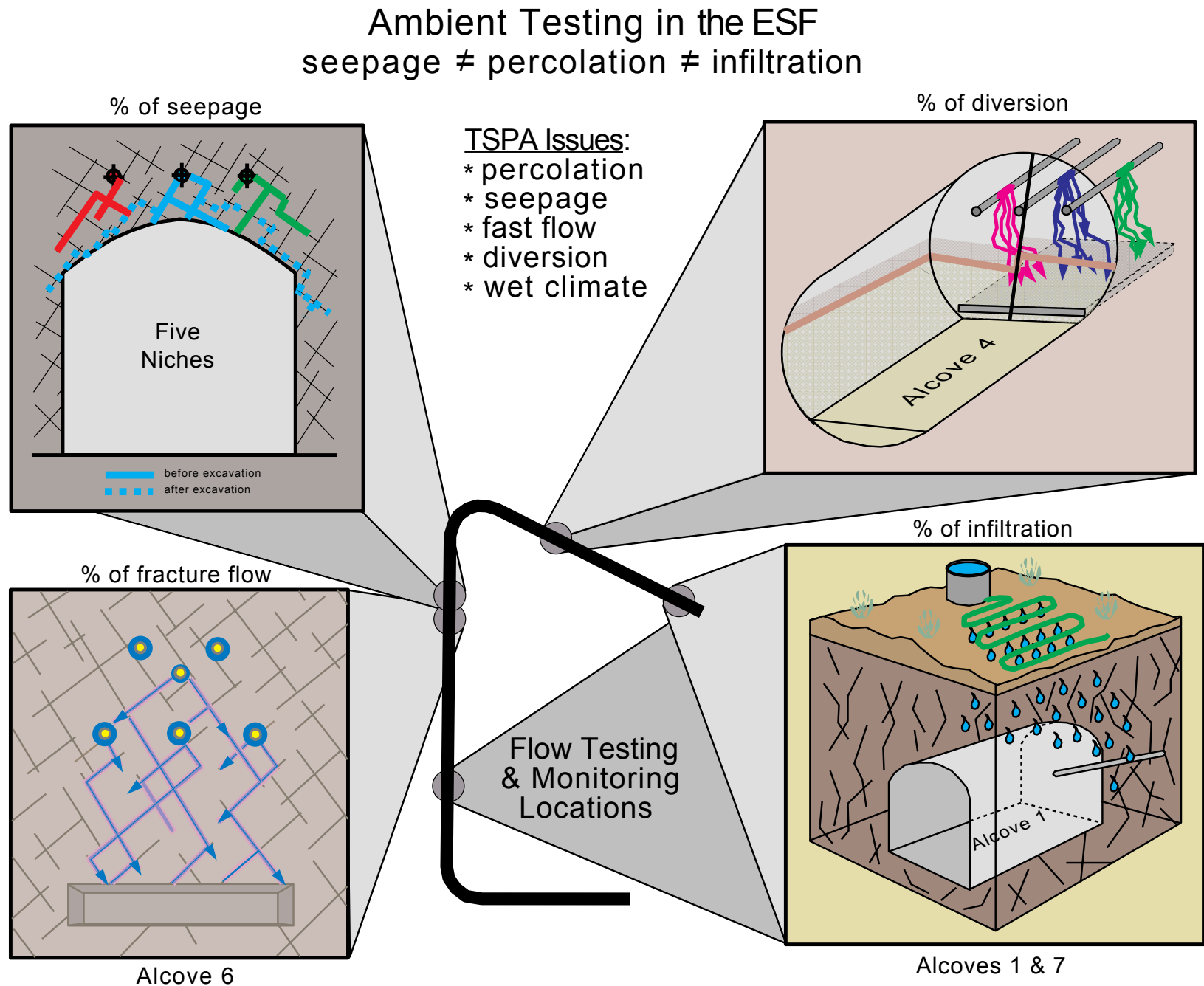

NOTE: The tests evaluate functional relationships between UZ processes to resolve TSPA issues. Different colors are used to schematically track the source of the water to its respective release point.

Figure 6-1. Schematic Illustration of Flow Tests in the Exploratory Studies Facility at Yucca Mountain 


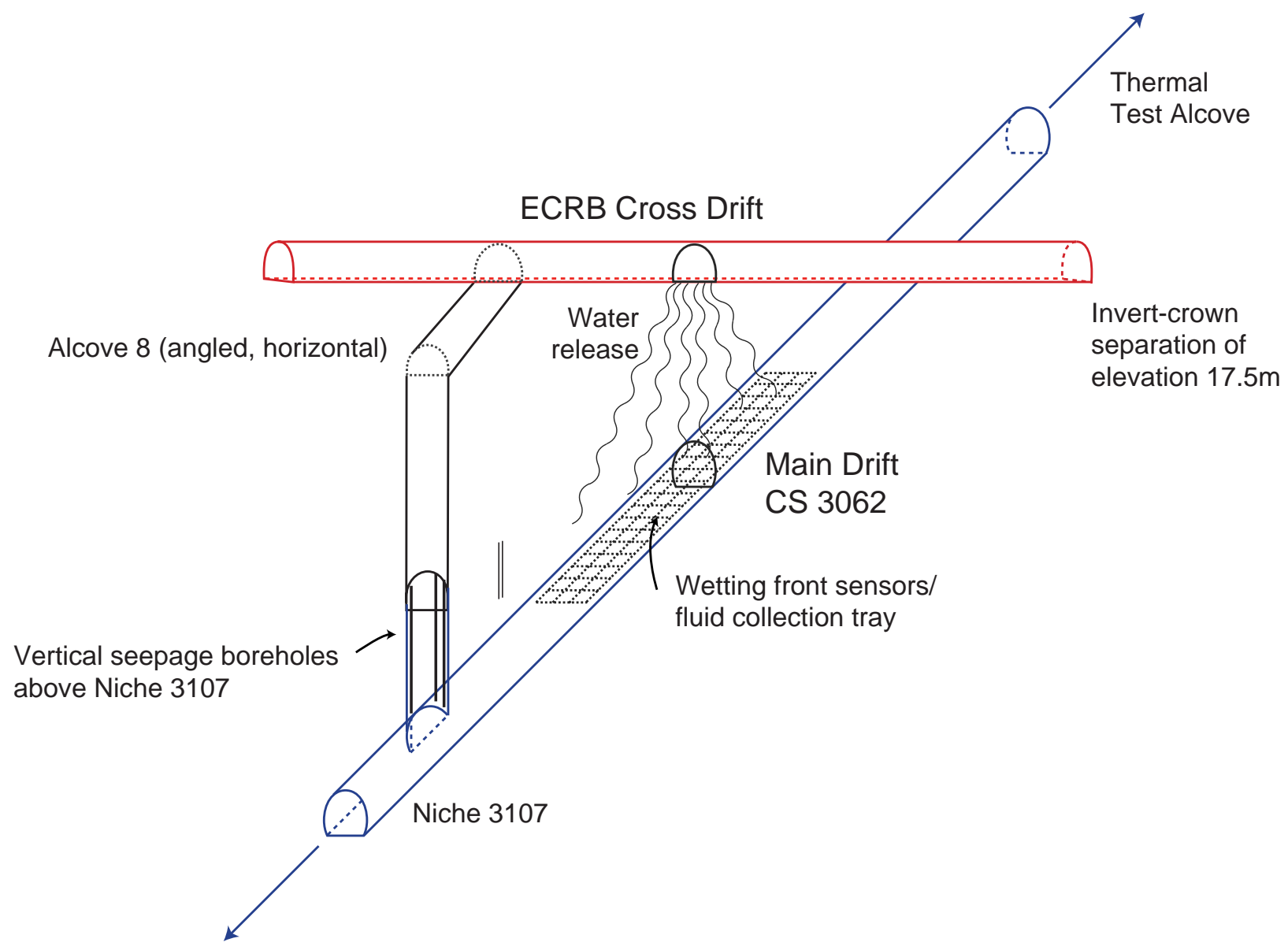

NOTE: Wetting-front sensors and fluid collection trays monitored the construction-water migration. Both the ECRB cross-drift and the main drift, together with Alcove 8 and Niche 3 (Niche 3107) and its boreholes, are horizontal in this illustration. Alcove 8 is directly above Niche 3 (Niche 3107).

Figure 6-2. Schematic Illustration of the Crossover Point of ECRB Cross-Drift with the Main Drift 
Table 6-1. Scientific Notebooks ${ }^{a}$

\begin{tabular}{|c|c|c|c|c|}
\hline $\begin{array}{c}\text { M\&O Scientific } \\
\text { Notebook ID }\end{array}$ & $\begin{array}{l}\text { Lab Scientific } \\
\text { Notebook ID }\end{array}$ & \begin{tabular}{|c|} 
Cited Pages or Page \\
Range(s) of Scientific \\
Notebook
\end{tabular} & $\begin{array}{c}\text { Relevant Section(s) } \\
\text { of This Report }\end{array}$ & Citation \\
\hline SN-LBNL-SCI-065-V1 & YMP-LBNL-JSW-6 & $1-158$ & $\begin{array}{l}6.1 \text { (air-K), } \\
6.2 \text { (seepage) }\end{array}$ & $\begin{array}{l}\text { Wang } 1997 \\
\text { [DIRS 156530] }\end{array}$ \\
\hline SN-LBNL-SCI-066-V1 & YMP-LBNL-JSW-6A & $1-159$ & $\begin{array}{l}6.1 \text { (air-K), } \\
6.2 \text { (seepage) }\end{array}$ & $\begin{array}{l}\text { Wang } 1997 \\
\text { [DIRS 156534] }\end{array}$ \\
\hline SN-LBNL-SCI-121-V1 & YMP-LBNL-JSW-6B & $1-159$ & $\begin{array}{l}6.1 \text { (air-K), } \\
6.2 \text { (seepage) }\end{array}$ & $\begin{array}{l}\text { Wang } 1999 \\
\text { [DIRS 156538] }\end{array}$ \\
\hline SN-LBNL-SCI-122-V1 & YMP-LBNL-JSW-6C & $1-159$ & $\begin{array}{l}6.1 \text { (air-K), } \\
6.2 \text { (seepage) }\end{array}$ & $\begin{array}{l}\text { Wang } 1999 \\
\text { [DIRS 153449] }\end{array}$ \\
\hline SN-LBNL-SCI-078-V1 & $\begin{array}{l}\text { YMP-LBNL-JSW- } \\
\text { PJC-6.2 }\end{array}$ & $\begin{array}{l}1-110,115-125,133- \\
135,144-146, \\
149-157\end{array}$ & $\begin{array}{l}6.1 \text { (air-K), } \\
6.5 \text { (cross-hole) }\end{array}$ & $\begin{array}{l}\text { Cook 2001 } \\
\text { [DIRS 156902] }\end{array}$ \\
\hline SN-LBNL-SCI-113-V1 & YMP-LBNL-RCT-1 & $62-73,80-157$ & 6.2 (seepage) & $\begin{array}{l}\text { Trautz } 1999 \\
\text { [DIRS 156563] }\end{array}$ \\
\hline SN-LBNL-SCI-156-V1 & YMP-LBNL-RCT-2 & $27-160$ & 6.2 (seepage) & $\begin{array}{l}\text { Trautz 2001 } \\
\text { [DIRS 156903] }\end{array}$ \\
\hline SN-LBNL-SCI-177-V1 & YMP-LBNL-RCT-3 & $4-94$ & 6.2 (seepage) & $\begin{array}{l}\text { Trautz } 2001 \\
\text { [DIRS 157022] }\end{array}$ \\
\hline SN-LBNL-SCI-177-V2 & YMP-LBNL-RCT-4 & $\begin{array}{l}88-91,116-117,120, \\
130-159,190-195, \\
198-221,298-299\end{array}$ & $\begin{array}{l}\text { 6.2-App. C4 } \\
\text { (seepage) }\end{array}$ & \begin{tabular}{|l} 
Trautz 2001 \\
[DIRS 161208]
\end{tabular} \\
\hline SN-LBNL-SCI- 221-V1 & YMP-LBNL-RCT-5 & $\begin{array}{l}\text { 154-160, 162-234, } \\
239-301\end{array}$ & $\begin{array}{l}\text { 6.2-App. C4 } \\
\text { (seepage) }\end{array}$ & $\begin{array}{l}\text { Trautz } 2003 \\
\text { [DIRS 166248] }\end{array}$ \\
\hline SN-LBNL-SCI- 221-V2 & YMP-LBNL-RCT-6 & $14-67$ & $\begin{array}{l}\text { 6.2-App. C4 } \\
\text { (seepage) }\end{array}$ & $\begin{array}{l}\text { Wang } 2003 \\
\text { [DIRS 165376] }\end{array}$ \\
\hline SN-LBNL-SCI-089-V1 & $\begin{array}{l}\text { YMP-LBNL-JSW- } \\
\text { QH-1 }\end{array}$ & $1-153$ & $\begin{array}{l}6.3 \text { (tracer migration), } \\
6.4 \text { (imbibition) }\end{array}$ & $\begin{array}{l}\text { Hu } 1999 \\
\text { [DIRS 156539] }\end{array}$ \\
\hline SN-LBNL-SCI-090-V1 & $\begin{array}{l}\text { YMP-LBNL-JSW- } \\
\text { QH-1A }\end{array}$ & \begin{tabular}{|l}
$20-22,37-48,54$, \\
$68-82,86-99$ \\
$103-126$
\end{tabular} & $\begin{array}{l}6.3 \text { (tracer migration), } \\
6.4 \text { (imbibition) }\end{array}$ & $\begin{array}{l}\text { Hu } 1999 \\
\text { [DIRS 156540] }\end{array}$ \\
\hline SN-LBNL-SCI-091-V1 & $\begin{array}{l}\text { YMP-LBNL-JSW- } \\
\text { QH-1B }\end{array}$ & $\begin{array}{l}9,27,35,40,42 \\
48-73,77,81-94 \\
107-110,115 \\
118-119,123-142 \\
149,154-155\end{array}$ & $\begin{array}{l}6.3 \text { (tracer migration), } \\
6.4 \text { (imbibition) }\end{array}$ & $\begin{array}{l}\text { Hu } 1999 \\
\text { [DIRS 156541] }\end{array}$ \\
\hline SN-LBNL-SCI-092-V1 & $\begin{array}{l}\text { YMP-LBNL-JSW- } \\
\text { QH-1C }\end{array}$ & $\begin{array}{l}13,16-25,39-41,51- \\
102,105-112,116 \\
128-133,139-140 \\
143-145\end{array}$ & $\begin{array}{l}6.3 \text { (tracer migration), } \\
6.4 \text { (imbibition) }\end{array}$ & $\begin{array}{l}\text { Hu } 1999 \\
\text { [DIRS 156542] }\end{array}$ \\
\hline SN-LBNL-SCI-093-V1 & $\begin{array}{l}\text { YMP-LBNL-JSW- } \\
\text { QH-1D }\end{array}$ & $3-153$ & $\begin{array}{l}6.3 \text { (tracer migration), } \\
6.4 \text { (imbibition) }\end{array}$ & $\begin{array}{l}\text { Hu } 1999 \\
\text { [DIRS 155691] }\end{array}$ \\
\hline
\end{tabular}


Table 6-1. Scientific Notebooks ${ }^{a}$ (Continued)

\begin{tabular}{|c|c|c|c|c|}
\hline $\begin{array}{c}\text { M\&O Scientific } \\
\text { Notebook ID }\end{array}$ & $\begin{array}{l}\text { Lab Scientific } \\
\text { Notebook ID }\end{array}$ & \begin{tabular}{|c|} 
Cited Pages or Page \\
Range(s) of Scientific \\
Notebook
\end{tabular} & $\begin{array}{c}\text { Relevant } \\
\text { Section(s) of } \\
\text { This Report } \\
\end{array}$ & Citation \\
\hline SN-LBNL-SCI-154-V1 & YMP-LBNL-JSW-QH-1E & $130-136,145-146$ & $\begin{array}{l}6.3 \text { (tracer } \\
\text { migration), } \\
6.4 \text { (imbibition) }\end{array}$ & $\begin{array}{l}\text { Hu } 2000 \\
\text { [DIRS 156473] }\end{array}$ \\
\hline SN-LBNL-SCI-102-V1 & YMP-LBNL-JSW-RS-1 & $1-117$ & $\begin{array}{l}6.6 \text { (fracture- } \\
\text { matrix } \\
\text { interaction } \\
\text { Alcove 6) }\end{array}$ & $\begin{array}{l}\text { Salve } 1999 \\
\text { [DIRS 155692] }\end{array}$ \\
\hline SN-LBNL-SCI-104-V1 & YMP-LBNL-JSW-RS-1A & $1-39$ & $\begin{array}{l}6.6 \text { (fracture- } \\
\text { matrix } \\
\text { interaction } \\
\text { Alcove 6) }\end{array}$ & $\begin{array}{l}\text { Salve } 1999 \\
\text { [DIRS 156547] }\end{array}$ \\
\hline SN-LBNL-SCI-105-V1 & YMP-LBNL-JSW-RS-2 & $1-7,8-127$ & $\begin{array}{l}6.6 \text { (fracture- } \\
\text { matrix } \\
\text { interaction } \\
\text { Alcove 6) } 6.7 \\
\text { (PTn Alcove 4) }\end{array}$ & $\begin{array}{l}\text { Salve } 2000 \\
\text { [DIRS 156548] }\end{array}$ \\
\hline SN-LBNL-SCI-042-V1 & YMP-LBNL-JSW-CMO-1 & $1-15,18,22,45-54$ & $\begin{array}{l}6.7 \text { (PTn Alcove } \\
4)\end{array}$ & $\begin{array}{l}\text { Oldenburg } 2000 \\
\text { [DIRS 156558] }\end{array}$ \\
\hline SN-LBNL-SCI-088-V1 & YMP-LBNL-JSW-JJH-1 & $1-71$ & $\begin{array}{l}6.7 \text { (PTn Alcove } \\
4)\end{array}$ & $\begin{array}{l}\text { Hinds } 2000 \\
\text { [DIRS 156557] }\end{array}$ \\
\hline SN-LBNL-SCI-048-VI & YMP-LBNL-JW-1.2 & $103-152$ & \begin{tabular}{|l|}
6.8 (water \\
potential) \\
6.9 (construction \\
water migration)
\end{tabular} & $\begin{array}{l}\text { Salve } 1999 \\
\text { [DIRS 156552] }\end{array}$ \\
\hline SN-LBNL-SCI-133-V1 & YMP-LBNL-JW-1.2A & $1-43$ & \begin{tabular}{|l|}
6.8 (water \\
potential) \\
6.9 (construction \\
water migration)
\end{tabular} & $\begin{array}{l}\text { Salve } 1999 \\
\text { [DIRS 156555] }\end{array}$ \\
\hline SN-LBNL-SCI-116-V1 & YMP-LBNL-JSW-4.3 & $1-24,61-67,74-81$ & $\begin{array}{l}6.10 \text { (ESF } \\
\text { moisture) }\end{array}$ & $\begin{array}{l}\text { Wang } 2000 \\
\text { [DIRS 156559] }\end{array}$ \\
\hline SN-LBNL-SCI-150-V1 & YMP-LBNL-JSW-JS-1 & 18,148 & $\begin{array}{l}6.10 \text { (ECRB } \\
\text { moisture) }\end{array}$ & $\begin{array}{l}\text { Stepek } 2000 \\
\text { [DIRS 156561] }\end{array}$ \\
\hline SN-LBNL-SCI-182-V1 & YMP-LBNL-JSW-RS-4 & $1-147$ & $\begin{array}{l}6.10 .1 \text { (ECRB } \\
\text { moisture) }\end{array}$ & $\begin{array}{l}\text { Salve } 2002 \\
\text { [DIRS 165378] }\end{array}$ \\
\hline SN-LBNL-SCI-182-V2 & YMP-LBNL-JSW-RS-6 & $1-59$ & $\begin{array}{l}6.10 .1 \text { (ECRB } \\
\text { moisture) }\end{array}$ & $\begin{array}{l}\text { Wang } 2003 \\
\text { [DIRS 165376] }\end{array}$ \\
\hline SN-USGS-SCI-110-V1 & $\mathrm{N} / \mathrm{A}$ & $1-99$ & $\begin{array}{l}6.10 \text { (Niche } \\
\text { Moisture) }\end{array}$ & $\begin{array}{l}\text { Guertal } 2000 \\
\text { [DIRS 165384] }\end{array}$ \\
\hline SN-USGS-SCI-128-V1 & $N / A$ & $1-301$ & $\begin{array}{l}6.10 .1(\mathrm{ECRB} \\
\text { moisture) }\end{array}$ & $\begin{array}{l}\text { Hudson } 2002 \\
\text { [DIRS 165391] }\end{array}$ \\
\hline SN-USGS-SCI-128-V2 & $N / A$ & $1-297$ & \begin{tabular}{|l}
$6.10 .1(E C R B$ \\
moisture)
\end{tabular} & $\begin{array}{l}\text { Hudson 2002 } \\
\text { [DIRS 165392] }\end{array}$ \\
\hline
\end{tabular}


Table 6-1. Scientific Notebooks ${ }^{a}$ (Continued)

\begin{tabular}{|c|c|c|c|c|}
\hline $\begin{array}{c}\text { M\&O Scientific } \\
\text { Notebook ID }\end{array}$ & $\begin{array}{l}\text { Lab Scientific } \\
\text { Notebook ID }\end{array}$ & $\begin{array}{c}\text { Cited Pages or Page } \\
\text { Range(s) of Scientific } \\
\text { Notebook }\end{array}$ & $\begin{array}{l}\text { Relevant } \\
\text { Section(s) of } \\
\text { This Report } \\
\end{array}$ & Citation \\
\hline SN-USGS-SCI-128-V3 & $\mathrm{N} / \mathrm{A}$ & $1-141$ & $\begin{array}{l}6.10 .4 \text { (Alcove } \\
7 \text { ) }\end{array}$ & $\begin{array}{l}\text { Hudson } 2003 \\
\text { [DIRS 165273] }\end{array}$ \\
\hline SN-USGS-SCI-133-V1 & N/A & $1-157$ & $\begin{array}{l}6.10 .1(\mathrm{ECRB} \\
\text { moisture) }\end{array}$ & $\begin{array}{l}\text { Hudson } 2002 \\
\text { [DIRS 163398] }\end{array}$ \\
\hline SN-USGS-SCI-133-V2 & $\mathrm{N} / \mathrm{A}$ & $1-147$ & $\begin{array}{l}6.10 .1(\mathrm{ECRB} \\
\text { moisture) }\end{array}$ & $\begin{array}{l}\text { Hudson } 2003 \\
\text { [DIRS 165393] }\end{array}$ \\
\hline SN-LBNL-SCl-179-V1 & YMP-LBNL-JSW-YWT-1 & $1-44$ & $\begin{array}{l}6.11 \text { (ECRB } \\
\text { systematic) }\end{array}$ & $\begin{array}{l}\text { Tsang and Wang } \\
2000 \text { [DIRS 165375] }\end{array}$ \\
\hline SN-LBNL-SCI-179-V2 & YMP-LBNL-JSW-YWT-2 & $\begin{array}{l}8-48,72-73,98-99 \\
114-129\end{array}$ & $\begin{array}{l}6.11 \text { (ECRB } \\
\text { systematic) }\end{array}$ & $\begin{array}{l}\text { Wang } 2003 \\
\text { [DIRS 165376] }\end{array}$ \\
\hline SN-LBNL-SCI-216-V1 & YMP-LBNL-JSW-PJC-6.3 & $\begin{array}{l}7-19,22-27,46,58- \\
60,70-76\end{array}$ & $\begin{array}{l}6.11 \text { (ECRB } \\
\text { systematic) }\end{array}$ & $\begin{array}{l}\text { Wang } 2003 \\
\text { [DIRS 165376] } \\
\end{array}$ \\
\hline SN-LBNL-SCI-181-V1 & YMP-LBNL-JSW-RS-5 & $1-156$ & $\begin{array}{l}6.12 \text { (Alcove 8- } \\
\text { Niche } 3 \text { [Niche } \\
3107] \text { ) }\end{array}$ & $\begin{array}{l}\text { Salve } 2003 \\
\text { [DIRS 165377] }\end{array}$ \\
\hline SN-LBNL-SCI-181-V2 & YMP-LBNL-JSW-RS-5.1 & $1-24$ & $\begin{array}{l}6.12 \text { (Alcove 8- } \\
\text { Niche } 3 \text { [Niche } \\
\text { 3107]) } \\
\end{array}$ & $\begin{array}{l}\text { Wang } 2003 \\
\text { [DIRS 165376] }\end{array}$ \\
\hline SN-USGS-SCI-120-V1 & $\mathrm{N} / \mathrm{A}$ & $1-172$ & $\begin{array}{l}6.12 \text { (Alcove 8- } \\
\text { Niche } 3 \text { [Niche } \\
\text { 3107]) }\end{array}$ & $\begin{array}{l}\text { Hudson 2002 } \\
\text { [DIRS 165385] }\end{array}$ \\
\hline SN-USGS-SCI-120-V2 & $\mathrm{N} / \mathrm{A}$ & $1-182$ & $\begin{array}{l}6.12 \text { (Alcove 8- } \\
\text { Niche } 3 \text { [Niche } \\
\text { 3107]) }\end{array}$ & \begin{tabular}{|l} 
Hudson 2002 \\
[DIRS 165386]
\end{tabular} \\
\hline SN-USGS-SCI-120-V3 & $\mathrm{N} / \mathrm{A}$ & $1-179$ & $\begin{array}{l}6.12 \text { (Alcove 8- } \\
\text { Niche } 3 \text { [Niche } \\
\text { 3107]) }\end{array}$ & $\begin{array}{l}\text { Hudson } 2002 \\
\text { [DIRS 165387] }\end{array}$ \\
\hline SN-USGS-SCI-120-V4 & $\mathrm{N} / \mathrm{A}$ & $1-190$ & $\begin{array}{l}6.12 \text { (Alcove 8- } \\
\text { Niche } 3 \text { [Niche } \\
\text { 3107]) }\end{array}$ & $\begin{array}{l}\text { Hudson and Guertal } \\
2002 \text { [DIRS 165388] }\end{array}$ \\
\hline SN-USGS-SCI-120-V5 & $\mathrm{N} / \mathrm{A}$ & $1-157$ & $\begin{array}{l}6.12 \text { (Alcove 8- } \\
\text { Niche } 3 \text { [Niche } \\
\text { 3107]) }\end{array}$ & $\begin{array}{l}\text { Hudson 2002 } \\
\text { [DIRS 166103] }\end{array}$ \\
\hline SN-USGS-SCI-120-V6 & $\mathrm{N} / \mathrm{A}$ & $1-147$ & $\begin{array}{l}6.12 \text { (Alcove 8- } \\
\text { Niche } 3 \text { [Niche } \\
\text { 3107]) } \\
\end{array}$ & $\begin{array}{l}\text { Hudson } 2002 \\
\text { [DIRS 165389] }\end{array}$ \\
\hline SN-USGS-SCI-120-V7 & $\mathrm{N} / \mathrm{A}$ & $1-148$ & $\begin{array}{l}6.12 \text { (Alcove 8- } \\
\text { Niche } 3 \text { [Niche } \\
\text { 3107]) } \\
\end{array}$ & $\begin{array}{l}\text { Hudson } 2003 \\
\text { [DIRS 165390] }\end{array}$ \\
\hline SN-USGS-SCI-108-V1 & $\mathrm{N} / \mathrm{A}$ & $1-98$ & $\begin{array}{l}6.12 .5 \text { (Alcove } \\
1 \text { ) }\end{array}$ & \begin{tabular}{|l} 
Guertal 2001 \\
[DIRS 164070] \\
\end{tabular} \\
\hline SN-LANL-SCI-038-V1 & LA-EES-1-NBK-99-005 & $1-161$ & $\begin{array}{l}6.13 \text { (sample } \\
\text { analyses) }\end{array}$ & \begin{tabular}{|l} 
Bussod 2001 \\
[DIRS 165281] \\
\end{tabular} \\
\hline
\end{tabular}


Table 6-1. Scientific Notebooks ${ }^{a}$ (Continued)

\begin{tabular}{|c|c|c|c|c|}
\hline $\begin{array}{c}\text { M\&O Scientific } \\
\text { Notebook ID }\end{array}$ & $\begin{array}{l}\text { Lab Scientific } \\
\text { Notebook ID }\end{array}$ & $\begin{array}{c}\text { Cited Pages or Page } \\
\text { Range(s) of Scientific } \\
\text { Notebook }\end{array}$ & $\begin{array}{c}\text { Relevant } \\
\text { Section(s) of } \\
\text { This Report } \\
\end{array}$ & Citation \\
\hline SN-LANL-SCI-039-V1 & LA-EES-5-NBK-98-020 & $1-161$ & 6.13 (UZTT) & \begin{tabular}{|l} 
Bussod 1999 \\
[DIRS 146978]
\end{tabular} \\
\hline SN-LANL-SCI-040-V1 & LA-EES-5-NBK-98-010 & $1-156$ & 6.13 (UZTT) & $\begin{array}{l}\text { Bussod } 1998 \\
\text { [DIRS 149129] }\end{array}$ \\
\hline SN-LANL-SCI-041-V1 & LA-EES-5-NBK-98-011 & $1-38$ & \begin{tabular}{|l}
6.13 .2 (UZTT \\
injection)
\end{tabular} & $\begin{array}{l}\text { Soll et al. } 2001 \\
\text { [DIRS 165296] }\end{array}$ \\
\hline SN-LANL-SCI-042-V1 & LA-EES-5-NBK-98-012 & $1-130$ & \begin{tabular}{|l}
6.13 .3 (UZTT \\
injection)
\end{tabular} & \begin{tabular}{|l} 
Dunn 2001 \\
[DIRS 165297]
\end{tabular} \\
\hline SN-LANL-SCI-043-V1 & LA-EES-5-NBK-98-013 & $1-26$ & $\begin{array}{l}6.13 .5(\text { UZTT } \\
\text { air-K) }\end{array}$ & $\begin{array}{l}\text { Bussod and Stockton } \\
1999 \text { [DIRS 165324] }\end{array}$ \\
\hline SN-LANL-SCI-044-V1 & LA-EES-5-NBK-98-014 & $1-11$ & $\begin{array}{l}6.13 .5 \text { (UZTT } \\
\text { air-K) }\end{array}$ & $\begin{array}{l}\text { Wyckoff } 1999 \\
\text { [DIRS 165298] }\end{array}$ \\
\hline SN-LANL-SCI-046-V1 & LA-EES-5-NBK-98-016 & $1-44$ & $\begin{array}{l}6.13 .5 \text { (UZTT } \\
\text { air-K) }\end{array}$ & \begin{tabular}{|l} 
Lowry 2001 \\
[DIRS 164632]
\end{tabular} \\
\hline SN-LANL-SCI-106-V1 & LA-EES-5-NBK-99-003 & $1-120$ & 6.13 (UZTT) & $\begin{array}{l}\text { Soll and Bussod } 2001 \\
\text { [DIRS 165299] }\end{array}$ \\
\hline SN-LANL-SCI-127-V1 & LA-CST-NBK-99-002 & $1-7$ & 6.13.1 (tracers) & $\begin{array}{l}\text { Bussod and Turin } \\
2000 \text { [DIRS 165300] }\end{array}$ \\
\hline SN-LANL-SCI-133-V1 & LA-CST-NBK-98-018 & $1-7$ & $\begin{array}{l}6.13 .3 \text { (tracer } \\
\text { analyses) }\end{array}$ & \begin{tabular}{|l} 
Bussod and \\
Wolfsberg 2000 \\
[DIRS 165301]
\end{tabular} \\
\hline SN-LANL-SCI-136-V1 & LA-CST-NBK-98-017 & $1-7$ & $\begin{array}{l}6.13 .3 \text { (tracer } \\
\text { analyses) }\end{array}$ & $\begin{array}{l}\text { Bussod and } \\
\text { Wolfsberg 2000 } \\
\text { [DIRS 165303] }\end{array}$ \\
\hline SN-LANL-SCI-145-V1 & LA-CST-NBK-98-001 & $1-159$ & 6.13.1 (tracers) & $\begin{array}{l}\text { Bussod et al. } 2000 \\
\text { [DIRS 165305] }\end{array}$ \\
\hline SN-LANL-SCI-159-V1 & LA-CST-NBK-98-002 & $1-9$ & $\begin{array}{l}6.13 .3 \text { (tracer } \\
\text { analyses) }\end{array}$ & $\begin{array}{l}\text { Bussod and } \\
\text { Wolfsberg 2000 } \\
\text { [DIRS 165306] }\end{array}$ \\
\hline SN-LANL-SCI-160-V1 & LA-CST-NBK-98-012 & $1-7$ & $\begin{array}{l}6.13 .3 \text { (tracer } \\
\text { analyses) }\end{array}$ & $\begin{array}{l}\text { Bussod and } \\
\text { Wolfsberg 2000 } \\
\text { [DIRS 165308] }\end{array}$ \\
\hline SN-LANL-SCI-161-V1 & LA-CST-NBK-98-015 & $1-7$ & $\begin{array}{l}6.13 .2,6.13 .3 \\
\text { (tracer analyses) }\end{array}$ & \begin{tabular}{|l} 
Bussod and \\
Wolfsberg 2000 \\
[DIRS 165310]
\end{tabular} \\
\hline SN-LANL-SCI-163-V1 & LA-CST-NBK-98-016 & $1-10$ & $\begin{array}{l}6.13 .2,6.13 .3 \\
\text { (tracer analyses) }\end{array}$ & \begin{tabular}{|l} 
Bussod and \\
Wolfsberg 2000 \\
[DIRS 165311] \\
\end{tabular} \\
\hline SN-LANL-SCI-169-V1 & LA-CST-NBK-98-009 & $1-7$ & $\begin{array}{l}6.13 .2,6.13 .3 \\
\text { (tracer analyses) }\end{array}$ & $\begin{array}{l}\text { Bussod and } \\
\text { Wolfsberg 2000 } \\
\text { [DIRS 165312] }\end{array}$ \\
\hline
\end{tabular}


Table 6-1. Scientific Notebooks ${ }^{a}$ (Continued)

\begin{tabular}{|c|c|c|c|c|}
\hline $\begin{array}{c}\text { M\&O Scientific } \\
\text { Notebook ID }\end{array}$ & $\begin{array}{l}\text { Lab Scientific } \\
\text { Notebook ID }\end{array}$ & $\begin{array}{c}\text { Cited Pages or Page } \\
\text { Range(s) of Scientific } \\
\text { Notebook }\end{array}$ & $\begin{array}{c}\text { Relevant } \\
\text { Section(s) of } \\
\text { This Report } \\
\end{array}$ & Citation \\
\hline SN-LANL-SCI-184-V1 & $\mathrm{N} / \mathrm{A}$ & $1-6$ & \begin{tabular}{|l}
$6.13 .2,6.13 .3$ \\
(tracer analyses)
\end{tabular} & $\begin{array}{l}\text { Soll and Wolfsberg } \\
2000 \text { [DIRS 165313] }\end{array}$ \\
\hline SN-LANL-SCI-188-V1 & N/A & $1-7$ & \begin{tabular}{|l}
$6.13 .2,6.13 .3$ \\
(tracer analyses)
\end{tabular} & $\begin{array}{l}\text { Soll and Wolfsberg } \\
2000 \text { [DIRS 165316] }\end{array}$ \\
\hline SN-LANL-SCI-191-V1 & LA-CST-NBK-99-004 & $1-10$ & 6.13 .2 (sorption) & $\begin{array}{l}\text { Bussod et al. } 2000 \\
\text { [DIRS 165317] }\end{array}$ \\
\hline SN-LANL-SCI-192-V1 & LA-CST-NBK-99-003 & $1-8$ & $\begin{array}{l}6.13 .2,6.13 .3 \\
\text { (tracer analyses) }\end{array}$ & \begin{tabular}{|l} 
Bussod and \\
Wolfsberg 2000 \\
[DIRS 165319]
\end{tabular} \\
\hline SN-LANL-SCI-193-V1 & $\mathrm{N} / \mathrm{A}$ & $1-8$ & $\begin{array}{l}6.13 .3 \text { (tracer } \\
\text { analyses) }\end{array}$ & $\begin{array}{l}\text { Soll and Wolfsberg } \\
2000 \text { [DIRS 165320] }\end{array}$ \\
\hline SN-LANL-SCI-199-V1 & LA-CST-NBK-98-004 & $1-810$ & $\begin{array}{l}6.13 \text { (pad } \\
\text { collection) }\end{array}$ & $\begin{array}{l}\text { Bussod and Turin } \\
2001 \text { [DIRS 165321] }\end{array}$ \\
\hline SN-LANL-SCI-205-V1 & N/A & $1-56$, photos $1-31$ & $\begin{array}{l}6.13 .6 \text { (BBTF } \\
\text { block) }\end{array}$ & $\begin{array}{l}\text { Drew } 1999 \\
\text { [DIRS 166105] }\end{array}$ \\
\hline SN-LANL-SCI-206-V1 & $\mathrm{N} / \mathrm{A}$ & $86326-86406$ & $\begin{array}{l}6.13 .6 \text { (BBTF } \\
\text { block) }\end{array}$ & $\begin{array}{l}\text { Drew } 2001 \\
\text { [DIRS 165323] }\end{array}$ \\
\hline SN-LANL-SCI-206-V2 & $\mathrm{N} / \mathrm{A}$ & 99176-99254 & $\begin{array}{l}6.13 .6 \text { (BBTF } \\
\text { block) }\end{array}$ & $\begin{array}{l}\text { Drew } 2001 \\
\text { [DIRS 165325] }\end{array}$ \\
\hline SN-LANL-SCI-206-V3 & N/A & 99326-99405 & $\begin{array}{l}6.13 .6 \text { (BBTF } \\
\text { block) }\end{array}$ & \begin{tabular}{|l} 
Drew 2002 \\
[DIRS 165326]
\end{tabular} \\
\hline SN-LANL-SCI-206-V4 & $\mathrm{N} / \mathrm{A}$ & $99551-99630$ & $\begin{array}{l}6.13 .6 \text { (BBTF } \\
\text { block) }\end{array}$ & $\begin{array}{l}\text { Drew } 2002 \\
\text { [DIRS 165328] }\end{array}$ \\
\hline SN-LANL-SCI-206-V5 & $\mathrm{N} / \mathrm{A}$ & 99701-99779 & $\begin{array}{l}6.13 .6 \text { (BBTF } \\
\text { block) }\end{array}$ & $\begin{array}{l}\text { Drew } 2002 \\
\text { [DIRS 165330] }\end{array}$ \\
\hline SN-LANL-SCI-206-V6 & $\mathrm{N} / \mathrm{A}$ & $92851-92930$ & $\begin{array}{l}6.13 .6 \text { (BBTF } \\
\text { block) }\end{array}$ & $\begin{array}{l}\text { Drew } 2002 \\
\text { [DIRS 165333] }\end{array}$ \\
\hline SN-LANL-SCI-206-V7 & $\mathrm{N} / \mathrm{A}$ & $100226-100303$ & $\begin{array}{l}6.13 .6 \text { (BBTF } \\
\text { block) }\end{array}$ & \begin{tabular}{|l} 
Drew 2003 \\
[DIRS 165335]
\end{tabular} \\
\hline SN-LANL-SCI-207-V1 & $\mathrm{N} / \mathrm{A}$ & $83101-83181$ & $\begin{array}{l}6.13 .6 \text { (BBTF } \\
\text { block) }\end{array}$ & $\begin{array}{l}\text { Drew } 2001 \\
\text { [DIRS 165336] }\end{array}$ \\
\hline SN-LANL-SCI-207-V2 & $\mathrm{N} / \mathrm{A}$ & $83326-83406$ & $\begin{array}{l}6.13 .6 \text { (BBTF } \\
\text { block) }\end{array}$ & \begin{tabular}{|l} 
Drew 2001 \\
[DIRS 165348]
\end{tabular} \\
\hline SN-LANL-SCI-207-V3 & $\mathrm{N} / \mathrm{A}$ & $83476-83556$ & $\begin{array}{l}6.13 .6 \text { (BBTF } \\
\text { block) }\end{array}$ & $\begin{array}{l}\text { Drew } 2001 \\
\text { [DIRS 165349] }\end{array}$ \\
\hline SN-LANL-SCI-207-V4 & $\mathrm{N} / \mathrm{A}$ & 97976-98055 & $\begin{array}{l}6.13 .6 \text { (BBTF } \\
\text { block) }\end{array}$ & \begin{tabular}{|l} 
Drew 2001 \\
[DIRS 165350]
\end{tabular} \\
\hline SN-LANL-SCI-207-V5 & $\mathrm{N} / \mathrm{A}$ & $98051-98130$ & $\begin{array}{l}6.13 .6 \text { (BBTF } \\
\text { block) }\end{array}$ & $\begin{array}{l}\text { Drew } 2001 \\
\text { [DIRS 165351] }\end{array}$ \\
\hline
\end{tabular}


Table 6-1. Scientific Notebooks ${ }^{a}$ (Continued)

\begin{tabular}{|c|c|c|c|c|}
\hline $\begin{array}{c}\text { M\&O Scientific } \\
\text { Notebook ID }\end{array}$ & $\begin{array}{l}\text { Lab Scientific } \\
\text { Notebook ID }\end{array}$ & $\begin{array}{c}\text { Cited Pages or Page } \\
\text { Range(s) of Scientific } \\
\text { Notebook }\end{array}$ & $\begin{array}{c}\text { Relevant } \\
\text { Section(s) of } \\
\text { This Report } \\
\end{array}$ & Citation \\
\hline SN-LANL-SCI-207-V6 & $\mathrm{N} / \mathrm{A}$ & $98126-98205$ & $\begin{array}{l}6.13 .6 \text { (BBTF } \\
\text { block) }\end{array}$ & \begin{tabular}{|l} 
Drew 2001 \\
[DIRS 165352]
\end{tabular} \\
\hline SN-LANL-SCI-207-V7 & $\mathrm{N} / \mathrm{A}$ & $99251-99329$ & $\begin{array}{l}6.13 .6 \text { (BBTF } \\
\text { block) }\end{array}$ & \begin{tabular}{|l} 
Drew 2001 \\
[DIRS 165354]
\end{tabular} \\
\hline SN-LANL-SCI-207-V8 & N/A & $99401-99480$ & $\begin{array}{l}6.13 .6 \text { (BBTF } \\
\text { block) }\end{array}$ & $\begin{array}{l}\text { Drew } 2002 \\
\text { [DIRS 165356] }\end{array}$ \\
\hline SN-LANL-SCI-207-V9 & $\mathrm{N} / \mathrm{A}$ & 99626-99705 & $\begin{array}{l}6.13 .6 \text { (BBTF } \\
\text { block) }\end{array}$ & $\begin{array}{l}\text { Drew } 2002 \\
\text { [DIRS 165358] }\end{array}$ \\
\hline SN-LANL-SCI-207-V10 & $\mathrm{N} / \mathrm{A}$ & 99776-99854 & $\begin{array}{l}6.13 .6 \text { (BBTF } \\
\text { block) }\end{array}$ & \begin{tabular}{|l} 
Drew 2002 \\
[DIRS 165338]
\end{tabular} \\
\hline SN-LANL-SCI-207-V11 & $\mathrm{N} / \mathrm{A}$ & $92776-92855$ & $\begin{array}{l}6.13 .6 \text { (BBTF } \\
\text { block) }\end{array}$ & $\begin{array}{l}\text { Drew } 2002 \\
\text { [DIRS 165340] }\end{array}$ \\
\hline SN-LANL-SCI-207-V12 & $\mathrm{N} / \mathrm{A}$ & $100151-100229$ & $\begin{array}{l}6.13 .6 \text { (BBTF } \\
\text { block) }\end{array}$ & \begin{tabular}{|l} 
Drew 2002 \\
[DIRS 165344]
\end{tabular} \\
\hline SN-LANL-SCI-207-V13 & N/A & $100451-100528$ & $\begin{array}{l}6.13 .6 \text { (BBTF } \\
\text { block) }\end{array}$ & $\begin{array}{l}\text { Drew } 2003 \\
\text { [DIRS 165346] }\end{array}$ \\
\hline SN-LANL-SCI-208-V1 & $\mathrm{N} / \mathrm{A}$ & $91276-91356$ & $\begin{array}{l}6.13 .6 \text { (BBTF } \\
\text { block) }\end{array}$ & \begin{tabular}{|l} 
Drew 2001 \\
[DIRS 165360]
\end{tabular} \\
\hline SN-LANL-SCI-208-V2 & $N / A$ & $86701-86780$ & $\begin{array}{l}\text { 6.13.6 (BBTF } \\
\text { block) }\end{array}$ & \begin{tabular}{|l} 
Drew 2001 \\
[DIRS 165361] \\
\end{tabular} \\
\hline SN-LANL-SCI-208-V3 & $\mathrm{N} / \mathrm{A}$ & 99476-99542 & $\begin{array}{l}6.13 .6 \text { (BBTF } \\
\text { block) }\end{array}$ & \begin{tabular}{|l} 
Drew 2002 \\
[DIRS 165362]
\end{tabular} \\
\hline SN-LANL-SCI-220-V1 & LA-EES-1-NBK-94-002 & $1-101$ & $\begin{array}{l}\text { 6.13.1, App. H } \\
\text { (CHn } \\
\text { mineralogy) }\end{array}$ & $\begin{array}{l}\text { Levy } 2001 \\
\text { [DIRS 165363] }\end{array}$ \\
\hline SN-LANL-SCI-228-V1 & LA-EES-5-NBK-98-019 & $1-4$ & 6.13 .2 (injection) & \begin{tabular}{|l} 
Bussod and \\
Wolfsberg 2000 \\
[DIRS 165364]
\end{tabular} \\
\hline SN-LANL-SCI-232-V1 & $\mathrm{N} / \mathrm{A}$ & $1-9$ & $\begin{array}{l}6.13 .3 \text { (tracer } \\
\text { analyses) }\end{array}$ & $\begin{array}{l}\text { Soll and Wolfsberg } \\
2000 \text { [DIRS 165365] }\end{array}$ \\
\hline SN-LANL-SCI-239-V1 & $\mathrm{N} / \mathrm{A}$ & $1-103,290-291$ & $\begin{array}{l}6.13 .3 \text { (tracer } \\
\text { analyses) }\end{array}$ & $\begin{array}{l}\text { Soll et al. 2002 } \\
\text { [DIRS 165366] }\end{array}$ \\
\hline SN-LANL-SCI-241-V1 & $\mathrm{N} / \mathrm{A}$ & $1-90$ & $\begin{array}{l}6.13 .3 \text { (tracer } \\
\text { analyses) }\end{array}$ & $\begin{array}{l}\text { Soll and Wolfsberg } \\
2002 \text { [DIRS 165367] }\end{array}$ \\
\hline SN-LANL-SCI-252-V1 & $\mathrm{N} / \mathrm{A}$ & $1-77$ & $\begin{array}{l}6.13 .3 \\
\text { (overcore) }\end{array}$ & $\begin{array}{l}\text { Turin } 2001 \\
\text { [DIRS 165368] }\end{array}$ \\
\hline SN-LANL-SCI-253-V1 & N/A & $1-168$ & \begin{tabular}{|l}
$6.13 .2,6.13 .3$ \\
(tracer analyses)
\end{tabular} & $\begin{array}{l}\text { Haga } 2001 \\
\text { [DIRS 165369] }\end{array}$ \\
\hline
\end{tabular}


Table 6-1. Scientific Notebooks ${ }^{a}$ (Continued)

\begin{tabular}{|c|c|c|c|c|}
\hline $\begin{array}{c}\text { M\&O Scientific } \\
\text { Notebook ID }\end{array}$ & $\begin{array}{c}\text { Lab Scientific } \\
\text { Notebook ID }\end{array}$ & $\begin{array}{c}\text { Cited Pages or Page } \\
\text { Range(s) of Scientific } \\
\text { Notebook }\end{array}$ & $\begin{array}{c}\text { Relevant } \\
\text { Section(s) of } \\
\text { This Report } \\
\end{array}$ & Citation \\
\hline SN-LANL-SCI-256-V1 & $\mathrm{N} / \mathrm{A}$ & $1-75$ & $\begin{array}{l}\text { 6.13.1, App. H } \\
\text { (CHn } \\
\text { mineralogy) }\end{array}$ & \begin{tabular}{|l} 
Levy 2002 \\
[DIRS 165370]
\end{tabular} \\
\hline SN-LANL-SCI-257-V1 & $\mathrm{N} / \mathrm{A}$ & 1 & 6.13 .3 & $\begin{array}{l}\text { Soll } 2001 \\
\text { [DIRS 165371] }\end{array}$ \\
\hline SN-LANL-SCI-261-V1 & $\mathrm{N} / \mathrm{A}$ & $1-53$ & $\begin{array}{l}\text { 6.13.1, App. H } \\
\text { (CHn } \\
\text { mineralogy) }\end{array}$ & $\begin{array}{l}\text { Soll and Aldrich } 2002 \\
\text { [DIRS 165372] }\end{array}$ \\
\hline SN-LBNL-SCI-119-V1 & YMP-LBNL-ELM-KHW-1 & $1-48$ & $\begin{array}{l}6.13 .4 \text { (ground } \\
\text { penetrating } \\
\text { radar) }\end{array}$ & $\begin{array}{l}\text { Williams 2000 } \\
\text { [DIRS 165373] }\end{array}$ \\
\hline SN-LBNL-SCI-119-V2 & YMP-LBNL-ELM-KHW-2 & $1-32$ & $\begin{array}{l}6.13 .4 \text { (ground } \\
\text { penetrating } \\
\text { radar) }\end{array}$ & $\begin{array}{l}\text { Williams } 2002 \\
\text { [DIRS 165374] }\end{array}$ \\
\hline SN-LBNL-SCI-193-V1 & YMP-LBNL-ELM-JP-1 & $1-25$ & $\begin{array}{l}6.13 .4 \text { (ground } \\
\text { penetrating } \\
\text { radar) }\end{array}$ & $\begin{array}{l}\text { Peterson 2002 } \\
\text { [DIRS 165379] }\end{array}$ \\
\hline SN-LLNL-SCI-421-V1 & $\mathrm{N} / \mathrm{A}$ & $1-155$ & $\begin{array}{l}6.13 .4 \text { (electrical } \\
\text { resistance } \\
\text { tomography) }\end{array}$ & $\begin{array}{l}\text { Daily and Buettner } \\
2002 \text { [DIRS 165380] }\end{array}$ \\
\hline SN-USGS-SCI-117-V1 & $\mathrm{N} / \mathrm{A}$ & $1-75$ & $\begin{array}{l}\text { 6.13.1, App. H } \\
\text { (hydrological } \\
\text { properties) }\end{array}$ & $\begin{array}{l}\text { Flint } 2001 \\
\text { [DIRS 165381] }\end{array}$ \\
\hline SN-USGS-SCI-117-V2 & $\mathrm{N} / \mathrm{A}$ & $1-98$ & $\begin{array}{l}\text { 6.13.1, App. H } \\
\text { (hydrological } \\
\text { properties) }\end{array}$ & $\begin{array}{l}\text { Flint } 2001 \\
\text { [DIRS 165382] }\end{array}$ \\
\hline SN-USGS-SCI-117-V3 & $\mathrm{N} / \mathrm{A}$ & $1-73$ & \begin{tabular}{|l}
6.13 .1$, App. H \\
(hydrological \\
properties)
\end{tabular} & $\begin{array}{l}\text { Flint et al. 2002 } \\
\text { [DIRS 165383] }\end{array}$ \\
\hline
\end{tabular}

${ }^{a}$ The list of scientific notebooks is sorted first by different tests (represented by the subsection number to the second heading in the fourth column), and then by the scientific notebook IDs (listed in the first column). The listed scientific notebooks contain relevant and corroborating data for testing activities discussed in Section 6. Some scientific notebooks have test pages specified, others have the whole notebook ranges listed. In addition to data collection, the scientific notebooks in general contain entries pertaining to test configuration, test design, equipment set-up, sensor calibration, review records, and other test-related data. Data analyses are primarily developed from entries in the scientific notebooks; data interpretations are supplemented by open literature surveys and professional exchanges, with the results documented in publications and in the scientific analysis report. Section 6.14 (geochemical and isotopic data collection) investigators use technical procedures instead of scientific notebooks in data collections. The technical procedures, together with other data such as test-site configurations and sensor accuracies, are in site-investigation test plans and fieldwork packages governing the testing activities, listed in Section 1 of this report, and in Section 1 and Table 2.4 of the TWP (BSC 2004 [DIRS 167969]).

NOTES:

BBTF = Busted Butte Test Facility; CHn = Calico Hills Non-welded Hydrogeologic Unit; ECRB = Enhanced Characterization of Repository Block; ESF = Exploratory Studies Facility; N/A not applicable; UZTT = Unsaturated Zone Transport Test. 
Standardized scientific analysis methods were used. Alternate scientific approaches and technical methods are evaluated in Section 6. For example, analytic solutions are used to analyze seepage data instead of numerical models (see Section 6.2); psychrometer data are compared with electrical resistivity probe data (see Section 6.9); and ion-microprobe results are compared with microdigestion results (see Section 6.14). Other alternate scientific approaches and/or technical methods were not used because the investigators are not familiar with them.

Variability and uncertainty are also evaluated in Section 6. Variability and uncertainty are described in Guidelines for Developing and Documenting Alternative Conceptual Models, Model Abstractions, and Parameter Uncertainty in the Total System Performance Assessment for the License Application (BSC 2002 [DIRS 158794], Section 4.1), as follows:

Variability, also referred to as aleatory uncertainty, arises due to natural randomness or heterogeneity. This first type of uncertainty cannot be reduced through further testing and data collection; it can only be better characterized. Thus, this first type of uncertainty is also referred to as irreducible uncertainty. It is typically accounted for using geostatistical approaches, e.g., using appropriate probability distribution functions.

Uncertainty, also referred to as epistemic uncertainty, arises from lack of knowledge about a parameter because the data are limited or there are alternative interpretations of the available data. This second type of uncertainty can be reduced because the state of knowledge can be improved by further testing or data collection. Consequently, this second type of uncertainty is also referred to as reducible uncertainty.

In this report, the term variability is used for aleatory uncertainty, and the term uncertainty is used for epistemic uncertainty.

Uncertainty may have different sources depending on how the parameter in question is derived (e.g., whether derived from measurements, analyses, or models), as follows:

- Measurement uncertainty refers to the exactness of the actual measurement method and related data processing.

- Spatial variability uncertainty refers to the uncertainty in parameters describing the spatial variability of data, typically arising from the limited number of samples.

- Conceptual model uncertainty arises when the appropriateness of a conceptual model developed for the physical system cannot be fully assessed.

- Estimation uncertainty arises if the resulting parameter is estimated from a random process (e.g., from noisy data or from a Monte Carlo analysis), giving a range of possible results.

This scientific analysis report focuses on spatial variability uncertainty of data collected from testing of processes. 


\subsection{AIR-PERMEABILITY DISTRIBUTIONS AND EXCAVATION-INDUCED ENHANCEMENTS}

Pneumatic air-permeability tests were undertaken at various locations in the ESF to characterize the potential fluid flow paths in the rock. The repository host rock consists predominantly of unsaturated, fractured welded tuff. Airflow occurs mainly through the fractures. Therefore, air-permeability tests characterize the fracture network and may be utilized to study fracture heterogeneity. Because the fracture network is very permeable, the pressure field returns to ambient conditions quickly, generally within minutes, after air injection is stopped. As a result, many tests can be performed quickly, allowing measurements of fracture heterogeneity.

The specific objectives for pneumatic testing include:

- Profiling the air permeability of boreholes along their length

- Investigating the effects of nearby excavation on the permeability of a rock mass

- Enabling a site-to-site comparison of air-permeability statistics and related scale effects.

In these tests, packer assemblies (see Appendix A) were inflated in clusters of boreholes drilled into the fractured rock, and air was injected into specific intervals at constant mass flux while pressure responses were monitored in other borehole intervals.

Two basic types of data are readily available from pneumatic testing and are used to satisfy these testing objectives:

(1) single-borehole air-permeability profiles, which are used for borehole-to-borehole and site-to-site comparisons, and

(2) crosshole pressure-response data, which enable a determination of connectivity (through fracture networks) between locations at a given site.

This section focuses on the permeability profiles for boreholes in niche and alcove sites. Permeability profiles before niche excavation are compared with profiles measured after niche and alcove excavation. Both pre- and post-excavation air-permeability tests were conducted before the seepage tests described in Section 6.2. The crosshole data analyses are presented in Section 6.5. Air-permeability data are used as the basis (1) for developing heterogeneous permeability fields for drift-scale models, and (2) for the distribution of permeabilities sampled during TSPA-LA calculations.

\subsubsection{Niche Test Site and Borehole Configuration}

Extensive air-permeability measurements have been made in borehole clusters at five niches and at three alcoves within the ESF tunnel, as part of a program to select locations for liquid-release tests. The air permeability along each borehole in a cluster serves as a guide to the selection of the liquid-release intervals. 


\subsubsection{Site Selection}

Various niche and alcove sites were selected for study, based on fracture and hydrologic data collected in the ESF, as illustrated in Figure 6-3. Four niches were excavated along the main drift of the ESF and a fifth in the ECRB Cross-Drift. The first niche site is located at Construction Station (CS) 35+66 (hereafter referred to as Niche 1 (Niche 3566), located $3566 \mathrm{~m}$ from the ESF North Portal) in a brecciated zone between the Sundance fault and a cooling joint, where a preferential flow path is believed to be present [based on elevated ${ }^{36} \mathrm{Cl} / \mathrm{Cl}$ ratios described in Yucca Mountain Site Description (BSC 2004 [DIRS 169734], Section 5.2)]. Niche 1 (Niche 3566) was sealed with a bulkhead to conduct long-term monitoring of in situ conditions. The second niche site is located at CS 36+50 [Niche 2 (Niche 3650)] in a competent rock mass with lower fracture density than Niche 1 (Niche 3566). The third niche is located at CS $31+07$ [Niche 3 (Niche 3107)] in close proximity to the crossover point located at CS $30+62$. A test alcove (Alcove 8) has been excavated from the ECRB Cross-Drift to a position immediately above Niche 3 (Niche 3107), so that a large-scale drift-to-drift test could be conducted at this location. The fourth niche site is located at CS 47+88 [Niche 4 (Niche 4788)] in a $950 \mathrm{~m}$ long exposure of the middle nonlithophysal zone, referred to by Buesch and Spengler (1998 [DIRS 101433], p. 19) as the intensely fractured zone. The fifth niche is located at ECRB Cross-Drift CS 16+20 [Niche 5 (Niche CD 1620)] near the center of the repository block. The first four niches described above were excavated on the west side of the ESF main drift within the middle nonlithophysal zone (Tptpmn) of the Topopah Spring welded tuff unit (TSw). The fifth niche in the ECRB Cross-Drift is excavated in the lower lithophysal zone (Tptpll) of the TSw, which is the tuff unit in which most of the repository emplacement drifts would be located. Alcove 8 is excavated in the upper lithophysal zone (Tptpul) of the ECRB Cross-Drift. (Air permeability tests in two other alcoves, Alcove 4 and Alcove 6, are described in Section 6.5; along a systematic hydrologic characterization borehole in Section 6.11.2.1; and along a borehole at Busted Butte in Section 6.13.5.2.)

\subsubsection{Borehole Configuration}

Prior to niche excavation, three boreholes were drilled at Niche 1 (Niche 3566), and seven boreholes per niche were drilled at Niche 2 (Niche 3650), Niche 3 (Niche 3107), and Niche 4 (Niche 4788). Boreholes were drilled before excavation into both the rock to be excavated and the surrounding rock to gain access to the testing and monitoring area. Figure 6-4 shows the schematics of borehole clusters tested at the first four niche sites. Both types of boreholes were tested before niche excavation, and the surrounding boreholes were retested after excavation, allowing a study of excavation effects on the permeability of the surrounding rock. All boreholes shown in Figure 6-4 are parallel to the niche axis, as illustrated in Figure 6-5. 


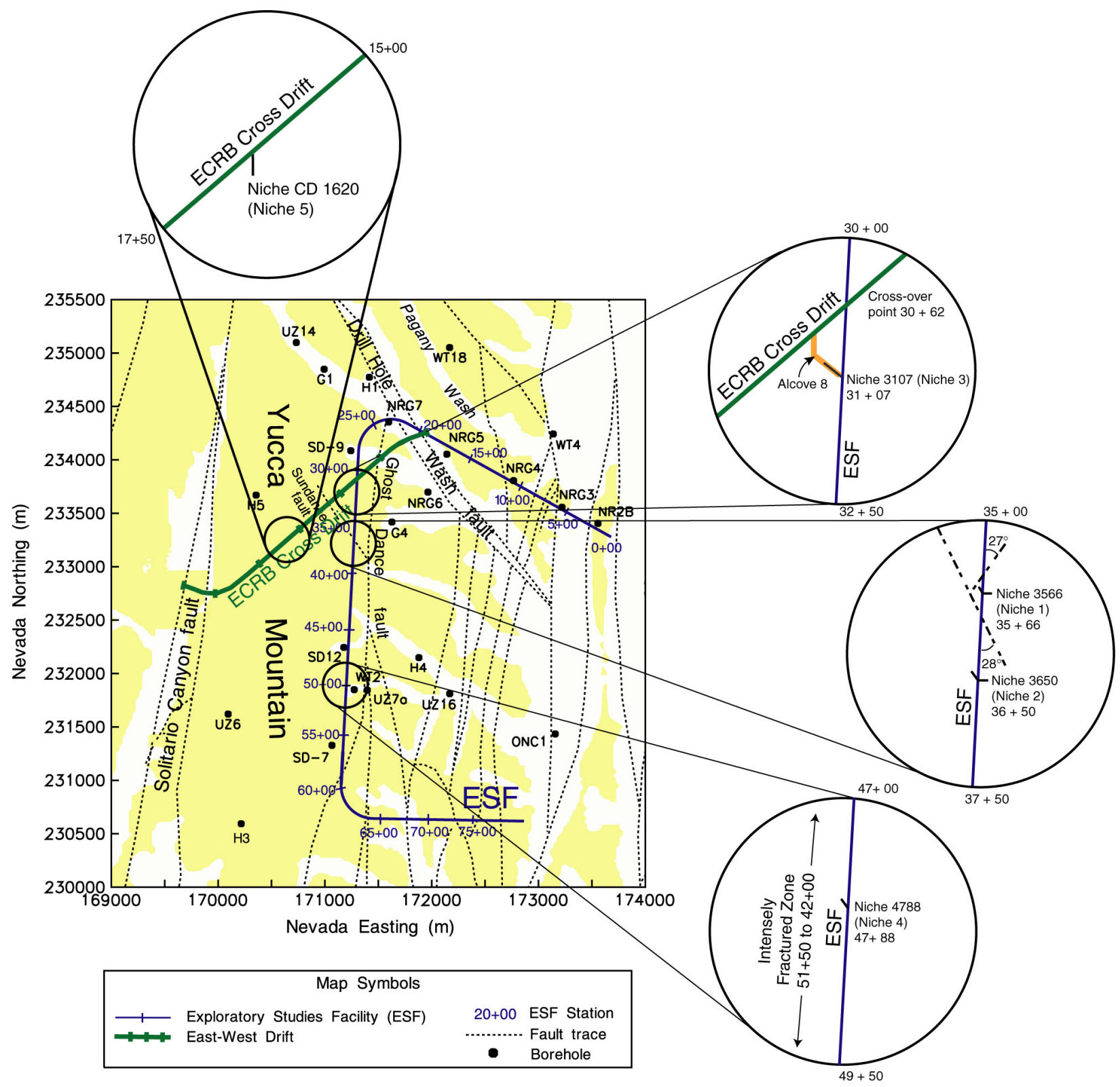

Figure 6-3. Location Map for Niche 3 (Niche 3107), Niche 1 (Niche 3566), Niche 2 (Niche 3650), Niche 4 (Niche 4788), and Niche 5 (Niche CD 1620) 

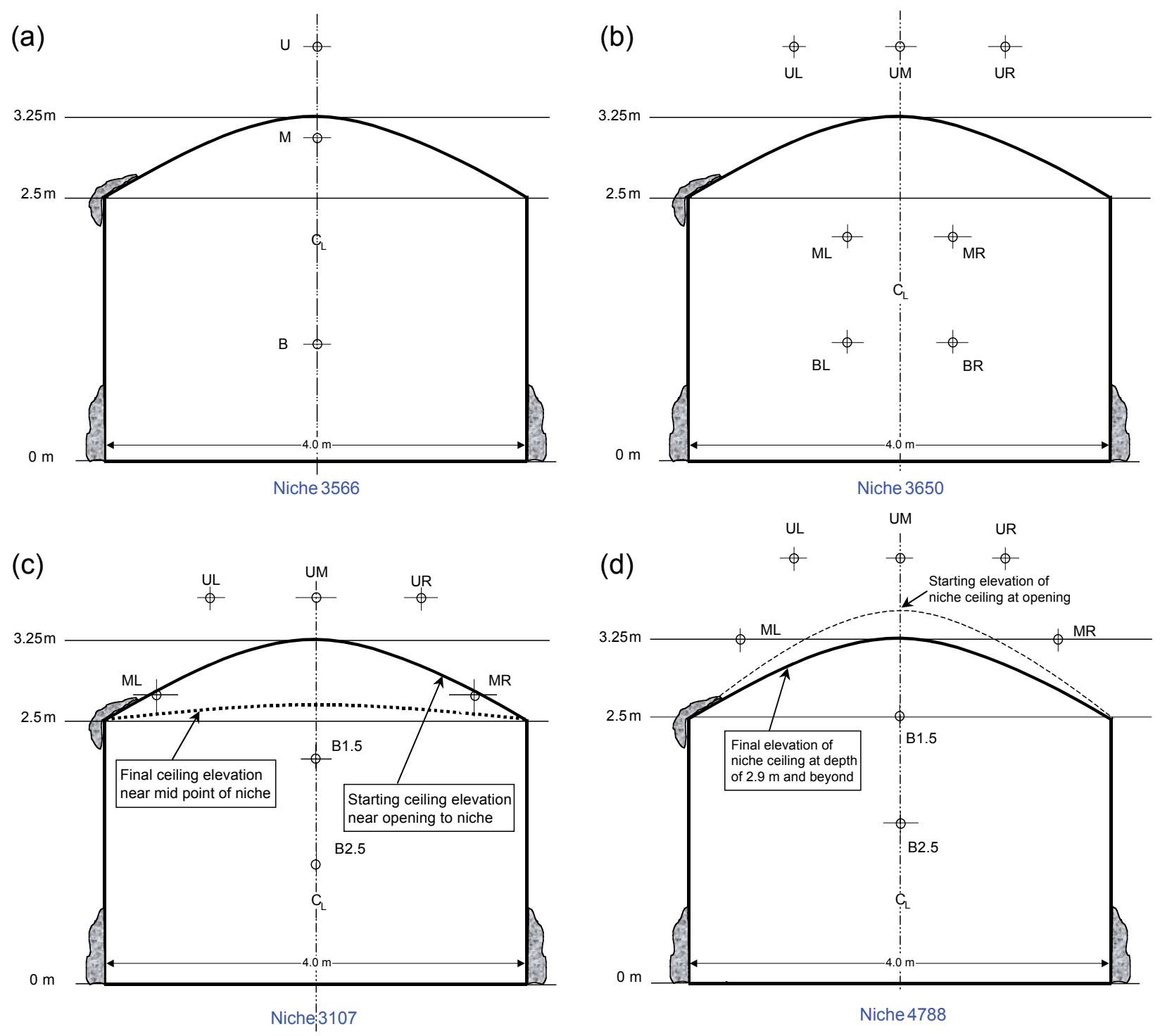

NOTES: All measurements are approximate and do not represent surveyed as-built conditions. The niche faces are on the west wall of the main drift of the Exploratory Studies Facility. See Figure 6-6 for borehole notations. $C_{L}$ denotes centerline.

Figure 6-4. Schematic Illustration of the End View of Borehole Clusters at Niche Sites 
(a) Niche Centerline-.-.-

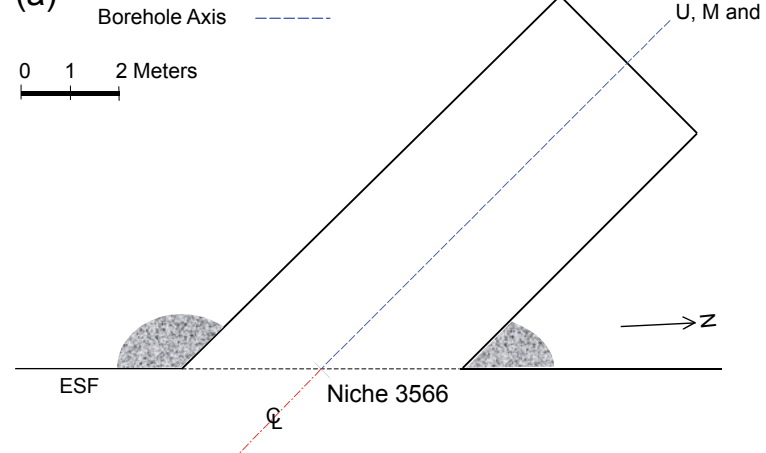

(c)

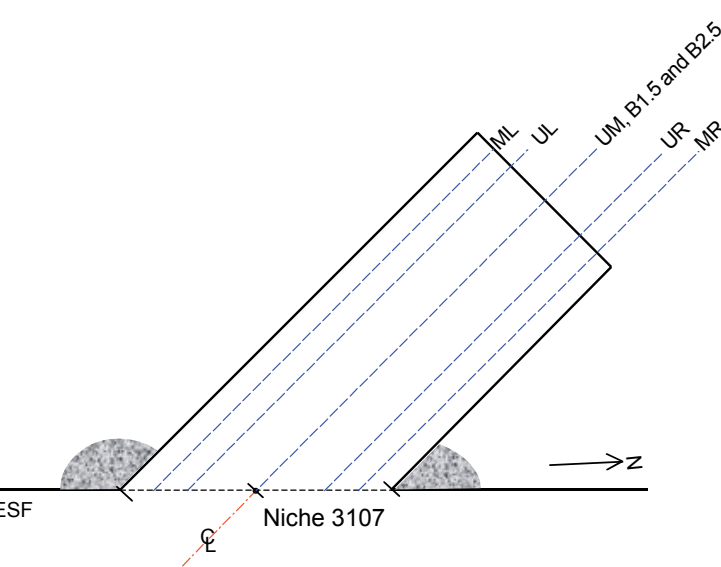

(b)

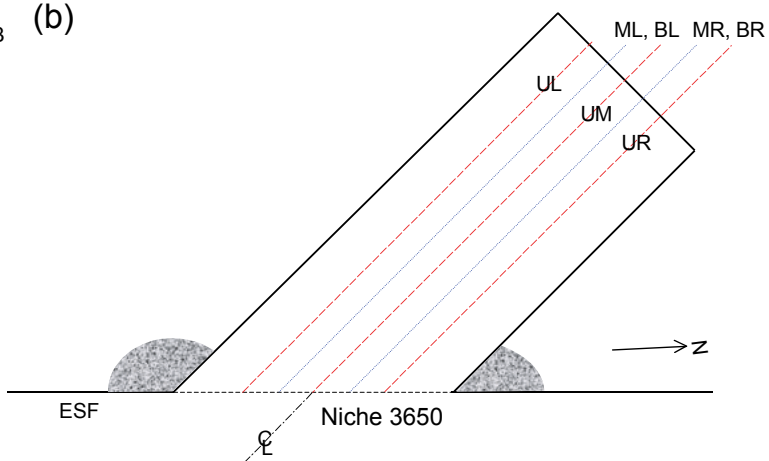

(d)

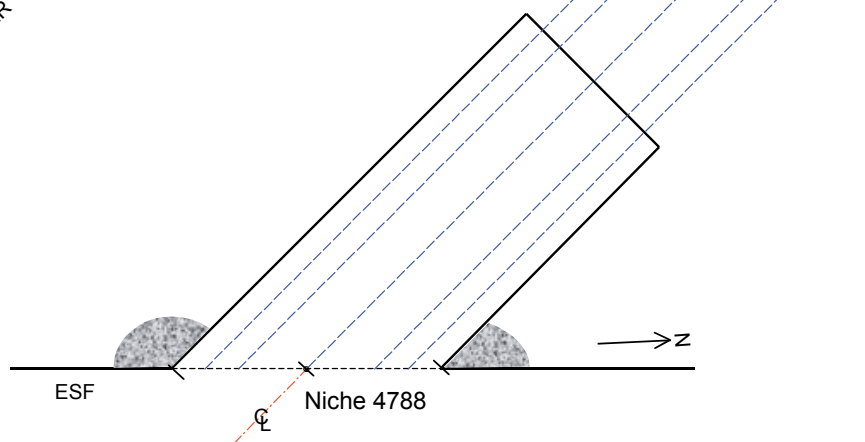

NOTES: All measurements are approximate and do not represent surveyed as-built conditions. The boreholes shown are oriented horizontally in the northwestern direction parallel to the niche axis. See Figure 6-6 for borehole notations. $\mathrm{C}_{\mathrm{L}}$ denotes centerline.

Figure 6-5. Schematic Illustration of the Plan View of Borehole Clusters at Niche Sites

Three boreholes were originally drilled at Niche 1 (Niche 3566) along the same vertical plane coincident with the center of the niche (Panel a of Figure 6-4 and Panel a of Figure 6-5). ${ }^{1}$ The three boreholes were assigned the designations $\mathrm{U}, \mathrm{M}$, and $\mathrm{B}$, corresponding to the upper, middle, and bottom borehole, respectively. Borehole $\mathrm{M}$ and Borehole $\mathrm{B}$ were subsequently removed when the rock was mined out to create the niche; Borehole $\mathrm{U}$ is still intact.

Panel $b$ of Figure 6-4 and Panel $b$ of Figure 6-5 show the location of the seven boreholes drilled at Niche 2 (Niche 3650). Three of the boreholes, designated UL, UM, and UR (upper left, upper middle, and upper right, respectively), were drilled approximately $1 \mathrm{~m}$ apart and $0.65 \mathrm{~m}$ above the crown of the niche in the same horizontal plane. The remaining boreholes, ML, MR, BL, and BR (middle left, middle right, bottom left, and bottom right, respectively), were drilled within

${ }^{1}$ Figures 6-4, 6-5, and 6-6 were generated using field measurements recorded in Scientific Notebooks (Wang 1997 [DIRS 156530], Wang 1997 [DIRS 156534]), Wang 1999 [DIRS 156538], Wang 1999 [DIRS 153449], and Trautz 1999 [DIRS 156563]) and/or using pre-built plans for niche excavation. Therefore, these figures show the idealized shape of the niches and approximate locations of the boreholes. Figure 6-7 was generated using the as-built data (DTN: MO0008GSC00269.000 [DIRS 166198]). 
the boundaries of the proposed niche and were subsequently mined out when the niche was excavated as planned.

Panel c of Figure 6-4 and Panel c of Figure 6-5 show the final configuration of the seven boreholes drilled at Niche 3 (Niche 3107). The original intent was to drill the middle boreholes (Borehole ML and Borehole MR) beyond the limits of the proposed excavation to monitor the movement of moisture around the niche during subsequent testing. Unfortunately, the middle boreholes were not drilled at the correct elevation above Niche 3 (Niche 3107) and were partially mined away during excavation. The three upper boreholes (UL, UM, and UR) remained intact and were used in wetting front detection in the Alcove 8/Niche 3 (Niche 3107) tests, as described in Section 6.12.2.2. Boreholes at Alcove 8 (located directly above Niche 3 (Niche 3107)) are described at the end of this section.

The final configuration of the seven boreholes drilled at Niche 4 (Niche 4788) is illustrated in Panel d of Figure 6-4 and Panel d of Figure 6-5. A misinterpretation of a survey mark, along with bad ground conditions (i.e., falling rock or collapsing ground conditions) at Niche 4 (Niche 4788), also resulted in the partial loss of Borehole ML at this site. The original plan was to drill the $\mathrm{U}$ and $\mathrm{M}$ series boreholes outside the excavation.

After the excavation of Niche 1 (Niche 3566), a special set of horizontal boreholes was drilled from within the niche into the walls and end of the niche in a radial pattern. A similar scheme was used at Niche 3 (Niche 3107) after its excavation. These boreholes are not shown on the plan views.

Air-permeability testing has been performed at Niche 5 (Niche CD 1620). Special boreholes to discern the effects of excavation on permeability were drilled alongside the proposed excavation site, parallel to the planned location of the niche wall. These boreholes were designated "AK" because they were intended primarily for air permeability use. Figure 6-6a and Figure 6-6c show (in plan and cross-sectional view, respectively) these three boreholes designated AK1, AK2, and AK3, which were drilled $1 \mathrm{~m}$ apart in a horizontal plane, with the first borehole $1 \mathrm{~m}$ from the proposed niche wall and level with the elevation of the ECRB spring line. Before the inner excavation at Niche 5 (Niche CD 1620), seven additional boreholes were drilled as shown in Panel b of Figure 6-6, Panel d of Figure 6-6, and Panel e of Figure 6-6 in plan, elevation, and side view respectively, designated B1.75, ML, MM, MR, UL, UM, and UR. All of these boreholes, except Borehole B1.75, were drilled above the proposed inner-niche location. Subsequent excavation of the inner part of the niche mined out Borehole B1.75. These seven boreholes are also designated as Borehole 1 through Borehole 7 in Section 6.2.1.3.5.2. After pre- and post-excavation air permeability tests at Niche CD 1620 (Niche 5), two slots (also referred to as "bat wings") were excavated into the sidewalls of the niche, as described in Section 6.2.1.3.5.2.

Alcove 8 is located directly above Niche 3 (Niche 3107). Air-permeability measurements were performed in the near-vertical boreholes drilled from the invert of Alcove 8, toward Niche 3 (Niche 3107). These boreholes were drilled to surround the area designated for the pond experiment, as described in Section 6.12.4. These air-permeability tests were made to provide correlation with the ground penetrating radar imaging in the same boreholes (Section 6.12.3), as opposed to providing direct locations for borehole water releases (as with the other 
air-permeability measurement intervals). They were also intended to allow retesting to observe changes in relative permeability caused by possible partial saturation as a result of the pond experiment. The alcove plan and face views are shown with approximate borehole locations, designated as \#1 to \#6, in Panel a of Figure 6-7 and Panel b of Figure 6-7, respectively.

(a)

AK boreholes on the Side

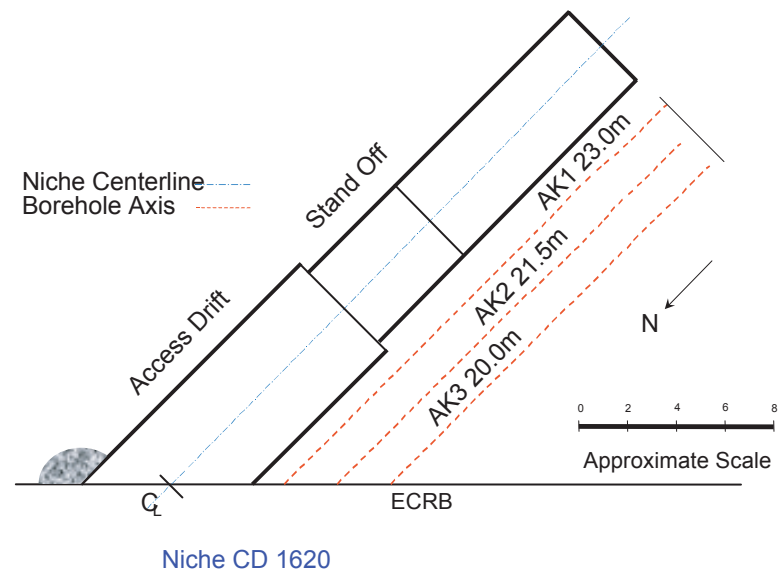

(c)

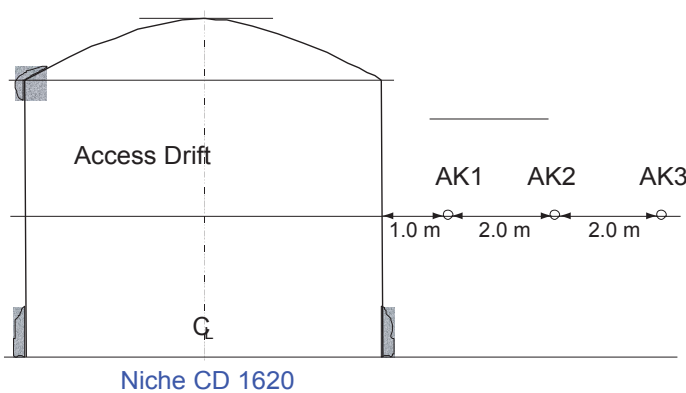

(b)

Liquid Release Boreholes In and Above the Niche

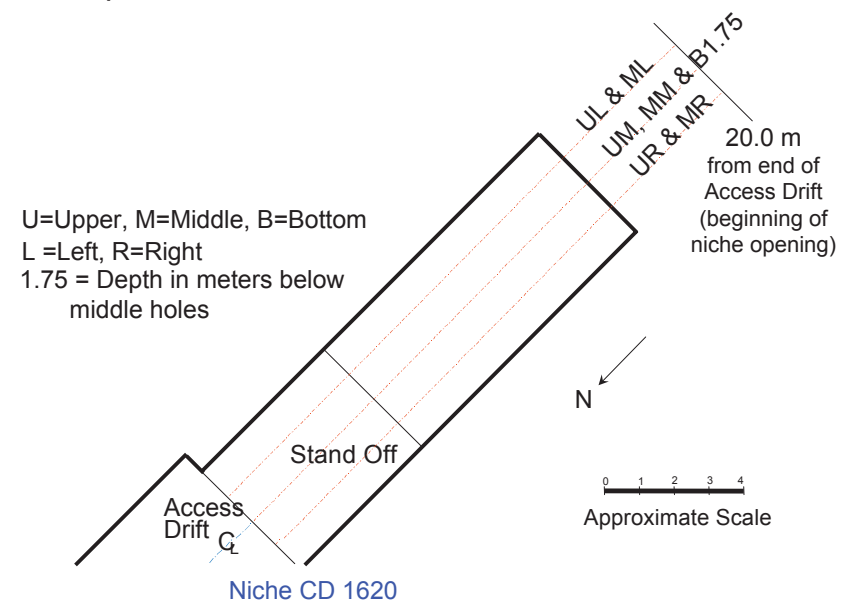

(d)

Liquid Release Boreholes In and Above the Niche

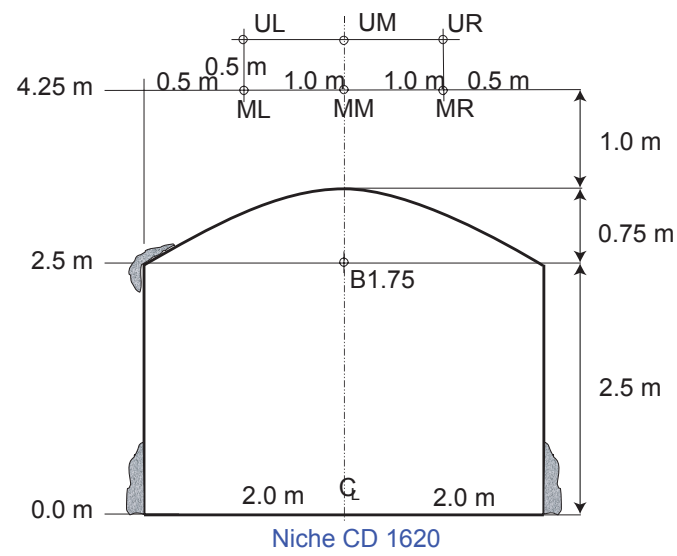

(e)

Liquid Release Boreholes In and Above the Niche

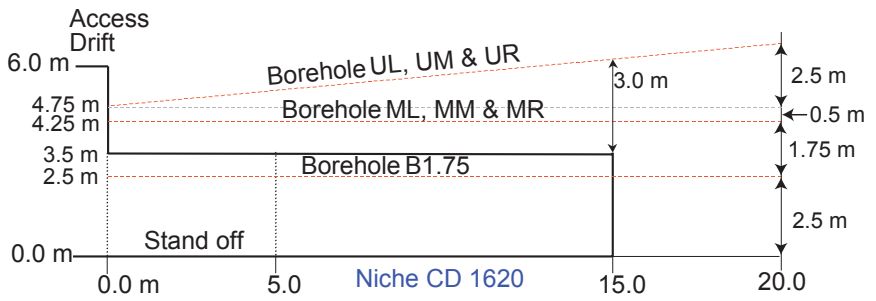

NOTES: All measurements are approximate and do not represent surveyed as-built conditions. The niche face is on the southeast wall of the ECRB Cross-Drift. $C_{L}$ denotes centerline.

Figure 6-6. Schematic Illustration of the End and Plan Views of Borehole Clusters at Niche 5 (Niche CD 1620) 
(a)

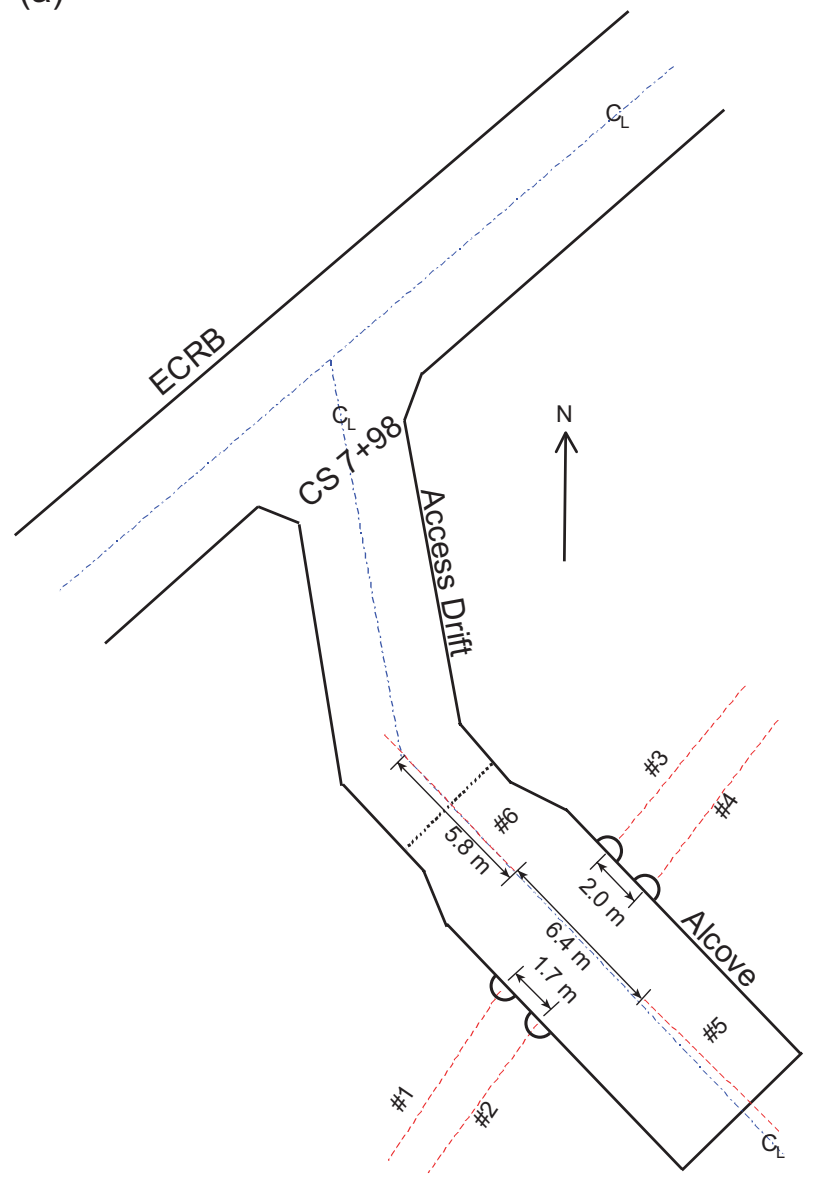

(b)

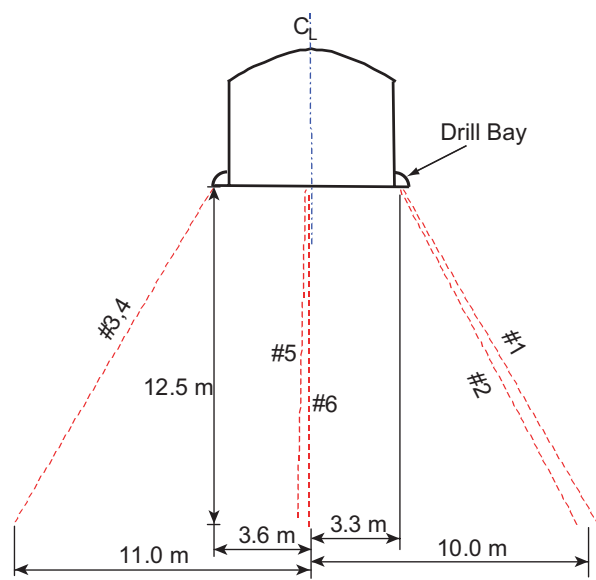

Alcove 8

NOTES: All measurements are approximate. Borehole as-built data are in DTN: MO0008GSC00269.000

[DIRS 166198]. The niche face is on the southeast wall of the ECRB Cross-Drift. $C_{L}$ denotes centerline.

Figure 6-7. Schematic Illustration of the Plan and End Views of Borehole Clusters at Alcove 8

\subsubsection{Air-Permeability Testing, Spatial Distribution, and Statistical Analysis}

Approximately 3,500 separate air injections have been undertaken in the in situ studies underground at Yucca Mountain. Nearly one quarter-million pressure-response curves have been logged in the studies. The number of tests lends itself to visualization and statistical comparison of the flow connections and distributions of permeability in the rock mass. The specially designed equipment for pneumatic testing is described in Appendix A. With this equipment, it is feasible to conduct tests for site-to-site and borehole-to-borehole comparisons, both before and after excavation. 


\subsubsection{Data Reduction and Air-Permeability Determination}

Data in the field were acquired in the form of voltage output from the various instruments and converted in real time or post-test time to physical units, using the calibration data of each instrument. At Niche 3 (Niche 3107), Niche 4 (Niche 4788), Niche 5 (Niche CD 1620), and Alcove 8 , data acquisition was fully automated, so that log entries for each individual injection test could be done by computer and correlation with the data files linked. Each of these tests was given three minutes to reach steady state. (An interval of three minutes was shown, by transient responses, to be sufficient time for the development of steady states.) To maximize the signal-to-noise ratio, the maximum flow rate obtainable with the system was chosen for the purpose of the permeability calculation, i.e., the rate was maximized but did not cause the interval pressure to exceed the pressure at which leakage around the packer might occur.

Because each injection test was repeated to accommodate two different observation-packer configurations, two tests for each injection location from which to choose flow and pressure data for the single-borehole results were conducted. When graphed, the two are usually indistinguishable. Preference is given to the lower of the two if a difference can be discerned, because the higher value is likely caused by leaks in the packer sealing.

Reported data consist of the acquisition filename, test location, time, date, channel or interval number, flow rate, ambient pressure, and steady-state injection pressure. The derived steady-state single-borehole permeability can be obtained using Equation (6-1).

In air-permeability tests conducted to characterize the fracture heterogeneity of the test sites, permeability values were obtained from pressure changes and flow rates using the following modified Hvorslev's formula (LeCain 1995 [DIRS 101700], p. 10, Equation 15):

$$
k=\frac{P_{s c} Q_{s c} \mu \ln \left(\frac{L}{r_{w}}\right) T_{f}}{\pi L\left(P_{2}^{2}-P_{1}^{2}\right) T_{s c}}
$$

$$
\text { where: } \begin{aligned}
k & =\text { permeability, } \mathrm{m}^{2} . \\
P_{s c} & =\text { standard pressure, } \mathrm{Pa} . \\
Q_{s c} & =\text { flow-rate at standard conditions, } \mathrm{m}^{3} / \mathrm{s} . \\
\mu & =\text { dynamic viscosity of air, } \mathrm{Pa} \cdot \mathrm{s} . \\
L & =\text { length of zone, } \mathrm{m} . \\
r_{w} & =\text { radius of bore, } \mathrm{m} .
\end{aligned}
$$

\footnotetext{
${ }^{2}$ The solution is derived for a steady-state ellipsoidal flow field around a finite line source. If the length $L$ in the natural logarithm term in Equation 6-1 is replaced by an external radius $R_{e}$, this formula is identical to the cylindrical flow solution with an ambient constant pressure boundary at the external radius (Muskat 1982 [DIRS 134132], p. 734). This replacement is used in Section 6.2.2.1 to estimate permeability for post-excavation liquid flow paths from the borehole interval to the niche ceiling. Note that "ln" is the natural logarithm.
} 


$$
\begin{array}{ll}
T_{f} & =\text { temperature of formation, } \mathrm{K} . \\
P_{2} & =\text { injection zone pressure at steady-state, } \mathrm{Pa} . \\
P_{1} & =\text { ambient pressure, } \mathrm{Pa} . \\
T_{s c} & =\text { standard temperature, } \mathrm{K} .
\end{array}
$$

In this calculation, standard pressure is $1.013 \times 10^{5} \mathrm{~Pa}$ (one atmosphere). The dynamic viscosity of air used is $1.78 \times 10^{-5} \mathrm{~Pa} \cdot \mathrm{s}$. Temperature contributions to Equation 6-1 are negligible, with $T_{f}$ approximately equal to $T_{s c}$ for ambient-temperature testing conditions. See Appendix Section I3 for details pertaining to how this calculation was performed.

Two approximations are used in calculating permeability using Equation 6-1. The Hvorslev's formula requires that air behave as an ideal gas. This requirement is approximately true at the ambient temperatures and pressures used in the air-permeability tests. In addition, a finite line source is used to represent a borehole injection interval. This representation is applied to the borehole injection interval, where all airflow is approximated to be in the radial direction (none in the axial direction). This is justified because in the air-permeability tests, the length of injection zone was $0.3048 \mathrm{~m}$ and the radius of the borehole was $0.0381 \mathrm{~m}$. The injection zone is a long, thin cylinder. Flows along axial directions were blocked by packers, and occurrences of packer leaks were monitored by pressures in adjacent borehole intervals, as described in Appendix A.

Although the fractured tuff of the niches is not a homogeneous or infinite medium, the Hvorslev equation provides a consistent method of calculating effective permeabilities on the scale of the injection interval, enabling comparison of the test results for various injection locations. Because the heterogeneity of the surrounding medium is not known a priori, the permeabilities calculated by analytic formula are estimates of effective values around the injection borehole intervals. The results of the air-permeability tests are used to characterize the heterogeneity of the medium of niche sites and test beds. Another requirement of this approach is that airflows are mainly through fractures and governed by Darcy's law. Darcy's law is used to relate flux to pressure gradients (Bear 1972 [DIRS 156269]). The justification for this is that: under the ambient unsaturated conditions in fractured tuff at Yucca Mountain, capillary forces confine the liquid mainly to the matrix. This leaves the fracture network, which is more permeable than the tuff matrix, available for gas flow.

Deviations from Darcy's law may result either from turbulent flow or from the gas slip-flow phenomenon (Klinkenberg 1942 [DIRS 106105]), but neither of these effects is considered significant. Slip flow is significant only in pores with dimensions similar to the mean free path of air molecules (Bear 1972 [DIRS 156269]). Apertures of the fractures in Yucca Mountain are much larger than the molecular mean free path. Pressure drop is proportional to flow rate in laminar flow, which is required for Darcy's law, but not in turbulent flow (Bear 1972 [DIRS 156269]). These experiments were conducted at multiple flow rates to detect any evidence of deviation from Darcy's law due to turbulence, and none was found. Finally, small effects potentially associated with movement of residual water within the fractures and the multirate approach to check packer leak-by and other nonlinear effects (e.g., turbulence) are discussed in Appendix A, Section A4. 


\subsubsection{Permeability Profiles}

All boreholes at niches as illustrated in Figure 6-4 and Figure 6-5 are nominally $10 \mathrm{~m}$ long and $0.0762 \mathrm{~m}$ in diameter. Those in Figure 6-6 and Figure 6-7 were nominally $15 \mathrm{~m}$ long and $0.0762 \mathrm{~m}$ in diameter. The boreholes were dry-drilled with compressed air to remove drill cuttings. Both the packer length and the test interval length are $0.3 \mathrm{~m}$ in all cases. Additional details pertaining to equipment configuration and test execution are provided in Appendix A.

Whereas most of the niches were excavated so as to preserve certain boreholes surrounding them (in order to remeasure the air permeability in these holes after excavation), Alcove 8 was constructed for other purposes and only later adapted for air-permeability testing; consequently, no pre-excavation air permeabilities are available.

\subsection{Pre- and Post-Excavation Permeability Profiles}

Permeability profiles along boreholes at the five niches show the permeability value from each test interval, plotted against the location of the middle of the test interval (also referred to as "test zone"). Figure 6-8 illustrates three Niche 1 (Niche 3566) permeability profiles along the upper, middle, and bottom boreholes, which are parallel to the niche axis. The air-permeability tests were conducted before niche excavation. Niche 1 (Niche 3566), the first niche excavated in the ESF, is located in the vicinity of the Sundance fault. All three boreholes penetrated brecciated zones in the last one-third of their lengths, with broken rock pieces preventing packer insertion beyond this depth. A wet feature within a brecciated zone was observed at the end of this niche, right after completion of dry excavation (Wang et al. 1999 [DIRS 106146], p. 331, Figure (4c)). The width of the wet feature is comparable to the borehole-interval length of $0.3 \mathrm{~m}$, used in the air-permeability tests (this section) and liquid-release seepage tests (Section 6.2).

After niche excavation, six additional horizontal boreholes were drilled from the inside of Niche 1 (Niche 3566), fanning out radially in different directions. Only two radial boreholes were tested and analyzed in Niche 1 (Niche 3566); this niche was sealed for moisture monitoring after testing the two radial boreholes, and additional air-permeability and seepage testing in this niche was deferred. The permeability profiles for two radial boreholes on the left side of the niche are illustrated in Figure 6-9. These boreholes also penetrated brecciated zones. The absence of data from the deeper portion of one of the boreholes in Figure 6-9 is related to the intrinsic difficulties of brecciated zone testing due to poor borehole conditions, which prevent the maintenance of a proper seal (see also Appendix Section A4 for a discussion of issues pertaining to packer leak-by in testing). 
a)

$\longrightarrow$ upper

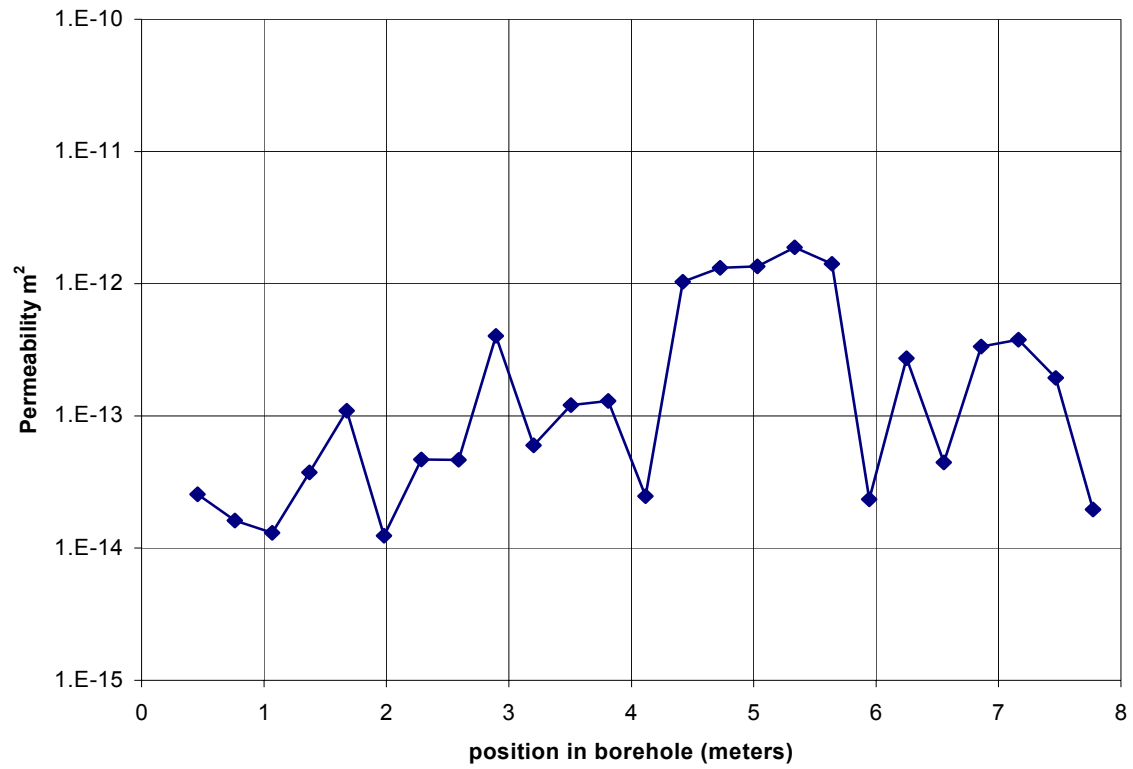

b)
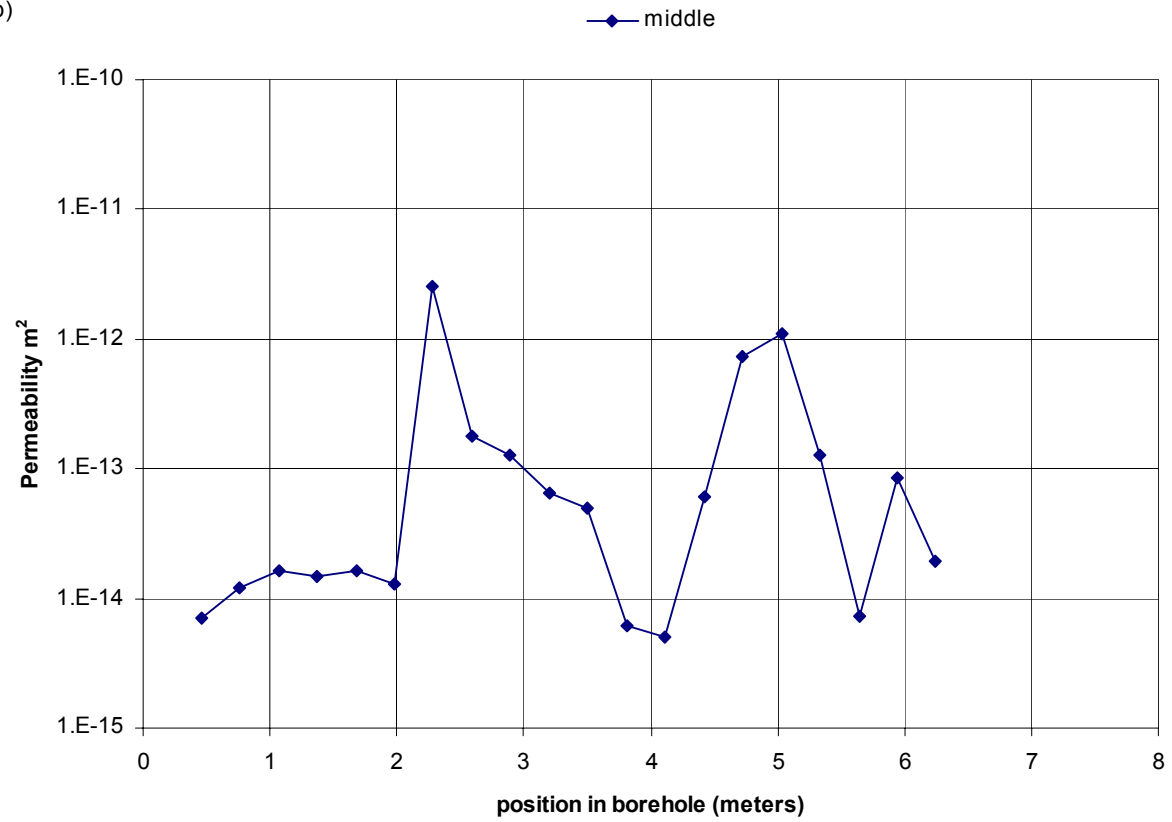

Source: DTN: LB0011AIRKTEST.001 [DIRS 153155].

NOTE: In DTN: LB0011AIRKTEST.001 [DIRS 153155], a zone number, rather than the actual position in the borehole, is reported. Zone 1 is centered at $0.5 \mathrm{~m}$, and each successive zone is $0.3 \mathrm{~m}$ further into the borehole (e.g., zone 2 is centered at $0.8 \mathrm{~m}$ ).

Figure 6-8. Pre-Excavation Air-Permeability Profiles along Axial Boreholes at Niche 1 (Niche 3566) 


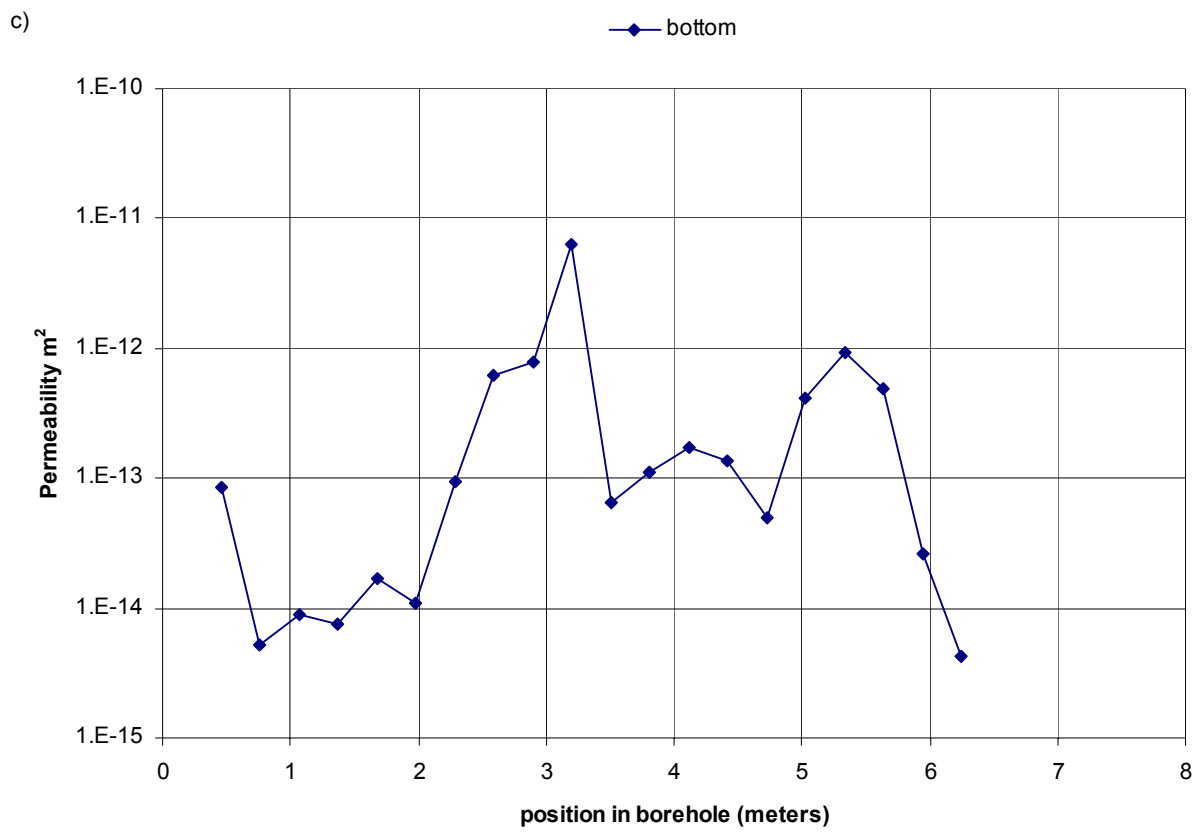

NOTE: In DTN: LB0011AIRKTEST.001 [DIRS 153155], a zone number, rather than the actual position in the borehole, is reported. Zone 1 is centered at $0.5 \mathrm{~m}$, and each successive zone is $0.3 \mathrm{~m}$ further into the borehole (e.g., zone 2 is centered at $0.8 \mathrm{~m}$ ).

Figure 6-8. Pre-Excavation Air-Permeability Profiles along Axial Boreholes at Niche 1 (Niche 3566) (Continued)

Figure 6-10 illustrates both the pre- and post-excavation permeability profiles along three upper boreholes at Niche 2 (Niche 3650). On all the plots with both pre- and post-excavation data, a line is drawn through the profiles to indicate the geometric average of each (see Appendix Section I1 for calculations). This mean includes only intervals that were tested in common both before and after excavation.

The permeability increases could be interpreted as the opening of pre-existing fractures induced by stress releases associated with niche excavation (Wang and Elsworth 1999 [DIRS 104366], pp. 751 to 757). The niches were excavated using an Alpine Miner (a mechanical device with a rotary head), as opposed to drilling and blasting, to cut the rocks below the upper-level boreholes, to minimize potential effects on permeability from excavation-induced damages and fracturing.

Intervals with high pre-excavation permeability recorded the smallest post-excavation permeability changes. In additional to mechanical effects, some of the permeability increases can be related to the intersection of previously dead-ended fractures with the excavated free surface. For borehole intervals, beyond the extent of the niche excavation, the permeability values are less altered. Figure 6-11 illustrates the pre-excavation permeability profiles of the other four boreholes. The middle- and bottom-level boreholes were available for air-injection testing only before niche excavation, because they were subsequently removed by excavation. 
a)

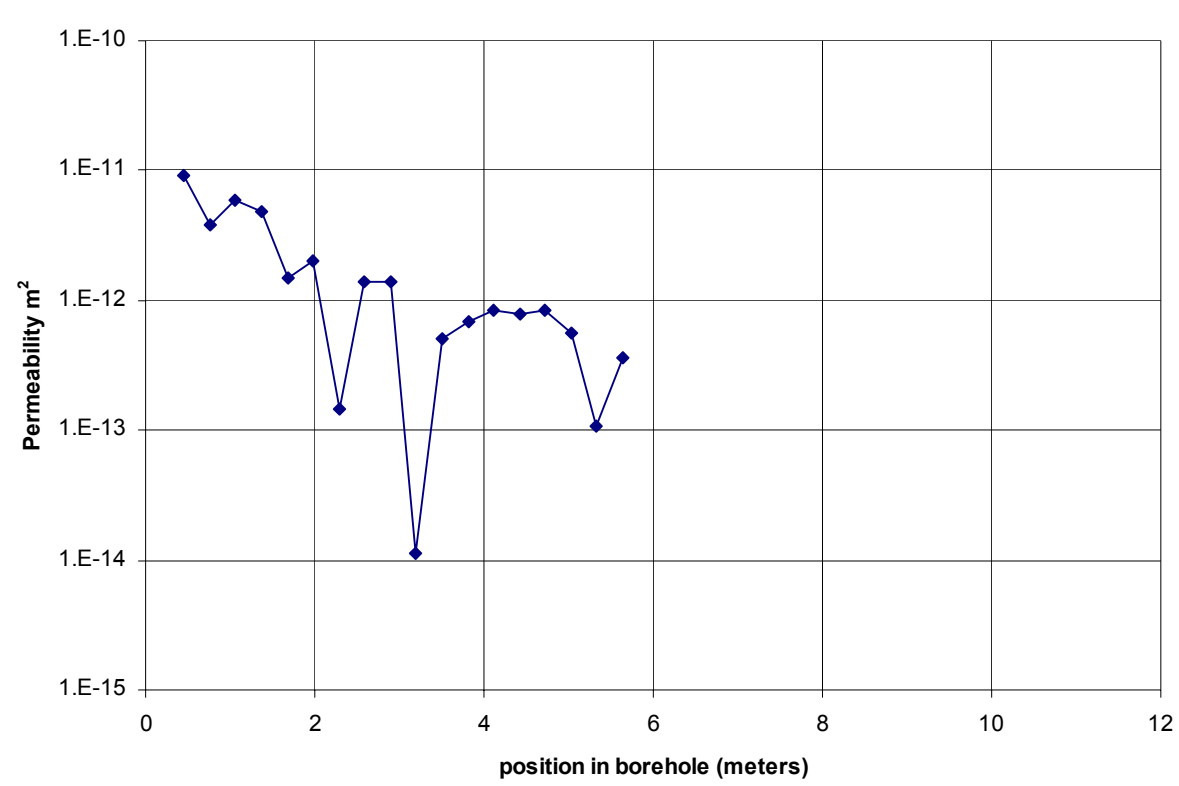

b)
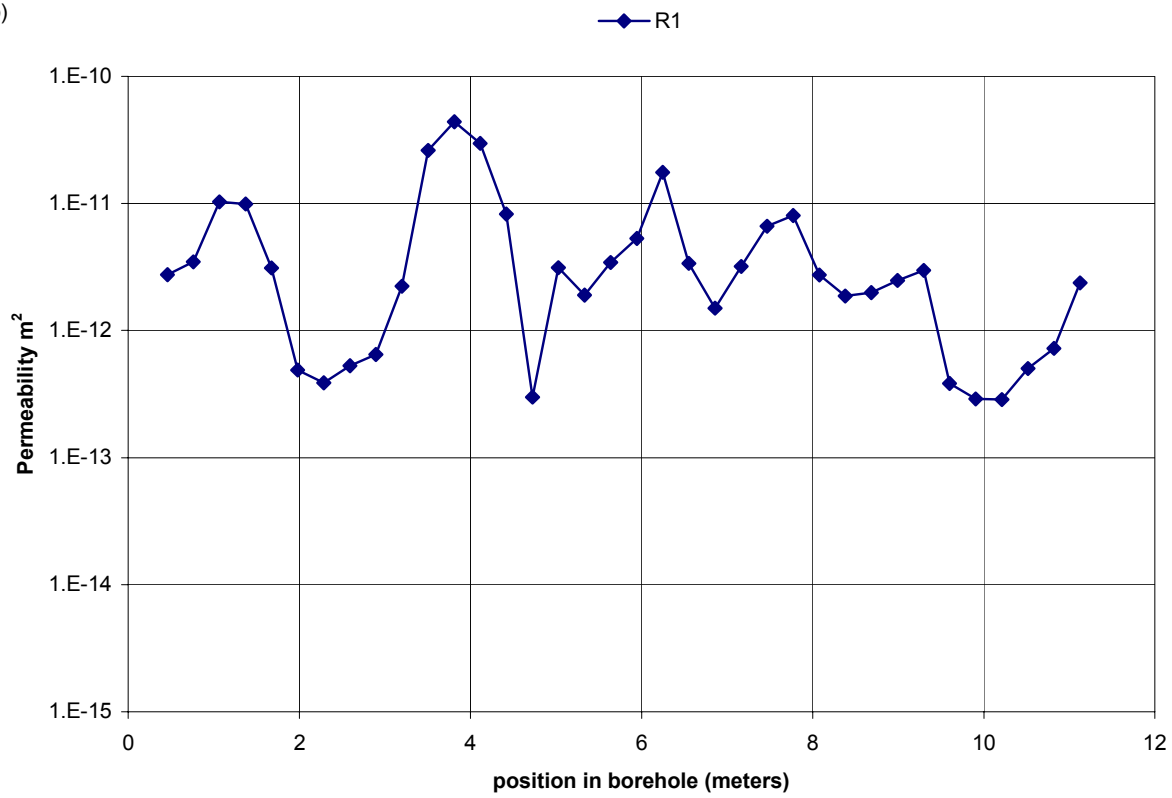

Source: DTN: LB0011AIRKTEST.001 [DIRS 153155].

NOTE: In DTN: LB0011AIRKTEST.001 [DIRS 153155], a zone number, rather than the actual position in the borehole, is reported. Zone 1 is centered at $0.5 \mathrm{~m}$, and each successive zone is $0.3 \mathrm{~m}$ further into the borehole (e.g., zone 2 is centered at $0.8 \mathrm{~m}$ ).

Figure 6-9. Post-Excavation Air-Permeability Profiles along Radial Boreholes at Niche 1 (Niche 3566) 

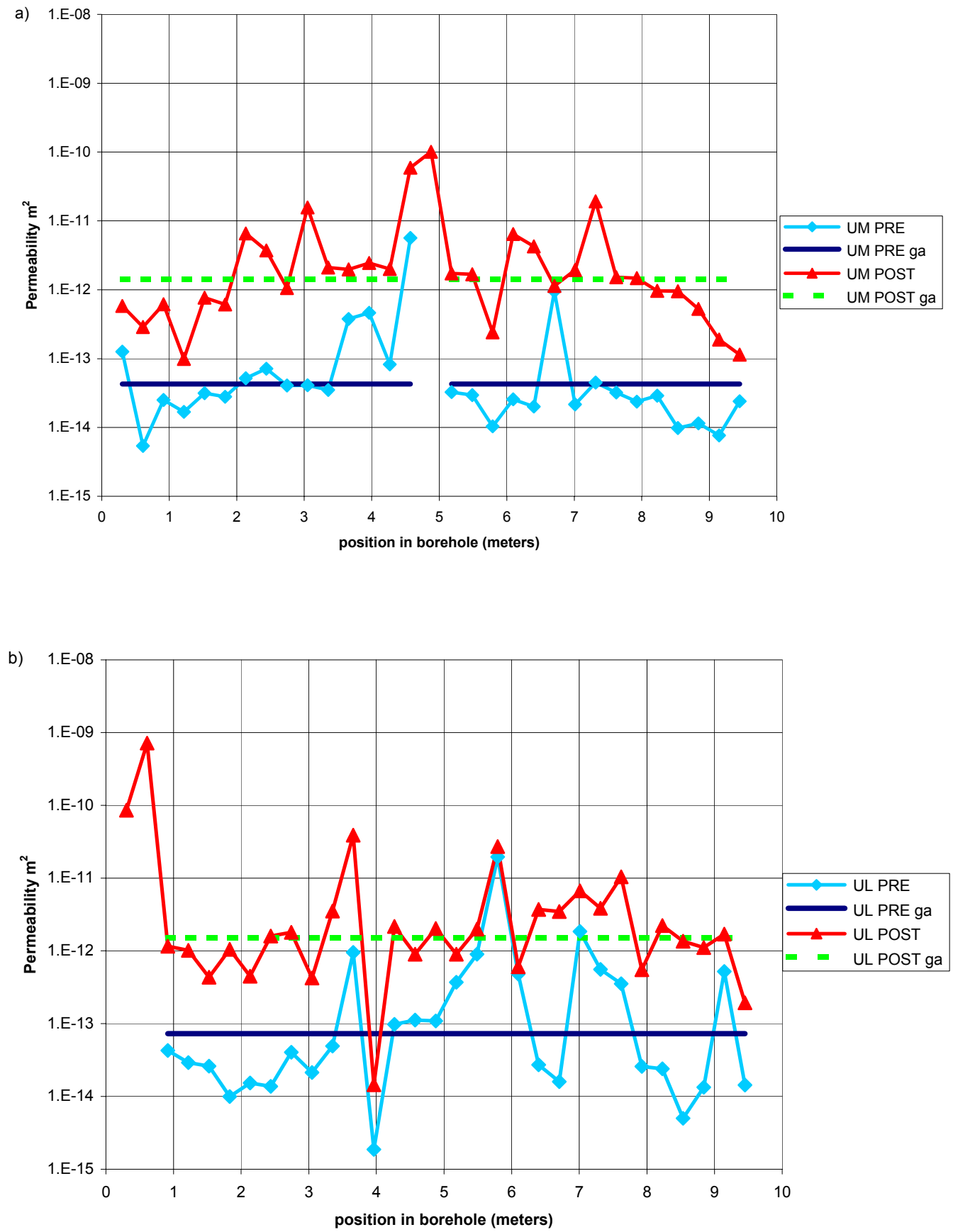

Source: DTN: LB0011AIRKTEST.001 [DIRS 153155].

NOTE: "ga" is the geometric average. In DTN: LB0011AIRKTEST.001 [DIRS 153155], a zone number, rather than the actual position in the borehole, is reported. Zone 1 is centered at $0.5 \mathrm{~m}$, and each successive zone is $0.3 \mathrm{~m}$ further into the borehole (e.g., zone 2 is centered at $0.8 \mathrm{~m}$ ).

NOTE: Tested borehole intervals are $0.3 \mathrm{~m}$ long; plotted position is at beginning of tested interval.

Figure 6-10. Pre- and Post-Excavation Air-Permeability Profiles along Upper Boreholes at Niche 2 (Niche 3650) 


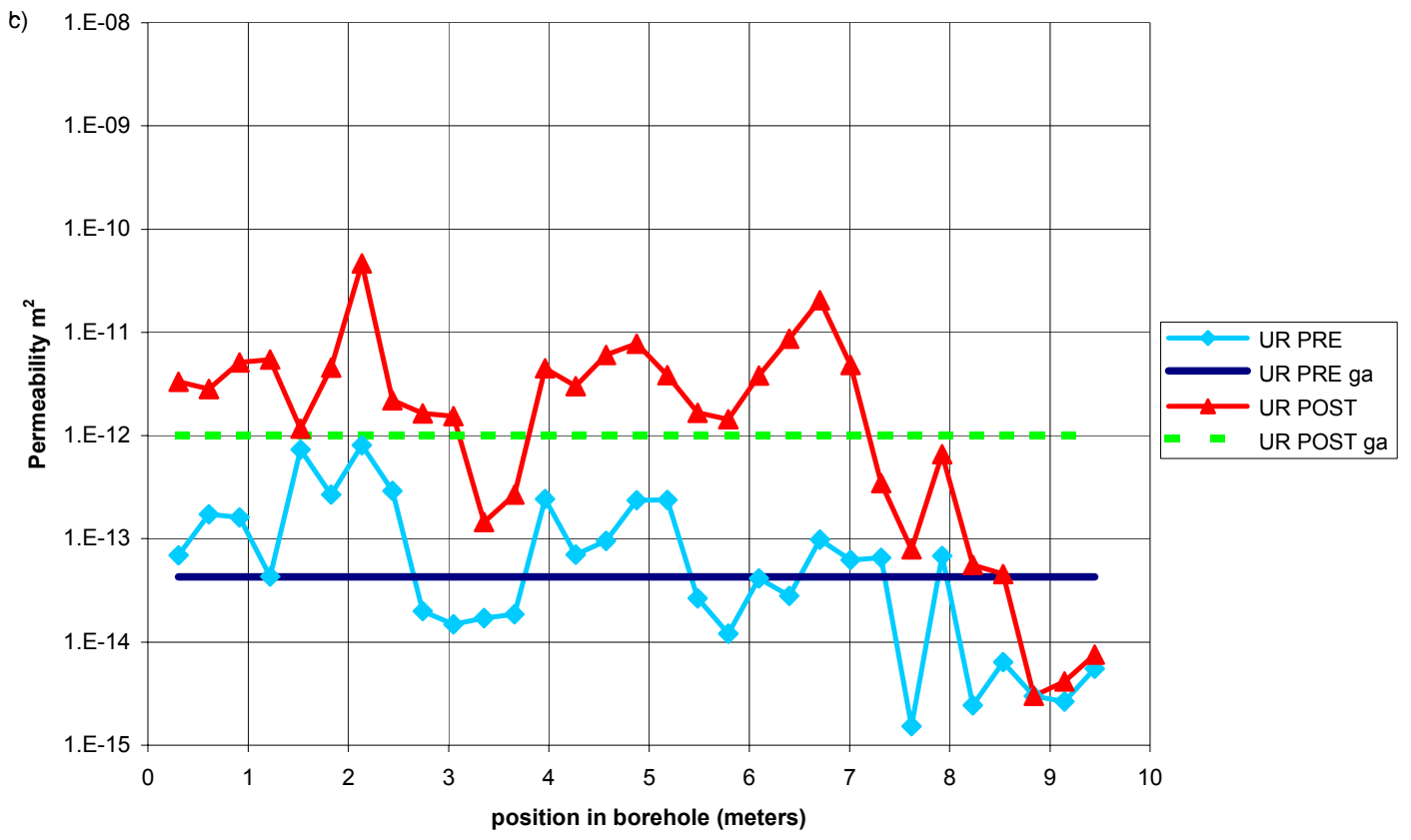

Source: DTN: LB0011AIRKTEST.001 [DIRS 153155].

NOTES: "ga" is the geometric average. In DTN: LB0011AIRKTEST.001 [DIRS 153155], a zone number, rather than the actual position in the borehole, is reported. Zone 1 is centered at $0.5 \mathrm{~m}$, and each successive zone is $0.3 \mathrm{~m}$ further into the borehole (e.g., zone 2 is centered at $0.8 \mathrm{~m}$ ).

Tested intervals are $0.3 \mathrm{~m}$ long; plotted position is at beginning of tested interval.

Figure 6-10. Pre- and Post-Excavation Air-Permeability Profiles along Upper Boreholes at Niche 2 (Niche 3650) (Continued) 
a)
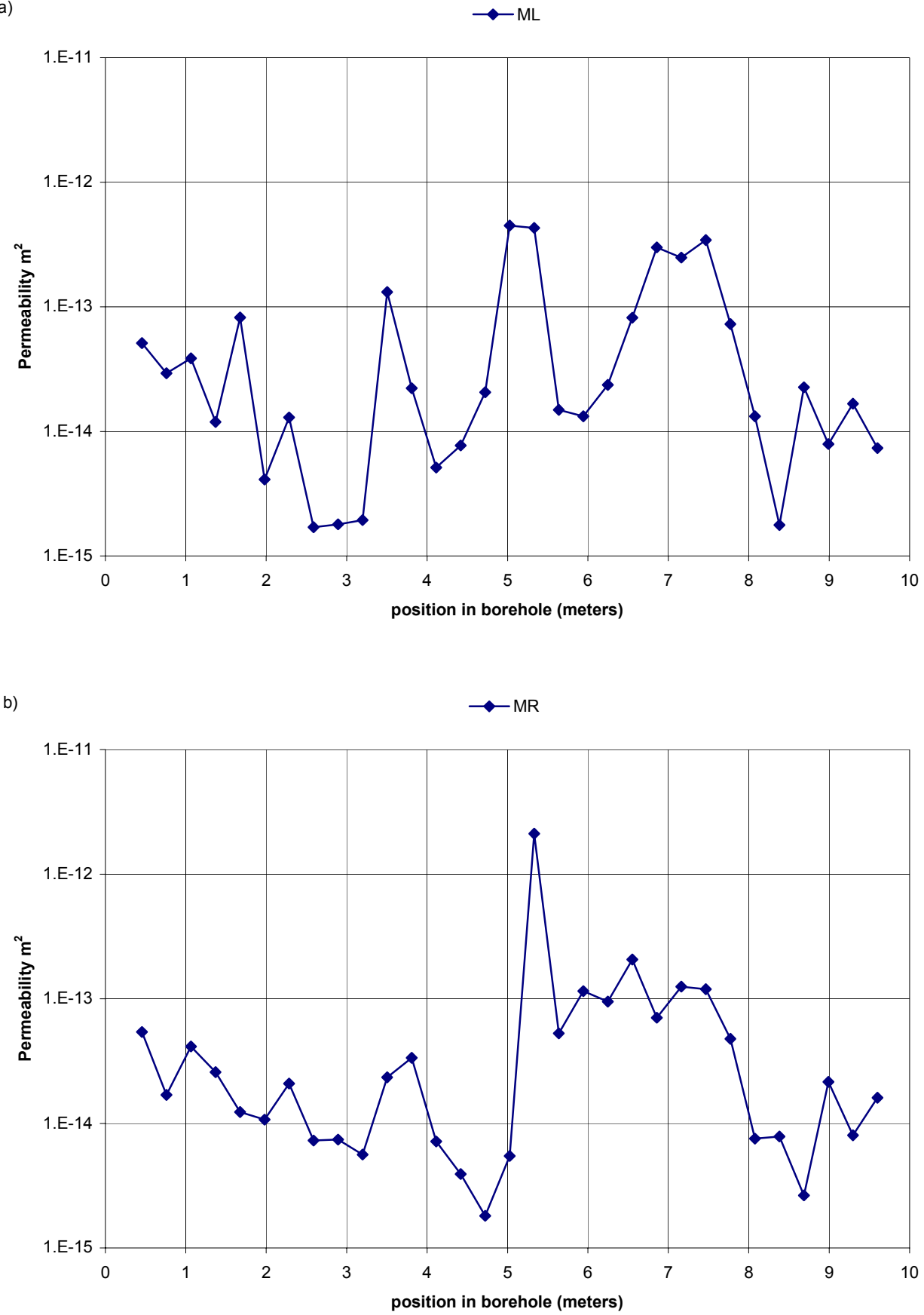

Source: DTN: LB0011AIRKTEST.001 [DIRS 153155].

NOTE: In DTN: LB0011AIRKTEST.001 [DIRS 153155], a zone number, rather than the actual position in the borehole, is reported. Zone 1 is centered at $0.5 \mathrm{~m}$, and each successive zone is $0.3 \mathrm{~m}$ further into the borehole (e.g., zone 2 is centered at $0.8 \mathrm{~m}$ ).

Figure 6-11. Pre-Excavation Air-Permeability Profiles along Middle and Bottom Boreholes at Niche 2 (Niche 3650) 


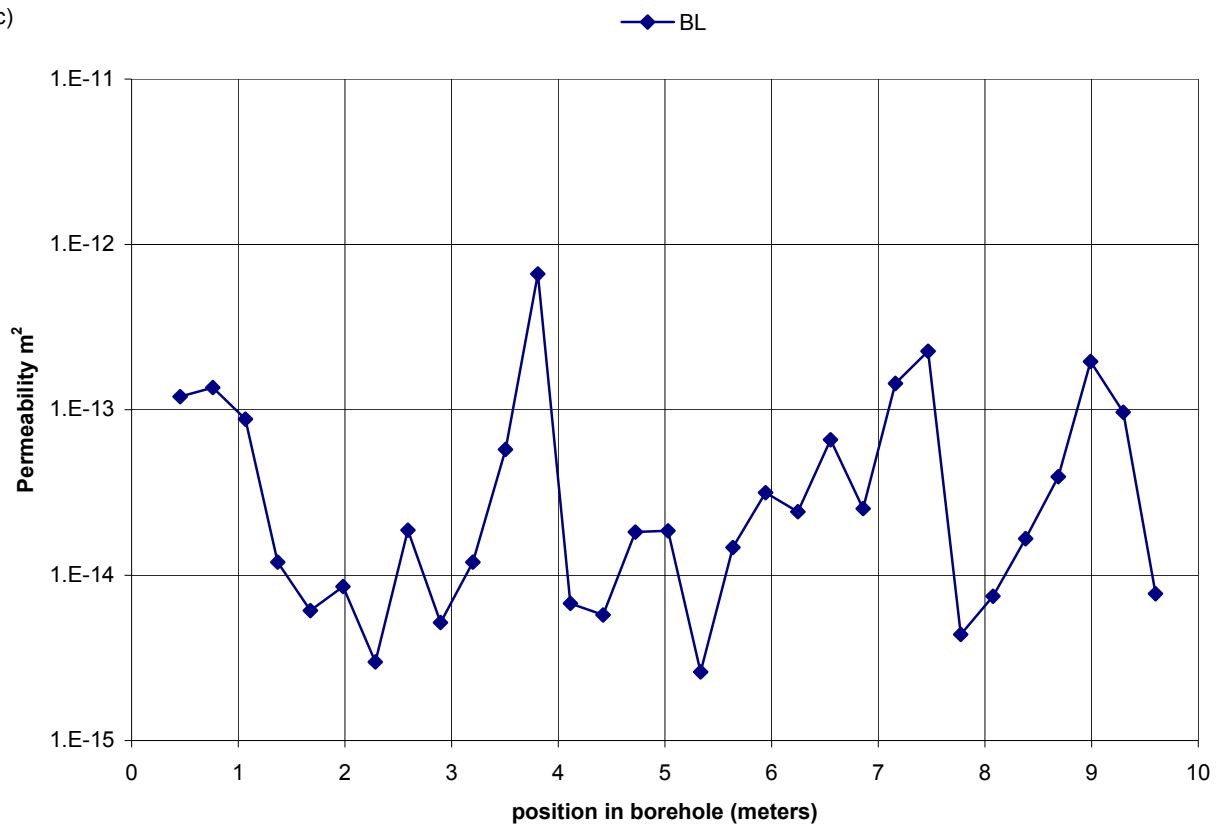

d)

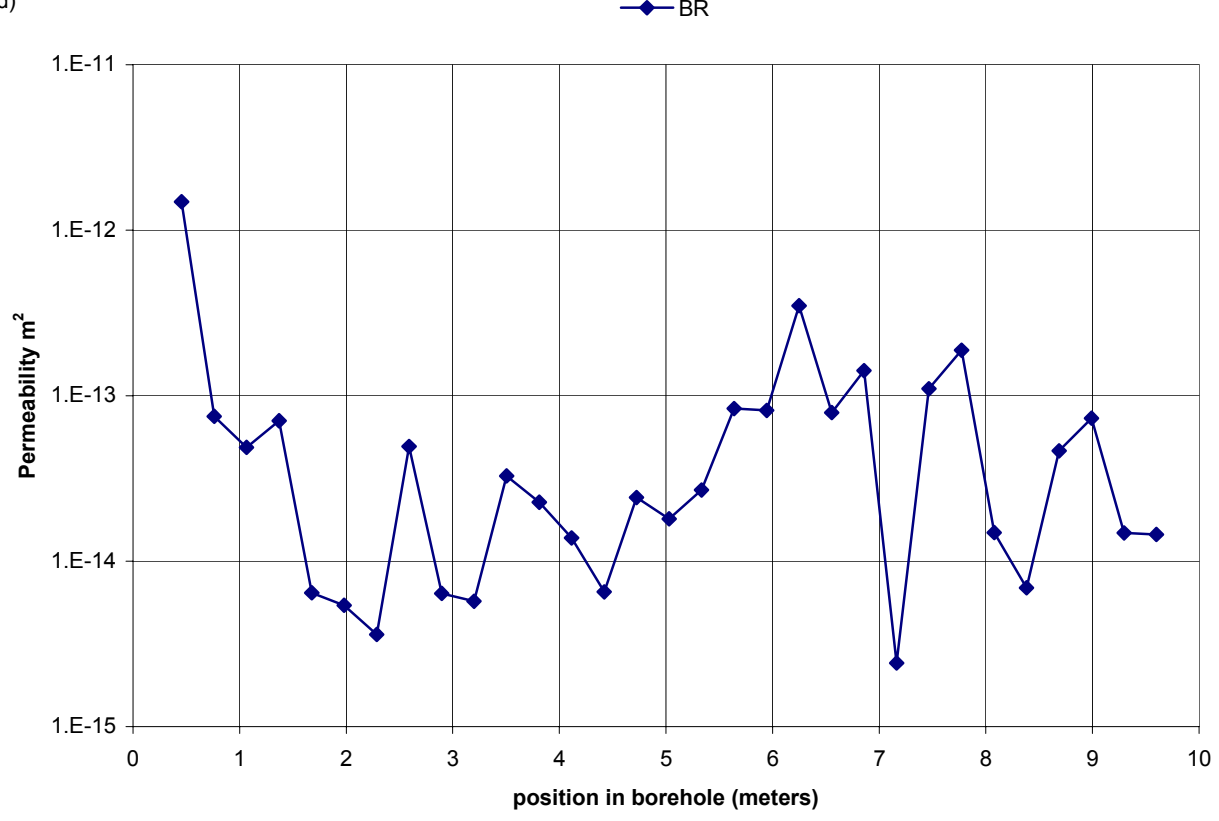

Source: DTN: LB0011AIRKTEST.001 [DIRS 153155].

NOTE: In DTN: LB0011AIRKTEST.001 [DIRS 153155], a zone number, rather than the actual position in the borehole, is reported. Zone 1 is centered at $0.5 \mathrm{~m}$, and each successive zone is $0.3 \mathrm{~m}$ further into the borehole (e.g., zone 2 is centered at $0.8 \mathrm{~m}$ ).

Figure 6-11. Pre-Excavation Air-Permeability Profiles along Middle and Bottom Boreholes at Niche 2 (Niche 3650) (Continued) 
The results of the permeability profiles are presented for Niche 3 (Niche 3107) in Figure 6-12 and Figure 6-13, and for Niche 4 (Niche 4788) in Figure 6-14 and Figure 6-15. Figure 6-12 and Figure 6-14, similarly to Figure 6-10, are for the upper boreholes, with both pre-excavation and post-excavation values presented for the evaluation of excavation-induced permeability changes. Figure 6-13 and Figure 6-15 are pre-excavation permeability profiles for the middle- and lower-level boreholes that were subsequently mined out from Niche 3 (Niche 3107) and Niche 4 (Niche 4788). The borehole layouts for these two niches are modified from the layout in Niche 2 (Niche 3650), as illustrated in Figure 6-4.

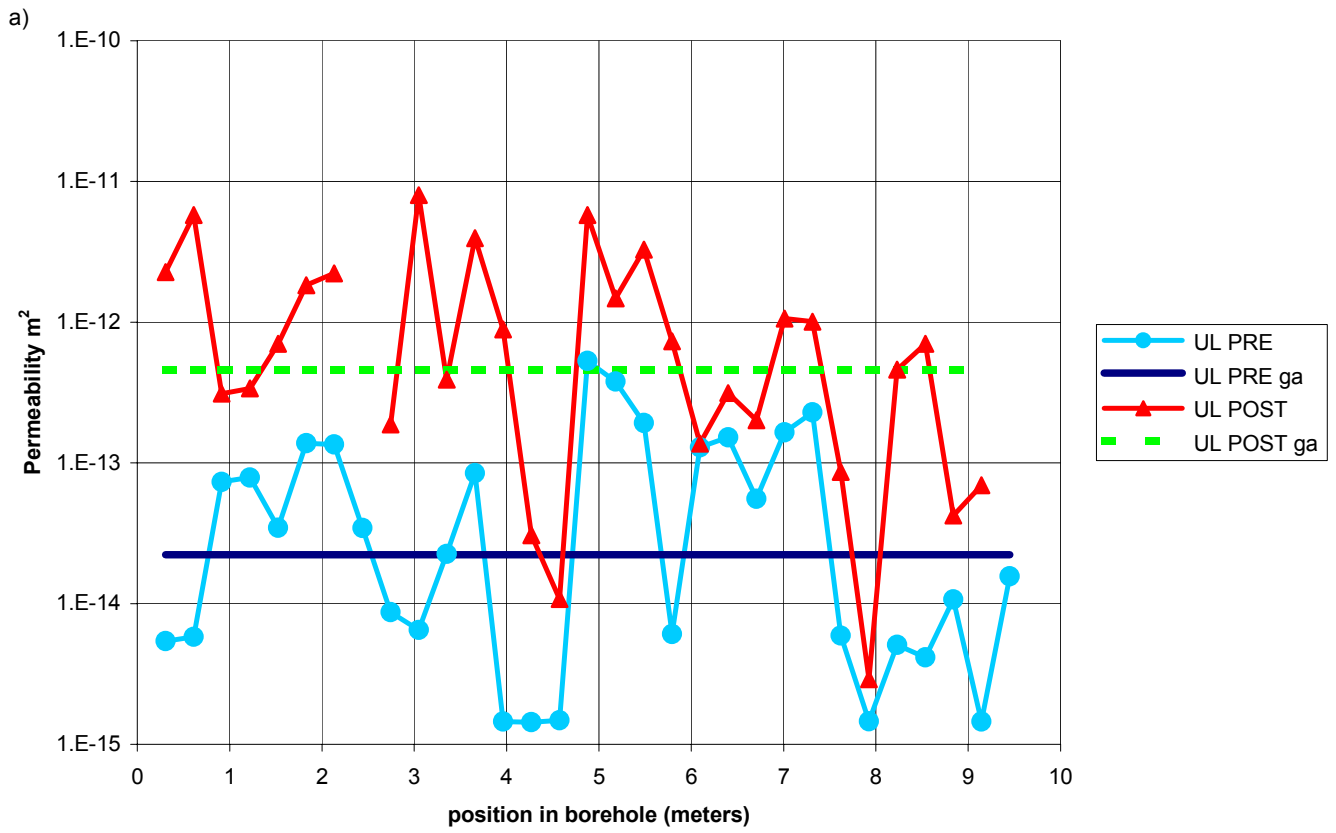

Source: DTNs: LB980901233124.101 [DIRS 136593] for pre-excavation data, LB990601233124.001 [DIRS 105888] for post-excavation data.

NOTE: Tested intervals are $0.3 \mathrm{~m}$ long; plotted position is at beginning of tested interval.

Figure 6-12. Pre- and Post-Excavation Air-Permeability Profiles along Upper Boreholes at Niche 3 (Niche 3107) 


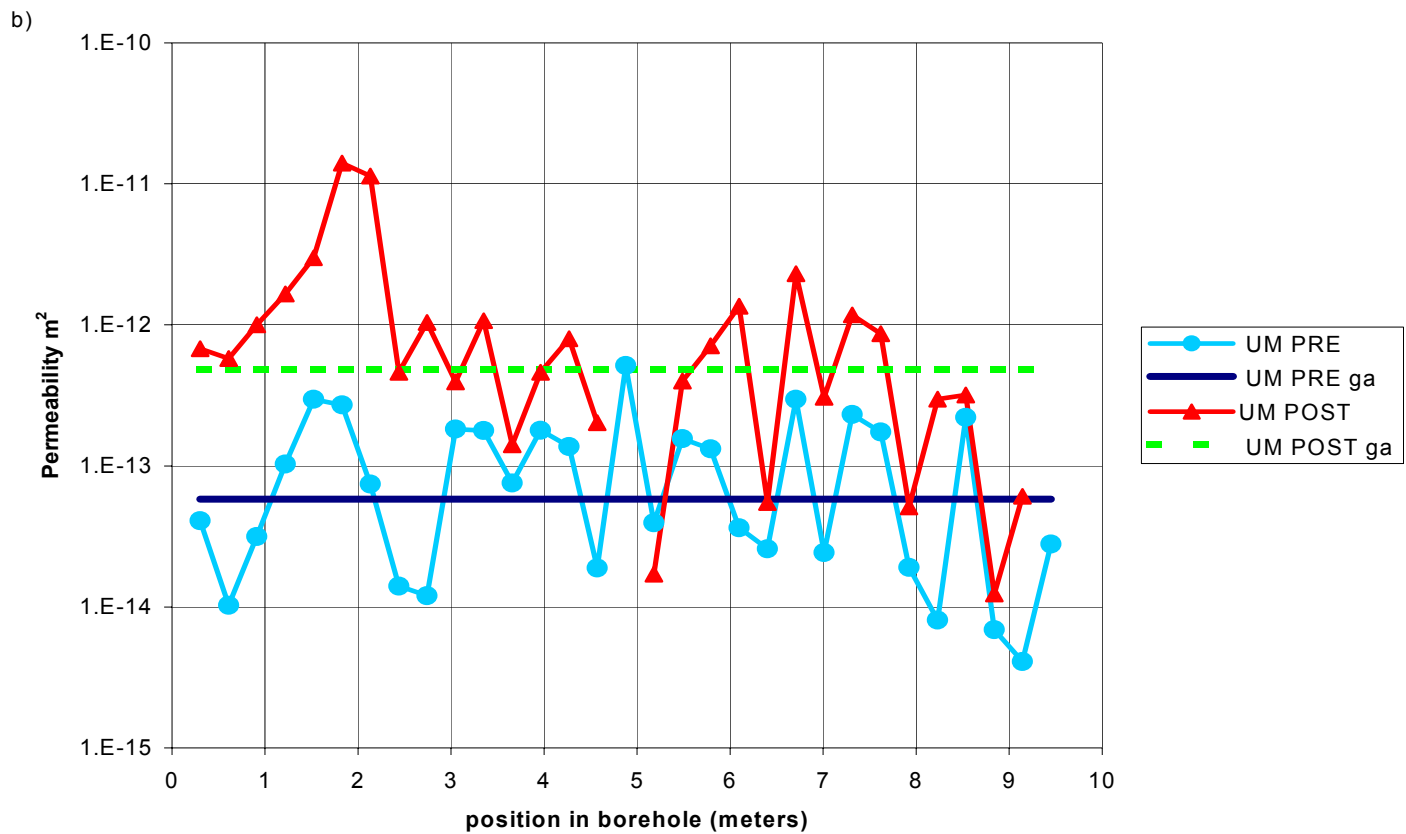

c)

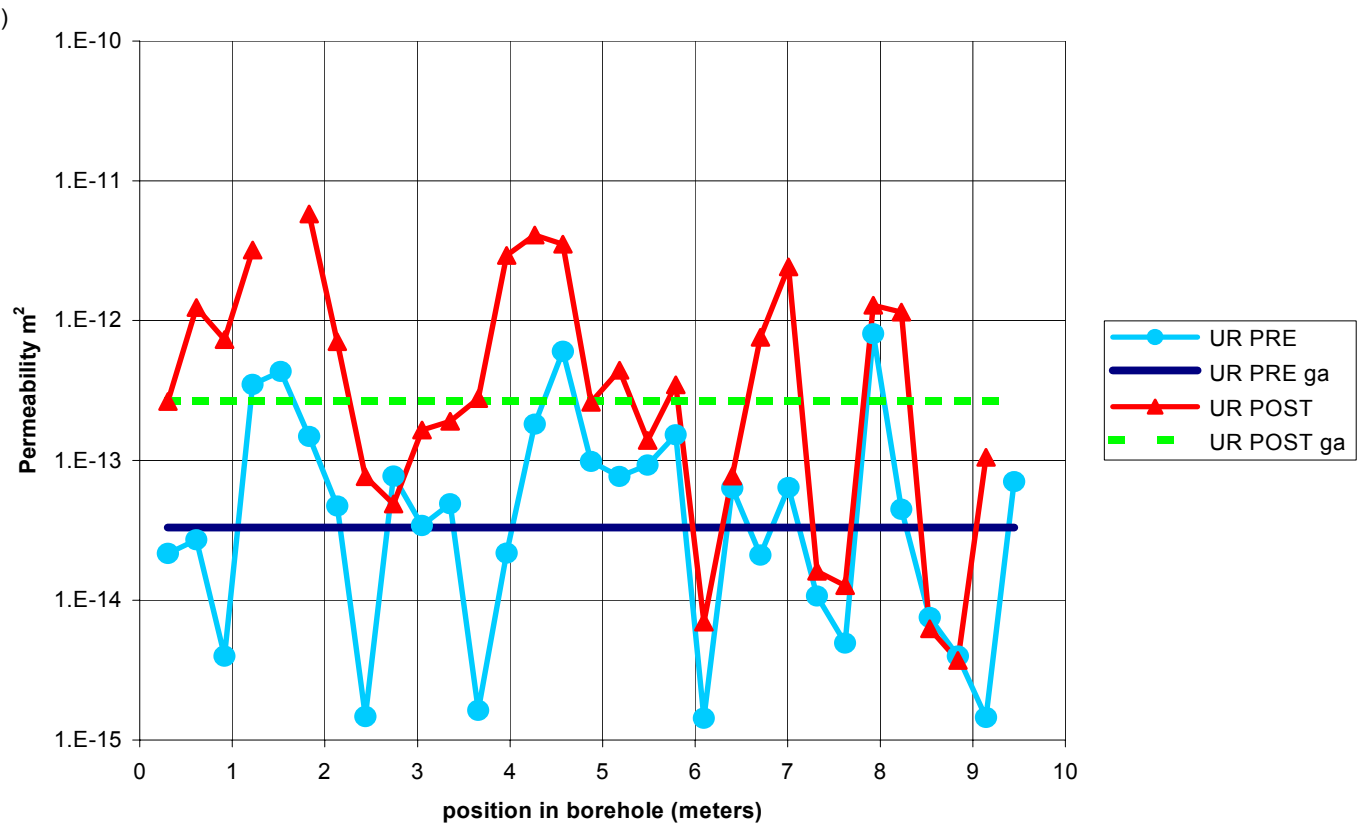

Source: DTNs: LB980901233124.101 [DIRS 136593] for pre-excavation data, LB990601233124.001 [DIRS 105888] for post-excavation data.

NOTE: Tested intervals are $0.3 \mathrm{~m}$ long; plotted position is at beginning of tested interval.

Figure 6-12. Pre- and Post-Excavation Air-Permeability Profiles along Upper Boreholes at Niche 3 (Niche 3107) (Continued) 
a)

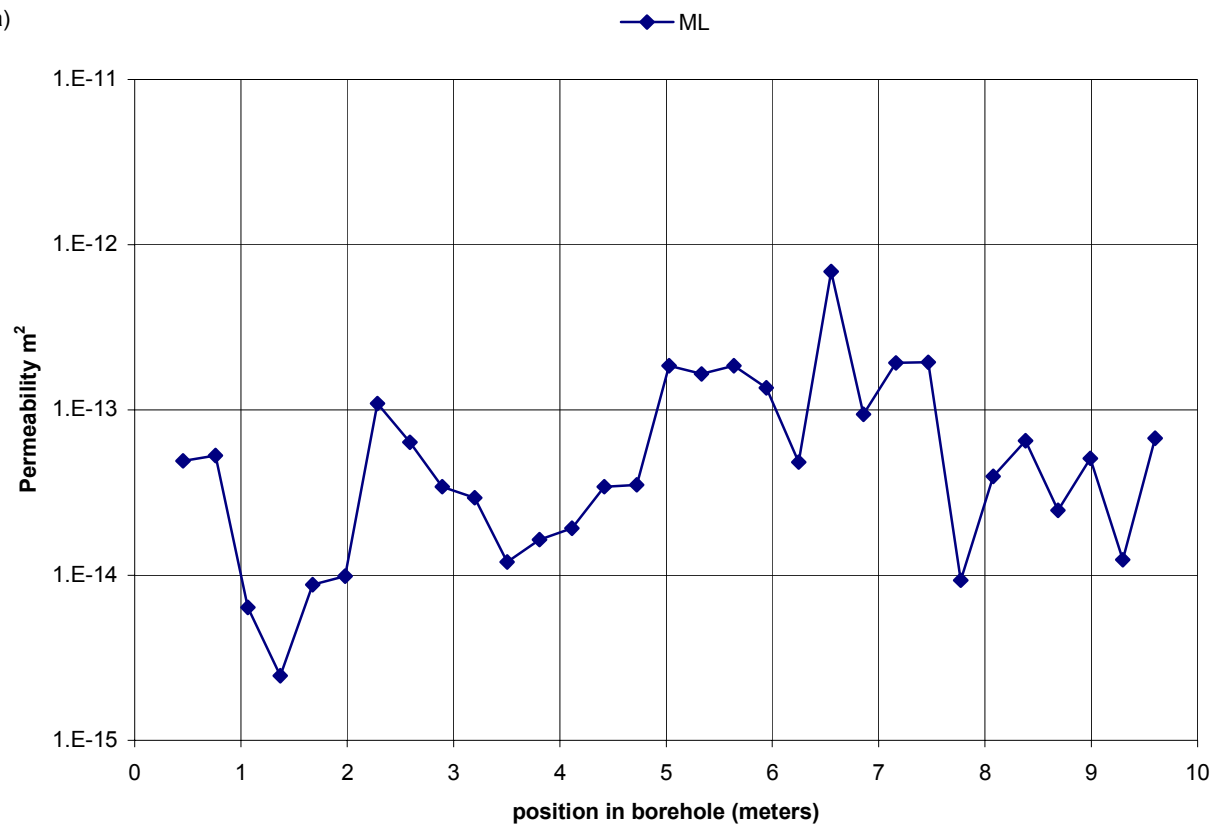

b)

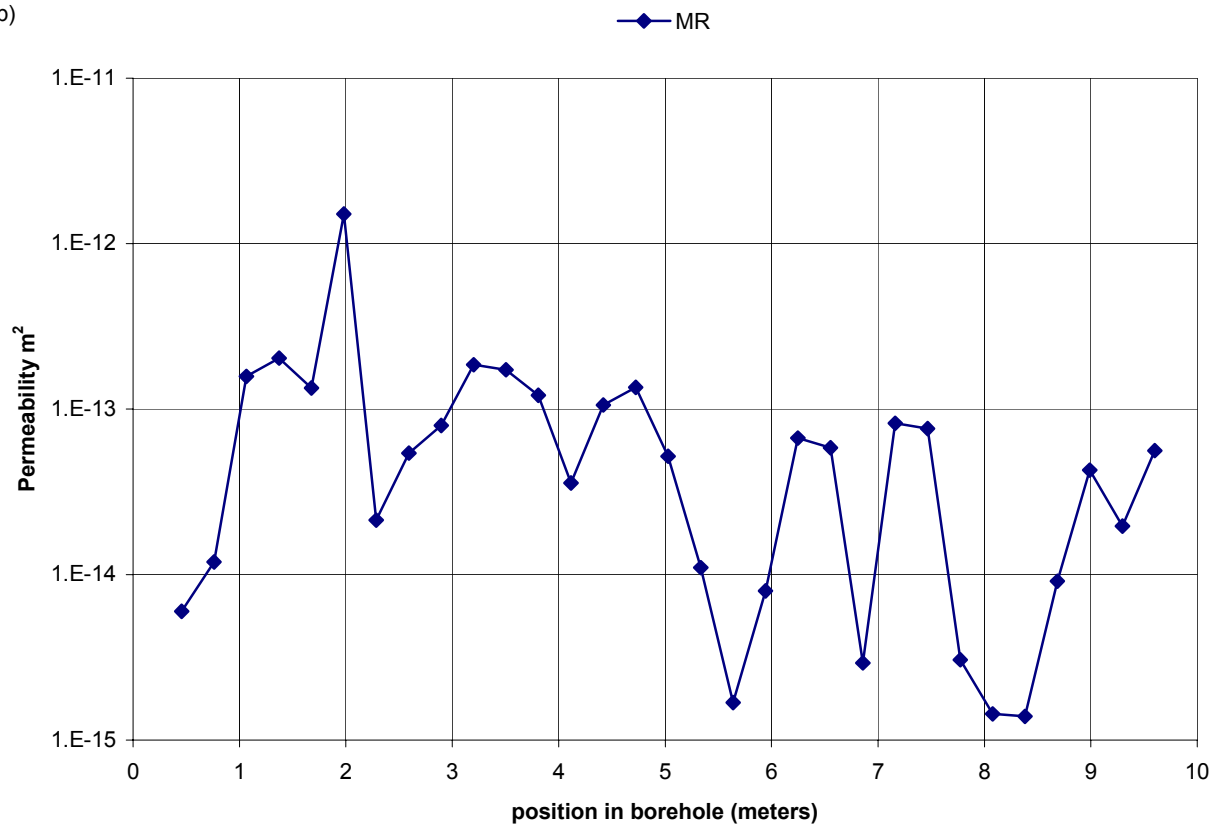

Source: DTN: LB980901233124.101 [DIRS 136593].

Figure 6-13. Pre-Excavation Air-Permeability Profiles along Middle and Bottom Boreholes at Niche 3 (Niche 3107) 
c)

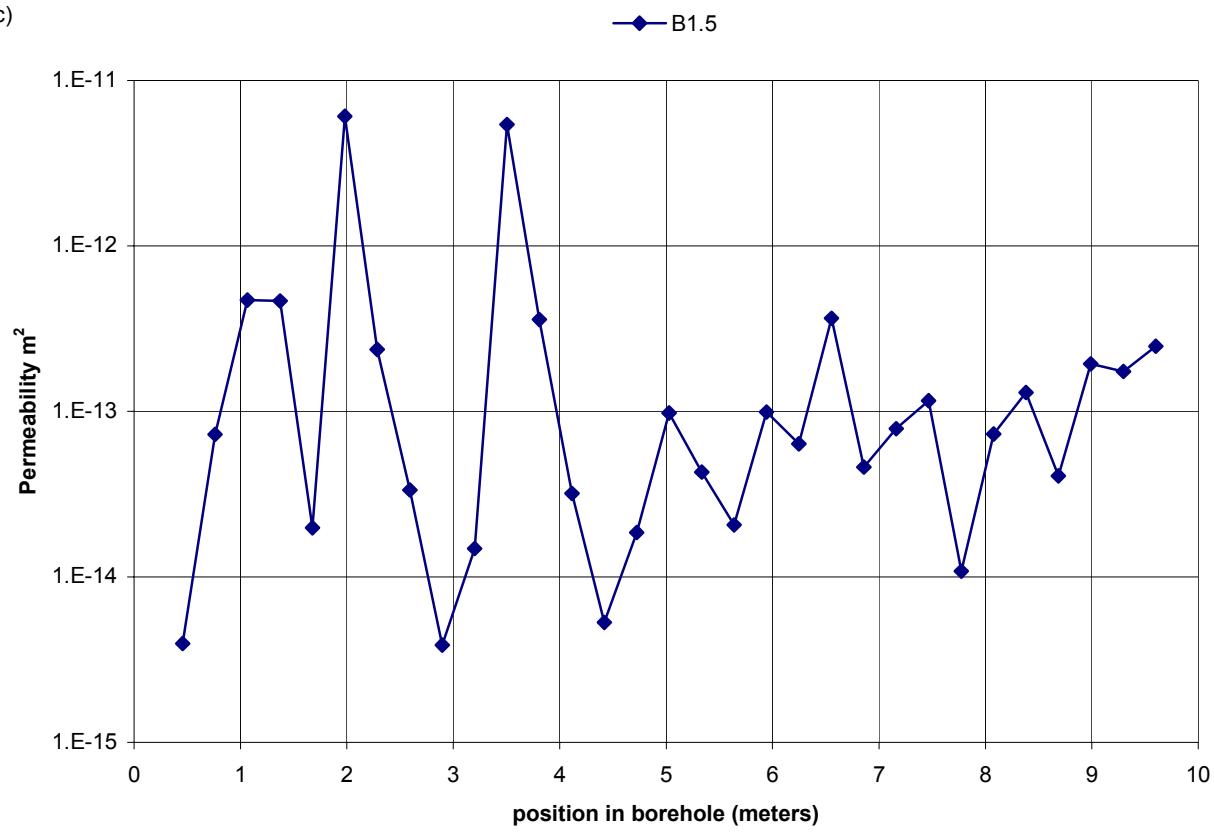

d)

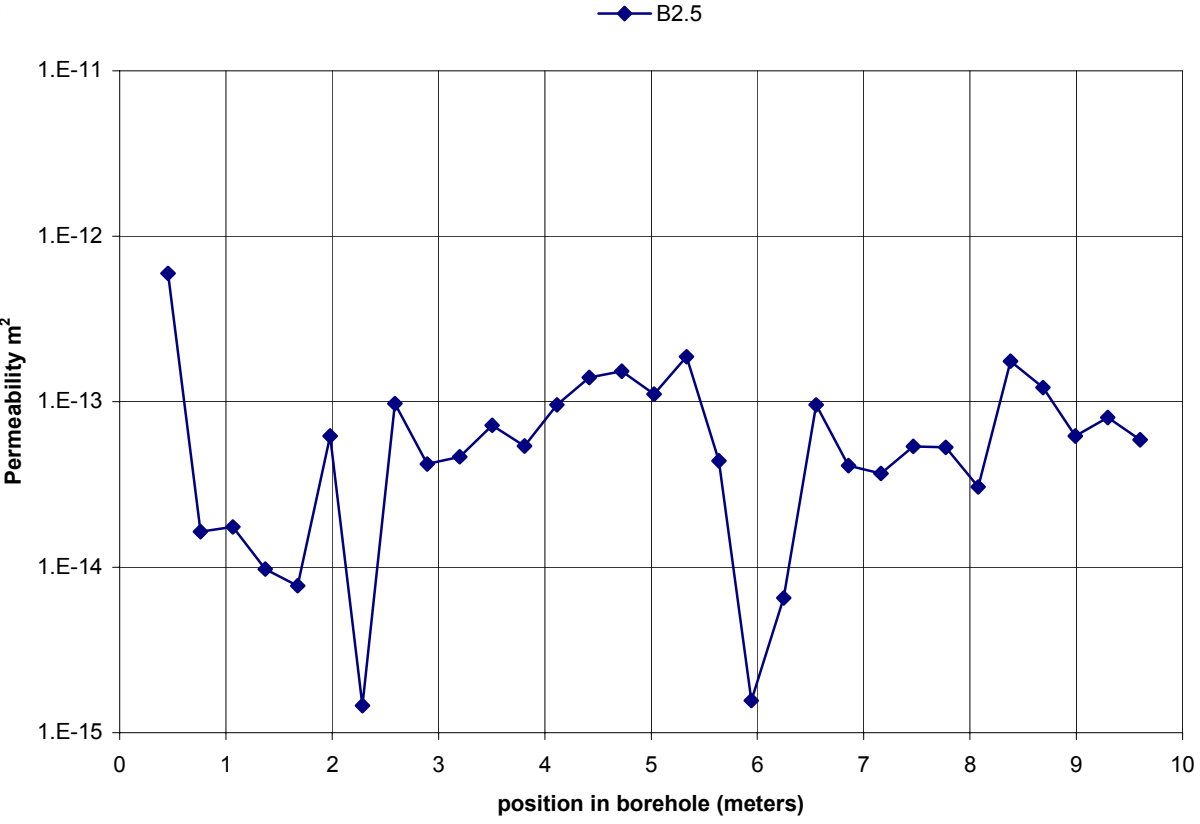

Source: DTN: LB980901233124.101 [DIRS 136593].

Figure 6-13. Pre-Excavation Air-Permeability Profiles along Middle and Bottom Boreholes at Niche 3 (Niche 3107) (Continued) 
a)
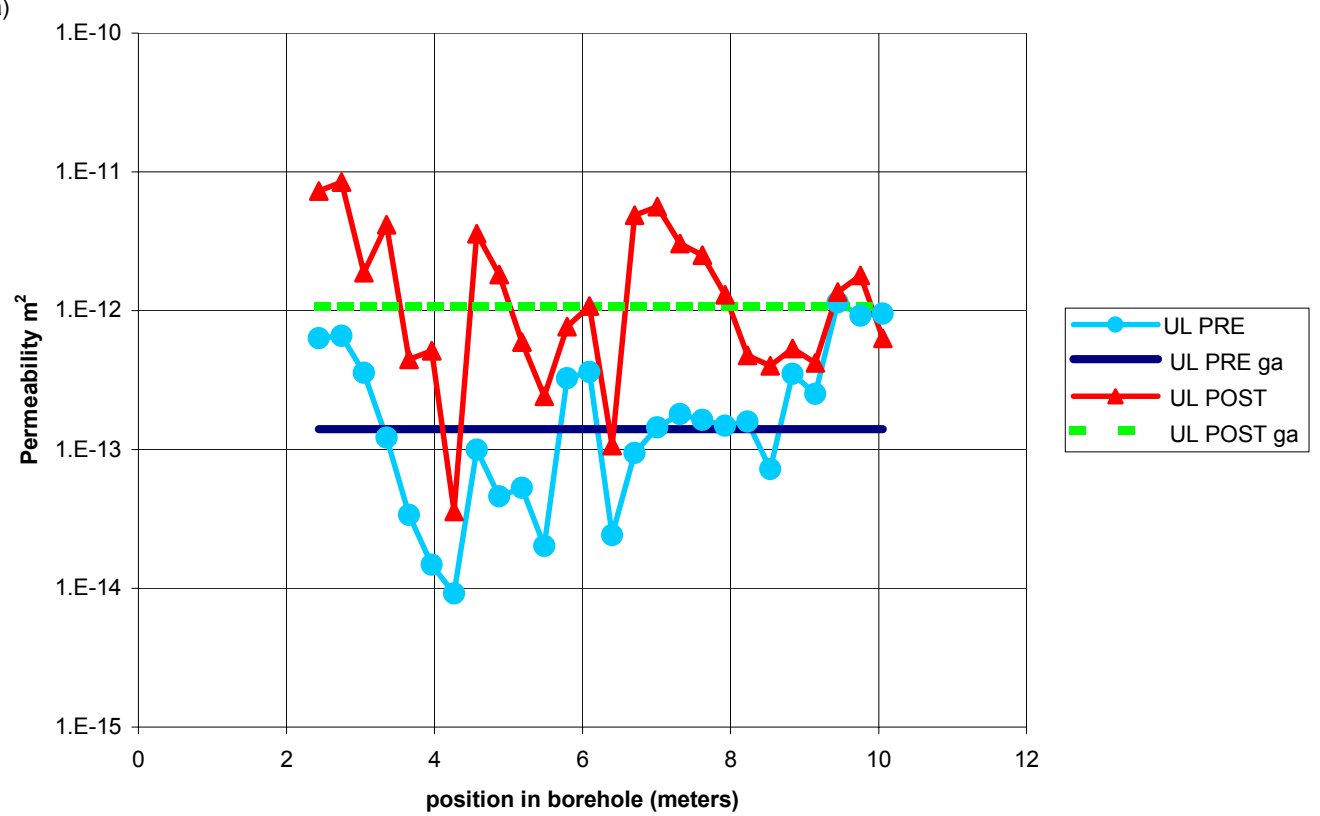

b)
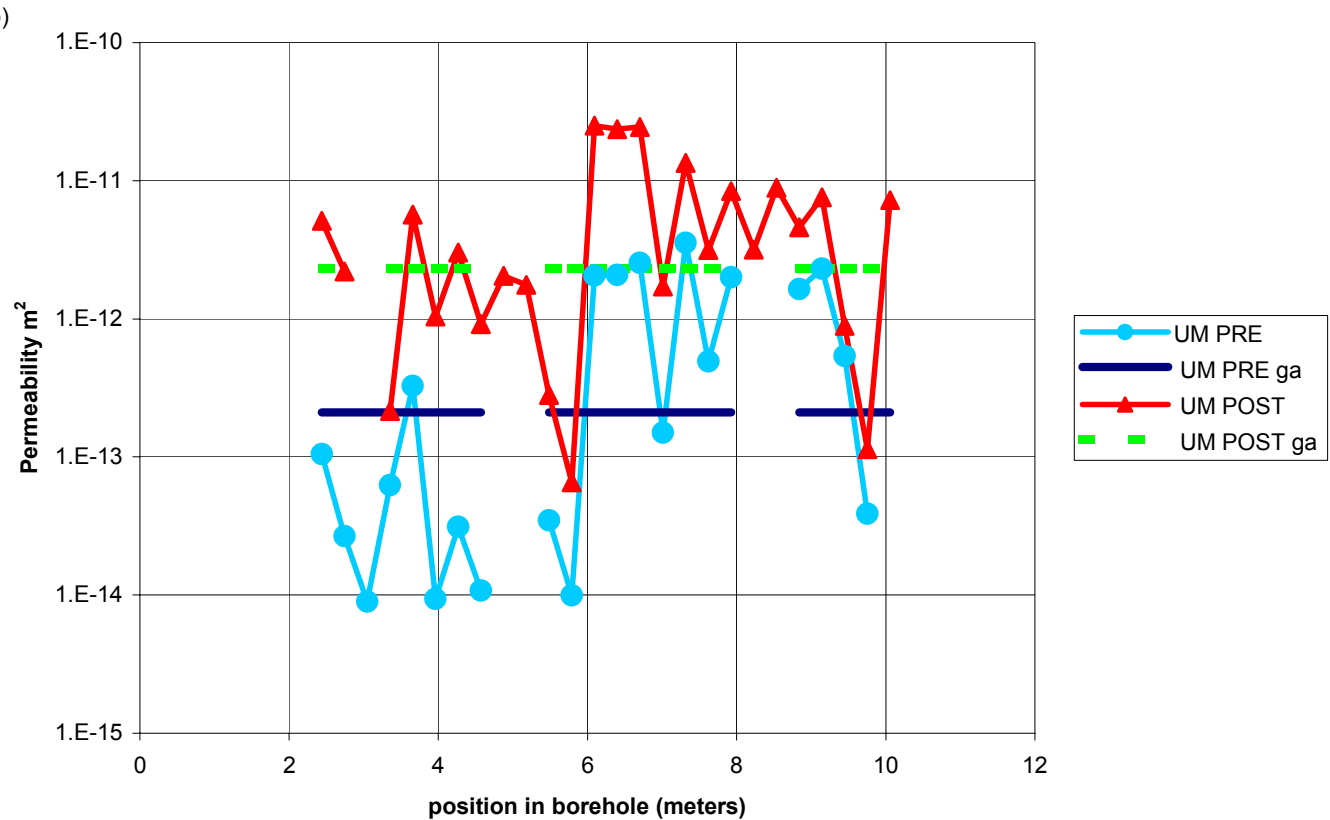

Source: $\quad$ DTNs: LB980901233124.101 [DIRS 136593] for pre-excavation data, LB990601233124.001 [DIRS 105888] for post-excavation data.

NOTE: Tested intervals are $0.3 \mathrm{~m}$ long; plotted position is at beginning of tested interval.

Figure 6-14. Pre- and Post-Excavation Air-Permeability Profiles along Upper Boreholes at Niche 4 (Niche 4788) 
c)

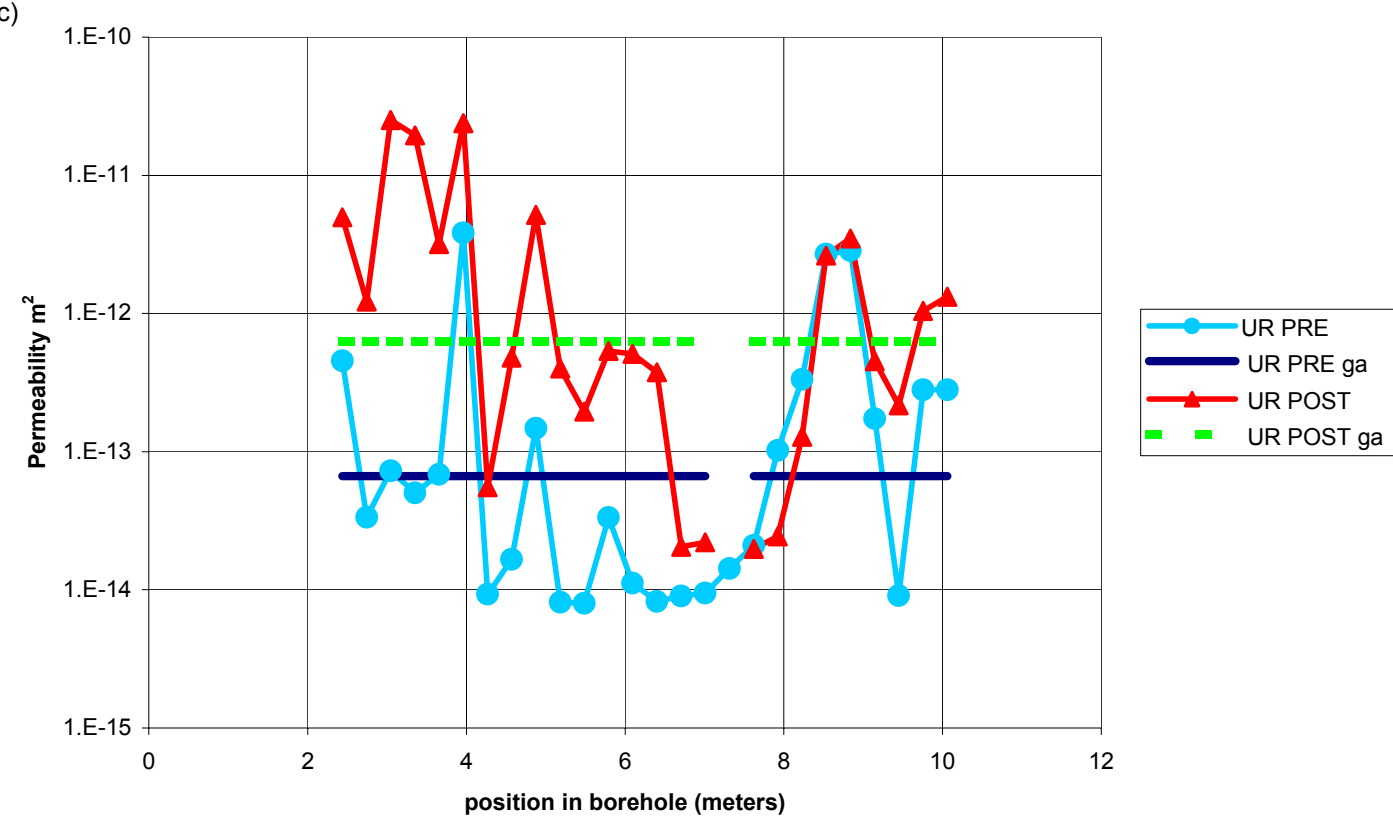

Source: DTNs: LB980901233124.101 [DIRS 136593] for pre-excavation data, LB990601233124.001 [DIRS 105888] for post-excavation data.

NOTE: Tested intervals are $0.3 \mathrm{~m}$ long; plotted position is at beginning of tested interval.

Figure 6-14. Pre- and Post-Excavation Air-Permeability Profiles along Upper Boreholes at Niche 4 (Niche 4788) (Continued) 
a)
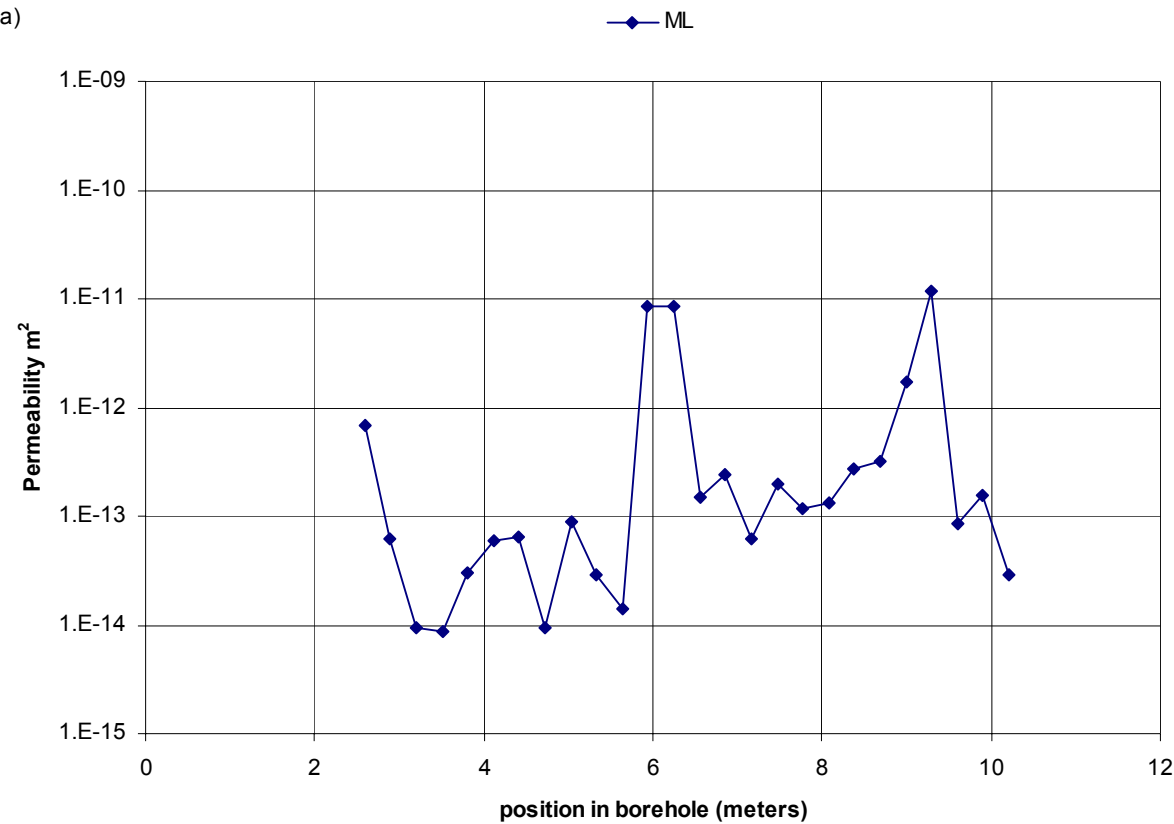

b)
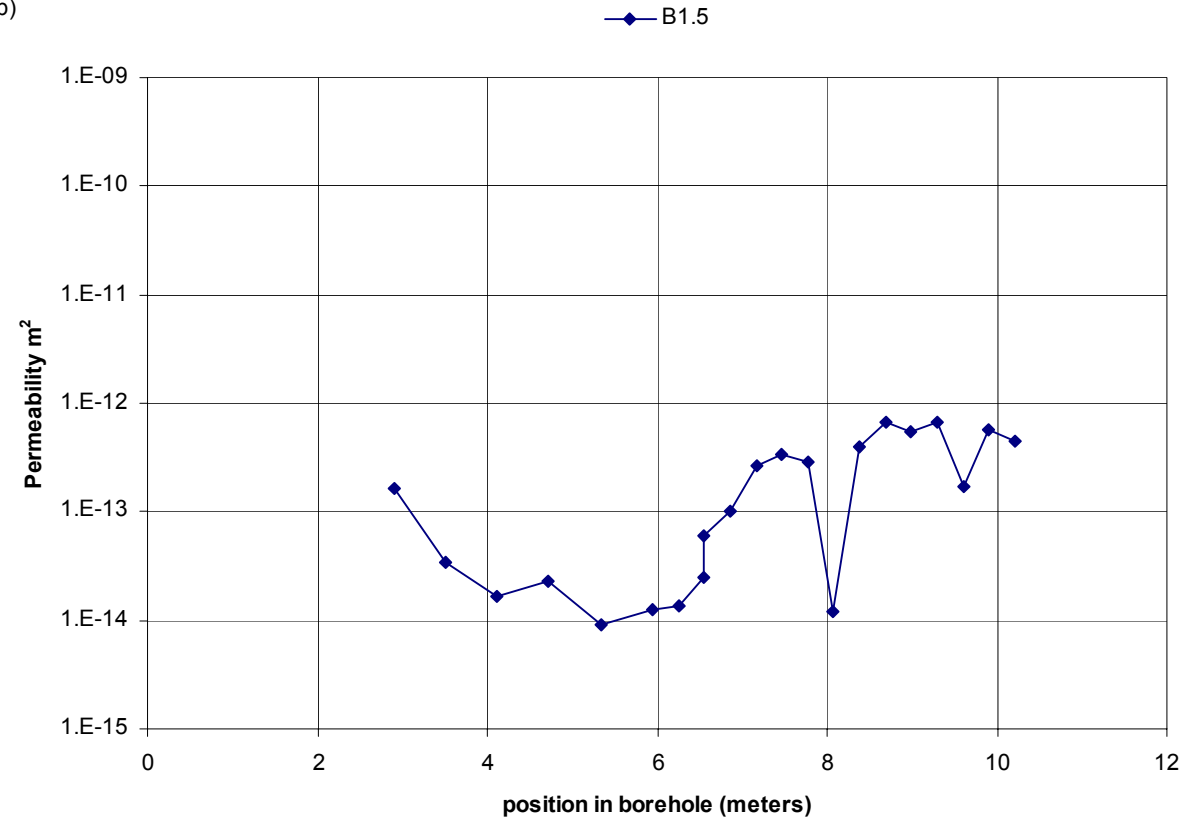

Source: DTN: LB980901233124.101 [DIRS 136593].

NOTE: Two or more measurements were made at each position. The least value of calculated permeability is reported here as being the most likely to be unaffected by leak-by.

Figure 6-15. Pre-Excavation Air-Permeability Profiles along Middle and Bottom Boreholes at Niche 4 (Niche 4788) 


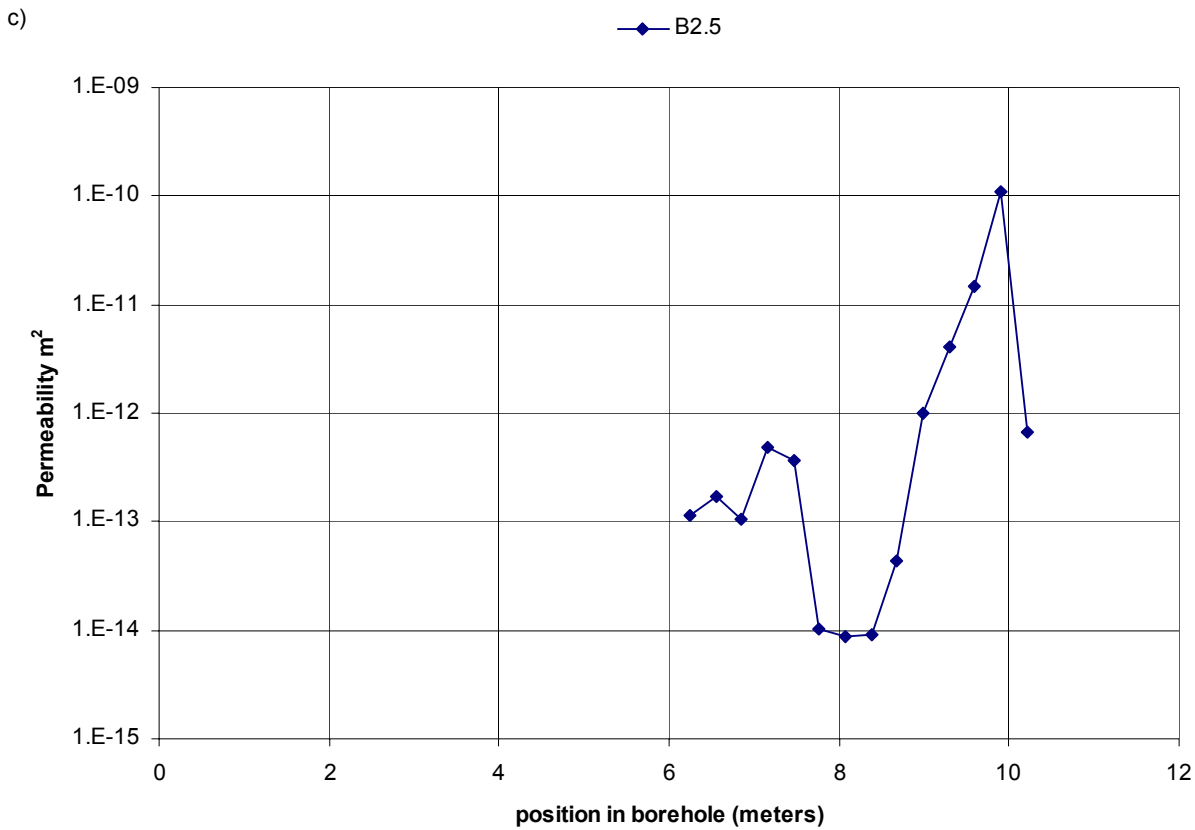

Source: DTN: LB980901233124.101 [DIRS 136593].

NOTE: Two or more measurements were made at each position. The least value of calculated permeability is reported here as being the most likely to be unaffected by leak-by.

Figure 6-15. Pre-Excavation Air-Permeability Profiles along Middle and Bottom Boreholes at Niche 4 (Niche 4788) (Continued)

At Niche 5 (Niche CD 1620), measurements taken before and after excavation at the inner niche area and alongside the outer niche area allowed comparison of excavation effects on permeability profiles for boreholes situated above the excavation versus those situated alongside the excavation. Profiles were taken of Borehole UL, Borehole UM, and Borehole ML over the inner niche area both before and after the inner niche excavation, as illustrated in Figure 6-16. (From all boreholes drilled above the niche, only Boreholes UL, UM, and ML were testable; all other boreholes were blocked by borehole debris.) Similarly, the AK borehole closest to the proposed niche wall became blocked close to the collar before any measurements could be taken. The other two, AK2 and AK3, were successfully profiled with air-k measurements at 0.3-m intervals. After excavation of the outer niche, the AK boreholes were again profiled. In Figure 6-17, comparison of the profiles of the two AK boreholes does not show as significant a change as the comparison of the profiles of the boreholes above the niche in Figure 6-16. For the overhead boreholes, certain borehole sections change permeability more than others do, whereas the change in the geometric average (subscript "ga" in figures in this report) for the AK boreholes alongside the excavation is smaller than it is for the overhead boreholes. Although the Borehole UL and the Borehole AK2 are roughly the same distance from their respective mined surfaces of the niche, they show a marked difference in the change of the geometric average of permeability. 
a)

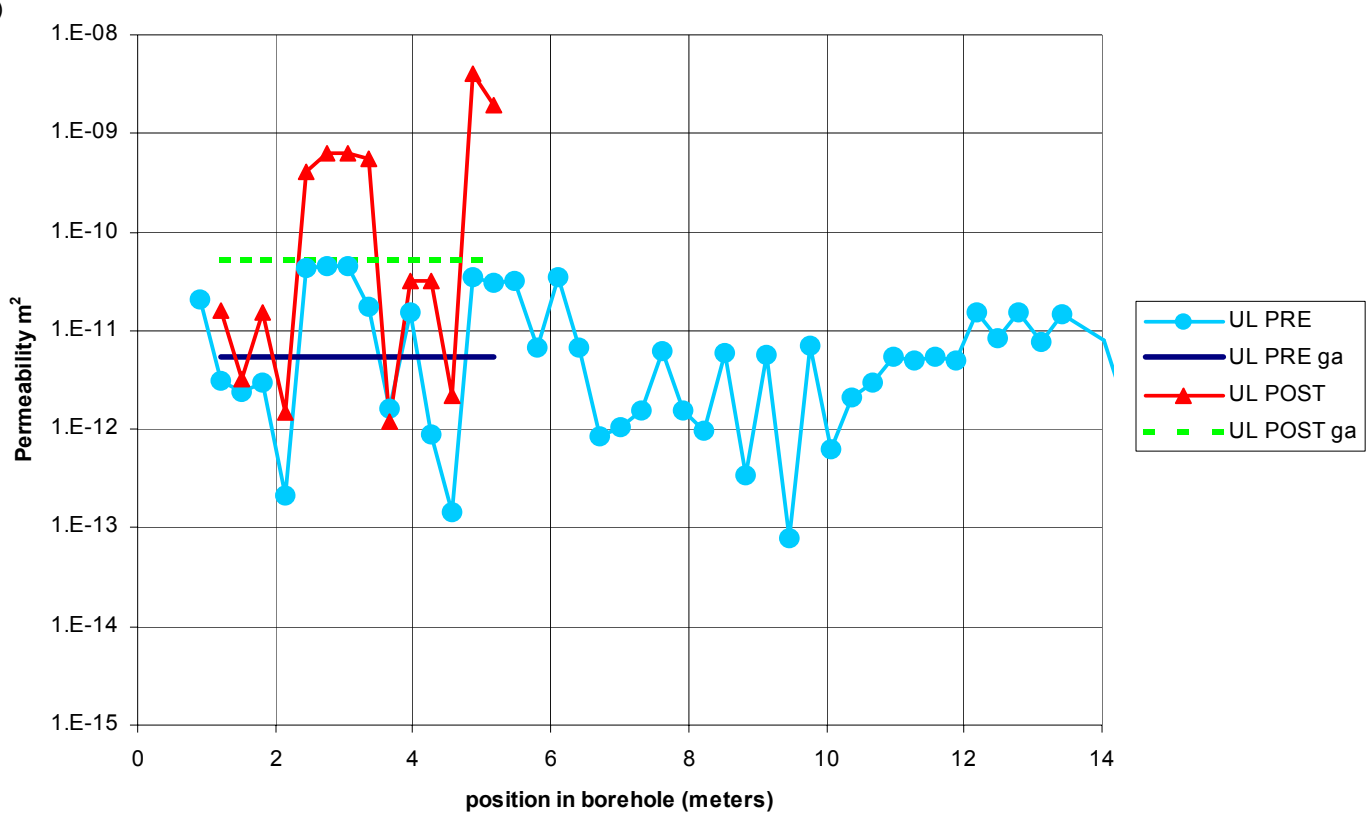

b)

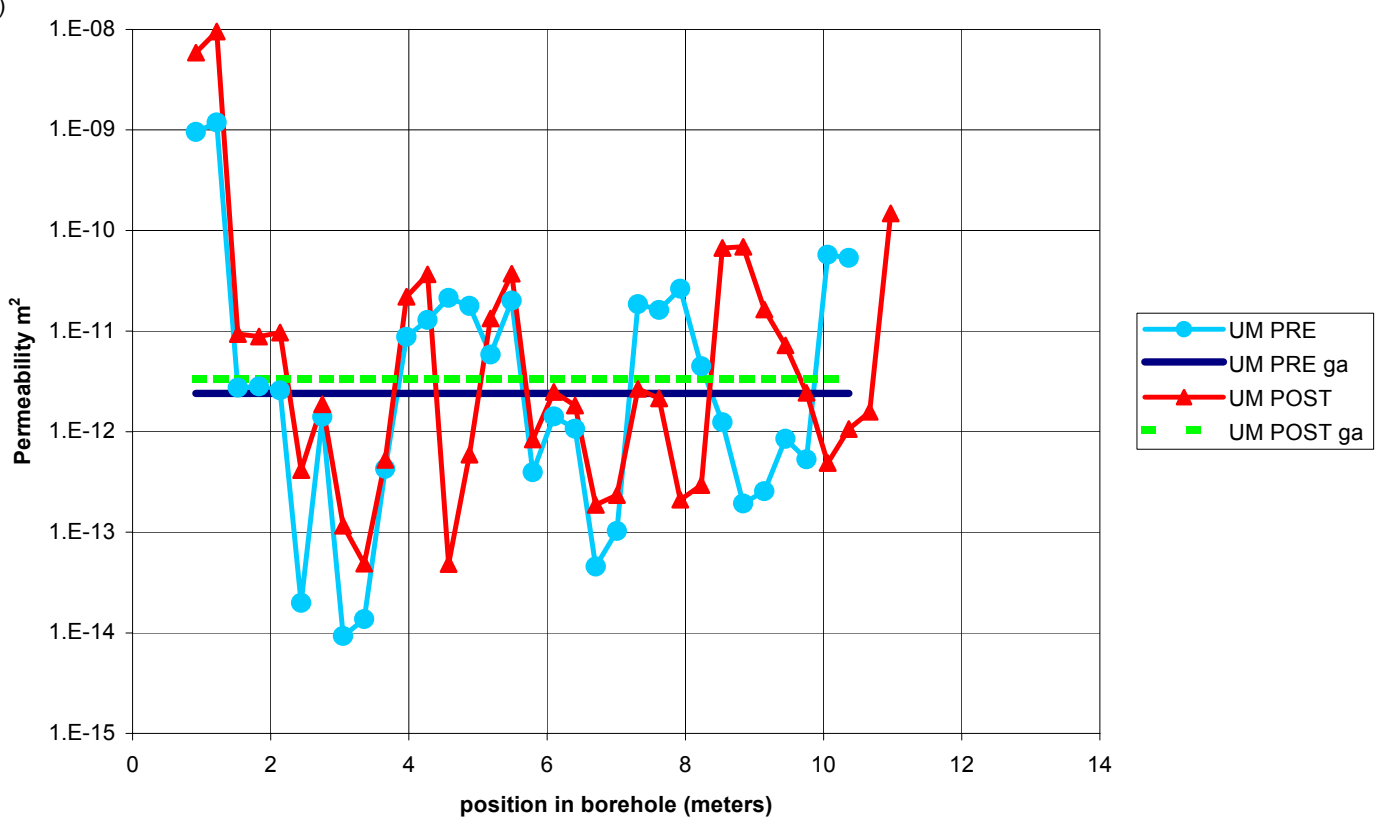

Source: DTNs: LB0012AIRKTEST.001 [DIRS 154586] for pre-excavation data; LB0110AKN5POST.001 [DIRS 156904] for post-excavation data.

Figure 6-16. Pre- and Post-Excavation Air-Permeability Profiles along Upper Boreholes at Niche 5 (Niche CD 1620) 


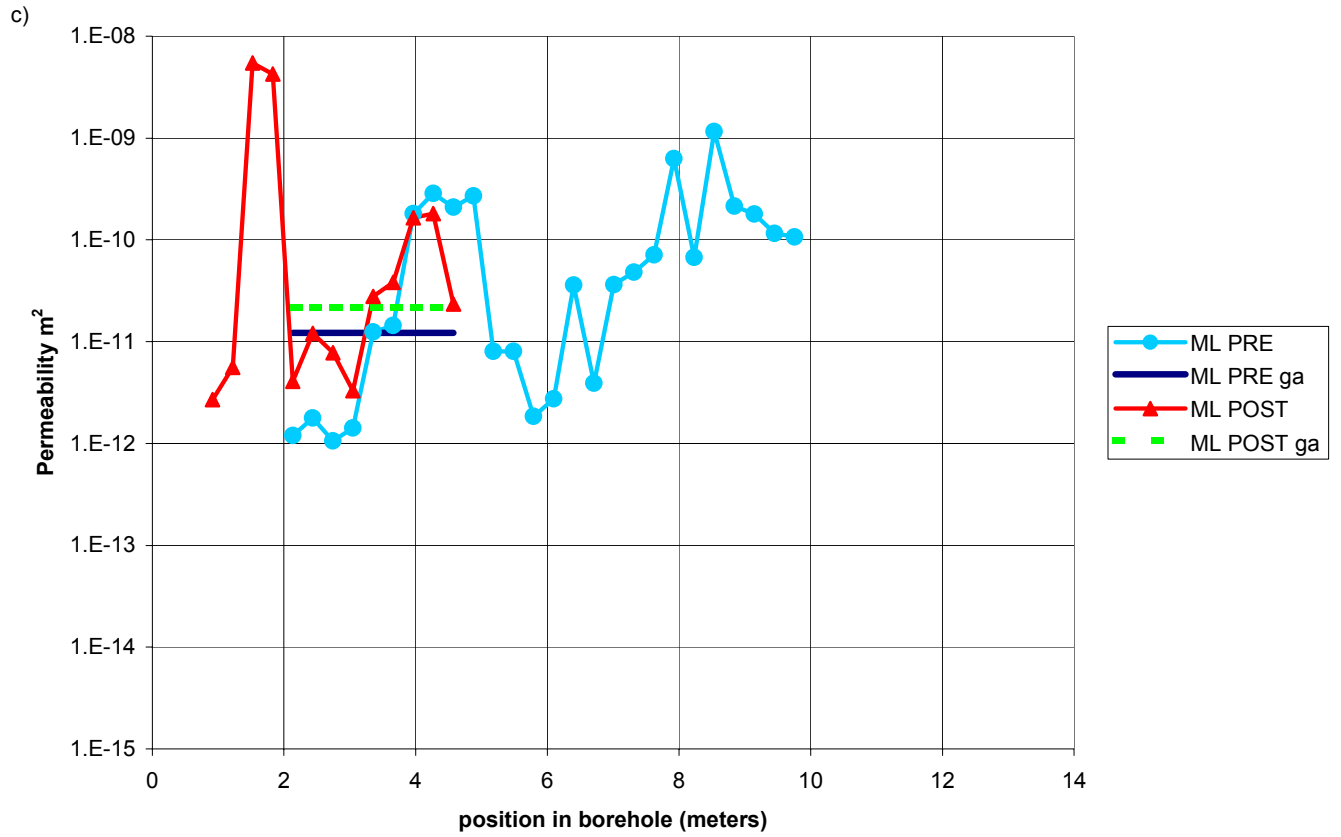

Source: DTNs: LB0012AIRKTEST.001 [DIRS 154586] for pre-excavation data; LB0110AKN5POST.001 [DIRS 156904] for post-excavation data.

Figure 6-16. Pre- and Post-Excavation Air-Permeability Profiles along Upper Boreholes at Niche 5 (Niche CD 1620) (Continued) 

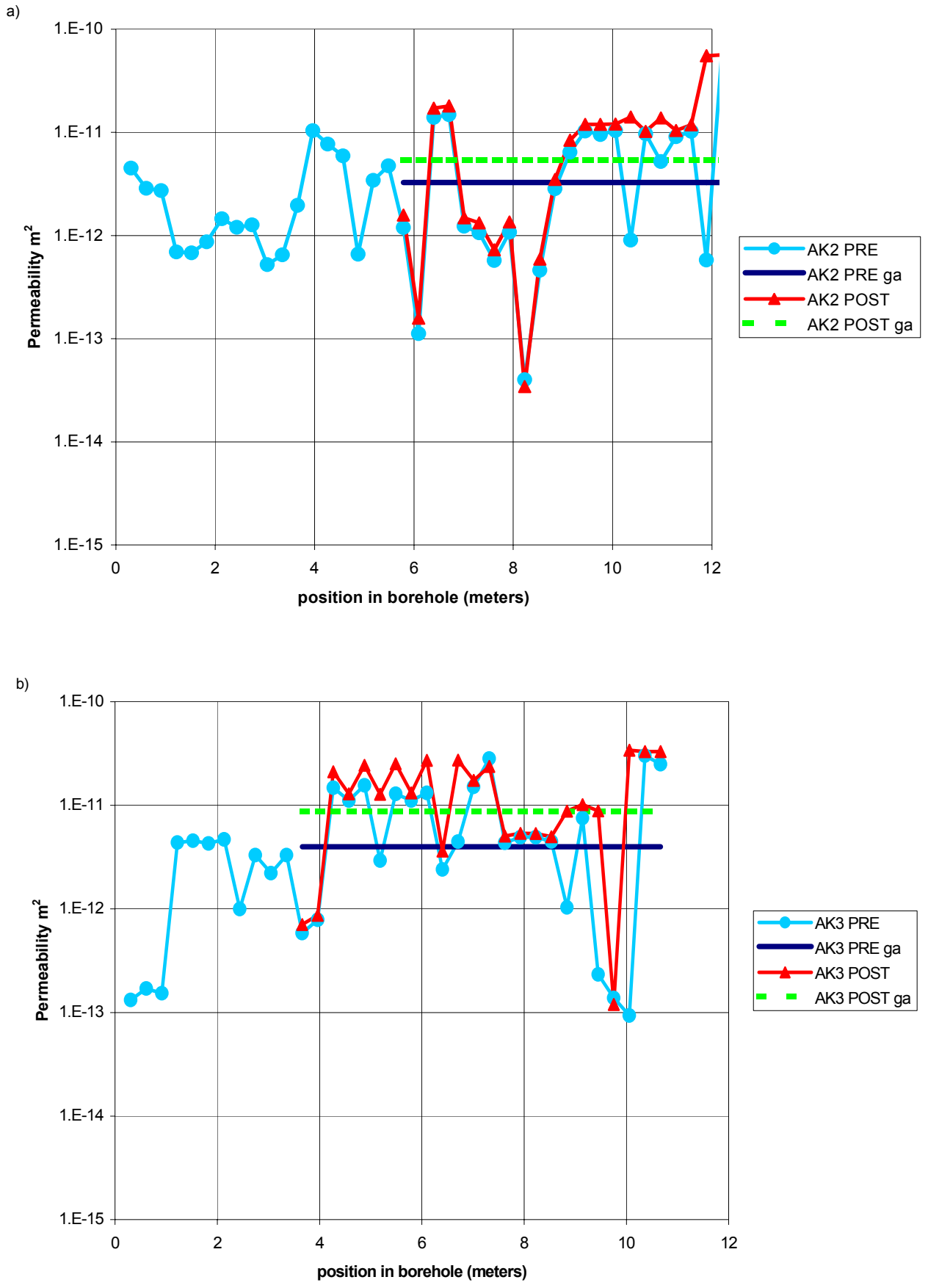

Source: DTNs: LB002181233124.001 [DIRS 146878]; LB0110AK23POST.001 [DIRS 156905].

NOTE: Tested intervals are $0.3 \mathrm{~m}$ long; plotted position is at beginning of tested interval.

Figure 6-17. Pre- and Post-Excavation Air-Permeability Profiles along AK Side Boreholes at Niche 5 (Niche CD 1620) 


\subsection{Vertical Permeability Profiles}

Near-vertical borehole air-permeability profile data were collected in Alcove 8 . Figure 6-18 (Panels a to $\mathrm{f}$ ) shows the permeability as a function of depth for each of the boreholes drilled from the invert of Alcove 8. All boreholes have local peaks and sections of relatively uniform permeabilities along their depths, and high permeabilities toward the bottom. Borehole 1, Borehole 3, and Borehole 4 exhibit relatively long sections of low permeability, followed by a 3 to 5 order-of-magnitude increase starting at approximately $6 \mathrm{~m}$ for Borehole 5 , $10 \mathrm{~m}$ for Borehole 3 , and $8 \mathrm{~m}$ for Borehole 4 . These permeability increases could be locally associated with the Tptpul-Tptpmn interface which is approximately midway between Alcove 8 and Niche 107 (Niche 3), as discussed in Section 6.12.1.2 on the geometry and in Section 6.12.3 on the results of geophysical imaging of the drift-to-drift test bed.

a)

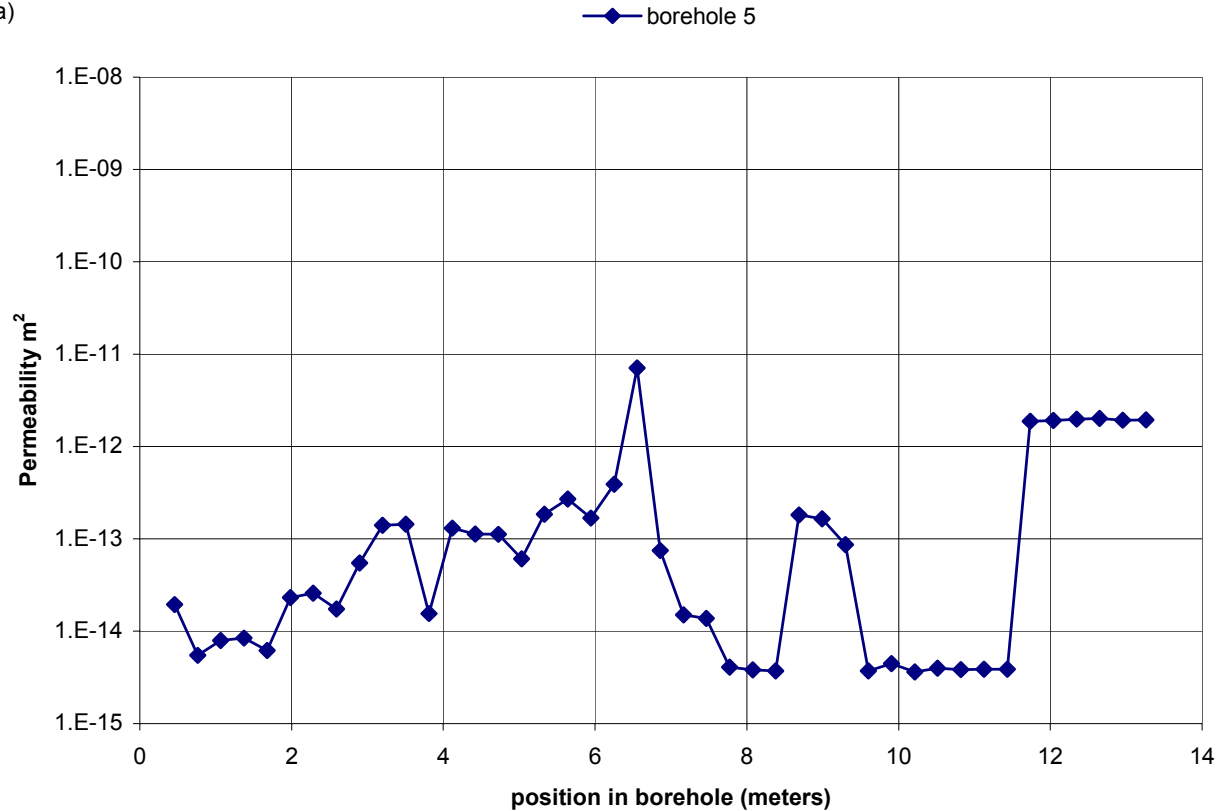

Source: DTN: LB0302ALC8AIRK.001 [DIRS 164748].

Figure 6-18. Air-Permeability Profiles along Boreholes Drilled from in Alcove 8 
b)
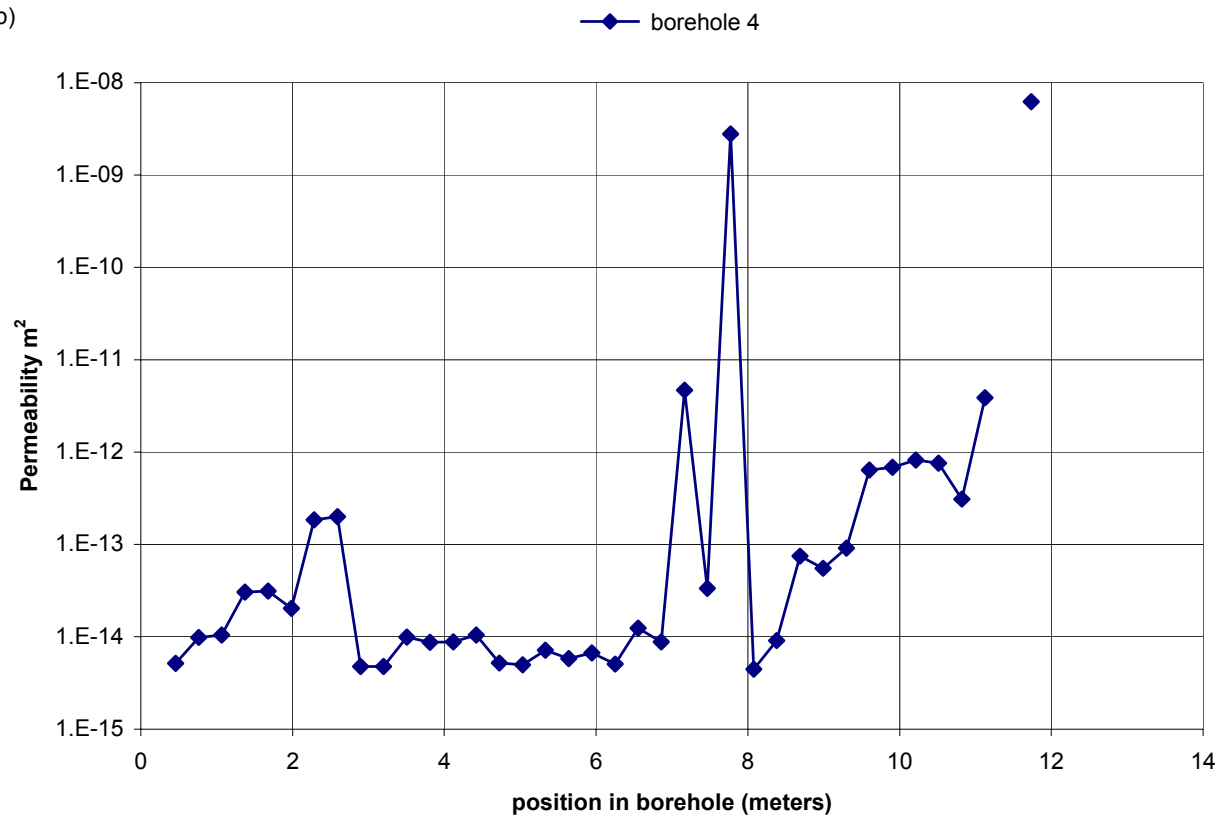

c)

$\leadsto$ borehole 2

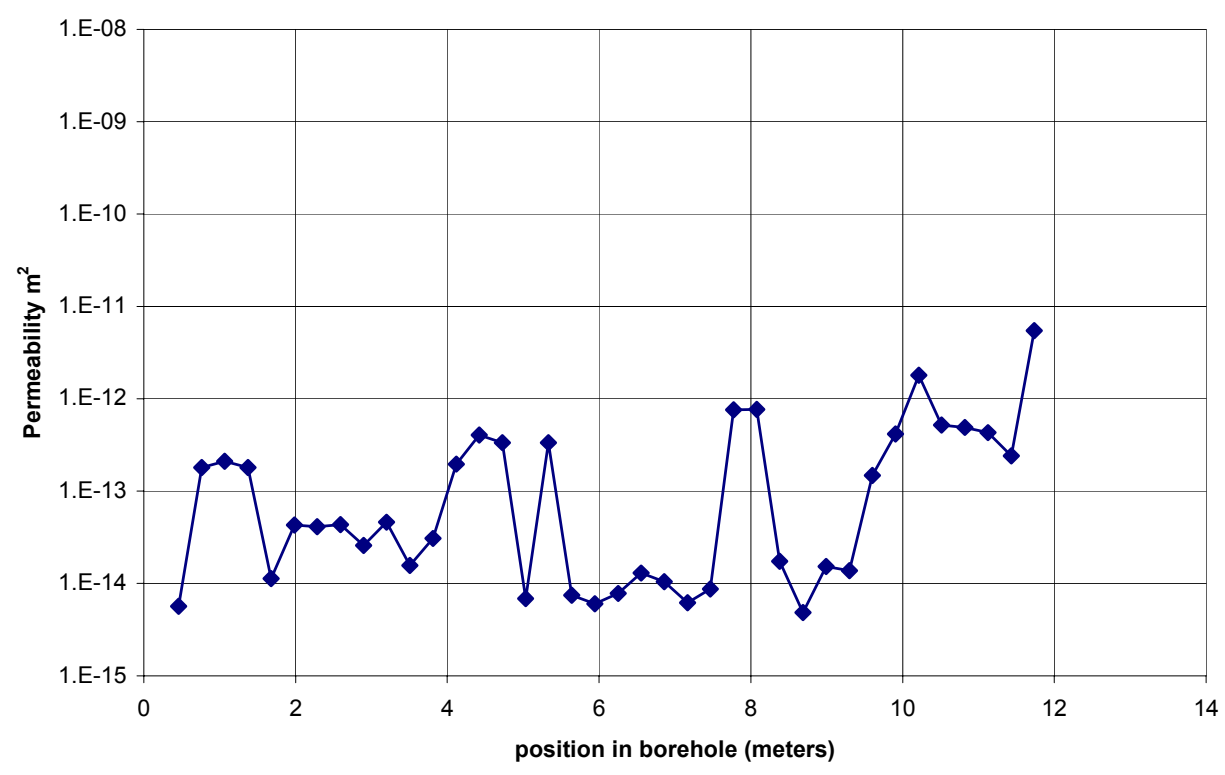

Source: DTN: LB0302ALC8AIRK.001 [DIRS 164748].

Figure 6-18. Air-Permeability Profiles along Boreholes Drilled from in Alcove 8 (Continued) 
d)

$\smile$ borehole 3

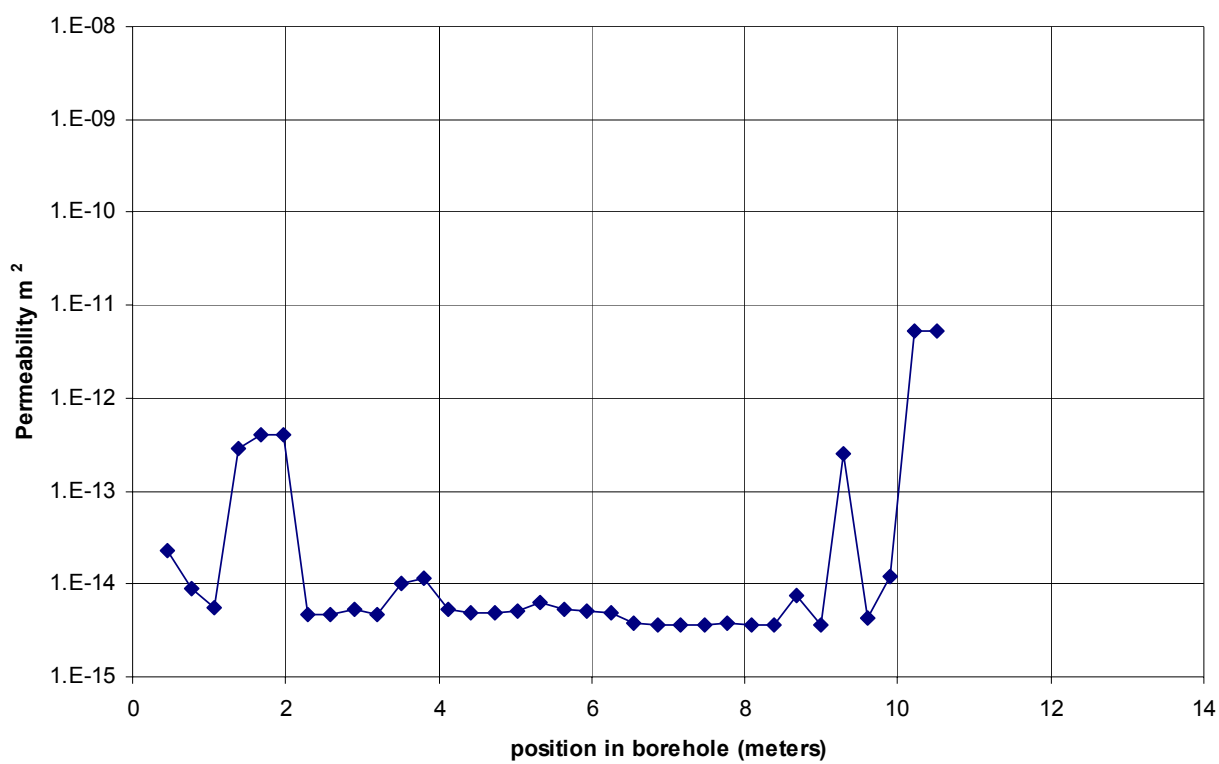

e)

$\multimap$ borehole 1

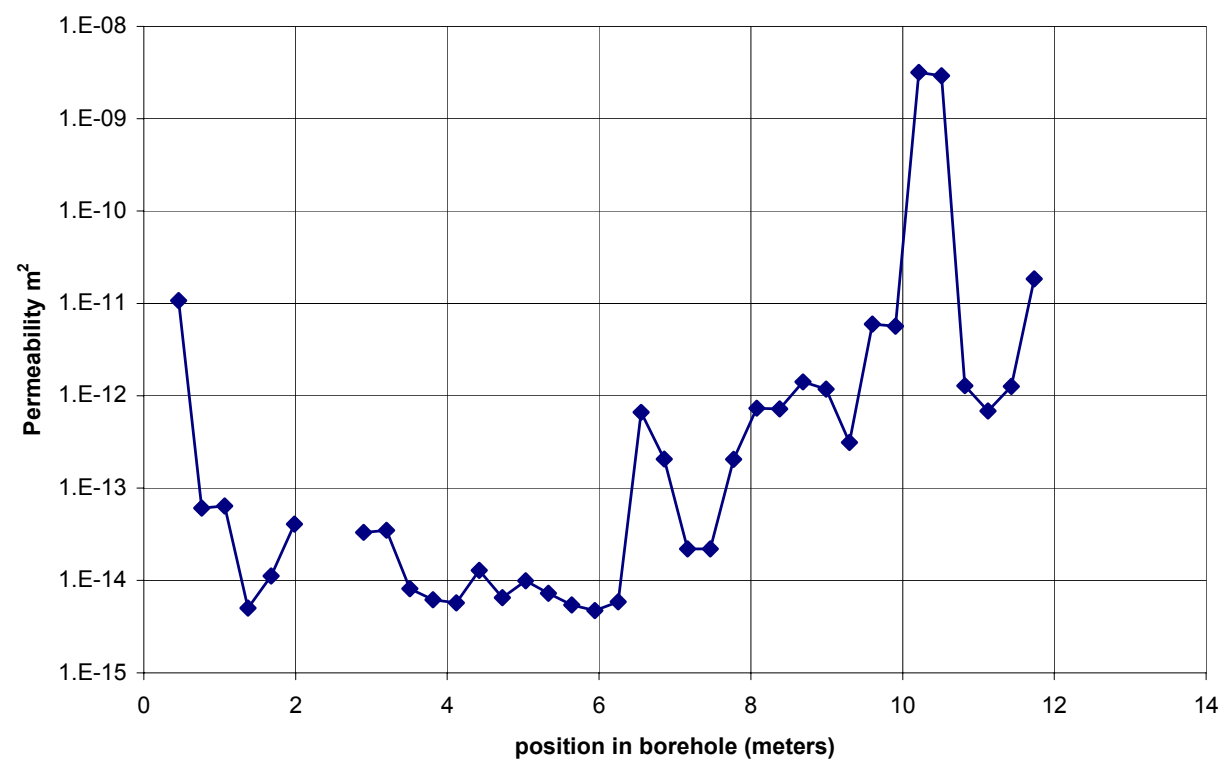

Source: DTN: LB0302ALC8AIRK.001 [DIRS 164748].

Figure 6-18. Air-Permeability Profiles down Boreholes in Alcove 8 (Continued) 


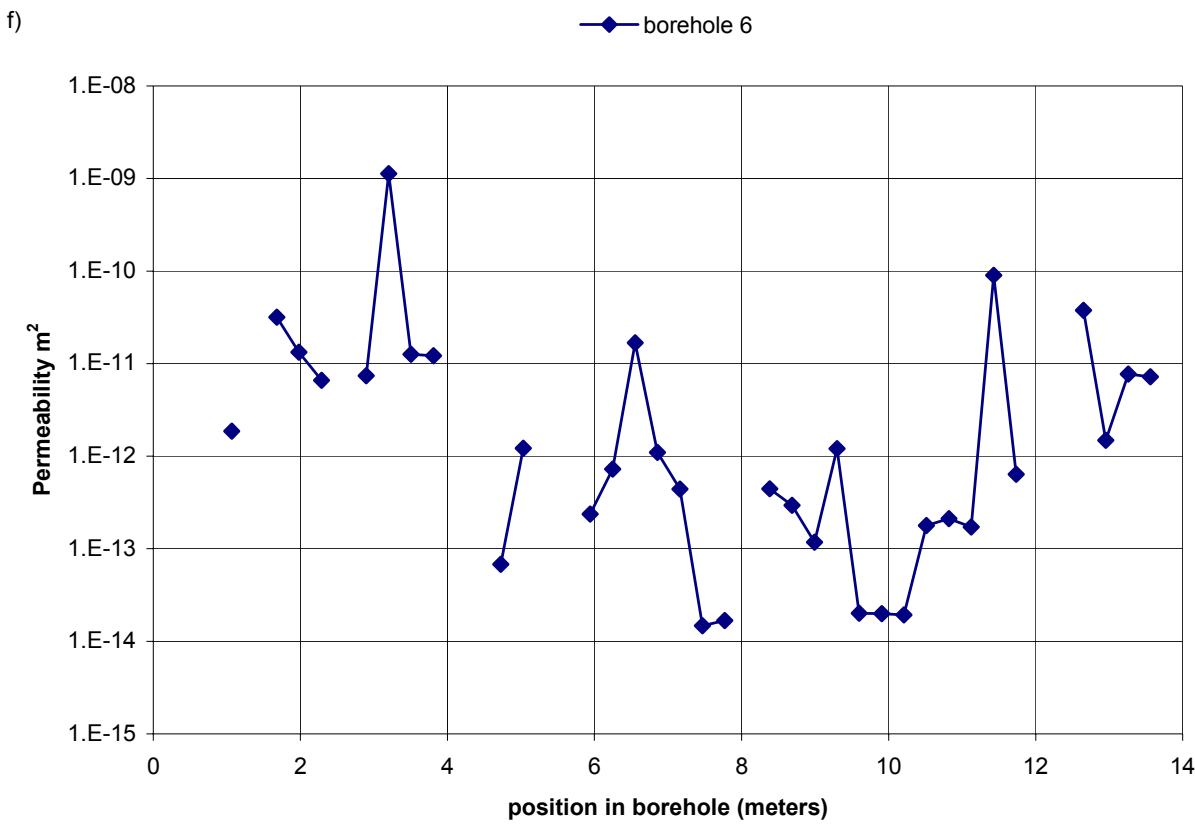

Source: DTN: LB0302ALC8AIRK.001 [DIRS 164748].

Figure 6-18. Air-Permeability Profiles down Boreholes in Alcove 8 (Continued)

\subsubsection{Permeability Change as a Function of Initial Permeability}

The plots presented in this section highlight the difference in the character of borehole permeability changes (caused by nearby excavation). The post-excavation permeability for a particular interval in a borehole, divided by the pre-excavation permeability for the same interval in a borehole, is the interval change ratio caused by excavation. A plot of the logarithmic change ratio versus the logarithm of the pre-excavation permeability shows a dependence of the change on the initial value. Figure 6-19 and Figure 6-20 show the changes for three of the overhead boreholes and two of the side boreholes, respectively, that were tested at Niche 5 (Niche CD 1620) (see Appendix Section I4 for details on ratio, trend, and slope calculations). The data for the overhead boreholes support the notion that the initially low permeability zones change the most. For the side boreholes (with borehole designation AK), however, the trend is weaker, and they can be divided into a small population of intervals with strong change dependency, and a larger population with no dependency. Initial permeabilities were evenly distributed in both populations.

Change ratios for the pre- and post-excavation testing previously undertaken at Niche 2 (Niche 3650), Niche 3 (Niche 3107), and Niche 4 (Niche 4788) (all in overhead boreholes) are shown in Figure 6-21, Figure 6-22, and Figure 6-23, respectively. The change-ratio plots for these niches in the middle nonlithophysal zone of TSw show stronger correlation between initial permeability and the change ratio. Additionally, from the geometric averages in the profile plots, it can be seen that all these middle nonlithophysal niches show a larger average excavation effect than the boreholes at Niche 5 (Niche CD 1620) in the lower lithophysal zone of the TSw. 


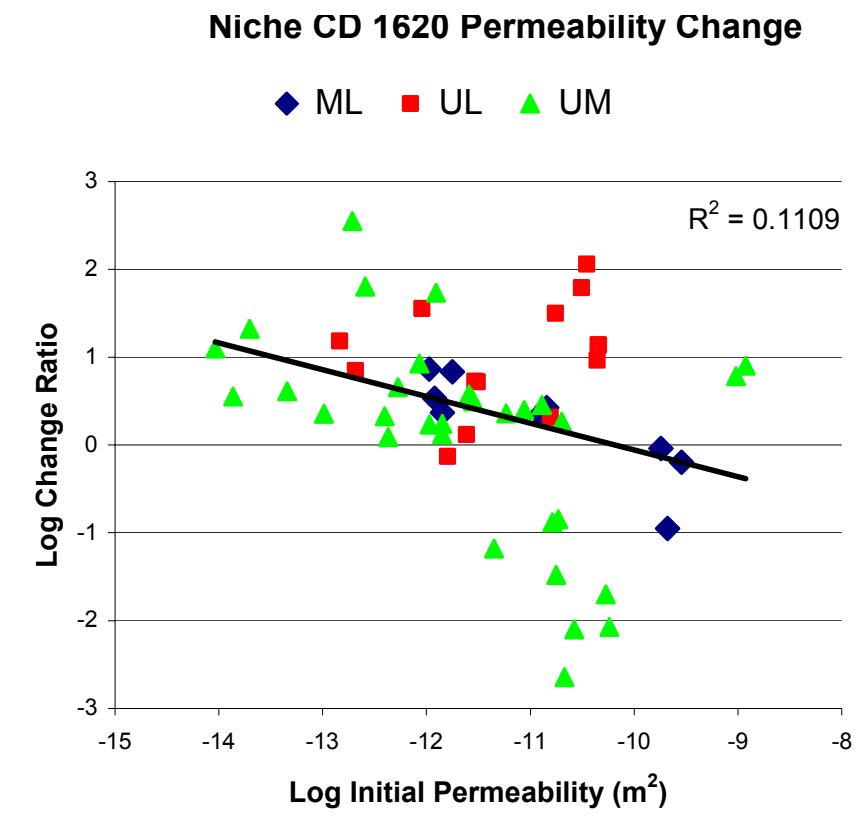

Output DTN: LB0310AIRK0015.001.

Figure 6-19. Change-Ratio Plot for Niche 5 (Niche CD 1620) Overhead Boreholes

Niche CD 1620 AK Holes Permeability Change

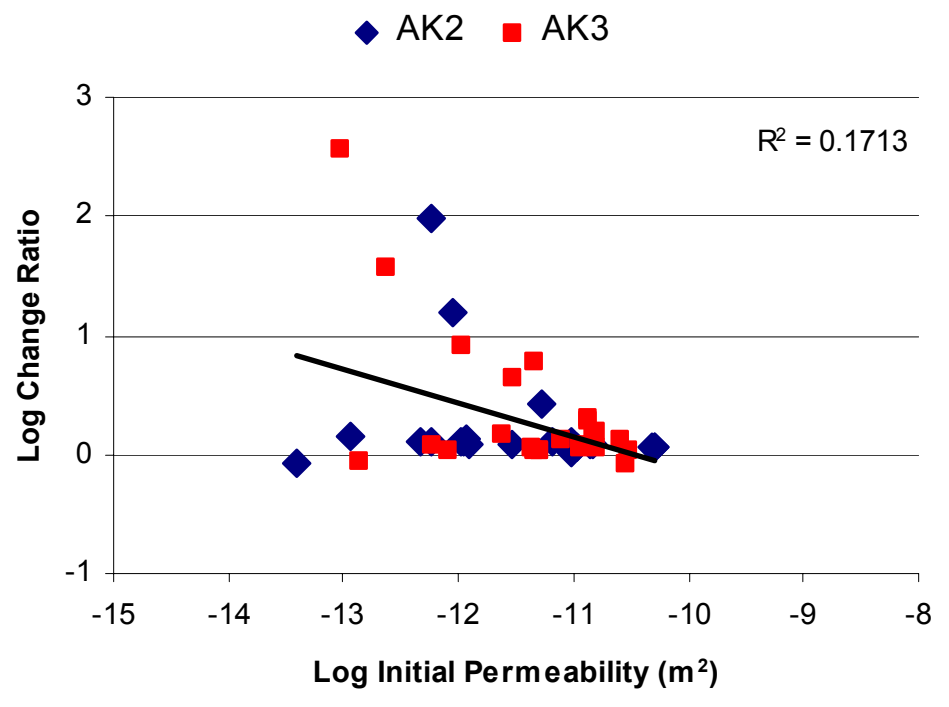

Output DTN: LB0310AIRK0015.001.

Figure 6-20. Change-Ratio Plot for Niche 5 (Niche CD 1620) AK Boreholes 


\section{Niche 3650 Permeability Change}

$\bullet$ UL - UM $\triangle$ UR

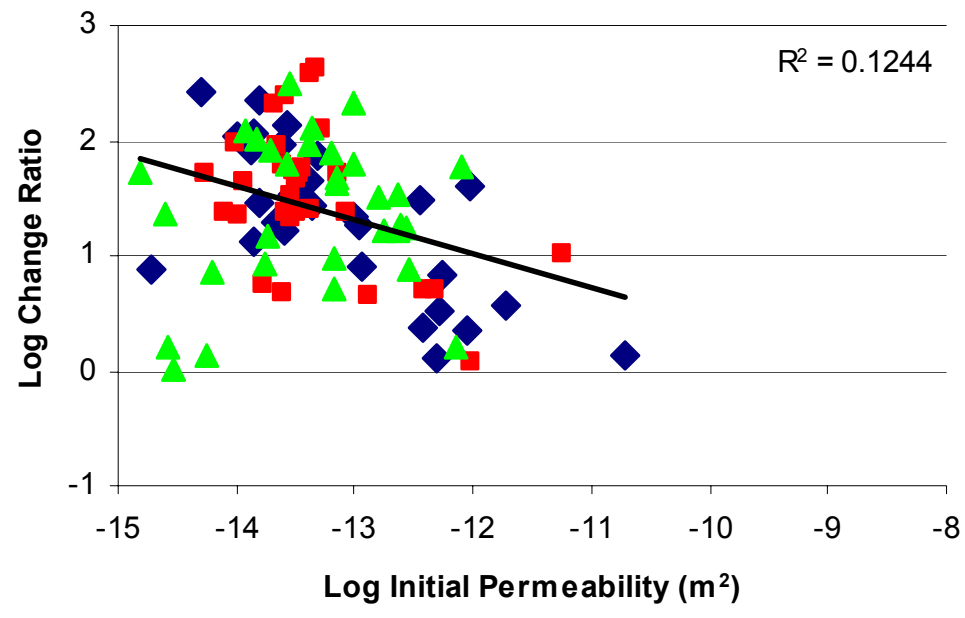

Output DTN: LB0310AIRK0015.001.

Figure 6-21. Change-Ratio Plot for Niche 2 (Niche 3650)

Niche 3107 Permeability Change

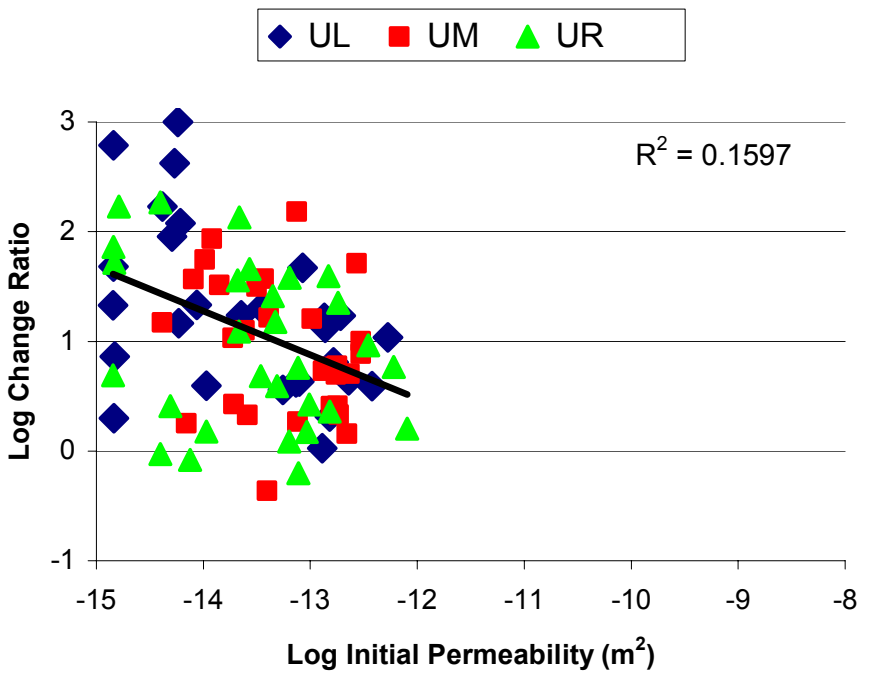

Output DTN: LB0310AIRK0015.001.

Figure 6-22. Change-Ratio Plot for Niche 3 (Niche 3107) 


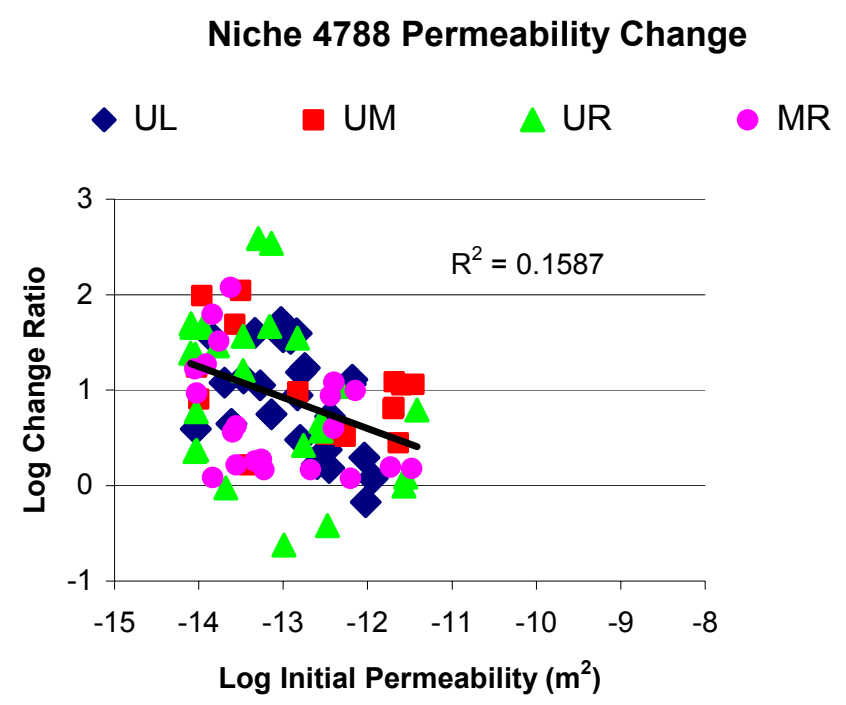

Output DTN: LB0310AIRK0015.001.

Figure 6-23. Change-Ratio Plot for Niche 4 (Niche 4788)

\subsubsection{Statistical Summary of Air-Permeability Distributions}

The air-permeability measurement is one of the most effective methods to quantify the natural variability of unsaturated fractured rocks (Cook 2000 [DIRS 165411]). Table 6-2 summarizes the average (arithmetic and geometric) values, standard deviations, and ranges of variations in pre- and post-excavation permeability of individual boreholes and of whole niche sites (see Appendix Section I1 for calculations). Also included are the averages, deviations, and ranges of interval change ratios for individual boreholes and whole niches. (The ratios are calculated from the pre- and post-excavation permeability values for each interval before the statistical analyses.) Table 6-3 shows similar data for the overhead boreholes at Niche 5 (Niche CD 1620). Table 6-4 shows this data for the side holes at Niche 5 (Niche CD 1620). For assessing the excavation-induced impacts, the analyses in Table 6-2, Table 6-3, and Table 6-4 incorporate retested boreholes only. Drift-scale variations along boreholes and between different boreholes within the same niche test site are larger than differences between different sites. Table 6-5 shows the statistics from the single data set for Alcove 8. Variability among intervals within boreholes in this case straddles that for the whole site. In addition, Alcove 8 shows the largest range of values of any site yet tested.

Table 6-6 summarizes the geometric means and standard deviations of all clusters of boreholes tested in the ESF as a function of site location and rock type. The permeability values from the excavated boreholes are included in these averaging results. Pre-excavation (log-geometric) means and standard deviations were derived from averaging permeability data from all available boreholes in each niche or alcove cluster. The middle- and lower-level boreholes supplement the upper boreholes to characterize the three-dimensional (3-D) space in the test beds, and locate flow paths during pre-excavation conditions. After excavation with only upper boreholes in a horizontal plane remaining, the air-permeability tests can characterize only the zones above the niche ceilings.) Because the pre-excavation holes at Niche 5 (Niche CD 1620) are the same set as those for post-excavation testing, both types of tests are included for this case. 
Each borehole cluster has a distinct air-permeability character. The spatial variability in permeability is considerable at the borehole-interval scale of $0.3 \mathrm{~m}$ before averaging the data over the $10 \mathrm{~m}$ scale along the boreholes and the $100 \mathrm{~m}^{3}$ volume, i.e., obtaining averages for borehole clusters ( 3 to 7 boreholes). Niche 3 (Niche 3107) and Niche 1 (Niche 3566) each have a "radial" entry in the table, which indicates boreholes that are drilled from inside the niches after excavation. Permeability values from these Niche 3 (Niche 3107) boreholes (profiles not shown) vary little from those of the pre-excavation boreholes, indicative of the uniformity of the formation around Niche 3 (Niche 3107). In the case of Niche 1 (Niche 3566), however, the radial boreholes that were tested ran through the brecciated zone within the niche wall, and thus exhibited higher permeability than that of the pre-excavation boreholes. The results for the borehole cluster at Alcove 8 show the highest standard deviation, which may be a result of the traversal of the contact (by the boreholes). The entries in Table 6-6 for Alcove 4 and Alcove 6 are included for completeness, and will be discussed in Section 6.5.

Standard deviation from the statistical analysis is a measure of variability, also referred to as aleatory uncertainty, for natural randomness or heterogeneity [as discussed in Section 6 and in Guidelines for Developing and Documenting Alternative Conceptual Models, Model Abstractions and Parameter Uncertainty in the Total System Performance Assessment for the License Application (BSC 2002 [DIRS 158794])]. 
Table 6-2. Summary Statistics of Air Permeability $\left(\mathrm{m}^{2}\right)$ from Boreholes above Niches 2, 3, and 4

\begin{tabular}{|c|c|c|c|c|c|c|c|c|c|}
\hline \multirow[t]{2}{*}{ Borehole } & \multicolumn{3}{|c|}{ Niche 2 (Niche 3650) } & \multicolumn{3}{|c|}{ Niche 3 (Niche 3107) } & \multicolumn{3}{|c|}{ Niche 4 (Niche 4788) } \\
\hline & $\begin{array}{c}\text { Pre- } \\
\text { Excavation }\end{array}$ & $\begin{array}{c}\text { Post- } \\
\text { Excavation }\end{array}$ & $\begin{array}{c}\text { Post/Pre } \\
\text { Ratio }^{\text {a }}\end{array}$ & $\begin{array}{c}\text { Pre- } \\
\text { Excavation }\end{array}$ & $\begin{array}{c}\text { Post- } \\
\text { Excavation }\end{array}$ & $\begin{array}{c}\text { Post/Pre } \\
\text { Ratio }^{\text {a }}\end{array}$ & $\begin{array}{c}\text { Pre- } \\
\text { Excavation }\end{array}$ & $\begin{array}{c}\text { Post- } \\
\text { Excavation }\end{array}$ & $\begin{array}{c}\text { Post/Pre } \\
\text { Ratio }^{a}\end{array}$ \\
\hline \multicolumn{10}{|l|}{ Geometric Mean } \\
\hline UL & $7.26 \mathrm{E}-14$ & $2.09 \mathrm{E}-12$ & 20.75 & $2.22 \mathrm{E}-14$ & $4.55 \mathrm{E}-13$ & 20.51 & $1.41 \mathrm{E}-13$ & $1.07 \mathrm{E}-12$ & 7.62 \\
\hline UM & $4.29 \mathrm{E}-14$ & 1.64E-12 & 33.29 & 5.81E-14 & $4.82 \mathrm{E}-13$ & 8.72 & $1.81 \mathrm{E}-13$ & $2.56 \mathrm{E}-12$ & 11.09 \\
\hline UR & 4.27E-14 & $1.01 \mathrm{E}-12$ & 23.56 & 3.32E-14 & $2.64 \mathrm{E}-13$ & 8.94 & $6.27 \mathrm{E}-14$ & $6.27 \mathrm{E}-13$ & 9.42 \\
\hline All 3 & $5.07 \mathrm{E}-14$ & $1.51 \mathrm{E}-12$ & 25.38 & $3.50 \mathrm{E}-14$ & $3.87 \mathrm{E}-13$ & 11.69 & $1.05 \mathrm{E}-13$ & $1.20 \mathrm{E}-12$ & 9.42 \\
\hline \multicolumn{10}{|l|}{ Arithmetic Mean } \\
\hline UL & $8.59 \mathrm{E}-12$ & $2.98 \mathrm{E}-11$ & 47.06 & $8.12 \mathrm{E}-14$ & $1.46 \mathrm{E}-12$ & 135.48 & $2.82 \mathrm{E}-13$ & $2.07 \mathrm{E}-12$ & 14.28 \\
\hline UM & 1.01E-12 & $7.78 \mathrm{E}-12$ & 72.98 & 1.14E-13 & $1.55 \mathrm{E}-12$ & 21.36 & 8.59E-13 & $6.19 \mathrm{E}-12$ & 26.43 \\
\hline UR & $1.27 \mathrm{E}-13$ & $4.59 \mathrm{E}-12$ & 53.62 & $1.14 \mathrm{E}-13$ & $1.04 \mathrm{E}-12$ & 30.95 & $4.42 \mathrm{E}-13$ & $3.79 \mathrm{E}-12$ & 45.09 \\
\hline All 3 & $3.24 \mathrm{E}-12$ & $1.40 \mathrm{E}-11$ & 57.89 & 1.03E-13 & 1.35E-12 & 62.60 & $5.05 \mathrm{E}-13$ & 3.99E-12 & 28.55 \\
\hline \multicolumn{10}{|l|}{ Minimum Value } \\
\hline UL & 1.86E-15 & 1.45E-14 & 0.67 & 1.44E-15 & $2.90 \mathrm{E}-15$ & 1.06 & $9.16 \mathrm{E}-15$ & 3.57E-14 & 0.67 \\
\hline UM & $5.40 \mathrm{E}-15$ & $9.88 \mathrm{E}-14$ & 1.19 & $4.10 \mathrm{E}-15$ & $1.24 \mathrm{E}-14$ & 0.43 & $8.99 \mathrm{E}-15$ & $6.56 \mathrm{E}-14$ & 1.64 \\
\hline UR & $1.53 \mathrm{E}-15$ & $3.02 \mathrm{E}-15$ & 1.01 & 1.43E-15 & $3.72 \mathrm{E}-15$ & 0.63 & $8.01 \mathrm{E}-15$ & $1.98 \mathrm{E}-14$ & 0.24 \\
\hline All 3 & 1.53E-15 & $3.02 \mathrm{E}-15$ & 0.67 & 1.43E-15 & $2.90 \mathrm{E}-15$ & 0.43 & $8.01 \mathrm{E}-15$ & $1.98 \mathrm{E}-14$ & 0.24 \\
\hline \multicolumn{10}{|l|}{ Maximum Value } \\
\hline UL & $1.27 \mathrm{E}-10$ & $7.15 \mathrm{E}-10$ & 271.15 & $5.32 \mathrm{E}-13$ & $7.99 \mathrm{E}-12$ & 1229.23 & $1.15 \mathrm{E}-12$ & $8.44 \mathrm{E}-12$ & 51.54 \\
\hline UM & $2.28 \mathrm{E}-11$ & $1.01 \mathrm{E}-10$ & 427.91 & $5.15 \mathrm{E}-13$ & $1.40 \mathrm{E}-11$ & 153.02 & $3.56 \mathrm{E}-12$ & $2.50 \mathrm{E}-11$ & 110.52 \\
\hline UR & 8.07E-13 & 4.66E-11 & 310.67 & 8.06E-13 & $5.80 \mathrm{E}-12$ & 184.13 & 3.83E-12 & $2.51 \mathrm{E}-11$ & 386.90 \\
\hline All 3 & 1.27E-10 & $7.15 \mathrm{E}-10$ & 427.91 & $8.06 \mathrm{E}-13$ & 1.40E-11 & 1229.23 & $3.83 \mathrm{E}-12$ & $2.51 \mathrm{E}-11$ & 386.90 \\
\hline \multicolumn{10}{|l|}{ Range of Log } \\
\hline UL & 4.83 & 4.69 & 2.61 & 2.57 & 3.44 & 3.06 & 2.10 & 2.37 & 1.89 \\
\hline UM & 3.63 & 3.01 & 2.56 & 2.10 & 3.05 & 2.55 & 2.60 & 2.58 & 1.83 \\
\hline UR & 2.72 & 4.19 & 2.49 & 2.75 & 3.19 & 2.47 & 2.68 & 3.10 & 3.21 \\
\hline All 3 & 4.92 & 5.38 & 2.80 & 2.75 & 3.68 & 3.45 & 2.68 & 3.10 & 3.21 \\
\hline
\end{tabular}


Table 6-2. Summary Statistics of Air Permeability $\left(\mathrm{m}^{2}\right)$ from Boreholes above Niches 2,3 , and 4 (Continued)

\begin{tabular}{|c|c|c|c|c|c|c|c|c|c|}
\hline \multirow[t]{2}{*}{ Borehole } & \multicolumn{3}{|c|}{ Niche 2 (Niche 3650) } & \multicolumn{3}{|c|}{ Niche 3 (Niche 3107) } & \multicolumn{3}{|c|}{ Niche 4 (Niche 4788) } \\
\hline & $\begin{array}{c}\text { Pre- } \\
\text { Excavation }\end{array}$ & $\begin{array}{c}\text { Post- } \\
\text { Excavation }\end{array}$ & $\begin{array}{c}\text { Post/Pre } \\
\text { Ratio }^{\text {a }}\end{array}$ & $\begin{array}{c}\text { Pre- } \\
\text { Excavation }\end{array}$ & $\begin{array}{c}\text { Post- } \\
\text { Excavation }\end{array}$ & $\begin{array}{c}\text { Post/Pre } \\
\text { Ratio }^{\text {a }}\end{array}$ & $\begin{array}{c}\text { Pre- } \\
\text { Excavation }\end{array}$ & $\begin{array}{c}\text { Post- } \\
\text { Excavation }\end{array}$ & $\begin{array}{c}\text { Post/Pre } \\
\text { Ratio }^{\text {a }}\end{array}$ \\
\hline \multicolumn{10}{|l|}{ Std. Dev. of Log } \\
\hline UL & 1.18 & 0.84 & 0.69 & 0.81 & 0.83 & 0.83 & 0.58 & 0.57 & 0.54 \\
\hline UM & 0.80 & 0.70 & 0.62 & 0.57 & 0.71 & 0.61 & 0.95 & 0.70 & 0.58 \\
\hline UR & 0.73 & 1.05 & 0.66 & 0.79 & 0.90 & 0.74 & 0.85 & 0.94 & 0.84 \\
\hline All 3 & 0.93 & 0.88 & 0.66 & 0.74 & 0.82 & 0.75 & 0.79 & 0.78 & 0.67 \\
\hline
\end{tabular}

Source(s): Niche 2 (Niche 3650) Pre- and Post-Excavation DTN: LB0011AIRKTEST.001 [DIRS 153155].

Niche 3 (Niche 3107) Pre-Excavation DTN: LB980901233124.101 [DIRS 136593], Post Excavation DTN: LB990601233124.001 [DIRS 105888].

Niche 4 (Niche 4788) Pre-Excavation DTN: LB980901233124.101 [DIRS 136593], Post-Excavation DTN: LB990601233124.001 [DIRS 105888].

Output DTN: LB0310AIRK0015.001 [Summary].

a The post/pre ratio is the ratio of post-excavation to pre-excavation permeabilities. This ratio was calculated for each interval in each borehole. Values reported are the statistical measures (maximum, minimum, mean, etc.) of all post/pre ratios calculated for each borehole.

in Where more than one measurement of permeability was made at a position, the least value is used in averaging.

UL = Upper Left; UM = Upper Middle; UR = Upper Right. 
Table 6-3. Summary Statistics of Air Permeability $\left(\mathrm{m}^{2}\right)$ from Boreholes above Niche 5 (Niche CD 1620)

\begin{tabular}{|c|c|c|c|}
\hline \multicolumn{4}{|c|}{ Niche 5 (Niche CD 1620) Overhead } \\
\hline Borehole & Pre-Excavation & Post-Excavation & Post/Pre Ratio $^{\text {a }}$ \\
\hline \multicolumn{4}{|c|}{ Geometric Mean } \\
\hline $\mathrm{ML}$ & $1.23 \mathrm{E}-11$ & 2.14E-11 & 1.75 \\
\hline UL & $5.54 \mathrm{E}-12$ & $5.48 \mathrm{E}-11$ & 9.89 \\
\hline UM & $2.40 \mathrm{E}-12$ & 3.32E-12 & 1.38 \\
\hline All 3 & $3.88 \mathrm{E}-12$ & 9.19E-12 & 2.37 \\
\hline \multicolumn{4}{|c|}{ Arithmetic Mean } \\
\hline ML & $7.88 \mathrm{E}-11$ & 5.15E-11 & 2.93 \\
\hline UL & $1.75 \mathrm{E}-11$ & $5.90 \mathrm{E}-10$ & 22.75 \\
\hline UM & $7.58 \mathrm{E}-11$ & $4.90 \mathrm{E}-10$ & 17.84 \\
\hline All 3 & $6.14 \mathrm{E}-11$ & $4.44 \mathrm{E}-10$ & 16.65 \\
\hline \multicolumn{4}{|l|}{ Minimum } \\
\hline ML & $1.06 \mathrm{E}-12$ & 3.30E-12 & 0.11 \\
\hline UL & $1.46 \mathrm{E}-13$ & 1.19E-12 & 0.74 \\
\hline UM & $9.28 \mathrm{E}-15$ & $4.82 \mathrm{E}-14$ & 2.26E-03 \\
\hline All 3 & $9.28 \mathrm{E}-15$ & $4.82 \mathrm{E}-14$ & $2.26 \mathrm{E}-03$ \\
\hline \multicolumn{4}{|l|}{ Maximum } \\
\hline ML & $2.86 \mathrm{E}-10$ & $1.82 \mathrm{E}-10$ & 7.33 \\
\hline UL & $4.53 \mathrm{E}-11$ & 4.03E-09 & 115.10 \\
\hline UM & 1.19E-09 & 9.51E-09 & 354.12 \\
\hline All 3 & 1.19E-09 & 9.51E-09 & 354.12 \\
\hline \multicolumn{4}{|c|}{ Log of Range } \\
\hline ML & 2.43 & 1.74 & 1.82 \\
\hline UL & 2.49 & 3.53 & 2.19 \\
\hline UM & 5.11 & 5.30 & 5.19 \\
\hline All 3 & 5.11 & 5.30 & 5.19 \\
\hline \multicolumn{4}{|c|}{ Std. Dev of Log } \\
\hline ML & 1.03 & 0.63 & 0.57 \\
\hline UL & 0.87 & 1.22 & 0.63 \\
\hline UM & 1.25 & 1.25 & 1.19 \\
\hline All 3 & 1.14 & 1.27 & 1.04 \\
\hline
\end{tabular}

Source: DTNs: LB0012AIRKTEST.001 [DIRS 154586] for pre-excavation data;

LB0110AKN5POST.001 [DIRS 156904] for post-excavation data.

a The post/pre ratio is the ratio of post-excavation to pre-excavation permeabilities. This ratio was calculated for each interval in each borehole. Values reported are the statistical measures (maximum, minimum, mean, etc.) of all post/pre ratios calculated for each borehole.

Output DTN: LB0310AIRK0015.001. 
Table 6-4. Summary Statistics of Air Permeability $\left(\mathrm{m}^{2}\right)$ from Boreholes alongside Niche 5 (Niche CD 1620)

\begin{tabular}{|c|c|c|c|}
\hline \multicolumn{4}{|c|}{ Niche 5 (Niche CD 1620) Side } \\
\hline Borehole & Pre-Excavation & Post-Excavation & Post/Pre Ratio \\
\hline \multicolumn{4}{|l|}{ Geometric Mean } \\
\hline AK2 & $3.28 \mathrm{E}-12$ & $5.41 \mathrm{E}-12$ & 1.65 \\
\hline AK3 & $3.98 \mathrm{E}-12$ & $8.81 \mathrm{E}-12$ & 2.22 \\
\hline Both & $3.61 \mathrm{E}-12$ & $6.90 \mathrm{E}-12$ & 1.91 \\
\hline \multicolumn{4}{|l|}{ Arithmetic Mean } \\
\hline AK2 & 1.09E-11 & $1.58 \mathrm{E}-11$ & 5.79 \\
\hline AK3 & $9.00 \mathrm{E}-12$ & $1.50 \mathrm{E}-11$ & 18.53 \\
\hline Both & 9.93E-12 & $1.54 \mathrm{E}-11$ & 12.16 \\
\hline \multicolumn{4}{|l|}{ Minimum } \\
\hline AK2 & $4.01 \mathrm{E}-14$ & $3.44 \mathrm{E}-14$ & 0.86 \\
\hline AK3 & $1.46 \mathrm{E}-13$ & 1.19E-12 & 0.84 \\
\hline Both & $4.01 \mathrm{E}-14$ & $3.44 \mathrm{E}-14$ & 0.84 \\
\hline \multicolumn{4}{|l|}{ Maximum } \\
\hline AK2 & 5.14E-11 & $5.88 \mathrm{E}-11$ & 95.51 \\
\hline AK3 & $3.01 \mathrm{E}-11$ & $3.40 \mathrm{E}-11$ & 363.64 \\
\hline Both & $5.14 \mathrm{E}-11$ & $5.88 \mathrm{E}-11$ & 363.64 \\
\hline \multicolumn{4}{|l|}{ Range of Log } \\
\hline AK2 & 3.11 & 3.23 & 2.05 \\
\hline AK3 & 2.51 & 2.45 & 2.64 \\
\hline Both & 3.11 & 3.23 & 2.64 \\
\hline \multicolumn{4}{|l|}{ Std Dev of Log } \\
\hline AK2 & 0.82 & 0.83 & 0.44 \\
\hline AK3 & 0.72 & 0.61 & 0.61 \\
\hline Both & 0.77 & 0.73 & 0.53 \\
\hline
\end{tabular}

Source: DTNs: LB002181233124.001 [DIRS 146878] for pre-excavation data; LB0110AK23POST.001 [DIRS 156905] for post-excavation data. 
Table 6-5. Summary Statistics of Air Permeability $\left(\mathrm{m}^{2}\right)$ from Boreholes under Alcove 8

\begin{tabular}{|c|c|c|}
\hline \multicolumn{3}{|c|}{ Alcove 8} \\
\hline Borehole & Geometric Mean & Arithmetic Mean \\
\hline $\mathrm{BH} 1$ & $1.76 \mathrm{E}-13$ & $1.71 \mathrm{E}-10$ \\
\hline $\mathrm{BH} 2$ & $6.41 \mathrm{E}-14$ & $3.48 \mathrm{E}-13$ \\
\hline $\mathrm{BH} 3$ & 1.33E-14 & $3.55 \mathrm{E}-13$ \\
\hline $\mathrm{BH} 4$ & $6.29 \mathrm{E}-14$ & $2.44 \mathrm{E}-10$ \\
\hline $\mathrm{BH} 5$ & $5.11 \mathrm{E}-14$ & $4.93 \mathrm{E}-13$ \\
\hline $\mathrm{BH} 6$ & $1.11 \mathrm{E}-12$ & 4.19E-11 \\
\hline All 6 & 8.67E-14 & $7.52 \mathrm{E}-11$ \\
\hline Borehole & Minimum & Maximum \\
\hline $\mathrm{BH} 1$ & 4.72E-15 & 3.17E-09 \\
\hline $\mathrm{BH} 2$ & 4.83E-15 & $5.46 \mathrm{E}-12$ \\
\hline $\mathrm{BH} 3$ & $3.61 \mathrm{E}-15$ & $5.28 \mathrm{E}-12$ \\
\hline $\mathrm{BH} 4$ & 4.45E-15 & $6.25 \mathrm{E}-09$ \\
\hline $\mathrm{BH} 5$ & $3.60 \mathrm{E}-15$ & 7.06E-12 \\
\hline $\mathrm{BH} 6$ & $1.48 \mathrm{E}-14$ & 1.13E-09 \\
\hline All 6 & $3.60 \mathrm{E}-15$ & $6.25 \mathrm{E}-09$ \\
\hline Borehole & Range of log & Std Dev of log \\
\hline $\mathrm{BH} 1$ & 5.83 & 1.51 \\
\hline $\mathrm{BH} 2$ & 3.05 & 0.83 \\
\hline $\mathrm{BH} 3$ & 3.17 & 0.89 \\
\hline $\mathrm{BH} 4$ & 6.15 & 1.46 \\
\hline $\mathrm{BH} 5$ & 3.29 & 0.98 \\
\hline $\mathrm{BH} 6$ & 4.88 & 1.20 \\
\hline All 6 & 6.24 & 1.29 \\
\hline
\end{tabular}

Source: DTN: LB0302ALC8AIRK.001 [DIRS 164748]. 
Table 6-6. Comparison of Geometric Means and Standard Deviations of Niches and Alcoves in the Exploratory Studies Facility at Yucca Mountain

\begin{tabular}{|c|c|c|c|}
\hline \multirow[b]{2}{*}{ Borehole Cluster } & \multirow[b]{2}{*}{ Comment/Type of Site } & \multicolumn{2}{|c|}{$\log (k)\left(m^{2}\right)$} \\
\hline & & Mean & $\begin{array}{l}\text { Standard } \\
\text { Deviation }\end{array}$ \\
\hline Niche 1 (Niche 3566) Pre-Excavation & Intersects brecciated zone & -13.0 & 0.92 \\
\hline Niche 1 (Niche 3566) Radial & Predominantly within brecciated zone & -11.8 & 0.66 \\
\hline Niche 2 (Niche 3650) Pre-Excavation & Moderately fractured welded tuff & -13.4 & 0.81 \\
\hline Niche 2 (Niche 3650) Post-Excavation & Post-excavation welded tuff & -11.8 & 0.88 \\
\hline Niche 3 (Niche 3107) Pre-Excavation & Moderately fractured welded tuff & -13.4 & 0.70 \\
\hline Niche 3 (Niche 3107) Post-Excavation & Post-excavation welded tuff & -12.4 & 0.82 \\
\hline Niche 3 (Niche 3107) Radial & Moderately fractured welded tuff & -13.8 & 0.92 \\
\hline Niche 4 (Niche 4788) Pre-Excavation & Highly fractured welded tuff & -13.0 & 0.85 \\
\hline Niche 4 (Niche 4788) Post-Excavation & Post-excavation welded tuff & -11.9 & 0.78 \\
\hline $\begin{array}{l}\text { Niche } 5 \text { (Niche CD 1620) Pre-Excavation } \\
\text { side }\end{array}$ & Lithophysal cavities; holes on side of excavation & -11.4 & 0.77 \\
\hline $\begin{array}{l}\text { Niche } 5 \text { (Niche CD 1620) Post-Excavation } \\
\text { side }\end{array}$ & Lithophysal cavities; holes on side of excavation & -11.2 & 0.73 \\
\hline $\begin{array}{l}\text { Niche } 5 \text { (Niche CD 1620) Pre-Excavation } \\
\text { overhead }\end{array}$ & Lithophysal cavities; holes above excavation & -11.4 & 1.14 \\
\hline $\begin{array}{l}\text { Niche } 5 \text { (Niche CD 1620) Post-Excavation } \\
\text { overhead }\end{array}$ & Lithophysal cavities; holes above excavation & -11.0 & 1.27 \\
\hline Alcove 4 & Discrete faulted and fractured non-welded tuff & -13.0 & 0.93 \\
\hline Alcove 6 & Highly fractured post-excavation welded tuff & -11.9 & 0.67 \\
\hline Alcove 8 & $\begin{array}{l}\text { Transition from upper lithophysal to welded } \\
\text { fractured nonlithophysal in near-vertical boreholes }\end{array}$ & -13.1 & 1.29 \\
\hline
\end{tabular}

Source: DTNs: LB0011AIRKTEST.001 [DIRS 153155], LB980901233124.101 [DIRS 136593], LB990601233124.001 [DIRS 105888], LB980901233124.004 [DIRS 105855], LB980901233124.009 [DIRS 105856], LB980912332245.001 [DIRS 110828], LB0302ALC8AIRK.001 [DIRS 164748], LB0012AIRKTEST.001 [DIRS 154586], LB002181233124.001 [DIRS 146878], LB0110AK23POST.001 [DIRS 156905], LB0110AKN5POST.001 [DIRS 156904].

Summary: DTN: LB990901233124.004 [DIRS 123273] (enhanced with Niche CD 1620 [Niche 5] and Alcove 8 results).

$\mathrm{CD}=$ Enhanced Characterization of Repository Block Cross-Drift.

\subsection{ANALYSIS AND INTERPRETATION OF THE NICHE LIQUID-RELEASE AND SEEPAGE-TEST DATA}

The ESF Drift Seepage Test and Niche Moisture Study (BSC 2004 [DIRS 167969]) characterize the seepage process and further the understanding of how moisture could seep into drifts. Specific objectives of the study were:

- To measure in situ hydrologic properties of the repository host rock for use in Seepage Calibration Model and Seepage Testing Data (BSC 2004 [DIRS 171764]) and Seepage Model for PA Including Drift Collapse (BSC 2004 [DIRS 167652]).

- To provide a database of liquid-release and seepage data that could be used to validate models of seepage and other related UZ processes. 
- To evaluate drift-scale seepage processes to quantify the extent to which seepage is excluded from entering an underground cavity.

- To determine the seepage threshold below which percolating water does not seep into a drift.

The objectives of the study are realized through a combination of field experiments, including air-injection, liquid-release, and seepage tests.

Analytic solutions are used in the data analyses presented in this section to estimate the seepage thresholds, capillary barrier strengths, water-potential values, and characteristic relationships along seepage flow paths. Local homogeneity is the main approximation in the analytic solutions used in estimating the air-permeability values and liquid seepage flow field. Numerical models have been formulated in the model report Seepage Calibration Model and Seepage Testing Data (BSC 2004 [DIRS 171764]) to evaluate the effects of spatial heterogeneity on the effective seepage parameters, with the heterogeneity field based on the air-permeability distribution (described in Section 6.1). The seepage calibration model is the basis for other model reports in estimating the seepage fraction and distribution over the waste-emplacement drifts. The downstream model reports include Seepage Model for PA Including Drift Collapse (BSC 2004 [DIRS 167652]) and Abstraction of Drift Seepage (BSC 2004 [DIRS 169131]).

Early results were based on short-duration releases of small amounts of water (on the order of one liter) above Niche 2 (Niche 3650), leading to limited coverage of the fracture network involved in flow diversion around the opening. Moreover, the seepage amount is likely affected by storage effects, which are insignificant for the prediction of long-term seepage behavior. These short-duration tests (originally designed to simulate the arrivals of episodic percolation events through fast flow paths into ventilated drifts), do not provide the data sets needed by the seepage calibration model and other PA models. In order to address this issue, later tests in Niche 3 (Niche 3107), Niche 4 (Niche 4788) and Niche 5 (Niche 1620) were redesigned as long-duration liquid-release test.

\subsubsection{Review of Data Obtained from Liquid-Release and Seepage Tests Conducted at Niches}

This section provides a general overview of the tests, including field activities performed before, during, and after the niches were excavated.

\subsubsection{Pre-Excavation Liquid-Release Test Data}

Before seepage tests in excavated niches were conducted, the niche test sites are characterized by air-permeability tests (Section 6.1) and by pre-excavation liquid-release tests discussed in this section. The pre-excavation liquid-release tests introduced a finite amount of dyed water to characterize the flow paths within the niche space. The main objective is to determine the relative strength between the gravity force that moves the liquid downward and the capillary forces that tend to spread the liquid laterally. The flow paths were subsequently characterized during niche excavation (Section 6.2.1.2). 
Hundreds of air-injection tests were conducted in the boreholes at niche sites before excavation. The test results were used to determine the distribution of single-borehole air permeabilities within the rock mass (see Section 6.1). These data were then used to select test intervals for subsequent liquid-release tests. Both high and low permeability intervals were selected for liquid-release tests.

Liquid-release tests were conducted in the same boreholes as the air-injection tests by pumping water containing colored or fluorescent dyes at a constant rate into various $0.3-\mathrm{m}$-long test intervals (for a description of the testing equipment, see discussion of Figure 6-39 in Section 6.2.1.3.5.2). A finite amount of dye-spiked water, typically $1 \mathrm{~L}$, was introduced into each test interval. The water was introduced slowly to minimize buildup of fluid pressure in the test interval. Various colored and fluorescent tracers were used during the study to document the flow paths traveled by the wetting front. For the remainder of this section, the term "water" will be used to describe the test fluid, which may or may not have contained a tracer.

Pre-excavation liquid-release tests were performed during early June and early August 1997, in boreholes installed before the excavation of Niche 1 (Niche 3566) and Niche 2 (Niche 3650), respectively. Pre-excavation liquid-release tests were performed at Niche 3 (Niche 3107) and Niche 4 (Niche 4788), starting in late April and late June 1998, respectively. Pre-excavation liquid-release tests were also performed at Niche 5 (Niche CD 1620) in the lower lithophysal zone in April 2000. The data from these pre-excavation tests, including the mass of water released, pumping rates and times, and liquid-release rates, were tabulated and entered into the TDMS, and assigned DTN: LB980001233124.004 [DIRS 136583] for Niche 1 (Niche 3566) and Niche 2 (Niche 3650); DTN: LB980901233124.003 [DIRS 105592] for Niche 3 (Niche 3107) and Niche 4 (Niche 4788); and DTN: LB0102NICH5LIQ.001 [DIRS 155681] for Niche 5 (Niche CD 1620). The tables include directly measured mass, pumping rates, return flow rates, and derived quantities of average liquid release rates from the differences of the measured rates.

\subsubsection{Niche Excavation Activities}

The niches were excavated with an Alpine Miner, a mechanical device, using minimal water in order to observe and photograph the distribution of fractures and dye within the welded tuff. As reported in DTN: LB980001233124.004 [DIRS 136583], dye was observed along individual fractures as well as along intersecting fractures to depths within the range of 0 to $2.6 \mathrm{~m}$ below the liquid-release points at the Niche 1 (Niche 3566) and Niche 2 (Niche 3650) sites. Dye was observed at a maximum depth of approximately $1.2 \mathrm{~m}$ below the release point at Niche 3 (Niche 3107) and approximately $1.8 \mathrm{~m}$ at Niche 4 (Niche 4788), as reported in DTN: LB980901233124.003 [DIRS 105592]. Dye was observed at a maximum depth of approximately $1.4 \mathrm{~m}$ below the release point at Niche 5 (Niche CD 1620), as reported in DTN: LB0102NICH5LIQ.001 [DIRS 155681]. (In this report, if a given DTN consists of multiple files, the DTN and data report table name are both identified.) Flow of water through a relatively undisturbed fracture-matrix system was documented in this manner.

During the mining operation at Niche 1 (Niche 3566) and Niche 2 (Niche 3650), two types of flow paths were observed in the field, based on the observed pattern of dye: (1) flow through individual or small groups of high-angle fractures; and (2) flow through several interconnected 
low- and high-angle fractures, creating a fracture network. Dye was observed along individual fractures and fracture networks to a maximum depth of $2.6 \mathrm{~m}$ below the release points in the middle nonlithophysal zone (Tptpmn) of the TSw. The vertically elongated dye pattern suggests that water is predominantly flowing downwards. In contrast, an approximately spherical dye pattern (centered at the release point) was observed at Niche 5 (Niche CD 1620), located in the lower lithophysal zone (Tptpll) of the TSw. Dye was observed in fractures and lithophysal cavities to a maximum depth of $1.4 \mathrm{~m}$. In comparison to the experiments performed in the middle nonlithophysal unit, the dye patterns observed in Niche 5 were more symmetric, with the lateral edges of the wetted area lying approximately equal distance from the release point.

Figure 6-24 compares examples of flow paths observed in the Tptpmn at Niche 1 (Niche 3566) with dye patterns observed in the Tptpll at Niche 5 (Niche CD 1620) (See Section 6.1.2.2.1 for the observation of a damp feature included in the figure). The observed damp feature and the dye patterns suggest that flow through fractures in the Tptpmn is predominately gravity-driven. In contrast, the symmetry of the dye patterns observed in the Tptpll suggests that capillary forces may be more important in this zone.

Dye was observed in numerous lithophysal cavities in the Tptpll. No direct field evidence exists showing that water accumulated and dripped into the cavities, even though the liquid-release fluxes applied during the test were 1,000 times greater than the natural flux, estimated at $10 \mathrm{~mm} /$ year. No dye stains on the ceiling were observed to line up directly above stains on the floor of the cavities. An example of dye observed on the floor of a lithophysal cavity is illustrated in Panel (d) of Figure 6-24, suggesting capillary-induced upward fluid movement is a likely mechanism to introduce fluid into the cavity.

Capillary forces appear to be stronger in the Tptpll despite the fact that the average air permeability of the Tptpll is greater than that of the Tptpmn. Typically, capillary forces are less important in higher-permeability media than in lower-permeability materials. This may indicate that the air-permeability measurements performed in the Tptpll are influenced by the lithophysal cavities, which may connect relatively large fractures with smaller fractures, effectively contributing to the relatively strong capillarity.

Note that some of the lithophysal cavities had a thick layer of drill cuttings (i.e., dust) coating their surfaces. This layer of dust could influence the flow patterns (as represented by the dye stain) and depth of wetting-front migration observed in the Tptpll. This dust was introduced into the cavities intersecting the borings when the boreholes were air-cored. The dust could act as a highly transmissive surface zone (compared to the rock matrix) that could enhance the uniform spread of the wetting front. The dust could also impede the movement of water and dye through the fractures by imbibing and retaining the moisture close to the point of release.

In general, the maximum distance that the wetting front traveled through the Tptpmn from the point of injection to the furthest point of observation increased with the mass of water injected. The data did not show that the type of flow (i.e., network or vertical fracture flow) had any significant influence on the maximum travel distance. Figure 6-25 shows that on average, results of tests conducted in the Tptpmn are far more gravity-dominated (i.e., had a higher aspect ratio) than results of tests performed in the Tptpll. Computation of the aspect ratio was performed in the Excel spreadsheet documented in Appendix Table B-1. The average line for Tptpll in 
Figure 6-25 is influenced by a single data point with a high aspect ratio [possibly associated with a fracture or fractures connected to the borehole (Trautz 2001 [DIRS 157022], p. 69). Without this data point, the average is much closer to 1 (i.e., the aspect ratio of a spherical pattern.)

(a)

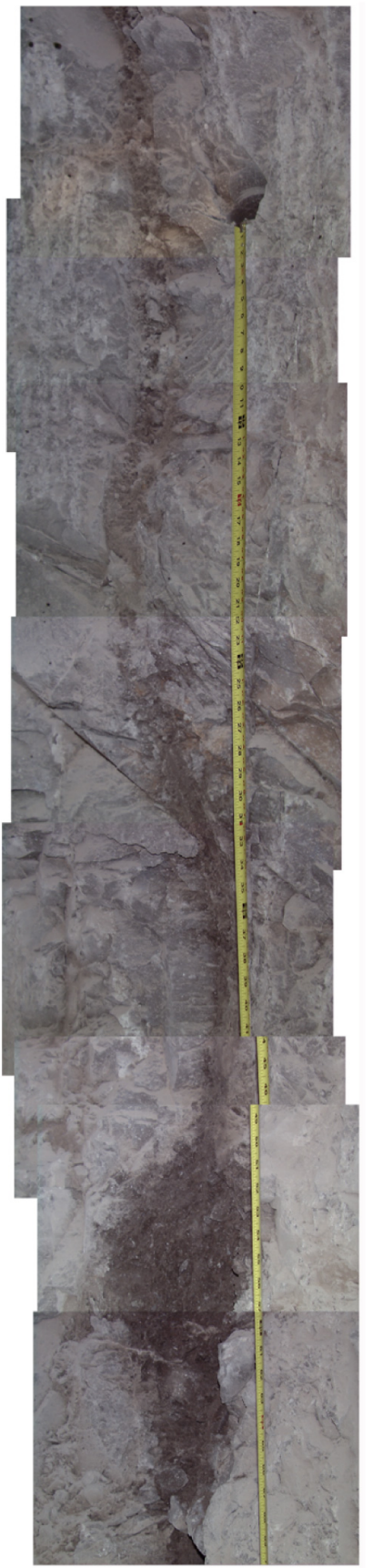

(b)

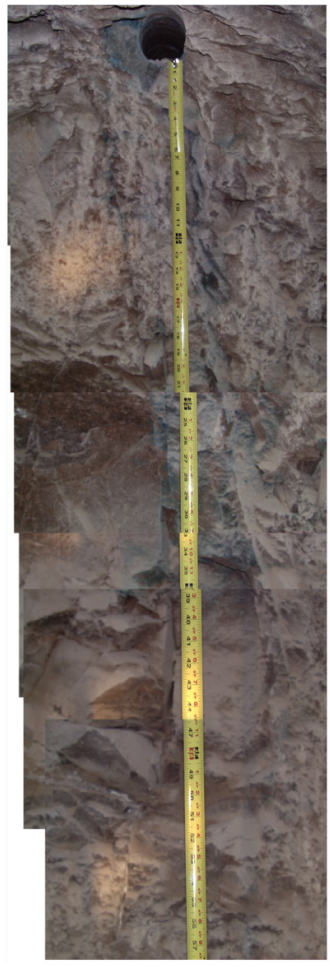

(c)

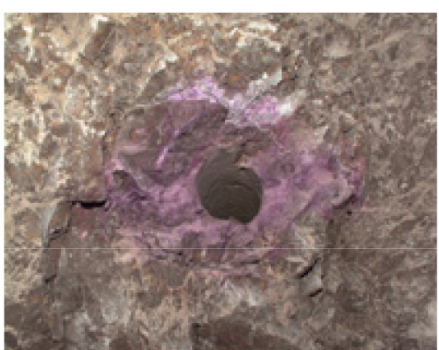

(d)

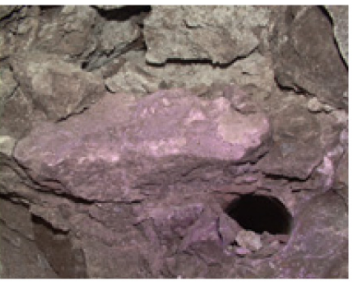

Sources: Wang et al. (1999 [DIRS 106146], Figures 4a, 4c); Trautz (2001 [DIRS 157022] pp. 79, 84).

NOTES: (a) Naturally Occurring Wet Feature at Niche 1 (Niche 3566), (b) Blue-Dyed Flow Path at Niche 1 (Niche 3566), (c) Pink-Dyed Flow Path at Niche 5 (Niche CD 1620), (d) Pink Stain on the Floor of a Lithophysal Cavity at Niche 5 (Niche CD 1620).

Figure 6-24. Photographic Illustrations of Flow Paths Observed During Niche Excavations 


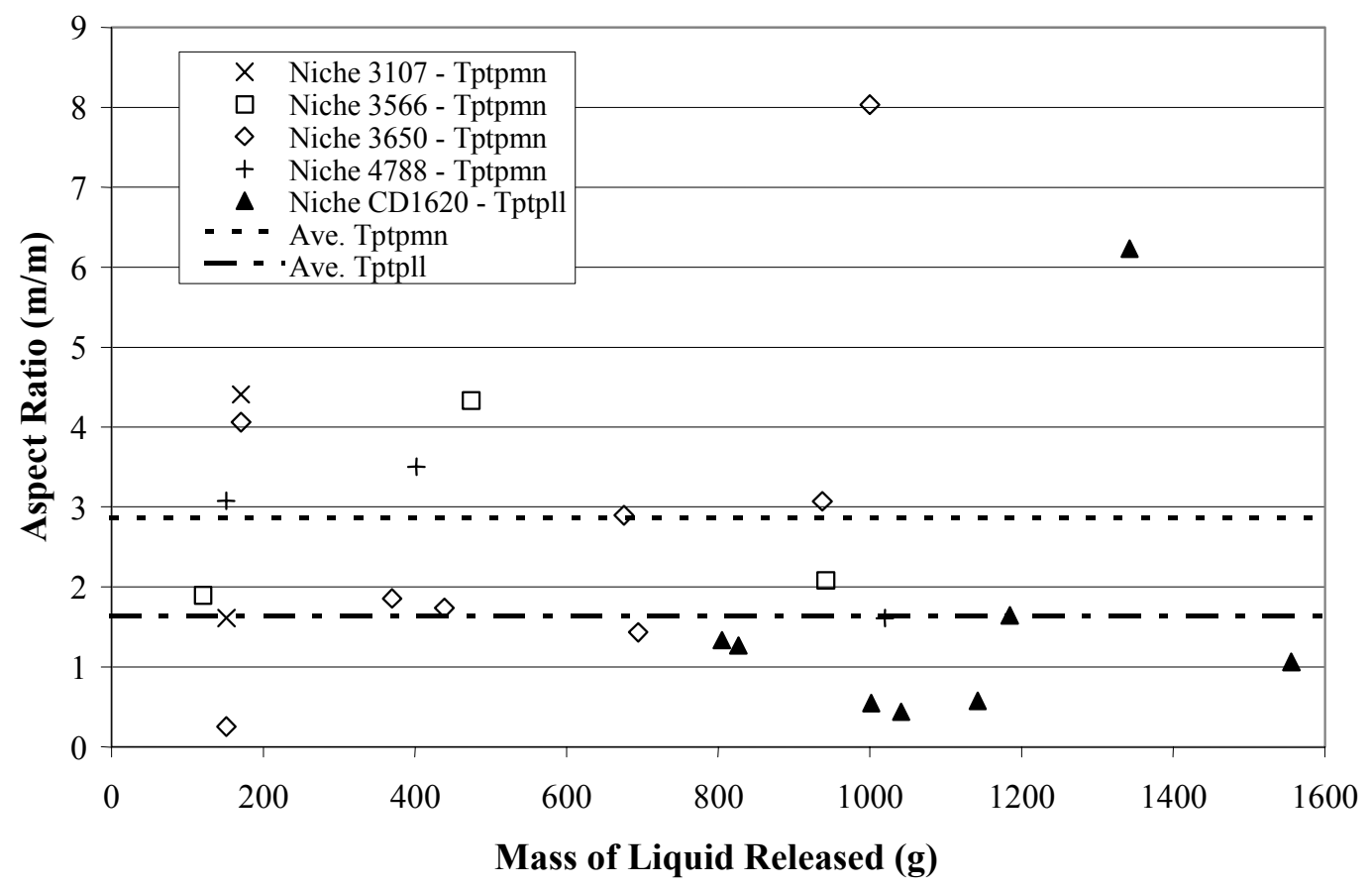

Source: DTNs: LB980001233124.004 [DIRS 136583]; LB980901233124.003 [DIRS 105592]; LB0102NICH5LIQ.001 [DIRS 155681].

Output DTN: LB0110LIQR0015.001.

Figure 6-25. Mass of Water Released versus Aspect Ratio

\subsubsection{Post-Excavation Seepage Tests}

A series of seepage tests was performed at Niche 2 (Niche 3650), Niche 3 (Niche 3107), and Niche 4 (Niche 4788). In general, the tests were used to quantify the amount of water seeping into the drift from a localized water source of known duration and intensity. The tests were also used to establish the niche seepage-threshold $\left(K_{o}^{*}\right)$, defined as the largest flux of water that can be introduced into the test borehole without resulting in seepage into the niche. The borehole flux values were derived from the pumping rate and the wetted area estimated for the borehole interval (i.e., a cylindrical, wetted area). This is different from the horizontal reference plane used in the definition of the percolation flux. Therefore, the resulting definition of niche seepage threshold is different from the definition used for performance assessment, where the seepage threshold is related to the steady-state background percolation flux averaged over an approximately 5-m long section of a waste emplacement drift.

After post-excavation air-permeability tests (described in Section 6.1), seepage tests were conducted by pumping water into select test intervals in Borehole UL, Borehole UM, and Borehole UR located above each niche. The distance from the test intervals to the niche ceiling is within the range of 0.58 to $1.23 \mathrm{~m}$ for all the niche sites. (Computation of the distance is inserted in an Excel spreadsheet documented in Appendix Table B-2.) The tests were performed by sealing a short interval of borehole using an inflatable packer system, similar to the system used in the air-injection tests described in Appendix A. Any water that migrated from the borehole to the niche ceiling and dripped into the opening was captured and weighed. 
For each packer interval, a liquid-return (overflow) line prevented buildup of excess pressure. If the liquid injection rate was higher than the release rate into the formation and return flow was observed, the liquid-release rate was determined by the difference between injection flow rate and return flow rate. The observation of return flows would indicate that the pumping rate exceeded the $\mathrm{K}_{\mathrm{s}}$ of the fracture network around the borehole interval. (For tests with low liquid volume, and in cases of significant storage in the borehole interval, instances of no return flow did not imply that the pumping conditions represented unsaturated conditions.)

While liquid-release tests in the open Niche 2 (Niche 3650) were conducted with semi-automated injection and manual seepage collection in an open niche, tests in Niche 3 (Niche 3107) and Niche 4 (Niche 4788) were conducted in sealed niches and with evaporation controls, and tests in Niche 5 (Niche 1620) involved fully automated operation and control. Detailed descriptions of the lower lithophysal (Tptpll) Niche 5 tests are presented in Section 6.2.1.3.5.2.

\subsection{Niche 2 (Niche 3650) Seepage-Test Data}

Forty niche seepage tests were performed on 16 test intervals positioned above Niche 2 (Niche 3650) beginning in late 1997 and ending in early 1998. Water migrated through the rock and seeped into the niche in 10 out of the 16 zones tested. The niche seepage threshold was determined for the 10 zones that seeped. Seepage and liquid-release data were tabulated and entered into the TDMS, where it was assigned DTN: LB980001233124.004 [DIRS 136583].

The mass of water released to the formation was computed by mass balance. In turn, the liquid-release rate $\left(Q_{s}\right)$ for each test was computed by dividing the mass released by the respective duration of each test; thus, these values represent time-averaged rates. The rate at which water was released to the formation was in the range of 0.007 to 2.892 grams per second $(\mathrm{g} / \mathrm{s})$, and the total mass released was in the range of 274.5 to 5597.5 grams (g) per test, as summarized in DTN: LB980001233124.004 [DIRS 136583].

When water appeared at the niche ceiling during a test and dripped into the opening, it was collected in the capture system and weighed. Figure 6-26 shows the approximate location of the capture system and test intervals relative to the niche boundaries, and the sequence of dyes and number of tests performed on each test interval. The wetting front typically arrived at the niche ceiling directly below the test zone. Most of the water was typically captured in only one or two $0.3-\mathrm{m}-\mathrm{by}-0.3-\mathrm{m}$ cells located directly beneath the test interval.

In the immediate vicinity of locations where the niche ceiling and the conducting fractures intersect, the relative humidity could be high from local evaporation. However, the localized humid conditions were not met everywhere within the niche and/or the ESF main drift. Maintenance of high relative humidity conditions was important for long-term seepage tests, because the evaporation effects could have a substantial impact on the analysis of the seepage data, with models setting postemplacement high-humidity conditions in the seepage threshold estimation. The potential impact of evaporation effects is discussed in Section 6.7 of Seepage Calibration Model and Seepage Testing Data (BSC 2004 [DIRS 171764]). 
The mass of water captured was in the range of 0.0 to $568.6 \mathrm{~g}$ per test, as reported in DTN: LB980001233124.004 [DIRS 136583]. The niche seepage percentage is defined as the mass of water that dripped into the capture system, divided by the mass of water released to the rock:

$$
\text { Niche Seepage Percentage }=100 \times \frac{\text { "Mass Captured }(g) "}{\text { "Mass Released }(g) "}
$$

The niche seepage percentage varied from 0 percent for zones that did not seep, to 56.2 percent for a predominantly gravity-driven flow through a highly saturated fracture (DTN: LB980001233124.004 [DIRS 136583]).

The niche seepage tests at Niche 2 (Niche 3650) were conducted with release of relatively small amounts of liquid over short durations. Multiple tests were conducted in multiple borehole intervals. To address the model needs of steady-state data in controlled relative humidity conditions, the later tests in Niche 3 (Niche 3107) and Niche 4 (Niche 4788) were conducted in selected borehole intervals with larger amounts of liquid over longer durations, as described in the following two sections.

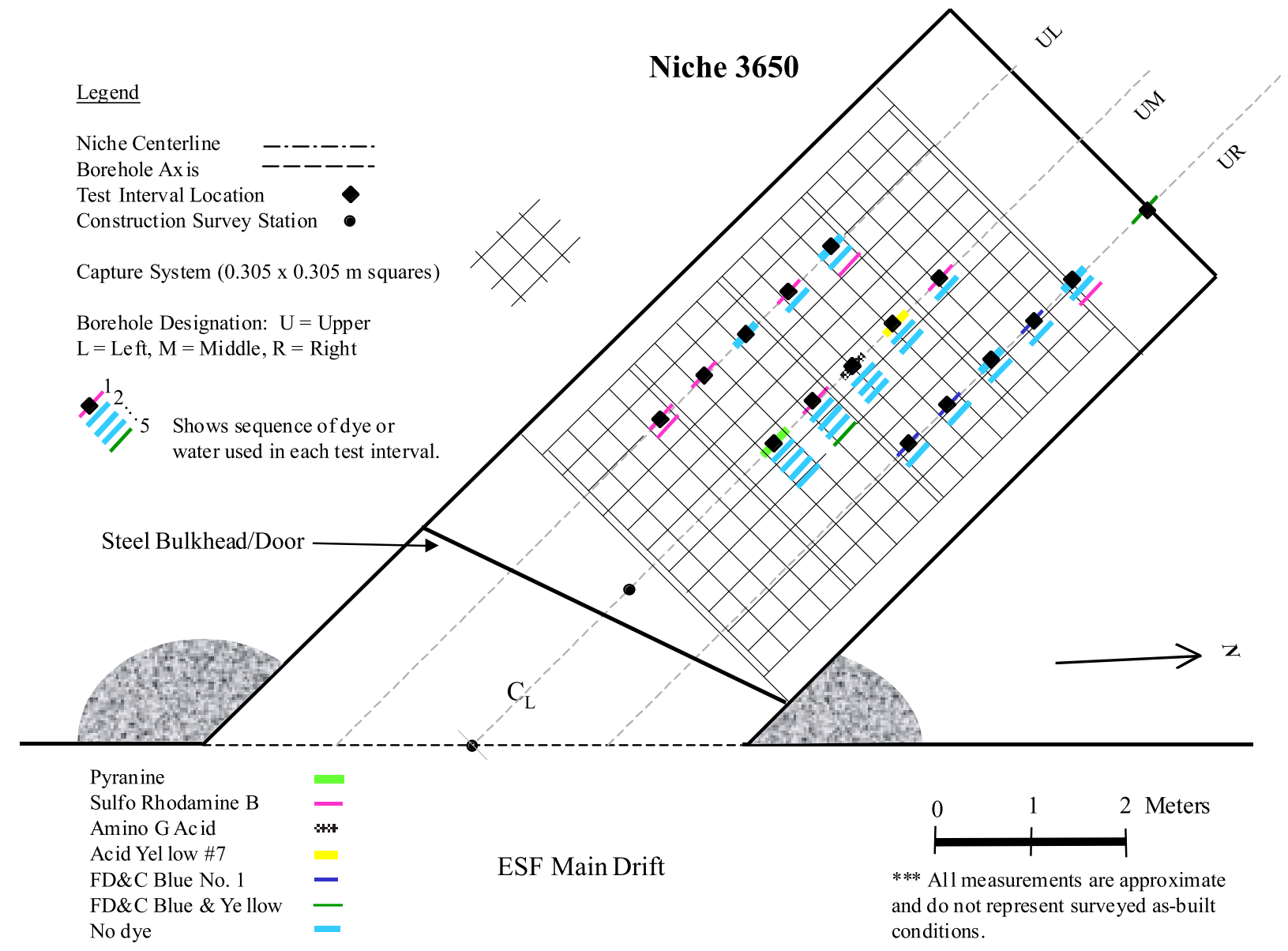

Figure 6-26. Schematic Illustration of Seepage Capture System and Test Intervals at Niche 2 (Niche 3650) 


\subsection{Niche 3 (Niche 3107) Seepage-Test Data}

Beginning in early 1999 and ending in late 1999, twelve niche seepage tests were performed on two test intervals positioned above Niche 3 (Niche 3107). Water migrated through the rock and seeped into the niche for one out of the two zones tested. The niche seepage threshold was determined for the zone that seeped. The seepage and liquid-release data were tabulated and entered into the TDMS, where it was assigned DTN: LB0010NICH3LIQ.001 [DIRS 153144]. The borehole flux values were derived from the pumping rate and the wetted area estimated for the borehole interval.

As with Niche 2 (Niche 3650), the mass of water released to the formation was computed by a mass balance. The liquid release-rate $\left(Q_{s}\right)$ for each test was computed by dividing the mass released by the respective duration of each test; thus, these values represent time-averaged rates. The rate at which water was released to the formation was in the range of 0.014 to $0.102 \mathrm{~g} / \mathrm{s}$ for all of the tests, and the mass released was in the range of 4229.5 to $23831.4 \mathrm{~g}$ per test. The mass of seepage water captured in the niche was in the range of 0.0 to $15715.1 \mathrm{~g}$ per test. The seepage percentage defined by Equation 6-2 varied from 0 percent (i.e., no seepage was observed), to 70.1 percent.

The niche seepage tests were conducted with the bulkhead doors at the entrance to the niche closed and sealed. In addition, the air space within the niche was artificially humidified to increase the relative humidity as high as practical to minimize the effects of evaporation resulting from ESF ventilation. One open-faced water bath was placed inside the niche to freely supply moisture to the niche space. The water loss volume resulting from evaporation was used to estimate the average evaporation rate over the niche space. The test conditions (e.g., high humidity and low evaporation rates) are representative of steady seepage into a drift that could potentially occur after the repository is closed, the heat load and temperature rise from the decaying waste have dissipated, and air in the sealed repository equilibrates with the surrounding rock and is at, or near, 100-percent relative humidity. The relative humidity and temperature within Niche 3 (Niche 3107) is shown in Figure 6-27. 


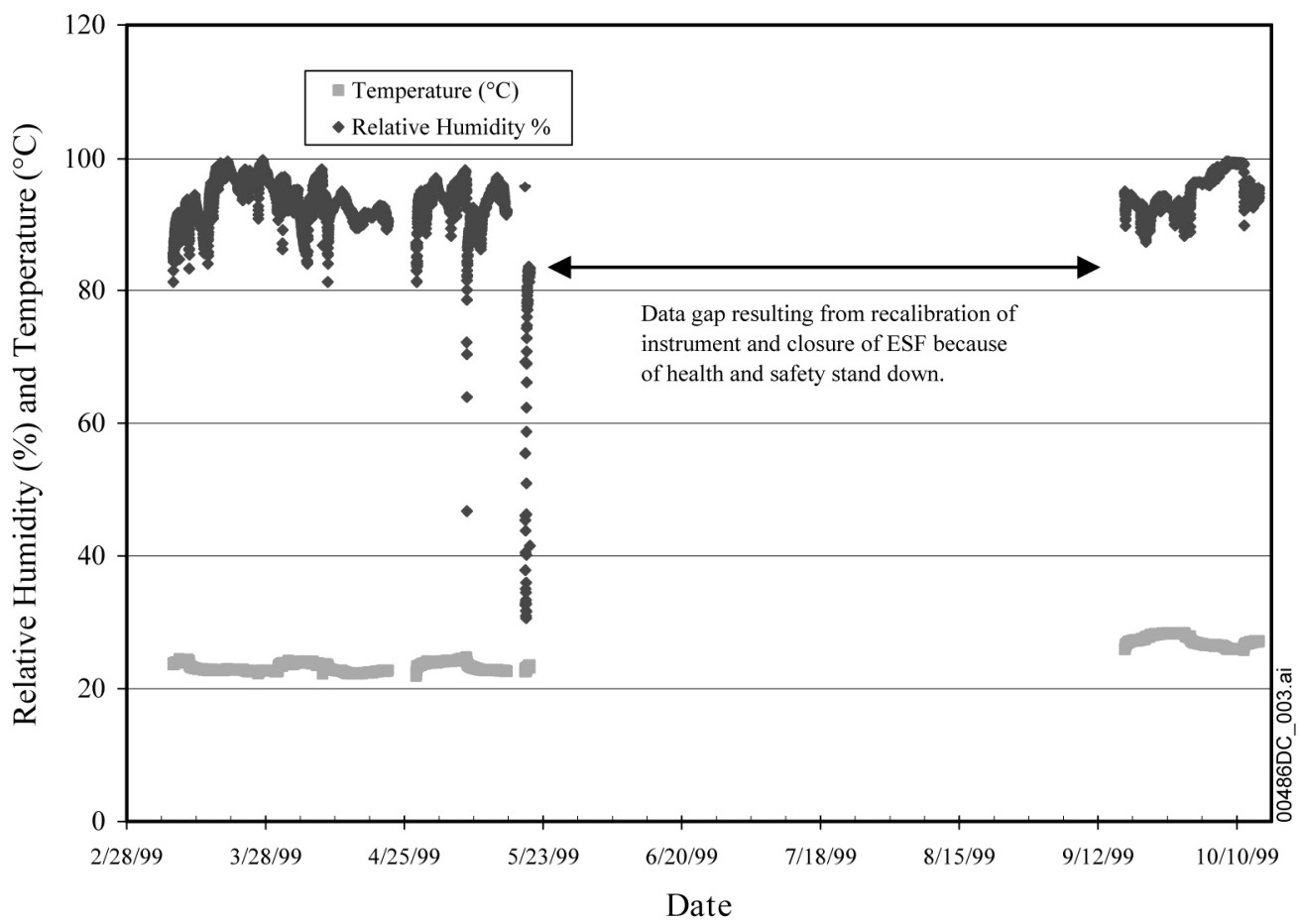

Source: DTN: LB0010NICH3LIQ.001 [DIRS 153144].

Figure 6-27. Relative Humidity and Temperature Inside Niche 3 (Niche 3107)

\subsection{Niche 4 (Niche 4788) Seepage-Test Data}

Beginning in late 1999 and ending in mid-2000, 13 niche seepage tests were performed on three test intervals positioned above Niche 4 (Niche 4788). Water migrated through the rock and seeped into the niche from all zones tested. The niche seepage threshold was determined for two of the three zones that seeped. The seepage and liquid-release data were tabulated and entered into the TDMS, where it was assigned DTN: LB0010NICH4LIQ.001 [DIRS 153145]. The borehole flux values for Niche 4 (Niche 4788) were derived from the pumping rate and the wetted area estimated for the borehole interval.

The long-duration data from Niche 4 (Niche 4788) were analyzed in Section 6.6 of the model report Seepage Calibration Model and Seepage Testing Data (BSC 2004 [DIRS 171764]). The seepage calibration model analyzed the transient behavior, storage effects, and memory effects (which may occur in a series of tests) to determine the effective seepage parameters. The parameters were then used in the model report Seepage Model for PA Including Drift Collapse (BSC 2004 [DIRS 167652]) to determine the seepage threshold flux relative to percolation flux. The final input to TSPA-LA is evaluated in Abstraction of Drift Seepage (BSC 2004 [DIRS 169131]). 
The rate at which water was released to the formation was in the range of 0.008 to 0.092 grams per second $(\mathrm{g} / \mathrm{s})$ for all of the tests, and the mass released was in the range of 1474.9 to $39514.6 \mathrm{~g}$ per test. The mass of seepage water captured in the niche was in the range of 0.0 to $15555.1 \mathrm{~g}$ per test. The niche seepage percentage defined by Equation 6-2 was within the range of 0 percent to 68.7 percent.

Again, the seepage tests were conducted with the bulkhead doors at the entrance to the niche closed and sealed, and the air space within the niche artificially humidified to minimize evaporation. Figure 6-28 shows the relative humidity and temperature inside of Niche 4.

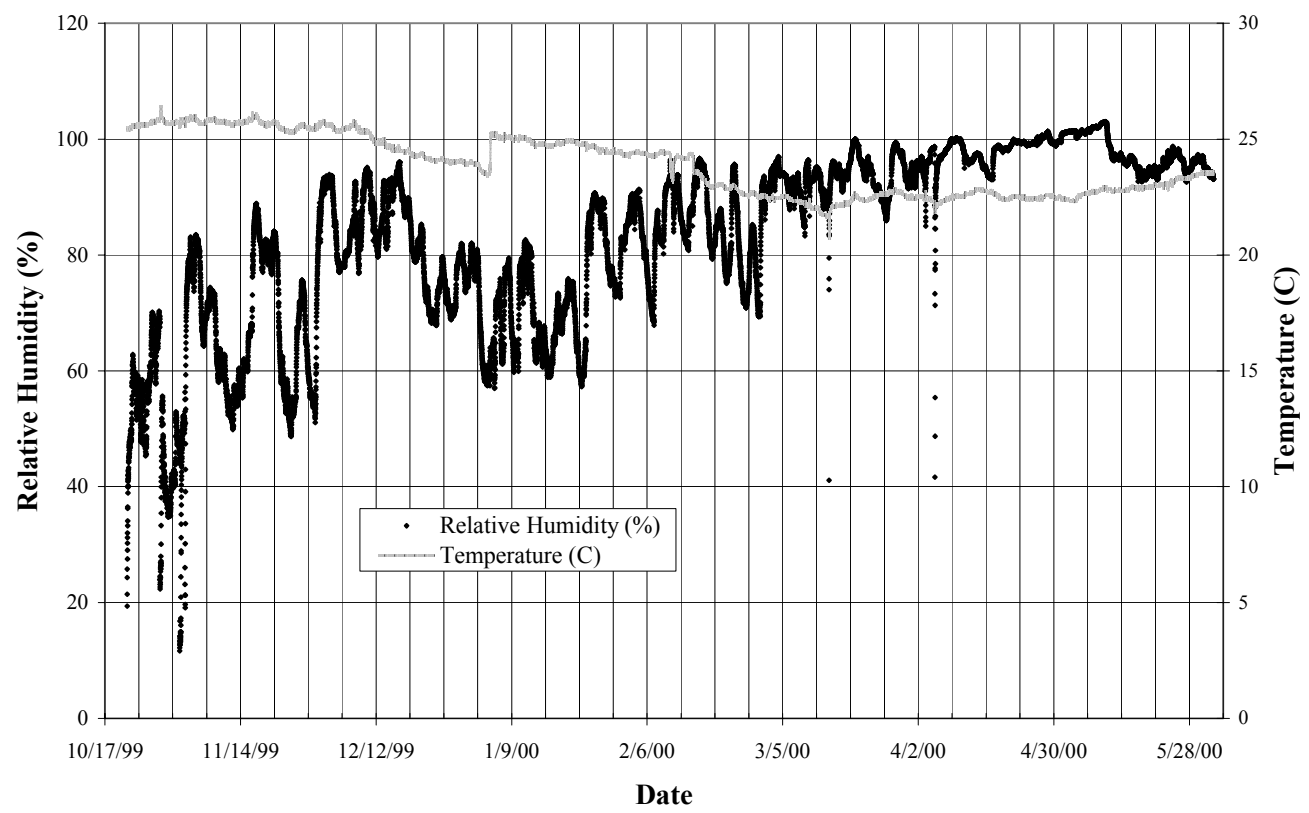

Source: DTN: LB0010NICH4LIQ.001 [DIRS 153145]: native data files Niche 4 h\&T 3-10-00.csv, Niche 4 RH\&T 4-1-00.csv, and Niche 4788 R\&T 6-8-00.csv; data report S00429 007.

Figure 6-28. Relative Humidity and Temperature Inside Niche 4 (Niche 4788)

Figure 6-29 illustrates the injection rate into a borehole interval, the return rate (a non-zero return rate is obtained if the injection rate exceeds the capacity of the fractured rock to take up the injected water), and the stabilization of niche seepage rate of water collected in the niche trays. If tests were not long enough before niche stabilization, the niche seepage ratio was not well defined. Various operating conditions and niche moisture conditions may contribute to the fluctuations observed in the early time data. The execution of long-duration tests to ensure quasi-steady conditions contributed to the robustness of seepage quantification at selected borehole intervals. 


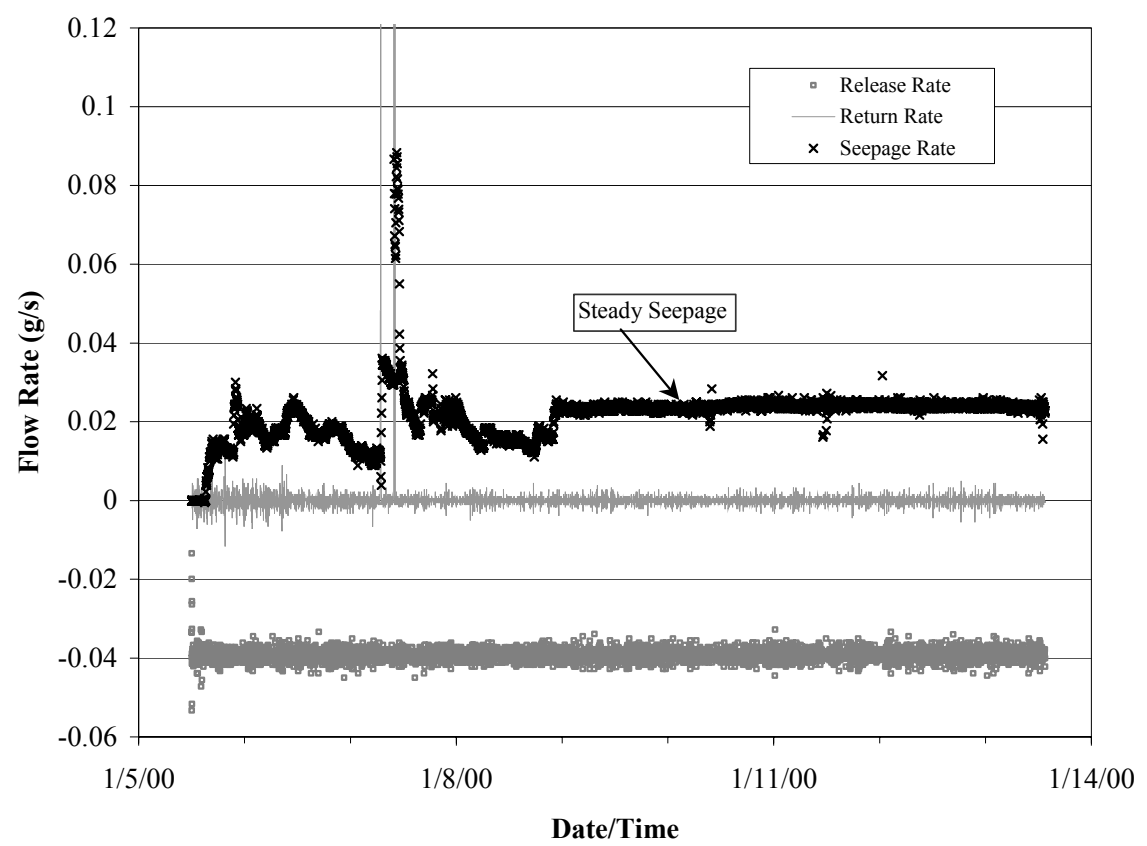

Source: DTN: LB0010NICH4LIQ.001 [DIRS 153145]: native data file Niche 4788 UR 5.18-5.48m 1-5-2000.csv, data report S00429_007.

Figure 6-29. Stabilized Flow Rates Observed during Test \#1 1-5-00 Conducted on Test Interval UR at Niche 4 (Niche 4788)

\subsection{Niche 4 (Niche 4788) Wetting-Area Data}

In this section, an example of niche wetting-area data from a seepage test run in Niche 4 (Niche 4788) is discussed. The progression of the wetting fronts along the niche ceiling with time was recorded on videotape, and still images from the videos were captured and digitized. Wetting fronts were traced from these captured still images; they were later adjusted by reference to marked grid points and other features on the niche crown, and to sketches made during the tests, to correct for distortion caused by the oblique camera view of the niche crown. They were then superimposed over corresponding areas of a fracture map of the niche crown (Trautz 2001 [DIRS 156903], pp. 57-62).

Figure 6-30 shows the wetting-front sequence for a seepage test begun June 26, 2000, with water released from the interval $7.62-7.93 \mathrm{~m}$ from the collar of Borehole UL. The release rate at the borehole interval was $0.02 \mathrm{~g} / \mathrm{s}$, and the seepage into the niche corresponded to 14 percent of the water released.

Several observations can be made from Figure 6-30. The influence of fractures on the shape and orientation of the wet spot appears to be relatively minor in the June 26, 2000, test. The initial wetting fronts in these tests are displaced laterally from the vertical projections (the shortest paths) of the release intervals onto the crown, and the wetting fronts overall are not symmetrical about those projections. Note that the niche ceiling is uneven and slightly curved. A borehole partly cut by the niche crown may have affected the lateral spreading of the wetting front. 
Figure 6-31 shows the wetting-front growth with time for the seepage test. Each data point corresponds to one of the numbered contours in Figure 6-30. The x-axis refers to time elapsed since the first wet spot appeared on the crown, rather than from the first release of water.

The plot in Figure 6-32 pertains to the shape progression of the wet spot. If the two-dimensional (2-D) shape of a front remained constant as it grew, with subsequent fronts expanding uniformly and maintaining shape similarity between them, the slope of its line in Figure 6-32 would be constant. This is nearly the case through the early part of the test, with somewhat greater irregularity seen after the eight or ninth front (or data point). The average value of the slope for this test is approximately 0.25 , somewhat less than the 0.28 slope, which would apply for a circle; this reflects the slightly elongated wetting fronts observed for this test.

The conclusions reached through this testing are:

1. There is either no correlation or only a weak correlation between fracture characteristics and the shape, extent, and orientation of the wet area developing at a niche or drift ceiling,

2. Drip locations are likely to be determined by the topography of the ceiling rather than fracture patterns, and

3. The area available for evaporation of potential seepage water is significantly larger than the area of the fractures intersected by the drift.

\subsection{Niche 5 (Niche CD 1620) Slot and Seepage-Threshold Tests}

The specific test plan for this series of tests is Niche 5 Seepage Testing, SITP-02-UZ-002 (BSC 2001 [DIRS 158200]). The objectives for the Niche 5 (Niche CD 1620) seepage tests are the same as for the other niche seepage tests. Niche 5 (Niche CD 1620) is in the lower lithophysal (Tptpll) unit; the first four niches are in the middle nonlithophysal (Tptpmn) unit. More automation was employed in the Niche 5 (Niche CD 1620) tests than was employed in the testing at the other niches.

\subsection{Background Information}

The study site is located at cross-drift construction station (CD) 16+20 near the center of the ECRB and the repository block shown in Figure 6-3, and is known as Niche 5 or Niche CD 1620. The site was selected because it is located near the center of the repository block within the lower lithophysal zone (Tptpll) of the Topopah Spring welded tuff (TSw). Approximately 80 percent of the repository would be constructed within the Tptpll zone, as described in Section 1.2. Thus, characterization of seepage into waste emplacement drifts constructed in this zone is important to the performance and design of natural and engineered barriers. 


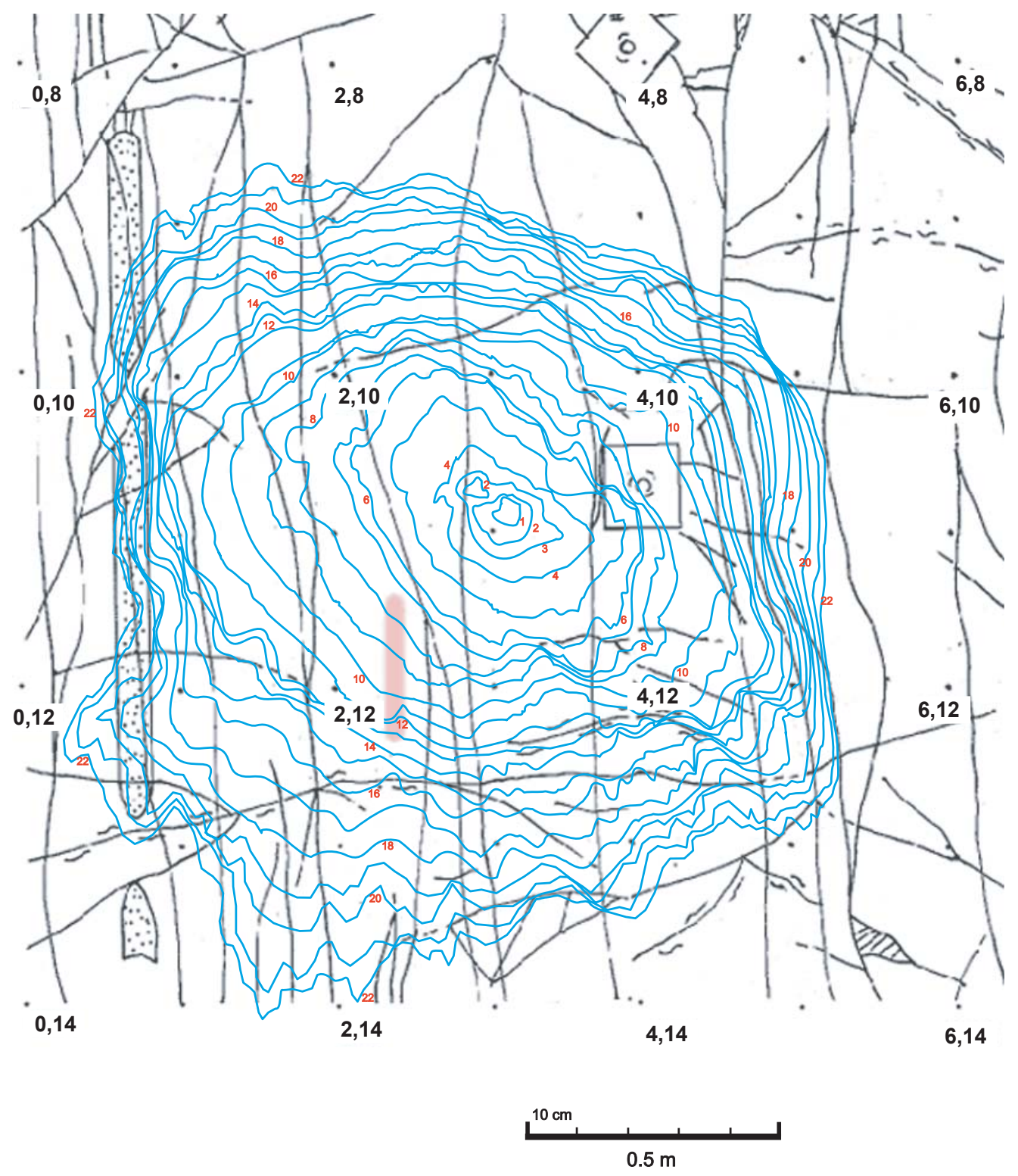

Map symbols:

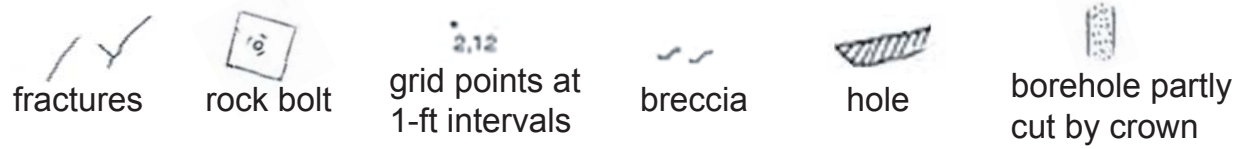

Output DTN: LB0110NICH4LIQ.001.

NOTES: Blue contours are outlines of wetting fronts. Numbers along wetting fronts correlate with the order of data points in Figure 6-31, and the time corresponding to each front can be determined from that figure. Pink bars indicate approximate positions of release intervals in boreholes above the niche, projected onto the crown.

Figure 6-30. Wetting-Front Sequences Overlying Fracture Map of Niche 4 (Niche 4788) Ceiling from Seepage Test Begun June 26, 2000 


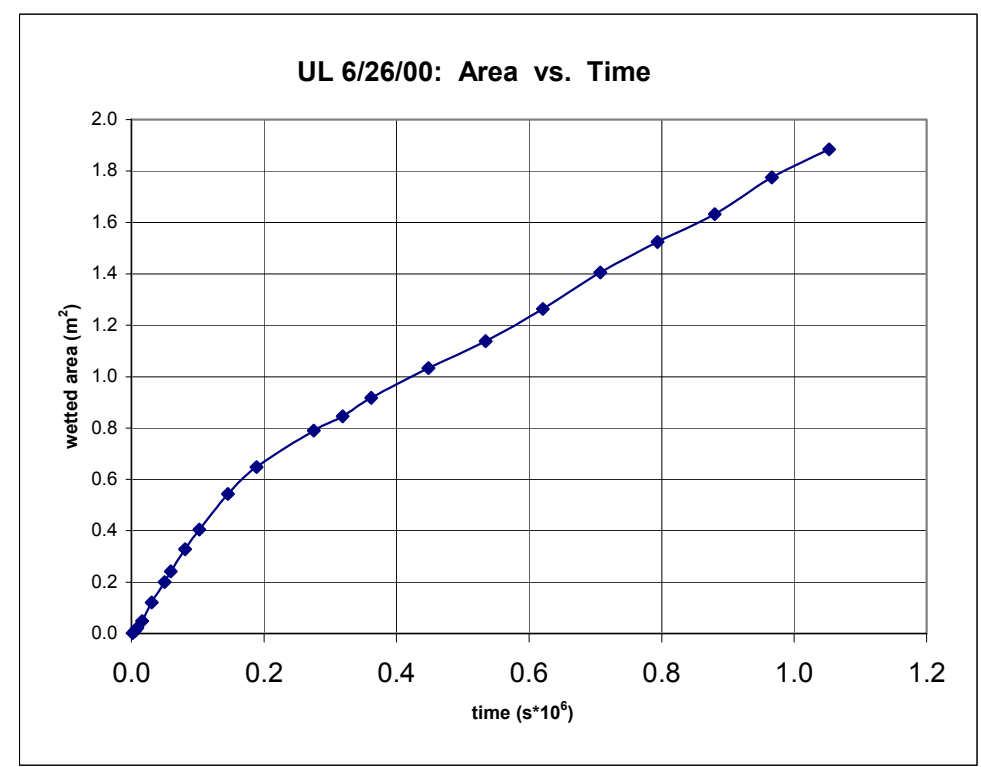

Output DTN: LB0110NICH4LIQ.001.

NOTE: Each plotted point represents data for one of the numbered curves shown in Figure 6-30.

Figure 6-31. Wetting-Front Area $\left(\mathrm{m}^{2}\right)$ versus Time (s) for the Seepage Test Shown in Figure 6-30

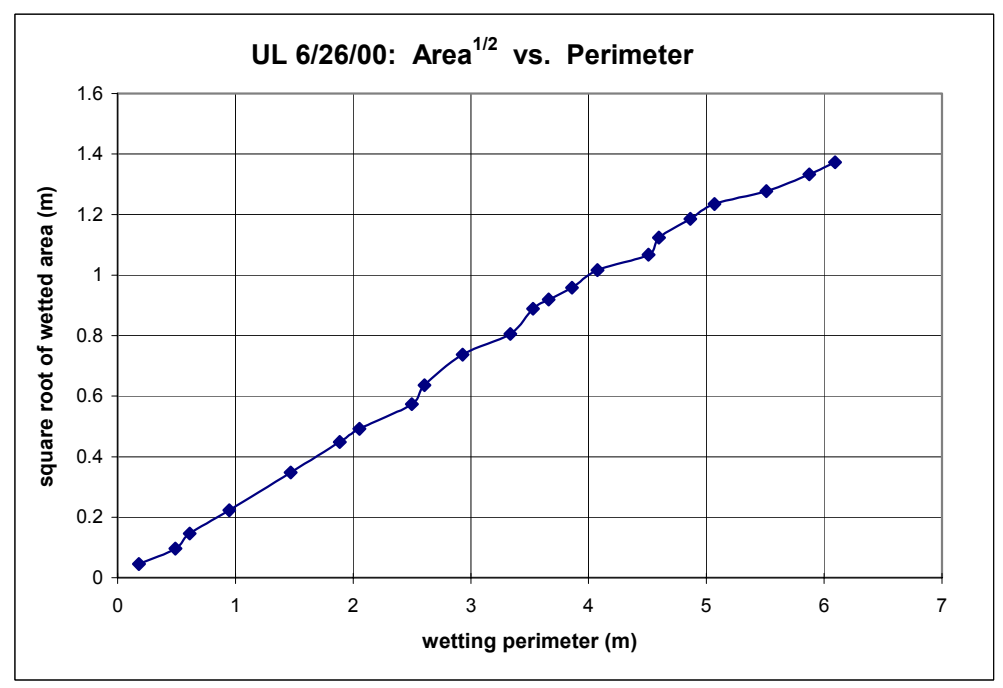

Output DTN: LB0110NICH4LIQ.001.

NOTE: Data points correspond to those in Figure 6-31.

Figure 6-32. Square Root of Area $(m)$ Plotted versus Perimeter $(m)$ for Each of the Wetting Fronts in the Niche 4 (Niche 4788) Seepage Test 
The Tptpll contains large naturally occurring cavities (referred to as lithophysal cavities or lithophysae) that are attributed to gas and vapor-phase constituents entrapped and redistributed during the initial deposition, compaction, and gas migration out of the TSw (Buesch and Spengle 1998 [DIRS 101433], p. 21). Lithophysal cavities are quite large at the site, with some in the range of 0.5 to $0.75 \mathrm{~m}$ in length and 0.2 to $0.3 \mathrm{~m}$ in height. Fractures are also present, but the majority of these appear to be cooling features associated with lithophysal cavities. These fractures primarily form halos or rinds around the cavities. Very few through-going fractures of significant length were mapped. However, given the high permeability of the rock observed at Niche 5 (Niche CD 1620) and reported in Section 6.1.2.2.1, the fracture rinds and lithophysal cavities do not appear to be dead-end features. Rather, short fractures appear to link the cavities and rinds, giving the entire network a larger average permeability than was observed in the densely welded, middle nonlithophysal zone (Tptpmn) of the TSw, where fractures dominate and lithophysal cavities are sparse.

As noted in Section 6.2.1.1, liquid-release tests were performed at Niche 5 (Niche CD 1620) in April 2000, before the construction of the access drift and niche in May 2000. Bulkhead doors were installed across the entrance to the excavation and sealed immediately upon construction to minimize evaporation and drying of the rock surrounding the drift. An initial post-excavation seepage test, performed in late February 2001, ended approximately 39 days later in April 2001. Water did not seep, nor did the wetting front appear at the niche ceiling during this test after releasing approximately $300 \mathrm{~L}$ of water. (Data are not provided for this test because, with the exception of observing that no seepage was observed after releasing a large volume of water, they are inconsequential.) This test showed that the Tptpll had a high storage capacity (because of the large lithophysal cavities) or was able to divert large quantities of water laterally around the drift through preferential flow paths not connected directly to the opening.

The lack of seepage into the niche and the failure of the wetting front to appear at the niche ceiling during the initial test prompted significant changes to the objectives of the seepage-testing program planned for Niche 5 (Niche CD 1620). Two slots were constructed in the sidewall of the original niche to accomplish the following objectives, supplementing those described in Section 6.2:

- Demonstrate that the capillary barrier moves water laterally around the opening to the walls of the niche, where it would collect in the slot.

- Provide a water mass balance. The mass balance was intended to show that the flow field had reached steady state by demonstrating that the amount of water released to the formation was balanced by the amount of water recovered as seepage from the niche ceiling and slot, plus the unrecovered amount of water lost to evaporation as the wetting front spread across the niche ceiling.

The sections that follow describe the test configuration, operation, and equipment used to address these objectives and provide representative test results showing the type of data collected. 


\subsection{Description of Post-Excavation Seepage Tests}

\section{Test Configuration}

Seven 15- to 17-m-long boreholes were drilled in January 2000 at the Niche 5 (Niche CD 1620) site (shown in Figures 6-33 through 6-35) before niche construction. (The same seven boreholes are also described in Section 6.1.1.2 with different borehole names, with the following corresponding borehole designations: Borehole $1=$ Borehole B1.75; Borehole $2=$ Borehole ML; Borehole 3 = Borehole NM; Borehole $4=$ Borehole MR; Borehole 5 = Borehole UL; Borehole $6=$ Borehole UM; and Borehole $7=$ Borehole UR. Boreholes will be referred to hereafter by number only [e.g., Borehole 7] and not by their full designation [e.g., ECRB-Niche1620\#7].) Each borehole is nominally $0.0762 \mathrm{~m}$ (3 inches) in diameter, with the exception of Borehole 7, which was mistakenly drilled to a nominal diameter of $0.1016 \mathrm{~m}$ (4 inches) using a larger-diameter core bit. Post-excavation seepage tests were not performed on Borehole 7, because the straddle packer system used to isolate the injection zone was not designed to fit the larger-diameter borehole.

The first borehole (Borehole 1) was installed at the approximate position shown in Figure 6-33 through Figure 6-35. Dye-spiked water was released into eight 0.3-m-long test intervals within this borehole before niche construction, as noted in Section 6.2.1.1. The position of the dye within the rock was then photographed and mapped during niche excavation, and Borehole 1 was intentionally removed during the mining process described in Section 6.2.1.2. A set of three boreholes (designated Borehole 2, Borehole 3, and Borehole 4) were drilled parallel to the axis of the niche in the same horizontal plane, located approximately 1.0 to $1.3 \mathrm{~m}$ above the opening of the niche. These boreholes are collectively referred to as the horizontal boreholes. The horizontal boreholes are spaced approximately $1 \mathrm{~m}$ apart.

A second set of three boreholes (designated Borehole 5, Borehole 6, and Borehole 7) was drilled directly above the horizontal boreholes, at a $6^{\circ}$ to $8^{\circ}$ upward inclined angle (based on as-built data in MO0312GSC03176.000 [DIRS 169532], approximately $1^{\circ}$ higher than the design angle in Figure 6-33). These boreholes are collectively referred to as the inclined boreholes. The collar of the inclined boreholes is located within 0.4 to $0.5 \mathrm{~m}$ of the horizontal boreholes. The upper boreholes are inclined so that the distance between the boreholes and the niche ceiling varies from approximately $1.4 \mathrm{~m}$ to $3.0 \mathrm{~m}$. In combination with the horizontal boreholes, the scale of the post-excavation seepage tests can vary from 1.0 to $3.0 \mathrm{~m}$, the latter measurement being slightly larger than the radius of the niche. 


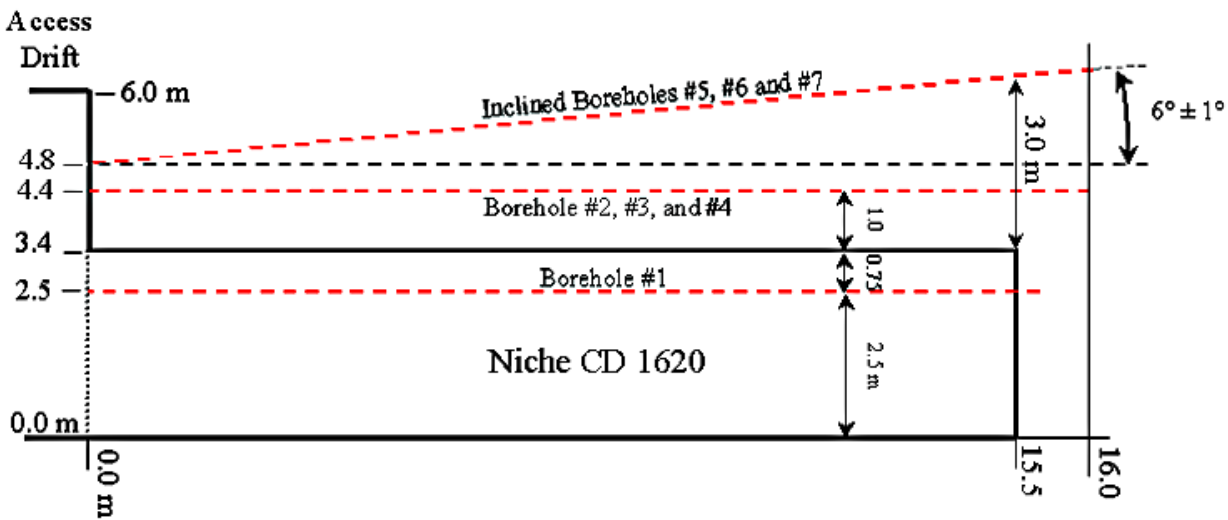

Source: Test Plan for: Niche 5 Seepage Testing (BSC 2001 [DIRS 158200], Figure 2).

Figure 6-33. Side View of the Boreholes at Niche 5 (Niche CD 1620)

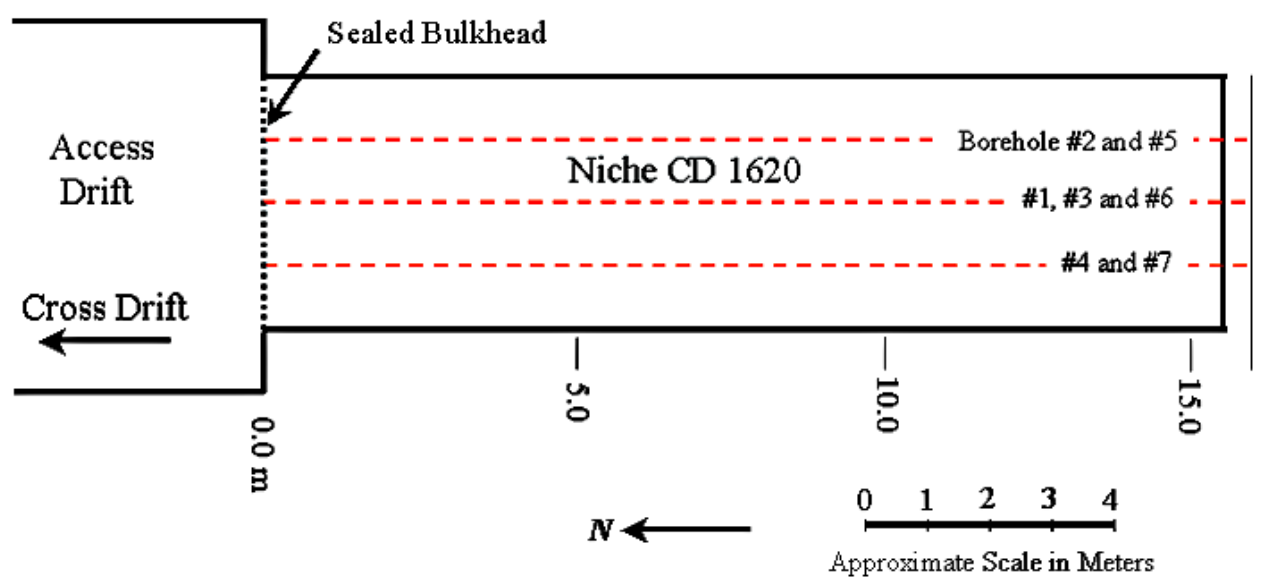

Source: Test Plan for: Niche 5 Seepage Testing (BSC 2001 [DIRS 158200], Figure 3).

Figure 6-34. Plan View of the Boreholes at Niche 5 (Niche CD 1620)

In May 2000, a mechanical excavator was used to mine out the rock to create Niche 5 (Niche CD 1620). The niche is approximately $15.5 \mathrm{~m}$ long by $4 \mathrm{~m}$ wide by $3.3 \mathrm{~m}$ high (Figure 6-33 through Figure 6-35). Niche 5 (Niche CD 1620) was constructed along the south side of the cross-drift (at the location shown in Figure 6-3) within the lower lithophysal zone of the TSw unit (Tptpll). Water was used during niche construction to suppress dust generated during mining activities. Split-set rock bolts were installed in the ceiling of the niche immediately following construction to provide ground support for the excavation.

In May 2001, construction began on two slots located in the sidewalls of the niche as shown in Figure 6-35 (the slots are also referred to as "bat wings"). The original intent was to construct a 6-m-long-by-1-m-high-by-1.5-m-deep slot in each wall of the niche to aid in the collection of water. The slot design was based on the premise that, because of the capillary barrier, water would move laterally around the opening, where it would collect at a low spot and drip into the slot (near Points A in Figure 6-35). The initial design was to slope the ceiling of the slot back toward the niche to produce a low point for water to collect and by creating a capillary barrier, to prevent water from flowing around the backside of the slot. 


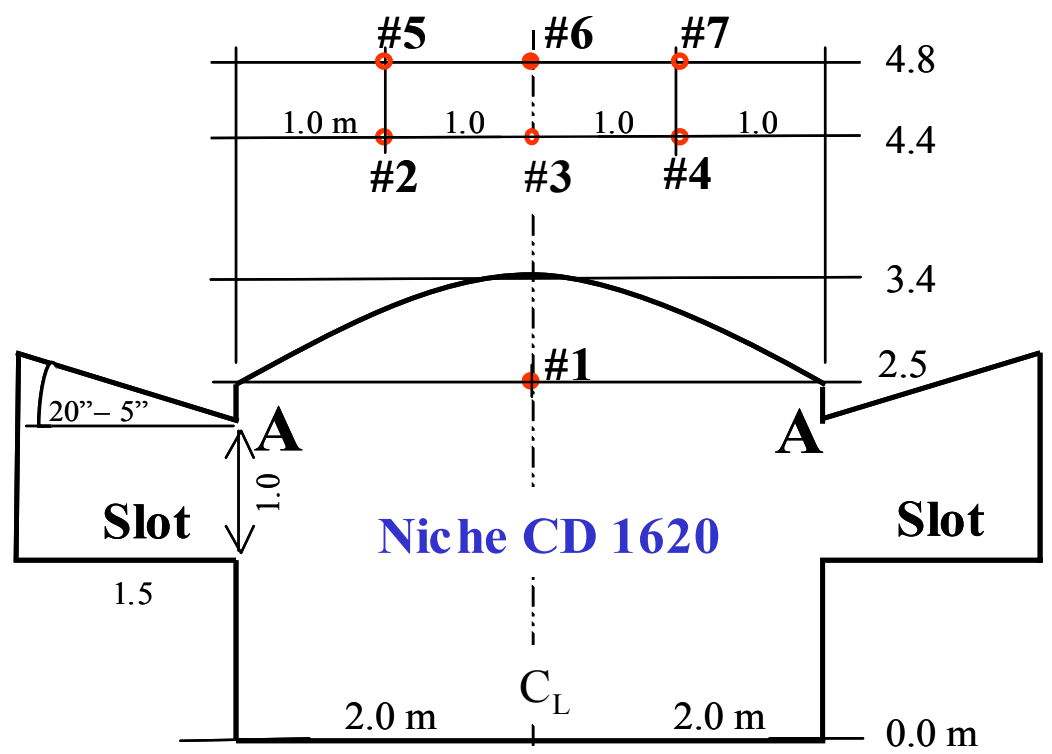

Source: Test Plan for: Niche 5 Seepage Testing (BSC 2001 [DIRS 158200], Figure 4).

Figure 6-35. Schematic Illustration of Front View of Niche 5 (Niche CD 1620) Facing South, Showing Location of Boreholes (\#1-\#7)

Additional ground support consisting of Williams' rock bolts was installed in the ceiling of the niche before slot construction, to help stabilize the underground opening. These bolts supplemented the split-set rock bolts already in place, effectively doubling the number of bolts and decreasing the rock bolt spacing to approximately $0.5 \mathrm{~m}$. Even with additional ground support, the unstable rock conditions at Niche 5 (Niche CD 1620) caused sections of the initial slot ceiling (Points A) to collapse during its construction, resulting in an excavation that did not meet the desired construction and testing specifications. Slot construction activities were halted after creating a 3.3-m-long irregular-shaped excavation in the left rib and a short (less than $1 \mathrm{~m}$ ) excavation in the right rib of the niche. Improvements to the 3.3-m-long slot were made after construction by installing a wooden header and post system to support the brow of the slot excavation (i.e., near Point A on the left), keeping it from collapsing further (Figure 6-36 through Figure 6-38). The rock behind the header was then chipped away by hand to create the best sloping ceiling possible, given the circumstances. Additional ground support, consisting of metal house jacks, was provided farther back in the slot to provide more stability.

Figure 6-36 shows the final size and shape of the slots. Note that there are five profiles (numbered 2 through 6) in Figure 6-36, showing the irregular shape of the longest slot. Profile 2 and Profile 6 define the lateral ends of the slot. The remaining profiles (3-5) are located between the two lateral ends with a distance of approximately 0.5 to $1.3 \mathrm{~m}$ separating the profiles and numbered sequentially. For additional detail on the slot profiles, refer to the surveyor drawing (DTN: MO0107GSC01061.000 [DIRS 155369]) provided in Appendix Section C1. 


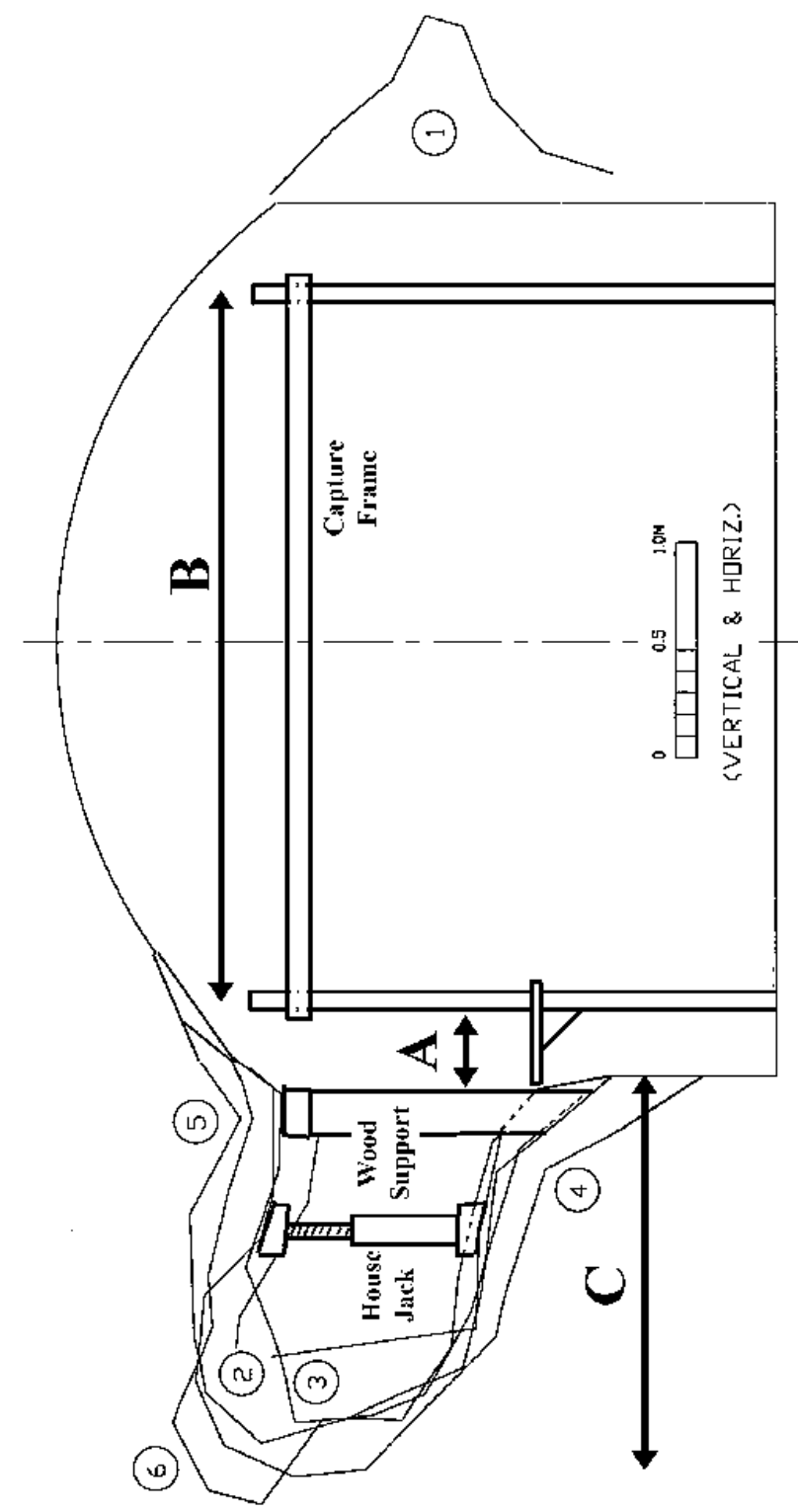

NOTE: Profile \#2 is located closest to the niche entrance and \# 6 is farthest away, based on DTN: MO0107GSC01061.000 [DIRS 155369].

Figure 6-36. Schematic Illustration of Front View of Niche 5 (Niche CD 1620) Facing South Showing Profiles 1-6 


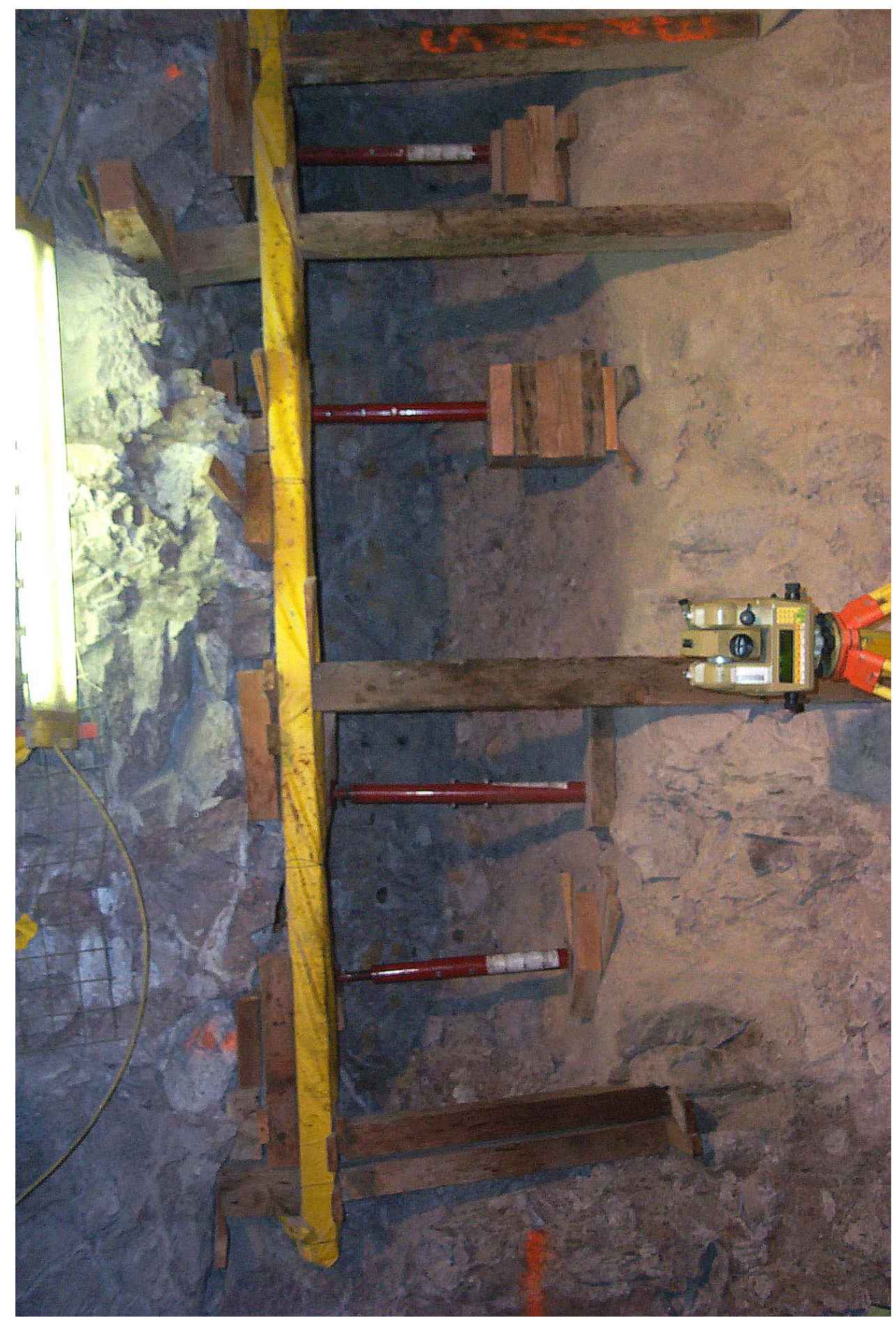

Source: DTN: LB0211NICH5LIQ.001 [DIRS 160792].

Figure 6-37. Photograph of Left (East) Rib of Niche 5 (Niche CD 1620) Facing the Opening of a 3.3-m-Long Slot and Showing Ground Support 


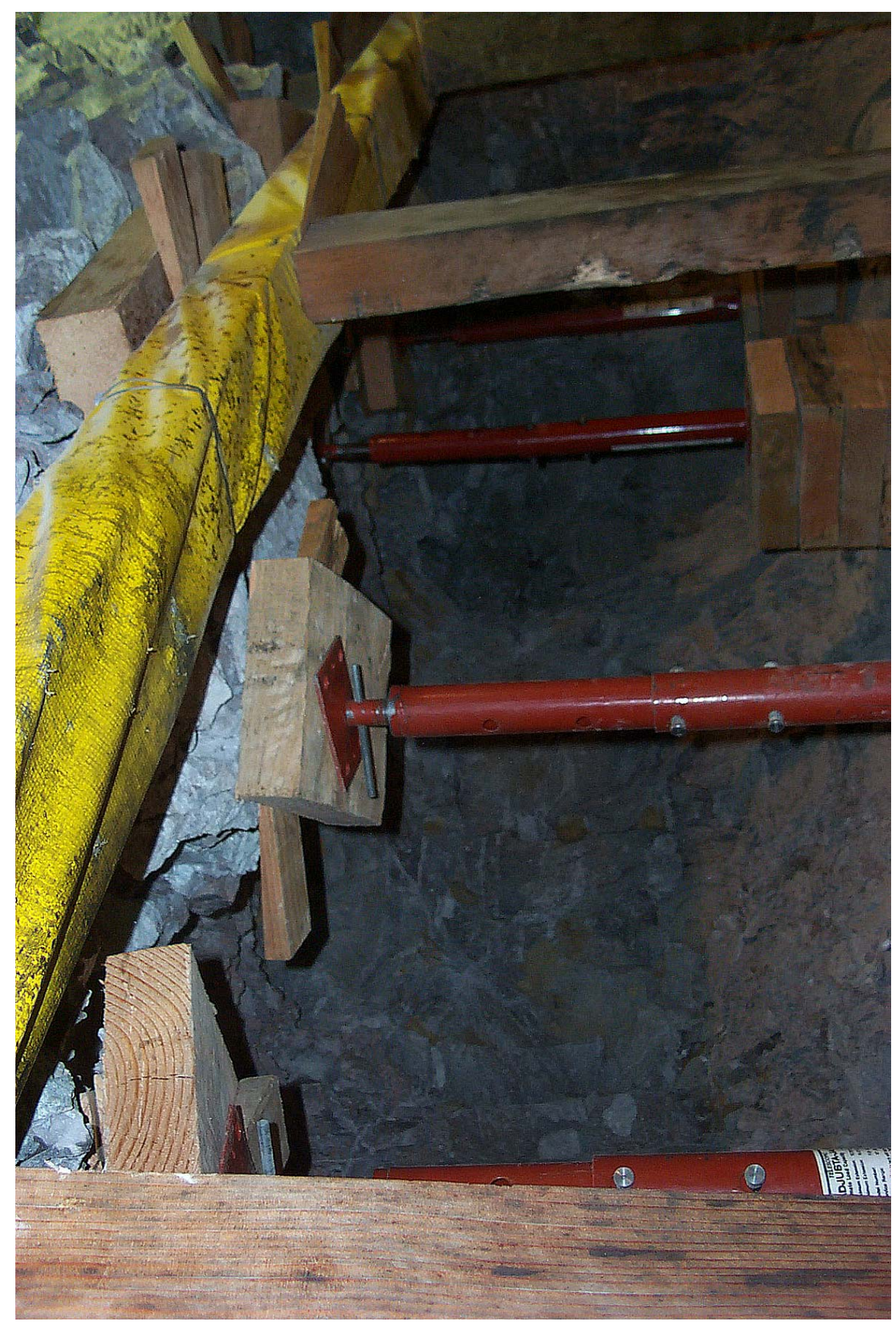

Source: DTN: LB0211NICH5LIQ.001 [DIRS 160792].

Figure 6-38. Photograph of Left (East) Rib of Niche 5 (Niche CD 1620) Showing Ceiling of Slot and Ground Support 
The pilot hole from one of the rock bolts struck two test boreholes, Boreholes 2 and 5. A rock bolt was subsequently installed in the pilot hole, blocking both test boreholes at a depth of $5.6 \mathrm{~m}$ from their collars, rendering the remaining $10 \mathrm{~m}$ of each borehole inaccessible. The rock bolts were subsequently removed by cutting through them laterally from within the test boreholes. This improved the depth available for testing from 5.6 to $7.9 \mathrm{~m}$ in Borehole 2 and from 5.6 to $10 \mathrm{~m}$ in Borehole 5. A straddle-packer assembly also became stuck in Borehole 4 when air-injection tests were conducted on this borehole. Numerous attempts to recover the packer were unsuccessful.

Unstable ground conditions, resulting in loose rock and debris sloughing off the walls of lithophysal cavities intersecting the boreholes, also contributed to several "natural" borehole blockages. The boreholes were vacuumed out to remove as much debris as possible before testing began. Borehole 3, Borehole 4, and Borehole 6 were blocked at approximately $12.0 \mathrm{~m}$, $9.0 \mathrm{~m}$, and $10.5 \mathrm{~m}$, respectively, by large rocks and debris that could not be extracted during the cleaning process. Table 6-7 summarizes the total depth and length of boreholes available for testing.

Table 6-7. Borehole Depth Summary

\begin{tabular}{|c|c|c|}
\hline $\begin{array}{l}\text { Borehole } \\
\text { Designation }\end{array}$ & $\begin{array}{l}\text { Available for } \\
\text { Testing (m) }\end{array}$ & $\begin{array}{c}\text { Total } \\
\text { Depth (m) }\end{array}$ \\
\hline ECRB-Niche1620\#1 & $N / A^{a}$ & 15.4 \\
\hline ECRB-Niche1620\#2 & $0-7.9$ & 16.0 \\
\hline ECRB-Niche1620\#3 & $0-12.0$ & 15.5 \\
\hline ECRB-Niche1620\#4 & $0-9.0$ & 15.0 \\
\hline ECRB-Niche1620\#5 & $0-10.0$ & 15.9 \\
\hline ECRB-Niche1620\#6 & $0-10.5$ & 16.0 \\
\hline ECRB-Niche1620\#7 & $N / A^{b}$ & 14.8 \\
\hline
\end{tabular}

Source: BSC 2001 ([DIRS 158200] Table 1).

$\mathrm{N} / \mathrm{A}=$ Not available.

${ }^{a}$ Borehole intentionally excavated during niche construction.

${ }^{\mathrm{b}}$ Borehole diameter is too large and inconsistent with dimensions of test equipment.

\section{Test Operation and Control Equipment}

Custom-designed and built test equipment described in this section was used to operate and control the tests. In general, a seepage test is performed by pumping water at a known rate from a release reservoir sitting on an electronic balance through the release line, release manifold, and downhole straddle packer to the release or test interval located in the borehole (Figure 6-39). The straddle packer consists of a series of rubber glands that the test operator inflates with compressed air (in the same manner as is done with a balloon) inside the borehole. When inflated with air, the packers create a 0.3-m-long test interval, isolated from up and downhole sections of the borehole, thus preventing water from migrating throughout the length of the borehole during the experiment. 
In the event that the pumping rate exceeds the infiltration capacity of the rock, water may begin to pond in the borehole and pressurize the test interval. An outlet (also called the "return port") located in the test interval prevents this from occurring. Water may rise to the level of the return port where it will flow by gravity back through the return line, straddle packer, and return manifold, to the return reservoir, where it will accumulate and be weighed by the return balance. The overflow line limits the maximum ponding depth of water within the borehole to approximately $0.05 \mathrm{~m}$, thus preventing overpressurization of the test zone by the pump.

Water that enters the test interval percolates down through the rock, where it may eventually seep into the niche opening. A capture manifold referred to as seepage collection system is used to capture the water seeping into the niche and to route it to the capture reservoir, where it will accumulate and be weighed by the capture balance(s).

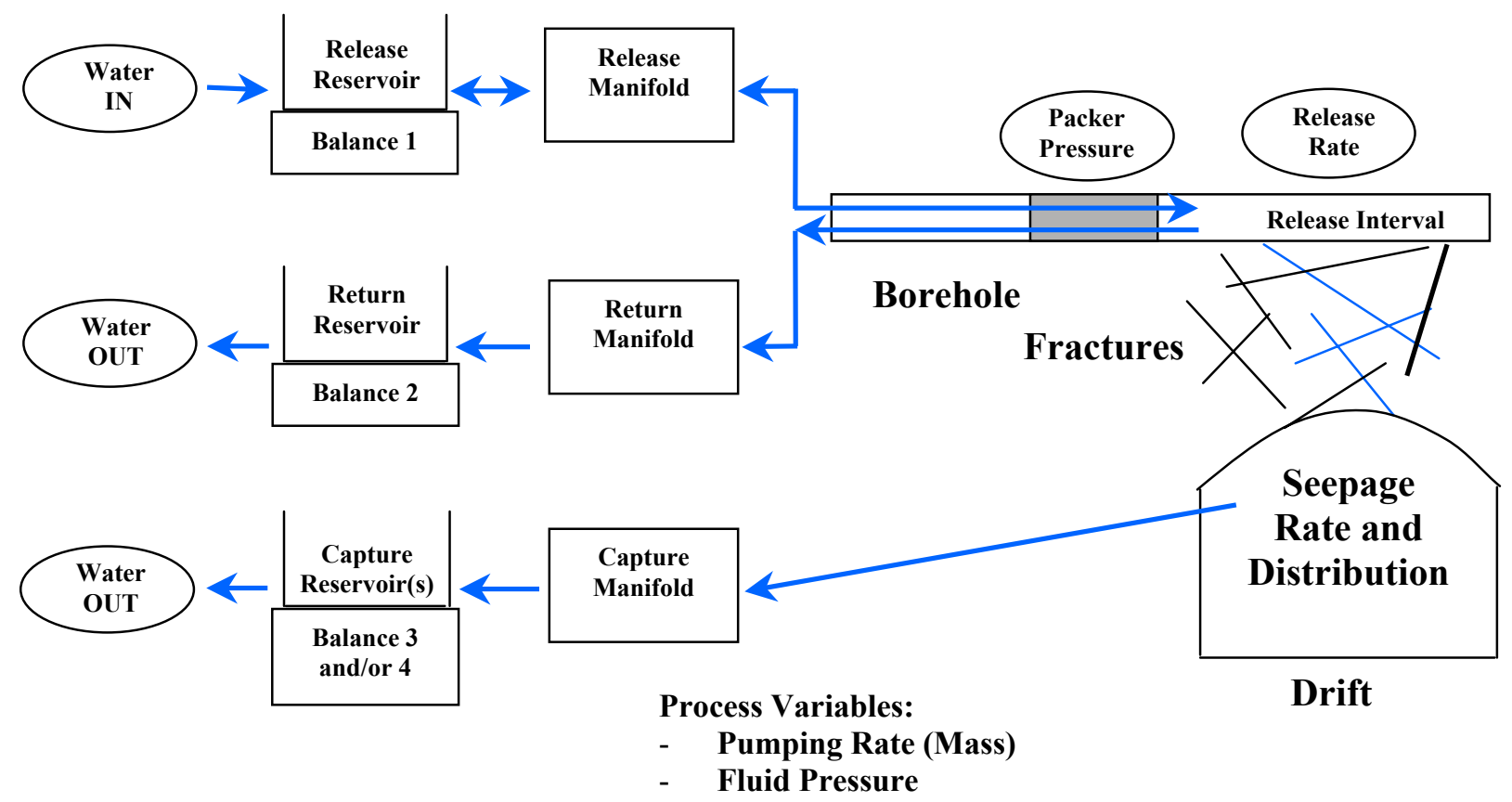

Figure 6-39. General Process Diagram for Seepage Testing at Niche 5 (Niche CD 1620)

Figure 6-39 provides a summary of the general processes that the test operator can change during a seepage test, including the release, return, and capture rates. The control variables are represented by ovals labeled in Figure 6-39. Control variables are affected by the process variables (e.g., pump speed, valve position) changed by the operator. Additional detail on the test operation and control equipment is provided in Appendix Section C2.

A plastic tarp was hung from the outside of the aluminum frame (shown in Figure 6-40 and Figure 6-41) to the wooden supports at the edge of the slot shown in Figure 6-36 through Figure 6-38 to collect water seeping into the slot. The outlet from the slot seepage collection system drained through a pinch valve (that could also be controlled by the operator) to the capture balance. 
Field personnel were not allowed to enter the slot, or hang the tarp off the wooden and steel ground support system inside the slot, because of health and safety issues concerning rock instability. This restriction prevented the entire slot area (with corresponding depth $\mathrm{C}$ shown in Figure 6-36) from being covered by the slot seepage collection system. The water diverted by the niche and flowing into the slot was not measured.

To meet, in part, the original objectives, a much smaller area (with corresponding depth A shown in Figure 6-36) was covered instead by the slot seepage collection system. The majority of the slot seepage collection system was not beneath the slot ceiling itself, but rather beneath the sharply curved section of the niche where the niche ceiling meets the wall. The flow along the wall and the portion of flow behind the wall in the proximity of the niche was captured in this remedial seepage collection configuration.

\section{Data Acquisition Equipment}

Calibrated instruments and data loggers were used to collect mass $(\mathrm{g})$, temperature $\left({ }^{\circ} \mathrm{C}\right)$, humidity (percent), and pressure (pounds per square inch gauge, psig) data during the tests.

Mettler Toledo model PG, PG-s, and SG series electronic balances were used to measure the mass that water was pumped into the test interval, that flowed back through the return line, and was captured as seepage. Initially, during the early stages of testing (May 3, 2002, through May 16, 2002), two Mettler Toledo balances were used to measure the seepage mass into the niche. Starting on May 16, 2002, only a single balance was used to measure these same data. Mettler Toledo balances were also set up inside and outside the niche to measure the rate of evaporation from an open pan of water sitting on the balance. The data acquisition control described in Appendix Section C3 was used to query the balance for the mass and to derive the mass rate on a user-defined time interval.

A calibrated Campbell Scientific, Inc. model CR10x datalogger was used to measure and record the measurements made by 12 calibrated Vaisala model HMP45C temperature and humidity probes located inside and outside the niche. Eleven of the probes were installed at various distances from the bulkhead to measure the air humidity and temperature distribution inside the niche. The twelfth sensor was installed outside the bulkheaded area of the niche to measure the temperature and humidity of the air in the ECRB; see Trautz (2003 [DIRS 166248], p. 162) for a detailed description of the probe locations.

The same calibrated Campbell datalogger was used to measure and record the measurements made by Setra model C204 pressure transducers (0-25 psig). The transducers were used to measure liquid pressures (air or water) inside the release and return lines leading to the test interval during the tests. These data were collected primarily for the purpose of monitoring and controlling the test equipment. 


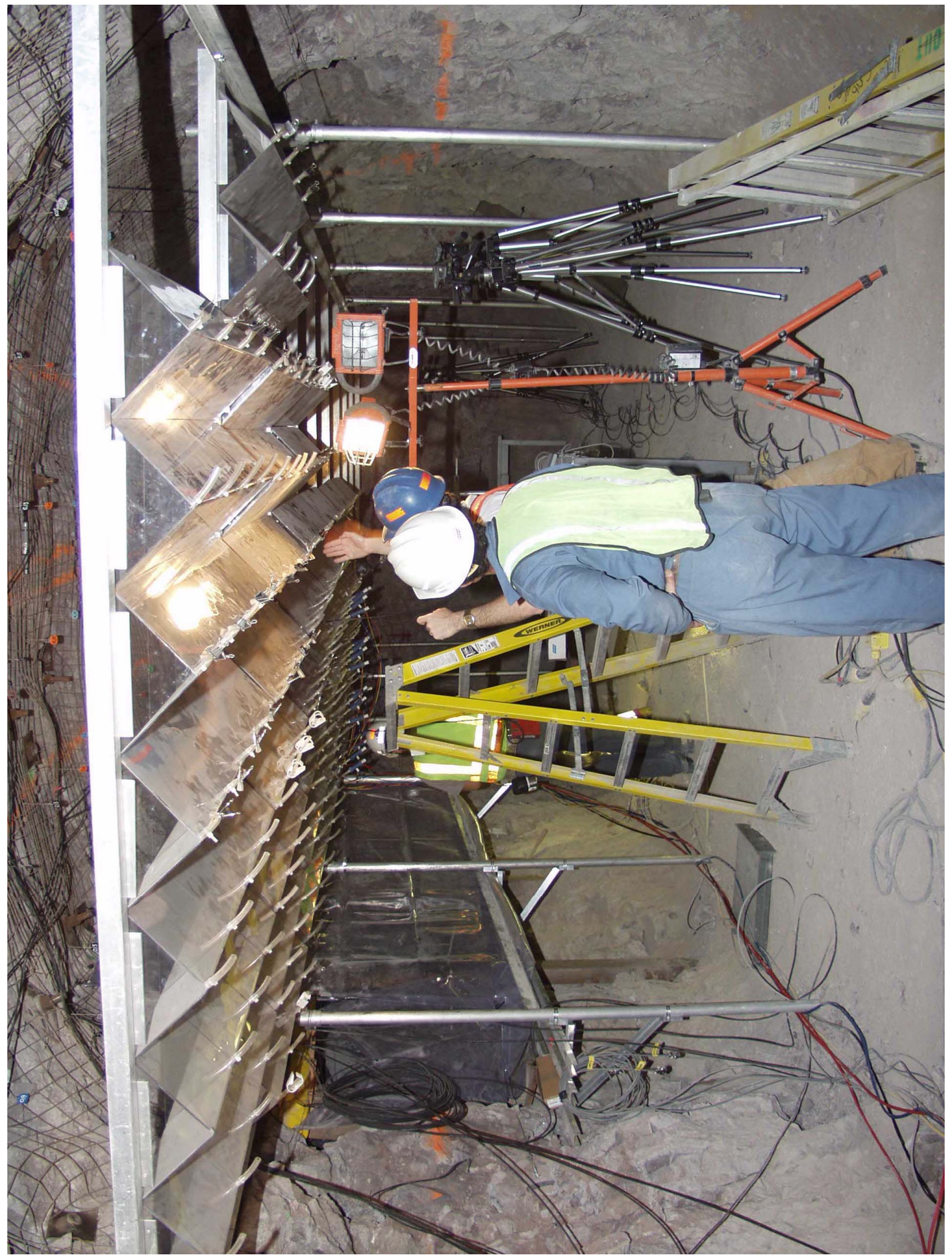

Source: DTN: LB0211NICH5LIQ.001 [DIRS 160792].

Figure 6-40. Capture System Installation Showing Plastic Capture Trays and Tarp in Slot 


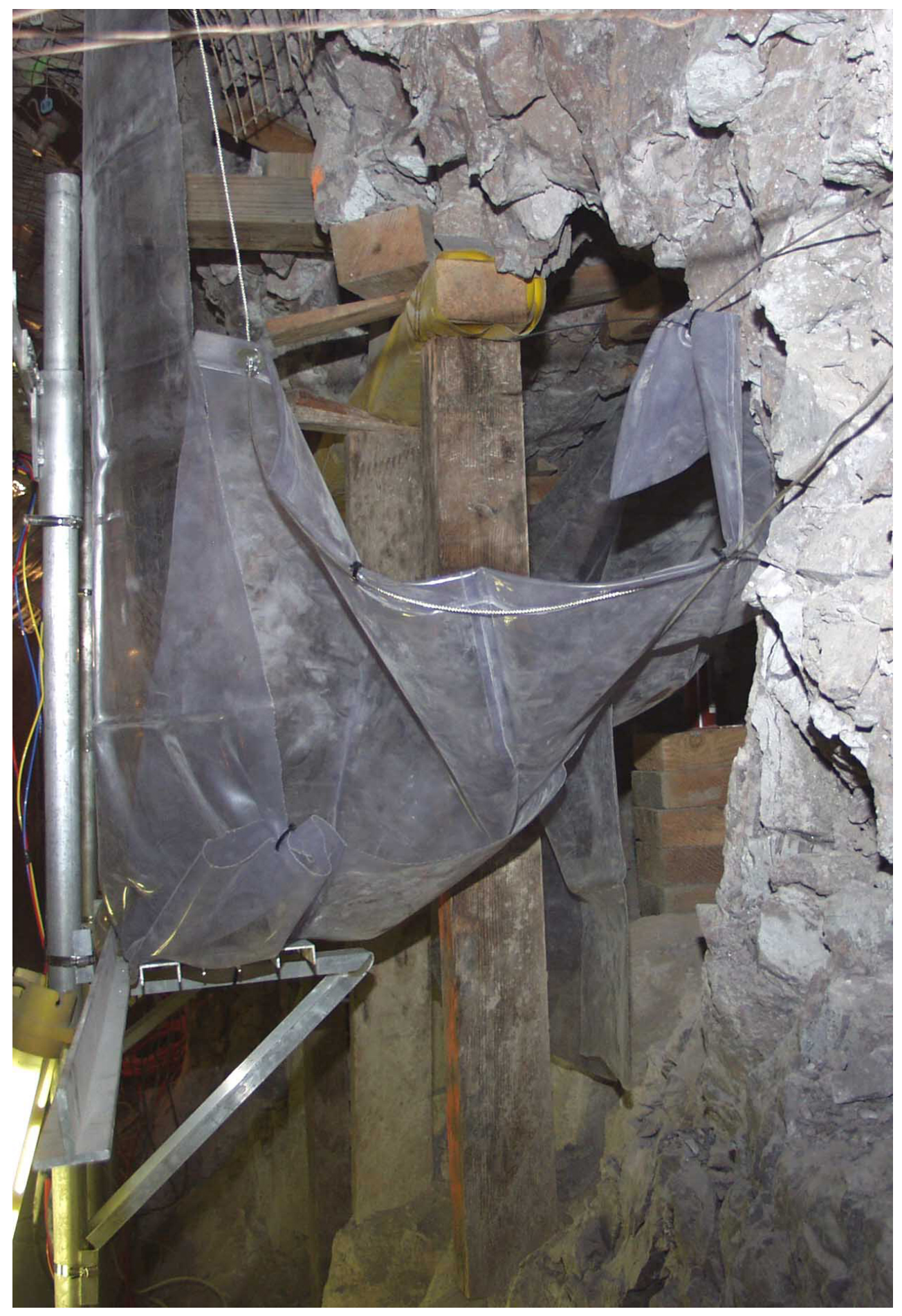

Source: DTN: LB0211NICH5LIQ.001 [DIRS 160792].

Figure 6-41. Capture System Showing Tarp Installed Next to Slot 
Time-lapse video recordings of the niche ceiling and bottom of the capture trays were made during the tests to record the spread of the wetting front across the ceiling and dripping into the capture system. Sony model DCR-TRV900 video camcorders (mini-DV format) were used for this purpose.

\section{Test Operating Conditions}

A seepage test was typically conducted by pumping water at a constant rate through an injection line into a $0.3-\mathrm{m}$-long isolated test interval, located in one of the boreholes described in Table 6-7. Electronic balances were used to monitor the cumulative mass at which water was pumped into the borehole, as well as return flow (if any occurred). Return flow occurred when the pumping rate exceeds the infiltration capacity of the rock.

Water migrating from the release point through the rock to the niche ceiling might drip into the niche, where it was collected in a capture system consisting of plastic trays and a tarp in the slot. Water drained by gravity through a network of tubes into a closed container, resting on an electronic balance. The balance was used to measure the cumulative mass of water that seeps into the niche and the seepage rate was determined by dividing the amounts accumulated by the time they took to collect. One or more containers and balances might be employed for collecting seepage water.

Evaporation of water from the containers, the capture system, and the wetted area of the niche ceiling during seepage tests can influence the outcome of the seepage experiments. The effects of evaporation on the test results were minimized by employing the following techniques:

1. The bulkhead door at the entrance to the niche was closed and sealed during the seepage tests. This helped limit the exchange of dry air in the ECRB (typically less than 40 percent relative humidity) with moist air found within the niche (typically greater than 85 percent relative humidity).

2. Access to the interior of the niche during testing was limited to authorized field-test personnel. Remote monitoring of the niche ceiling, and the capture trays, using digital video and remote monitoring of test equipment, minimized the number of trips inside the niche, thus limiting the exchange of air.

3. Fluid containers and transmission lines were closed systems, minimizing the effect of evaporation.

4. The potential existed for water to evaporate from the niche ceiling and diffuse into the air within the niche. Seepage water may have potentially evaporated from the capture trays before the water had time to accumulate and drain into the tubing connecting the trays to the closed container on the seepage balance(s). Therefore, the relative humidity of the air inside the niche was artificially elevated to minimize evaporation, using a centrifugal-type humidifier capable of producing water vapor at a rate of approximately $1 \mathrm{~kg}$ per hour. Humidification occurred 24 hours per day, 7 days a week, under the condition that electrical power was available to operate the humidifier. 
5. Electrical lighting within the niche was minimized to limit sources of heat that enhance evaporation. Sufficient lighting was provided, however, for video imaging of the wetted area spreading across the niche ceiling.

6. A small pan, resting on an electronic balance, was set inside the drift to directly measure the mass evaporative flux.

\subsection{Test Summary}

This section provides an overview of the seepage tests performed at Niche 5 (Niche CD 1620) and summarizes the type of data collected by evaluating and interpreting data for Test \#2 9-17-02 conducted from September 17, 2002, through October 28, 2002. The analysis of the Niche 5 (Niche CD 1620) seepage test data (together with analyses of other niche seepage data) for model calibration can be found in the model report, Seepage Calibration Model and Seepage Testing Data (BSC 2004 [DIRS 171764]).

Appendix Section C4 summarizes general test information, including borehole number, depth of the test interval measured in meters from the datum near the borehole collar, test name, and test start and end dates. Seepage tests, initiated at Niche 5 (Niche CD 1620) in early May 2002, ran through late May 2002, when the instruments and sensors were removed for routine calibration. Testing resumed in mid-July 2002, upon reinstalling the calibrated instruments, and continued through late October 2002 with seven tests performed over this period.

\section{Evaporation Pan Data}

Evaporation pan data were measured using a single balance loaded with a container filled with water. Figure 6-42 shows the evaporation flux inside and outside the niche during Test \#2 9-17-02. The plot indicates that the average evaporation flux outside of the niche is approximately a factor of 20 greater than the average evaporation flux inside the niche. (Note that the evaporation data collected during the study and found in the original data files are the evaporation rates $[\mathrm{g} / \mathrm{s}]$. These were converted to evaporation fluxes $\left[\mathrm{g} / \mathrm{s}-\mathrm{m}^{2}\right]$ shown in Figure 6-42 by dividing the evaporation rate by the surface area of the evaporation pan [i.e., $\pi r^{2}$, where $r$ is the radius of the pan].) The radius of the evaporation pan inside the niche was $0.075 \mathrm{~m}$ (0.15-m diameter reported by Trautz (2003 [DIRS 166248], p. 187) divided by 2) and the pan outside the niche was $0.122 \mathrm{~m}$ ( $95 / 8 \mathrm{in}$. diameter reported by Trautz (2003 [DIRS 166248], p. 187), converted as follows to radius $r$ in meters $(95 / 8$ in. $\times 2.54 \mathrm{~cm} / \mathrm{in}$. $\times 1 / 100 \mathrm{~m} / \mathrm{cm}$ ) divided by 2). Details of this calculation may be found in Appendix Section I6.1.

The peak evaporation rates associated with the saw-tooth pattern, observed in the evaporation pan data collected outside the niche, correspond to refilling the evaporation container with fresh warm water from the water supply of the mine. Warm water evaporates faster until it cools down. 


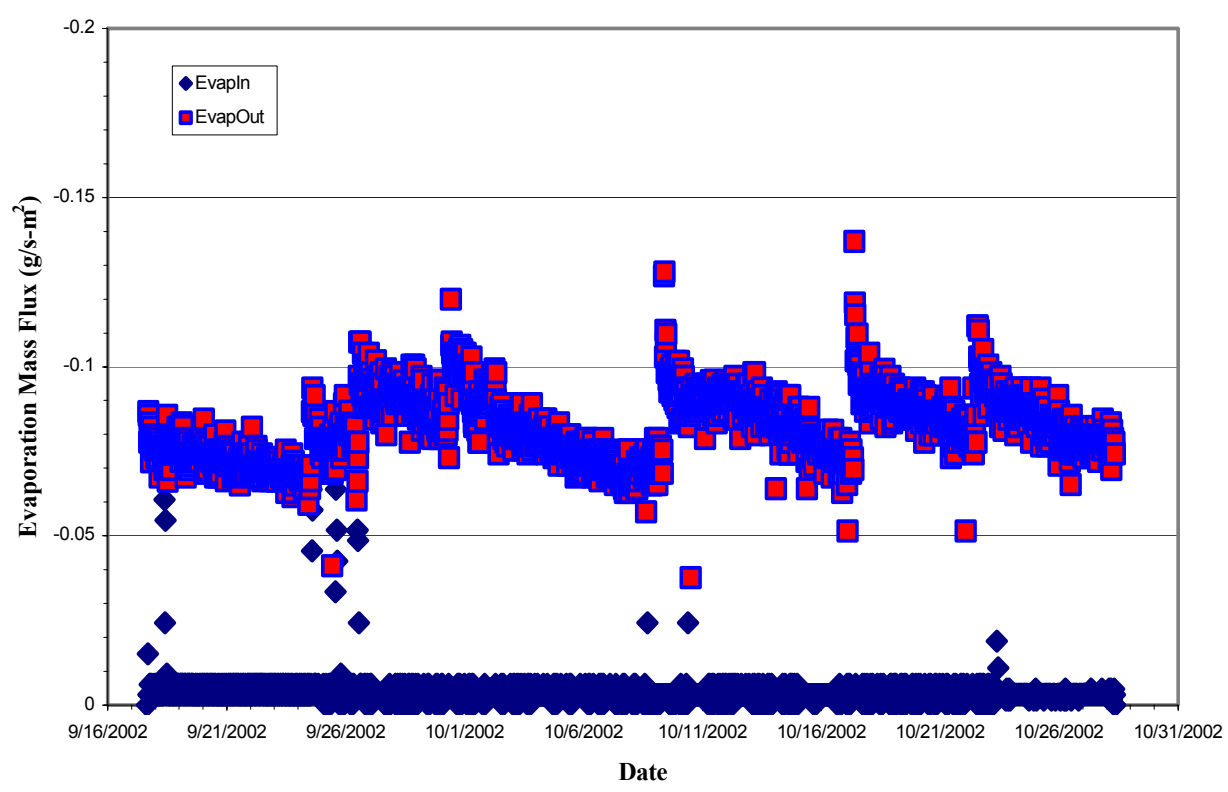

Source: DTN: LB0211NICH5LIQ.001 [DIRS 160792] Test \#2 9-17-02: native data files Tes\#1_BH\#4_10-11_ft_9-17-02_\#1.csv and Test\#2_b5_20-21_ft_9-17-02_\#1.csv.

Figure 6-42. Evaporation Rate Inside and Outside Niche 5 (Niche CD 1620) During Test \#2 9-17-02

\section{Relative Humidity and Temperature}

The data files that contain relative humidity and temperature data from measurements taken inside and outside the niche, and the liquid pressure data measured in the release and return lines during the test, are identified in Appendix Section C4. (The pressure in the release and return lines were relatively constant during a given test and, therefore, no further discussion of these results is included in this report.) These data were collected using the sensors and Campbell Scientific, Inc., dataloggers described in Appendix Section C3.

Figure 6-43 shows the relative humidity and temperature of the air inside and outside the niche during Test \#2 9-17-02 (September 17, 2002, to October 28, 2002). The relative humidity and temperature inside the niche were very stable, within the range of approximately 90 to 94 percent and $24^{\circ} \mathrm{C}$ to $25^{\circ} \mathrm{C}$, respectively. The sudden drop in relative humidity observed in mid- and late-September was caused by the exchange of cool moist air inside the drift with dry warm air outside the niche when field personnel opened the bulkhead and entered the niche. A slight rise in inside air temperature is noted over the measurement period. This is probably caused by the cooler inside temperatures slowly equilibrating with the warming temperature outside the niche. 


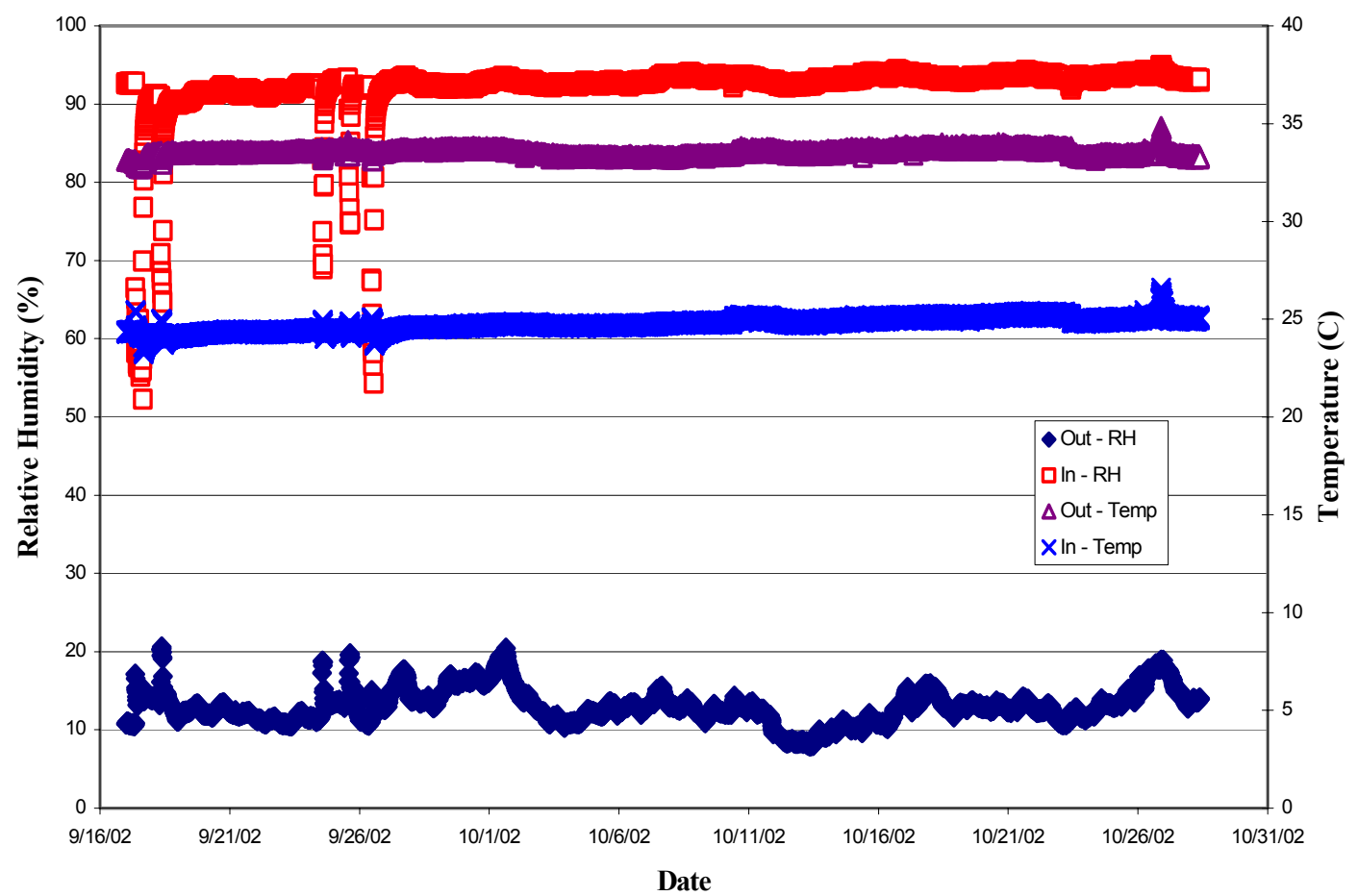

Source: DTN: LB0211NICH5LIQ.001 [DIRS 160792] Test \#2 9-17-02: native data files N5_RH-T-p_9-18-02.csv, N5_RH-T-p_10-18-02.csv, and N5_RH-T-p_10-29-02.csv.

Figure 6-43. Relative Humidity and Temperature of Air Inside and Outside Niche 5 (Niche CD 1620) During Test \#2 9-17-02

The air temperature outside the niche in the ECRB is also quite stable $\left(33^{\circ} \mathrm{C}\right.$ to $\left.34^{\circ} \mathrm{C}\right)$, but the relative humidity fluctuates between 8 and 21 percent. The fluctuation in relative humidity can be attributed to the tunnel ventilation system that draws moisture into the ECRB from outside the ESF. Relative humidity conditions in this case are influenced by outside weather conditions.

\section{Test Data-Liquid Release and Seepage Rates}

Figure 6-44 shows a plot of the liquid-release mass flow rate into the formation from the borehole and the total seepage mass flow rate entering the niche during Test \#2 9-17-02. A peristaltic pump was used to pump water into the borehole, creating small surges in the rate that give the appearance that the release rate varies with time (i.e., the somewhat parallel release-rate "lines" in Figure 6-44). The average release rate (approximately $0.023 \mathrm{~g} / \mathrm{s}$ ) was fairly constant from September 17, 2002, to October 19, 2002, after which time it steadily declined between October 20, 2002, and October 28, 2002, to a rate of $0.019 \mathrm{~g} / \mathrm{s}$.

Seepage into the niche began on October 1, 2002, based on a definitive increase in mass observed on the capture balance. The seepage rate continued to increase through October 20, 2002, when it suddenly started to decline and stopped seeping on October 23, 2002. This corresponds within a day to the decline in the liquid release rate noted in the previous paragraph. The sudden halt in seepage caused by a 10- to 20 -percent reduction in the release rate suggests that a seepage threshold exists in the Tptpll that is very sensitive to the release mass flow rate. 


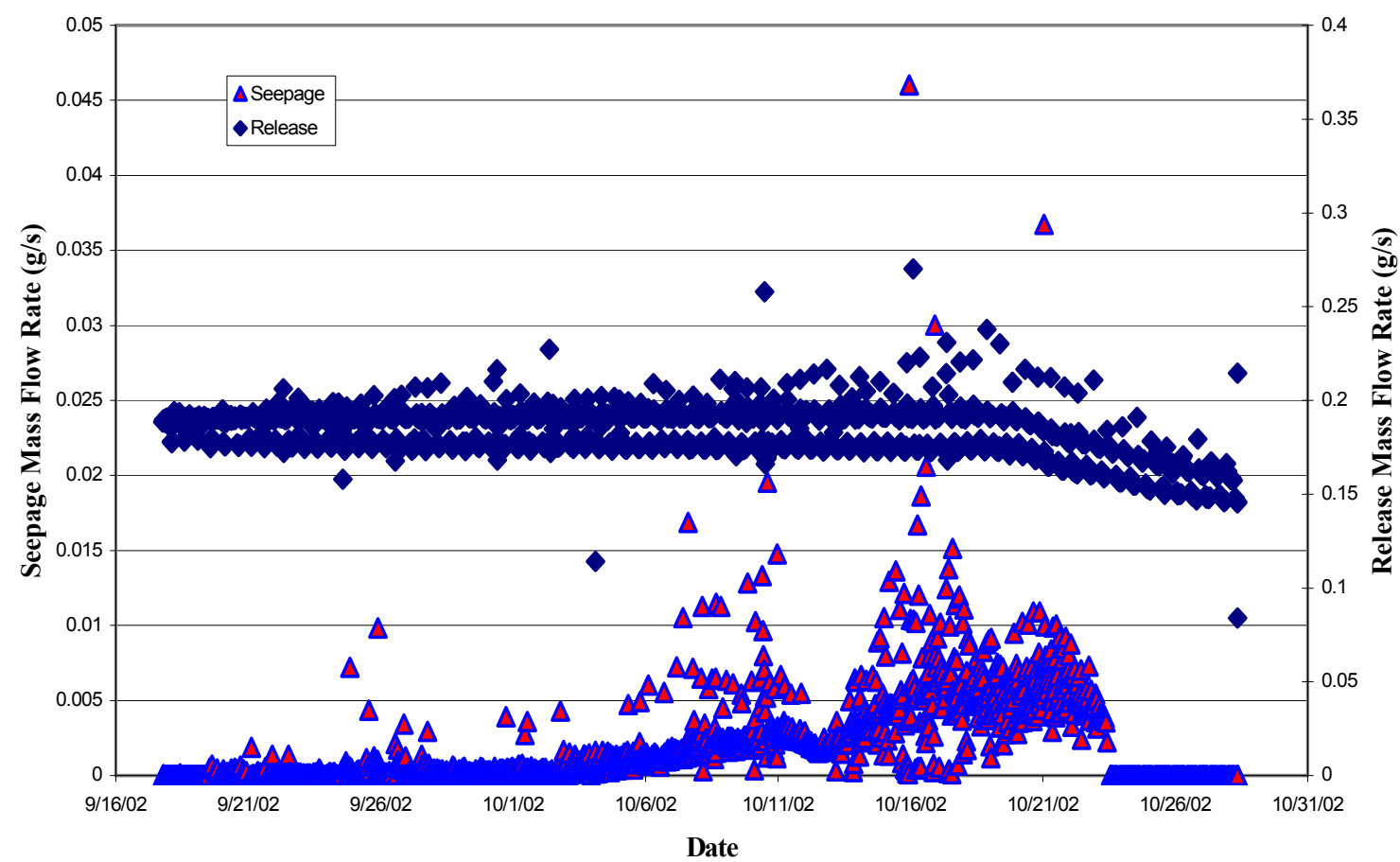

Source: DTN: LB0211NICH5LIQ.001 [DIRS 160792] Test \#2 9-17-02: native data files Test \#2_b5_20-21_ft_917-02_\#1a (srate).csv and Test \#2_b5_20-21_ft_9-17-02_\#2 (srate).csv.

Figure 6-44. Liquid-Release Rate into Borehole 5 and Seepage of Water into the Capture System of Niche 5 (Niche CD 1620) during Test \#2 9-17-02

Figure 6-45 shows a plot of the total seepage rate into the niche (triangles) and the seepage rate captured by the tarp (diamonds) installed at the entrance to the slot (Area A, Figure 6-36). Seepage captured by the tarp follows the same pattern over time as the total seepage, the latter of which represents water collected from all the capture compartments. Seepage captured by the tarp is a large component of the total seepage into the drift, approaching 80 to 90 percent of the total during specific periods of time. Both seepage and the seepage captured by the tarp declined and dropped off to zero as the release rate declined after October 20, 2002.

\subsection{Summary-Niche 5 (Niche CD 1620)}

Tests performed during the study (including the example experiment, Test \#2 9-17-02) indicate that a measurable seepage threshold exists for the Tptpll-a stated objective of the niche study. Unfortunately, because of the constraints associated with installation of the slot collection system described in Section 6.2.1.3.5.2, investigators were unable to determine whether the water seeping onto the tarp during Test \#2 9-17-02 and Test \#1 7-15-02 (the only two tests in which seepage onto the tarp occurred) originated from the slot or from the niche ceiling next to the slot. Several attempts to observe seepage were made, but the seepage rates were so slow that visual evidence of seepage from the slot was not obtained. With the approximation that all of the seepage was derived from the slot, the results of Test \#2 9-17-02 demonstrate that the slot did not effectively capture lateral movement of water around the niche, because seepage into the slot ceased when the seepage threshold was reached. The lack of seepage into the slot implies that the revised objectives of the test stated in Section 6.2.1.3.5.1 were not met in this study. Specifically, a water mass balance was not achieved because the laterally diverted seepage water 
was not collected in the slot. Photographic evidence has been collected in Niche 5 (Niche CD 1620), showing the wetted area spreading down the sidewall during the test (Figure 6-46), providing qualitative evidence that flow was diverted around the niche. Trautz and Wang (2002 [DIRS 160335]) showed (using photographic evidence) that the wetted area spreads across the ceiling and down the terminal face and sidewall of Niche 4 (Niche 4788) in Tptpmn.

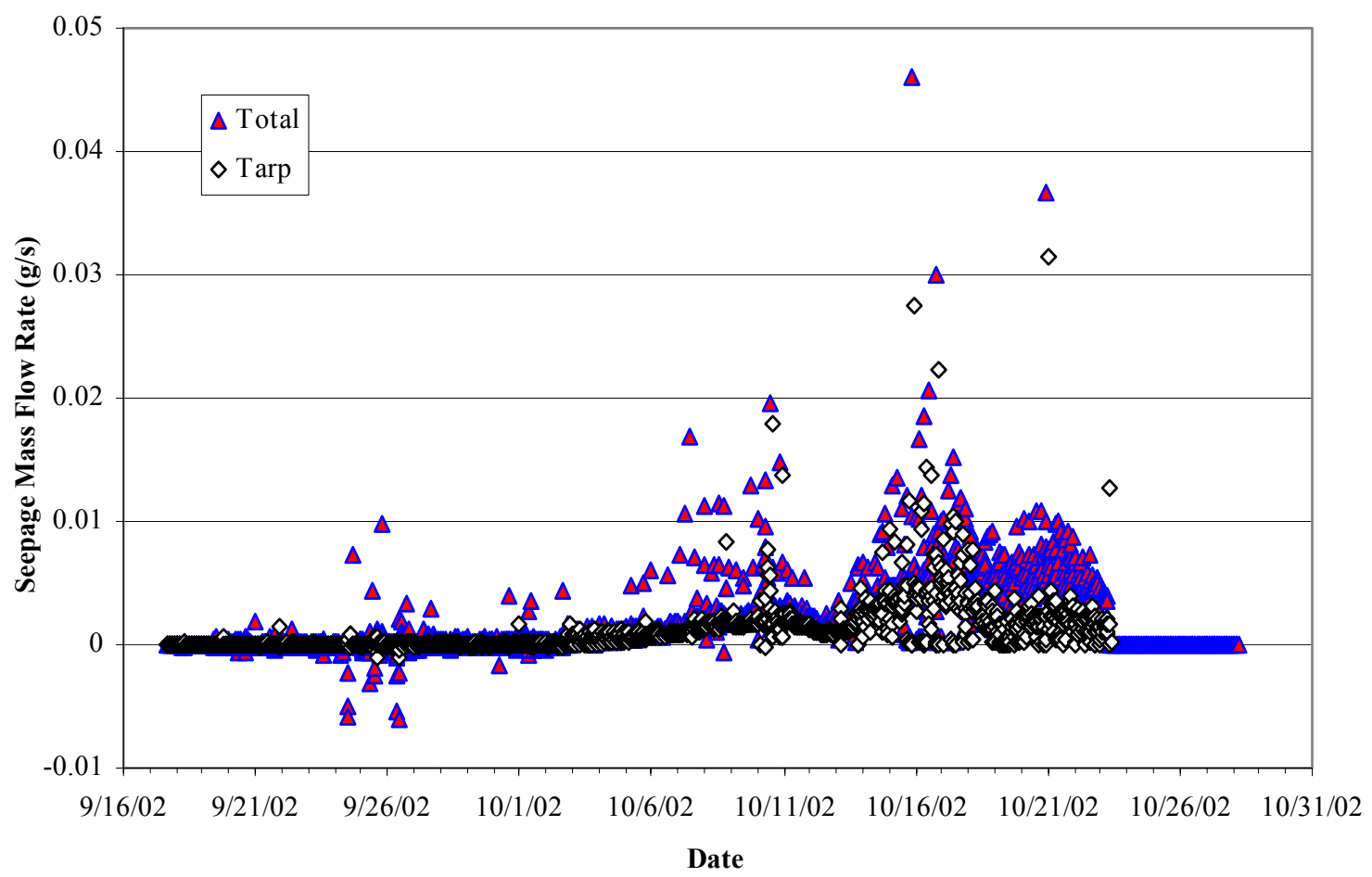

Source: DTN: LB0211NICH5LIQ.001 [DIRS 160792] Test \#2 9-17-02: native data files Test \#2_b5_20-21_ft_917-02_\#1.csv, Test \#2_b5_20-21_ft_9-17-02_\#1a (srate).csv, and Test \#2_b5_20-21_ft_9-17-02_\#2 (srate).csv.

Figure 6-45. Total Seepage and Seepage into the Tarp Area at the Entrance to the Slot

\subsubsection{Niche Seepage Threshold and Fracture Characteristic Curves}

This section is presented to document an alternate analysis of seepage data based on analytic solutions developed for capillary barriers. The analysis is different from the PA methodology presented in Seepage Calibration Model and Seepage Testing Data (BSC 2004 [DIRS 171764]), which is based on a numerical model with a heterogeneous fracture continuum representation and inverse modeling of primarily steady-state seepage data. The parameters determined by numerical calibration are related to the conceptual and numerical model used during calibration (i.e., the estimated value for the capillary-strength parameter depends, for example, on the numerical discretization used (BSC 2004 [DIRS 171764], Section 6.3.3.3)). The dependence of the estimated values on the model structure is acceptable and even desired as long as the structure of the model used for seepage predictions is consistent with that used for calibration (see the discussion in Seepage Calibration Model and Seepage Testing Data (BSC 2004 [DIRS 171764], Section 8.1)). Therefore, the analysis results (specifically, the derived capillary-strength parameter and seepage-threshold value) presented in this section are not comparable with the PA results. This constraint applies to both the seepage threshold 
analyses and fracture characteristic curves (derived from transient seepage data) described in this section. However, they are valid within the context of the analysis presented in this section, and they corroborate the presence of a capillary barrier and a seepage threshold.

The niche seepage data collected from short-duration tests in ten intervals at Niche 2 (Niche 3650), long-term tests in one interval at Niche 3 (Niche 3107), and long-term tests in three intervals at Niche 4 (Niche 4788) are analyzed in this section. As stated in Section 6.2.1.3.1, Section 6.2.1.3.2, and Section 6.2.1.3.3, the niche seepage threshold is defined in terms of the pumping rate and the wetted area estimated for the borehole interval. This definition of the niche seepage threshold is different from the definition used by PA, which relates the seepage threshold to the steady-state background percolation flux averaged over drift-scale and site-scale areas.

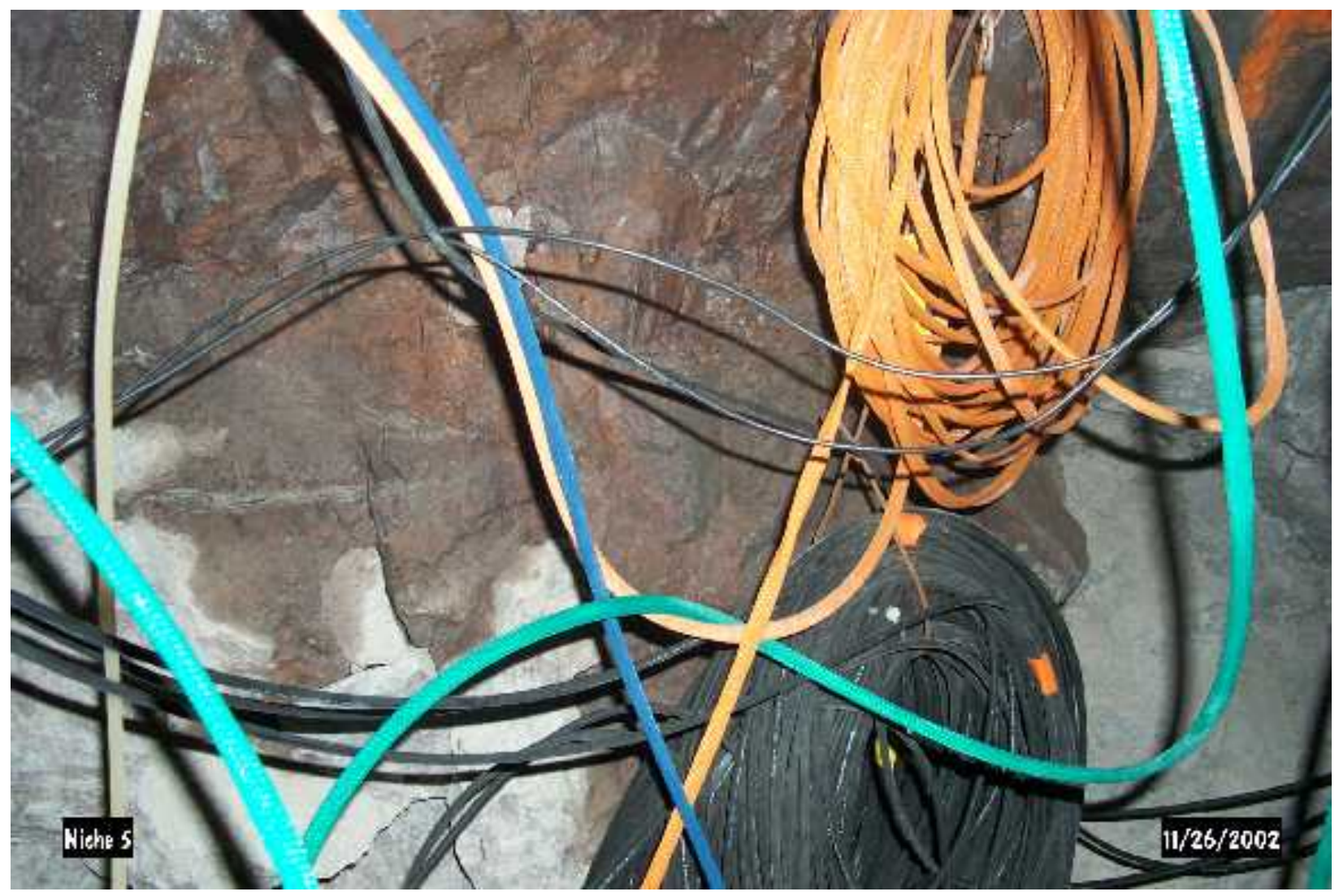

Source: DTN: LB0211NICH5LIQ.001 [DIRS 160792].

Figure 6-46. Wetted Area Spreading Down the Sidewall in Niche 5 (Niche CD 1620) 


\subsubsection{Post-Excavation Liquid-Release and Niche Seepage Threshold}

For a given test interval, seepage tests were initially conducted at high liquid-release rates (injection rates into borehole interval without excessive pressure buildup). Subsequent tests were performed at lower liquid-release rates to determine whether a threshold could be estimated below which seepage into the niche would no longer occur.

Figure 6-47 shows a plot of the seepage percentages observed during four tests conducted at different release flux $\left(q_{s}\right)$ in Borehole UM at the same interval, located 5.49 to $5.79 \mathrm{~m}$ from the borehole collar at Niche 2 (Niche 3650). A linear regression was performed on the four data points to compute the equation for the trendline and the R-squared values $\left(R^{2}\right)$ reported in Figure 6-47 and tabulated in Table 6-8. This exercise was repeated for the tested intervals at all the niches, to produce the regression data reported in Table 6-8 for all the zones that seeped. The R-squared values are computed separately for each interval and are listed for those intervals where three or more data points are available. (The linear regression was performed in an Excel spreadsheet documented in Appendix Tables B-3a through B-4e.) For the purposes of this analysis, $q_{s}$ is approximately equal to the net downward flux $\left(K_{o}\right)$. This approximation is a conservative estimate of $K_{o}$ (Trautz and Wang 2002 [DIRS 160335]).

Table 6-8 also summarizes the niche seepage threshold $\left(K_{o}^{*}\right)$, defined as the liquid-release flux below which water will not seep into the drift (i.e., see $K_{o}{ }^{*}$ defined in Figure 6-47). The $K_{o}{ }^{*}$ values were determined using the regression equations provided in Table 6-8 by setting the seepage percentage, $y$, equal to 0 , and then solving for $K_{o}=K_{o} *\left[K_{o}^{*}=K_{o}(y=0)\right]$. Details on this analysis and calculation procedures are in Appendices B and I. Here, the symbol $K_{o}$ is used to denote the liquid-release flux used in the regression model to distinguish it from the liquid-release flux computed using the field data $\left(q_{s}\right)$. In terms of $K_{o}$ and $K_{o}{ }^{*}$, the niche seepage threshold is defined as follows:

- If the liquid-release flux exceeds the seepage threshold flux $\left(K_{o}\right.$ greater than $\left.K_{o}{ }^{*}\right)$ for the given interval, then water will seep into the drift.

- If the liquid-release flux is less than the seepage threshold flux ( $K_{o}$ less than $\left.K_{o}{ }^{*}\right)$, then water will not enter the cavity. 


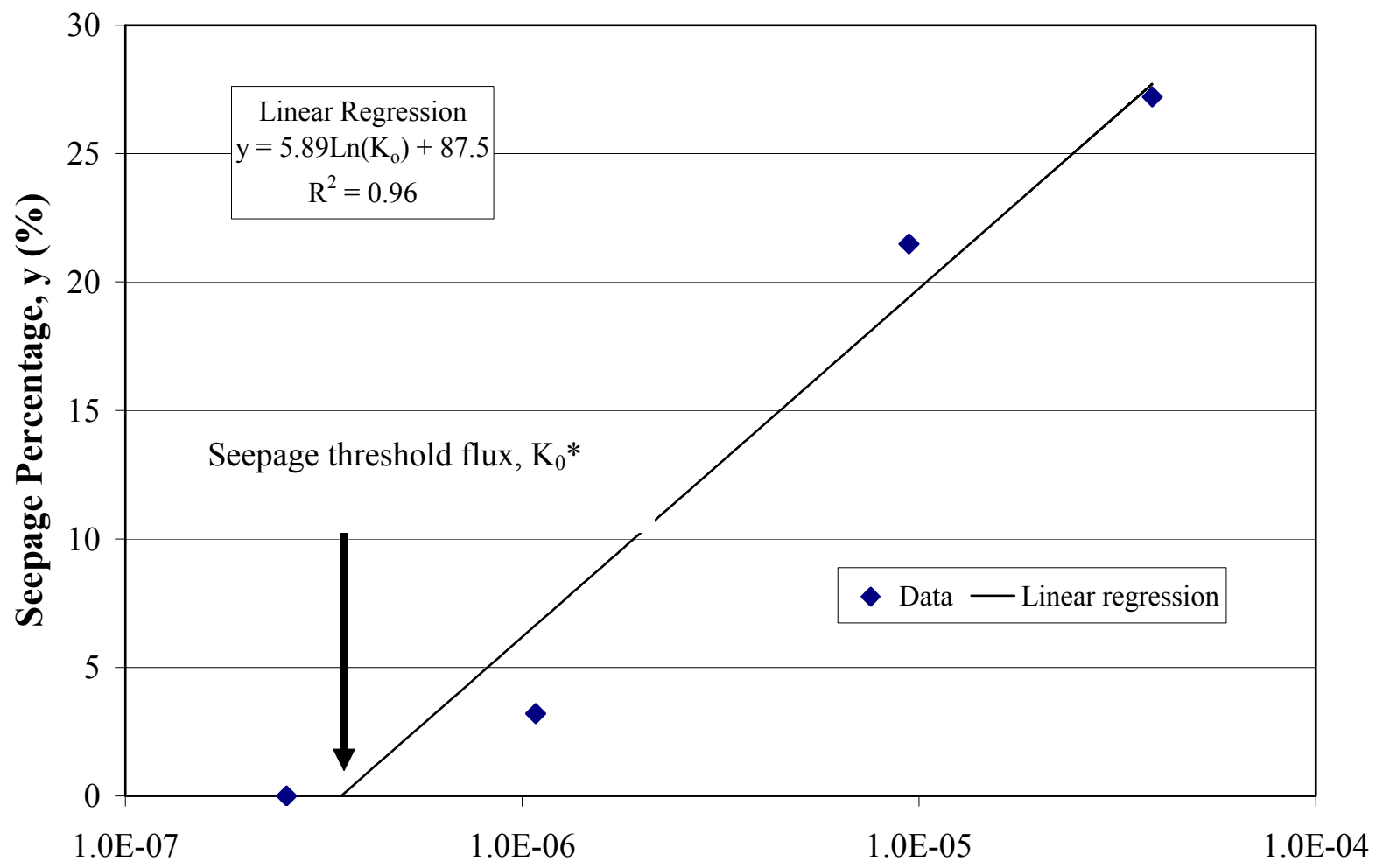

\section{Liquid-Release Flux, $\mathrm{q}_{\mathrm{s}}(\mathrm{m} / \mathrm{s})$}

Source: DTN: LB980901233124.003 [DIRS 105592].

NOTES: Seepage tests were conducted for the interval 5.49 to $5.79 \mathrm{~m}$ from the collar of Borehole UM at Niche 2 (Niche 3650).

The parameter $\alpha^{-1}$ is also referred as the capillary strength.

Figure 6-47. Liquid-Release Flux versus Seepage Percentage

Table 6-8. Seepage Threshold Fluxes $\left(K_{o}^{*}\right)$.

\begin{tabular}{|c|c|c|c|c|c|c|}
\hline Niche & \begin{tabular}{|c|} 
Borehole \\
Name and \\
$\begin{array}{c}\text { Depth Interval } \\
(\mathrm{m})\end{array}$ \\
\end{tabular} & Linear Regression Equation & $\begin{array}{c}\text { Data } \\
\text { Points }\end{array}$ & $\begin{array}{c}\text { Correlation } \\
\text { Coefficient } \\
\left(\mathbf{R}^{2}\right) \\
\end{array}$ & $\begin{array}{c}\text { Niche } \\
\text { Seepage } \\
\text { Threshold } \\
K_{o}^{*}(\mathrm{~m} / \mathrm{s}) \\
\end{array}$ & $\begin{array}{c}\text { Saturated } \\
\text { Hydraulic } \\
\text { Conductivity } \\
K_{l}(\mathrm{~m} / \mathrm{s}) \\
\end{array}$ \\
\hline 3107 & UM 4.88-5.18 & $y=30.440 \ln \left(K_{0}\right)+456.085$ & 8 & 0.820 & 3.11E-07 & $\mathrm{N} / \mathrm{A}$ \\
\hline \multirow[t]{6}{*}{3650} & UL 7.01-7.32 & $y=0.6833 \ln \left(K_{o}\right)+8.5742$ & 2 & $N / R$ & $3.55 \mathrm{E}-06$ & 8.98E-05 \\
\hline & UL 7.62-7.92 & $y=5.7394 \ln \left(K_{o}\right)+92.627$ & 3 & 0.979 & $9.80 \mathrm{E}-08$ & $1.51 \mathrm{E}-04$ \\
\hline & UM 4.27-4.57 & $y=5.2757 \ln \left(K_{o}\right)+79.443$ & 4 & 0.921 & 2.89E-07 & 2.62E-05 \\
\hline & UM 4.88-5.18 & $y=2.304 \ln \left(K_{o}\right)+31.767$ & 3 & 0.975 & $1.03 \mathrm{E}-06$ & $2.52 \mathrm{E}-03$ \\
\hline & UM 5.49-5.79 & $y=5.8876 \ln \left(K_{o}\right)+87.528$ & 4 & 0.963 & $3.50 \mathrm{E}-07$ & 2.16E-05 \\
\hline & UR 4.27-4.57 & $y=0.314 \ln \left(K_{o}\right)+4.3283$ & 2 & $\mathrm{~N} / \mathrm{R}$ & 1.03E-06 & 4.08E-05 \\
\hline
\end{tabular}


Table 6-8. Seepage Threshold Fluxes $\left(K_{o}^{*}\right)$ (Continued)

\begin{tabular}{|c|c|c|c|c|c|c|}
\hline Niche & $\begin{array}{c}\text { Borehole } \\
\text { Name and } \\
\text { Depth Interval } \\
(\mathrm{m})\end{array}$ & Linear Regression Equation & $\begin{array}{c}\text { Data } \\
\text { Points }\end{array}$ & $\begin{array}{c}\text { Correlation } \\
\text { Coefficient } \\
\left(\mathbf{R}^{2}\right)\end{array}$ & $\begin{array}{c}\text { Niche } \\
\text { Seepage } \\
\text { Threshold } \\
K_{\circ}^{*}(\mathrm{~m} / \mathrm{s})\end{array}$ & $\begin{array}{c}\text { Saturated } \\
\text { Hydraulic } \\
\text { Conductivity } \\
K_{l}(\mathrm{~m} / \mathrm{s}) \\
\end{array}$ \\
\hline \multirow[t]{4}{*}{3650} & UR 4.88-5.18 & $y=0.3165 \ln \left(K_{o}\right)+4.3751$ & 2 & $\mathrm{~N} / \mathrm{R}$ & 9.92E-07 & 9.87E-05 \\
\hline & UR 5.49-5.79 & $y=28.419 \ln \left(K_{o}\right)+351.09$ & 2 & $\mathrm{~N} / \mathrm{R}$ & 4.31E-06 & $1.71 \mathrm{E}-05$ \\
\hline & UR $6.10-6.40$ & $y=4.2169 \ln \left(K_{o}\right)+79.596$ & 2 & $\mathrm{~N} / \mathrm{R}$ & 6.35E-09 & 3.01E-05 \\
\hline & UR 6.71-7.01 & $y=10.574 \ln \left(K_{o}\right)+165.28$ & 3 & 0.974 & 1.63E-07 & $2.28 \mathrm{E}-04$ \\
\hline \multirow[t]{3}{*}{4788} & UL 7.62-7.93 & $y=9.273 \ln \left(K_{o}\right)+148.119$ & 4 & 0.929 & 1.16E-07 & $2.46 \mathrm{E}-05$ \\
\hline & UM 6.10-6.40 & $\mathrm{y}=15.697 \ln \left(K_{o}\right)+243.611$ & 4 & 0.980 & $1.82 \mathrm{E}-07$ & $2.45 \mathrm{E}-04$ \\
\hline & UR 5.18-5.48 & $y=25.415 \ln \left(K_{o}\right)+410.285$ & 3 & 0.970 & 9.75E-08 & $3.92 \mathrm{E}-06$ \\
\hline
\end{tabular}

Source: DTN: LB980901233124.003 [DIRS 105592].

Output DTN: LB0110LIQR0015.001.

NOTES: Various data sets were used to generate Table 6-8. Refer to Appendix Tables B-3 and B-4, and Appendix Section 15 for details. The saturated conductivity in the last column was calculated from the fracture permeability for the zone measured in the air-injection tests (Appendix Section D2).

N/A = Not applicable. The test could not be completed as planned because of rock properties outside the measurable range of the equipment.

$N / R=$ Not reported, because two data points result in perfect correlation $\left(R^{2}=1.0\right)$, therefore, correlation coefficient is meaningless.

$y=$ Predicted seepage percentage.

$K_{0}=$ Net downward liquid-release flux from regression model $(\mathrm{m} / \mathrm{s})$.

In $=$ Natural logarithm.

In the capillary barrier conceptual model, the flow can be easily diverted if the liquid permeability is large (see Section 6.2.2.2). To illustrate and evaluate this concept, the air permeabilities obtained from the post-excavation air-injection tests were converted into equivalent saturated hydraulic conductivity $\left(K_{l}\right)$ for liquid flow (DTN: LB980001233124.004 [DIRS 136583]) as shown by Wang (1999 [DIRS 153449], pp. 34-38) for Niche 2 (Niche 3650), to produce the values recorded in Table 6-8 and plotted in Figure 6-48. Figure 6-48 shows a $\log -\log$ plot of $K_{o}{ }^{*}$ versus $K$ for 10 test intervals at Niche 2 (Niche 3650) and three test intervals at Niche 4 (Niche 4788) where seepage occurred. For each test interval, multiple tests with different release rates were conducted to estimate the niche seepage threshold. (Computation of $K_{o}{ }^{*}$ and $K_{l}$ was performed in an Excel spreadsheet documented in Appendix Table B-4. $K_{l}$ could not be calculated for Niche 3 [Niche 3107] because the air-permeability test could not be completed as planned: the rock properties were outside the measurable range of the equipment.) The straight line in Figure 6-48 is derived from an analytic solution described in Section 6.2.2.2. The estimation of $K_{l}$ using air-permeability test data is evaluated in Appendix Section D2. 


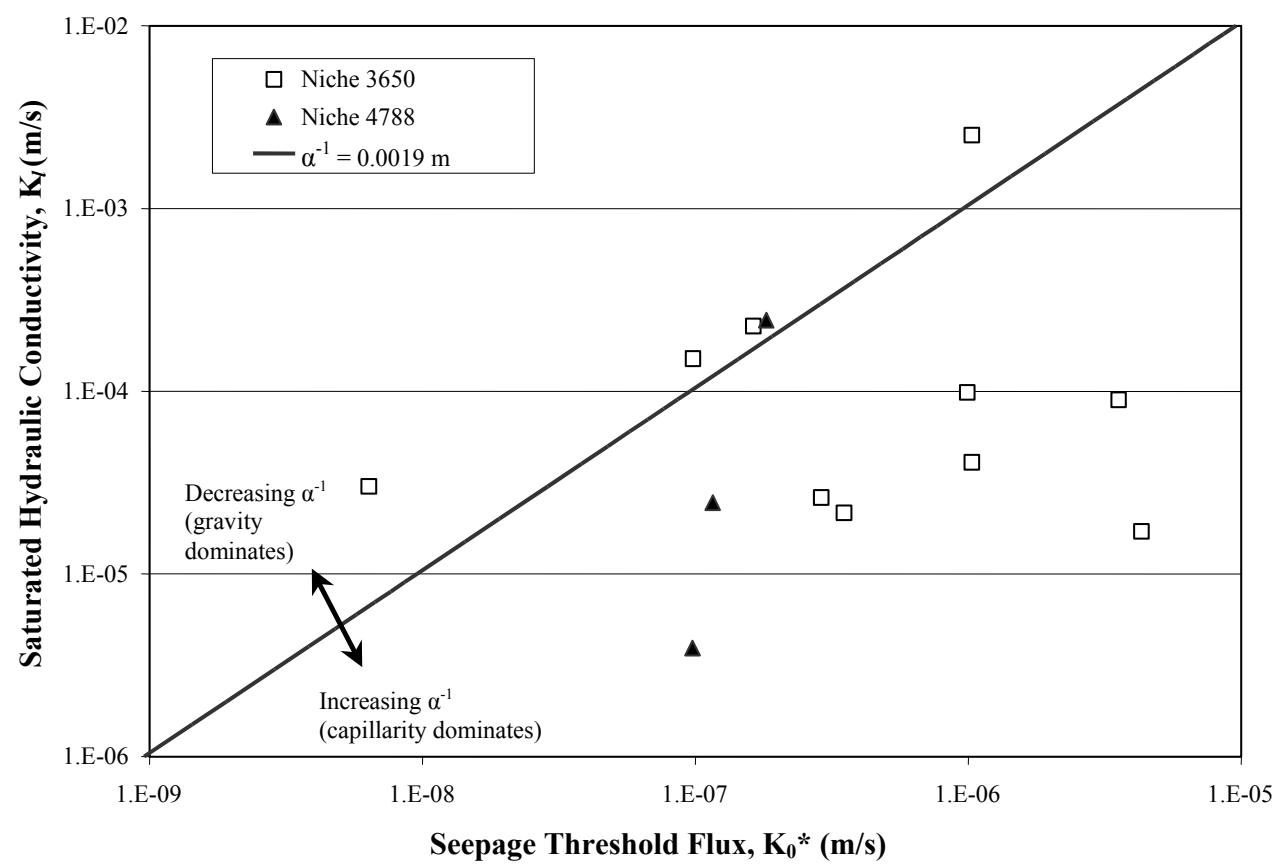

Source: DTNs: LB980001233124.004 [DIRS 136583]; LB0010NICH4LIQ.001 [DIRS 153145]; LB980901233124.003 [DIRS 105592].

Output DTN: LB0110LIQR0015.001.

NOTES: Various data sets were used to generate this figure. See Appendix Tables B-4 and B-6 for details. $1 / \alpha$ is referred to as the capillary-strength parameter.

Figure 6-48. Seepage Threshold Flux

\subsubsection{Capillary Strength $\left(\alpha^{-1}\right)$ of Fractures}

Philip et al. (1989 [DIRS 105743]) recognized that buried cylindrical cavities are obstacles to flow, preventing water from entering the cavity. The following theoretical relation between $K_{o}{ }^{*}$ and $K_{l}$ was provided by Philip et al. (1989 [DIRS 105743], p. 19, Section 3.4):

$$
K_{o}^{*}=K_{l}\left[\vartheta_{\max }(s)\right]^{-1}
$$

where $s$ is the value of the dimensionless cavity length and $\vartheta_{\max }$ is the maximum value of the dimensionless potential $\vartheta$ at the boundary of the cavity. Philip et al. (1989 [DIRS 105743], p. 20, Equation 56) show that $\vartheta_{\max }$ occurs at the apex or crown of a cylindrical cavity. The dimensionless cavity length, $s$, is a measure of the relative importance of gravity and capillarity in determining flow. As $s$ approaches zero, capillarity dominates, whereas gravity dominates as $s$ tends toward infinity

An exponential functional relation between unsaturated hydraulic conductivity, $K(\psi)$, and water potential, $\psi$, is used (Philip et al. 1989 [DIRS 105743], Equation 12, p. 18):

$$
K(\psi)=K_{l} e^{\alpha\left(\psi-\psi_{e}\right)}
$$


$K_{l}$ is the saturated hydraulic conductivity (Pullan 1990 [DIRS 106141], p. 1221), $\psi_{e}$ is the air-entry potential, $K_{l}$ is the conductivity at $\psi=\psi_{e}$, and $\alpha^{-1}$ is the capillary-strength parameter. For fractures, the air-entry potential is small and negligible.

This Gardner exponential functional relation is used by Philip et al. (1989 [DIRS 105743], p. 18, Equation 12) and by Braester (1973 [DIRS 106088], p. 688, Equation 5)] to transform and linearize the unsaturated governing equations. Equation 6-4 is also used in Section 6.2.2.4 to estimate water potential.

Another model for unsaturated hydraulic conductivity and water potential is the van Genuchten model with its own capillary-strength parameter and pore-size distribution parameter (BSC 2004 [DIRS 171764], Section 6.3.2.3). The distinction between model-dependent capillary-strength parameters should be noted when comparing results from the analysis presented in this section and the results from the seepage calibration model (BSC 2004 [DIRS 171764]) and the seepage model for PA (BSC 2004 [DIRS 167652]).

Philip et al. (1989 [DIRS 105743], p. 18, Equation 14) note that the dimensionless cavity length $s$ in Equation 6-3 is related to the capillary strength parameter $\alpha^{-1}$ (Equation 6-4) and a characteristic length of the cavity $\ell$ by the following expression:

$$
s=0.5 \alpha \ell
$$

When $s$ is large, Philip et al. (1989 [DIRS 105743], Section 6, pp. 23-25) demonstrate that a boundary layer adjoining the ceiling of the cavity surface will develop. This allows the steady flow equation to be replaced by a boundary-layer equation that is readily solved. The asymptotic expansion of $\vartheta_{\max }$ for large values of $s$ yields (Philip et al. 1989 [DIRS 105743], p. 23, Equation 84):

$$
\vartheta_{\max }=2 s+2-\frac{1}{s}+\frac{2}{s^{2}}-\ldots
$$

Philip et al. (1989 [DIRS 105743], Table 1) note that when $s$ is greater than or equal to 1, the first three terms on the right side of Equation 6-6 produce an adequate estimate that is within 12 percent (or less) of the exact value of $\vartheta_{\max }$. Therefore, using appropriate values for $K_{o}{ }^{*}, \ell$, and $K_{l}$, the capillary strength $\left(\alpha^{-1}\right)$ for the porous medium from Equation 6-3, Equation 6-5, and the first three terms in Equation 6-6, can be estimated. This technique was utilized to compute the $\alpha^{-1}$ values reported in Table 6-9, using the values for $K_{o}{ }^{*}$ derived in Section 6.2.2.1. The $K_{l}$ values were derived from post-excavation air-injection tests summarized in Table 6-8, and a value of two was used for $\ell$, which is approximately equal to the radius of the curvature of the niche ceiling. By taking the reciprocal of the $\alpha^{-1}$ reported in Table 6-9, which in this case also equals s, all the s-values (with the exception of Niche 3 [Niche 3107] Borehole UM, Interval 4.88-5.18 m) are greater than one, justifying the use of Equation 6-6. The $s$-value for Niche 3 (Niche 3107) Borehole UM, Interval 4.88-5.18 $\mathrm{m}$ is slightly less than one (i.e., 0.43), implying that the use of Equation 6-6 will result in a larger error in $\alpha^{-1}$ for this test. 
Table 6-9. Alpha $(\alpha)$ Values Estimated for the Fractures

\begin{tabular}{|c|c|c|}
\hline Niche & $\begin{array}{c}\text { Borehole and } \\
\text { Interval (m) }\end{array}$ & $\begin{array}{l}\text { Output Capillary } \\
\text { Strength } \alpha^{-1}(\mathrm{~m})\end{array}$ \\
\hline \multirow[t]{10}{*}{3650} & UL 7.01-7.32 & 0.0855 \\
\hline & UL 7.62-7.92 & 0.0013 \\
\hline & UM 4.27-4.57 & 0.0225 \\
\hline & UM 4.88-5.18 & 0.0008 \\
\hline & UM 5.49-5.79 & 0.0334 \\
\hline & UR 4.27-4.57 & 0.0532 \\
\hline & UR 4.88-5.18 & 0.0205 \\
\hline & UR 5.49-5.79 & 0.71 \\
\hline & UR $6.10-6.40$ & 0.0004 \\
\hline & UR 6.71-7.01 & 0.0014 \\
\hline \multirow[t]{3}{*}{4788} & UL 7.62-7.93 & 0.0095 \\
\hline & UM 6.10-6.40 & 0.0015 \\
\hline & UR 5.18-5.48 & 0.0523 \\
\hline \multicolumn{2}{|c|}{ Theoretical limit } & 0.0019 \\
\hline \multicolumn{3}{|r|}{$\begin{array}{l}\text { IRS 105592]; } \\
\text { 05888]. }\end{array}$} \\
\hline NOTE: & $\begin{array}{l}\text { s data sets wer } \\
\text { o Appendix Tab }\end{array}$ & $\begin{array}{l}\text { ed to derive } \alpha^{-1} \text {. } \\
-5 \text { for details. }\end{array}$ \\
\hline
\end{tabular}

An early analysis based on visual inspection and straight-line fitting of Niche 2 (Niche 3650) short-duration test data in Figure 6-48 is documented by Trautz and Wang (2001 [DIRS 165419]). In this section of this scientific analysis report, the Niche 2 (Niche 3650) data analyses are compared with the results of long-duration tests at Niche 4 (Niche 4788).

Philip, in "The Scattering Analog for Infiltration in Porous Media" (1989 [DIRS 156974]) reports that $\alpha^{-1}$ varies from $0.05 \mathrm{~m}$ or less (for coarse-grained soils) to $5 \mathrm{~m}$ or more (for fine-textured soils). In comparison, the values reported in Table 6-9 range from 0.001 to $0.71 \mathrm{~m}$ for the fractures tested, with the lower bound below that normally reported in the literature for soils. Philip (1989 [DIRS 156974]) and White and Sully (1987 [DIRS 106152], p. 1514) recognized that $\alpha^{-1}$ is a permeability-weighted mean soil-water potential directly related to the macroscopic capillary length, or pore radius, $r$, of the medium, as follows:

$$
2 \alpha^{-1}=\frac{2 \gamma \cos (\theta)}{\rho g r}
$$

where $\gamma, \rho$, and $\theta$ are the surface tension, density, and contact angle of the fluid, respectively, and $\mathrm{g}$ is gravitational acceleration. The surface tension $\gamma$ is the surface energy per unit area, or equivalent, surface force per unit length. The right-side of Equation 6-7 is known as Laplace's capillary formula, which is equal to the height $|\mathrm{h}|$ of fluid rise in a small diameter cylindrical tube. 
For a pair of parallel plates with width $L$ much greater than the aperture $\mathrm{b}$, the upward force component along two liquid-air-solid interfaces with contact angle $\theta$ is $\gamma \cos (\theta) \times(2 \mathrm{~L})$, and the downward weight of the liquid rise is $\rho g \times(\mathrm{Lb}|\mathrm{h}|)$. From force balance, the capillary equation relating the capillary rise $|\mathrm{h}|$ with fracture aperture $\mathrm{b}$ is obtained. Therefore, Equation 6-7 can also be used to estimate the height of fluid rise between two smooth parallel plates (analogous to a fracture) by substituting the aperture $b$, or separation distance between plates for $r$ in Equation 6-7.

Bouwer (1966 [DIRS 155682], p. 733) and Raats and Gardner (1971 [DIRS 155683], p. 922) described the macroscopic capillary length, and hence $2 \alpha^{-1}$, as a "mean" height of capillary rise above a water table, or the "mean" air-entry head. In this case, the significance of $2 \alpha^{-1}$ is that it represents the mean height that water can be retained in the fractures above the drift (without seeping) because of the capillary barrier.

Note that the capillary mechanism has a limited range of validity. If the fracture aperture or capillary radius is large, the radius of curvature of the meniscus will be infinite and the capillary effect will be negligible. For a wetting fluid with contact angle $\theta=0$, the hemispherical surface at top of the rise can no longer be defined when $b$ or $r$ is greater than the height $|\mathrm{h}|$. Therefore the maximum capillary size (with $b=|h|$ or $r=|h|$ in Equation 6-7) is (Wang and Narasimhan (1993 [DIRS 106793], p. 329)):

$$
\mathrm{b}_{\max }=\left(\frac{2 \gamma}{\rho g}\right)^{1 / 2}
$$

For $\gamma=0.072 \mathrm{~kg} / \mathrm{s}^{2}, \rho=998 \mathrm{~kg} / \mathrm{m}^{3}$, and $\mathrm{g}=9.8 \mathrm{~m} / \mathrm{s}^{2}$ the nominal aperture size is $3.84 \mathrm{~mm}$, which, using Equation 6-7, corresponds to a limiting value for $\alpha^{-1}$ equal to $0.0019 \mathrm{~m}$.

Figure 6-48 was generated by plotting the $K_{o}{ }^{*}$ values derived in Section 6.2.2.1 along with their corresponding $K_{l}$ values reported in Table 6-8. The line in Figure 6-48 represents the practical limit of Equation 6-3 calculated using the limiting value of $\alpha^{-1}$ derived from Equation 6-7 and Equation 6-8. Therefore, values of $\alpha^{-1}$ less than $0.0019 \mathrm{~m}$ correspond to nominal apertures that are greater than $3.84 \mathrm{~mm}$, the point at which capillary forces vanish and gravity forces dominate flow. Several data points are slightly above the line in Figure 6-48. This implies that gravity forces dominate fluid flow through these features.

\subsubsection{Estimated Volumetric Water Content $(\theta)$ of Fractures}

The niche seepage data can also be used to obtain estimates of the change in volumetric water content $\theta$, where $\theta$ is equal to (volume of water in fractures)/(bulk volume of fractured tuff) of the fractures. Direct measurement of fracture $\theta$ in the field is difficult at best using conventional hydrologic techniques (e.g., using neutron moisture logs). Therefore, an alternate method of measuring average volumetric water contents indirectly, using wetting-front arrival times observed at the niche ceiling during the seepage tests, is described in the remainder of this subsection. 
Based on mass conservation along the vertical flow path, the depth of the wetting front below the water source is:

$$
z_{p}=\frac{q_{s} t}{\left(\theta_{\text {ave }}-\theta_{n}\right)}
$$

where $z_{p}$ is the depth from the water-supply surface to the leading edge of the wetting front, $q_{s}$ is the constant flux of water supplied at the source, $t$ is the arrival time of the front at depth $z_{p}, \theta_{\text {ave }}$ is the average water content, and $\theta_{n}$ is the initial or antecedent (or residual) water content.

Using the arrival time for the wetting front observed at the niche ceiling (DTN: LB980001233124.004 [DIRS 136583]) and the $q_{s}$ data (DTN: LB980001233124.004 [DIRS 136583]), it is possible to estimate the change in volumetric water content change $\Delta \theta=\theta_{\text {ave }}-\theta_{n}$ for each seepage test by applying Equation 6-9. (Computation of $\Delta \theta$ was performed in an Excel spreadsheet documented in Appendix Table B-8 for Niche 4788 [Niche 4]. The $\Delta \theta$ was not computed for Niche 3 [Niche 3107]; see Section 6.2.2.4.) Table 6-10 provides a summary of the estimated $\Delta \theta$ values for zones where three or more seepage tests were conducted. With the approximation that the initial, antecedent, or residual moisture content $\theta_{n}$ is negligible compared to $\theta_{\text {ave }}$, then $\Delta \theta$ becomes a measure of the average volumetric water content.

The water-content values, shown in Table 6-10, are within the range of 0.09 percent to 5.0 percent. Surprisingly, this indicates that the saturated water contents or porosities of the fractures could be as high as 5 percent, which is greater than expected. In turn, these values could influence travel-time calculations computed for the UZ, because water transport time is proportional to water content. Using larger water content for the fractures would result in longer transport times.

The approach used to estimate water contents for the fractures are evaluated in Appendix Section D1 and Appendix Section D3.

Table 6-10. Estimated Changes in Volumetric Water Content $(\Delta \theta)$

\begin{tabular}{|c|c|c|c|c|}
\hline Niche & $\begin{array}{c}\text { Borehole } \\
\text { Name and } \\
\text { Interval (m) }\end{array}$ & Test Name & $\begin{array}{c}\text { Liquid Release } \\
\text { Flux } \\
q_{s},(\mathrm{~m} / \mathrm{s})\end{array}$ & $\begin{array}{c}\text { Average Water Content } \\
\text { Change } \\
\Delta \theta=\theta_{\text {ave }}-\theta_{n}\left(\mathrm{~m}^{3} / \mathrm{m}^{3}\right)\end{array}$ \\
\hline \multirow[t]{9}{*}{3650} & UL 7.62-7.92 & Test \#2 1-6-98 & $9.49 \mathrm{E}-06$ & 0.0101 \\
\hline & UL 7.62-7.92 & Test \#1 2-12-98 & $1.89 \mathrm{E}-06$ & 0.0017 \\
\hline & UL 7.62-7.92 & Test \#1 3-4-98 & 2.33E-07 & 0.0009 \\
\hline & UM 4.27-4.57 & Test 5 Niche 3650 (11-13-97) & 3.78E-05 & 0.0242 \\
\hline & UM 4.27-4.57 & Test \#1 12-3-97 & $9.42 \mathrm{E}-06$ & 0.0146 \\
\hline & UM 4.27-4.57 & Test \#2 12-3-97 & $9.47 \mathrm{E}-06$ & 0.0075 \\
\hline & UM 4.27-4.57 & Test \#1 1-7-98 & 8.82E-07 & 0.0120 \\
\hline & UM 4.27-4.57 & Test \#2 2-10-98 & 3.09E-07 & 0.0063 \\
\hline & UM 4.88-5.18 & Test 1 Niche 3650 (11-12-97) & $5.41 \mathrm{E}-05$ & 0.0150 \\
\hline
\end{tabular}


Table 6-10. Estimated Changes in Volumetric Water Content $(\Delta \theta)$ (Continued)

\begin{tabular}{|c|c|c|c|c|}
\hline Niche & $\begin{array}{c}\text { Borehole } \\
\text { Name and } \\
\text { Interval (m) }\end{array}$ & Test Name & $\begin{array}{c}\text { Liquid Release } \\
\text { Flux } \\
q_{s},(\mathrm{~m} / \mathrm{s})\end{array}$ & $\begin{array}{c}\text { Average Water Content } \\
\text { Change } \\
\Delta \theta=\theta_{\text {ave }}-\theta_{n}\left(\mathrm{~m}^{3} / \mathrm{m}^{3}\right)\end{array}$ \\
\hline \multirow[t]{11}{*}{3650} & UM 4.88-5.18 & Test \#1 12-4-97 & 9.49E-06 & 0.0043 \\
\hline & UM 4.88-5.18 & Test \#2 12-5-97 & $2.70 \mathrm{E}-06$ & 0.0040 \\
\hline & UM 4.88-5.18 & Test \#1 1-8-98 & 8.75E-07 & 0.0082 \\
\hline & UM 4.88-5.18 & Test \#1 3-6-98 & 2.48E-07 & 0.0083 \\
\hline & UM 5.49-5.79 & Test 4 Niche 3650 (11-13-97) & 3.87E-05 & 0.0124 \\
\hline & UM 5.49-5.79 & Test \#2 12-4-97 & 9.43E-06 & 0.0061 \\
\hline & UM 5.49-5.79 & Test \#1 1-9-98 & $1.08 \mathrm{E}-06$ & 0.0046 \\
\hline & UM 5.49-5.79 & Test \#1 2-11-98 & $2.55 \mathrm{E}-07$ & 0.0040 \\
\hline & UR 6.71-7.01 & Test \#1 1-13-98 & $3.68 \mathrm{E}-06$ & 0.0024 \\
\hline & UR 6.71-7.01 & Test \#1 2-3-98 & $1.91 \mathrm{E}-06$ & 0.0018 \\
\hline & UR 6.71-7.01 & Test \#1 3-5-98 & $2.48 \mathrm{E}-07$ & 0.0017 \\
\hline \multirow[t]{11}{*}{4788} & UL 7.62-7.93 & Test \#1 11-3-99 & $1.65 \mathrm{E}-06$ & 0.0200 \\
\hline & UL 7.62-7.93 & Test \#1 11-30-99 Niche 4788 & $9.22 \mathrm{E}-07$ & 0.0057 \\
\hline & UL 7.62-7.93 & Test \#1 6-26-2000 & 3.59E-07 & 0.0101 \\
\hline & UL 7.62-7.93 & Test \#1 01-24-00 & 1.46E-07 & 0.0115 \\
\hline & UM 6.10-6.40 & Test \#1 Niche 4788 11-16-99 & $1.72 \mathrm{E}-06$ & 0.0489 \\
\hline & UM 6.10-6.40 & Test \#1 Niche 4788 12-10-99 & 7.33E-07 & 0.0503 \\
\hline & UM 6.10-6.40 & Test \#1 06-08-2000 & $3.83 \mathrm{E}-07$ & 0.0331 \\
\hline & UM $6.10-6.40$ & Test \#1 3-14-2000 & $1.66 \mathrm{E}-07$ & 0.0355 \\
\hline & UR 5.18-5.48 & Test \#1 Niche 4788 12-7-99 & 1.69E-06 & 0.0092 \\
\hline & UR 5.18-5.48 & Test \#1 1-5-2000 & 7.11E-07 & 0.0055 \\
\hline & UR 5.18-5.48 & Test \#1 02-14-2000 & $1.65 \mathrm{E}-07$ & 0.0055 \\
\hline
\end{tabular}

Source: DTN: LB980901233124.003 [DIRS 105592].

Output DTN: LB0110LIQR0015.001.

\subsubsection{Estimated Water Potentials $(\psi)$ of Fractures}

The direct measurement of water potentials is difficult to make in unsaturated fractures because hydrologic instruments are not readily adaptable to measuring such small features. Therefore, an indirect measure of the water potential $(\psi)$ was formulated using the $\alpha$ values computed in Section 6.2.2.2. Dividing both sides of Equation 6-4 by $K_{l}$ (saturated hydraulic conductivity), setting the liquid injection rate as the unsaturated conductivity (i.e., $q_{s}=K(\psi)$ ), and taking the natural logarithm of both sides of the equation, produces the following solution:

$$
\psi=\frac{\ln \left(q_{s} / K_{l}\right)}{\alpha}
$$


(The air-entry potential $\psi_{e}$ is set to zero in the solution.) Using the values for $q_{s}$ and $K_{l}$ reported in DTN: LB980001233124.004 [DIRS 136583] and the $\alpha$-values from Table 6-9, $\psi$ was computed for several Niche 2 (Niche 3650) tests by employing Equation 6-10. (Computation of $\psi$ was performed in an Excel spreadsheet documented in Appendix Table B-7 for Niche 4 (Niche 4788) ( $\psi$ was not computed for Niche 3 [Niche 3107] because a value for $K_{l}$ could not be computed: the corresponding air permeability value was not measurable with the equipment that was used.) A summary of the resulting $\psi$ values is provided in Table 6-11.

Table 6-11. Estimated Water Potential $(\psi)$ for the Fractures

\begin{tabular}{|c|c|c|c|}
\hline Niche & Borehole and Interval (m) & Test Name & $\begin{array}{l}\text { Absolute Value of the Water } \\
\text { Potential } \\
\psi(\mathrm{m})\end{array}$ \\
\hline \multirow[t]{20}{*}{3650} & UL 7.62-7.92 & Test \#2 1-6-98 & $3.59 \mathrm{E}-03$ \\
\hline & UL 7.62-7.92 & Test \#1 2-12-98 & $5.68 \mathrm{E}-03$ \\
\hline & UL 7.62-7.92 & Test \#1 3-4-98 & 8.39E-03 \\
\hline & UM 4.27-4.57 & Test 5 Niche 3650 (11-13-97) & 8.26E-03 \\
\hline & UM 4.27-4.57 & Test \#1 12-3-97 & 2.30E-02 \\
\hline & UM 4.27-4.57 & Test \#2 12-3-97 & 2.29E-02 \\
\hline & UM 4.27-4.57 & Test \#1 1-7-98 & 7.64E-02 \\
\hline & UM 4.27-4.57 & Test \#2 2-10-98 & $1.00 \mathrm{E}-01$ \\
\hline & UM 4.88-5.18 & Test 1 Niche 3650 (11-12-97) & 3.13E-03 \\
\hline & UM 4.88-5.18 & Test \#1 12-4-97 & 4.56E-03 \\
\hline & UM 4.88-5.18 & Test \#2 12-5-97 & $5.58 \mathrm{E}-03$ \\
\hline & UM 4.88-5.18 & Test \#1 1-8-98 & $6.50 \mathrm{E}-03$ \\
\hline & UM 4.88-5.18 & Test \#1 3-6-98 & 7.53E-03 \\
\hline & UM 5.49-5.79 & Test 4Niche 3650 (11-13-97) & 1.95E-02 \\
\hline & UM 5.49-5.79 & Test \#2 12-4-97 & 2.77E-02 \\
\hline & UM 5.49-5.79 & Test \#1 1-9-98 & $1.00 \mathrm{E}-01$ \\
\hline & UM 5.49-5.79 & Test \#1 2-11-98 & $1.48 \mathrm{E}-01$ \\
\hline & UR 6.71-7.01 & Test \#1 1-13-98 & $5.90 \mathrm{E}-03$ \\
\hline & UR 6.71-7.01 & Test \#1 2-3-98 & $6.84 \mathrm{E}-03$ \\
\hline & UR 6.71-7.01 & Test \#1 3-5-98 & $9.76 \mathrm{E}-03$ \\
\hline \multirow[t]{11}{*}{4788} & UL 7.62-7.93 & Test \#1 11-3-99 & $2.56 \mathrm{E}-02$ \\
\hline & UL 7.62-7.93 & Test \#1 11-30-99 Niche 4788 & $3.12 \mathrm{E}-02$ \\
\hline & UL 7.62-7.93 & Test \#1 6-26-2000 & 4.01E-02 \\
\hline & UL 7.62-7.93 & Test \#1 01-24-00 & 4.86E-02 \\
\hline & UM 6.10-6.40 & Test \#1 Niche 4788 11-16-99 & 7.38E-03 \\
\hline & UM 6.10-6.40 & Test \#1 Niche 4788 12-10-99 & $8.65 \mathrm{E}-03$ \\
\hline & UM 6.10-6.40 & Test \#1 06-08-2000 & 9.61E-03 \\
\hline & UM 6.10-6.40 & Test \#1 3-14-2000 & 1.09E-02 \\
\hline & UR 5.18-5.48 & Test \#1 Niche 4788 12-7-99 & 4.41E-02 \\
\hline & UR 5.18-5.48 & Test \#1 1-5-2000 & 8.93E-02 \\
\hline & UR 5.18-5.48 & Test \#1 02-14-2000 & 1.66E-01 \\
\hline
\end{tabular}

Source: DTNs: LB980001233124.004 [DIRS 136583]; LB980901233124.003 [DIRS 105592].

NOTE: Various data sets were used to generate this table. See Appendix Table B-7 for details. 


\subsubsection{Fracture-Water Characteristic Curves}

The volumetric water-content values from Section 6.2.2.3 and the water-potential values derived in Section 6.2.2.4 are plotted in Figure 6-49 to create a water-characteristic curve for the fractures. Only those test intervals where three or more tests were conducted are included in the figure. (Inclusion of zones that have only two data points, joined by a straight line, contributes little to an understanding of the functional relation between $\theta$ and $\psi$.)

Note that the data fall into two groups, exhibiting similar water-retention characteristics. The first group (designated in Figure 6-49 as N3650 UL 7.62-7.92 m, N3650 UR 6.71-7.01 m, and $\mathrm{N} 36504.88-5.18 \mathrm{~m}$ ) consists of high-permeability fractures that drain over a narrow range of water potentials. The second group (N3650 UM 4.27-4.57 m, N3650 UM 5.49-5.79 m, N4788 UM 6.10-6.40 m, N4788 UL 7.62-7.93 m, and N4788 UR 5.18-5.48 m) consists of lower-permeability fractures that drain over a relatively larger range of water potentials.

Residual water remaining in the fracture after the initial test can cause subsequent test data (collected during a test performed at a similar rate) to shift to the left, parallel to the x-axis, as shown in Figure 6-50 for test interval N3650 UM 4.27-4.57 m. The second and third tests from this interval were conducted at nearly identical fluxes $\left(9.42 \times 10^{-6}\right.$ versus $\left.9.47 \times 10^{-6} \mathrm{~m} / \mathrm{s}\right)$ separated in time by less than two hours. The wetting front arrived at the niche ceiling during the second test in approximately half the time required for the first test, resulting in a $\Delta \theta$ value that is half that for the second test compared to the first. The fourth and fifth tests in the sequence were performed approximately one and two months later, respectively. Evidence of the effects of wetting history is not readily apparent for these tests, which were conducted at lower fluxes (corresponding to lower water contents), indicating that the fractures drained or dried out prior to retesting.

\subsection{ANALYSES OF TRACER-MIGRATION DELINEATION AT NICHE 2 (NICHE 3650)}

Upon completion of the series of seepage tests at Niche 2 (Niche 3650) described in Section 6.2.1.3.1, an episodic tracer migration test was conducted to elucidate the flow paths above the niche ceiling. The distribution of tracers from both the final tracer migration test and previous liquid-release and seepage-threshold tests are presented in this section. Tracer-stained rock samples were analyzed in the laboratory for the determination of tracer distributions. 


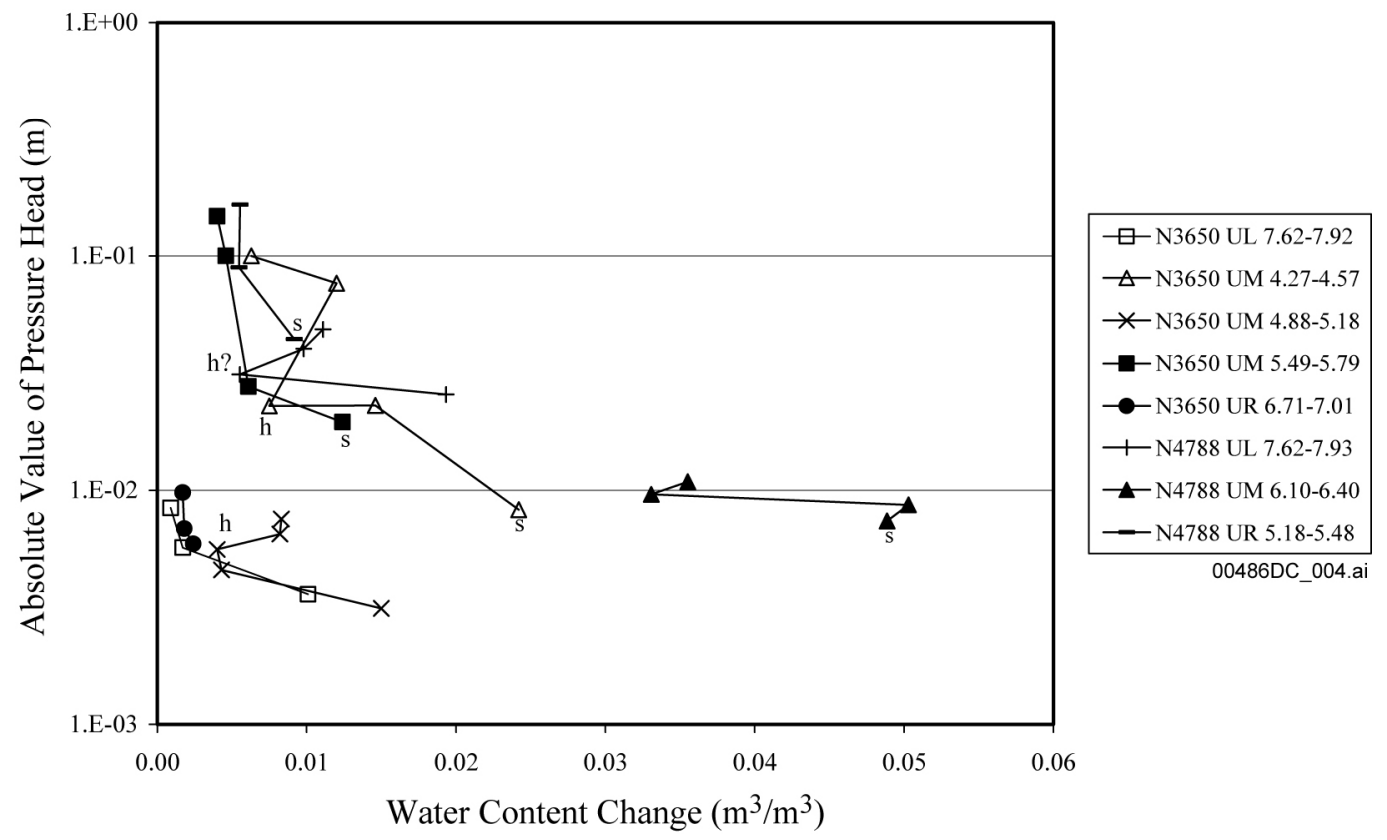

Source: DTN: LB980901233124.003 [DIRS 105592].

Output DTN: LB0110LIQR0015.001.

NOTES: Various data sets were used to generate this figure. See Appendix Tables B-7 and B-8 for details. $\mathrm{s}=$ Saturated conditions.

$\mathrm{h}=$ Data point influenced by wetting history.

Figure 6-49. Water Retention Curves for Fractures

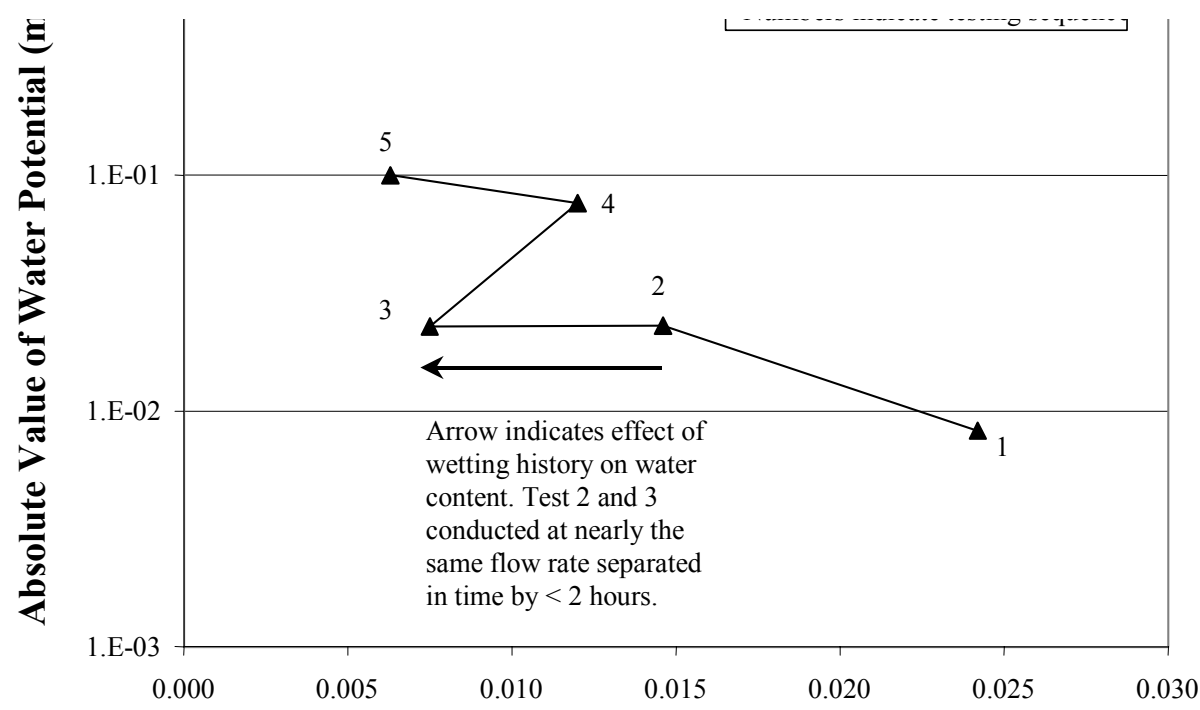

Source: DTN: LB980901233124.003 [DIRS 105592].

NOTE: Various data sets were used to generate this figure. Refer to Appendix Tables B-7 and B-8 for details.

Figure 6-50. Effect of Wetting History on Water Retention Curves for Test Interval N3650 UM 4.27-4.57 m 


\subsubsection{Tracer Distribution from the Tracer-Migration Test}

\subsubsection{Field Studies at Niche 2 (Niche 3650)}

As described in Section 6.1, seven 0.0762-m-diameter boreholes were drilled at Niche 2 (Niche 3650). Three of these boreholes, designated UL, UM, and UR, were drilled approximately $1 \mathrm{~m}$ apart and $0.65 \mathrm{~m}$ above the niche ceiling in the same horizontal plane as shown in Panel (b) of Figure 6-4. An array of twelve sampling boreholes was drilled to collect core samples for tracer analyses, as shown in Figure 6-51. The core analyses delineated the extent of tracer migration from the final episodic liquid-release event as well as for all previous tracer and liquid-release tests.

There were three sets of liquid injection tests conducted at Niche 2 (Niche 3650) in the following order:

1. Before the Niche excavation, liquid release tests with dye-spiked water were conducted in early August 1997, as described in Section 6.2.1.1. Flow paths were observed during niche excavation as described in Section 6.2.1.2.

2. Seepage tests were performed with water on borehole test intervals along Borehole UL, Borehole UM, and Borehole UR positioned above the niche from late 1997 to early 1998, as described in Section 6.2.1.3.1.

3. The episodic tracer migration test was conducted in September 1998, as described in Section 6.3.1.2.

Liquid-release tests were conducted before the niche excavation to evaluate how far a finite pulse of liquid would travel through unsaturated fractured rock (Section 6.2.1). Water containing colored dyes was used to mark the wetted area and flow paths resulting from each test. The niche was then dry-excavated (using an Alpine Miner) to observe and photograph the distribution of fractures and dye within the welded tuff (see Section 6.2.1 of this report, and Wang et al. 1999 [DIRS 106146], pp. 329-332).

Along the three upper boreholes (Borehole UL, Borehole UM, Borehole UR), two Federal Food, Drug, and Cosmetic Act (FD\&C) dyes were released before niche excavation: FD\&C Blue No. 1 and FD\&C Red No. 40. Blue and red bars in Panel (a) of Figure 6-51 on the upper-left side of test-interval locations represent the pre-excavation liquid-release tests.

After niche excavation, a series of short-duration seepage tests was performed to determine the amount of liquid that would seep into the mined opening (Section 6.2.1.3.1). Post-excavation liquid-injection tests were conducted both with and without tracers. Post-excavation tracers included FD\&C Blue No. 1, Sulpho Rhodamine B, Pyranine, FD\&C Yellow No. 6, Acid Yellow 7, and Amino G Acid. The post-excavation seepage test sequences are summarized schematically on the lower right side of test-interval locations in Panel (a) of Figure 6-51.

\subsubsection{Tracer Migration Test}

The tracer migration test was conducted at Niche 2 (Niche 3650) six months after the seepage tests. From September 16, 1998, to September 18, 1998, water containing seven tracers 
(4.60 g/L NaI, $4.60 \mathrm{~g} / \mathrm{L} \mathrm{CaI}_{2}, 4.60 \mathrm{~g} / \mathrm{L} \mathrm{CaBr}_{2}, 1.56 \mathrm{~g} / \mathrm{L}$ FD\&C Blue No. $1,1.76 \mathrm{~g} / \mathrm{L}$ FD\&C Yellow No. 5, $0.019 \mathrm{~g} / \mathrm{L}$ 2,3-difluorobenzoic acid, and $0.018 \mathrm{~g} / \mathrm{L}$ pentafluorobenzoic acid) was released into a highly permeable zone located in Borehole UM, 4.88-5.18 m from the borehole collar. Iodide, bromide, and fluorinated benzoic acids were used as nonreactive tracers; the others were applied as sorbing tracers. The release rate was $0.013 \mathrm{~g} / \mathrm{s}$, with a total released volume of approximately $1.52 \mathrm{~L}$. The wetting front was observed to reach the niche ceiling in a large fracture/breakout, but water did not drip into the niche.

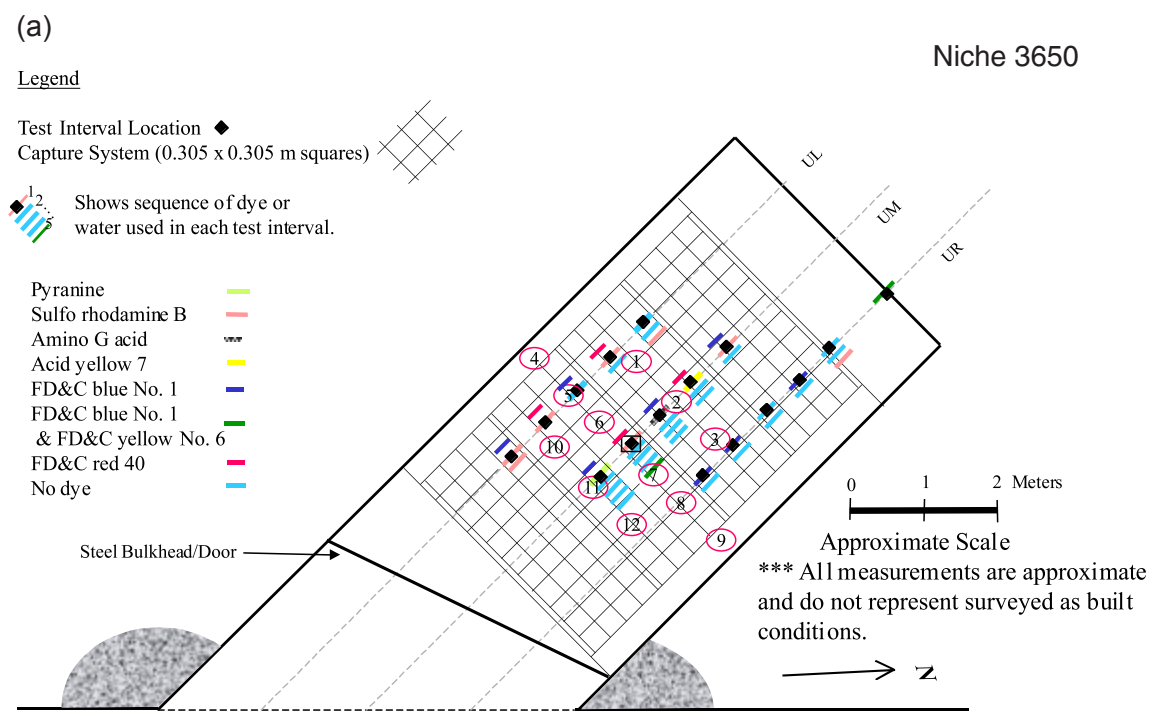

(1) - (12) : twelve radial drill ing boreholes.

: tracer release interval for migration delineation study.

ESF Main Drift

(b)

Niche 3650

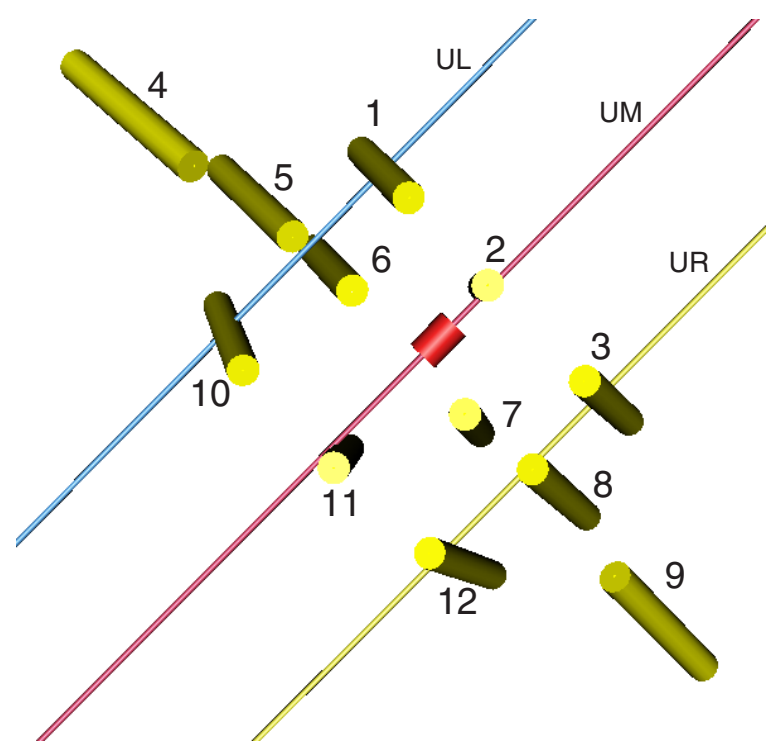

NOTES: The red-colored cylinder denotes the release interval of the tracer migration test.

(a) = Plan view with liquid-release/dye application history.

(b) = 3-D view from inside the niche.

Figure 6-51. Schematic of Sampling Borehole Array 
From September 23 to October 1, 1998, twelve sampling boreholes, nominally $1.5 \mathrm{~m}$ long, were drilled into the niche ceiling around the liquid-release interval to determine the extent of the tracer migration. Rock-core samples were collected during the drilling process for subsequent laboratory chemical analyses. (Refer to Wang 1999 [DIRS 153449], pp. 99-107, 123, and 124 for a detailed description of this tracer migration test.)

Panel (b) of Figure 6-51 shows a 3-D perspective view of the sampling borehole array. The cores from the boreholes were $4.47 \mathrm{~cm}$ in diameter and were divided into sections during coring, with each section separately wrapped in Saran Wrap ${ }^{\circledR}$. Each wrapped sample was placed inside a Lexan ${ }^{\circledR}$ liner (with tape wrapping sealing both ends of the liners) and sealed in a Protecore ${ }^{\circledR}$ packet. The interval for each section was noted on the packet, which was assigned a unique numeric identifier.

The tracer chemical information is shown by $\mathrm{Hu}$ (1999 [DIRS 156541], pp. 154-155), and $\mathrm{Hu}$ (1999 [DIRS 155691], p. 151). Tracer analysis results and discussions are presented as concentration ratios (independent of chemical purity). Appendix E, Sections E2 and E3 describe core sample processing and aqueous tracer measurement for the analyses of tracer distribution.

Iodide and FD\&C Yellow No. 5 concentrations were not detected above background levels in the samples collected from the twelve boreholes drilled around the release interval. Iodide and FD\&C Yellow No. 5 were applied only during the tracer migration test and were not used in earlier seepage tests at Niche 2 (Niche 3650). These results indicate that the sampling borehole array did not capture the tracer plume of the tracer migration test. Liquid migration was most likely localized and very possibly confined within the $1.0-\mathrm{m}-\mathrm{by}-1.6-\mathrm{m}$ area directly below the liquid-release interval.

Several rock-chip samples were collected from the ceiling of Niche 2 (Niche 3650) in March 2001. These samples were obtained directly under the release interval of the tracer migration test (within a radius of approximately $20 \mathrm{~cm}$ ), and within the twelve sampling boreholes. Six samples have been processed for chemical concentration measurements as documented by $\mathrm{Hu}$ (1999 [DIRS 155691], pp. 143-144), and Hu (2000 [DIRS 156473]). Iodide was detected in all six of the analyzed samples, confirming the arrival of iodide from the wetting front observed at the niche ceiling during the tracer migration test. FD\&C Yellow No. 5 was not found among the samples, possibly because of its higher sorption compared to iodide.

\subsubsection{Delineation of Tracer Distributions from Previous Liquid-Release Tests}

Tests before the tracer migration test were conducted at different borehole intervals at various flow rates to determine the seepage thresholds for each interval. A total of 40 liquid-release tests over 16 borehole intervals were conducted at Niche 2 (Niche 3650), using both water with and without dye tracers as shown in Panel (a) of Figure 6-51. The distributions of these tracers were evaluated through the analyses of cores from the twelve sampling boreholes drilled into the flow domains. Examples of measured dye concentration versus borehole interval are shown in Figure 6-52 and Figure 6-53. The distribution of the tracers above the niche is used to assess the extent of tracer spreading and to provide data for the evaluation of seepage processes. 
Tracer data are presented as dimensionless ratios of the detected tracer level to the background level. A higher ratio indicates the stronger presence of the tracer in the particular interval of a borehole. These detection ratios provide sufficient information about the spatial distributions of tracers, reconcile the difference in measurement techniques (i.e., ultraviolet/visible and fluorescence spectrophotometers), and eliminate the need to use and verify chemical purity information provided by the manufacturers. In Section 6.3.2.2, the measured dye distributions are illustrated in three dimensions, based on as-built borehole survey coordinates using EARTHVISION V4.0 software (LBNL 1998 [DIRS 152835]).

\subsubsection{Detection of Tracers}

Several dyes from previous applications of seepage tests (discussed in Section 6.2.1.3.1) were detected within the borehole samples, as summarized in Table 6-12. FD\&C Blue No. 1 was present in seven out of 12 boreholes, with some of the boreholes containing relatively high concentrations of the tracer. Sulpho Rhodamine B was detected within four borehole samples. Overall, the dye distribution pattern was relatively spotty, reflecting the complex interplay of preferential flow paths and liquid application history. All of the previous liquid-release and seepage tests were conducted at least six months before the tracer migration test (see Section 6.3.1).

Table 6-12. Compilation of Tracer Detection versus Borehole Location

\begin{tabular}{|l|c|c|c|c|c|c|}
\hline $\begin{array}{c}\text { Borehole } \\
\text { ID }\end{array}$ & $\begin{array}{c}\text { FD\&C Blue } \\
\text { No. 1 }\end{array}$ & $\begin{array}{c}\text { Sulpho } \\
\text { Rhodamine B }\end{array}$ & $\begin{array}{c}\text { FD\&C Yellow } \\
\text { No. 6 }\end{array}$ & Pyranine & $\begin{array}{c}\text { Acid Yellow 7 } \\
\text { Acid }\end{array}$ & $\begin{array}{c}\text { Amino G } \\
\text { Acid }\end{array}$ \\
\hline 1 & - & +++ & - & - & - & - \\
\hline 2 & +++ & - & - & - & +++++ & + \\
\hline 3 & +++ & - & - & - & - & - \\
\hline 4 & - & - & - & - & - & - \\
\hline 5 & - & - & - & - & - & - \\
\hline 6 & - & - & - & - & - & - \\
\hline 7 & ++++ & +++++ & +++ & - & - & - \\
\hline 8 & +++ & - & - & - & - & - \\
\hline 9 & + & - & - & - & - & - \\
\hline 10 & +++ & ++++ & - & + & & - \\
\hline 11 & ++++ & + & - & +++ & - & - \\
\hline 12 & - & - & - & - & & - \\
\hline
\end{tabular}

Source: DTN: LB990601233124.003 [DIRS 106051].

NOTES: $\quad$ - $\quad=$ Detection ratio is less than 3 (treated as absent) within this particular borehole.

$+\quad=$ The highest detection ratio is between 3 and 100 within this particular borehole.

$+++\quad=$ The highest detection ratio is between 100 and 1,000 within this particular borehole.

$+++++=$ The highest detection ratio is greater than 1,000 within this particular borehole. 

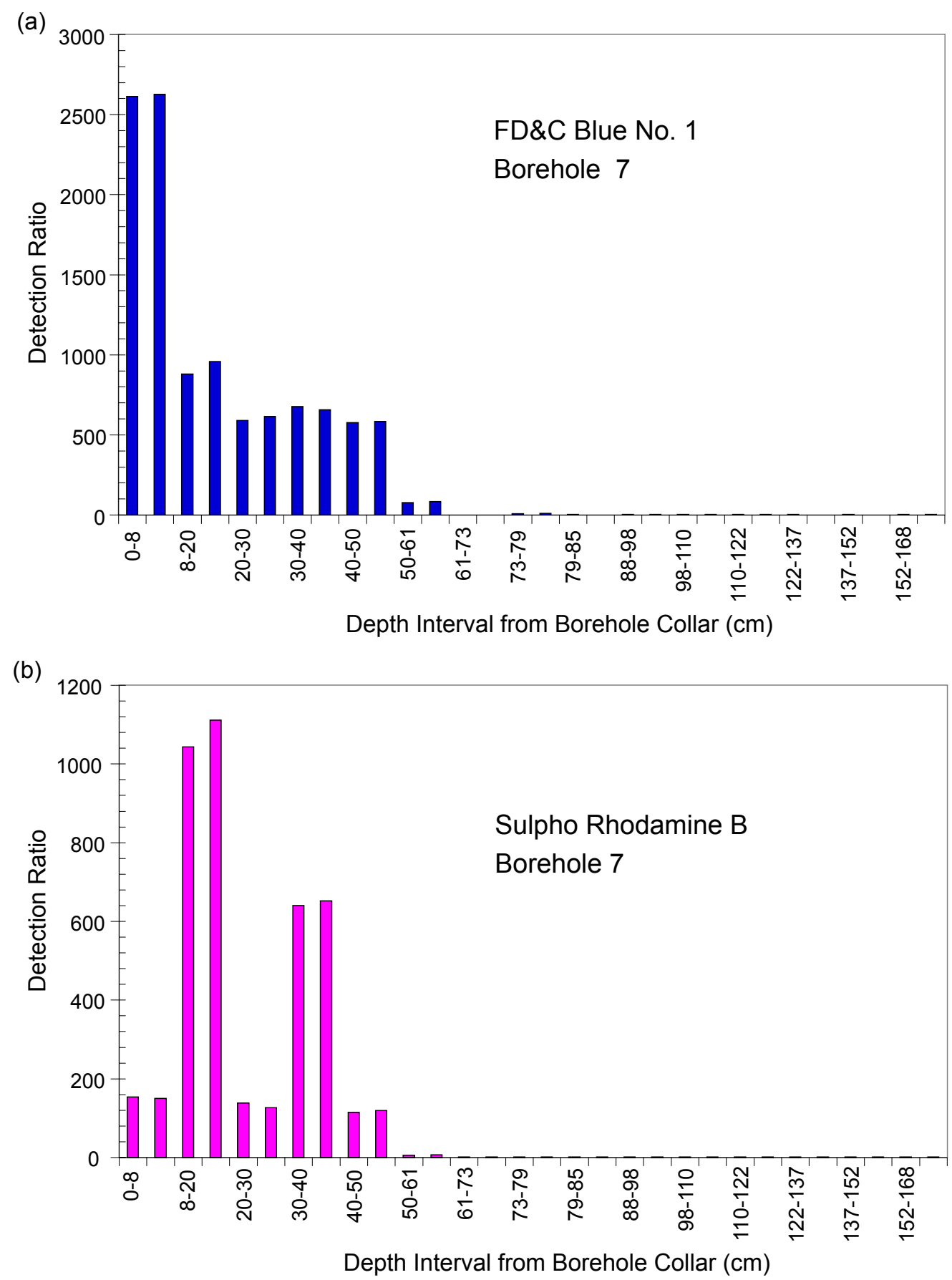

Source: DTN: LB990601233124.003 [DIRS 106051].

NOTES: Duplicate measurements were taken at each specific interval.

(a) = FD\&C Blue No. 1.

(b) = Sulpho Rhodamine B.

Figure 6-52. Dye Detection along Borehole 7 of Niche 3650 


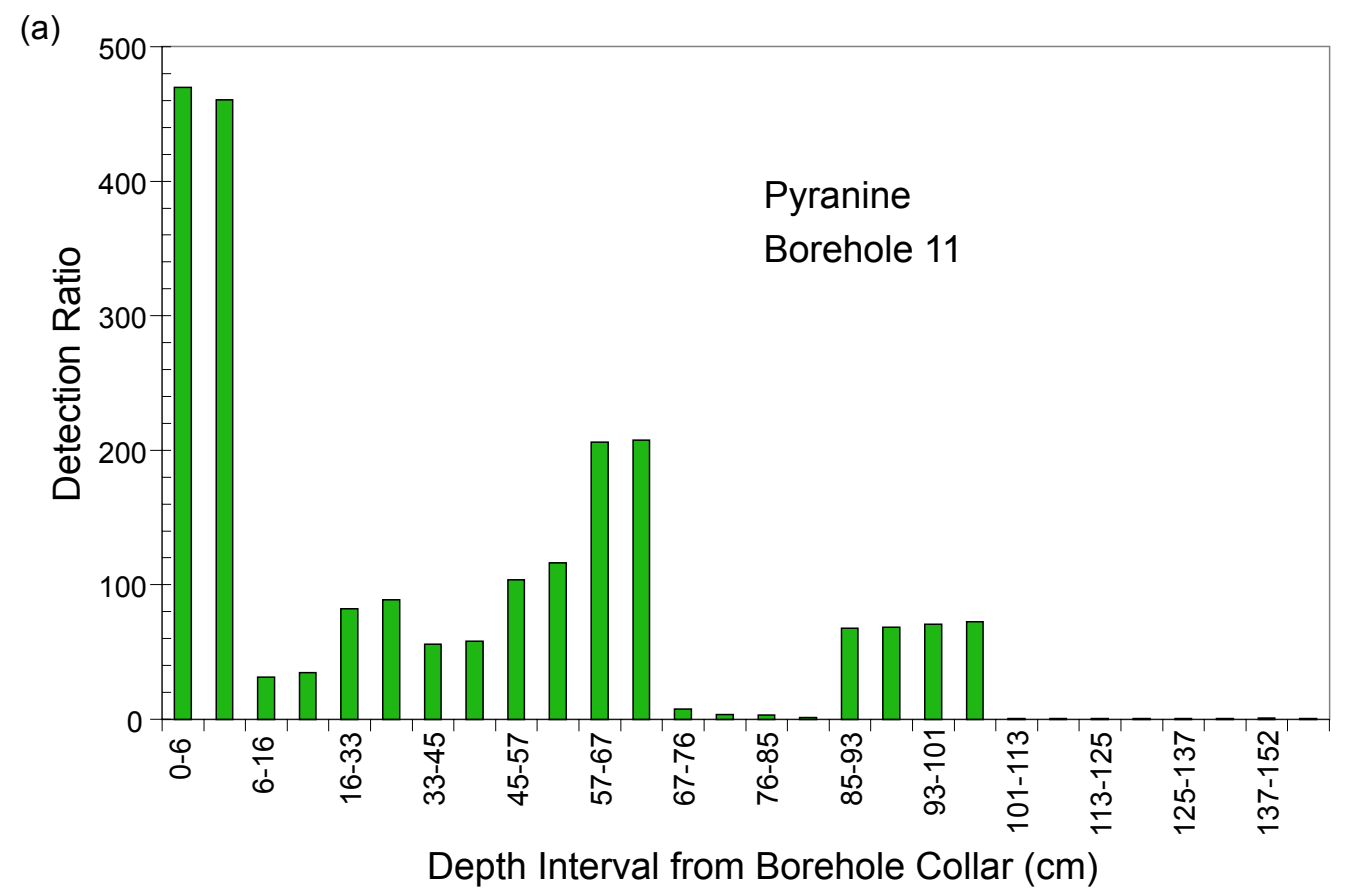

(b)

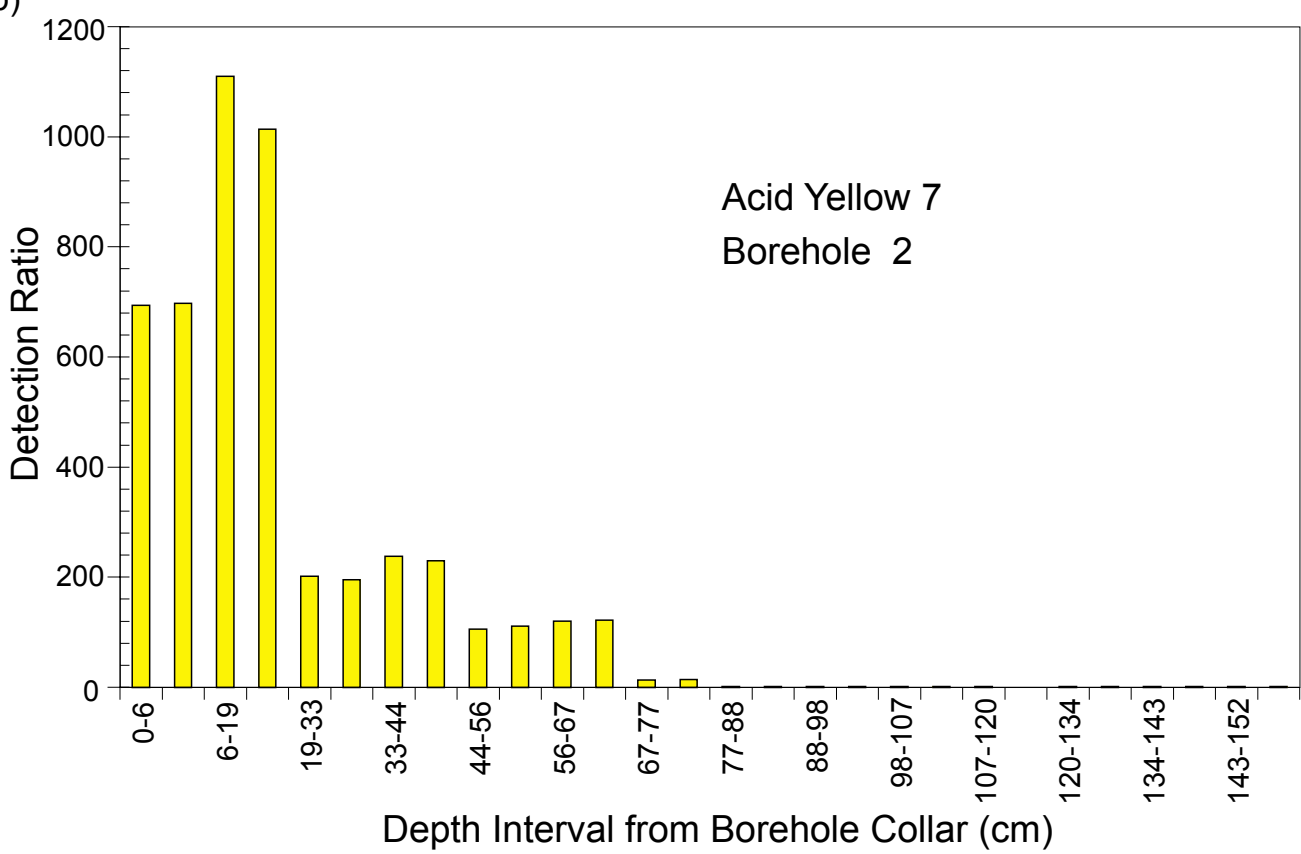

Source: DTN: LB990601233124.003 [DIRS 106051].

Figure 6-53. Dye Detection of (a) Pyranine along Borehole 11 and (b) Acid Yellow 7 along Borehole 2 of Niche 3650 


\subsubsection{Distribution of Dyes}

FD\&C Blue No. 1 was released in six intervals during pre-excavation liquid-release tests and in four intervals during post-excavation seepage tests (including one with a mixture of blue and yellow dyes). The blue dye distributions, together with release-interval locations, are illustrated in Figure 6-54. Boreholes where the tracer was not detected are represented by narrow lines. The multiple releases and dilutions introduced a complex application history. Overall results suggested that most regions containing blue dye were associated with tracer tests from nearby release intervals.

Sulpho Rhodamine B was used in eight seepage tests along seven borehole intervals. Figure 6-55 illustrates the results for Sulpho Rhodamine B. Near Borehole 7, Sulpho Rhodamine B was released once (in the interval UM 4.88-5.18 m), followed by three releases of water without dyes, and once with a mixture of FD\&C Blue No. 1 and FD\&C Yellow No. 6. The Sulpho Rhodamine B in Borehole 7, and near the niche ceiling in Borehole 8, most likely originated from this release episode. There was no Sulpho Rhodamine B detected in Borehole 3, Borehole 9, and Borehole 12. This suggested that the Sulpho Rhodamine B was likely migrating downward, rather than spreading laterally.

In Niche 2 (Niche 3650), Pyranine, Acid Yellow 7, and Amino G Acid were used only once. Pyranine, Acid Yellow 7, and Amino G Acid are fluorescent dyes, and the low detection limits achievable with the fluorescence spectrophotometer provide confidence for the delineation of dye-stained flow paths within the sampling borehole array. Additionally, FD\&C Yellow No. 6 was used once at Borehole UM, Interval 4.88-5.18 $\mathrm{m}$ within the sampling borehole array, and another time at Borehole UL, Interval 7.62-7.92 $\mathrm{m}$ outside the borehole array (Panel (a) of Figure 6-51). The observations from these tracer distributions also showed localized distributions of tracers, confirming downward migration (not the lateral spreading that was observed in the earlier tests).

Pyranine, for example, was detected at neighboring Boreholes 10 and 11; its presence was much stronger at Borehole 10 than at Borehole 11 (Table 6-12 and Figure 6-56). Borehole 11 is located almost exactly below the interval of UM 4.27-4.57 m where Pyranine was released. Four episodes of water-only seepage tests were conducted following this Pyranine application. These liquid releases did not seem to enhance extensive lateral spreading. Overall, the lateral spreading of Pyranine was observed to be approximately $0.75 \mathrm{~m}$ to the left (i.e., at Borehole 10), resulting from these five release tests. However, its presence at Borehole 10 was only slightly above the background level. 
FD\&C Blue No.1
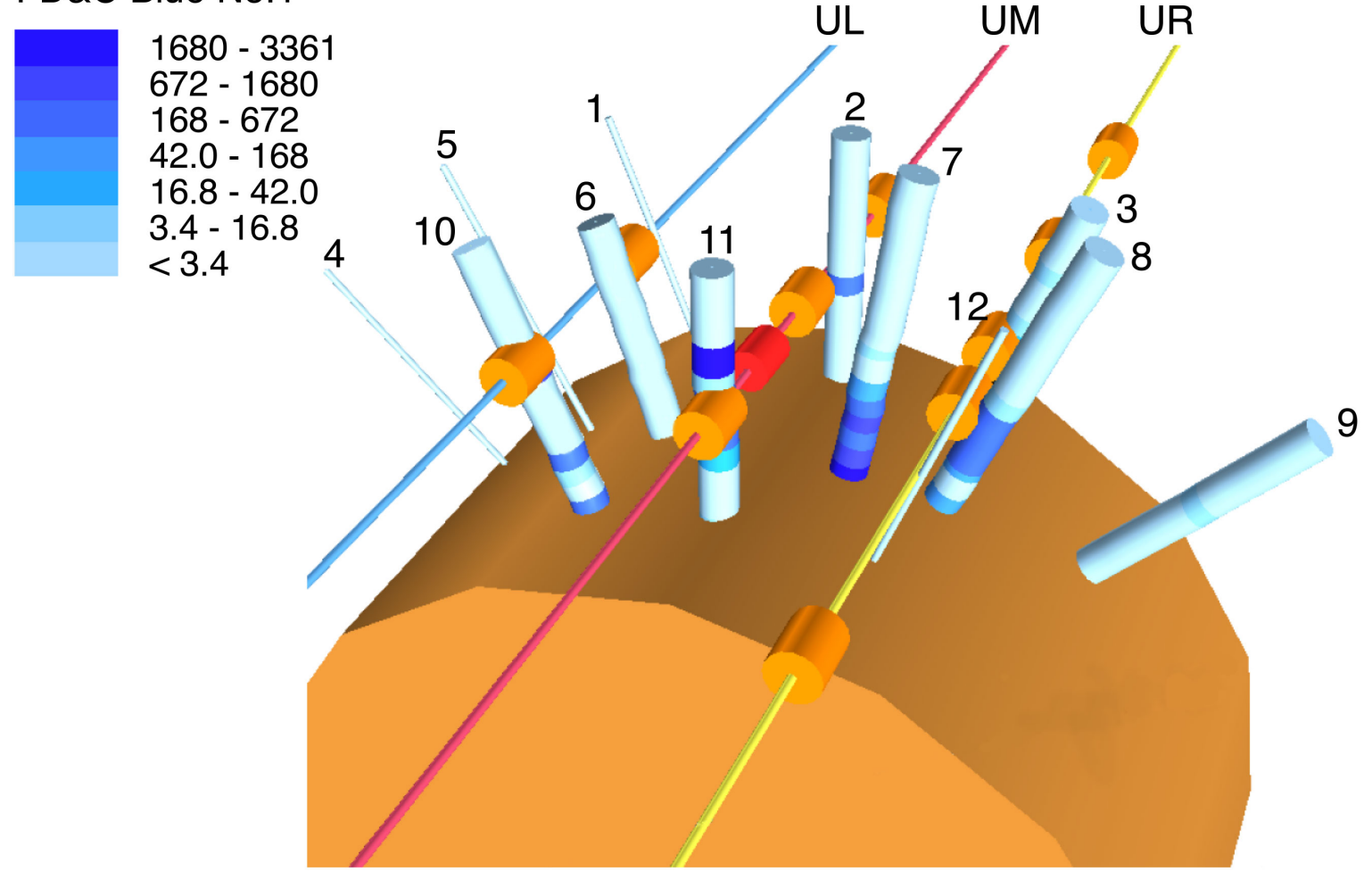

\section{Niche 3650 \\ Exploratory Studies Facility}

Source: DTN: LB990601233124.003 [DIRS 106051].

NOTES: The red cylinder denotes the tracer release interval of the tracer migration test; the orange cylinders denote intervals of early-release events. The sampling boreholes are individually identified. Detection ratios (dimensionless) are presented in the legend. Tracer concentrations are presented in dimensionless detection ratios as described in Section 6.3.2.

Figure 6-54. Three-Dimensional View of FD\&C Blue No. 1 Detection Related to the Release Interval above Niche 2 (Niche 3650) 


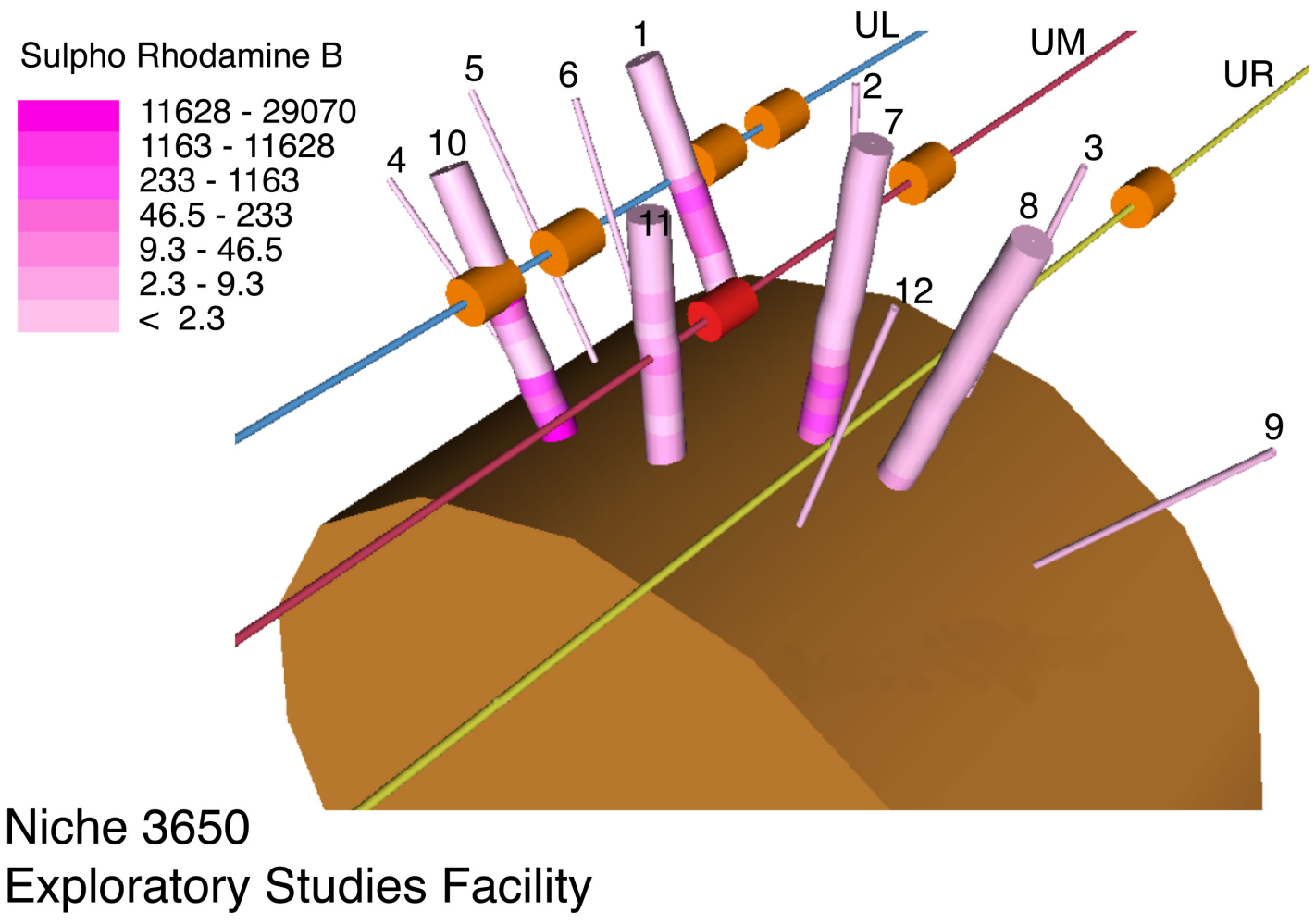

Source: DTN: LB990601233124.003 [DIRS 106051].

NOTES: The red cylinder denotes the tracer release interval of the tracer migration test; the orange cylinders denote intervals of early-release events. The sampling boreholes are individually identified. Detection ratios (dimensionless) are presented in the legend. Tracer concentrations are presented in dimensionless detection ratios as described in Section 6.3.2.

Figure 6-55. Three-Dimensional View of Sulpho Rhodamine B Detection Related to the Release Interval above Niche 2 (Niche 3650) 


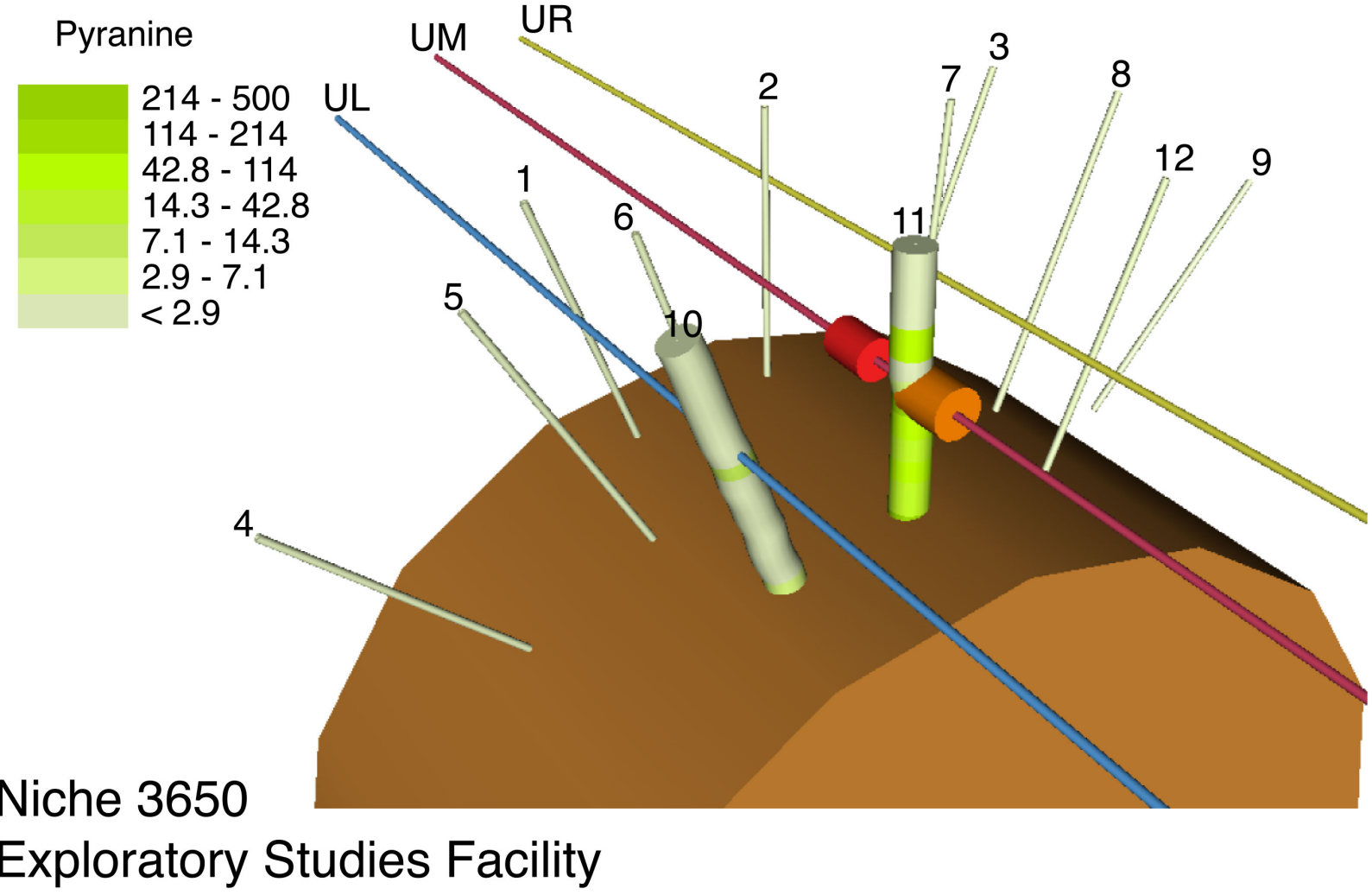

Source: DTN: LB990601233124.003 [DIRS 106051].

NOTES: The red cylinder denotes the tracer release interval of the tracer migration test; the orange cylinderdenotes an interval of an early-release event. The sampling boreholes are individually identified. Detection ratios (dimensionless) are presented in the legend. Tracer concentrations are presented in dimensionless detection ratios as described in Section 6.3.2.

Figure 6-56. Three-Dimensional View of Pyranine Detection Related to the Release Interval above Niche 2 (Niche 3650)

Acid Yellow 7 was detected only at Borehole 2, approximately $0.3 \mathrm{~m}$ from Interval UM 6.10-6.40 $\mathrm{m}$ where it was released (see Figure 6-57). Amino G Acid was also detected near the detection limit at Borehole 2, approximately $0.3 \mathrm{~m}$ from Interval UM 5.49-5.79 $\mathrm{m}$ where it was released (see Figure 6-58). Note that although the Interval UM 5.49-5.79 $\mathrm{m}$ was encompassed within the sampling borehole array, Amino G Acid was not detected in any other borehole. 


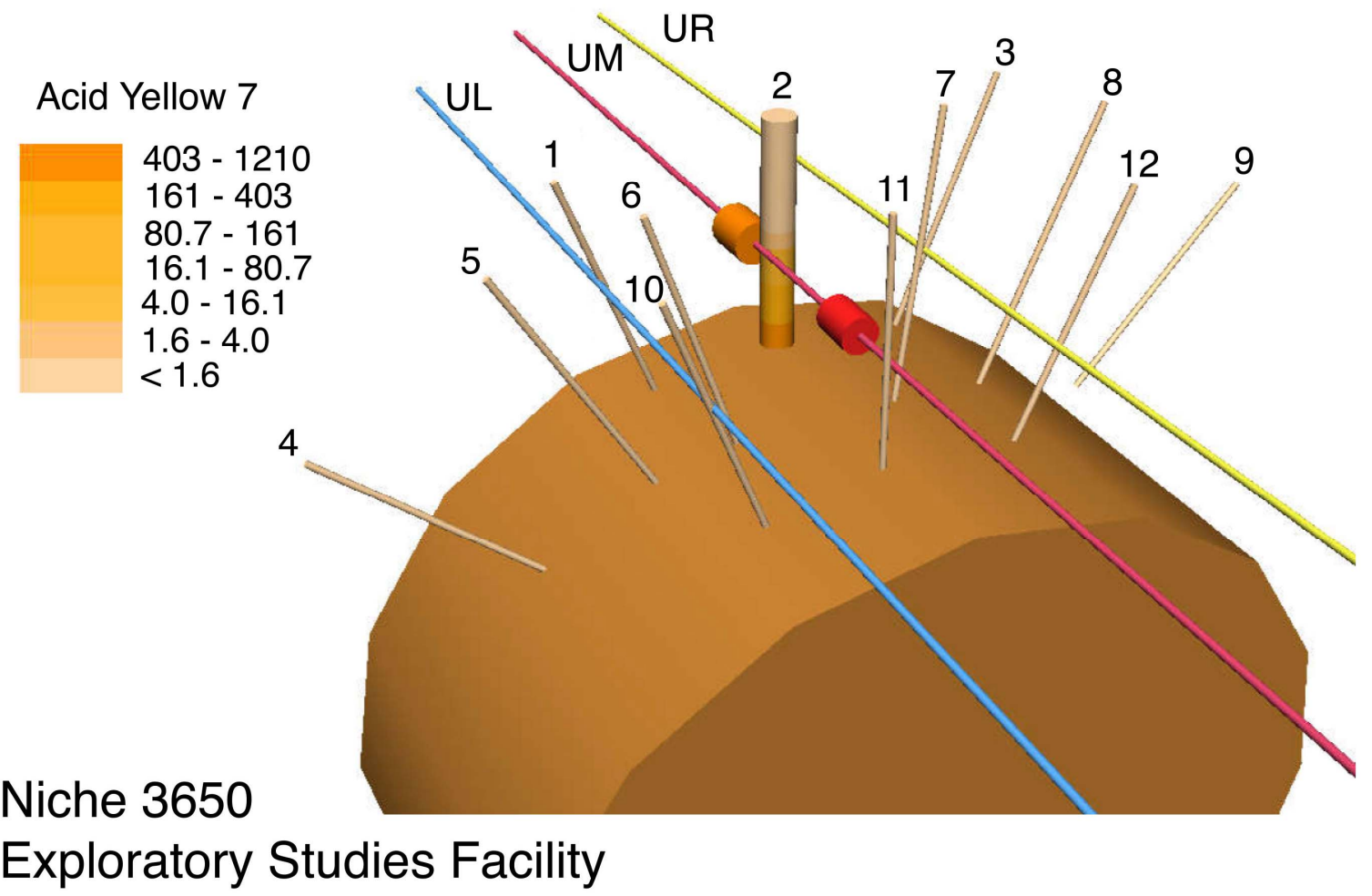

Source: DTN: LB990601233124.003 [DIRS 106051].

NOTES: The red cylinder denotes the tracer-release interval of the tracer migration test; the orange cylinder denotes an interval of an earlier release event. The sampling boreholes are individually identified. Detection ratios (dimensionless) are presented in the legend. Tracer concentrations are presented in dimensionless detection ratios as described in Section 6.3.2.

Figure 6-57. Three-Dimensional View of Acid Yellow 7 Detection Related to the Release Interval above Niche 2 (Niche 3650) 


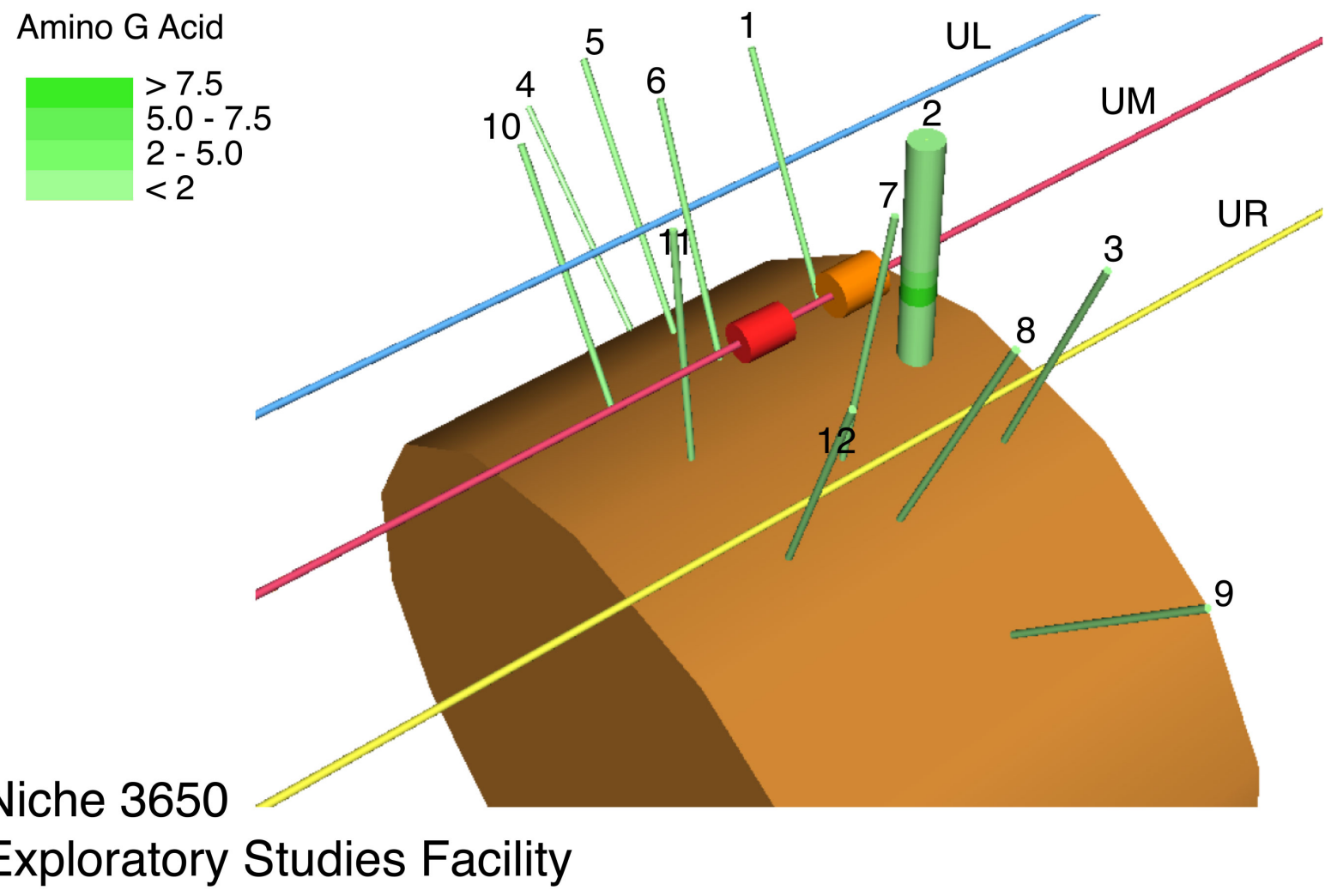

Source: DTN: LB990601233124.003 [DIRS 106051].

NOTES: The red cylinder denotes the tracer release interval of the tracer migration test; the orange cylinder denotes an interval of an early-release event. The sampling boreholes are individually identified. Detection ratios (dimensionless) are presented in the legend. Tracer concentrations are presented in dimensionless detection ratios as described in Section 6.3.2.

Figure 6-58. Three-Dimensional View of Amino G Acid Detection Related to the Release Interval above Niche 2 (Niche 3650)

The last dye distribution shown pertains to FD\&C Yellow No. 6 (Figure 6-59). The dye was present at Borehole 7. Borehole 7 was approximately $0.5 \mathrm{~m}$ from Interval UM 4.88-5.18 m where both FD\&C Yellow No. 6 and FD\&C Blue No. 1 were simultaneously released. This release episode had one of the lowest release rates $(0.013 \mathrm{~g} / \mathrm{s})$, and one of the largest release volumes $(5597 \mathrm{~g})$ of all liquid-release tests conducted at Niche 2 (Niche 3650) (see Section 6.2). Borehole 7 is located in the middle of the sampling borehole array. The observation that FD\&C Yellow No. 6 was only present in Borehole 7 further demonstrated the localized characteristics of liquid flow with limited lateral spreading, even in this case with comparatively large release volume. 


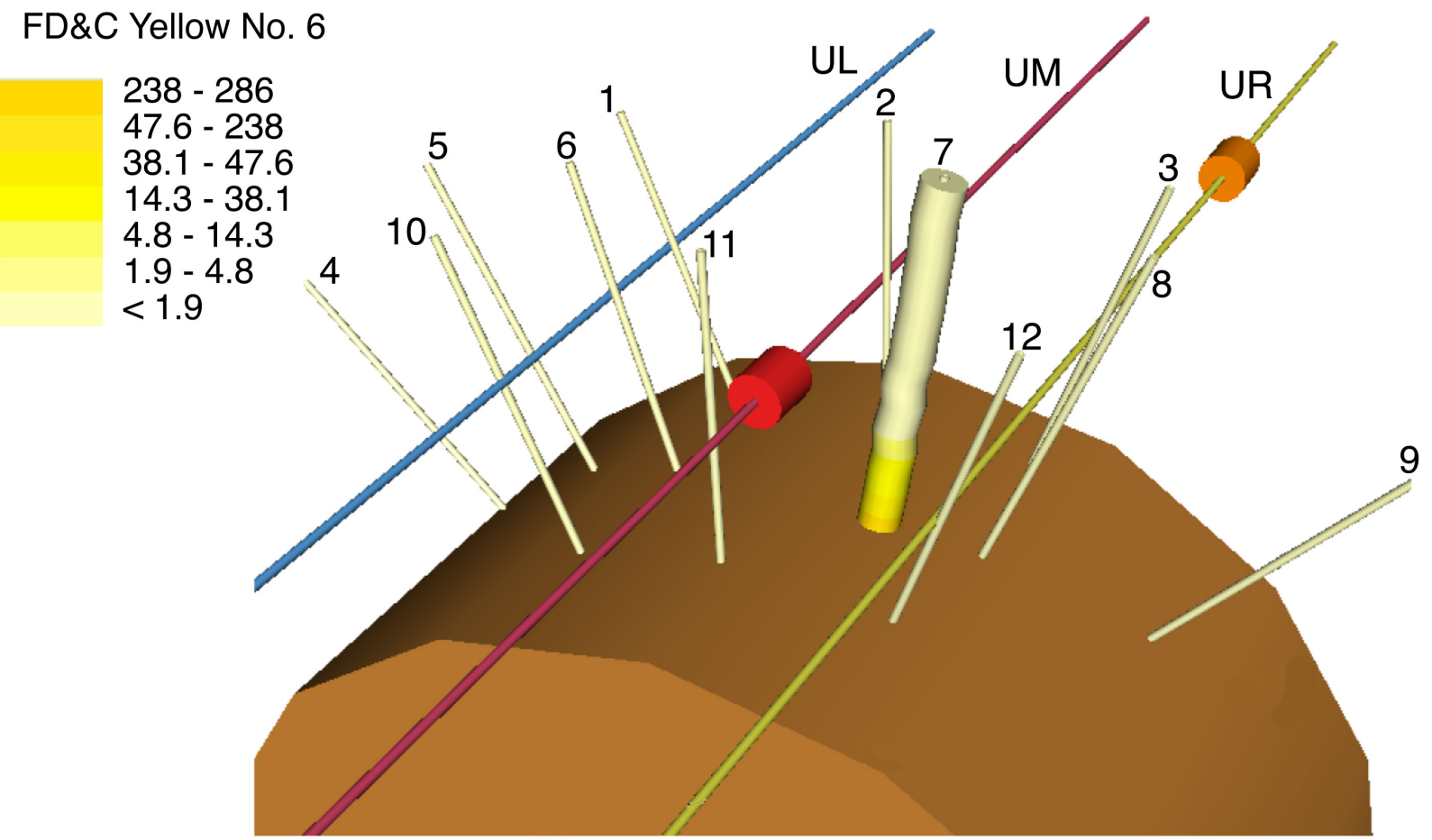

\section{Niche 3650 \\ Exploratory Studies Facility}

\section{Source: DTN: LB990601233124.003 [DIRS 106051].}

NOTE: The red cylinder denotes the tracer release interval of the tracer migration test; the orange cylinder denotes an interval of an early-release event. (One of the two release intervals is the same as the last release event, represented by the red cylinder.) The sampling boreholes are individually identified. Detection ratios (dimensionless) are presented in the legend. Tracer concentrations are presented in dimensionless detection ratios as described in Section 6.3.2.

Figure 6-59. Three-Dimensional View of FD\&C Yellow No. 6 Detection Related to the Release Intervals above Niche 2 (Niche 3650) 
The dye distribution plots also indicate that some dyes migrated above the injection intervals, as illustrated in Figure 6-54 for FD\&C Blue No. 1, in Figure 6-56 for Pyranine; and to a lesser degree in Figure 6-55 for Sulpho Rhodamine B, in Figure 6-57 for Acid Yellow 7, and in Figure 6-58 for Amino G Acid. This is an interesting observation, indicating that fairly strong capillary forces may induce upward movements against gravity. Similar behavior was also observed in the Busted Butte test, as described in Section 6.13.3.1.1.

\subsection{ANALYSES OF TRACER PENETRATION AND WATER IMBIBITION INTO WELDED TUFF MATRIX}

The objectives of this study are to investigate water flow and tracer transport, focusing on the relative extents of fracture flow and fracture-matrix interaction in the unsaturated, fractured tuff through a combination of field and laboratory experiments. Fieldwork was conducted in the ESF niches with liquid containing tracers released at specified borehole intervals. Tracer-stained rock samples were collected during niche excavation for subsequent laboratory analyses. Clean rock samples, collected from the same stratigraphic unit, were machined into cylinders for laboratory studies of tracer penetration into the rock matrix under different initial water-saturation levels. The use of laser-ablation inductively coupled-plasma mass spectrometry (ICP-MS) to investigate chemical transport and sorption in unsaturated tuff is also presented.

\subsubsection{Penetration of Dyes into Rocks from the Niches}

Samples for laboratory analyses were collected from Niche 2 (Niche 3650) and Niche 4 (Niche 4788). The niche test sites, borehole configurations, liquid-release tests, and tracers used in the field are described in Section 6.2 and Section 6.3. Laboratory tests under controlled conditions were conducted to compare the travel front behavior of moisture, nonreactive bromide, and sorbing dye tracers (FD\&C Blue No. 1 and Sulpho Rhodamine B). Sample drilling and tracer profiling techniques were developed. The descriptions and evaluations of laboratory analyses are presented in Appendix E.

\subsubsection{Field Observations}

During the niche excavation, as described in Section 6.2.1.2, dye was observed along individual fractures and intersecting fractures to a maximum depth of $2.6 \mathrm{~m}$ below the liquid-release points at Niche 2 (Niche 3650), and to a maximum depth of approximately $1.8 \mathrm{~m}$ at Niche 4 (Niche 4788). In general, the dye remained relatively close to the release interval and did not spread laterally more than $0.5 \mathrm{~m}$. Figure 6-60 is a photograph taken during the excavation of Niche 4 (Niche 4788), showing the wall face with the fracture network stained by FD\&C Blue No. 1. Results of post-excavation liquid-seepage tests at Niche 2 (Niche 3650) also indicate fast fracture flow with limited lateral spreading, because seepage water was captured in trays that are either directly below the test interval or next to them. 


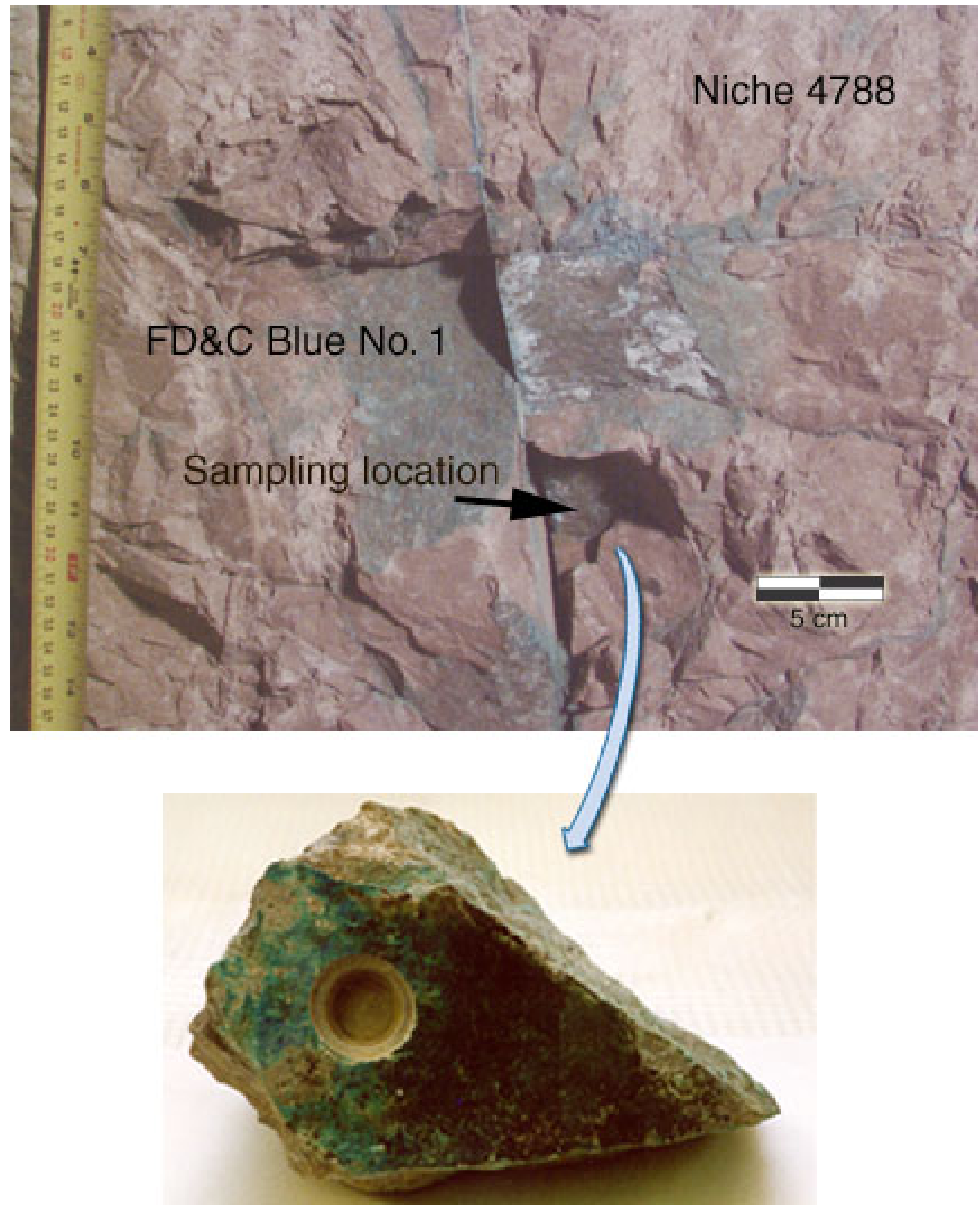

Source: Hu et al. (2002 [DIRS 165412], Figure 2).

NOTE: Stained by FD\&C Blue No. 1 during pre-excavation tests at Niche 4 (Niche 4788).

Figure 6-60. Photograph Showing the Wall Face of Niche 4 (Niche 4788) with Fracture Network and Sampling Location of Rock, and Stained Rock Sample 


\subsubsection{Dye Penetrations into Rocks}

Visual inspection of dyed rocks collected from the field studies showed that the dye stained the fracture surfaces and the color decreased with distance from the dye release point and disappeared within a few millimeters of the fracture surfaces (Figure 6-60). The plot of Sulpho Rhodamine B detection ratio versus depth from the fracture surface is shown in Figure 6-61. (The dimensionless detection ratio is the measured tracer level divided by the background level.) The depth on the x-axis denotes the mid-point of the drilling interval. For example, the measured tracer concentration from a 1 to $2 \mathrm{~mm}$ drilling interval is shown at the $1.5 \mathrm{~mm}$ location from the sample surface. For three rock samples stained with either FD\&C Blue No. 1 or Sulpho Rhodamine $\mathrm{B}$, each dye concentration decreased from the highest concentration to the background level in less than 6-7 $\mathrm{mm}$. These results quantify the noticeable tracer matrix imbibitions from liquid flowing through the fractures.

Table 6-13 provides relevant experimental conditions used during the liquid-release tests resulting in the three dyed rock samples collected during excavation. The samples were collected 7 to 13 days after the dye-spiked water was released into the formation.

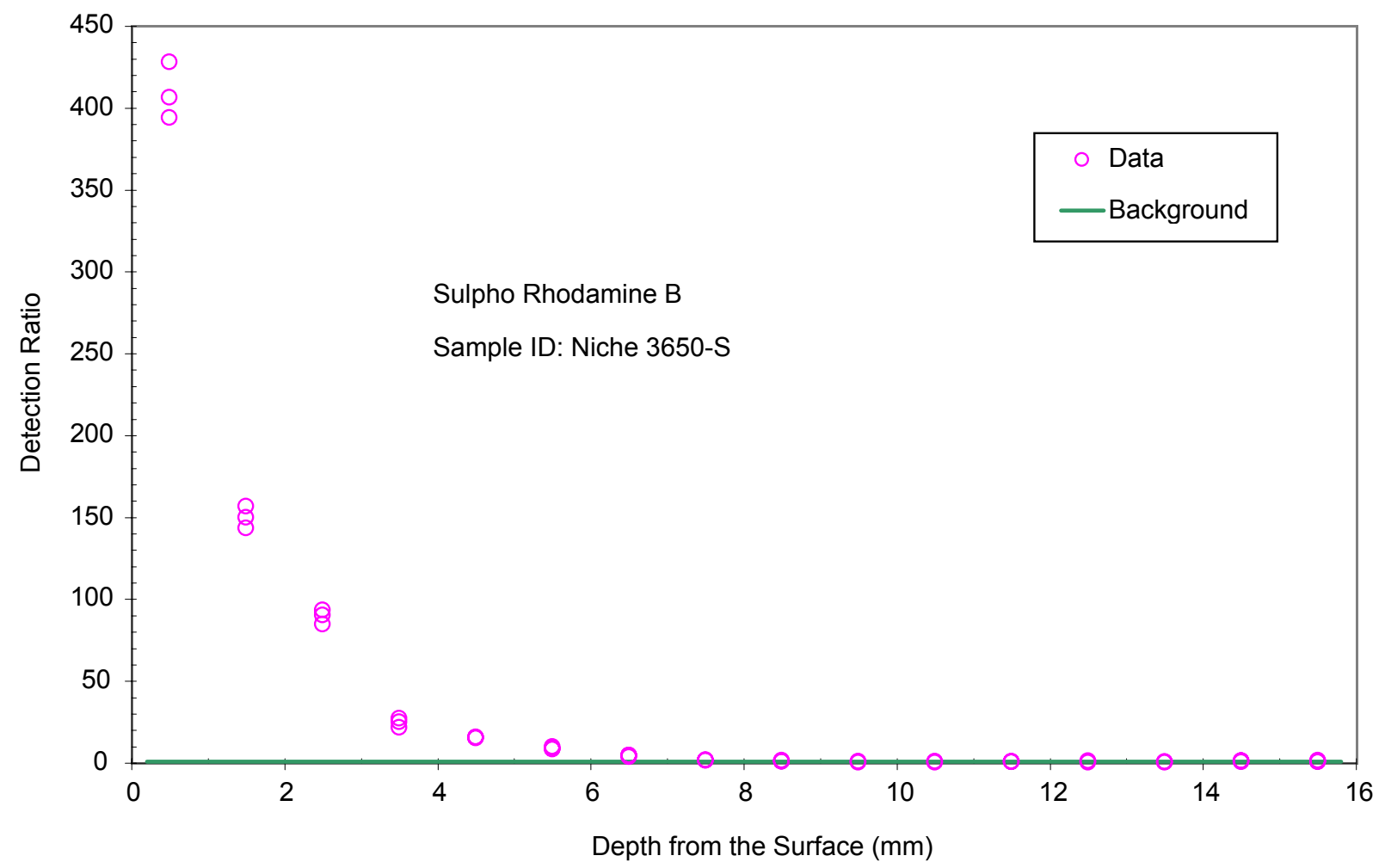

Source: DTN: LB990901233124.003 [DIRS 155690].

Figure 6-61. Sulpho Rhodamine B Penetration Profiles into Rock Matrix from the Fracture Surface 
Table 6-13. Liquid-Release Tests and Experimental Conditions

\begin{tabular}{|c|c|c|c|c|c|c|c|}
\hline Tracer & $\begin{array}{l}\text { Test } \\
\text { Date }\end{array}$ & Test Location $^{c}$ & $\begin{array}{l}\text { Tracer } \\
\text { Conc. } \\
\text { (g/L) }\end{array}$ & $\begin{array}{c}\text { Release } \\
\text { Rate } \\
(\mathbf{g} / \mathbf{s})\end{array}$ & $\begin{array}{c}\text { Release } \\
\text { Duration } \\
\text { (min) }\end{array}$ & $\begin{array}{c}\text { Mass } \\
\text { Released } \\
\text { (g) }\end{array}$ & $\begin{array}{c}\text { Sampling } \\
\text { Date }\end{array}$ \\
\hline $\begin{array}{l}\text { Sulpho } \\
\text { Rhodamine B }\end{array}$ & $8 / 8 / 97$ & ML 6.71-7.01 m & 2.0 & 2.0 & 8.22 & 170.9 & $8 / 19 / 97$ \\
\hline FD\&C Blue No. $1^{a}$ & $8 / 6 / 97$ & UM 6.71-7.01 m & 7.7 & 1.9 & 8.20 & 438.7 & $8 / 19 / 97$ \\
\hline FD\&C Blue No. $1^{b}$ & $7 / 2 / 98$ & UM 6.40-6.70 m & 6.77 & 0.49 & 35.0 & 1019.7 & $7 / 9 / 98$ \\
\hline
\end{tabular}

Sources: DTNs: LB980001233124.004 [DIRS 136583], LB980901233124.003 [DIRS 105592].

a Tests conducted at Niche 2 (Niche 3650) location.

${ }^{\mathrm{b}}$ Test conducted at Niche 4 (Niche 4788) location.

${ }^{c}$ Depth measurement (in meters) is from the collar of the borehole to the test interval.

FD\&C $=$ Federal Food, Drug \& Cosmetics Act.

Water flow in the post-excavation seepage tests was found to be very rapid, traversing $0.65 \mathrm{~m}$ in approximately 4 minutes, at a release rate of approximately $1.9 \mathrm{~g} / \mathrm{s}$ (Table 6-14). It is therefore expected that the fluid-rock contact time is relatively short. Short transport times, together with high ratios of dye concentration in seepage water versus release water (in the far-right column of Table 6-14), indicate that the contacts between flowing water in the fractures and the tuff matrix were highly transient. The exact duration of contacts on the fracture surfaces could not be measured.

Table 6-14. Post-Excavation Tracer-Release Tests at Niche 2 (Niche 3650)

\begin{tabular}{|l|c|c|c|c|c|c|}
\hline \multicolumn{1}{|c|}{ Tracer } & Test Location ${ }^{\text {a }}$ & $\begin{array}{c}\text { Release } \\
\text { Rate } \\
(\mathbf{g} / \mathbf{s})\end{array}$ & $\begin{array}{c}\text { Mass } \\
\text { Released } \\
(\mathbf{g})\end{array}$ & $\begin{array}{c}\text { Mass of } \\
\text { Seepage } \\
\text { Recovered } \\
(\mathbf{g})\end{array}$ & $\begin{array}{c}\text { Wetting Front } \\
\text { Arrives at } \\
\text { (min:sec) }\end{array}$ & $\begin{array}{c}\text { Ratio of } \\
\text { Seepage } \\
\text { vs. Release } \\
\text { Conc. (\%) }\end{array}$ \\
\hline Sulpho Rhodamine B & UL 7.01-7.32 m & 1.949 & 1005.5 & 16.0 & $4: 00$ & 95.6 \\
\hline FD\&C Blue No. 1 & UR 4.27-4.57 m & 0.198 & 995.7 & 4.0 & $56: 08$ & 77.0 \\
\hline FD\&C Blue No. 1 & UR 4.88-5.18 m & 0.190 & 1016.4 & 4.0 & $29: 50$ & 103.9 \\
\hline
\end{tabular}

Source: DTN: LB980001233124.004 [DIRS 136583].

a Depth measurement (in meters) is from the collar of the borehole to the test interval.

b Time wetting front arrives at niche ceiling following the start of water release to the formation. Summary data are found in DTN: LB990901233124.003 [DIRS 155690].

FD\&C $=$ Federal Food, Drug, and Cosmetic Act.

\subsubsection{Fast Fracture Flow}

Fast fracture flow was demonstrated during the post-excavation seepage tests where dye-spiked water was released and collected, if possible, at the collection system below the niche ceiling. The last column of Table 6-14 shows the ratios of collected to released concentrations for FD\&C Blue No. 1 and Sulpho Rhodamine B. The average seepage versus release-concentration ratio is $92.2 \pm 13.8$ percent over three tests with dyes. The seepage solution is a composite sample, which could be diluted by the resident water, if any, in the flowing fractures. Also, note that the release concentrations were obtained from the known dye mass dissolved in the known liquid volume, and no liquid sample was collected for the released solution during these tests. This uncertainty could contribute to the ratio of 103.9 percent (over the theoretical limit of 
100 percent) for one of the FD\&C Blue No. 1 tests. Significant dilutions (approximately 1,000 times), needed to bring the sample concentration down to the linear standard curve needed for measurement, could also contribute to the uncertainty.

\subsubsection{Concentration Profiles of Dye Tracer}

For the dye-stained samples from the field, tracer concentrations were measured on rock powders collected from drilling intervals of the rock. Two FD\&C Blue No. 1 dye profiles are illustrated in Figure 6-62. The scales of detection ratios described in Section 6.4.1.2 are plotted on the left side. The scales of concentration ratios of measured concentration $C$ divided by the released concentration $C_{o}, C / C_{o}$, are plotted on the right side. The first few millimeters from the fracture surface contain the key portion of the tracer concentration profiles that indicate the extent of fracture-matrix interaction (Hu et al. 2002 [DIRS 165412], p. 106).

Panel (a) of Figure 6-62 for the sample Niche 2-F (Niche 3650-F) has relatively low values of $C / C_{o}$ (compared with those obtained with Core $\mathrm{D}$ and Core $\mathrm{H}$ to be discussed in Section 6.4.2) for the first millimeter (i.e., $0-1 \mathrm{~mm}$ from the fracture surface). This sample could be associated with fast transient flow. Noticeable water and tracer imbibition into the surrounding matrix was observed, even though fracture flow could have been fast.

In contrast, Panel (b) of Figure 6-62 for sample Niche 4 (Niche 4788) has a high value of $C / C_{o}$ in the first millimeter. This sample was collected next to a vertical flowing fracture that apparently dead-ended near the sampling location (Figure 6-60). For this sample, the fluid-rock contact time could have been longer, contributing to the higher concentration ratio at the first interval. The measured concentration ratio in the second (1-2 $\mathrm{mm})$ interval drops drastically to a level similar to the samples in Panel (a) of Figure 6-62. With longer contact time, stronger surface sorption of the dye might also have occurred in this rock sample. The dye patterns observed in the samples highlight the fact that flow in the factures and matrix are coupled, but governed by different processes that need to be considered when interpreting data.

\subsubsection{Retardation and Tracer Front Movement}

Laboratory tests were conducted to quantify the imbibition of water and the retardation of tracers into rock cores. In the laboratory, tests can be conducted under controlled conditions, with concentrations in rock samples and in the core reservoir measured simultaneously. The flow paths along cores are well defined compared to the flow paths in the field. The laboratory test results can assist in interpreting data collected on dye-stained samples from the field tests.

Two approaches are presented for measuring the retardation factor: front separation and local measurements at the core-reservoir contact, where the sample is saturated. The consistency between these two approaches lends credence to the quantification of retardation factors on core samples. 

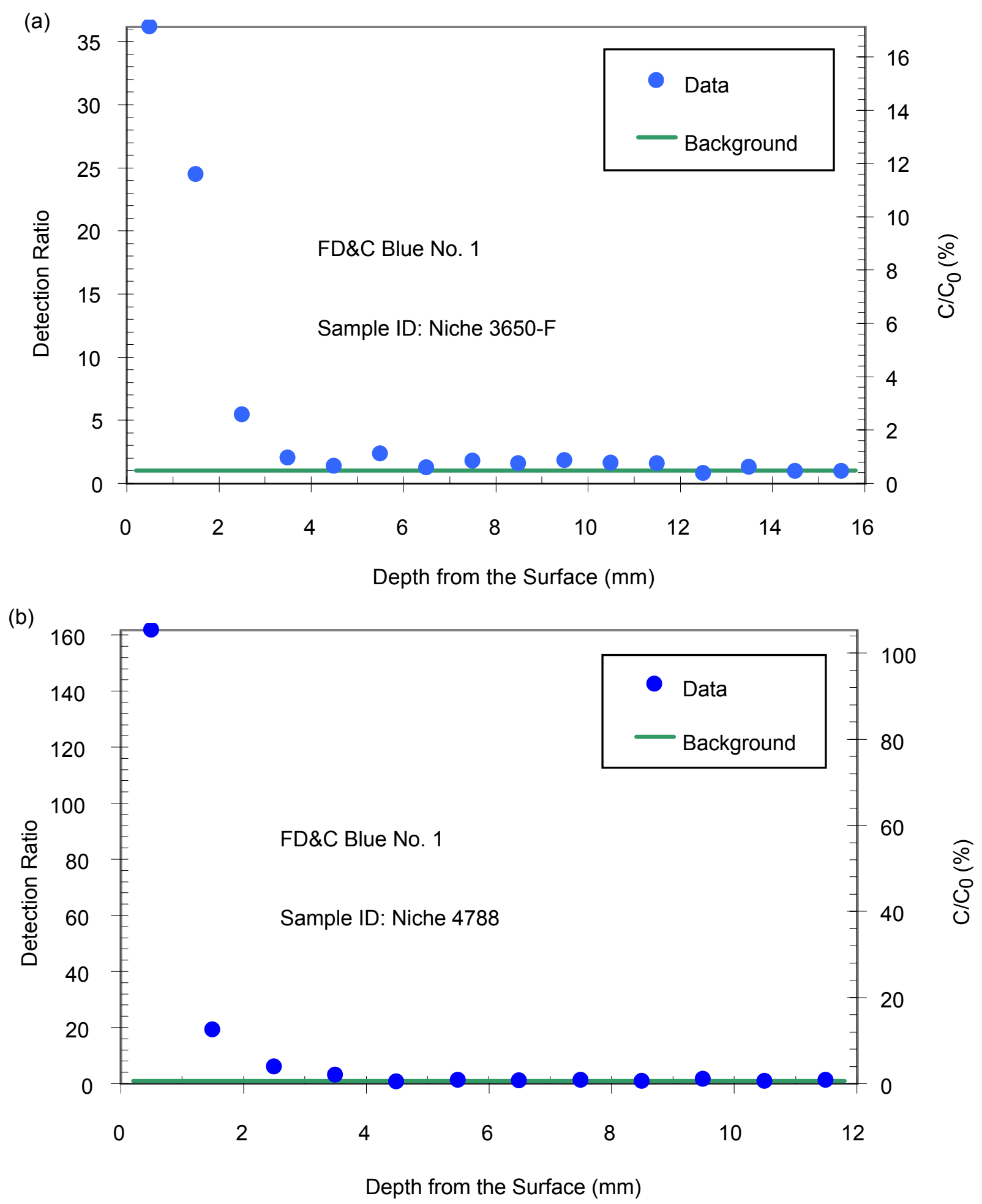

Source: DTN: LB990901233124.003 [DIRS 155690].

NOTES: $\quad(a)=$ FD\&C Blue No. 1 from samples taken at Niche 2 (Niche 3650 ).

(b) = FD\&C Blue No. 1 from samples taken at Niche 4 (Niche 4788).

Figure 6-62. Tracer Penetration Profile from the Fracture Surface into Rock Matrix 


\subsubsection{Dye Retardation Factor Determined by Front Separation}

The descriptions and evaluations of laboratory tracer tests on core samples are presented in Appendix E. Figures 6-63 and 6-64 compare the concentration profile of nonreactive bromide with the concentration profiles of both FD\&C Blue No. 1 and Sulpho Rhodamine B, relative to the moisture fronts obtained from visual inspection. The dyes lag behind the bromide front, indicating dye sorption to the rock. FD\&C Blue No. 1 and Sulpho Rhodamine B were the most visible in the tuffs of the tested dyes. Sorption of these dyes on rock is not surprising, considering their complex chemical structure with various functional groups, even though they are negatively charged under normal $\mathrm{pH}$ conditions.

From the tracer profiles, the retardation factor $R$ can be derived as the ratio of travel distance of nonreactive tracer divided by the travel distance of sorbing tracer. For practical purposes, bromide can be considered a nonreactive tracer in tuff, as indicated by its nearly coincident front with the wetting front at low initial water saturation. In Figure 6-63 for Core D at low initial saturation, the bromide front is located at 17 to $18 \mathrm{~mm}$ from the core bottom $\left(d_{0.5}=17.5 \mathrm{~mm}\right.$, where $d_{0.5}$ is the depth at which the concentration is half of the steady-state concentration in the profile). The first data point at the 0 to $1 \mathrm{~mm}$ interval was excluded for bromide front determination. The 0 to $1 \mathrm{~mm}$ interval measurement was systematically higher than those at deeper intervals and was consistently observed for bromide in all core measurements. Because the 0 to $1 \mathrm{~m}$ interval at the core-reservoir interface is in direct contact with the tracers, it is not included in the calculation of the travel distance used to determine the retardation factor $(R)$. This does not seem to affect the sorbing tracers (FD\&C Blue No. 1 and Sulpho Rhodamine B), as evident in the steady-state concentration of the first three intervals in Core D (Figure 6-63). For the sorbing tracers, $d_{0.5}$ is located at $3.5 \mathrm{~mm}$ (Figure 6-63). The retardation factor for both dyes is estimated to have the value $5(=17.5 \mathrm{~mm} / 3.5 \mathrm{~mm})$. Similarly, $R$ is estimated to be $2.33(=3.5 \mathrm{~mm} / 1.5 \mathrm{~mm})$ for both dyes in Core $\mathrm{H}$ with high initial liquid saturation $S_{w}$ (Figure 6-64).

The saturation dependence of the retardation factor is derived from the following functional relationship (Porro and Wierenga 1993 [DIRS 134083], pp. 193-194):

$$
R=1+\rho_{b} \times K_{d} / \theta
$$

where $K_{d}(\mathrm{~mL} / \mathrm{g})$ is the sorption distribution factor representing the distribution of solutes between aqueous and solid phases, $\rho_{b}$ is the bulk density $(\mathrm{g} / \mathrm{mL})$, and $\theta$ is the water content. This equation explicitly shows that solute retardation is inversely related to water content. If the effective $\theta$ value is estimated as the average of the initial water content and the final water content (which is set to be the measured porosity), the $K_{d}$ value can be derived from the $R$-value. For the two core samples, the $K_{d}$ value was calculated to be $0.089 \mathrm{~mL} / \mathrm{g}$ for Core D and $0.047 \mathrm{~mL} / \mathrm{g}$ for Core H (Appendix Section I3). The bulk density and porosity values for each core were measured independently, with values listed in Table 6-15. These measured values in Table 6-15 were used in calculating $K_{d}$ values from measured $R$ values. 

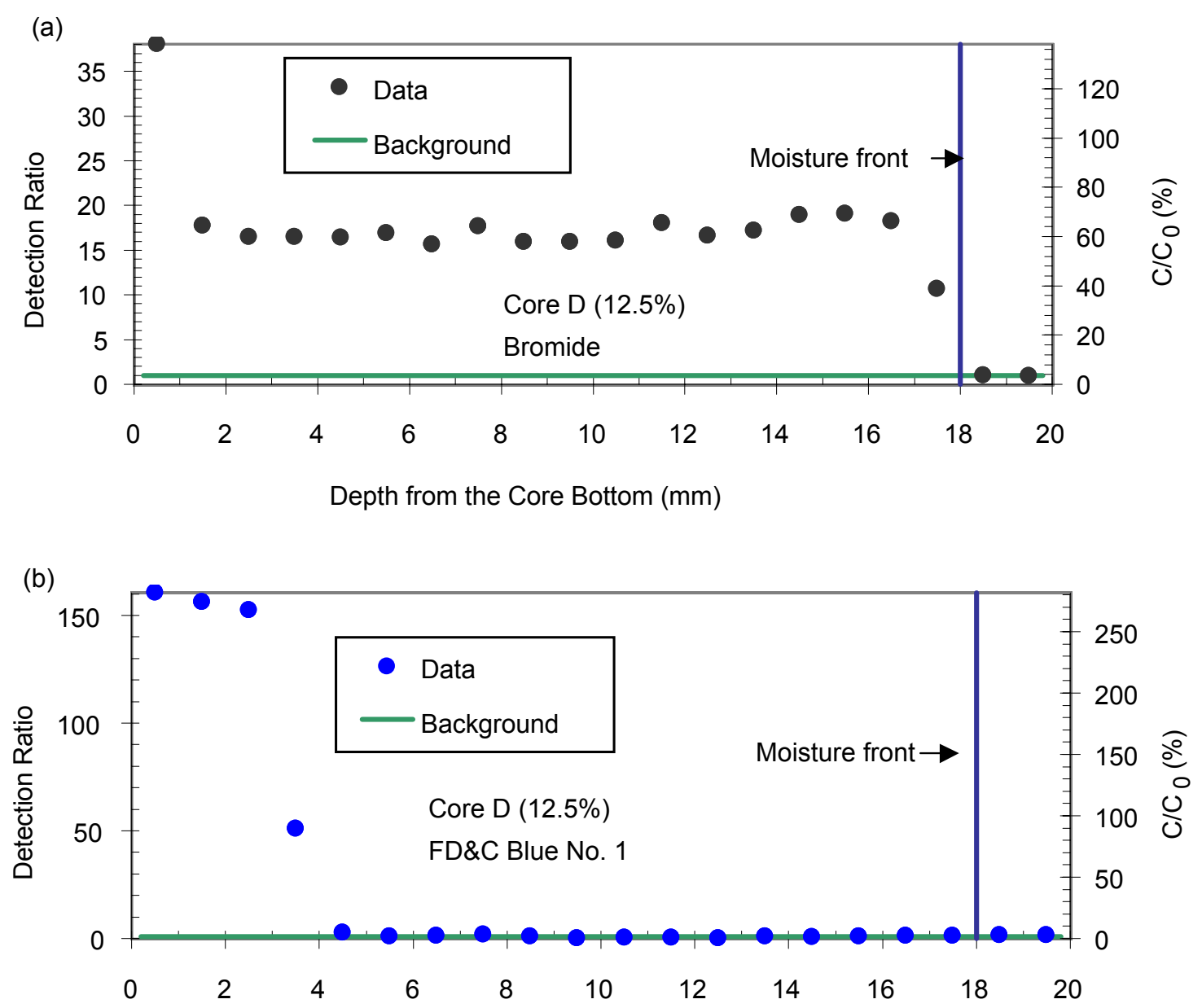

Depth from the Core Bottom (mm)

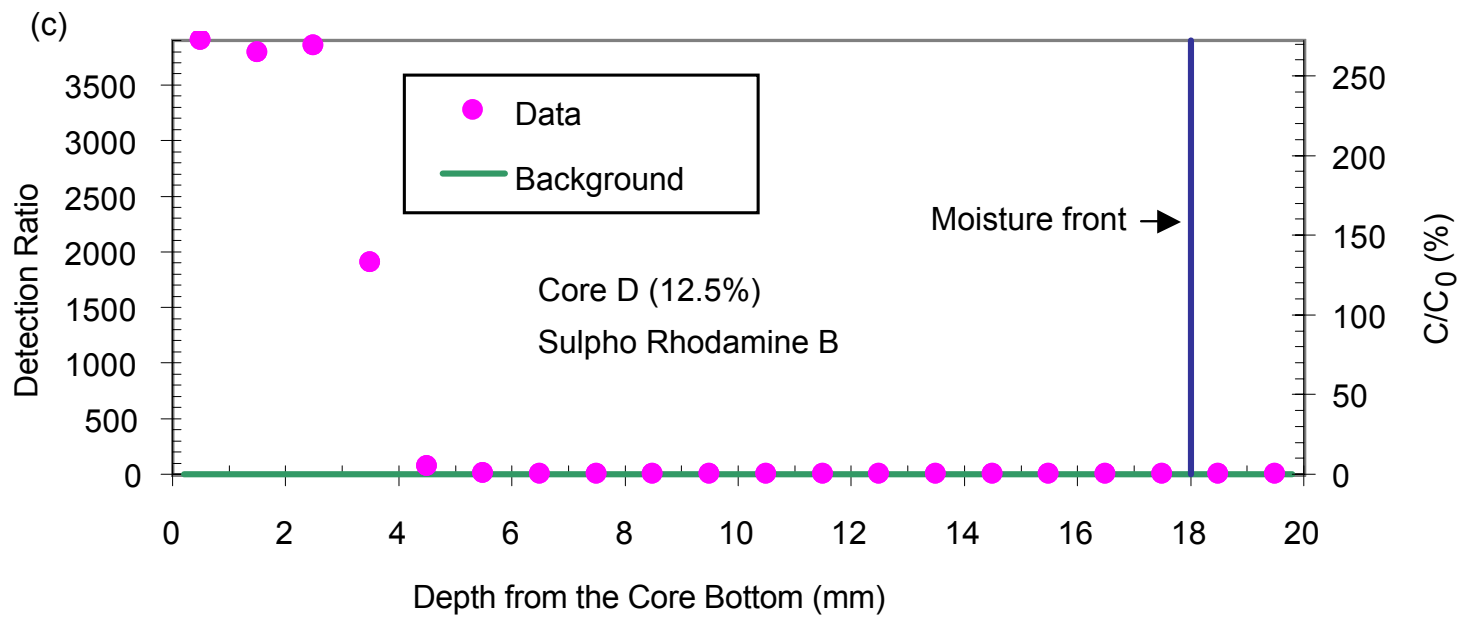

Source: DTN: LB990901233124.003 [DIRS 155690].

NOTES: $\quad(a)=$ Bromide; $(b)=$ FD\&C Blue No. $1 ;(c)=$ Sulpho Rhodamine B.

Core $D$ had initial saturation of 12.5 percent and was in contact with the saturated boundary for 19.5 hours.

Figure 6-63. Comparison of Tracer Concentration Profiles for Different Tracers in a Core with Low Initial Saturation 
(a)

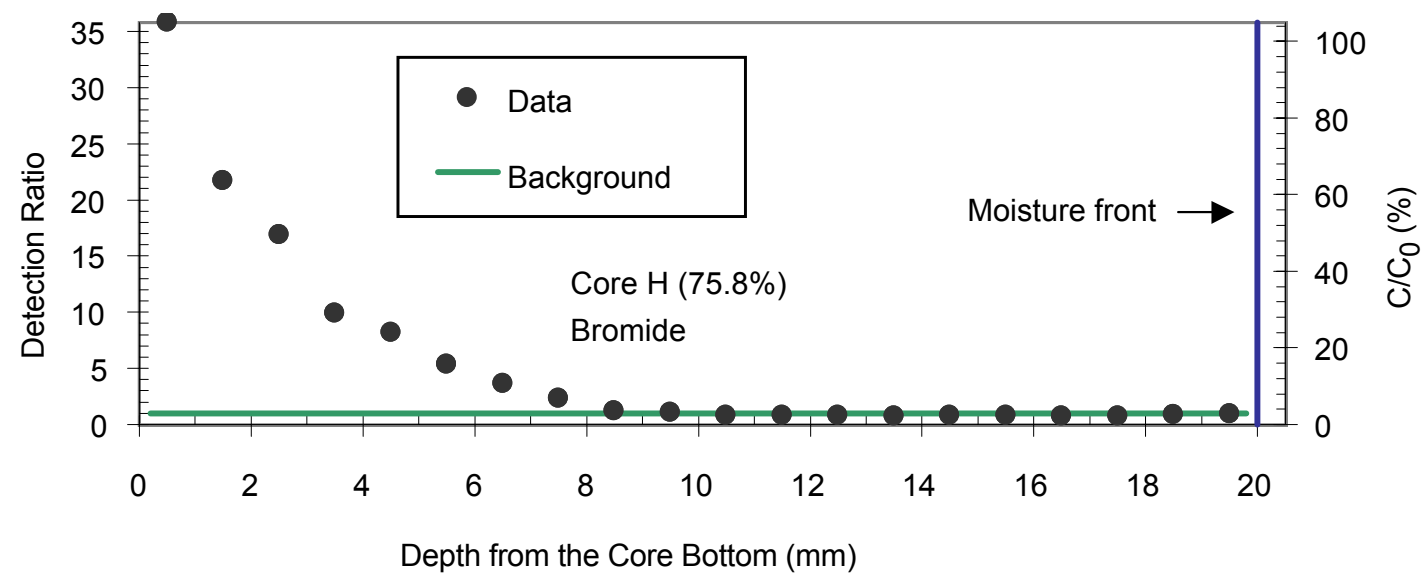

(b)

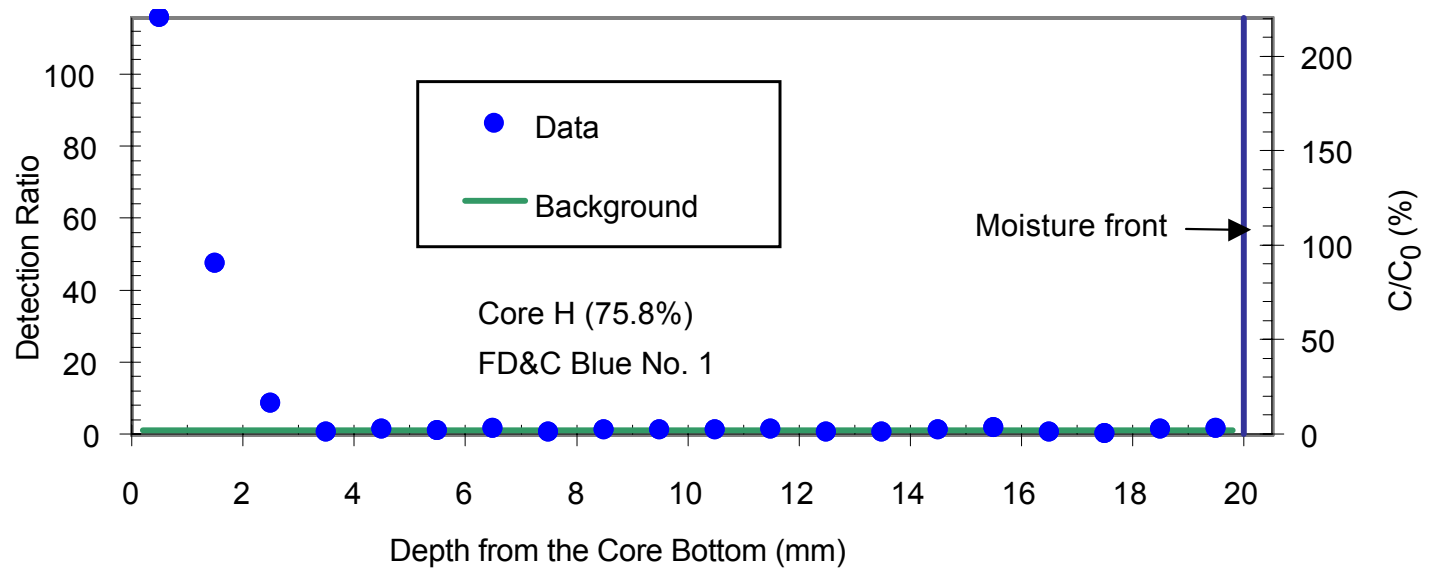

(c)

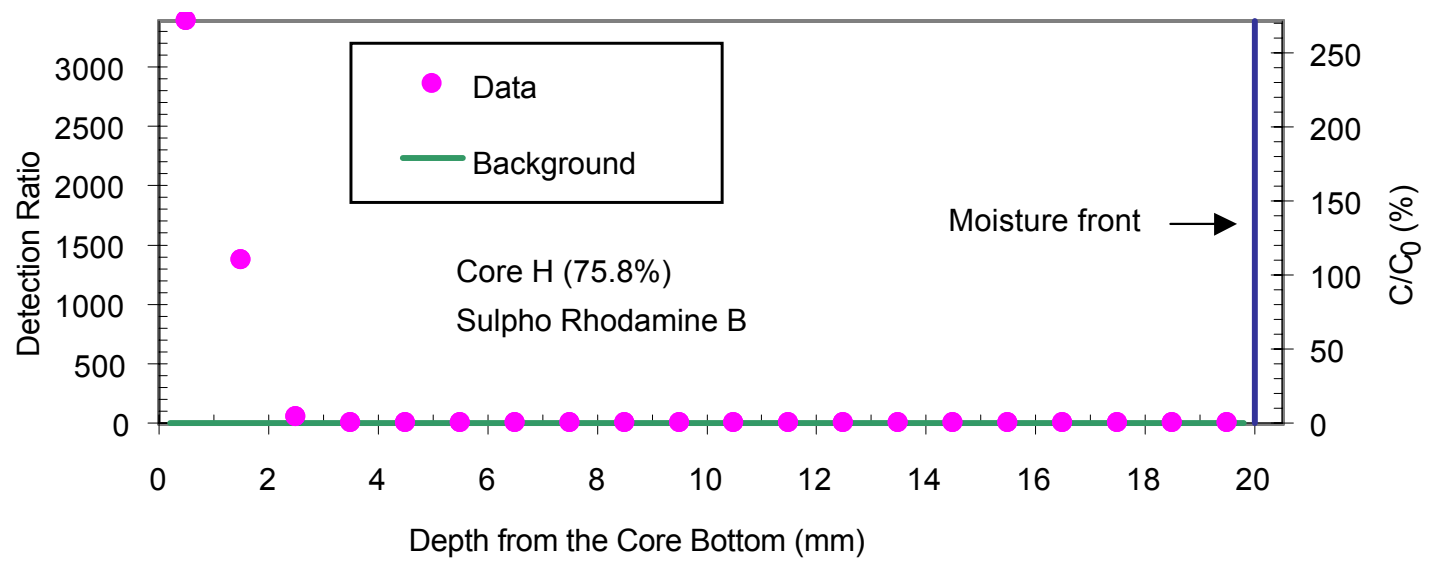

Source: DTN: LB990901233124.003 [DIRS 155690].

NOTES: $\quad(a)=$ Bromide; $(b)=$ FD\&C Blue No. $1 ;(c)=$ Sulpho Rhodamine $B$.

Core $\mathrm{H}$ had initial saturation of 75.8 percent and was in contact with the saturated boundary for 17.9 hours.

Figure 6-64. Comparison of Tracer Concentration Profiles for Different Traces in a Core with a High Initial Saturation 
Table 6-15. Measured Properties for Core Samples

\begin{tabular}{|l|c|c|}
\hline \multicolumn{1}{|c|}{ Sample ID } & $\begin{array}{c}\text { Porosity } \\
\left(\mathbf{c m}^{3} / \mathbf{c m}^{3}\right)\end{array}$ & $\begin{array}{c}\text { Bulk Density } \\
\left(\mathbf{g} / \mathbf{c m}^{3}\right)\end{array}$ \\
\hline Core D & 0.0888 & 2.248 \\
\hline Core E & 0.0849 & 2.251 \\
\hline Core F & 0.0890 & 2.239 \\
\hline Core H & 0.0896 & 2.245 \\
\hline Core J & 0.0823 & 2.266 \\
\hline
\end{tabular}

Source: DTN: LB990901233124.003 [DIRS 155690].

As an additional consistency check, the calculations can be inverted and the $R$ values derived from the $K_{d}$ values for a fully saturated condition (i.e., 100-percent saturation). The $R_{100 \%}$ is 3.25 for Core $\mathrm{D}$ and 2.17 for Core $\mathrm{H}$ from the inverse calculations. The average $R_{100 \%}$ is $2.71 \pm$ 0.76 for both FD\&C Blue No. 1 and Sulpho Rhodamine B. Both $K_{d}$ value and $R_{100 \%}$ are constants independent of saturation. This simple check verifies the functional relationship of Equation 6-11. For comparison, Andreini and Steenhuis (1990 [DIRS 106071], pp. 85, 98) found that the retardation factor for FD\&C Blue No. 1 varied from 1.5 to 7 in a fine, sandy loam soil.

Note that the core measurements presented in this study can generate $K_{d}$ values for intact rock under in situ partially saturated conditions. Most of the $K_{d}$ values for sorbing solutes have been acquired by batch experiments using crushed rock, with the sizes chosen more or less arbitrarily and mainly for experimental convenience. The batch experiments were performed under saturated conditions with large water/rock ratios. Concerns exist regarding the use of crushed-rock samples versus solid-rock samples in batch experiments on tuff rocks. The water/rock ratios used in the sorption experiments with crushed samples were large in comparison with the water/rock ratios likely to exist in the UZ. This unsaturated transport-sorption approach can be used to check the results commonly obtained from batch sorption experiments as well as to provide a more representative sorption under field conditions (Hu et al. 2002 [DIRS 165412], p. 111).

\subsubsection{Travel-Front Separation}

As a nonreactive tracer, bromide is frequently used for flow tracking. The bromide front is comparable to the moisture front in the rock core at the initial water saturation of 12.5 percent, as illustrated in Panel (a) of Figure 6-63. The bromide front lags significantly behind the moisture front at the higher initial water saturation of 75.8 percent, as shown in Panel (a) of Figure 6-64. Note that the core top was wet to $20 \mathrm{~mm}$ when the experiment was ended, although the moisture front is shown at the $18 \mathrm{~mm}$ location in Panel (b) of Figure 6-63. This observation of a nonreactive solute front lagging behind the moisture front agrees with the findings in moist soils (Warrick et al. 1971 [DIRS 106150], pp. 1216, 1221; Ghuman and Prihar 1980 [DIRS 106099], pp. 17, 19; Porro and Wierenga 1993 [DIRS 134083], pp. 193, 196).

Warrick et al. (1971 [DIRS 106150]) first reported that the advance of a solute front was highly dependent on the soil moisture content during infiltration. During infiltration, no solute was found in the advancing wetting front where soil moisture contents were increasing, although the initially infiltrating water contained nonreactive tracer. The importance of this front separation, observed 
under a transient flow condition, might be more pronounced for low porosity materials under conditions of high moisture saturation, such as tuff at Yucca Mountain. Under these circumstances, a relatively small amount of invading solution can push the antecedent water further into the matrix.

For the imbibition experiment in Core D with low initial water saturation, the bromide front is sharp, with the strong capillary force driving the advection-controlled transport. Conversely, for the Core $\mathrm{H}$ with high initial water saturation, the bromide front is quite diffuse, because dispersion and dilution become important processes compared to advective flow. Analysis of the sharp and diffused front separations between the bromide nonreactive tracer front and the moisture front, as well as between the sorbing tracer front and the bromide front, provides the data for elucidating flow and transport in unsaturated, fractured tuff.

\subsubsection{Application of LA-ICP-MS to Investigate Chemical Transport and Sorption}

Laser ablation refers to the process in which an intense burst of energy delivered by a short laser pulse is used to vaporize a minute sample from a specific location. Chemical composition of the vaporized sample is then analyzed with inductively coupled plasma-mass spectrometry (ICP-MS). Laser ablation, coupled with ICP-MS, has recently evolved as a powerful analytical tool for solid samples (Russo et al. 2000 [DIRS 155697]). Laser ablation ICP-MS can simultaneously determine a large number of chemical elements, with very low detection limits. The applications of laser ablation ICP-MS have recently been reported in studies of tree rings, airborne particulates, and geochemistry. However, previous studies on transport, sorption, or diffusion of contaminants in rocks do not report the use of laser ablation ICP-MS. The high spatial resolution achieved by a focused laser beam makes laser ablation ICP-MS a very attractive approach to such environmental pollution studies.

This section describes the investigation of transport and sorption of chemicals that are of interest to the YMP in unsaturated tuff. The laboratory tracer imbibition tests are similar to those presented in Appendix E, except that an initially dry tuff cube $(1.5 \mathrm{~cm}$ in each side) was used in this laser ablation ICP-MS work, compared to core cylinders used in the drilling work as described in Section 6.4.1 and Section 6.4.2. Compared to the drilling technique presented in Appendix E, employment of laser ablation ICP-MS provides a quick way of profiling tracer chemical concentration with high spatial resolution. Surrogate compounds are chosen based on their chemical similarity to radionuclides of interest. The tracer solution used in this study contained a mixture of $\mathrm{NaBr}, \mathrm{NaReO}_{4}, \mathrm{CsBr}$, and $\mathrm{RbBr}$. Both $\mathrm{Br}^{-}$and perrhenate $\left(\mathrm{ReO}_{4}{ }^{-}\right)$are used as nonsorbing tracers, with perrhenate serving as an analogue to technetium, which exists in a form of pertechnetate $\left({ }^{99} \mathrm{TcO}_{4}{ }^{-}\right)$. Cesium $\left(\mathrm{Cs}^{+}\right)$and rubidium $\left(\mathrm{Rb}^{+}\right)$were used as cationic tracers to examine the sorption effect on delayed transport of radionuclides in unsaturated tuff. Nonradioactive cesium is directly used for radioactive ${ }^{137} \mathrm{Cs}$. Experimental conditions and analyses are recorded by Hu (2000 [DIRS 156473], pp. 130-136, 145-146).

Figure 6-65 shows the spatial-distribution results obtained from laser ablation ICP-MS profiling for the tuff cube face in contact with the tracer solution. Intensity in the y-axis indicates the signal, measured by ICP-MS, from the laser-abated mass for both the applied tracers and elements (aluminum, potassium, cerium, thorium) intrinsic to the tuff sample. Peterman and Cloke (2001 [DIRS 155696]) reported a very uniform distribution of elemental compositions in tuff. Signals shown in Figure 6-65 are in direct relationship to the reported elemental 
compositions: weight-percent level for aluminum and potassium, trace (parts per million) level for cerium and thorium. As expected, the spatial distribution of all elements measured is fairly uniform, because this cube face was in contact with the tracer solution throughout the imbibition test duration.

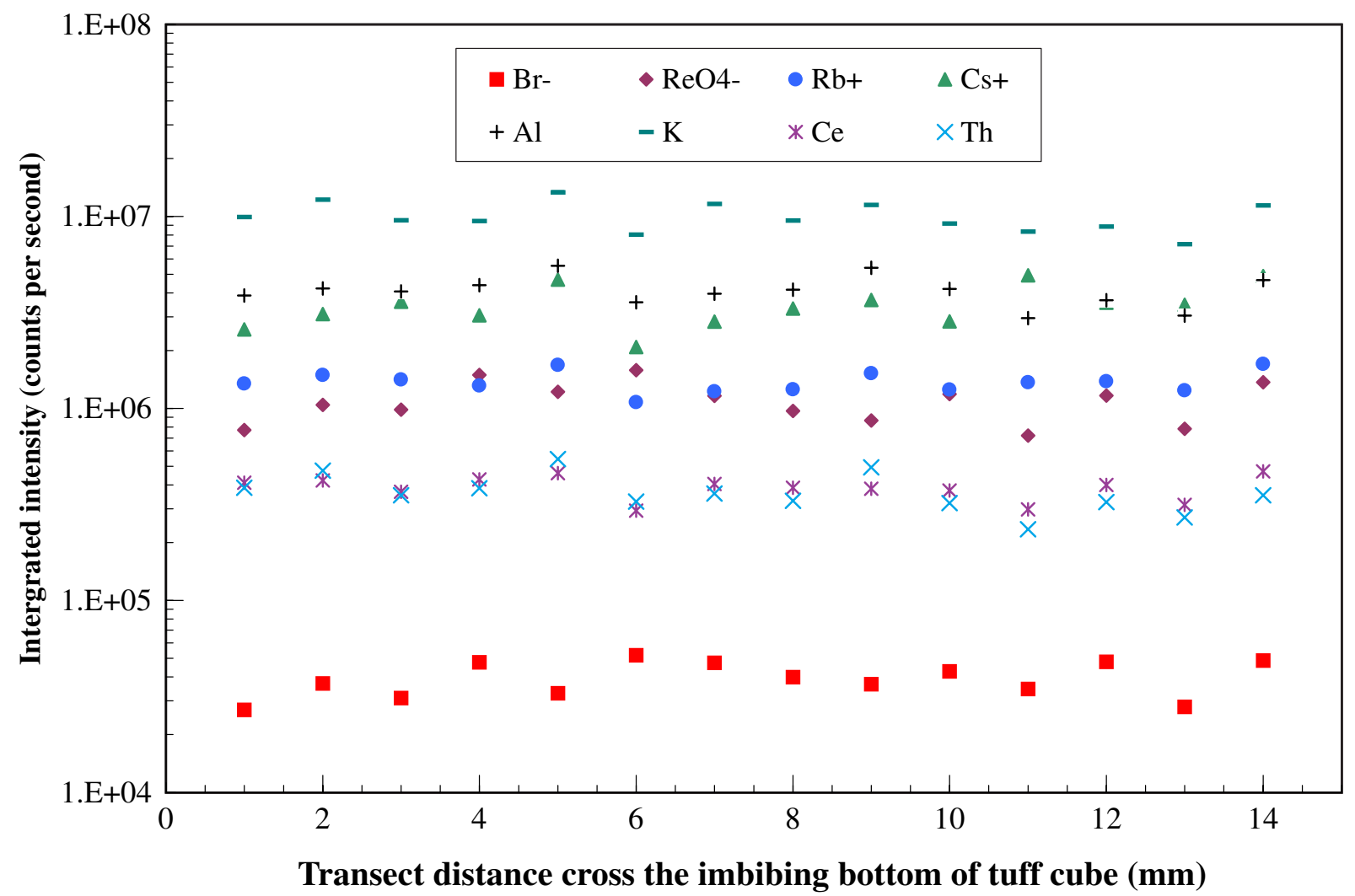

Source: DTN: LB0110TUFTRACR.001 [DIRS 156979].

Figure 6-65. Spatial Distribution along the Tracer Solution Contact Surface of Applied Tracers and the Distribution of Intrinsic Tuff Elements Profiled Using Laser Ablation ICP-MS

Figure 6-66, on the other hand, presents the spatial distributions of applied tracers, as well as uniform distribution of potassium as it exists inherently in the tuff sample, for a side cube face parallel to the direction of imbibition. Anionic tracers, $\mathrm{Br}^{-}$and $\mathrm{ReO}_{4}{ }^{-}$, travel much further than cationic tracers $\left(\mathrm{Cs}^{+}\right.$and $\left.\mathrm{Rb}^{+}\right)$that sorb to the tuff. This is similar to those tracers discussed in Section 6.4.2.1, where sorption of dyes is observed. By the same approach, $\mathrm{d}_{0.5}$ is located at approximately $10.15 \mathrm{~mm}$ for both $\mathrm{Br}^{-}$and $\mathrm{ReO}_{4}{ }^{-}$, and $\mathrm{d}_{0.5}$ is located at approximately $2.95 \mathrm{~mm}$ and $3.50 \mathrm{~mm}$ for $\mathrm{Cs}^{+}$and $\mathrm{Rb}^{+}$, respectively. The retardation factors for $\mathrm{Cs}^{+}$and $\mathrm{Rb}^{+}$, therefore, are estimated to be $3.44(=10.15 \mathrm{~mm} / 2.95 \mathrm{~mm})$ and $2.90(=10.15 \mathrm{~mm} / 3.50 \mathrm{~mm})$, respectively. Similar behavior is observed from the measurements made on another side cube face parallel to the direction of imbibition. Overall, laser ablation ICP-MS provides a useful way of sampling and understanding tracer (and-by analogy_radionuclide) imbibition and transport in the rock matrix at small spatial scales and reasonable sampling times. 


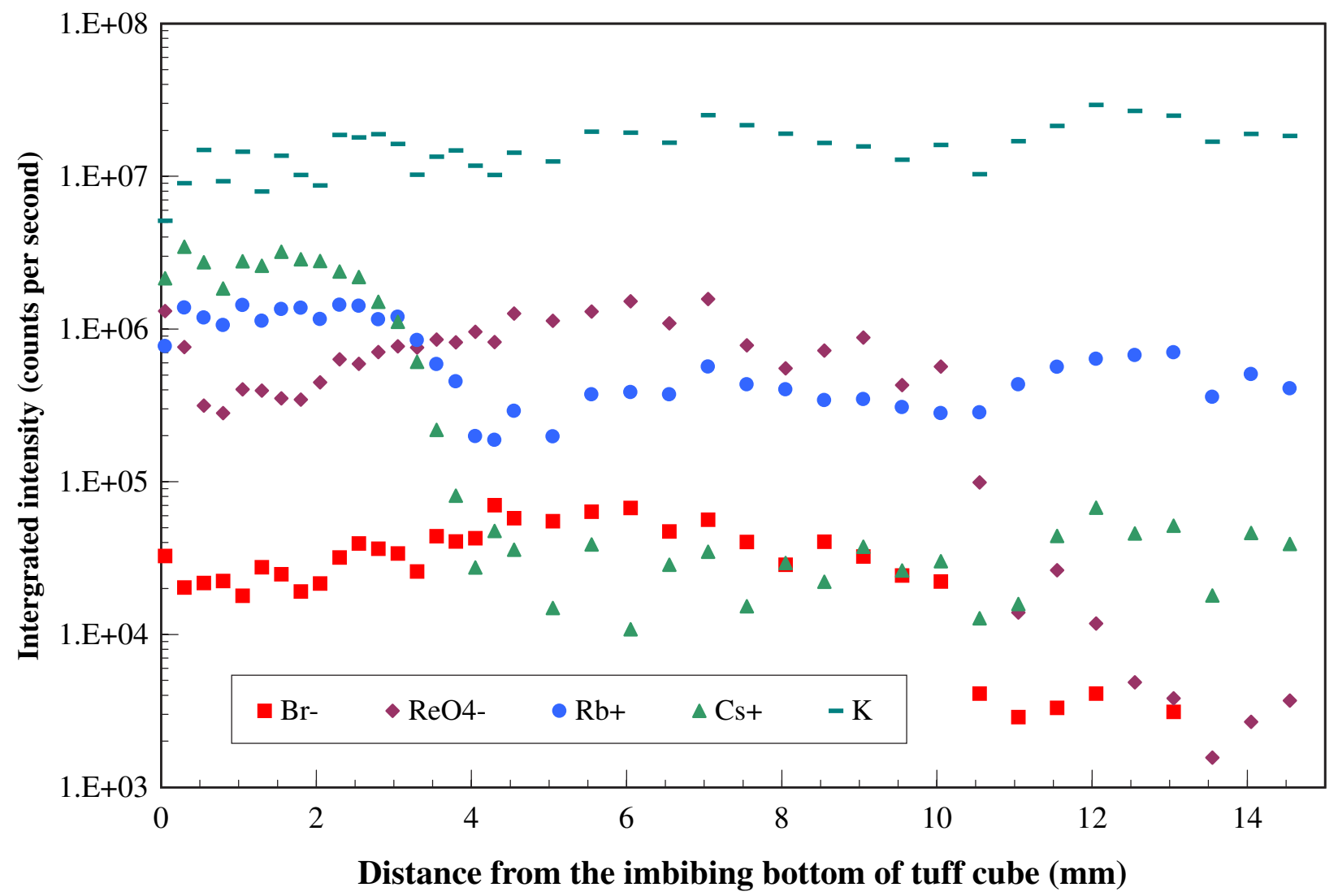

Source: DTN: LB0110TUFTRACR.001 [DIRS 156979].

Figure 6-66. Spatial Distribution Normal to the Tracer Solution Contact Surface (in the Direction of Liquid Imbibition) of Applied Tracers and Distribution of Intrinsic Tuff Elements Profiled Using Laser Ablation ICP-MS

\subsection{ANALYSES OF CROSSHOLE AIR-INJECTION TESTS}

This section continues the pneumatic air-permeability test analyses first presented in Section 6.1. Section 6.1 focuses on the air-permeability variations along boreholes in niches. The permeability profiles provide initial inputs to liquid-release-test interval selection, as described in Section 6.2. The permeability profiles were also used in Seepage Calibration and Seepage Test Data (BSC 2004 [DIRS 171764], Section 6.6.2) when defining the heterogeneity of the permeability structure used in modeling.

This section focuses on analyses of crosshole data for fracture-network connectivity. Fracture-network connectivity is one of the most important characteristics in evaluating flow paths from the inlets to the outlets of a given regime. The larger the system, the more difficult it is to determine the dominant flow paths. Air flow paths elucidated in this section are used to characterize test beds for liquid-flow test design and analysis, as described in Section 6.6 and Section 6.7 for two slotted test beds in the ESF. 
Crosshole tests used the same pneumatic testing equipment described in Appendix A. Up to seven identical packer strings were fabricated and installed in the boreholes to test a rock volume in the niches and in the test beds. The packer can isolate $0.3 \mathrm{~m}$ intervals along its length. Each interval can become either an observation or response zone, used to monitor pressure, or an injection zone, where air is introduced under pressure during the test. The automation system controls the permutations through pre-assigned sequences of injection tests in all borehole intervals in the borehole cluster.

Crosshole data are acquired at the same time as single-borehole data, by logging the steady-state pressure response in all observation zones while performing an injection. The observation response pressure is divided by the injection pressure to provide a relative measure of how well a response zone is connected to an injection zone. The normalization with injection pressure enables all the observation responses from all injections at a site to be directly compared. The crosshole connections can all be viewed on a single 3-D diagram instead of individual diagrams for each tested injection zone.

The niches and Alcove 6 are located within the TSw unit in the repository horizon. The Alcove 4 test site is in the PTn unit along the north ramp of the ESF. Both the fractured TSw and the predominately porous PTn were evaluated by the pneumatic air-permeability tests.

\subsubsection{Crosshole Responses in Welded Tuff}

In Section 6.1.2, the single-borehole permeability profiles were presented for niches as the basis for selecting liquid-release intervals for drift seepage testing. The first example of crosshole analysis in fractured rock is for Niche 4 (Niche 4788), located in an intensely fractured zone. The crosshole analysis for Niche 4 (Niche 4788) is illustrated in Figure 6-67. The single-borehole permeability values (presented in Section 6.1 as profile plots in Figure 6-14 and Figure 6-15) are represented by circles in the crosshole plot, with each circle centered along the test interval within each of the boreholes. The size of the circles indicates the single-borehole permeability at each interval. Grayscale pins are shown with their points at the centers of the circles of the injection zones and heads intersecting through the centers of other circles at the observation zones. Direction of flow is toward the pinhead, and the grayscale indicates the normalized response ratio ("Resp. Ratio" in Figure 6-67 and similar figures below).

Figure 6-67 for Niche 4 is fairly representative of a fractured site, showing discrete connections. Note that very few of the connections have an opposite counterpart; the connections are predominantly one-way. This observation by no means indicates that flow is limited to one direction between points in the rock, but rather that the influence of local connections on the pressure response is strong. The pressure at a response zone discretely connected to the injection zone (and no other zone) will yield a large response. However, if the original injection zone in the reversed injection-observation combination is also well connected to the fracture network or a free surface, then it will not respond strongly to an injection in the original observation zone. 


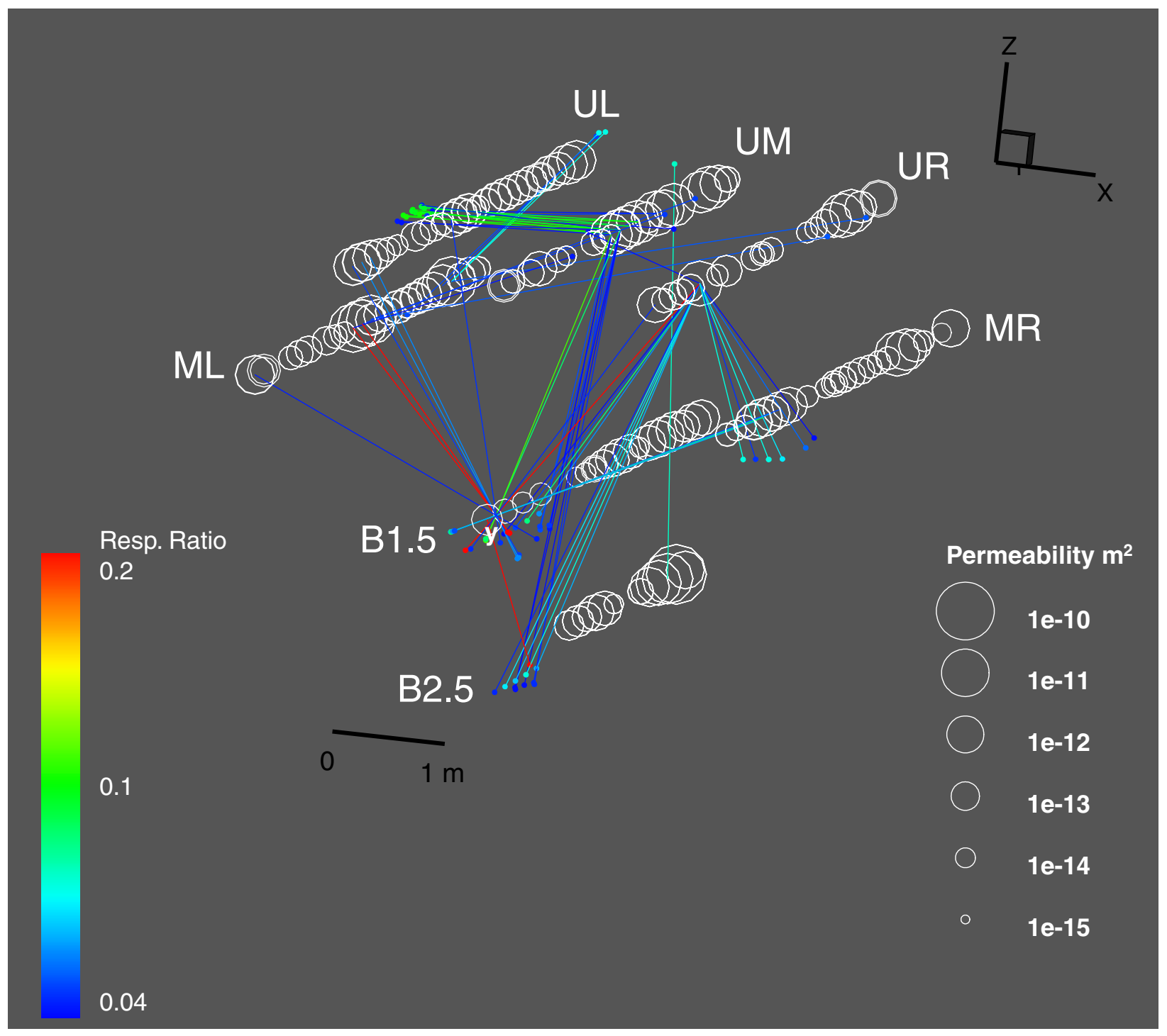

Source: DTN: LB990901233124.004 [DIRS 123273].

Figure 6-67. Crosshole Responses for the Borehole Cluster in Niche 4

The fracture-matrix interaction test site in Alcove 6 of the ESF is in rock that is fractured, with discrete, subvertical fractures and relatively few subhorizontal fractures. The single-borehole permeability profiles for three boreholes tested in Alcove 6 are illustrated in Figure 6-68. Borehole A was used for a series of liquid-release tests, as described in Section 6.6. Borehole C and Borehole $\mathrm{D}$ were used for wetting-front monitoring. Borehole $\mathrm{C}$ and Borehole $\mathrm{D}$ are located $0.7 \mathrm{~m}$ and $0.6 \mathrm{~m}$ below Borehole A, respectively, and $0.7 \mathrm{~m}$ apart. The crosshole responses for this triangular cluster of boreholes are illustrated in Figure 6-69. Both Figure 6-68 and Figure 6-69 correspond to the first series of tests conducted in the region between $1.3 \mathrm{~m}$ and $5.3 \mathrm{~m}$ from the borehole collars. Another series of tests was conducted with a straddle packer system (two-packer string to isolate one zone for liquid releases) right before liquid-release tests along the injection borehole. 

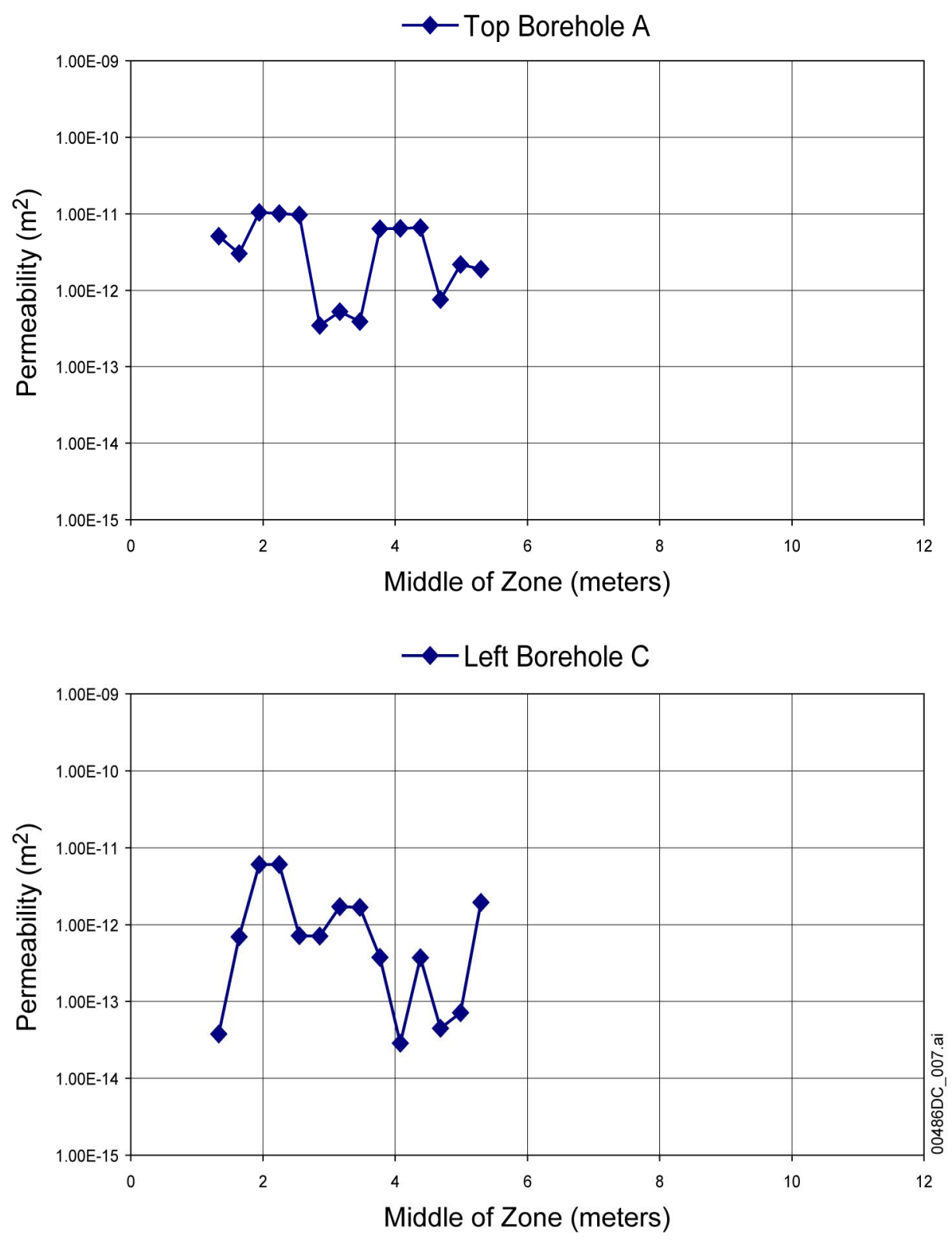

Source: DTN: LB980901233124.004 [DIRS 105855].

Figure 6-68. Air-Permeability Profiles along Boreholes in Alcove 6 


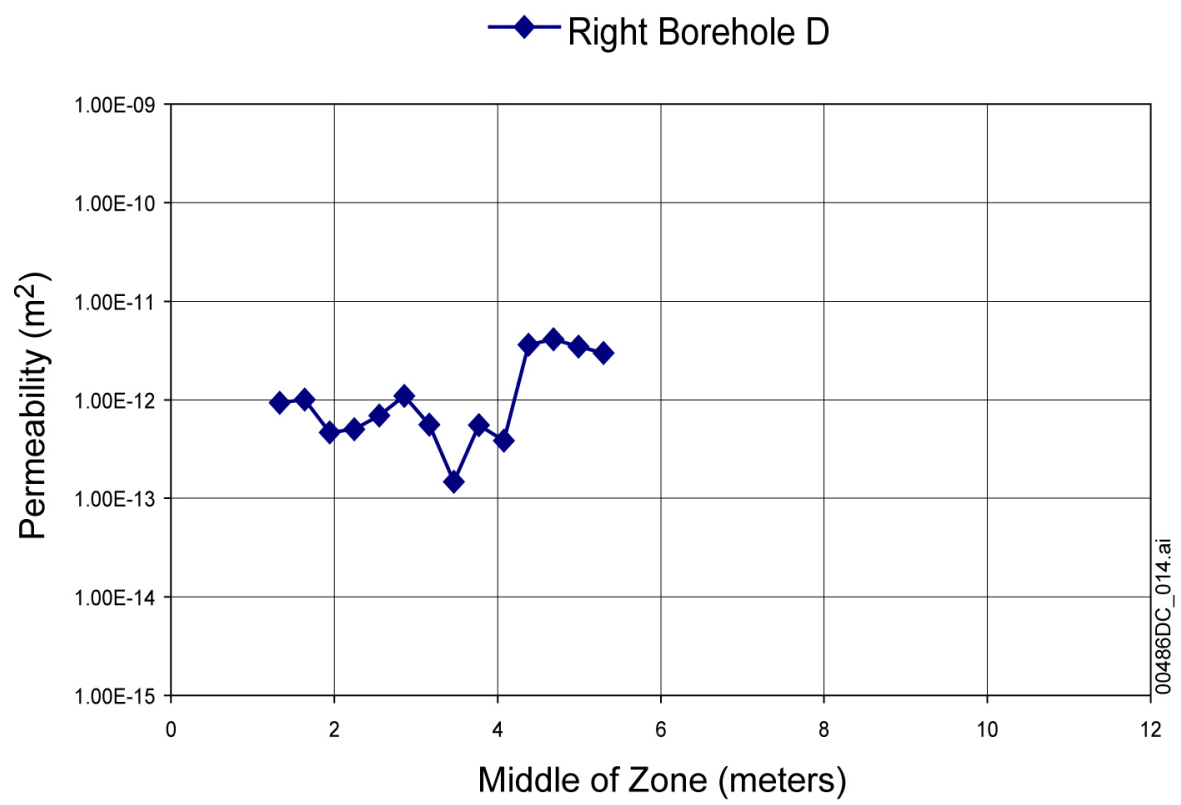

Source: DTN: LB980901233124.004 [DIRS 105855].

Figure 6-68. Air-Permeability Profiles along Boreholes in Alcove 6 (Continued)

Both Figure 6-67, for Niche 4 (Niche 4788), and Figure 6-69, for Alcove 6, represent crosshole responses in fractured rock. The ratios of pressure response in the observation borehole interval to pressure in the injection borehole interval ("Resp. Ratio" in Figures 6-67 and 6-69) were displayed in the figures for the maximum value of 0.2 (or 20 percent). Niche 4 (Niche 4788), in an intensely fractured zone, has wider range (or larger standard deviation, as shown in Table 6-6) of distribution in permeability than the variations over a smaller scale at Alcove 6. Both fracture sites contain discrete and well-defined flow paths between boreholes.

During tests in the welded tuff (see Section 6.2 for liquid-release tests in niches, and Section 6.6 for tracer tests), in some cases, the liquid flux at certain zones was observed to not always be commensurate with the air-permeability values at these zones (see Appendix Section D2). In addition to water preferentially entering small-aperture fractures on account of capillarity, another possible explanation for this observation is that liquid tries to flow downward by gravity and is thus more sensitive to the directionality of permeability than is air. Directionality of flow is not available from single-borehole data and requires crosshole data analyses. 


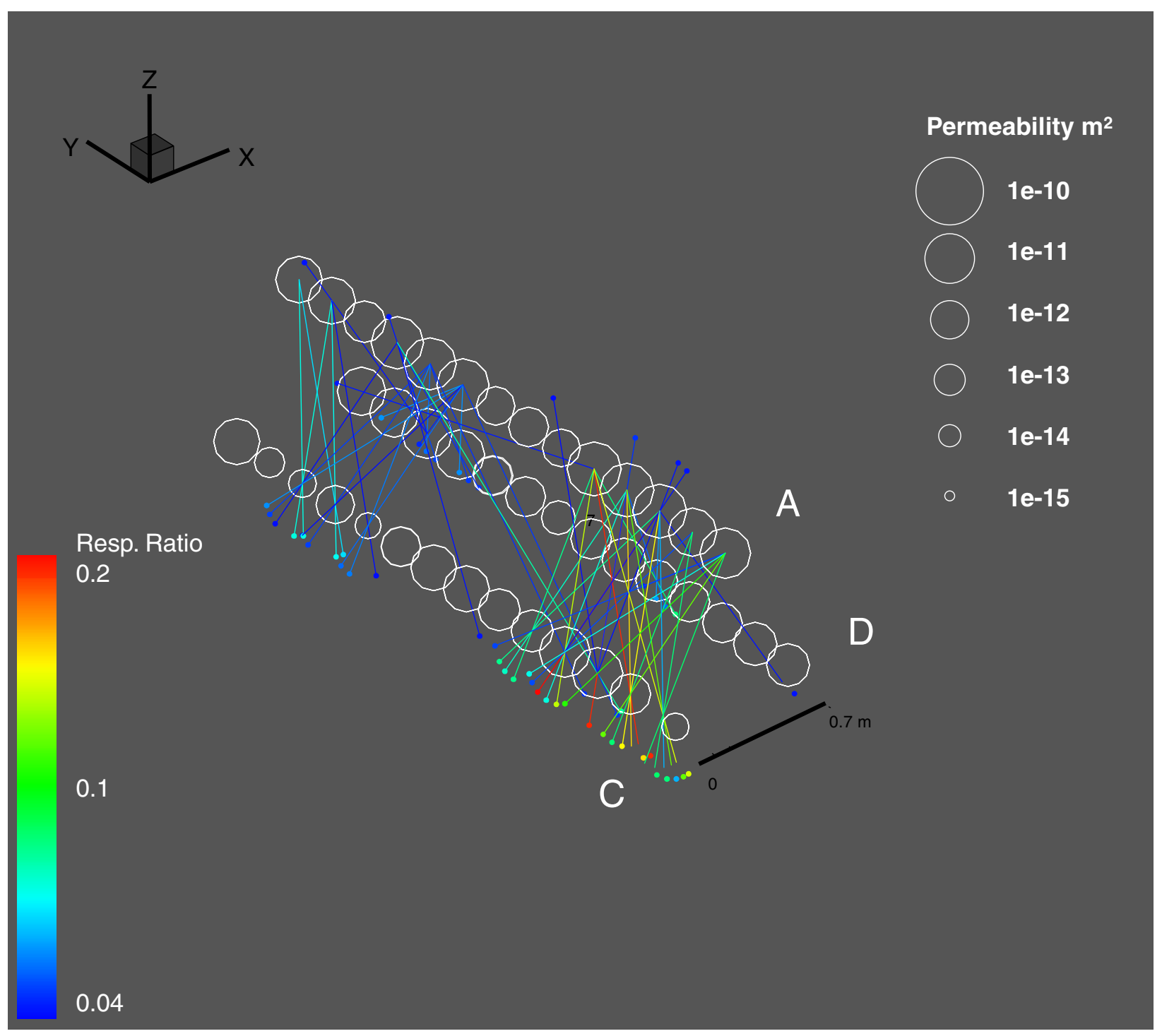

Source: DTN: LB990901233124.004 [DIRS 123273].

Figure 6-69. Crosshole Responses for the Borehole Cluster in Alcove 6

\subsubsection{Permeability Distributions and Crosshole Responses in Nonwelded Tuff}

The Alcove 4 test bed is located in the PTn unit. The test bed contains several nonwelded and bedded subunits, including a pinkish-colored argillic layer. The test bed is located within a fault plane, as illustrated in Figure 6-70. Section 6.7 describes in more detail the borehole configuration and specifications. Not shown in Figure 6-70 is the presence of an excavated slot below all the boreholes and the layer contacts illustrated. (The slot is shown in Figure 6-83 and Figure 6-84.) In this section, the focus is on the cluster of seven boreholes. Boreholes 1, 4, 11, and 12 intersected the projected fault plane in the front part of the test block; Borehole 2, Borehole 15, and Borehole 16 penetrated other features in the test block, with potential fault zone influences (if any) confined near the ends of the boreholes. If the fault is perfectly planar, the last three boreholes would not be intercepted by the fault. 


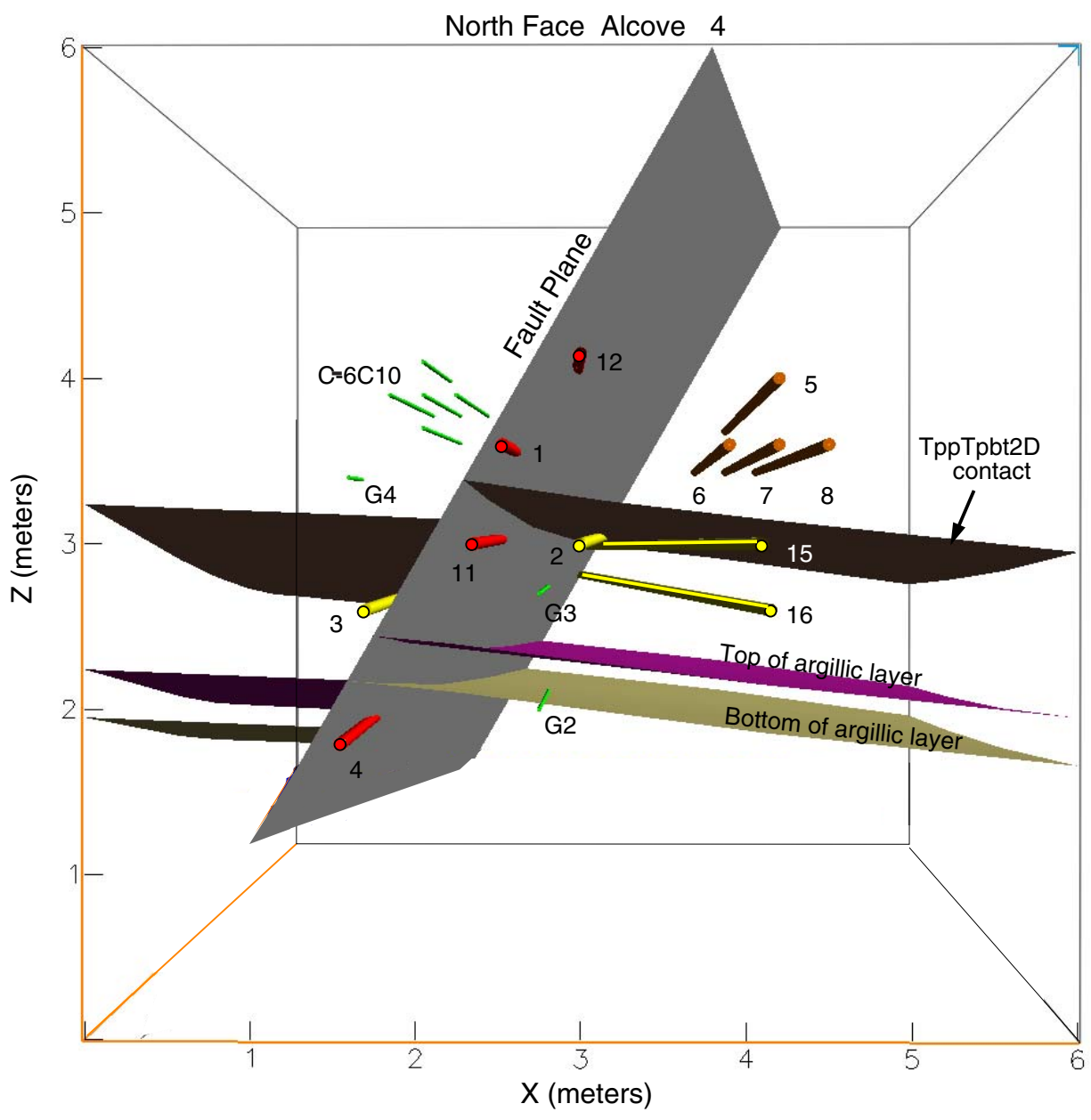

Figure 6-70. Perspective Illustration of Alcove 4 Test Bed

Figure 6-71 illustrates the single-borehole air-permeability profiles along the boreholes. Layer variations and the influence of faults could contribute to the widely distributed set of permeabilities over a broad range, both along individual boreholes and among different boreholes. With the exception of Borehole 12, the other six boreholes penetrate a high-permeability zone near the end of the boreholes. In comparison with borehole clusters in the middle nonlithophysal Tptpmn unit along the ESF main drift, the Alcove 4 PTn cluster shows the largest standard deviation of any of the sites (see Table 6-6 in Section 6.1.2.3). Even the cluster at the intensely fractured site at Niche 4 (Niche 4788) has a lower standard deviation of log permeability (0.85) than the value at Alcove $4(0.93)$. The mean permeabilities of these two distinct sites (which differ in lithological, geological, and fracture characteristics) happen to be nearly identical. In comparison, the standard deviation for the Alcove 6 cluster is 0.67 , and the mean is more than one order of magnitude higher. On the other hand, both Alcove 8 in the upper lithophysal Tptpul and Niche 5 (Niche CD 1620) in lower lithophysal Tptpll have higher standard deviation values than the Alcove 4 PTn value. 
Figure 6-72 shows the connections for Alcove 4 at the same shading scale used in the welded tuff plots (Figure 6-67 and Figure 6-69). The number of connections is much higher for this nonwelded tuff site. To better display the stronger connections, Figure 6-73 portrays the data at Alcove 4 on a more appropriate scale and trims off the connections that showed a weak pressure response during air-injection testing. By focusing on the strong connections, the salient features of the site become apparent. Strong vertical connections are apparent between the upper and middle boreholes, but very little connectivity exists between the middle borehole and the lower-left borehole, despite similar flow rates and distances. The argillic layer exists between these locations. The single strong connection running from left to right is most likely associated with a high-permeability zone identified by the single-borehole profiles. The high-permeability zone could be associated with the fault intersecting the boreholes near the end. Interceptions were not identified in pre-test design in Figure 6-70. The connections were identified by crosshole analyses of pneumatic air-permeability test data.

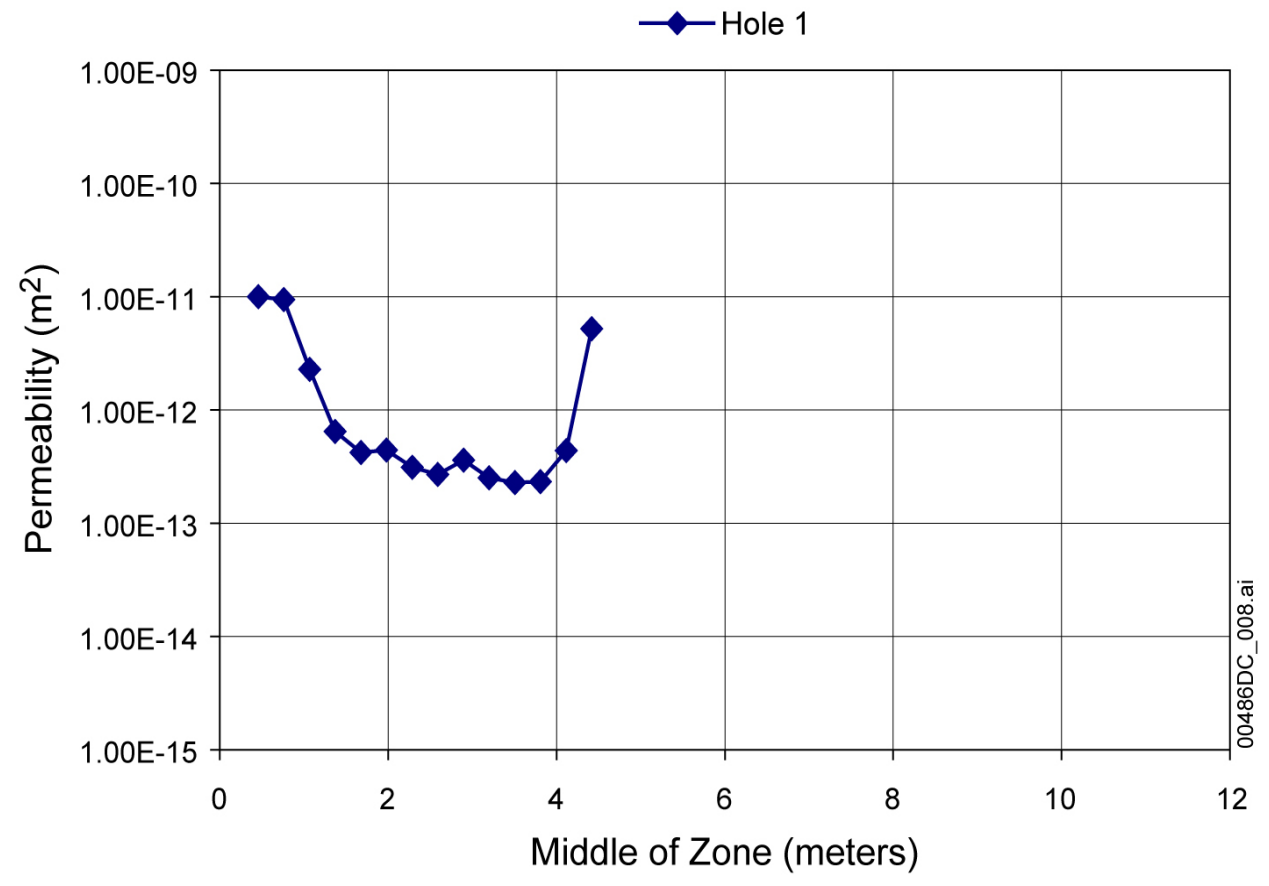

Source: DTN: LB980901233124.009 [DIRS 105856].

Figure 6-71. Air-Permeability Profiles along Boreholes in Alcove 4 

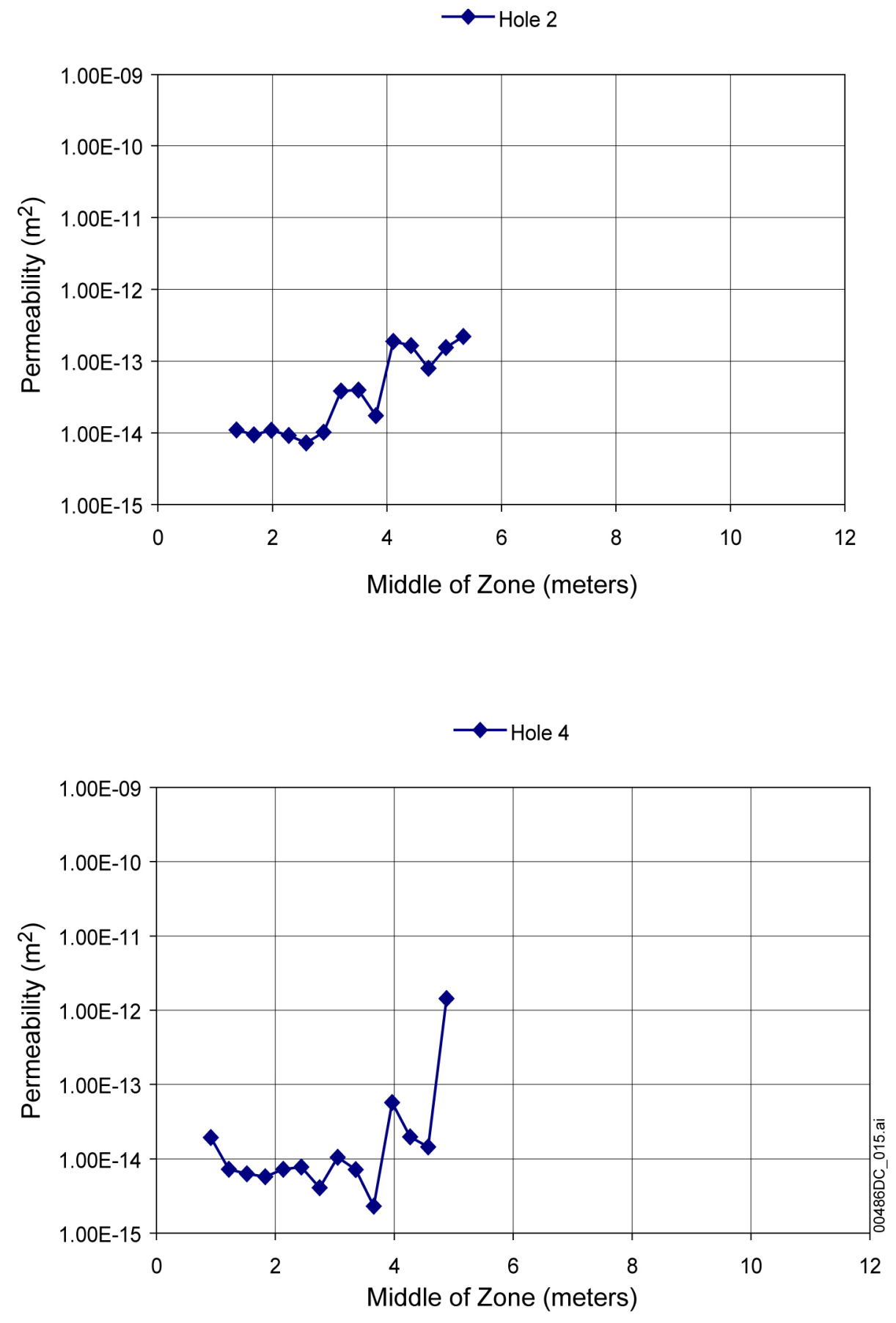

Source: DTN: LB980901233124.009 [DIRS 105856].

Figure 6-71. Air-Permeability Profiles along Boreholes in Alcove 4 (Continued) 

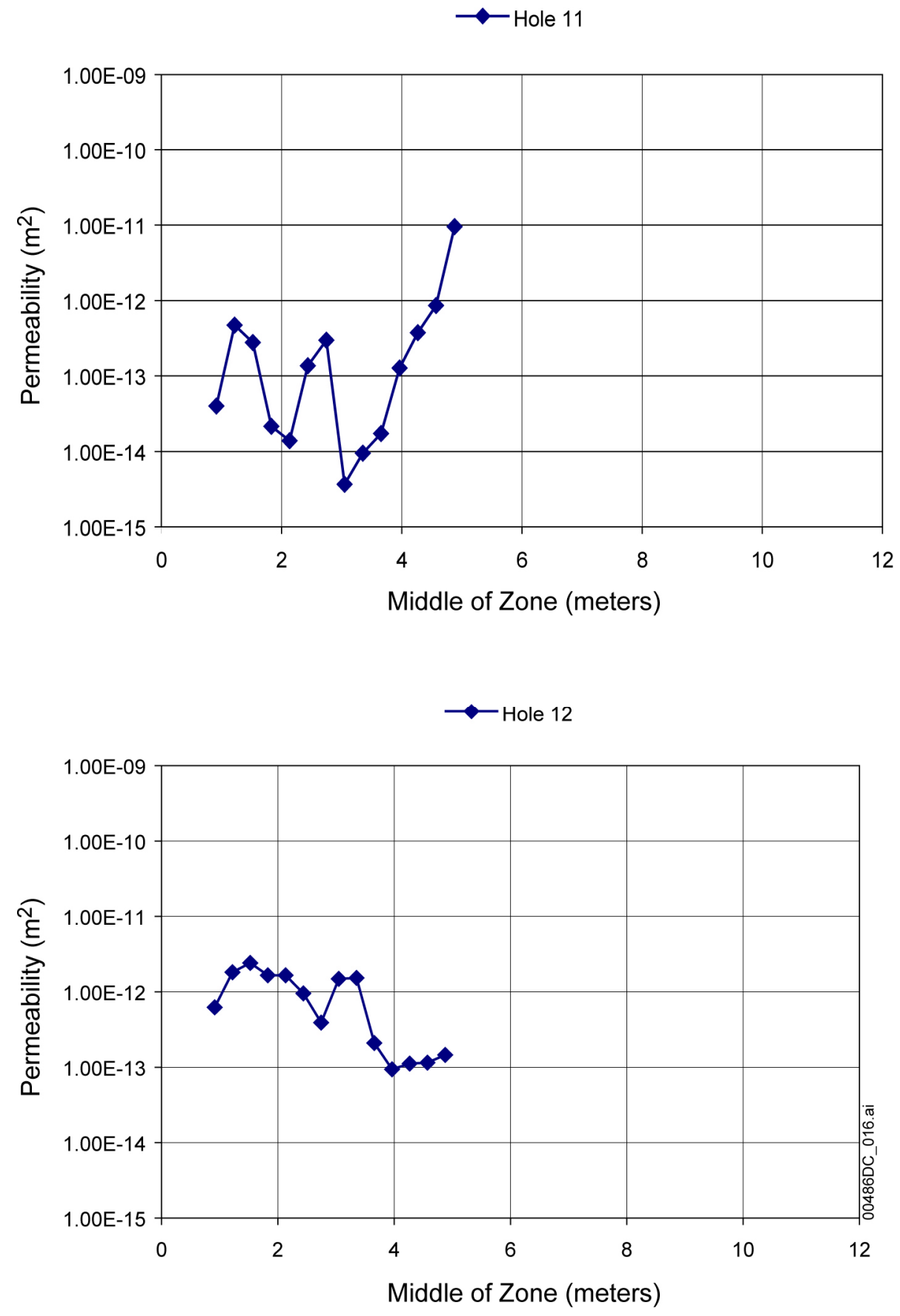

Source: DTN: LB980901233124.009 [DIRS 105856].

Figure 6-71. Air-Permeability Profiles along Boreholes in Alcove 4 (Continued) 

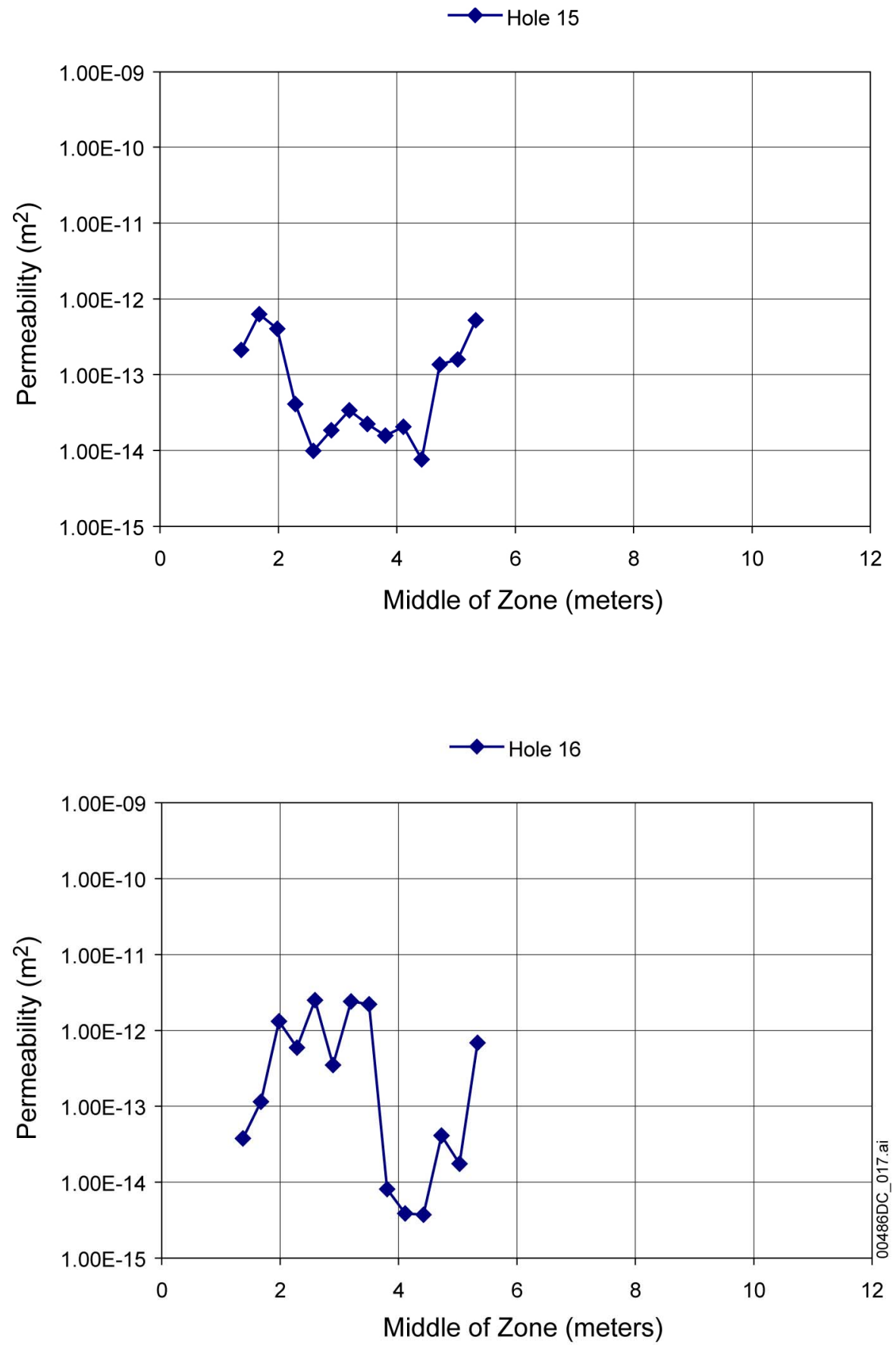

Source: DTN: LB980901233124.009 [DIRS 105856].

Figure 6-71. Air-Permeability Profiles along Boreholes in Alcove 4 (Continued) 


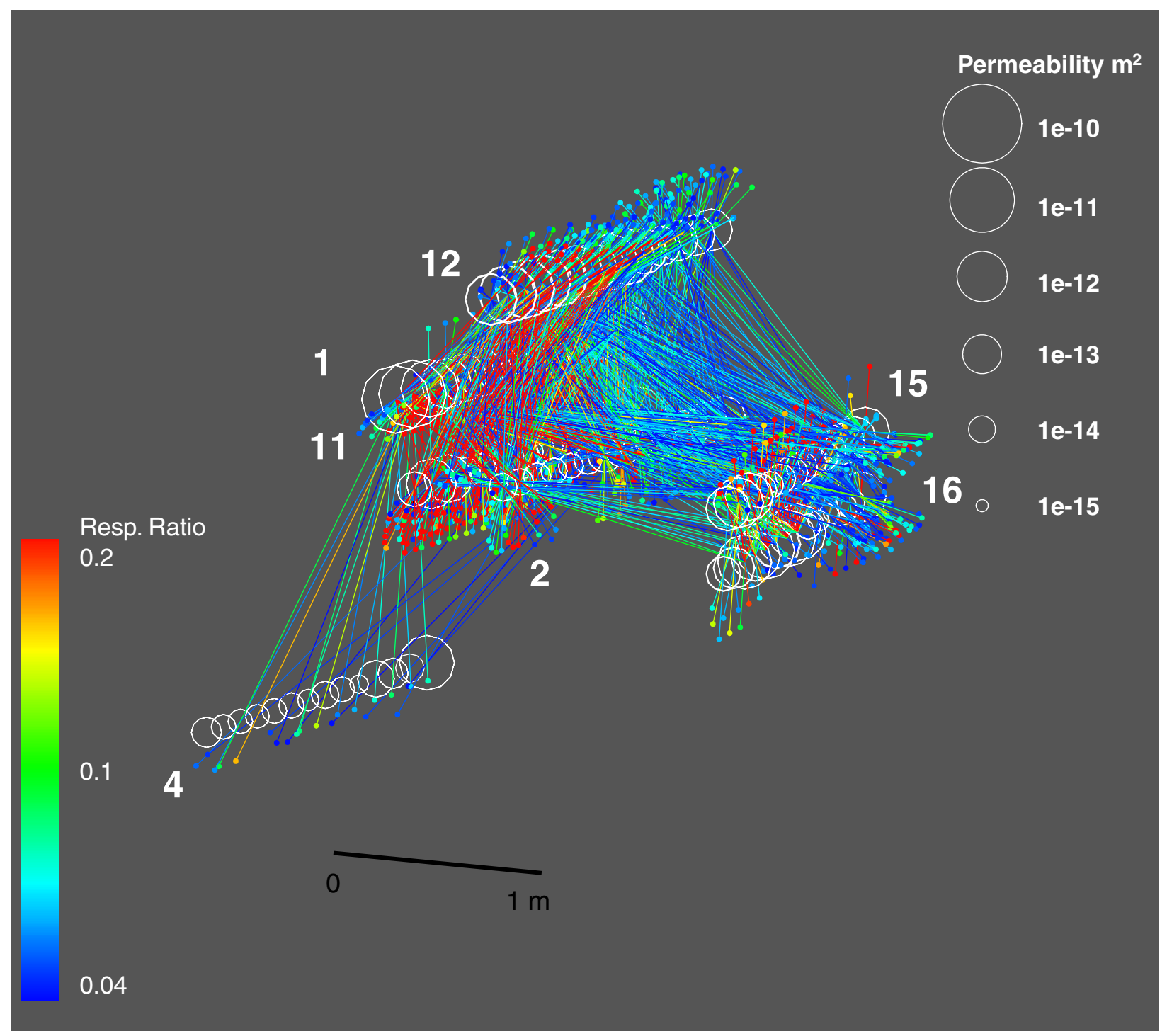

Source: DTN: LB990901233124.004 [DIRS 123273].

Figure 6-72. Crosshole Responses for the Borehole Cluster at Alcove 4 PTn Test Bed with All Response Pressure (Resp.) Ratios below 0.2 Included 


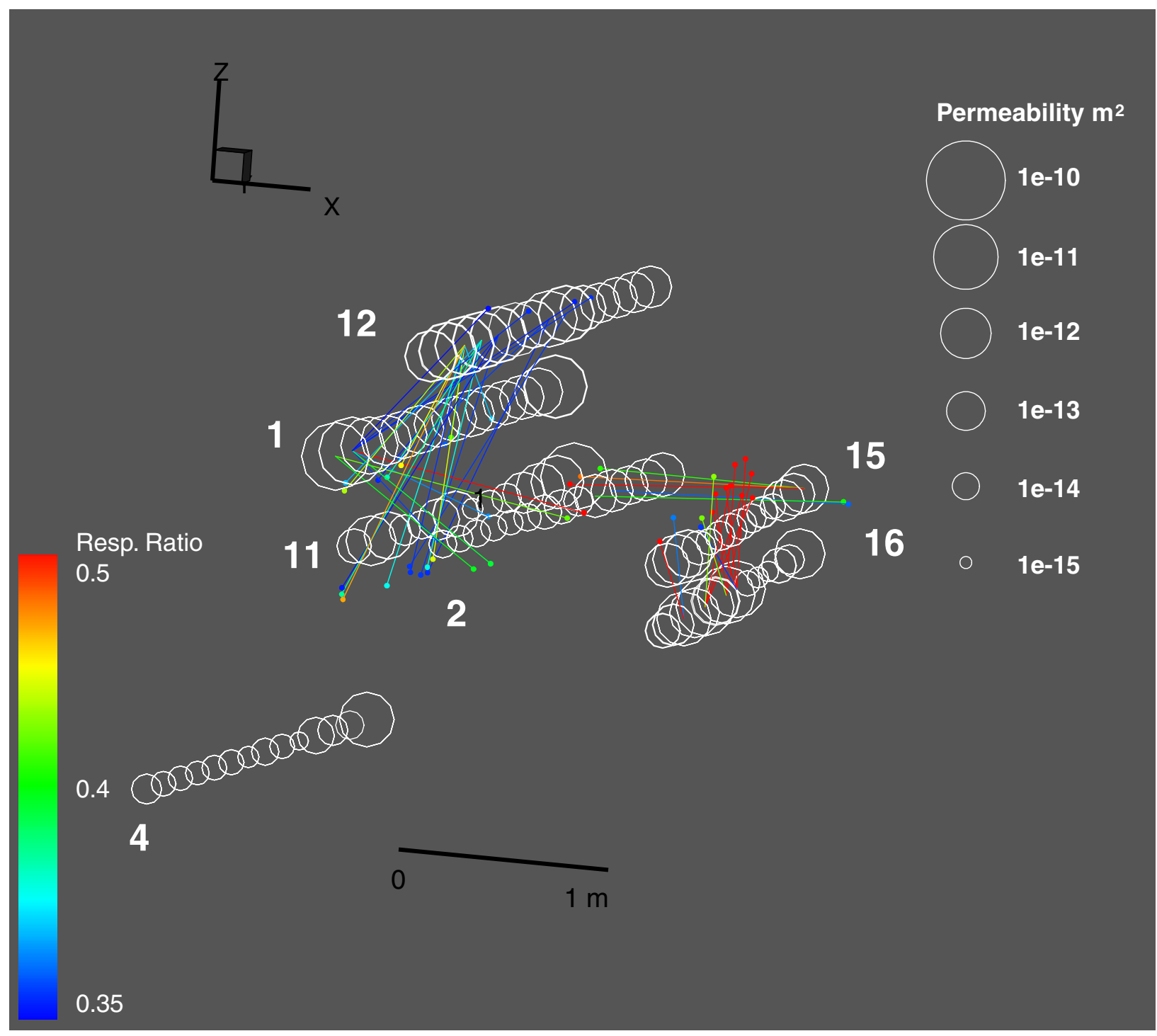

Source: DTN: LB990901233124.004 [DIRS 123273].

Figure 6-73. Crosshole Responses for Borehole Cluster at Alcove 4 PTn Test Bed with Small Response Pressure (Resp.) Ratios Filtered

\subsection{ANALYSES OF FRACTURE FLOW IN FRACTURE-MATRIX TEST BED AT ALCOVE 6}

Wetting-front movement, flow-field evolution, and drainage of fracture flow paths were evaluated in a test bed with a slot excavated below a cluster of boreholes. The slotted test bed is located within the Topopah Spring welded tuff (TSw) at Alcove 6 in the ESF at Yucca Mountain, Nevada. Hydraulic parameters such as formation intake rates, flow velocities, seepage rates, and fracture volumes were measured under controlled boundary conditions, using techniques developed specifically for in situ testing of flow in fractured rock. The test-bed configuration and field instrumentation are described in Section 6.6.1, followed by a discussion 
of the results in Section 6.6.2. The air-permeability profiles and connectivity evaluation of the cluster of boreholes at Alcove 6 are presented in Section 6.5.

\subsubsection{Liquid-Release Tests in Low- and High-Permeability Zones}

Field tests were conducted at Alcove 6 for a period of six weeks, starting in late July 1998. These included multiple releases of tracer-laced water in one high-permeability zone (HPZ) and one low-permeability zone (LPZ) along an injection borehole. The permeabilities of these zones were determined from air-permeability measurements conducted over $0.3-\mathrm{m}$ sections along the borehole, using a straddle packer that also was used for liquid releases. The HPZ had an air-permeability value of $6.7 \times 10^{-12} \mathrm{~m}^{2}$, and the LPZ had an air-permeability value of $2.7 \times 10^{-13} \mathrm{~m}^{2}$ (Salve 1999 [DIRS 155692], pp. 48-49; and Cook 2001 [DIRS 156902], pp. 51-53). During and following liquid-release events, changes in saturation and water potential in the fractured rock were measured in three monitoring boreholes, with changes continuously recorded by an automated data acquisition system. The water that seeped into the excavated slot below the injection zone was collected, volumes and rates measured, and water analyzed for tracers.

\subsubsection{The Test Bed}

The test bed was located at Alcove 6 in the ESF (Panel (a) of Figure 6-74), lying within the middle nonlithophysal zone of the TSw. The rock was visibly fractured, with predominantly vertical fractures and a few subhorizontal fractures. The relatively wide fracture spacing (on the order of tens of centimeters) facilitated the choice of injection zones, allowing discrete fractures and well-characterized fracture networks to be isolated by packers for localized flow testing.

A horizontal slot and a series of horizontal boreholes are the distinct features of the test bed (Panel (b) of Figure 6-74). The slot, located below the test bed, was excavated by an over-coring method. The excavation sequence required the drilling of parallel pilot holes, $0.10 \mathrm{~m}$ in diameter, more than $4 \mathrm{~m}$ in length with a $0.22-\mathrm{m}$ spacing, normal to the alcove wall. The pilot holes were then over-cored by a $0.3-\mathrm{m}$ drill-bit to excavate the 2.0 -m-wide, $4.0-\mathrm{m}$-deep and 0.3-m-high slot located approximately $0.8 \mathrm{~m}$ above the alcove floor. Three I-beams were installed along the length of the slot for support. Four horizontal boreholes, $0.1 \mathrm{~m}$ in diameter and $6.0 \mathrm{~m}$ in length, were drilled perpendicular to the alcove wall above the slot. Borehole A and Borehole B were located $1.6 \mathrm{~m}$ above the slot ceiling; Borehole $\mathrm{C}$ and Borehole $\mathrm{D}$ were $0.9 \mathrm{~m}$ and $1.0 \mathrm{~m}$ above the slot ceiling, respectively, and $0.7 \mathrm{~m}$ apart (Panel (b) of Figure 6-74).

Borehole A was used for fluid injection; Borehole B, Borehole C, and Borehole D were monitored for changes in moisture conditions. The slot was used to collect water seeping from the fractured rocks above. A flexible plastic curtain $3.0 \mathrm{~m}$ wide and $0.9 \mathrm{~m}$ high was installed to cover the slot face and to minimize air movement between the alcove and the slot. 
(a)

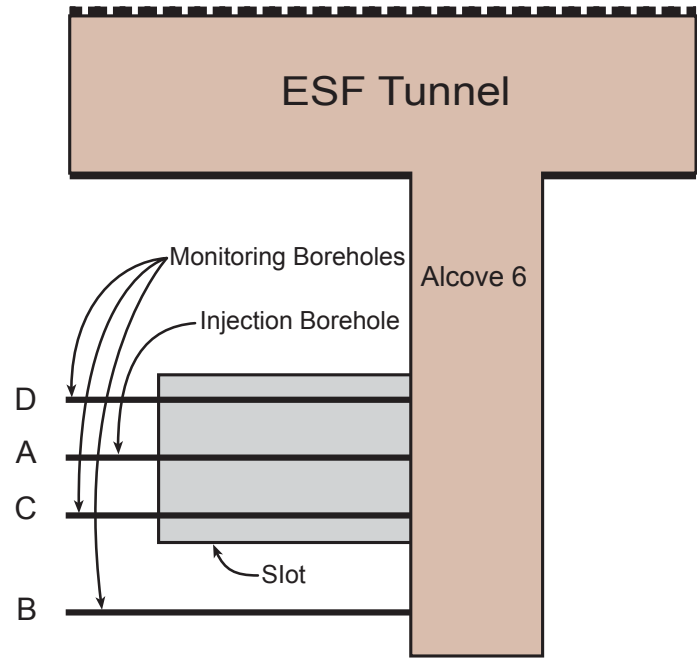

(b)

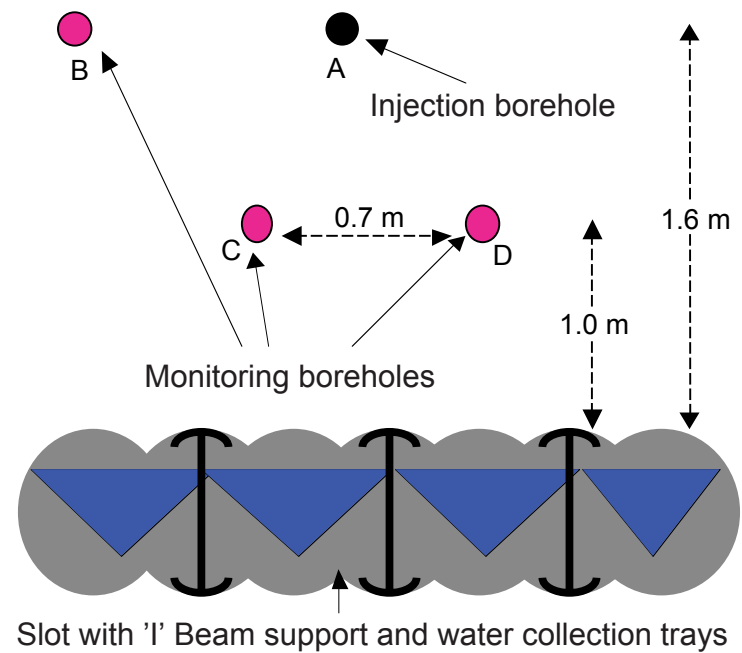

NOTES: Figures are not drawn to scale.

(a) = Plan view of Location.

(b) = Vertical View of Layout of Test Bed.

Figure 6-74. Schematic Illustration of Location and Layout of Alcove 6 in the ESF at Yucca Mountain

\subsubsection{Instrumentation}

Three distinct components to the flow investigation were studied:

- controlled release of water into isolated zones,

- borehole monitoring for changes in saturation and water potential, and

- collection of seepage from the slot ceiling.

The key features of new instruments developed for this field investigation (as well as for Alcove 4 PTn fault and matrix tests described in Section 6.7.1.2) are presented in Appendix F.

\subsubsection{Liquid-Release Experiments}

Air-permeability measurements were done along $0.3-\mathrm{m}$ sections of the injection borehole as described in Section 6.1 and Section 6.5. The HPZ is located 2.3 to $2.6 \mathrm{~m}$ from the borehole collar, whereas the LPZ is 0.75 to $1.05 \mathrm{~m}$ from the collar. In both HPZ and LPZ, a series of constant-head tests were conducted to determine the temporal changes in the rate at which the formation could take in water. In the HPZ, a second series of tests was conducted with different injection rates. Tests conducted in this field investigation are summarized in Table 6-16. Seepage rates into the slot were monitored.

All the water used in the ESF was spiked with lithium bromide for mining-related activities and for most of the scientific investigations. Additional tracers were added to the water injected into the LPZ and during the first set of experiments in the HPZ (Table 6-16). During the tests, water that seeped into the slot was periodically sampled and analyzed for tracer concentrations. 
Water was released into the LPZ three times over a period of two weeks, starting on July 23, 1998 (Table 6-16). For the first release, water was injected at a constant pump rate of approximately $56 \mathrm{~mL} / \mathrm{min}$. At 66 minutes, water was observed in the overflow line, indicating that water was being injected at a rate higher than the intake capacity of the zone. At this time, the flow rate on the pump was immediately reduced to approximately $6.0 \mathrm{~mL} / \mathrm{min}$. Within 22 minutes, return flow ceased, and water was injected continuously at this rate for the next 4 hours and 23 minutes. Based on the actual flow rate determined from transducers located at the bottom of the water reservoir (see Appendix Section F1), a total of $6.3 \mathrm{~L}$ of water was injected into the zone, of which $0.7 \mathrm{~L}$ was recovered as return flow. The other $5.6 \mathrm{~L}$ was released into the formation. The average net release rate into the formation rate was approximately $16 \mathrm{~mL} / \mathrm{min}$.

For the second liquid release in the LPZ, the constant-head injection system was used. The constant-head chamber was located next to the injection borehole, such that the head of water was $0.07 \mathrm{~m}$ in the injection zone. This constant head was maintained for 4 hours in the injection zone, while the water level in the reservoir was continuously monitored. At the end of this constant-head period, water supply to the injection zone was discontinued, resulting in a falling-head boundary condition inside the injection zone. A total of $1.4 \mathrm{~L}$ of water was introduced into the LPZ from both the constant-head and falling-head periods.

The final release into the LPZ was initiated on July 29, 1998, when water was introduced into the formation under a constant head (of $0.07 \mathrm{~m}$ ) maintained for 43 hours, after which the ponded water in the injection zone continued to percolate into the formation under a falling-head condition. During the test, 1.0 L of water was released under the constant-head boundary, whereas $1.2 \mathrm{~L}$ were released under the falling head.

Summing up all three tests in the LPZ, 9.2 L of water were released to the formation under a combination of constant and falling-head boundary conditions at the point of injection.

Water was injected into the HPZ during two groups of tests over a period of two weeks (Table 6-16). The first group of four tests was conducted between August 4 and 6, 1998, and the second group of four tests was conducted between August 25 and 28, 1998. The first two tests (Test HPZ-1 and Test HPZ-2) in the first group were constant-head tests (of head $0.07 \mathrm{~m}$ ) that served to establish the intake rates at which the injection zone could release water to the formation. The HPZ-1 constant-head test rate was approximately $119 \mathrm{~mL} / \mathrm{min}$. The HPZ-2 constant-head test rate was approximately $98 \mathrm{~mL} / \mathrm{min}$. After the HPZ-2 test, tests were conducted at constant flow rates. During the third test (Test HPZ-3) conducted on the next day, water was injected at approximately half the intake rates observed with the constant-head system (i.e., approximately $53 \mathrm{~mL} / \mathrm{min}$ ). During the fourth test (Test HPZ-4) on August 6, 1998, water was injected at a constant rate of approximately $5 \mathrm{~mL} / \mathrm{min}$ over a 12 -hour period. During the second group of tests (Tests HPZ-5 through HPZ-8) over a 4-day period starting on August 25, 1998, the injection rate was sequentially reduced from approximately $69 \mathrm{~mL} / \mathrm{min}$, to approximately $38 \mathrm{~mL} / \mathrm{min}$, then to approximately $29 \mathrm{~mL} / \mathrm{min}$, and finally to approximately $14 \mathrm{~mL} / \mathrm{min}$. 
Table 6-16. Amount of Water and Types of Tracers Released into the Injection Borehole

\begin{tabular}{|c|c|c|c|c|c|}
\hline Date & Test \# & Injection type & $\begin{array}{c}\text { Infiltration } \\
\text { rate } \\
\text { (mL/min) }\end{array}$ & $\begin{array}{l}\text { Volume of } \\
\text { water } \\
\text { injected } \\
\text { (L) }\end{array}$ & Additional Tracer $^{\mathrm{a}}$ \\
\hline $7 / 23 / 98$ & LPZ-1 & Constant rate & $\sim 16$ & 5.6 & $\begin{array}{l}\text { Sodium Bromide } \\
2,3,6 \text { Trifluorobenzoic acid }\end{array}$ \\
\hline $7 / 24 / 98$ & LPZ-2 & Constant head & $\sim 1.2$ & 0.3 & 2,4,5 Trifluorobenzoic acid \\
\hline 7/24/98-7/25/98 & LPZ-2 & Falling head & & 1.1 & 2,4,5 Trifluorobenzoic acid \\
\hline 7/29/98-7/30/98 & LPZ-3 & Constant head & $\sim 0.5$ & 0.4 & 3,5 Difluorobenzoic acid \\
\hline 7/30/98-7/31/98 & LPZ-3 & Constant head & $\sim 0.5$ & 0.6 & 3,5 Difluorobenzoic acid \\
\hline 7/31/98-8/4/98 & LPZ-3 & Falling head & & 1.2 & 3,5 Difluorobenzoic acid \\
\hline $8 / 4 / 98$ & HPZ-1 & Constant head & $\sim 119$ & 16.3 & $\begin{array}{l}\text { Potassium Fluoride } \\
\text { Pentafluorobenzoic acid }\end{array}$ \\
\hline $8 / 4 / 98$ & HPZ-2 & Constant head & $\sim 98$ & 17.3 & 2,3,4 Trifluorobenzoic acid \\
\hline $8 / 5 / 98$ & HPZ-3 & Constant rate & $\sim 53$ & 17.5 & 3,4 Difluorobenzoic acid \\
\hline $8 / 6 / 98$ & HPZ-4 & Constant rate & $\sim 5$ & 3.4 & 2,3,4,5 Tetrafluorobenzoic acid \\
\hline $8 / 25 / 98$ & HPZ-5 & Constant rate & $\sim 69$ & 18.4 & - \\
\hline $8 / 26 / 98$ & HPZ-6 & Constant rate & $\sim 38$ & 18.4 & - \\
\hline $8 / 27 / 98$ & HPZ-7 & Constant rate & $\sim 29$ & 18.2 & - \\
\hline $8 / 28 / 98$ & HPZ-8 & Constant rate & $\sim 14$ & 9.4 & - \\
\hline
\end{tabular}

Source: DTN: LB990901233124.002 [DIRS 146883].

NOTES: LPZ located $0.75-1.05 \mathrm{~m}$ from borehole collar.

HPZ located 2.30-2.60 $\mathrm{m}$ from borehole collar.

${ }^{a}$ All injected water was tagged with lithium bromide.

\subsubsection{Observations of Wetting-Front Migration and Fracture Flow}

Water released in the injection borehole flowed through the fractured rock and, in the case of the HPZ, some of the water seeped into the slot located $1.6 \mathrm{~m}$ below the HPZ. Liquid-release rates in the injected zone were measured, saturation and water-potential changes were observed along monitoring boreholes, and seepage water into the slot was collected.

\subsubsection{Liquid-Release Rates}

Measurements of liquid-release rates in the LPZ in this fractured-welded-tuff test bed exhibited a response similar to that observed for (unfractured) porous media. The initially high rates asymptotically approached low steady-state values of approximately $0.35 \mathrm{~mL} / \mathrm{min}$ (Panel (a) of Figure 6-75). Near continuity was observed in the decreasing liquid-release rates, even with a five-day gap between liquid releases into the formation (Panel (b) of Figure 6-75). 
(a)

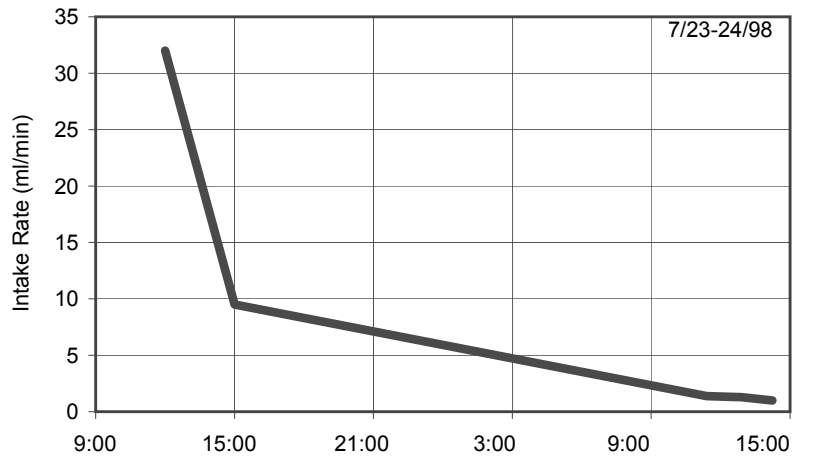

(b)

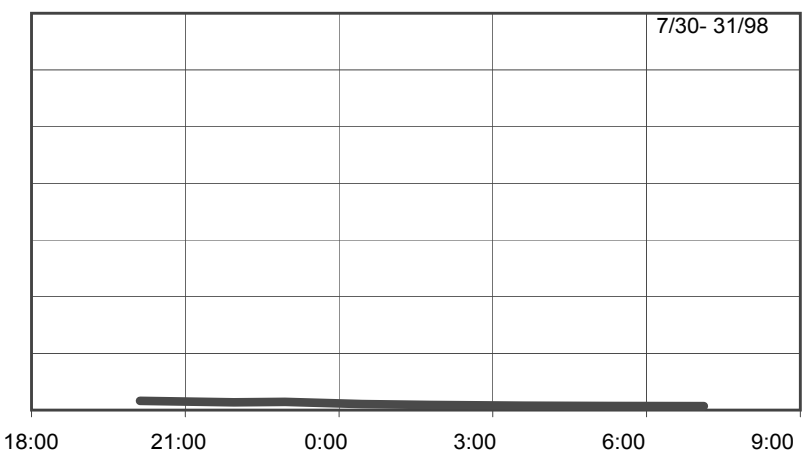

Source: DTN: LB990901233124.002 [DIRS 146883].

NOTES: $\quad(a)=$ During test LPZ-1 and test LPZ-2.

(b) = During test LPZ-3.

Figure 6-75. Water Intake Rates Observed in the Low Permeability Zone as a Function of Time

For the first two constant-head tests conducted in the HPZ, the rates of liquid release varied significantly during and between tests (Figure 6-76). In the first test, the liquid-release rate continued to climb for the first sixty minutes and then remained steady for the next 15 minutes before briefly increasing sharply. For the remainder of the test it continued to fluctuate between 70 and $160 \mathrm{~mL} / \mathrm{min}$. In the second test, the liquid-release rate rapidly increased for the first 15 minutes. The rate then slowly decreased and steadied off to approximately $100 \mathrm{~mL} / \mathrm{min}$. Ninety minutes into the test, the liquid-release rate briefly fell to $35 \mathrm{~mL} / \mathrm{min}$, sharply increased to $130 \mathrm{~mL} / \mathrm{min}$, and slowly decreased to a quasi-steady rate of $90 \mathrm{~mL} / \mathrm{min}$ in the next 80 minutes.

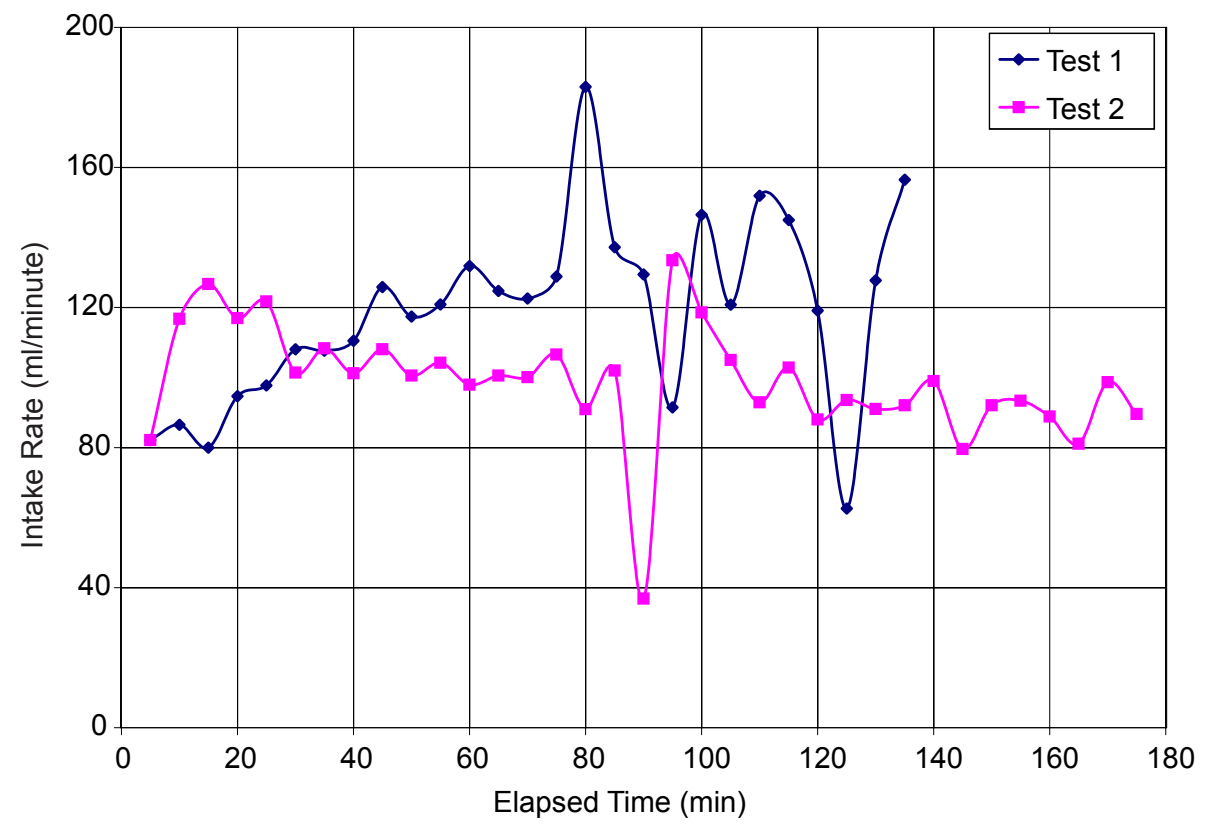

Source: DTN: LB990901233124.002 [DIRS 146883].

Figure 6-76. Water Intake Rates Observed in the High Permeability Zone 


\subsubsection{Formation Wetting and Drying}

Both electrical resistance probes (ERPs) and psychrometers were used for Alcove 6 wetting front detection and formation saturation change measurements, as well as in the other three testing activities (fault and matrix flow in Section 6.7, construction water migration in Section 6.9, drift-to-drift flow and transport in Section 6.12, as summarized in Table 1-1.) The ERPs consist of two electrical leads sandwiched between pieces of filter paper, with electrical resistance changes indicating saturation change. The psychrometers are moisture sensors imbedded in small cavities in the borehole wall. Appendix Section F2 and Appendix G describe the supplemental details for both types of sensors.

In the two monitoring boreholes (Borehole $\mathrm{C}$ and Borehole $\mathrm{D}$, shown in Panel (b) of Figure 6--74) located below the injection borehole (Borehole A), changes in saturation were detected both by the ERPs, as shown in Panels (a) and (c) of Figure 6-77, and by the psychrometers, as shown in Panels (b) and (d) of Figure 6-77. The results in Figure 6-77 are the responses to liquid release in the LPZ located 0.75 to $1.05 \mathrm{~m}$ from the borehole collar. In both boreholes, large changes in saturation were detected by either the ERPs or psychrometers, or both, located between 0.9 and $1.9 \mathrm{~m}$ from the borehole collar. At a distance of $2.15 \mathrm{~m}$ from the borehole collar, the changes were much smaller.

The wetting process reduces electrical resistance and increases the water potential (making it less negative). The drying process induces the opposite changes. In Borehole $\mathrm{C}$, the first drying response was detected by the ERP $0.90 \mathrm{~m}$ from the borehole collar, as illustrated in Panel (a) of Figure 6-77. A step increase in resistance was observed 30 minutes after water had been released, suggesting some initial drying with dry air preceding a wetting front. Two hours later, an abrupt increase in wetting was indicated by a stepped decrease in resistance. ERPs located at $1.15,1.40$, and $1.65 \mathrm{~m}$ also detected the arrival of a wetting front within 2 to 4 hours of liquid release. In Borehole D (Panel (c) of Figure 6-77), the ERPs located at 0.9 and $1.15 \mathrm{~m}$ from the collar were first to detect increases in saturation, 30 minutes after the first release of water. At distances of 1.40 and $1.65 \mathrm{~m}$, the wetting front arrived 6 hours later.

In both boreholes, the probes that had the largest and quickest responses (i.e., probes located between 1.15 and $1.65 \mathrm{~m}$ ) were also the ones that showed some drying between the two injection events. Probes located at a distance of 0.90-1.15 m detected a continuous drying trend after the initial period of injection. 
The Borehole $\mathrm{C}$ psychrometer data in Panel (b) of Figure 6-77 supported the ERP data in Panel (a) of Figure 6-77 with smoother and more systematic changes induced by wetting-front arrivals. The sensors closest to the release point had larger changes in water potential. At distances between 1.40 and $2.15 \mathrm{~m}$ from the borehole collar, water potentials were between -140 and $-75 \mathrm{~m}$ before the first injection. Immediately after water was introduced, water potentials began to rise steadily for the next four days, reaching values between -70 and $-30 \mathrm{~m}$. In response to the second injection period (i.e., July 29, 1998, through August 4, 1998, in Table 6-16), the most noticeable increases in potentials were observed in the psychrometer located at $1.40 \mathrm{~m}$, where water potentials increased from -40 to $-15 \mathrm{~m}$ after the second injection period. In Borehole D, illustrated in Panel (d) of Figure 6-77, changes in water potential were observed between 0.90 and $1.90 \mathrm{~m}$ following the first injection. However, the extent of drying, as seen in the decrease in water potentials at 1.40 and $1.65 \mathrm{~m}$, was greater than observed in Borehole C. During the second wetting event, water potentials in this zone were similar to those observed following the first event. Oscillatory responses could be related to variations of drift conditions for sensors near the borehole collars. This is a speculative interpretation, to be substantiated or refuted.

Similar to the injection response in the LPZ, changes in saturation were detected both by the ERPs and psychrometers in the monitoring boreholes (Figure 6-78) from liquid releases into the HPZ located 2.30-2.60 m from the borehole collar. In Borehole C, changes in saturation were observed between 1.9 and $3.4 \mathrm{~m}$ from the borehole collar, with the largest changes observed between 2.15 and $3.15 \mathrm{~m}$. Both the ERPs and the psychrometers detected the changes. The largest changes in water potentials were detected between 2.15 and $2.40 \mathrm{~m}$ from the borehole collar in Borehole $\mathrm{C}$, where pre-injection water potentials, which were between -70 to $-60 \mathrm{~m}$, climbed to between -20 and $-10 \mathrm{~m}$ after the first set of releases. These values persisted after the second set of releases. In Borehole D, saturation changes were observed over a slightly wider span along the borehole (i.e., 1.65 to $3.65 \mathrm{~m}$ from the borehole collar), with the noticeable changes observed between 1.90 and $3.40 \mathrm{~m}$ from the borehole collar. After the initial release of water in the HPZ, water potentials between locations $2.15 \mathrm{~m}$ and $2.90 \mathrm{~m}$ increased over period of one week. The water potentials remained between -15 to $-5 \mathrm{~m}$ for the duration of the remaining liquid releases.

In both boreholes, the psychrometer data suggest that after the first batch of water releases (i.e., August 4 to 6, 1998), water potentials significantly increased (e.g., -60 to $-20 \mathrm{~m}$ ), and persisted at those levels until the start of the second period of injection (August 25 to 28, 1998). During this second set of injections, more water was retained by the formation, resulting in further increases in water potentials. The ERP and psychrometer data indicate that the zones between 2.15 and $2.40 \mathrm{~m}$ in Borehole $\mathrm{C}$, and between 2.15 and 2.65 in Borehole $\mathrm{D}$, showed the largest changes during active testing. 

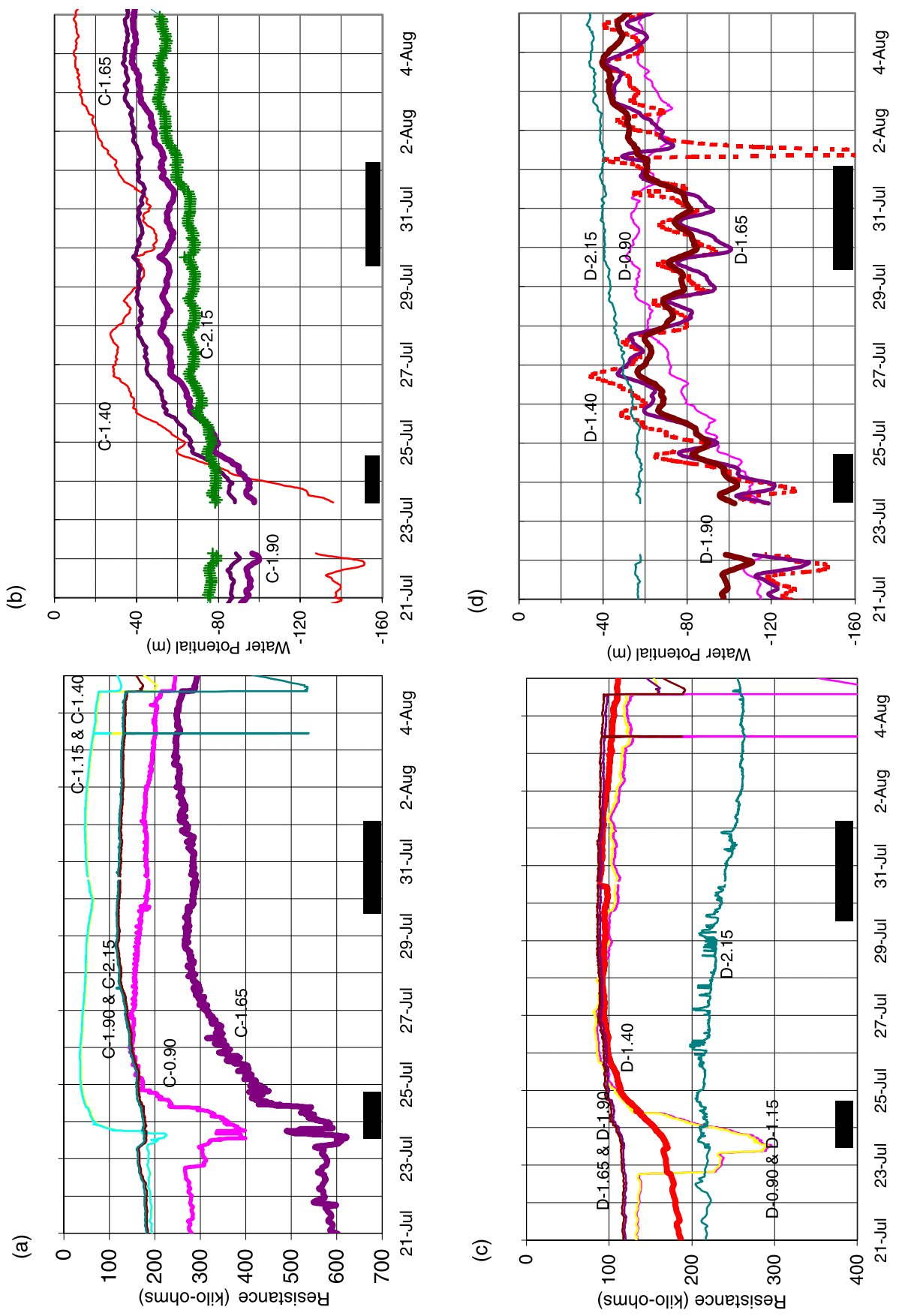

Source: DTN: LB990901233124.002 [DIRS 146883].

NOTES: The legends identify the sensor locations in the boreholes (Borehole $C$ and Borehole D) and the distance of the sensors from the borehole collar. Shaded zones indicate the duration of liquid-release events. Note resistance axis is inverted.

Figure 6-77. Changes in Electrical Resistance and Water Potential Detected during Liquid Release into the Low Permeability Zone 

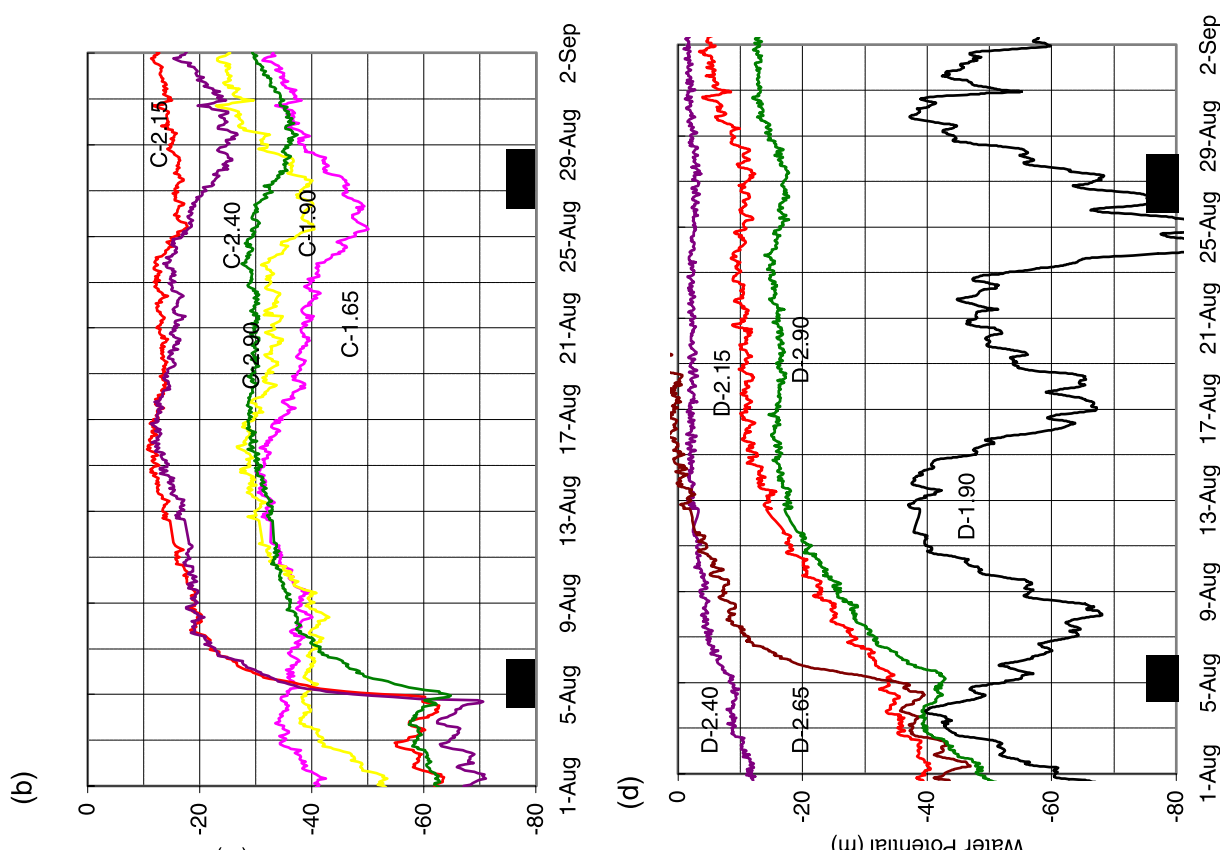

(u) ןе!циәюо дәңем

(u) ןе!̣uәџод ләңем
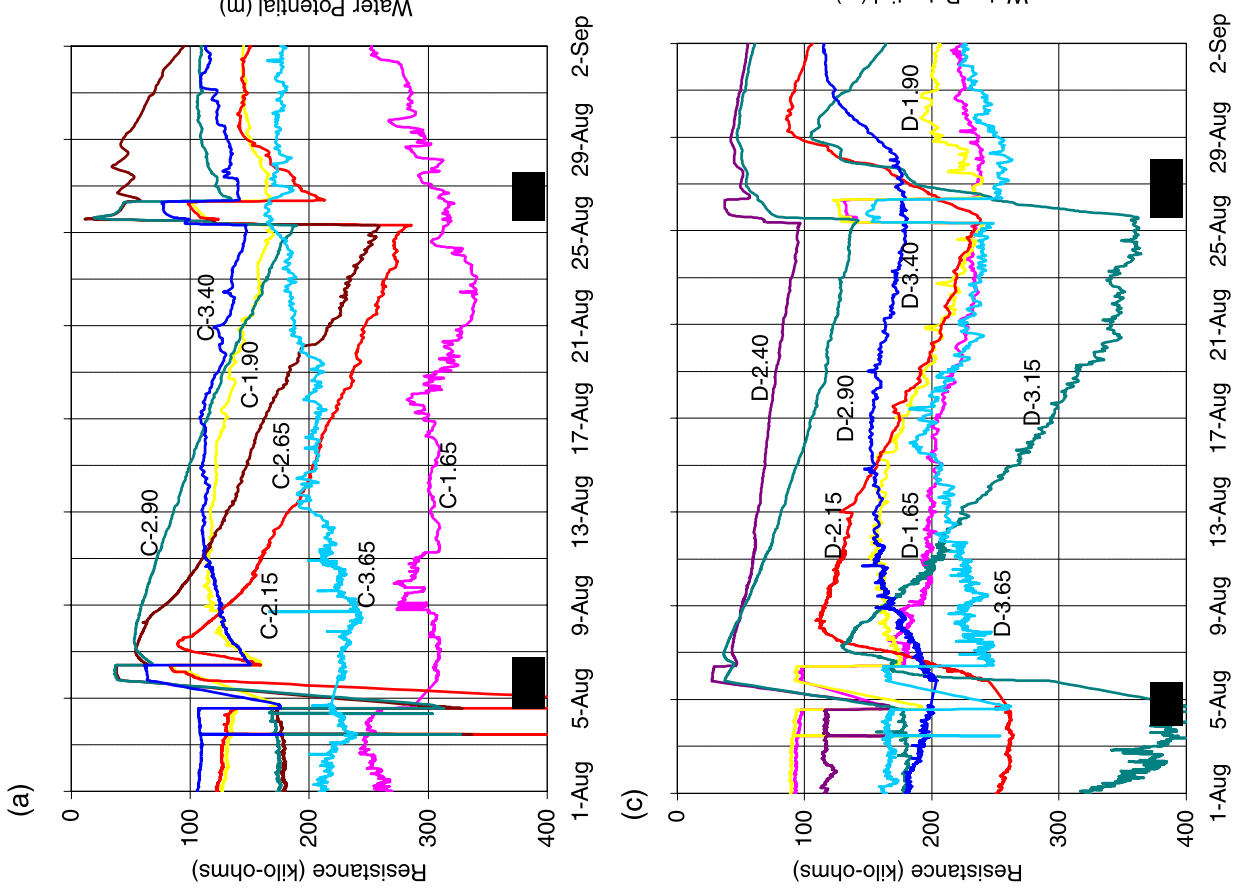

Source: DTN: LB990901233124.002 [DIRS 146883].

NOTES: The HPZ is located between 2.30 and $2.60 \mathrm{~m}$ from the borehole collar. The legends identify the sensor locations in the boreholes (Borehole $\mathrm{C}$ and Borehole $\mathrm{D}$ ) and the distance of sensors from the borehole collar. Shaded zones indicate the duration of two groups of liquid-release events. Note resistance axis is inverted.

Figure 6-78. Changes in Electrical Resistance and Water Potential Detected during Liquid Release into the High Permeability Zone 


\subsubsection{Seepage into the Slot}

Seepage into the slot was observed during all eight tests in the HPZ and was not observed during any of the LPZ tests. Compared to water flowing in and seeping from the HPZ, the absence of seepage from the LPZ tests could be a result of insufficient water flow combined with a higher effectiveness of the capillary barrier forming at the slot. The eight HPZ tests were conducted in two groups (Table 6-16). The test results are summarized in Table 6-17 and illustrated in Figure 6-77 and Figure 6-78 as two test periods highlighted by black bars. During the first test in the first group (Test HPZ-1), water was first observed on the slot ceiling five minutes after the start with 0.41 liters of water released under constant-head conditions. In the HPZ-2 and HPZ-3 tests, water appeared in the slot within 3 minutes after 0.17 and $0.14 \mathrm{~L}$, respectively, had been released. In the HPZ-4 test, water appeared in the slot after five hours with $1.50 \mathrm{~L}$ of water injected at a rate of $5 \mathrm{~mL} / \mathrm{min}$.

In the second group of tests, the water travel time for the first drop of water was 3 minutes after $0.14 \mathrm{~L}$ was injected at a rate of approximately $69 \mathrm{~mL} / \mathrm{min}$ (Test HPZ-5). In the HPZ-6 and HPZ-7 tests, the arrival time of the wetting front was seven minutes after 0.26 and $0.20 \mathrm{~L}$ of water were injected at rates of 38 and $29 \mathrm{~mL} / \mathrm{min}$, respectively. In the final HPZ-8 test, water first appeared in the slot after 68 minutes, with $0.90 \mathrm{~L}$ injected into the formation at a rate of $14 \mathrm{~mL} / \mathrm{min}$.

Table 6-17. Summary of Liquid-Injection Tests in the High Permeability Zone

\begin{tabular}{|c|c|c|c|c|c|c|c|}
\hline \multirow[b]{2}{*}{$\begin{array}{c}\text { Test } \\
\text { Number }\end{array}$} & \multirow{2}{*}{$\begin{array}{l}\text { Injection } \\
\text { Rate } \\
\text { (mL/min) }\end{array}$} & \multirow{2}{*}{$\begin{array}{c}\text { Duration } \\
\text { of } \\
\text { Injection } \\
\text { (hh:mm) }\end{array}$} & \multirow{2}{*}{$\begin{array}{l}\text { Volume } \\
\text { Recovered } \\
\text { (L) }\end{array}$} & \multirow{2}{*}{$\begin{array}{c}\text { Water } \\
\text { Travel } \\
\text { Time of } \\
\text { First Drop } \\
\text { (hh:mm) }\end{array}$} & \multicolumn{2}{|c|}{$\begin{array}{l}\text { Volume of Water In } \\
\text { Formation } \\
\text { (L) }\end{array}$} & \multirow{2}{*}{$\begin{array}{c}\text { Water } \\
\text { Retained in } \\
\text { Formation } \\
(\%)\end{array}$} \\
\hline & & & & & At First Drop & $\begin{array}{l}\text { At End of } \\
\text { Injection }\end{array}$ & \\
\hline HPZ-4 & 5 & $11: 54$ & 0.36 & 5:00 & 1.51 & 3.03 & 89 \\
\hline HPZ-8 & 14 & $11: 19$ & 4.56 & 1:08 & 0.90 & 4.82 & 51 \\
\hline HPZ-7 & 29 & $10: 36$ & 13.21 & $0: 07$ & 0.20 & 5.02 & 28 \\
\hline HPZ-6 & 38 & 8:00 & 14.73 & $0: 07$ & 0.26 & 3.71 & 20 \\
\hline HPZ-3 & 53 & $5: 25$ & 11.14 & $0: 03$ & 0.14 & 6.31 & 36 \\
\hline HPZ-5 & 69 & $4: 26$ & 11.47 & $0: 03$ & 0.14 & 6.90 & 38 \\
\hline HPZ-2 & 98 & $2: 56$ & 12.17 & $0: 03$ & 0.17 & 5.15 & 30 \\
\hline HPZ-1 & 119 & $2: 17$ & 11.61 & $0: 05$ & 0.41 & 4.67 & 29 \\
\hline
\end{tabular}

Source: DTN: LB990901233124.002 [DIRS 146883].

$\mathrm{HPZ}=$ high permeability zone.

The fraction of injected water recovered in the slot continued to increase as each test progressed. Significant variability was observed in the percentage of water recovered and the seepage rate during and between tests (Panels (a) and (b) of Figure 6-79). Seepage variability was related to both the amount of water injected and the rate at which water was released into the formation. Early in each test, the amount of water recovered sharply increased. The percentage of injected water recovered approached relatively constant values after approximately $10 \mathrm{~L}$ of water had been injected. Intermittent seepage behavior (Panel (b) of Figure 6-79) was observed during all the tests. 
(a)

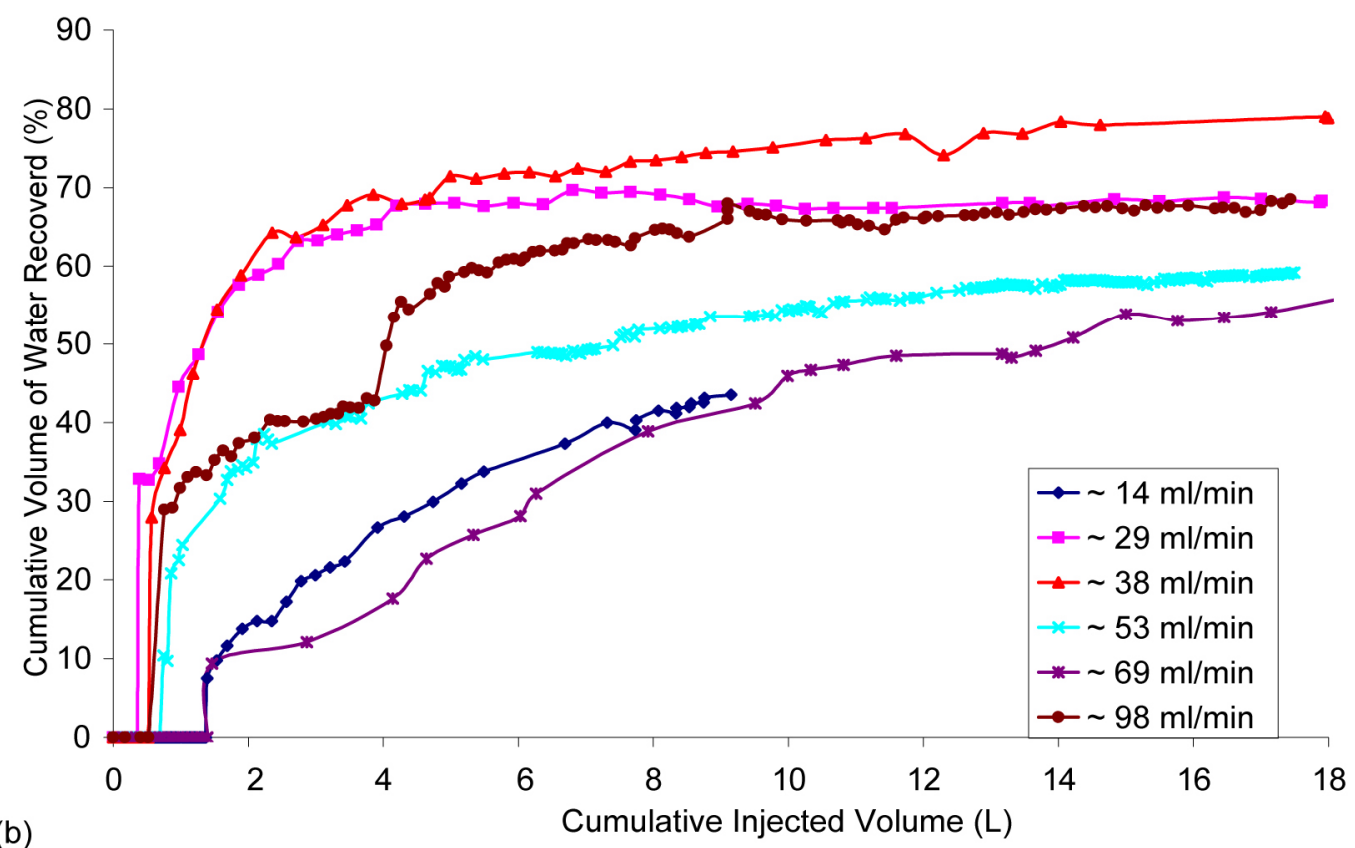

(b)

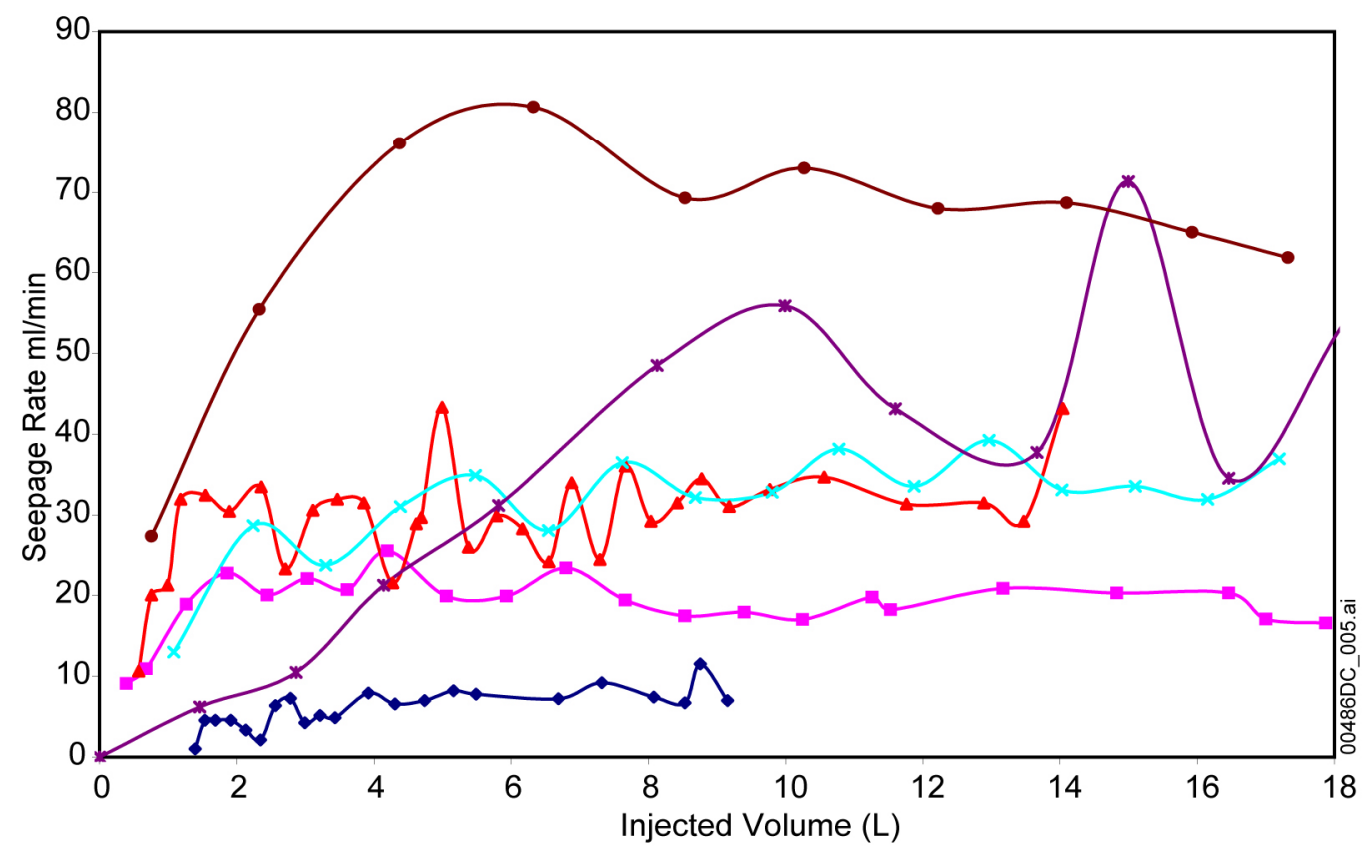

Source: DTN: LB990901233124.002 [DIRS 146883].

NOTES: $\quad(a)=$ Percentage of injected water recovered.

(b) = Seepage rates for various release rates.

Figure 6-79. Seepage from High Permeability Zone into Slot in Alcove 6 
As illustrated in Panel (a) of Figure 6-79 the percentage of injected water recovered at the release rate of $38 \mathrm{~mL} / \mathrm{min}$ was higher than the percentages recovered at other injection rates. The first maximum percentage could be associated with the dominant flow path connecting the injection zone with the outflow slot boundary. With increasing injection rate, additional flow paths, either through other fractures or through other areas in the same fracture, could contribute to the storage and flow of additional water.

Figure 6-80 illustrates the distribution of seepage among the collection trays in the slot. As each test progressed, water initially appeared on the slot ceiling at one single point directly below the injection zone, and seepage water was collected from four trays located around the point of entry. During these tests, water seeping into the slot was largely concentrated in a single tray, with the three other trays collecting significantly smaller amounts of water. Slight increases at higher injection rates were noticeable in some of the secondary trays. The remaining 24 trays stayed dry during all the liquid-release tests.

In all the tests during which there was seepage, 0.5 to $1.3 \mathrm{~L}$ of water entered the slot after the water supply to the formation was switched off (Figure 6-81). Most of this water was collected within one hour, with recovery rates being largest immediately after the test. The constant-head test with an approximate release rate of $98 \mathrm{~mL} / \mathrm{min}$ had a "stepped" nature to the post-injection recovery. During the first fifteen minutes, the $0.8 \mathrm{~L}$ of water collected appeared in four bursts, each containing $0.1-0.3 \mathrm{~L}$ of water. Changes of similar magnitudes were observed in the tests with injection rates of approximately $53 \mathrm{~mL} / \mathrm{min}$ and approximately $14 \mathrm{~mL} / \mathrm{min}$ (with one late burst each shown in Figure 6-81).

\subsubsection{Tracer Recovery}

Tracers injected in the HPZ were detected in the water samples collected in the slot. (None of the tracer solution introduced in the LPZ was recovered.) Typically, tracers introduced in one test were rapidly flushed out of the system during the subsequent test (Figure 6-82). The pattern of recovered concentrations of tracers suggests that plug flow was the dominant process by which "new" water replaced "old" water from the previous test. This behavior contrasts that observed in the PTn (see Section 6.4.2), which shows a more diffuse, damped front propagation due to the higher matrix permeability of that unit. Some recovery of tracers from the formation was observed during subsequent tests. 
(a)

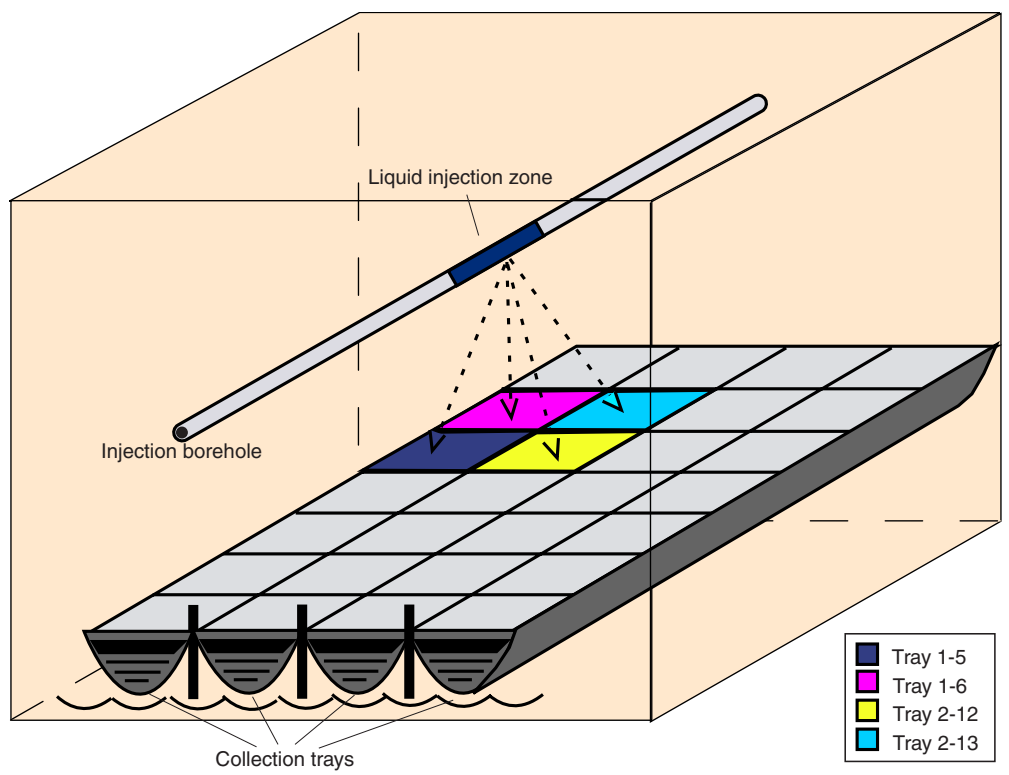

(b)

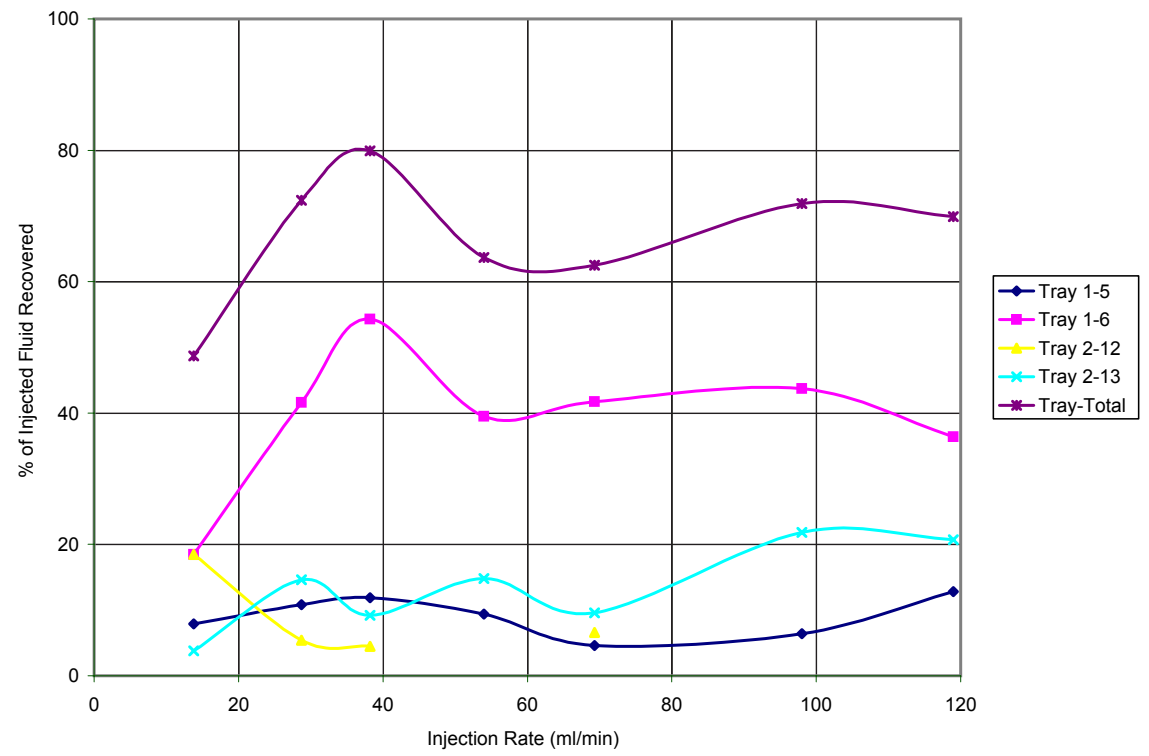

Source: DTN: LB990901233124.002 [DIRS 146883].

NOTES: $\quad(a)=$ Tray configuration.

(b) = Percentages of injected water recovered for different trays.

Figure 6-80. Seepage into Collection Trays in the Slot in Alcove 6 


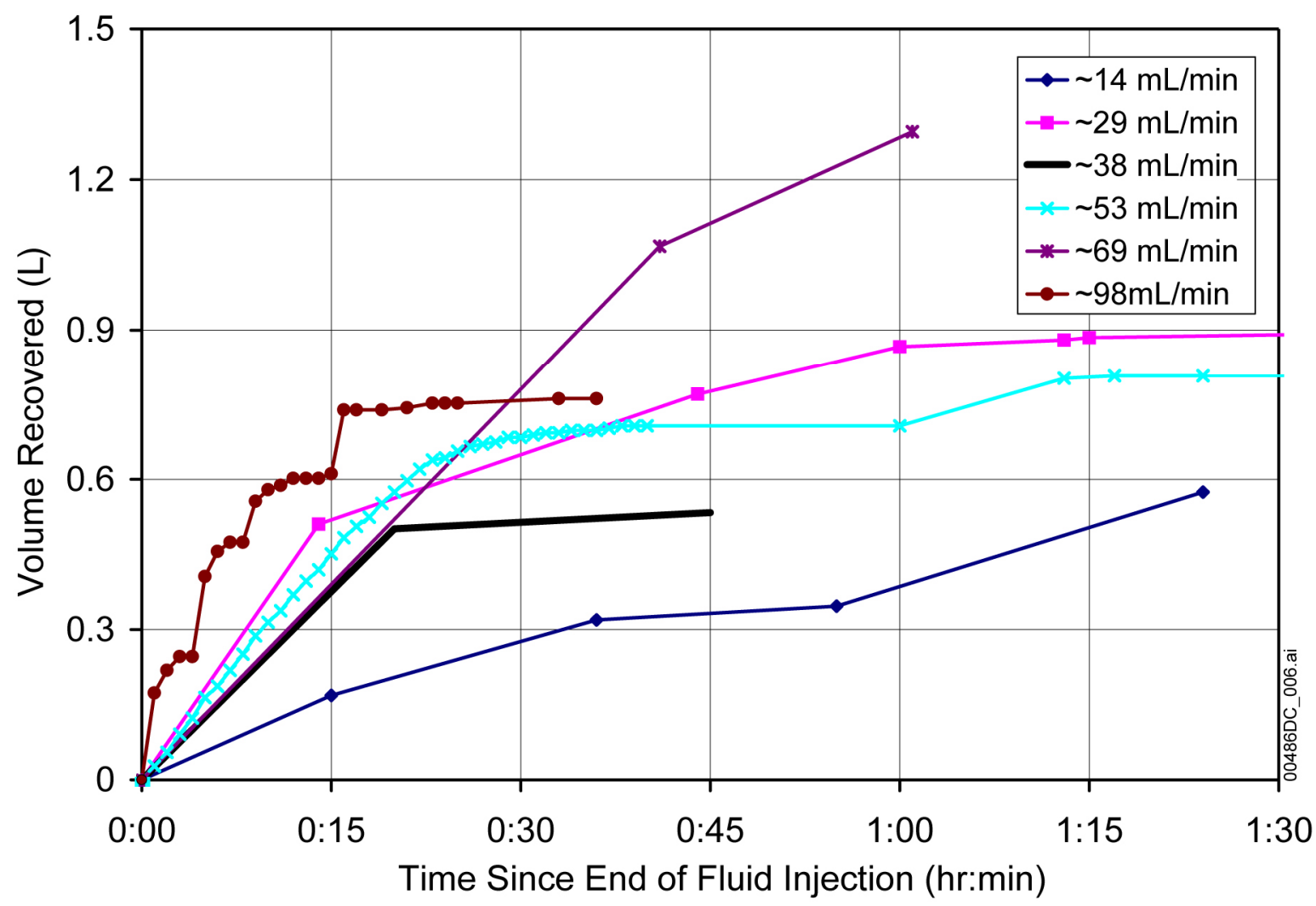

Source: DTN: LB990901233124.002 [DIRS 146883].

Figure 6-81. Volume of Water Recovered in the Slot after Liquid Injection at Various Rates into the High Permeability Zone was Stopped

\subsection{ANALYSES OF FLOW THROUGH THE FAULT AND MATRIX IN THE TEST BED AT ALCOVE 4}

To investigate the potential for damping fast flow through the Paintbrush nonwelded tuff (PTn), the evolution of a flow field and the migration of a wetting front following the release of liquid into a fault and matrix were evaluated in a test bed using a cluster of horizontal boreholes at Alcove 4 . The air-permeability profiles and connectivity evaluation of this cluster of boreholes are presented in Section 6.5. 


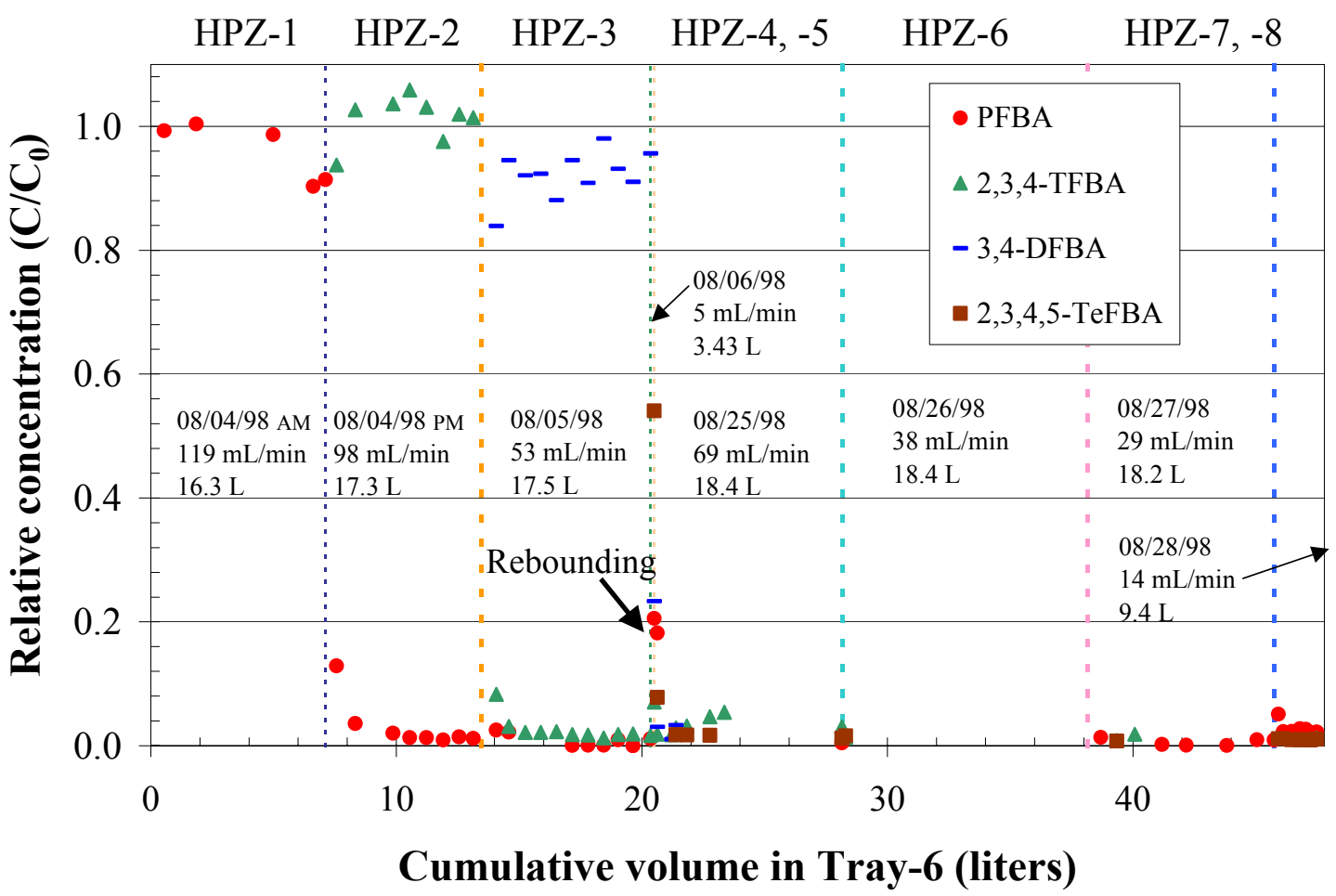

Sources: DTNs: Flow Rate Data: LB990901233124.002 [DIRS 146883], and Chemical Data: LB990901233124.001 [DIRS 155694].

Figure 6-82.Tracer Concentrations in Seepage Water Following Injection into the High Permeability Zone

\subsubsection{Flow Tests in Paintbrush Tuff Unit Layers and Fault}

Field experiments were conducted in the PTn within the ESF at Yucca Mountain. These experiments included multiple releases of tracer-laced water in isolated zones along three horizontal boreholes. The zones into which water was released were selected based on air-permeability measurements conducted over $0.3-\mathrm{m}$ sections of borehole (Section 6.5.2). The plumes that developed from these releases were monitored in six separate horizontal boreholes. During and following liquid-release events, changes in saturation and water potential along horizontal monitoring boreholes were continuously recorded by an automated data acquisition system.

\subsubsection{The Test Bed}

The test bed is located at Alcove 4 in the ESF. It is accessed through an alcove excavated (by an Alpine miner) at approximately $67^{\circ}$ to the central axis of the ESF north ramp. Alcove 4 transects portions of the lower Pah Canyon Tuff (Tpp) and the upper Pre Pah Canyon bedded tuffs (Tpbt2) of the PTn (nomenclature of Buesch et al. 1996 [DIRS 100106], p. 7). The central axis of the alcove has an azimuth of $6^{\circ}$, which coincides with the approximate strike of the PTn units in the vicinity. The north face of the alcove, in which the test bed is located, is approximately $6 \mathrm{~m}$ wide and $5.3 \mathrm{~m}$ high (Figure 6-83). 


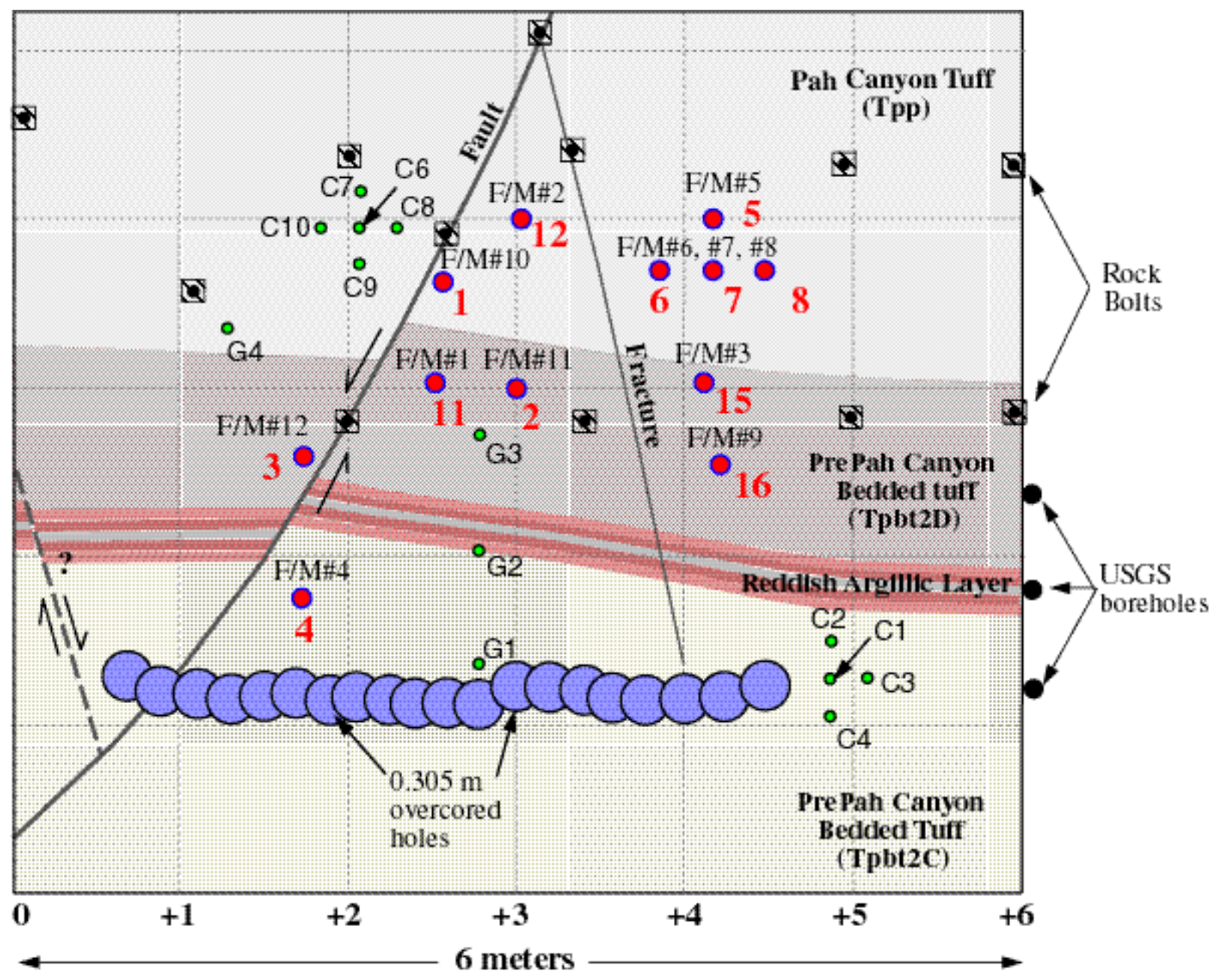

$0.0762 \mathrm{~m}$ diameter (NQ) boreholes, approximate depth $=6 \mathrm{~m}$

- $0.0254 \mathrm{~m}$ diameter boreholes, depth of "G" holes $=1 \mathrm{~m}$, depth of "C $\mathrm{C}$ " holes $=2 \mathrm{~m}$

NOTE: Also included are location of boreholes and the slot.

Figure 6-83. Geological Sketch and Schematic Illustration for the North Face of Alcove 4 in the ESF at Yucca Mountain

The lower Tpp and upper Tpbt2 units D and C [units from Stratigraphic Relations and Hydrologic Properties of the Paintbrush Tuff Nonwelded (PTn) Hydrologic Unit, Yucca Mountain, Nevada (Moyer et al. 1996 [DIRS 100162], pp. 46-50)] are exposed along the north face of Alcove 4. Tpp is nonwelded and pumice-rich, exhibiting a chalky-white color. It is apparently zeolitically altered [based on destruction of the texture of the matrix ash and destruction of the integrity of the glass shards (Moyer et al. 1996 [DIRS 100162], p. 46)]. Zeolitic alteration in the north ramp of the ESF commonly follows fractures and faults that cut through the Tpp and Tpbt2 units (Barr et al. 1996 [DIRS 100029], p. 44). The contact between the lower Tpp and upper Tpbt2D is sharp in Alcove 4, marked by distinct color changes. Tpbt2D is also nonwelded, possibly reworked, and has variably abundant (zeolitically altered) pumice within a fine- to coarse-grained, medium-brown matrix. 
Below Tpbt2D, lying in the upper Tpbt2C is a thin $(0.20$ to $0.30 \mathrm{~m})$, light-pink-to-red argillically altered layer that is almost completely offset by a small, westward-dipping normal fault. Alteration within this layer can be traced from the end of Alcove 4 out into the north ramp. Whether the argillic alteration seen in Alcove 4 is laterally continuous is uncertain, though reddish alteration is commonly observed in several boreholes and in outcrops across Yucca Mountain at the same stratigraphic horizon (Moyer et al. 1996 [DIRS 100162], pp. 54-55). The remaining Tpbt2C exposed along the north face below the argillic layer is massive and nonwelded, has very pale tan coloring, and contains abundant, coarse pumice and lithic fragments.

Cutting the north face of Alcove 4 is a normal fault with a small offset $(0.25 \mathrm{~m})$. As mapped along the crown at the end of the alcove (Barr et al. 1996 [DIRS 100029]; full-periphery geological map OA-46-289, DTN: GS960908314224.020 [DIRS 106059] for the crown, but not for the end face), the fault has a strike of approximately $195^{\circ}$ and a westward dip of $58^{\circ}$. The fault is open in the ceiling and is closed, with knife-edge thickness, near the invert on the north face. Intersecting the fault near the alcove crown along the north face is a high-angle fracture. The cause of the fracture is uncertain and could have been induced by drilling or drying, considering the location of rock bolts and the clay content of the rocks. The orientation of the fracture is unknown, though it has an apparent eastward dip of approximately $75^{\circ}$. Similar to the fault, the fracture appears to have a large aperture near the ceiling and a much smaller aperture (eventually becoming undetectable) near the invert. This fault feature has no visually apparent "zone" of alteration associated with the fault trace, i.e., it is identified as a fault by the offset alone.

Two distinct features that were imposed on the formation define the layout of the field experiment, i.e., a horizontal slot and a series of horizontal boreholes. The slot, located immediately below the test bed, was designed to capture any seepage resulting from gravity drainage. It was excavated by a drilling sequence that required 0.10 -m-diameter pilot holes drilled parallel at $0.22-\mathrm{m}$ spacing, perpendicular to the alcove wall. These pilot holes were then over-cored by a $0.3-\mathrm{m}$ drill-bit to excavate a 6.0-m-wide, 4.0-m-deep and 0.3-m-high cavity located approximately $1.5 \mathrm{~m}$ above the alcove floor. I-beam supports were installed along the length of the slot to prevent it from collapsing during the duration of the field tests.

Twelve 6.0-m-long boreholes were drilled into the alcove face, as illustrated in Figure 6-83 and Figure 6-84. Borehole 1, Borehole 4, Borehole 11, and Borehole 12 were positioned to intersect the fault for the purpose of conducting flow tests within the fault. Borehole 2 was located to detect moisture that could migrate through the matrix below Borehole 12. Borehole 12 was the injection borehole for the fault flow tests conducted. The configuration of Borehole 5, Borehole 6, Borehole 7, and Borehole 8 was designed to investigate the nature of matrix flow in the Tpp, with Borehole 5 serving as the injection borehole and Borehole 6, Borehole 7, and Borehole 8 equipped with probes to detect changes in moisture conditions. Borehole 3 on the left side of the fault, and Borehole 15 and Borehole 16 away from the injection boreholes, were not instrumented for the tests conducted. (Borehole 9, Borehole 10, Borehole 13, and Borehole 14 were planned but not drilled.) 


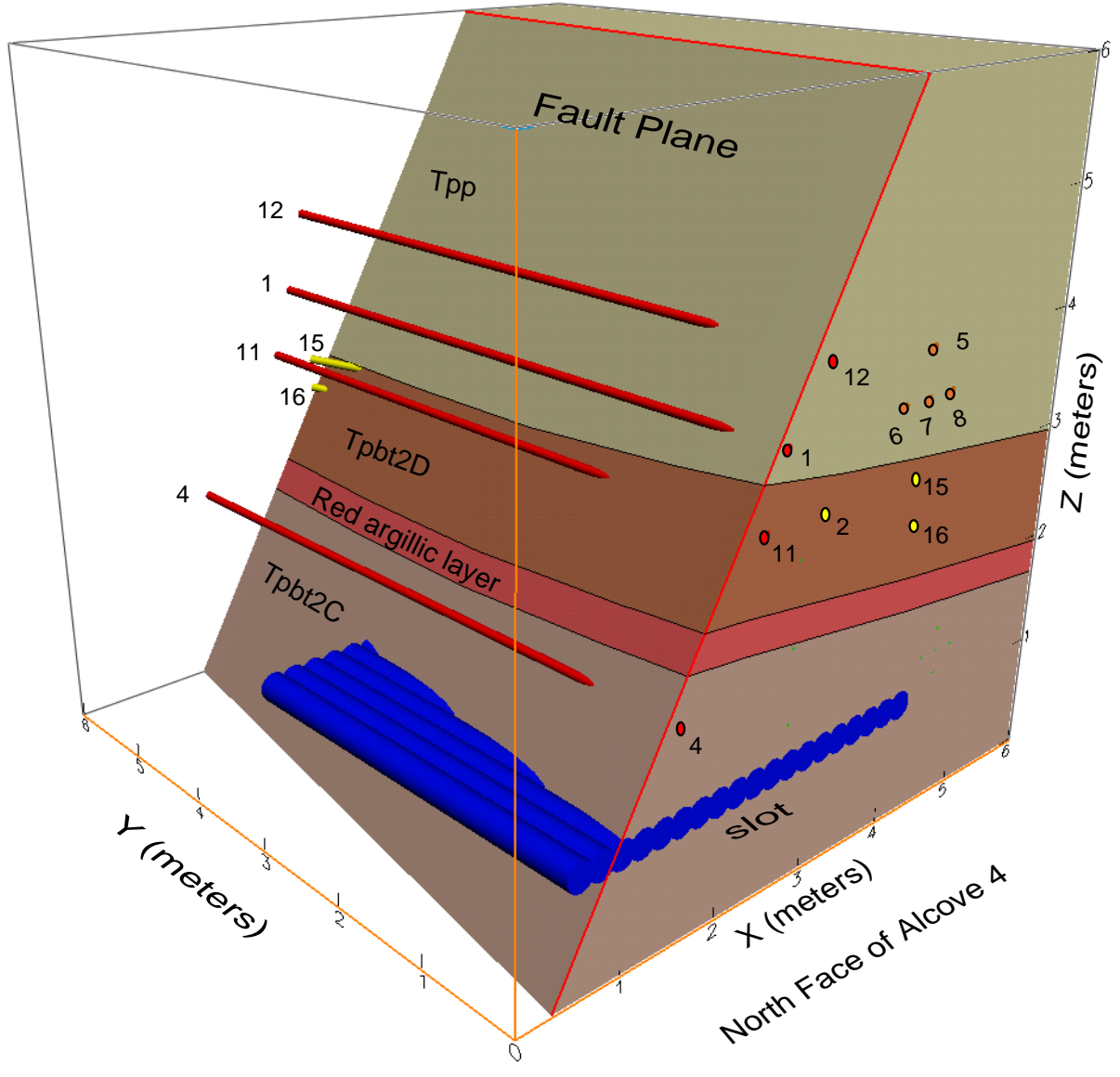

Figure 6-84. Perspective Illustration of Three-Dimensional View of the Boreholes, Slot, and Lithological Unit Contacts in the Alcove 4 Test Bed

\subsubsection{Instrumentation}

The flow investigation had three distinct components:

1. controlled release of water into isolated zones,

2. borehole monitoring for changes in saturation and water potential, and

3. the monitoring of seepage from the slot ceiling.

For each component, new instruments were developed (for both the Alcove 6 Tptpmn TSw fracture-matrix test described in Section 6.6.1.2 and the Alcove 4 PTn fault and matrix tests described in this section), details for which are given in Appendix F. Because water did not seep into the slot, the seepage monitoring system was not used. Key features of the liquid-injection and borehole-monitoring system are presented in the following subsections. 


\subsection{Fluid Injection}

The liquid-release experiments required water to be injected into the formation over a $0.3-\mathrm{m}$ section of borehole with a constant-head boundary condition to determine the maximum rates at which the zone could take in water. The main components of the fluid-release apparatus included an inflatable packer system used to isolate the injection zone, a pump to deliver water to a constant-head chamber from which water was introduced into the injection zone, and a reservoir to provide a continuous supply of water. To capture the temporal variability in vertical flux of water from the injection zone, an automated liquid-release system was developed to measure changing flow rates as a constant level was maintained on a ponded surface. This system allowed for continuous measurement of local liquid-release rates during the entire experiment.

\subsection{Borehole Monitoring}

In six monitoring boreholes (Boreholes 1, 2, 6, 7, 8, and 11 in Figure 6-84) located above the slot, changes in saturation and water potential were continuously recorded during the entire investigation. Changes in saturation along boreholes were measured with ERPs located at $0.25-\mathrm{m}$ intervals along the $6.0-\mathrm{m}$-long boreholes. Water-potential measurements were made with psychrometers, as described in Section F2 for Alcove 6 testing. The psychrometers and ERPs were housed in special borehole sensor trays (BSTs) installed along the length of each monitoring borehole.

\subsubsection{Liquid-Release Experiments}

Air-permeability measurements were made along $0.3-\mathrm{m}$ sections of all nine boreholes to determine the exact location of the fault in Borehole 4, Borehole 11, and Borehole 12, as discussed in Section 6.5.2. All water used in the ESF (for mining-related activities and scientific investigations) was spiked with the same concentration of lithium bromide. For the entire duration of the experiments, saturation and water-potential changes along the monitoring boreholes were continuously measured.

A total of $193 \mathrm{~L}$ of water was released into Borehole 12 during seven events, under constant-head conditions, between October 21 and November 5, 1998, as summarized in Table 6-18. In this borehole, as in all others, water was released over a 0.30 -m interval. The injection interval was centered at a distance of $1.4 \mathrm{~m}$ from the borehole collar (see Figure 6-83), determined from air-permeability measurements (see Figure 6-71) to be the location of the fault. 
Table 6-18. Summary of Liquid Releases into the Fault Zone in Borehole 12

\begin{tabular}{|c|c|c|c|c|}
\hline $\begin{array}{c}\text { Test } \\
\text { Number }\end{array}$ & $\begin{array}{c}\text { Date } \\
\text { (mm/dd/yy) }\end{array}$ & $\begin{array}{c}\text { Volume Injected } \\
\text { (L) }\end{array}$ & $\begin{array}{c}\text { Duration } \\
\text { (hh: } \mathbf{m m})\end{array}$ & $\begin{array}{c}\text { Average Intake } \\
\text { Rate (mL/min) }\end{array}$ \\
\hline 1 & $10 / 21 / 98$ & 42.90 & $5: 12$ & 138 \\
\hline 2 & $10 / 22 / 98$ & 41.44 & $5: 59$ & 115 \\
\hline 3 & $10 / 26 / 98$ & 21.34 & $4: 22$ & 81 \\
\hline 4 & $10 / 27 / 98$ & 29.53 & $6: 59$ & 70 \\
\hline 5 & $10 / 28 / 98$ & 22.16 & $6: 10$ & 60 \\
\hline 6 & $11 / 04 / 98$ & 17.08 & $5: 48$ & 49 \\
\hline 7 & $11 / 05 / 98$ & 18.85 & $6: 31$ & 48 \\
\hline
\end{tabular}

Source: DTN: LB990901233124.005 [DIRS 146884].

In Borehole 5 away from the fault, water was released into two zones. In the first zone (located 1.50 to $1.80 \mathrm{~m}$ from the collar), $1.37 \mathrm{~L}$ of water were released to the zone on October 19, 1998, and a similar volume was released on October 20, 1998. Because a problem was detected with the constant-head system, no more water was injected into this zone. On October 27, 1998, after the injection system was repaired, water was released into Borehole 5 at 2.44 to $2.74 \mathrm{~m}$ from the borehole collar. In this zone, $6.5 \mathrm{~L}$ of water were released under constant-head conditions over a 23-day period.

\subsubsection{Observations of Fault Flow and Matrix Flow}

During and following the release of water into the test bed, intake rates (rates of water moving into the formation during constant-head tests), water travel times, and lateral dispersion of the plume (as seen along the length of horizontal boreholes) were continuously monitored. In the following section, the observed hydrologic responses to liquid releases in the three zones as detected by ERPs and psychrometers are presented.

\subsubsection{Fault Responses}

\subsection{Intake Rates}

Water was injected into the section of Borehole 12 that intercepted the fault approximately $1.40 \mathrm{~m}$ from the collar. $193 \mathrm{~L}$ of water were released into the formation during seven events that extended over a two-week period, as illustrated in Figure 6-85. Each event lasted between 4 and 7 hours, during which time 20 to $43 \mathrm{~L}$ of water entered the injection zone. Each release event began with water filling the 1.37-L injection cavity in approximately 3 minutes, after which the liquid-release apparatus kept the injection zone filled by maintaining a constant-head boundary for the period of injection. After water was injected into the formation, the $1.37 \mathrm{~L}$ of water occupying the injection zone were released to the formation under falling-head conditions. 


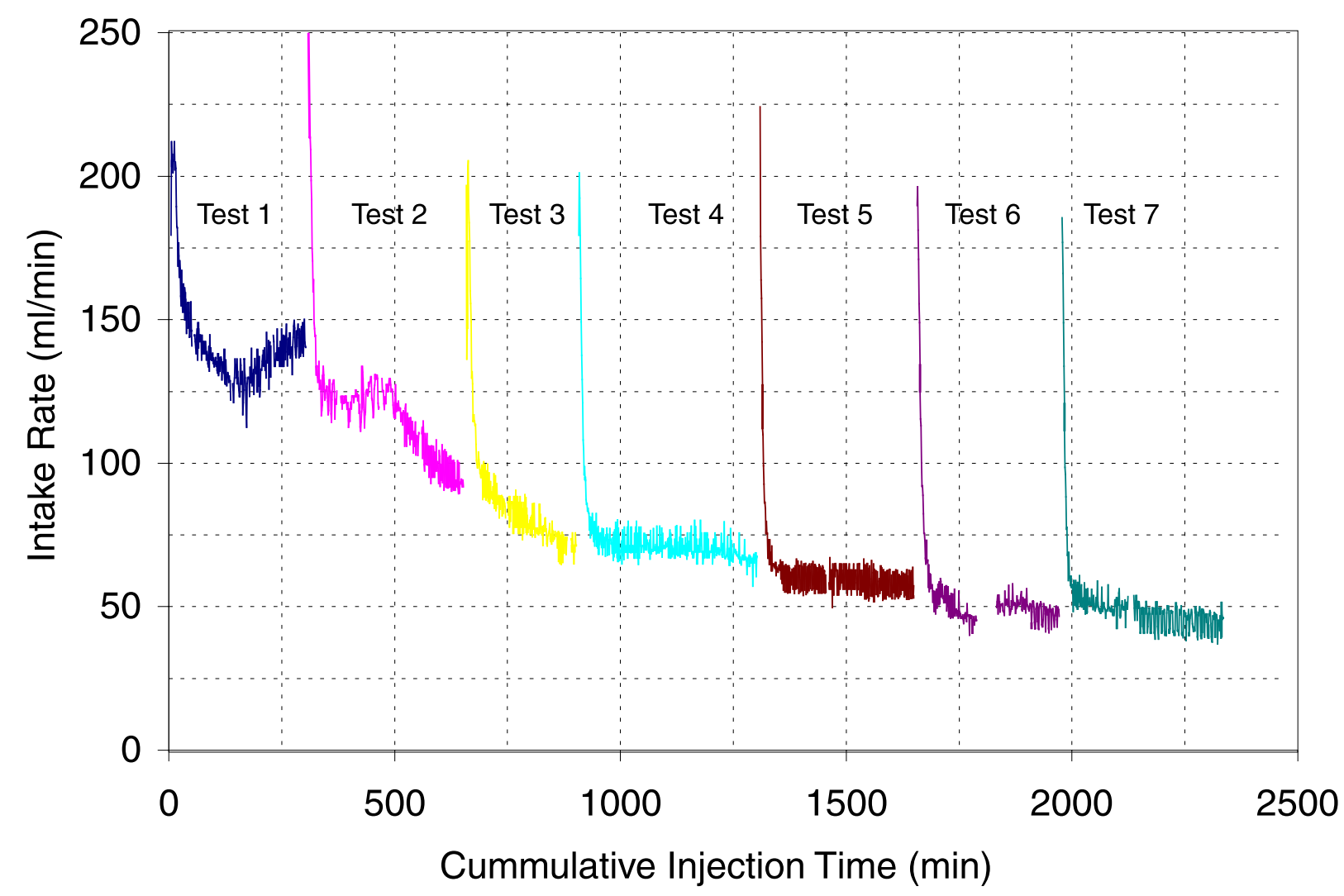

Source: DTN: LB990901233124.005 [DIRS 146884].

Figure 6-85. Intake Rates along the 0.3-m Zone Located on the Fault in Borehole 12

During Test 1, the intake rate into the fault dropped from $200 \mathrm{~mL} / \mathrm{min}$ to $120 \mathrm{~mL} / \mathrm{min}$ over a 180 -minute period, before recovering to $145 \mathrm{~mL} / \mathrm{min}$ in the next 120 minutes. In Test 2, conducted one day later, the intake rate dropped from $200 \mathrm{~mL} / \mathrm{min}$ to $120 \mathrm{~mL} / \mathrm{min}$ over an 80-minute period before remaining fairly constant for the next 100 minutes. Approximately 180 minutes after this release event started, the intake rates began to drop steadily, reaching a rate of $95 \mathrm{~mL} / \mathrm{min}$ by the end of the test. In Test 3, which was initiated four days later, the intake rates rapidly dropped to $95 \mathrm{~mL} / \mathrm{min}$ during the first $40 \mathrm{~min}$ and then continued to decrease at a more gradual rate for the next 200 minutes to a rate of $70 \mathrm{~mL} / \mathrm{min}$. During Test 4 and Test 5 , conducted during the next two days, the pattern of rate change was similar, with an initially high intake rate quickly dropping to a near constant value ( 70 to $60 \mathrm{~mL} / \mathrm{min}$, respectively). In Test 4 , this constant value persisted 300 minutes into the test, after which there was a gradual decrease in intake rates for the remainder of the test. During Test 6 , which began after a six-day hiatus, water was injected during two intervals. During this test, water was introduced under constant-head conditions for 140- and 158-minute periods with a gap of 22 minutes, during which water imbibed into the formation under a falling head. The intake rates rapidly dropped to $50 \mathrm{~mL} / \mathrm{min}$. In Test 7 into this zone, the intake rates again dropped to $50 \mathrm{~mL} / \mathrm{min}$ after 100 minutes of release. The rates gradually decreased during the 200 minutes of injection, which approached $40 \mathrm{~mL} / \mathrm{min}$ after $18 \mathrm{~L}$ of water had been injected. 


\subsection{Water Transport Times in Fault}

When water was introduced into Borehole 12, the time taken for the wetting front to travel $1.07 \mathrm{~m}$ along the fault to Borehole 11 varied among the seven tests (Figure 6-86). In the first test, water was detected in the lower borehole approximately 300 minutes after the first release; in the second test, the water transport time was reduced to approximately 200 minutes. For the third test, this water transport time was approximately $250 \mathrm{~min}$; in the fourth test, water appeared in the fault in Borehole 11 within approximately 150 minutes. The fastest water transport time was observed for the fifth test, when the front arrived within approximately 120 minutes in Borehole 11. In the last two tests, the water transport times were significantly slower, with increasing saturations observed 400 and 700 minutes after the initial release of water.

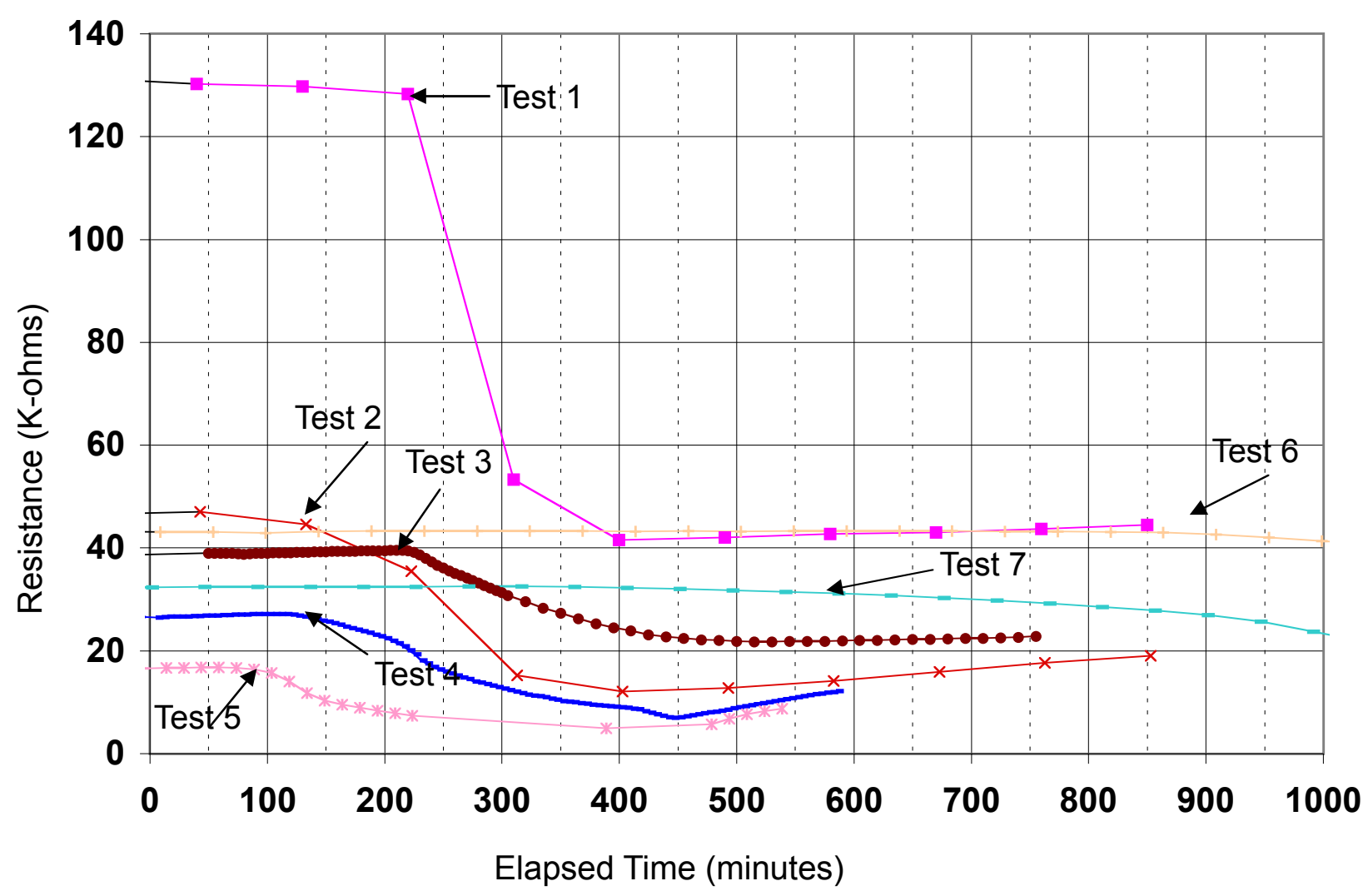

Source: DTN: LB990901233124.005 [DIRS 146884].

Figure 6-86. Wetting Front Arrival in Borehole 11 Following Liquid Released into the Fault in Borehole 12

\subsection{Dispersion}

Water injected into the fault in Borehole 12 was detected along the length of Borehole 11 by ERPs located between 0.65 and $2.40 \mathrm{~m}$ (Figure 6-87) from the borehole collar. Unlike the ERP located on the fault (1.40 $\mathrm{m}$ from the borehole collar), which showed a stepped response to individual release events, these other ERPs showed a slow, gradual decrease in resistance measurements. The first response was seen in the ERPs located on either side of the fault, with the one at $1.65 \mathrm{~m}$ responding first. ERPs located between the alcove face and the fault appeared 
to be significantly drier at the start of the experiment than those located deeper in the test bed. These ERPs responded with larger decreases in resistance measurements following the start of the water release. The largest response to the injection events in Borehole 12 was detected between 0.9 and $1.65 \mathrm{~m}$ from the collar in Borehole 11 .

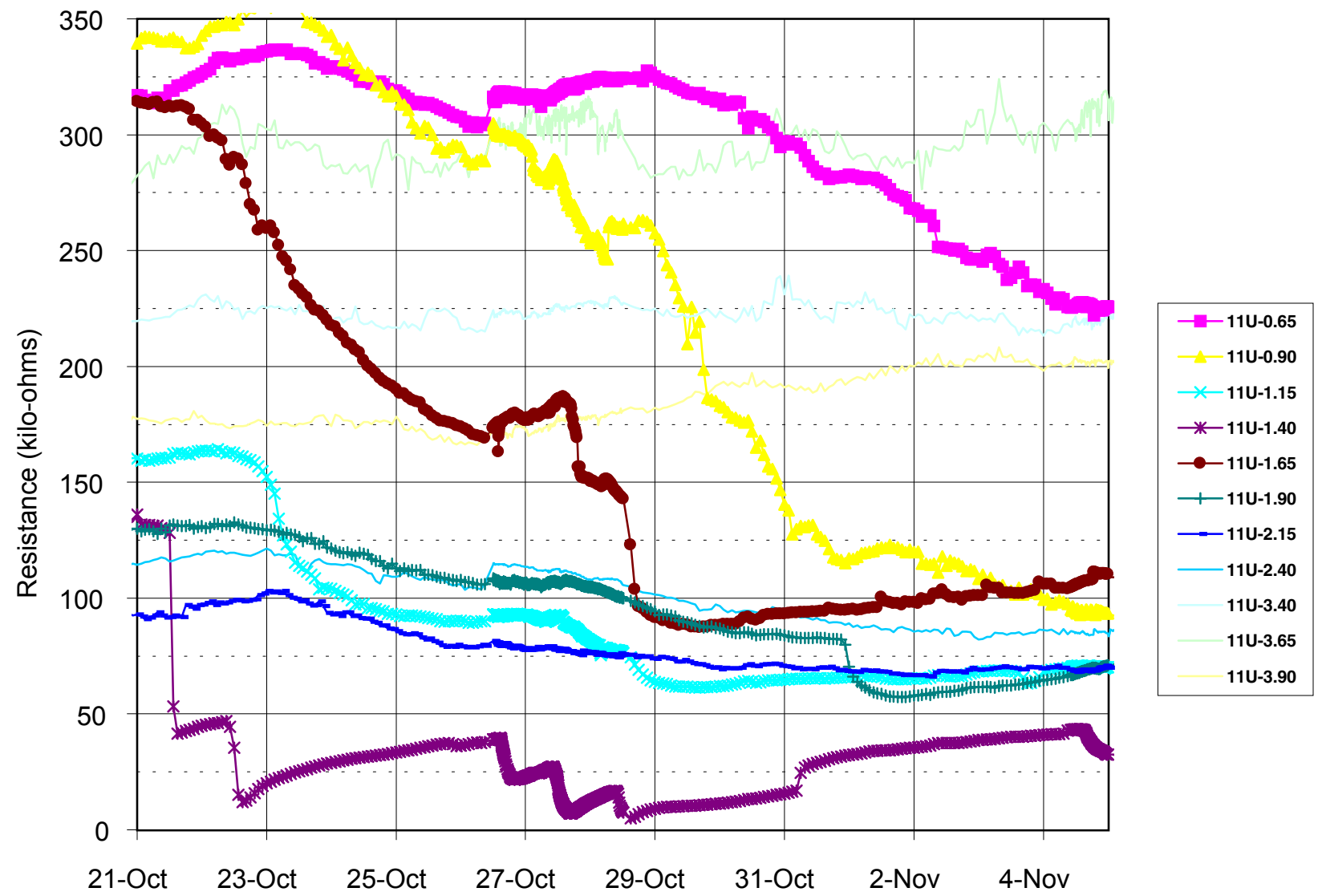

Source: DTN: LB990901233124.005 [DIRS 146884].

NOTES: The legend indicates the location of the measurement (in meters) from the collar. The "U" indicates that these are measurements from the upper BSTs in the borehole.

Figure 6-87. Changes in Electrical Resistance in Borehole 11 in Response to Liquid Released into the Fault in Borehole 12

In Borehole 2, located $0.97 \mathrm{~m}$ vertically below Borehole 12, the first ERPs to detect the wetting front were centered immediately below the fault (Figure 6-88). At a distance of 1.15 to $1.65 \mathrm{~m}$ from the borehole collar, changes in saturation were detected almost one week after the first injection event on October 21, 1998. Over the next three weeks, ERPs at 1.15 and $1.40 \mathrm{~m}$ continued to detect increasing saturations; the ERP at $1.65 \mathrm{~m}$ was wetting for four days before maintaining a relatively constant saturation level for the next 18 days. At depths between 1.90 and $2.40 \mathrm{~m}$, the response was delayed very slightly. 


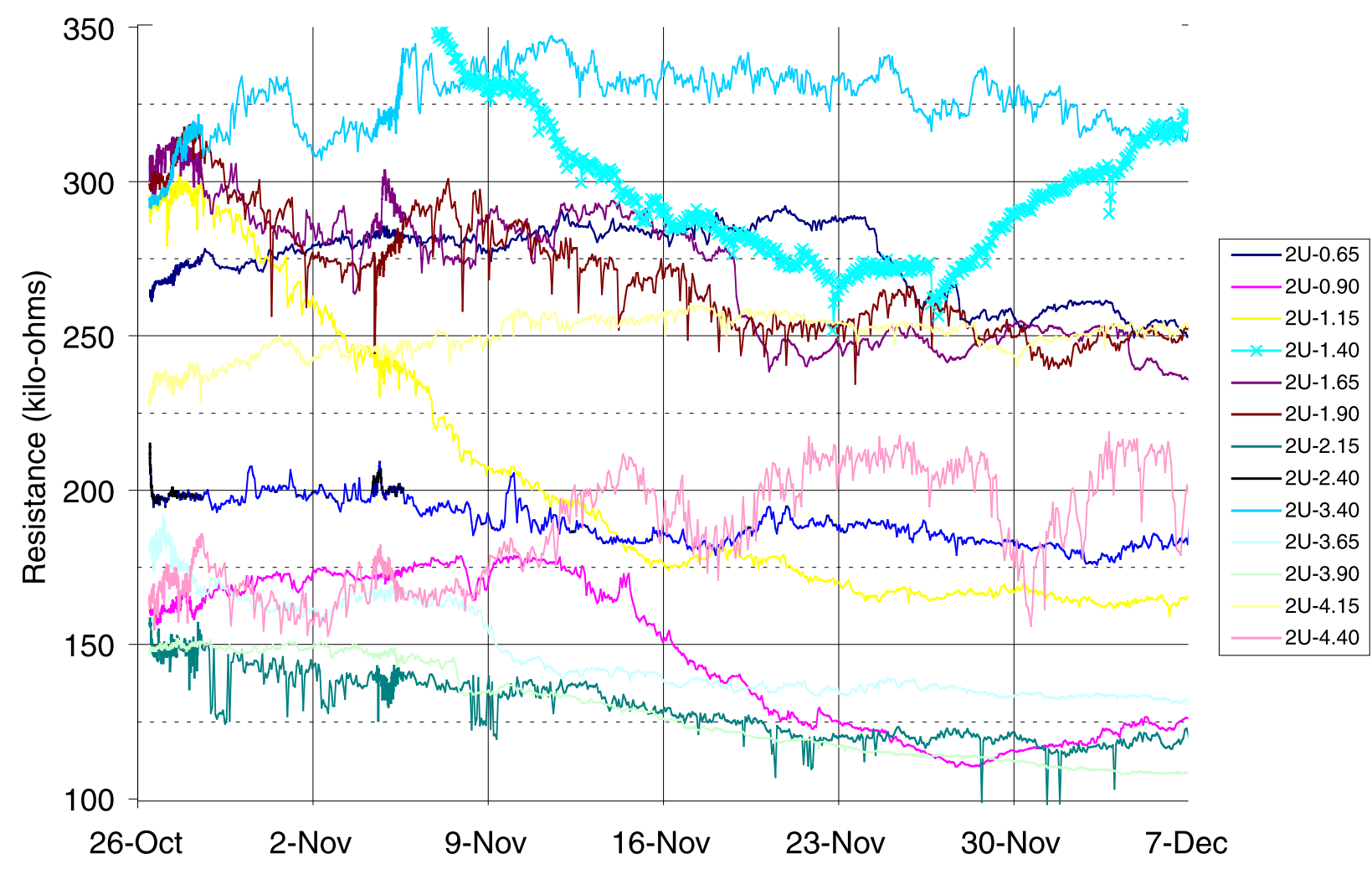

Source: DTN: LB990901233124.005 [DIRS 146884].

NOTES: The legend indicates the location of the measurement (in meters) from the collar. The " $U$ " indicates that these are measurements from the upper BSTs in the borehole.

Figure 6-88. Changes in Electrical Resistance in Borehole 2 in Response to Liquid Released into the Fault in Borehole 12

\subsubsection{Matrix Responses}

\subsection{Intake Rates}

When water was released into Borehole 5 , in the zone 2.44 to $2.74 \mathrm{~m}$ from the collar, the intake dropped steeply to $1 \mathrm{~mL} / \mathrm{min}$ within 150 minutes (Figure 6-89). The intake rate then continued to gradually decrease over the next 2,000 minutes, before reaching a constant rate of approximately $0.1 \mathrm{~mL} / \mathrm{min}$. This rate remained approximately constant for the entire duration of the test. 


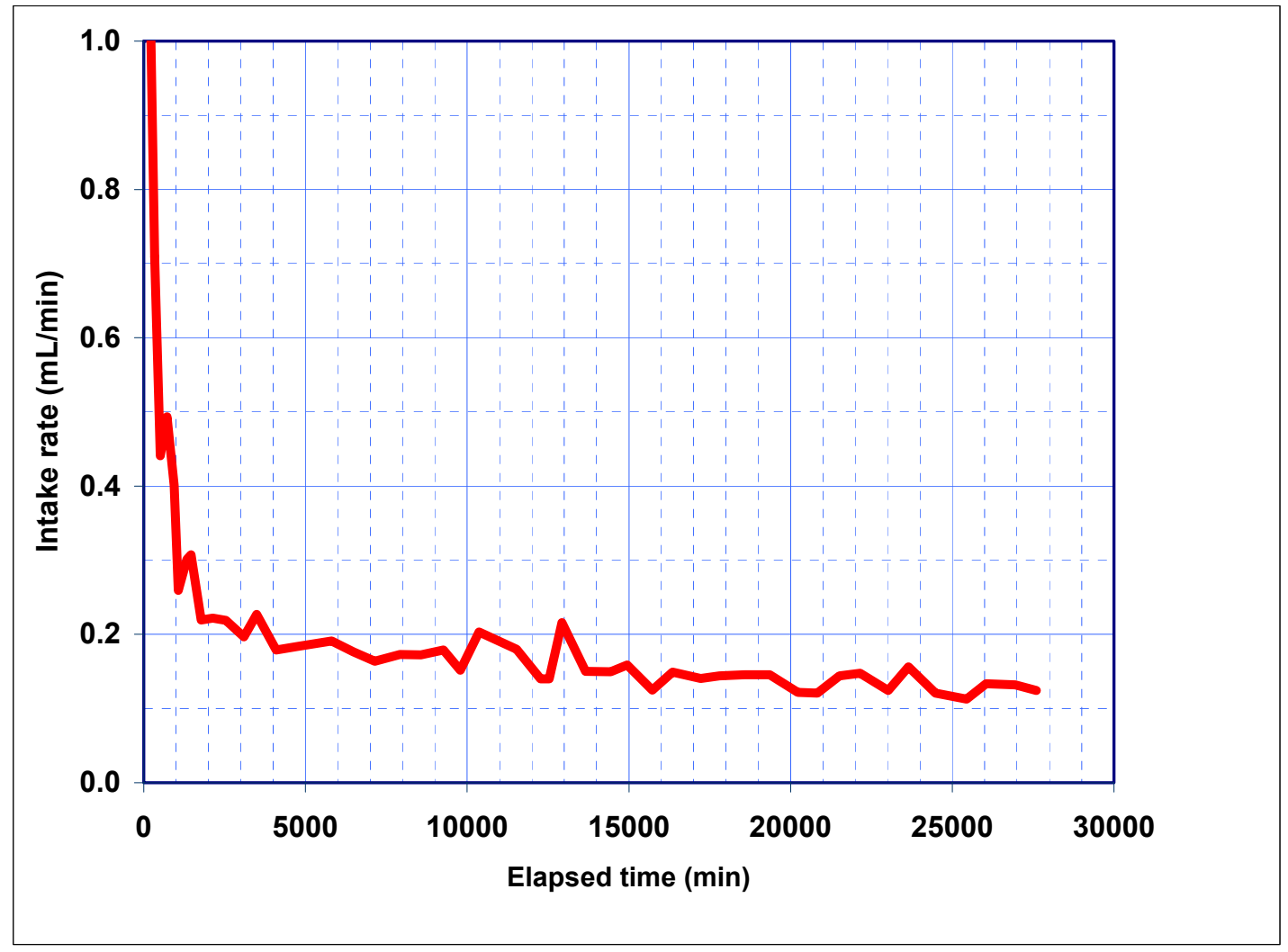

Source: DTN: LB990901233124.005 [DIRS 146884].

Figure 6-89. Intake Rates along a 0.3-m Zone in the Matrix Located 2.44-2.74 $\mathrm{m}$ from the Collar in Borehole 5

\subsection{Wetting Front Migration}

Following the first release of water in Borehole 5 on October 27, 1998 (at 2.44 to $2.74 \mathrm{~m}$ from the collar), the wetting front was detected in the upper section of Borehole 6 (located 0.45 from Borehole 5) after a period of 14 days on November 10, 1998, at a distance of $2.90 \mathrm{~m}$ from the collar (Figure 6-90). Some of the sensors near the collar had high resistance values and fluctuating changes that might represent responses to additional drying and wetting processes near the borehole collar.

The wetting front migration pattern demonstrates potentially substantial matrix imbibition from the fault and matrix flow, providing the means to effectively dampen liquid pulses in the PTn. 


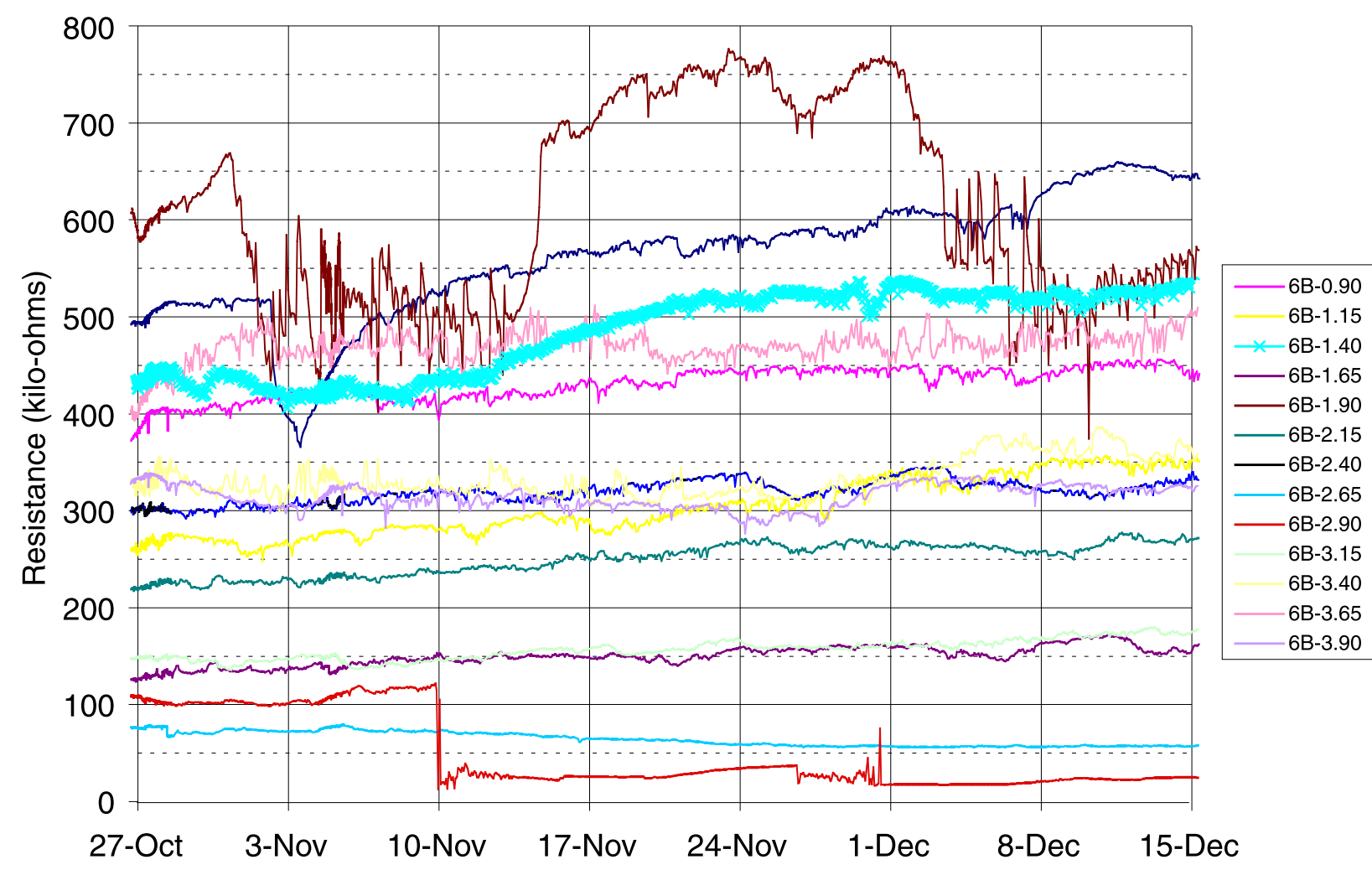

Source: DTN: LB990901233124.005 [DIRS 146884].

NOTES: The legend indicates the location of the measurement (in meters) from the collar. The "B" indicates that these are measurements from the lower BSTs in the borehole.

Figure 6-90. Changes in Electrical Resistance in Borehole 6 in Response to Liquid Released in Borehole 5

\subsection{COMPILATION OF WATER-POTENTIAL MEASUREMENTS IN NICHES}

Measurements of water potentials from three niche sites in the ESF are presented. These sites are located on the west side of the ESF main drift at Niche 1 (Niche 3566), Niche 2 (Niche 3650), and Niche 3 (Niche 3107). Niche 1 (Niche 3566) lies between the Sundance fault and a cooling joint branching out from the fault. The primary objective of this effort was to establish the water potential at various points within the three niche sites, to determine whether wet conditions exist at Niche 1 (Niche 3566) near the fault, when other niches are drier.

To meet this objective, psychrometers were used as a method to measure water potential in the boreholes. The psychrometers were also used in wetting-front detection, as described in Section 6.6 for Alcove 6 and Section 6.7 for Alcove 4. The sensitivity of psychrometer performance is described in Appendix G. The results of this section need to take into account the uncertainties associated with the sensitivities of psychrometer readings (to operating conditions and to handling of the sensors, as discussed in Appendix G). Data from psychrometers in the boreholes were taken over long periods of time after sensor emplacement, so that the sensors were in approximate equilibrium with the moisture in the borehole intervals. 


\subsubsection{Location and Timing of Water-Potential Measurements at Niches}

Water potentials were measured either along the length or at the ends of the 0.0762-m-diameter boreholes. Three different types of housing units were used to locate psychrometers in the boreholes. The main feature of the housings was the creation of a small air chamber that allowed for quick equilibration and measurements of humidity close to the borehole wall.

At Niche 1 (Niche 3566), two separate sets of measurements were made: before and after niche excavation. Pre-excavation measurements were made during May 1997 in three boreholes (Borehole U, Borehole M, and Borehole B) at a distance of $10 \mathrm{~m}$ from the borehole collar (Panel (a) of Figure 6-91). Between July and September 1997, two sets of measurements were made along Borehole $U$ at distances between 3.5 and $8.0 \mathrm{~m}$ from the collar. Post-excavation measurements of water potential were made in October 1997 in five boreholes extending radially along a horizontal plane from the niche cavity (Panel (b) of Figure 6-91).

At Niche 2 (Niche 3650), two separate sets of water-potential measurements were made in July 1997, before and after air-permeability tests were conducted in the boreholes. In three boreholes at this location (Borehole ML, Borehole BR, and Borehole BL), water potentials were measured at the end of the boreholes $(10 \mathrm{~m})$. In Borehole UM, measurements were made close to the borehole collar (i.e., between 0.6 and $1.2 \mathrm{~m}$ ) (Figure 6-92).

At Niche 3 (Niche 3107), four boreholes were instrumented with psychrometers (Figure 6-93). One set of potential measurements was made in December 1997 and January 1998. In the upper-middle borehole (Borehole UM), multiple measurements were made along the first $3.0 \mathrm{~m}$; in the remaining three boreholes (Borehole ML, Borehole UL, Borehole UR), single measurements were made using different lengths of borehole cavity. In the upper-right borehole (Borehole UR), sensors were located at the back of the borehole and sealed off with inflation packers such that the borehole cavity was less than $0.04 \mathrm{~m}$ long. In the upper-left borehole (Borehole UL), sensors were located $5 \mathrm{~m}$ from the borehole collar, with the cavity sealed off by inflation packers. In this case, the sensing cavity extended over $5 \mathrm{~m}$ of the borehole. In the middle-lower borehole (Borehole ML), sensors were located $0.3 \mathrm{~m}$ from the borehole collar, with an inflation packer installed to isolate the entire 10-m length of borehole from the ESF main drift. 


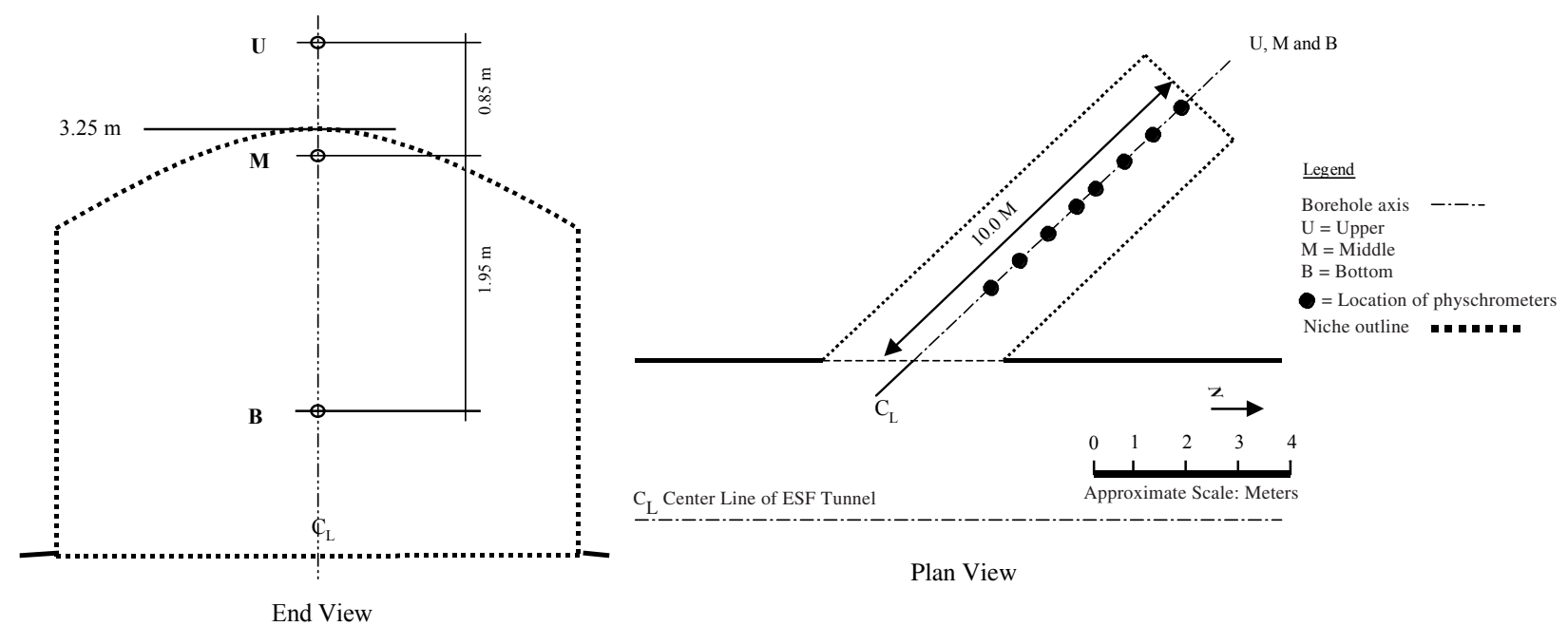

(a)

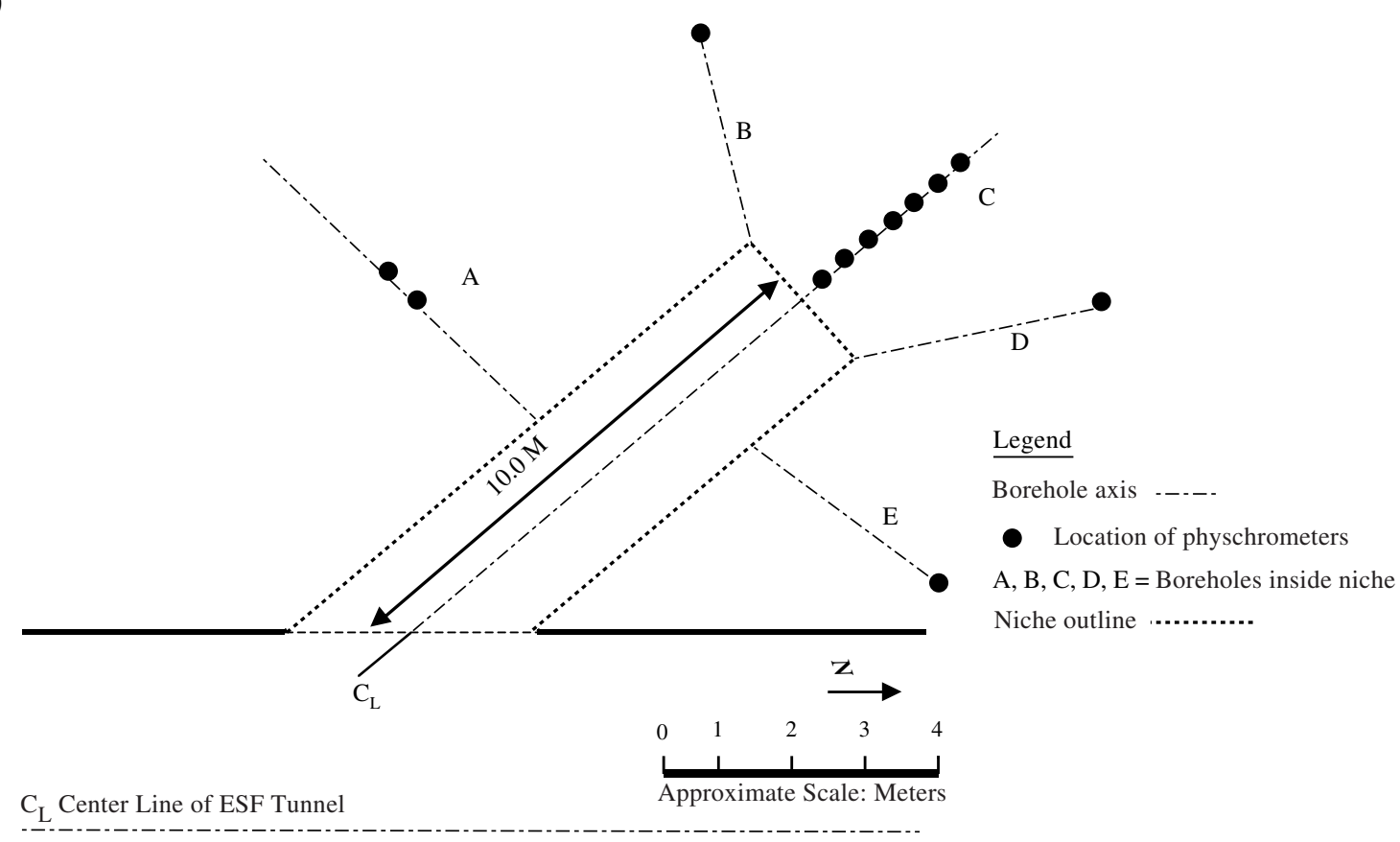

(b)

Plan View

NOTES: $\quad(a)=$ Pre-excavation conditions.

(b) = Post-excavation conditions .

Figure 6-91. Schematic Illustration of the Location of Psychrometers in Niche 1 (Niche 3566) 


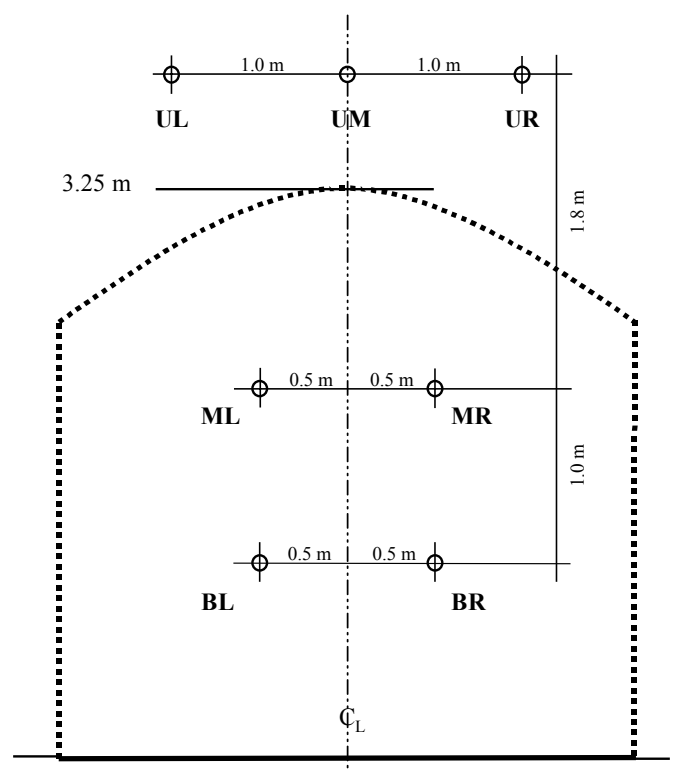

End View

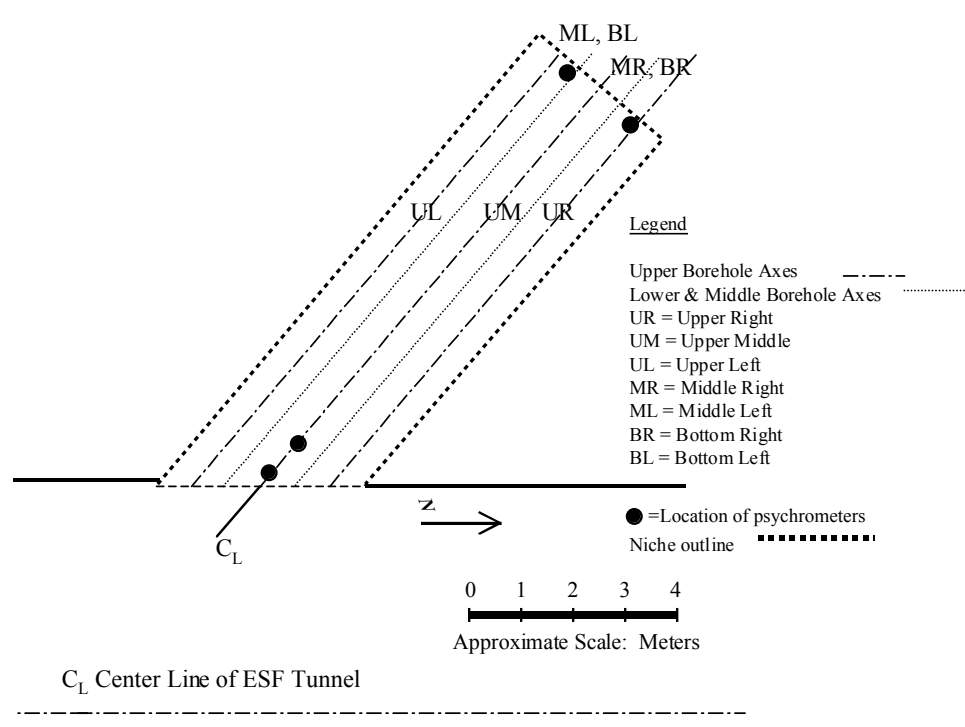

Plan View

Figure 6-92. Schematic Illustration of Location of Psychrometers in Niche 2 (Niche 3650)

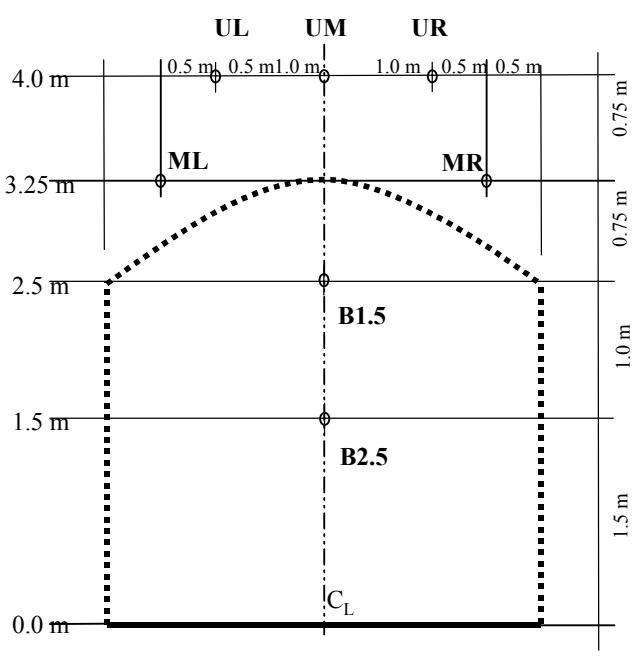

End View

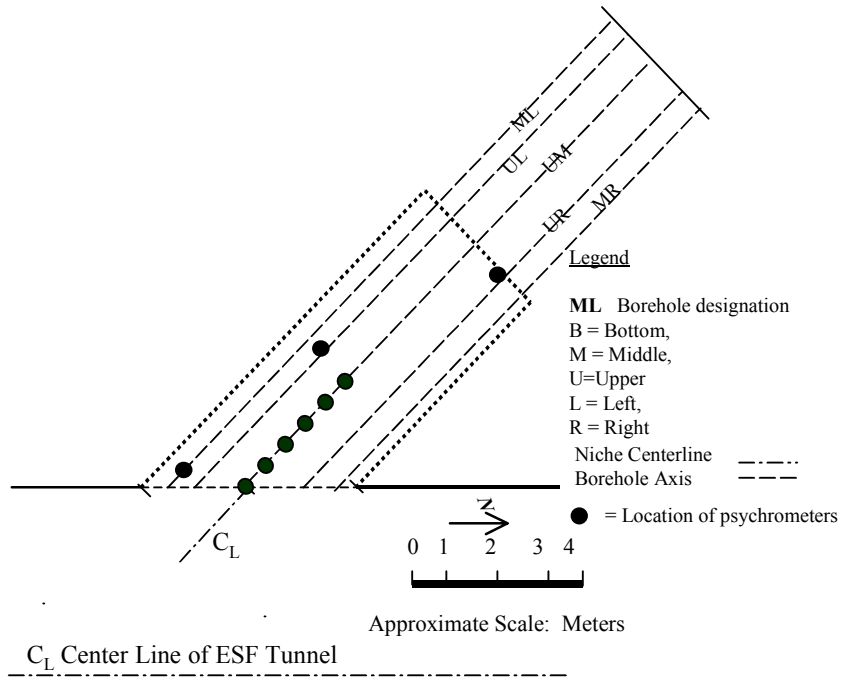

Plan View

Figure 6-93. Schematic Illustration of Location of Psychrometers in Niche 3 (Niche 3107) (Pre Excavation) 


\subsubsection{Observations of Dryout in Niche Boreholes}

Water-potential measurements obtained from the three niches are summarized in Table 6-19 and Table 6-20. The time and duration of measurements are presented for each location.

Table 6-19. Water-Potential Measurements in Niche 1 (Niche 3566)

\begin{tabular}{|c|c|c|c|c|}
\hline Borehole ID & $\begin{array}{l}\text { Dist. from Collar } \\
(\mathrm{m})\end{array}$ & $\begin{array}{c}\text { Duration of } \\
\text { Measurement }\end{array}$ & Psych \# & $\begin{array}{l}\text { Water Potential } \\
(\mathrm{m})\end{array}$ \\
\hline \multicolumn{5}{|l|}{ Pre-Excavation } \\
\hline$U$ & 10.0 & $5 / 9-16 / 97$ & Psy -51 & -13 \\
\hline U & 10.0 & $5 / 9-16 / 97$ & Psy -52 & -13 \\
\hline M & 10.0 & $5 / 9-16 / 97$ & Psy -53 & -7 \\
\hline M & 10.0 & $5 / 9-16 / 97$ & Psy -54 & 0.4 \\
\hline B & 10.0 & $5 / 9-16 / 97$ & Psy -55 & -12 \\
\hline U & 6.1 & $7 / 8-14 / 97$ & Psy -42 & -49 \\
\hline U & 5.5 & $7 / 8-14 / 97$ & Psy -43 & -46 \\
\hline U & 5.5 & $7 / 8-14 / 97$ & Psy -44 & -34 \\
\hline$U$ & 4.9 & $7 / 8-14 / 97$ & Psy -45 & -46 \\
\hline U & 4.3 & $7 / 8-14 / 97$ & Psy -48 & -68 \\
\hline U & 3.7 & $7 / 8-14 / 97$ & Psy -50 & -62 \\
\hline U & 7.9 & $9 / 16-24 / 97$ & Psy -42 & -49 \\
\hline $\mathrm{U}$ & 7.3 & $9 / 16-24 / 97$ & Psy -60 & -46 \\
\hline U & 6.7 & $9 / 16-24 / 97$ & Psy -45 & -71 \\
\hline U & 6.1 & $9 / 16-24 / 97$ & Psy -48 & -67 \\
\hline U & 5.5 & $9 / 16-24 / 97$ & Psy -50 & -36 \\
\hline \multicolumn{5}{|l|}{ Post-Excavation } \\
\hline A & 6.25 & October $18-21,1997$ & Psy-43a & -2 \\
\hline A & 6.75 & October $18-21,1997$ & Psy-60 & -30 \\
\hline $\mathrm{B}$ & 6.00 & October 18-21, 1997 & Psy-51 & -43 \\
\hline C & 0.15 & October 18-21, 1997 & Psy-49 & -132 \\
\hline C & 0.76 & October 18-21, 1997 & Psy-42 & -33 \\
\hline $\mathrm{C}$ & 1.98 & October 18-21, 1997 & Psy-45 & -22 \\
\hline C & 1.98 & October 18-21, 1997 & Psy-47 & -47 \\
\hline C & 1.37 & October 18-21, 1997 & Psy-48 & -40 \\
\hline $\mathrm{C}$ & 2.60 & October 18-21, 1997 & Psy-43 & -57 \\
\hline $\mathrm{D}$ & 6.00 & October 18-21, 1997 & Psy-54 & -22 \\
\hline $\mathrm{D}$ & 6.00 & October 18-21, 1997 & Psy-56 & -32 \\
\hline $\mathrm{E}$ & 6.00 & October $18-21,1997$ & Psy-57 & -75 \\
\hline $\mathrm{E}$ & 6.00 & October $18-21,1997$ & Psy-59 & -81 \\
\hline
\end{tabular}

Source: DTN: LB0406ESFNH2OP.001 [DIRS 171588]. 
Table 6-20. Water-Potential Measurements in Niche 2 (Niche 3650)

\begin{tabular}{|c|c|c|c|c|}
\hline Borehole ID & $\begin{array}{l}\text { Dist. from Collar } \\
(\mathrm{m})\end{array}$ & $\begin{array}{c}\text { Duration of } \\
\text { Measurement }\end{array}$ & Psych \# & $\begin{array}{l}\text { Water Potential } \\
(\mathrm{m})\end{array}$ \\
\hline \multicolumn{5}{|c|}{ Pre-Air-Injection Testing } \\
\hline UM & 1.2 & July $1-8,1997$ & Psy -48 & -127 \\
\hline UM & 0.6 & July $1-8,1997$ & Psy -49 & -139 \\
\hline UM & 0.6 & July $1-8,1997$ & Psy -50 & -165 \\
\hline $\mathrm{BR}$ & 10.0 & July $1-8,1997$ & Psy -51 & -37 \\
\hline $\mathrm{BR}$ & 10.0 & July $1-8,1997$ & Psy -52 & -39 \\
\hline $\mathrm{BR}$ & 10.0 & July 1-8, 1997 & Psy -53 & -32 \\
\hline $\mathrm{BL}$ & 10.0 & July $1-8,1997$ & Psy -54 & -24 \\
\hline $\mathrm{BL}$ & 10.0 & July $1-8,1997$ & Psy -55 & -36 \\
\hline ML & 10.0 & July $1-8,1997$ & Psy -57 & -1 \\
\hline \multicolumn{5}{|c|}{ Post-Air-Injection Testing } \\
\hline ML & 10.0 & July 24-28, 1997 & Psy -51 & -29 \\
\hline $\mathrm{ML}$ & 10.0 & July 24-28, 1997 & Psy -52 & -38 \\
\hline ML & 10.0 & July 24-28, 1997 & Psy -53 & -39 \\
\hline $\mathrm{BR}$ & 10.0 & July 24-28, 1997 & Psy -54 & -58 \\
\hline $\mathrm{BR}$ & 10.0 & July 24-28, 1997 & Psy -55 & -49 \\
\hline $\mathrm{BR}$ & 10.0 & July 24-28, 1997 & Psy -56 & -48 \\
\hline $\mathrm{BL}$ & 10.0 & July 24-28, 1997 & Psy -57 & -21 \\
\hline $\mathrm{BL}$ & 10.0 & July 24-28, 1997 & Psy -58 & -15 \\
\hline $\mathrm{BL}$ & 10.0 & July 24-28, 1997 & Psy -59 & -28 \\
\hline
\end{tabular}

Source: DTN: LB0406ESFNH2OP.001 [DIRS 171588].

Table 6-21. Water-Potential Measurements in Niche 3 (Niche 3107)

\begin{tabular}{|c|c|c|c|c|}
\hline Borehole ID & $\begin{array}{c}\text { Dist. from Collar } \\
(\mathbf{m})\end{array}$ & $\begin{array}{c}\text { Duration of } \\
\text { Measurement }\end{array}$ & $\begin{array}{c}\text { Water Potential } \\
(\mathbf{m})\end{array}$ \\
\hline UM & 0.45 & $12 / 22 / 97-1 / 8 / 98$ & Psy-86 & -273 \\
\hline UM & 1.06 & $12 / 22 / 97-1 / 8 / 98$ & Psy-83 & -154 \\
\hline UM & 1.67 & $12 / 22 / 97-1 / 8 / 98$ & Psy-75 & -83 \\
\hline UM & 2.90 & $12 / 22 / 97-1 / 8 / 98$ & Psy-68 & -28 \\
\hline UL & 10.00 & $12 / 22 / 97-1 / 8 / 98$ & Psy-64 & -15 \\
\hline ML & 10.00 & $12 / 22 / 97-1 / 8 / 98$ & Psy-66 & -84 \\
\hline
\end{tabular}

Source: DTN: LB0406ESFNH2OP.001 [DIRS 171588].

\subsubsection{Niche 1 (Niche 3566) Pre-Excavation}

Water potentials measured at the ends of the three pre-excavation boreholes (Borehole $U$, Borehole M, and Borehole B) in Niche 1 (Niche 3566) were close to saturation values, indicating that approximately $10 \mathrm{~m}$ from the ESF, the formation is relatively wet. Of the three, the end of the middle borehole appeared to be wettest, with water potentials between 0.4 and $-7 \mathrm{~m}$. Measurements made along the profile of Borehole $U$ (between 3.7 and $7.9 \mathrm{~m}$ from the collar) varied between -34 and $-71 \mathrm{~m}$ (Figure 6-94 and Table 6-19). 


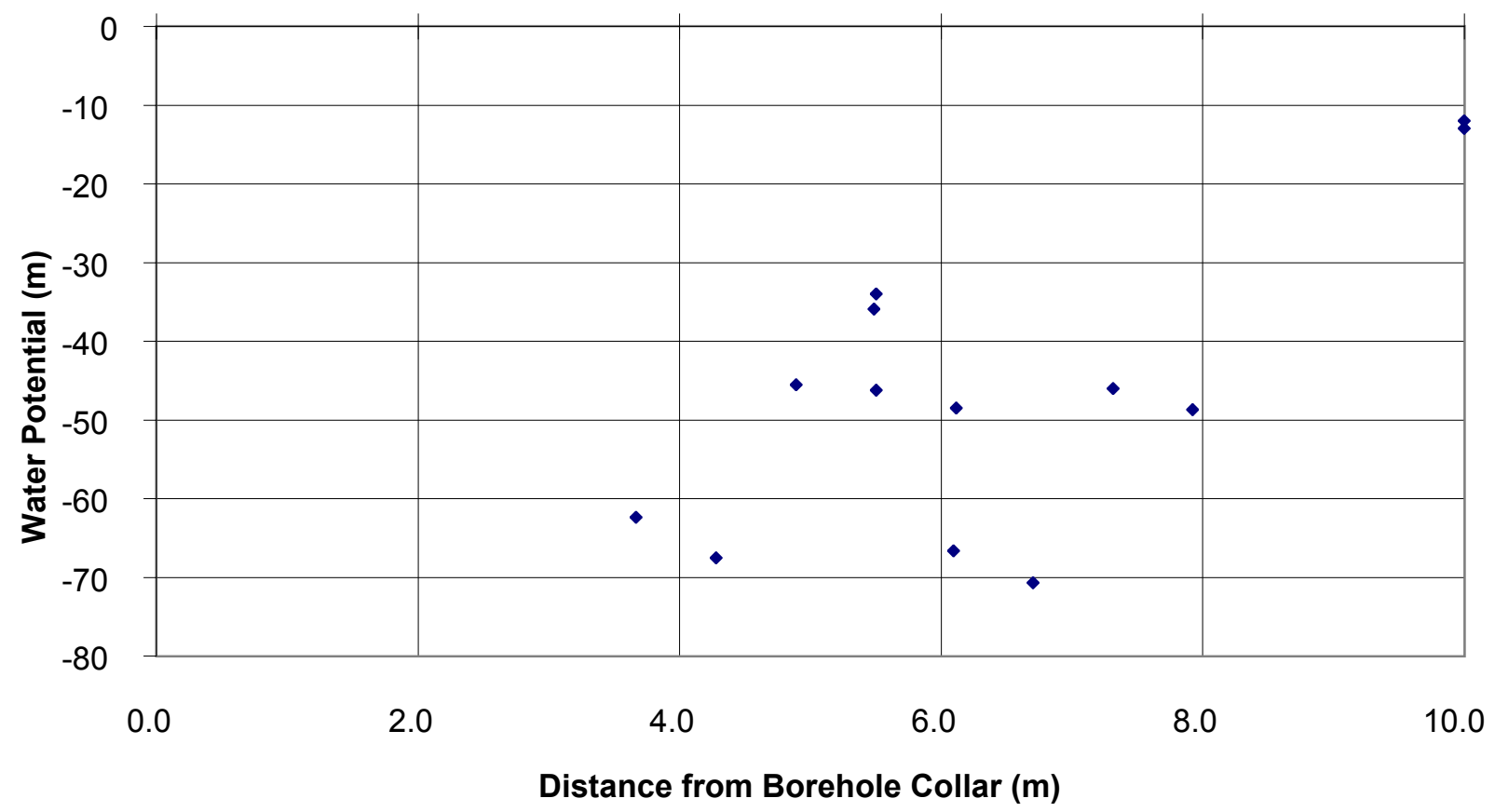

Source: DTN: LB0406ESFNH2OP.001 [DIRS 171588].

Figure 6-94. Pre-Excavation Water Potential Measured along Borehole U in Niche 1 (Niche 3566)

\subsubsection{Niche 1 (Niche 3566) Post-Excavation}

In the excavated niche cavity, water potentials were monitored in five boreholes. The monitored locations in Borehole A (Panel (b) of Figure 6-91) were at 6.25 and $6.75 \mathrm{~m}$ from the collar. High water potentials were measured at these points $(-2$ and $-30 \mathrm{~m}$, respectively). In three of the remaining boreholes (Borehole $\mathrm{B}$, Borehole $\mathrm{D}$, and Borehole $\mathrm{E}$ ) water potentials measured at depths of $6.0 \mathrm{~m}$ varied significantly between boreholes. Borehole $\mathrm{D}(-27 \mathrm{~m})$ was wettest, followed by Borehole B $(-43 \mathrm{~m})$, and then Borehole E $(-78 \mathrm{~m})$. These observations appear to be consistent with those made in the pre-excavation boreholes, which indicated that the formation tended to get wetter with increasing distance from the main drift.

Measurements made close to the collar in Borehole $\mathrm{C}$ suggest that there was significant dryout in the rock surrounding the niches to a depth of at least $0.15 \mathrm{~m}$, extending possibly to $2.6 \mathrm{~m}$.

\subsubsection{Niche 2 (Niche 3650) Pre-Excavation}

Measurements were made at the end of three boreholes (Borehole BR, Borehole BL, and Borehole ML) (Figure 6-92, Table 6-20), each $10 \mathrm{~m}$ long, before and after a series of air-permeability tests. Pre-test water-potential values varied between -1 and $-39 \mathrm{~m}$. However, following the test, water potentials in one borehole (Borehole BR) dropped to between -48 and $-58 \mathrm{~m}$, whereas in Borehole BL, the measurements did not show significant changes. Closer to the borehole collar of Borehole UM, readings made between 0.6 and $1.2 \mathrm{~m}$ indicate a relatively dry zone, with water potentials between -125 and $-137 \mathrm{~m}$. 


\subsubsection{Niche 3 (Niche 3107)}

The observations made in Niche 3 (Niche 3107) and presented in Table 6-21 indicate significant differences among the boreholes in the niche. Measurements made at the ends of Borehole UL $(-15 \mathrm{~m})$ and Borehole ML $(-84 \mathrm{~m})$ indicate that at a depth of $10 \mathrm{~m}$, with a separation distance of $0.9 \mathrm{~m}(0.75 \mathrm{~m}$ vertically and $0.5 \mathrm{~m}$ horizontally, as illustrated in Figure 6-93), a steep potential gradient exists. Furthermore, from observations within Borehole UM, a prominent dryout zone (Figure 6-95) is observed to emanate from the main drift of the ESF.

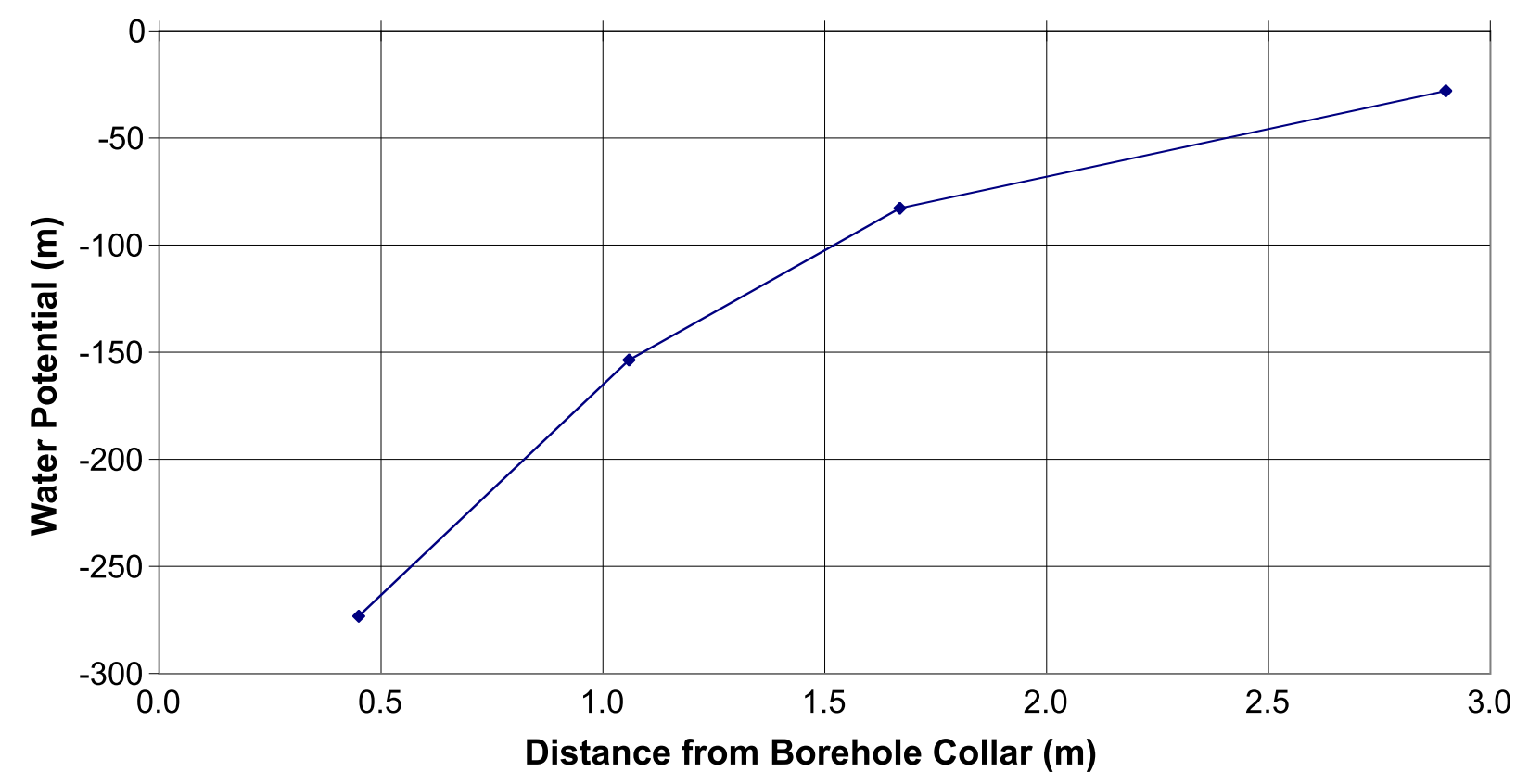

Source: DTN: LB0406ESFNH2OP.001 [DIRS 171588].

Figure 6-95. Water Potential Measured along Borehole UM in Niche 3 (Niche 3107)

\subsection{OBSERVATIONS OF CONSTRUCTION-WATER MIGRATION}

During the ECRB Cross-Drift excavation, sensors and water-collection trays were placed in a borehole below the Starter Tunnel and along the ESF main drift at the crossover point. This section summarizes the results of monitoring the migration of water plumes from tunneling activities. A secondary objective was to evaluate the performance of ERP as a tool to detect the migration of wetting fronts in the UZ of fractured tuffs. Time domain reflectrometry (TDR) was also used to monitor construction-water arrivals in drift walls. TDR is based on electric measurement of waveguide reflection signals from changes in the dielectric constant associated with water-content changes. 


\subsubsection{Equipment Setup for Construction-Water Monitoring}

\subsubsection{Starter Tunnel Borehole}

To monitor the migration of a water plume resulting from construction of the ECRB Cross-Drift, a 30 -m-long borehole $\left(0.10 \mathrm{~m} \mathrm{ID)}\right.$ ), at an angle of $30^{\circ}$ (from the horizontal), was constructed along the proposed path of the ECRB Cross-Drift tunnel (Figure 6-96). This borehole was located in the Tptpul unit. The borehole originated at the end of a starter tunnel that was the launching pad for the tunnel boring machine (TBM) used to excavate the ECRB Cross-Drift. Changes in water saturation and potential were monitored along the entire length of the borehole, using psychrometers and ERPs, as the TBM advanced through the formation above.

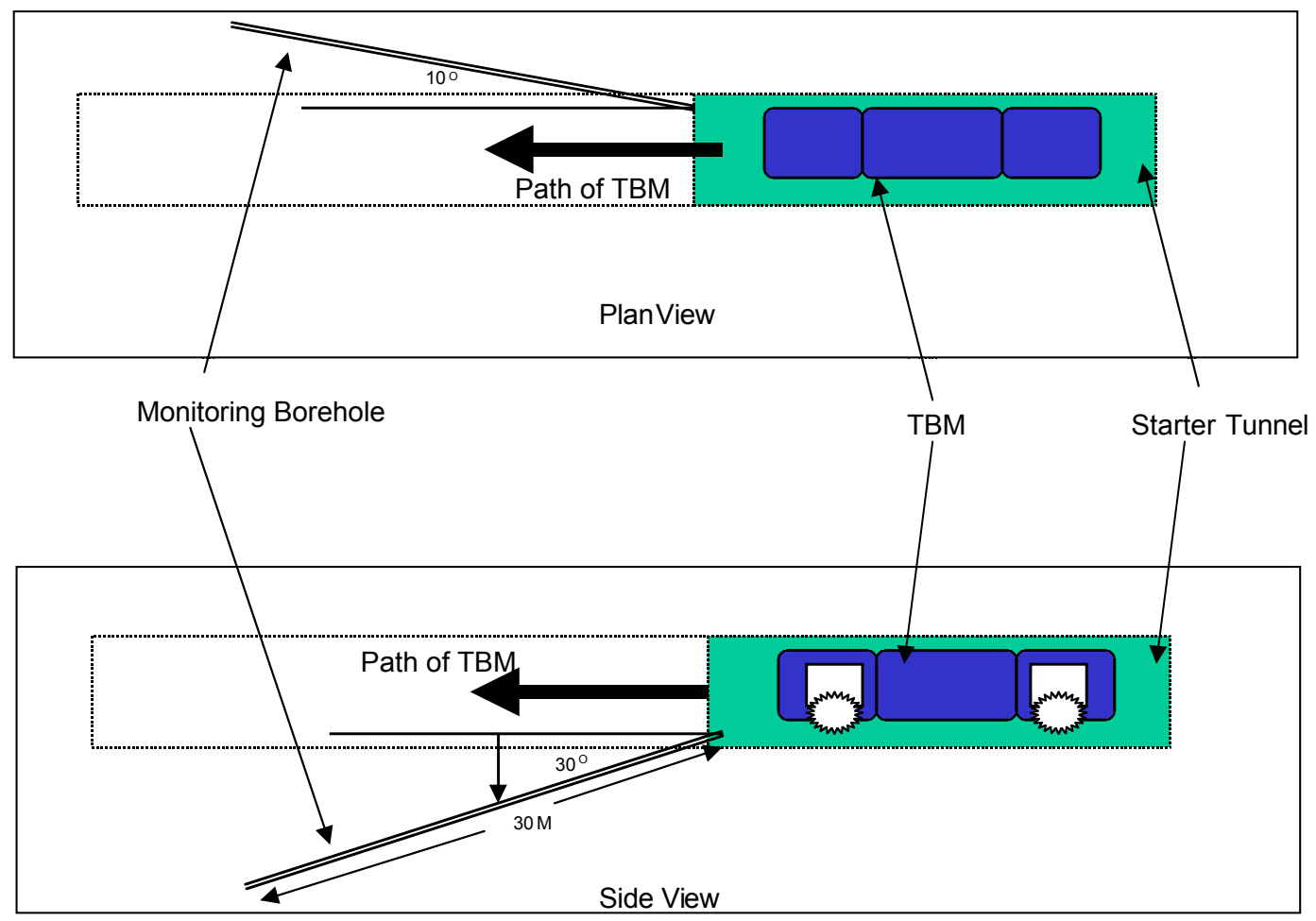

Figure 6-96. Schematic Illustration of the Location of Wetting-Monitoring Borehole at the Starter Tunnel of the ECRB Cross-Drift

\subsubsection{Electrical Resistance Probes and Psychrometers}

The psychrometers and ERPs were housed in PVC trays. These trays were fabricated from PVC pipes $(0.10 \mathrm{~m} \mathrm{OD})$ bisected along the lengths. On each tray, psychrometers were installed at a spacing of $1.0 \mathrm{~m}$ along the borehole, and ERPs were installed at $0.5-\mathrm{m}$ intervals. To locate the psychrometers, squares of PVC $(0.02 \mathrm{~m})$ were glued at the $1.0-\mathrm{m}$ mark and small-diameter holes (approximately $0.003 \mathrm{~m} \mathrm{ID)} \mathrm{were} \mathrm{drilled} \mathrm{through} \mathrm{the} \mathrm{tray.} \mathrm{Psychrometers} \mathrm{were} \mathrm{then} \mathrm{installed} \mathrm{in}$ these holes (Figure 6-97). ERPs were attached to the outer surface of the PVC trays with strips of Velcro. This housing permitted close contact between the ERPs and borehole wall, and also allowed the psychrometers to contact the borehole wall through a small cavity. 
A steel spoon, $3.0 \mathrm{~m}$ long and having the same configuration as the trays, was used to locate each PVC tray along the borehole. Typically, each tray was placed on the steel spoon and carried to the desired location, at which point the spoon was slipped out, allowing the tray to settle snugly against the borehole wall.

Twenty-seven psychrometers and 54 electrical resistance probes located on nine PVC trays were installed in the borehole (Figure 6-97) on February 26, 1998 (i.e., preceding the excavation by the TBM occurring on April 8, 1998). Psychrometer data were collected at 1.5-hour intervals starting on February 28, 1998, for a period of four months. ERP data collection started on March 25, 1998, and was collected at the same frequency and for the same duration as the psychrometers.
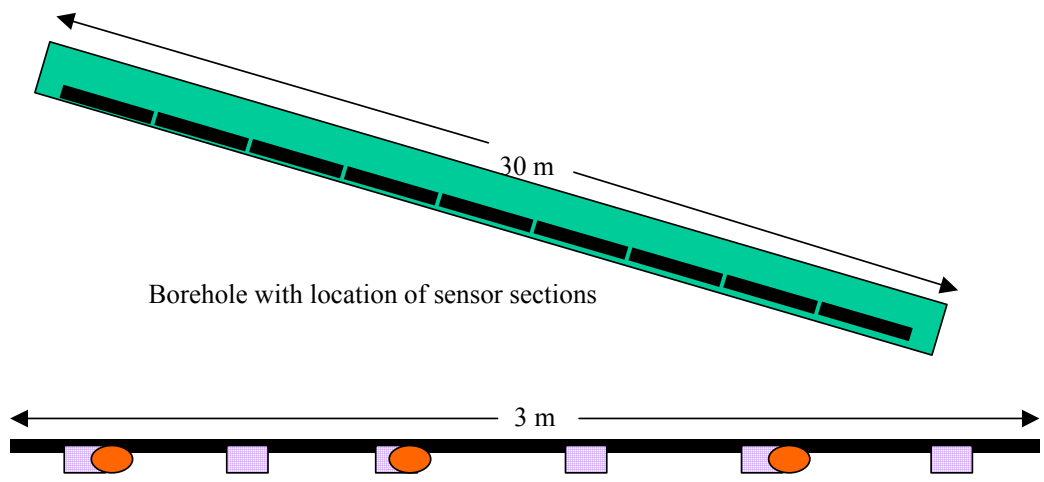

Single section with sensors

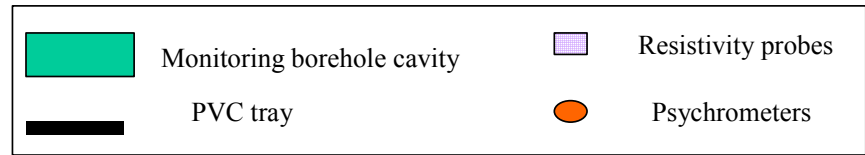

NOTE: Sections containing 7 ERPs and 4 psychrometers (as illustrated) can be placed alternatively with sections containing 5 ERPs and 2 psycrometers (without end sensors) to have, on average, 6 ERPs and 3 psychrometers for each section unit.

Figure 6-97. Schematic Illustration of the Borehole Wetting Front Monitoring System with Psychrometers and Electrical Resistance Probes

\subsubsection{Drift Monitoring at the Crossover Point}

The schematics of the seepage detection system, with fluid collection trays hanging below the ceiling of the ESF main drift, are illustrated in Figure 6-2. The schematics of the associated sensor arrays are illustrated in Figure 6-98. The seepage monitoring system was used to detect the wetting front in the ESF main drift as the result of releases of traced water in the ECRB Cross-Drift above. 

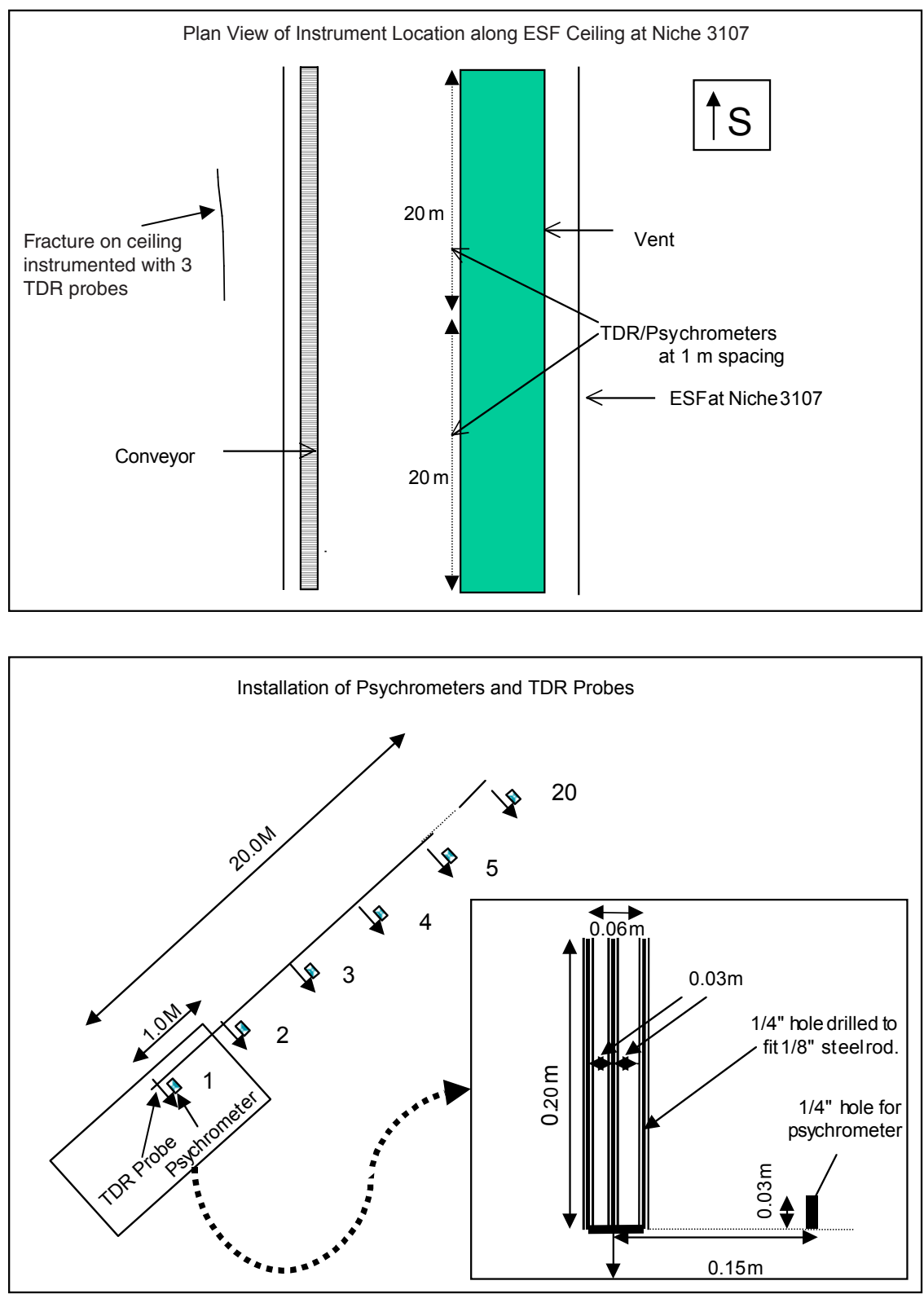

Figure 6-98. Schematic Illustration of Sensor Arrays for Wetting Front Monitoring

At the crossover monitoring station, 132 collection trays were installed, each $0.3 \mathrm{~m}$ wide and $1.23 \mathrm{~m}$ long, from Station $30+40$ to Station $30+80$. The trays were hung below the tunnel ceiling next to the ventilation duct along the ESF main drift. On the drift walls above the spring line (3.18 $\mathrm{m}$ above the floor), psychrometers and TDR probes were installed. A horizontal sensor array with 40 psychrometer-TDR pairs at 1-m spacing was installed along the west wall (right rib). At the crossover location, vertically along the west wall, between the spring line and the ventilation duct (ventilation duct illustrated in Figure 6-98 is near the ceiling and above the spring line), three psychrometers were installed. On the east wall (left rib), three TDR probes were installed along the trace of a major fracture. In addition to the sensors on the walls, an infrared camera and a video camera periodically monitored the area around one TDR probe on 
the fracture trace. Infrared images are sensitive to temperature changes associated with evaporation processes.

\subsubsection{Wetting-Front Detection and Monitoring below the ECRB Cross-Drift}

The following results are presented to show that the wetting front was detected up to a distance of $12.15 \mathrm{~m}$ below the ECRB Cross-Drift Starter Tunnel, and no seepage was observed at the crossover point in the main drift $17.5 \mathrm{~m}$ below the ECRB Cross-Drift. The Starter Tunnel is located in the upper lithophysal TSw tuff unit, and the crossover point is located in the middle nonlithophysal TSw tuff unit.

\subsubsection{Wetting-Front Detection at the Starter Tunnel}

The responses of all psychrometers and ERPs used in this investigation are summarized in Table 6-22 and Table 6-23. In the last columns of both tables, all working sensors with signals in response to construction-water usage are labeled "yes," and those with no response are labeled "no." With the arrival of a wetting front, the water potential measured by psychrometers and the electrical resistance measured by ERPs change to near-zero values.

Table 6-22. Psychrometers Response to Excavation at the Starter Tunnel of the ECRB Cross-Drift

\begin{tabular}{|c|c|c|c|}
\hline PSY_ID & $\begin{array}{l}\text { Dist. Collar } \\
(\mathrm{m})\end{array}$ & $\begin{array}{l}\text { Vertical Depth } \\
(\mathrm{m})\end{array}$ & $\begin{array}{c}\text { Response to } \\
\text { Tunneling }\end{array}$ \\
\hline Psy_30.3 & 30.3 & 15.15 & (not analyzed) \\
\hline Psy_29.3 & 29.3 & 14.65 & (not analyzed) \\
\hline Psy_28.3 & 28.3 & 14.15 & No \\
\hline Psy_27.3 & 27.3 & 13.65 & (not analyzed) \\
\hline Psy_26.3 & 26.3 & 13.15 & No \\
\hline Psy_25.3 & 25.3 & 12.65 & No \\
\hline Psy_24.3 & 24.3 & 12.15 & Yes \\
\hline Psy_23.3 & 23.3 & 11.65 & No \\
\hline Psy_22.3 & 22.3 & 11.15 & Yes \\
\hline Psy_21.3 & 21.3 & 10.65 & No \\
\hline Psy_20.3 & 20.3 & 10.15 & No \\
\hline Psy_19.3 & 19.3 & 9.65 & (not analyzed) \\
\hline Psy_18.3 & 18.3 & 9.15 & Yes \\
\hline Psy_17.3 & 17.3 & 8.65 & Yes \\
\hline Psy_16.3 & 16.3 & 8.15 & Yes \\
\hline Psy_15.3 & 15.3 & 7.65 & Yes \\
\hline Psy_14.3 & 14.3 & 7.15 & Yes \\
\hline Psy_13.3 & 13.3 & 6.65 & Yes \\
\hline Psy_11.4 & 11.4 & 5.7 & Yes \\
\hline Psy_10.4 & 10.4 & 5.2 & Yes \\
\hline Psy_9.4 & 9.4 & 4.7 & Yes \\
\hline Psy_7.2 & 7.2 & 3.6 & (not analyzed) \\
\hline Psy_6.2 & 6.2 & 3.1 & Yes \\
\hline
\end{tabular}


Table 6-22. Psychrometers Response to Excavation at the Starter Tunnel of the ECRB Cross-Drift (Continued)

\begin{tabular}{|c|c|c|c|}
\hline PSY_ID & $\begin{array}{c}\text { Dist. Collar } \\
(\mathbf{m})\end{array}$ & $\begin{array}{c}\text { Vertical Depth } \\
(\mathbf{m})\end{array}$ & $\begin{array}{c}\text { Response to } \\
\text { Tunneling }\end{array}$ \\
\hline Psy_5.2 & 5.2 & 2.6 & Yes \\
\hline Psy_3.9 & 3.9 & 1.95 & (not analyzed) \\
\hline Psy_2.6 & 2.6 & 1.3 & (not analyzed) \\
\hline Psy_1.6 & 1.6 & 0.8 & Yes \\
\hline
\end{tabular}

NOTE: This table summarizes the interpretation of water-potential data in DTN: LB98091233124.014 [DIRS 105858] with detailed example curves shown in Figure 6-99.

Table 6-23. Electrical Resistance Probe Responses to Excavation at the Starter Tunnel of the ECRB Cross-Drift

\begin{tabular}{|c|c|c|c|}
\hline ER_ID & Dist. Collar (m) & Vertical Depth (m) & $\begin{array}{c}\text { Response to } \\
\text { Tunneling }\end{array}$ \\
\hline ER $30.3 \mathrm{~m}$ & 30.3 & 15.2 & No \\
\hline ER $29.8 \mathrm{~m}$ & 29.8 & 14.9 & No \\
\hline ER_29.3 m & 29.3 & 14.7 & No \\
\hline ER_28.8 m & 28.8 & 14.4 & No \\
\hline ER_28.3 m & 28.3 & 14.2 & No \\
\hline ER_27.8 m & 27.8 & 13.9 & No \\
\hline ER_27.3 m & 27.3 & 13.7 & Yes \\
\hline ER_26.8 m & 26.8 & 13.4 & Yes \\
\hline ER $26.3 \mathrm{~m}$ & 26.3 & 13.2 & No \\
\hline ER_25.8 m & 25.8 & 12.9 & No \\
\hline ER_25.3 m & 25.3 & 12.7 & No \\
\hline $\mathrm{ER} \_24.8 \mathrm{~m}$ & 24.8 & 12.4 & No \\
\hline $\mathrm{ER} \_24.3 \mathrm{~m}$ & 24.3 & 12.2 & Yes \\
\hline $\mathrm{ER} \_23.8 \mathrm{~m}$ & 23.8 & 11.9 & No \\
\hline ER $23.3 \mathrm{~m}$ & 23.3 & 11.7 & No \\
\hline ER $22.8 \mathrm{~m}$ & 22.8 & 11.4 & No \\
\hline ER_22.3 m & 22.3 & 11.2 & Yes \\
\hline ER_21.8 m & 21.8 & 10.9 & Yes \\
\hline ER_21.3 m & 21.3 & 10.7 & Yes \\
\hline ER_20.8 m & 20.8 & 10.4 & No \\
\hline ER_20.3 m & 20.3 & 10.2 & Yes \\
\hline ER_19.8 m & 19.8 & 9.9 & Yes \\
\hline ER_19.3 m & 19.3 & 9.7 & Yes \\
\hline ER_18.8 m & 18.8 & 9.4 & Yes \\
\hline ER $18.3 \mathrm{~m}$ & 18.3 & 9.2 & Yes \\
\hline
\end{tabular}


Table 6-23. Electrical Resistance Probe Responses to Excavation at the Starter Tunnel of the ECRB Cross-Drift (Continued)

\begin{tabular}{|c|c|c|c|}
\hline ER_ID & Dist. Collar (m) & Vertical Depth (m) & $\begin{array}{c}\text { Response to } \\
\text { Tunneling }\end{array}$ \\
\hline ER_17.8 m & 17.8 & 8.9 & Yes \\
\hline ER_17.3 m & 17.3 & 8.7 & Yes \\
\hline ER_16.8 m & 16.8 & 8.4 & Yes \\
\hline ER_16.3 m & 16.3 & 8.2 & Yes \\
\hline ER_15.8 m & 15.8 & 7.9 & Yes \\
\hline ER_ $15.3 \mathrm{~m}$ & 15.3 & 7.7 & Yes \\
\hline ER_14.8 m & 14.8 & 7.4 & Yes \\
\hline $\mathrm{ER} \_14.3 \mathrm{~m}$ & 14.3 & 7.2 & Yes \\
\hline ER_13.8 m & 13.8 & 6.9 & Yes \\
\hline $\mathrm{ER} \_13.3 \mathrm{~m}$ & 13.3 & 6.7 & Yes \\
\hline ER_12.8 m & 12.8 & 6.4 & Yes \\
\hline ER_11.4 m & 11.4 & 5.7 & Yes \\
\hline ER_10.9 m & 10.9 & 5.5 & Yes \\
\hline ER_10.4 m & 10.4 & 5.2 & Yes \\
\hline ER_9.9 m & 9.9 & 5.0 & Yes \\
\hline ER_9.4 m & 9.4 & 4.7 & Yes \\
\hline ER_8.9 m & 8.9 & 4.5 & Yes \\
\hline $\mathrm{ER} \_7.2 \mathrm{~m}$ & 7.2 & 3.6 & Yes \\
\hline ER_6.7 m & 6.7 & 3.4 & Yes \\
\hline ER_6.2 m & 6.2 & 3.1 & Yes \\
\hline ER $\_5.7 \mathrm{~m}$ & 5.7 & 2.9 & Yes \\
\hline ER_5.2 m & 5.2 & 2.6 & Yes \\
\hline $\mathrm{ER} \_4.7 \mathrm{~m}$ & 4.7 & 2.4 & Yes \\
\hline ER_3.9 m & 3.9 & 2.0 & Yes \\
\hline ER_3.1 m & 3.1 & 1.6 & Yes \\
\hline ER_2.6 m & 2.6 & 1.3 & Yes \\
\hline ER_2.1 m & 2.1 & 1.1 & Yes \\
\hline ER_1.6 m & 1.6 & 0.8 & Yes \\
\hline ER_1.1 m & 1.1 & 0.6 & Yes \\
\hline
\end{tabular}

NOTE: This table summarizes the interpretation of electrical resistivity data in DTN: LB98091233124.014 [DIRS 105858] with detailed example curves shown in Figure 6-100. 


\subsection{Psychrometers}

The data from the psychrometers illustrated in Figure 6-99 show that along the entire length of the borehole, the walls were at water potentials approximately $-500 \mathrm{~m}$ when the sensors were installed in late February 1998. A uniform, steep increase in water-potential values over the first two weeks in March 1998 suggests the recovery of the borehole wall from drying that occurred during the dry drilling of this borehole. The following four months of data show all psychrometers approaching equilibrium values, with water potentials varying from -70 to $0 \mathrm{~m}$ (Figure 6-99).

Superimposed on this asymptotic trend in water-potential values are periodic deviations, with psychrometers nearer the borehole collar showing a larger number of such events. These events were restricted to the first two months of monitoring, and by the third week of April, the last of these events had occurred. Three of the psychrometers (located at distances of 1.6, 6.2, and $9.4 \mathrm{~m}$ from the borehole collar) showed evidence of wetting events, which increased water potential to near zero. The psychrometer at $1.6 \mathrm{~m}$ had near-zero water potential for three distinct periods. The first extended from the start of monitoring until March 3, and the second extended for four days beginning on March 8. A final period, significantly shorter, lasted for almost 24 hours on March 22. The psychrometer located at $6.2 \mathrm{~m}$ measured water potential close to zero for a three-day period starting on March 8. The psychrometer located at $9.4 \mathrm{~m}$ detected water-potential values close to zero for a single event on March 13, for nearly eleven hours.

One concern that could arise from the use of a slanting borehole to measure wetting-front migration is the possibility of the bore cavity short-circuiting flow paths. For this particular investigation, this short-circuiting does not appear to have happened, as indicated by the analysis of recovery responses observed at the depth of $5.2 \mathrm{~m}$. The response to a wetting event was negligible when compared with other psychrometers close to this location (above and below), suggesting that this zone was well isolated (hydraulically) from the adjacent zones and did not detect the wetting front. In the remaining eight psychrometers located between $9.4 \mathrm{~m}$ and $17.3 \mathrm{~m}$ from the borehole collar, investigators found evidence of small increases in water potential that extend beyond the projected recovery rate. Some of these increases coincided with periods when the psychrometers at distances of 1.6, 6.2, and $9.4 \mathrm{~m}$ along the borehole showed near-zero potentials; the rest of the psychrometer data remained uncorrelated until the end of April 1998. The psychrometers up to a distance of $10.4 \mathrm{~m}$ maintained a sinusoidal response, which fluctuated around a trend of slow water-potential increase.

By early May 1998, the rates at which water potential was increasing had decreased significantly, and by mid-June all psychrometer readings appeared to have stabilized. In the case of two deep psychrometers (i.e., at $18.3 \mathrm{~m}$ and $22.3 \mathrm{~m}$ ), there appears to have been individual events that for brief periods increased the rate at which water potentials were increasing. The deep psychrometers maintained nearly constant readings once they approached equilibrium, without the oscillations observed for shallow psychrometers. 

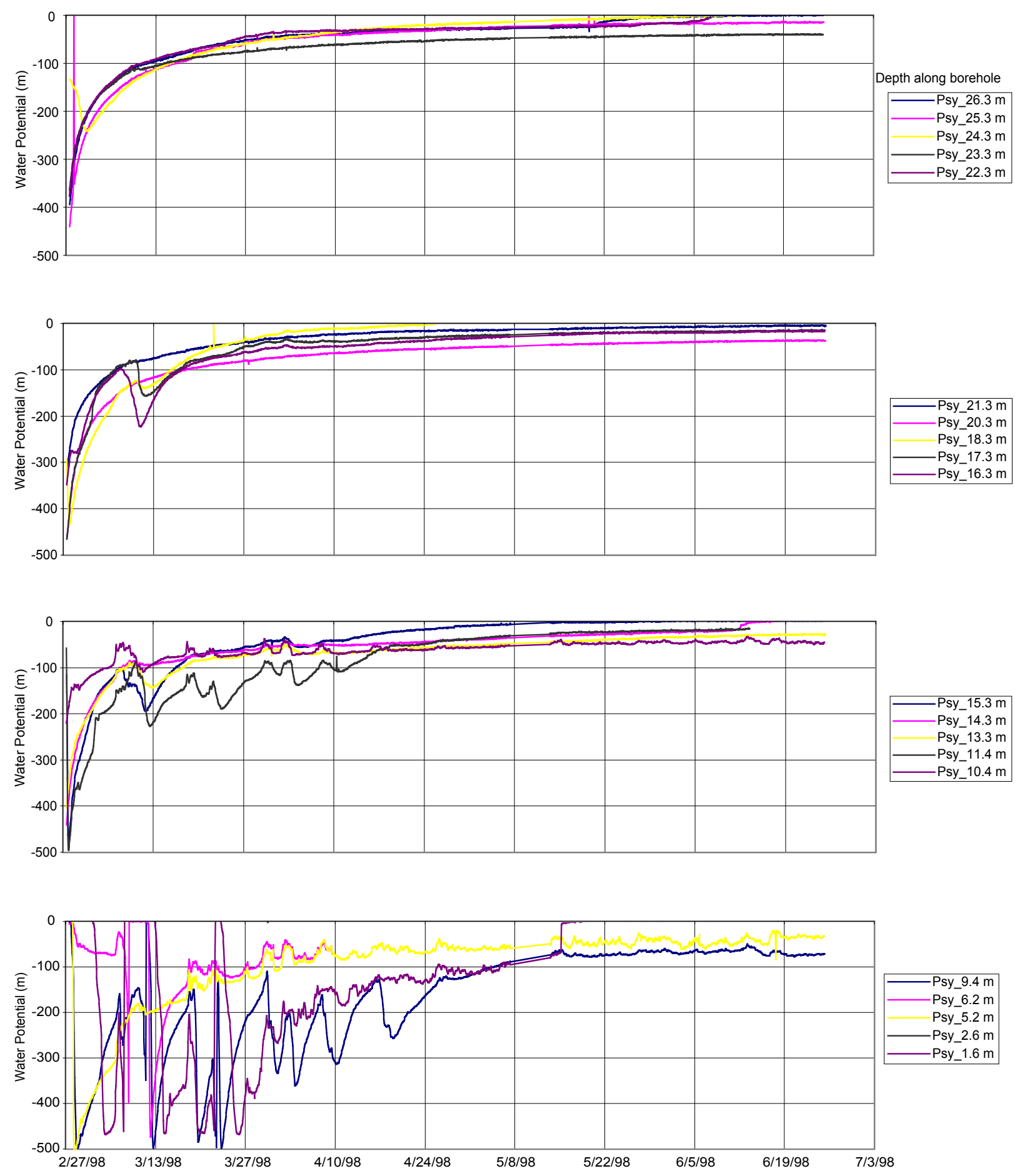

Source: DTN: LB980901233124.014 [DIRS 105858].

Figure 6-99. Changes in Water Potential Observed along the Wetting Front Monitoring Borehole at the Starter Tunnel of the ECRB Cross-Drift 


\subsection{Electrical Resistance Probe}

Measurements of electrical resistance were initiated in late March and continued until late June. Figure 6-100 summarizes the responses observed from probes located at 0.5-m intervals along the walls of the borehole between 17.3 and $29.8 \mathrm{~m}$ from the borehole collar.
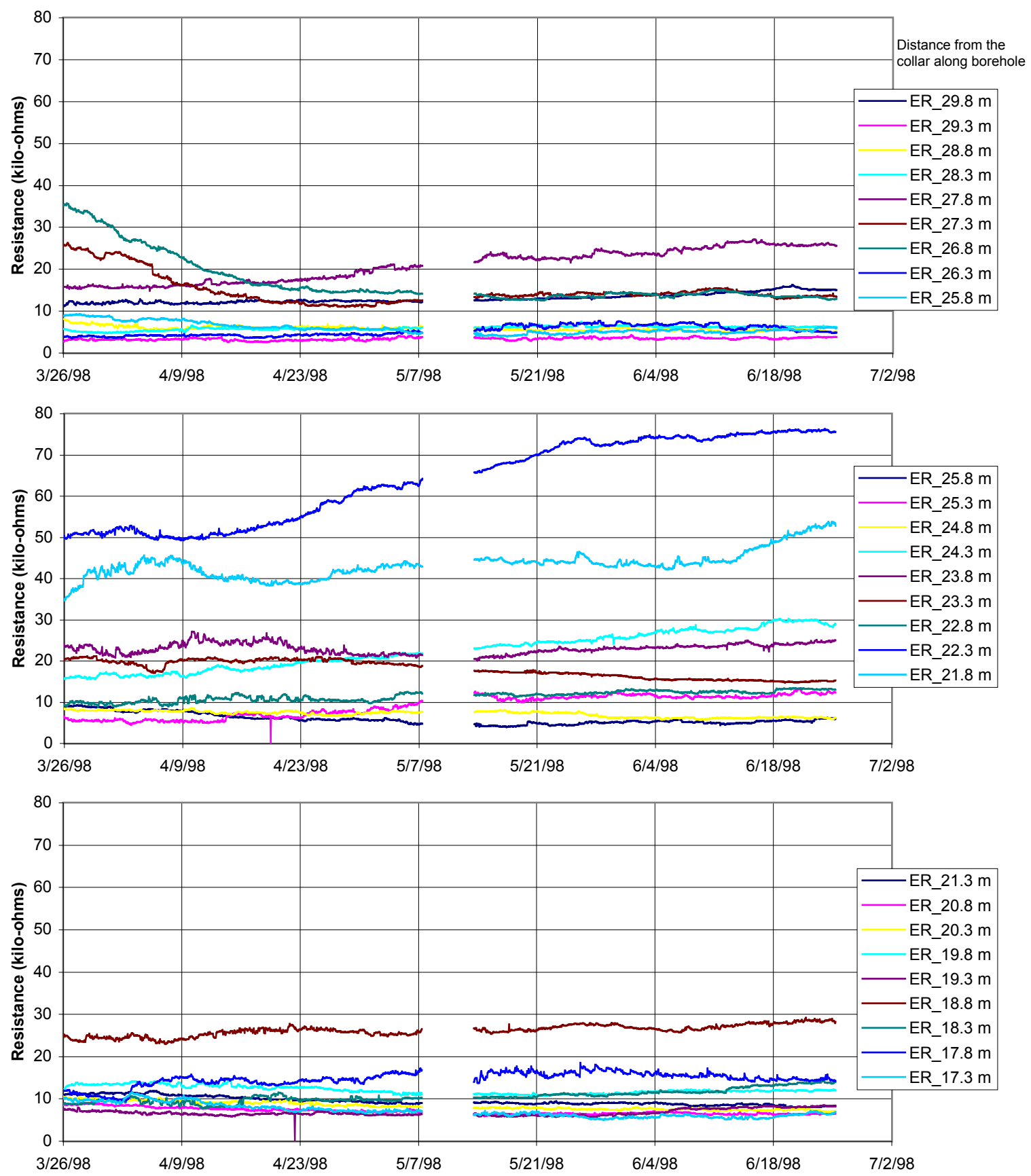

Source: DTN: LB980901233124.014 [DIRS 105858].

Figure 6-100. Changes in Electrical Resistance Observed along the Wetting-Front Monitoring Borehole at the Starter Tunnel of the ECRB Cross-Drift 


\subsection{Potential Sensor Comparison}

As part of an effort to evaluate the performance of ERPs as a sensor to monitor the arrival and movement of a wetting front, a series of probes was installed next to psychrometers along the borehole length. The performance of the ERPs was compared with those of psychrometers.

From the psychrometer data collected between late March and June 1998, as illustrated in Figure 6-101, the events of interest were:

- Sinusoidal responses in the shallower psychrometers (e.g., psychrometers at a distance of $5.2 \mathrm{~m}$ )

- The wetting and drying cycles observed in the shallower zones as the borehole walls approached equilibrium (e.g., psychrometers at a distance of $9.4 \mathrm{~m}$ )

- Steady approaches to equilibrium as seen in the deeper psychrometers (i.e., at depths greater than $10.4 \mathrm{~m})$.

Panels (a) to (c) of Figure 6-101 summarize responses of both psychrometers and ERPs for the three response patterns observed in the psychrometer data. (The y-axes for resistance were presented in decreasing scales, so that wetter sensors have higher y-values.) In two of the three cases, the ERPs responded in a pattern similar to that of psychrometers located next to the probes. With the exception of the sensor at $5.2 \mathrm{~m}$, the sinusoidal response observed by the psychrometer was well tracked by the ERPs, with points of changing trends fairly well synchronized. However, the direction of the trends between small time intervals is not consistent, suggesting that the response times of the probes are significantly different. The ERPs at shallow depths might be sensitive to air flows through the fractures in addition to moisture conditions in the vicinity of the probes. The psychrometers measure the moisture conditions in the vicinity of the probes.

At a distance of $9.4 \mathrm{~m}$, the water potential increased steadily from $-400 \mathrm{~m}$ to $-70 \mathrm{~m}$ between late March 1998 and June 1998, and the corresponding ERP measurements followed a similar pattern. Large fluctuations in water potentials in relatively short periods of time $(-200 \mathrm{~m}$ in 4 days) were comparably detected by both types of probes. The slower, more gradual recovery observed by psychrometers deeper in the formation was generally well tracked by the ERPs (e.g., at $21.3 \mathrm{~m}$ ). 
(a)

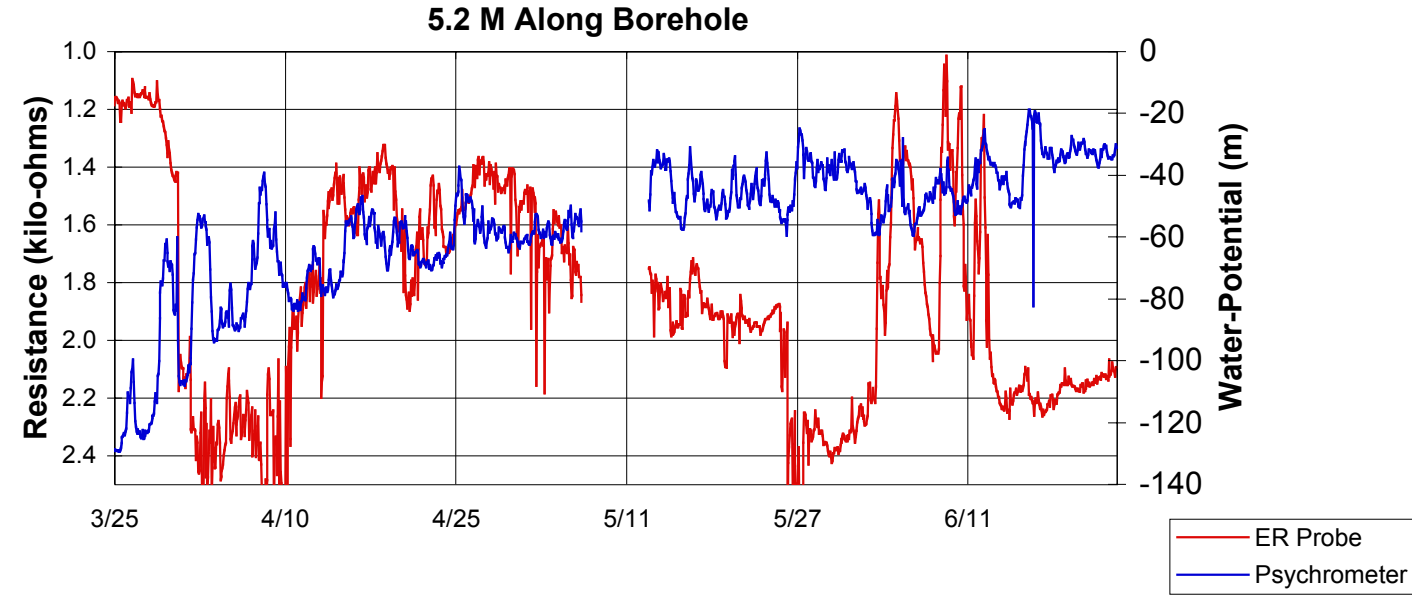

(b)

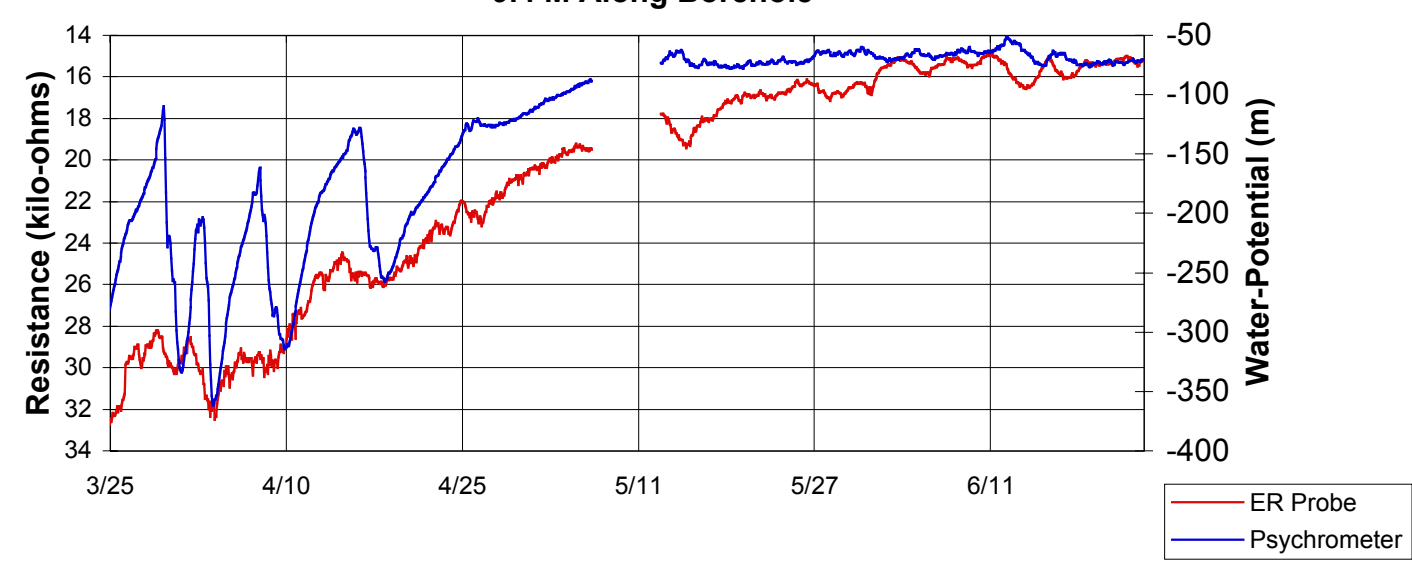

(c)

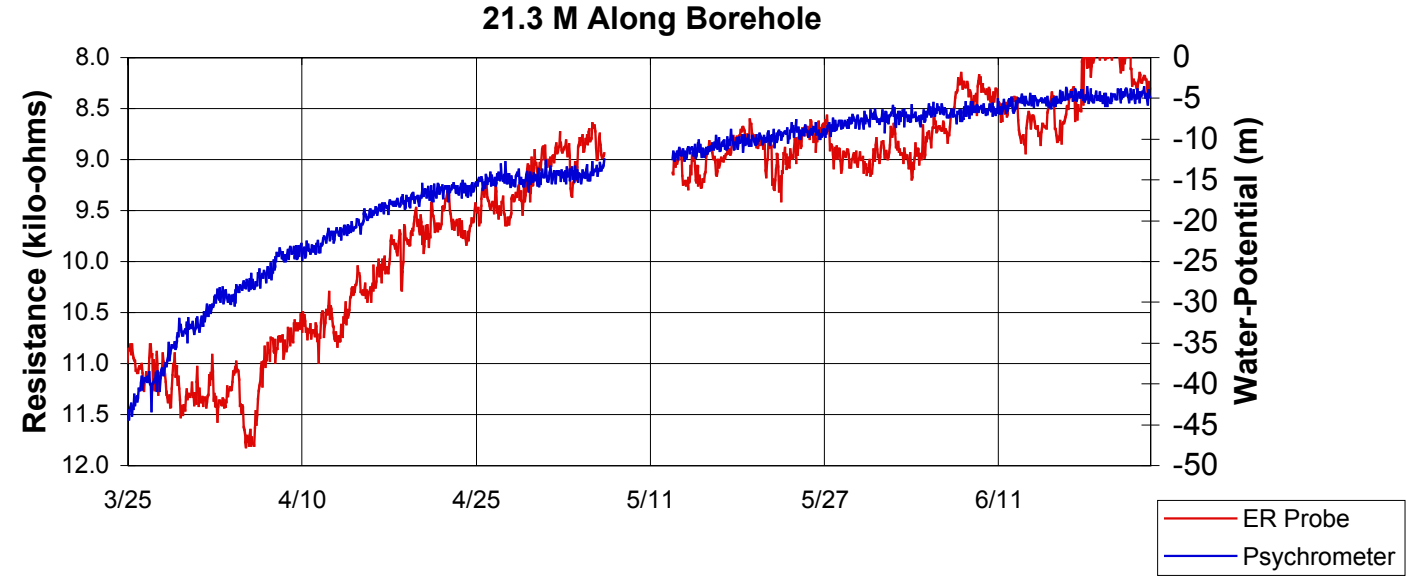

Source: DTN: LB980901233124.014 [DIRS 105858].

Figure 6-101. Comparison of Performance of Electrical Resistance Probe and Psychrometer 


\subsubsection{Wetting-Front Monitoring at the Crossover Point}

Figure 6-2 schematically illustrated the potential movement of construction water from the ECRB Cross-Drift to the ESF main drift seepage collection system. Monitoring the potential migration allowed the study of water and tracer flow from one drift to another.

The TBM excavating the ECRB Cross-Drift passed over the ESF main drift on the second shift of July 1, 1998. No seepage was observed. The observers in the ESF main drift could hear rumbling noises from the TBM and feel vibrations on the railroad tracks and tunnel wall. However, no falling of loosened rock was observed.

Figure 6-102 illustrates an example of the data collected by the TDR probes. No evident signals were associated with wetting-front arrivals. These null results from the sensors substantiate the field observations of no seepage associated with the TBM passing over the ESF main drift. The confirmation of no seepage at the crossover point establishes the lower limit for the drift-to-drift flow and drift seepage processes associated with localized construction-water usage. It also provides a guide to the design of controlled drift-to-drift experiments at this unique location, with one drift above another drift.

The underground water usage in the ECRB Cross-Drift was monitored by YMP Science and Engineering Testing on a shift-by-shift basis; the tunnel-water use logs were evaluated by the YMP Testing Safety Assurance group.

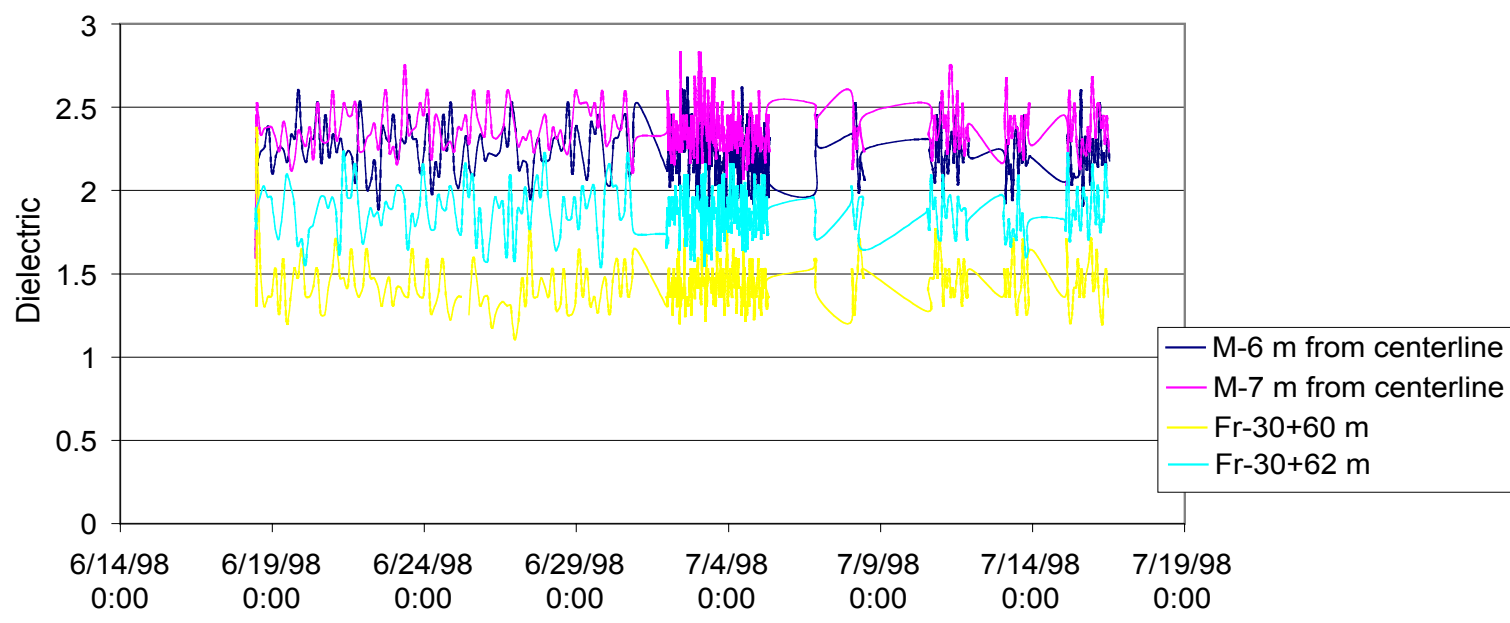

Measurement of Dielectric in Formation Matrix (M-6, M-7)

and Fracture (Fr) at Crossover Point

Source: DTN: LB980901233124.014 [DIRS 105858].

Figure 6-102. Example of Time Domain Reflectometry Probe Data at the Crossover Point in the ESF Main Drift 


\subsection{MOISTURE MONITORING AND WATER ANALYSIS IN UNDERGROUND DRIFTS}

In ventilated drift sections, no continuous dripping (or seepage) has been observed either in the ESF Loop or in the ECRB Cross-Drift. This lack of seepage may be explained by the capillary barrier mechanism, as described in Section 6.2, with capillary forces holding water within the rock mass. The other explanation pertains to ventilation. Ventilation can remove large amounts of moisture, dry the rock behind the drift walls, and suppress seepage. To determine whether seepage returns when ventilation effects are mitigated, the last one-third of the ECRB Cross-Drift was sealed through use of multiple bulkheads. Section 6.10.1 summarizes the moisture conditions and construction-water migration associated with drift excavation. Section 6.10.2 describes the preliminary results from the ongoing moisture monitoring in the ECRB Cross-Drift. This section summarizes the data on both the moisture conditions during drift operation and the post-emplacement environment in sealed drifts.

Water potential data measured along the ESF were used as part of the validation of the UZ flow model (BSC 2004 [DIRS 169861], Section 7.2).

\subsubsection{Construction (Drift Excavation) Effects on Moisture Conditions}

\subsubsection{ESF Moisture Monitoring Study}

The moisture conditions in the ESF tunnels were monitored at 17 stations in the ESF main tunnel (from station 7+20 to station 73+50) and 10 stations in the ECRB Cross-Drift (from station $0+25$ to station 25+55), as summarized in Table 6-24. Relative humidity, temperature, barometric pressure, and air velocity were measured at various stations. The moisture-monitoring stations were supplemented by measurements from sensors with humidity/temperature probes and barometers mounted on the TBM during excavations. Additionally, periodic surveys were conducted along the tunnels with these types of sensors, mounted on a mobile platform. An infrared camera was used in mobile surveys to measure the temperature changes on the tunnel walls.

Table 6-24. Moisture-Monitoring Stations in the Exploratory Studies Facility and in the Enhanced Characterization of the Repository Block Cross-Drift

\begin{tabular}{|c|c|c|}
\hline $\begin{array}{c}\text { Moisture-Monitoring } \\
\text { Station Location/ } \\
\text { ID }^{\mathrm{a}}\end{array}$ & Description $^{\text {b }}$ & DTN \\
\hline \multirow{2}{*}{$\begin{array}{l}21+00 / \text { LB20, } \\
28+30 / \text { LB50, } \\
35+00 / \text { LB40, } \\
42+50 / \text { LB60, } \\
47+00 / \text { LB70, } \\
51+73 / \text { LB80, } \\
57+50 / \text { LB90, } 64+59, \\
67+00,73+50, \\
\text { AOD5, BKH5 }\end{array}$} & $\begin{array}{l}\text { Relative Humidity, Temperature, and } \\
\text { Pressure in ESF Monitoring Stations in } \\
\text { Report "Evaluation of Moisture Evolution in } \\
\text { the Exploratory Studies Facility." VA } \\
\text { Supporting Data }\end{array}$ & LB960800831224.001 [DIRS 105793] \\
\hline & $\begin{array}{l}\text { Moisture Data Report from October, } 1996 \text { to } \\
\text { January, } 1997\end{array}$ & LB970300831224.001 [DIRS 105794] \\
\hline
\end{tabular}


Table 6-24. Moisture-Monitoring Stations in the Exploratory Studies Facility and in the Enhanced Characterization of the Repository Block Cross-Drift (Continued)

\begin{tabular}{|c|c|c|}
\hline $\begin{array}{l}\text { Moisture-Monitoring } \\
\text { Station Location/ } \\
\text { ID }^{\mathrm{a}}\end{array}$ & Description $^{\text {b }}$ & DTN \\
\hline & $\begin{array}{l}\text { Moisture-Monitoring Data Collected at ESF } \\
\text { Sensor Stations, Moisture Monitoring Before } \\
\text { and After the Completion of the ESF }\end{array}$ & LB970801233124.001 [DIRS 105796] \\
\hline & $\begin{array}{l}\text { Moisture-Monitoring Data Collected at } \\
\text { Stationary Moisture Stations }\end{array}$ & LB970901233124.002 [DIRS 105798] \\
\hline \multirow{3}{*}{$\begin{array}{l}\text { 7+20/GS\#3, } \\
\text { 10+93/GS\#4, 28+93, } \\
51+64,67+20, \\
\text { Operator-Shack/GS\# } \\
1 \text { (on TBM), } \\
\text { Vent-Line-Intake/GS\# } \\
2 \text { (on TBM) }\end{array}$} & $\begin{array}{l}\text { Moisture Monitoring in the ESF, Oct. 1, 1996, } \\
\text { through Jan. 31, } 1997\end{array}$ & $\begin{array}{l}\text { GS970208312242.001 } \\
\text { [DIRS 135119] }\end{array}$ \\
\hline & $\begin{array}{l}\text { Moisture Monitoring in the ESF, Feb. 1, 1997, } \\
\text { through July 31, } 1997\end{array}$ & $\begin{array}{l}\text { GS970708312242.002 } \\
\text { [DIRS 135123] }\end{array}$ \\
\hline & $\begin{array}{l}\text { Moisture Monitoring in the ESF, August } 1 \text {, } \\
\text { 1997, through July 31, } 1998\end{array}$ & $\begin{array}{l}\text { GS980908312242.024 } \\
\text { [DIRS 135132] }\end{array}$ \\
\hline $\begin{array}{l}\text { ECRB Cross-Drift } \\
\text { GS: } 0+25,2+37 \\
2+88,3+38,10+03 \\
21+07,24+75 ; \text { LB: } \\
14+35,21+40,25+55\end{array}$ & $\begin{array}{l}\text { Moisture Monitoring in the ECRB Cross-Drift, } \\
04 / 08 / 98 \text { through } 7 / 31 / 98\end{array}$ & $\begin{array}{l}\text { GS980908312242.035 } \\
\text { [DIRS 135133], } \\
\text { LB990901233124.006 [DIRS 135137] } \\
\text { (see Section 6.10.2.1 of this report) }\end{array}$ \\
\hline \multicolumn{3}{|c|}{$\begin{array}{l}\text { a LB for stations maintained by Lawrence Berkeley National Laboratory, and GS for stations maintained by } \\
\text { United States Geological Survey. } \\
\text { b Description taken from Automated Technical Data Tracking database. }\end{array}$} \\
\hline \multicolumn{3}{|c|}{$\begin{aligned} \text { DTN } & =\text { data tracking number. } \\
\text { ECRB } & =\text { Enhanced Characterization of the Repository Block. } \\
\text { ESF } & =\text { Exploratory Studies Facility. } \\
\text { TBM } & =\text { tunnel boring machine. }\end{aligned}$} \\
\hline
\end{tabular}

The moisture data in the drifts, together with ventilation data and construction-water usage data, can be used to evaluate the amounts of moisture removed from the ESF drifts and the net quantities of construction water drained into the surrounding tuff formations. In this report, examples of moisture-monitoring data collected after excavation of the ECRB Cross-Drift are presented. Simple observations are qualitatively discussed to highlight the importance of excavation data and operation data for determining site perturbations. Potential sources for corroborative evidence of the induced effects are presented in Table 6-24, Table 6-25, and Table 6-26.

Table 6-24 summarizes the data collected in moisture monitoring stations during and after drift excavations. The tuffs around the drifts dry out as a result of moisture being removed by ventilation. The use of construction water also changes the saturation distribution in the vicinity of the drifts.

Water-potential measurements are listed in Table 6-25.

Table 6-26 summarizes the saturation measurements for both perturbed conditions and ambient conditions. 
Table 6-25. Water-Potential Measurements in the Exploratory Studies Facility and in the Enhanced Characterization of the Repository Block Cross-Drift

\begin{tabular}{|c|c|c|}
\hline Potential Measurement & Description $^{a}$ & DTN \\
\hline $\begin{array}{l}\text { Niche } 1 \text { (Niche 3566)_- } \\
\text { psychrometer } \\
\text { Niche } 2 \text { (Niche 3650)_- } \\
\text { psychrometer }\end{array}$ & $\begin{array}{l}3 \text { main boreholes, } 5 \text { lateral boreholes } \\
\text { in Niche } 1 \text { (Niche } 3566 \text { ), 5/9/97- } \\
\text { 10/21/97; } \\
6 \text { main boreholes in Niche } 2 \text { (Niche } \\
3650 \text { ), } 7 / 1 / 97-7 / 28 / 97\end{array}$ & $\begin{array}{l}\text { LB0406ESFNH2OP.001 } \\
\text { [DIRS 171588] } \\
\text { (see Section } 6.8 .2 \text { of this report) }\end{array}$ \\
\hline $\begin{array}{l}\text { Niche } 1 \text { (Niche } 3566 \text { )-heat } \\
\text { dissipation probe }\end{array}$ & $\begin{array}{l}21 \text { heat dissipation probe drill holes, } \\
11 / 4 / 97-7 / 31 / 98\end{array}$ & $\begin{array}{l}\text { GS980908312242.022 } \\
\text { [DIRS 135157] }\end{array}$ \\
\hline $\begin{array}{l}\text { Niche } 3 \text { (Niche } 3107)- \\
\text { psychrometer }\end{array}$ & 3 main boreholes, $12 / 22 / 97-1 / 8 / 98$ & $\begin{array}{l}\text { LB0406ESFNH2OP.001 } \\
\text { [DIRS 171588] } \\
\text { (see Section 6.8.2.4 of this report) }\end{array}$ \\
\hline Alcove 7-heat dissipation probe & $\begin{array}{l}\text { Heat dissipation probe drill holes, } \\
12 / 9 / 97-1 / 31 / 98\end{array}$ & $\begin{array}{l}\text { GS980908312242.022 } \\
\text { [DIRS 135157] }\end{array}$ \\
\hline $\begin{array}{l}\text { Alcove 3-filter paper } \\
\text { Alcove 4-filter paper }\end{array}$ & $\begin{array}{l}1 \text { core hole in Alcove } 3 \\
2 \text { core holes in Alcove } 4\end{array}$ & $\begin{array}{l}\text { GS980908312242.033 } \\
\text { [DIRS 107168], } \\
\text { GS980908312242.032 } \\
\text { [DIRS 107177] }\end{array}$ \\
\hline $\begin{array}{l}\text { North Ramp } 7+27 \text { to } 10+70 \\
\text { South Ramp } 69+65 \text { to } 76+33 \text { - } \\
\text { filter paper }\end{array}$ & $\begin{array}{l}18 \text { North Ramp boreholes, } 3 \text { Alcove } 4 \\
\text { boreholes, and } 46 \text { South Ramp } \\
\text { boreholes, HQ, 2-m length }\end{array}$ & $\begin{array}{l}\text { GS980308312242.004 } \\
\text { [DIRS 107172] }\end{array}$ \\
\hline $\begin{array}{l}\text { South Ramp-heat dissipation } \\
\text { probe }\end{array}$ & $\begin{array}{l}\text { Heat dissipation probe drill holes, } \\
8 / 1 / 97-1 / 4 / 98\end{array}$ & $\begin{array}{l}\text { GS980308312242.002 } \\
\text { [DIRS 135163] }\end{array}$ \\
\hline $\begin{array}{l}\text { ECRB Cross-Drift Starter } \\
\text { Tunnel_psychrometer \& } \\
\text { electrical resistivity probe }\end{array}$ & 1 slant borehole below the invert & $\begin{array}{l}\text { LB980901233124.014 } \\
\text { [DIRS 105858] } \\
\text { (see Section 6.9.2.1 of this report) }\end{array}$ \\
\hline $\begin{array}{l}\text { ECRB Cross-Drift } 0+50 \text { to } \\
7+75 \text { - heat dissipation probe }\end{array}$ & $\begin{array}{l}6 \text { heat dissipation probe drill holes, } \\
4 / 23 / 98-7 / 31 / 98\end{array}$ & $\begin{array}{l}\text { GS980908312242.036 } \\
\text { [DIRS 119820] }\end{array}$ \\
\hline $\begin{array}{l}\text { Surface Based Boreholes- } \\
\text { psychrometer }\end{array}$ & $\begin{array}{l}\text { USW NRG-7a, UE-25 UZ\#4, UE-25 } \\
\text { UZ\#5, USW UZ-7a and USW SD-12; } \\
\text { 1/1/97-6/30/97; 7/1/97-9/30/97; } \\
\text { 10/1/98-3/31/98; 4/1/98-9/30/98 }\end{array}$ & $\begin{array}{l}\text { GS970808312232.005 } \\
\text { [DIRS 105978], } \\
\text { GS971108312232.007 } \\
\text { [DIRS 105980], } \\
\text { GS980408312232.001 } \\
\text { [DIRS 105982], } \\
\text { GS031208312232.002 } \\
\text { [DIRS 171748] }\end{array}$ \\
\hline
\end{tabular}


Table 6-26. Saturation Measurements in the Exploratory Studies Facility and in the Enhanced Characterization of the Repository Block Cross-Drift

\begin{tabular}{|c|c|c|}
\hline Saturation Measurement & Description $^{a}$ & DTN(s) \\
\hline $\begin{array}{l}\text { Niche } 1 \text { (Niche 3566) - core } \\
\text { Niche } 2 \text { (Niche 3650) - core }\end{array}$ & $\begin{array}{l}3 \text { main boreholes, } 6 \text { lateral } \\
\text { boreholes in Niche } 1 \text { (Niche 3566) } \\
\text { and } 7 \text { main boreholes in Niche } 2 \\
\text { (Niche } 3650 \text { ) }\end{array}$ & $\begin{array}{l}\text { GS980908312242.018 [DIRS 135170] } \\
\text { GS980908312242.020 [DIRS 135172] }\end{array}$ \\
\hline $\begin{array}{l}\text { Alcove } 6 \text { - core } \\
\text { Alcove } 7 \text { - core }\end{array}$ & $\begin{array}{l}3 \text { boreholes in Alcove } 6, \\
1 \text { borehole in Alcove } 7\end{array}$ & $\begin{array}{l}\text { GS980908312242.029 [DIRS 135175] } \\
\text { GS980908312242.028 [DIRS 135176] }\end{array}$ \\
\hline $\begin{array}{l}\text { Alcove } 3 \text { - core } \\
\text { Alcove } 4 \text { - core }\end{array}$ & $\begin{array}{l}1 \text { core hole in Alcove } 3, \\
2 \text { core holes in Alcove } 4\end{array}$ & $\begin{array}{l}\text { GS980908312242.033 [DIRS 107168] } \\
\text { GS980908312242.032 [DIRS 107177] }\end{array}$ \\
\hline $\begin{array}{l}\text { North Ramp } 7+27 \text { to } 10+70 \\
\text { South Ramp } 59+65 \text { to } 76+33- \\
\text { core }\end{array}$ & Borehole samples & $\begin{array}{l}\text { GS980308312242.005 [DIRS 107165] } \\
\text { GS980308312242.003 [DIRS 135180] }\end{array}$ \\
\hline $\begin{array}{l}\text { South Ramp - time domain } \\
\text { reflectrometry }\end{array}$ & $\begin{array}{l}\text { TDR measurements, 8/1/97 - } \\
1 / 4 / 98\end{array}$ & GS980308312242.001 [DIRS 135181] \\
\hline $\begin{array}{l}\text { ECRB Cross-Drift Starter Tunnel } \\
\text { - Core }\end{array}$ & 1 slant borehole core & GS980908312242.030 [DIRS 135224] \\
\hline $\begin{array}{l}\text { Cross-Over Point } 30+62 \text { in the } \\
\text { ESF Main Drift Below the ECRB } \\
\text { Cross-Drift - time domain } \\
\text { reflectrometry }\end{array}$ & $\begin{array}{l}\text { TDR probes on ESF drift walls, } \\
6 / 19 / 98-7 / 16 / 98\end{array}$ & $\begin{array}{l}\text { LB980901233124.014 [DIRS 105858] } \\
\text { (see Section 6.9.2.2 of this report) }\end{array}$ \\
\hline
\end{tabular}

${ }^{a}$ Description taken from Automated Technical Data Tracking database.

ECRB = Enhanced Characterization of the Repository Block.

ESF $=$ Exploratory Studies Facility.

TDR = time domain reflectrometry.

\subsubsection{Moisture Conditions and Perturbations Observed in Drifts}

\subsection{Observation of Moisture Conditions in Ventilated ESF Main Drift}

The ESF was excavated from 1994 to 1997. Wang et al. (1996 [DIRS 101309]) estimated the capacity of the ventilation system to remove moisture, starting August 1996, when the ESF main drift was excavated to a length of $6250 \mathrm{~m}$; at that time, the south ramp had not yet been constructed.

Preliminary evaluation of the moisture data during ESF excavation showed that the moisture conditions were sensitive to construction activities. The daily usage of water for excavation, muck transport, dust-control, and other operations introduced rapid changes in moisture conditions throughout the tunnel atmosphere and in the wall rock. During weekends in 1996, when construction activities were absent, the tunnel atmosphere generally stabilized to either high-humidity conditions (if the ventilation was turned off), or low-humidity conditions (if the ventilation was left on) (DTN: LB960800831224.001 [DIRS 105793]). After completion of the ESF main tunnel with two portals for entrance and exit, high-humidity conditions were suppressed by natural ventilation through the portals (DTN: LB970801233124.001 [DIRS 105796]). 
The following order-of-magnitude estimate of moisture removal capacity represents the ESF system under the conditions of August 1996, at which time the ESF Main Drift had already been excavated, and the ESF south ramp had not yet been constructed; at that time, the ESF had a total length of $6250 \mathrm{~m}$. (The ESF was excavated from 1994 to 1997.) The tunnel is $6250 \mathrm{~m}$ long, and has a cross-sectional area of $40 \mathrm{~m}^{2}$ (circular cross-sectional area with invert, vent line, and conveyor blockage areas subtracted); the humid tunnel air can contain 2500 kilograms of excess water mass (if the estimate used in the tunnel is on average 50 percent higher in relative humidity than the outside air), with the corresponding vapor density difference on the order of $0.01 \mathrm{~kg} / \mathrm{m}^{3}$. If tunnel air is ventilated with a flow rate of $47 \mathrm{~m}^{3} / \mathrm{s}$ or $100,000 \mathrm{ft}^{3} / \mathrm{min}$ (cubic feet per minute, or $\mathrm{cfm}$ ), it requires 5,300 seconds or 1.5 hours to replace the tunnel air. The water-removal rate of $2500 \mathrm{~kg}$ over 1.5 hours corresponds to $285 \mathrm{~m}^{3} /$ week ( $285 \mathrm{kiloliter} /$ week or 75,000 gallons/week). If all the moisture in the tunnel air is from evaporation, the equivalent evaporation rate from the tunnel walls and inverts (with a total area of $6250 \mathrm{~m}$ by $23.7 \mathrm{~m}$ ) is on the order of $100 \mathrm{~mm} / \mathrm{yr}$ (Wang et al. 1996 [DIRS 101309]).

Estimates that are more specific were made for sections in different tuff units, using measured relative humidity changes (Wang et al. 1996 [DIRS 101309]). Vapor-density differences between different locations, together with a simple approximation of airflow in the tunnel, were used to estimate the moisture removal rate and the equivalent evaporation rate. The amount of water removed weekly by ventilation was a substantial fraction of the water used in the tunnel. Estimated equivalent evaporation rates were on the order of $200 \mathrm{~mm} /$ year, with standard deviation over $90 \mathrm{~mm} / \mathrm{year}$, for both the Topopah Spring welded tuff units (in a 1400-m section centered at Alcove 5 (the thermal test alcove)), and the Paintbrush nonwelded units (in a $380 \mathrm{~m}$ section between Alcove 3 and Alcove 4). The uncertainties were related to fluctuations in the moisture conditions introduced by construction activities, including air ventilation and water usage.

The equivalent evaporation rate of more than $100 \mathrm{~mm} /$ year is an order of magnitude larger than the ambient percolation flux. The large evaporation rate could suppress the observations of active seeps and contribute to the apparent dry tunnel conditions. Rock temperatures near the TBM were observed to change spatially and temporally, which could be related to evaporation from rock surfaces. Water potentials near the rock surfaces were measured with heat dissipation probes, and water potential profiles along boreholes were measured through the use of psychrometers in niches and alcoves along the ESF main drift and along the ECRB Cross-Drift, as summarized in Table 6-25. Field measurements in boreholes, and laboratory measurements of physical and hydrologic properties of cores, were conducted to measure saturation distributions, as summarized in Table 6-26 and Section 6.8. The dryout zones could extend nominally 1 to $3 \mathrm{~m}$ into the walls, with fractures and faults potentially extending the depths of the dry-out zone.

Because the fractured TSw is highly permeable to air flow, the presence of underground drifts in the vicinity of pneumatic pressure sensors can result in observed drift barometric pressure changes that are nearly identical to the atmospheric signals at the portals outside the ESF. The progress in the ESF tunnel excavations was detected pneumatically by sensors in 10 surface-based boreholes within $200 \mathrm{~m}$ of the ESF. In comparison to the damping of 
barometric signals from the ground surface, less attenuation and phase lag were observed for signals from the ESF. For Borehole NRG-7a, which is within $30 \mathrm{~m}$ (in horizontal distance) from the ESF tunnel, the changes in water potential could also be related to the ESF dryout (see the last entry of Table 6-25 for DTNs of surface-based boreholes).

The main effects of ESF ventilation are the drying of rocks around the tunnel, the suppression of potential seepage into tunnels, and the perturbation of the gas flow field around the tunnel. Niche 1 (Niche 3566), Alcove 7, and the last section of the ECRB Cross-Drift (Figure 1-1 and Figure 1-2) have been closed for long periods (see Section 6.10.2 below), to minimize or eliminate the ventilation effects, and to gain additional information on the rewetting processes and potential seepage events under near-natural conditions (with drift entrances blocked off). Both the data collected during active ventilation phases and the data collected during passive nonventilation phases will contribute to the assessment of UZ responses to large-scale perturbations at Yucca Mountain.

\subsection{Observation of Moisture Effects in Alcove 3 and Alcove 4}

The north ramp of the ESF penetrates the TCw, the PTn, and reaches the TSw in sequence, as illustrated in Figure 1-1 and Figure 1-2. Alcove 3 and Alcove 4 were excavated in the vicinity of the TCw-PTn and PTn-TSw interfaces, respectively (Section 1.2). Corroborating studies have been performed between Alcove 3 and Alcove 4 that quantified in situ water-potential, moisture, and temperature fluctuations in the nonwelded units of the Paintbrush Group (PTn), to identify gradients between the PTn and adjacent Tiva Canyon tuff and Topopah Spring tuff (DTN: GS021008312242.003 [DIRS 162178]). The studies identified an effect of ventilation-induced drying to a depth of $4.9 \mathrm{~m}$ into the tuff from the ESF. As a result, water-potential values were more negative (lower moisture content) near the tunnel surface and greater (higher moisture content) beyond the zone influenced by ventilation. From surface to depth, water-potential values were:

- Tiva Canyon -27.0 bars to -3.5 bars (ventilation effects),

- Paintbrush

nonwelded -1.7 bars to -0.1 bars, and

- Topopah Spring -1.4 bars to -0.6 bars.

The combined evidence of high moisture values at the Tpbt $2 / \operatorname{Tptrv} 3$ contact $(-0.1$ and -0.3 bars), along with the $10^{\circ}$ east dip of the beds, indicates a high potential for lateral water flow in the PTn (DTN: GS021008312242.003 [DIRS 162178]; LeCain et al. 2002 [DIRS 158511]). The PTn lateral flow has been evaluated in UZ Flow Models and Submodels (BSC 2004 [DIRS 169861]). 


\subsection{Observation of Moisture Conditions in Ventilated ECRB Cross-Drift}

The drift conditions at the ECRB Cross-Drift in 1998 were similar to the conditions of the ESF main drift in 1996. High-humidity conditions existed in the just-excavated sections. Relative humidity data from three moisture stations in the ECRB Cross-Drift are illustrated in Figures 6-103 and 6-104 for the month of November 1998, which was the month that immediately followed the completion of the ECRB excavation. The moisture sensor assembly at ECRB Cross-Drift Construction Station CD 25+55 (2555 m from the ECRB Cross-Drift entrance) is located near the Solitario Canyon fault on the western boundary of the repository block. The other two stations, at CD 14+43 and CD 21+40, measured the moisture conditions in the middle part of the ECRB Cross-Drift within the repository block.

Figures 6-103 and 6-104 illustrate the temporal fluctuations and the spatial distributions of moisture conditions along the ECRB Cross-Drift. The data were collected every 15 minutes. CD 25+55 was much more humid than the other two stations under the control of the same ventilation system. The day shifts had more activities than did either of the other two shifts. During the week of the Thanksgiving holiday (November 26, 1998), there were increases in moisture conditions that might be correlated with ventilation shutdown. The monthly averaged relative-humidity values are $15 \pm 3$ percent for $\mathrm{CD} 14+43,18 \pm 4$ percent for $\mathrm{CD} 21+40$, and $28 \pm 5$ percent for CD $25+55$.

The spatial variations illustrated in Figure 6-104 are based on weekly averaging over the day shifts. The differences in relative humidity are more clearly shown with the spatial distribution plot; the magnitude varied from week to week, and the spatial gradients were relatively constant. Average gradients for the two sections were 3.4 percent per kilometer between CD $14+35$ and CD 21+40, and 25.2 percent per kilometer between CD 21+40 and CD 25+55. The section near the end of the tunnel apparently had more moisture removed than the section near the entrance.

The temporal and spatial distributions in Figure 6-103 and Figure 6-104 are presented to illustrate the characteristics of the moisture evolution in a newly excavated tunnel. Moisture gradients, together with the ventilation rates, are needed to calculate the moisture removal rates. The ECRB Cross-Drift is a simple tunnel system compared to the ESF main drift. In November 1998 (i.e., before Alcove 8 and Niche 5 (Niche CD 1620) were excavated), only one ventilation line operated along the ECRB Cross-Drift, without any secondary branches separating the airflows into side alcoves and niches. 


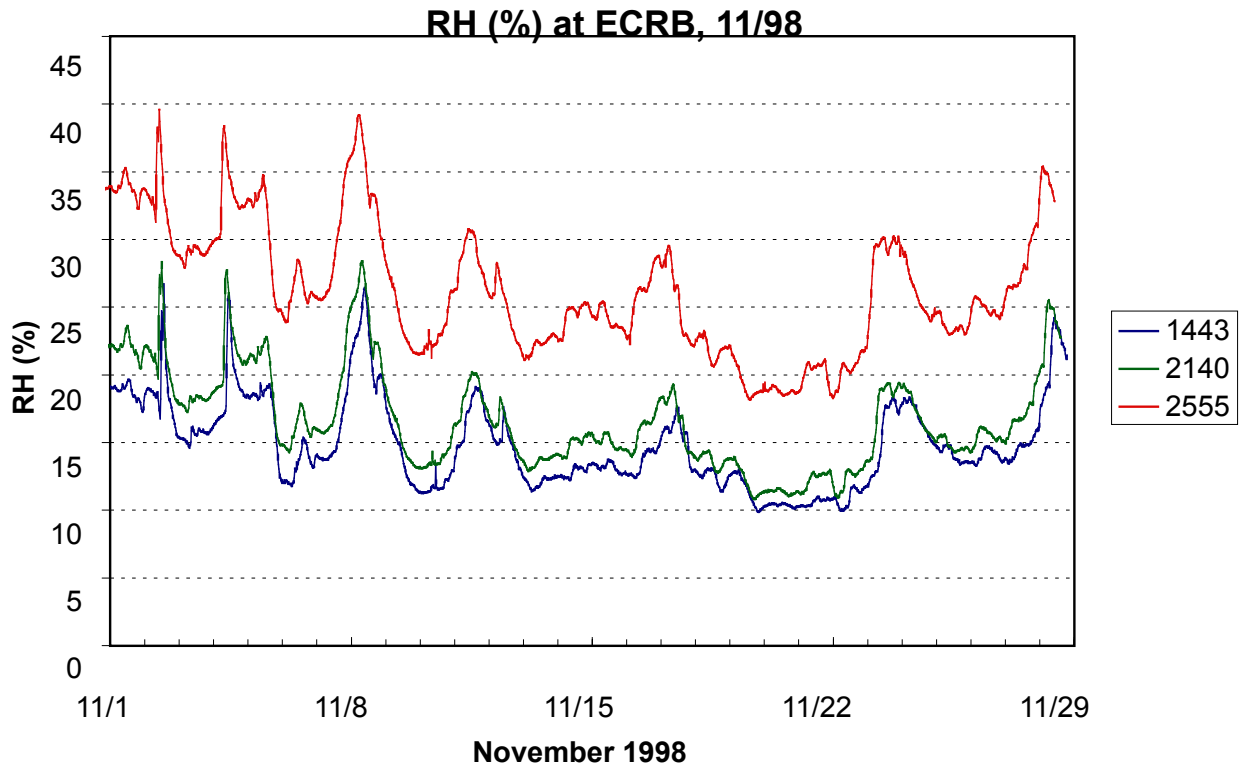

Source: DTN: LB990901233124.006 [DIRS 135137].

NOTE: The data were collected in November 1998 after completion of ECRB excavation. The legends are the distances, in meters, from the respective moisture station to the ECRB Cross-Drift entrance.

Figure 6-103. Relative Humidity Temporal Variations in the ECRB Cross-Drift

\section{RH (\%) Along Cross Drift, Weekly (Day-Shift) Average, 11/98}

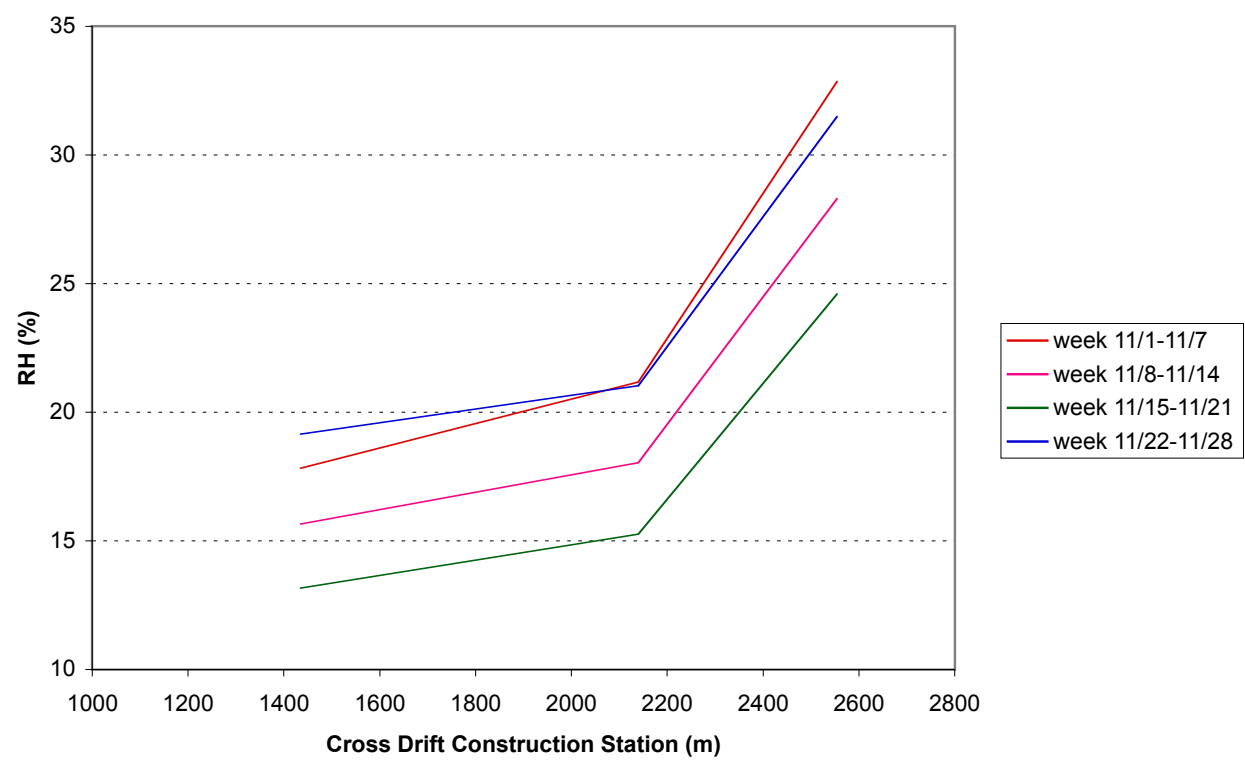

Source: DTN: LB990901233124.006 [DIRS 135137].

NOTE: The weekly averages of day-shift data are presented for November 1998 (the first month after completion of ECRB excavation).

Figure 6-104. Relative Humidity Spatial Variations along the ECRB Cross-Drift 


\subsubsection{Construction Water Migration below Invert from Excavation}

Construction water used in the excavation of the ESF contained lithium bromide as a tracer. The presence of the tracer (measured as a bromide to chloride ratio, $\mathrm{Br} / \mathrm{Cl}$, leached out of crushed borehole samples) is illustrated in Figure 6-105 along three construction-water boreholes (CWAT boreholes) boreholes drilled in the ESF. The deepest tracer penetration was at Borehole CWAT\#2, in which construction water had reached the bottom of the borehole $(30 \mathrm{~m})$. Borehole CWAT\#2 is located in an intensely fractured zone of the middle nonlithophysal zone of the TSw (Tptpmn). In Borehole CWAT\#1 (also located in the Tptpmn), the construction water was detected in all samples to a depth of $2.4 \mathrm{~m}$, with two isolated peaks at greater depths. In CWAT\#3, located in the upper lithophysal zone (Tptpul), the construction water was detected only in the top two meters. Figure 6-105 illustrates the areal distributions of three tuff units in the repository horizon: the middle nonlithophysal zone (Tptpmn), the lower lithophysal zone (Tptpll), and the lower nonlithophysal zone (Tptpln), along with $\mathrm{Br} / \mathrm{Cl}$ profiles indicating the minimum penetration depth of the construction water. The variations in both the hydrologic properties of different tuff units, and in the construction usage rates, could have affected the construction-water penetrations.

\subsubsection{Observation along the Nonventilated Sections of the ECRB Cross-Drift}

The moisture monitoring study conducted in the ECRB Cross-Drift is designed to detect drips in sealed drift sections. To observe potential seepage, ventilation effects to the terminal section of the ECRB Cross-Drift were minimized by means of a series of four bulkheads (Figure 6-106). These nonventilated sections include the area below the Solitario Canyon wall, and intercept the Solitario Canyon fault. The specific test plan for this study is Moisture Monitoring in the ECRB Bulkhead Cross-Drift (BSC 2001 [DIRS 158187]).

The first two bulkhead doors were emplaced at Station CD 17+63 and Station CD 25+03 in June of 1999. A third bulkhead door was emplaced at Station CD 25+99 in July of 2000, and a fourth bulkhead was emplaced at Station CD 22+01 in November of 2001. 


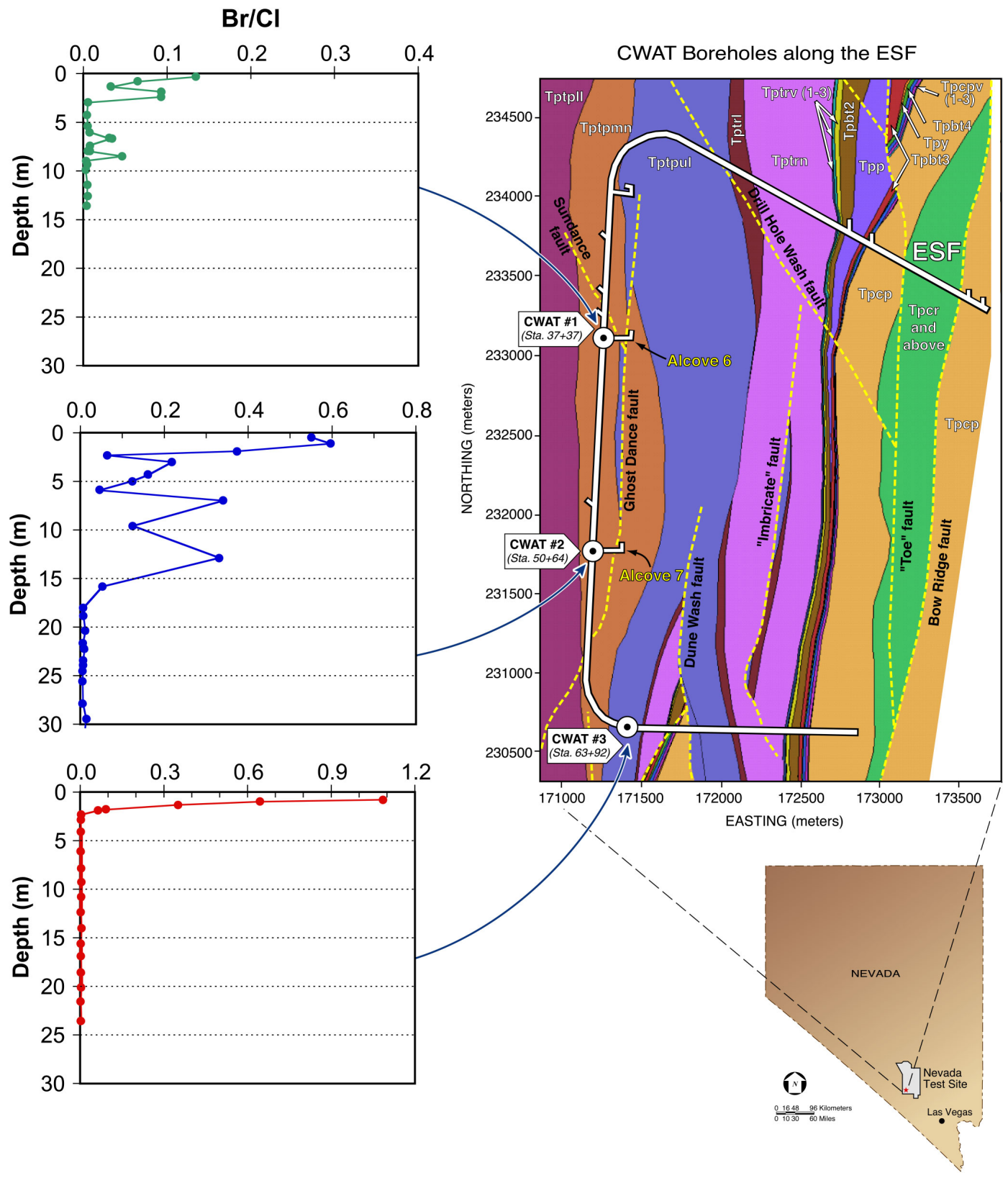

Source: DTN: LAJF831222AQ98.007 [DIRS 122730].

Source: Geological framework model (BSC 2004 [DIRS 170029]).

Figure 6-105. Construction Water Distribution below Exploratory Studies Facility Drift 


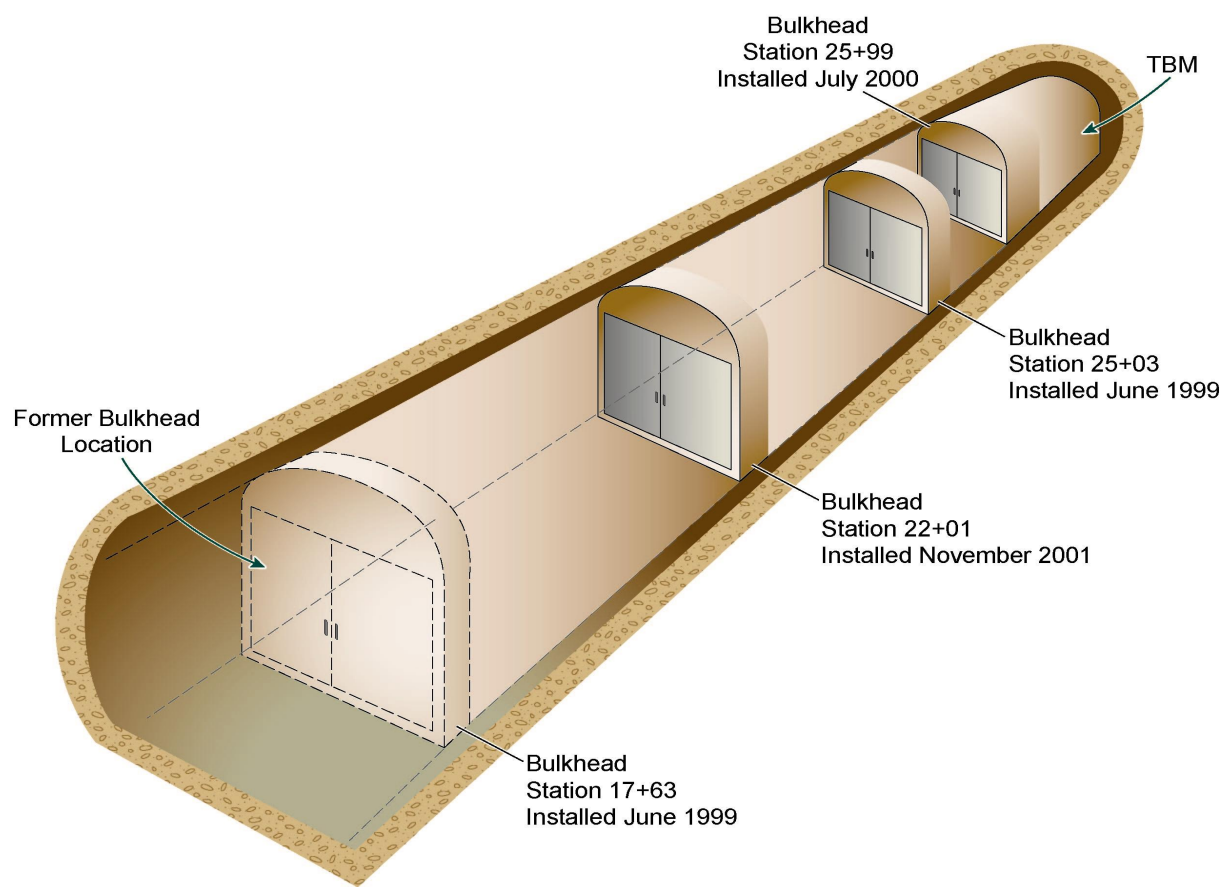

Figure 6-106. Schematic Illustration of Bulkhead Locations in the ECRB Cross-Drift

Along seven boreholes in the ECRB Cross-Drift (shown in Figure 6-107), psychrometer measurements of water potential were made. Within the drift opening, humidity, temperature, wind speed, and barometric pressure are measured at various stations to provide data on moisture dynamics along the ECRB Cross-Drift. During November 2002, Electrical Resistivity Probes (ERPs) were laid out at $0.5-\mathrm{m}$ intervals between Stations CD 24+00 and CD 26+36 to measure saturation changes along the drift wall. Additionally, relative humidity and temperature probes were located at Stations CD 15+02, CD 20+40, CD 21+40, CD 21+90, CD 22+50, CD 23+45, CD 24+40, CD 25+10, CD 25+36, CD 25+52, CD 25+90, CD 26+00, CD 26+30, and CD 26+60. Six water-collection units were also installed between Station CD 24+85 and Station CD 24+95. Figure 6-107 shows the location of moisture monitoring stations along sections of the ECRB.

Additional data on moisture conditions within the nonventilated zone has been gleaned during periods when the bulkhead doors were opened, including the following pre-2003 periods:

1. January 12 to January 13,2000 ;

2. May, June, and July 2000 (to install the third bulkhead),

3. January 22 to January 25, 2001,

4. May 22, 2001 (to repair electrical power),

5. October 1 to December 20, 2001, and

6. June 24 to June $27,2002$. 


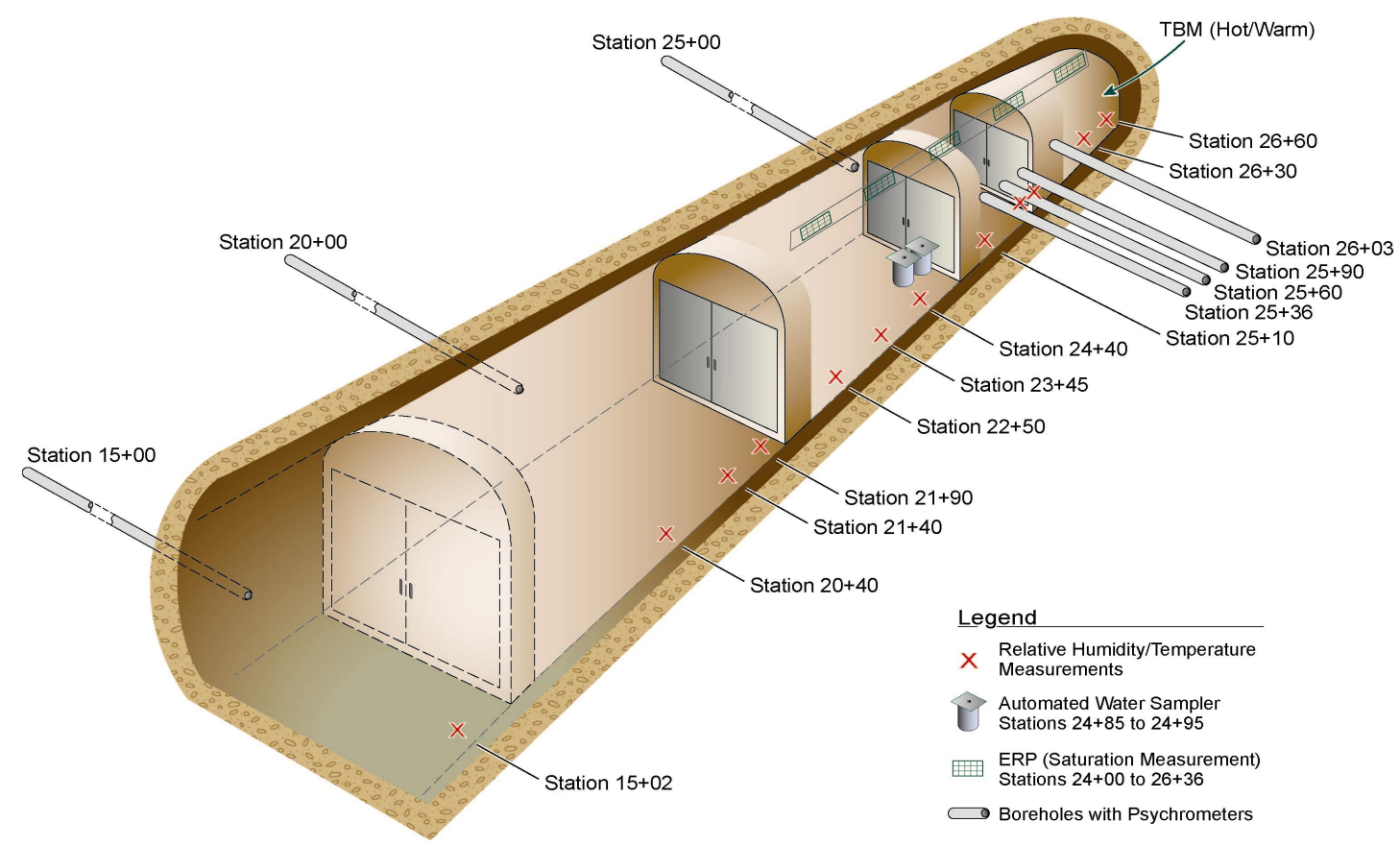

Figure 6-107. Schematic Illustration Showing Berkeley Lab Monitoring Station in Locations in the ECRB Cross-Drift

During most of the entries, the entire ECRB was accessible for visual inspection. The June 2002 entry was restricted to the area between the bulkhead at CD 17+63 and the bulkhead at CD 22+01. During each of these entries, observations of wet spots were documented and, when feasible, water samples were manually collected from small pools of water.

Figure 6-108 provides a geological cross section at the terminal end of the ECRB Cross-Drift; it shows the locations of the last two bulkheads and the TBM. These sections have higher potential for seepage because of higher surface net-infiltration rates and higher percolation flux distributions in the repository level. The region of high percolation flux is expected to coincide with areas with no overlying nonwelded tuff. The section between Station CD 25+03 and Station CD 26+01 also intersects the Solitario Canyon fault at CD 25+84. The section behind the bulkhead at CD 25+99 contains the TBM used for ECRB Cross-Drift excavation. This is noteworthy because the electrical power supplied to the TBM causes the TBM to be a heat source. Table 6-27 provides information pertaining to rock unit contacts intersected by the tunnel sections behind the bulkheads.

Section 6.10.2.1 summarizes the water potential and moisture monitoring data. Section 6.10.2.2 presents the observations made during periodic entries to the areas behind the bulkheads, to observe wet zones. Section 6.10.3 presents data from water samples collected during entries into the sealed drift sections. 


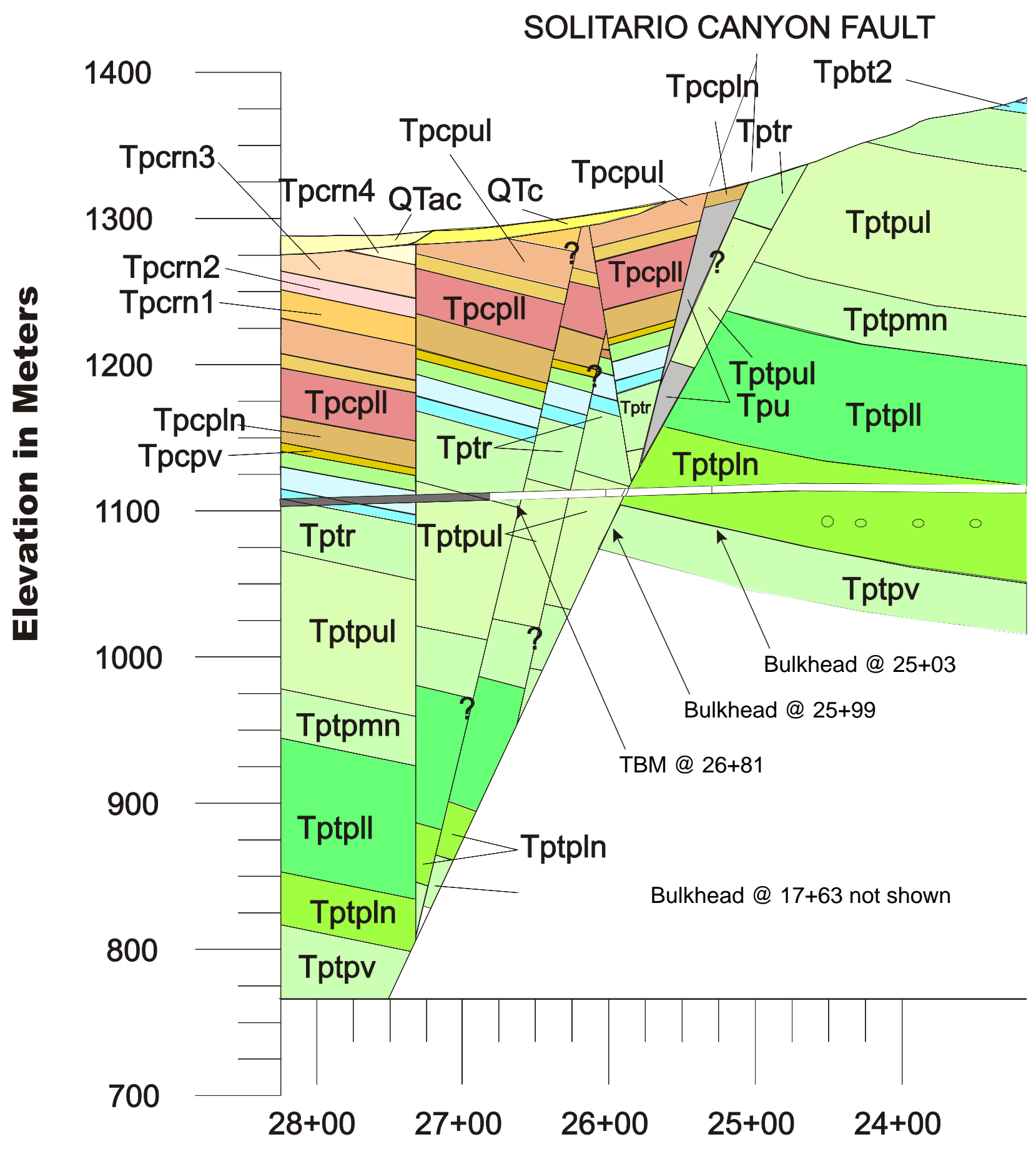

Source: DTN: GS990908314224.010 [DIRS 152631].

NOTE: Bulkheads at 17+63 and 22+01 are not shown. The question marks indicate uncertain fault geometry.

Figure 6-108. As-Built Cross Section of the Terminal End of the ECRB Cross-Drift $(23+00 \mathrm{~m}$ to $26+81 \mathrm{~m}$ ) Showing the Bulkhead Locations 
Table 6-27. Rock Unit Contacts Intersected by the Bulkhead Sections (All within the Topopah Spring Tuff)

\begin{tabular}{|c|l|}
\hline Station & \multicolumn{1}{|c|}{ Mapped Contact } \\
\hline $23+26$ & Tptpll / Tptpln (Topopah Spring Tuff lower lithophysal / lower nonlithophysal Contact) \\
\hline $25+84$ & $\begin{array}{l}\text { Tptpln / Tptpul (Topopah Spring Tuff lower nonlithophysal / upper lithophysal Solitario Canyon Fault } \\
\text { Zone) }\end{array}$ \\
\hline $26+64$ & $\begin{array}{l}\text { Tptpul / Tptr (Topopah Spring Tuff upper lithophysal / crystal rich lithophysal Solitario Canyon Fault } \\
\text { Zone) }\end{array}$ \\
\hline
\end{tabular}

Source: DTN: GS990408314224.006 [DIRS 108409].

\subsubsection{Water-Potential Measurements and Drift Relative Humidity and Temperature Variations}

Past observations have shown that, in an open tunnel in the UZ, the evaporation potential of ventilation is much greater than any expected seepage. Observations from boreholes installed perpendicular to the tunnel wall suggest a clear dryout zone associated with ventilation of the tunnel. General conclusions from current understanding of the UZ suggest that if seepage into drifts were to occur, it would most likely be in the western portion of the repository block, where geological conditions are most conducive to infiltration, percolation, and seepage. The characteristics of this portion of the tunnel that make it most suitable for the detection of seeps are:

- the absence of an overlying PTn past approximately CD 23+50, and

- the relatively high percolation rates, caused by high infiltration from shallow soils and higher elevations at the surface.

The 918-m-long drift section (from the bulkhead at CD 17+63 to the TBM end at CD 26+81) is located in the Topopah Spring lower lithophysal (Tptpll) and the lower nonlithophysal (Tptpln) tuff units, and it includes the Solitario Canyon fault (the western boundary of the primary repository block) (see Figure 6-106).

\subsection{Water-Potential Measurements}

Water-potential measurements along three horizontal boreholes in the ECRB Cross-Drift are summarized in Figure 6-109. These three boreholes are located at CD 15+00, CD 20+00, and $\mathrm{CD} 25+00$, and are $6 \mathrm{~m}$ long. The borehole at CD 15+00 is located before the first bulkhead; the boreholes at CD 20+00 and CD 25+00 are located in bulkheaded sections.

There are three components to the water-potential measurements in the ECRB Cross-Drift:

1. spatial variability within boreholes,

2. spatial variability between boreholes, and

3. the temporal variability within boreholes located between the first and second bulkhead. 
Spatial variability within boreholes begins with low water potentials close to the drift. Water potentials then increase rapidly over a distance of 1 to $2 \mathrm{~m}$, and remain close to saturated values along the deeper profile. Among the three monitored boreholes, the one located at CD 15+00 had its lowest water potential (i.e., driest location) close to the drift wall. Prior to the emplacement of the bulkhead doors, the borehole at CD 20+00 also had lower water potentials, up to a distance of approximately $1.5 \mathrm{~m}$ from the borehole collar, which have increased since the installation of the bulkhead doors. The borehole located furthest into the ECRB Cross-Drift (at CD 25+00) did not show large drops in water potential closer to the collar, and the borehole did not show any increases in water potentials following the installation of the bulkhead doors.
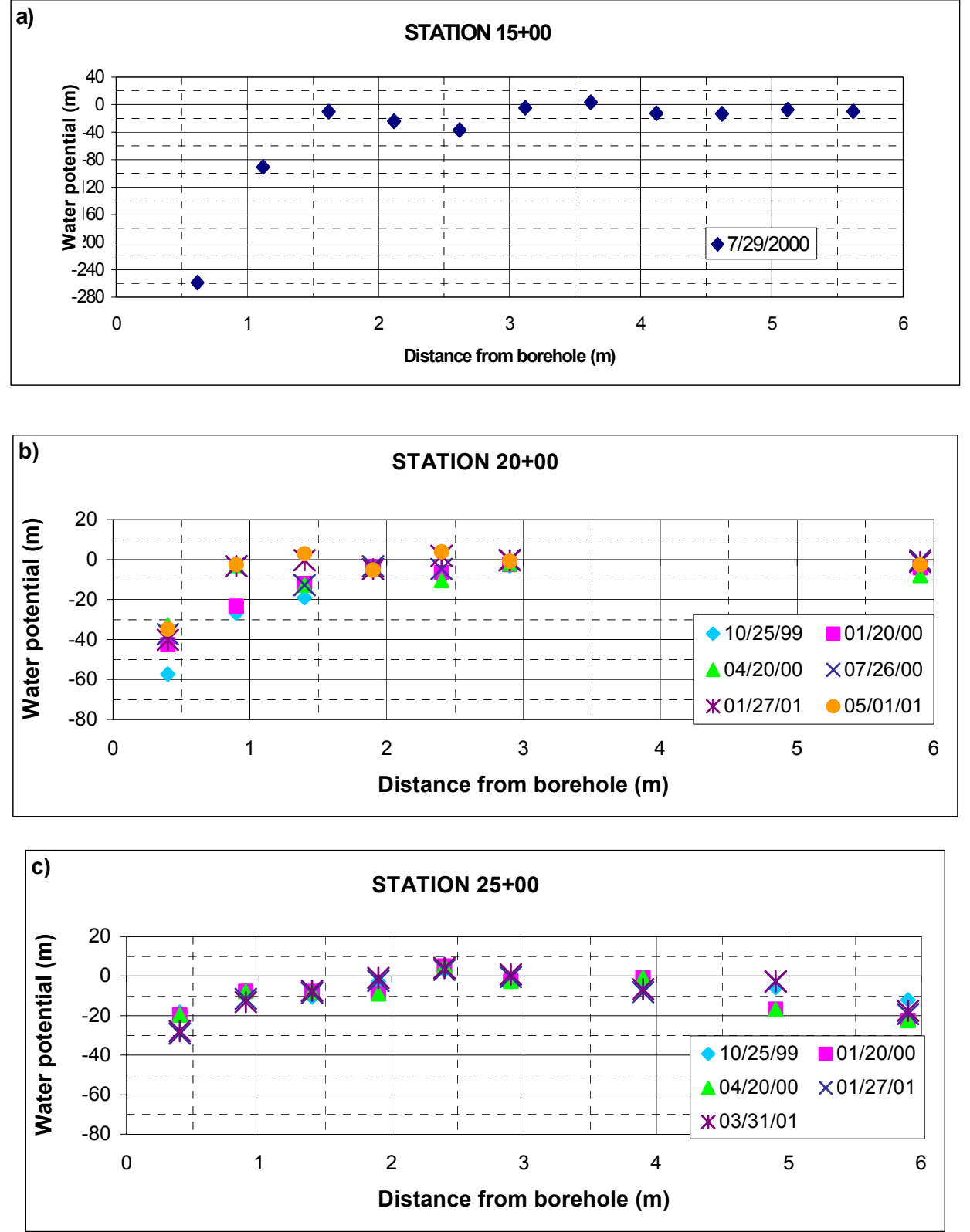

Source: DTN: LB0110ECRBH2OP.001 [DIRS 156883].

NOTES: $(a)=$ Station $15+00 ;(b)=$ Station 20+00; $(c)=$ Station $25+00$.

Figure 6-109. Water-Potential Measurements along the ECRB Cross-Drift 


\subsection{Barometric Pressure Variations}

Barometric pressure measured in the ECRB Cross-Drift did not show any spatial variability, but had a pronounced change over time (Figure 6-110). The range of the temporal variability was between approximately 870 and approximately 905 millibars (mbars). From May to September 2000, the barometric pressure along the ECRB Cross-Drift was restricted between approximately 880 and approximately 895 mbars. Larger fluctuations in the barometric pressure were observed between October 2000 and May 2001.

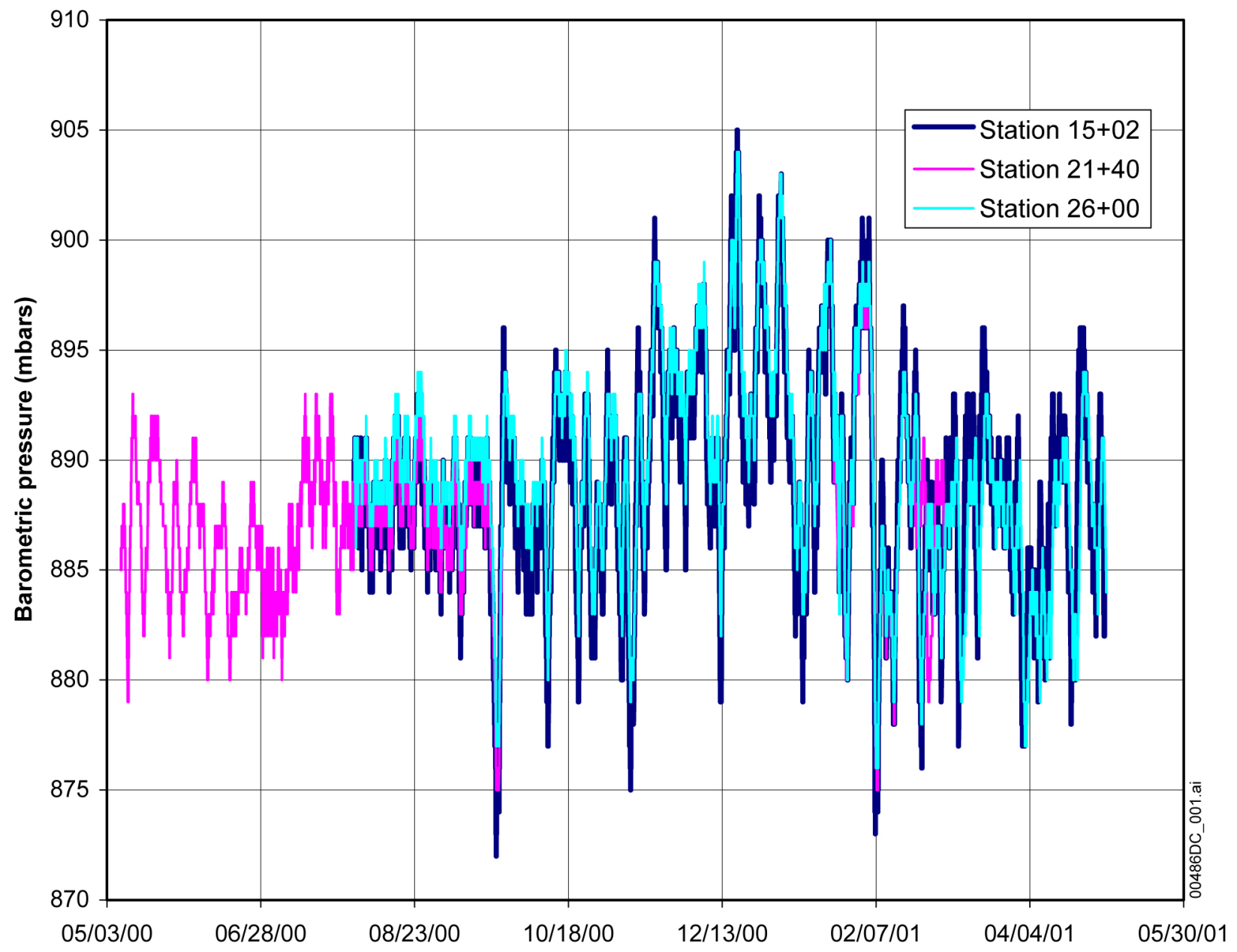

Source: DTN: LB0307ECRBRHTB.001 [DIRS 164843].

Figure 6-110. Barometric Pressure Measured along the ECRB Cross-Drift 


\subsection{Temperature Variations between May 2000 and May 2001}

Temperature measurements along the ECRB Cross-Drift, made over a period of nine months starting in early August 2000, show a clear temperature gradient extending through the section of the ECRB Cross-Drift located behind the bulkhead doors (Figure 6-111).

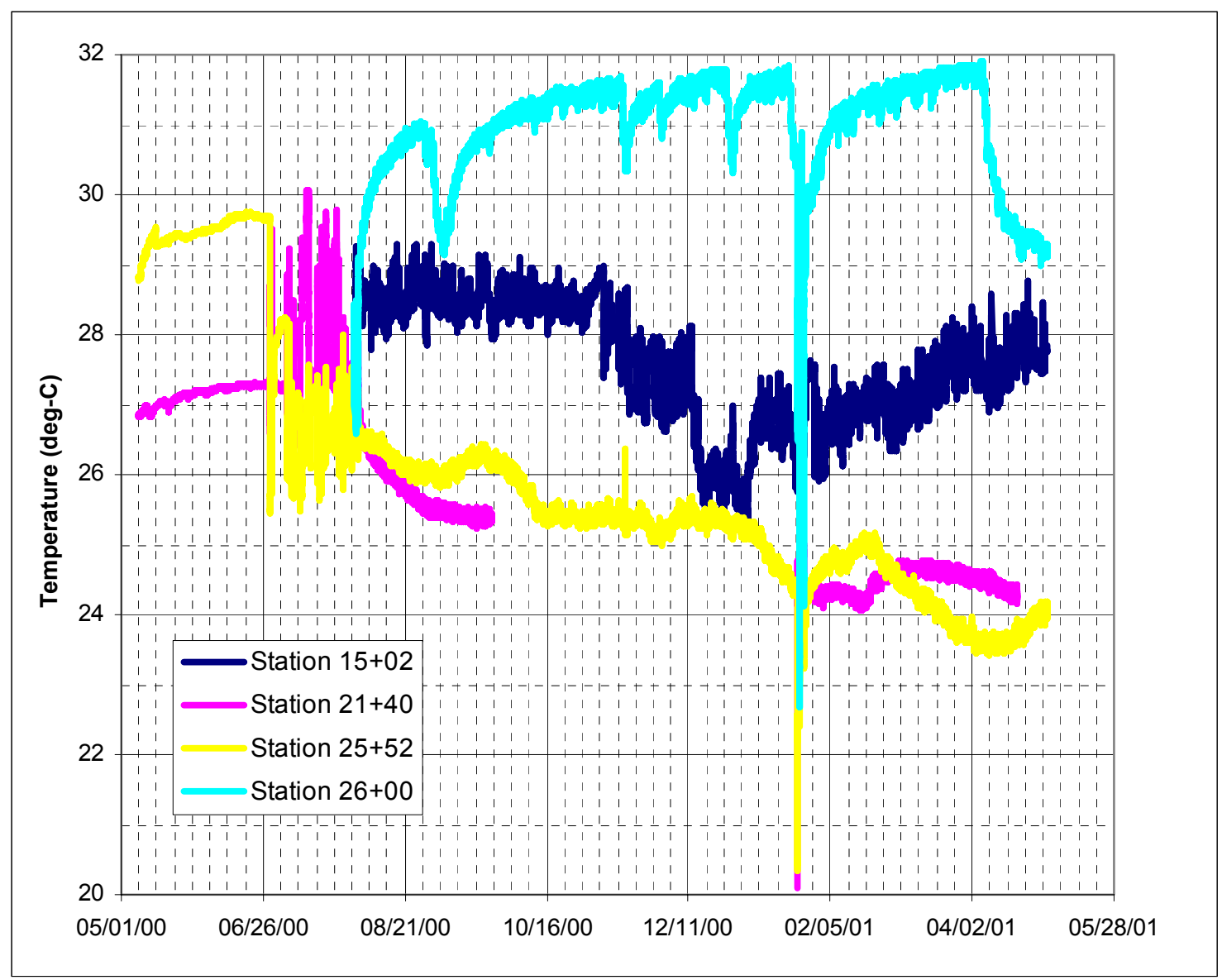

Source: DTN: LB0307ECRBRHTB.001 [DIRS 164843].

Figure 6-111. Temperature Measured in the Four ECRB Cross-Drift Stations

The highest temperatures were recorded in the zone behind the last bulkhead, which houses the TBM. In this zone, the temperature fluctuated between $30^{\circ} \mathrm{C}$ and $32^{\circ} \mathrm{C}$ during most of the monitoring periods. However, there were three distinct periods during which the temperature in this zone dropped below $30^{\circ} \mathrm{C}$. The first occurred in early September 2000 , and was most likely caused by power interruptions which, in turn, caused the TBM to cool. The second temperature drop was in late January 2001, when all bulkhead doors were opened. During this brief period, the temperature in the vicinity of the TBM dropped to approximately $22.5^{\circ} \mathrm{C}$. The temperature in this zone again dropped to below $30^{\circ} \mathrm{C}$ in early April 2001, which coincides with the date when the TBM was turned off. 
In the zone between the third and fourth bulkheads, the temperature tended to continuously drop from approximately $26.5^{\circ} \mathrm{C}$ to approximately $24^{\circ} \mathrm{C}$ between August 2000 and May 2001. Significant deviations from this trend were observed in early September 2000, when the temperature increased briefly. These deviations coincide with the temperature decreases in the zone that housed the TBM. Because similar observations were not recorded outside the first bulkhead, it is likely that this perturbation occurred when the fourth bulkhead door was left open for a few days.

The temperature data collected between the first and second bulkhead shows the region steadily cooling immediately after the closure of the bulkhead doors in July 2000. (Because of the lack of temperature data from this region between late September 2000 and February 2001, temperature dynamics in this region cannot be compared with the other two zones during this time.) Following the closure of the bulkhead doors in late January 2001, the temperature between the first and second bulkhead immediately reached approximately $24^{\circ} \mathrm{C}$, and remained close to that value during the following two months.

Temperatures in the ECRB Cross-Drift measured immediately outside the first bulkhead showed diurnal and seasonal fluctuations. Diurnal fluctuations appeared to be restricted to a range of three degrees (Celsius); seasonal temperature changes varied from approximately $29^{\circ} \mathrm{C}$ in late August 2000 , to approximately $25^{\circ} \mathrm{C}$ in late December 2000 .

In summary, measurements suggest that, thermally, the zones defined by the bulkhead in the ECRB Cross-Drift were partially isolated from each other, and from the region outside the bulkhead, but that the partial thermal isolation occurs only when the doors were closed. The zone housing the TBM was warmer than the region outside the first bulkhead; the other two zones were consistently cooler when the doors were closed. During the periods when the bulkhead doors were left open, the temperature in each of the zones rapidly approached that of the zone outside the bulkheads.

\subsection{Relative Humidity Variations between May 2000 and May 2001}

The relative humidity in the three zones defined by the bulkheads shows spatial variability similar to that found in the temperature data (Figure 6-112). The lowest humidity was observed in the area before the first bulkhead, where it fluctuated between approximately 10 and 40 percent, with a few instances where the humidity was greater than 60 percent. In the two zones monitored behind the bulkheads, the relative humidity remained close to approximately 95 percent, with some changes observed in March 2001, when the humidity in the third zone gradually fell closer to approximately 90 percent. 


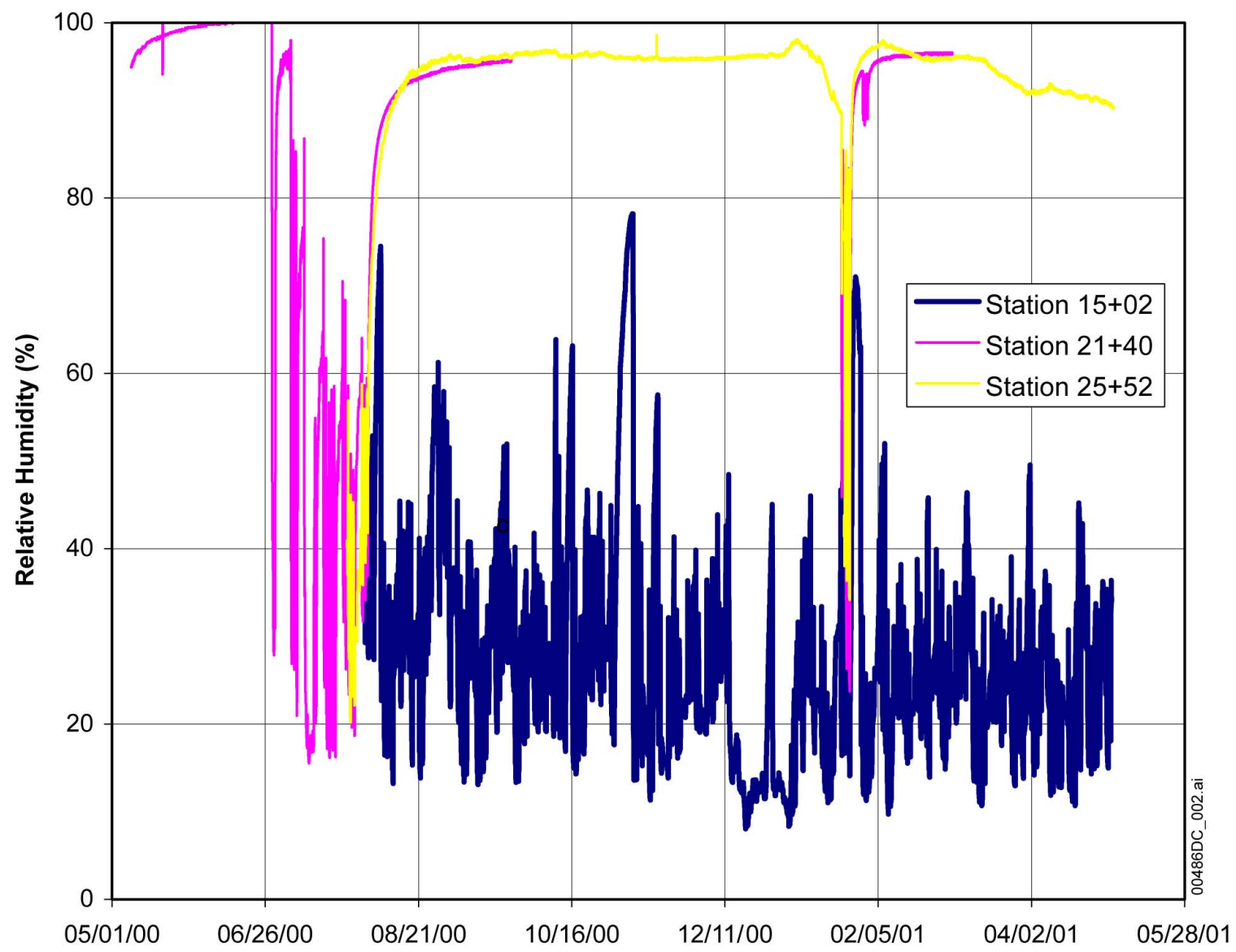

Source: DTN: LB0307ECRBRHTB.001 [DIRS 164843].

Figure 6-112. Relative Humidity Measured in the ECRB Cross-Drift Stations

\subsubsection{Observations of Wet Zones During Bulkhead Entries}

Additional data on the moisture conditions within the nonventilated zone has been collected during periods when the bulkhead doors were opened. During periodic entries for visual inspection, wet spots were observed and water samples were manually collected. Observations made in the nonventilated sections include the existence of liquid water, as well as rust spots and organic growths (i.e., indicators of the prolonged presence of water). Although the presence of liquid water is evident, no continuous seepage from the rock into the closed sections of the ECRB Cross-Drift was observed. Figure 6-113 summarizes the times and locations of liquid-water observations (during bulkhead entries), with details described in the following Sections 6.10.2.2.1 through 6.10.2.2.3. Photographic evidence of the October 1 to 2, 2001, entry into the closed-off regions (DTN: LB0301ECRBRHTB.001 [DIRS 164605]) is presented in Section 6.10.2.2.2, representing similar observations during other entries (see DTN: GS030608312231.002 [DIRS 165547] for additional images of the ECRB moisture monitoring entries between January 22, 2002, and February 3, 2003). 


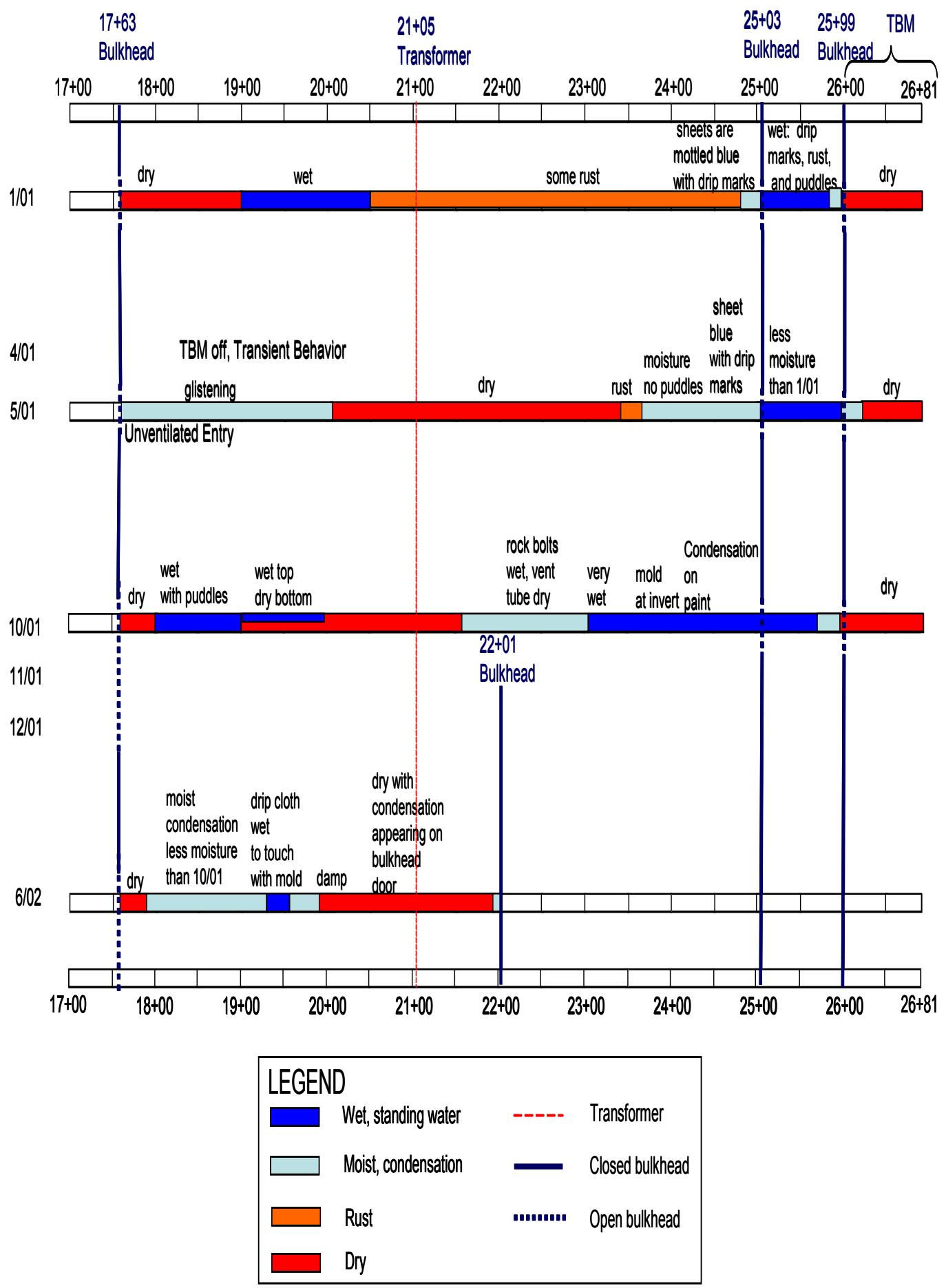

Sources: Entry 1/23/01 to 1/25/01: Hudson (2002 [DIRS 165391], pp. 23-24, 91-98);

Entry 5/22/01:

Hudson (2002 [DIRS 165391], pp. 38-39, 140-150);

Entry 10/1/01 to 12/20/01: Hudson (2002 [DIRS 165391], pp. 218-301); Hudson (2002 [DIRS 163398], pp. 1-47);

Entry 6/24/02 to 6/27/02: Hudson (2002 [DIRS 163398], pp. 143-147).

NOTE: TBM = tunnel boring machine.

Figure 6-113. Distribution of Wet Zones during ECRB Bulkhead Entries 


\subsection{Comparison of Observations During Nonventilated Entries: January 22-25, 2001 and May 22, 2001}

During the January 22 to 25 (2001) entry, distinctly wet zones were observed, as shown in Figure 6-113. The power to the ECRB was interrupted in April 2001. To avoid loss of data, an unventilated entry behind the bulkheads occurred on May 22, 2001, to restore power to the dataloggers and to the TBM. The first bulkhead at CD 17+63 was opened at 11:10 am on May 22, 2001. No ventilation was established, and entry was permitted at 11:20 am. This entry was restricted to the same day, with bulkheads closed after the entry.

Less moisture was observed during the May 22, 2001, entry than had been observed during the January 22 to 25,2001 , entry. The moisture had not accumulated into puddles. The canvas drip detection sheet at CD 24+10, and the observed rust spots at CD 23+50, indicated that liquid moisture had been present at least that far into the tunnel. The continued power loss to the TBM resulted in a decreased temperature gradient within the tunnel. Moisture behind the third bulkhead, and the smaller amount of moisture between the second and third bulkhead, indicated that as the temperature gradient decreased, observable moisture tended to move toward the TBM.

The presence of water was initially observed (as "glistening") on the utility and vent lines in the first $250 \mathrm{~m}$. The water appeared to be present only on the surface and, within two hours, the water had evaporated. At CD 21+00, all exposed surfaces appeared to be dry. Moisture was again detected on the utility and vent lines at approximately CD 23+50. Rust spots were observed on the steel channels and on the tracks. Moisture was observed at approximately 1-m intervals on the conveyor belt, although water had not accumulated into puddles. A canvas sheet hung at CD 24+10 on January 25, 2001, was mottled blue, and drip marks covered the entire sheet. The sheets between CD 24+75 and CD 24+95 were moist, and moisture also appeared on the utility and vent lines, and on the bulkhead at CD 25+03, opened on May 22 at 12:06 pm. Canvas sheets between the CD 25+03 and the CD 25+99 bulkheads were moist, but there was much less puddled water than was found during the January 22 to 25, 2001, entry. Moisture was evident on the canvas sheets, conveyor belt, and metal surfaces. The bulkhead at CD 25+99 was opened on May 22 at 12:17 pm. Moisture was observed on utility lines and instrument cables to approximately $10 \mathrm{~m}$ behind the bulkhead. Beyond $10 \mathrm{~m}$ behind the bulkhead at CD 25+99, all exposed surfaces appeared to be dry.

\subsection{Observations of Entry Made on October 1-2, 2001}

An entry occurred on October 1, 2001, and a follow-up entry occurred on October 2, 2001. On the first day, October 1, $2001(12: 03 \mathrm{pm}$ to 1:37 pm), conditions were observed to alternate between dry and wet in four sections lying between the first and second bulkhead. On the next day (October 2, 2001), most water droplets had evaporated (note that the bulkhead was open overnight). Some of the rock and especially the traces of the in-filled fractures remained damp (see DTN: LB0301ECRBRHTB.001 [DIRS 164605] for photos of this entry).

In the wet sections observed on October 1, 2001, the dampness was more pronounced on the upper part of the drift walls. The fault between the CD 25+03 and CD 25+99 bulkhead was dry. The last section behind the CD 25+99 bulkhead was dry, with no rust observed (implying that the section was not wet during the closure period). By the next day (October 2, 2001), most 
water droplets had evaporated, although some rock remained damp. A patch of paint was observed to have water droplets on its surface, and no similar beads were observed on the surrounding rock surfaces (Figure 6-114). Because the paint is essentially impermeable, so the observed beads were likely the result of condensation, not the result of seepage through the rocks below the painted patch. The paint observation substantiated the hypothesis that the observed water was condensation that occurred as a result of local temperature variations. This hypothesis is based on observations made during previous bulkhead entries, and on chemical analyses (see Section 6.10.3) from the limited water samples that were collected.

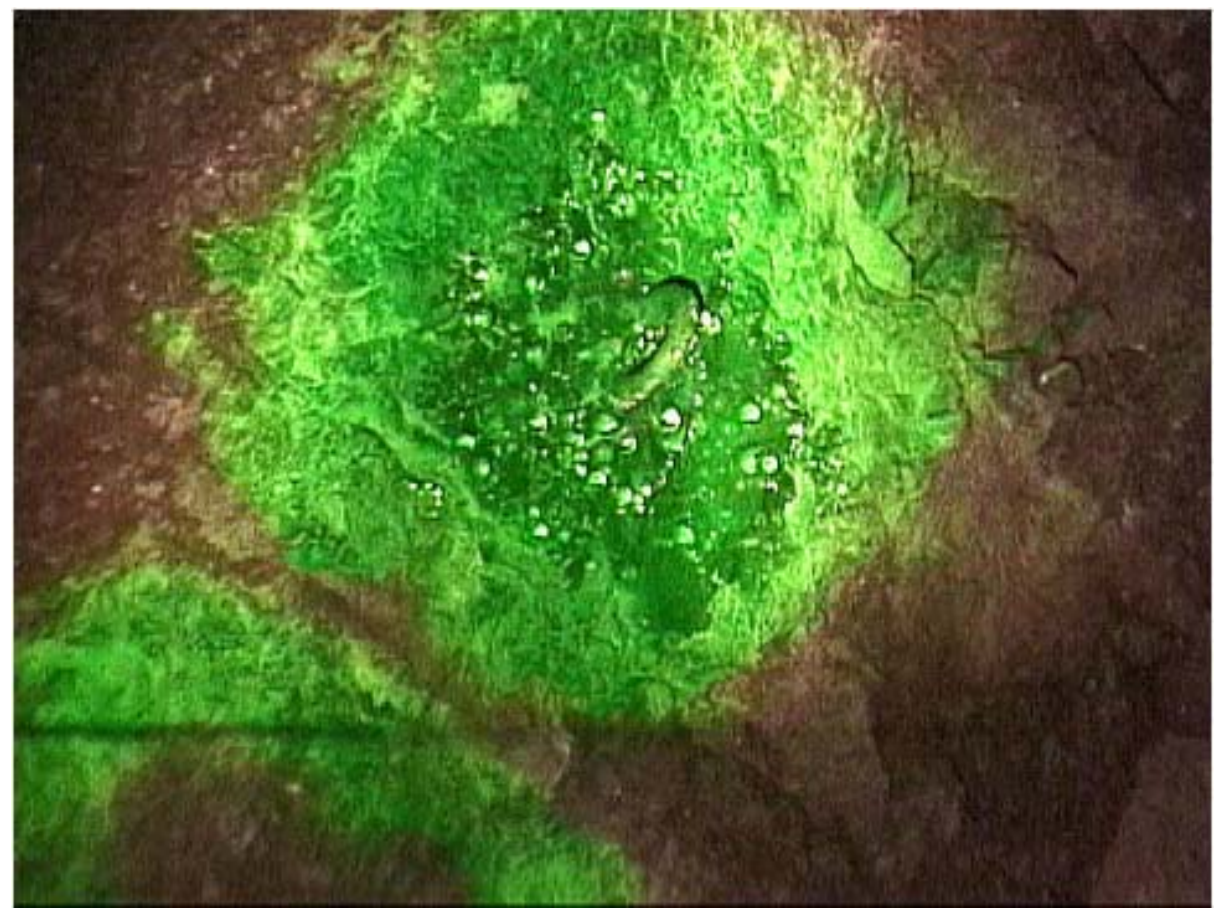

Source: DTN: LB0301ECRBRHTB.001 [DIRS 164605].

NOTES: Photo taken on October 2, 2001.

The green paint on the crown of the ECRB had condensate hanging from it, but surrounding rock surface did not at CD $24+70$.

Figure 6-114. Visibly Different Moisture Levels on Adjoining Rock Surfaces at CD 24+70

\section{Detailed Descriptions of Visual and Photographic Observations}

The bulkhead at CD 17+63 was entered on October 1, 2001, 12:03 pm. Dry features with stalactite-like shapes were observed on the vent tube, just inside of the first bulkhead (Figure 6-115). The deposits were likely a result of a redistribution of vent tube materials from dissolutions associated with early condensations, driven by temperature variations near the bulkhead. The lights in the same area had precipitate on them, but were dry during the observation. The drift was dry from the first bulkhead to approximately CD 18+00. 


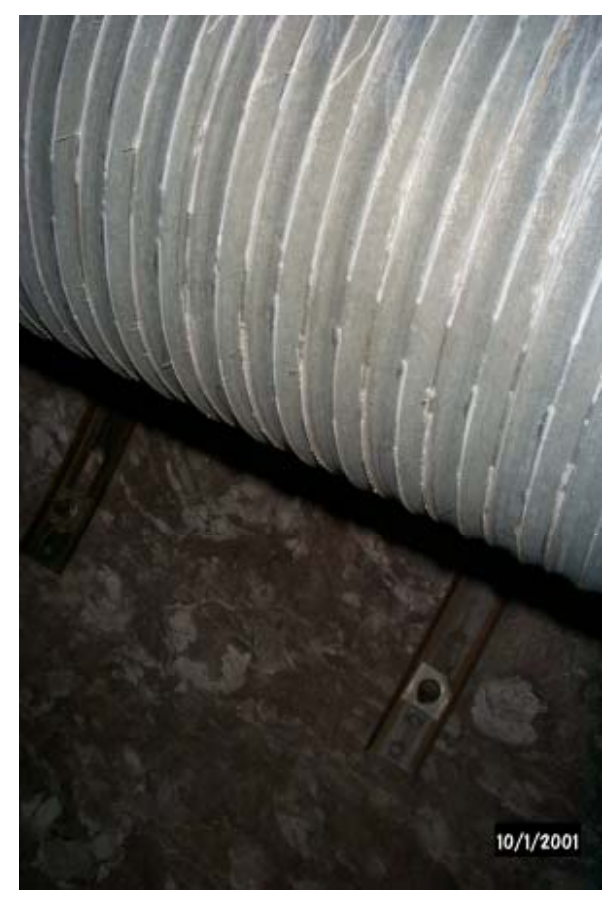

Source: DTN: LB0301ECRBRHTB.001 [DIRS 164605].

NOTE: Photo taken on October 1, 2001, at 11:43.

Figure 6-115. Stalactite-Like Features near First Bulkhead at CD 17+63

The drift was wet from CD $18+00$ to approximately CD 19+00. The first sign of moisture was observed on the left rib at CD 17+90, with condensate drip-marks (from overhead cables) on utilities. The drip-marks on the utilities were dry and the associated surface area was a little bit rusty. The ventline and walls were very wet, puddles were found on the conveyor belt, and condensate was found on the conveyor belt. A large puddle was observed on the conveyor belt at CD 18+25 (Figure 6-116). 


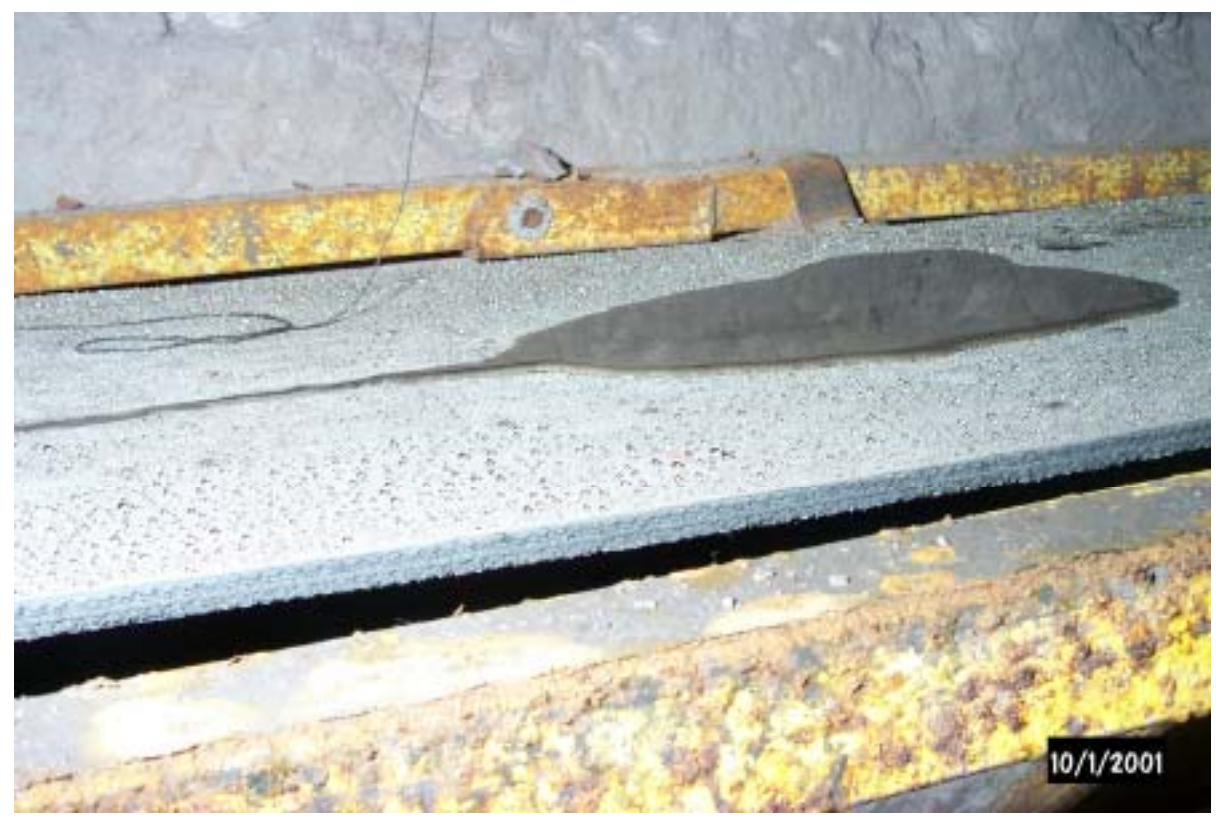

Source: DTN: LB0301ECRBRHTB.001 [DIRS 164605].

NOTE: Photo taken on October 1, 2001, at 12:26 pm.

Figure 6-116. Water Puddle and Condensate on Conveyor at CD 18+25

The wet sections on the conveyor belt had droplets of very clear water (presumed to be condensate), approximately evenly spaced on all rubber surfaces, except where droplets ran together at depressions in the belt, thereby creating puddles on the belt.

In the wet areas, dampness on the rock surface was restricted on the upper half of the drift. On the second day (October 2, 2001), the previously wet outer area was much drier. However, moisture was retained in small, calcite-filled fractures, whereas the matrix was essentially dry (Figure 6-117). The fracture infill occurred more on the upper half of the drift than on the lower half.

The inner wet area was as wet on the second day as it was on the first day, with the exception that the droplets on the conveyor belt had mostly disappeared on the second day. 


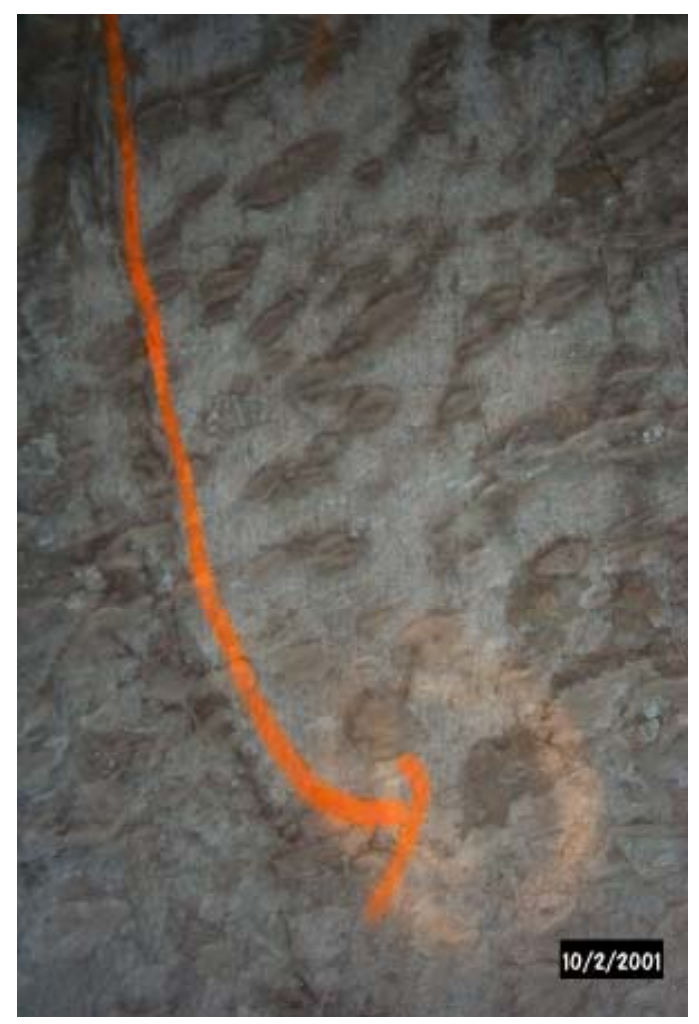

Source: DTN: LB0301ECRBRHTB.001 [DIRS 164605].

NOTE: Photo taken on October 1, 2001, at 2:30 pm.

Figure 6-117. Water Surrounding Inclusions

Condensate was prevalent on the shotcrete beyond the CD 25+03 bulkhead (Figure 6-118) and behind the CD 25+99 bulkhead. The drift was dry again from CD 19+00 to approximately CD 21+50. The walls began to be drier closer to the TBM. The Solitario Canyon fault appeared relatively dry (Figure 6-119). The cloth tarp hanging on the portal side of the CD 25+99 bulkhead showed discoloration (a blue color was evident until approximately $6 \mathrm{~m}$ from the bulkhead), indicating that it was wet at some point. Further toward the portal, there was no discoloration (Figure 6-120). Inside the CD 25+99 bulkhead, the drift was relatively dry (Figure 6-121). 


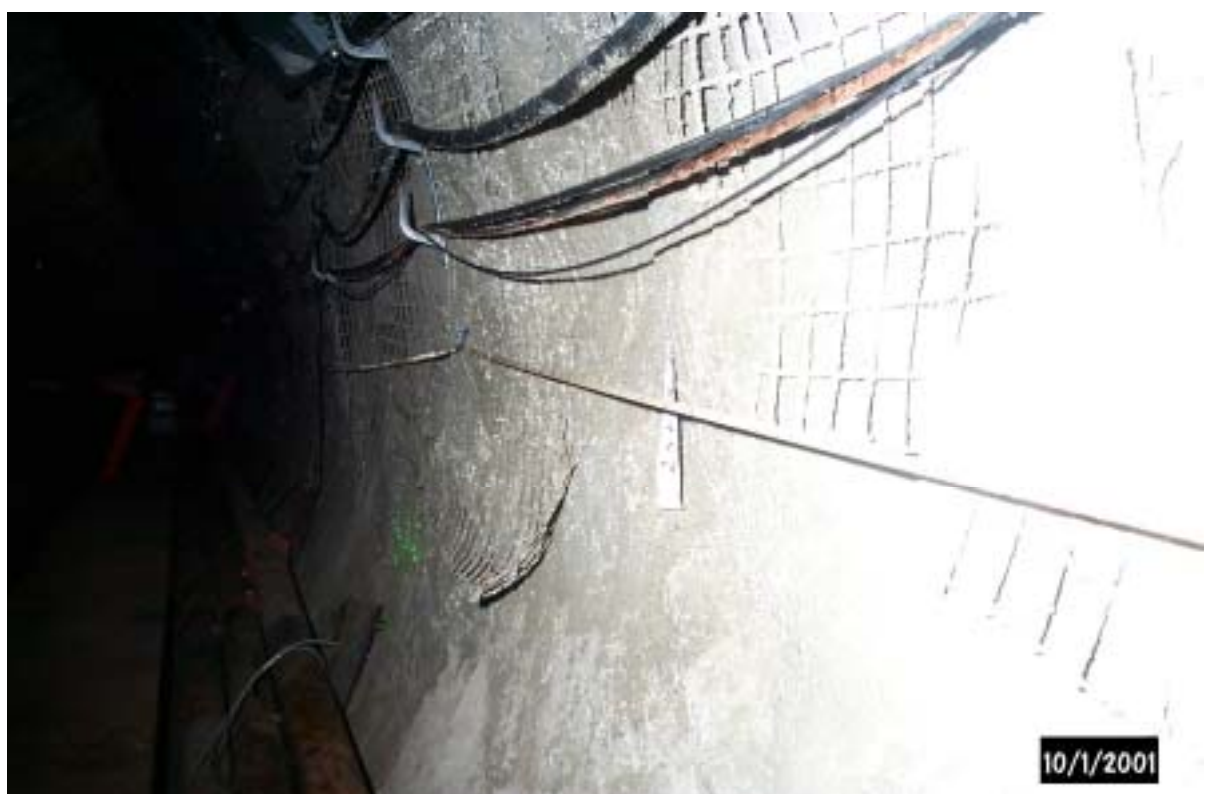

Source: DTN: LB0301ECRBRHTB.001 [DIRS 164605].

NOTE: Photo taken on October 1, 2001, at 1:19 pm.

Figure 6-118. Condensate on Shotcrete after Second Bulkhead

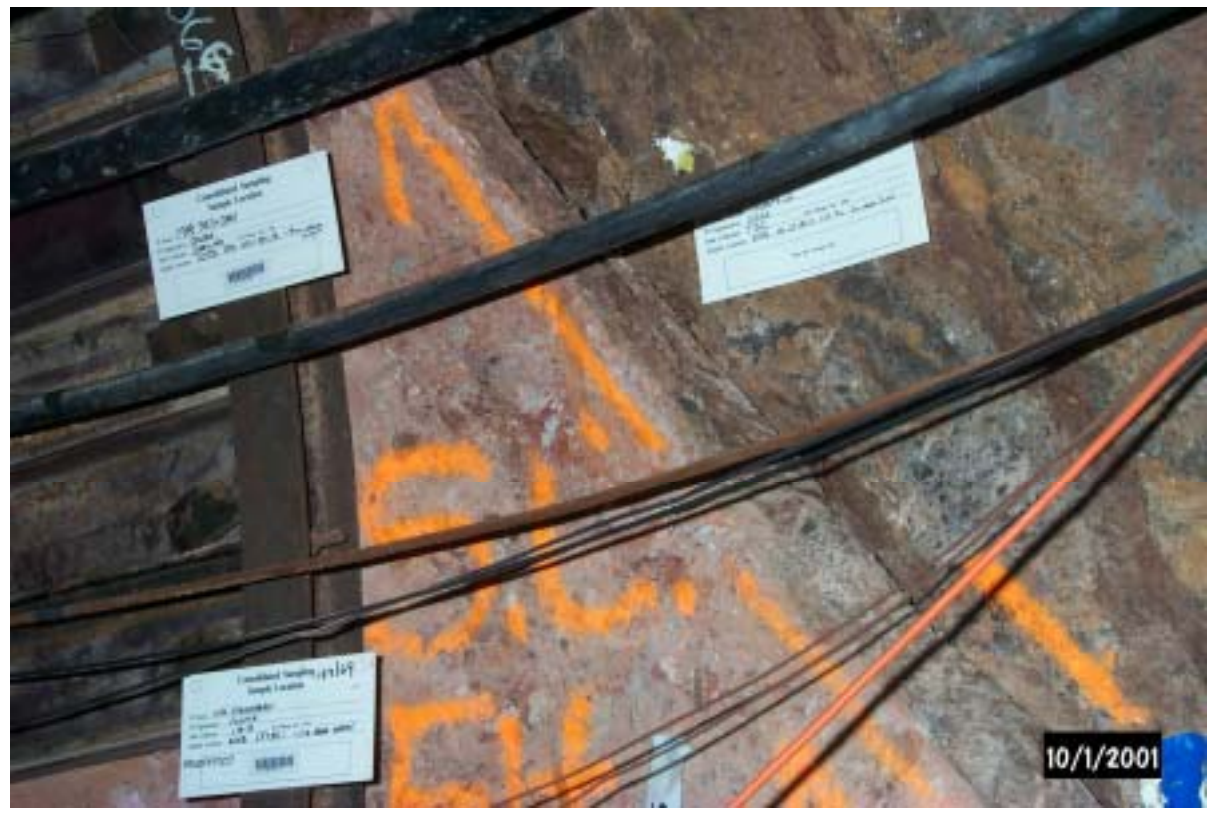

Source: DTN: LB0301ECRBRHTB.001 [DIRS 164605].

NOTE: Photo taken on October 1, 2001, at 1:14 pm.

Figure 6-119. Solitario Canyon Fault Left Rib 


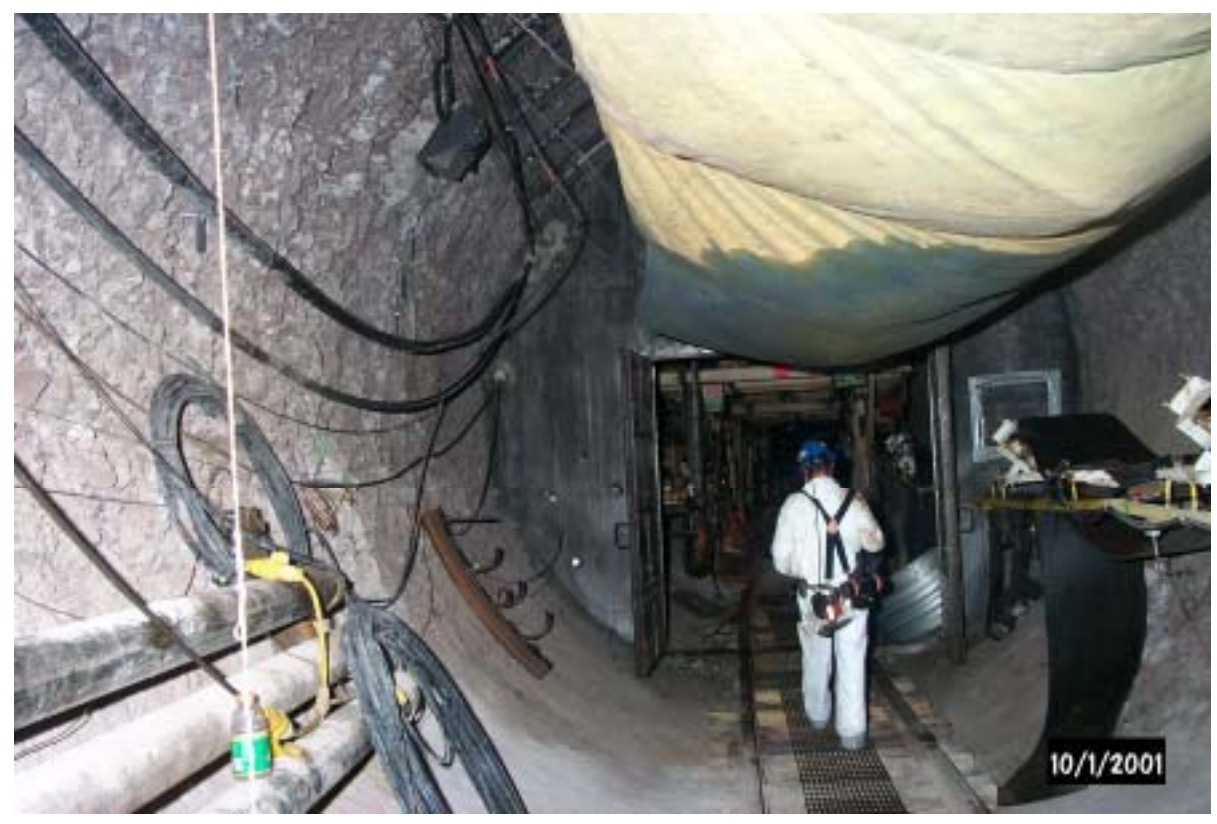

Source: DTN: LB0301ECRBRHTB.001 [DIRS 164605].

NOTE: Photo taken on October 1, 2001, at 1:15 pm.

Figure 6-120. Tarp Discoloration before CD 25+99 Bulkhead

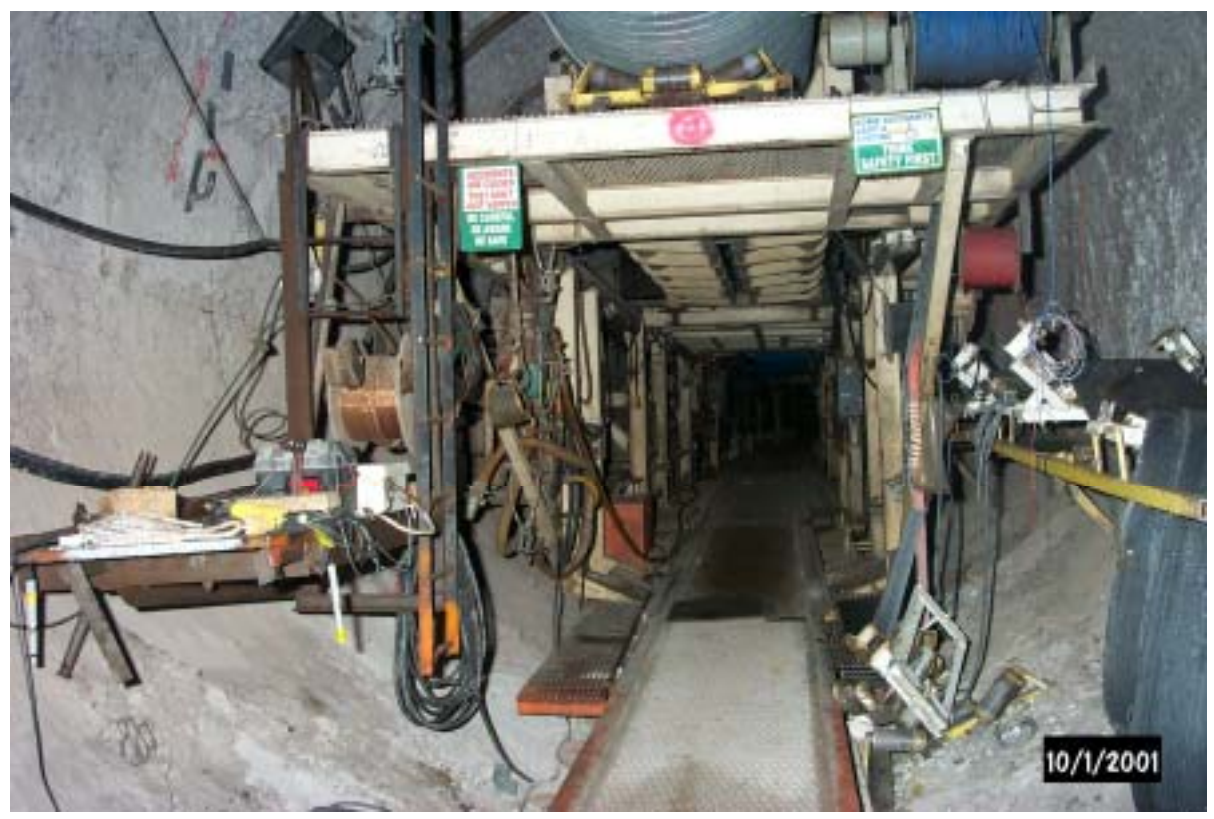

Source: DTN: LB0301ECRBRHTB.001 [DIRS 164605].

NOTE: Photo taken on October 1, 2001, at 1:13 pm.

Figure 6-121. Relatively Dry Section Inside Bulkhead at CD 25+99 (with TBM) 


\subsection{Observations of Entry Made on June 24, 2002}

During the nonventilated entry made on June 24, 2002, access to the ECRB was restricted to the areas between Station CD 17+63 and Station CD 22+01. During this entry, no standing pools of water were observed. However, some evidence of water was present at various locations. For example, at Station CD 19+15, a few brown water spots were visible on plastic sheets that had been placed over the railroad tracks. Similar brown spots were visible on plastic sheets suspended from the ceiling at the same location. Mold was visible along specific sections (e.g., Station CD 19+50) of the railroad tracks, and on some of the canvas tarps suspended from the ceiling (see DTN: LB0301ECRBRHTB.001 [DIRS 164605] for photos of this entry).

At Station CD 20+00, where a canvas sheet was located next to the transformer, a color contrast was observed on the canvas sheet, and suggested the existence of a microclimate resulting from temperature gradients. Water was observed as rivulets along the bulkhead doors at Station CD 22+01. However, immediately above the doors, the bulkhead remained dry.

\subsubsection{Estimates of Mass of Vapor in Nonventilated Sections of the ECRB}

From measurements of relative humidity (i.e., the ratio of the existing vapor pressure to the saturation vapor pressure at the same temperature), the density of water vapor (i.e., the mass of water vapor per unit volume of air) along the ECRB can be estimated from the relationship between temperature and the vapor density in saturated air (Figure 6-122). This relationship is accurately captured $\left(\mathrm{R}^{2}=0.999\right)$ by the second-order polynomial equation:

$$
\mathrm{V}_{\sigma_{\mathrm{S}}}=0.00002 t^{2}+0.0001 t-0.0053
$$

where $\mathrm{V}_{\sigma \mathrm{s}}$ is the vapor density of saturated air $\left(\mathrm{kg} / \mathrm{m}^{3}\right)$ and $t$ is the temperature $\left({ }^{\circ} \mathrm{C}\right)$ of the saturated air.

The actual vapor density $\left(\mathrm{V}_{\sigma \mathrm{\sigma a}}\right)$ is then calculated from the relative humidity as:

$$
\mathrm{V}_{\sigma_{\mathrm{a}}}=\mathrm{V}_{\sigma s} \times R h
$$




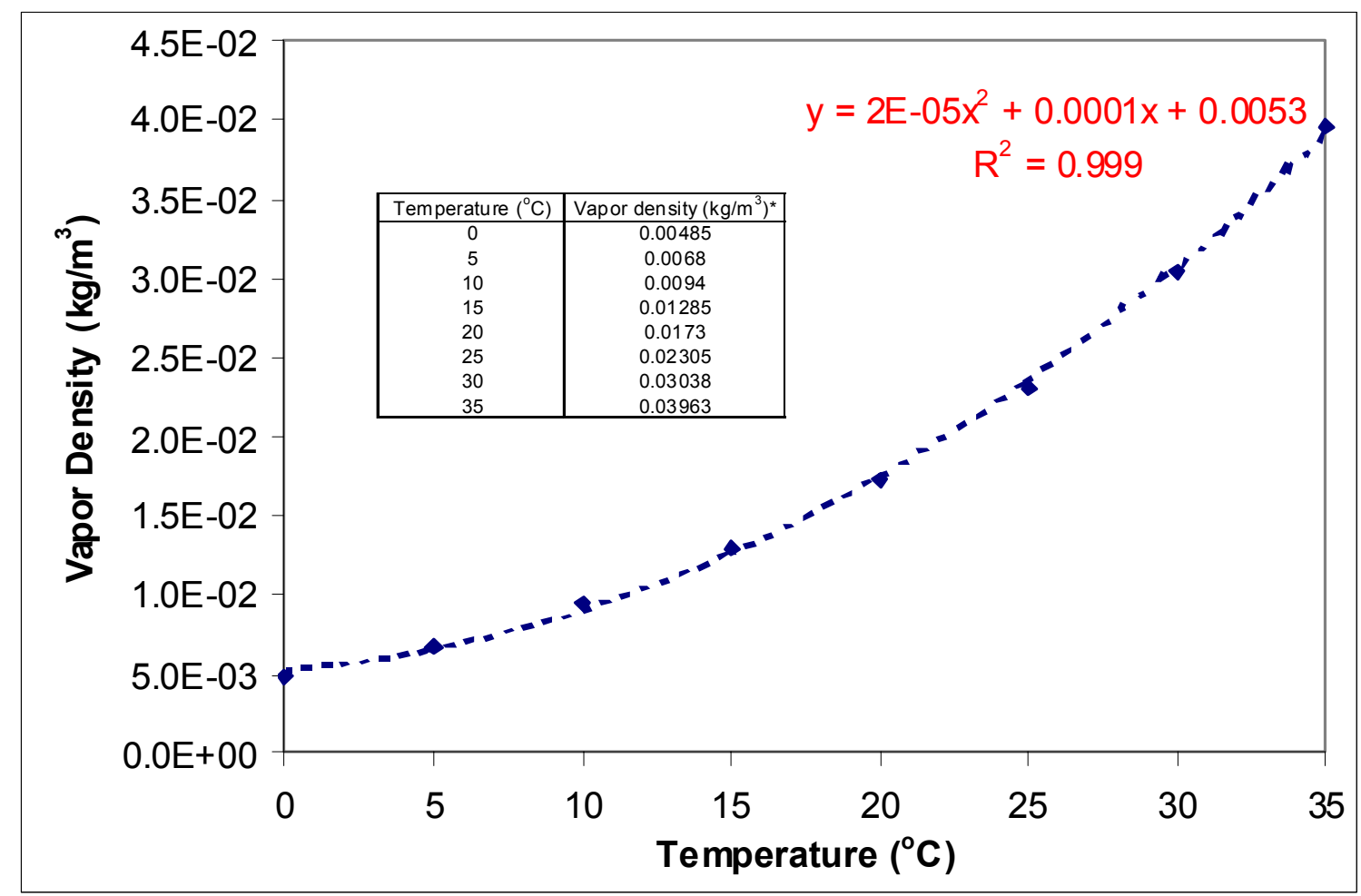

Source: DTN: LB0307ECRBRHTB.001 [DIRS 164843].

NOTES: Table shows the data from which the plot was developed. The polynomial equation describing this relationship is included in the plot.

Data for table is from Environmental Soil Physics (Hillel 1998 [DIRS 165404], p. 37).

Figure 6-122. Vapor Density at Various Temperatures

Subsequently, for a given length of drift, along which the temperature and relative humidity (which are approximated to be fairly constant), the following can also be determined (see Appendix Section I4 for the calculation):

- flux of moisture in to or out of the drift, and the

- amount of moisture contained per unit length of drift at any given time.

For example, after the bulkhead doors in the ECRB were closed during the last week of January 2001, the relative humidity measurements at the monitoring stations CD $21+40$ and CD 25+52 (DTN: LB0307ECRBRHTB.001 [DIRS 164843]) showed a rapid rise in the in-drift humidity (see Figure 6-123).

A first-order estimate of the amount (mass) of vapor for the period immediately following the closure of the bulkhead doors can be made by determining the mass of vapor associated with the given temperature, using Equation 6-12 and Figure 6-122. The temporal response of the mass of vapor is presented in Figure 6-123, which shows that once nonventilated conditions prevailed behind closed bulkheads, the mass of vapor rapidly increased to approximately $37 \mathrm{~kg}$ per $100 \mathrm{~m}$ of tunnel. 


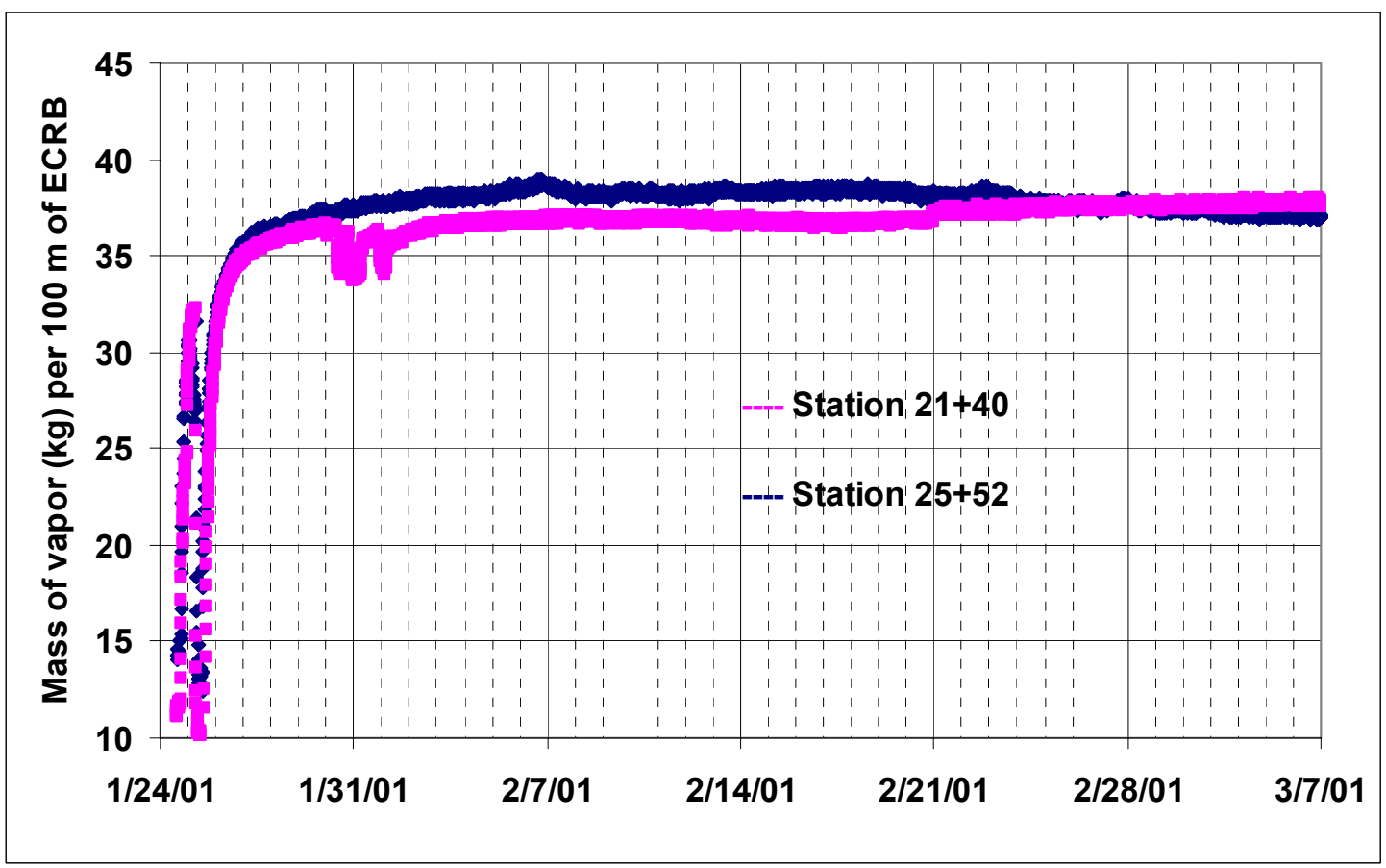

Source: DTN: LB0307ECRBRHTB.001 [DIRS 164843].

Figure 6-123. Mass of Vapor in Sections of ECRB Determined from Temperature and Relative Humidity Measurements at Station CD 21+40 and Station CD 25+52

\subsubsection{Chemical and Isotopic Analysis of Water Samples Collected During Bulkhead Entries}

The nonventilated sections of the ECRB Cross-Drift were opened four times from January 2000 to January 2001, and water samples were collected. Both chemical analyses and isotopic measurements were conducted on the samples. The chemical analyses were on major anionic and cationic constituents (including bromide, chloride, and lithium) in the liquid samples. The hydrogen $(\delta \mathrm{D})$ and oxygen $\left(\delta^{18} \mathrm{O}\right)$ isotope compositions were also analyzed.

\subsubsection{Chemical Analysis}

Most of the initial samples were collected directly from pools that had formed on the conveyor belt, and these samples were of light- to dark-brown color (see Figure 6-124 for examples). Their chemical compositions showed high and spurious concentrations of many constituents, as shown in Table 6-28. These samples were likely contaminated by the conveyor belt (as a result of belt usage/operation before ECRB Cross-Drift closure), with the degree of contamination unknown and unquantifiable. 

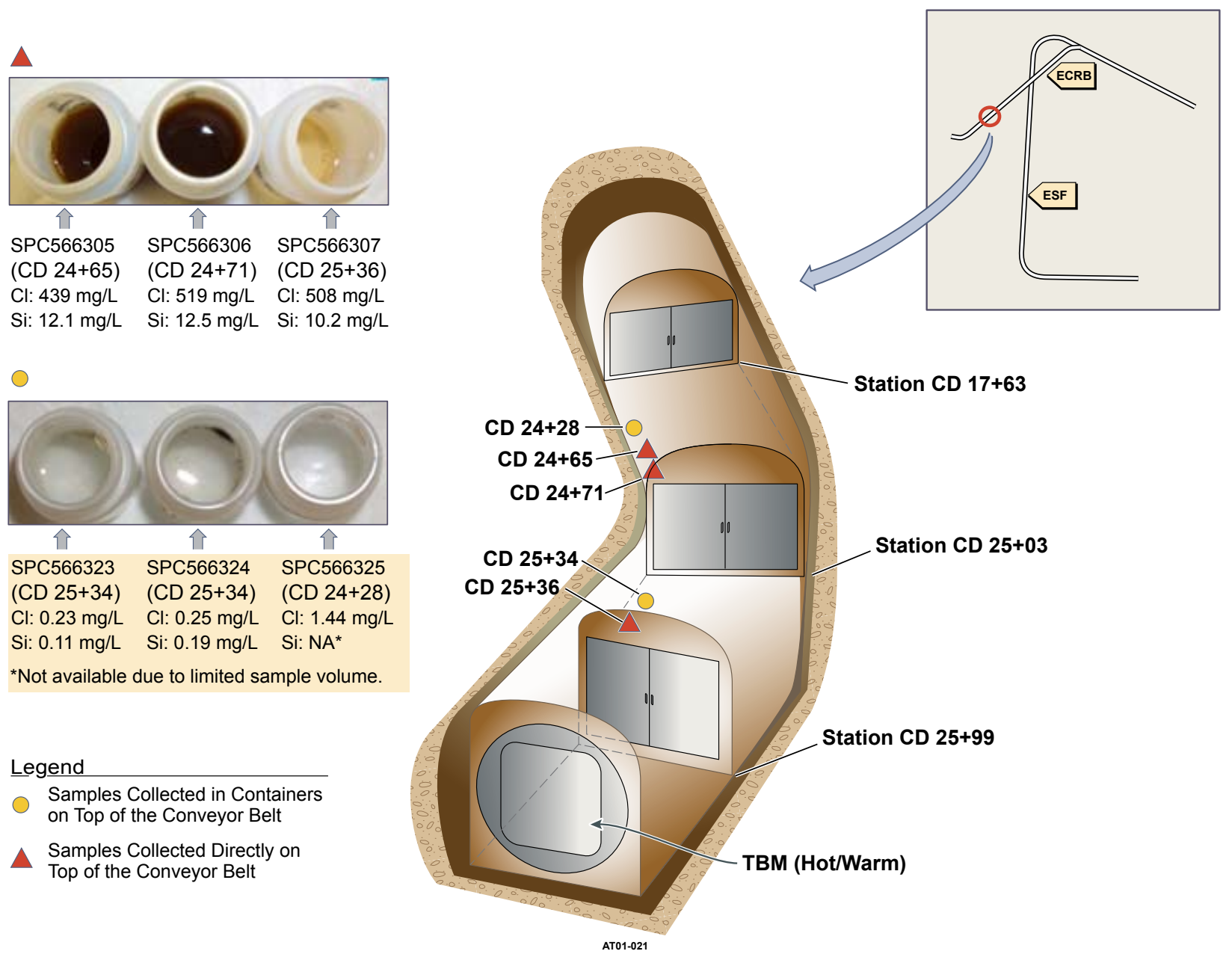

Source: DTN: LB0110ECRBH2OA.001 [DIRS 156886].

Figure 6-124. Chemical Analyses of Liquid Samples Collected during Bulkhead Entries

Conveyor-belt contamination could have included salt accumulated from water evaporation following transportation of the tuff debris, in addition to other, miscellaneous, contamination. Similarly, water collected on the cloth tarp was contaminated by dust and by the cloth itself, which had previously been treated with a moisture-sensitive dye. Because of the uncertainty regarding contamination, these samples might not yield useful data regarding the origin (condensate or seepage) of the water observed in the ECRB Cross-Drift behind bulkheads.

Subsequently, three samples were collected from collection containers placed on the top of the conveyor belt. These samples were clear (Figure 6-124). Their chemistry, particularly their low chloride and low silica contents, indicated that the water was condensate (Figure 6-125). The water did not have the chemical signature of the construction water, which contained approximately $20 \mathrm{mg} / \mathrm{L}$ of lithium bromide added to $\mathrm{J}-13$ well water. Condensate, and subsequent dripping, could have occurred as a result of vapor-to-liquid transition associated with local temperature variations in a humid environment. The moisture conditions measured by humidity and temperature probes support the presence of drift moisture variations (Section 6.10.2.2). The clear samples shown in Figure 6-124 also show a relatively high amount 
of calcium and a high sulfate/chloride ratio, which suggests minor contamination from either rock grout or rock dust (Figure 6-125). (Some rock grout or rock dust that was present along the drift crown above the sampling containers might have dissolved in the condensate prior to collection.) Samples collected on the drift wall (using a needle syringe for SPC566308 in Table 6-28, and absorbent pads attached to the wall) show an even higher concentration of calcium and a higher sulfate/chloride ratio, resulting from the direct contact of the sample with the rock.

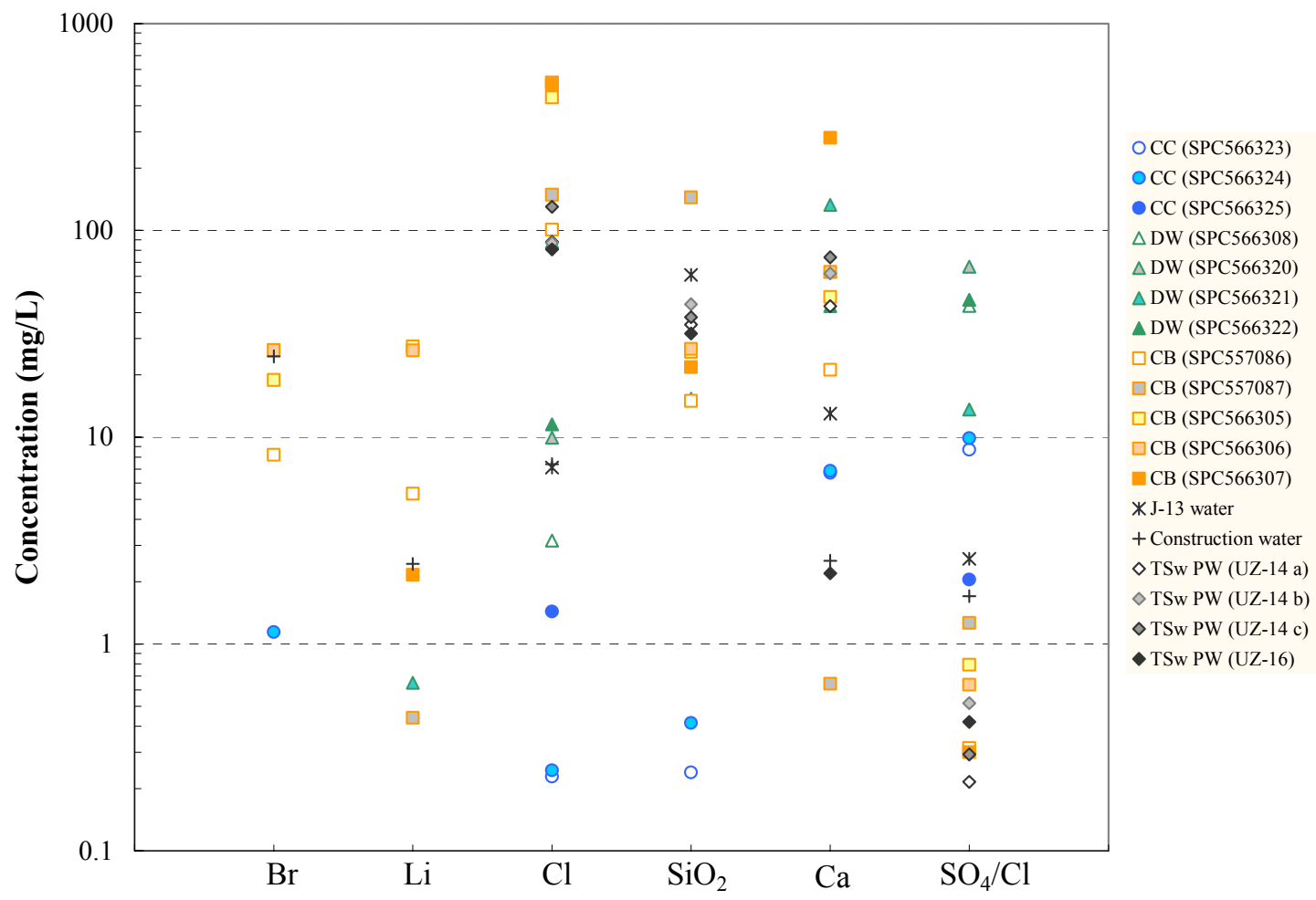

Sources: J-13 well water composition from DTN: MO0006J13WTRCM.000 [DIRS 151029].

TSw pore-water data from BSC 2004 [DIRS 169734].

ECRB water data from DTN: LB0110ECRBH2OA.001 [DIRS 156886].

NOTES: Unit of the $\mathrm{Y}$-axis is $\mathrm{mg} / \mathrm{L}$, except for the ratio of sulfate to chloride (dimensionless).

ECRB samples are grouped as follows: CC in collection container, DW on drift wall, and CB on conveyor belt.

Construction water data presented here represent average values from seven samples.

TSw PW = pore water in Topopah Spring welded tuff unit.

Figure 6-125. Comparison of Chemical Signatures 


\begin{tabular}{|c|c|c|c|c|c|c|c|c|c|c|c|c|c|c|c|}
\hline \multirow[b]{2}{*}{ Specimen ID\# } & \multirow[b]{2}{*}{ Sample Location } & \multirow{2}{*}{$\begin{array}{c}\text { Collection } \\
\text { Date }\end{array}$} & $\mathrm{Br}^{-}$ & $\mathrm{Cl}^{-}$ & $\mathbf{F}^{-}$ & $\mathrm{NO}_{3}^{-}$ & $\mathrm{SO}_{4}{ }^{2-}$ & $\mathrm{Ca}^{2+}$ & $\mathrm{Li}^{+}$ & $\mathrm{Mg}^{2+}$ & $\mathrm{K}^{+}$ & $\mathrm{Na}^{+}$ & $\mathrm{SiO}_{2}$ & $\delta \mathrm{D}$ & $\delta^{18} \mathrm{O}$ \\
\hline & & & \multicolumn{11}{|c|}{ (mg/L) } & \multicolumn{2}{|c|}{$(\%)$} \\
\hline SPC557086 & \begin{tabular}{|l|} 
Conveyor belt - \\
Station CD $24+83$
\end{tabular} & $1 / 31 / 00$ & 8.23 & 101 & ND & ND & 31.7 & 21.2 & 5.33 & 3.10 & 19.0 & 88.6 & 15.0 & -59 & -7.1 \\
\hline SPC557087 & \begin{tabular}{|l|} 
Conveyor belt - \\
Station CD $25+17$
\end{tabular} & $1 / 31 / 00$ & ND & 149 & 29 & ND & 188 & 0.64 & 0.44 & 0.10 & 160 & 139733 & 144 & -80 & -9.3 \\
\hline SPC566305 & \begin{tabular}{|l|} 
Conveyor belt - \\
Station CD 24+65 \\
\end{tabular} & $5 / 03 / 00$ & 18.9 & 439 & ND & ND & 349 & 47.6 & 27.5 & 9.00 & 27.9 & 195 & 25.9 & -79 & -9.3 \\
\hline SPC566306 & \begin{tabular}{|l|} 
Conveyor belt - \\
Station CD $24+71$
\end{tabular} & $5 / 03 / 00$ & 26.3 & 519 & 9.19 & ND & 330 & 62.9 & 26.3 & 12.0 & 35.3 & 230 & 26.7 & -80 & -8.9 \\
\hline SPC566307 & \begin{tabular}{|l|} 
Conveyor belt - \\
Station CD $25+36$
\end{tabular} & $5 / 03 / 00$ & ND & 508 & 6.41 & 24.1 & 152 & 280 & 2.16 & 34.0 & 36.3 & 191 & 21.8 & -79 & -8.7 \\
\hline SPC566308 & $\begin{array}{l}\text { Shotcrete- } \\
\text { Station CD } 25+50\end{array}$ & $5 / 03 / 00$ & ND & 3.16 & ND & 4.29 & 136 & --- & --- & --- & --- & --- & --- & --- & --- \\
\hline SPC566300 & $\begin{array}{l}\text { Construction } \\
\text { Water }\end{array}$ & $5 / 31 / 00$ & 25.1 & 6.82 & --- & ND & 13.4 & 6.64 & 2.02 & --- & 5.94 & 59.1 & --- & -- & --- \\
\hline SPC566320 & \begin{tabular}{|l|} 
Absorbent pad - \\
Station CD $25+62$ \\
\end{tabular} & 6/28/00 & ND & 9.95 & 7.05 & 3.99 & 665 & 63.5 & ND & 11.5 & 172 & 105 & $<1.0$ & --- & -- \\
\hline SPC566321 & \begin{tabular}{|l|} 
Absorbent pad - \\
Station CD $25+62$ \\
\end{tabular} & 6/28/00 & ND & 88.0 & 15.8 & 5.79 & 1197 & 133 & 0.65 & 18.1 & 163 & 233 & 15.4 & -69 & -6.9 \\
\hline SPC566322 & \begin{tabular}{|l|} 
Absorbent pad - \\
Station CD $25+62$ \\
\end{tabular} & $6 / 28 / 00$ & ND & 11.5 & 8.02 & 2.20 & 531 & 43.0 & ND & 6.50 & 141 & 78.6 & $<1.0$ & -71 & -7.8 \\
\hline SPC566323 & \begin{tabular}{|l|} 
Collection \\
container - Station \\
CD $25+34$ \\
\end{tabular} & 6/28/00 & ND & 0.23 & ND & 1.63 & 1.99 & 6.73 & ND & 0.40 & 0.84 & 1.56 & 0.24 & -83 & -9.4 \\
\hline SPC566324 & $\begin{array}{l}\text { Collection } \\
\text { container - Station } \\
\text { CD 25+34 } \\
\end{array}$ & 6/28/00 & 1.14 & 0.25 & ND & ND & 2.42 & 6.87 & ND & 0.40 & 0.90 & 1.65 & 0.42 & -84 & -9.4 \\
\hline SPC566325 & \begin{tabular}{|l|} 
Collection \\
container - Station \\
CD 24+28 \\
\end{tabular} & 6/28/00 & ND & 1.44 & ND & 2.34 & 2.95 & --- & --- & --- & --- & --- & --- & -67 & -8.1 \\
\hline
\end{tabular}




\begin{tabular}{|c|c|c|c|c|c|c|c|c|c|c|c|c|c|c|c|}
\hline \multirow[b]{2}{*}{ Specimen ID\# } & \multirow[b]{2}{*}{ Sample Location } & \multirow{2}{*}{$\begin{array}{c}\text { Collection } \\
\text { Date }\end{array}$} & $\mathrm{Br}^{-}$ & $\mathrm{Cl}^{-}$ & $\mathbf{F}^{-}$ & $\mathrm{NO}_{3}^{-}$ & $\mathrm{SO}_{4}{ }^{2-}$ & $\mathrm{Ca}^{2+}$ & $\mathrm{Li}^{+}$ & $\mathrm{Mg}^{2+}$ & $\mathrm{K}^{+}$ & $\mathrm{Na}^{+}$ & $\mathrm{SiO}_{2}$ & $\delta \mathbf{D}$ & $\delta^{18} \mathrm{O}$ \\
\hline & & & \multicolumn{11}{|c|}{ (mg/L) } & \multicolumn{2}{|c|}{$(\%)$} \\
\hline SPC573600 & $\begin{array}{l}\text { Conveyor belt - } \\
\sim 5 \mathrm{~m} \text { from } 2 \mathrm{nd} \\
\text { bulkhead } \\
\end{array}$ & $1 / 22 / 01$ & 45.4 & --- & -- & --- & --- & --- & 0.11 & --- & -- & --- & --- & -90 & -10.6 \\
\hline SPC573602 & \begin{tabular}{|l|} 
Conveyor belt - \\
Station CD $25+37$ \\
\end{tabular} & $1 / 22 / 01$ & 79.7 & -- & -- & -- & --- & -- & 0.17 & -- & -- & -- & -- & -74 & -- \\
\hline SPC573604 & $\begin{array}{l}\text { Conveyor belt - } \\
\sim 7 \mathrm{~m} \text { from } 2 \mathrm{nd} \\
\text { bulkhead } \\
\end{array}$ & $1 / 22 / 01$ & 56.3 & --- & --- & --- & --- & --- & 12.31 & --- & --- & --- & --- & -89 & -10.7 \\
\hline SPC573605 & \begin{tabular}{|l|} 
Conveyor belt - \\
Station CD $25+42$ \\
\end{tabular} & $1 / 22 / 01$ & ND & --- & -- & --- & --- & --- & 0.22 & --- & -- & --- & --- & -55 & -3.7 \\
\hline SPC573601 & \begin{tabular}{|l|} 
Conveyor belt - \\
Station CD $25+10$
\end{tabular} & $1 / 23 / 01$ & 72.5 & --- & -- & --- & --- & --- & 14.8 & --- & -- & -- & --- & -48 & -5.0 \\
\hline SPC573603 & \begin{tabular}{|l|} 
Conveyor belt - \\
Station CD $25+21$
\end{tabular} & $1 / 23 / 01$ & 52.5 & --- & -- & --- & --- & --- & 0.13 & --- & -- & -- & --- & -55 & -4.9 \\
\hline
\end{tabular}

Source: DTNs: LB0110ECRBH2OA.001 [DIRS 156886]; LB0110ECRBH2OI.001 [DIRS 156887].

NOTES: Liquid samples were filtered through $0.45 \mu \mathrm{m}$ filters prior to chemical analyses. Phosphate was not detected in any of the liquid samples.

$\mathrm{ND}=$ Not detected (e.g., below the analytical detection limit (approximately $0.1 \mathrm{mg} / \mathrm{L})$ ).

$---\quad$ = Data not available. 


\subsubsection{Isotopic Analysis}

Results of isotopic analyses that were performed on the collected water samples are presented in Table 6-28 and illustrated in Figure 6-126. The $\delta \mathrm{D}$ values of the ECRB Cross-Drift water range from $-48 \%$ o to $-9 \%$, and the $\delta^{18} \mathrm{O}$ values range from $-3 \%$ o to $-10.7 \%$. These values are higher than those found in the construction water. As a health and safety measure (to establish proper ventilation for reentry), a delay (3 to 4 hours) is imposed between the opening of bulkheads and the beginning of sample collection. This lag time is sufficient to allow significant evaporation losses from the samples. In Figure 6-126, all samples from the ECRB Cross-Drift are shown to have shifted from the global meteoric water line, which is similar to the shift found in samples from Alcove 5. The offset is characteristic of waters that have undergone some degree of vapor loss. The same degree of shift for both the contaminated samples and the relatively clean samples might indicate that approximately the same degree of evaporation occurred for water collected in the ECRB Cross-Drift.

\subsubsection{Summary of ECRB Entries}

During most entries, the entire ECRB Cross-Drift was accessible for visual inspection. Wet areas were observed and water samples were manually collected from small pools of water. The visual observations suggest that the water observed in the ECRB originated from condensation. (For example, water droplets were observed on the surface of a small patch of paint, an impermeable barrier to the rock.) Water collected from collection containers during the second entry (June 28, 2000) was low in chloride and silicate contents, which is characteristic of condensate. The water did not have the chemical signature of construction water (which was spiked with approximately $20 \mathrm{mg} / \mathrm{L}$ of lithium bromide). Condensates, and consequent dripping, could have occurred by water phase transition (from vapor to liquid) associated with local temperature variations. The moisture conditions measured by humidity and temperature probes support the presence of drift moisture variations. The potential measurements in the boreholes indicate that the tuff matrix was partially unsaturated near the borehole collars.

\subsubsection{Ambient Monitoring in Alcove 7}

Ambient monitoring of temperature, barometric pressure, and relative humidity was also performed inside Alcove 7, located in the ESF at station 50+64. This alcove, constructed to a depth of $203 \mathrm{~m}$, penetrated the Ghost Dance fault at $167 \mathrm{~m}$. Bulkhead doors were installed $64 \mathrm{~m}$ and $132 \mathrm{~m}$ from the entrance of the alcove during Fall of 1997 (Kurzmack et al. 2002 [DIRS 162333]). 


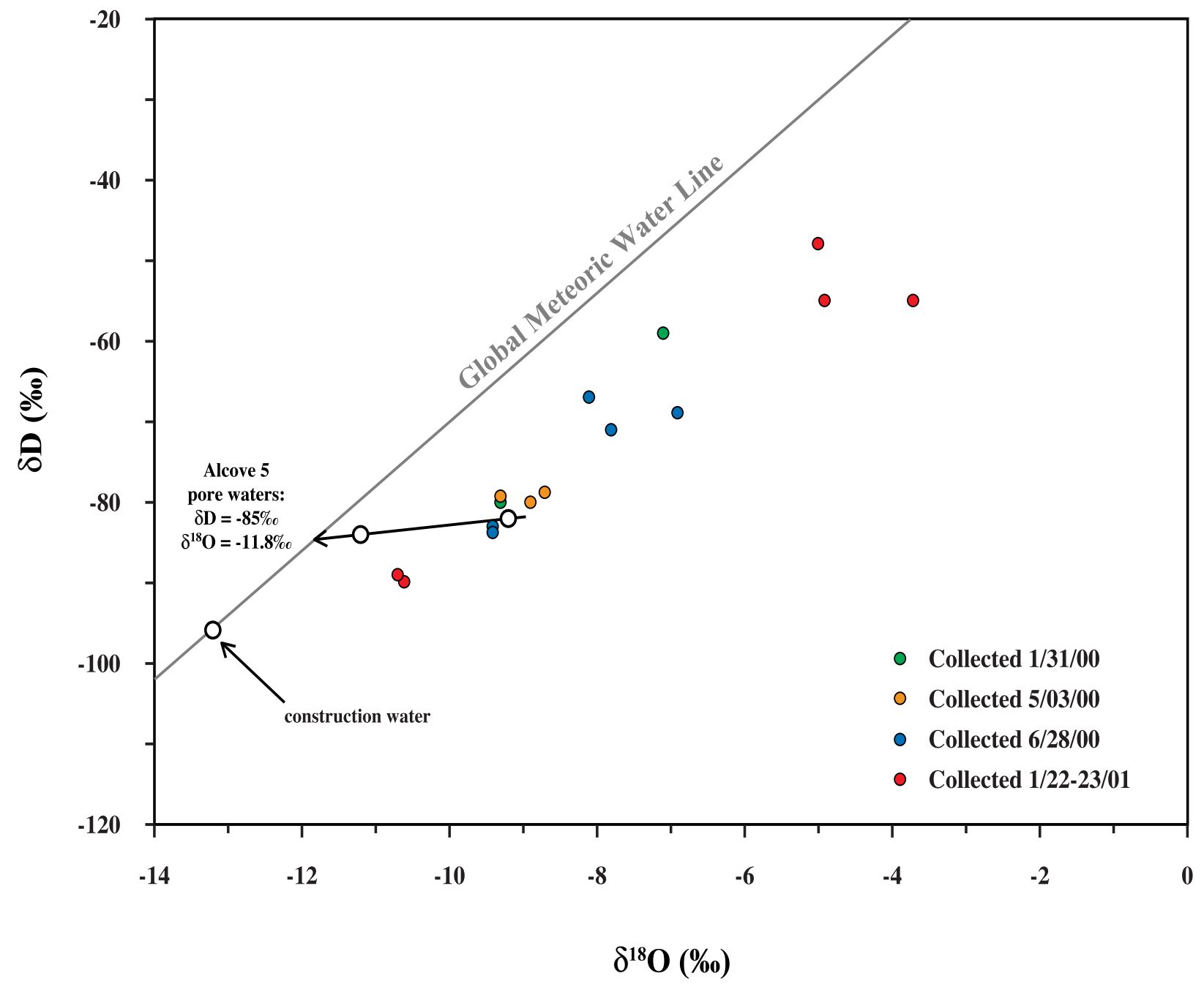

Source: DTNs: LB0110ECRBH2OI.001 [DIRS 156887]; LB0108CO2DST05.001 [DIRS 156888]; LB0011CO2DST08.001 [DIRS 153460].

NOTE: Also plotted is the isotopic composition of construction water, two pore-water samples extracted from core samples from Alcove 5 and the location of the Global Meteoric Water Line.

Figure 6-126. Plot of the Hydrogen and Oxygen Isotope Compositions of Water Samples Collected from the ECRB Cross-Drift 
The Alcove 7 bulkhead door was first closed on December 11, 1997. Although there were many entries during the period from December 1997 to October 30, 2000, relative humidity measurements were close to 100 percent throughout this period. Fluctuating temperature and relative humidity measurements indicated that the bulkheads were not perfectly sealed (DTN: GS990108312242.005 [DIRS 166000]).

On September 18, 2001, the bulkheads were opened (after being closed since October 30, 2000). Evidence of moisture was observed during this entry. Signs of moisture included drip spots on the drip collection sheets, moisture drops on the utility lines, moisture drops on the shotcrete around the bulkheads, and moisture spots in the dust on an instrument enclosure. In addition, the rock in the crown had a dark, moist appearance.

The next time the bulkhead doors were opened was May 20, 2003. Drip spots were observed on the drip collection sheets, moisture drops were observed on the utility lines, and moisture spots were observed in the dust on an instrument enclosure. The rock in the crown had a dark, moist appearance and the fractures in the rib appeared wet (Hudson 2003 [DIRS 165273]).

Between September 25, 2001, and June 10, 2002, the relative humidity behind the bulkhead doors was less than 95 percent (i.e., the dry end of the thermocouple psychrometers) and was therefore not measured. Pressure monitoring indicated that the atmospheric pressure fluctuations were only minimally dampened (less than 5 percent) by the bulkhead doors, and the transmission lead to only short time lags (on the order of hours). Large temperature fluctuations $\left(19.5^{\circ} \mathrm{C}\right.$ to $\left.27.5^{\circ} \mathrm{C}\right)$ at the monitoring station located $4 \mathrm{~m}$ from the entrance of the alcove (outside the bulkhead doors) were caused by seasonal temperature fluctuations along the ESF and by the ventilation system. Diurnal temperature fluctuations caused by ventilation were as large as $1.2^{\circ} \mathrm{C}$. Temperatures behind the bulkheads indicated no discernable annual fluctuation, and the diurnal temperature fluctuations were less than $0.05^{\circ} \mathrm{C}$. Abrupt temperature decreases (up to $1.0^{\circ} \mathrm{C}$ ) were occasionally measured behind the bulkheads. These temperature decreases were correlated with the pressure recovery period following a low-pressure event. The temperature decrease might have been caused by a pressure gradient driving warm-dry ESF air through the fractures around the bulkheads, thereby evaporating water and cooling the air. 


\subsection{ANALYSES AND INTERPRETATIONS OF SYSTEMATIC HYDROLOGIC CHARACTERIZATION}

A systematic approach (testing at regular intervals regardless of specific features arising from spatial heterogeneity) was chosen for performing hydrologic characterization along the ECRB Cross-Drift (Cook et al. 2003 [DIRS 165424]). These tests took place in boreholes drilled at regular intervals along the ECRB Cross-Drift within the lower lithophysal zone of the TSw. The lower lithophysal welded tuff unit is intersected by many small fractures (less than $1 \mathrm{~m}$ long) and interspersed with many lithophysal cavities (ranging in size from 15 to $100 \mathrm{~cm}$ ). The size and spacing of both the fractures and lithophysal cavities vary appreciably along the drift walls (the drift is $5 \mathrm{~m}$ in diameter) over an $800-\mathrm{m}$ stretch. This indicates that hydrologic characteristics at one particular location may not be representative of the entire unit. Therefore, a systematic approach of testing at regular intervals was adopted to acquire knowledge of the heterogeneous hydrologic characteristics of this unit, in which more than 80 percent of the repository will reside. The specific test plan for this series of tests is Systematic Hydrological Characterization, SITP-02-UZ-004 (BSC 2001 [DIRS 158202]).

The data from the systematic hydrologic characterization in the ECRB Cross-Drift (i.e., air-permeability data and the data from liquid-release tests, including injection rates, seepage rates, relative humidity, and evaporation rate) were used as part of the model development, calibration, and validation of the seepage calibration model (BSC 2004 [171764]).

The systematic approach was to complement other hydrologic testing in the ambient testing program, in which test locations were selected either by avoiding or focusing on specific features (such as large fractures or an abundance of fractures or cavities). Systematic hydrologic characterization investigated the hydrologic properties that are important to repository performance. Field measurements included:

- Air-injection tests that give a measure of fracture permeability

- Liquid-release tests that determine the ability of the open drift to act as a capillary barrier (diverting water around itself) as well as the potential for water seeping into the drift

- Crosshole gas-tracer tests to measure the effective porosity of the rock mass.

\subsubsection{Systematic Borehole Testing Setup}

\subsubsection{Systematic Borehole Configuration}

Figure 6-127 shows a schematic of the arrays of boreholes (all $20 \mathrm{~m}$ in length) drilled at regular intervals along the ECRB Cross-Drift. The borehole arrays are divided into three groups. Group I consists of low-angled boreholes drilled from the crown of the 5-m-diameter ECRB Cross-Drift, inclined at 15 degrees from the drift axis. These boreholes were intended for both air-injection and liquid-release tests, with the spacing of adjacent boreholes from collar to collar at $30 \mathrm{~m}$. Group II consists of near-vertical boreholes drilled from the crown of the drift. Group III consists of pairs of parallel horizontal boreholes, spaced $3 \mathrm{~m}$ apart and drilled from the 
side of the drift. The former (Group II) were intended for air-injection tests to determine the effect of drift excavation on fracture properties, and the latter (Group III) were for gas-tracer tests to determine the effective porosity. Group II and III boreholes are in groups of three, spaced $90 \mathrm{~m}$ apart, as shown in Figure 6-127.

The Group I boreholes are the primary ones used for study in this investigation. Four boreholes were tested. Their collars are located at CD 17+49, CD 17+26, CD 16+95, and CD 16+65, respectively, from the ECRB portal. Because of the location of a bulkhead at CD 17+63, drilling operations in the ECRB-Cross-Drift are precluded beyond CD 17+63; as a result, the first two boreholes are separated by only $23 \mathrm{~m}$. All of the boreholes are inclined up toward the portal end of the ECRB Cross-Drift.

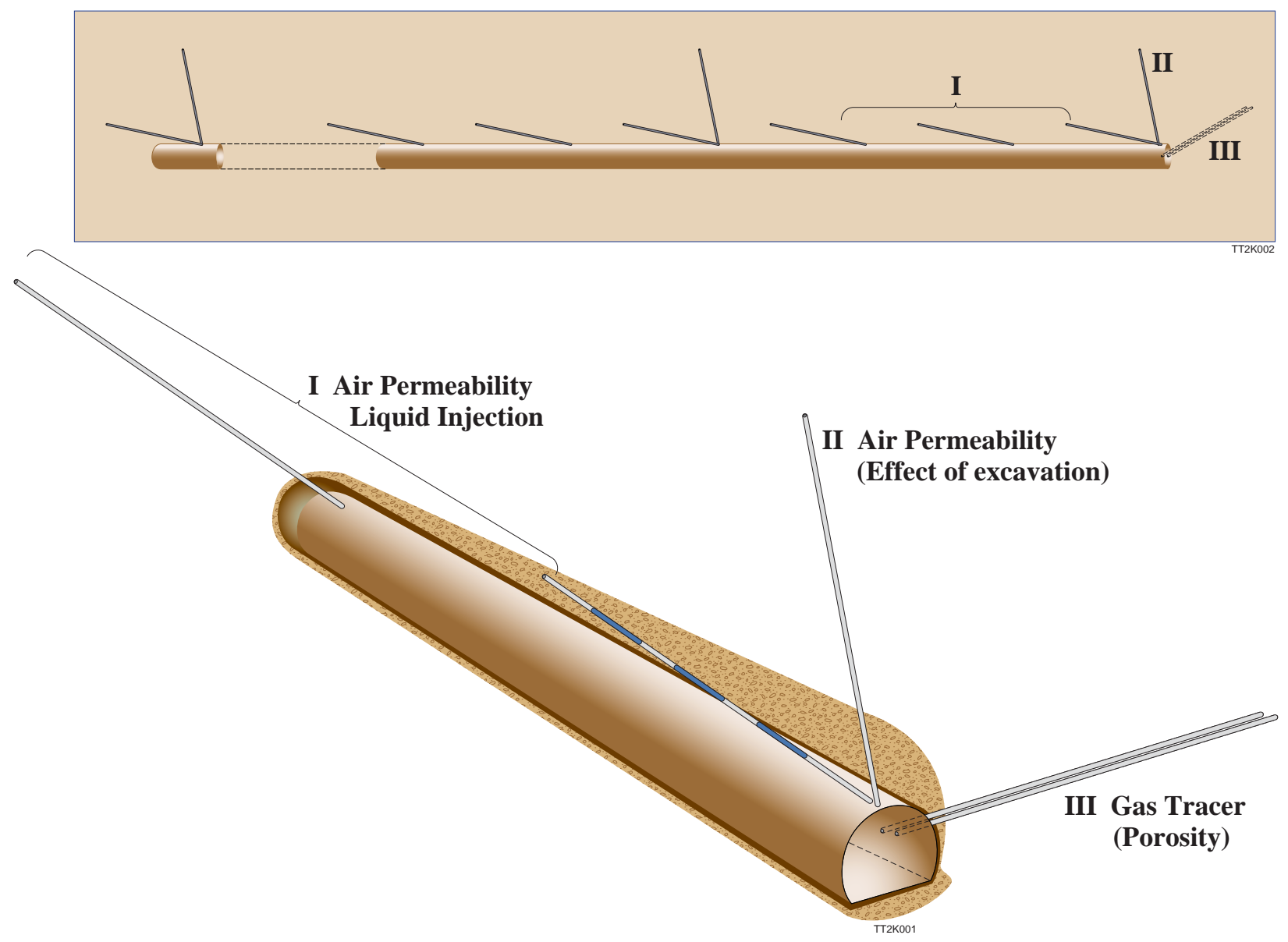

NOTE: The drift portal is to the left of the schematic.

Figure 6-127. Schematic of Borehole Configuration in the ECRB Cross-Drift for Systematic Characterization of the Lower Lithophysal Unit 


\subsubsection{Equipment}

The equipment system was custom-designed for the systematic characterization study, based on two criteria: automation and mobility. Field-scale measurements involving liquid flow in unsaturated rock require continuous testing, lasting for weeks to months, whereas the ECRB Cross-Drift was open only for eight hours, four days every week. Therefore, the control of test equipment was fully automated, allowing remote manipulation via computer network when there is no human presence at the field site. The second criterion, mobility, was achieved by designing all equipment needed for the systematic characterization as units to fit on flatbed rail cars. This enabled investigators to efficiently transport equipment from one test station to another along the ECRB Cross-Drift.

A schematic of the testing equipment for air injection and liquid release is shown in Figure 6-128. The main function of the equipment was to distribute water at a specified rate along a specified length of borehole and to capture and quantify any water that makes its way from the borehole through the rock formation as seepage into the drift. The key components of the system are the packer assembly, water supply hardware, and seepage capture system.

\subsection{Packer Assembly}

The packer assembly used inflatable-rubber-packer units to seal off sections of the borehole (so that released water cannot reach these sections) and separated each borehole into three nonsealed 1.83-m-long water-release sections. The three sealing sections of the packer assembly use 3-m-long, soft inflatable rubber tubing $(0.64-\mathrm{cm}$-thick wall) supported by and clamped at each end onto a 5-cm stainless-steel core, for an overall diameter of $6.3 \mathrm{~cm}$. The relatively long $(3 \mathrm{~m})$ packers were intended to provide effective sealing in a lithophysal unit, where cavities can be as deep as $1 \mathrm{~m}$. The cores of these rubberized sections contain internal tubing to inflate the rubber up to the size of the borehole diameter $(7.6 \mathrm{~cm})$, by means of compressed air.

Of the three water-delivery sections, also made of 5-cm-diameter stainless tubing, two lie between the three rubberized sections in the borehole, and the third lies beyond the farthest rubber section into the borehole. Because of the small-angle incline of the borehole, the vertical distance from the nearest section to the drift crown is approximately $1 \mathrm{~m}$, whereas the vertical distance between the second and the farthest (that is, farthest into the borehole) sections and the crown are approximately $2.5 \mathrm{~m}$ and $4 \mathrm{~m}$, respectively. (Note that if used for air-injection tests, Zone 3 is longer than the other zones (which are $1.83 \mathrm{~m}$ long), because the last zone begins at the end of the third packer and extends to the end of the 20-m-long borehole.) Water was released into these unsealed sections or zones by one of two means. One method used a single release point close to the rubber sealing section at the upper end of the unsealed zone. The other method used multiple orifices along an unsealed section to enable water to be released at six evenly spaced locations along the entire unsealed section. Tubing resides inside each of the delivery sections for single-point injection, for multipoint injection at six evenly spaced locations, and for drainage of overflow, should the delivery rate prove to be too high for all the water to completely enter the formation. One additional tube from each delivery section connected it to a pressure transducer located outside the hole, to measure air pressure in each zone. 


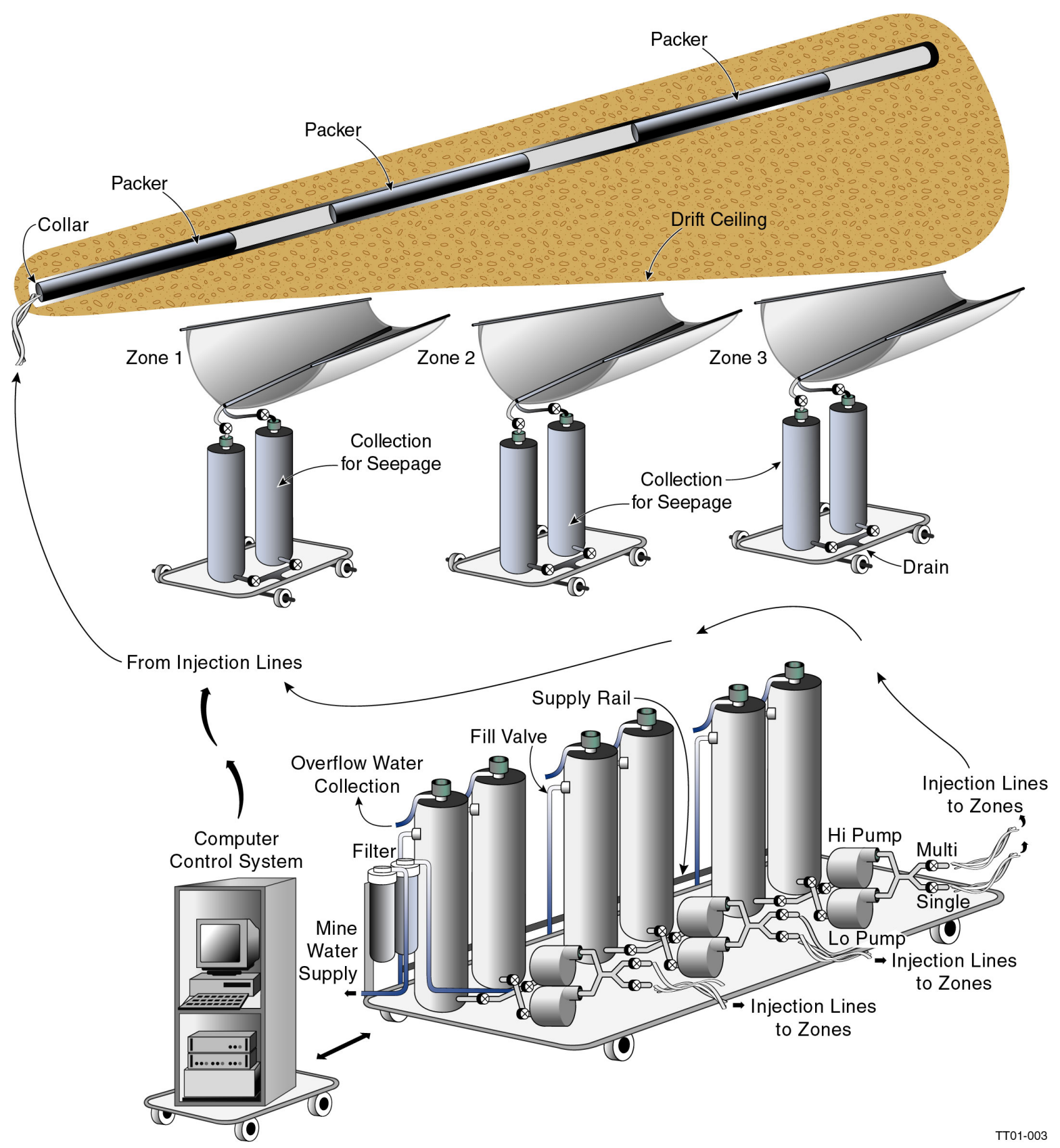

Figure 6-128. A Schematic of the Equipment System: Packer Assembly, Water Supply and Air-Injection Component, Seepage Collection Component, and Data Acquisition and Control

In keeping with the design requirements of the testing site, the sections of packer assembly were shipped as separate parts and assembled at the site. O-rings at the connections between sections ensured that the annuli left in the vicinity of the water-delivery sections were sealed from atmospheric conditions inside the hollow, open-packer core. The packer inflation, water supply, and water drain tubing from all sections extended through the core of the packer assembly to the outside of the borehole, where it was connected to the water supply system. 


\subsection{Water Supply System}

Each delivery section in the borehole had its own water supply system. The triplicate design allowed testing in all three zones of the same borehole simultaneously. The water supply hardware controlled the amount of water delivered to a section and measured the total quantity of water supplied to that section over time. In addition, the supply hardware also measured, over time, the quantity of any return flow through the drain port from the delivery section. Each supply system made use of twin vertical, cylindrical bottles to supply and measure the water that was delivered. The bottles were $1.5 \mathrm{~m}$ tall and $20 \mathrm{~cm}$ in diameter, a size that enabled mobility of the units between test locations without sacrificing volume resolution or supply volume. One bottle could fill from the tunnel water supply, while the other was pumped, so that the supply and measurement system could run without interruption. Located at the base of each bottle, differential-pressure transducers (which cancel atmospheric changes) measured the head of water in each bottle. These transducers, when multiplied by the known area of a bottle, yield the water quantity residing in the bottle. One of two sizes of electronically controlled gear pumps pushed water from the bottom of the active supply bottle up to the packer assembly for water delivery. The two different-sized pumps were used to provide a supply-rate range of $10 \mathrm{~mL} / \mathrm{min}$ to $2000 \mathrm{~mL} / \mathrm{min}$. The crossover from the small pump to the large pump was at approximately $300 \mathrm{~mL} / \mathrm{min}$. Valves enabled either bottle to supply either pump with the single-point delivery tube or the multipoint delivery tube. Another valve attached to each bottle directed any return flow to run back into the inactive bottle, so that this flow could be measured. One more valve at each bottle supplied each with refill water from the tunnel supply when needed. All the valves were pneumatically actuated via airlines controlled by solenoids. Electronic relays under computer control operated the solenoids. Voltage signals delivered by digital-to-analog converters under computer control governed the pumps, and an analog-to-digital converter with multiplexor converted the current-loop output of the transducers to digital format, which was recorded by the same computer used for valve and pump control.

\subsection{Seepage-Capture System}

Hardware for seepage capture at each zone consisted of a horizontally mounted U-shaped polyvinyl chloride (PVC) curtain, which captured seepage from the rock under the release zone and funneled it into twin collection bottles designed similarly to the supply bottles. A valve at the bottom of each bottle allows drainage into a continuous drain, while another valve at the top of each determines whether collected water can enter. This configuration allowed drainage of one bottle without interruption of seepage collection and measurement in the other. The collection system also utilized differential-pressure transducers to obtain the head of water (and, therefore, the quantity of water) in the bottles. The $20-\mathrm{cm}$ diameter of the collection system implies that a volume of $0.03 \mathrm{~L}$ of seepage water needs to be accumulated for every millimeter rise of water level. As with the supply system, the collection system is serviced by computer recording and control system. Figure 6-128 shows the arrangement of the capture curtains relative to the packer system. The capture curtain is $4 \mathrm{~m}$ long (more than double the $1.83-\mathrm{m}$ length of the release zone). 


\subsection{Air-Injection System}

The packer system also included an air-injection system for determining the air permeability of each delivery zone. The single-point delivery tubes included valves that allowed water to drain and air to be introduced into each zone. Mass-flow controllers deliver air at constant-mass flux through the single-point injection line. Dedicated absolute-pressure transducers for each zone enabled air-pressure measurements during air injection and thus allow calculation of air permeability. The mass-flow controllers were computer-controlled, and airflow rates were recorded by the data acquisition system. Measurements of air-permeability in other test beds in the underground drifts were presented in Section 6.1 and Section 6.5.

\subsection{Control and Recording System}

In addition to continuous recording of all transducer outputs, the computer interface for the supply and collection systems enabled the processes to be controlled manually or automatically. The computer incorporated remote-control capability, so that the systems could be started and controlled through computer networks.

Figure 6-129 shows the front panel from the user interface on the computer control. Depicted are the supply bottles at the top and the collection bottles at the bottom. Three completely independent systems are used, one for each zone. The Zone 1 system is shown operating on automatic control, using the low flow pump at 50-percent flow capacity from Bottle A. Return flow is being collected in supply Bottle B. Seepage is being collected in Bottle B while Bottle A is draining. Operational water paths are highlighted with thicker lines. The toggle switch on the Zone 1 control panel ( $\mathrm{z} 1$ auto) is on to enable automatic operation. When this switch is enabled, manual operation of the valve and pump controls is disabled, and they merely function as indicators from which to monitor the automatic operation. The controls are then operated automatically. Other zones are not operating.

\subsection{Automation Program}

The operator specifies pump rate and selects the water-delivery zone. All other aspects of control are performed automatically. Pumping starts in Bottle A, while Bottle B collects return water, until the water content read by the Bottle A transducer indicates that this bottle is nearly empty. At this point, Bottle B is filled to a preset limit (as monitored by the pressure transducer) if it is not at this limit already. When Bottle B is filled, pumping is switched from Bottle A to Bottle B. Bottle A is then able to collect any return flow. While filling from the main water supply, bottles are unable to collect return flow. Because filling is a rapid event, this pause in recording does not affect data collection. If filling does not occur rapidly enough to prepare the second bottle before the first one runs dry, the pump is switched to the second bottle even before it is completely full when a lower limit is passed (as read by the transducer of the first bottle). To obtain a continuous record of all the water delivered to a zone, the total volume of water from the bottle being emptied is subtracted from the water content at the start of the emptying of that bottle. This net refill value is then added to the previous total. A similar arrangement works for the return-water record. 


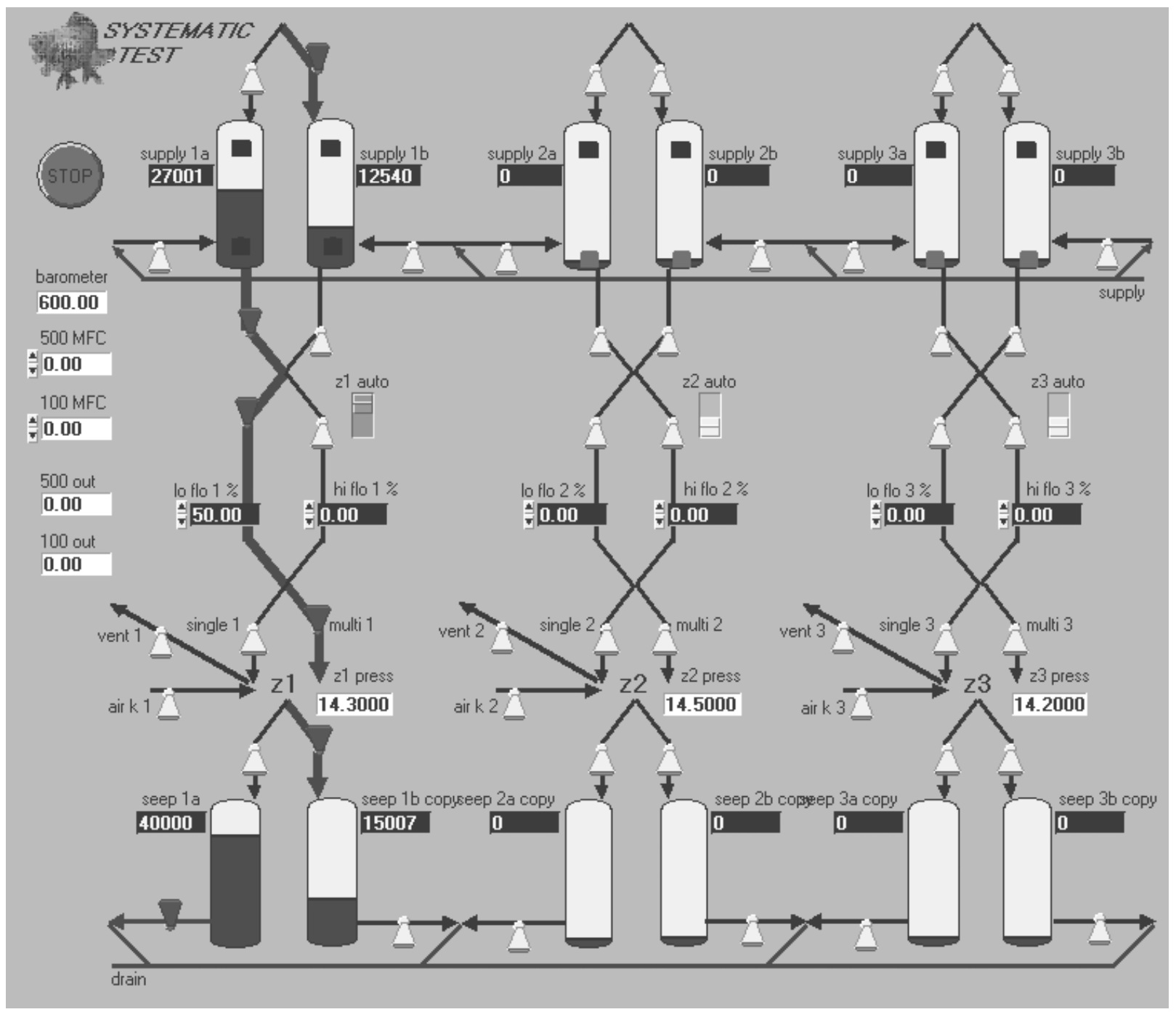

Figure 6-129. Schematic Illustration of Front Panel for Control Interface on Computer

\subsection{System Fail-Safes}

To avoid overfilling of the bottles or the pumps running dry in the event of a failure in the automatic control system, or inadvertent use of the controls on manual setting, the system employs float switches at the top and bottom of the bottles as a backup to the automation. The bottom float switches when triggered (depicted in light gray in Figure 6-129 for the Zone 2 and Zone 3 systems), forcing the associated pumps to stay off even if requested by a user or automation system to operate. The top float switches interrupt the electrical current to the fill valves when triggered. In the event of a computer shutdown such as during a power failure, all the relays and pump controls are turned off, causing the system to default to a stand-by mode. 


\subsubsection{Systematic Testing Results and Observations}

Sets of completed tests in four low-angle boreholes (belonging to Group I as noted in Figure 6-127), Borehole ECRB-SYBT-LA\#1, Borehole ECRB-SYBT-LA\#2, Borehole ECRB-SYBT-LA\#3, and Borehole ECRB-SYBT-LA\#4, will be described in Sections 6.11.2.1 through 6.11.2.12 in the order in which tests were performed.

\subsubsection{Air-Injection Tests and Liquid-Release Tests in LA\#2, Initiated on May 11, 2000}

Borehole ECRB-SYBT-LA\#2 (also referred to as LA\#2) is collared at ECRB Cross-Drift Station CD 17+26. Three packers isolated the borehole into three zones. The vertical distance from the middle of the 1.83-m-long liquid-release interval of Zone 1, Zone 2, and Zone 3 to the drift crown is $1.58 \mathrm{~m}, 2.84 \mathrm{~m}$, and $4.10 \mathrm{~m}$, respectively.

Air-permeability estimates for the three zones are calculated from the steady-state pressure response induced by constant-flow-rate air injection; the estimates are summarized in Table 6-29 (DTN: LB00090012213U.001 [DIRS 153141]).

Table 6-29. Air-Permeability Values for the Three Zones in Borehole LA\#2

\begin{tabular}{|c|c|c|c|}
\hline Zone ID & $\begin{array}{c}\text { Zone Length } \\
(\mathbf{m})\end{array}$ & $\begin{array}{c}\text { Air Permeability } \mathbf{k}\left(\mathbf{m}^{\mathbf{2}}\right), \\
\text { for Packer Inflation at } \\
\mathbf{2 7 . 5} \text { PSI }\end{array}$ & $\begin{array}{c}\text { Air Permeability } \mathbf{k}\left(\mathbf{m}^{2}\right) \\
\text { for Packer Inflation at } \\
\mathbf{3 2 . 5} \text { PSI }\end{array}$ \\
\hline LA\#2 Zone 1 & 1.83 & $2.5 \times 10^{-11}$ & $2.3 \times 10^{-11}$ \\
\hline LA\#2 Zone 2 & 1.83 & $2.7 \times 10^{-11}$ & $2.5 \times 10^{-11}$ \\
\hline LA\#2 Zone 3 & 5.18 & $1.1 \times 10^{-11}$ & $0.95 \times 10^{-11}$ \\
\hline
\end{tabular}

Source: DTN: LB00090012213U.001 [DIRS 153141].

$\mathrm{PSI}=$ pounds per square inch.

Pressure response and injection flow rates are shown in Figure 6-130. The fast rise and decay of the pressure in response to initiation and termination of air injection indicate very little storage effect. The air-permeability measurements were repeated for a lower and higher packer inflation pressure. The repeatability of the two measurements for different packer inflation pressure indicates that there was minimal between-zone leakage from improper sealing of the packers.

Following the air-injection tests in all three zones, a liquid-release test was conducted in Zone 1 only. A large liquid release rate of approximately $450 \mathrm{~mL} / \mathrm{min}$ was initiated in Zone 1 through one single release point in the 1.83-m-long injection zone. No return flow was detected; this indicated that all released water was able to enter the rock formation through the injection section. Figure 6-131 gives the cumulative volume of water supplied to Zone 1 (left axis) and the cumulative volume of water collected in the seepage-collection system (right axis) as a function of time. Figure 6-131 indicates that the initiation of water release was at 9:31 am and the start of seepage collection was at 12:00 (although a wet spot first appeared at the drift ceiling at 11:10, and water began to seep shortly after). Understandably, a time lag existed between the first wetting of the drift ceiling and the time when enough water had collected in the seepage-collection cylinder to cause a measurable change in the water level (nominally, a 3-mm change in water level for every $100 \mathrm{~mL}$ of water). The wetting of the drift ceiling expanded with time, and by $15: 15$, the wetted area was approximately $0.8 \mathrm{~m}^{2}$. The following morning 
(May 12, 2000), it was noted that in addition to the seepage from the wetted drift ceiling directly below the injection zone, water was also seeping through a rock bolt borehole beyond the edge of the capture curtain. The capture curtain was $4 \mathrm{~m}$ in length and was approximately centered below the $1.83-\mathrm{m}$ liquid injection zone. Seeped water from the rock bolt borehole was missed by the seepage collection data acquisition and may be related to the recorded decrease in seepage rate after approximately 20:00 on May 11 (as shown in Figure 6-131). The water release into Zone 1 was terminated at 8:36 on May 12, 2000.

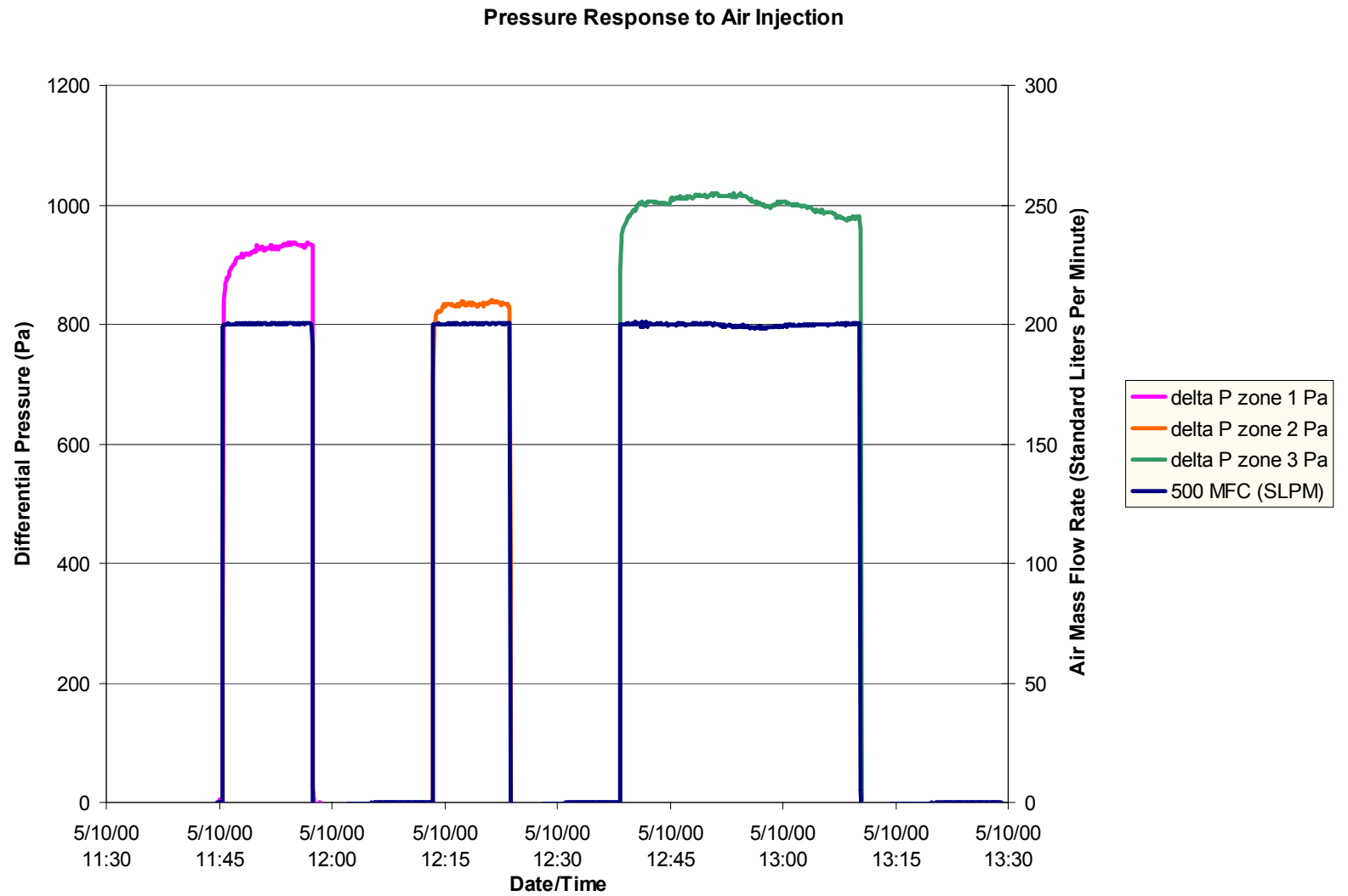

Source: DTN: LB00090012213U.001 [DIRS 153141].

Output DTN: LB0110SYST0015.001.

NOTE: $M F C=$ mass flow controller; $\mathrm{Pa}=$ Pascals; SLPM $=$ Standard liters per minute .

Figure 6-130. Pressure Responses (Pink, Orange, and Green) to Constant Mass Flow of Air-Injection (Blue) for Estimation of Fracture Permeability in Borehole ECRB-SYBT-LA\#2 


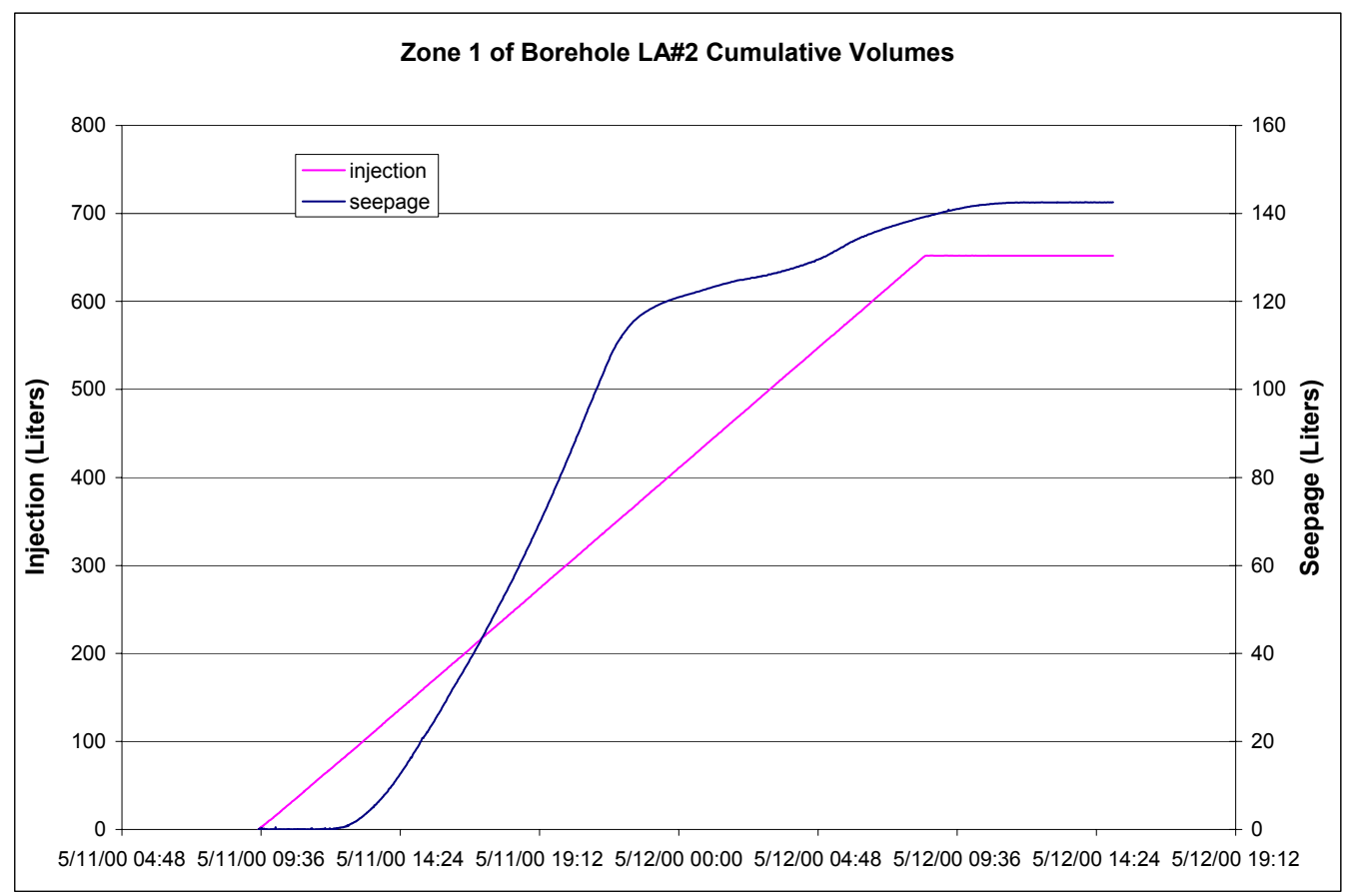

Source: DTN: LB00090012213U.002 [DIRS 153154].

Output DTN: LB0110SYST0015.001.

Figure 6-131. Cumulative Water Supplied to Zone 1 of Borehole ECRB-SYBT-LA\#2 and Cumulative Seepage into the ECRB Cross-Drift for a Test Performed between May 11 and May 12, 2000

\subsubsection{Liquid-Release Test in Zone 1, Zone 2, and Zone 3 in Borehole LA\#2, Initiated on May 17, 2000}

Between 11:45 am and 11:49 am on May 17, 2000, liquid release into Zones 1, 2, and 3 was initiated (Figure 6-132). The multipoint mode of injection was used so that water was evenly spread along each 1.83-m-long zone. A liquid-release rate of $30 \mathrm{~mL} / \mathrm{min}$ was intended for each zone. However, for the same specified water-release pump rate, the actual release rate to each zone would differ because of the difference in zone elevation. Figure 6-132 shows the cumulative volume of water supplied to Zones 1, 2, and 3 (left axis) and the cumulative volume of seepage (right axis). Note that seepage from Zone 1 was recorded beginning on May 18, 2000 (3:11), but seepage from Zone 2 and Zone 3 was never above the noise level of the data. In the morning of May 18, 2000, it was found that the software controlling the filling of supply Bottle B was not functioning properly. Delivery of water to all three zones was therefore terminated May 18, 2000 (9:08). Figure 6-132 shows that the cumulative volume of water supplied to Zone 1, Zone 2, and Zone 3 ceases to increase after May 17, 2000 (21:23), May 18, 2000 (0:39), and May 18, 2000 (7:13), respectively. These were the times at which Bottle A was empty and the water supply was switched to Bottle B. However, onsite inspection revealed that refill of Bottle B was being mechanically controlled by the float switches. Consequently, water was continually being released from Bottle $\mathrm{B}$, presumably at the prevailing pumping rate prior to the fill problem. Therefore, although Figure 6-132 gives the false impression of no cumulative 
increase in supply water, in fact water was being supplied to the rock formation from Bottle B, possibly at the prevailing rate (as supplied by Bottle A), until May 18, 2000 (9:08).

The noise in the cumulative seepage data in Figure 6-132 (and in subsequent figures showing seepage rate data) can be attributed to the slow response time of the differential-pressure transducers to atmospheric pressure fluctuations. Although the water level in the seepage-collection cylinders responded instantaneously to the atmospheric fluctuations, filters placed in the differential-pressure-transducer ports caused a delayed response. The filters were originally put in place to keep the ports clean; they were removed in late May 2001. As a result of this and other random errors and fluctuations, cumulative seepage rates presented in the figures below may occasionally show a decline. Such temporal declines in cumulative volumes associated with small seepage rates are not physical.

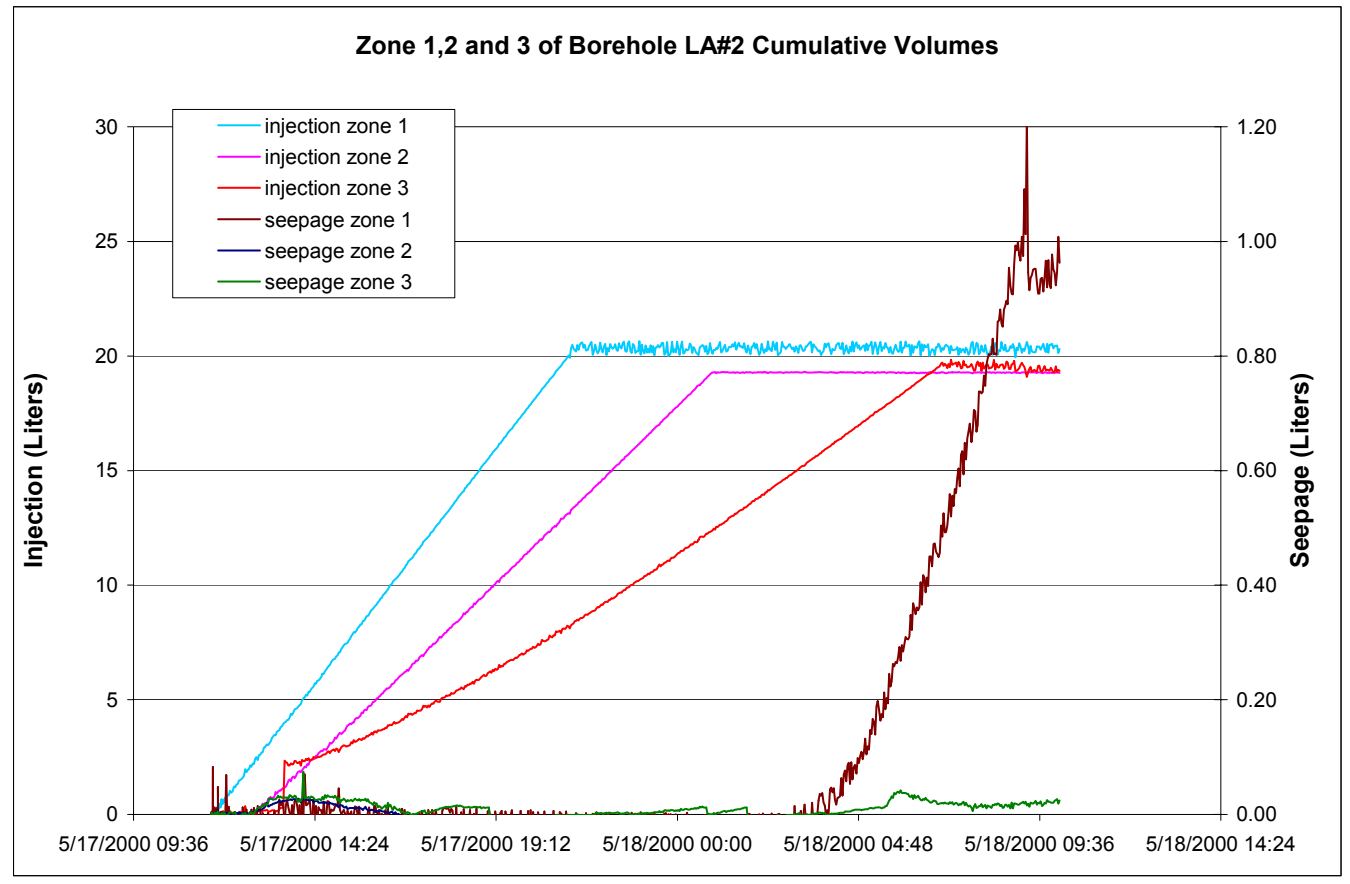

Source: DTN: LB00090012213U.002 [DIRS 153154].

Output DTN: LB0110SYST0015.001.

NOTE: Temporal declines in cumulative volumes associated with small seepage rates are not physical; they are a result of slow response times of the differential-pressure transducers and other random fluctuations.

Figure 6-132. Cumulative Water Supplied to Zones 1, 2, and Zone 3 of Borehole ECRB-SYBT-LA\#2 and Cumulative Seepage into the ECRB Cross-Drift for Tests Performed between May 17 and May 18, 2000 


\subsubsection{Liquid-Release Test in Zone 1, Zone 2, and Zone 3 in Borehole LA\#2, Initiated on May 23, 2000}

The faulty software control of the filling function in the May 17, 2000, tests was resolved. Liquid-release tests from multiple points in Zone 1, Zone 2, and Zone 3 were resumed at 14:25 on May 23, 2000, at the intended rate of $30 \mathrm{~mL} / \mathrm{min}$. Data for the three zones will be discussed separately.

\subsection{Zone 1}

Figure 6-133 shows cumulative supply (left axis) and cumulative seepage volume (right axis) as a function of time from May 23, 2000, to June 1, 2000, 11:14, when water release was terminated. Data show that seepage collection initiated on May 24, 2000, 13:19, although a wetted spot approximately $0.5 \mathrm{~m}$ in diameter was observed as early as 8:40. The rate of supply water was approximately $28 \mathrm{~mL} / \mathrm{min}$, and the rate of seepage stabilized to approximately 4 to $5 \mathrm{~mL} / \mathrm{min}$ within a week.

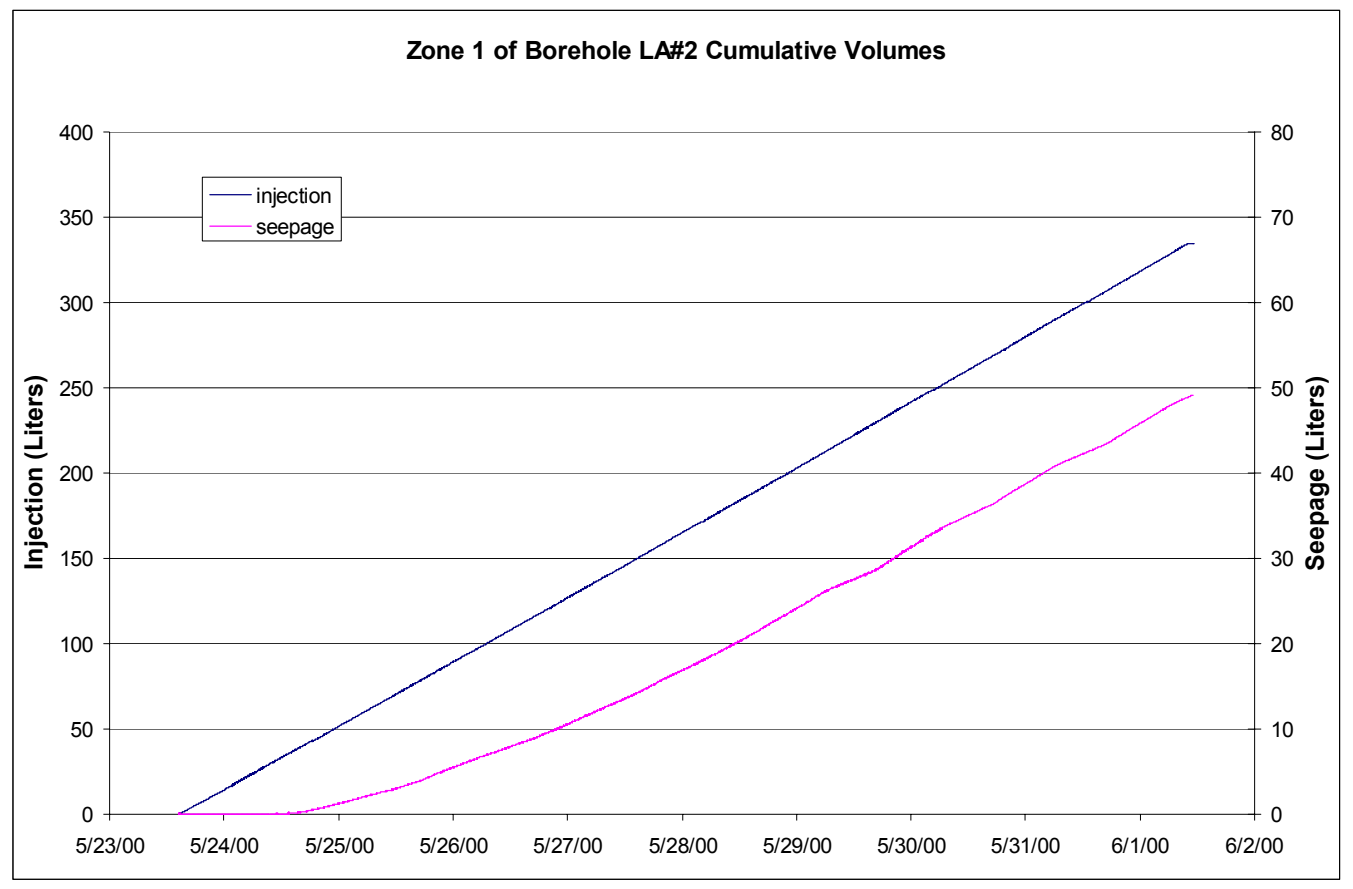

Source: DTN: LB00090012213U.002 [DIRS 153154].

Output DTN: LB0110SYST0015.001.

Figure 6-133. Cumulative Water Supplied to Zone 1 of Borehole ECRB-SYBT-LA\#2 and Cumulative Seepage into the ECRB Cross-Drift for Tests Performed between May 23 and June 1, 2000

\subsection{Zone 2}

Water release continued from May 23, 2000, through June 8, 2000. Multiweek liquid-release tests were stopped and restarted periodically to keep data files at a manageable size. Every time the software control routine was restarted, new data files with date/time stamp were generated, 
and cumulative supply and seepage reference was restarted at zero. Figure 6-134 shows cumulative supply (left axis) and cumulative seepage volume (right axis) in two graphs:

Panel a - (representing the period from May 23 to June 1) and

Panel $\mathrm{b}-$ (representing the period from June 1 to June 8)

because the test was stopped on June 1, 2000, 11:14 and restarted at June 1, 11:23. Panel a of Figure 6-134 shows that seepage from Zone 2 initiates on May 29, 2000, at 20:26. Step-like structures are very prominent in the cumulative volume of seepage water data in Panel b of Figure 6-134, indicating two different slopes and therefore different rates of seepage. The periods of larger slope (higher seepage rate of approximately $2-3 \mathrm{~mL} / \mathrm{min}$ ) in Panel $b$ of Figure 6-134 can be correlated to evenings and weekends when the underground tunnels were closed for access and the ventilation system was not in operation. Data in Figure 6-133 for Zone 1 also give different slopes for seepage-water volume versus time, depending on whether ventilation is on or off. The step-like signature in Figure 6-133 is subtler than that in Panel b of Figure 6-134 because of the higher seepage rate in Zone 1. That water seeping into the drift has partly evaporated places uncertainty on the seepage data, because even when the ventilation is not in operation in the evenings and on weekends, the relative humidity in the underground tunnels is still far below 100 percent. As a result, although data in Figure 6-133 and Figure 6-134 give a measure of the amount of water lost to evaporation promoted by active ventilation, they do not provide data on the amount of water lost to evaporation in the absence of active ventilation. In response to these initial results, subsequent tests the systematic measuring system was modified for subsequent tests to incorporate measurements of relative humidity and evaporation rate (from an open pan) in the tunnel space between the drift crown and the seepage-collection PVC curtain enclosure. No direct measurement system exists to ascertain the evaporation rate from within the fracture system.

\subsection{Zone 3}

Cumulative supply and cumulative seepage data for Zone 3 between May 23, 2000, and June 27, 2000, are presented in Panels a through d of Figure 6-135. Because of unanticipated experimental problems concerning the interface between the software control and the valves controlling the water supply system for this zone, the release of water was interrupted for two periods during 34 days of testing. The periods where no water was supplied were:

(1) two days (between May 30 and June 1), and

(2) 11 days (between June 3 and June 14).

The problem was fully corrected from June 14 onwards, and the first indication of seepage water being collected in the seepage bottles for Zone 3 was recorded by the data acquisition system on June 26, 2000, at noon. Other testing activities in the underground tunnel necessitated the termination of water release in Zone 3 (as well as monitoring of data), only approximately eight hours after the first onset of seepage. 
(a)

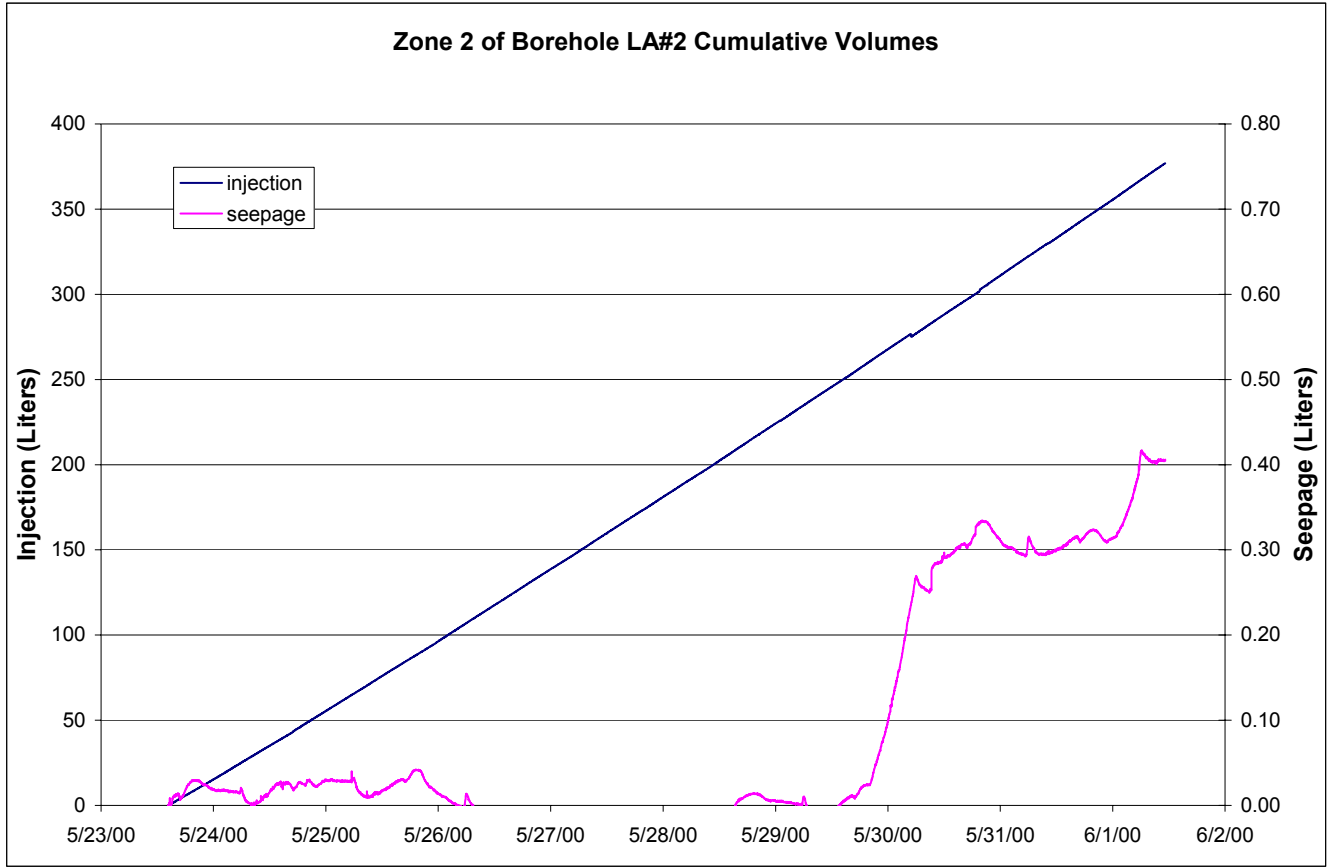

(b)

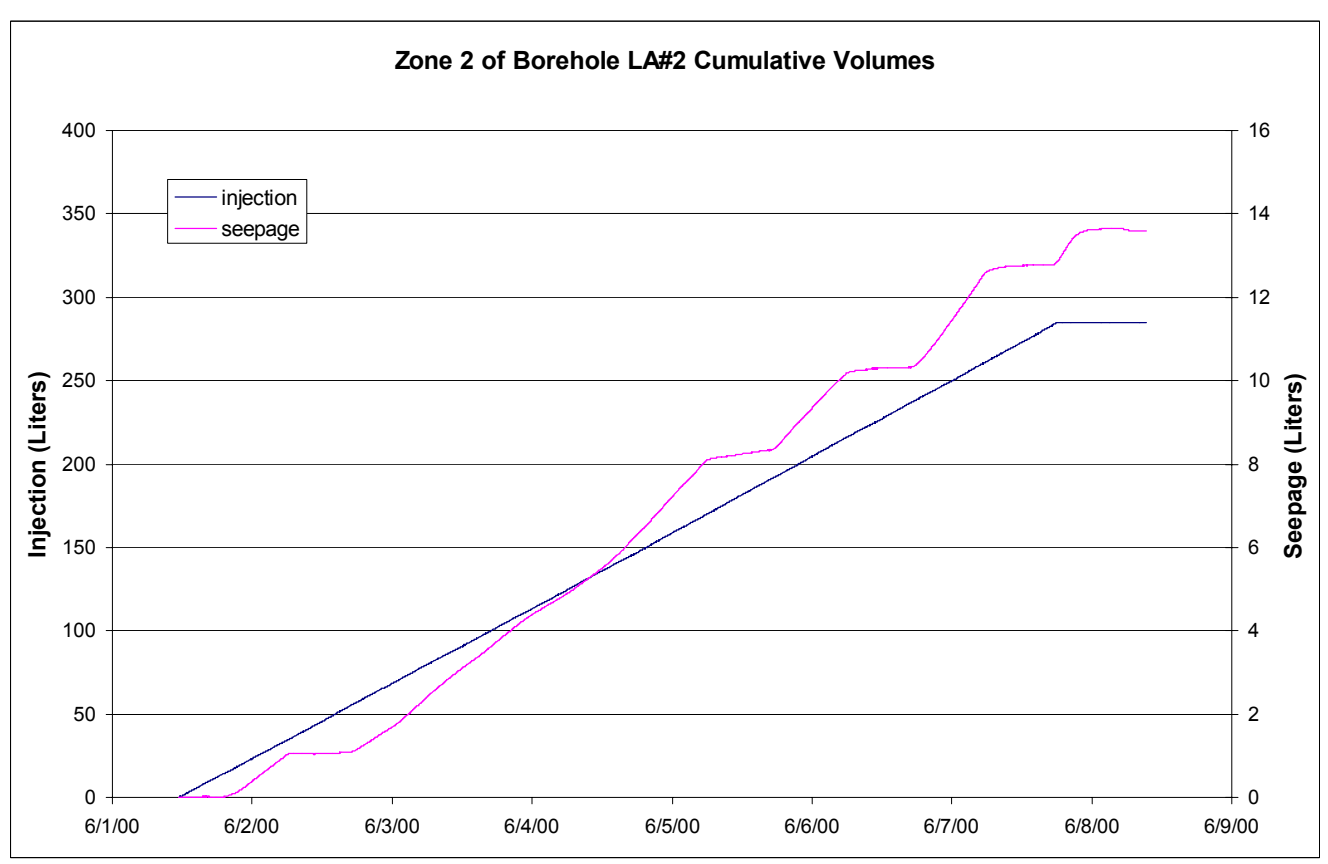

Source: DTN: LB00090012213U.002 [DIRS 153154].

Output DTN: LB0110SYST0015.001.

NOTES: Temporal declines in cumulative volumes associated with small seepage rates shown in Panel a of Figure 6-134 are not physical; they are a result of slow response times of the differential-pressure transducers and other random fluctuations.

Panel $a$ = May 23-June 1, 2000; Panel $b=$ June 1-June 8, 2000

Figure 6-134. Cumulative Water Supplied to Zone 2 of Borehole ECRB-SYBT-LA\#2 and Cumulative Seepage into ECRB Cross-Drift for Tests Performed between May 23 and June 8, 2000 
(a)

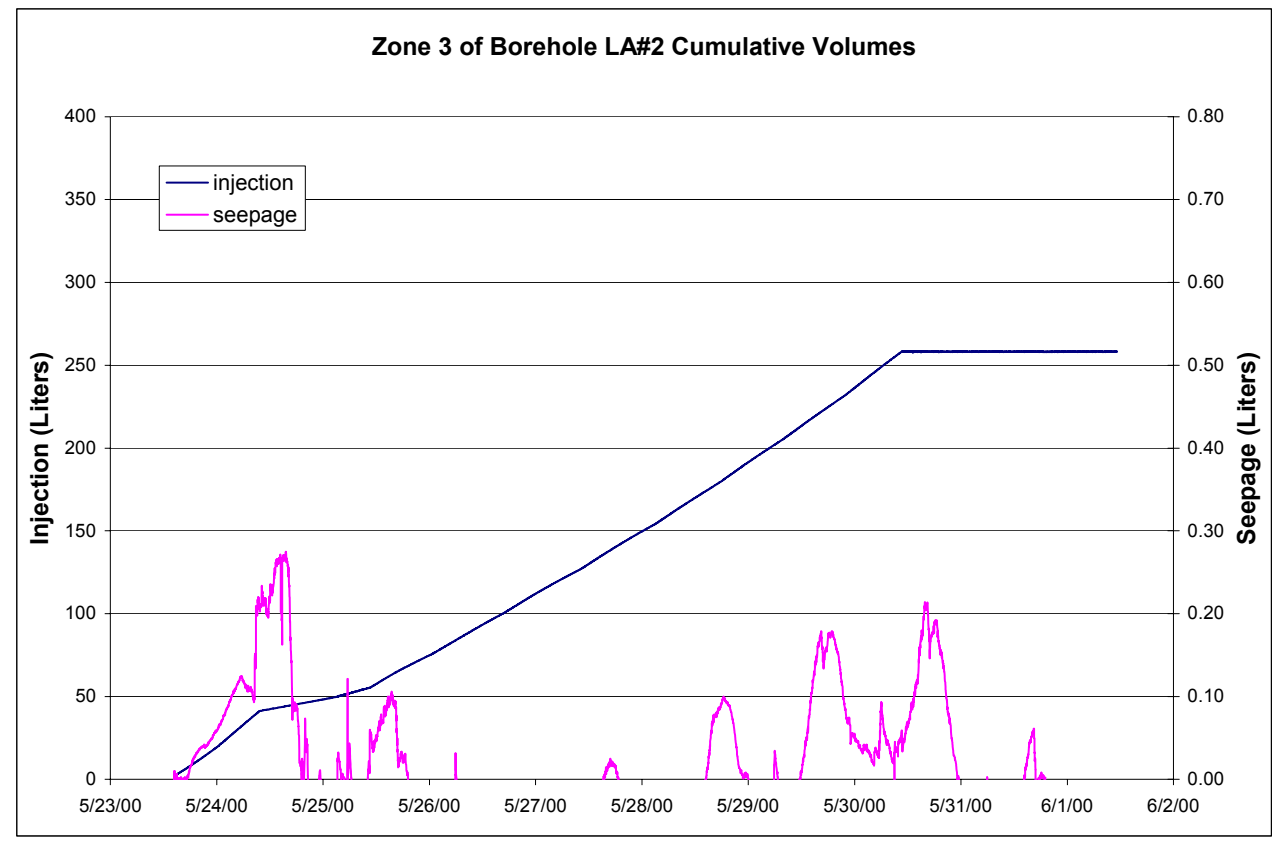

(b)

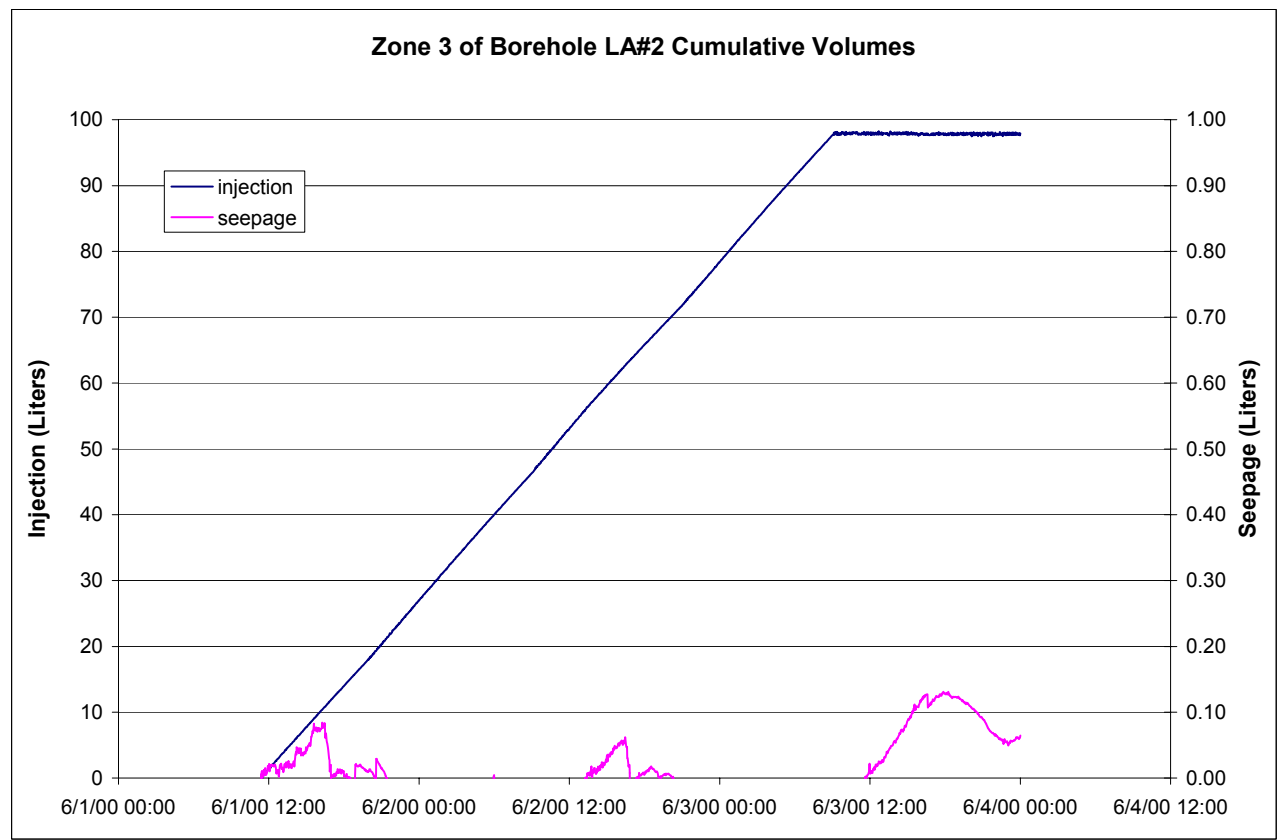

Source: DTN: LB00090012213U.002 [DIRS 153154].

Output DTN: LB0110SYST0015.001.

NOTES: Temporal declines in cumulative volumes associated with small seepage rates are not physical; they are a result of slow response times of the differential-pressure transducers and other random fluctuations.

Panel $a=$ May 23-June 1; Panel b = June 1-June 4; Panel c = June 14-June 18; and Panel $\mathrm{d}=$ June 18-June 27.

Figure 6-135. Cumulative Water Supplied to Zone 3 of Borehole ECRB-SYBT-LA\#2 and Cumulative Seepage into ECRB Cross-Drift for Tests Performed between May 23 and June 27, 2000 
(c)

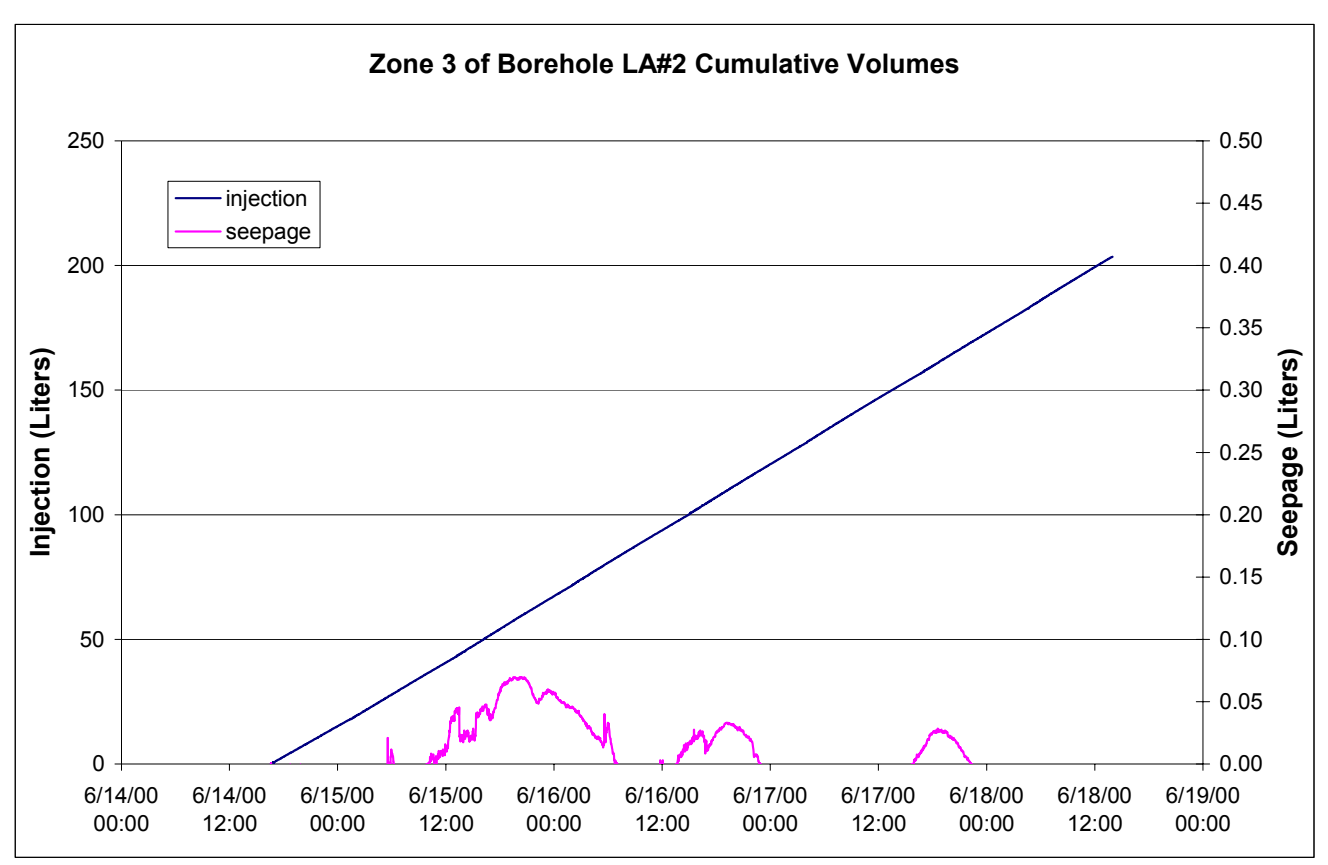

(d)

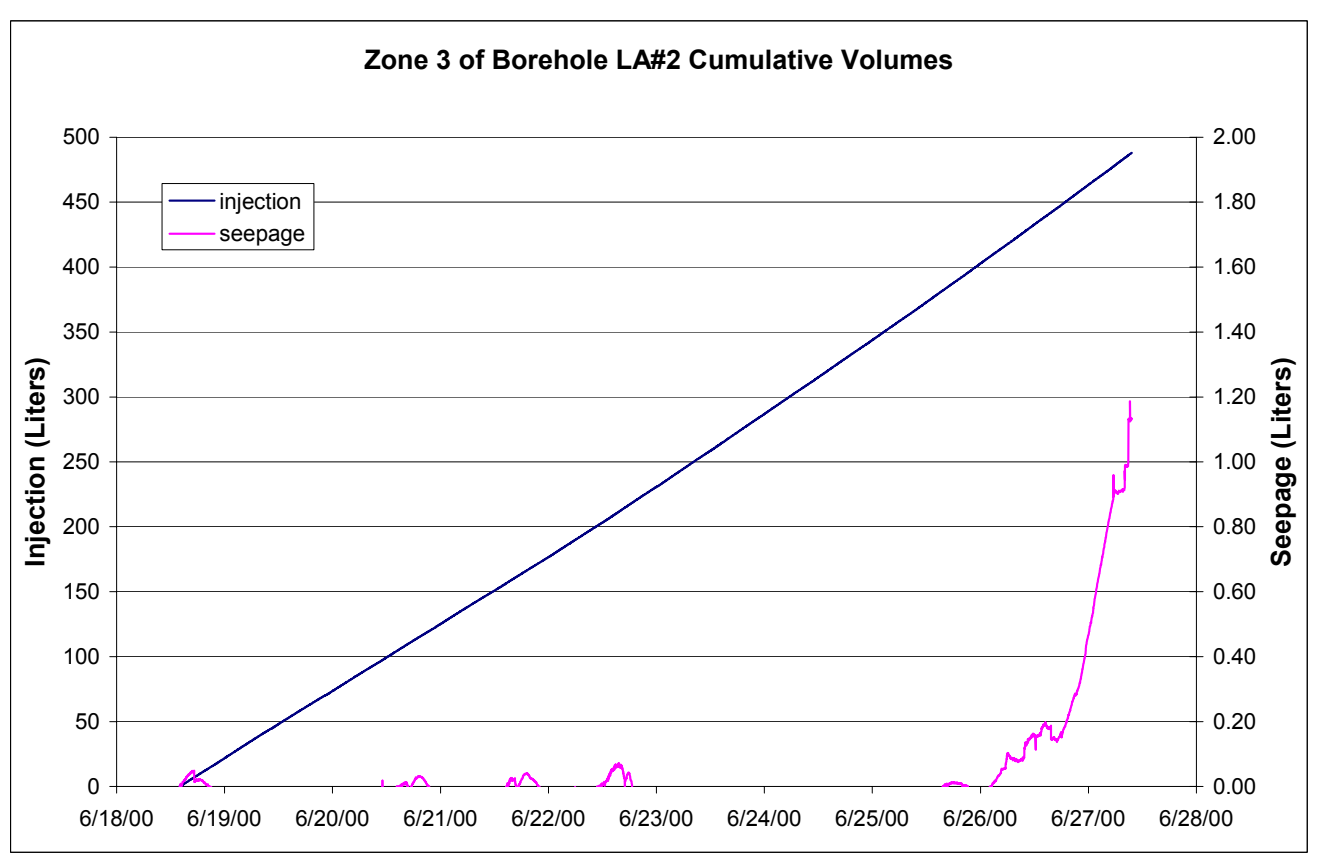

Source: DTN: LB00090012213U.002 [DIRS 153154].

Output DTN: LB0110SYST0015.001.

NOTES: Temporal declines in cumulative volumes associated with small seepage rates are not physical; they are a result of slow response times of the differential-pressure transducers and other random fluctuations.

Panel $a=$ May 23-June 1; Panel $b=$ June 1-June 4; Panel $c=$ June 14-June 18; and Panel $\mathrm{d}=$ June 18-June 27.

Figure 6-135. Cumulative Water Supplied to Zone 3 of Borehole ECRB-SYBT-LA\#2 and Cumulative Seepage into ECRB Cross-Drift for Tests Performed between May 23 and June 27, 2000 (Continued) 


\subsubsection{Liquid-Release Test in Zone 2 and Zone 3 in Borehole LA\#2: October 23 to December 1, 2000}

Other activities in the ECRB Cross-Drift prevented the redeployment of systematic testing equipment for four months after the tests described in Section 6.11.2.3. In this later set of testing, liquid-release tests were repeated in Zone 2 and Zone 3 of Borehole LA\#2, specifically to evaluate the impact of evaporation from active ventilation and less-than-100-percent relative humidity on seepage data. The following modifications to the test design and measuring system were made after completion of the previous test in June 2000:

- Additional curtains were installed on the two ends of the V-shaped seepage-capture PVC curtains shown in Figure 6-128, to mitigate drying of the wetted drift crown from ventilation.

- Humidity and temperature sensors were placed within the curtain enclosures of Zone 2 and Zone 3 to investigate the correlation of humidity conditions to seepage data.

- A camera was installed to observe the drift ceiling below the injection section of Zone 2 to monitor the evolution of wetting.

Cumulative water supply and cumulative seepage data for Zones 2 and 3 are shown in Figure 6-136. Data show that the first recorded seepage (as indicated by a rise in water level in the seepage collection cylinder) occurred on October 31 at approximately 20:00, for both Zone 2 and Zone 3. Observations taken periodically of the drift ceiling below Zone 2 indicate that a wetted area first appeared on October 27 around 8:00 and expanded with time. The wetted area on the drift ceiling could be estimated by counting the number of ground-support wire-mesh grids it covered. Observations indicate that by November 7, 2000, the wetted area stopped expanding and stabilized at approximately $6.8 \mathrm{~m}^{2}$.

Derivatives of the cumulative supply and cumulative seepage from Figure 6-136 give the rates of supply and seepage. Supply rate, seepage rate, and relative humidity and temperature within the capture curtain enclosure for Zone 2 and Zone 3 are shown in Figure 6-137 and Figure 6-138, respectively. Note that the relative humidity was approximately 35 percent prior to initiation of seepage on October 31, 2000. Coincidentally, the vent line in the ECRB Cross-Drift collapsed on October 31, 2000, cutting off the ventilation. Note that the humidity within the capture curtain enclosures of Zone 2 and Zone 3 rose to almost 90 percent by November 7, 2000. Following the collapse of the vent line, ventilation was only partially restored (that is, power was on at times and off at times) in the ECRB Cross-Drift throughout the then-current set of tests, and the humidity reading varied with time between the pre-seepage value of 35 percent and the high of 90 percent.

Figure 6-137 and Figure 6-138 show that the seepage rates in Zones 2 and 3 track the relative humidity (that is, seepage rates increase and decrease with the rise and fall of relative humidity values). The seepage rate in Zone 3 is higher than that in Zone 2, reaching a high of approximately $6 \mathrm{~mL} / \mathrm{min}$. This may result from the higher water-release rate in Zone 3 (approximately $38 \mathrm{~mL} / \mathrm{min}$, as compared to approximately $34 \mathrm{~mL} / \mathrm{min}$ in Zone 2). Possibly, the smaller size of the wetted area on the drift ceiling in Zone 3 (compared to that in Zone 2) led to 
less evaporation and thus higher seepage in Zone 3. Note that the measuring system had only one camera positioned to monitor Zone 2, and the vent-line collapse and subsequent delay in repair prevented access to the Borehole LA\#2 test site for direct observation of the drift ceiling. Note also that there were several brief periods of interruption of liquid release on November 26 , 29, and 302000 (these show up as abrupt changes in Figure 6-136) as a result of network-connection power outages and problems with the equipment-computer interface. These control-program shutdowns required a few restarts of liquid injection. Liquid release to Zone 2 and Zone 3 was terminated on December 1, 2001.

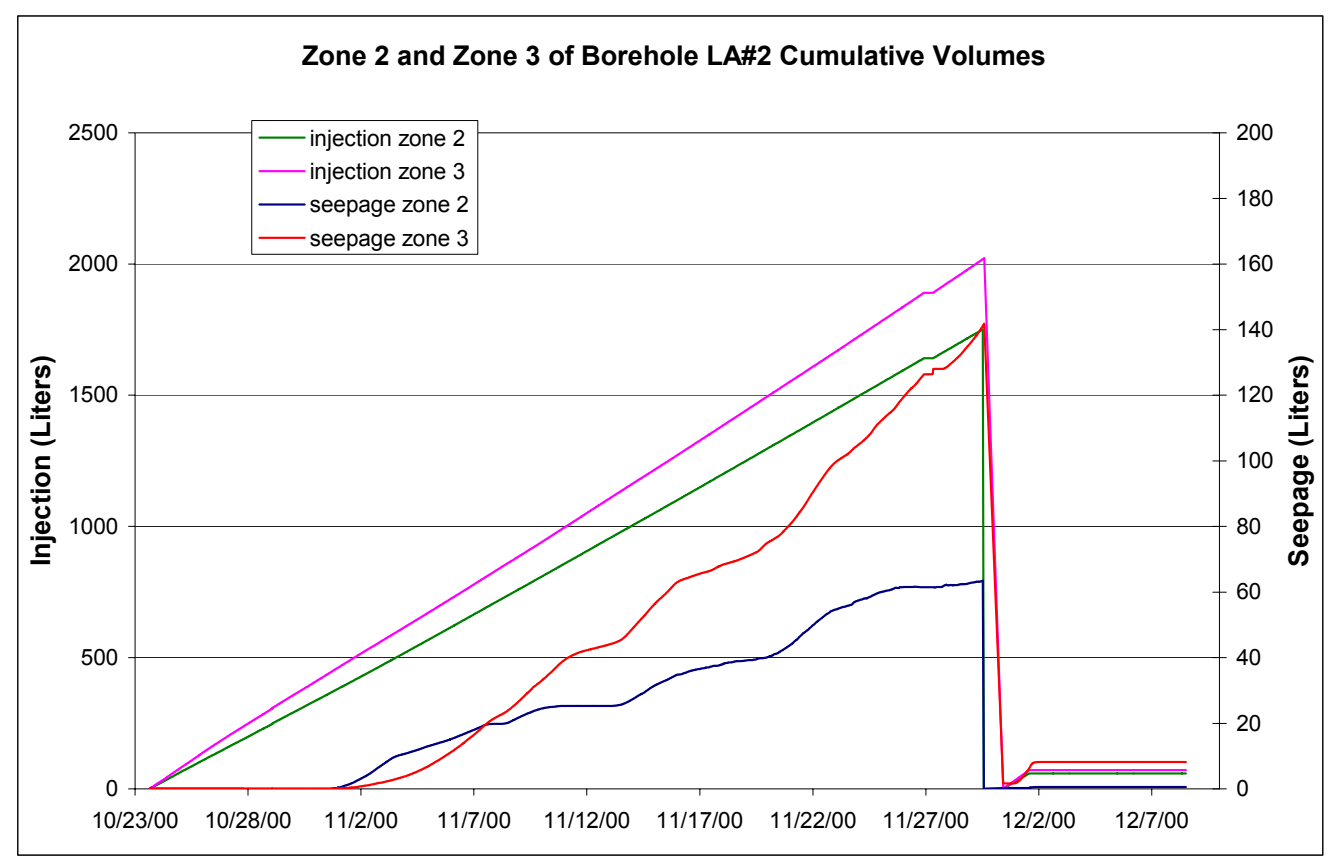

Source: DTN: LB0110ECRBLIQR.003 [DIRS 156877].

Output DTN: LB0110SYST0015.001.

NOTE: Temporal declines in cumulative injection and seepage volumes shown in Panel a of Figure 6-140 are a result of resetting the water level in the supply and seepage bottles.

Figure 6-136. Cumulative Water Supplied to Zone 2 and Zone 3 of Borehole ECRB-SYBT-LA\#2 and Cumulative Seepage into ECRB Cross-Drift for Test Performed between October 23, 2000, and December 1, 2000 


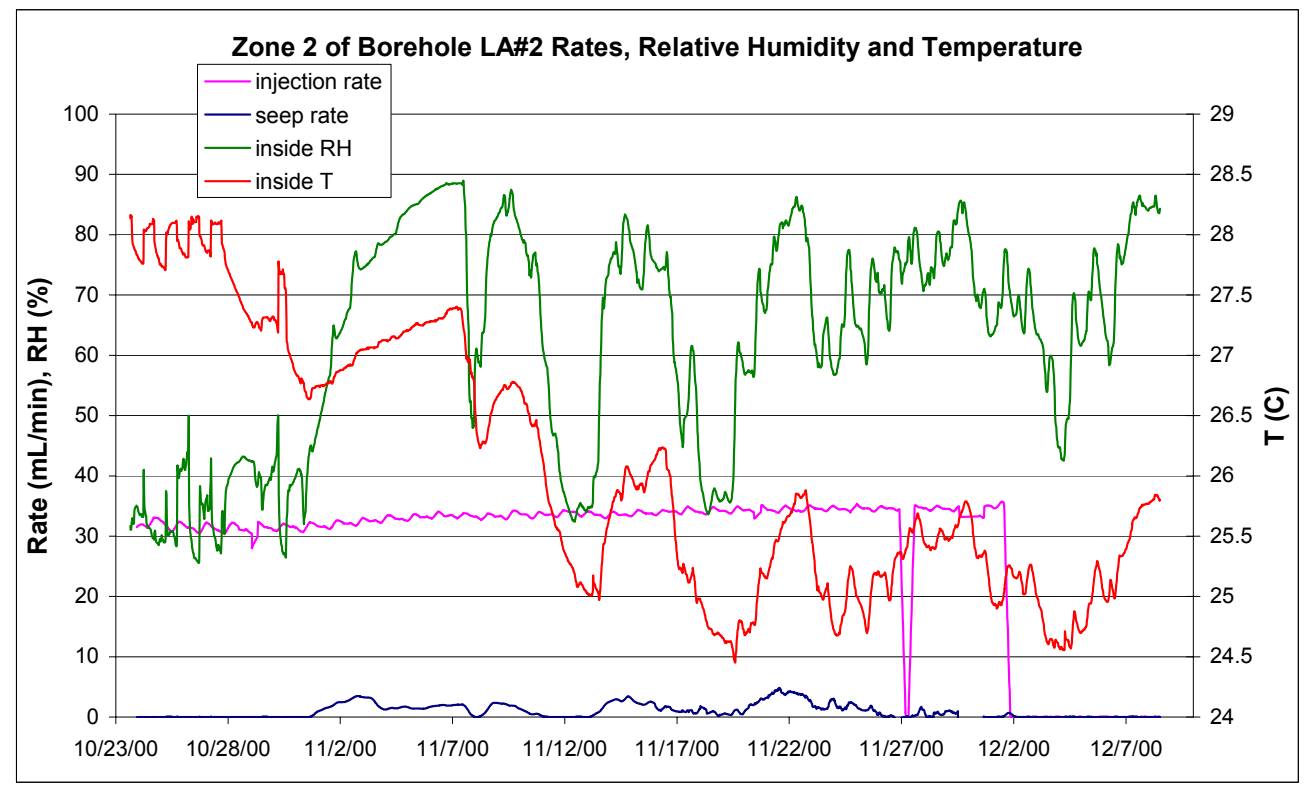

Source: DTN: LB0110ECRBLIQR.003 [DIRS 156877].

Output DTN: LB0110SYST0015.001.

Figure 6-137. Supply Rate, Seepage Rate and Relative Humidity and Temperature for Liquid-Release Test Performed in Zone 2 of Borehole ECRB-SYBT-LA\#2 between October 23, 2000, and December 1, 2000

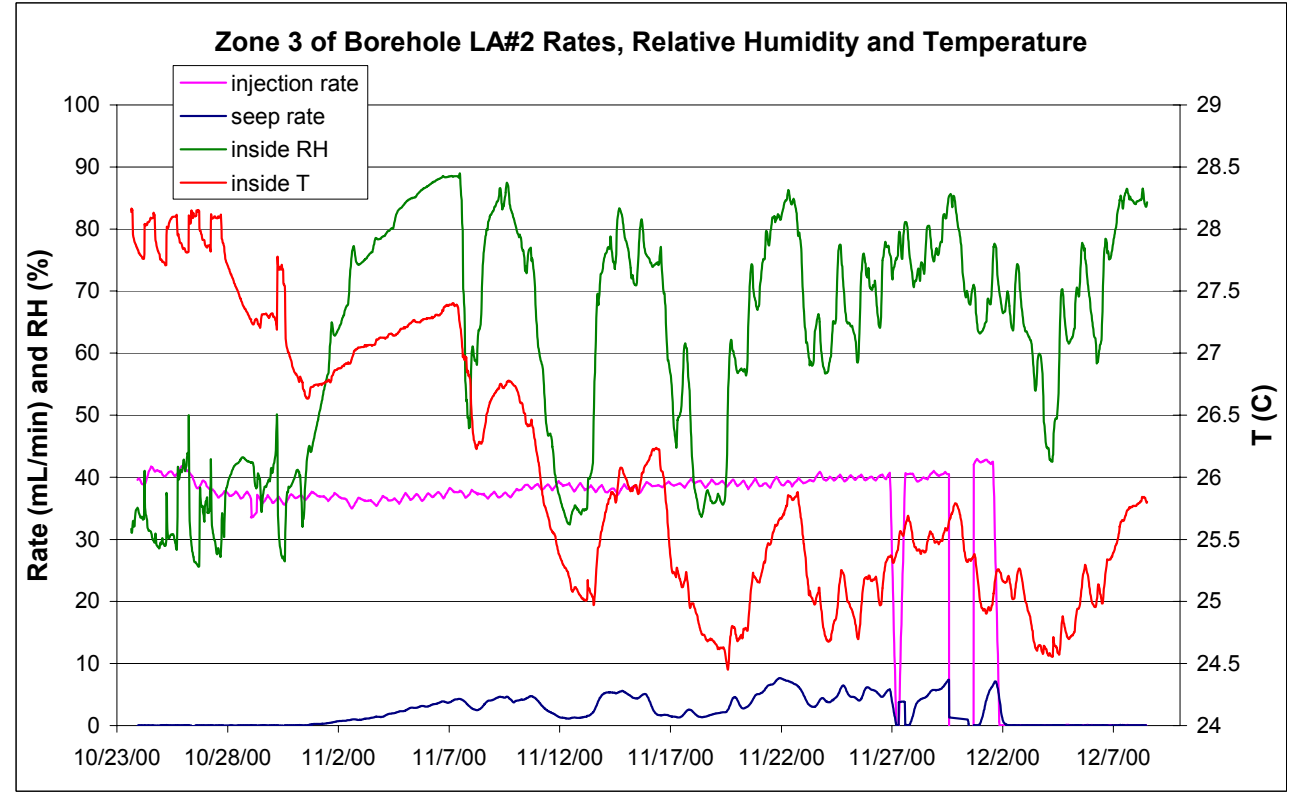

Source: DTN: LB0110ECRBLIQR.003 [DIRS 156877].

Output DTN: LB0110SYST0015.001.

Figure 6-138. Supply Rate, Seepage Rate, and Relative Humidity and Temperature for Liquid-Release Test Performed in Zone 3 of Borehole ECRB-SYBT-LA\#2 between October 23, 2000, and December 1, 2000 


\subsubsection{Liquid-Release Test in Zone 2 of Borehole LA\#1: December 20, 2000, to January 2, 2001}

Similar to Borehole ECRB-SYBT-LA\#2, Borehole LA\#1 is a low-angle near-horizontal borehole (inclination of 15 degrees from the ECRB Cross-Drift axis), drilled from the ECRB Cross-Drift crown. It is collared at ECRB Cross-Drift Station CD 17+49, immediately outside of the first bulkhead. Rock fragments that fell into the borehole (postdrilling) caused the borehole to be totally obstructed from the point $8.2 \mathrm{~m}$ from the collar to the end of the 20 -m-long hole. Therefore, only one zone instead of the intended three (as in Borehole LA\#2) was accessible for fluid testing.

Zone 2 was isolated by two inflated packers and nominally at $3.0-4.9 \mathrm{~m}$ from the collar. Therefore, height of mid-zone from drift crown was $1.03 \mathrm{~m}$. Liquid release carried out in this zone took place through the six equally spaced outlet nozzles. To better evaluate the impact of evaporation on the seepage data, an evaporation pan within the space enclosed by the seepage capture and end curtains was installed. A differential-pressure transducer monitored the drop in water level from evaporation. Liquid release into Zone 2 started on December 20, 2000, 14:56, with a water-release rate of $15 \mathrm{~mL} / \mathrm{min}$. The ECRB Cross-Drift was closed and not ventilated during the experimental period, so the test was run and monitored remotely. A power outage occurred shortly after 12:00 a.m. December 25 terminated the liquid injection and data acquisition at 0:22, December 26, 2000. Power was restored on December 28, 2000, and the data acquisition system was restarted remotely. Unfortunately, the pumps that deliver water could not be restarted properly. Also, observations taken periodically of the drift ceiling show the beginning of a wet spot the morning of December 25 prior to the power outage, indicating the first arrival of water to the drift ceiling. Panel a of Figure 6-139 shows that approximately $103 \mathrm{~L}$ of water had been released into Zone 2 at the time of this first arrival of water at the drift ceiling. Because the water release stopped approximately 15 hours later and could not be resumed, the test did not run long enough to generate seepage. Panels a and b of Figure 6-139 also show that the relative humidity within the curtain enclosure remained between approximately 12 and 14 percent, and temperature between approximately $26^{\circ} \mathrm{C}$ and $26.3^{\circ} \mathrm{C}$ throughout the data acquisition period. Panel $\mathrm{b}$ of Figure 6-139 shows that the data from the evaporation pan indicate the evaporation rate was approximately $3 \mathrm{~mm} /$ day.

The ECRB Cross-Drift was reopened January 2, 2001, but other field activities (such as opening of the bulkhead) required the removal of systematic test equipment from the ECRB Cross-Drift and prevented resumption of the liquid release test in Borehole LA\#1. Data acquisition in Borehole LA\#1 was terminated on January 2, 2001. 
(a)

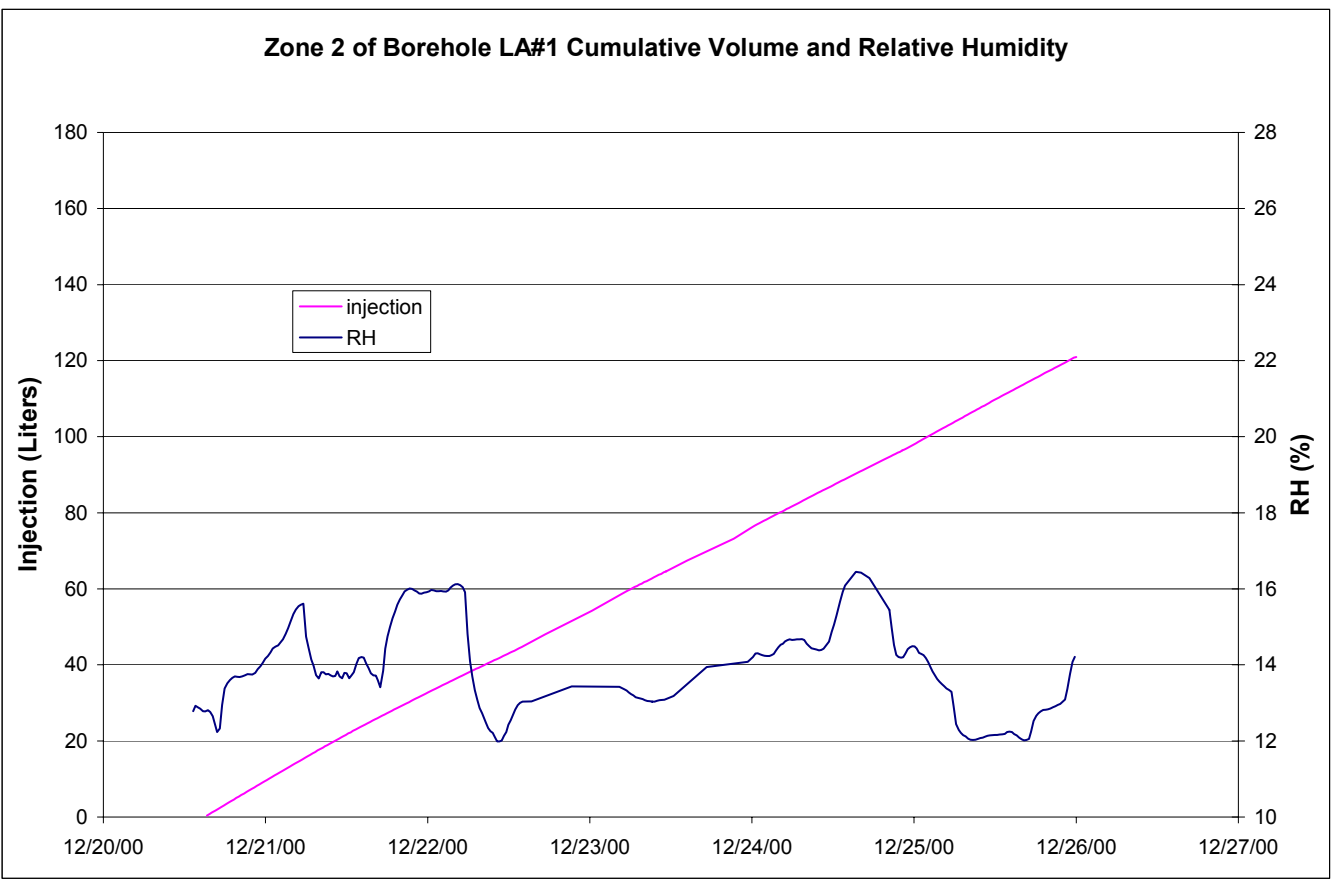

(b)

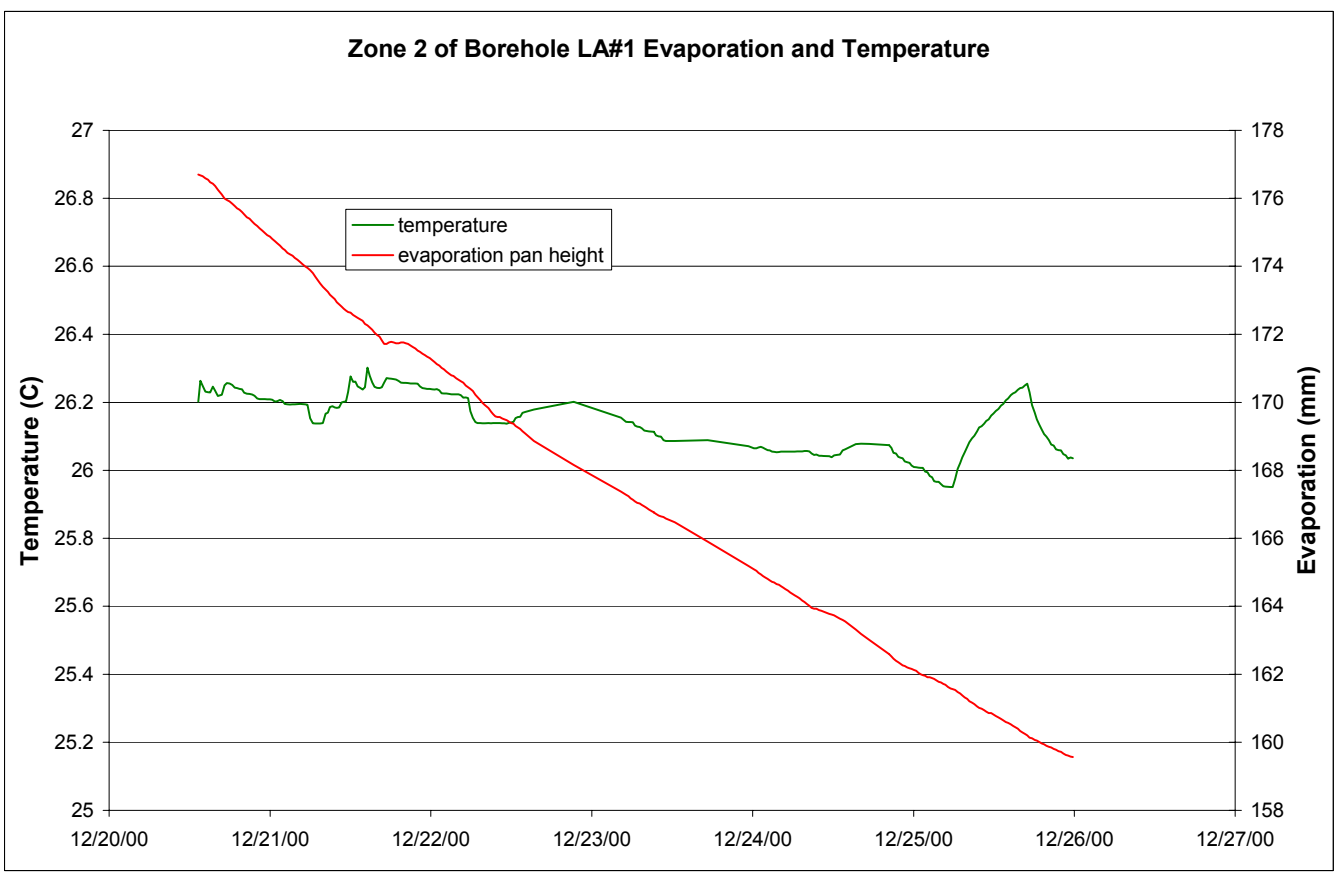

Source: DTN: LB0110ECRBLIQR.001 [DIRS 156878].

Output DTN: LB0110SYST0015.001.

NOTES: $\quad$ Panel $a=$ Relative humidity and cumulative water supplied to Zone 2 of Borehole ECRB-SYBT-LA\#1.

Panel $b=$ Temperature and water level in the evaporation pan for liquid-release test performed between December 20, 2000, and December 26, 2000.

Figure 6-139. Cumulative Supply Volume, Relative Humidity, Evaporation, and Temperature Measurements for Zone 2 of Borehole ECRB-SYBT-LA\#1 


\subsubsection{Liquid-Release Test in Zone 2 of Borehole LA\#1: February 28 to April 30, 2001}

This test, initiated on February 28, 2001, was a resumption of the test conducted in December 2000. Line release of water over a $1.83-\mathrm{m}$-long zone was initially set at the same rate as that of the December tests (approximately $15 \mathrm{~mL} / \mathrm{min}$ ). Observations show that the first appearance of a wet spot (water arriving at the drift ceiling) was on March 3, 2001, 16:23; that is, approximately 75 hours after initiation of water release. Panel a of Figure 6-140, which shows the cumulative supply and seepage of water, indicates that approximately $60 \mathrm{~L}$ of water had been introduced into the formation at this time. The seepage collection system (rise in water level in the seepage collection cylinder) registered the initiation of seepage at approximately 22:00 on March 15, 12 days after the observation of the first wetting on the drift ceiling. During this period, the actual water-release rate had increased from $14 \mathrm{~mL} / \mathrm{min}$ to more than $20 \mathrm{~mL} / \mathrm{min}$. Following March 15 was a three-day weekend when ventilation was turned off, during which time the average injection remained at approximately $20 \mathrm{~mL} / \mathrm{min}$, and average seepage was approximately $1 \mathrm{~mL} / \mathrm{min}$. Panel b of Figure 6-140 shows that on Monday, March 19, when ventilation resumed, the seepage rate decreased dramatically (almost to zero). This was true even during the next three-day weekend (March 23 to March 25). Recorded seepage continued to be approximately zero through the following week. Observations also show that the wetted area on the drift ceiling had shrunk. A study of the plotted data (Panel b of Figure 6-140) indicates that the average release rate during this period had fallen to around $18 \mathrm{~mL} / \mathrm{min}$. Data therefore indicate that, in general, the actual water-release rate needed to be above a threshold of $20 \mathrm{~mL} / \mathrm{min}$ for recorded seepage.

An unplanned interruption of water release occurred on March 29, 2001, 4:43, because of an air-compressor problem. Water release was resumed on April 3, 2001, 9:50, at $42 \mathrm{~mL} / \mathrm{min}$, and seepage-collection data acquisition began to record non-zero seepage at approximately 20 hours after resumption of water release.

A planned power outage caused another interruption of water release between April 5, 2001, 17:48, and April 9, 2001, 12:08. Water-release to Borehole LA\#1 resumed on April 9, 2001, 12:08, at a rate of approximately $42 \mathrm{~mL} / \mathrm{min}$. Data indicate the onset of seepage at approximately 20 hours after resumption of water release. The seepage rate increases from approximately $7 \mathrm{~mL} / \mathrm{min}$ to approximately $10 \mathrm{~mL} / \mathrm{min}$ on April 16, 2001. Water release was intentionally interrupted twice, each pause lasting for less than a day. The first pause of water release occurred on April 16, 2001, 15:22. After a pause of 18 hours and 20 minutes, water release was resumed, and seepage was observed approximately 16 hours later. On April 24, 2001, 16:54, water release was again interrupted, and restarted on April 25, 2001, 11:39. Seepage began approximately 16 hours after restart. Following both of these planned water-release pauses, the water-release rate was approximately $42 \mathrm{~mL} / \mathrm{min}$, and seepage was approximately $10 \mathrm{~mL} / \mathrm{min}$.

The declining water level in the evaporation pan (Panel c of Figure 6-140) indicated that the evaporation rate is approximately $3 \mathrm{~mm} /$ day. Coupling this data with the largest, relatively stable, wetted area estimated from observations of the drift ceiling (approximately $4.5 \mathrm{~m}^{2}$ ) would give an upper bound of the evaporation from the wetted drift surface a rate of $9.5 \mathrm{~mL} / \mathrm{min}$. Testing in Borehole LA\#1 was concluded on April 30, 2001. 
(a)

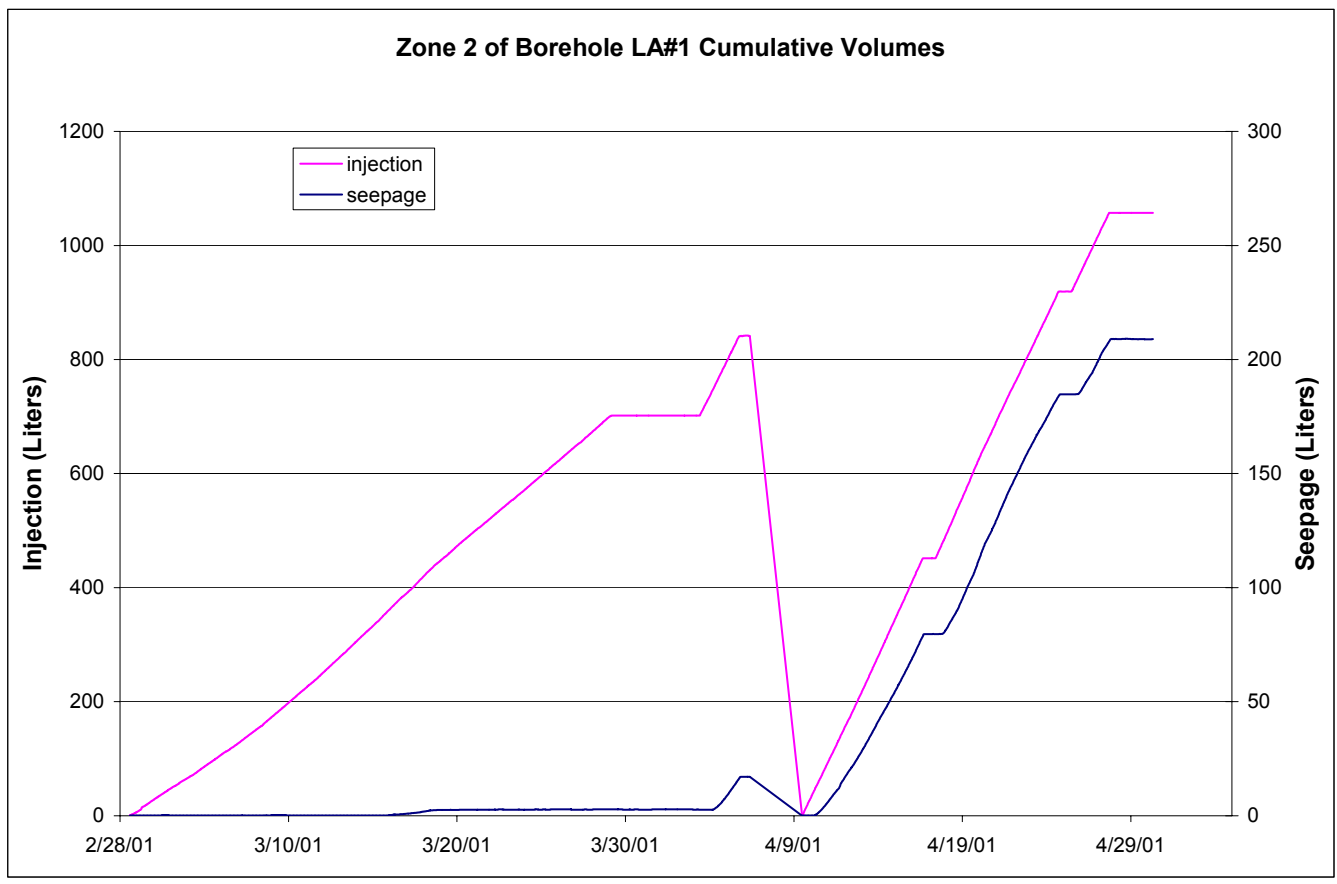

(b)

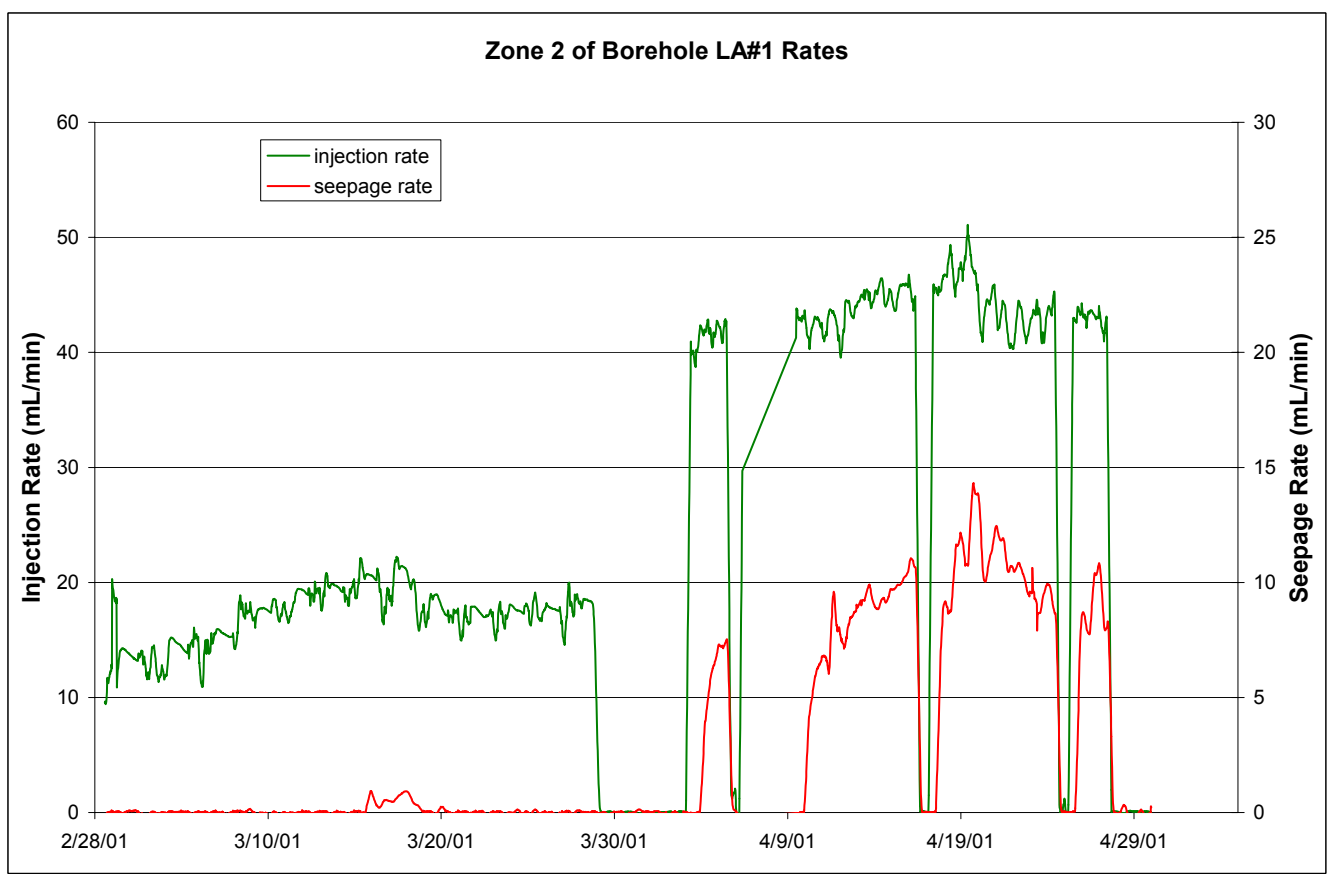

Source: DTN: LB0110ECRBLIQR.002 [DIRS 156879].

NOTES: Temporal declines in cumulative volumes shown in Panel a of Figure 6-140 are a result of resetting the water level in the supply and seepage bottles.

Panel a = Cumulative water supplied to Zone 2 of Borehole ECRB-SYBT-LA\#1 and related seepage for test performed between February 28 and April 30, 2001.

Panel $b=$ Water supply rate and seepage rate.

Panel c = Relative humidity, temperature, and the water level in the evaporation pan.

Figure 6-140. Measurements for Borehole Zone 2 of Borehole ECRB-SYBT-LA\#1 
(c)

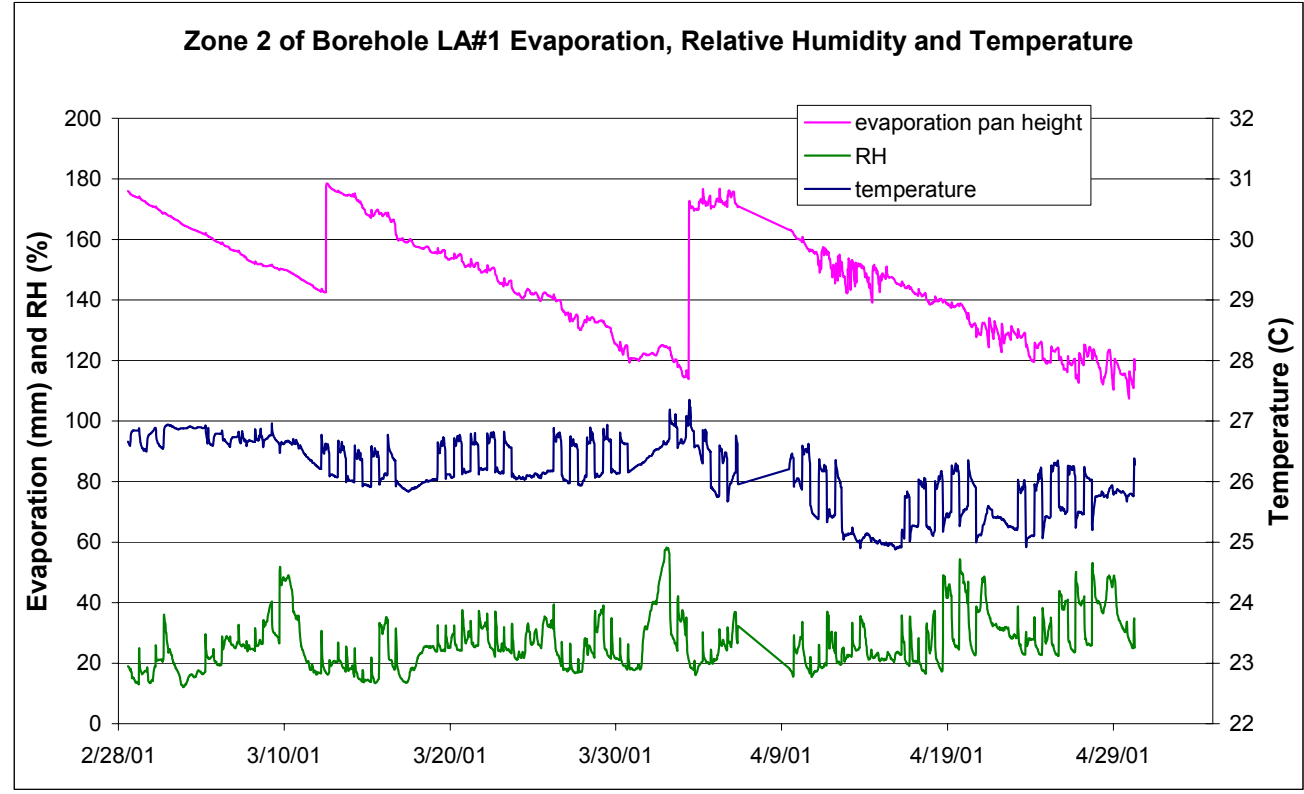

Source: DTN: LB0110ECRBLIQR.002 [DIRS 156879].

NOTES: Temporal declines in cumulative volumes shown in Panel a of Figure 6-140 are a result of resetting the water level in the supply and seepage bottles.

Panel a = Cumulative water supplied to Zone 2 of Borehole ECRB-SYBT-LA\#1 and related seepage for test performed between February 28 and April 30, 2001.

Panel $b=$ Water supply rate and seepage rate.

Panel $\mathrm{c}=$ Relative humidity, temperature, and the water level in the evaporation pan.

Figure 6-140. Measurements for Borehole Zone 2 of Borehole ECRB-SYBT-LA\#1 (Continued)

\subsubsection{Borehole LA\#3 and Liquid-Release Test in Zone 1, Borehole LA\#3: May 10 to June 18, 2001}

Tests in Borehole ECRB-SYBT-LA\#3 (also known as Borehole LA\#3) began on May 10, 2001. This 15-degree low-angle hole was collared at ECRB Station CD 16+95 in the drift crown. The borehole was divided into three sections for water release using the systematic hydrologic packer system. The three sections for water release spanned $5.5 \mathrm{~m}$ to $7.3 \mathrm{~m}, 10.4 \mathrm{~m}$ to $12.2 \mathrm{~m}$, and $15.2 \mathrm{~m}$ to $17.1 \mathrm{~m}$, respectively, from the collar. The midpoints of each of the zones were therefore $1.7 \mathrm{~m}, 2.9 \mathrm{~m}$, and $4.2 \mathrm{~m}$, respectively, above the crown of the drift. The rubber on the first two packer sealing sections could not maintain inflation due to piercing of the rubber, and therefore could not seal the first two zones of the borehole. With Zone 1 lower in elevation than Zone 2 and Zone 3, the test of water release into Zone 1 proceeded, with no release into Zone 2 during most of Zone 1 test period (see Section 6.11.2.8 for tests in Zone 2 of Borehole LA\#3). 
Plots of Zone 1 injection and seepage from May 17, 2001, to May 23, 2001, (Figure 6-141) show no seepage with a constant liquid injection rate of approximately $36 \mathrm{~mL} / \mathrm{min}$; however, some seepage water missed the collection system. When test was resumed on May 23, 2001, the injection rate was maintained at approximately $24 \mathrm{~mL} / \mathrm{min}$, and the tarp for Zone 1 was repositioned (closer to the collar) to capture all seepage water.

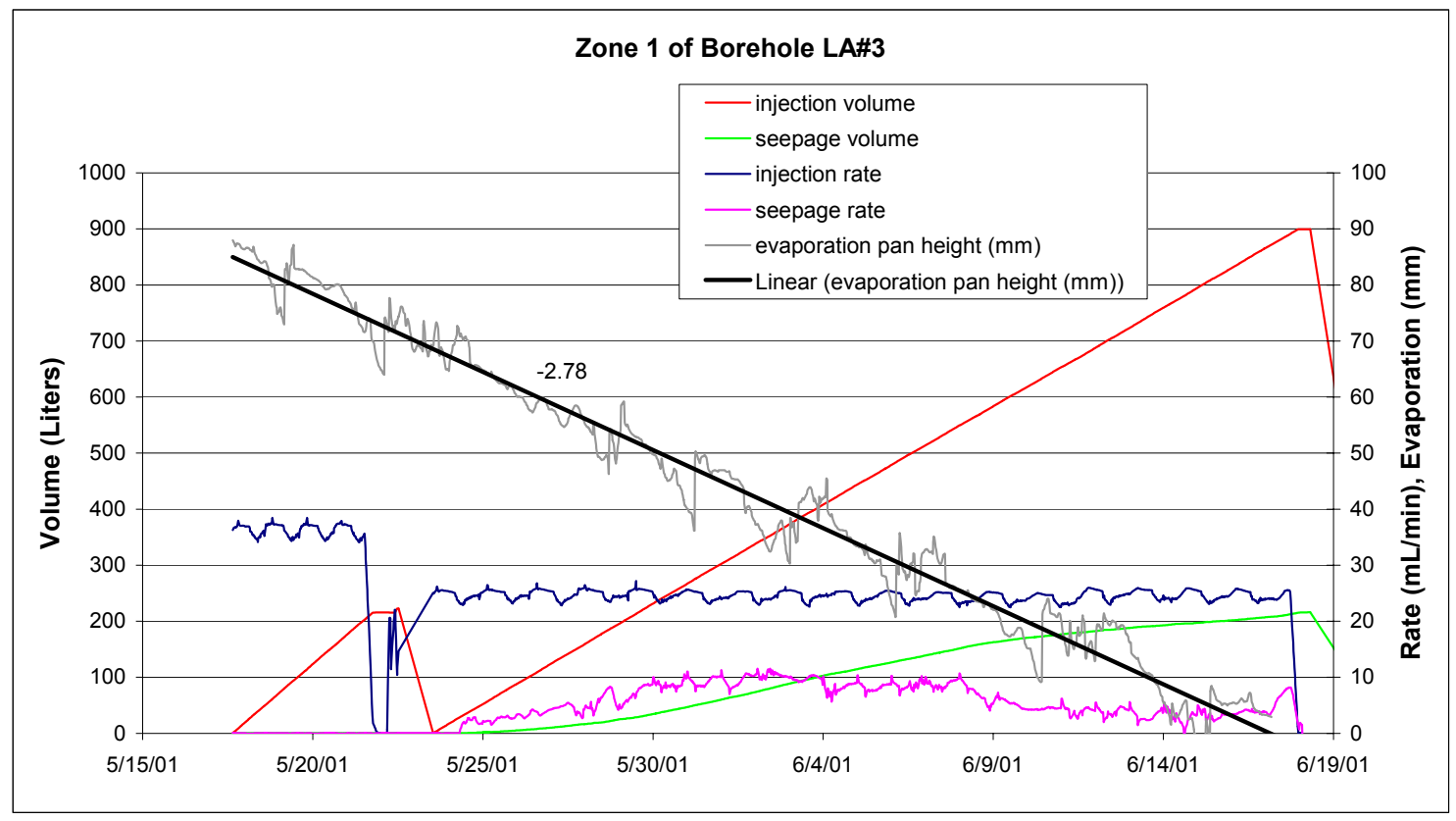

Source: DTN: LB0203ECRBLIQR.001 [DIRS 158462].

NOTE: Linear curve fit for evaporation uses Excel trendline option for putting a curve fit onto an existing plot. Slope is from the equation generated by Excel for the fit. See Appendix Section 16.3 for calculation details. The slope for the fitted evaporation drop is -2.78 millimeters per day. Temporal declines in cumulative volumes are a result of resetting the water level in the supply and seepage bottles.

Figure 6-141. Cumulative Water Volume and Rate Supplied to Zone 1 of Borehole ECRB-SYBT-LA\#3, Related Seepage Rate, and Evaporation with Linear Fit and Slope ( $\mathrm{mm}$ drop per day) for the Test Performed between May 17 and June 19, 2001 
Figure 6-141 shows that the seepage rate reached steady state by May 31, 2001, at approximately $8 \mathrm{~mL} / \mathrm{min}$. A wet spot on the ceiling was noted as early as May 24, 2001, near the edge of the tarp closest to the borehole collar. Another wetted area developed toward the opposite end of the tarp and started seeping by May 29, 2001. This second spot was $1.2 \mathrm{~m}$ in diameter, and on May 31, 2001, it increased to $1.37 \mathrm{~m}$ in diameter, extending from approximately $3.66 \mathrm{~m}$ from the collar to approximately $5.03 \mathrm{~m}$ from the collar. The estimated rate lost to evaporation from the 1.37-m-diameter wet spot was determined as follows:

1. The area of the wet spot is $3.1416 \times((100 \times 1.37) / 2)^{2}=14741 \mathrm{~cm}^{2}$ (Appendix Section I6).

2. Data on drop of water level in the evaporation pan shows an average rate of $2.78 \mathrm{~mm} /$ day $\left(1.93 \times 10^{-4} \mathrm{~cm} / \mathrm{min}\right)$ from the slope of the evaporation line in Figure 6-141, so that the evaporation rate from the wetted area is $1.93 \times 10^{-4} \times 14741=2.85 \mathrm{~mL} / \mathrm{min}$.

3. With an injection rate of $25 \mathrm{~mL} / \mathrm{min}$, a recorded seepage of approximately $8 \mathrm{~mL} / \mathrm{min}$, and an evaporation rate of approximately $2.85 \mathrm{~mL} / \mathrm{min}$, the rate of water being diverted around the drift is approximately $14 \mathrm{~mL} / \mathrm{min}$ (assuming steady-state conditions). 
The decline in seepage rate starting on June 7, 2001, may in part be attributed to increased evaporation caused by a larger wetted area observed on the drift ceiling. The increasing size of the wetted area may itself be regarded as a form of surface water flow that suppresses the formation of seeps by both growing in size (and thus accommodating more water) and by increasing the evaporation area. On June 6,2001 , this wetted spot was observed to be $1.83 \mathrm{~m}$ in length (along the drift axis) and $2.44 \mathrm{~m}$ in width. On June 13, 2001, 11:25, the wetted spot that had first appeared on May 24, 2001, closer to the collar edge of the tarp, that had not seeped, had expanded to approximately $0.91 \mathrm{~m}$ in diameter and had started to drip. By June 13, 2001, 15:45, the two wetted spots had merged and formed one spot approximately $3.05 \mathrm{~m}$ in length.

When comparing the wetted area (on June 13, 2001) consisting of one ellipse (with principal axes of $1.83 \mathrm{~m}$ and $2.44 \mathrm{~m}$ ) and a circle of $0.91 \mathrm{~m}$ in diameter to that of one circle of diameter $1.37 \mathrm{~m}$ (the previous wet spot from May 31, 2001), a ratio of $[(2.44 / 2 \times 1.83 / 2)+$ $\left.(0.91 / 2)^{2}\right] /(1.37 / 2)^{2}=2.82$ is obtained (Appendix Section I6). If the evaporation rate from the wetted area on May 31, 2001, was $2.85 \mathrm{~mL} / \mathrm{min}$, then the evaporation rate from the wetted area on June 13, 2001, could have been as high as $2.82 \times 2.85=8.04 \mathrm{~mL} / \mathrm{min}$, or $5.2 \mathrm{~mL} / \mathrm{min}$ higher than that on May 31, 2001 (assuming that the pan evaporation rate was the same). This is the same order of magnitude as the observed seepage rate decline from approximately $8 \mathrm{~mL} / \mathrm{min}$ in the beginning of June to approximately $3.0 \mathrm{~mL} / \mathrm{min}$ by mid-June. On June 17, 2001, injection to Zone 1 was stopped. Seepage stopped within 40 minutes of turning off the injection. On June 19, 2001, all work was stopped, including seepage collection, so that the equipment could be temporarily moved to allow other tunnel activities to take place. The results from Zone 1, Borehole LA\#3, highlighted some of the complexity of flow paths occurring during the course of systematic testing. They showed that subtle changes occur in the geometry and number of the wetted areas, even at steady water-release rates.

\subsubsection{Liquid-Release Test in Zone 2, Borehole LA\#3: May 10 to July 23, 2001}

Liquid release in Zone 2 was also initiated on May 17, 2001, but seepage missed the collection tarps immediately below Zone 2. Moreover, it is possible that some test interference occurred between release at Zone 1 and release at Zone 2. Consequently, testing at Zone 2 was terminated on May 21, 2001, and resumed on June 20, 2001, following the conclusion of a liquid release test in Zone 1. Seepage from water released in Zone 2 was then expected to fall on collection tarp 1, which had been moved $2.7 \mathrm{~m}$ closer to the collar of Borehole LA\#3 on May 23, 2001. Collection tarp 2 was moved back on June 19, 2001, to directly under injection Zone 2. (It had previously been repositioned directly under Zone 1 to take the place of the Zone 1 tarp when it was placed near the collar.) Liquid injection in Zone 2 started on June 20, 2001. There was a power outage on July 1, 2001, and testing was resumed on July 5, 2001.

For the test on May 17, 2001, only release data exists (seepage missed the collection tarps). For the tests on June 20, 2001, and July 5, 2001, when water was injected into Zone 2, seepage was collected from the Zone 1 tarp. The fact that seepage in the Zone 1 collection tarp contained water released in Zone 2 with no other seepage location evident indicates that the packer system may indeed have failed, so that water ran along the borehole to Zone 1. 


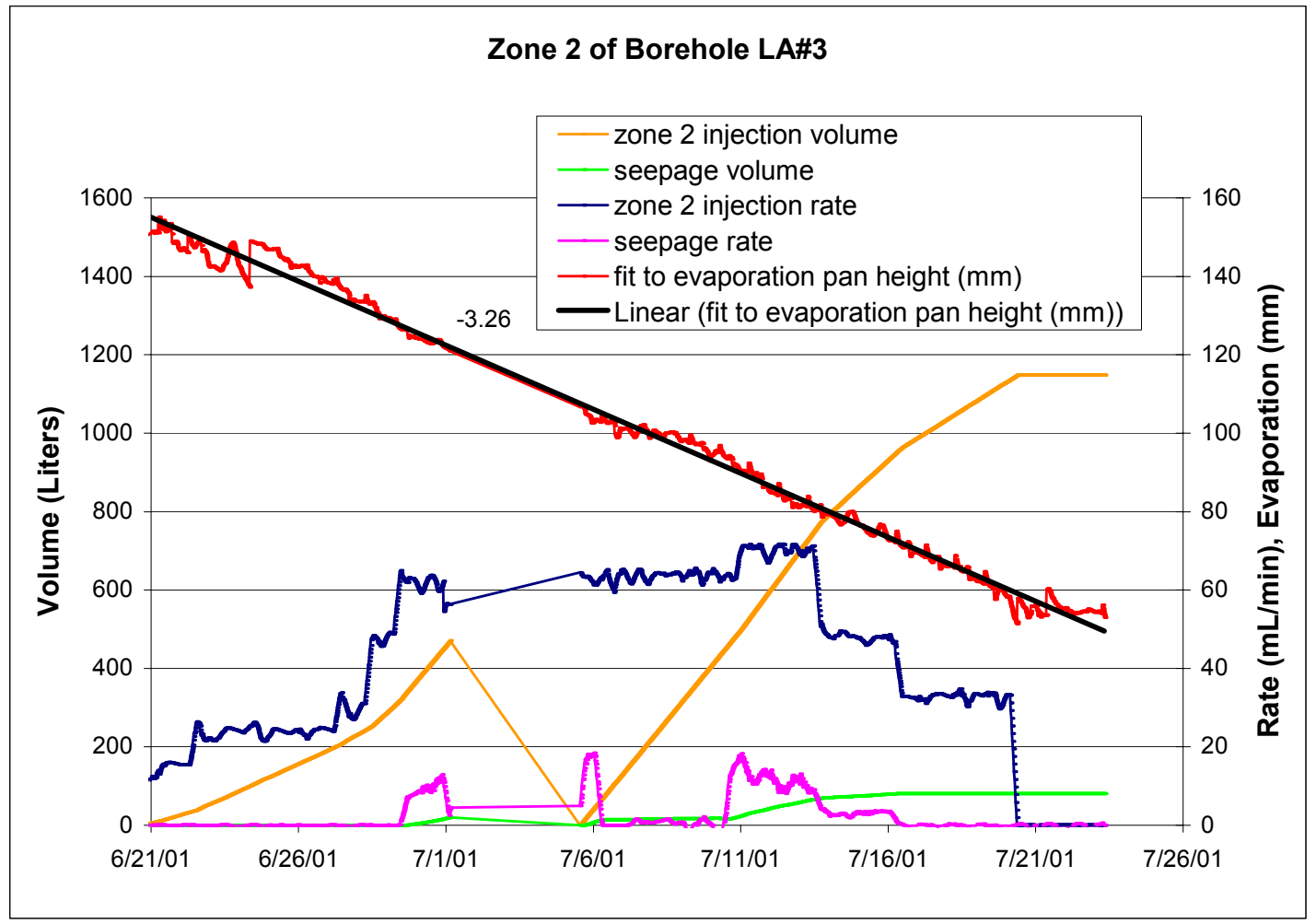

Source: DTN: LB0203ECRBLIQR.001 [DIRS 158462].

NOTE: Linear curve fit for evaporation uses Microsoft Excel trendline option for putting a curve fit onto an existing plot. The slope of $-3.26 \mathrm{~mm} /$ day is from the equation generated by Microsoft Excel for the fit. See Appendix Section 16.3 for calculation details. Temporal declines in cumulative volumes are a result of resetting the water level in the supply bottle.

Figure 6-142. Cumulative Water Volume and Rate Supplied to and Seeped from Zone 2 of Borehole ECRB-SYBT-LA\#3 and Evaporation with Linear Fit and Slope (millimeter drop per day) for Test Performed from June 20 to July 24, 2001

Figure 6-142 shows that the injection rate in Zone 2 was changed in discrete steps. It started from the low of approximately $11 \mathrm{~mL} / \mathrm{min}$ at the initiation of test on June 20, 2001, to approximately $25 \mathrm{~mL} / \mathrm{min}$ between June 22, 2001, and June 27, 2001, to approximately $30 \mathrm{~mL} / \mathrm{min}$ until June 28, 2001, at 11:00, at which time the rate was increased to approximately $49 \mathrm{~mL} / \mathrm{min}$. On June 29, 2001, at 10:30, the rate was increased to $63 \mathrm{~mL} / \mathrm{min}$. Seepage collection initiated on June 29, 2001, at 16:11 and the rate was approximately $10-15 \mathrm{~mL} / \mathrm{min}$ just before an unplanned power outage on July 1, 2001, at 3:16. When the work was restarted on July 5, 2001, testing continued at the higher rate of injection, approximately $65 \mathrm{~mL} / \mathrm{min}$, as before the power outage. The seepage resumed almost immediately, confirming that the fast paths (connected paths for liquid flow comprised mostly of fractures) between release point and drift ceiling had been established. The seepage rate had increased to the pre-power-outage level within approximately five hours of resumption of water release. The drop of seepage to zero on July 6,2001 , turned out to be from a leak in the tubing of a collection bottle. The leak was repaired on July 10, 2001, at 14:31, accompanied by a quick response of the seepage rate, which increased to approximately $16 \mathrm{~mL} / \mathrm{min}$. In an attempt to estimate the seepage threshold, the liquid release was reduced stepwise. On July 13, 2001, at 17:04, the release rate was reduced 
from approximately $71 \mathrm{~mL} / \mathrm{min}$ to approximately $48 \mathrm{~mL} / \mathrm{min}$. The seepage rate decreased from the average of approximately $16 \mathrm{~mL} / \mathrm{min}$ to approximately $3 \mathrm{~mL} / \mathrm{min}$. Assuming that the loss due to evaporation had not changed (the slope of the evaporation drop is similar before July 13, 2001, and after July 13,2001), the data may indicate that the difference in diversion of release water around the drift opening caused by varying inflow rates is approximately (71-16)-(48-3) $=10 \mathrm{~mL} / \mathrm{min}$ (Appendix Section I6). The water release rate was further decreased on July 16, 2001, at 11:53, from $48 \mathrm{~mL} / \mathrm{min}$, to $33 \mathrm{~mL} / \mathrm{min}$ and the recorded seepage almost disappeared. However, field observations in the morning of July 16 also indicated the presence of a small seep between the tarps of Zone 1 and Zone 2. That small seep was missed by the data collection system. Field observations indicated that that missed seepage rate could still be approximately $2 \mathrm{~mL} / \mathrm{min}$. That is, the prevailing release rate of $33 \mathrm{~mL} / \mathrm{min}$ was still above the seepage threshold. Because the field schedule for testing in the ECRB Cross-Drift, there was no opportunity for additional investigation of the seepage threshold, and water release was terminated on July $20,2001$.

\subsubsection{Liquid-Release Test in Zone 3, Borehole LA\#3: May 10 to July 23, 2001}

Testing in Zone 3 of Borehole ECRB-SYBT-LA\#3 took place from May 10 to July 23, 2001, concurrently with the testing at other zones in the same borehole. However, the net inflow into Zone 3 was very small, with most of the introduced water returning from the release zone as a result of low formation permeability. Therefore, no test interference with the other zones from Zone 3 was expected. Plots of injection, return, and net inflow rates are shown in Figure 6-143. Liquid-release tests in the periods May 17 to 22, May 23 to June 18, June 21 to July 1, and July 5 to July 20 indicate that (except for brief periods on May 17 and May 23), the formation essentially could not take in any significant amount of water, regardless of the rate of injection. The average rate of water intake was approximately $0.5 \mathrm{~mL} / \mathrm{min}$ when the injection rate was set quite high. At lower injection rates, the net inflow was close to zero after steady state conditions had been reached. This seems to indicate that Zone 3 was possibly lined with cavities that initially filled up, but whose bottoms are sealed so that little water can leave the cavities. In other words, the cavity population around injection Zone 3 is so large and the fracture population so small that very little introduced water can access the connected fractures that form the "fast paths" that lead to the crown. The "fast paths" are those that allow intake of water at tens and even hundreds of $\mathrm{mL} / \mathrm{min}$ in all the liquid release tests until this one.

Seepage was seen only from Zone 1, the zone closest to the previous borehole, which had multiple fast path characteristics. This seepage came from both Zone 1 and Zone 2 injections, indicating that the borehole may have participated in movement of water from the Zone 2 release line to the seep seen at Zone 1. Various patterns and rates of seepage were apparent on the Zone 1 crown. In addition, there was almost 100-percent water return from Zone 3 testing, but zero return from Zone 1 and Zone 2 testing. 


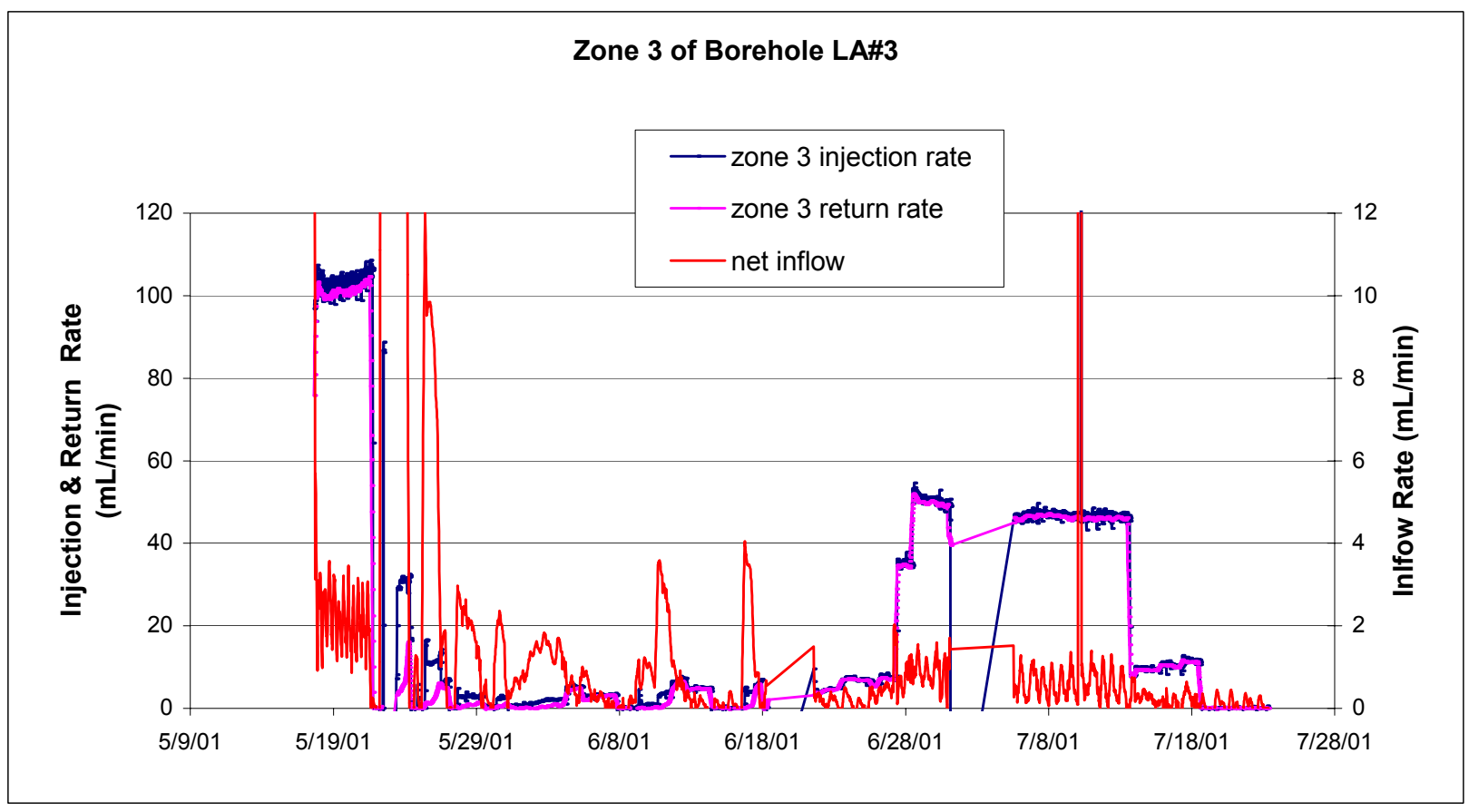

Source: DTN: LB0203ECRBLIQR.001 [DIRS 158462].

NOTE: See Appendix Section 16.3 for calculation details.

Figure 6-143. Rate Supplied to, Returned from, and Rate of Net Inflow from Zone 3 of Borehole ECRB-SYBT-LA\#3 for Test Performed from May 17, 2001, to July 24, 2001

\subsubsection{Borehole LA\#4 and Liquid-Release Test in Zone 1 of Borehole LA\#4: February 5 to March 11, 2002}

Tests in Borehole ECRB-SYBT-LA\#4 (also referred to as Borehole LA\#4) began on February 5, 2002, and ended in November 2002. This fourth 15-degree low-angle hole was collared at ECRB CS $16+65$ in the drift crown. The borehole was again divided into three sections for water release using the systematic hydrologic packer system. The three sections for water release spanned $3.9 \mathrm{~m}$ to $5.7 \mathrm{~m}, 8.8 \mathrm{~m}$ to $10.6 \mathrm{~m}$, and $13.6 \mathrm{~m}$ to $15.5 \mathrm{~m}$, respectively, from the collar. The midpoints of each of the zones were therefore $1.2 \mathrm{~m}, 2.5 \mathrm{~m}$, and $3.8 \mathrm{~m}$, respectively, above the crown of the drift. At Borehole LA\#4, a modification to the packer system whereby the durability of the rubber sections was enhanced, ensured that a proper seal formed between the rock and the inflated sealing sections in the borehole. Water-leak problems at the sealing sections were therefore not an issue at Borehole LA\#4, as they may have been at Borehole LA\#3.

Testing at Zone 1, Borehole LA\#4 started on February 5, 2002, and proceeded through March 11, 2002. Plots for injection and water return volumes and rates into Zone 1 at Borehole LA\#4 (see Figure 6-144) show a behavior similar to that in Zone 3 of Borehole LA\#3 (i.e., a relatively high percentage of return flow occurred). An initial high rate of inflow into the formation occurred upon initiation of water release, after which the net inflow becomes quite small. As in Zone 3, Borehole LA\#3, the net inflow increased slightly when the absolute 
injection rate was increased most likely because of the slight rate dependency of the water-delivery-system geometry in that the water is more evenly distributed at higher rates and thus is more likely to enter the formation. The combination of results from Zone 3, Borehole LA\#3, and Zone 1, Borehole LA\#4, indicate that the tight formation properties seen in both possibly continue through both zones over a distance of slightly less than $18 \mathrm{~m}$. No seepage was captured from the testing at Zone 1, Borehole LA\#4. Unlike Zone 3, Borehole LA\#3, however, some wetting occurred at the crown. During the course of testing, the evaporation averaged approximately $2.8 \mathrm{~mm}$ per day (the closest estimate for that time of year-see Figure 6-142), which, combined with a maximum observed wetted area of $12000 \mathrm{~cm}^{2}$, gives $2.3 \mathrm{~mL} / \mathrm{min}$ of evaporation from the crown. The maximum infiltration rate of approximately $30 \mathrm{~mL} / \mathrm{min}$ was obtained at the maximum injection rate of $120 \mathrm{~mL} / \mathrm{min}$, so that the diversion around the crown measured $27.7 \mathrm{~mL} / \mathrm{min}$ or 92 percent of inflow.

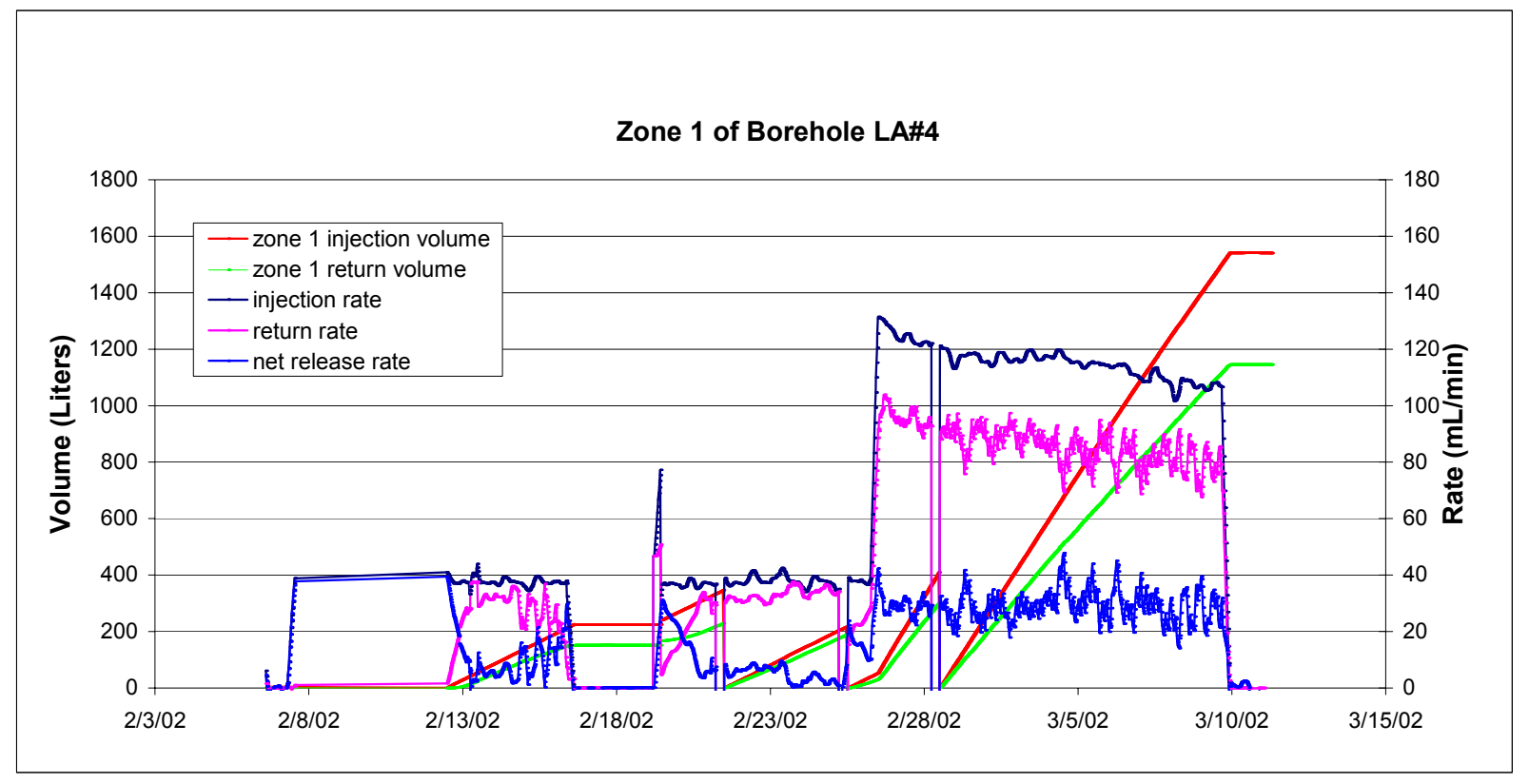

Source: DTN: LB0301SYTSTLA4.001 [DIRS 165227].

NOTE: See Appendix Section 16.3 for calculation details. Temporal declines in cumulative volumes are a result of resetting the water levels in the supply and return bottles.

Figure 6-144. Volume and Rate of Water Supplied to, Returned from, and Rate of Net Inflow from Zone 1 of Borehole ECRB-SYBT-LA\#4 for Test Conducted from February 6 to March 9, 2002

\subsubsection{Liquid-Release Test in Zone 2, Borehole LA\#4: October 8 to November 18, 2002}

Testing at Zone 2 of Borehole LA\#4 ran from October 8, 2002, to November 18, 2002. Owing to scheduling complexities, testing was performed some time after the other tests at Borehole LA\#4 but with no noticeable effects on the systematic type of testing. Figure 6-145 shows plots of volumes injected and captured with rates and evaporation drop during testing at Zone 2, Borehole LA\#4. The difference between the injection rate and the seepage rate (net loss rate) indicates the rate of water diverted around the drift or lost due to evaporation. No return flow at this location occurred regardless of the injection rate. The average evaporation rate was 
measured at approximately $5.73 \mathrm{~mm} /$ day over the course of testing at Zone 2. Observations indicated that on October 23, 2002, the wet patch on the crown had an area of approximately $8 \mathrm{~m}^{2}$. Evaporation from the crown surface is therefore estimated to be approximately $32 \mathrm{~mL} / \mathrm{min}$. Given a net loss rate of $40 \mathrm{~mL} / \mathrm{min}$, the diversion rate is approximately $8 \mathrm{~mL} / \mathrm{min}$. (i.e., approximately 18 percent of the injection rate of $44 \mathrm{~mL} / \mathrm{min}$ ).

From the plots, the loss rate (water diverted or evaporated) appears to be slightly higher (as a fraction of injection rate) at lower injection rates. This phenomenon suggests that at very high injection rates in Zone 2, a higher percentage of introduced water would have seeped into the drift.

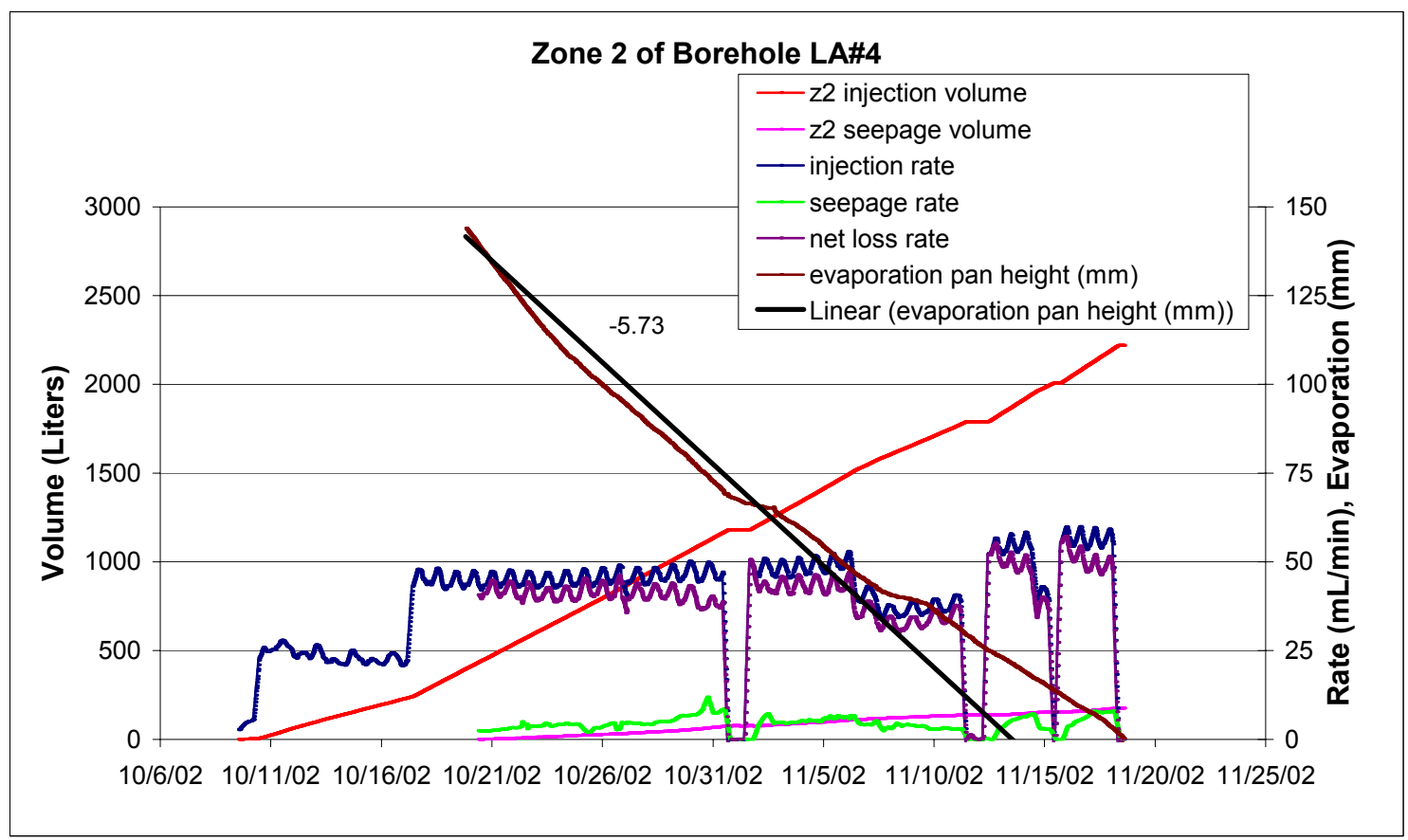

Source: DTN: LB0301SYTSTLA4.001 [DIRS 165227].

NOTE: Linear curve fit for evaporation uses Microsoft Excel trendline option for putting a curve fit onto an existing plot. Slope is from the equation generated by Microsoft Excel for the fit. See Appendix Section I6.3 for calculation details.

Figure 6-145. Injection and Seepage Volumes; Injection, Seepage, and Net Rates; and Evaporation Drop for Liquid-Release Test Conducted in Zone 2 of ECRB-SYBT-LA\#4 2 between October 8 and November 18, 2002

\subsubsection{Liquid-Release Test in Zone 3, Borehole LA\#4: February 5 to February 28, 2002}

During the Zone 1 testing at Borehole LA\#4, Zone 3 at Borehole LA\#4 underwent testing from February 5, 2002, to February 28, 2002. The two zones were sufficiently far apart along the drift (approximately $10 \mathrm{~m}$ ) to ensure that no test interference was likely. In contrast to the flow characteristics observed at Borehole LA\#4 Zone 2, Zone 3 provided an example of another as-yet-unseen flow characteristic. Again, like Zone 2, no return flow occurred, regardless of injection rate. However, all flow into the zone was accepted, and no seepage or wetted areas were observed. Even at inflow rates in excess of $200 \mathrm{~mL} / \mathrm{min}$., no water flowed into the drift. 
Figure 6-146 shows plots of the injected volume and corresponding injection and inflow rates into Zone 3.

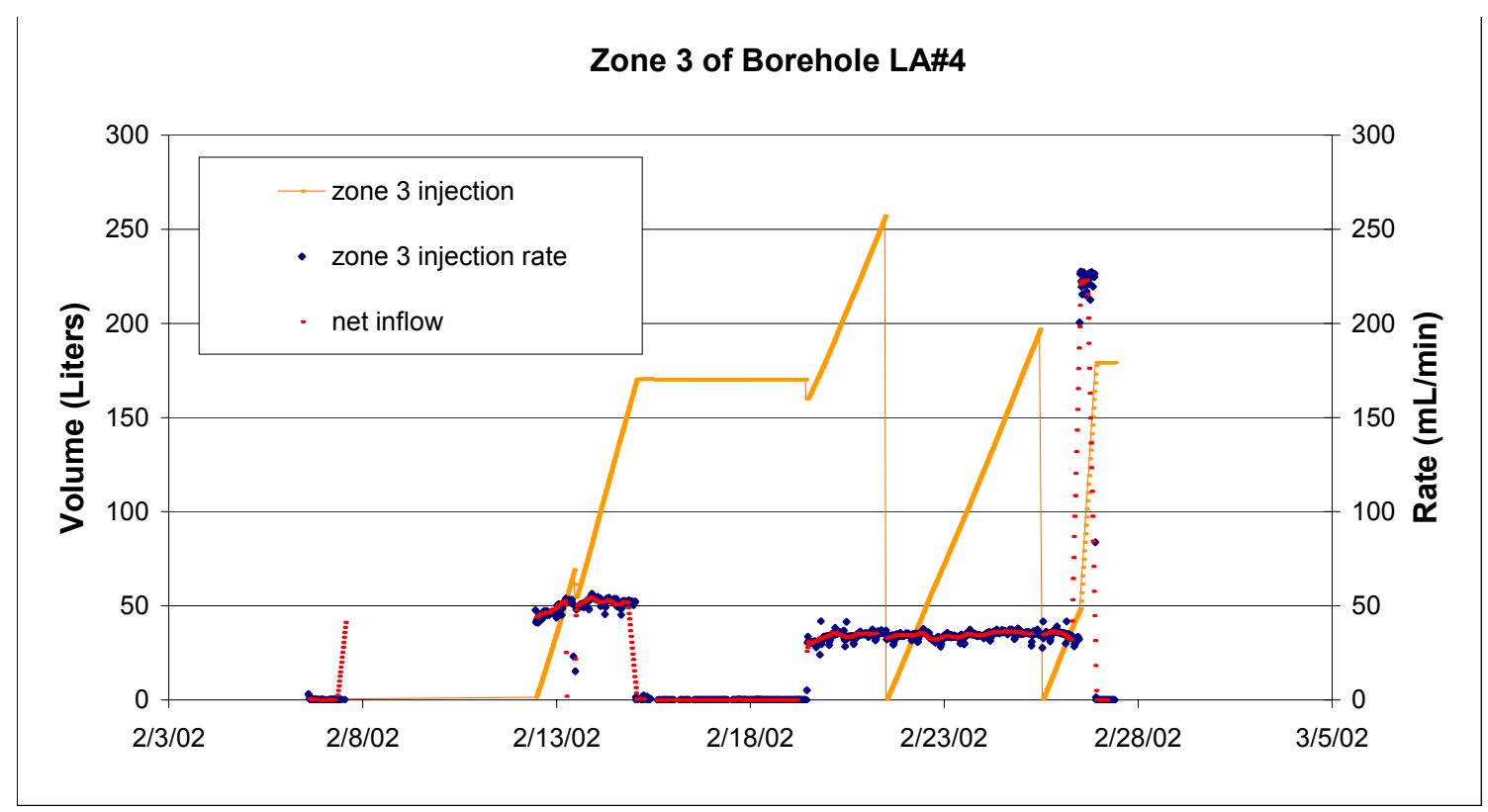

Source: DTN: LB0301SYTSTLA4.001 [DIRS 165227].

NOTE: See Appendix Section 16.3 for calculation details.

Figure 6-146. Volume and Rate of Water Supplied to, Returned from, and Rate of Net Inflow from Zone 3 of Borehole ECRB-SYBT-LA\#4 for Test Conducted from February 6 to February 28, 2002

\subsubsection{Systematic Testing Discussion and Interpretation}

Several important results become apparent when examining the data presented in Section 6.11.2. One result is the insight into the role of fractures, matrix, and lithophysal cavities in liquid flow through the partially saturated lower lithophysal unit. Another is the assessment of the nonintersecting flow (a combination of diversion by capillary barrier and of alternate flow paths) around the drift excavation. A third important result is the estimation of a threshold flux at the water-release borehole, below which seepage into the drift does not occur. The first few locations that were tested allowed for significant progress in understanding these hydrologic characteristics of the lower lithophysal unit. Direct comparisons of the same type of data from location to location provide knowledge applicable to a portion of the ECRB Cross-Drift.

\subsubsection{Participation of Lithophysal Cavities in Storage and Flow Paths}

Lithophysal cavities, fractures, and matrix contribute to the overall porosity of the lower lithophysal rock. Drift-wall mapping along the ECRB Cross-Drift indicates a mean lithophysal cavity porosity of 0.125 in the lower lithophysal unit (Mongano et al. 1999 [DIRS 149850]). Gas-tracer measurements of the effective porosity in the middle nonlithophysal unit indicate that fracture porosity is approximately 0.01 (DTN: LB980912332245.002 [DIRS 105593]). Both cavities and fractures are expected to be essentially dry at ambient conditions. Laboratory 
measurements from 453 samples from surface-based boreholes give the mean matrix porosity of 0.13 and a mean saturation of 0.78 for the lower lithophysal unit (Flint 1998 [DIRS 100033]). Fourteen measurements on cores from boreholes drilled for systematic testing at the ECRB Cross-Drift Station CD 17+49 (DTN: LB0110COREPROP.001 [DIRS 157169]) give results similar to those reported by Flint (1998 [DIRS 100033]): mean values of 0.12 for matrix porosity and 0.72 for liquid saturation. Because of the high ambient liquid saturation, the matrix contributes only approximately 0.03 in porosity that is available for liquid storage from systematic testing.

In liquid-release tests (such as those conducted for the systematic testing), fractures and possibly large cavities determine the steady-state flow behavior of the fractures-matrix-lithophysal-cavity system; slow-draining cavities and the matrix contribute to the initial storage. Of the initial test storage features, slow-draining cavities and the matrix contribute to one-time storage; only fractures and open cavities contribute to subsequent "steady-state" storage. Thus, in a flow test at a new borehole where no water has yet been introduced, all the storage components should be in full effect. The water released into the formation will partition into storage and steady flow paths. If the fast paths themselves have a significant storage component, this should lengthen the first arrival time for water (from the delivery point in the borehole to the exit point in the drift) and increase the amount of water needed to do so.

Data from pre-excavation liquid-release tests (Section 6.2) and the dye observations during excavation of Niche 5 (Niche 1620) suggest that the shape of the flow plume in close vicinity to the release point is roughly circular. During a liquid-release test, as soon as water is observed at the crown of the drift, the maximum distance of any flow can be interpreted to have reached (along fast paths) the surface of a cylinder, the diameter of which is the distance between the middle of the release zone and the crown, as illustrated in Panel a of Figure 6-147. The cylinder length would be roughly that of the release zone. This cylindrical volume concept is applied during the first-time test period when the connected paths are being developed, as a bounding envelope that contains the fast, connected paths. At later times in the test, during the steady-state phase, water may have moved well beyond the bounds of this cylinder. The volume of water injected up to the point of first wetting at the drift ceiling, divided by the volume of this cylinder, gives the effective porosity for establishing fast paths. Note that the effective porosity measured this way is very much injection-rate-dependent, because the degree to which different components of actual porosity participate in the flow path varies according to their time of exposure to the flow (in this case, the time of exposure to the flow is the time needed for water to reach the edge of the cylinder).

For the test in Borehole LA\#2 Zone 1 (see Section 6.11.2.1), Figure 6-131 shows that $46 \mathrm{~L}$ $\left(0.046 \mathrm{~m}^{3}\right)$ of water had been introduced at the first wetting of the drift crown. The volume of the cylindrical plume (diameter $1.58 \mathrm{~m}$ and length $1.83 \mathrm{~m}$ ) is estimated to be $3.6 \mathrm{~m}^{3}$. Hence, the estimated effective porosity used to establish fast paths is $0.046 \mathrm{~m}^{3} / 3.6 \mathrm{~m}^{3}=0.013$. Water was released into Borehole LA\#2 Zone 1 at a relatively high rate of $450 \mathrm{~mL} / \mathrm{min}$.

For the test in Borehole LA\#1 (see Section 6.11.2.5), the diameter of the cylinder is $1.03 \mathrm{~m}$, and the length is $1.83 \mathrm{~m}$, for a volume of $1.53 \mathrm{~m}^{3}$. Flow volume for the initial wetting of Borehole LA\#1 was $103 \mathrm{~L}\left(0.103 \mathrm{~m}^{3}\right)$, which gives an effective porosity of 0.067 . In this case, the water was released at a much slower rate of $15 \mathrm{~mL} / \mathrm{min}$. 
The two estimated values of 0.013 and 0.067 representing the effective porosity prior to the establishment of fast paths lead to the following interpretation:

In the case of Borehole LA\#2 Zone 1, when the release rate was as high as $450 \mathrm{~mL} / \mathrm{min}$., the fracture porosity was accessed with little imbibition into the matrix at the time of intersection with the drift. In addition, for the lithophysal cavities that act as a capillary barrier with the very high release rate, little water would be expected to seep into these cavities. For Borehole LA\#1, when the release rate was approximately 30 times slower at $15 \mathrm{~mL} / \mathrm{min}$., the flowing water would have time to access the matrix porosity, and less would be diverted around the lithophysal cavities. The difference in effective-porosity results from these two tests could thus be a measure of the component of storage due to matrix and slow-filling cavities. Because cavities are the primary contributor to actual porosity in the system, even a little participation in the flow path would raise the effective porosity. In the case of Borehole LA\#1, cavities seem to contribute up to a maximum of approximately 0.057 (effective porosity minus fracture porosity, not accounting for matrix participation) and a minimum of 0.027 (if all available matrix porosity participates). These values indicate that only one quarter to one half of the lithophysal cavity volume (porosity of 0.125 ) participates in the liquid storage.

One refinement in the evaluation of effective porosity was to study the process of restarting a water-release test after some pauses in activity. For Borehole LA\#1, after slightly more than two months, a new test was performed (Section 6.11.2.6). The first arrival was observed after only $60 \mathrm{~L}$, giving a new effective porosity of 0.039 . Therefore, evidence suggests the liquid storage from the matrix and cavities filled in the initial test (Section 6.11.2.5) did not drain completely during this two-month lapse. The difference between the new value and that of 0.067 from the previous test in the same location is 0.028 and could be a measure of the capacity of the matrix and the slow-draining lithophysal cavities. Lastly, the difference between the storage measured from the already wet slow test (storage from fast-draining cavities and fractures) and the initially dry high-rate tests (storage by fractures only) gives the drainable cavity porosity of $0.039-0.013=0.026$, or slightly less than one quarter of the estimated porosity representing slow-draining lithophysal cavities and the matrix.

\subsubsection{Estimation of the Steady-State Diversion Flow around the Drift}

At steady state, the saturation of fractures, cavities, and matrix is not changing. All the water that is injected (a known rate) can be partitioned into water collected as seepage (measured), water lost to evaporation, and water that does not seep into the drift because it bypasses the drift or is diverted on account of the capillary barrier. The rate of water loss to evaporation can be quantified from pan measurements and the size of the wetted area; the rate of diverted flow can be derived from a water balance.

One of the key outcomes of seepage testing is to estimate the fraction of introduced water that is diverted around the opening during steady-state flow, i.e., after the establishment of connected paths between the borehole and drift ceiling. A fraction of the water will bypass the drift opening because of nonuniform flow introduced by discrete features and heterogeneity. At the drift crown, additional flow will be diverted around the drift, because the drift acts as a capillary barrier. The total component of diverted water (from flow channeling and capillary effects) can, 
as a rough approximation, be thought of as the difference between the rate of injection and the rate of seepage into the drift when the test has reached steady-state conditions, provided that there are no other losses. However, the systematic data (Section 6.11.2.3, Section 6.11.2.4, and Section 6.11.2.6) show clearly that evaporation contributes to the difference in the recorded injected and seeped volume of water. Evaporation is essential and thus must be taken into account.

The evaporation contribution to the wetted-drift ceiling can be estimated by multiplying the flux from an evaporation pan mounted just below the seep by the wetted area associated with the seep. All monitoring data for the water-level drop in the evaporation pan show that the evaporation flux is approximately $3 \mathrm{~mm}$ /day for the wide range (15 to 90 percent) of relative humidity encountered. An upper bound of evaporation rate from systematic testing may be obtained by multiplying the evaporation flux of $3 \mathrm{~mm} /$ day by the largest wetted area recorded (in the form of photographs) during bi-hourly (every half hour) observations at Borehole LA\#2, $6.8 \mathrm{~m}^{2}$ (Section 6.11.2.4). The resultant evaporation rate is approximately $14.4 \mathrm{~mL} / \mathrm{min}$. Note that the potential for injected water to leave the test system from barometric pumping and from vapor transport in a drying front behind the drift wall has not been included; the estimate is thus uncertain.

During the period from February 28, 2001, to April 30, 2001 (see Section 6.11.2.6), injection proceeded at an approximate rate of $17.5 \mathrm{~mL} / \mathrm{min}$. at Borehole LA\#1. Observational evidence showed that the crown underneath the injected zone was wet, but no seepage was collected during this period. The exception was for the period from the afternoon of March 15, 2001, to the morning of March 19, 2001, corresponding to a weekend shutdown of the ventilation, during which seepage occurred at a rate of $0.6 \mathrm{~mL} / \mathrm{min}$. The next weekend shutdown did not cause any seepage. Given that slight variations in ventilation conditions determined whether seepage occurred at a very low rate or not at all, indicates that the system was near the seepage threshold. The evaporation rate from the largest wetted area at Borehole LA\#1 $\left(4.6 \mathrm{~m}^{2}\right)$ of $9.5 \mathrm{~mL} / \mathrm{min}$. left $8 \mathrm{~mL} / \mathrm{min}$. of flow from the injection unaccounted for; this can be interpreted to be the diverted flow.

Section 6.11.2.6 (Panel b of Figure 6-140) also shows that a seepage collection rate of $8.5 \mathrm{~mL} / \mathrm{min}$. was obtained at Borehole LA\#1 for a higher injection rate of approximately $40 \mathrm{~mL} / \mathrm{min}$. during the period from April 10, 2001, to April 16, 2001. The diverted flow (i.e., the injection rate minus seepage and evaporation) is $22.0 \mathrm{~mL} / \mathrm{min}$, , or approximately 55 percent of the injection rate.

An estimate of the diverted component can also be obtained from the seepage volume drained after long-term injection has been stopped. This volume can be compared to the volume required to initiate seepage after water release has been restarted. Water will drain out of the system and be collected as seepage for some time after injection is terminated. In all systematic tests for which data is provided in this report, the drainage period lasted less than 24 hours. This is the fraction of the storage volume between the release zone and the drift that overcomes the seepage threshold. Upon resumption of water release, the volume required to initiate seeping into the drift, the refill volume, is that which has to supply both the flow path for seepage the diversion paths. The difference between the drainage seep volume and the refill volume suggests the volume of the diversion paths. 
Several pause studies were performed at Borehole LA\#1 to obtain this volume of diversion pathways. Correction for effects of rock-surface evaporation to both the drainage value and the volume to reinitiate seep is incorporated into this estimate. Evaporation decreases the measured drainage volume, and increases the required refill volume. During one test pause in Borehole LA\#1, on April 16, 2001, the seep drainage was $1.1 \mathrm{~L}$, but an additional $10.3 \mathrm{~L}$ can be attributed to evaporation for the whole period that the injection is turned off. Evaporation is interpreted to be at its maximum of $9.5 \mathrm{~mL} / \mathrm{min}$. for the duration of 18 hours. This interpretation is conservative, because observations of the drift ceiling indicate that size reduction of the wetted surface commences with the termination of water release, and evaporation would decrease and cease within this period. Consequently, longer duration pauses would cause approximately the same amount of surface evaporation. When injection is restarted on April 17, 2001, at the same rate as on April 10, 2001, it took 16 hours to refill (releasing $40 \mathrm{~L}$ ) before seepage resumed. This volume is partly evaporated at a rate of $9.5 \mathrm{~mL} / \mathrm{min}$, so that the real refill volume is $34 \mathrm{~L}$. Some of volume contributing to drainage collection can be associated with the water hanging from the ceiling, i.e., water that is contained in the wet spot. If the component exists, it should be fairly well cancelled out by a converse contribution to the wet spot during refill. Even when accounting for strong evaporation, the refill volume is approximately twice the drainage volume, meaning that more than half the flow is nonintersecting. This number agrees favorably with the rate method of obtaining nonintersection steady-state flow for the period of injection just before the April 16, 2001, pause and also for the earlier lower-rate test. Note that this method of calculating the nonintersecting component of flow, even though transient, will nevertheless be independent of injection rate because the time-dependent features (slow-filling cavities and the matrix) no longer participate in a refill test.

\subsubsection{Minimum Injection Rate Needed to Induce Seepage}

At the scale of the drift, flow is more likely to occur in concentrated regions than as a uniform front; a line release from a borehole occurs locally over the projected area of the borehole zone. This area emulates one of these concentrated regions at a given distance above the drift. During the testing at Borehole LA\#1 (Section 6.11.2.5) for the period from December 20, 2001, to December 26, 2001, observations (in the form of photographs) every half-hour confirmed that at the flow rate of $15 \mathrm{~mL} / \mathrm{min}$., with no ventilation, seepage on the ceiling was just observable as a tiny spot on the morning of December 25, 2001. Little evaporation was expected to occur from the surface because the spot had no significant area. The spot stayed small for the remainder of the test, indicating that the system as a whole was approaching steady state. The $15 \mathrm{~mL} / \mathrm{min}$. of injected flow in this case appears to barely reach the crown. Thus, the threshold below which seepage into the drift does not occur is $15 \mathrm{~mL} / \mathrm{min}$. for this location.

\subsubsection{Estimation of Evaporation from within the Fracture System}

Along Zone 2 of Borehole LA\#1 in Zone 2, the test sequence with water release at the relatively high rate of $42 \mathrm{~mL} / \mathrm{min}$. (Panel b of Figure 6-40) leads to the interpretation illustrated in Figure 6-147. Seepage was observed within a day of water-injection resumption on April 3, 2001; and April 9, 2001 (after pauses of 4 and 5 days); and on April 17, 2001, after a pause of 18 hours. These observations indicated that "fast paths," connected paths comprised of flowing higher-permeability features, had been established as depicted in Panel a of Figure 6-147. This delay in the onset of seepage after a pause-induced drainage (depicted in 
Panel b of Figure 6-147) enabled the measurement of the capacity of water needed to refill the transient storage (that is, the storage volume needed before seepage occurs, depicted in yellow in Panel c Figure 6-147) of these fast paths upon resumption of water release.

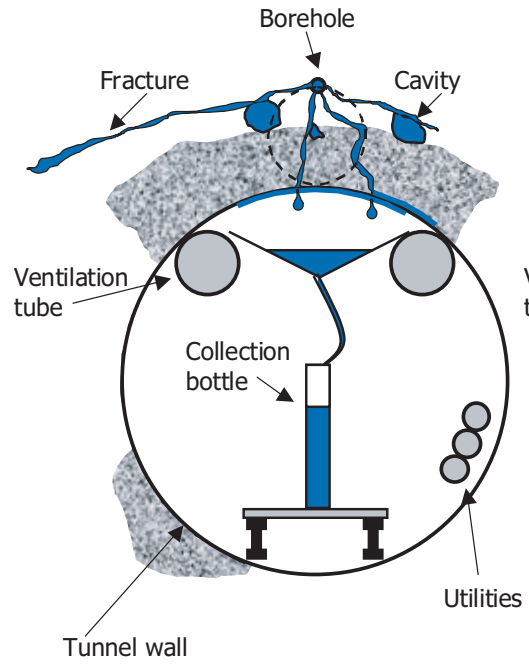

(a)

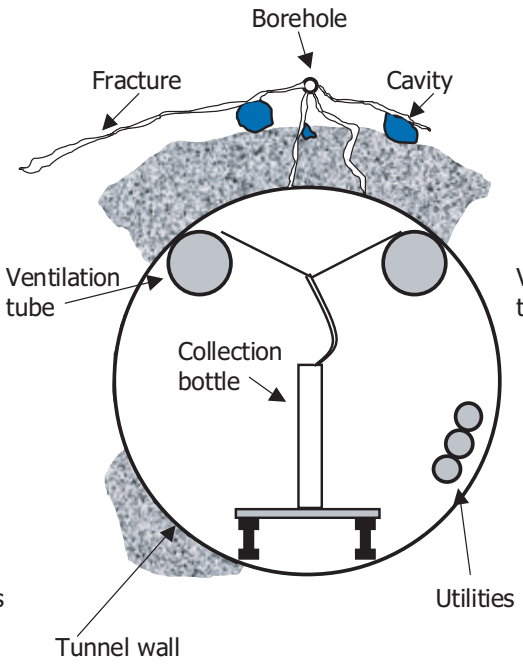

(b)

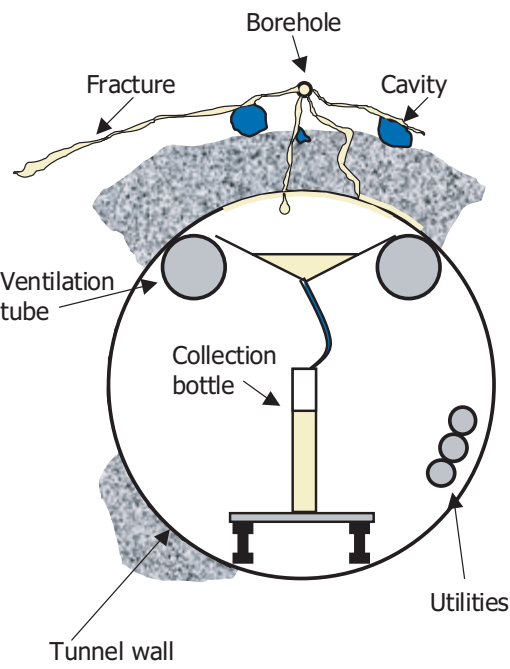

(c)

NOTES: $\quad$ Panel $a=$ Depiction of fast paths and storage areas for flowing seepage.

Panel $b=$ Pause in flow and subsequent drainage.

Panel $c=$ Refill of fast paths.

Figure 6-147. Borehole Flow and Path Details

This volume exists because flow through fractures takes a finite amount of time to travel and needs to refill its paths before seepage again takes place. This volume is the same as that of the water lost from all the paths during the pauses. After the 5-day pause, refill took 20 hours at a rate of $42 \mathrm{~mL} / \mathrm{min}$. The refill volume in this case was approximately $50 \mathrm{~L}$. For a pause of 18 hours, the refill volume was approximately $40 \mathrm{~L}$. The refill volume is thus seen as not very sensitive to the pause time. Drainage during each pause was the same and was complete long before the end of each of these pauses. Any additional loss was a result of longer-lasting processes, such as drainage of the residual water (i.e., water between the injection point and the niche that flows at rates below the seepage threshold, evaporation within the fracture system, or matrix imbibition). The small difference in refill volumes provides a measure of the rate of water moving out of the flow path by evaporation (or any other process) after drainage. An estimate of this rate can be generated by dividing the difference in refill volumes by the difference in pause length. The result for this rate is $2.0 \mathrm{~mL} / \mathrm{min}$. If the surface area of the hanging water is not greatly different from that of the moving water, then this number also gives an indication of the rate of maximum evaporation from the fracture system at other times during the testing phase. No other quantifiable factors are included in the evaporation estimation.

\subsubsection{Characteristics and Scale of Flow Heterogeneity along the Drift}

As the systematic hydrologic testing progressed toward the ECRB portal, a catalogue of flow characteristics for a growing length of drift was developed. Not only can the various flow characteristics themselves be logged, but the distances for which they persist along the drift can 
also be measured (for a summary, see Figure 6-148). The larger rock volume tested with the systematic approach revealed flow characteristics (such as 100-percent return flow and 100-percent flow diversion) that were not observed in the niche studies. The results indicate the level and the physical dimensions of the heterogeneity at the drift scale. This flow heterogeneity and its scales are not immediately apparent by simple visual observation and feature mapping of the surface of the drift, and were only discernable with a systematic approach to hydrologic testing.

\subsubsection{Summary of Systematic Hydrologic Testing}

The following provides a summary of the work performed for the Systematic Hydrologic Testing activities in the ECRB:

A graphical summary of the results for nonintersecting (diverted) flow at steady state is provided in Figure 6-148. Ten tests have been performed in arrays of 20-m-long boreholes, with collar-to-collar nominal spacing of $30 \mathrm{~m}$. Additional curtains were installed on the two ends of the V-shaped seepage-capture PVC curtains, and a camera was installed to take observations of the drift ceiling below the injection section. After completion of testing in Zone 1 of Borehole LA\#2, two evaporation pans were installed within the space enclosed by the seepage capture and end curtains; i.e., ventilation effects were reduced and evaporation rates were measured for all remaining tests, starting with liquid release into Zone 2 of Borehole LA\#1 Zone 2, and ending with the test in Zone 3 of Borehole LA\#4 Zone 3). As a result of the Borehole LA\#2 and Borehole LA\#1 tests, effective porosity for one-time fill cavities was 0.028 , for drainable cavities 0.027 , and for fractures 0.013 . Effective porosity is defined here as total volume water necessary to initiate seepage, divided by the potential volume of participating formation; thus, it is rate dependent. The threshold flux determined from testing in Zone 2 of Borehole LA\#1 was found to be $15 \mathrm{~mL} / \mathrm{min}$. 


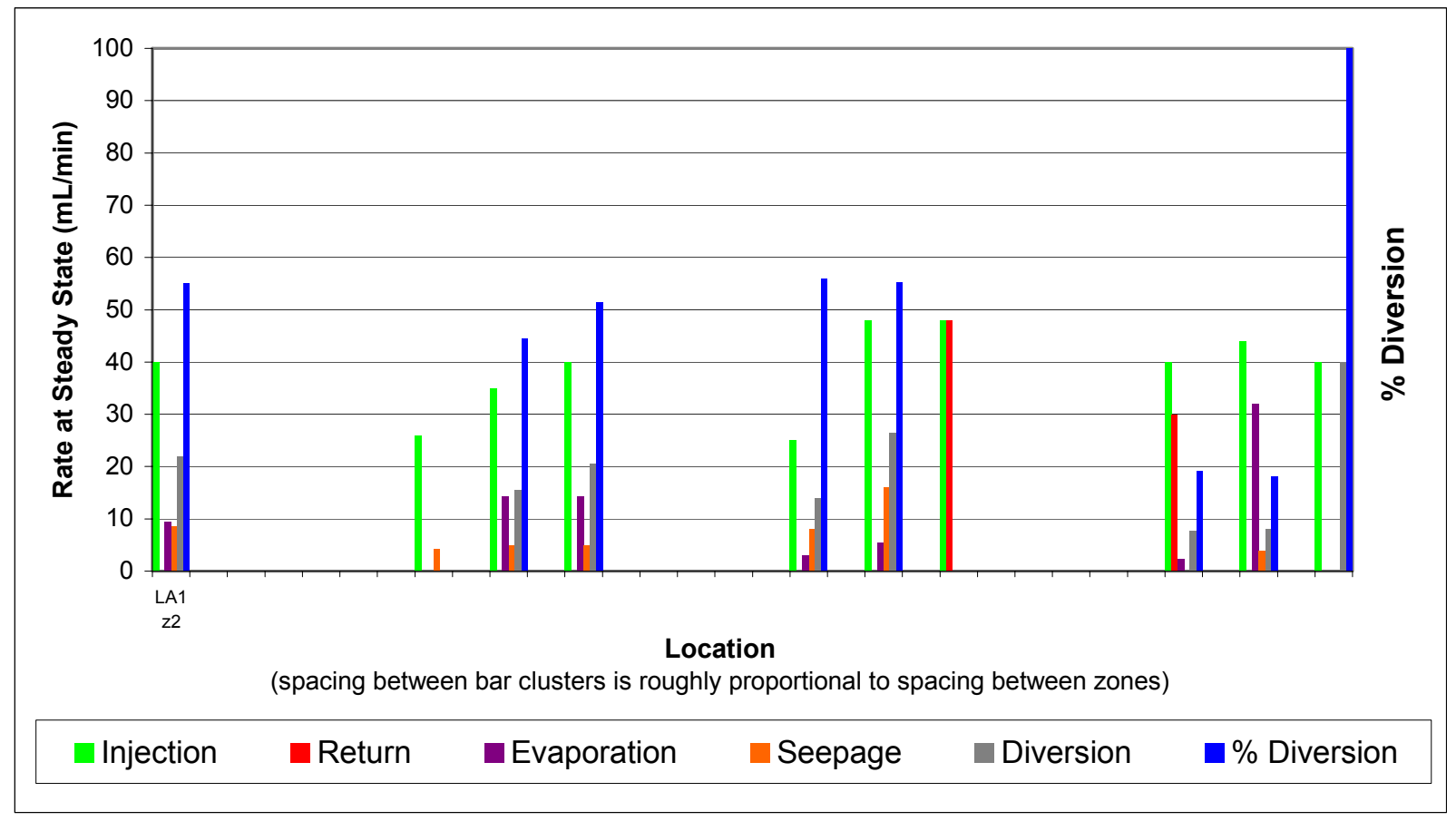

Source: DTNs: LB0110ECRBLIQR.001 [DIRS 156878]; LB0110ECRBLIQR.003 [DIRS 156877]; LB0110ECRBLIQR.002 [DIRS 156879]; LB00090012213U.001 [DIRS 153141]; LB00090012213U.002 [DIRS 153154]; LB0203ECRBLIQR.001 [DIRS 158462] LB0301SYTSTLA4.001 [DIRS 165227].

NOTES: Injection, return, evaporation, and seepage are all either from the text in Section 6.11 of this report, or are estimates based on figures in this report that have the relevant data. Diversion is injection minus return, evaporation, and seepage. Percent diverted is diversion divided by the difference between injection and return.

No evaporation data are available for testing in Zone 1 of Borehole LA\#2 (because no ventilation control curtains were in use at the time) and, therefore, no diversion or percent diverted was calculated.

Percent diverted for Borehole LA\#3 Zone 3 is not quantifiable because there was 100-percent return flow.

Some of the evaporation rates are estimates from tests run under similar conditions.

Figure 6-148. Summary Plot Showing Injection, Return Flow, Evaporation, and Diversion in All Systematic Hydrologic Tests 


\subsection{DRIFT-TO-DRIFT ALCOVE-8 / NICHE-3 (NICHE 3107) AND SURFACE-TO- DRIFT ALCOVE 1 TESTS}

Two large-scale tests (with a vertical distance in the range of 20 to $30 \mathrm{~m}$ ) have been conducted in the ESF. These tests are compared with tests having vertical distances of less than $1 \mathrm{~m}$ (primarily niche seepage tests presented in Section 6.2) and up to $3 \mathrm{~m}$ (fracture-matrix tests in Alcove 6, Section 6.6; and fault and matrix tests in Alcove 4, Section 6.7). Over longer distances, matrix diffusion processes become more significant as shown in this section. The specific test plan for this drift-to-drift test series is Test Plan for: Alcove 8 Flow \& Seepage Testing (BSC 2002 [DIRS 157606]).

Alcove-8 / Niche-3 (Niche 3107) tests were designed based on experience gained from surface infiltration tests and niche seepage tests. The Alcove- 8 / Niche-3 tests are aimed at evaluating unsaturated zone flow, seepage response, and matrix diffusion processes. Alcove 8 (located in the ECRB Cross-Drift) has been excavated for liquid releases through a fault (fault tests) and a network of fractures (large-plot tests). Niche 3 (Niche 3107; located in the Main Drift of the ESF) serves as the site for monitoring wetting-front migration, seepage originating from releases at Alcove 8, and tracer concentration of seeping water. The plan discusses tests with water and tracer releases along an exposed fault (referred to as "Alcove-8/Niche-3 fault tests") and releases to the fracture network from a large infiltration plot (referred to as "large-plot tests"). Each test was planned to consist of two phases, where Phase I corresponds to an experimental condition in which a positive water pressure head $(2 \mathrm{~cm})$ is applied at the infiltration plots. In this case, the fault or fracture network is saturated (at least near the infiltration plots). Phase II corresponds to releases with much smaller infiltration rates (or more negative water pressure heads) than Phase I. From the planned test phases, only Phase I has been performed.

Section 6.12.1 describes the test setup between Alcove 8 and in Niche 3. Section 6.12.2 presents the results of Phase I of the fault tests. Section 6.12 .3 presents the results of geophysical imaging of the drift-to-drift test block between Alcove 8 and Niche 3. Section 6.12.4 presents data from the large-plot tests. The available data from the early Alcove 1 tests and their implication for the understanding of surface infiltration processes are summarized in Section 6.12.5.

The drift-to-drift tests at Alcove-8 / Niche- 3 and the completed surface-to-drift tests at Alcove 1 provide data over large scales in the range of 20 to $30 \mathrm{~m}$. This is the relevant scale to relate site-scale processes of infiltration and percolation with drift-scale processes of diversion and seepage. Along long flow paths, fracture-matrix interaction is shown to be an important component of transport, with the matrix contributing to delays in water and tracer movements through the unsaturated units. The data from Alcove- 8 / Niche-3 fault tests were used to partly validate the UZ flow model (BSC 2004 [DIRS 169861], Section 7.6) and UZ radionuclide transport model (BSC 2004 [DIRS 164500], Section 7.4). Data from the Alcove 1 tests were used to corroborate estimates of hydrogeologic properties (BSC 2004 [DIRS 170038], Section 6.1.3.4). 


\subsubsection{Drift-to-Drift Alcove-8 / Niche-3 (Niche 3107) Tests}

\subsubsection{Test Sequence of Liquid and Tracer Releases}

A series of tests was conducted in the Alcove- 8 / Niche-3 fault test bed. Water was introduced along the fault under ponding condition (with a 2-cm water head) until quasi-steady-state seepage was observed in Niche 3. A finite volume of water, containing two tracers with different molecular diffusion coefficients ( $\mathrm{Br}^{-}$and pentafluorobenzoic acid (PFBA)), was then introduced into the fault. Once the tracer-laced water had been released into the fault, more tracer-free water was released. Both tracer-laced and tracer-free releases occurred under the same ponding condition. This release of tracer-free water continued until a few months after breakthrough of the two tracers ( $\mathrm{Br}^{-}$and PFBA) was observed in the seepage collected in Niche 3.

\subsubsection{The Test Bed}

Panel A of Figure 6-149 shows the location of the test site within the ESF main drift and the ECRB Cross-Drift. Panel B of Figure 6-149 shows a 3-D representation of the test area, including several slanted (near-vertical) boreholes. Alcove 8 was excavated within the upper lithophysal zone of the TSw (Tplpul) in the ECRB Cross-Drift, located directly above Niche 3 in the middle nonlithophysal zone (Tptpmn) in the ESF main drift. Shortly after the Alcove 8 excavation, liquid water was observed toward the end of Niche 3 (Niche 3107, DTN: GS030508312242.004 [DIRS 165545]).

Alcove 8 begins at ECRB Cross-Drift Station CD 7+98.236, (CRWMS M\&O 1999 [DIRS 156876]). An elevation of 1093.973 masl is calculated for CD 7+98.236 using the software ECRB-XYZ V.03 (CRWMS M\&O 1999 [DIRS 147402]). (No other software or calculation method was considered, because no software alternative is available for this project-specific task.) The elevation at STA $0+00$ of Alcove 8 is approximately $0.510 \mathrm{~m}$ above CD 7+98.236, or $1094.483( \pm 0.15 \mathrm{~m})$ masl, based on Alcove 8 design drawings (CRWMS M\&O 1999 [DIRS 156876]). Niche 3 is located in the middle nonlithophysal zone of the TSw (Tptpmn). The crown of Niche 3 is approximately 2 to $3 \mathrm{~m}$ lower than the 1076.7-masl crown elevation of the ESF at Station 31+07. The location of the Tptpul-Tptpmn contact is approximately 1080 masl, based on GFM3.1 data (DTN: MO9901MWDGFM31.000 [DIRS 103769]).

The distinctive feature of the test bed in Alcove 8 is a near-vertical fault that cuts across the floor (Figure 6-150). It is open on the ceiling, and appears to be closed along the floor of the alcove. To facilitate ponded releases of water, a trench approximately $5 \mathrm{~cm}$ wide and approximately $5 \mathrm{~cm}$ deep was dug along this fault. 


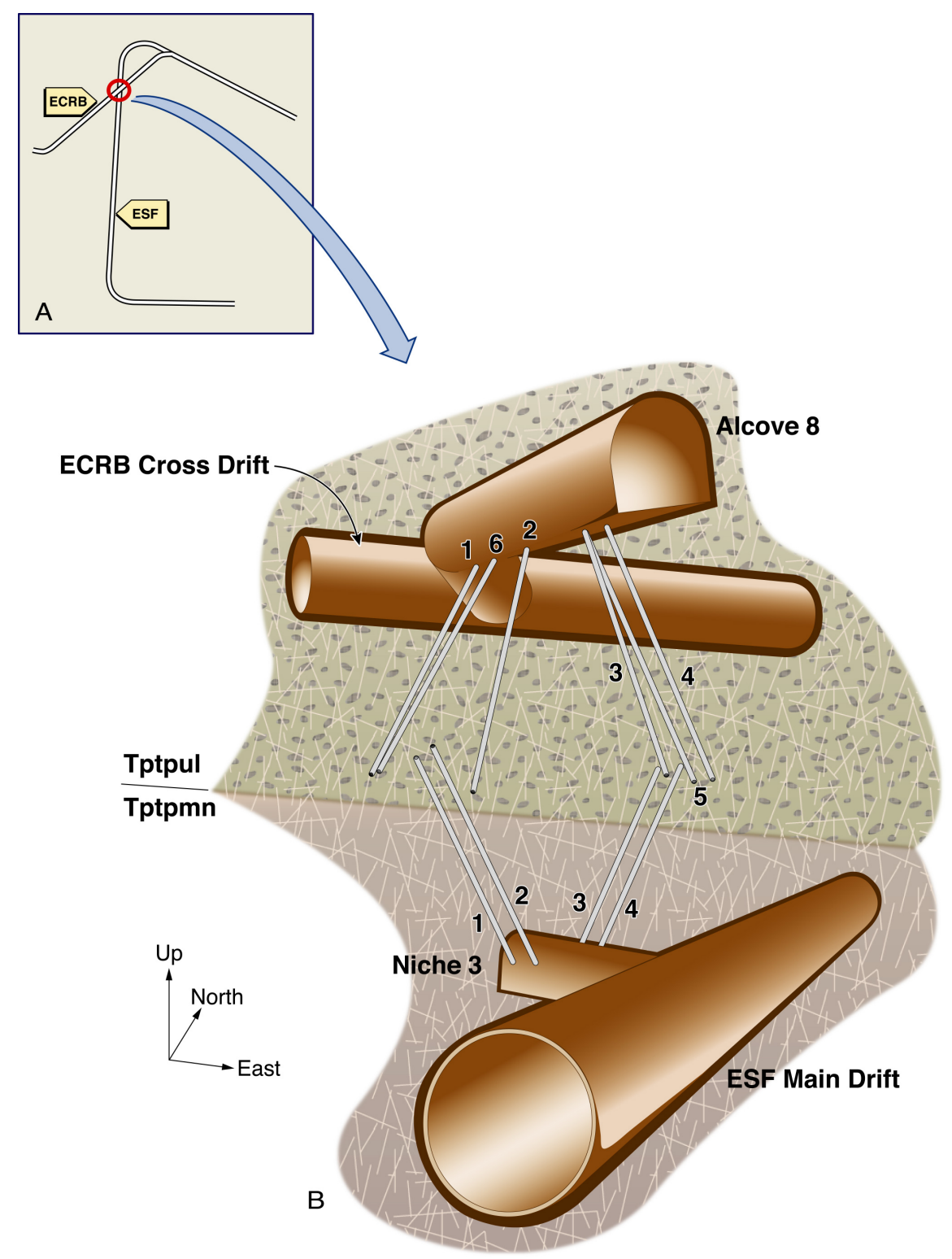

NOTES: Panel $\mathrm{A}=$ Test location.

Panel $\mathrm{B}=$ Test layout.

Figure 6-149. Schematic Illustration of the Test Bed for the Alcove-8 / Niche-3 Tests 


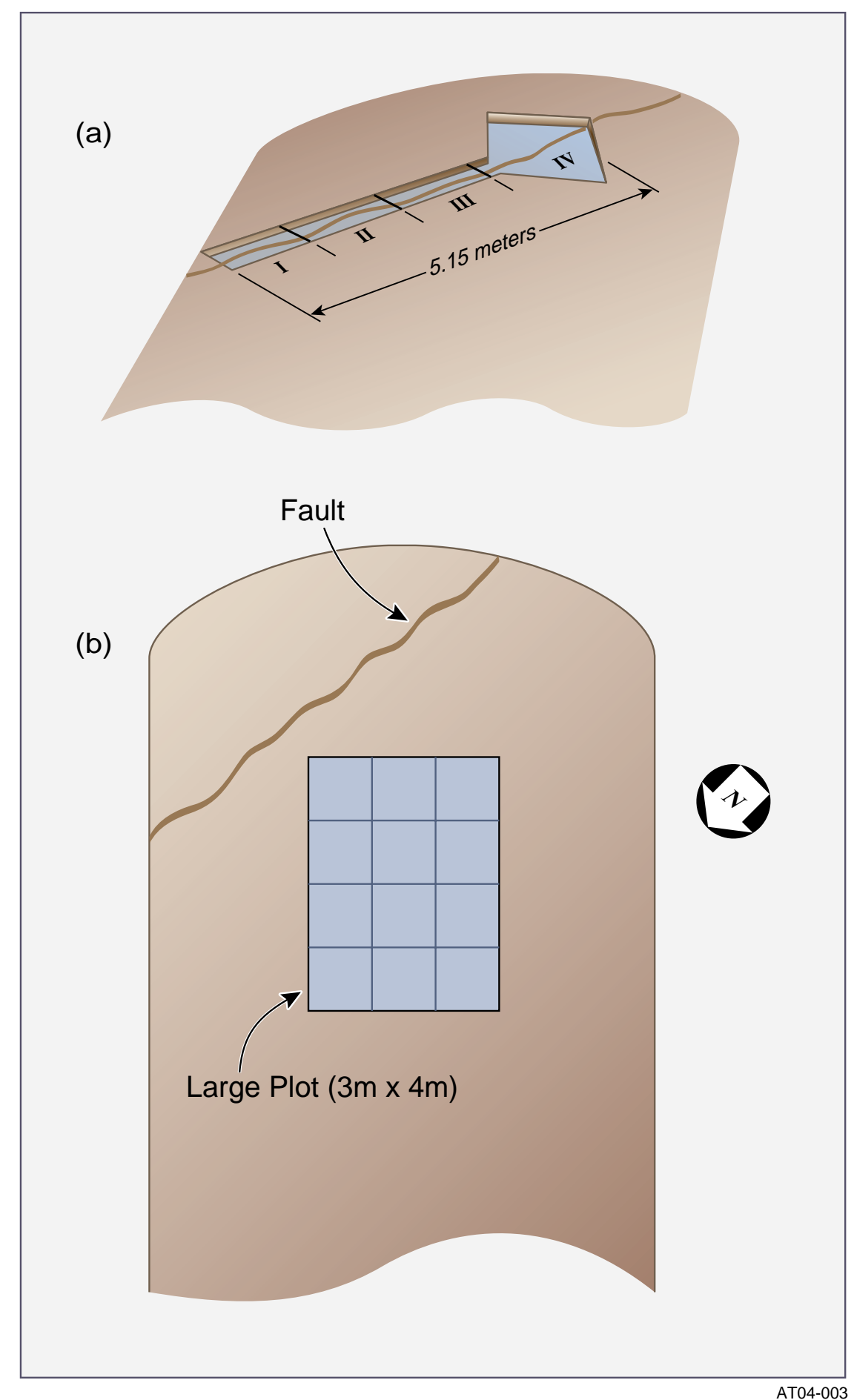

NOTES: $\quad$ Panel $(a)=$ Fault test (also referred to as the Small Plot Test); individual compartments (trenches) are labeled by Roman numerals.

Panel $(b)=$ Large plot test.

Figure 6-150. Schematic Illustration of the Infiltration Zones along the Floor of Alcove 8 
The physical set up of the trench is in two parts. The first part of the fault was exposed in a trench that is $3.3 \mathrm{~m}$ long and 43 to $46 \mathrm{~cm}$ wide. The entire trench was divided into three compartments (Trench I through III). The second part (Trench IV) was the area that was dug out for the original cylinder (and box) experiments. It is a rectangle approximately $1.4 \mathrm{~m}$ by $1.5 \mathrm{~m}$, with the fault running diagonally through it. The area of each trench section is as follows:

- Trench I (left rib to right rib) is $4005 \mathrm{~cm}^{2}$,

- Trench II is $4680 \mathrm{~cm}^{2}$,

- Trench III is $5265 \mathrm{~cm}^{2}$, and

- Trench IV is $21000 \mathrm{~cm}^{2}$,

for a total area (exposed to water application) of $34950 \mathrm{~cm}^{2}$.

Niche 3 is approximately $4 \mathrm{~m}$ wide, and extends to approximately $14 \mathrm{~m}$ from the centerline in the ESF main drift. The ceiling of the niche steps from $3.25 \mathrm{~m}$ at the opening to $2.5 \mathrm{~m}$ toward the midpoint of the niche. In addition to the near-vertical holes, three 9.0-m-long, 7.62-cm-diameter horizontal boreholes were drilled approximately $0.5 \mathrm{~m}$ above the ceiling. Additionally, seven 6.0-m-long, 7.62-cm-diameter boreholes extend horizontally to subhorizontally from the niche walls (Figure 6-151). The fault is visible along the ceiling of Niche 3, directly below the trace along the floor in Alcove 8.

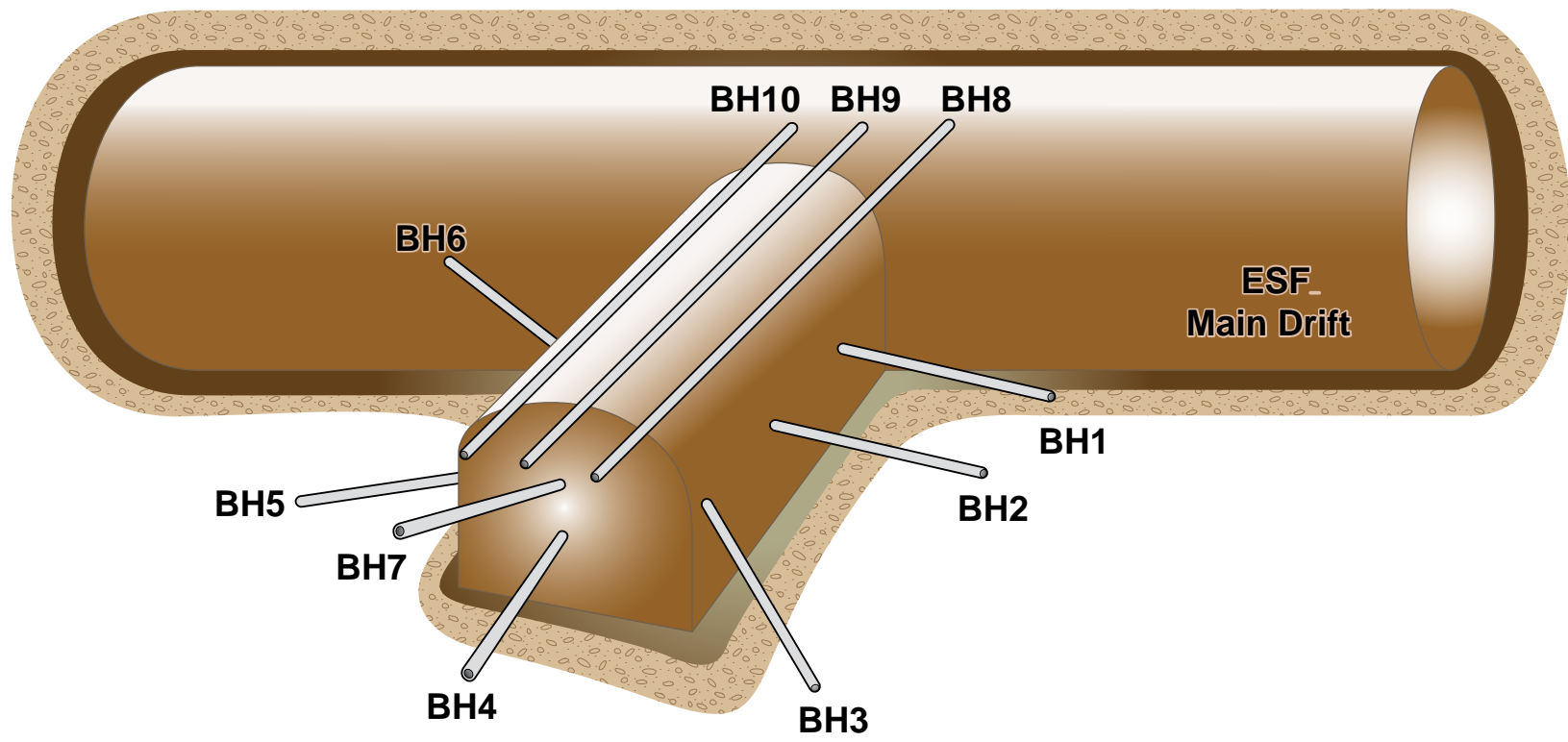

Niche 3107

NOTE: Not included in this figure are four boreholes drilled almost vertically upward from the niche; these boreholes are shown in Figure 6-149.

Figure 6-151. Schematic Illustration of the Horizontal Monitoring Boreholes in Niche 3 


\subsubsection{Instrumentation}

The flow investigation consisted of three distinct components:

(1) controlled release of water into isolated zones along the fault in Alcove 8,

(2) borehole monitoring for changes in saturation and water potential, and

(3) collection of seepage from the ceiling of Niche 3.

The key features of techniques used in this field investigation are presented in Section 6.12.1.3.1 through 6.12.1.3.4.

\subsection{Fluid and Tracer Injection}

Water was applied along the fault in Alcove 8 at three different times. Initially, the application area was over a small section of the fault. The length of test zone along the fault was increased to $1.0 \mathrm{~m}$, and then to $5.15 \mathrm{~m}$. In the small injection zone, water was first released with an infiltrometer, which is a cylinder $30 \mathrm{~cm}$ in diameter. During the second release, the infiltrometer cylinder was replaced with a box that measured $70 \mathrm{~cm}$ by $70 \mathrm{~cm}$. These two releases are referred to as the small plot tests (DTNs: GS010608312242.004 [DIRS 165542]; GS010608312242.002 [DIRS 165543]). For the third set of water releases, the 5.15-m long fault trace was divided into four sections, with each section serving as a separate release zone. In each of these applications, water along the release zone was ponded to a head of approximately $2 \mathrm{~cm}$.

Ponded release of water to the extended fault section began on March 6, 2001, and continued for more than a year. The fault was divided into four sections, each of which had a permeameter for water application measurement; all four permeameters were supplied by a single water tank. (Note that Trench IV includes the area previously infiltrated during the Small Plot test.)

A mix of conservative tracers (pentafluorobenzoic acid (PFBA) and lithium bromide (LiBr)) was released along the fault over a period of nine days, beginning on October 1, 2001. The concentration of $\mathrm{LiBr}$ in the tracer-mix was approximately $500 \mathrm{ppm}$; the concentration of the injected PFBA was approximately $25 \mathrm{ppm}$. These concentrations were achieved by dissolving 50 grams of PFBA and 1 kilogram of $\mathrm{LiBr}$ in a 1893-L (500-gallon) water tank that was used to supply the water injected into the fault.

\subsection{Borehole Monitoring}

In nine monitoring boreholes (i.e., Boreholes 1 to 7, Borehole 9, and Borehole 10 in Figure 6-151), changes in saturation were measured continuously with electrical resistivity probes (ERPs) located at $0.25-\mathrm{m}$ intervals along the length of each borehole during the entire field investigation. Water-potential measurements were made with psychrometers along a single borehole (i.e., Borehole 8 in Figure 6-151).

The psychrometers and ERPs were housed in borehole sensor trays (BSTs) installed along the length of each monitoring borehole. The BSTs were fabricated from 3.0-m-long, 0.10-m OD (outside diameter), PVC pipes. Each pipe section was cut lengthwise to produce a 7.5 -cm-wide curved tray. The BST housing permitted immediate contact between ERPs and the borehole wall. The psychrometers were installed inside small cavities $(0.5 \mathrm{~cm}$ in diameter $)$ drilled through the BST wall to measure water potentials of the rock. 
There are six boreholes (ECRB-COA-AL \# 8-1 to ECRB-COA-AL \# 8-6) surrounding the large plot, 30 degrees out from vertical and drilled to an approximate depth of $15 \mathrm{~m}$. The right and left sides of the large plot each have two boreholes, and the front and back of the large plot each have one hole, as illustrated in Figure 6-149. These six boreholes were monitored periodically with neutron meters for water content.

\subsection{Seepage Collection}

An automated water-collection system was designed to capture seepage from the niche ceiling. With this system, water dripping from the niche ceiling was collected in plastic trays and diverted to PVC collection bottles. These bottles were installed with pressure transducers to periodically measure the collected amount of seepage water.

\subsection{Tracer Sampling System}

Immediately after the release of tracers into the fault in early October 2001, a water-sampling device (the passive-discrete water sampler (PDWS)) was connected to three of the collection trays in Niche 3 into which water was seeping. The PDWS, which was designed to direct continuous seepage from each tray into discrete samples for chemical analysis, remained connected to the trays for three months. During this time, water that seeped into the three trays was captured sequentially into sampling bottles and analyzed for concentrations of PFBA and LiBr.

\subsubsection{Phase I Observations from the Fault Liquid Test}

Observations from Phase I testing include the intake rates measured along the fault, the time taken for the wetting front to arrive at the monitoring boreholes directly above Niche 3 , the seepage rates measured at various locations, and the concentration of tracers in the seeping water.

\subsubsection{Fault Intake Rates}

During the first two months of water release (under ponded conditions), a stable boundary condition could not be maintained along the fault because of power interruptions and equipment failure. The resulting disruptions to the daily application rate are apparent in the intake data, which show large fluctuations from early March 2001 through mid-May 2001 (Figure 6-152). During this period, approximately $15000 \mathrm{~L}$ of water were applied to the four sections of the fault. Once the supply of water to the fault was stabilized, the variability in infiltriation rates was greatly reduced, and remained within the range of approximately $25 \mathrm{~L} /$ day to approximately $100 \mathrm{~L} /$ day along the sections (DTNs: GS020508312242.001 [DIRS 162129]; GS020908312242.002 [DIRS 162141]; GS030208312242.003 [DIRS 165544]).

Within the next nine months, an additional $57000 \mathrm{~L}$ of water were released into the fault with large spatial and temporal variability in infiltration rates along the fault. In Trench I, infiltration rates that were approximately $100 \mathrm{~L} /$ day in early May 2001, steadily dropped to approximately $25 \mathrm{~L} /$ day by the end of January 2002. In Trench II, intake rates of approximately $25 \mathrm{~L} /$ day in early May 2001 gradually decreased to $15 \mathrm{~L}$ /day over a period of nine months. In both Trench III and Trench IV, the temporal fluctuations in the infiltration rates were much larger 
than those in Trench I and Trench II. In both trenches, the infiltration rates decreased from approximately 100 L/day early in May 2001 to approximately 70 L/day by late January 2002 .

The observed infiltration rates likely reflect the permeability of the infill material that clogged the near-surface sections of the fault rather than an "open fault." The variability measured in the four sections was most likely determined by the depth to which this infill material had penetrated in each of the sections.

On April 8, 2002, the fault was switched from saturated application to unsaturated application. This was done by applying a known amount of water per minute using pumps. On July 9, 2002, all dividers were removed from the trench, and two of the pumps were turned off, at which point all water to the fault unit was supplied by two pumps. The infiltration rates are illustrated in Figure 6-152 for the daily rates and in Figure 6-153 for the cumulative rate. On August 20,2002, the water application to the trench was stopped, and water application to the large plot started (as described in Section 6.12.4).

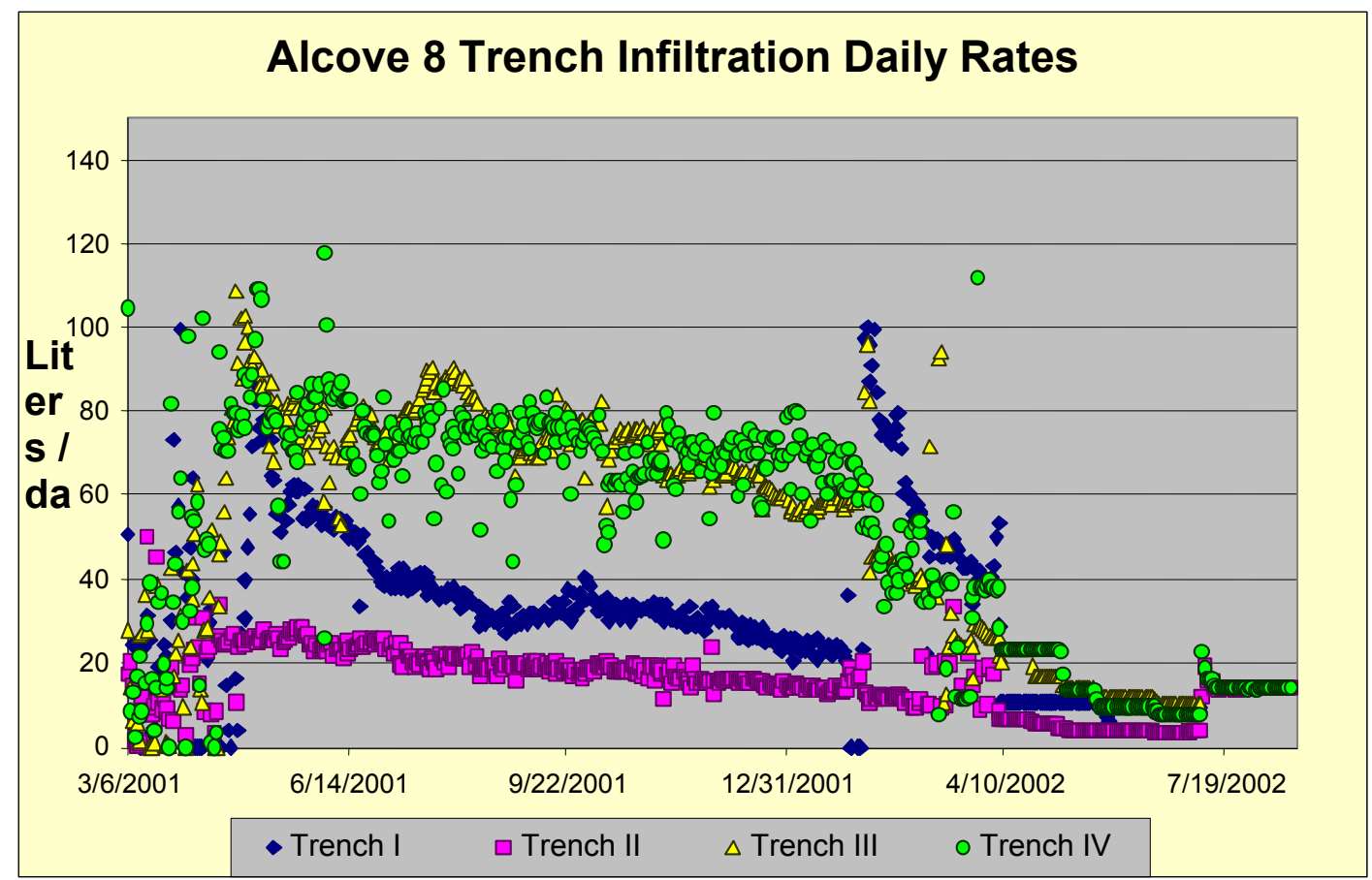

Source: DTNs: GS020508312242.001 [DIRS 162129] for March 5, 2001, to June 1, 2001; GS020908312242.002 [DIRS 162141] for June 1, 2001, to March 26, 2002; GS030208312242.003 [DIRS 165544] for March 26, 2002, to August 20, 2002.

Figure 6-152. Alcove 8 Trench Infiltration Daily Rates for Saturated and Unsaturated Conditions in the Fault Experiment 


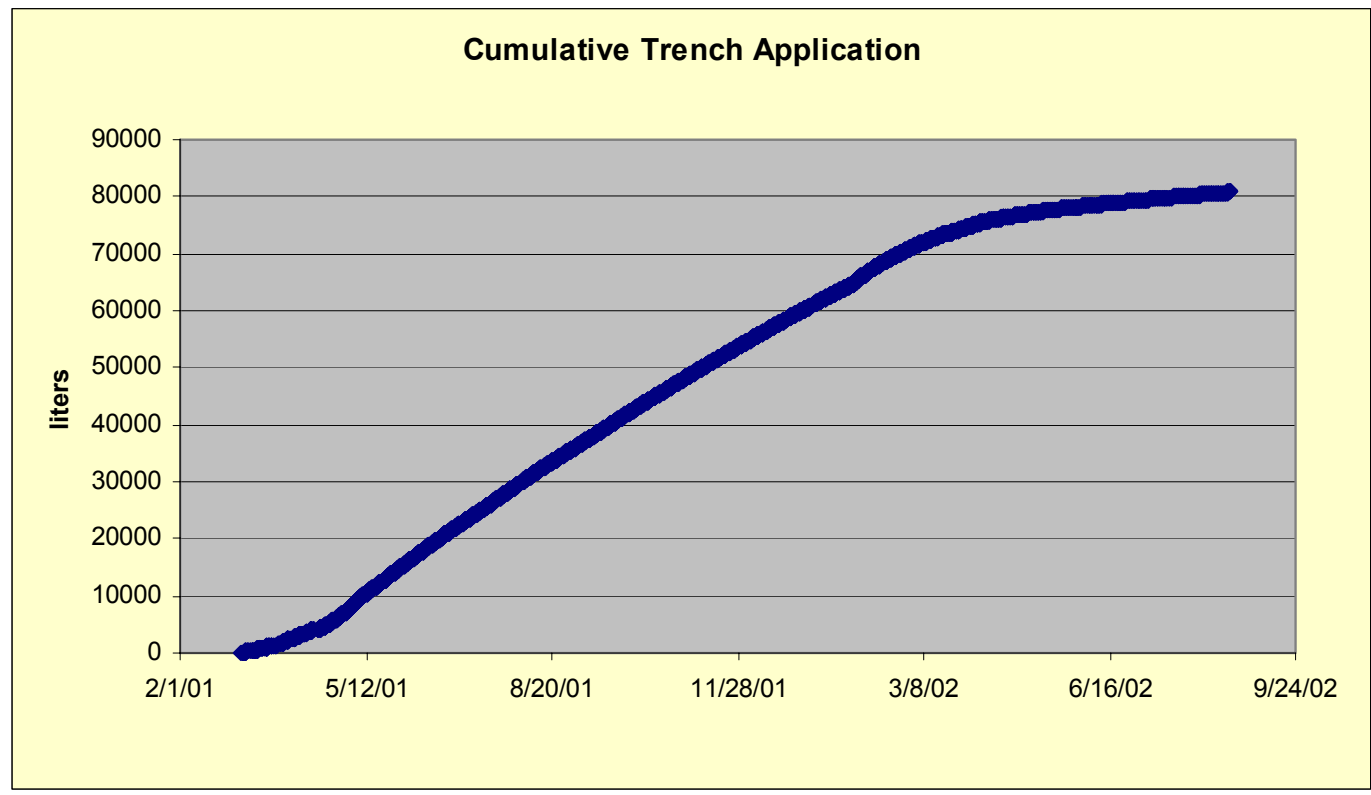

Source: DTNs: GS020508312242.001 [DIRS 162129] for March 5, 2001, to June 1, 2001; GS020908312242.002 [DIRS 162141] for June 1, 2001, to March 26, 2002; GS030208312242.003 [DIRS 165544] for March 26, 2002, to August 20, 2002.

Figure 6-153. Cumulative Trench Application from March 5, 2001, to August 20, 2002

\subsubsection{Wetting-Front Migration and Development of the Wetting Plume}

The three horizontal boreholes located directly above the ceiling of Niche 3 (i.e., Borehole 8 , Borehole 9, and Borehole 10), intercept the fault at a distance of 1.27, 1.93, and $2.08 \mathrm{~m}$, respectively, from the collars (Figure 6-151). The vertical distance from the liquid-release zone in Alcove 8 to these boreholes is approximately $20 \mathrm{~m}$.

The advancing edge of the wetting front was detected $1.9 \mathrm{~m}$ from the collar of Borehole 10 on April 9, 2001, 34 days after the start of liquid releases along the fault in Alcove 8 (Figure 6-154). This plume was observed to extend between $1.65 \mathrm{~m}$ and $2.40 \mathrm{~m}$ from the collar in Borehole 10 over the next seven days. At this location, the ERP response suggests that wetting was quick, with measured resistance dropping to a relatively constant value within two days.

After water was detected along sections of the three boreholes intersecting the fault, the spread of the edge of the plume was recorded by ERPs located along Borehole 1, Borehole 9, and Borehole 10. Figure 6-155 shows the velocity of the wetting front of the plume as it reaches various locations surrounding Niche 3. The data from ERPs located along the length of Borehole 9 suggest that the fastest velocities (approximately $0.65 \mathrm{~m} /$ day) were observed along an approximately $0.75-\mathrm{m}$-wide zone located between $1.25 \mathrm{~m}$ to slightly less than $2.0 \mathrm{~m}$ from the borehole collar. The second fastest velocities (approximately $0.6 \mathrm{~m} /$ day) were detected over an approximately $1.0-\mathrm{m}$-wide zone in Borehole 10 that was centered $2.0 \mathrm{~m}$ from the borehole collar.

In both Borehole 9 and Borehole 10, the velocity of the wetting front continued to linearly decrease with depth (i.e., further into the niche), dropping to 0.1 to $0.3 \mathrm{~m} /$ day at distances between 4 and $7 \mathrm{~m}$ from the borehole collars. Deeper in these boreholes changes in saturation 
were not detected during the 12 months of liquid release. In the sections of Borehole 9 and Borehole 10 close to the ESF main drift (i.e., at depths from 0 to $1.0 \mathrm{~m}$ from the collars), the wetting front was detected 75 to 125 days after the start of water release along the fault. This delayed signal is possibly the result of evaporation effects closer to the drift.

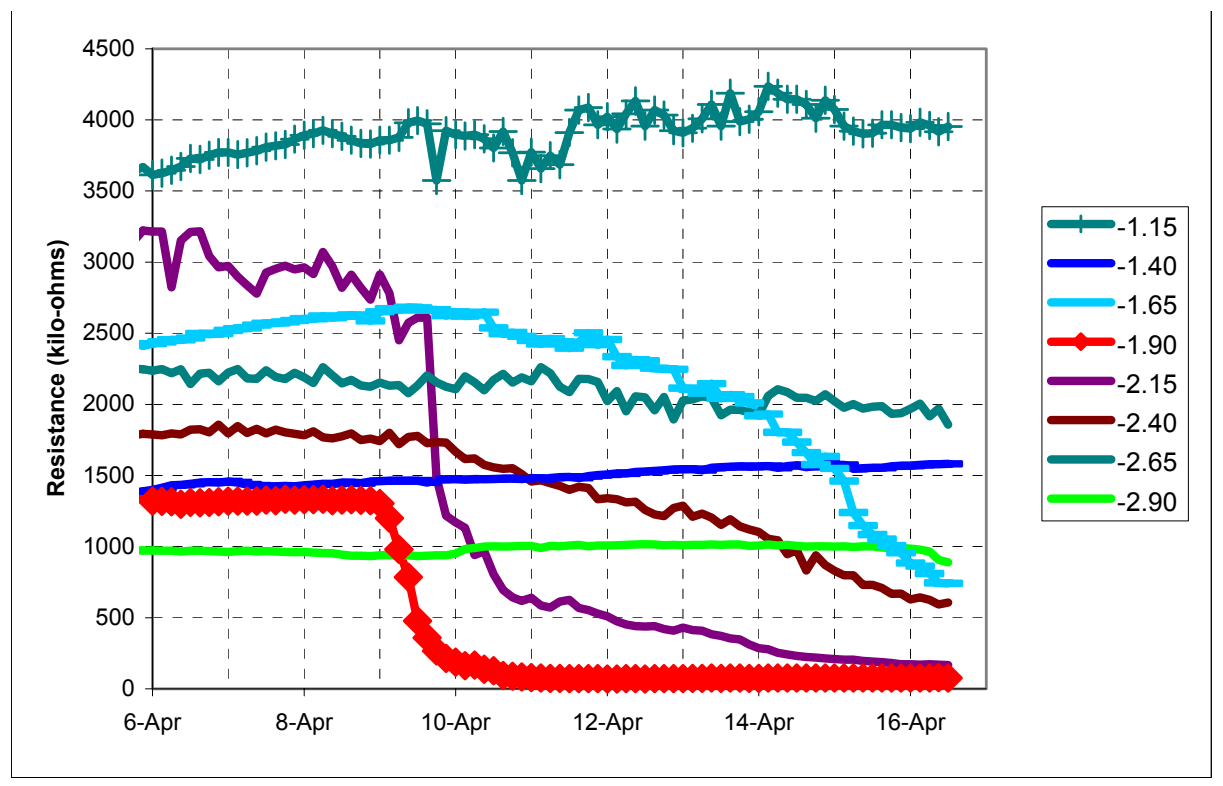

Source: DTN: LB0110A8N3LIQR.001 [DIRS 157001].

NOTE: Legend indicates the distance of the measurement (in meters) from the borehole collar.

Figure 6-154. Illustration of Wetting-Front Arrival Detected in Borehole 10 in Niche 3

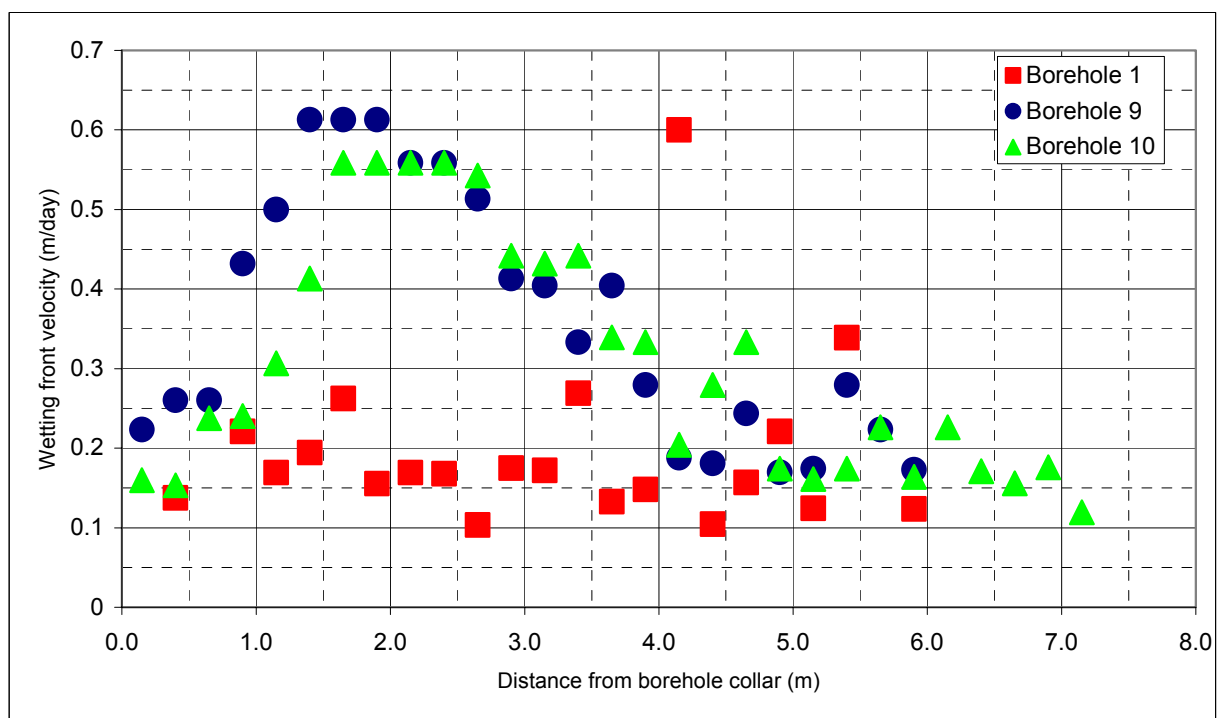

Source: DTNs: LB0110A8N3LIQR.001 [DIRS 157001]; LB0209A8N3LIQR.001 [DIRS 165461]; LB0303A8N3LIQR.001 [DIRS 162570].

NOTE: See Appendix Section 16.5 for calculation details.

Figure 6-155. Wetting-Front Velocities as Determined from Boreholes 1, 9, and 10 in Niche 3 


\subsubsection{Seepage in Niche 3 (Niche 3107)}

Water was first observed along the fault at Niche 3 on April 10, 2001. Over the next few weeks, the number of seeps along the fault exposed in Niche 3 gradually increased. By June 18, 2001, approximately $1100 \mathrm{~L}$ of water had been collected from seeps into Niche 3 (Figure 6-156). The seepage rate from a single seep collection tray suggests that, following the first measurable seepage (which occurred by mid-April 2001), seepage rates climbed to near-steady values by the end of the fourth week.

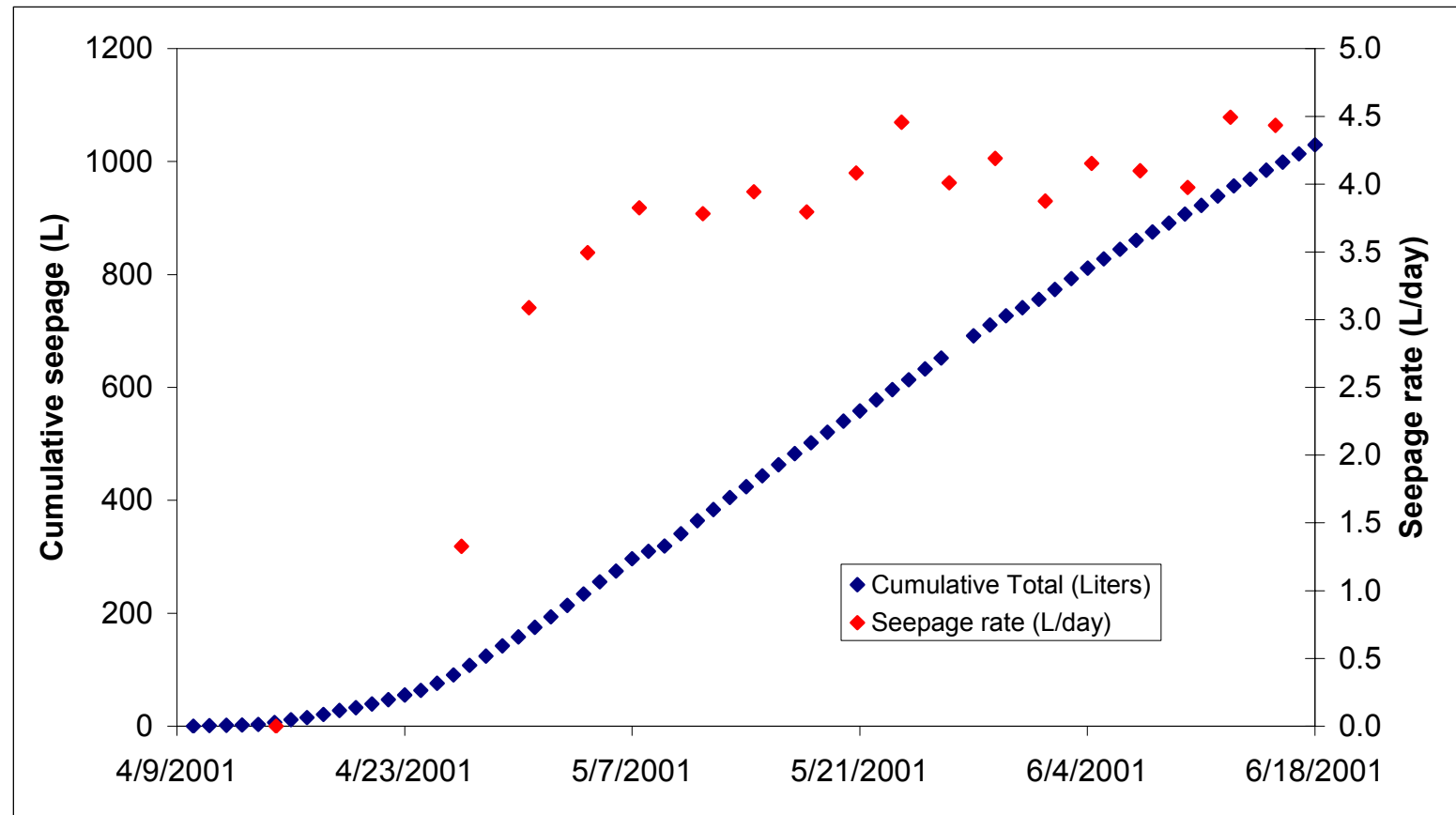

Source: DTN: LB0110A8N3LIQR.001 [DIRS 157001].

NOTE: Figure represents data as measured in Tray U3-B4 (also referred to as Tray 6).

Figure 6-156. Cumulative Seepage (Blue) from All Collection Trays in Niche 3 and the Seepage Rate Observed (Red) along a Section of Fault in Niche 3

Over the next 7 months, measurable seepage was observed in 10 trays located close to the fault trace along the ceiling of Niche 3 (Figure 6-157). Further into the niche (to a depth of $4 \mathrm{~m}$ ), the ceiling was visibly damp (though not dripping). 

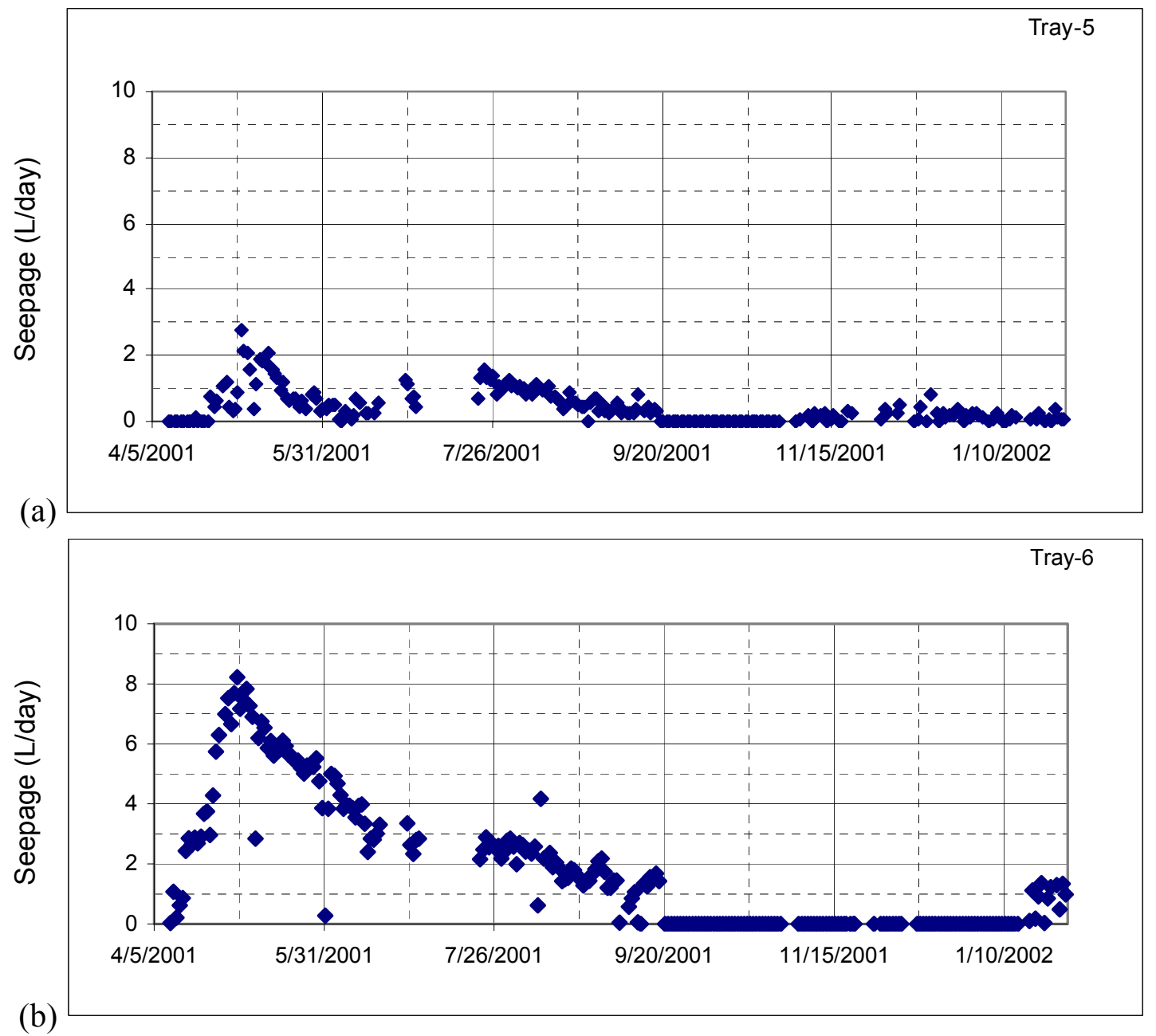

(b)

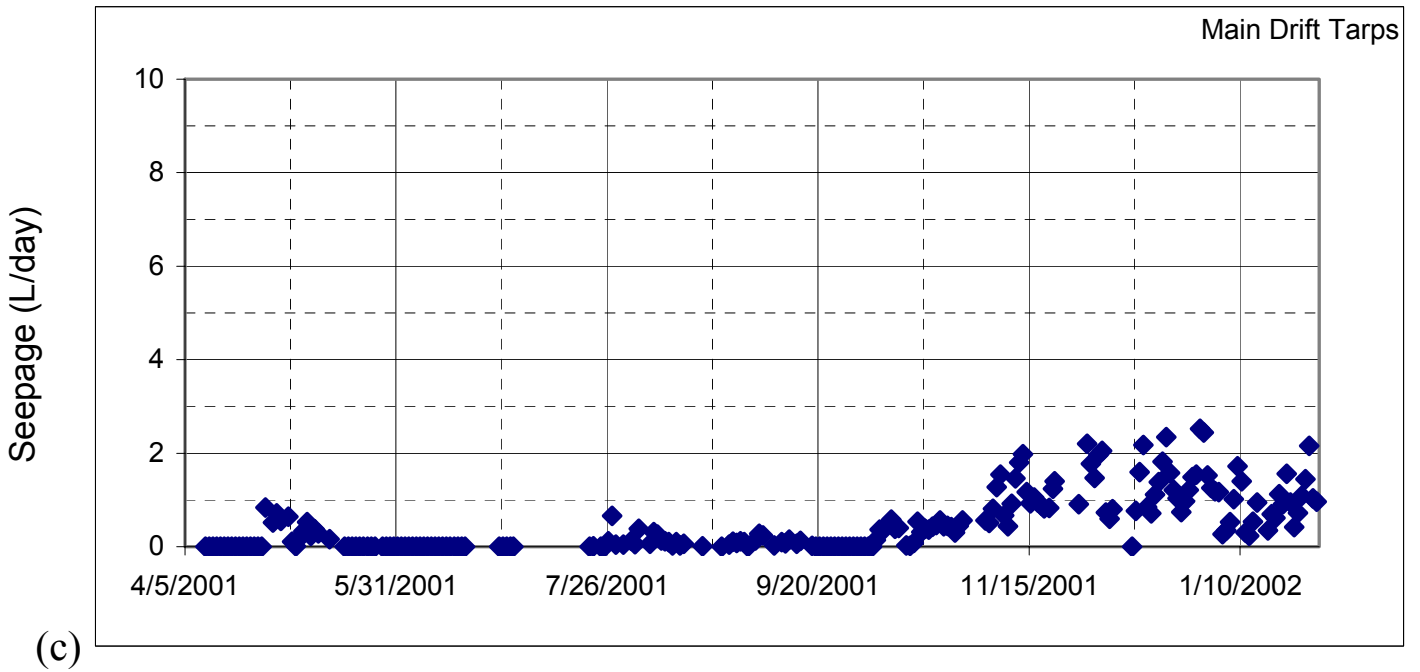

Source: DTN: LB0303A8N3LIQR.001 [DIRS 162570].

Figure 6-157. Seepage Rates (L/day) Measured from 10 Trays Located along the Ceiling of Niche 3 

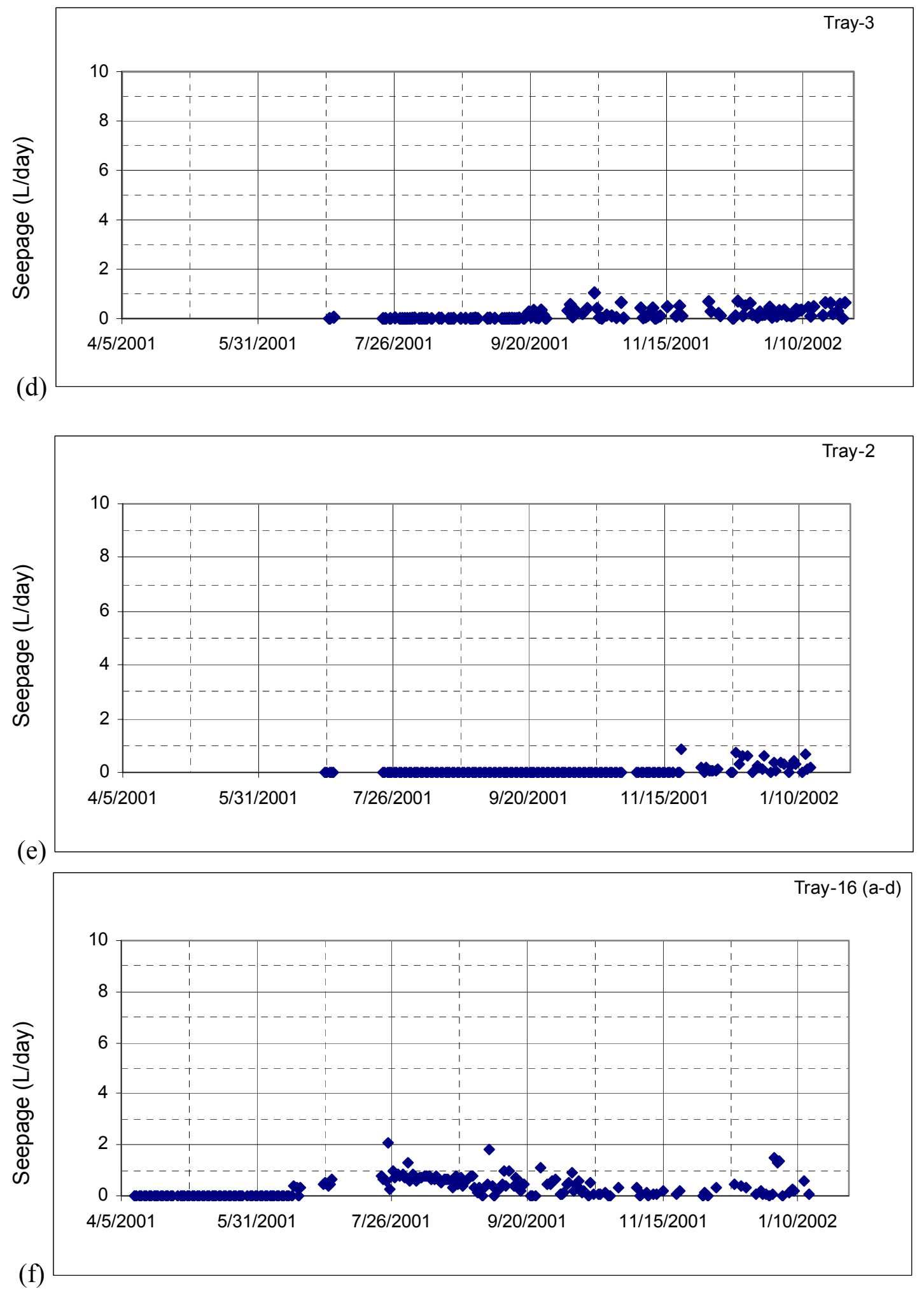

Source: DTN: LB0303A8N3LIQR.001 [DIRS 162570].

Figure 6-157. Seepage Rates (L/day) Measured from 10 Trays Located along the Ceiling of Niche 3 (Continued) 

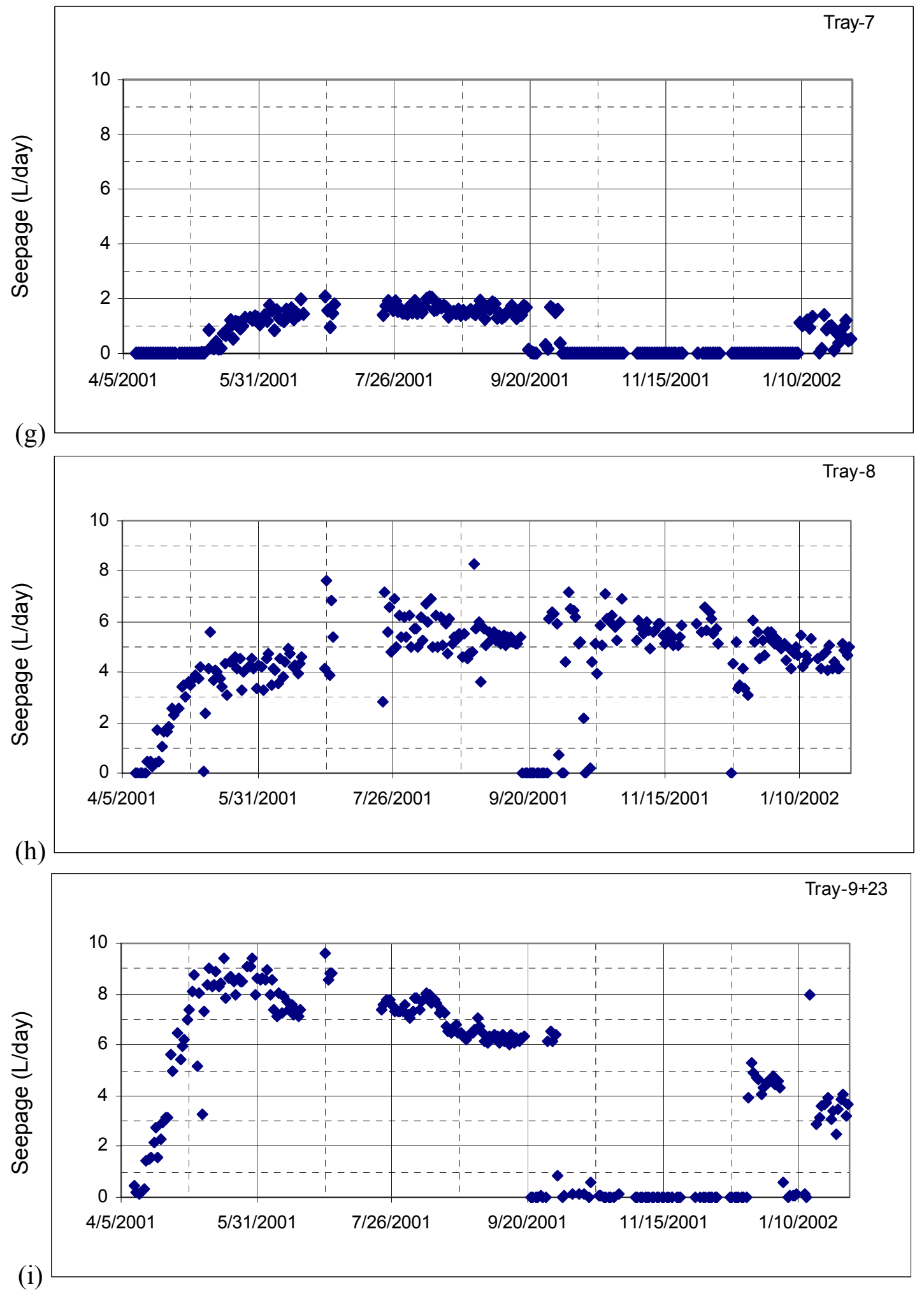

Source: DTN: LB0303A8N3LIQR.001 [DIRS 162570].

Figure 6-157. Seepage Rates (L/day) Measured from 10 Trays Located along the Ceiling of Niche 3 (Continued) 


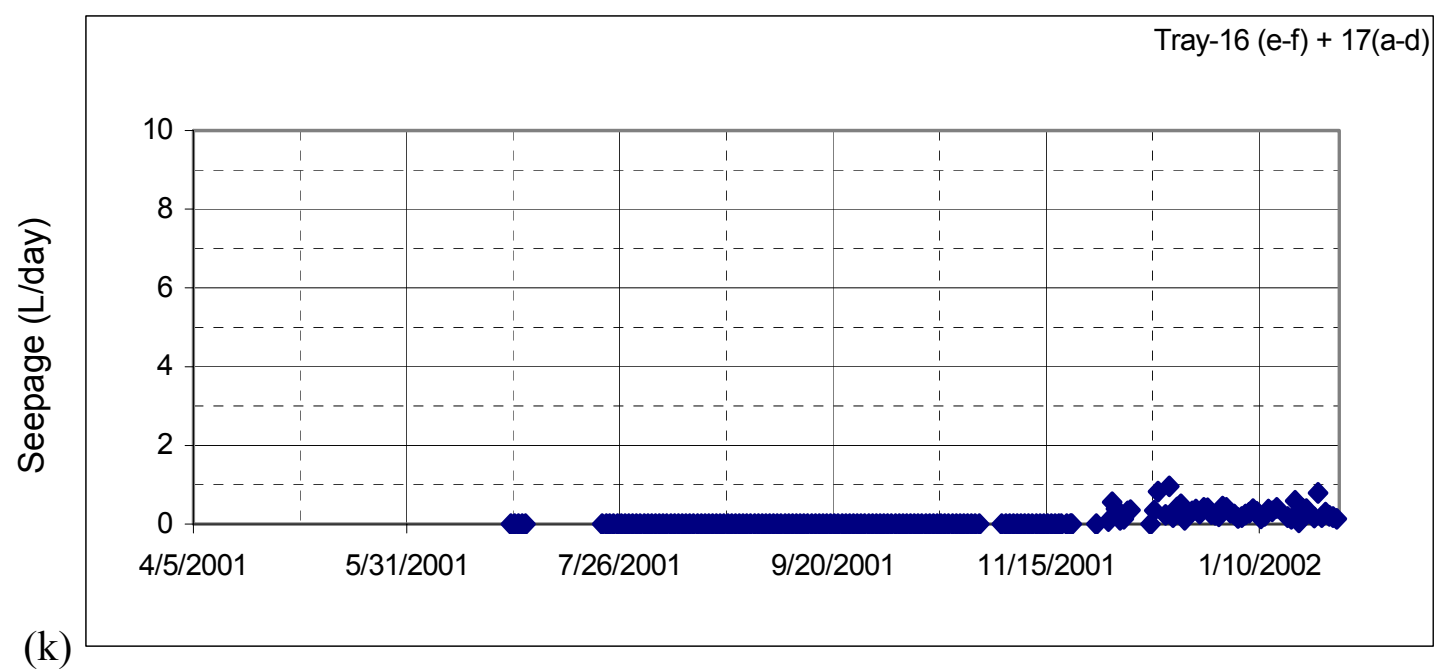

Source: DTN: LB0303A8N3LIQR.001 [DIRS 162570].

Figure 6-157. Seepage Rates (L/day) Measured from 10 Trays Located along the Ceiling of Niche 3 (Continued)

Seepage was first seen above Tray 6 on April 9, 2001, the same day as the advancing edge of the wetting front was detected by the ERP in Borehole 10, located directly above the ceiling of Niche 3 (Section 6.12.2.2). At this location, seepage rates climbed rapidly to approximately $8 \mathrm{~L} /$ day over a period of two weeks, before dropping sharply to rates of less than $2 \mathrm{~L} /$ day by early August 2001. A similar temporal pattern was observed from Tray 9+23, where the seepage rates reached approximately $9 \mathrm{~L}$ /day over a period of 2 to 3 weeks before steadily decreasing to approximately $3 \mathrm{~L} /$ day by late January 2002. (For the period from October 2001 to early January 2002, seepage water into Trays 6,7 , and 9+23 were diverted to tracer samplers, and the seepage rates were not measured.) The most consistent seepage rates (i.e., between approximately 4 and 7 L/day) were maintained at the location of Tray 8. At other locations along the niche ceiling, seeps were observed much later and occurred sporadic and at rates that were consistently less than $3 \mathrm{~L} /$ day.

\subsubsection{Tracer Recovery in Niche 3 (Niche 3107)}

From the time that the first seep was observed in Niche 3 on April 9, 2001 until the end of the experiment, water samples were periodically collected from the location of the first seep (Tray 6) and analyzed for $\mathrm{LiBr}$ concentrations. Six months later, when the tracer-mix comprising $\mathrm{LiBr}$ and PFBA was injected with the infiltrating water, seeping water from three locations along the Niche 3 ceiling was sampled. During this sampling, all water seeping from the three locations was collected as discrete 0.5 - or 1.0-L samples, and analyzed for concentrations of $\mathrm{Li}^{+}, \mathrm{Br}^{-}$, and PFBA.

Figure 6-158 shows the concentration of $\mathrm{Br}^{-}$measured in the seepage water, along with the daily seepage rates for a 1.5-month period, after arrival of the wetting front. The $\mathrm{Br}^{-}$concentration was initially low (approximately $3 \mathrm{ppm}$ ), increasing gradually with time to a value of $30 \mathrm{ppm}$ (the same concentration as for water applied at the infiltration plot) approximately 30 days later. 
This may be an indication of dispersion occurring within the fractures or matrix diffusion. If no matrix diffusion exists and dispersion is small, $\mathrm{Br}^{-}$will arrive as a sharp front and $\mathrm{Br}^{-}$ concentration should be a constant (30 ppm) with time. In addition to matrix diffusion, other mechanisms, such as sorption, may also contribute to the observed retardation of $\mathrm{Br}^{-}$transport. However, $\mathrm{Br}^{-}$is generally considered conservative (not retarded), and the potential sorption is expected to play only a minor role in the observed retardation.

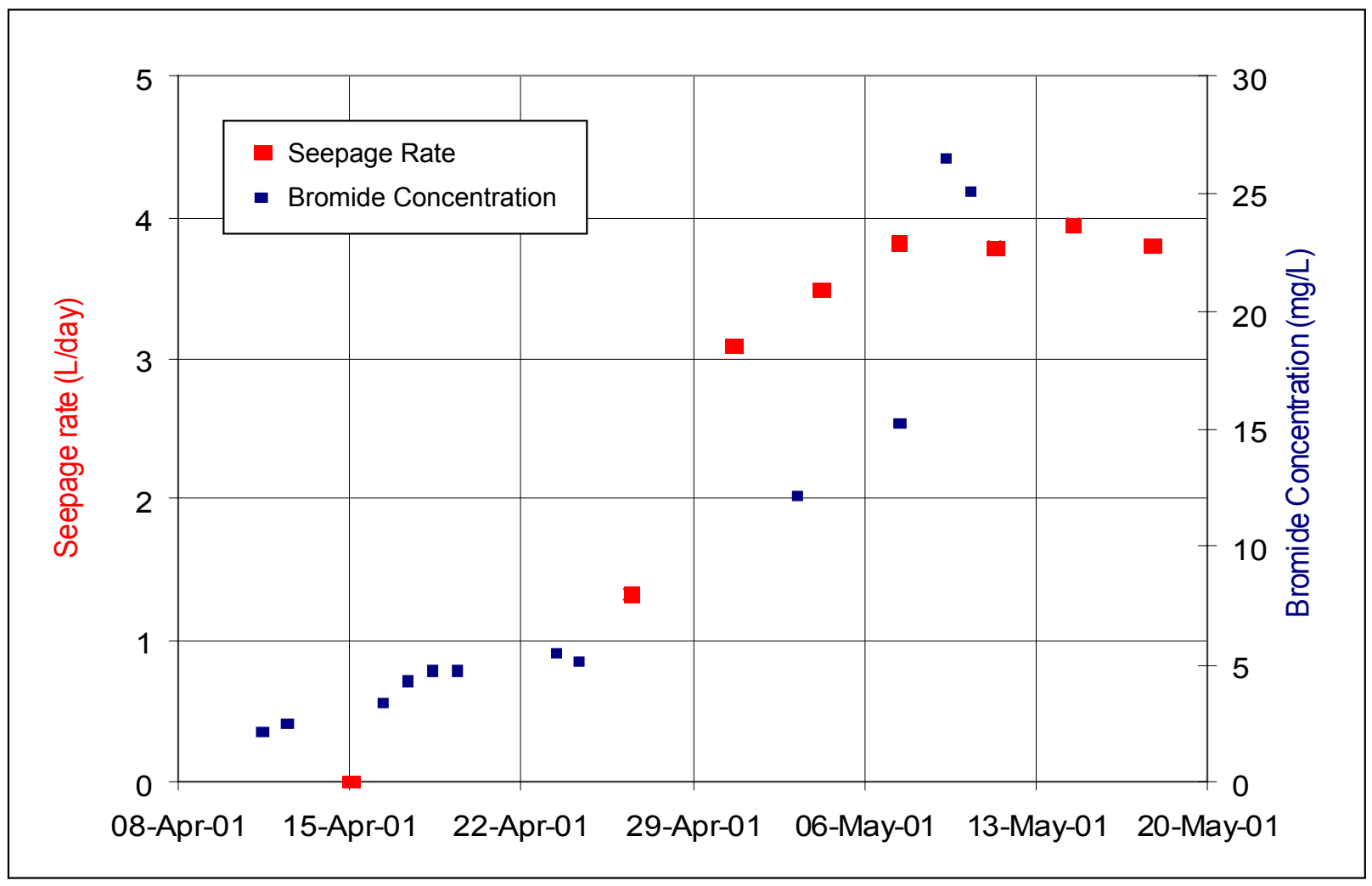

Source: DTNs: LB0110A8N3LIQR.001 [DIRS 157001]; LB0204NICH3TRC.001 [DIRS 158478].

Figure 6-158. Concentration of Bromide and Seepage Rates Plotted for a Period of 45 Days after First Observations of Drips in Tray 6

Figure 6-159 presents the tracer concentration in the seepage water collected from two sampling locations. In Tray 7, both bromide and PFBA were first detected three weeks after initial application of the tracers along the fault. In the following month, the concentration of the tracers gradually increased. Concentration changes of PFBA clearly preceded those of bromide. Peak concentrations of PFBA at this location were observed 61 days after the start of tracer release in Alcove 8 , suggesting a transport velocity of approximately $0.34 \mathrm{~m} /$ day. Over the next three months, the concentration of both tracers gradually decreased. During the final month of sampling, the tracer concentrations remained relatively constant.

In Tray 9+23 (except for the period between mid-October and late November 2001, when the PFBA concentrations suggest faster travel through the fault zone) both tracers showed a similar temporal recovery pattern. The peak concentrations of tracers at this location were observed 
43 days after the start of tracer release in Alcove 8, suggesting a transport velocity of approximately $0.46 \mathrm{~m} /$ day.
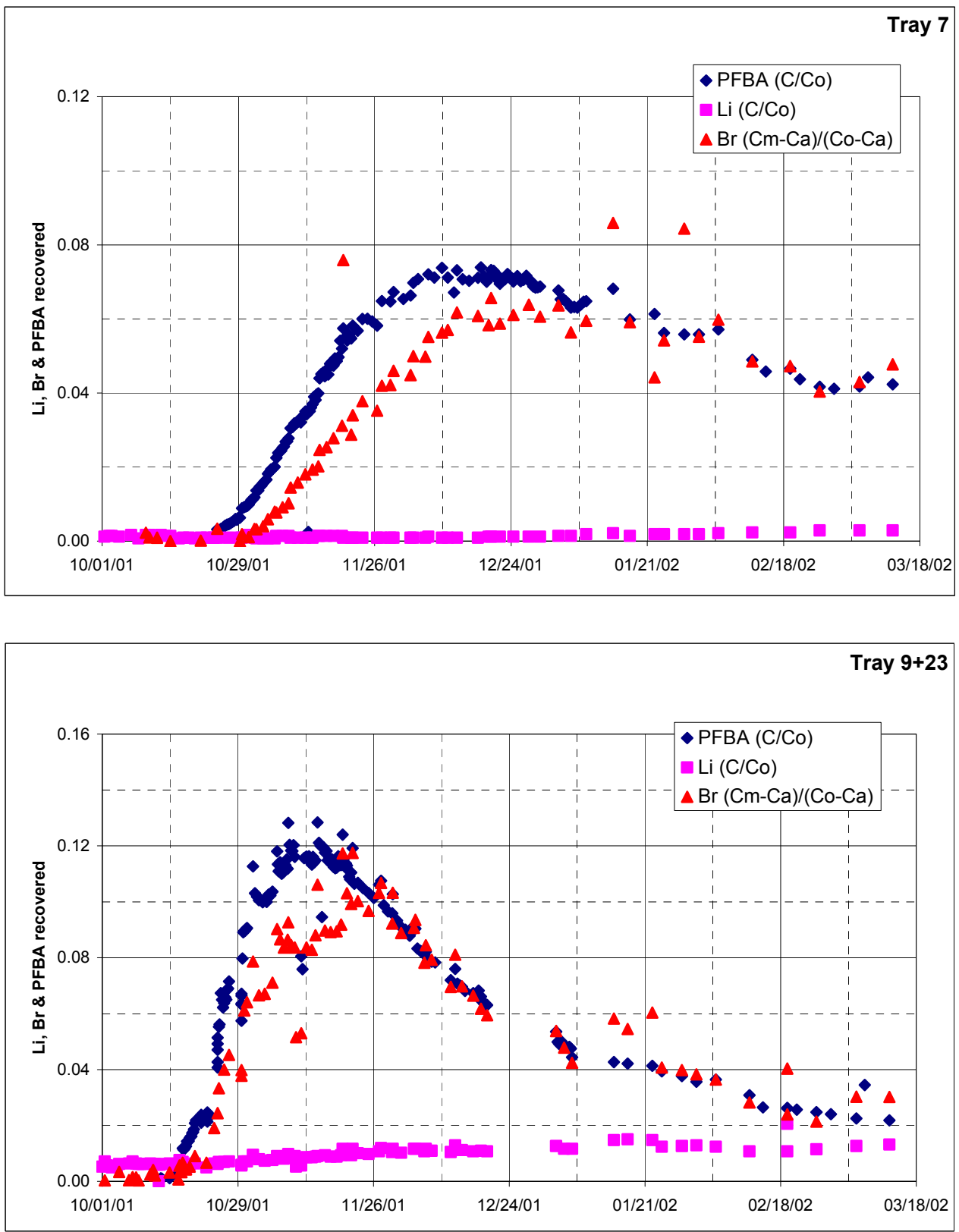

Source: DTNs: LB0204NICH3TRC.001 [DIRS 158478], LB0303A8N3LIQR.001 [DIRS 162570].

NOTE: $\quad \mathrm{Co}$ is the concentration of the injected water, $\mathrm{C}$ and $\mathrm{Cm}$ denote the measured concentration, and $\mathrm{Ca}$ is the background concentration in the seepage water.

Figure 6-159. Relative Mass Recovery of Tracers Measured in Seepage in Niche 3 


\subsubsection{Geophysical Imaging of the Drift-to-Drift Test Block}

Baseline images of the test block between Alcove 8 and Niche 3 have been collected through use of either seismic tomography or ground penetrating radar (GPR) tomography. The objective of seismic tomography data acquisition was to acquire baseline data to help monitor fluid infiltration. The GPR data are presented in detail within this scientific analysis report, and are compared with documented seismic tomography data. The comparison helps to constrain the interpretation of the local lithology. Both geophysical tomography studies used the slanted (near-vertical) boreholes drilled around the test block, as illustrated in Figure 6-149 and Figure 6-150, around a large plot prepared for planar infiltration tests.

\subsubsection{Background and Ground Penetrating Radar Experimental Approach}

In the borehole radar method, modified surface radar antennas are emplaced into a rock formation, and high-frequency electromagnetic signals are transmitted through the formation, to a receiving antenna. Electrical properties of the subsurface material greatly influence the transmitted electromagnetic signal. In particular, the dielectric permittivity $(\mathrm{K})$ of the rock has a strong influence on the propagation of the signal, and on whether it travels at a high or low velocity. Furthermore, moisture content also affects dielectric permittivity. The high dielectric permittivity of water ( $\mathrm{K}$ approximately 80 ) or wet rock ( $\mathrm{K}$ approximately 20 to 30 ), in contrast to drier rock ( $\mathrm{K}$ approximately 3 to 6 ), typically results in greatly reduced signal velocities. Changing chemical compositions (i.e., tracers) may also alter the bulk dielectric permittivity of the rock and, hence, the propagation velocity of the radar wave. Any changes to signal character could be measured over the course of the Alcove- 8 / Niche-3 infiltration experiment, and any increase (or decrease) in the background moisture content or chemical composition resulting from the fluid infiltration (or rock dryout) would result in changes in the received radar velocity.

The transmitted signals are represented as multiple ray paths crossing through a zone within the drift-to-drift test block. If sufficient ray paths are recorded, a tomographic image is obtained through computer processing. Extracted from such data is the radar wave travel time, which is dependent upon wave velocity values. This data set, in the form of a processed radar velocity tomogram, provides a high-resolution method to monitor changes that occurred in the rock over the duration of the tracer-injection experiment. Information from previous experiments at Yucca Mountain indicates that ground penetrating radar should provide relatively high-resolution imaging of the zone of interest. The peculiar orientation of the boreholes between Alcove 8 and Niche 3, however, may provide decreased image resolution relative to previous radar experiments (e.g., Busted Butte, Drift Scale Test, Single Heater Test).

A detailed description of the equipment used, the component specifications, the operating principles, and the GPR survey methodology can be found in the Technical Implementing Procedure, YMP-LBNL-TIP/GP 5.0, Ground Penetrating Radar Data Acquisition, governing all GPR data acquisition done in support of the Yucca Mountain site characterization effort. 


\subsubsection{Results of the Radar Data Acquisition}

Radar data were acquired in the six boreholes (Boreholes 1 to 6) located within Alcove 8. Additionally, two of the boreholes (Borehole 2 and Borehole 3) in Niche 3 were used in combination with two of the boreholes in Alcove 8. The configuration, and layout, of the boreholes that were used are illustrated in Figure 6-149.

The radar data were acquired in the 2-D planes defined by the two boreholes, more commonly referred to as "well pairs." Data were acquired in well pairs 1-2, 3-4, 1-3, 4-2, and 5-6 in Alcove 8. Because well pairs in this test block do not include the boundary between two lithologic units, data were also acquired in well pairs consisting of one borehole in Alcove 8 and one in Niche 3, such as well pairs 1-3 and 4-2 (note that the first number in a well pair refers to a borehole in Alcove 8, and the second number to a borehole in Niche 3).

Higher frequencies generally result in data of higher resolution, but also result in greater attenuation of radar energy with increasing distance. Therefore, a $100-\mathrm{MHz}$ antenna frequency was used for the Alcove 8 well pairs, giving approximately $25.0-\mathrm{cm}$ resolution, and a $50-\mathrm{MHz}$ antenna frequency, giving approximately $5.0-\mathrm{cm}$ resolution, was used for measurements between Alcove 8 and Niche 3 . The data were processed to produce velocity tomograms. All data presented in Sections 6.12.3.2.1 and 6.12.3.2.2 were collected before the start of liquid releases and, therefore, represent baseline conditions.

\subsection{Alcove 8 Well Pairs 1-2, 3-4, 1-3, 2-4, and 5-6}

All of the radar data processed between the boreholes in Alcove 8 showed similar results, and are therefore discussed in this section (Panel a to Panel e of Figure 6-160). The radar velocity images suggest that the lithologic formation directly below Alcove 8 varies little with respect to its dielectric properties. This is as expected, because none of the boreholes penetrates the lithologic contact between Alcove 8 and Niche 3. As far as smaller structures are concerned (e.g., lithophysal cavities), they may be of too small a size or of insignificant-enough dielectric contrast to be imaged. Close inspection of the images, however, reveals some zones of anomalous velocity that may or may not correspond to such small structures. What the data do suggest is that any changes resulting from wetting or fluid flow upon commencement of the infiltration experiment are not expected to follow any particular path. In previous experiments using this method, potential flow paths had been defined by the baseline radar velocity images prior to infiltration, and velocity change results from wetting were subsequently observed in these regions. Again, this is not observed for the baseline images acquired between the Alcove 8 boreholes. 

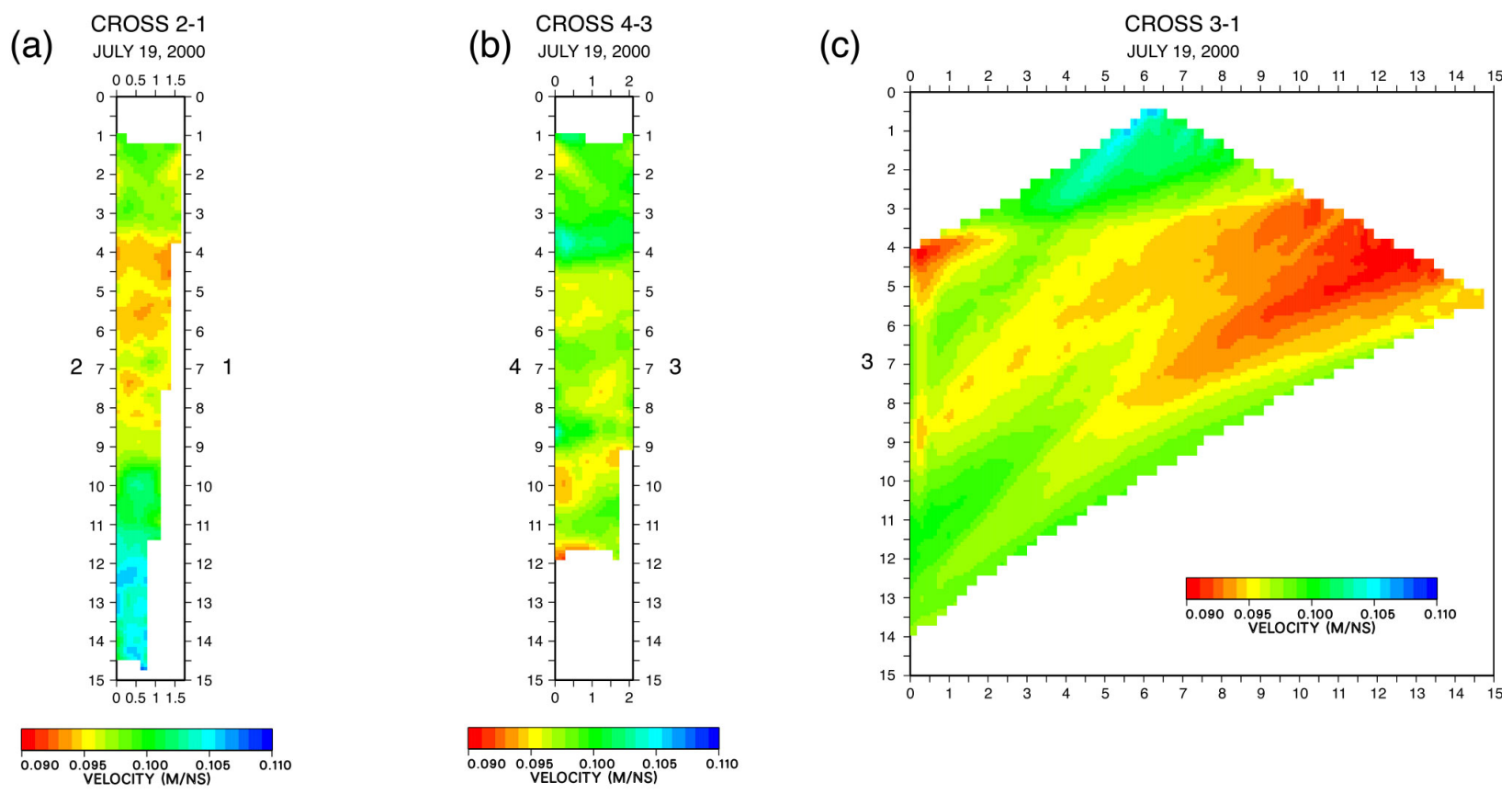

(d)

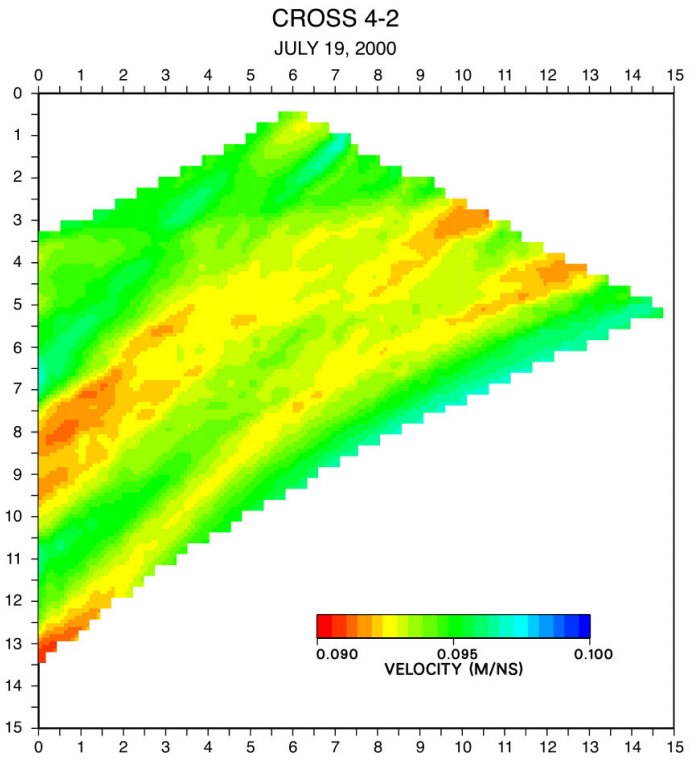

(e)

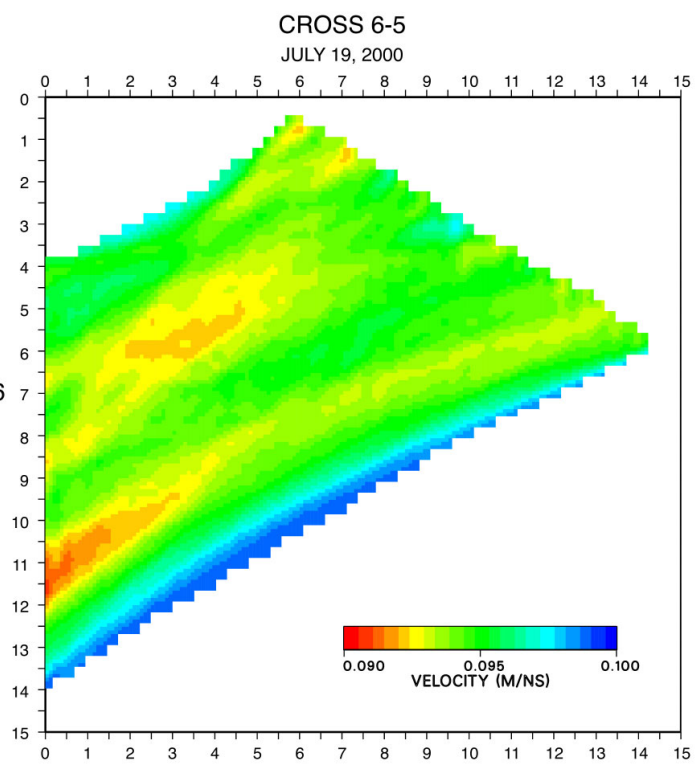

Source: DTN: LB0110A8N3GPRB.001 [DIRS 156912].

NOTE: All axes are distance in meters. Velocity is given in meters per nano-second.

Figure 6-160. Radar Velocity Tomograms between Alcove-8 Well Pairs 


\subsection{Well Pairs 1 (Alcove 8) - 3 (Niche 3) and 4 (Alcove 8) - 2 (Niche 3)}

After acquiring the radar data between the boreholes in Alcove 8, additional data were acquired in boreholes between Alcove 8 and Niche 3. The drift-to-drift tests imaged the lithologic contact occurring between the two locations, and allowed for monitoring of this contact during the infiltration. Panel a and Panel $b$ of Figure 6-161 are the baseline radar velocity data for the two well pairs. Immediately obvious is the higher velocity subhorizontal interface near the upper portions of the Niche 3 boreholes. This region is inferred to be the lithologic contact between the two locations. Comparing the two radar velocity images, this contact is quite similar, although it appears to be dipping at slightly different angles from one image to the other. The imaged contact will be a point of focus in infiltration tests.

Seismic tomography is another geophysical technique that is sensitive to structure heterogeneity. The seismic method relies on differences in the mechanical properties of the rock to produce a tomographic image. Results of the seismic tomographic images are presented in Seismic Tomography Technology for the Water Infiltration Experiment (2001 [DIRS 156869]).

(a)

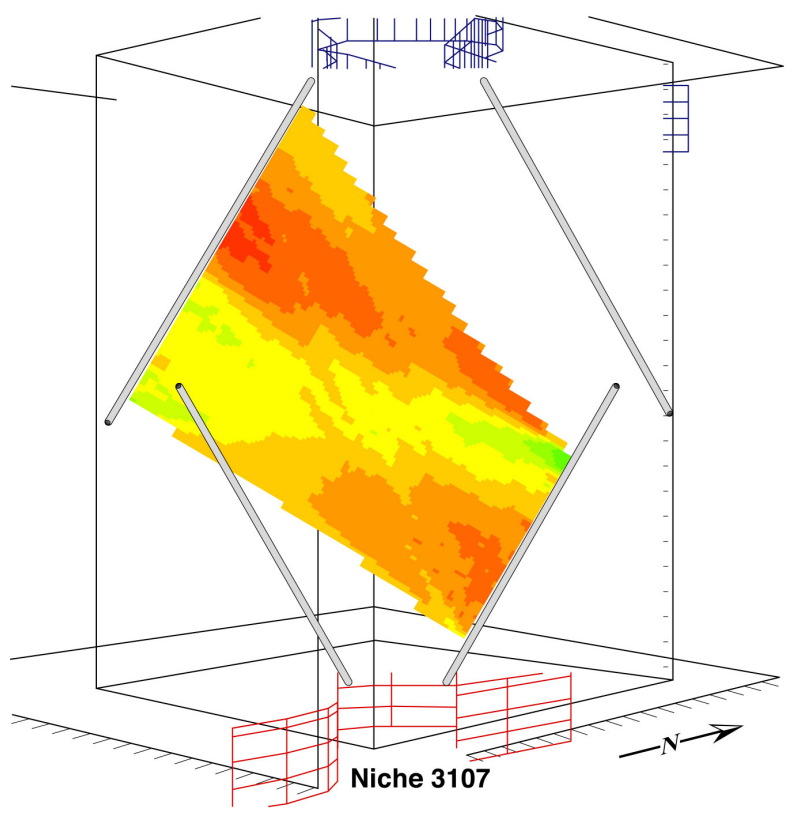

Masked Velocity Image

$\perp$ to Niche Axis

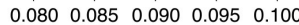
velocity (meters per nano-second) (b) $\quad$ Alcove 8

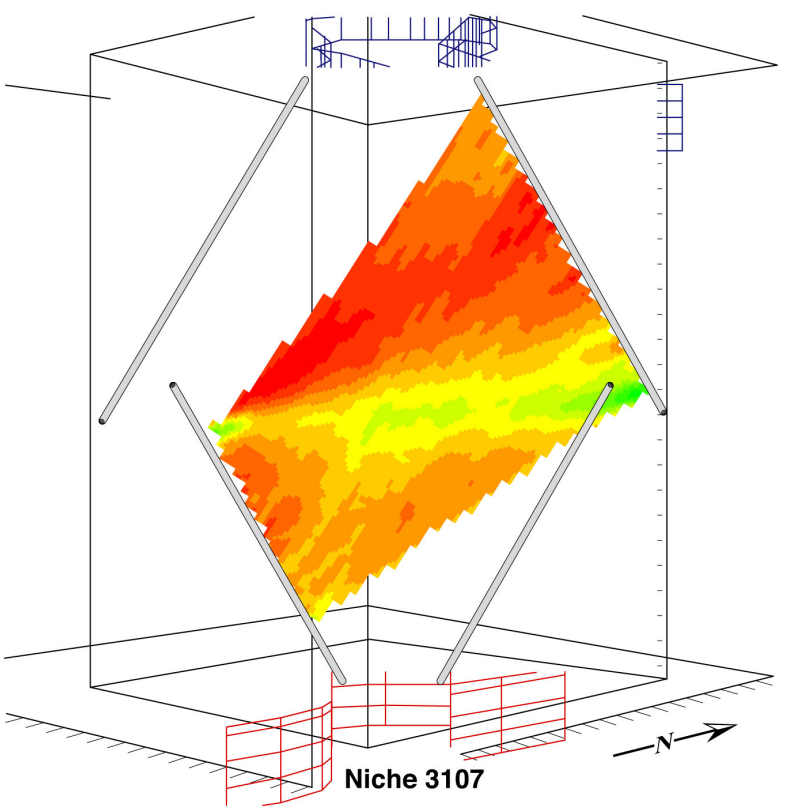

Masked Velocity Image $\perp$ to Niche Axis

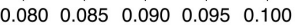
velocity (meters per nano-second)

Source: DTN: LB0110A8N3GPRB.001 [DIRS 156912].

Figure 6-161. Radar Velocity Tomograms between Alcove 8 and Niche 3 Well Pairs, Baseline Survey 07-19-2000 


\subsubsection{Large Plot Test}

The test series involves the release of water (laced with tracers) under both ponding and non-ponding conditions in a 4-m-by-3-m plot (Figure 6-162). During this phase, water was released into the plot under a controlled rate. Details of the site, experimental setup, and monitoring for the large-plot test are the same as for the fault liquid test (Section 6.12.2). Ponded release of water to the 4-m-by-3-m plot along the floor of Alcove 8 began on August 20, 2002 (DTN: GS031008312242.007 [DIRS 166089]). The infiltration zone was divided into 12 sections, each $1 \mathrm{~m}$ by $1 \mathrm{~m}$ (Figure 6-162).

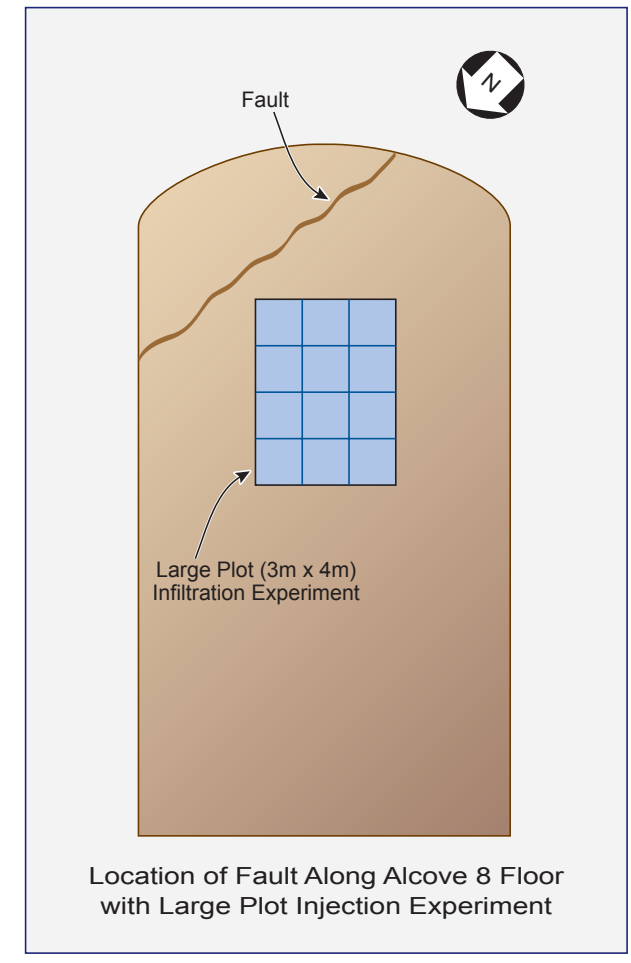

Figure 6-162. Schematic Illustration of the Infiltration Zones along the Floor of Alcove 8 in Large-Plot Test

Infiltration was initiated in the large-plot on August 20, 2002, and this upper boundary condition was constrained to an approximately $2-\mathrm{cm}$ head of ponded water. The amount of water necessary to maintain the $2 \mathrm{~cm}$ of ponding was continuously recorded (Figure 6-163). The cumulative application of all 12 plots is illustrated in Figure 6-164 for the period from August 20, 2002, to November 12, 2002.

The data in Figure 6-163 show that there was spatial and temporal variability in the infiltration rates. In most plots, the early high fluctuations in infiltration rates gradually approached steady rates that were in the range of approximately $120 \mathrm{~L} /$ day to less than $10 \mathrm{~L} /$ day. 

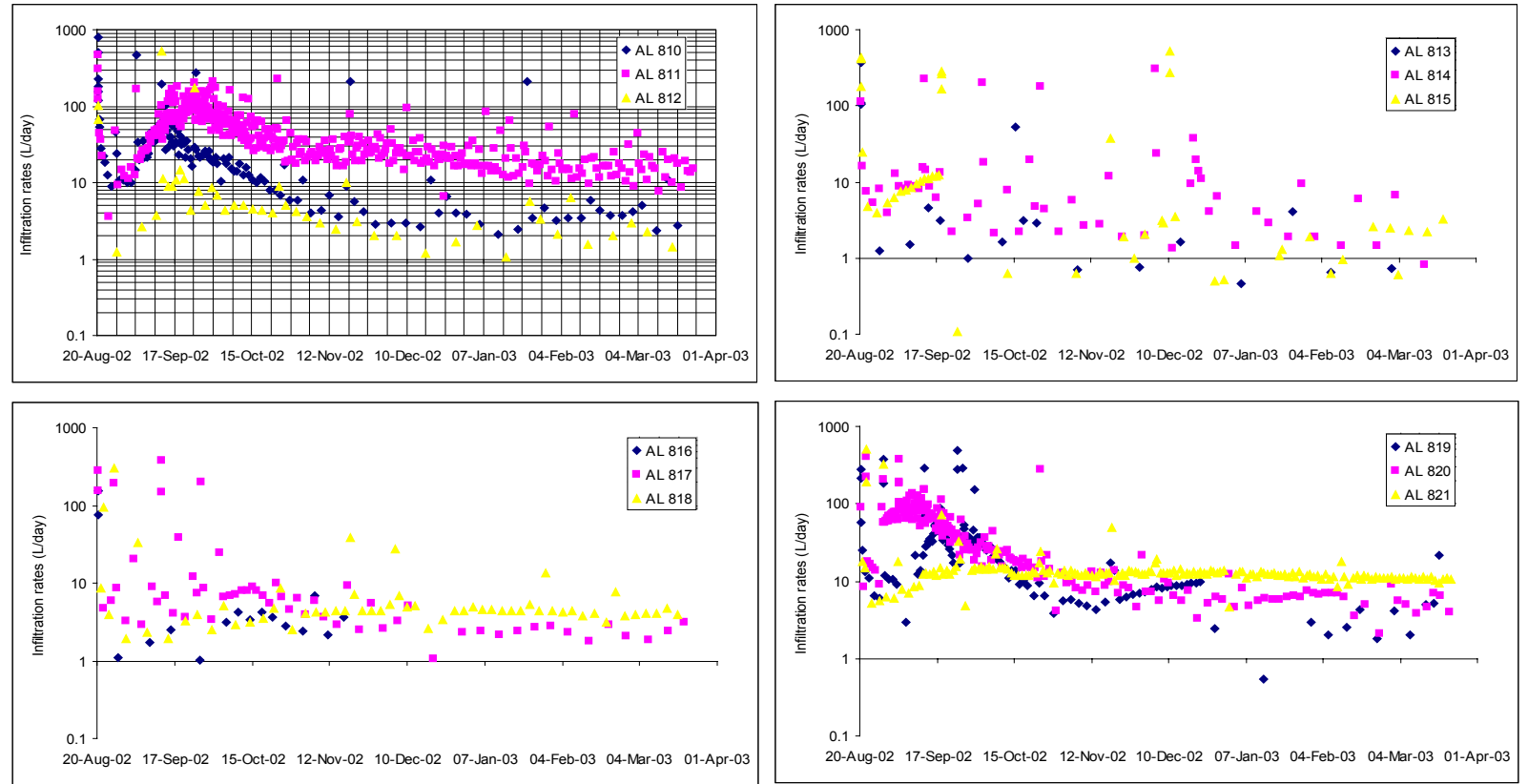

Source: DTNs: GS031008312242.007 [DIRS 166089] from August 20, 2002, to November 19, 2002; GS030608312242.005 [DIRS 166200] from November 19, 2002, to March 21, 2003.

NOTE: The numbers in the figure legends refer to the subplots shown in Figure 6-162; the plot numbers increase sequentially along the rows beginning with the plot on the top left (i.e., the first plot is AL 810 and the last plot located at the bottom row last column is AL 821).

Figure 6-163. Infiltration Rates of Individual Plots from August 20, 2002, to November 19, 2002

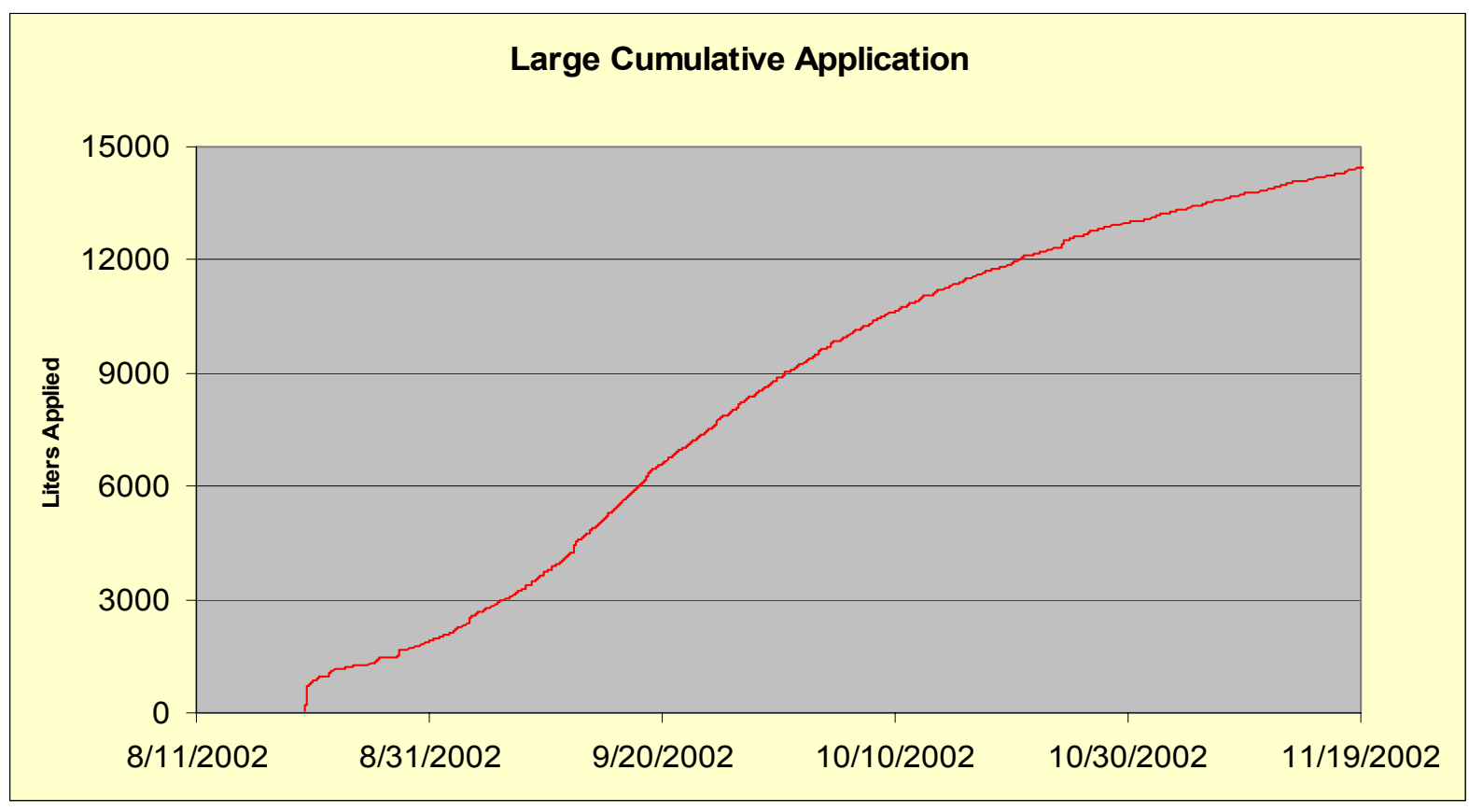

Source: DTN: GS031008312242.007 [DIRS 166089].

Figure 6-164. Cumulative Application of All Twelve Plots in Alcove 8 Large-Plot Experiment 
Observations from this preliminary phase of testing include the total seepage rates measured at Niche 3. Water was first observed along the fault at Niche 3 on September 10, 2002. Measurable seepage was recorded after a week. By the last week of September, the total daily seepage rate measured in Niche 3 was approximately 25 L/day (Figure 6-165). Over the next few weeks, the daily seepage rates remained fairly steady.

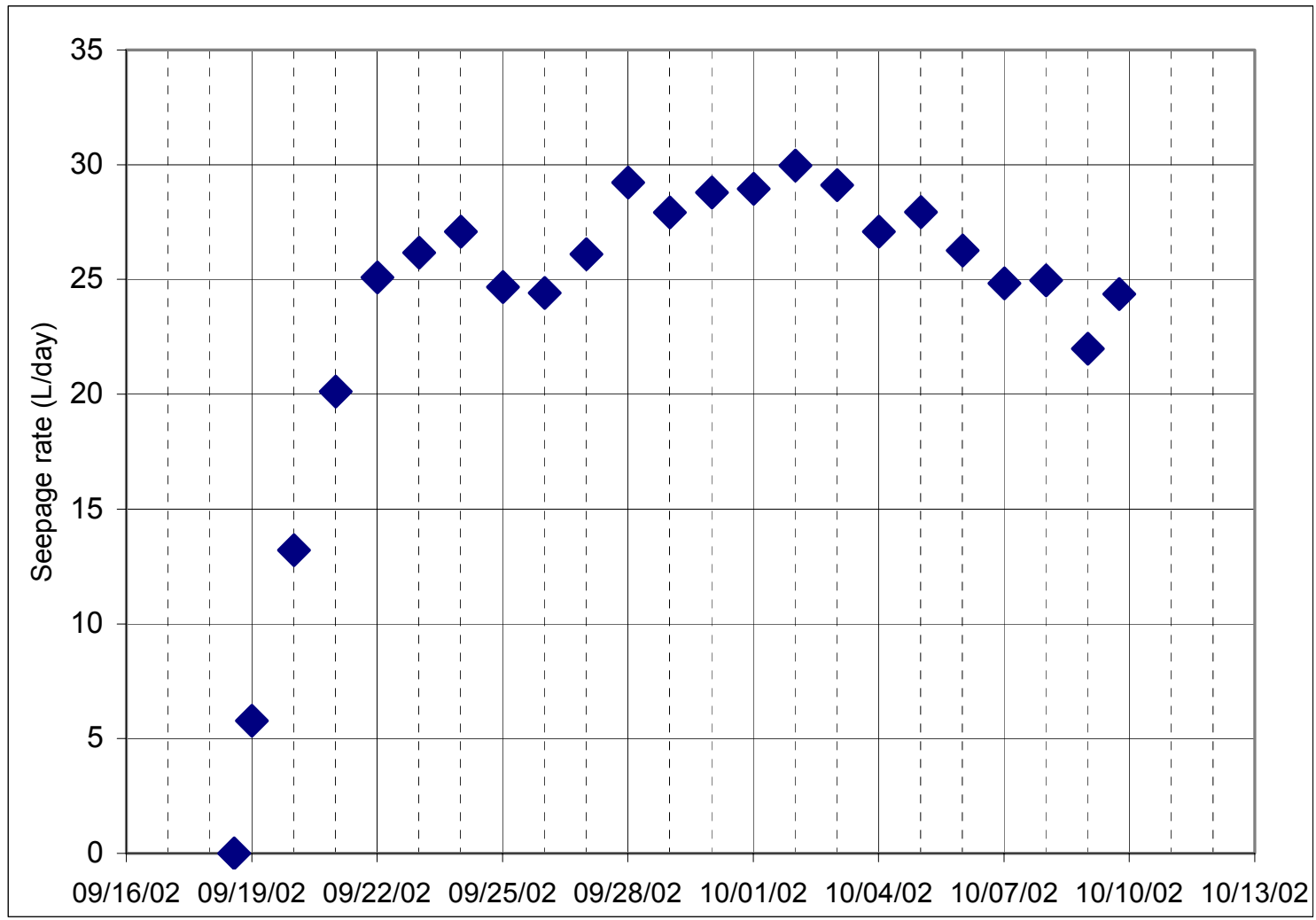

Source: DTN: LB0306A8N3LIQR.001 [DIRS 165405].

Figure 6-165. Daily Seepage Rates Measured in Niche 3 Following Release of Water in the Large Infiltration Plot in Alcove 8 

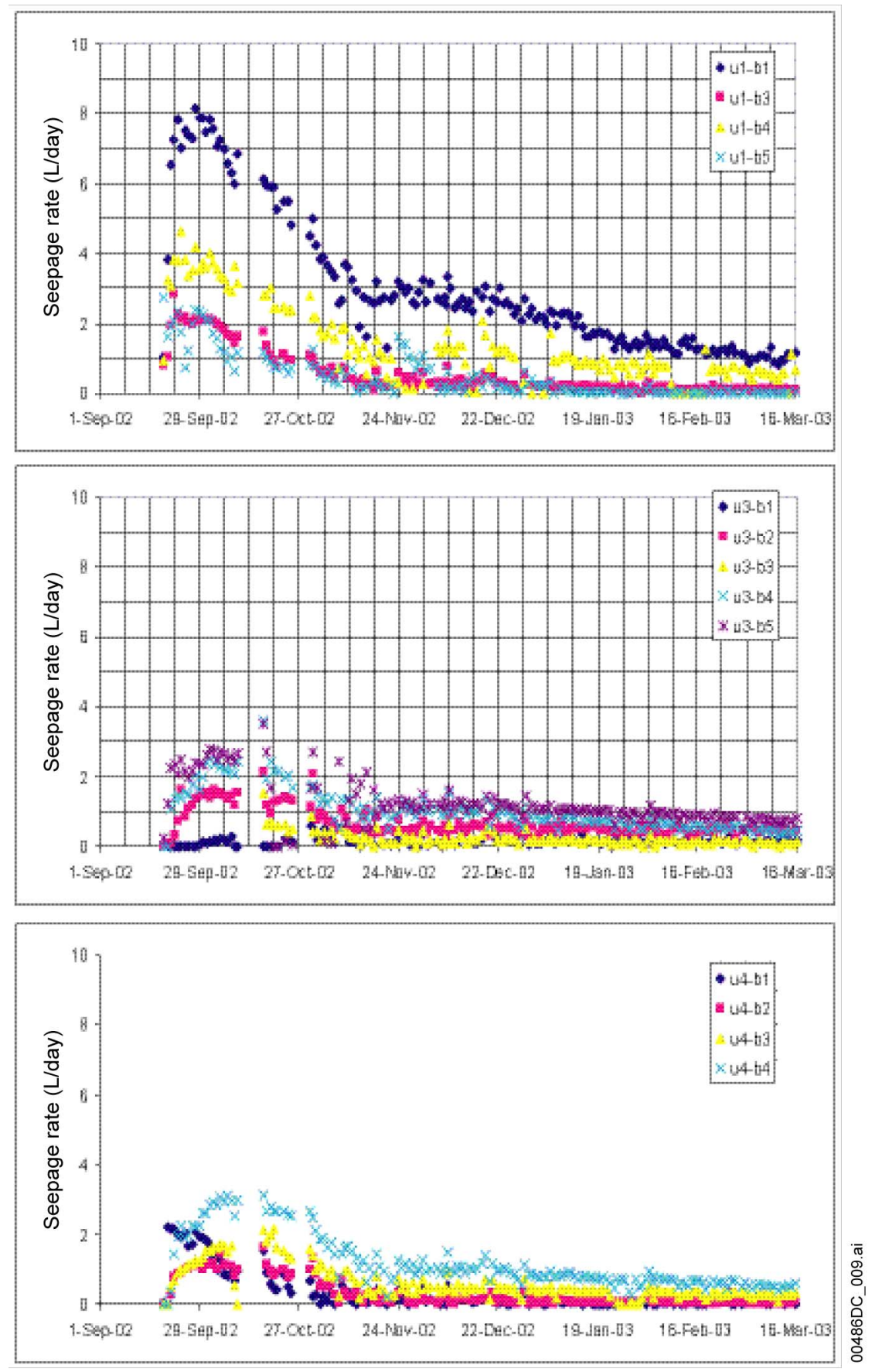

Source: DTNs: LB0306A8N3LIQR.001 [DIRS 165405] from September 18, 2002, to October 16, 2002; LB0308A8N3SEEP.001 [DIRS 166090] from October 16, 2002, to April 2, 2003.

NOTE: Sample bottle-collection locations (designations "u1-b1, u1-b3, ...") are documented in the scientific notebook by Salve (2002 [DIRS 165378], pp. 71, 88, 97).

Figure 6-166. Seepage Rates Measured in Niche 3 Following Release of Water in the Large Plot in Alcove 8 
The seepage measured over time from each tray for the period of September 16, 2002, to March 16, 2003, is plotted in Figure 6-166. Early seepage was measured approximately 30 days after the initial application of water along the infiltration plot. Following the arrival of the wetting front, seepage at most monitored locations appeared to increase over a period of approximately 1 to 4 weeks before gradually decreasing. The highest seepage rate measured during this peak event was approximately $8 \mathrm{~L} /$ day. Following peak values, the seepage rates at all locations continuously decreased with maximum rates measured at approximately $1 \mathrm{~L} /$ day by the second week of March 2003.

\subsubsection{Available Data from Alcove 1 Surface-to-Drift Tests and Implications for Infiltration Processes}

\subsubsection{Alcove 1 Test Data}

Alcove 1 is located near the North Portal of the ESF in the upper lithophysal zone of the Tiva Canyon Tuff, near the Bow Ridge fault and other faults and fault intersections. The alcove is approximately $5.5 \mathrm{~m}$ high and $5.8 \mathrm{~m}$ wide. In the Alcove 1 tests, water was applied in a plot on the ground surface approximately $30 \mathrm{~m}$ directly above the alcove. The size of the infiltration plot was $7.9 \mathrm{~m}$ by $10.6 \mathrm{~m}$ (Liu et al. 2003 [DIRS 162470], pp. 174-175). Irrigation drip tubing, with 490 drippers uniformly distributed within the infiltration plot, was used to apply the water. The vertical cross section and plan view of the test site is illustrated in Figure 6-167 (Guertal 2001 [DIRS 164070], pp. 29-30). Table 6-30 describes the data present in the TDMS for two phases of tests.

Alcove 1 surface-to-drift testing included two phases. Phase I was a water infiltration test. $\mathrm{LiBr}$ tracer was added to the infiltration water during Phase II. 


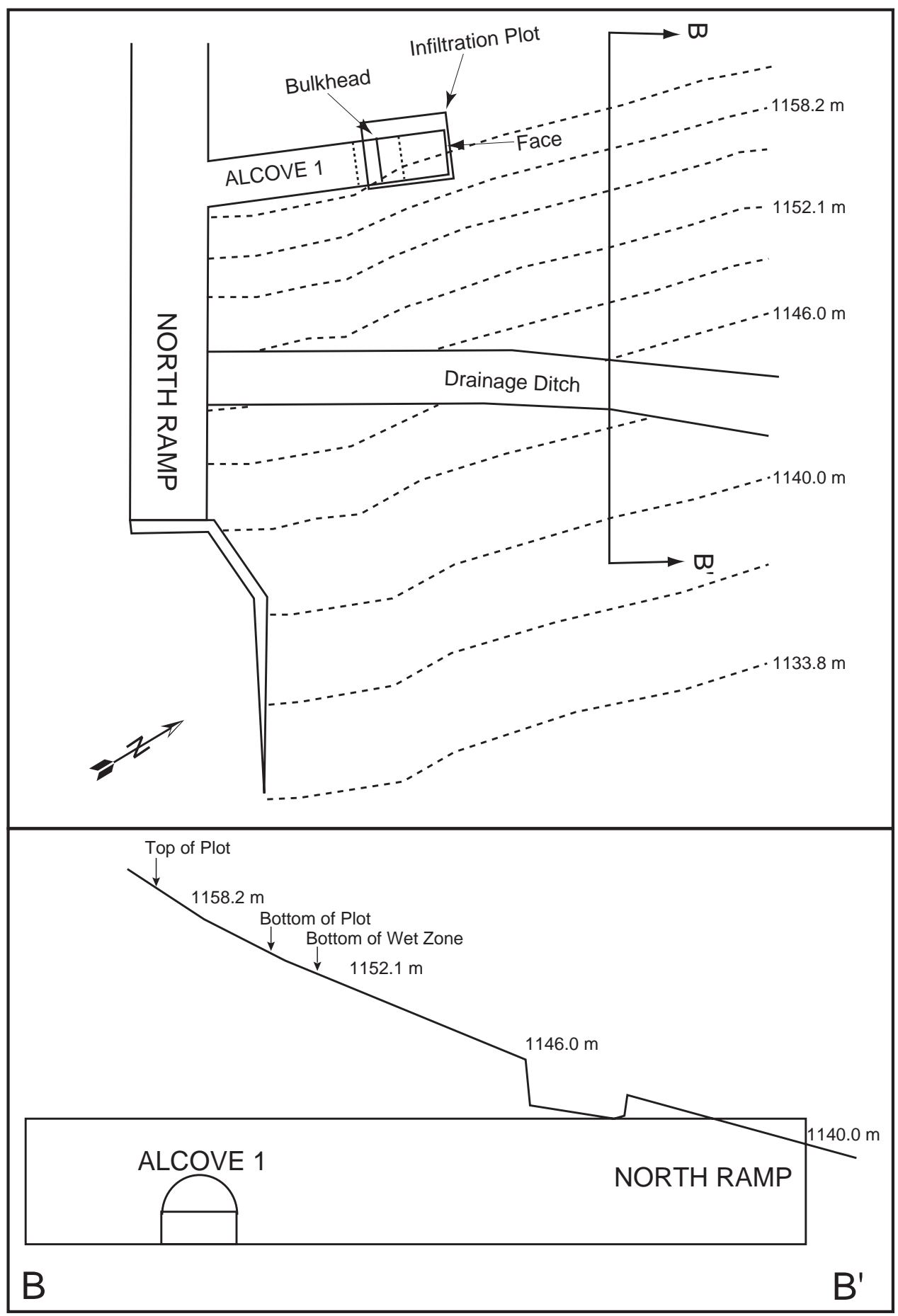

Source: Guertal (2001 [DIRS 164070], pp. 29-30).

Figure 6-167. Schematic Illustration of Alcove 1 Test Site Inside the ESF North Portal 
Table 6-30. Alcove 1 Infiltration Test Data

\begin{tabular}{|l|l|}
\hline \multicolumn{1}{|c|}{ DTN } & \multicolumn{1}{c|}{ Description } \\
\hline $\begin{array}{l}\text { GS990108312242.006 } \\
\text { [DIRS 162979] }\end{array}$ & Pulse flow meter data for infiltration on surface, Phase I, 3/9/98-12/4/98 \\
\hline $\begin{array}{l}\text { GS000308312242.002 } \\
\text { [DIRS 156911] }\end{array}$ & Seepage data for water collected in Alcove 1, Phase I, 05/05/98-08/27/98 \\
\hline $\begin{array}{l}\text { GS000808312242.006 } \\
\text { [DIRS 162980] }\end{array}$ & Pulse flow meter data for infiltration on surface, Phase II, 2/19/99-6/20/00 \\
\hline $\begin{array}{l}\text { GS000399991221.003 } \\
\text { [DIRS 147024] }\end{array}$ & Preliminary infiltration, seepage, tracer data, Phase II, 2/19/99-12/15/99 \\
\hline $\begin{array}{l}\text { GS001108312242.009 } \\
\text { [DIRS 165202] }\end{array}$ & Tracer data for water collected in Alcove 1, Phase II, 5/9/99-7/5/00 \\
\hline
\end{tabular}

DTN = data tracking number.

Phase I infiltration and seepage is summarized in DTN: GS000308312242.002 [DIRS 156911]. Water was applied between March 9, 1998, and August 13, 1998, and was collected by a series of 1-foot-square (approximately $0.3 \mathrm{~m}$ by $0.3 \mathrm{~m}$ ) drip trays inside Alcove 1 (May 5, 1998, to August 27, 1998). The irrigated area was $83.7 \mathrm{~m}^{2}$ and the collection area was $40.2 \mathrm{~m}^{2}$. The amount of seepage as a percentage of the water applied on the surface depends on the areas chosen for comparison and on the time of observations:

- 2.9 percent of the total applied water seeped into Alcove 1;

- 6.1 percent of the water applied vertically above the collection area seeped in Alcove 1;

- 5.4 percent of the total applied water seeped into Alcove 1 after the rock above Alcove 1 became wet; and

- 11.1 percent of the water applied vertically above the collection area seeped into Alcove 1 after the rock above Alcove 1 was wetted.

Both Phase I and Phase II data were used to interpret the test, with seepage rate data from Phase I used for calibration, and seepage and tracer data from Phase II used to test the ability of the model to make predictions (Liu et al. 2003 [DIRS 162470], Figure 1 (for infiltration rates) and Figure 3 (for seepage rates)). The study of $\mathrm{LiBr}$ tracer data shows that matrix diffusion may have a significant effect on overall transport behavior in unsaturated fractured rocks (Liu et al. 2003 [DIRS 162470]).

\subsubsection{Alcove 1 and Pagany Wash Infiltration Comparison}

In addition to providing insights into seepage and transport processes, Alcove 1 test data are also affected by net infiltration processes through the bedrock. The upper surfaces of Yucca Mountain are either exposed bedrock with a thin veneer of soil cover, or washes filled with alluvium. Results from an Alcove 1 infiltration test are compared to an analysis of infiltration data from Pagany Wash. 
In the Alcove 1 test, several factors controlled the infiltration processes. The infiltration plot was located on a hill slope. The range of flux was from 0 to $30 \mathrm{~mm} /$ day during February 19, 1999, to December 15, 1999. The range of $18 \mathrm{~mm} /$ day to $25 \mathrm{~mm} /$ day was maintained from September 21, 1999, to October 15, 1999, before a test (with tracer) application began. In both the Phase I test (from March 8, 1998, to December 4, 1998) and the Phase II test (from January 29, 1999, to June 20, 2000), water applications were controlled such that no surface runoff occurred. Thus, an infiltration rate of more than $30 \mathrm{~mm} /$ day could induce surface runoff.

This infiltration rate $(30 \mathrm{~mm} /$ day $)$ is orders of magnitude smaller than the hydraulic conductivity values of the Tiva Canyon fractured rock. This was determined based on measured values from air-injection tests in boreholes drilled from the interior of the alcove, varying from $169 \mathrm{~mm} /$ day to $7.20 \times 10^{4} \mathrm{~mm} /$ day, with the geometric mean of $1.36 \times 10^{4} \mathrm{~mm} /$ day (LeCain 1998 [DIRS 100052], p. 1 and Tables 1 to 3). One implication is that the fractures on the surface in the infiltration plot are filled with soils or other in-fill material, with the conductivity determined by the filling material. At depths below the zone of soil influence, fractures may be open and highly connected, based on the measurements of high air-permeability or conductivity values. The net infiltration is controlled by the filled fractures near the surface.

Such a difference between near-surface conductivity (inferred from the infiltration rate) and formation conductivity (inferred from air-permeability tests) may not exist in alluvium, as evaluated in an analysis at Pagany Wash. Pagany Wash is an alluvium/colluvium filled channel located northeast of Yucca Mountain. An analytical estimation of infiltration was made using the temperature data between sensors at $3.0 \mathrm{~m}$ and $6.1 \mathrm{~m}$ below the surface in Borehole UZ \#4 (LeCain et al. 2002 [DIRS 158511], p. 18, Table 1). The hydraulic conductivity used in the analytical solution to fit the temperature data is $149 \mathrm{~mm} /$ day. This value is of the same order of magnitude as the conductivity value of $500 \mathrm{~mm} /$ day used in the infiltration estimation (USGS 2001 [DIRS 160355]). Alluvium can be treated as a porous medium without fractures, based on the relatively close agreement between the alluvium conductivity value and the model parameter used in the interpretation of temperature signal propagation.

Both the Alcove 1 test result and Pagany Wash analysis suggest that surface soils have significant influence on the infiltration process. The surface soils above Alcove 1 are likely to be less permeable than the underlying fractured rock, and limit the infiltration. The thick soil layer in Pagany Wash controls the near-surface infiltration processes.

\subsection{BUSTED BUTTE UNSATURATED ZONE TRANSPORT TEST}

This section presents the field data collected at the Unsaturated Zone Transport Test (UZTT) at Busted Butte in a distal extension of the Calico Hills formation below Yucca Mountain. The UZTT was described in the scientific analysis report, Unsaturated Zone and Saturated Zone Transport Properties (U0100) (CRWMS M\&O 2001 [DIRS 154024]). This cancelled document is suitable for intended use in this analysis report, because the information presented in that report demonstrates the properties of interest for the Busted Butte test site. Some of the early results are presented in this section for completeness. The overview in Section 6.13.1 of this report is equivalent to Sections 6.8.1 and 6.8.2 of the previous report (CRWMS M\&O 2001 [DIRS 154024]). 
The UZTT was conducted in two phases. The Phase 1 results are presented in Section 6.13.2 of this report (and are also presented in Unsaturated Zone and Saturated Zone Transport Properties (U0100) (CRWMS M\&O 2001 [DIRS 154024], Section 6.8.5)). An update of Phase 2 tracer test results is presented in Section 6.13.3 of this report. Early geophysical imaging results (CRWMS M\&O 2001 [DIRS 154024], Section 6.8.4) and updates of the GPR tomograph results from the Phase 2 test block are presented in Section 6.13 .4 of this report.

The neutron moisture measurements are summarized in Section 6.13 .5 of this report. The laboratory test of radionuclide transport through blocks of Busted Butte tuff are summarized in Section 6.13 .6 of this report.

Because of the focus on the flow-and-transport-related results, the mineral evaluation of the Busted Butte samples and the geological implications regarding the applicability of Busted Butte results for Yucca Mountain study are presented in Appendix H (CRWMS M\&O 2001 [DIRS 154024]). The specific test plan for this series of tests is Busted Butte Transport Testing (BSC 2002 [DIRS 158459]).

Data from the UZTT at Busted Butte were used for the partial validation of the UZ radionuclide transport model (BSC 2004 [DIRS 164500], Section 7.3).

\subsubsection{Overview of Unsaturated Zone Transport Test}

\subsubsection{Unsaturated Zone Transport Test Location}

The Busted Butte test facility is located in Area 25 of the Nevada Test Site (NTS) approximately $160 \mathrm{~km}$ northwest of Las Vegas, Nevada, and $8 \mathrm{~km}$ southeast of the Yucca Mountain repository area. The site was chosen based on the presence of a readily accessible exposure of the Topopah Spring Tuff (Tpt) and the Calico Hills formation (Tac) and the similarity of these units to those beneath the repository horizon. The test facility consists of an underground excavation along a geologic contact between Tpt and Tac. The corresponding hydrogeologic contact between the Topopah Spring welded (TSw) unit and the Calico Hills nonwelded (CHn) unit, is comprised of the nonwelded portion of the basal vitrophyre of Tac (Tptpv1) and of Tpt (Tptpv2).

\subsubsection{Unsaturated Zone Transport Test Objectives}

The principal objectives of the test are to address uncertainties associated with flow and transport in the UZ site-process models for Yucca Mountain. These include, but are not restricted to:

- The effect of heterogeneities on flow and transport in unsaturated and partially saturated conditions near the TSw-CHn contact; in particular, issues relevant to fracture-matrix interactions and permeability contrast boundaries

- The applicability of sorption parameters determined from laboratory experiments to field tests conducted in unsaturated Calico Hills rocks

- The effect of scaling from laboratory scale to field scale and site scale

- The validation of the radionuclide transport process model

- The migration behavior of colloids in fractured and unfractured Calico Hills rocks. 


\subsubsection{Unsaturated Zone Transport Test Concept}

The UZTT is comprised of three integrated efforts: the field test, a parallel laboratory-scale testing program, and validation and assessment of models used for PA. The field test involves design of the test, analysis of the geology, identification of tracer breakthrough using chemical analyses, in situ imaging of liquid and tracer migration through geophysical techniques, and ultimately, destructive testing to quantify tracer migration. Only the field test results are described in this scientific analysis report. The laboratory and modeling efforts are summarized in the following paragraphs and reported in the UZ and SZ transport properties report (CRWMS M\&O 2001 [DIRS 154024]).

In addition to field-testing, parallel laboratory analytical and testing programs in geochemistry, tracer evaluation, hydrology, and mineralogy were designed to help interpret the field results. The geochemistry program included measurement of in situ pore-water chemistry and development of a synthetic injection matrix. The tracer evaluation program included batch-sorption studies on Busted Butte rock samples using nonreactive and reactive surrogate tracers and radionuclides. The laboratory program also included modeling of the geochemical behavior of those tracers in the ambient water chemistry, and tracer stability in the rock environments. The hydrology program involved the measurement of the potentials and conductivities as a function of saturation for core samples from Busted Butte. The porosity of each core sample was also characterized. Mineralogy/petrology activities involved the mineralogic characterization of the Busted Butte samples from cores.

The laboratory investigations undertaken are listed below:

- Unsaturated hydraulic characterization of Busted Butte rocks

- Detailed mineralogic and oxide-coating characterization of Busted Butte rocks

- Batch measurements of radionuclide sorption to Busted Butte rocks

- Batch measurements of tracer sorption to Busted Butte rocks

- Short-term and long-term stability measurements of tracer solutions

- Short-term and long-term stability measurements of tracer-affected collection pads

- Short-term and long-term stability measurements of tracer-affected rock samples.

Geological, mineralogical, and hydrologic properties form the basis for assessing the applicability of Busted Butte UZTT for the Calico Hills formation below the nuclear waste repository at Yucca Mountain, as depicted in detail in Appendix H.

The flow and transport study is the third aspect of UZTT. The principal objective of the test is to evaluate the validity of the flow and transport site-scale process models used in support of PA abstractions. This effort makes it possible to improve or enhance the site-scale transport model by simulating and predicting experimental field results and by addressing the effects of scaling from laboratory to field scales.

\subsubsection{Test Design}

The UZTT is comprised of the main adit, which is $75 \mathrm{~m}$ in length, and a test alcove, which is $19 \mathrm{~m}$ in length. The configuration of the UZTT site is shown in Figure 6-168. Details of the 
design and construction criteria can be found elsewhere (SubTerra 1998 [DIRS 147703], pp. 9 to 21 , and pp. 33 to 44 ).

The UZTT was designed as two test phases. The first phase, including test Phases 1A and 1B, was designed as a scoping study to assist in design and analysis of Phase 2, and as a short-term experiment aimed at providing initial transport data on fractures near an interface. The second phase, incorporated a larger region than Phase 1, with a broader, more complex scope of tracer injection, monitoring, and collection.

Test Phase 1-Test Phase 1 was comprised of two small scale scoping tests, Phase 1A and Phase 1B. Phase 1A was in Tac and Tptpv1, and Phase 1B in Tptpv2. Phase 1A was a "blind" single-point injection test using four boreholes, at either $1 \mathrm{~mL} / \mathrm{hr}$ or $10 \mathrm{~mL} / \mathrm{hr}$ rates. Following the injection period, a "mini-mineback" was done to expose the distribution of the tracer in the rock mass.

Phase 1B involved two pairs of injection and collection boreholes in Tptpv2. Phase 1B also used two injection rates $(1 \mathrm{~mL} / \mathrm{hr}$ and $10 \mathrm{~mL} / \mathrm{hr})$. Because of the paucity of data on fracture-matrix interactions in these lithologies, this test was designed as a "calibration" test for fracture-matrix interactions to be used in Phase 2 simulations. The 2-m-long, Phase 1B collection boreholes, immediately below the injection boreholes, were used to capture arrival of tracers. At the culmination of injection, overcoring was done to collect rock samples for tracer analysis.

Test Phase 2-Phase 2 involved a large $(7 \mathrm{~m}$ by $10 \mathrm{~m}$ by $10 \mathrm{~m}$ ) block comprising all of the lithologies of Phase 1. Unlike the single-point injection geometries in Phase 1, the injection systems in Phase 2 were designed to activate large surfaces of the block. Phase 2 included eight injection boreholes drilled from the test alcove and distributed in two horizontal, parallel planes. Injection boreholes were placed to test the properties of the lower Topopah Spring Tuff (Tptpv2) and the hydrologic Calico Hills (Tptpv1 and Tac). In addition, there were 12 collection boreholes, drilled from the main adit. Collection holes were perpendicular in plan view to the injection holes and distributed at various distances from the injectors.

\subsubsection{Site Characterization}

The site characterization of the potential test block included core sampling from boreholes and grab samples from outcrops. Core samples were collected from the dry drilling of the boreholes from the main adit and the test adit for geological, hydrologic, and geochemical laboratory investigations and scoping calculations. The boreholes were then surveyed and instrumented for the injection tests.

Design, construction, and scientific teams were all involved in ensuring that the test block itself remained undisturbed by construction activities. Minimal disturbance of the in situ test block in the initial stages of UZTT was the foremost objective. Sodium silicate was applied to the wall of the test block to minimize evaporation. 


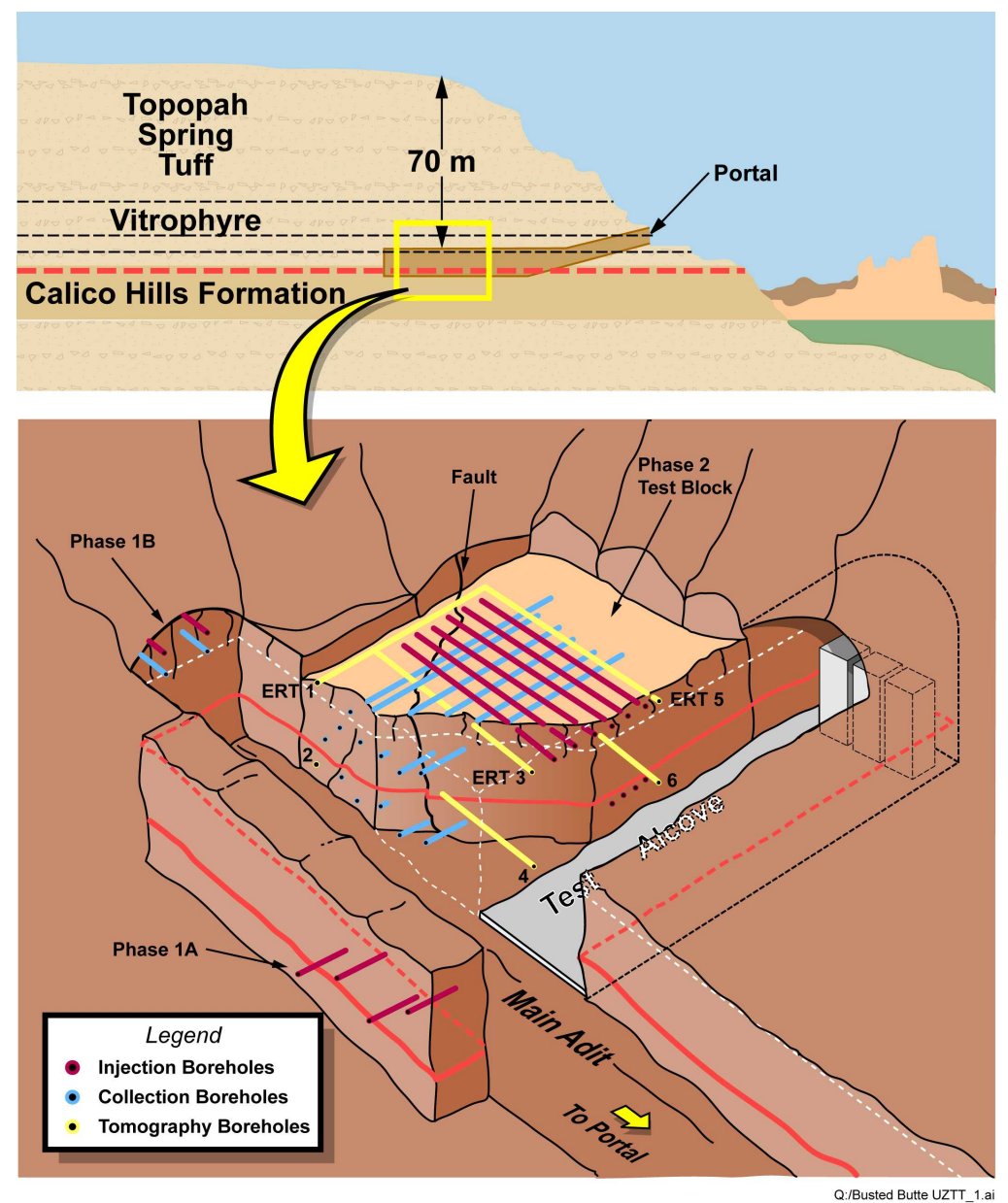

Source: Derived from CRWMS M\&O (2001 [DIRS 154024], Figure 34) (this source citation indicates the origin of the information in this figure, which is for illustration purposes only; the cited report was not used as direct input).

NOTE: This schematic of the Busted Butte UZTT shows the relative locations of the different experiment phases and borehole locations. Figure not drawn to scale.

Figure 6-168. Busted Butte Unsaturated Zone Transport Test Site

\subsubsection{Borehole Injection and Sampling Systems}

Injection and sampling of the liquid tracers was accomplished by two pneumatically inflated borehole sealing and measurement systems (Figure 6-169). To allow visual inspection of the injection points under both standard and ultraviolet (UV) illumination, a transparent packer system was developed for the tracer-injection systems. Moisture sensing and sampling were accomplished using pneumatically emplaced inverting membranes, which were fabricated with mesh pockets to retain absorbent sample pads. The inverting membranes were removed from the boreholes regularly (at intervals ranging from daily to biweekly) for sample-pad removal and replacement, whereas the injection packers remained in the holes for the duration of the test program. Each system was maintained at slight overpressure (1.7 to $3.5 \mathrm{kPa})$ to maintain contact between the sampling/injection pads and the tuff and to prevent circulation of air within the borehole. 


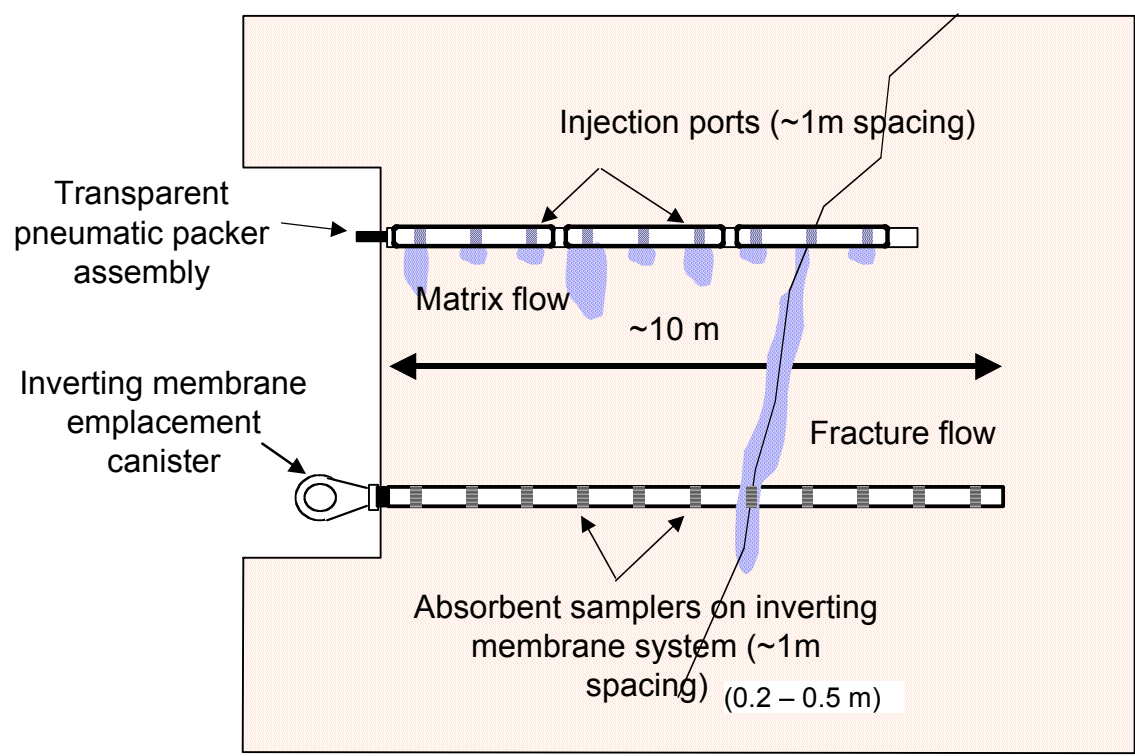

Source: CRWMS M\&O (2001 [DIRS 154024], Figure 35) (this source citation indicates the origin of the schematic in this figure, which is for illustration purposes only; the cited report was not used as direct input).

NOTE: Injection and collection boreholes are actually perpendicular in plan view. Absorbent sampler spacing is 0.25 to $0.50 \mathrm{~m}$.

Figure 6-169. Schematic of Vertical Cross Section of Injection and Collection System Configuration

\subsubsection{Electrical-Resistance Moisture Sensors}

Simple electrical-resistance moisture sensors were installed to monitor the relative moisture state of the injection pads and the arrival of liquid tracer at the sampling-pad data collection. Two Campbell Scientific dataloggers were used to collect measurement data from sensors and instrumentation.

Phase 1-For the Phase 1A test, the dataloggers measured the pressure in the injection/sampling manifold, 12 to 14 moisture sensors, the datalogger panel temperature and battery voltage, the number of times the syringe pumps cycled in a given period of time, and the relative humidity, air temperature, and atmospheric pressure in the experimental area. For the Phase 1B test, the same data were collected, except 32 moisture sensors were logged, as well as an anemometer in the ventilation shaft.

Phase 2-Phase 2 was subdivided into three subphases (2A, 2B, and 2C) according to location and the injection rates used. Phase $2 \mathrm{~A}$ consisted of a single borehole in the upper injection plane instrumented with 10 injection points and 10 moisture sensors, one at each injection point. The injection rate was $1 \mathrm{~mL} / \mathrm{hr}$ per injection point. This borehole is restricted to the Tptpv2 lithology, which consists of fractured, moderately welded tuff from the basal vitrophyre. Phase 2A injection was begun on July 23, 1998, and was terminated on October 30, 2000.

Phase 2B consisted of four injection boreholes in the lower-injection plane, each instrumented with 10 injection points and 10 moisture sensors, one at each injection point. The injection rate was $10 \mathrm{~mL} / \mathrm{hr}$ per injection point. This injection plane is restricted to the Calico Hills formation 
(Tac) and was planned to activate the lower section of the test block simultaneously with the upper section (Phases 2A and 2C). Phase 2B injection began on July 30, 1998, and was terminated on October 30, 2000.

Phase $2 \mathrm{C}$ consisted of three upper injection boreholes, each instrumented with 10 injection points and 12 moisture sensors, one at each injection point, and two additional sensors located toward the borehole collar to detect tracer movement toward the front of the borehole. The injection rate was $50 \mathrm{~mL} / \mathrm{hr}$ per injection point. This injection system was restricted to a horizontal plane in the Tptpv2 lithology. Phase 2C injection was initiated on August 5, 1998, and was terminated on October 30, 2000.

For the Phase-2 experiment, data from more than 200 different sensors were measured. The data collected include:

- Environmental information data, such as ambient pressure, temperature, and relative humidity and wind speed in the ventilation system

- Experimental control information data, such as injection pressure, the number of times pumps are activated, and relative saturation at injection points, at the face of boreholes or along sampling membranes.

\subsubsection{Nonreactive and Reactive Tracers and Microspheres}

Measurements on a small scale can be conducted in the laboratory, but validating the extrapolation of these data in the presence of larger-scale heterogeneities requires field-tracer tests. The behavior of actual radionuclides of concern has been extensively studied in the laboratory, but regulatory and environmental concerns prevent the use of these materials in the field. For the Busted Butte field tests, nonreactive and reactive tracers were used as surrogates for radionuclides. The tracers were chosen so that nonreactive, reactive, and colloidal behaviors could be monitored in a single continuous injection scenario. They were mixed together to normalize the hydrologic conditions of the injection. The tracer matrix was synthetic pore water, which is based on the measured composition of Busted Butte pore waters.

The tracers selected for the Busted Butte field experiments include nonreactive anionic tracers with a range of diffusivities, metal tracers displaying a range of reactivity, and organic dyes with a variety of characteristics (Turin et al. 2002 [DIRS 164633]).

Nonreactive tracers used in the field experiments included bromide, iodide, five different fluorinated benzoic acids (FBAs), sodium fluorescein (uranine, acid yellow 73), and 3-carbamoyl-2(1H)-pyridone (also referred to as "pyridone" in this report). From the inception of testing, bromide was used in all the injection boreholes. Iodide and bromide are both monovalent anions that are typically conservative tracers. Iodide was introduced approximately one year into the experiment, after the system approached a hydraulic steady state.

The FBAs include 2,4-difluorobenzoic acid (2,4-DdiFBA), 2,6-difluorobenzoic acid (2,6-DFBA), 2,4,5-trifluorobenzoic acid (2,4,5-triFBA), 2,3,4,5-tetrafluorobenzoic acid (2,3,4,5-tetraFBA), and pentafluorobenzoic acid (PFBA) (Farnham et al. 2000 [DIRS 165254]). The number of FBAs available makes them valuable for "tagging" individual injection 
boreholes. Each of the injection boreholes was tagged with a single FBA; FBA analyses provided the basis to determine the extent of mixing between the different tracer plumes and to estimate transverse dispersion.

Sodium fluorescein and "pyridone" are organic dye tracers. The strong fluorescence of sodium fluorescein under ultraviolet illumination enables qualitative determination of breakthrough during sample collection at the field site, but its susceptibility to photodegradation and the sensitivity of its fluorescence to matrix variations limit its usefulness as a quantitative tracer. "Pyridone" is an experimental tracer that has been used by the USGS for saturated-zone tracer testing at the C-Wells (Geldon et al. 1997 [DIRS 100397]), and was added to the Busted Butte tracer mixture to further evaluate its usefulness for future field studies.

Reactive metal tracers include $\mathrm{Li}^{+}, \mathrm{Mn}^{2+}, \mathrm{Co}^{2+} \mathrm{Ni}^{2+}, \mathrm{Ce}^{3+}$, and $\mathrm{Sm}^{3+}$. $\mathrm{Li}^{+}$is a weakly sorbing tracer whose value has been demonstrated in saturated-zone tracer tests at the Yucca Mountain C-Wells complex (Reimus et al. 1999 [DIRS 126243]). $\mathrm{Li}^{+}$is quite soluble, and the breakthrough concentrations at the collection boreholes are readily analyzed. The transition metals $\mathrm{Mn}^{2+}, \mathrm{Co}^{2+}$, and $\mathrm{Ni}^{2+}$ sorb more strongly than $\mathrm{Li}^{+}$, are far less soluble, and are less susceptible to transport. Therefore, breakthrough concentrations are lower, and analytical difficulties abound. Furthermore, $\mathrm{Mn}^{2+}$, unlike the other metals, has a significant background level that may interfere with breakthrough detection. The rare-earth metals $\mathrm{Ce}^{3+}$ and $\mathrm{Sm}^{3+}$ were also added to the tracer mixture at Busted Butte. These metals have very low solubilities under field conditions, and it is likely that they precipitated within the tracer tanks (Kearney et al. 2000 [DIRS 165255]).

Rhodamine WT (acid red 388) was also added to the Busted Butte tracer mixture. This intensely colored organic dye is known to sorb to rock and soil materials (Kasnavia et al. 1999 [DIRS 164629]; Sabatini and Austin 1991 [DIRS 164630]), and was used primarily to help locate tracer plumes in rock samples collected during post-test excavation.

\subsubsection{Phase 1 Tracers}

Phase 1 tracers were chosen based on the list of tracers permitted for use in the C-wells tests. Surrogate nonreactive and reactive tracers and colloids were mixed together to normalize the hydrologic conditions they encounter and provide for higher accuracy of the results. The tracers used in the Busted Butte experiments of Phase 1 included the following:

- Lithium bromide,

- Fluorescent polystyrene latex microspheres,

- Sodium fluorescein,

- "Pyridone" (3-carbamoyl-2(1H)-pyridone),

- 2,6-difluorobenzoic acid (2,6-DFBA), and

- PFBA.

The reactive sorbing tracer used is lithium, and the colloid analogues are fluorescent polystyrene latex microspheres of two sizes: 0.3 and $1 \mu \mathrm{m}$ diameter. The 2,6-DFBA and PFBA are nonreactive tracers used to tag the various injection boreholes with their associated injection rates (i.e., 1 and $10 \mathrm{~mL} / \mathrm{hr}$ rates). Sodium fluorescein and pyridone are UV fluorescent and are 
used as nonreactive tracer markers that can be detected in the field at a concentration level of approximately $10 \mathrm{ppm}$, using UV illumination. Borehole numbers are shown in Figure 6-170 for Phase 1A and Figure 6-171 for Phase 1B and Phase 2.

\section{Borehole 1}

Tptpv1

Borehole 3

\section{Calico Hills}

\section{Borehole 2}

\section{Borehole 4}

Source: $\quad$ CRWMS M\&O (2001 [DIRS 154024], Figure 37) (this source citation indicates the origin of the information in this figure, which is for illustration purposes only; the cited report was not used as direct input).

NOTE: Figure not drawn to scale.

Figure 6-170. Schematic of Phase-1A Borehole Numbers and Relative Locations

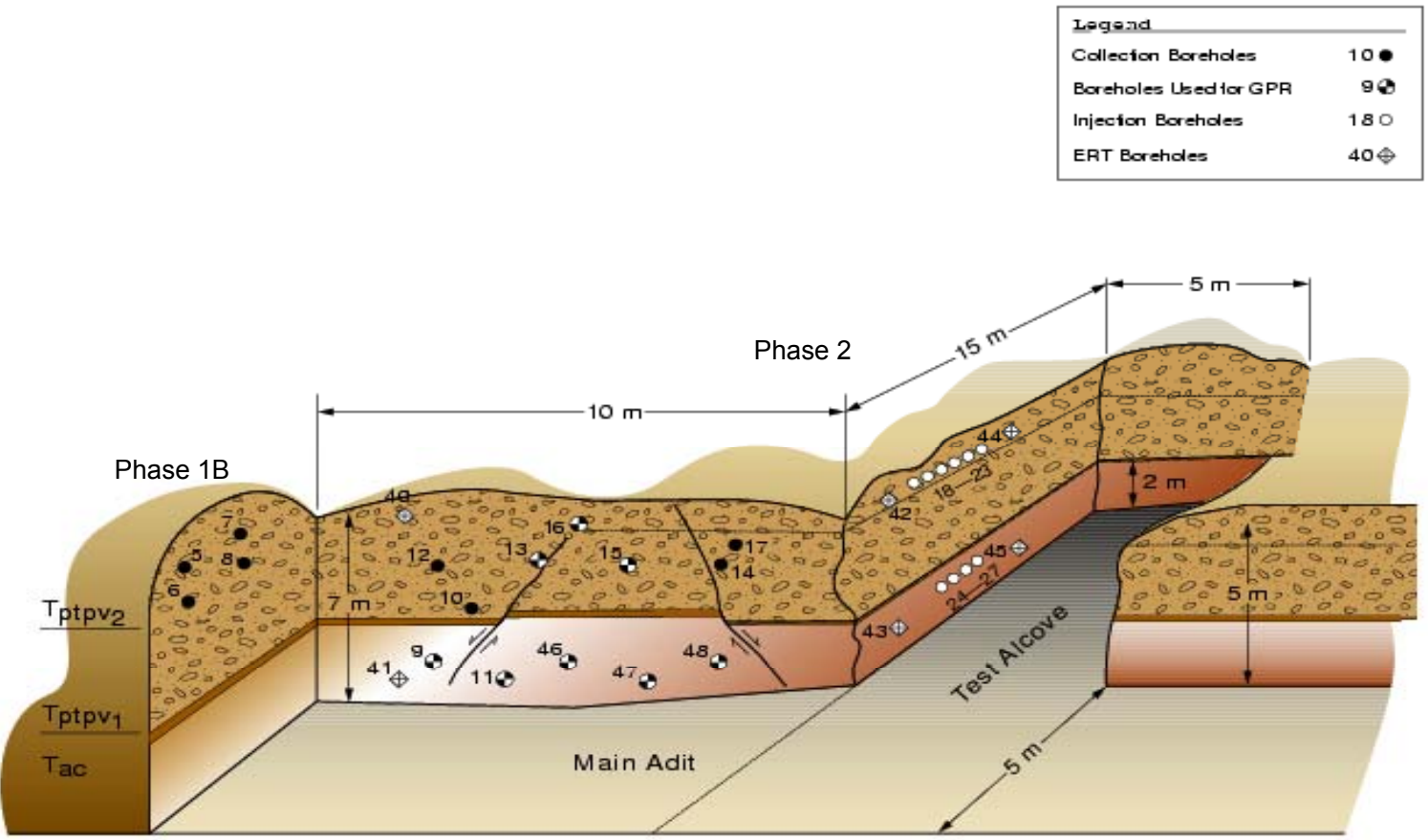

Source: CRWMS M\&O (2001 [DIRS 154024], Figure 38) (this source citation indicates the origin of the information in this figure, which is for illustration purposes only; the cited report was not used as direct input).

Figure 6-171. Phase-1B and Phase-2 Borehole Numbers and Relative Locations 
Table 6-31 summarizes the initial concentrations of Phase 1B injection with the lithium and bromide elemental concentrations derived from the $500-\mathrm{mg} / \mathrm{kg}$ lithium bromide value, based on the elemental atomic weights of lithium and bromide. Table 6-32 summarizes the concentrations used for Phase 1A and Phase 1B injections.

Table 6-31. Tracer $C_{0}$ Values for Phase $1 \mathrm{~B}$ Injection

\begin{tabular}{|l|c|}
\hline \multicolumn{1}{|c|}{ Tracer } & C $_{\text {o }}(\mathbf{m g} / \mathbf{k g})$ \\
\hline Lithium & 40 \\
\hline Bromide & 460 \\
\hline 2,6-DFBA (Borehole 5 only) & 100 \\
\hline Pyridone & 100 \\
\hline Sodium fluorescein & 500 \\
\hline
\end{tabular}

Source: CRWMS M\&O (2001 [DIRS 154024], Table 30).

$\mathrm{DFBA}=$ difluorobenzoic acid.

Table 6-32. Summary of Concentrations Used for Phase 1 Injections

\begin{tabular}{|c|}
\hline Phase 1A-10 mL/hr Injection Rate; Boreholes 1 and 3: \\
\hline $500 \mathrm{mg} \mathrm{kg}^{-1}$ lithium bromide \\
\hline $500 \mathrm{mg} \mathrm{kg}^{-1}$ sodium fluorescein \\
\hline $100 \mathrm{mg} \mathrm{kg}^{-1} 2,6-\mathrm{DFBA}$ \\
\hline $1 \mathrm{~mL} \mathrm{~kg}^{-1}$ fluorescent polystyrene microspheres \\
\hline Phase $1 \mathrm{~A}-1 \mathrm{~mL} / \mathrm{hr}$ Injection Rate; Boreholes 2 and 4: \\
\hline $500 \mathrm{mg} \mathrm{kg}^{-1}$ lithium bromide \\
\hline $500 \mathrm{mg} \mathrm{kg}^{-1}$ sodium fluorescein \\
\hline $100 \mathrm{mg} \mathrm{kg}^{-1}$ PFBA \\
\hline $1 \mathrm{~mL} \mathrm{~kg}^{-1}$ fluorescent polystyrene microspheres \\
\hline Phase 1B-10 mL/hr Injection Rate; Borehole 5: \\
\hline $500 \mathrm{mg} \mathrm{kg}^{-1}$ lithium bromide \\
\hline $500 \mathrm{mg} \mathrm{kg}^{-1}$ sodium fluorescein \\
\hline $100 \mathrm{mg} \mathrm{kg}^{-1} 2,6-\mathrm{DFBA}$ \\
\hline $100 \mathrm{mg} \mathrm{kg}^{-1}$ pyridone \\
\hline $1 \mathrm{~mL} \mathrm{~kg}^{-1}$ fluorescent polystyrene microspheres \\
\hline Phase 1B-1 mL/hr Injection Rate; Borehole 7: \\
\hline $500 \mathrm{mg} \mathrm{kg}^{-1}$ lithium bromide \\
\hline $500 \mathrm{mg} \mathrm{kg}^{-1}$ sodium fluorescein \\
\hline $100 \mathrm{mg} \mathrm{kg}^{-1}$ PFBA \\
\hline $100 \mathrm{mg} \mathrm{kg}^{-1}$ pyridone \\
\hline $1 \mathrm{~mL} \mathrm{~kg}^{-1}$ fluorescent polystyrene microspheres \\
\hline Source: CRWMS M\&O (2001 [DIRS 154024], Section 6.8.2.4). \\
\hline DFBA = difluorobenzoic acid; PFBA = pentafluorobenzoic acid. \\
\hline
\end{tabular}




\subsubsection{Phase 2 Tracers}

Phase 2 tracers include those used in Phase 1, but also include three additional FBAs (2,4-DFBA, 2,4,5-triFBA, 2,3,4,5-tetraFBA), iodide, a fluorescent reactive tracer (Rhodamine WT), and additional reactive ions that serve as analogues for neptunium, plutonium, and americium. (See Figure 6-171 for Phase-2 borehole locations.)

- Neptunium Analogues $\left(\mathrm{NpO}_{2}{ }^{+}, \mathrm{Np}(\mathrm{V})\right)$ :

- Nickel $\left(\mathrm{Ni}^{2+}\right)$

- Cobalt $\left(\mathrm{Co}^{2+}\right)$

- Manganese $\left(\mathrm{Mn}^{2+}\right)$.

- Plutonium Analogue $\left(\mathrm{Pu}^{3+}\right)$ :

- Samarium $\left(\mathrm{Sm}^{3+}\right)$.

- Plutonium Analogues (colloidal form):

- Polystyrene microspheres.

- Americium Analogue $\left(\mathrm{Am}^{3+}\right)$ :

- Cerium $\left(\mathrm{Ce}^{3+}\right)$.

The Phase 2 tracer recipes are presented in Table 6-33, Table 6-34, and Table 6-35.

Table 6-33. Summary of Concentrations Used for Phase 2A Injections

\begin{tabular}{|c|}
\hline Phase 2A-1 mL/hr Injection Rate; Borehole 23: \\
\hline Starting July 23, 1998 \\
\hline 1000 mg/kg lithium bromide \\
\hline $10 \mathrm{mg} / \mathrm{kg}$ sodium fluorescein \\
\hline $100 \mathrm{mg} / \mathrm{kg}$ 2,4,5-triFBA \\
\hline $10 \mathrm{mg} / \mathrm{kg}$ pyridone \\
\hline $1 \mathrm{~mL} / \mathrm{kg}$ microspheres \\
\hline Starting October 7, 1998 \\
\hline $10 \mathrm{mg} / \mathrm{L}$ rhodamine WT \\
\hline $10 \mathrm{mg} / \mathrm{kg} \mathrm{NiCl} 2 \cdot 6 \mathrm{H}_{2} \mathrm{O}\left(2.47 \mathrm{mg} / \mathrm{kg}\right.$ of $\left.\mathrm{Ni}^{2+}\right)$ \\
\hline $10 \mathrm{mg} / \mathrm{kg} \mathrm{MnCl} \cdot 4 \mathrm{H}_{2} \mathrm{O}\left(2.78 \mathrm{mg} / \mathrm{kg}\right.$ of $\left.\mathrm{Mn}^{2+}\right)$ \\
\hline $10 \mathrm{mg} / \mathrm{kg} \mathrm{CoCl} \cdot 6 \mathrm{H}_{2} \mathrm{O}\left(2.48 \mathrm{mg} / \mathrm{kg}\right.$ of $\left.\mathrm{Co}^{2+}\right)$ \\
\hline $5 \mathrm{mg} / \mathrm{kg} \mathrm{SmCl}{ }_{3} \cdot 6 \mathrm{H}_{2} \mathrm{O}\left(2.06 \mathrm{mg} / \mathrm{kg}\right.$ of $\left.\mathrm{Sm}^{3+}\right)$ \\
\hline $5 \mathrm{mg} / \mathrm{kg} \mathrm{CeCl}{ }_{3} \cdot 7 \mathrm{H}_{2} \mathrm{O}\left(1.88 \mathrm{mg} / \mathrm{kg}\right.$ of $\left.\mathrm{Ce}^{3+}\right)$ \\
\hline Starting September 30, 1999 \\
\hline Stop release of microspheres \\
\hline $500 \mathrm{mg} / \mathrm{kg}$ potassium iodide \\
\hline
\end{tabular}

Source: CRWMS M\&O (2001 [DIRS 154024], Section 6.8.2.4).

triFBA = trifluorobenzoic acid. 
Table 6-34. Summary of Concentrations Used for Phase 2B Injections

\begin{tabular}{|c|}
\hline Phase 2B-10 mL/hr Injection Rate; Boreholes 24, 25, 26, 27: \\
\hline Starting July 30,1998 \\
\hline $1000 \mathrm{mg} / \mathrm{kg}$ lithium bromide \\
\hline $10 \mathrm{mg} / \mathrm{kg}$ sodium fluorescein \\
\hline 100 mg/kg 2,6-DFBA (Borehole 26, Borehole 27) \\
\hline $100 \mathrm{mg} / \mathrm{kg} \mathrm{2,3,4,5-TetraFBA}$ (Borehole 24, Borehole 25) \\
\hline $10 \mathrm{mg} / \mathrm{kg}$ pyridine \\
\hline $10 \mathrm{mg} / \mathrm{kg}$ rhodamine WT \\
\hline $1 \mathrm{~mL} / \mathrm{kg}$ microspheres \\
\hline Starting September 2, 1998 \\
\hline $10 \mathrm{mg} / \mathrm{kg} \mathrm{NiCl} 2 \cdot 6 \mathrm{H}_{2} \mathrm{O}\left(2.47 \mathrm{mg} / \mathrm{kg}\right.$ of Ni$\left.{ }^{2+}\right)$ \\
\hline $10 \mathrm{mg} / \mathrm{kg} \mathrm{MnCl} 2 \cdot 4 \mathrm{H}_{2} \mathrm{O}\left(2.78 \mathrm{mg} / \mathrm{kg}\right.$ of $\left.\mathrm{Mn}^{2+}\right)$ \\
\hline $10 \mathrm{mg} / \mathrm{kg} \mathrm{CoCl} 2 \cdot 6 \mathrm{H}_{2} \mathrm{O}\left(2.48 \mathrm{mg} / \mathrm{kg}\right.$ of $\left.\mathrm{Co}^{2+}\right)$ \\
\hline $5 \mathrm{mg} / \mathrm{kg} \mathrm{SmCl}{ }_{3} \cdot 6 \mathrm{H}_{2} \mathrm{O}\left(2.06 \mathrm{mg} / \mathrm{kg}\right.$ of $\left.\mathrm{Sm}^{3+}\right)$ \\
\hline $5 \mathrm{mg} / \mathrm{kg} \mathrm{CeCl}{ }_{3} \cdot 7 \mathrm{H}_{2} \mathrm{O}\left(1.88 \mathrm{mg} / \mathrm{kg}\right.$ of $\left.\mathrm{Ce}^{3+}\right)$ \\
\hline Starting August 18, 1999 \\
\hline Stop release of microspheres \\
\hline $500 \mathrm{mg} / \mathrm{kg}$ potassium iodide \\
\hline End of Test: October 30, 2000 \\
\hline
\end{tabular}

Source: CRWMS M\&O (2001 [DIRS 154024], Section 6.8.2.4).

DFBA = diflourobenzoic acid; TetraFBA = tetrafluorobenzoic acid.

Table 6-35. Summary of Concentrations Used for Phase 2C Injections

\begin{tabular}{|c|}
\hline Phase 2C-50 mL/hr Injection Rate; Boreholes 18, 20, 21: \\
\hline Starting August 5, 1998 \\
\hline $1000 \mathrm{mg} / \mathrm{kg}$ lithium bromide \\
\hline $10 \mathrm{mg} / \mathrm{kg}$ sodium fluorescein \\
\hline 100 mg/kg 2,6-DFBA (Borehole 18) \\
\hline 100 mg/kg PFBA (Borehole 20) \\
\hline 100 mg/kg 2,4-DFBA (Borehole 21) \\
\hline $10 \mathrm{mg} / \mathrm{kg}$ pyridine \\
\hline $10 \mathrm{mg} / \mathrm{kg}$ rhodamine WT \\
\hline $1 \mathrm{~mL} / \mathrm{kg}$ microspheres \\
\hline Starting September 2, 1998 \\
\hline $10 \mathrm{mg} / \mathrm{kg} \mathrm{NiCl} 2 \cdot 6 \mathrm{H}_{2} \mathrm{O}\left(2.47 \mathrm{mg} / \mathrm{kg}\right.$ of Ni$\left.{ }^{2+}\right)$ \\
\hline $10 \mathrm{mg} / \mathrm{kg} \mathrm{MnCl} \cdot 4 \mathrm{H}_{2} \mathrm{O}\left(2.78 \mathrm{mg} / \mathrm{kg}\right.$ of $\left.\mathrm{Mn}^{2+}\right)$ \\
\hline $10 \mathrm{mg} / \mathrm{kg} \mathrm{CoCl} 2 \cdot 6 \mathrm{H}_{2} \mathrm{O}\left(2.48 \mathrm{mg} / \mathrm{kg}\right.$ of $\left.\mathrm{Co}^{2+}\right)$ \\
\hline $5 \mathrm{mg} / \mathrm{kg} \mathrm{SmCl}{ }_{3} \cdot 6 \mathrm{H}_{2} \mathrm{O}\left(2.06 \mathrm{mg} / \mathrm{kg}\right.$ of $\left.\mathrm{Sm}^{3+}\right)$ \\
\hline $5 \mathrm{mg} / \mathrm{kg} \mathrm{CeCl} 3 \cdot 7 \mathrm{H}_{2} \mathrm{O}\left(1.88 \mathrm{mg} / \mathrm{kg}\right.$ of $\left.\mathrm{Ce}^{3+}\right)$ \\
\hline Starting August 18, 1999 \\
\hline Stop release of microspheres \\
\hline $500 \mathrm{mg} / \mathrm{kg}$ potassium iodide \\
\hline End of Test: October 30, 2000 \\
\hline
\end{tabular}




\subsubsection{Synthetic Pore-Water Recipe}

Composition of the UZTT pore water is found in DTNs: LA9909WS831372.015 [DIRS 140089], LA9909WS831372.016 [DIRS 140093], LA9909WS831372.017 [DIRS 140097], and LA9909WS831372.018 [DIRS 140101]; the composition of the synthetic pore water used in the UZTT is found in Table 29 in Section 6.8.5.2 of the UZ and SZ transport properties report (CRWMS M\&O 2001 [DIRS 154024]).

\subsubsection{Field-Scale Tracer Transport-Phase 1}

\subsubsection{Test Phase 1A}

Phase 1A was located in the nonwelded Calico Hills (CHn) hydrogeologic unit spanning both the geologic Calico Hills formation (Tac) and the nonwelded subzone of the lowermost Topopah Spring Tuff (Tptpv1). It was a noninstrumented or "blind" test consisting of four single-point injection boreholes. All Phase 1 boreholes were $2 \mathrm{~m}$ in length and $10 \mathrm{~cm}$ in diameter. The injection point was located $90 \mathrm{~cm}$ from the borehole collar. Continuous injection started on April 2, 1998, and ended on January 12, 1999 (286 days). Injection rates were $10 \mathrm{~mL} / \mathrm{hr}$ (Boreholes 1 and 3 ) and $1 \mathrm{~mL} / \mathrm{hr}$ (Boreholes 2 and 4). Borehole 3 had the greater average injection rate with less variability in the injection rate over the test period as compared with Borehole 1 (DTN: LA0008WS831372.001 [DIRS 156582]). A mixture of nonreactive tracers (bromide, fluorescein, pyridone, and FBAs), a reactive tracer (lithium), and fluorescent polystyrene microspheres were used to track nonreactive transport, reactive transport, and colloid migration, respectively. The tracer solutions were injected at a depth of $1.30 \mathrm{~m}$, measured from the rock face into the horizontal injection boreholes. Water samples from horizontal boreholes were collected and analyzed regularly during the injection period (Tseng and Bussod 2001 [DIRS 166793]).

The field test was completed through excavation by "mineback" and auger sampling. Mineback of the Phase 1A test block began on January 15, 1999, and ended on March 3, 1999. During mineback, as successive layers of the adit wall were removed, digital photographs were taken under visible and UV illumination, and the exposed face was surveyed. In addition, rock samples were collected by augering for laboratory analysis of tracer and moisture content. Modeling and analysis were significant elements of this effort, for which the work is reported in the model report, Radionuclide Transport Models Under Ambient Conditions (BSC 2004 [DIRS 164500]).

\section{Results}

The Phase 1A mineback consisted of four faces exposed 50,90,115, and $140 \mathrm{~cm}$ from the adit wall. At each face, the stratigraphy was mapped and surveyed, and images of the fluorescein plume were taken under UV light. The visualization of the fluorescein tracer plume using UV illumination was very successful, and the digital imagery resulting from this effort serves as the primary result of Phase 1A (for this purpose, the concentration of fluorescein for this test phase was very high). Figure 6-172 (Panels a through d) shows the fluorescein plume at each of the mineback faces. 


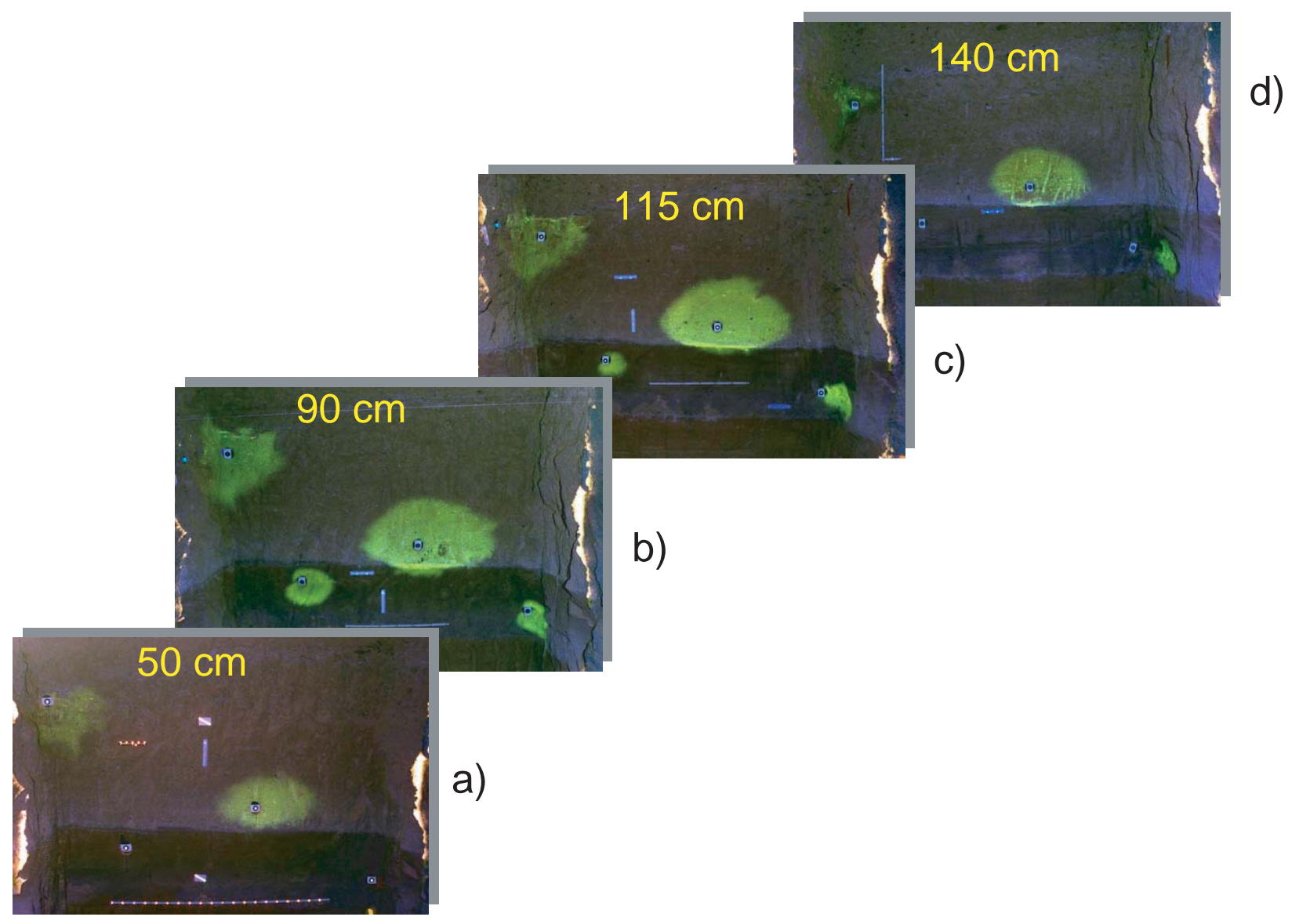

Source: DTN: LA0302WS831372.001 [DIRS 162765].

Figure 6-172. Fluorescein Plume at Each of the Four Phase-1A Mineback Faces

Observations from the Phase 1A test demonstrate strong capillary dominated flow for both the 1 and $10 \mathrm{~mL} / \mathrm{hr}$ injection rates. Injection is at "3 o'clock" with respect to the borehole. The plumes are distributed relatively uniformly around the injection sites, though some borehole shielding effects (tracer blocked or delayed from moving in the direction of the borehole) can be seen. Lithological contacts, however, clearly influence the flow. At all of the mineback faces, the plumes are more oval than they are round. This reflects the ash layers just above Boreholes 2 and 4 and just below Borehole 3.

Although difficult to see from the image itself, Figure 6-173 shows the location of a small fracture near the injection point in Borehole 3. This image demonstrates that fractures have a relatively minor effect on the flow in Tac and Tptpv1 units. A slight perturbation exists in the upper right that may have resulted from the presence of the fracture. It indicates that this particular fracture is acting as a permeability barrier rather than as a fast path under the prevalent Phase 1A conditions. 


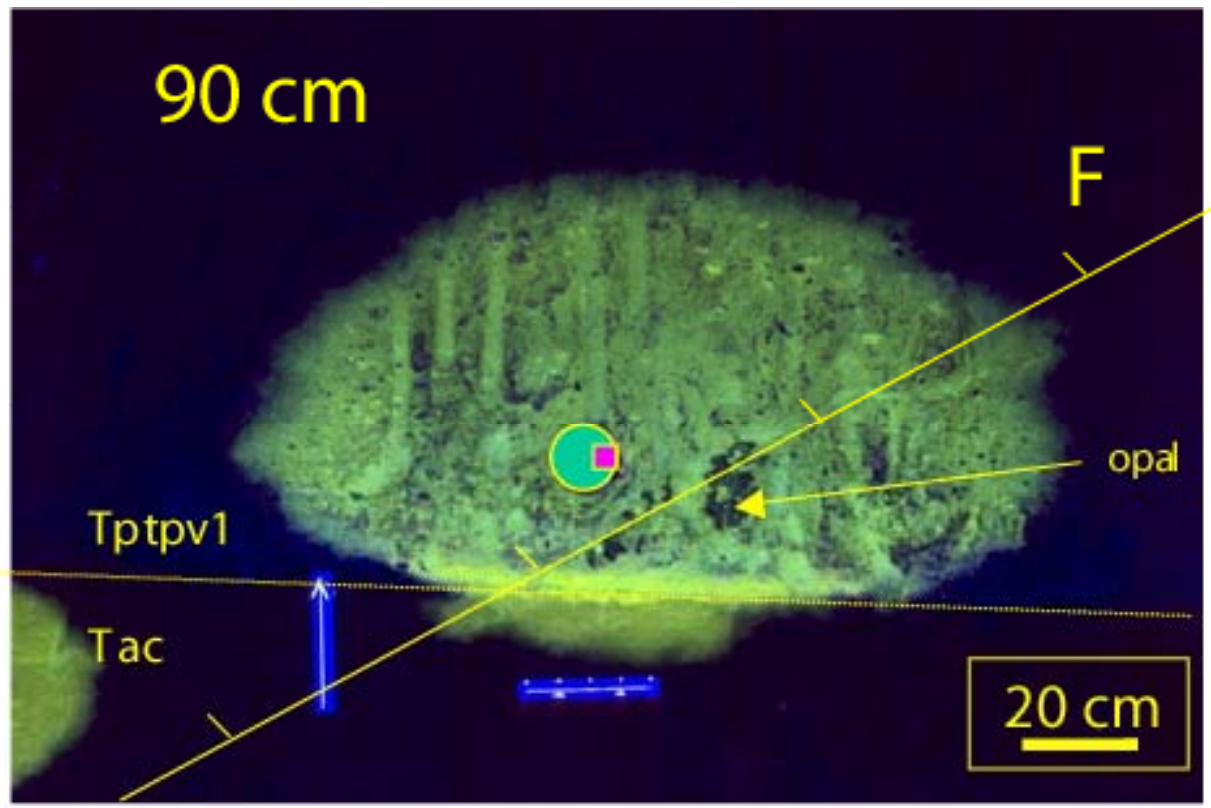

Source: DTN: LA0302WS831372.001 [DIRS 162765] (scale bar modified from that in DTN to reflect correct scale).

Figure 6-173. Fluorescein Plume at 90-cm Mineback Face at Borehole 3

A small number of augered rock samples have been analyzed for bromide and moisture content (DTN: LA9910WS831372.008 [DIRS 147156]). Table 6-36 reports measured data from these samples. Samples 1, 2, 3, and 4 are taken at increasing distance below Borehole 3. Sample 1 and Sample 2 are above the ash layer; Sample 3 and Sample 4 are located vertically beneath the injector. Samples 5 to 12 are taken at increasing lateral distance from the injection point.

Table 6-36. Phase 1A Samples Taken from the 90-cm Mineback Face at Borehole 3

\begin{tabular}{|l|c|c|c|c|c|}
\hline \multicolumn{1}{|c|}{ Sample Name } & $\begin{array}{c}\mathbf{X} \\
(\mathbf{m})\end{array}$ & $\begin{array}{c}\mathbf{Y} \\
(\mathbf{m})\end{array}$ & $\begin{array}{c}\mathbf{Z} \\
(\mathbf{m})\end{array}$ & $\begin{array}{c}\text { Gravimetric moisture } \\
\text { content } \mathbf{( g / g})\end{array}$ & $\begin{array}{c}\text { Bromide } \\
\mathbf{C} / \mathbf{C o}\end{array}$ \\
\hline Borehole Coordinates & -3.929 & 59.093 & -2.684 & -- & -- \\
\hline BBR-990204-3-1-B & -3.788 & 59.092 & -2.825 & 0.078 & 0.74 \\
\hline BBR-990204-3-2-B & -3.790 & 59.089 & -2.933 & 0.112 & 0.49 \\
\hline BBR-990204-3-3-B & -3.798 & 59.083 & -3.056 & 0.115 & 0.00 \\
\hline BBR-990204-3-4-B & -3.807 & 59.070 & -3.164 & 0.122 & 0.00 \\
\hline BBR-990205-3-5-HS & -3.831 & 59.147 & -2.675 & 0.064 & 2.77 \\
\hline BBR-990204-3-6-B & -3.822 & 59.219 & -2.652 & 0.081 & 0.87 \\
\hline BBR-990204-3-7-B & -3.806 & 59.336 & -2.629 & 0.077 & 0.75 \\
\hline BBR-990204-3-8-B & -3.804 & 59.434 & -2.637 & 0.074 & 0.75 \\
\hline BBR-990204-3-9-B & -3.819 & 59.528 & -2.661 & 0.077 & 0.81 \\
\hline BBR-990204-3-10-B & -3.780 & 59.636 & -2.666 & 0.078 & 0.79 \\
\hline BBR-990204-3-11-B & -3.763 & 59.765 & -2.675 & 0.074 & 0.32 \\
\hline BBR-990204-3-12-B & -3.770 & 59.894 & -2.693 & 0.077 & 0.01 \\
\hline
\end{tabular}

Source: DTN: LA9910WS831372.008 [DIRS 147156].

NOTES: Samples were analyzed for moisture content and bromide concentration.

Sample 5 was a hand sample of polystyrene microspheres at the injection point. 


\subsubsection{Test Phase 1B}

Phase 1B involved both injection of a tracer mixture and collection of pore-water/tracer samples in the lower section of the Topopah Spring Tuff (Tptpv2). Because of the paucity of data on fracture-matrix interactions in these lithologies, this test was designed to provide data on fracture-matrix interactions in the TSw. The results were used to calibrate fracture properties for Phase 2 analysis. In addition, modeling and analysis were significant elements of this effort, for which the work is reported in the model report, Radionuclide Transport Models Under Ambient Conditions (BSC 2004 [DIRS 164500]).

Phase 1B consisted of two 2-m injection boreholes (Boreholes 5 and 7) and two 2-m collection boreholes (Boreholes 6 and 8). The tracer mixture was injected at $10 \mathrm{~mL} / \mathrm{hr}$ in Borehole 5 and at $1 \mathrm{~mL} / \mathrm{hr}$ in Borehole 7. Phase 1B injection began on May 12, 1998. Injection from Borehole 7 was terminated on November 9, 1998; injection from Borehole 5 was terminated on November 18, 1998. Throughout the experiment, rock pore-water samples were collected at regular intervals using collection pads installed in Boreholes 6 and 8.

Moisture pad collection was conducted in the collection borehole (Borehole 8) directly below the injection borehole (Borehole 7), until injection was stopped on November 9, 1998. While tracer injection and moisture pad collection continued in Boreholes 5 and 6, two 10-inch-diameter overcores were drilled approximately tangential to one another, with their centerlines in a vertical plane and contained in the area between the top of Borehole 7 and the bottom of Borehole 8. When Borehole 5 injection ceased, three 10-inch-diameter overcores were drilled approximately tangential to one another, with their centerlines in a vertical plane and contained in the area between the top of injection boreholes, 5 and 10 inches below the bottom of the collection borehole (Borehole 6). As soon as injection into each of the injection boreholes was stopped, the injection and collection boreholes were surveyed, as well as video and neutron logged.

The results can be summarized as follows:

There were 176 selected pads extracted for tracers, and the extracts were analyzed by ion chromatograph (IC), inductively coupled plasma/mass spectroscopy (ICP/MS), high-pressure liquid chromatograph (HPLC), spectrofluorimetry, and epifluorescent microscopy. The extraction/analysis procedure is shown schematically in Figure 6-174. Altogether, 883 individual analyses were conducted, and full results were submitted (DTNs: LA9909WS831372.001 [DIRS 122739] and LA9909WS831372.002 [DIRS 122741]). Breakthrough of all five solute tracers was detected in Borehole 6, directly below the $10-\mathrm{mL} / \mathrm{hr}$ injection site in Borehole 5. No breakthrough was detected in Borehole 8 below the $1-\mathrm{mL} / \mathrm{hr}$ injection site in Borehole 7. No clear evidence of microsphere breakthrough was detected in either borehole, but this may be result from analytical difficulties, discussed below in this section. The Borehole 6 breakthrough results are summarized in Figure 6-175 through Figure 6-179, which shows tracer concentration in pad $(C)$ normalized by the input tracer concentration $\left(C_{0}\right)$ listed in Table 6-31 (see Section 6.13.1.9). 


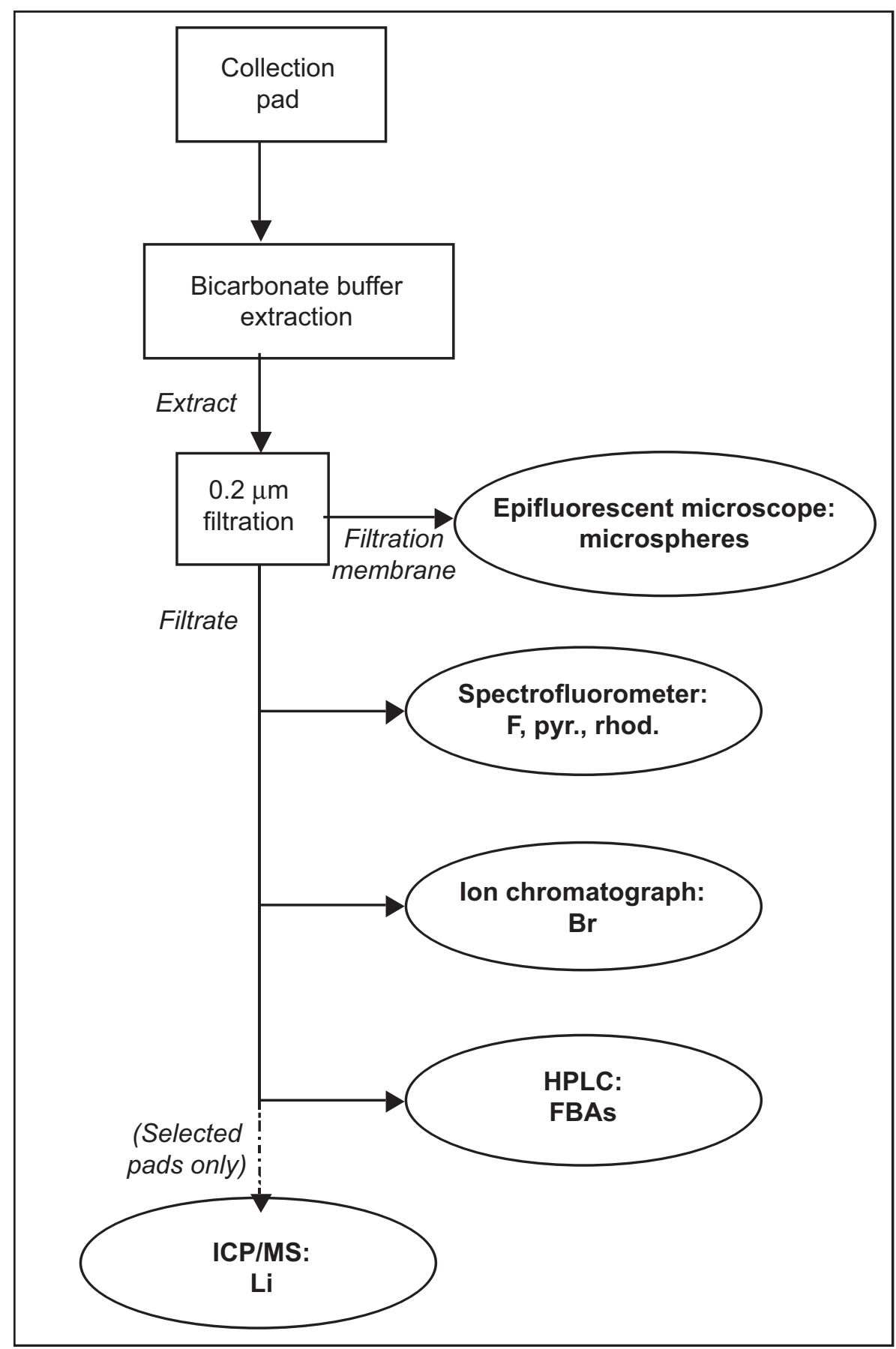

Source: CRWMS M\&O (2001 [DIRS 154024], Figure 57) (this source citation indicates the origin of the information in this figure, which is for illustration purposes only; the cited report was not used as direct input).

Figure 6-174. Phase-1B Pad Extraction/Analysis Scheme 
All five tracers shown in Figure 6-175 through Figure 6-179 give clear evidence of breakthrough by the end of the experiment. All of the figures show peak concentrations at a (horizontal) depth of approximately $130 \mathrm{~cm}$, directly below the injection port in Borehole 5; but maximum recovery varies greatly. Bromide and 2,6-DFBA, both nonreactive anionic tracers, show similar and reasonable breakthrough patterns, with initial breakthrough detected in mid-late June 1998, after approximately 1 month of injection. Both bromide and 2,6-DFBA reached 50-percent injection concentrations in mid-July, after 2 months of injection. The fluorescein breakthrough pattern is more erratic. In particular, the peak concentration measured is more than twice the injected concentration, which is clearly not reasonable. These anomalies probably reflect analytical difficulties associated with the extremely high concentration of fluorescein injected. The high concentration succeeded in improving field visualization of the plumes during mineback and overcore, even though it hurt the laboratory quantification. The later breakthrough and lower detected concentrations of pyridone may also reflect analytical difficulties; if the readings reflect actual concentrations, they may indicate either sorption or degradation of this supposedly nonreactive tracer. Finally, although detected lithium concentrations are quite low, their contrast with background levels and their consistent location both in time and in space indicate that true lithium breakthrough was observed in the field. The low and late breakthrough indicates that lithium was sorbed quite significantly.

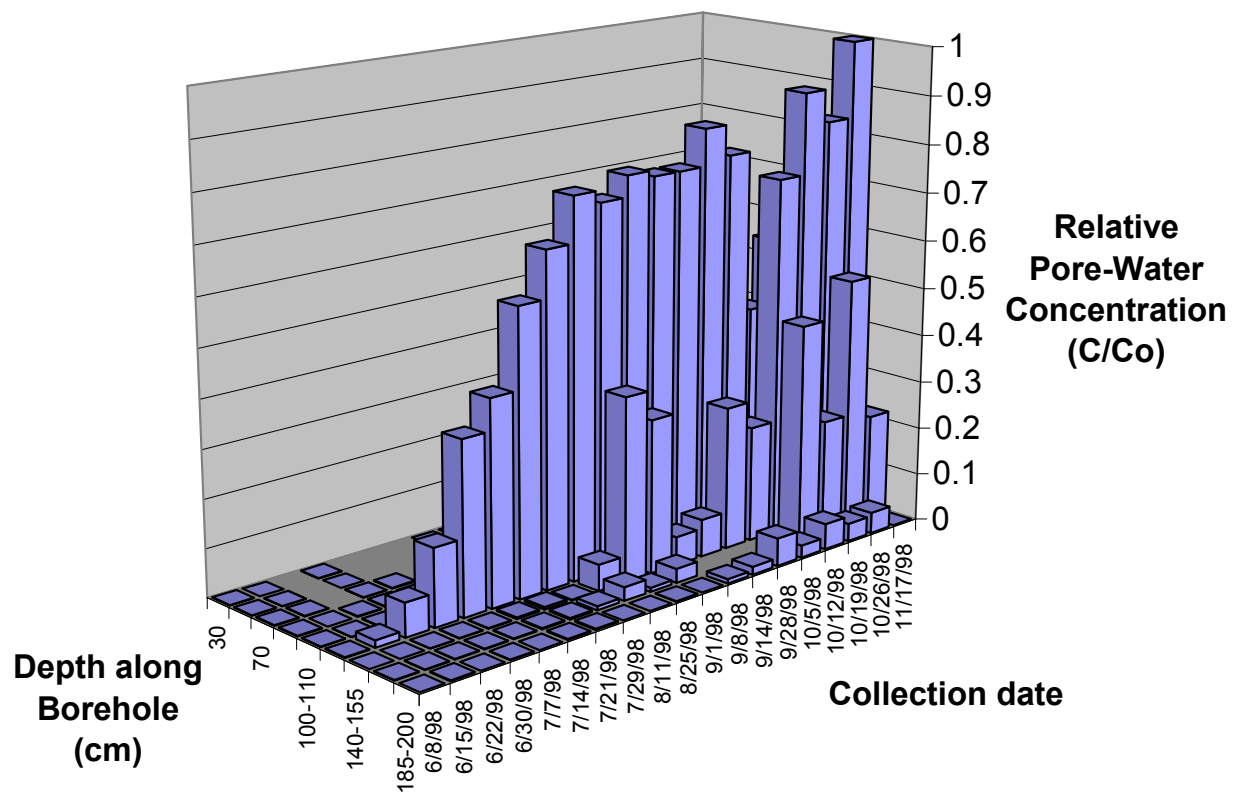

Sources: CRWMS M\&O (2001 [DIRS 154024], Figure 58a).

DTNs: LA9909WS831372.001 [DIRS 122739]; LA9909WS831372.002 [DIRS 122741].

Figure 6-175. Bromide Concentrations in Borehole 6 for Phase 1B 


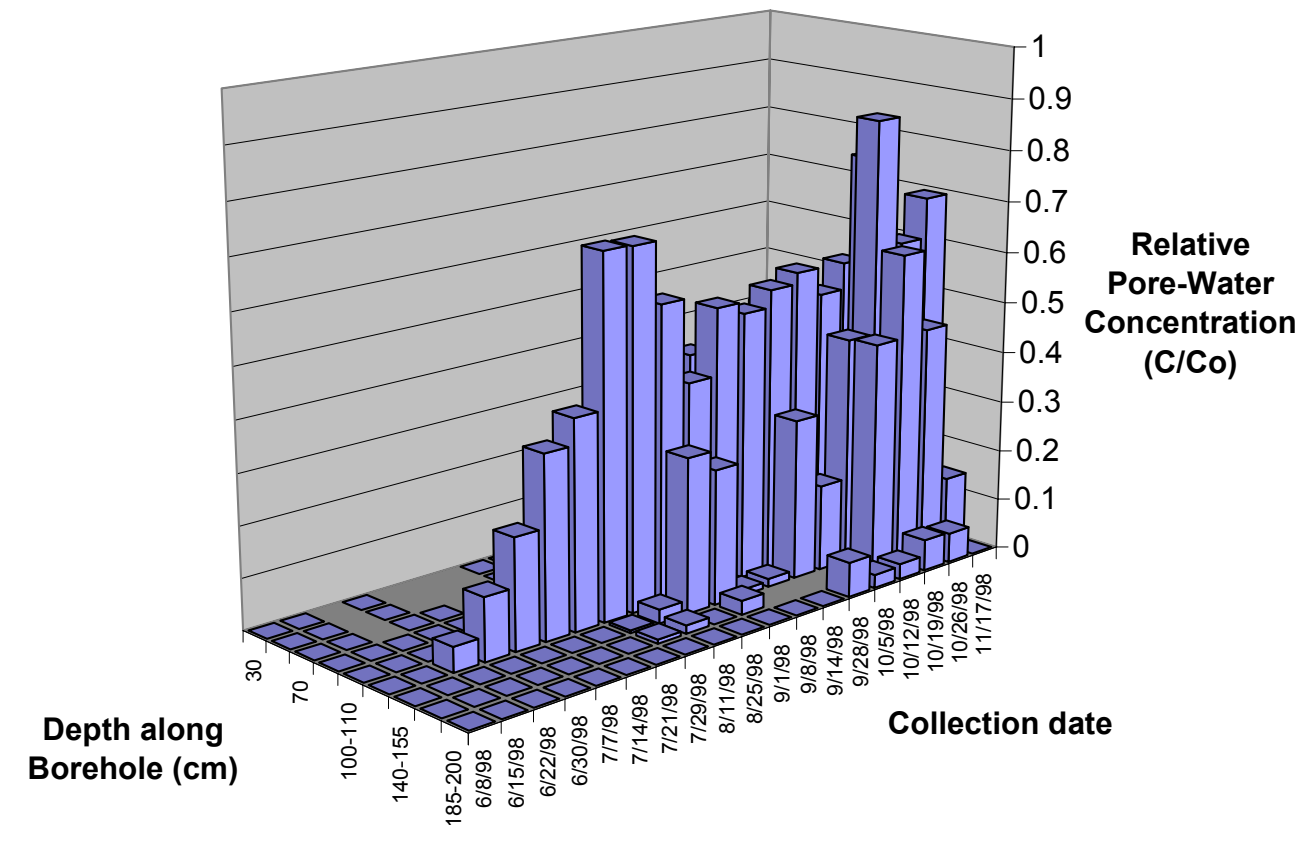

Sources: CRWMS M\&O (2001 [DIRS 154024], Figure 58b).

DTNs: LA9909WS831372.001 [DIRS 122739]; LA9909WS831372.002 [DIRS 122741].

Figure 6-176. 2,6-DFBA Concentrations in Borehole 6 for Phase 1B

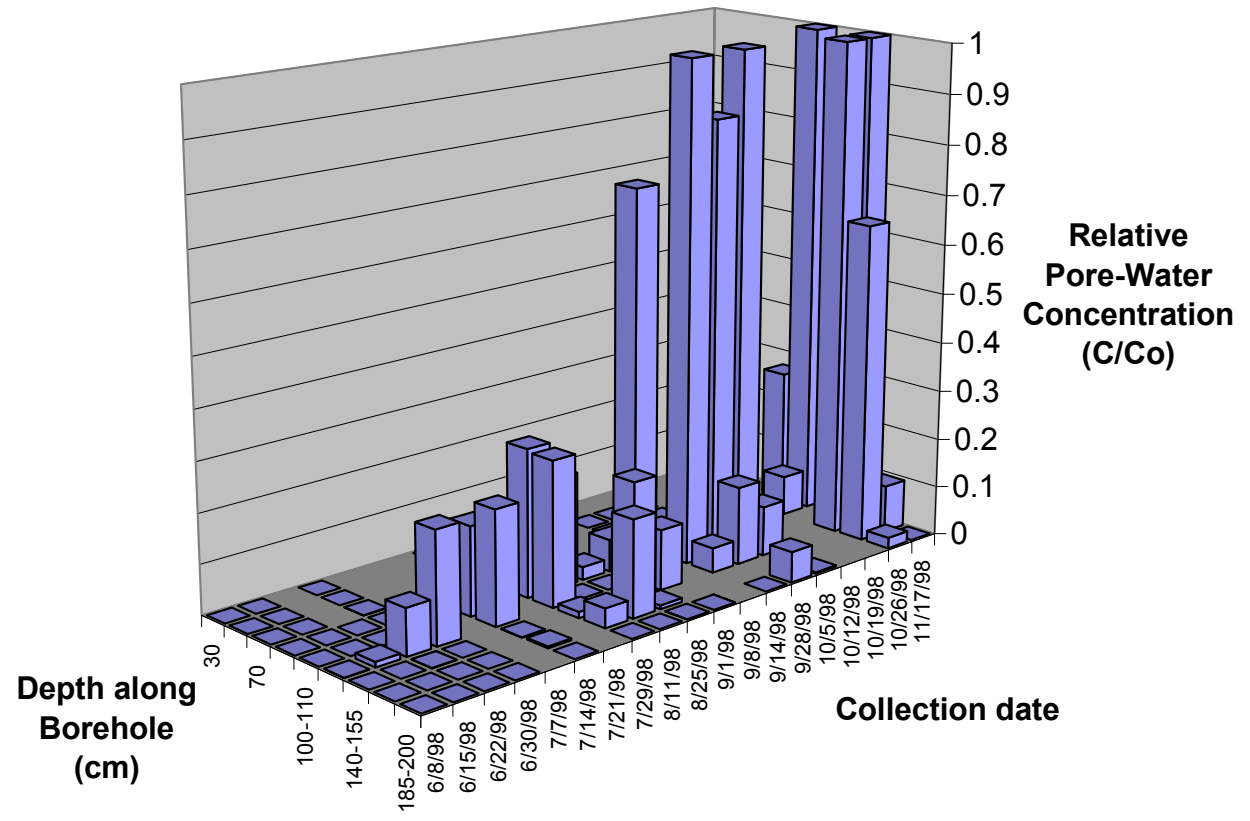

Sources: CRWMS M\&O (2001 [DIRS 154024], Figure 58c).

DTNs: LA9909WS831372.001 [DIRS 122739]; LA9909WS831372.002 [DIRS 122741].

Figure 6-177. Fluorescein Concentrations in Borehole 6 for Phase 1B 


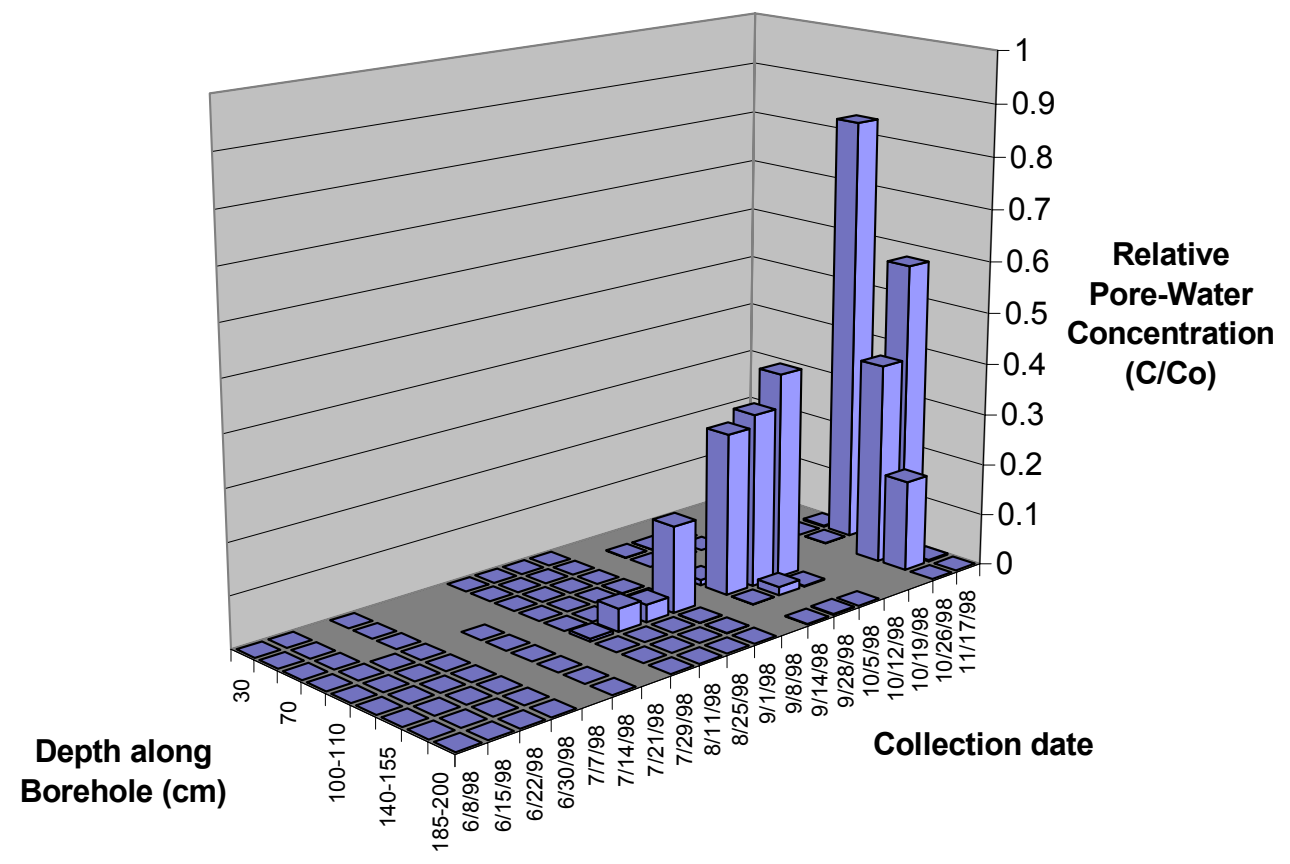

Sources: CRWMS M\&O (2001 [DIRS 154024], Figure 58d).

DTNs: LA9909WS831372.001 [DIRS 122739]; LA9909WS831372.002 [DIRS 122741].

Figure 6-178. Pyridone Concentrations in Borehole 6 for Phase 1B

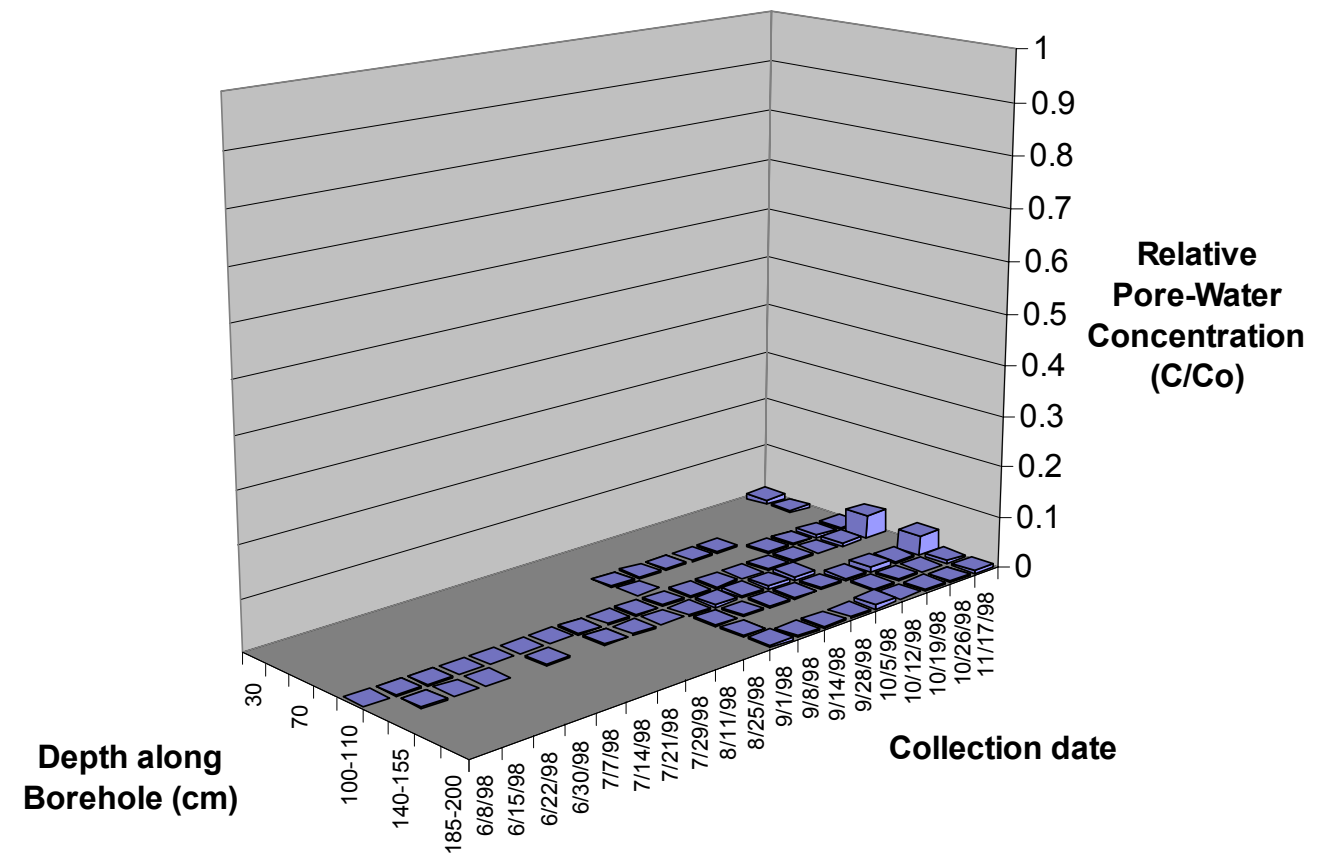

Sources: CRWMS M\&O (2001 [DIRS 154024], Figure 58e).

DTNs: LA9909WS831372.001 [DIRS 122739]; LA9909WS831372.002 [DIRS 122741].

Figure 6-179. Lithium Concentrations in Borehole 6 for Phase 1B 


\subsubsection{Field-Scale Tracer Transport-Phase 2}

\subsubsection{Test Configuration}

Phase 2 testing involved a 7-m-high, 10-m-wide, 10-m-deep block comprising all of the lithologies of Phase 1 (Figure 6-171). The injection systems in Phase 2 were designed to activate large surfaces of the block. The injection points for this phase are distributed in two horizontal, parallel planes arranged to test the properties of the lower Topopah Spring Tuff (Tptpv2) and the hydrologic Calico Hills Tuff (Tptpv1 and Tac). Six upper injection boreholes were drilled (four of which were used for injection) and four lower injection boreholes were drilled from the test alcove. The upper injection plane consists of fractured Topopah Spring Tuff (Tptpv2). As in Phase $1 \mathrm{~B}$, this unit represented the base of the TSw basal vitrophyre and is characterized by subvertical fractured surfaces representing columnar joints. Thirty-seven injection points, distributed along four injection holes that were each approximately $8 \mathrm{~m}$ deep, were used for tracer injection along a horizontal surface. The natural fracture pattern present in this unit serves as the conduit for tracer migration into the nonwelded Calico Hills. The lower horizontal injection plane was located in the Calico Hills formation (Tac). There were 40 injection points distributed in four horizontal and parallel boreholes. These boreholes were designed to activate the lower part of the block in the event that the top injection system did not activate the entire block during the testing program.

Phase 2 included 15 collection boreholes drilled from the Main Adit, perpendicular to the injection boreholes. Twelve of the collection boreholes were drilled prior to the initiation of Phase 2 injection; three additional collection boreholes were drilled during injection. These boreholes were 8.5 to $10.0 \mathrm{~m}$ in length, and each contained 15 to 20 collection pads that were evenly distributed on inverted membranes.

Figure 6-180 is a view of the collection face, showing the positions of all the boreholes (to scale). It also shows the locations of the injection holes as horizontal lines. In describing the results of the field test, refer to Figure 6-180 to visualize the relative locations.

As discussed in Section 6.13.1.10, Phase 2 injected a mixed tracer solution that included those tracers used in Phase 1 plus three additional FBAs, and a mixture of new reactive tracers $\mathrm{Nii}^{2+}$, $\mathrm{Co}^{2+}, \mathrm{Mn}^{2+}, \mathrm{Sm}^{3+}, \mathrm{Ce}^{3+}$, and Rhodamine WT). Beginning in August 1999, an additional nonreactive tracer $\left(\mathrm{I}^{-}\right)$was added to the solution to study flow and transport response at higher system saturations.

Natural infiltration rates at Yucca Mountain vary between 0.01 and $250 \mathrm{~mm} / \mathrm{year}$, with an average of $5 \mathrm{~mm}$ /year (Flint et al. 1996 [DIRS 100147]). Phase 2A falls within the range of natural present-day infiltration rates at Yucca Mountain, whereas Phase 2B lies at the high end of predicted values for a pluvial-climate scenario. Phase $2 \mathrm{C}$ infiltration rates are artificially higher than those expected under natural infiltration conditions for the region, but provide for the longest travel distances given the short duration of the experiment. 


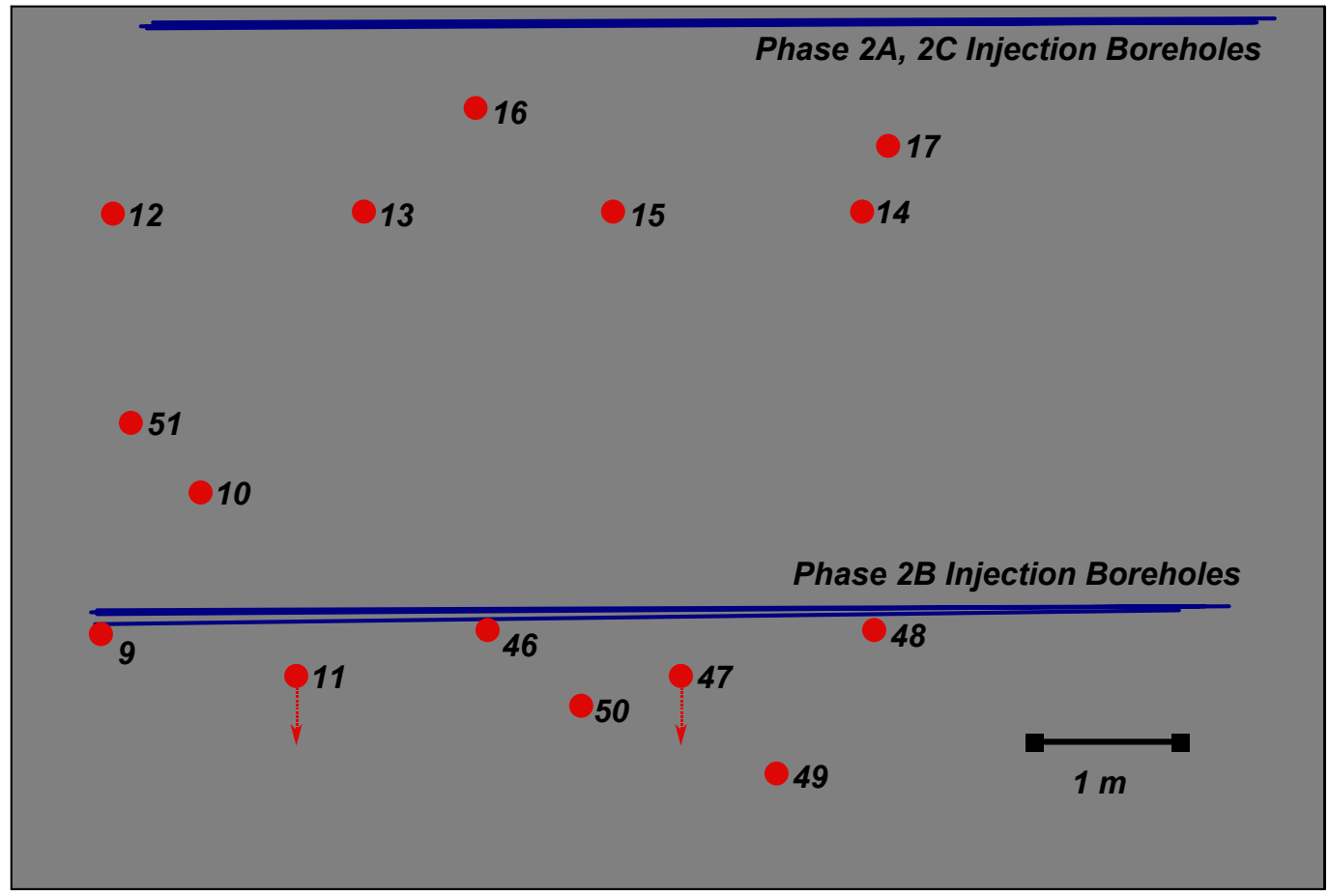

Source: CRWMS M\&O (2001 [DIRS 154024], Figure 59) (this source citation indicates the origin of the information in this figure, which is for illustration purposes only; the cited report was not used as direct input).

NOTE: Arrows (shown with Borehole 11 and Borehole 47) indicate inclined boreholes.

Figure 6-180. Borehole Configuration on the Collection Face

In addition to the tracer collection system, two geophysical imaging techniques (electrical resistivity tomography (ERT), and ground-penetrating radar (GPR) tomography) were used to image the in situ 2-D and 3-D saturation state of the block at approximately bimonthly intervals.

\subsubsection{Additional Coring}

From February to March 2000, three additional cores were extracted from the Phase 2 collection face (see illustration of Boreholes 49 to 51 in Figure 6-180). These boreholes were located to sample volumes of the block that were not being captured by existing boreholes. The cores from these boreholes were analyzed in the laboratory for tracers. The boreholes were also instrumented for pad collection, and these additional pads/locations were also analyzed. Results are presented in Section 6.13.3.4.

Following termination of tracer injection, five large-diameter (10 inches) boreholes were drilled around and below injection holes (Figure 6-181) to analyze the rock for tracers. These large-diameter cores were located to obtain the broadest spectrum of information data on metals and microspheres, which had not been observed on any collection pads. 


\subsubsection{Mineback}

The Phase 2 block was partially mined back. The purposes of the mineback were:

1. To collect additional data about the geology of the block, particularly faults and permeability contrasts, and

2. To obtain rock samples (for tracer analysis) that represented a larger portion of the test-block volume than did the collection boreholes.

Observations of block geology at this point have identified at least one fault. An ash layer was observed in the lower Tptpvl unit. At least one of the injection boreholes was fully contained within this layer. Observations of in situ fluorescing tracer indicate that this layer strongly affected flow by impeding movement of injected tracer mix into the remainder of the block.

INJECTION FACE

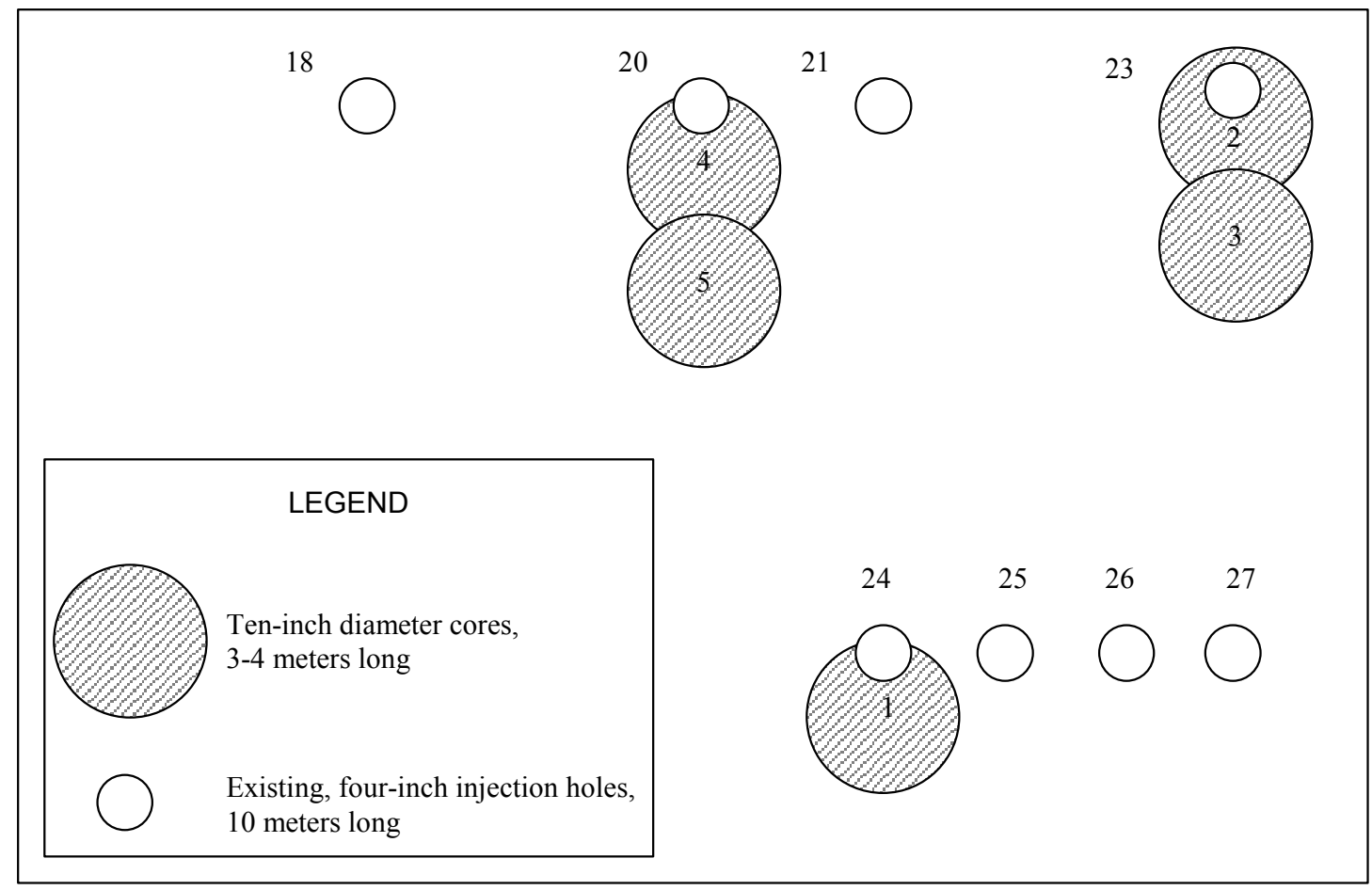

NOTES: Only general core location shown. Core 1 did not stay intact; Cores 2 and 3 completed 12-21-2000; Cores 4 and 5 completed 1-18-2001.

Injection rate into Boreholes 18, 20, and 21: $\quad 50 \mathrm{~mL} / \mathrm{h}$ per injection point Injection rate into Borehole 23: Injection rate into Boreholes 24, 25, 26, and 21: $10 \mathrm{~mL} / \mathrm{h}$ per injection point

Figure 6-181. Schematic Illustration of Locations of Phase 2 Post-Test Overcores

\subsubsection{Pad Analyses}

Phase 2 injection was begun in July 1998, and was terminated on October 30, 2000. Slightly fewer than 19,000 Phase 2 sampling pads were collected. Selected pads were analyzed via the tracer extraction process. More than 5,000 pads were extracted, and more than 32,000 individual analyses were completed. 
Pad analyses confirm breakthrough of nonreactive tracers in 14 of the 15 collection boreholes (all boreholes except Borehole 10). Lithium breakthrough has been confirmed in 10 of the 15 collection boreholes (all boreholes except Boreholes 10, 11, 47, 49, and 51). No other sorbing tracers were unequivocally detected.

Breakthrough data are presented in Figures 6-182 through 6-186. These figures show distance in centimeters from the collection face on the horizontal axis, and time in days on the vertical axis, increasing from the top of the figure down. Note that the location of the injection boreholes varies slightly at the different collection holes because the starting location of the collection boreholes varies: the collection face is neither precisely perpendicular nor flat with respect to the injection face. The contour maps in Section 6.13.3 were generated by using Microsoft Excel to process the data and using NOeSYS V2.0 to interpolate irregularly spaced data points into a regular grid for visualization purposes.

\subsubsection{Moisture Movement}

Figure 6-182 presents the moisture data at collection Boreholes 10 and 15 compared with the bromide tracer breakthrough. As expected, the breakthrough of moisture onto the collection pads precedes the breakthrough of tracer. Initial saturation of the UZTT Phase 2 block was estimated at approximately 16 percent. Because the block was not totally dry, tracer displaced existing water ahead of it as it was injected.

\subsubsection{Scaling/Travel Distance}

The configuration of the injection and collection boreholes was designed to allow analysis of a variety of different processes. Collection boreholes were placed at different distances from the injection boreholes to assess the influence of travel distance. Differing travel distances also provide a range of scales for studying transport, from tens of centimeters to meters.

The effect of travel distance on tracer transport is shown in Figure 6-183. Collection Boreholes 16, 17, 15, and 10 are parallel and at increasing distance from the upper injection boreholes. All of the collection boreholes reside in unit hydrologic Calico Hills (Tptpv1).

Breakthrough times at the different distances scale approximately linearly with travel distance. Fifty-percent breakthrough of bromide in Borehole 16 occurred after slightly less than 125 days; at Borehole 15, almost twice as far from the injection boreholes, fifty-percent breakthrough occurred at approximately 250 days.

\subsubsection{Heterogeneity}

Boreholes 12, 13, 15, and 14 are all equidistant from the upper injection boreholes, and are parallel to each other. The flow distance is approximately $1.3 \mathrm{~m}$, and Boreholes $12,13,15$, and 14 are all in the same unit. The difference in breakthrough pattern between these boreholes is thus a result of heterogeneities in the test block. Figure 6-184 demonstrates noticeable variability in both breakthrough times and concentrations for bromide in these boreholes. 
The significant delay between breakthrough in Borehole 12 versus Boreholes 13 and 15 possibly results from the presence of a fault that runs through the back of the block. This fault appears to cut between the injection boreholes and Borehole 12 .
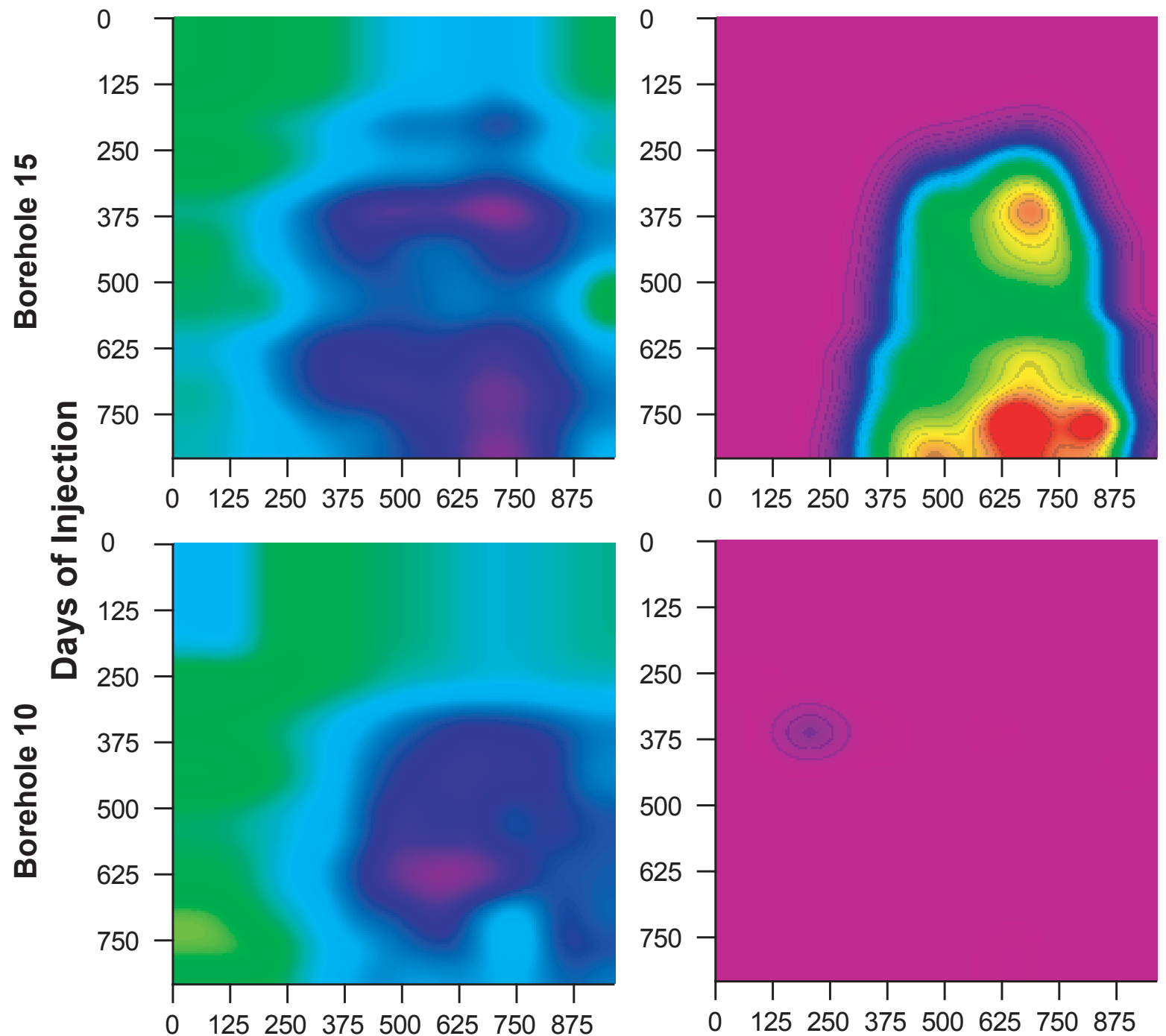

Distance Along Borehole (cm)

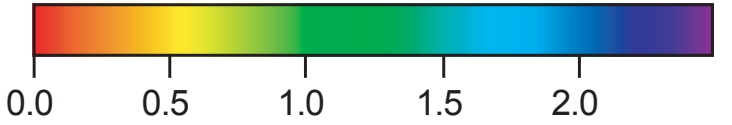

Pad moisture content $(\mathrm{g})$

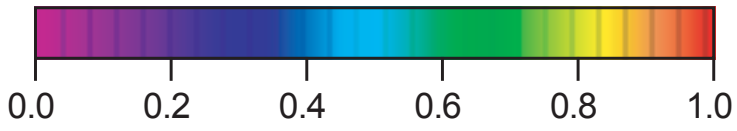

Normalized Bromide Concentration

Source: DTNs: LA0112WS831372.001 [DIRS 157100], LA0112WS831372.002 [DIRS 157115], LA0112WS831372.003 [DIRS 157106].

NOTE: The moisture content distribution is shown on the left; the $\mathrm{Br}^{-}$concentration distribution is shown on the right.

Figure 6-182. Moisture Front Precedes Tracer Front 


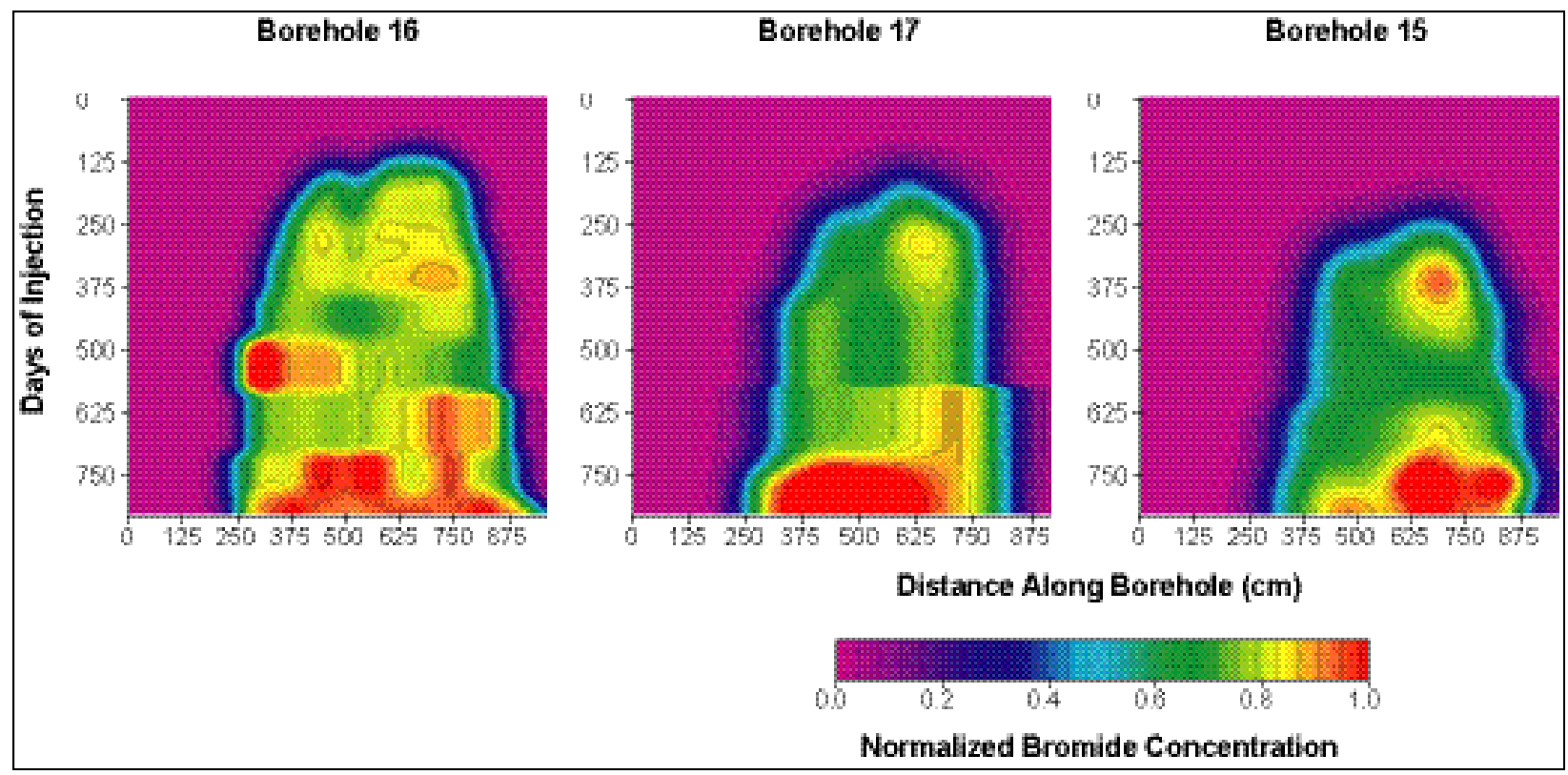

Source: DTNs: LA0112WS831372.001 [DIRS 157100], LA0112WS831372.002 [DIRS 157115], LA0112WS831372.003 [DIRS 157106].

Figure 6-183. Influence of Scaling/Travel Distance on Tracer Transport in UZTT for Phase 2

\subsubsection{Transverse Dispersion}

In each of the injection holes, a mix of a number of tracers was introduced. The tracer mix was the same for all boreholes except with regard to the FBAs. Each injection borehole injected a different FBA to allow identification of the source of the tracer when collection pads are analyzed. Thus, by looking at tracer breakthrough patterns in a single collection borehole, the extent of lateral dispersion can be assessed.

Tracer breakthrough in Borehole 16 is shown in Figure 6-185. Borehole 16 is $0.7 \mathrm{~m}$ below the injection boreholes. The vertical marks on Figure 6-185 show the location of the borehole that is injecting the particular FBA that was plotted. Bromide was injected in all holes, so the bromide plot shows overall breakthrough in Borehole 16.

The breakthrough pattern in Borehole 16 indicates that there is little transverse dispersion or mixing of the tracer that was injected at the various injection boreholes. 

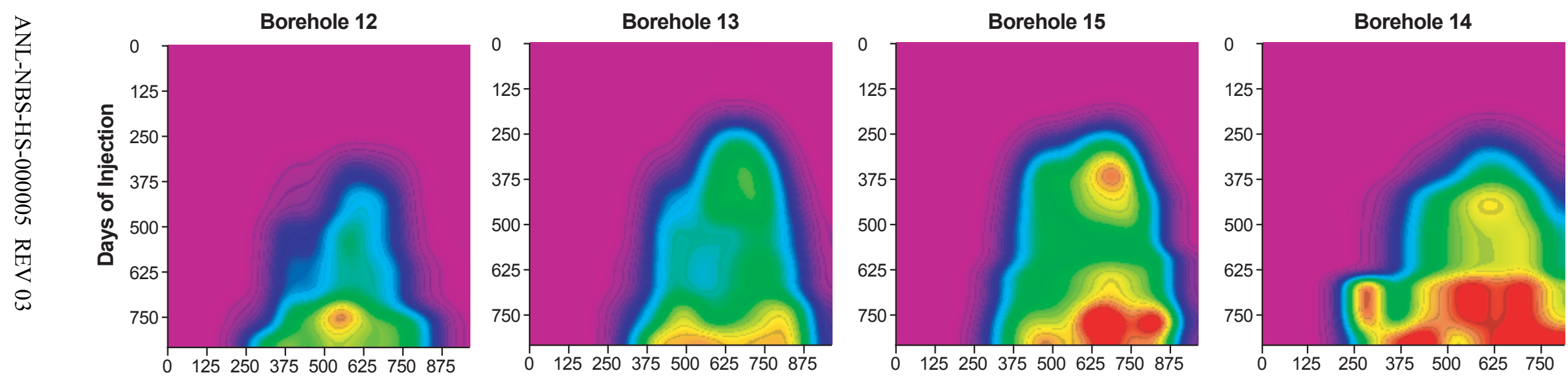

Source: DTNs: LA0112WS831372.001 [DIRS 157100], LA0112WS831372.002 [DIRS 157115], LA0112WS831372.003 [DIRS 157106].

Figure 6-184. Influence of Rock Heterogeneity on Tracer Transport in UZTT for Phase 2 

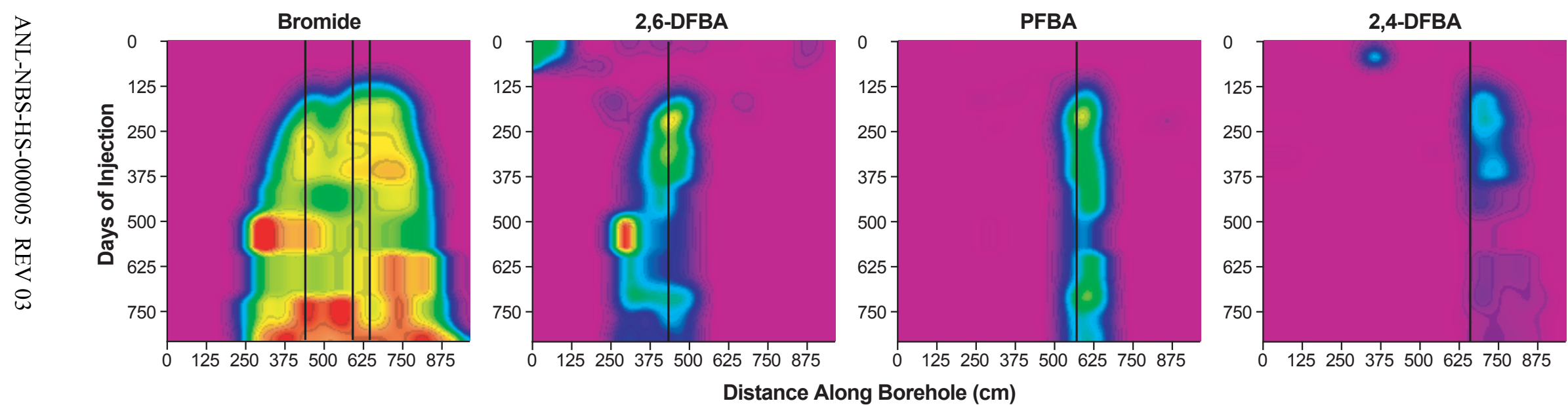

Source: DTNs: LA0112WS831372.001 [DIRS 157100], LA0112WS831372.002 [DIRS 157115], LA0112WS831372.003 [DIRS 157106].

NOTE: In each of the four graphs, the locations of injection boreholes are shown by vertical lines.

Figure 6-185. Extent of Transverse Dispersion on Tracer Transport Measured in Borehole 16 of the UZTT for Phase 2 


\subsubsection{Sorption/Retardation}

The influence of sorption/retardation is analyzed by comparing breakthrough curves for bromide versus lithium at various boreholes. Figure 6-186 shows breakthrough curves for the two tracers at three different boreholes. Boreholes 16 and 15 are, respectively, $0.7 \mathrm{~m}$ below and $1.3 \mathrm{~m}$ below the upper injection boreholes in Tptpv1. The injection rate was $50 \mathrm{~mL} / \mathrm{hr}$ per injection point. Borehole 48 is located in the Tac below the lower injection boreholes (with an injection rate of $10 \mathrm{~mL} / \mathrm{hr}$ per injection point).

As expected, lithium breakthrough was retarded with respect to bromide. Laboratory sorption measurements calculate lithium $K_{\mathrm{d}}$ values at between 0.35 and $1.3 \mathrm{~g} / \mathrm{g}$ (Turin et al. 2002 [DIRS 164633], p. 834). All other reactive tracers that were used have significantly higher $K_{\mathrm{d}}$ values. In addition, they were not expected to break through at any of the boreholes after the relatively short monitoring time.

\subsubsection{Tomographic Studies: Geophysical Techniques at the Busted Butte Unsaturated Zone Test Facility}

Geophysical monitoring techniques were used to provide real-time data on the advance of fluid fronts and tracer fronts through the block. Combining two geophysical techniques enables the collection of detailed, high-resolution, 3-D, calibrated, real-time monitoring of moisture and tracer movement through the unsaturated fractured medium. Specifically, ERT provides 3-D global coverage, and ground penetrating radar (GPR) tomography provides high spatial resolution.

\subsubsection{Busted Butte Ground Penetrating Radar Tomography}

The GPR tomography data acquisition was conducted in the Phase 2 test block to monitor the tracer injection, both spatially and temporally, and to investigate the nature of fluid migration through the Calico Hills formation. The data collected, analyzed, and submitted to the Technical Data Management System (TDMS) include the pre-injection/baseline radar velocity measurements as well as the subsequent velocity measurements made after the start of tracer injection (nine data collection visits through November 2000). All analyzed data were periodically compared to the other available geophysical data (as well as to the tracer breakthrough data) to constrain the interpretation of the fluid/tracer migration within the block. 

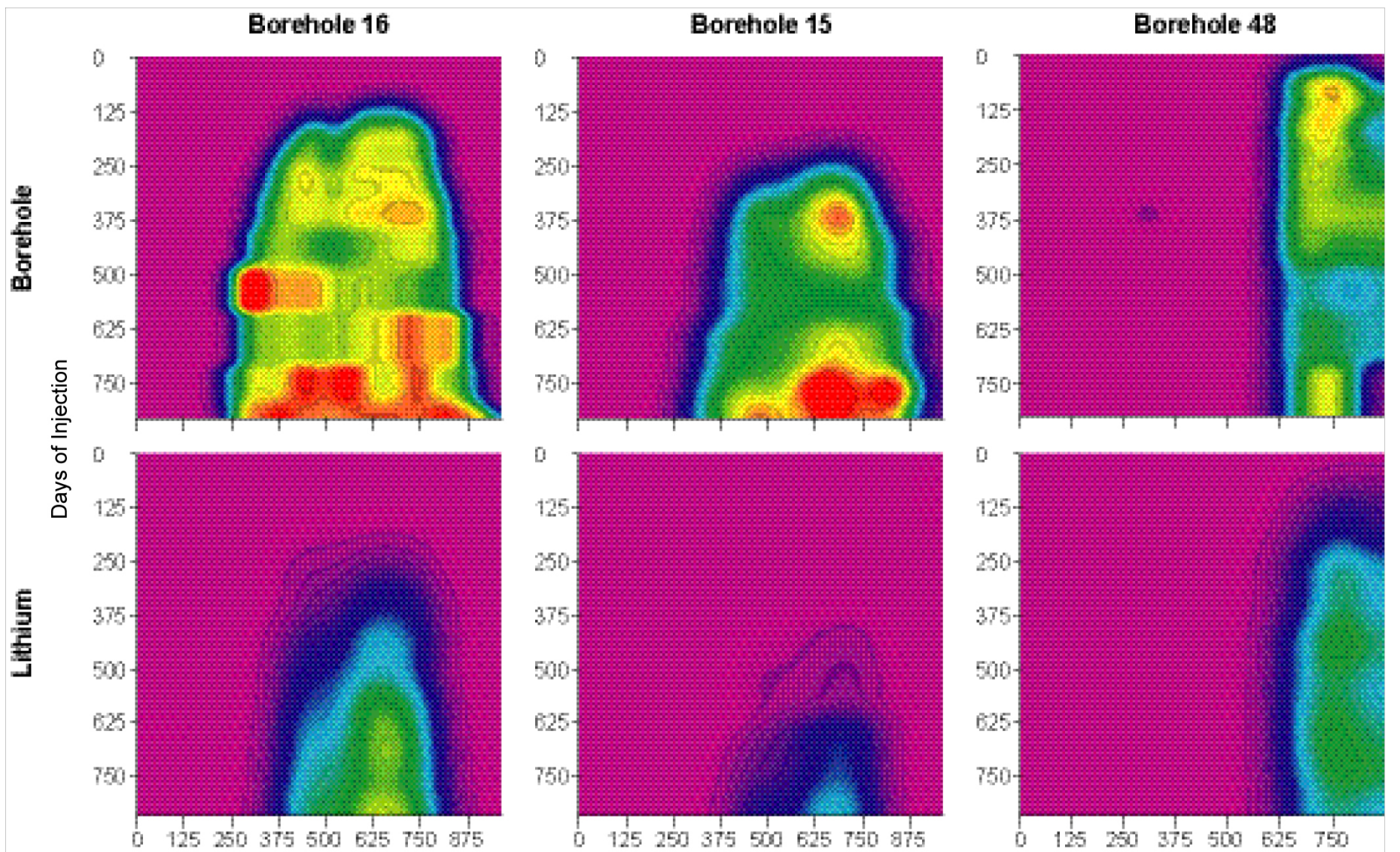

Distance along Borehole $(\mathrm{cm})$

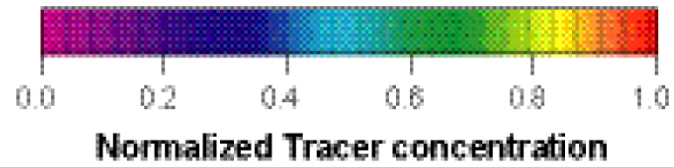

Source: DTNs: LA0112WS831372.001 [DIRS 157100], LA0112WS831372.002 [DIRS 157115], LA0112WS831372.003 [DIRS 157106].

Figure 6-186. Effect of Sorption/Retardation on Tracer Transport in UZTT for Phase 2 


\subsection{Background and Experimental Approach}

In the borehole radar method, modified surface radar antennas are emplaced into a rock formation, and high-frequency electromagnetic signals are transmitted through the formation to a receiving antenna. The electrical properties of the subsurface material greatly influence the transmitted electromagnetic signal. In particular, the dielectric permittivity $(\mathrm{K})$ of the rock has a strong influence on the propagation of the signal and whether it travels at a high or low velocity. Moisture content also affects dielectric permittivity. The high dielectric permittivity of water (K approximately 80 ) or wet rock ( $\mathrm{K}$ approximately 20-30) in contrast to drier rock (K approximately 3-6) typically results in greatly reduced signal velocities. Changing chemical compositions (i.e., tracers) may also alter the bulk dielectric permittivity of the rock and, hence, the propagation velocity of the radar waves. Because such changes in signal character are what are measured over the course of the Busted Butte UZTT, any increase (or decrease) in background moisture content or chemical composition resulting from the tracer injection (or rock dryout) should result in changes in the received radar velocity.

The transmitted signals are represented as multiple ray paths crossing through a zone of interest within the block. If sufficient ray paths are recorded, a tomographic image is obtained through computer processing. The information extracted from such data consists of the radar wave travel time, which depends on the wave velocity. This information data, in the form of a processed radar velocity tomogram, offers a high-resolution approach to monitoring the changes occurring in the rock over the duration of the tracer-injection experiment.

A detailed description of the equipment used, the component specifications, the operating principles, and the GPR survey methodology can be found in the Technical Implementing Procedure, Ground Penetrating Radar Data Acquisition, that governs all GPR data acquisition done in support of the Yucca Mountain site characterization effort.

\subsection{Equipment Description, Component Specifications, Operating Principles, and Survey Methodology}

A detailed description of the equipment used, the component specifications, the operating principles, and the GPR survey methodology can be found in LA Testing Status Report: Busted Butte Unsaturated Zone Transport Test FY 98 (Bussod et al. 1998 [DIRS 131513], Section 5.1.6). Additional information can be found in Ground Penetrating Radar Data Acquisition, the Technical Implementing Procedure that governs all GPR data acquisition done in support of the Yucca Mountain site characterization effort.

\subsection{Results of the Busted Butte Unsaturated Zone Transport Test Radar Data Acquisition}

The radar data were acquired in eight of the Phase 2 collection boreholes orthogonal to the direction of the Phase 2 injection boreholes. Additionally, two of the Phase 2 injection boreholes (Borehole 22 and Borehole 19) were used to acquire data, albeit only once because subsequent to the first use it was determined that they were most likely affected by grout infiltration, as a result of nearby ERT borehole grouting. The ten boreholes are: Boreholes 9, 11, 13, 15, 16, 46, 47, 
and 48 (Phase 2 collection); and Boreholes 19 and 22 (Phase 2 injection). The configuration and layout of the boreholes that were used are illustrated in Figure 6-180.

The radar data were acquired in the 2-D planes defined by the two boreholes, more commonly referred to as "well pairs." The six well pairs are: 15-13, 48-46, 47-11, 46-9, 46-16, and 22-19 (well pair 22-19 was only used once). The decision to acquire data in these particular well pairs was made based on the relative proximity to the injection boreholes. Data from both the upper horizontal well pair 15-13 and the vertical well pair 46-16 were acquired to monitor tracer injection associated with the upper injection Boreholes 18, 20, 21, and 23. Data from the lower horizontal well pairs 46-9, 47-11, and 48-46 were acquired to monitor tracer injection associated with the lower injection Boreholes 24, 25, 26, and 27. The vertical well pair 46-16 may also be used to image any tracer injection associated with the lower injection boreholes and the progress of the tracer beneath the horizontal well pair 15-13.

The data were processed for travel times, and from this information radar velocity tomograms were produced. Differencing or subtraction of the velocity tomograms over time has also been completed for each of the well pairs. Such differencing or subtraction allows for the highlighting of the tracer or moisture front as it changes spatially and temporally. In essence, the background formation remains static in those areas not affected by the changing tracer or moisture front. By subtracting one velocity tomogram from another, areas remaining static are de-emphasized, and areas undergoing changes are highlighted.

Two of the well pairs differ slightly in the acquisition method used between the baseline and the post-injection surveys. These well pairs are 46-16 and 46-9. Data for well pair 46-16 was collected at a high frequency $(200 \mathrm{MHz})$ during the post-injection surveys to better match the data collected in all of the other well pairs. Higher frequencies generally result in data of higher resolution (approximately $10.0 \mathrm{~cm}$ for $200 \mathrm{MHz}$ ), so the highest-frequency antennas should be used if possible. Data were not originally acquired in well pair 46-9 because well pair 48-46 was expected to provide sufficient coverage in the area of the lower injection boreholes. A decision was subsequently made after tracer injection began to gather more spatial information data below the lower injection boreholes and, therefore, well pair 46-9 was added to the GPR acquisition list. In addition, note that the pre-injection baseline data for several of the well pairs differs significantly from data acquired just one month after tracer injection began. The differences were likely the result of changes in the overall block assemblies (grouting of the ERT boreholes, addition of the injection apparatus, etc.) rather than the immediate consequence of the tracer injection. To enhance the subsequent differencing tomography, the "baseline" set of radar velocity tomograms chosen were those collected during the period of August-September 1998, approximately one month after tracer injection began. Comparison with tracer breakthrough data on the collection pads indicated that tracer had not yet significantly entered those regions imaged by the GPR tomograms. Therefore, the data from the August-September 1998 survey were selected because they would provide an adequate starting point from which to evaluate the changes in the block over time. 
Each of the well pairs witnessed some degree of velocity change over the course of the experiment. For the purposes of this report, however, only four of the well pairs will be discussed in detail: 46-16, 46-9, 11-47, and 15-13. Interpretation of the data suggested that the results for all of the well pairs are similar. Again, all data from each of the well pairs have been submitted to the TDMS and are available for review.

\section{Well Pair 46-16}

This well pair represents the only vertical slice through the block (approximately $9.5 \mathrm{~m}$ long and $3.5 \mathrm{~m}$ wide). It images tracer and moisture contributions from both the upper and the lower injection boreholes. When changes in velocity over time are evaluated, such changes are expected to occur in regions in the immediate vicinity of the injection boreholes, with decreased velocities representing areas of increased moisture content. This is exactly what is seen in the differenced tomograms. The diagrams in Figure 6-187 represent several time steps throughout the course of the experiment (dates of data acquisition are noted above each tomogram). The velocity relative to the baseline (the August-September 1998 period) data decreases significantly in the vicinity of the high and low injections boreholes (these locations are marked on the tomograms as small white dots), and the zones of decreased velocity can be seen to expand away from the injection boreholes over time, in both a vertical as well as a horizontal direction. Such vertical and horizontal spreading is to be expected as a result of the matrix or capillary-driven flow and was, in fact, confirmed in the Phase $1 \mathrm{~A}$ excavation.

Also of note is the seemingly large extent of decreased velocity. Note that low velocities are indicative of zones of higher dielectric permittivity. Zones of decreased velocity may represent regions of elevated moisture content and simply the presence of tracer. This subtlety is borne out when comparing the tracer breakthrough data with the tomography results. The zones of increased moisture content (i.e., decreased velocity) do not directly overlay the tracer breakthrough within Boreholes 16 and 46. In fact, the tracer-breakthrough locations are contained within the zones of decreased velocity. This implies that, as the fluid front (that contains the tracer) spreads away from the injection boreholes, some of the tracer may be retarded relative to the spread of the moisture front. In effect, the tracer may be moving more slowly through the block than its associated fluid or water component.

Conversely, the fluid front leaving the injection boreholes may be simply displacing existing pore fluid and mobilizing it within the block. The radar velocities are insensitive to this effect and thus are incapable of distinguishing between existing pore fluid, introduced pore fluid, and tracer. The extent to which the velocities are decreasing is unlikely to be fully accounted for by natural pore water existing within the block prior to the experiment. Again, comparing the tomography results with those recorded in the tracer breakthrough logs, some form of fluid breakthrough appears to have occurred in the collection boreholes. This breakthrough (imaged by the differential radar tomograms) does not appear to be associated with a tracer breakthrough (so-called "contamination of pads" in the breakthrough logs). 

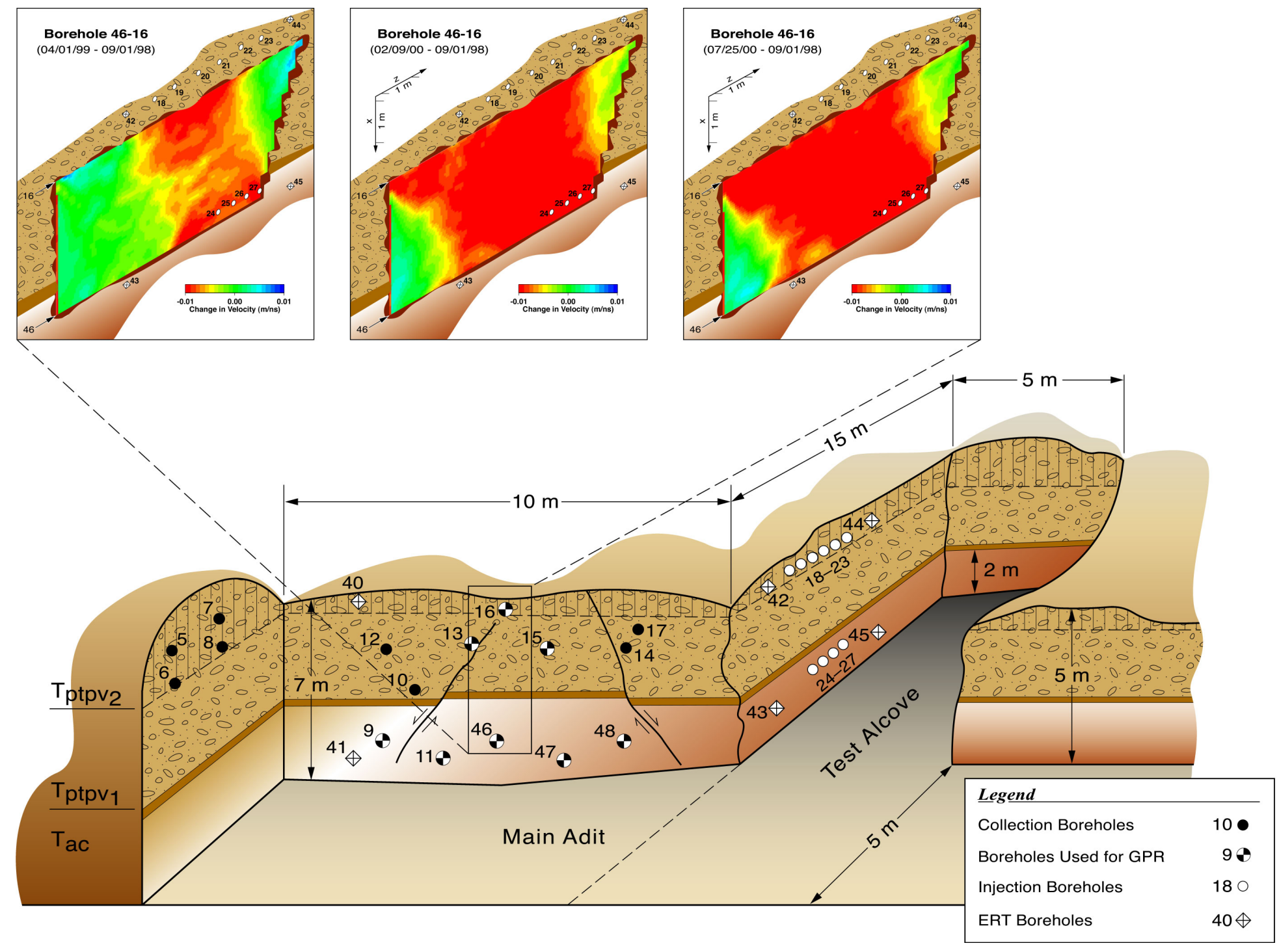

Source: DTNs: MO0004GSC00167.000 [DIRS 150300] (for location); LB00032412213U.001 [DIRS 149214].

Figure 6-187. GPR Tomography Results for Well Pair 46-16 from April 1999, February 2000, and July 2000 
Additionally, when compared to the radar results, the neutron probe data collected in these two boreholes imply a similar pattern of increased moisture content. Those zones indicated by the neutron probe data to be wetting as well as those that remain dry agree nicely with the same regions on the tomograms.

\section{Well Pair 46-9}

This well pair represents a horizontal slice (approximately $8.0 \mathrm{~m}$ long and $2.6 \mathrm{~m}$ wide) through the block and images the tracer/moisture front associated with the lower injection boreholes. Figure 6-188 represents several time steps throughout the course of the injection (dates of acquisition are noted above each tomogram). The velocity relative to the baseline (the August-September 1998 period) data decreases significantly in the vicinity of the lower injection boreholes (these locations are marked as cylinders on the tomograms). Over time, zones of decreased velocity expanded away from the injection boreholes in a horizontal direction. Because a horizontal well pair cannot capture the vertical flow of moisture away from the boreholes, only the extent of the horizontal flow can be imaged. The decrease in velocity (i.e., the increase in moisture content) moves rapidly away from the injection boreholes early on in the experiment and then remains relatively constant (aside from localized changes). This would imply that much of the moisture front moves away from the injection apparatus to its greatest possible extent at which time it can no longer spread in such a direction. Presumably, the majority of fluid flow from the lower injection boreholes continues in a vertical direction. Later in the course of the experiment, however, decreases in velocity (i.e., increases in moisture content) begin to show up at distances farther removed from the lower injection boreholes. This contribution possibly results from the upper injection boreholes. As the fluid/tracer front moves away from the upper injection boreholes in the downward direction, it ultimately comes into contact with the lower horizontal well pairs (i.e., 48-46, 46-9, 11-47). That this occurs is seen in the vertically oriented tomograms described for well pair 46-16 (see Figure 6-187).

The results implied by the radar tomograms support the tracer breakthrough logs for Borehole 9 and Borehole 48. Again, those zones of decreased velocity overlay those locations in the boreholes where tracer has been seen to break through onto the collection pads. The additional contribution of the moisture front relative to the tracer (as described earlier for well pair 46-16) does not appear to be as significant for this well pair. It is not yet clear whether this is because the region imaged is smaller or spatially close to the injection boreholes. Additionally, the neutron probe data collected in these two boreholes implies a very similar pattern of increased moisture content. Those zones that appear to be wetting as well as those that remain dry agree well with the same regions on the tomograms. 

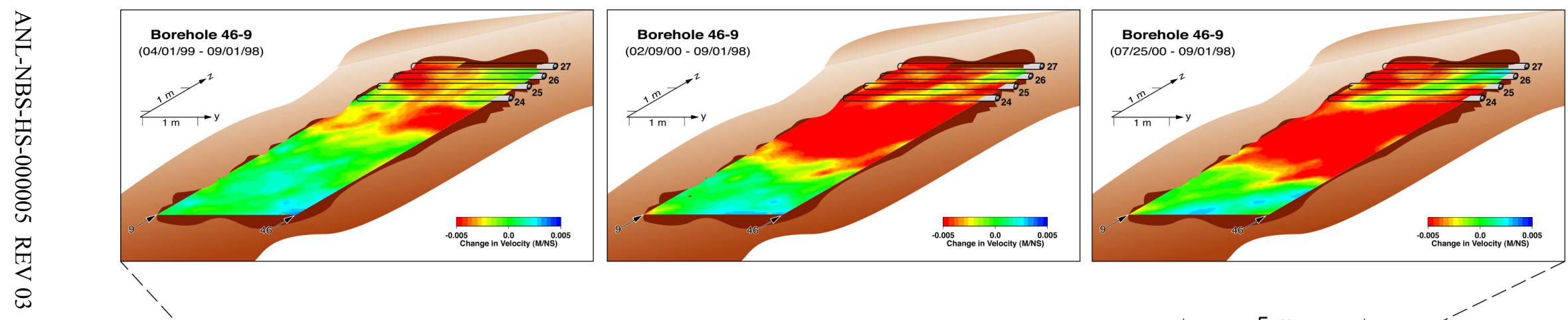

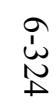

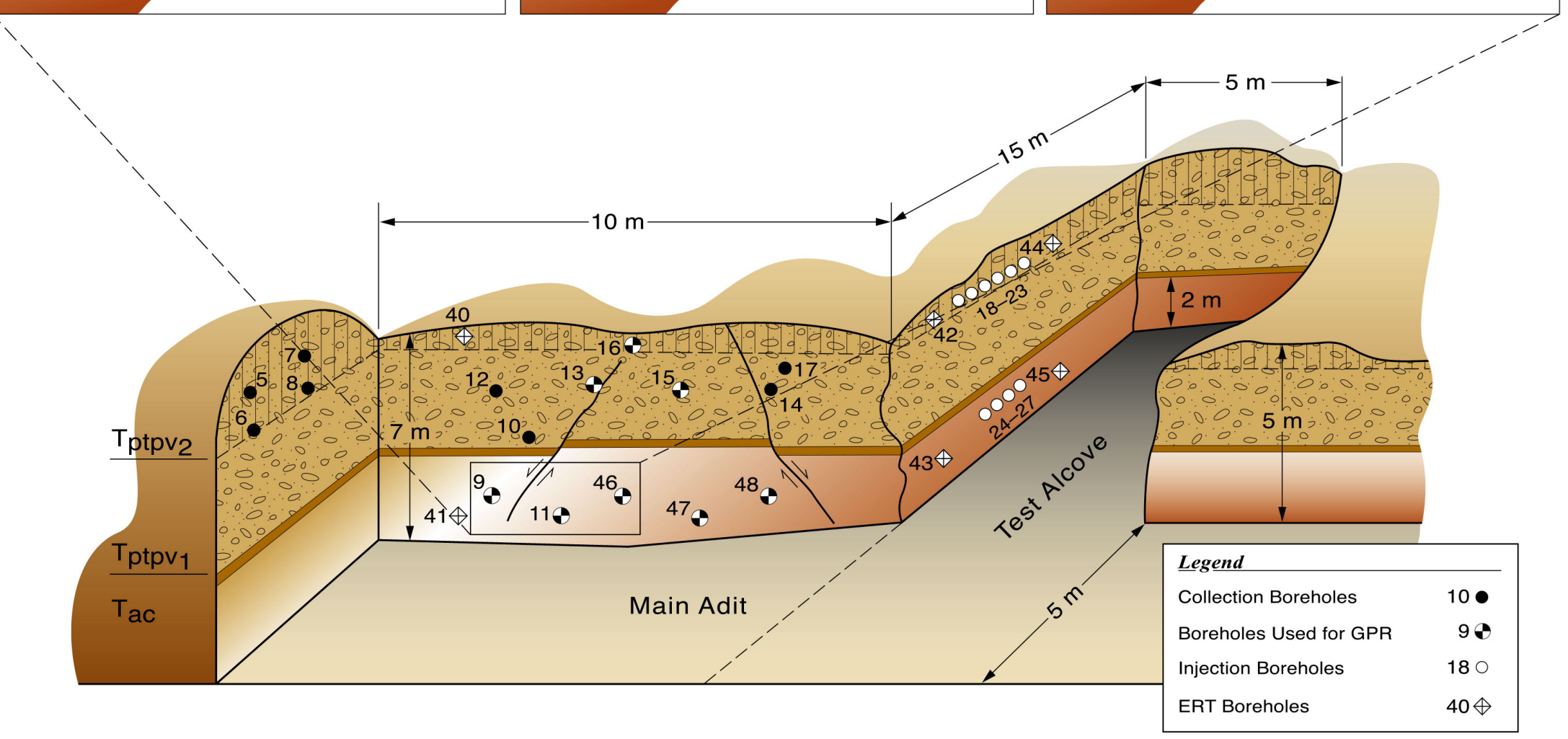

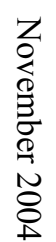

Source: DTNs: MO0004GSC00167.000 [DIRS 150300] (for location); LB00032412213U.001 [DIRS 149214].

Figure 6-188. GPR Tomography Results for Well Pair 46-9 from April 1999, February 2000, and July 2000 


\section{Well Pair 11-47}

This well pair represents a subhorizontal slice (approximately $10.0 \mathrm{~m}$ long and $2.6 \mathrm{~m}$ wide) through the block and images the tracer/moisture front associated with the lower injection boreholes. This well pair is of interest because of its component of dip, which allows the collection boreholes to get progressively farther away from the injection boreholes as a function of depth. Figure 6-189 represents several time steps throughout the course of the injection (dates of acquisition are noted above each tomogram). Decreases in velocity relative to the baseline (June 1998) data are immediately obvious surrounding the lower injection boreholes (these locations are marked as cylinders on the tomograms). The zones of decreased velocity expand away from the injection boreholes over time in a horizontal direction. Again, the dip of these two boreholes was designed to provide a means to measure sequential breakthrough down the length of the boreholes. The radar data do not appear to show such an effect. Either because of the time step chosen or to smearing inherent in the tomographic processing, no obvious "staggering" in the moisture/tracer breakthrough locations exists. The region of decreased velocity (i.e., the area of increased moisture content) moves away from the injection boreholes early on in the experiment and then continues in a similar fashion up to a point at which moisture spreading seems to cease. As for the other horizontal well pairs, this would imply that much of the moisture front moves away from the injection apparatus to the greatest possible extent, at which time it can no longer spread in such a direction. Presumably, the majority of fluid flow from the lower injection boreholes continues in a vertical direction.

The results, implied by the radar tomograms, support the tracer breakthrough logs for Boreholes 11 and 47. Again, those zones of decreased velocity overlay those locations in the boreholes where tracer has been seen to break through onto the collection pads. Additionally, the neutron probe data collected in these two boreholes implies a very similar pattern of increased moisture content. Those zones that appear to be wetting as well as those that remain dry agree well with the same regions on the tomograms. 


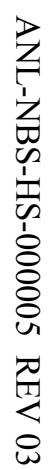
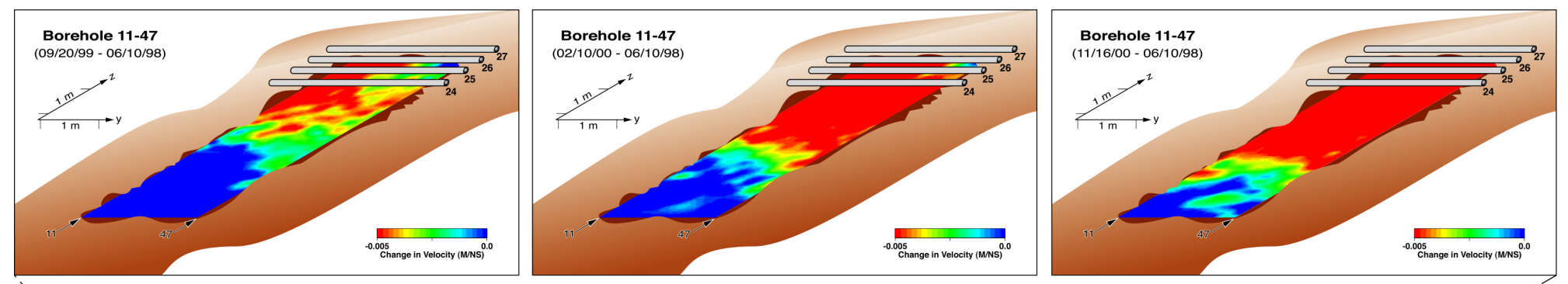

岕

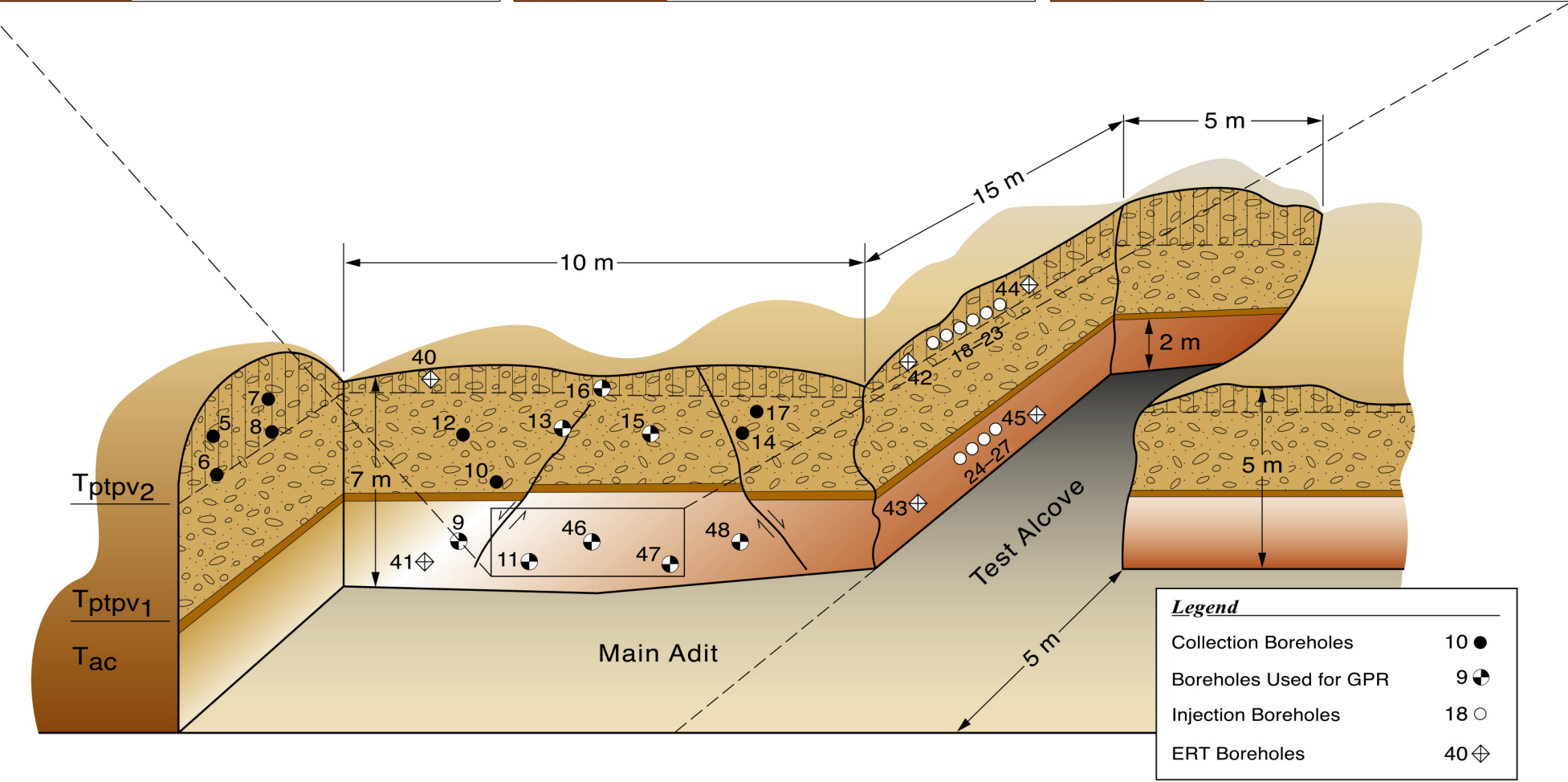

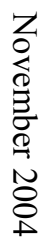

Source: DTNs: LB00032412213U.001 [DIRS 149214]; LB0110BSTBTGPR.001 [DIRS 156913].

Figure 6-189. GPR Tomography Results for Well Pair 11-47 from September 1999, February 2000, and November 2000 


\section{Well Pair 15-13}

This well pair represents a horizontal slice (approximately $9.5 \mathrm{~m}$ long and $2.0 \mathrm{~m}$ wide) through the upper part of the block. Figure 6-190 represents several time steps throughout the course of the experiment (dates of data acquisition are noted above each tomogram). The velocity relative to the baseline data (data obtained during the August-September 1998 period) decrease significantly in the vicinity of the upper injection boreholes (these locations are marked as cylinders on the tomogram). Over time, the zones of decreased velocity expanded away from the injection boreholes in a horizontal direction. The decrease in velocity (i.e., the increase in moisture content) moves steadily away from the injection boreholes throughout the course of the experiment. This varies a bit from the analogous well pair 48-46. Rather than reaching a maximum extent, the moisture front appears to be continually expanding away from the boreholes. This is probably the result of the increased distance of well pair 48-16 beneath the injection boreholes, and the much larger volume of fluid that was introduced by the upper injection boreholes $(50 \mathrm{~mL} / \mathrm{hr}$ as compared to $10 \mathrm{~mL} / \mathrm{hr})$.

The results implied by the radar tomograms are in concurrence with the tracer breakthrough logs for Boreholes 13 and 15. Again, those zones of decreased velocity overlay those locations in the boreholes where tracer has been seen to break through onto the collection pads. The additional input of the moisture front relative to the tracer (as described for well pair 46-16) does not appear to be as significant for this well pair. As for well pair 48-46, it is not yet clear whether this is because the region imaged is smaller or spatially closer to the injection boreholes. In addition, the much larger volume of tracer injected into the region of this well pair may account for the lack of a discrepancy (i.e., there is simply more tracer in the area of the collection boreholes). Additionally, the neutron-probe data collected in these two boreholes imply a very similar pattern of elevated moisture content. Those zones that appear to be wetting as well as those that remain dry agree nicely with the same regions on the tomograms.

\subsection{Summary of Ground-Penetrating Radar Tomography}

The radar data collected in support of the Busted Butte UZTT suggest that this method is appropriate for investigating subsurface velocity anomalies that may be related to some combination of the injected tracer and its associated fluid component. The regions of low velocity (i.e., elevated moisture content) appear to be in very close agreement with the other complementary evidence, including the tracer breakthrough logs and the neutron logging results. At this time, the differenced radar tomograms are likely defining the total extent of elevated moisture content within the zones defined by the radar well pairs. 

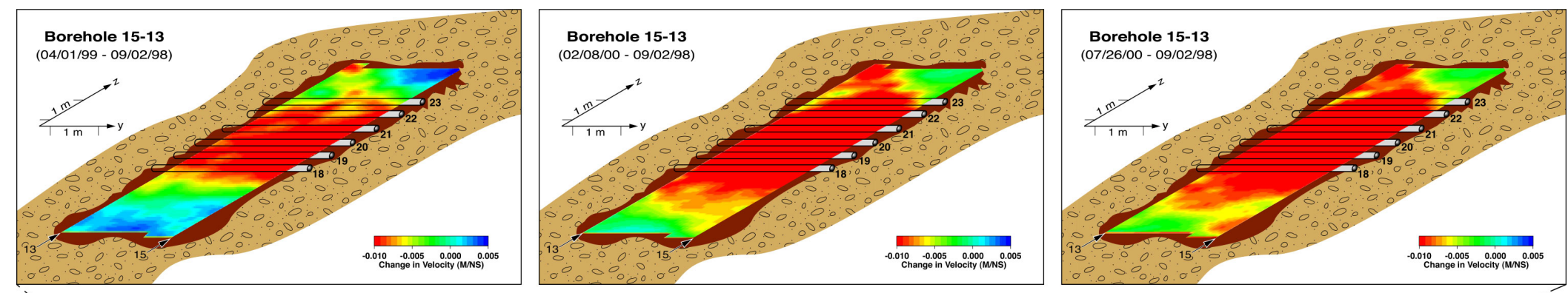

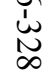

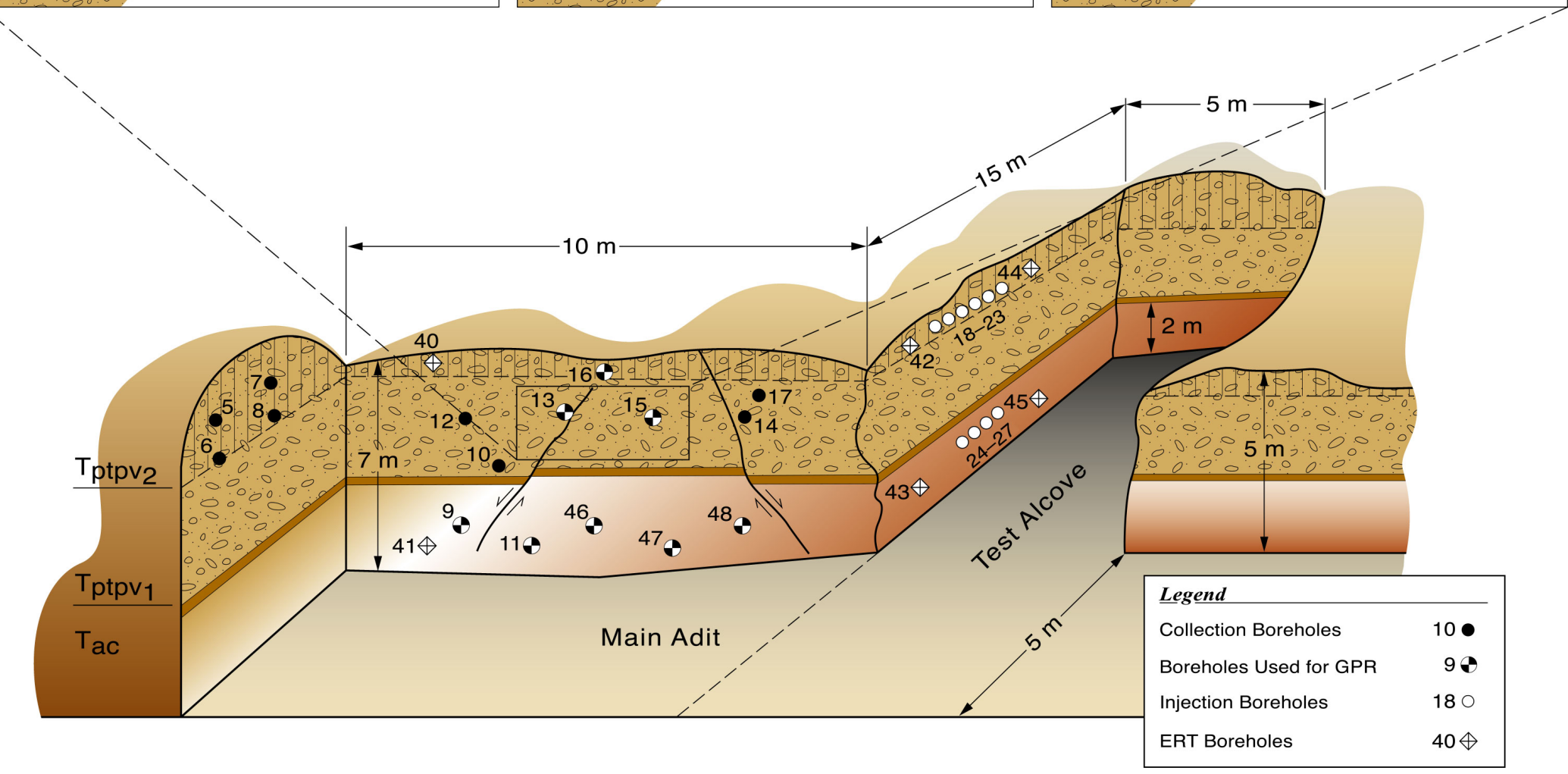

$z$
0
0
0
0
0
0
0
0

Source: DTNs: LB00032412213U.001 [DIRS 149214]; LB0110BSTBTGPR.001 [DIRS 156913].

Figure 6-190. GPR Tomography Results for Well Pair 15-13 from April 1999, February 2000, and July 2000 


\subsubsection{Electrical-Resistance Tomography}

Another geophysical technique (3-D ERT) was applied to the UZTT block at Busted Butte. The 3-D ERT images were collected to globally track the movement of a tracer through the test block at the UZTT at Busted Butte. The electrode assignments and ERT images were presented in the UZ and SZ transport properties report (CRWMS M\&O 2000 [DIRS 154024], Figure 53 through Figure 57). The results were obtained during four separate data collections: July 2, July 14, August 19, and September 9, 1998. These data have been submitted to the YMP Technical Data Management System (DTN: LL990612704244.098 [DIRS 147168]).

ERT can be used to map subsurface liquids as flow occurs and to map geologic structure. ERT is a technique for reconstruction of subsurface electrical resistivity. The result of such a reconstruction is a 2-D or 3-D map of the electrical resistivity distribution underground made from a series of voltage and current measurements from buried electrodes. The ERT approach relies on detection and mapping of the changes in electrical resistivity associated with the movement of a tracer through the test block at the UZTT site.

The results indicated that the baseline images (July 2, 1998) showed a layered structure consistent with the lithology in part of the block. The effects of injections in the boreholes were consistent with presence of regions of resistivity decrease. For details, the ERT results and interpretations are discussed in the UZ and SZ transport properties report (CRWMS M\&O 2000 [DIRS 154024], text associated with Figure 53 through Figure 57).

\subsubsection{Neutron Moisture Measurements}

Neutron probes were used to sample the moisture content in the UZTT test block using collection boreholes as sampling locations. Neutron moisture data were collected using the CPN 503DR Hydroprobe ${ }^{\mathrm{TM}}$ Moisture Depth Gauge (Lowry 2001 [DIRS 164632]). The two major components of this instrument are (1) a source of fast neutrons, and (2) a detector that counts slow neutrons. Neutron measurements were taken by inserting the probe into each selected borehole and taking readings at $10-\mathrm{cm}$ intervals. At each position, the probe was held fixed for the required interval of time and the number of slow neutrons that the probe detected was recorded.

\subsubsection{Neutron Logging Background and Calibration}

Collisions with hydrogen atoms are much more effective at reducing the speed of neutrons than are collisions with other atoms. It takes approximately 18 collisions with hydrogen atoms to slow a fast neutron sufficiently that it will react with the detector. A neutron would need at least two hundred collisions with other atoms to have the same effect. A material that contains many water molecules (which have two hydrogen atoms) is more efficient at slowing neutrons than the same material with less moisture content. 
The emitted neutrons scatter through the neighboring ground material. Those that are slowed down sufficiently and return to the detector will have followed various paths and traveled various distances from the source. The radius of measurement is that distance beyond which only 2 percent of the counted neutrons will have strayed; this radius is a function of the moisture content and the density.

Instrument calibration is necessary because other atoms, including the hydrogen atoms in rock compounds, will also slow neutrons. Twelve test cells with known density and water content were constructed to calibrate the neutron logging systems. Measurements taken on the test cells established calibration curves for use in converting neutron counts to moisture content. Lowry (2001 [DIRS 164632]) documented the recorded counts and the resulting values of water content. Note, however, that if the composition of the rock varies from that used for calibration, the calibration curve may be in error at some locations in the borehole.

Most of the readings taken at the Busted Butte site measured moisture contents of between 10 percent and 25 percent moisture by volume. The distance between measurements is approximately one-half of the distance sampled by a measurement. Substantial overlap exists between the regions covered by the measurements. Each sampled region overlaps somewhat with adjacent regions on each side. This reduces measurement error.

Both the emission of neutrons and their collisions with atoms are random processes. The uncertainty in the final count is approximately the square root of the number of measured counts. Most of the neutron measurements resulted in counts of between 4,000 and 9,000. The uncertainty in counts resulted in a measurement error of 1.0 percent to 1.6 percent. The contribution of this uncertainty to the uncertainty in moisture content is 1.4 to $2.4 \mathrm{~kg} / \mathrm{m}^{3}$ ( 0.14 percent to 0.24 percent by volume).

\subsubsection{Pre-injection Neutron Logging}

Figure 6-191 shows the neutron moisture data taken in Borehole 16 before Phase 2 injection began. Notice that the moisture content decreases near the opening of the borehole due to evaporation at the face. This discussion does not consider measurements taken within $1 \mathrm{~m}$ of the face because of edge effects.

Above the Tptpv1-Tac interface, moisture content (MC) down Borehole 16 may be visually grouped into distinct regions. The first region next to the main adit face has a moisture content of approximately 9 percent by volume $\left(90 \mathrm{~kg} / \mathrm{m}^{3}\right)$. The second region of increasing $\mathrm{MC}$ is the third region with a MC of 16.5 percent $\left(165 \mathrm{~kg} / \mathrm{m}^{3}\right)$. The last region deep in rock away from the collar has a measured MC of 13.5 percent $\left(135 \mathrm{~kg} / \mathrm{m}^{3}\right)$. Within each region, fluctuations in MC are consistent with the measurement uncertainty of approximately 0.2 percent by volume $\left(2 \mathrm{~kg} / \mathrm{m}^{3}\right)$. The initial MC below the interface within Tac $(\mathrm{CHnv})$, as reflected in Borehole 46 (and shown in Figure 6-192), has much less variation with position than does Borehole 16 (and shown in Figure 6-191) above the interface.

Even before moisture injection began, the variations in measured $\mathrm{MC}$ from region to region in the rock are significantly larger than would be expected as a result of measurement error. These variations are most likely caused by variation in the retention capacity of the rock. 
Moisture Content at Borehole 16 before Injection Point-Wise Phase 2 Neutron Data

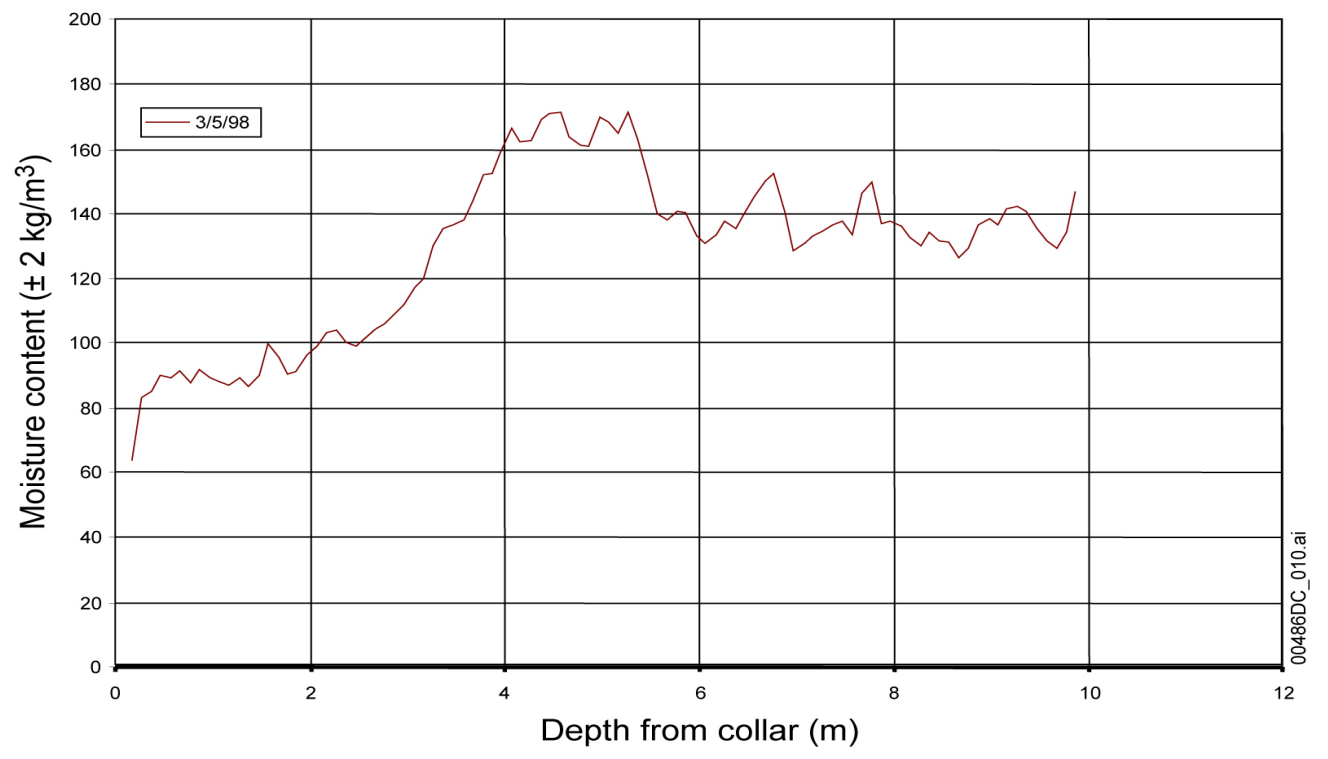

Source: DTN: LA0201WS831372.004 [DIRS 165422].

Figure 6-191. Initial Moisture Content at Borehole 16

Moisture Content at Borehole 46 before Injection

Point-Wise Phase 2 Neutron Data

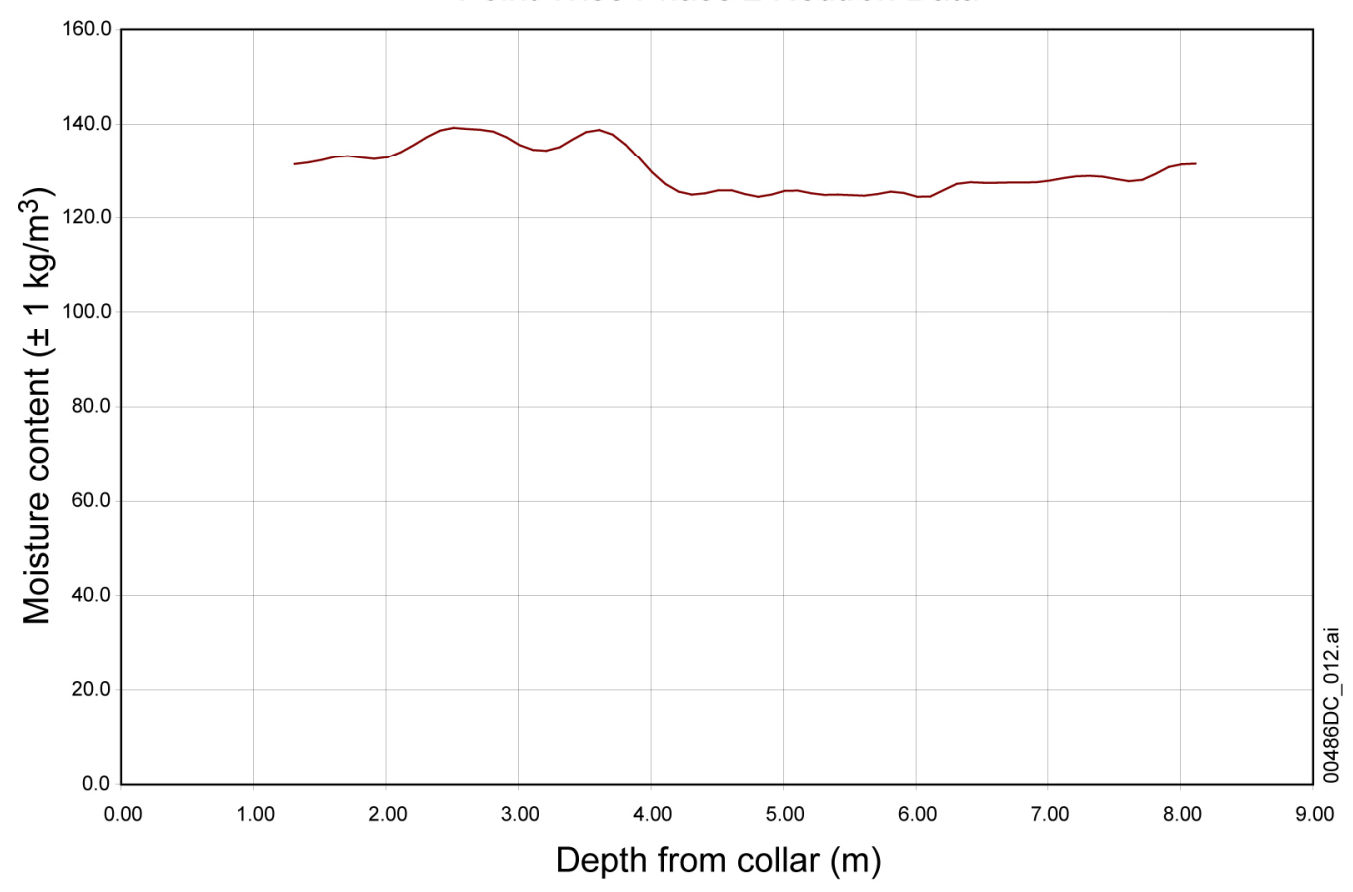

Source: DTN: LA0201WS831372.004 [DIRS 165422].

Figure 6-192. Initial Moisture Content at Borehole 46 
In addition to neutron moisture data, air permeability measurements were collected to illustrate heterogeneity of hydraulic properties down the length of a borehole. The air-permeability data have been submitted to the YMP Technical Data Management System (DTN: LA0311SD831372.001 [DIRS 166197]).

\subsubsection{After Beginning Injection}

By subtracting the original measurements from later measurements, those changes to the rock that were caused by the injected water can be determined. This section presents both spatial and temporal changes in moisture content in the Phase 2 block. Although the amount of hydrogen in the solid rock affects the absolute measurement, taking the difference in measurements cancels any systematic errors. In the example, the amount of uncertainty in the difference is 0.13 percent $\left(1.3 \mathrm{~kg} / \mathrm{m}^{3}\right)$. Because there are other sources of uncertainty (such as the calibration procedure), 0.2 percent $\left(2 \mathrm{~kg} / \mathrm{m}^{3}\right)$ is a reasonable estimate of the total measurement uncertainty for the change in moisture content.

Figure 6-193 shows the changes in moisture content at Borehole 16 for each of the days that the measurements were taken. Also shown are the locations of the four upper-region injection boreholes. Each of these injection boreholes was perpendicular to Borehole 16. The red circles represent the positions of these boreholes at their closest approach to Borehole 16. According to the average flow rates (see Figure 6-193), Borehole 23 provided less than 1 percent of the total moisture.

Change in Moisture Content at Borehole 16 Smoothed Phase 2 Neutron Data

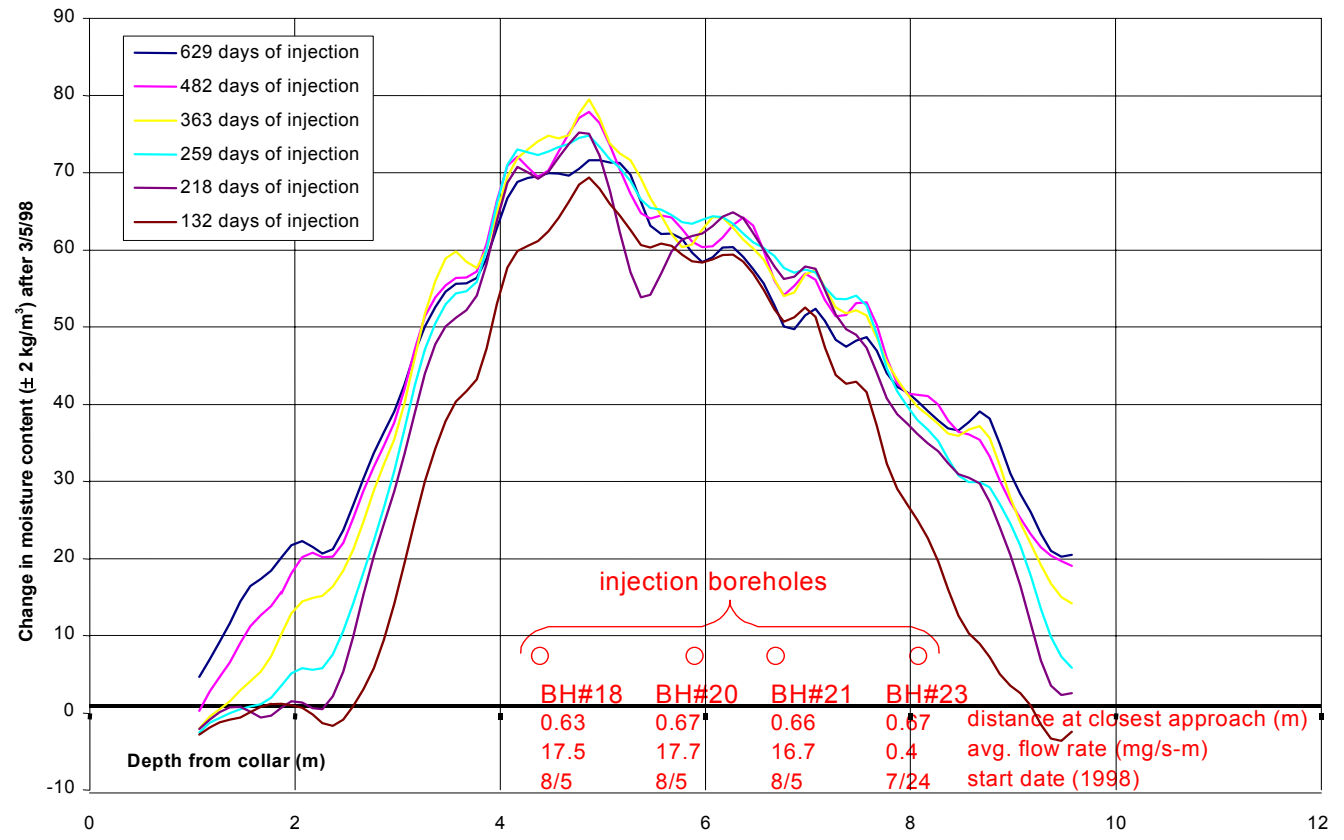

Source: DTN: LA0008WS831372.001 [DIRS 156582].

Figure 6-193. Moisture Increase at Borehole 16 at Various Times after Injection 
For the lower region, Figure 6-194 displays the changes in moisture content at Borehole 46 for each of the days that measurements were taken. Also shown are the locations of the four lower-region injection boreholes.

\subsubsection{Summary of Laboratory Radionuclide Migration Experiments}

Migration experiments under unsaturated conditions have been conducted at the Whiteshell Laboratories (of Atomic Energy of Canada Limited), in Pinawa, Manitoba, on blocks excavated from the Busted Butte Test Facility. The site was chosen based on the presence of a readily accessible exposure of the Topopah Spring Tuff (Tpt) and the Calico Hills formation (Tac) and the similarity of these units to those beneath the repository horizon. The test facility consists of an underground excavation along a geologic contact between Tpt and Tac. The corresponding hydrogeologic contact between the Topopah Spring welded (TSw) unit and the Calico Hills nonwelded ( $\mathrm{CHn})$ unit, is comprised of the nonwelded portion of the basal vitrophyre of Tac (Tptpv1) and of Tpt (Tptpv2). The following summary is based on an abstracts by Vandergraaf et al. (2002 [DIRS 165133]) and a report by Vandergraaf et al. (2003 [DIRS 165099]). The migration experiments were conducted with radionuclides to collaborate and compare with field experiments that use nonradioactive chemical analogues for tracers to evaluate flow and transport through nonwelded tuff.

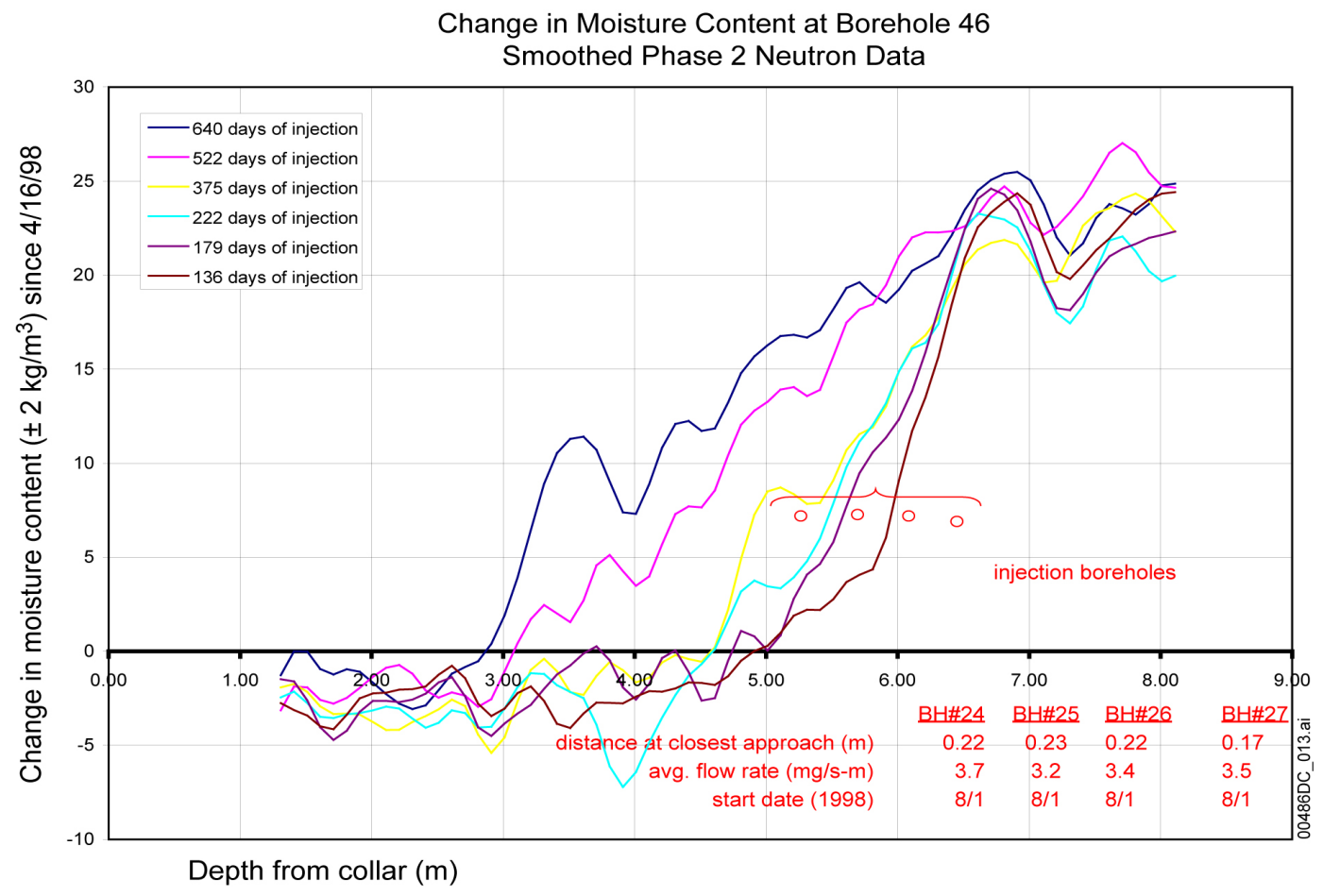

Source: DTN: LA0008WS831372.001 [DIRS 156582].

Figure 6-194. Moisture Increase at Borehole 46 at Various Times after Injection 
The duration of the migration experiment on a trial block (of a nominal 1-cubic-foot (approximately $0.3 \mathrm{~m}$ by $0.3 \mathrm{~m}$ by $0.3 \mathrm{~m}$ ) size) was 87 days. The trial block was removed from $60 \mathrm{~cm}$ below the interface between the Vitric Zone 1 of the Topopah Spring tuff and the Calico Hills formations. After a vertical flow of synthetic Busted Butte pore water as transport solution was set up under unsaturated conditions, a suite of conservative and chemically reactive radionuclide tracers was injected at volumetric flow rates of $20 \mathrm{~mL} / \mathrm{hr}$. Na-fluorescein dye, ${ }^{3} \mathrm{H}$ (as tritiated water), ${ }^{22} \mathrm{Na},{ }^{60} \mathrm{Co},{ }^{95 \mathrm{~m}+99} \mathrm{Tc}$ (as the pertechnetate anion), ${ }^{137} \mathrm{Cs}$, and ${ }^{237} \mathrm{~Np}$ were used as tracers. Results showed that transport of ${ }^{95 \mathrm{~m}+99} \mathrm{Tc}$ was slightly faster than that of the transport solution, using tritiated water $\left({ }^{3} \mathrm{H}_{2} \mathrm{O}\right)$ as a flow indicator. The finding of Tc and dye tracer eluted ahead of triatiated water has been attributed to an anion exclusion effect. Retardation of ${ }^{237} \mathrm{~Np}$ was consistent with that predicted from results obtained in supporting static-batch-sorption studies. Post-migration analysis of the flow field in the trial block showed that the front of the ${ }^{22} \mathrm{Na}$ had migrated approximately half the distance through the block and that ${ }^{60} \mathrm{Co}$ and ${ }^{137} \mathrm{Cs}$ had been retained near the inlet. This agrees qualitatively with that predicted from the results from static-batch-sorption studies.

The migration experiment on a nominally $1-\mathrm{m}^{3}$ (approximately $1 \mathrm{~m}$ by $1 \mathrm{~m}$ by $1 \mathrm{~m}$ ) block lasted for more than 700 days, and was initiated in April 2001. The tracer solution was injected continuously at two locations at the top of the block, at a flow rate of $10 \mathrm{~mL} / \mathrm{h}$ per injection point ( $20 \mathrm{~mL} / \mathrm{h}$ with both injections). By June 2002, the normalized concentrations of ${ }^{3} \mathrm{H}$, ${ }^{99} \mathrm{Tc}$, and dye tracer in the water collected from the bottom of the block had reached a value of approximately 0.08 . The transport behavior of Tc is very similar to that of the transport solution. None of the other tracers was observed in the effluent from the larger block. This is consistent with the observations from the smaller block.

The static batch sorption coefficients and retardation coefficients of Tc and $\mathrm{Np}$ are available in DTN: LA0108TV12213U.001 [DIRS 161525].

\subsection{GEOCHEMICAL AND ISOTOPIC OBSERVATIONS AND ANALYSIS OF THE UNSATURATED ZONE}

A series of geochemical examinations have been performed using rock, mineral, and water samples collected from both the ESF and ECRB. These studies provide evidence of a long-term hydrologic regime in the Yucca Mountain. Sections 6.14.1 to 6.14.4 examine the following:

- Pore water and rock geochemistry (Section 6.14.1).

- Measurements of ${ }^{36} \mathrm{Cl}$ and tritium, isotopes that were introduced to the atmospheres primarily in the 1950s as a result of nuclear weapon testing. These isotopes, if detected at depth, might indicate evidence of fast-flow pathways for water infiltration and seepage into drifts. Oxygen-18 in calcite data are analyzed in terms of depositional temperatures (Section 6.14.2). 
- The application of uranium isotope ratios to indicate past climate conditions and examine infiltration flow paths in the unsaturated zone (UZ) (Section 6.14.3).

- Determinations of mineralogy in fractures as evidence of water flow and mineral deposition (Section 6.14.4).

The evidence and analysis provided in Sections 6.14.1 to 6.14.4 offer critical data on mineral formation and deposition, as well as indicating potential flow rates and pathways for water through the UZ. The test plans for this section include UZ Hydrochemistry Investigations (USGS 2002 [DIRS 158194]) and ${ }^{36} \mathrm{Cl}$ Validation (USGS 2002 [DIRS 158196]). For completeness, both direct and indirect inputs are identified in tables and figures in this section (see Section 4 for tables for different data categories).

Chloride data were used as part of the model development and calibration of the UZ flow model (BSC 2004 [DIRS 169861], Section 6.5). Chloride, calcite, and strontium isotope data were used as part of the validation of the UZ flow model (BSC 2004 [DIRS 169861], Sections 7.8, 7.9, and 7.10).

\subsubsection{PORE WATER AND ROCK GEOCHEMISTRY}

\subsubsection{Analysis and Interpretation of Pore-Water Data}

Pore water in the welded Tiva Canyon Tuff (TCw), the bedded tuff of the Paintbrush nonwelded (PTn), and the underlying welded Topopah Spring Tuff (TSw) is a calcium-chloride or calcium-sulfate type (Yang et al. 1996 [DIRS 100194], pp. 13 and 55; Yang et al. 1998 [DIRS 101441], p. 53; Yang et al. 2003 [DIRS 164631]; Peterman and Marshall 2002 [DIRS 162992], p. 308). A major compositional change occurs in pore water in the zeolitized Calico Hills nonwelded $(\mathrm{CHn})$ unit; within this unit, the pore water rapidly evolves to a sodium-bicarbonate type in which the relative abundances of alkalies (sodium and potassium) and alkaline earths (calcium and magnesium) reflect different degrees of ion exchange with zeolitized tuff (Yang et al. 2003 [DIRS 164631]). The ion exchange process is clearly reflected in the alkaline earth and alkali contents of the zeolitized rocks (Vaniman et al. 2001 [DIRS 157427]). The downward chemical evolution is shown clearly by analyses of pore water from USW SD-6 (Yang et al. 2003 [DIRS 164631]) and by analyses of pore water extracted from core of the welded Topopah Spring Tuff (TSw) in the ECRB Cross-Drift (Peterman and Marshall 2002 [DIRS 162992], p. 308). The chemical changes from the Tiva Canyon Tuff (TCw), Paintbrush nonwelded (PTn), and Topopah Spring Tuff (TSw), into the Calico Hills nonwelded $(\mathrm{CHn})$ include decreases in $\mathrm{Ca}^{2+}, \mathrm{Mg}^{2+}, \mathrm{SO}_{4}{ }^{2-}$, and $\mathrm{NO}_{3}{ }^{-}$, and increases in $\mathrm{HCO}_{3}{ }^{-}$, $\mathrm{Na}^{+}$, and $\mathrm{K}^{+}$. The decrease in $\mathrm{NO}_{3}{ }^{-}$and increase in $\mathrm{HCO}_{3}{ }^{-}$are suggestive of microbially mediated denitrification and concomitant production of organic $\mathrm{HCO}_{3}{ }^{-}$. Most of the denitrification occurs in the Topopah Spring welded (TSw) unit where $\mathrm{NO}_{3}{ }^{-}$decreases by as much as three orders of magnitude relative to mean values in the Paintbrush nonwelded (PTn). Similarly, the decrease in $\mathrm{SO}_{4}{ }^{2-}$ can be explained by microbially induced sulfate reduction. The processes of denitrification and sulfate reduction processes would imply the presence of bacterially controlled reducing microenvironments at the pore-scale in the otherwise oxidizing environment of the Yucca Mountain UZ. 
Early extractions of pore water were limited to compression of nonwelded or zeolitized units such as those of the Paintbrush nonwelded (PTn) or the Calico Hills nonwelded (CHn). The analyses of these pore waters (Yang et al. 1996 [DIRS 100194]; 1998 [DIRS 101441]) are summarized in the Yucca Mountain Site Description (BSC 2004 [DIRS 169734], Section 5). Pore water data are also summarized in DTN: LA0002JF12213U.001 [DIRS 154760] (surfacebased boreholes), DTN: LA0002JF122123U.002 [DIRS 156281] (underground drifts), DTN: LAJF831222AQ98.011 [DIRS 145402] (waters), and DTN: LA9909JF831222.012 [DIRS 122736] (Niche 1 [Niche 3566] and Niche 2 [Niche 3650]).

In more rescent studies, extractions made by ultracentrifugation emphasized pore water from the welded Topopah Spring Tuff (TSw), in which emplacement drifts of the repository will be constructed (Yang et al. 2003 [DIRS 164631]; Peterman and Marshall 2002 [DIRS 162992]). The most recent analyses of pore water from this unit are summarized as means and statistical parameters in Table 6-37. Normalcy tests for the cations and anions indicate that only $\mathrm{Na}^{+}$, $\mathrm{Mg}^{2+}$, and $\mathrm{SiO}_{2}$ (and perhaps $\mathrm{Rb}^{+}$) approximate a normal distribution.

Table 6-37. Summary of Statistical Parameters of the Analyses of Pore Water from Topopah Spring Tuff (TSw)

\begin{tabular}{|l|c|c|c|c|c|c|c|}
\hline & & \multicolumn{7}{|c|}{ ECRB and ESF (Alcove 7) } \\
\cline { 3 - 8 } & Units & Mean & Std. Dev. & SE mean & Min & Max & $n$ \\
\hline $\mathrm{pH}$ & -- & 7.5 & 0.4 & 0.1 & 6.7 & 8.2 & 24 \\
\hline $\mathrm{SC}$ & $\mu \mathrm{S} / \mathrm{cm}$ & 867 & 262 & 53 & 520 & 1490 & 24 \\
\hline $\mathrm{Ca}$ & $\mathrm{mg} / \mathrm{L}$ & 122 & 57 & 11 & 55 & 240 & 28 \\
\hline $\mathrm{Mg}$ & $\mathrm{mg} / \mathrm{L}$ & 16.8 & 9.6 & 1.8 & 3.3 & 44.2 & 28 \\
\hline $\mathrm{Na}$ & $\mathrm{mg} / \mathrm{L}$ & 88.3 & 27.3 & 5.2 & 39.0 & 140.0 & 28 \\
\hline $\mathrm{K}$ & $\mathrm{mg} / \mathrm{L}$ & 10.5 & 4.0 & 0.7 & 5.9 & 24.8 & 28 \\
\hline $\mathrm{HCO}_{3} \mathrm{Calc}$ & $\mathrm{mg} / \mathrm{L}$ & 559 & 215 & 41 & 287 & 1116 & 28 \\
\hline $\mathrm{Cl}$ & $\mathrm{mg} / \mathrm{L}$ & 35.8 & 19.8 & 3.7 & 17.0 & 97.0 & 28 \\
\hline $\mathrm{SO}_{4}$ & $\mathrm{mg} / \mathrm{L}$ & 56.8 & 34.7 & 6.6 & 13.0 & 147.0 & 28 \\
\hline $\mathrm{NO}_{3}$ & $\mathrm{mg} / \mathrm{L}$ & 6.0 & 7.7 & 1.5 & 0.0 & 25.0 & 27 \\
\hline $\mathrm{F}$ & $\mathrm{mg} / \mathrm{L}$ & 3.0 & 2.3 & 0.4 & 0.7 & 11.0 & 28 \\
\hline $\mathrm{SiO}{ }_{2}$ & $\mathrm{mg} / \mathrm{L}$ & 51.8 & 7.2 & 1.4 & 40.0 & 70.0 & 28 \\
\hline $\mathrm{Mn}$ & $\mu \mathrm{g} / \mathrm{L}$ & 122 & 124 & 23 & 14 & 470 & 28 \\
\hline $\mathrm{Rb}$ & $\mu \mathrm{g} / \mathrm{L}$ & 21.8 & 9.3 & 1.8 & 9.3 & 51.2 & 28 \\
\hline $\mathrm{Sr}$ & $\mu \mathrm{g} / \mathrm{L}$ & 1539 & 909 & 172 & 480 & 4090 & 28 \\
\hline $\mathrm{As}$ & $\mu \mathrm{g} / \mathrm{L}$ & 7.2 & 2.9 & 0.7 & 3.4 & 15.0 & 17 \\
\hline $\mathrm{Mo}$ & $\mu \mathrm{g} / \mathrm{L}$ & 14.7 & 13.1 & 2.5 & 3.4 & 67.0 & 28 \\
\hline $\mathrm{Ba}$ & $\mu \mathrm{g} / \mathrm{L}$ & 97.1 & 117.1 & 35.3 & 23.0 & 420.0 & 11 \\
\hline $\mathrm{U}$ & $\mu \mathrm{g} / \mathrm{L}$ & 8.1 & 8.3 & 1.6 & 0.1 & 28.7 & 26 \\
\hline $\mathrm{Saunyyy}$ & & &
\end{tabular}

Source: DTNs: GS020408312272.003 [DIRS 160899]; GS030408312272.002 [DIRS 165226].

ECRB = Enhanced Characterization of the Repository Block; ESF = Exploratory Studies Facility; $n=$ sample size . 
In addition to the downward compositional evolution, the dissolved ion composition of pore water from within hydrostratigraphic units shows considerable stratigraphic and lateral variability (Table 6-37). The existence of this compositional variability deep in the rock mass at the repository level, testifies to the inefficiency of advective or diffusional mixing in the downward percolation of pore water.

The strontium isotopic composition of pore water and pore water salts is summarized by Marshall and Futa (2003 [DIRS 162717]). Pore water salts from the relatively shallow core samples of three drill holes have ${ }^{87} \mathrm{Sr} /{ }^{86} \mathrm{Sr}$ ratios between 0.7117 and 0.7124 , values that are consistent with values for soil carbonates $(0.7113$ to 0.7127$)$ at Yucca Mountain. The variability in ${ }^{87} \mathrm{Sr} /{ }^{86} \mathrm{Sr}$ decreased as depth increased: salts from 35 core samples from the Topopah Spring Tuff (TSw) had ${ }^{87} \mathrm{Sr} /{ }^{86} \mathrm{Sr}$ values between 0.7122 and 0.7127 . This range is consistent with seven samples of pore water extracted from core taken along the ECRB Cross-Drift and yielding values between 0.7121 and 0.7127 . The decrease in variability of pore-water ${ }^{87} \mathrm{Sr} /{ }^{86} \mathrm{Sr}$ ratios from the Tiva Canyon Tuff (TCw) to the Topopah Spring Tuff (TSw) indicates that percolation through the Paintbrush nonwelded (PTn) matrix is sufficiently slow to allow pore water to partially acquire a strontium isotope signature through water/rock interaction.

Yang et al. (1998 [DIRS 101441], pp. 34-44) evaluated various water-extraction methods to determine which would be most suitable for stable isotope measurements of hydrologically active pore water, and concluded that vacuum distillation was suitable for densely welded tuffs or tuffs with little or no secondary alteration. However, vacuum distillation was not suitable for altered tuff in which the secondary minerals had fractionated oxygen isotopes, and water extracted from these rocks was relatively depleted in ${ }^{2} \mathrm{H}$, with ${ }^{18} \mathrm{O}$ typically plotting to the left of the global meteoric water line.

The most comprehensive suite of $\delta^{2} \mathrm{H}$ and $\delta^{18} \mathrm{O}$ analyses is for pore water extracted from USW UZ-14 dry-drilled core samples (Yang et al. 1998 [DIRS 101441], Figures 15 and 16) by both compression and by vacuum distillation. These data show that water extracted from the lower part of the Topopah Spring Tuff is significantly depleted in ${ }^{2} \mathrm{H}$ and ${ }^{18} \mathrm{O}$ relative to water in the middle and upper part of the unit. The lower part of the Topopah Spring Tuff in UZ-14 contains zeolites and clays, which probably explain the spurious stable isotope compositions. Despite these excursions, there appear to be real isotopic variations in pore water through the rock column. Considering the stable isotope compositions of water compressed from the Paintbrush nonwelded (PTn) and from the Calico Hills nonwelded (CHn) in UZ-14 (Yang et al. 1998 [DIRS 101441], Figures 15 and 16), mean $\delta^{2} \mathrm{H}$ and $\delta^{18} \mathrm{O}$ values are $-90.3 \pm 2.6 \%$ and $-12.3 \pm$ $0.4 \%$ for the Paintbrush nonwelded (PTn) (9 values); and $-101.1 \pm 1.5 \%$ and $-13.3 \pm 0.3 \%$ for the Calico Hills nonwelded (CHn) (14 values), respectively. Most of the isotopic values for pore water distilled from the intervening Topopah Spring Tuff (TSw) form a curvilinear continuum between the Paintbrush nonwelded (PTn) and Calico Hills nonwelded (CHn) values. The mean isotopic composition of pore water from the Paintbrush nonwelded (PTn) is well within the range of values for snow collected at Yucca Mountain, which Benson and Klieforth (1989 [DIRS 104370], p. 51) considered the likely source of recharge. The mean $\delta^{2} \mathrm{H}$ and $\delta^{18} \mathrm{O}$ values for the Calico Hills nonwelded (CHn) are similar to mean values for Yucca Mountain SZ water of $-101.4 \pm 3.9 \%$ and $-13.5 \pm 0.4 \%$, respectively, based on analyses reported by Benson and Klieforth (1989 [DIRS 104370], Table 1a). 
Benson and Klieforth (1989 [DIRS 104370], p. 50) calculated a best-fit line to the stable isotope compositions of snow at Yucca Mountain, and the following equation is considered a local meteoric water line for Yucca Mountain:

$$
\delta^{2} \mathrm{H}=8.0 * \delta^{18} \mathrm{O}+8.9
$$

Pore water samples from the Paintbrush nonwelded (PTn) and the Topopah Spring Tuff (TSw) (excluding obvious outliers) have a mean deuterium excess of $8.3 \pm 0.3 \%$ (uncertainty is standard error of the mean), with a median value of 8.1. Thus, the departure of the pore-water isotopic compositions from the local meteoric water line with a deuterium excess value of 8.9 is small, indicating that the effects of evaporation during infiltration were small. In contrast, the mean deuterium excess value for the Calico Hills nonwelded $(\mathrm{CHn})$ pore waters of $5.4 \pm 0.5 \%$ and median of 5.9 is distinct from the local meteoric water line of Benson and Klieforth (1989 [DIRS 104370], p. 50), and all of the individual values plot to the right of the line. Given the 0.8 to $3.2 \mathrm{~cm} /$ year transport-velocity range calculated by Yang (2002 [DIRS 160839], p. 814), the pore water in the Calico Hills and older tuffs in UZ-14 could be several tens of thousands of years old. Such old ages are consistent with uncorrected radiocarbon ages for groundwater beneath Yucca Mountain, which range from $12 \mathrm{ka}$ to $18 \mathrm{ka}$ (Benson and Klieforth 1989 [DIRS 104370], Table 1a).

\subsubsection{Compilation of Rock Chemistry in the ECRB Cross-Drift}

At the request of the YMP Waste Package Department, the U.S. Geological Survey (USGS) conducted geochemical analyses of samples from various zones of the crystal-poor member of the Topopah Spring Tuff intersected by the ECRB Cross-Drift. The chemical analyses were published by Peterman and Cloke (2002 [DIRS 162576], pp. 683-698) and are in the TDMS (DTN: GS000308313211.001 [DIRS 162015]). To represent the relevant lithostratigraphic zones, 20 samples were selected from existing holes cored to a 2-m depth and located on 50-m centers throughout the ECRB Cross-Drift. These drill holes are designated ECRB-SYS-CS\#\#\#\# where the distance "\#\#\#\#" records the location of the drill holes in meters from a survey control point near the intersection of the ECRB Cross-Drift and the ESF. Samples, for analyses, were selected at locations from station $10+00$ to station $25+00$ to represent the middle nonlithophysal zone, the lower lithophysal zone, and the lower nonlithophysal zone of the Topopah Spring Tuff (TSw). The core samples used for chemical analyses were encapsulated in cans at the time of drilling to retain moisture. Core displaying vapor-phase minerals or calcite and opal were avoided in sampling.

Core samples are considered to be a reasonable size/volume representative of a larger portion of the sampled rock mass. The size of samples is commonly dictated by the grain size of the rock being sampled. Coarse-grained granite may require a few kilograms of samples, whereas fine-grained volcanic rock, such as the crystal-poor Topopah Spring rhyolite, may be represented by samples of much smaller mass. For rock units with sparsely distributed heterogeneities, such as mineralized lithophysal cavities in certain zones of the Topopah Spring Tuff, direct sampling may be impractical for capturing these features in determining the large-scale chemical composition. 
Core samples were removed from the cans and air-dried overnight under a heat lamp. Each core was broken with a hammer on a steel anvil and crushed in a laboratory jaw crusher to fragments of approximately $1 \mathrm{~cm}$ or smaller. The crushed material (typically, 200 to $500 \mathrm{~g}$ ) was weighed, mixed by rolling on paper, split by cone, and quartered to yield a subsample of approximately $100 \mathrm{~g}$. The 100-g subsample was then pulverized in a hardened steel mill for 2 minutes to yield a 200-mesh powder. Aliquots of the powder were taken for duplicate chemical analyses.

Previous analyses indicated limited chemical variability of the crystal-poor zone of the Topopah Spring Tuff (Lipman et al. 1966 [DIRS 100773]; Broxton et al. 1989 [DIRS 100024]; Flood et al. 1989 [DIRS 164636]; Schuraytz et al. 1989 [DIRS 107248]). Accordingly, duplicate analyses of each sample were used to assess analytical reproducibility and to compare with intersample variability (Youden 1951 [DIRS 153339]). Accuracy was assessed by five analyses, with two USGS reference materials (GSP-2 and RGM-1) submitted as blind standards interspersed with the samples. Results for the standards are given in Peterman and Cloke (2002 [DIRS 162576], Tables 2 and 3).

The means, ranges, and standard deviations for major and selected trace elements for the 20 analyses of crystal-poor rhyolite from the ECRB Cross-Drift are given in Table 6-38. A more comprehensive suite of trace elements analyzed by inductively coupled plasma mass spectrometry is given in Table 6-39 from Peterman and Cloke (2001 [DIRS 155696]). Mean normative mineral contents are given in Table 6-40. These tabulations show that the variability of the crystal-poor rhyolite in major and trace element contents is exceedingly small. The intersample variability of the 20 samples was compared with the analytical variability based on the duplicate analyses (Peterman and Cloke 2002 [DIRS 162576], p. 692) using the Fisher test (or "F Test") (Youden 1951 [DIRS 153339]) (see Appendix Section I5). The intersample variability of $\mathrm{SiO}_{2}$ and $\mathrm{TiO}_{2}$ is commensurate solely with the estimated analytical uncertainty, based on duplicate samples. The other major oxides (Table 6-38) show greater variability, with $\mathrm{CaO}$ exhibiting a Fisher value (or "F value") (intersample variance/analytical variance) of 25.9, versus the critical Fisher value of 1.84 at the 0.05 -significance level. The mean $\mathrm{CaO}$ concentration is 0.50 percent, with a standard deviation of 0.03 , whereas the standard deviation of the duplicates is only 0.005 .

Table 6-38. Mean Composition of the Crystal-Poor Member of the Topopah Spring Tuff in the ECRB Cross-Drift

\begin{tabular}{|c|c|c|c|c|c|}
\hline Analyte & Mean & $\sigma$ & \multicolumn{1}{c|}{ SDOM } & Min & Max \\
\hline \multicolumn{7}{|c|}{ Major elements and oxides, in weight percent } \\
\hline $\mathrm{SiO}_{2}$ & 76.29 & 0.366 & 0.071 & 75.4 & 77.1 \\
\hline $\mathrm{Al}_{2} \mathrm{O}_{3}$ & 12.55 & 0.147 & 0.032 & 12.3 & 12.9 \\
\hline $\mathrm{FeO}$ & 0.14 & 0.050 & 0.010 & $<0.05$ & 0.2 \\
\hline $\mathrm{Fe}_{2} \mathrm{O}_{3}$ & 0.97 & 0.076 & 0.016 & 0.77 & 1.1 \\
\hline $\mathrm{MgO}$ & 0.13 & 0.021 & 0.005 & $<0.10$ & 0.17 \\
\hline $\mathrm{CaO}$ & 0.50 & 0.027 & 0.006 & 0.41 & 0.54 \\
\hline $\mathrm{Na}_{2} \mathrm{O}$ & 3.52 & 0.109 & 0.024 & 3.35 & 3.70 \\
\hline $\mathrm{K}_{2} \mathrm{O}$ & 4.83 & 0.063 & 0.014 & 4.74 & 4.97 \\
\hline $\mathrm{TiO}_{2}$ & 0.11 & 0.004 & 0.001 & 0.10 & 0.11 \\
\hline $\mathrm{ZrO}_{2}{ }^{2}$ & 0.016 & 0.001 & $<0.001$ & 0.015 & 0.016 \\
\hline
\end{tabular}


Table 6-38. Mean Composition of the Crystal-Poor Member of the Topopah Spring Tuff in the ECRB Cross-Drift (Continued)

\begin{tabular}{|c|c|c|c|c|c|}
\hline Analyte & Mean & $\sigma$ & SDOM & Min & Max \\
\hline \multicolumn{6}{|c|}{ Major elements and oxides, in weight percent (Continued) } \\
\hline $\mathrm{P}_{2} \mathrm{O}_{5}$ & $<0.05$ & $\mathrm{~N} / \mathrm{A}$ & $\mathrm{N} / \mathrm{A}$ & $\mathrm{N} / \mathrm{A}$ & N/A \\
\hline $\mathrm{MnO}$ & 0.07 & 0.008 & 0.002 & 0.06 & 0.09 \\
\hline $\mathrm{Cl}$ & 0.02 & 0.004 & 0.001 & 0.01 & 0.03 \\
\hline $\mathrm{F}$ & 0.04 & 0.008 & 0.002 & 0.03 & 0.06 \\
\hline$S$ & $<0.05$ & N/A & $\mathrm{N} / \mathrm{A}$ & N/A & N/A \\
\hline $\mathrm{CO}_{2}$ & 0.01 & 0.003 & 0.001 & $<0.01$ & 0.02 \\
\hline $\mathrm{H}_{2} \mathrm{O}^{-}$ & 0.24 & 0.081 & 0.016 & 0.10 & 0.4 \\
\hline $\mathrm{H}_{2} \mathrm{O}^{+}$ & 0.40 & 0.113 & 0.020 & 0.10 & 0.6 \\
\hline SUM & 99.79 & & & & \\
\hline \multicolumn{6}{|c|}{ Trace elements, in micrograms per gram } \\
\hline RB & 188 & 5.3 & 1.2 & 183 & 198 \\
\hline $\mathrm{Sr}$ & 25 & 3.4 & 0.8 & 20 & 31 \\
\hline $\mathrm{Y}$ & 32 & 2.9 & 0.6 & 30 & 37 \\
\hline $\mathrm{Zr}$ & 116 & 3.8 & 0.8 & 111 & 126 \\
\hline $\mathrm{Nb}$ & 25 & 1.1 & 0.2 & 23 & 27 \\
\hline $\mathrm{Ba}$ & 55 & 6.8 & 1.5 & 49 & 78 \\
\hline $\mathrm{La}$ & 51 & 5.5 & 1.2 & 38 & 58 \\
\hline $\mathrm{Ce}$ & 84 & 5.1 & 1.1 & 72 & 95 \\
\hline
\end{tabular}

Source: DTN: GS000308313211.001 [DIRS 162015], see Appendix I, Section I6.6 for calculations.

NOTE: $\sigma$ is standard deviation; SDOM is standard deviation of the mean; Min and Max are the mean values plus or minus two times SDOM (see Appendix I, Section 16.6 for details).

${ }^{a} \mathrm{ZrO}_{2}$ values were calculated from the $\mathrm{Zr}$ trace element values (see Appendix Table I-13).

$\mathrm{N} / \mathrm{A}=$ not available; SDOM=standard deviation of the mean

Normative mineral compositions were calculated from the means of each pair of duplicate analyses (Table 6-40). The abundances of normative quartz and feldspars (orthoclase, albite, and anorthite) range from 95 to 98 percent of the total rock, and closely approximate the abundances of silica polymorphs and feldspars actually in the rock (Bish and Vaniman 1985 [DIRS 101196]). 
Table 6-39. Mean Trace Element Concentrations of the Phenocryst-Poor Member of the Topopah Spring Tuff in the ECRB Cross-Drift

\begin{tabular}{|c|c|c|c|c|c|}
\hline Element & Mean & $\sigma_{\mathbf{x}}$ & SDOM & Min & Max \\
\hline \multicolumn{6}{|c|}{ Micrograms per gram (parts per million) } \\
\hline $\mathrm{Ag}$ & $<1$ & --- & --- & --- & --- \\
\hline As & 5.4 & 1.9 & 0.60 & 4.1 & 6.6 \\
\hline $\mathbf{B a}$ & 51.3 & 12.1 & 3.83 & 43.7 & 59.0 \\
\hline$\overline{\mathrm{Be}}$ & 3.4 & 0.1 & 0.03 & 3.4 & $\overline{3.5}$ \\
\hline $\mathbf{B i}$ & 0.06 & 0.03 & 0.01 & 0.04 & 0.08 \\
\hline Cd & 0.07 & 0.03 & 0.01 & 0.05 & 0.09 \\
\hline $\mathrm{Ce}$ & 70.8 & 5.84 & 1.85 & 67.1 & 74.5 \\
\hline Co & 0.23 & 0.05 & 0.02 & 0.19 & 0.26 \\
\hline $\mathbf{C r}$ & 8.7 & 2.9 & 0.92 & 6.9 & 10.6 \\
\hline Cs & 4.2 & 0.3 & 0.09 & 4.0 & 4.4 \\
\hline $\mathrm{Cu}$ & 13.7 & --- & $-\cdots$ & --- & --- \\
\hline $\mathbf{G a}$ & 15.6 & 0.50 & 0.16 & 15.3 & 16.0 \\
\hline La & 34.2 & 3.31 & 1.05 & 32.1 & 36.3 \\
\hline Li & 25.1 & 8.9 & 2.82 & 19.4 & 30.7 \\
\hline Mo & 2.21 & 0.95 & 0.30 & 1.61 & 2.82 \\
\hline Nb & 20.6 & 1.4 & 0.45 & 19.7 & 21.5 \\
\hline $\mathrm{Ni}$ & 1.4 & 0.3 & 0.11 & 1.2 & 1.6 \\
\hline $\mathbf{P b}$ & 27.2 & 1.1 & 0.36 & 26.5 & 27.9 \\
\hline Rb & 185.6 & 8.8 & 2.78 & 180.0 & 191.1 \\
\hline Sb & 0.33 & 0.06 & 0.02 & 0.29 & 0.37 \\
\hline Sc & 2.45 & 0.10 & 0.03 & 2.39 & 2.51 \\
\hline$\overline{S r}$ & 27.1 & 3.3 & 1.06 & 25.0 & 29.2 \\
\hline Th & 26.0 & 1.4 & 0.45 & 25.1 & 26.9 \\
\hline $\mathrm{TI}$ & 1.10 & 0.21 & 0.07 & 1.0 & 1.2 \\
\hline $\mathbf{U}$ & 3.92 & 0.30 & 0.10 & 3.73 & 4.11 \\
\hline V & 1.3 & 0.6 & 0.20 & 0.9 & 1.7 \\
\hline $\bar{Y}$ & 30.1 & 3.06 & \begin{tabular}{|l|}
0.97 \\
\end{tabular} & 28.2 & 32.1 \\
\hline $\mathrm{Zn}$ & 35.9 & 4.3 & 1.35 & 33.2 & 38.6 \\
\hline
\end{tabular}

Source: DTN: GS000308313211.001 [DIRS 162015]; see Appendix I for calculations.

$\mathrm{SDOM}=$ standard deviation of the mean. 
Table 6-40. Mean Normative Mineral Contents of the Phenocryst-Poor Rhyolite Member of the Topopah Spring Tuff in the ECRB Cross-Drift

\begin{tabular}{|c|c|c|c|c|c|}
\hline Normative Minerals & Mean & $\sigma_{\mathbf{x}}$ & SDOM & Min & Max \\
\hline & & & \multicolumn{2}{|l|}{ Weight Percent } & \\
\hline$\overline{Q \text { (quartz) }}$ & 36.41 & 0.899 & 0.201 & 36.01 & 36.81 \\
\hline or (orthoclase) & 28.55 & 0.375 & 0.084 & 28.38 & 28.71 \\
\hline$\overline{a b}$ (albite) & 29.65 & 0.930 & 0.208 & 29.24 & 30.07 \\
\hline an (anorthite) & 1.92 & 0.138 & 0.031 & 1.85 & 1.98 \\
\hline C (corundum) & 0.85 & 0.133 & 0.030 & 0.79 & 0.91 \\
\hline hy (hypersthene) & 0.30 & 0.052 & 0.012 & 0.27 & 0.32 \\
\hline mt (magnetite) & 0.19 & 0.171 & 0.038 & 0.11 & 0.26 \\
\hline il (ilmenite) & 0.18 & 0.031 & 0.007 & 0.16 & 0.19 \\
\hline hem (hematite) & 0.89 & 0.132 & 0.029 & 0.84 & 0.95 \\
\hline ap (apatite) & 0.12 & 0.000 & 0.000 & 0.12 & 0.12 \\
\hline hl (halite) & 0.03 & 0.007 & 0.002 & 0.02 & 0.03 \\
\hline zr (zircon) & 0.03 & 0.000 & 0.000 & 0.03 & 0.03 \\
\hline fl (fluorite) & 0.07 & 0.018 & 0.004 & 0.06 & 0.08 \\
\hline pr (pyrite) & 0.09 & 0.000 & 0.000 & 0.09 & 0.09 \\
\hline ru (rutile) & 0.04 & 0.017 & 0.004 & 0.03 & 0.04 \\
\hline
\end{tabular}

Source: DTN: GS000308313211.001 [DIRS 162015], see Appendix I for calculations.

SDOM = standard deviation of the mean.

Statistical analyses of major and trace element compositions indicate that the 200 - to 500-g core samples selected for analyses are representative of the crystal-poor Topopah Spring rhyolite (Table 6-38). However, no attempt was made in this approach to capture the compositional influence of localized deposits of vapor-phase minerals and low-temperature calcite and opal. Random sampling of the unit at the $200-$ to-500-g scale would produce a number of samples with compositions within the range of those reported in Table 6-38, and a few samples with widely divergent compositions. In addition, large numbers of samples would be required to capture this compositional variability solely by random sampling. Alternatively, large multi-ton bulk samples would have captured these features at the zonal scale, but would have to have been taken during construction of the drifts. Neither of these approaches was feasible, but data on the amount of calcite present in the crystal-poor member of the Topopah Spring Tuff was used to assess the compositional effects of considering these heterogeneities in estimating the zonal compositions (Peterman and Cloke 2002 [DIRS 162576], pp. 695-696). Using detailed analyses of $\mathrm{CO}_{2}$ and calculated normative calcite abundances of cuttings from WT-24 (DTN: GS020608315215.002 [DIRS 162126] and DTN: GS021008315215.007 [DIRS 162127]), Peterman and Cloke (2002 [DIRS 162576], p. 696) noted that the mean values of $\mathrm{CaO}$ and $\mathrm{CO}_{2}$ determined from the rock analyses would only have to be increased slightly to incorporate the effects of calcite in cavities and fractures at the zonal scale. Similarly, the effect of opal $\left(\mathrm{SiO}_{2} \bullet \mathrm{nH}_{2} \mathrm{O}\right)$ on the zonal compositions would be trivial. In addition, Peterman and Cloke (2002 [DIRS 162576], p. 696) argued that incorporation of vapor phase minerals in the estimate of zonal compositions would be negligible because the process of vapor-phase corrosion and deposition could be approximated as a closed system at the zonal scale. 


\subsubsection{ISOTOPE GEOCHEMISTRY EXAMINATIONS}

Isotope geochemistry has been used to provide (in this report) data pertaining to the "fast path" signals (Section 6.14.2.1, on ${ }^{36} \mathrm{Cl} / \mathrm{Cl}$ ratios; and Section 6.14.2.2, on tritium data) and pertaining to the inferred thermal history of Yucca Mountain (Section 6.14.2.3, on fluid inclusion data). Early results of geochemical and isotope studies were reported in Yucca Mountain Site Description (BSC 2004 [DIRS 169734]).

The data submitted to the TDMS from the ${ }^{36} \mathrm{Cl}$ Validation Study (VS) are summarized in Section 6.14.2.1 and Section 6.14.2.1.1. The description of analysis and interpretation by Paces et al. in "Summary of Chlorine-36 Validation Studies at Yucca Mountain, Nevada" (2003 [DIRS 162738]), together with development of alternate interpretations, are summarized.

\subsubsection{Chlorine-36 Validation Study}

The upper limit of ${ }^{36} \mathrm{Cl} / \mathrm{Cl}$ ratios for Pleistocene meteoric input is approximately $1,250 \times 10^{-15}$. Atmospheric nuclear testing in the Pacific Ocean during the 1950s contributed additional "bomb-pulse" ${ }^{36} \mathrm{Cl}$ to the atmosphere, which can be detected in meteoric water from that period; any measurements of ${ }^{36} \mathrm{Cl} / \mathrm{Cl}$ values that exceed $1,250 \times 10^{-15}$ indicate that at least some meteoric water has percolated through the UZ from the surface to the repository horizon in the last 50 years. Such elevated ${ }^{36} \mathrm{Cl} / \mathrm{Cl}$ ratios have been reported from Yucca Mountain at the ESF (Fabryka-Martin et al. 1996 [DIRS 144839]; Fabryka-Martin et al. 1997 [DIRS 100145]; Fabryka-Martin et al. 1998 [DIRS 162737]; Levy et al. 1999 [DIRS 162740]). "Fast paths" from the repository horizon to the water table may compromise the barrier capability of the UZ, depending on their specific flow characteristics and location with respect to the repository and possible sources of radionuclides. The VS was therefore initiated in late 1999 to independently verify the presence of "bomb-pulse" ${ }^{36} \mathrm{Cl}$ in the ESF. The study primarily entailed analyses of core from 50 new boreholes drilled across two zones, the Sundance fault and the Drill Hole Wash fault, where significant ${ }^{36} \mathrm{Cl} / \mathrm{Cl}$ bomb-pulse ratios were identified in the late $1990 \mathrm{~s}$.

\section{Results}

Previous studies reported numerous samples from the ESF with elevated levels of ${ }^{36} \mathrm{Cl}$ in a $165-\mathrm{m}$-wide zone associated with the Sundance fault (Figure 6-195). Ratios of ${ }^{36} \mathrm{Cl} / \mathrm{Cl}$ near or exceeding $1250 \times 10^{-15}$ were obtained for 11 of 16 samples between $3428 \mathrm{~m}$ and $3593 \mathrm{~m}$ in the $\mathrm{ESF}\left({ }^{36} \mathrm{Cl} / \mathrm{Cl}\right.$ ratios from 1,339 to $\left.4,105 \times 10^{-15}\right)$. In addition, nine of fifteen samples from Niche 1 (Niche 3566), also associated with the Sundance fault, had ${ }^{36} \mathrm{Cl} / \mathrm{Cl}$ values from $1,235 \times 10^{-15}$ to $2,038 \times 10^{-15}$. This zone was selected for study to maximize the probability of reproducing the commonly sporadic "bomb-pulse" ${ }^{36} \mathrm{Cl}$ signal. 


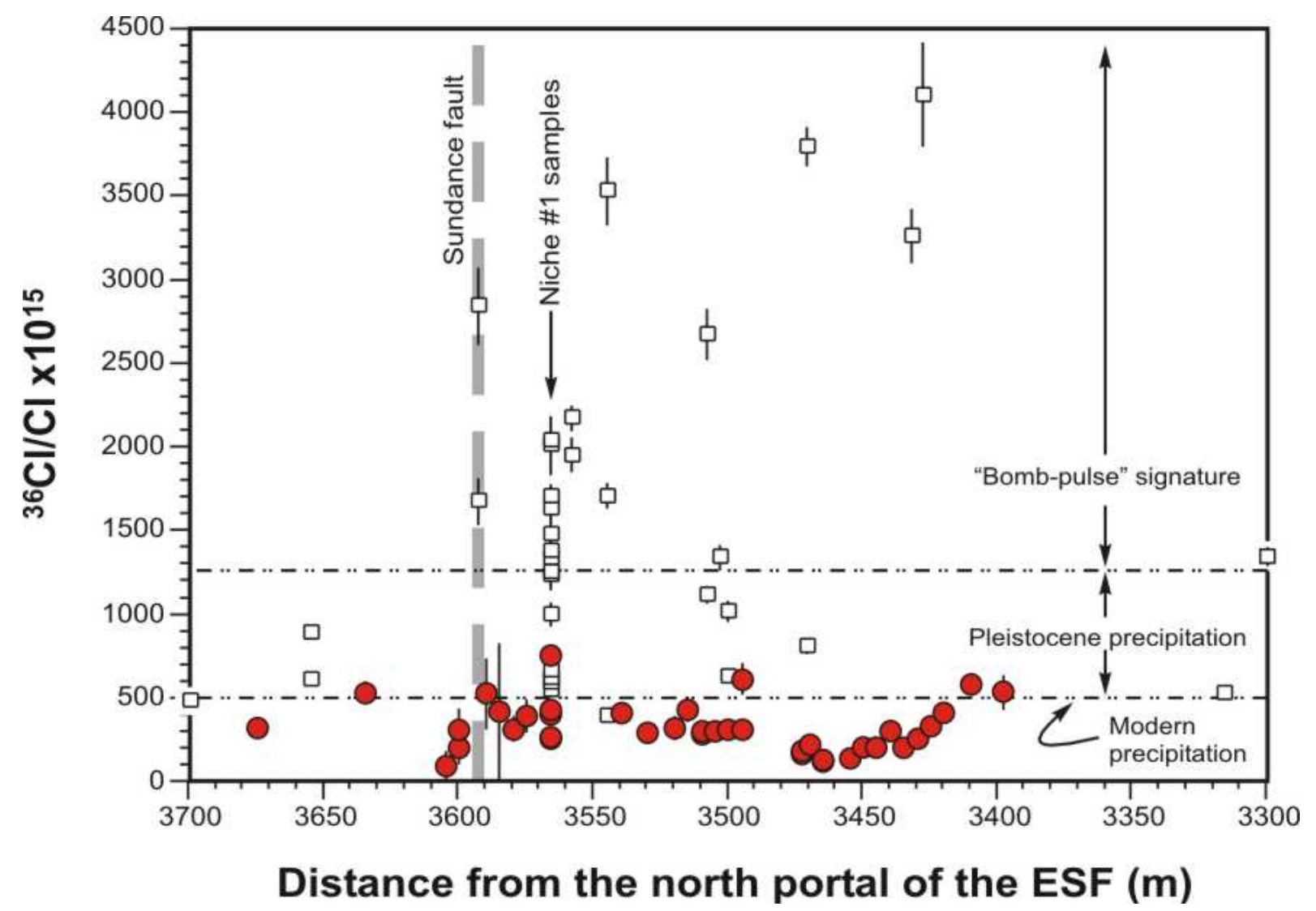

Source: DTNs: LAJF831222AQ98.004 [DIRS 107364]; LAJF831222AQ98.009 [DIRS 145650]; LL031200223121.036 [DIRS 168531].

NOTE: Although the main trace of the Sundance fault (shaded bars) is exposed at a distance of $3593 \mathrm{~m}$ from the ESF North Portal, the entire zone between 3400 and 3650 m (approximately) is intensely fractured. Analytical errors $(2 \sigma)$ are shown as vertical lines if the errors are larger than the size of the symbol. The USGS-LLNL validation-study samples are shown as filled circles. Previously published LANL data (Fabryka-Martin et al. 1996 [DIRS 144839], 1997 [DIRS 100145], 1998 [DIRS 162737]) are shown as open squares. Ranges for different ${ }^{36} \mathrm{Cl} / \mathrm{Cl}$ signatures are from Fabryka-Martin et al. (1996 [DIRS 144839]; 1997 [DIRS 100145]).

Figure 6-195. ${ }^{36} \mathrm{Cl} / \mathrm{Cl}$ Ratio Plotted against Sample Location in the Exploratory Studies Facility

Initially, VS samples were crushed at Lawrence Livermore National Laboratory (LLNL) and leached by deionized water in slowly rotating tumblers for 7 hours ("active" leach). Resulting leachates (Table 6-41) had high chlorine concentrations $(1.3$ to $3.5 \mathrm{mg} / \mathrm{kg})$ and low ${ }^{36} \mathrm{Cl} / \mathrm{Cl} \mathrm{ratios}$ $\left(48 \times 10^{-15}\right.$ to $\left.248 \times 10^{-15}\right)$ from overextraction of rock $\mathrm{Cl}^{-}$, which is low in ${ }^{36} \mathrm{Cl}$. Consequently, less-aggressive leach protocols were adopted. Subsequent samples were subjected to a "passive" leach method at USGS-Denver labs, where 1 to $2 \mathrm{~kg}$ of the 2- to 19-mm rock fragments were leached for 1 hour in an approximately equal weight of deionized water. This process approximated the passive-leaching methods used in earlier LANL studies except for a substantial reduction in the leach times ( 24 to 72 hours at LANL). Shorter leach times yield lower chlorine concentrations (Gascoyne 2003 [DIRS 162716]) with smaller proportions of rock chlorine and greater proportions of easily extracted meteoric $\mathrm{Cl}^{-}$. 
Table 6-41. Comparison of Chlorine-36 $\left({ }^{36} \mathrm{Cl}\right)$ Validation Study Results with Other ${ }^{36} \mathrm{Cl}$ Results

\begin{tabular}{|c|c|c|c|c|}
\hline & $\begin{array}{c}\text { Initial LLNL } \\
{ }^{36} \mathrm{CI} \text { Validation } \\
\text { Study }\end{array}$ & $\begin{array}{l}\text { USGS-LLNL } \\
{ }^{36} \mathrm{CI} \text { Validation } \\
\text { Study }\end{array}$ & $\begin{array}{c}\text { LANL } \\
\text { Previous Studies }^{c}\end{array}$ & $\begin{array}{c}\text { LANL } \\
{ }^{36} \mathrm{CI} \text { Validation } \\
\text { Study }^{\mathrm{d}} \\
\end{array}$ \\
\hline Sample locations ${ }^{\mathrm{e}}$ & $\begin{array}{l}\text { ESF } 3398 \text { to } 3470 \\
\text { and } 3580 \text { to } 3675\end{array}$ & $\begin{array}{l}\text { ESF } 3398 \text { to } 3675 \\
\text { and Niche } 1 \\
\text { (Niche } 3566 \text { ) }\end{array}$ & $\begin{array}{l}\text { ESF } 3300 \text { to } 3768 \\
\text { and Niche } 1 \\
\text { (Niche } 3566 \text { ) }\end{array}$ & $\begin{array}{l}\text { ESF } 3300 \text { to } 3768 \\
\text { and Niche } 1 \\
\text { (Niche } 3566) \text {, ECRB }\end{array}$ \\
\hline Sample form & Drill core & Drill core & $\begin{array}{l}\text { ESF tunnel walls } \\
\text { and Niche } 1 \text { (Niche } \\
\text { 3566) drill core }\end{array}$ & $\begin{array}{l}\text { Drill core, ECRB } \\
\text { tunnel walls, muck } \\
\text { pile }\end{array}$ \\
\hline Crushing & Jaw crusher & $\begin{array}{l}\text { Jaw crusher and } \\
\text { hammer/plate }\end{array}$ & Hammer/plate & $\begin{array}{l}\text { Hammer/plate, jaw } \\
\text { crusher }\end{array}$ \\
\hline Size fraction & 6 to $13 \mathrm{~mm}$ & 2 to $19 \mathrm{~mm}$ & $\begin{array}{l}\text { Typically, } 10 \text { to } 20 \\
\mathrm{~mm}\end{array}$ & $\begin{array}{l}\text { Various sizes } \\
\text { studied }\end{array}$ \\
\hline $\begin{array}{l}\mathrm{Cl} \text { in } \\
\text { crushing blank }\end{array}$ & Not determined & $<0.01 \mathrm{mg} / \mathrm{kg}$ & Not determined & Not determined \\
\hline Leaching protocol & Active (7 hr) & Passive (1 hr) & Passive (24 to $72 \mathrm{hr}$ ) & Passive and Active \\
\hline $\begin{array}{l}\mathrm{Cl} \text { in } \\
\text { leaching blank }\end{array}$ & Not determined & 0.004 to $0.020 \mathrm{mg} / \mathrm{kg}$ & Unknown & 0.0024 to $0.0254 \mathrm{mg}$ \\
\hline $\begin{array}{l}\text { AMS analytical } \\
\text { facility }\end{array}$ & LLNL (CAMS lab) & LLNL (CAMS lab) & Purdue (PRIME lab) & $\begin{array}{l}\text { Purdue (PRIME lab), } \\
\text { LLNL (CAMS lab) }\end{array}$ \\
\hline $\mathrm{Cl}_{\text {concentrations }}{ }^{f}$ & 1.3 to $3.5 \mathrm{mg} / \mathrm{kg}$ & 0.05 to $0.38 \mathrm{mg} / \mathrm{kg}$ & 0.20 to $2.3 \mathrm{mg} / \mathrm{kg}$ & 0.07 to $3.59 \mathrm{mg} / \mathrm{kg}$ \\
\hline $\begin{array}{l}\text { Average } \mathrm{Cl} \\
\text { concentration }^{f}\end{array}$ & $2.1 \mathrm{mg} / \mathrm{kg}$ & $0.15 \mathrm{mg} / \mathrm{kg}$ & $0.71 \mathrm{mg} / \mathrm{kg}$ & $0.47 \mathrm{mg} / \mathrm{kg}$ \\
\hline Minimum ${ }^{36} \mathrm{Cl} / \mathrm{Cl}^{f}$ & $48 \times 10^{-15}$ & $177 \times 10^{-15}$ & $363 \times 10^{-15}$ & $161 \times 10^{-15}$ \\
\hline Maximum ${ }^{36} \mathrm{Cl} / \mathrm{Cl}{ }^{\mathrm{f}}$ & $248 \times 10^{-15}$ & $709 \times 10^{-15}$ & $4,105 \times 10^{-15}$ & $8,558 \times 10^{-15}$ \\
\hline Average ${ }^{36} \mathrm{Cl} / \mathrm{Cl}{ }^{\mathrm{f}}$ & $97 \times 10^{-15}$ & $357 \times 10^{-15}$ & $1,414 \times 10^{-15}$ & $787 \times 10^{-15}$ \\
\hline $\begin{array}{l}\text { Standard } \\
\text { Deviation }\end{array}$ & $43 \times 10^{-15}$ & $130 \times 10^{-15}$ & $1,145 \times 10^{-15}$ & $959 \times 10^{-15}$ \\
\hline Median ${ }^{36} \mathrm{Cl} / \mathrm{Cl}^{\mathrm{f}}$ & $88 \times 10^{-15}$ & $333 \times 10^{-15}$ & $888 \times 10^{-15}$ & $560 \times 10^{-15}$ \\
\hline $\begin{array}{l}\text { Number of } \\
\text { analyses }\end{array}$ & 25 & 40 & 29 & 136 \\
\hline
\end{tabular}

Source: DTNs: LL030408023121.027 [DIRS 162949]; LL031200223121.036 [DIRS 168531].

${ }^{a}$ Initial ${ }^{36} \mathrm{Cl}$ Validation Study by LLNL, unpublished data.

b USGS-LLNL, this report based on cited DTNs.

c Source DTN: LAJF831222AQ98.004 [DIRS 107364].

d Source DTNs: LA0305RR831222.001 [DIRS 163422]; LA0307RR831222.001 [DIRS 164091]; LA0307RR831222.002 [DIRS 164090].

e ESF values are given in meters from the ESF North Portal.

${ }^{\mathrm{f}} \mathrm{Cl}$ concentrations and ${ }^{36} \mathrm{Cl} / \mathrm{Cl}$ ratios have been corrected for contributions from spike and background.

AMS = accelerator mass spectrometry; CAMS $=$ Center for Accelerator Mass Spectrometry; ECRB $=$ Enhanced Characterization of the Repository Block; ESF = Exploratory Studies Facility; LANL = Los Alamos National Laboratory; LLNL = Lawrence Livermore National Laboratory; USGS = U.S. Geological Survey. 
The ${ }^{36} \mathrm{Cl} / \mathrm{Cl}$ ratios were analyzed by accelerator mass spectrometry (AMS) and corrected for ${ }^{36} \mathrm{~S}$ interference, background, and both spike and blank chlorine contributions. None of the differences in measured blanks is sufficient to account for differences in measured bomb-pulse ${ }^{36} \mathrm{Cl} / \mathrm{Cl}$ values.

The ${ }^{36} \mathrm{Cl} / \mathrm{Cl}$ ratios (from 34 leachates from 20 VS boreholes, and from six leachates from the Niche 1 (Niche 3566) boreholes) range from $177 \times 10^{-15}$ to $709 \times 10^{-15}$ (Figure 6-195 and Table 6-41, USGS-LLNL ${ }^{36} \mathrm{Cl}$ Validation Study column). These values are considerably smaller than the values obtained in $1990 \mathrm{~s}$, with values of $363 \times 10^{-15}$ to $4,105 \times 10^{-15}$ (Table 6-41, LANL Previous Studies column). The average ${ }^{36} \mathrm{Cl} / \mathrm{Cl}$ ratio for $\mathrm{VS}$ samples is $357 \times 10^{-15}$ (standard deviation of $130 \times 10^{-15}, \mathrm{~N}=40$ ); almost 5 times lower than the average of $1,437 \times 10^{-15}$ (standard deviation of $998 \times 10^{-15}, \mathrm{~N}=39$ ) for early samples collected from around the Sundance fault.

Chlorine concentrations in VS leachates (Table 6-41, USGS-LLNL study column) vary from 0.05 to $0.38 \mathrm{mg} / \mathrm{kg}$ (average of $0.15 \mathrm{mg} / \mathrm{kg}$ ), and are consistently lower than chlorine concentrations in early leachates (Table 6-41, LANL previous studies column) (0.20 to $2.3 \mathrm{mg} / \mathrm{kg}$; average of $0.72 \mathrm{mg} / \mathrm{kg}$ ). These results are consistent with shorter leach times for VS samples (Table 6-41, USGS-LLNL study column). Therefore, it is expected that chlorine leached from the VS samples (Table 6-41, USGS-LLNL study column) better represent the easily extracted meteoric component present in the Sundance fault zone. Any "bomb-pulse" ${ }^{36} \mathrm{Cl}$ should be more readily identifiable in VS leachates (Table 6-41, USGS-LLNL study column) than in previous leachates (Table 6-41, LANL study column) with higher chlorine concentrations.

Table 6-41 also includes data of additional and recent studies (in the LANL ${ }^{36} \mathrm{Cl}$ validation study column) with drill core samples, ECRB tunnel wall samples, and muck samples. In general, this set of results supports the previous results with the presence of "bomb-pulse" signals. In addition to VS borehole samples, the results from different laboratories are also different on splits of Niche 1 (Niche 3566) core samples, as reported in different DTNs.

\subsubsection{Tritium Distribution in the ESF and ECRB}

Low-level tritium measurements of pore water distilled from UZ core samples are used to identify the presence of fast pathways that allow the percolation of young water to the repository horizon. Natural tritium, with a half-life of 12.43 years, is produced in the atmosphere by neutron bombardment and enters into the hydrologic system as precipitation. Estimates of tritium activities in precipitation near Yucca Mountain prior to atmospheric testing of nuclear weapons (which occurred in the early 1950s) vary from 5 to 8 tritium units (TU). After weapons testing began, tritium activities in precipitation increased to thousands of TU. Water isolated from the atmosphere by entering the UZ prior to nuclear weapons testing, with a tritium activity of $8 \mathrm{TU}$, would contain less than $1 \mathrm{TU}$, based on radioactive decay alone. Therefore, it is assumed that water that has tritium activities in excess of 1 TU must contains some component of water that entered the UZ within the last 50 years. 


\subsection{Sample Collection and Low-level Analyses of Tritium Activity}

Water samples for tritium analyses were obtained from core samples collected during the drilling of horizontal boreholes in the ESF and the ECRB. These boreholes were dry-drilled using compressed air for cutting removal. After core was retrieved from each run, the borehole was video logged and the core was then wrapped in plastic film, inserted into Lexan ${ }^{\circledR}$ tubing with caps taped on each end, and sealed in ProtecCore ${ }^{\mathrm{TM}}$ packages.

Samples were collected from locations within the ESF and ECRB. Eleven samples were collected from boreholes that crossed the Bow Ridge fault in Alcove 2, off the north ramp of the ESF. Thirteen samples were collected from the north ramp of the ESF, with 10 of those coming from the Drill Hole Wash fault. Forty-two samples were collected from the Sundance fault area within the main drift of the ESF. Both Drill Hole Wash and Sundance faults are locations that the chlorine-36 studies had indicated the presence of fast pathways. Ten samples were collected from the northern Ghost Dance fault access drift and alcove, and five from the southern Ghost Dance fault access drift along the main drift of the ESF. Twenty-three samples were collected along the south ramp of the ESF and 22 from the ECRB.

All pore water used for tritium analyses was extracted from core samples by vacuum distillation, using the method described by Yang et al. (1998 [DIRS 101441], pp. 25-27). Resulting water volumes varied (from 39 to $169 \mathrm{~mL}$ ). Samples from Alcove \#2 were processed and analyzed by the USGS in Denver. All other extracted pore water was processed by the USGS in Denver and sent to the University of Miami, Rosenstiel School of Marine and Atmospheric Science Tritium Laboratory for low-level analysis. Details of the analytical procedure are described by Ostlund (1987 [DIRS 163335], pp. 8-10). Pore-water samples with low-level tritium concentrations were processed through an electrolytic enrichment step, in which tritium concentrations are increased approximately 60 -fold through volume reduction from the original starting volume to approximately $5 \mathrm{~mL}$ of sodium hydroxide solution. Low activities of ${ }^{3} \mathrm{H}$ were measured by internal gas proportional counting of $\mathrm{H}_{2}$ gas made from the water sample. The counting equipment consists of nine proportional gas counters of various sizes, operating in anticoincidence with a surrounding cosmic-ray detector system. The whole system is encased in a 30-ton iron shield. Accuracy of the low-level measurement with enrichment is $0.10 \mathrm{TU}$ $\left(0.3 \mathrm{pCi} \mathrm{L}^{-1}\right.$ of $\left.\mathrm{H}_{2} \mathrm{O}\right)$, or 3.5 percent, whichever is greater.

Potential contamination effects increase as measurements are made on lower levels of tritium. Prolonged exposure of the samples to the atmosphere could potentially increase tritium activity within the sample to that of the atmosphere (8-10 TU). Within the ESF and ECRB, the samples could be contaminated with construction water. The sampling techniques used are specifically designed to minimize any atmospheric exposure of the core or water samples, and the preponderance of samples with tritium activities below $1 \mathrm{TU}$ indicates that the sampling techniques are sufficient in eliminating this effect. The effects of construction water contamination are more difficult to eliminate. The construction water used in the ESF and ECRB derives from water well UE $25 \mathrm{~J}-13$, which was sampled several times, and results indicated the well did not contain measurable tritium. Therefore, the result of construction water contamination of the core samples would be the dilution of any evidence of young water. During the process of selecting core for tritium analyses, core from the deepest part of the borehole, farthest from the application of construction water, was selected to minimize these effects. 
In situ production of tritium in the subsurface does occur because of the spontaneous fission of uranium and thorium. However, in most groundwater, in situ production of tritium in the subsurface is assumed to be approximately 0.1 TU (Clark and Fritz 1997 [DIRS 105738]).

Because of these considerations (those noted in this section (Section 6.14.2.2.1)), it is expected that the interpretation-based estimate of the number of fast pathways in the ESF and ECRB would be conservative, and lower than the actual number of pathways that would have been active since the advent of weapons testing. However, because of the large number of samples analyzed, the general distribution of recently active pathways should be well represented by the tritium data.

\subsection{Results and Interpretation of Tritium Analyses}

There were two different interpretations of tritium-analysis results. In interpretation (1), the tritium levels were interpreted as exceeding the threshold if the measured value after subtraction of the $2 \sigma$ error was greater than $1 \mathrm{TU}$. In cases where the tritium levels were less than the $2 \sigma$ error, this was interpreted as a condition in which no tritium was present (Scanlon 2000 [DIRS 171740], p. 403). In interpretation (2), the tritium levels were interpreted as exceeding the threshold if the measured value was greater than $1 \mathrm{TU}$; this is a more straightforward and more conservative interpretation. Both interpretations are presented in this section (Section 6.14.2.2.2).

All the direct inputs from results of tritium activities are listed in Table 6-42. In the north ramp of the ESF, the tritium activities that exceeded the 1-TU threshold were found in most samples from the Bow Ridge fault in Alcove 2 (Borehole ESF-AL\#2-HPF\#1) (8 out of 11 samples according to interpretation (1), and 10 out of 11 samples according to interpretation (2)). These samples are from the Tiva Canyon Tuff, which lies above the Paintbrush Tuff nonwelded units. Samples from Borehole ESF-LPCA-MOISTSTDY\#02 and boreholes with designations ESF-NR did not show elevated tritium activities.

Along the Drill Hole Wash fault (boreholes with designation ESF-DHW, located in the Topopah Spring Tuff, which lies below the Paintbrush Tuff nonwelded units), no tritium activity that exceeded the 1-TU threshold was found according to interpretation (1), and 2 out of 10 samples contained tritium activities of $1.6 \mathrm{TU}$ (i.e., above the 1-TU threshold) according to interpretation (2).

In the ESF main drift along the Sundance fault (boreholes with designation ESF-SD), only 1 out of 42 samples from 40 boreholes in the vicinity of the Sundance fault zone (Boreholes ESF-SD-CIV\#01 through ESF-SD-CIV\#40) contained tritium activities in excess of $1 \mathrm{TU}$, according to interpretation (1); 5 out of 42 samples had measured values that exceeded the 1-TU threshold, according to interpretation (2).

Among the remaining 15 samples from the ESF main drift $(10$ samples from Alcove 6 (Borehole ESF/NAD/GTB\#1A and designation ESF-AL6), and 5 samples from Alcove 7 (Borehole ESF/SAD/GTB\#1)), there were two samples with high tritium-activity values, according to interpretation (1); and there were 10 samples with measured values that exceeded the 1-TU threshold, according to interpretation (2). Both Alcove 6 and Alcove 7 intercept the 
Ghost Dance fault, which is a potential fast path from the ground surface to reach the repository level.

In the south ramp of the ESF (borehole designation ESF-SR), where the Paintbrush Tuff nonwelded units are faulted and offset in a number of locations, most of the 23 samples contained tritium-activity values greater than the 1-TU threshold (15 samples, according to interpretation (1); and 19 samples, according to interpretation (2)). The young pore water present along the ESF south ramp occurs both above and below the nonwelded units. This indicates significant, rapid infiltration in this part of the ESF that is able to quickly bypass the nonwelded units, probably because of the extensive faulting.

In the ECRB (borehole designation ECRB-SYS), a significant fraction of the 22 samples that were analyzed had tritium-activity values greater than the 1-TU threshold limit (9 samples according to interpretation (1), and 11 samples according to interpretation (2)). All samples between station $7+50$ and $9+50$ in the upper lithophysal unit of the Topopah Spring Tuff in the ECRB indicated the presence of young pore water. Other more isolated locations indicating the presence of young pore water occurred in the middle nonlithophysal and lower lithophysal zones of the Topopah Spring Tuff (TSw) at station 13+50, 15+00, 19+50, and 21+50 in the ECRB. Attempts to duplicate the high tritium-activity levels found at two locations yielded mixed results. Three samples from the borehole at station 15+00 in the ECRB were analyzed, with two of the three samples containing elevated tritium-activity levels according to interpretation (1) and all three samples according to interpretation (2). Two samples from the borehole at station $21+50$ in the ECRB were analyzed, and only one contained elevated tritium activity for both interpretations.

VS cores from the Sundance fault zone also were analyzed for whole-rock ${ }^{234} \mathrm{U} /{ }^{238} \mathrm{U}$ compositions, assuming that fast pathways would result in long-term differences in the degree of uranium-series isotope disequilibrium. Results from samples within the highly fractured and faulted VS study area are statistically identical to samples of unfaulted tuff elsewhere in the repository (Gascoyne et al. 2002 [DIRS 154800]).

Corroborative tritium data were also measured from samples collected along vertical surface-based boreholes (DTN: GS951208312272.002 [DIRS 151649]) and from other ESF borehole intervals (DTN: GS990183122410.004 [DIRS 146129]) not included in Table 6-42.

Table 6-42. Tritium Activities Found in Samples from Locations in the ESF and ECRB

\begin{tabular}{|l|c|c|c|}
\hline \multicolumn{1}{|c|}{ Borehole Name $^{\text {a }}$} & $\begin{array}{c}\text { Interval } \\
\text { (ft) }\end{array}$ & $\begin{array}{c}\text { Tritium } \\
\text { (TU) }\end{array}$ & $\begin{array}{c}\text { Tritium Error } \\
\text { (TU) }\end{array}$ \\
\hline ESF-AL\#2-HPF\#1 & $16.4-16.7$ & $<0.1$ & 3.9 \\
\hline ESF-AL\#2-HPF\#1 & $23.2-23.5$ & 2.0 & 3.9 \\
\hline ESF-AL\#2-HPF\#1 & $27.8-28.0$ & 5.1 & 3.9 \\
\hline ESF-AL\#2-HPF\#1 & $34.3-34.6$ & 28.8 & 4.2 \\
\hline ESF-AL\#2-HPF\#1 & $47.2-47.6$ & 30.9 & 4.2 \\
\hline ESF-AL\#2-HPF\#1 & $50.5-50.7$ & 118.3 & 9.4 \\
\hline ESF-AL\#2-HPF\#1 & $55.4-55.7$ & 128.1 & 5.2 \\
\hline ESF-AL\#2-HPF\#1 & $58.9-59.0$ & 78.6 & 4.7 \\
\hline ESF-AL\#2-HPF\#1 & $61.2-61.3$ & 65.3 & 4.6 \\
\hline ESF-AL\#2-HPF\#1 & $68.6-68.9$ & 154.6 & 5.5 \\
\hline
\end{tabular}


Table 6-42. Tritium Activities Found in Samples from Locations in the ESF and ECRB (Continued)

\begin{tabular}{|c|c|c|c|}
\hline Borehole Name $^{a}$ & $\begin{array}{c}\text { Interval } \\
\text { (ft) }\end{array}$ & $\begin{array}{c}\text { Tritium } \\
\text { (TU) }\end{array}$ & $\begin{array}{c}\text { Tritium Error } \\
\text { (TU) }\end{array}$ \\
\hline ESF-AL\#2-HPF\#1 & $83.6-83.8$ & 32.9 & 4.3 \\
\hline ESF-LPCA-MOISTSTDY\#02 & $6.4-7.0$ & $<0.1$ & 0.2 \\
\hline ESF-NR-MOISTSTDY\#03 & $4.4-5.0$ & 0.2 & 0.4 \\
\hline ESF-NR-MOISTSTDY\#10 & $4.6-6.5$ & 0.2 & 0.2 \\
\hline ESF-DHW-CIV\#01 ${ }^{\mathrm{b}}$ & $10.9-13.2$ & 1.0 & 0.4 \\
\hline ESF-DHW-CIV\#02 ${ }^{b}$ & $6.5-8.2$ & 0.5 & 0.7 \\
\hline ESF-DHW-CIV\#03 ${ }^{b}$ & $12.0-13.3$ & 1.6 & 0.4 \\
\hline ESF-DHW-CIV\#04 ${ }^{\mathrm{b}}$ & $12.3-13.7$ & 0.9 & 0.3 \\
\hline ESF-DHW-CIV\#05 ${ }^{\mathrm{b}}$ & $26.7-28.7$ & 0.7 & 0.3 \\
\hline ESF-DHW-CIV\#06 ${ }^{\mathrm{b}}$ & $12.2-13.9$ & 0.5 & 0.3 \\
\hline ESF-DHW-CIV\#07 ${ }^{\mathrm{b}}$ & $9.6-11.0$ & 1.6 & 0.4 \\
\hline ESF-DHW-CIV\#08 ${ }^{\mathrm{b}}$ & $11.7-13.1$ & 0.2 & 0.5 \\
\hline ESF-DHW-CIV\#09 ${ }^{b}$ & $11.5-12.5$ & 0.6 & 0.6 \\
\hline ESF-DHW-CIV\#10 ${ }^{b}$ & $11.2-12.4$ & 0.9 & 0.2 \\
\hline ESF-SD-CIV\#01 ${ }^{\mathrm{b}}$ & $11.5-12.6$ & 0.5 & 0.4 \\
\hline ESF-SD-CIV\#02 ${ }^{b}$ & $8.0-9.9$ & 0.1 & 0.3 \\
\hline ESF-SD-CIV\#03 ${ }^{b}$ & $10.7-11.4$ & 0.6 & 0.3 \\
\hline ESF-SD-CIV\#04 ${ }^{\mathrm{b}}$ & $11.8-13.4$ & 0.3 & 0.4 \\
\hline ESF-SD-CIV\#0 ${ }^{b}$ & $7.9-9.7$ & 0.7 & 0.2 \\
\hline ESF-SD-CIV\#06 ${ }^{b}$ & $9.3-10.5$ & 1.1 & 0.5 \\
\hline ESF-SD-CIV\#07 ${ }^{\text {b }}$ & $8.1-9.7$ & 0.3 & 0.4 \\
\hline ESF-SD-CIV\#08 ${ }^{b}$ & $7.9-9.9$ & 0.6 & 0.3 \\
\hline ESF-SD-CIV\#09 ${ }^{b}$ & $10.1-11.5$ & 0.2 & 0.3 \\
\hline ESF-SD-CIV\#10 ${ }^{b}$ & $11.8-13.0$ & 0.4 & 0.3 \\
\hline ESF-SD-CIV\#11 ${ }^{\mathrm{b}}$ & $11.0-12.5$ & 0.2 & 0.3 \\
\hline ESF-SD-CIV\#12 ${ }^{b}$ & $11.8-13.4$ & 0.2 & 0.3 \\
\hline ESF-SD-CIV\#13 ${ }^{b}$ & $30.5-32.3$ & 0.6 & 0.4 \\
\hline ESF-SD-CIV\#14 ${ }^{\mathrm{b}}$ & $11.6-13.4$ & $<0.1$ & 0.2 \\
\hline ESF-SD-CIV\#15 ${ }^{b}$ & $12.0-13.5$ & 0.6 & 0.5 \\
\hline ESF-SD-CIV\#16 ${ }^{b}$ & $12.0-13.2$ & 0.2 & 0.3 \\
\hline ESF-SD-CIV\#17 ${ }^{\mathrm{b}}$ & $10.5-12.0$ & 1.0 & 0.3 \\
\hline ESF-SD-CIV\#17 ${ }^{\mathrm{b}}$ & $12.0-13.2$ & 0.7 & 0.4 \\
\hline ESF-SD-CIV\#18 ${ }^{b}$ & $10.9-11.8$ & 1.4 & 0.8 \\
\hline ESF-SD-CIV\#18 ${ }^{b}$ & $12.3-13.5$ & 2.6 & 0.5 \\
\hline ESF-SD-CIV\#19 ${ }^{b}$ & $11.7-13.1$ & 0.6 & 0.4 \\
\hline ESF-SD-CIV\#20 ${ }^{b}$ & $10.5-13.0$ & $<0.1$ & 0.2 \\
\hline ESF-SD-CIV\#21 ${ }^{\mathrm{b}}$ & $9.8-11.1$ & 0.4 & 0.3 \\
\hline ESF-SD-CIV\#22 ${ }^{b}$ & $10.4-11.2$ & 0.2 & 0.3 \\
\hline ESF-SD-CIV\#23 ${ }^{b}$ & $12.6-13.7$ & 0.2 & 0.3 \\
\hline ESF-SD-CIV\#24 ${ }^{\mathrm{b}}$ & $12.1-13.4$ & 0.4 & 0.3 \\
\hline ESF-SD-CIV\#25 ${ }^{\mathrm{b}}$ & $8.7-9.9$ & 0.2 & 0.4 \\
\hline ESF-SD-CIV\#26 ${ }^{b}$ & $12.2-13.2$ & 0.1 & 0.4 \\
\hline ESF-SD-CIV\#27 ${ }^{b}$ & $12.0-13.4$ & 0.2 & 0.2 \\
\hline ESF-SD-CIV\#28 ${ }^{b}$ & $8.0-11.3$ & 1.1 & 0.3 \\
\hline ESF-SD-CIV\#29 ${ }^{b}$ & $10.7-12.2$ & 0.3 & 0.2 \\
\hline ESF-SD-CIV\#30 ${ }^{\mathrm{b}}$ & $12.2-13.4$ & 0.2 & 0.3 \\
\hline
\end{tabular}


Table 6-42. Tritium Activities Found in Samples from Locations in the ESF and ECRB (Continued)

\begin{tabular}{|c|c|c|c|}
\hline Borehole Name ${ }^{a}$ & $\begin{array}{c}\text { Interval } \\
\text { (ft) }\end{array}$ & $\begin{array}{l}\text { Tritium } \\
\text { (TU) }\end{array}$ & $\begin{array}{c}\text { Tritium Error } \\
\text { (TU) }\end{array}$ \\
\hline ESF-SD-CIV\#31 ${ }^{\mathrm{b}}$ & $11.0-12.6$ & 0.3 & 0.4 \\
\hline ESF-SD-CIV\#32 ${ }^{b}$ & $11.6-13.2$ & 0.3 & 0.2 \\
\hline ESF-SD-CIV\#33 ${ }^{b}$ & $7.7-8.9$ & 0.9 & 0.3 \\
\hline ESF-SD-CIV\#34 ${ }^{\mathrm{b}}$ & $10.5-12.0$ & 0.5 & 0.2 \\
\hline ESF-SD-CIV\#35 ${ }^{\mathrm{b}}$ & $10.0-11.4$ & 0.3 & 0.2 \\
\hline ESF-SD-CIV\#36 ${ }^{\mathrm{b}}$ & $6.7-8.1$ & $<0.1$ & 0.2 \\
\hline ESF-SD-CIV\#37 ${ }^{\mathrm{b}}$ & $9.7-11.2$ & 0.3 & 0.1 \\
\hline ESF-SD-CIV\#38 ${ }^{b}$ & $11.0-12.5$ & 1.4 & 0.8 \\
\hline ESF-SD-CIV\#39 ${ }^{b}$ & $11.2-12.7$ & 0.2 & 0.1 \\
\hline ESF-SD-CIV\#40 ${ }^{\mathrm{b}}$ & $12.3-13.3$ & 0.3 & 0.2 \\
\hline ESF/NAD/GTB\#1A & $114.0-115.0$ & 0.5 & 0.3 \\
\hline ESF/NAD/GTB\#1A & $120.3-121.6$ & 1.0 & 0.4 \\
\hline ESF/NAD/GTB\#1A & $127.0-129.0$ & 1.6 & 0.6 \\
\hline ESF/NAD/GTB\#1A & $165.8-166.7$ & 0.8 & 0.5 \\
\hline ESF-AL6-NDR-MF\#01 & $53.9-55.6$ & 1.3 & 0.5 \\
\hline ESF-AL6-NDR-MF\#02 & $42.3-43.9$ & 1.6 & 0.7 \\
\hline ESF-AL6-NDR-MF\#02 & $47.3-49.0$ & 1.2 & 0.2 \\
\hline ESF-AL6-NDR-MF\#02 & $49.3-51.3$ & 1.1 & 0.5 \\
\hline ESF-AL6-NDR-MF\#02 & $55.3-57.0$ & 1.0 & 0.6 \\
\hline ESF-AL6-NDR-MF\#02 & $61.1-62.9$ & 0.9 & 0.7 \\
\hline ESF/SAD/GTB\#1 & $85.1-86.0$ & 1.2 & 0.5 \\
\hline ESF/SAD/GTB\#1 & $103.4-104.1$ & 3.7 & 0.7 \\
\hline ESF/SAD/GTB\#1 & $124.3-125.9$ & 1.1 & 0.3 \\
\hline ESF/SAD/GTB\#1 & $175.4-177.0$ & 1.8 & 0.7 \\
\hline ESF/SAD/GTB\#1 & $214.5-216.9$ & 2.3 & 0.3 \\
\hline ESF-SR-MOISTSTDY\#03 & $2.9-5.7$ & 1.7 & 0.4 \\
\hline ESF-SR-MOISTSTDY\#10 & $2.4-6.4$ & 28.6 & 1.8 \\
\hline ESF-SR-MOISTSTDY\#11 & $3.2-6.9$ & 4.8 & 0.4 \\
\hline ESF-SR-MOISTSTDY\#13 & $6.0-6.8$ & 3.1 & 0.3 \\
\hline ESF-SR-MOISTSTDY\#16 & $4.6-6.8$ & 8.2 & 0.5 \\
\hline ESF-SR-MOISTSTDY\#17 & $5.8-6.7$ & 3.8 & 0.3 \\
\hline ESF-SR-MOISTSTDY\#17 & $5.8-6.7$ & 3.5 & 0.5 \\
\hline ESF-SR-MOISTSTDY\#18 & $4.6-6.7$ & 1.1 & 0.4 \\
\hline ESF-SR-MOISTSTDY\#19 & $4.5-6.9$ & 14.3 & 1.0 \\
\hline ESF-SR-MOISTSTDY\#20 & $4.2-6.8$ & 7.4 & 0.4 \\
\hline ESF-SR-MOISTSTDY\#23 & $16.2-17.0$ & 0.5 & 0.2 \\
\hline ESF-SR-MOISTSTDY\#23 & $16.2-17.0$ & 0.3 & 0.2 \\
\hline ESF-SR-MOISTSTDY\#25 & $5.0-6.9$ & 4.4 & 0.4 \\
\hline ESF-SR-MOISTSTDY\#26 & $7.4-9.6$ & 4.9 & 0.3 \\
\hline ESF-SR-MOISTSTDY\#27 & $5.9-6.8$ & 1.5 & 0.4 \\
\hline ESF-SR-MOISTSTDY\#28 & $2.5-6.8$ & 3.2 & 0.4 \\
\hline ESF-SR-MOISTSTDY\#29 & $4.5-6.8$ & 0.8 & 0.2 \\
\hline ESF-SR-MOISTSTDY\#30 & $3.8-6.7$ & 12.5 & 0.6 \\
\hline ESF-SR-MOISTSTDY\#31 & $4.7-7.0$ & 5.4 & 0.3 \\
\hline ESF-SR-MOISTSTDY\#33 & $5.9-6.9$ & 2.7 & 0.3 \\
\hline ESF-SR-MOISTSTDY\#34 & $5.9-6.8$ & 1.2 & 0.2 \\
\hline
\end{tabular}


Table 6-42. Tritium Activities Found in Samples from Locations in the ESF and ECRB (Continued)

\begin{tabular}{|c|c|c|c|}
\hline Borehole Name ${ }^{a}$ & $\begin{array}{l}\text { Interval } \\
\text { (ft) }\end{array}$ & $\begin{array}{c}\text { Tritium } \\
\text { (TU) }\end{array}$ & $\begin{array}{l}\text { Tritium Error } \\
\text { (TU) }\end{array}$ \\
\hline ESF-SR-MOISTSTDY\#38 & $5.9-6.8$ & 1.7 & 0.3 \\
\hline ESF-SR-MOISTSTDY\#40 & $5.9-6.9$ & 0.6 & 0.2 \\
\hline ECRB-SYS-CS0600 ${ }^{\circ}$ & $3.2-6.0$ & 0.8 & 0.3 \\
\hline ECRB-SYS-CS0750 ${ }^{\circ}$ & $3.6-6.2$ & 6.2 & 0.5 \\
\hline ECRB-SYS-CS0800 ${ }^{\circ}$ & $2.9-5.8$ & 1.7 & 0.3 \\
\hline ECRB-SYS-CS0900 ${ }^{\circ}$ & $3.5-6.4$ & 6.5 & 0.6 \\
\hline ECRB-SYS-CS0950 ${ }^{\circ}$ & $2.8-5.6$ & 6.1 & 0.4 \\
\hline ECRB-SYS-CS1000 ${ }^{c}$ & $17.4-18.2$ & 0.5 & 0.3 \\
\hline ECRB-SYS-CS1200 ${ }^{\circ}$ & $2.9-6.9$ & 0.4 & 0.2 \\
\hline ECRB-SYS-CS1300 ${ }^{\circ}$ & $3.0-5.5$ & 0.7 & 0.7 \\
\hline ECRB-SYS-CS1350 ${ }^{\circ}$ & $3.6-6.4$ & 3.8 & 0.5 \\
\hline ECRB-SYS-CS1450 ${ }^{\circ}$ & $4.0-6.5$ & 0.3 & 0.5 \\
\hline ECRB-SYS-CS1500 ${ }^{\circ}$ & $4.3-7.1$ & 10.3 & 0.9 \\
\hline ECRB-SYS-CS1500 ${ }^{\circ}$ & $9.5-12.1$ & 1.5 & 0.4 \\
\hline ECRB-SYS-CS1500 ${ }^{\mathrm{C}}$ & $14.4-17.4$ & 2.5 & 0.4 \\
\hline ECRB-SYS-CS1600 ${ }^{\circ}$ & $3.4-4.3$ & 1.7 & 0.9 \\
\hline ECRB-SYS-CS1750 ${ }^{\circ}$ & $5.5-5.9$ & 0.6 & 0.4 \\
\hline ECRB-SYS-CS1800 ${ }^{\circ}$ & $3.6-6.1$ & 0.1 & 0.8 \\
\hline ECRB-SYS-CS1950 ${ }^{\circ}$ & $4.0-6.5$ & 3.6 & 0.5 \\
\hline ECRB-SYS-CS2000 ${ }^{\circ}$ & $11.0-11.9$ & 0.1 & 0.5 \\
\hline ECRB-SYS-CS2150 ${ }^{\circ}$ & $3.4-4.1$ & $<0.1$ & 0.9 \\
\hline ECRB-SYS-CS2150 ${ }^{\circ}$ & $5.5-6.7$ & 9.8 & 0.5 \\
\hline ECRB-SYS-CS2250 ${ }^{\circ}$ & $2.9-3.9$ & 0.8 & 0.4 \\
\hline ECRB-SYS-CS2500 ${ }^{\circ}$ & $16.7-19.8$ & 0.6 & 0.3 \\
\hline
\end{tabular}

Source: DTNs: GS990183122410.001 [DIRS 146125]; GS020408312272.002 [DIRS 162342]; GS021208312272.005 [DIRS 162934]; GS030208312272.001 [DIRS 162935].

a Borehole location designations are as follows:

ESF-AL\#2 (Bow Ridge fault), EDF-LPCA-MOISTSTDY (Alcove 4), ESF-NR-MOISTSTDY (ESF north ramp), ESF-DHW-CIV (Drill Hole Wash fault), ESF-SD-CIV (Sundance fault), ESF/NAD/GTB\#1A (Alcove 6 access drift), ESF-AL6 (Alcove 6), ESF/SAD/GTB\#1 (Alcove 7 access drift), ESF-SR-MOISTSTDY (ESF south ramp), and ECRB-SYS (ECRB systematic testing).

b Validation Study (VS) boreholes.

${ }^{c}$ The last four digits of the borehole name correspond to the ECRB station number, which indicates distance from the ESF main drift (e.g., Borehole ECRB-SYS-CS0600 is located at ECRB station 06+00, which is $600 \mathrm{~m}$ from the ESF main drift).

\subsubsection{Reconstruction of the Paragenetic Sequence and Thermal History of Fracture- Hosted Secondary Mineral Deposits}

Detailed mapping of the secondary mineral deposits has shown that in high-angle fracture settings, the deposits generally are restricted to the fracture footwalls; in cavity settings, deposits are restricted to the cavity floors. The mineral coatings typically are:

1. Heterogeneously distributed, and found on less than 10 percent of open fractures and cavities,

2. Discontinuous and patchy within fractures, 
3. Of irregular thickness in cavities and without geopetal features indicating ponding,

4. Adjoining or intersected by barren fractures and cavities (Paces et al. 2001 [DIRS 156507]; Whelan et al. 2002 [DIRS 160442]; and Whelan et al. 2003 [DIRS 163590]).

This distribution of coatings is consistent with studies of gravity-controlled fracture flow in UZ settings that predict that percolating waters would concentrate in a small percentage of the available flow paths (Tokunaga and Wan 1997 [DIRS 139195]; Pruess 1999 [DIRS 104250]). Although some have argued that the deposits formed from upwelling of hydrothermal fluids (Dublyansky et al. 1996 [DIRS 109204], 2001 [DIRS 161543]), the sparse and patchy distribution of the deposits on open-space lower surfaces, coupled with the lack of evidence that fluids filled available openings (such as coatings on the hanging-walls of fractures or completely lining the interiors of cavities), indicates that the deposits formed from descending percolating water in a vadose setting (Paces et al. 2001 [DIRS 156507]; Whelan et al. 2002 [DIRS 160442]; and Whelan et al. 2003 [DIRS 163590]).

Most coatings are consistent with the following generalized paragenetic sequence:

(1) Many deposits begin with an early stage of calcite \pm fluorite and, on rare occasions, zeolites; this stage is commonly capped by botryoidal chalcedony \pm drusy quartz.

(2) The intermediate stage is largely calcite and opal, on rare occasions, with minor fluorite.

(3) The late stage consists of calcite and opal (Whelan et al. 2002 [DIRS 160442]).

Thin, patchy coatings of manganese-oxides are common on fracture walls, where such coatings may underlie the secondary mineral coatings (Carlos et al. 1993 [DIRS 105210]).

\subsection{Results}

Some of the deposits contained early- or intermediate-stage calcite that had two-phase, liquid and vapor, fluid inclusions (FIs) suitable for thermometric determinations of depositional temperature. Based on measurements of Homogenization Temperature $\left(T_{h}\right)$ in approximately 4,000 FIs in samples from 52 underground locations, measured depositional temperatures range from $37^{\circ} \mathrm{C}$ to $89^{\circ} \mathrm{C}$ in calcite, and from $57^{\circ} \mathrm{C}$ to $93^{\circ} \mathrm{C}$ in fluorite (Figure 6-196). Fluid-inclusion $\mathrm{T}_{\mathrm{h}}$ in calcite decreases: from east to west along the ESF north ramp in the north bend (from approximately $90^{\circ} \mathrm{C}$ to approximately $60^{\circ} \mathrm{C}$ ); from northeast to southwest along the ECRB Cross-Drift from approximately $60^{\circ} \mathrm{C}$ to $50^{\circ} \mathrm{C}$; and from north to south along the ESF main drift from approximately $60^{\circ} \mathrm{C}$ to approximately $45^{\circ} \mathrm{C}$ (Figure 6-196). Temperature trends are not apparent in the ESF south ramp data. Where paragenetic relations indicate that multiple generations of calcite in a deposit provide $T_{h}$ data, depositional temperatures decrease with time. These results are in close agreement with measurements obtained from the same samples by Wilson et al. (2000 [DIRS 154279]); 2000 [DIRS 154280]); and by Wilson and Cline (2001 [DIRS 155426]). 

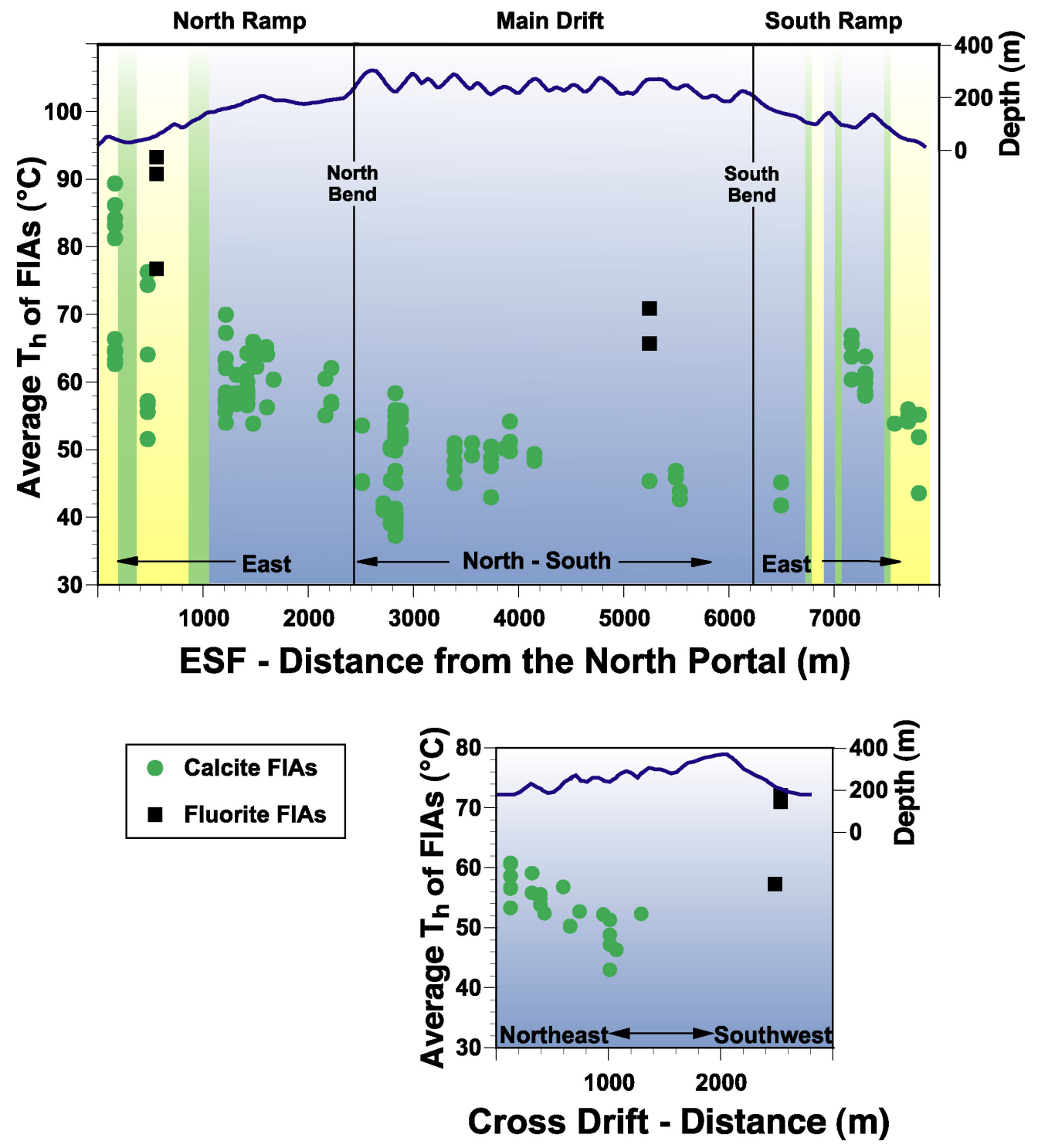

Source: DTNs: GS010808315215.003 [DIRS 164844]; GS020908315215.003 [DIRS 164846].

NOTES: Figure illustrates liquid ratios in Fluid Inclusion Assemblages (FIA) in calcite and fluorite from secondary mineral coating samples from the Exploratory Studies Facility (ESF) and Enhanced Characterization of the Repository Block (ECRB) Cross-Drift tunnels.

Yellow and blue backgrounds for the welded tuffs of the Tiva Canyon and Topopah Spring Tuffs, respectively, and a green background for the intervening bedded and nonwelded tuffs illustrate tunnel stratigraphy. Depth of the tunnel below ground surface is plotted along the tops of the graphs.

Figure 6-196. The Average Homogenization Temperatures $\left(T_{h}\right)$ of Two-Phase Fluid Inclusions with Small and Consistent Vapor

Although FIs suitable for $\mathrm{T}_{\mathrm{h}}$ determinations are common in the early stage and locally observed in the intermediate stage, they have not been observed in the late stage of deposits. Fluid inclusions in the late stage are largely all-liquid, with no two-phase inclusions that might indicate calcite deposition at higher-than-modern-ambient temperatures. 
Calcite $\delta^{18} \mathrm{O}$ values from 135 ESF main-drift and 34 ECRB Cross-Drift locations range widely: from approximately -1 to almost $24 \%$, with the lowest $\delta^{18} \mathrm{O}$ values in the paragenetically older calcites (Figure 6-197). Most early-stage calcite $\delta^{18} \mathrm{O}$ values are in the range of 5 to $15 \%$. Minimum $\delta^{18} \mathrm{O}$ values of early-stage calcite tend to increase westward along both the ESF north and south ramps, from less than $10 \%$ to approximately $12 \%$ in the ESF main drift and the ECRB Cross-Drift. Intermediate calcite $\delta^{18} \mathrm{O}$ values are in the range of 10.9 to $23.0 \%$, with most values between 13 and $18 \%$. Late-stage calcite $\delta^{18} \mathrm{O}$ values are in the range of 14.4 to $21.3 \%$, with most values between 16 and 20\% (Figure 6-197). Late-stage calcite values decrease systematically with depth, and are relatively constant within the ESF main drift and ECRB Cross-Drift.
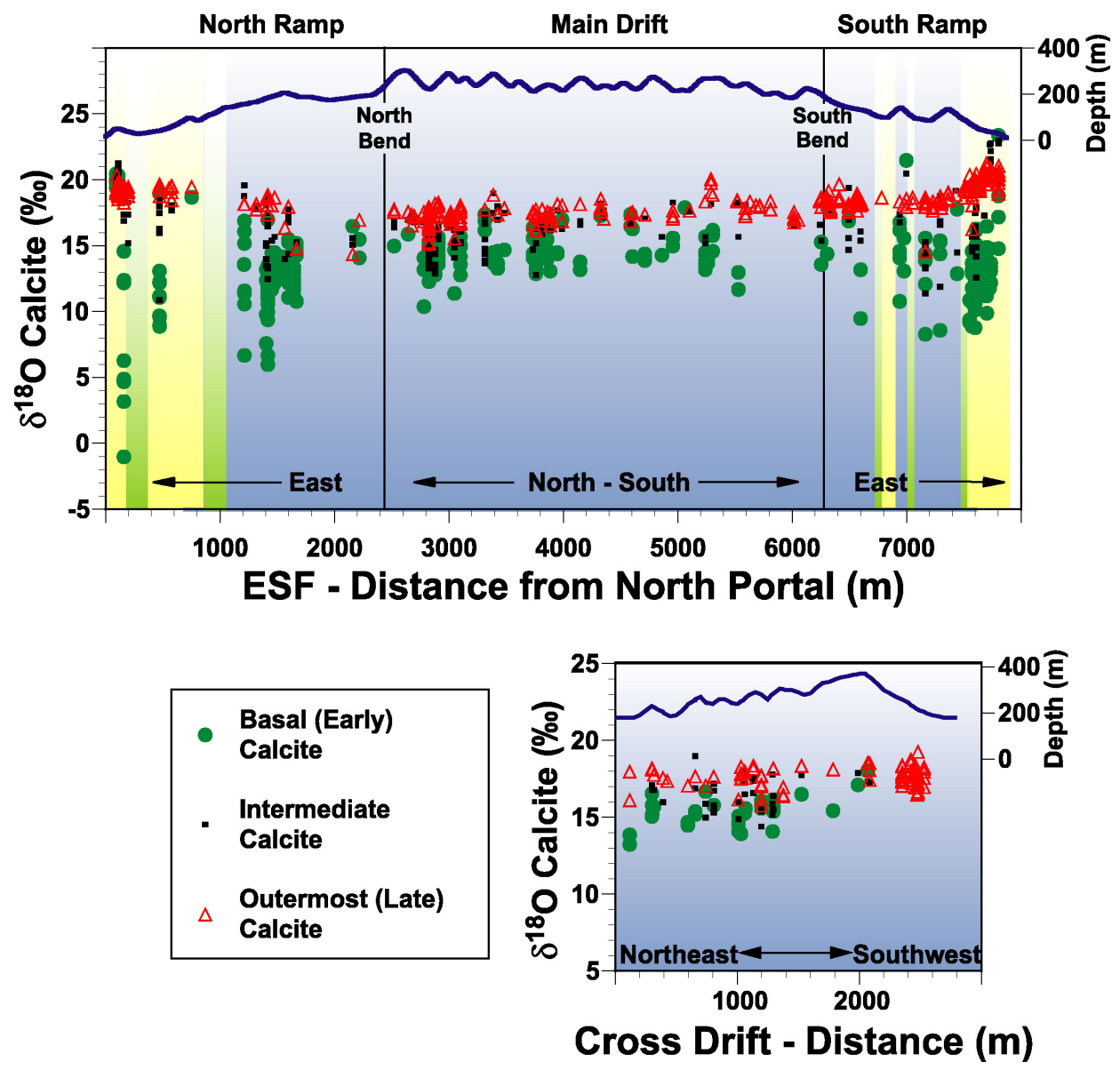

Source: DTNs: GS020908315215.004 [DIRS 164846]; GS970208315215.005 [DIRS 107351]; GS970808315215.010 [DIRS 145920]; GS980908315213.002 [DIRS 146088]; GS990908315213.001 [DIRS 153379].

NOTES: Yellow and blue backgrounds for the welded tuffs of the Tiva Canyon and Topopah Spring Tuffs, respectively, and a green background for the intervening bedded and nonwelded tuffs illustrate tunnel stratigraphy. Depth of the tunnel below ground surface is plotted near the tops of the graphs. Calcite $\delta^{18} \mathrm{O}$ values are reported versus the standard mean ocean water (SMOW) scale wherein the $\delta^{18} \mathrm{O}$ value of NBS-19 calcite is 28.65 percent (Coplen et al. 2003 [DIRS 165235], pp. 36-37). The $\delta^{18} \mathrm{O}$ value of water is estimated from $\delta^{18} \mathrm{O}$ values from calcite as in Marshall et al. (2000 [DIRS 151018]).

Figure 6-197. The $\delta^{18} \mathrm{O}$ Values of Calcite from Secondary Mineral Coating Samples in the ESF and ECRB Cross-Drift Tunnels 
The $\delta^{18} \mathrm{O}$ values of the outermost (most recently developed) calcite in the UZ coatings decrease with depth (Figure 6-198). Assuming a $\delta^{18} \mathrm{O}_{\mathrm{H} 2 \mathrm{O}}$ of $-13 \%$, consistent with recent recharge in the tuffs (Yang et al. 1996 [DIRS 100194]), the decrease of the $\delta^{18} \mathrm{O}$ value with depth in the Topopah Spring Tuff (TSw) displayed by the latest calcite is consistent with a geothermal gradient of approximately $27^{\circ} \mathrm{C} / \mathrm{km}$ (Figure 6 in Whelan et al. 2002 [DIRS 160442]), slightly higher than the measured gradient of approximately $24^{\circ} \mathrm{C} / \mathrm{km}$ determined from Sass et al. (1988 [DIRS 100644]; 1995 [DIRS 101288]). Within the overlying Tiva Canyon Tuff (TCw), however, outermost calcite $\delta^{18} \mathrm{O}$ values decrease rapidly with depth at a rate that, if solely a function of temperature, would suggest a geothermal gradient of more than $100^{\circ} \mathrm{C} / \mathrm{km}$, which is a high gradient, and one clearly at odds with that of the underlying Topopah Spring Tuff (TSw). It is more likely that much of the decrease of fracture-hosted calcite $\delta^{18} \mathrm{O}$ values with depth in the Tiva Canyon Tuff (TCw) reflects decreasing amounts of evaporative ${ }^{18} \mathrm{O}$-enrichment of water deeper in the fracture network. In the Topopah Spring Tuff (TSw), evaporation and ${ }^{18} \mathrm{O}$-enrichment are inhibited by the much less fractured bedded tuffs of the overlying Paintbrush nonwelded (PTn), which inhibit upward transport of the vapor phase (Thorstenson et al. 1998 [DIRS 126827]). The temperature estimates based on latest calcite $\delta^{18} \mathrm{O}$ values support the conclusion that late-stage deposition has been at or near modern ambient temperatures.

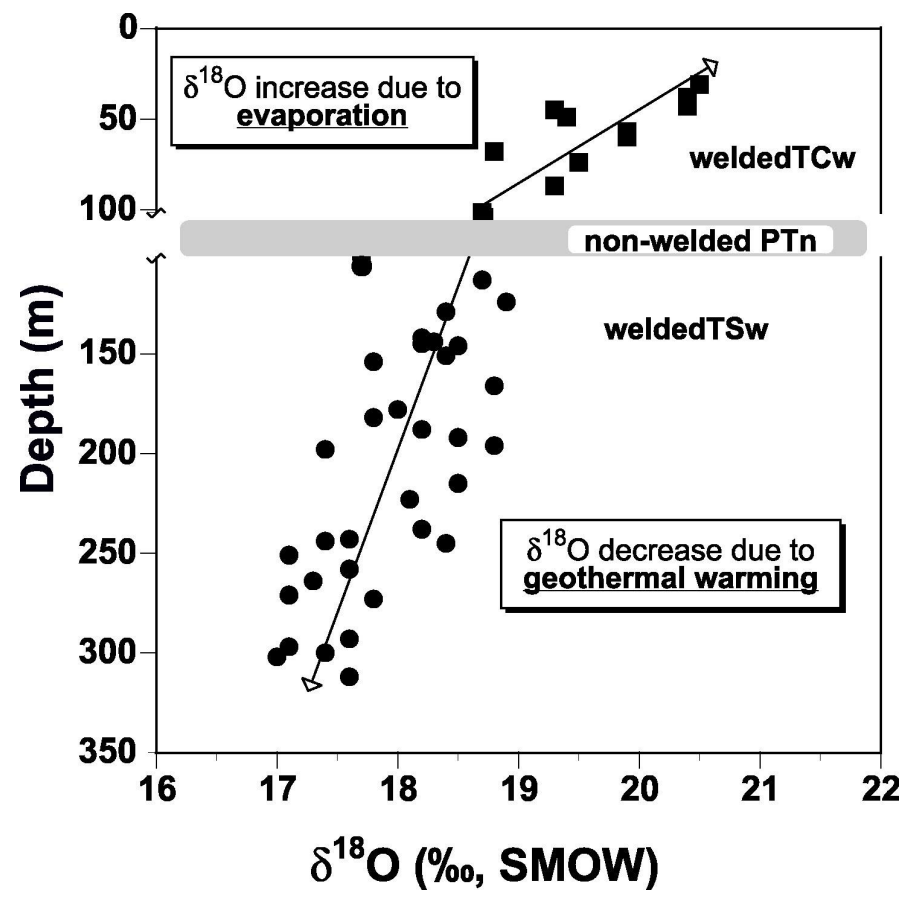

Source: DTNs: GS020908315215.004 [DIRS 164846]; GS970208315215.005 [DIRS 107351]; GS970808315215.010 [DIRS 145920]; GS980908315213.002 [DIRS 146088]; GS990908315213.001 [DIRS 153379].

NOTES: Modified from Whelan et al. (2002 [DIRS 160442]).

SMOW=standard mean ocean water

Legend: $\quad$ = Tiva Canyon Tuff (TCw).

$\bullet=$ Topopah Spring Tuff (TSw).

Figure 6-198. Calcite $\delta^{18} \mathrm{O}$ Values Plotted versus Depth Below the Surface in the ESF, Reflecting Separate Trends in the Tiva Canyon and Topopah Spring Welded Tuffs 
Calcite and fluorite hosting elevated temperature FIs were typically the earliest minerals precipitated. The timing of trapping for those FIs is constrained only to after initial cooling of the tuffs to less than $100^{\circ} \mathrm{C}$, and before deposition of the overlying chalcedony or opal that was dated. The ${ }^{207} \mathrm{~Pb} /{ }^{235} \mathrm{U}$ ages of subsamples of silica (which were collected above calcite that contained fluid inclusions with small and consistent vapor-to-liquid ratios) range from $1.14 \pm 0.16$ to $8.99 \pm 0.07 \mathrm{Ma}$. Similar data from four subsamples of opal/chalcedony overlying calcite with low $\delta^{18} \mathrm{O}$ values - indicative of higher depositional temperatures (Whelan et al. 2001 [DIRS 154773])—-have ${ }^{207} \mathrm{~Pb} /{ }^{235} \mathrm{U}$ ages ranging from $3.97 \pm 0.05$ to $9.7 \pm 1.5 \mathrm{Ma}$ (Neymark et al. 2002 [DIRS 158673]).

A graph of age versus temperature of deposition (Figure 6-199) shows that the highest temperatures occurred when the age is greater than or equal to $10 \mathrm{Ma}$, and that temperatures cooled gradually to near-modern ambient temperatures over the next six or more million years, where they have remained for the past 2 to 4 million years. The protracted cooling of the UZ since approximately $10 \mathrm{Ma}$ is consistent with published thermal models (Marshall and Whelan 2000 [DIRS 154415]; Marshall and Whelan 2001 [DIRS 163591]), which show that the large magma chamber less than $10 \mathrm{~km}$ to the north was responsible for the voluminous ash eruptions that formed the tuff sequence, could have supplied heat to the surrounding crust for that long.

ESF Stations 5+57 (fluorite), $1+62$ and $4+73$ are anomalously hot, with maximum temperatures between $76^{\circ} \mathrm{C}$ and $93^{\circ} \mathrm{C}$. These samples are only 40 to $60 \mathrm{~m}$ below the surface and do not appear to be compatible with subsurface magma-chamber-sourced heating. Geological relations and alteration rinds on the walls of the host fractures suggest that they formed from fluids hot enough to alter the tuffs. Such alteration is not observed from other locations. These minerals are consistent with deposition from fumarolic systems, such as occur elsewhere near the tops of the ash flows. Formation from deeper-sourced hydrothermal systems cannot be ruled out, although no evidence exists of the hotter roots of such systems, such as alteration of the deeper stratigraphic units in the UZ, or of ${ }^{18} \mathrm{O}$-enriched minerals that a fluid having undergone extensive water-rock interaction at hydrothermal temperatures would produce.

\subsubsection{URANIUM ISOTOPE STUDIES}

\subsubsection{Mineral-Climate Records of UZ Flow}

Although infiltrating water is expected to flow through connected fracture pathways in the tuffs (Bodvarsson and Bandurraga 1996 [DIRS 100102]; Flint et al. 2001 [DIRS 164506]; and Wu et al. 2001 [DIRS 156399]), modern fracture flow has not been observed in extensive underground excavations. Coatings of hydrogenic calcite and silica in fractures and lithophysal cavities represent a record of past percolation, and they are studied to determine the sources of solutions, timing of flow, thermal history of the rock mass, and amount of past seepage (Whelan et al. 1994 [DIRS 100091]; Paces et al. 1998 [DIRS 107408]; Whelan and Moscati 1998 [DIRS 109179]; Whelan et al. 1998 [DIRS 137305]; Marshall et al. 2000 [DIRS 151018]; Neymark and Paces 2000 [DIRS 127012]; Neymark et al. 2000 [DIRS 162710]; Paces et al. 2001 [DIRS 156507]; Neymark et al. 2002 [DIRS 158673]; Whelan et al. 2002 [DIRS 160442]; and Wilson and Cline 2001 [DIRS 155426]). 


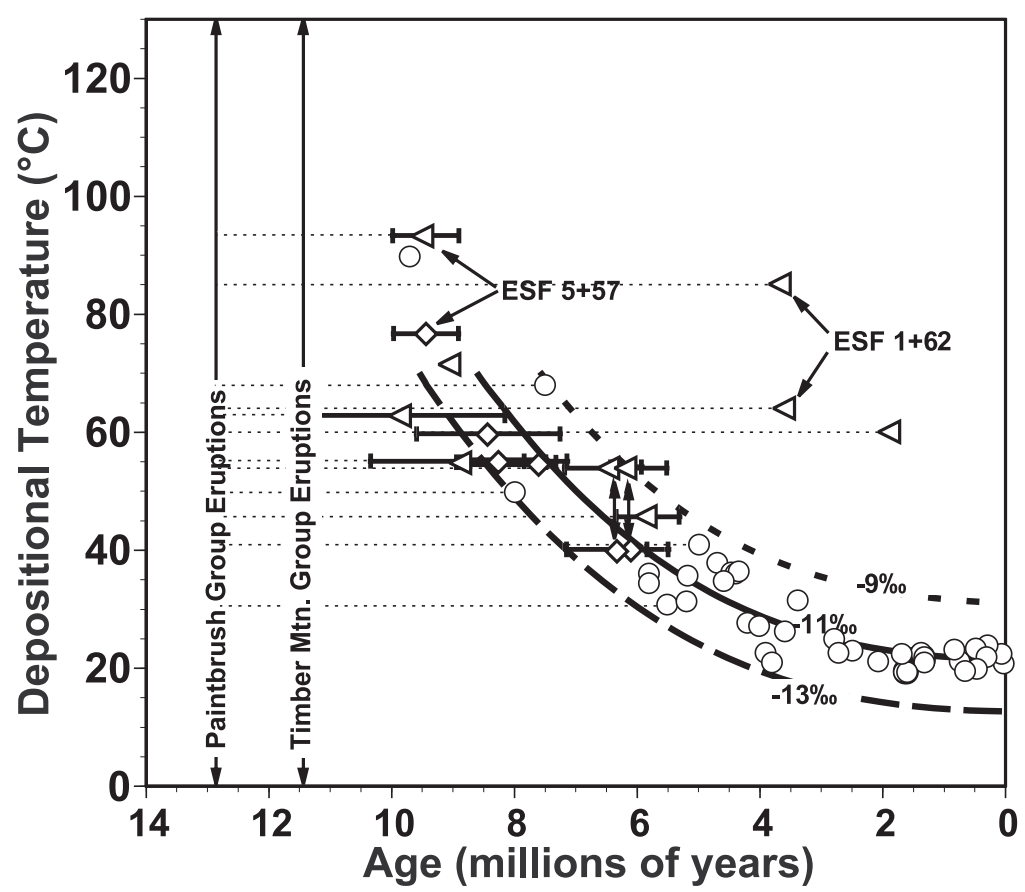

DTNs: GS020908315215.004 [DIRS 164846]; GS021008315215.005 [DIRS 164848]; GS970208315215.005 [DIRS 107351]; GS010808315215.004 [DIRS 164850]; GS970808315215.010 [DIRS 145920]; GS980908315213.002 [DIRS 146088]; GS990908315213.001 [DIRS 153379]; GS010808315215.003 [DIRS 164844]; GS020908315215.004 [DIRS 164847]; see also (Paces et al. 2001 [DIRS 156507])

NOTE: Temperatures determined from Fluid Inclusion Assemblages (FIA) $T_{h}$ are shown as open triangles for calcite that is older than the associated chalcedony/opal, with dotted lines connecting the age to the eruptive age of the host tuffs; the true age of the calcite lies somewhere along these dotted lines. Ages where paragenetic relations indicate the calcite and chalcedony/opal formed nearly contemporaneously are shown as open diamonds. Temperatures calculated from the $\delta^{18} \mathrm{O}$ value of calcite, assuming a $\delta^{18} \mathrm{O}$ for the depositing water of $-11 \%$, are shown as open circles. A best-fit curve for a water of $-11 \%$, as well as curves for waters of -13 and $-9 \%$, are shown.

Figure 6-199. Graph of Calcite Depositional Temperatures versus ${ }^{235} \mathrm{U} /{ }^{207} \mathrm{~Pb}$ or ${ }^{230} \mathrm{Th} / \mathrm{U}$ Depositional Ages of Chalcedony or Opal Associated with the Calcite

Previous uranium-series and uranium-lead dating of calcite and opal suggested uniform long-term average growth rates of fracture minerals at Yucca Mountain on the order of millimeters per million years (mm/Ma) (Neymark and Paces 2000 [DIRS 127012]; Paces et al. 2001 [DIRS 156507]; and Neymark et al. 2002 [DIRS 158673]). However, to more directly assess mineral growth histories and inferred hydrologic flow (seepage), improvements in the spatial resolution of age determinations are required. If hydrogenic mineral growth rates determined at finer scales of resolution can be established, growth histories may be compared to known cycles of Pleistocene climate variation at Yucca Mountain to help evaluate numerical models of UZ flow and seepage. 
Recent uranium-series investigations use two analytical methods, ion microprobe (IMP) and in situ microdigestions, followed by Thermal-Ionization Mass Spectrometry (TIMS). These methods result in ages for thinner layers (approximately 2 to $35 \mu \mathrm{m}$ ) of clear, hyalitic opal hemispheres. Opal reported in this section is from sample HD2074, an irregular mineral coating covering the floor of a large lithophysal cavity, $270 \mathrm{~m}$ below the land surface and $3051 \mathrm{~m}$ from the ESF North Portal of the ESF tunnel. The total mineral coating thickness varies between 1 and $4 \mathrm{~cm}$. Equant to elongated hemispheres up to 1 to $2 \mathrm{~mm}$ in diameter are present on the tips of thin calcite blades and show fine layering on micrometer scales.

\subsection{Results}

\section{Ion-Microprobe Results}

IMP traverses consisting of 7 to 10 spots were conducted across the outer 305 to $740 \mu \mathrm{m}$ of two opal hemispheres (Figure 6-200). The primary beam of ${ }^{16} \mathrm{O}_{2}{ }^{-}$ions resulted in roughly circular ablation pits approximately $45 \mu \mathrm{m}$ in diameter and 15 to $20 \mu \mathrm{m}$ deep. However, given the uniform layering, 91 percent of the mass analyzed in each spot represents the central, $35-\mu \mathrm{m}$-thick layers within the spot diameter. Resulting isotope ratios and ${ }^{230} \mathrm{Th} / \mathrm{U}$ ages are given in Table 6-43. Measured uranium isotope activity ratios range from 1.1 to 6.7. In spite of the relatively large analytical errors, IMP data follow paths expected for closed-system isotope evolution from a uniform initial ${ }^{234} \mathrm{U} /{ }^{238} \mathrm{U}$ of between 7 and 8 (the cross-hatched area in Figure 6-201). In contrast, mechanically separated total digestions of hemispheres and sheets of Yucca Mountain opal determined by TIMS are shifted toward lower ${ }^{230} \mathrm{Th} /{ }^{238} \mathrm{U}$ AR at a given value for ${ }^{234} \mathrm{U} /{ }^{238} \mathrm{U}$ (Neymark and Paces 2000 [DIRS 127012], Figure 4; and Paces et al. 2001 [DIRS 156507], Figure 13). The differences between these two patterns of isotope behavior are caused by integrating materials of widely varying ages in mechanically separated TIMS subsamples compared to the greater spatial resolution offered by the IMP spots. Sample weights for the opal residues analyzed by total digestion varied from approximately $0.2 \mathrm{mg}$ to $32 \mathrm{mg}$ (Paces et al. 2001 [DIRS 156507], Attachment 2b), compared to total masses of less than $0.05 \mu \mathrm{g}$ for IMP spots.

Table 6-43. Microstratigraphic Depth, Date, and Initial ${ }^{234} \mathrm{U} /{ }^{238} \mathrm{U}$ Activity Ratios for Sample HD2074 Opal as Determined by lon Probe

\begin{tabular}{|c|c|c|c|c|c|c|}
\hline $\begin{array}{l}\text { Spot } \\
\text { No. }\end{array}$ & Spot ID & $\begin{array}{c}\text { Micro- } \\
\text { stratigraphic } \\
\text { depth from } \\
\text { outer surface, } \\
(\mu \mathrm{m})\end{array}$ & $\begin{array}{c}{ }^{230} \mathrm{Th} / \mathrm{U} \text { date }{ }^{\mathrm{a}} \\
\text { (ka) }\end{array}$ & $\begin{array}{c}\text { Initial } \\
{ }^{234} U /^{238} U\end{array}$ & $\rho^{\mathrm{b}}$ & $\begin{array}{c}{ }^{234} \mathrm{U} / /^{238} \mathrm{U} \\
\text { estimated date } \\
(\mathrm{ka})^{\mathrm{C}}\end{array}$ \\
\hline 17 & 2074-g2-1.1 & N/A & $441 \pm 750$ & $1.39 \pm 0.71$ & 0.96 & $1426 \pm 379$ \\
\hline 18 & 2074-g2-2.1 & 27 & $51.9 \pm 8.2$ & $7.57 \pm 0.33$ & 0.11 & $42 \pm 29$ \\
\hline 19 & 2074-g2-3.1 & 75 & $137 \pm 19$ & $7.53 \pm 0.35$ & 0.63 & $128 \pm 27$ \\
\hline 20 & 2074-g2-4.1 & 135 & $183 \pm 36$ & $6.62 \pm 0.51$ & 0.81 & $228 \pm 32$ \\
\hline 21 & 2074-g2-5.1 & 237 & $268 \pm 110$ & $6.0 \pm 1.4$ & 0.95 & $353 \pm 48$ \\
\hline 22 & 2074-g2-6.1 & 340 & $298 \pm 120$ & $4.5 \pm 1.1$ & 0.97 & $516 \pm 46$ \\
\hline 23 & 2074-g2-7.1 & 467 & $560 \pm 600$ & $5.4 \pm 7.2$ & 1.00 & $693 \pm 39$ \\
\hline 24 & 2074-g2-8.1 & 740 & Excess ${ }^{230} \mathrm{Th}$ & Undefined & Undefined & $1041 \pm 78$ \\
\hline
\end{tabular}


Table 6-43. Microstratigraphic Depth, Date, and Initial ${ }^{234} U /{ }^{238} U$ Activity Ratios for Sample HD2074 Opal as Determined by lon Probe (Continued)

\begin{tabular}{|c|c|c|c|c|c|c|}
\hline $\begin{array}{c}\text { Spot } \\
\text { No. }\end{array}$ & Spot ID & $\begin{array}{c}\text { Micro- } \\
\text { stratigraphic } \\
\text { depth from } \\
\text { outer surface, } \\
(\mu \mathrm{m}) \\
\end{array}$ & $\begin{array}{c}{ }^{230} \mathrm{Th} / \mathrm{U} \text { date }{ }^{\mathrm{a}} \\
\text { (ka) }\end{array}$ & $\begin{array}{c}\text { Initial } \\
{ }^{234} U /^{238} U\end{array}$ & $\rho^{\mathrm{b}}$ & $\begin{array}{c}{ }^{234} \mathrm{U} / /^{238} \mathrm{U} \\
\text { estimated date } \\
(\mathrm{ka})^{\mathrm{C}}\end{array}$ \\
\hline 25 & 2074-g2-9.1 & 29 & $47.7 \pm 7.1$ & $7.26 \pm 0.29$ & 0.09 & $54 \pm 28$ \\
\hline 26 & $2074-g 2-10.1$ & 31 & $51.7 \pm 9.8$ & $7.33 \pm 0.37$ & 0.11 & $55 \pm 33$ \\
\hline 27 & 2074-g1-1.1 & 36 & $51.7 \pm 7.5$ & $7.46 \pm 0.29$ & 0.11 & $47 \pm 28$ \\
\hline 28 & $2074-g 1-2.1$ & 95 & $177 \pm 29$ & $7.69 \pm 0.49$ & 0.80 & $160 \pm 28$ \\
\hline 29 & $2074-g 1-3.1$ & 158 & $266 \pm 65$ & $7.18 \pm 0.99$ & 0.96 & $278 \pm 31$ \\
\hline 30 & 2074-g1-4.1 & 60 & $131 \pm 32$ & $7.40 \pm 0.59$ & 0.59 & $130 \pm 41$ \\
\hline 31 & 2074-g1-5.1 & 211 & $314 \pm 200$ & $5.5 \pm 2.3$ & 0.98 & $437 \pm 61$ \\
\hline 32 & $2074-g 1-6.1$ & 305 & $675 \pm 1700$ & $9 \pm 38$ & 1.00 & $584 \pm 52$ \\
\hline 33 & $2074-g 1-7.1$ & 10 & $34.4 \pm 7.6$ & $7.32 \pm 0.48$ & -0.09 & $38 \pm 40$ \\
\hline
\end{tabular}

Source: DTN: GS021208315215.008 [DIRS 164851]. Note that this DTN is not qualified. The values in this table are thus presented for information only, and this table cannot be referenced as direct input in other technical products.

${ }^{a}$ Date and $95 \%$ confidence errors calculated using decay-constants given by Cheng et al. ["The Half-Lives of Uranium-234 and Thorium-230" (2000 [DIRS 153475])].

${ }^{b}$ Correlation coefficient between date and initial ${ }^{234} \mathrm{U} /{ }^{238} \mathrm{U}$.

${ }^{c}$ Calculation of estimated ${ }^{234} \mathrm{U} /{ }^{238} \mathrm{U}$ ages is summarized in Appendix Section 14.2, specifically Appendix Equation I-9.

The ${ }^{230} \mathrm{Th} / \mathrm{U}$ dates calculated for IMP spots range from $34.4 \pm 7.6$ to $675 \pm 1,700 \mathrm{ka}$ and, below the outermost surface, increase with depth (Table 6-43, Figure 6-200). The very large errors for spots older than 200 to $300 \mathrm{ka}$ are a consequence of large uncertainties in measured ${ }^{230} \mathrm{Th} /{ }^{238} \mathrm{U}$ activity ratios (ARs) and the reduced dating resolution as ${ }^{230} \mathrm{Th}$ approaches approximately five half lives. For the nine spots with dates younger than $200 \mathrm{ka}$, calculated initial ${ }^{234} \mathrm{U}^{238} \mathrm{U}$ ARs vary from 6.62 to 7.69. Approximating that percolating fracture water retained this ${ }^{234} \mathrm{U} /{ }^{238} \mathrm{U}$ AR over longer time periods, measured ${ }^{234} \mathrm{U} /{ }^{238} \mathrm{U}$ ARs can be used to estimate model dates as old as several million years. Using the average initial ${ }^{234} \mathrm{U} /{ }^{238} \mathrm{U}$ AR value for spots younger than $200 \mathrm{ka}$, model ${ }^{234} \mathrm{U} /{ }^{238} \mathrm{U}$ dates between approximately 280 and $1,430 \mathrm{ka}$ are estimated for spots with ${ }^{230} \mathrm{Th} / \mathrm{U}$ dates older than $200 \mathrm{ka}$ (Table 6-43). Relative uncertainties between 6 and 14 percent for most of these estimated dates are propagated using both the ${ }^{234} \mathrm{U} /{ }^{238} \mathrm{U}$ analytical errors and the error for the weighted initial ${ }^{234} \mathrm{U} /{ }^{238} \mathrm{U} A R$, and may underestimate the true age uncertainty. Nevertheless, they allow further comparisons of data from younger and older parts of the hemispheres not possible with ${ }^{230} \mathrm{Th} / \mathrm{U}$ dating alone. In most cases, estimated ${ }^{234} \mathrm{U} /{ }^{238} \mathrm{U}$ dates agree (within error overlap) with ${ }^{230} \mathrm{Th} / \mathrm{U}$ dates over the entire dated range (Table 6-43). 


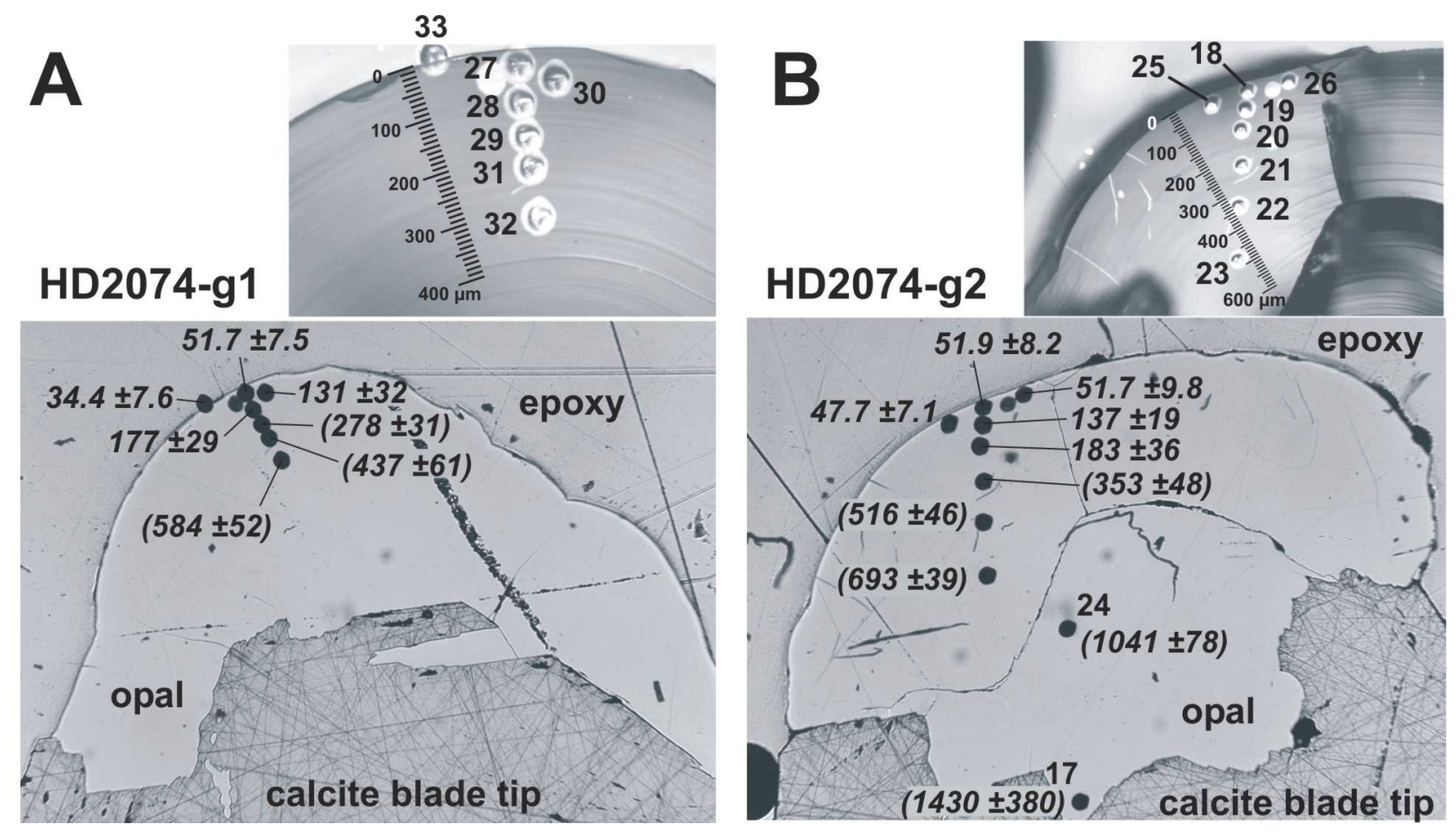

Source: DTN: GS021208315215.008 [DIRS 164851]. Note that this DTN is not qualified. The values shown in this figure are thus presented for information only, and this figure cannot be referenced as direct input in other technical products.

NOTES: Upper panels are transmitted-light images. Lower panels are reflected-light images.

Ablation pits are numbered for reference to Table 6-43. ${ }^{230} \mathrm{Th} / \mathrm{U}$ dates in thousands of years are given for microstratigraphically higher pits, and model ${ }^{234} \mathrm{U} /{ }^{238} \mathrm{U}$ dates in thousands of years (in parentheses) are given for microstratigraphically lower pits. Calculation of estimated ${ }^{234} \mathrm{U} /{ }^{238} \mathrm{U}$ ages is summarized in Appendix Section 14.2, using Appendix Equation I-9.

Figure 6-200. Cross Sections of Two Opal Hemispheres Analyzed by lon Microprobe Shown under Transmitted Light and Reflected Light 

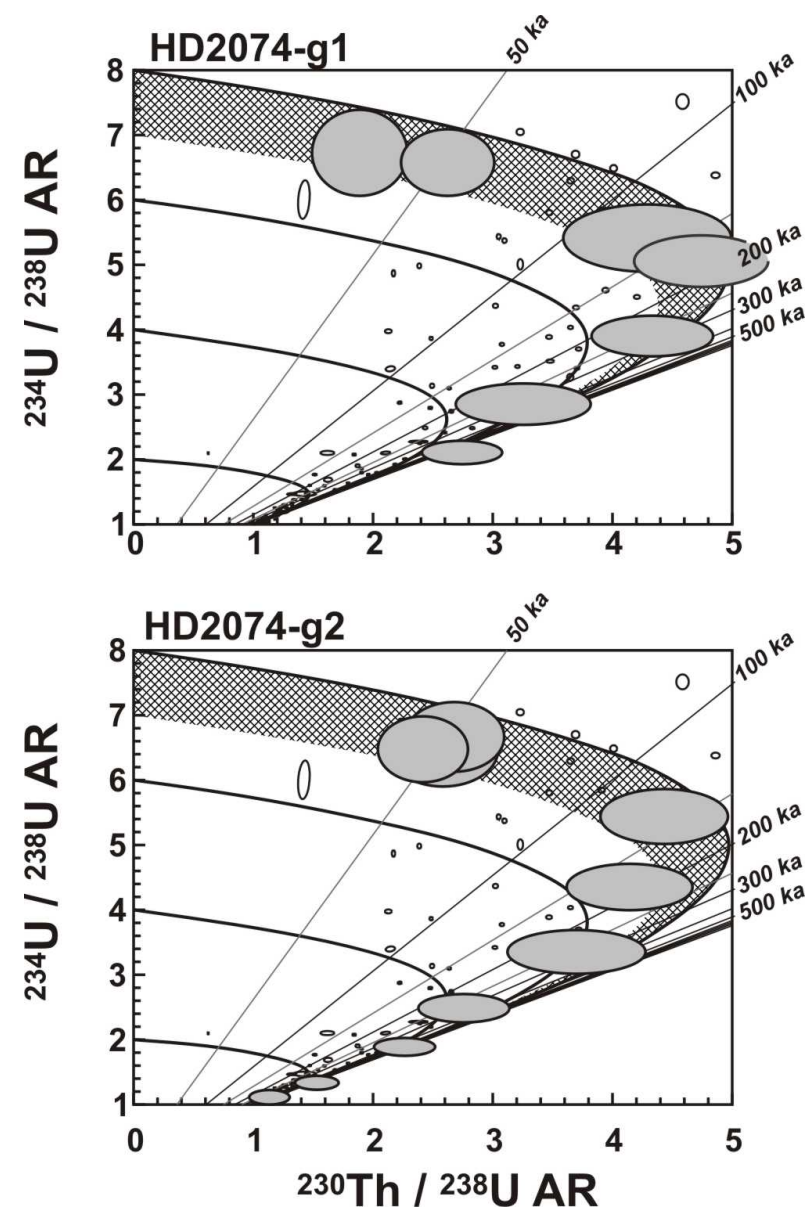

Source: DTN: GS021208315215.008 [DIRS 164851]. Note that this DTN is not qualified. The values shown in this figure are thus presented for information only, and this figure cannot be referenced as direct input in other technical products.

NOTES: In the figure, uncertainty regions are represented as large, shaded $2 \sigma$ ellipses.

Dark curved lines are the traces of activity ratios (ARs) developed through time in a closed isotopic system. The shaded areas show the isotopic compositions of material evolving from initial ${ }^{234} \mathrm{U} /{ }^{238} \mathrm{U} A R$ values between 7 and 8 . Thin straight lines represent isochrones with ages in thousands of years (ka). Analyses of whole opal hemispheres and sheets from Paces et al. (2001 [DIRS 156507], Figure 13) are shown as small, open $2 \sigma$ error ellipses. Calculation of estimated ${ }^{234} \mathrm{U} /{ }^{238} \mathrm{U}$ ages is summarized in Appendix Section 14.2, using Appendix Equation I-9.

Figure 6-201. U/Th Isotope Evolution Plot for Ion-Microprobe Analyses of Opal Hemispheres

The IMP dates are correlated with microstratigraphic depth within each transect of the two opal hemispheres analyzed (Figure 6-202). Both ${ }^{230} \mathrm{Th} / \mathrm{U}$ dates and ${ }^{234} \mathrm{U} /{ }^{238} \mathrm{U}$ model dates were used to calculate slopes (Appendix Section I5) that represent average growth rates of $0.56 \pm 0.14 \mu \mathrm{m} / \mathrm{ka}$ (note that $1 \mu \mathrm{m} / \mathrm{ka}$ equals $1 \mathrm{~mm} / \mathrm{Ma}$ ) for subsample HD2074-g1, and $0.683 \pm 0.045 \mu \mathrm{m} / \mathrm{ka}$ for subsample HD2074-g2. These rates are approximately 2 to 10 times smaller than the long-term average growth rates reported by Neymark et al. (1998 [DIRS 109140]; 2002 [DIRS 158673]) calculated from ${ }^{207} \mathrm{~Pb} /{ }^{235} \mathrm{U}$ dates of interior opal and chalcedony. IMP data indicate that individual opal hemispheres take more than 1 million years to form, and that, at the scale of resolution used for IMP analyses, growth rates remained uniform throughout the late and middle Pleistocene. 

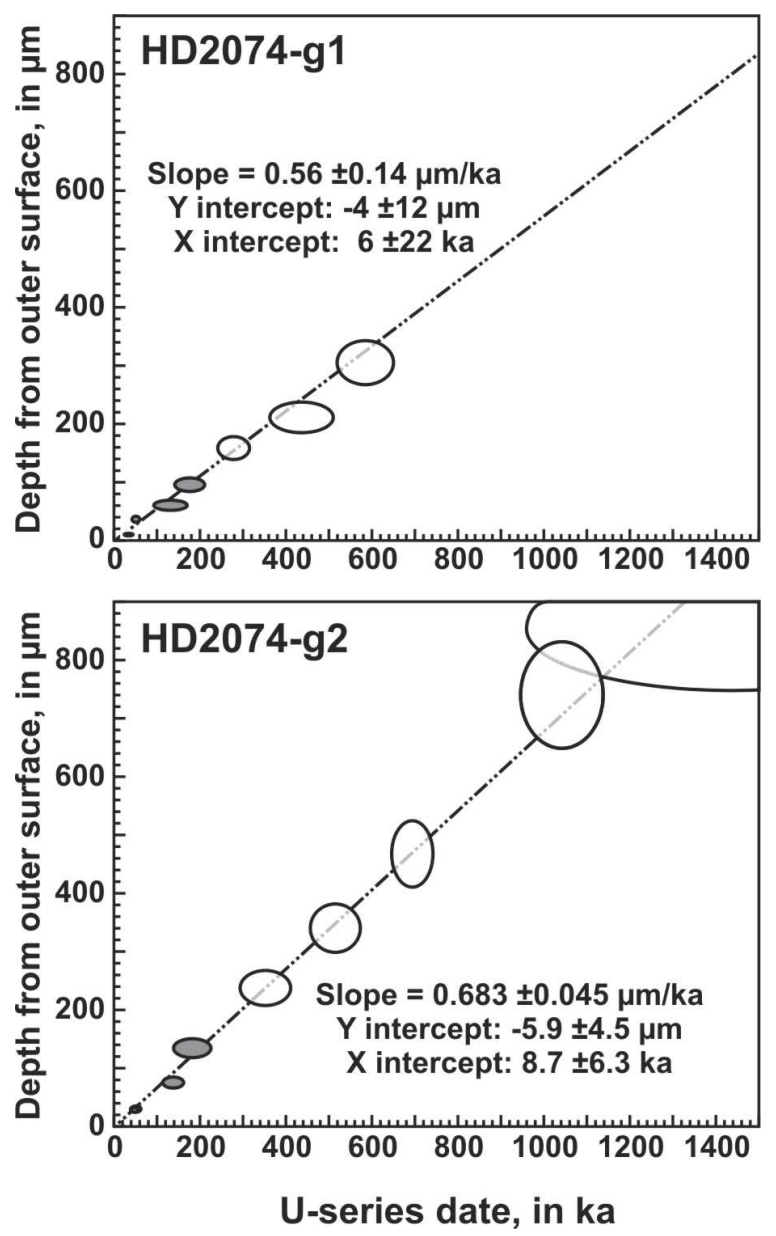

Source: DTN: GS021208315215.008 [DIRS 164851]. Note that this DTN is not qualified. The values shown in this figure are thus presented for information only, and this figure cannot be referenced as direct input in other technical products.

NOTES: ${ }^{230} \mathrm{Th} / \mathrm{U}$ dates are shown as shaded symbols with $2 \sigma$ error ellipses and mode ${ }^{234} \mathrm{U} /{ }^{238} \mathrm{U}$ dates (based on an initial ${ }^{234} U /{ }^{238} U$ ratio of $7.38 \pm 0.19$ ) are shown as open symbols with $2 \sigma$ error ellipses. Errors for microstratigraphic depth are assumed to be 10 percent of the measured value. Calculation of estimated ${ }^{234} \mathrm{U} /{ }^{238} \mathrm{U}$ ages is summarized in Appendix Section 14.2, using Appendix Equation I-9. The spot locations are shown in Figure 6-200.

Figure 6-202. Depth-Age Relations for Profiles of Opal Hemispheres Analyzed by Ion Microprobe

\section{Microdigestion TIMS Results:}

Previous conventional TIMS analyses of three 1-mm-diameter whole opal hemispheres from sample HD2074 (Paces et al. 2001 [DIRS 156507]) yielded ${ }^{230} \mathrm{Th} / \mathrm{U}$ dates ranging from $153.0 \pm 1.9$ to $226.8 \pm 7.4 \mathrm{ka}$, with initial ${ }^{234} \mathrm{U} /{ }^{238} \mathrm{U}$ ARs of between 4.2 and 2.7 (Table 6-44). These initial ${ }^{234} \mathrm{U} /{ }^{238} \mathrm{U}$ ratios are much lower than those observed in other analyses of opal (Paces et al. 2001 [DIRS 156507]), or for IMP results presented in Figure 6-202 with an AR of 7.38. In addition, initial ${ }^{234} \mathrm{U} /{ }^{238} \mathrm{U}$ ARs for these three sample-HD2074 whole-hemisphere digestions are negatively correlated with age. These features are indications that whole-hemisphere digestions represent mixtures of older and younger material (Neymark and Paces 2000 [DIRS 127012]; Neymark et al. 2002 [DIRS 158673]). Because of this, in situ microdigestions of similar materials were conducted to refine growth histories of individual hemispheres. 
Table 6-44. Uranium and Thorium Isotopic Results from Sample HD2074 Opal Hemispheres

\begin{tabular}{|c|c|c|c|c|c|c|c|c|c|c|c|}
\hline $\begin{array}{c}\text { Subsample } \\
\text { Name }^{a}\end{array}$ & $\begin{array}{c}\text { Digestion } \\
\text { duration, } \\
\text { minutes }\end{array}$ & $\begin{array}{c}\text { Estimated } \\
\text { thickness } \\
(\mu \mathrm{m})^{\mathrm{b}}\end{array}$ & $\begin{array}{c}\text { Estimated } \\
\text { weight } \\
(\mu \mathrm{g})^{\mathrm{b}}\end{array}$ & $\begin{array}{l}\text { Measured U } \\
\text { abundance } \\
\text { (ng) })^{b}\end{array}$ & $\begin{array}{c}U \text { con- } \\
\text { centration } \\
(\mu \mathrm{g} / \mathrm{g})^{\mathrm{b}}\end{array}$ & $\begin{array}{l}\text { Th con- } \\
\text { centration } \\
(\mu \mathrm{g} / \mathrm{g})^{\mathrm{b}}\end{array}$ & $\begin{array}{c}\text { Measured } \\
{ }^{230} \mathrm{Th} /{ }^{232} \mathrm{Th} \\
\text { AR }\end{array}$ & ${ }^{230} \mathrm{Th} /{ }^{238} \mathrm{U} A R^{\mathrm{c}}$ & ${ }^{234} \mathrm{U} /{ }^{238} \mathrm{U} A R^{\mathrm{c}}$ & $\begin{array}{c}{ }^{230} \mathrm{Th} / \mathrm{U} \text { date }{ }^{\mathrm{d}} \\
\text { (ka) }\end{array}$ & $\begin{array}{c}\text { Initial } \\
{ }^{234} \mathrm{U}^{238} \mathrm{U} \text { AR }{ }^{\mathrm{d}}\end{array}$ \\
\hline \multicolumn{12}{|c|}{ Whole hemisphere total digestions } \\
\hline HD2074-U1R & n.a. & $\sim 1000$ & 2870 & 467 & 162.64 & 0.009 & 641,700 & $2.629 \pm 0.014$ & $3.089 \pm 0.012$ & $153.0 \pm 1.9$ & $4.220 \pm 0.016$ \\
\hline HD2074-U3R & n.a. & $\sim 1000$ & 10090 & 1278 & 126.71 & 0.008 & 278,700 & $2.464 \pm 0.014$ & $2.787 \pm 0.011$ & $166.2 \pm 2.2$ & $3.859 \pm 0.016$ \\
\hline HD2074-U4R & n.a. & $\sim 1000$ & 9120 & 878 & 96.29 & 0.007 & 137,900 & $1.865 \pm 0.015$ & $1.899 \pm 0.016$ & $226.8 \pm 7.4$ & $2.706 \pm 0.023$ \\
\hline \multicolumn{12}{|c|}{ Single in situ microdigestions } \\
\hline HD2074 - HF1 & $<3$ & n.d. & n.d. & 0.474 & n.d. & n.d. & 20.0 & $0.525 \pm 0.12$ & $6.80 \pm 0.14$ & $8.7 \pm 2.0$ & $6.95 \pm 0.14$ \\
\hline HD2074-HF2 & $<3$ & n.d. & n.d. & 0.043 & n.d. & n.d. & 3.34 & $0.25 \pm 0.11$ & $6.80 \pm 0.63$ & $4.0 \pm 1.9$ & $6.86 \pm 0.63$ \\
\hline HD2074-HF3 & $<3$ & n.d. & n.d. & 0.571 & n.d. & n.d. & 99.5 & $0.68 \pm 0.03$ & $6.63 \pm 0.13$ & $11.6 \pm 0.6$ & $6.82 \pm 0.13$ \\
\hline HD2074-MD2 & $<3$ & n.d. & n.d. & 0.519 & n.d. & n.d. & 1.72 & $0.57 \pm 0.17$ & $8.41 \pm 0.98$ & $7.6 \pm 2.8$ & $8.57 \pm 0.97$ \\
\hline \multicolumn{12}{|c|}{ Sequential in situ microdigestions } \\
\hline HD2074-T1a & $1-2$ & n.d. & n.d. & 12.647 & n.d. & n.d. & 1,250 & $0.344 \pm 0.005$ & $6.043 \pm 0.082$ & $6.34 \pm 0.12$ & $6.134 \pm 0.082$ \\
\hline HD2074-T1b & 3 & n.d. & n.d. & 0.744 & n.d. & n.d. & 130 & $0.901 \pm 0.069$ & $6.421 \pm 0.058$ & $16.2 \pm 1.3$ & $6.674 \pm 0.061$ \\
\hline HD2074-T1c & 12 & n.d. & n.d. & 1.635 & n.d. & n.d. & 720 & $1.490 \pm 0.056$ & $6.089 \pm 0.054$ & $29.5 \pm 1.3$ & $6.531 \pm 0.058$ \\
\hline HD2074-T1d & 12 & n.d. & n.d. & 1.220 & n.d. & n.d. & 1,430 & $2.393 \pm 0.076$ & $5.213 \pm 0.049$ & $61.4 \pm 2.5$ & $6.011 \pm 0.059$ \\
\hline HD2074-g2-L1 & 2 & 1.5 & 7.2 & 2.21 & 310 & 1.3 & 550 & $0.430 \pm 0.038$ & $6.574 \pm 0.089$ & $7.3 \pm 0.7$ & $6.691 \pm 0.090$ \\
\hline HD2074-g2-L2 & 2 & 1.5 & 7.2 & 3.13 & 430 & 2.7 & 580 & $0.671 \pm 0.074$ & $6.561 \pm 0.058$ & $11.6 \pm 1.3$ & $6.747 \pm 0.062$ \\
\hline HD2074-g2-L3 & 3 & 2.3 & 11 & 4.81 & 450 & 2.4 & 940 & $0.932 \pm 0.011$ & $6.649 \pm 0.084$ & $16.1 \pm 1.2$ & $6.913 \pm 0.086$ \\
\hline HD2074-g2-L4 & 3 & 2.3 & 11 & 4.50 & 420 & 0.9 & 3,300 & $1.350 \pm 0.077$ & $6.435 \pm 0.041$ & $24.9 \pm 1.6$ & $6.831 \pm 0.048$ \\
\hline HD2074-g2-L5 & 4 & 3.0 & 14 & 5.10 & 350 & 0.0 & 5,700 & $1.427 \pm 0.034$ & $6.492 \pm 0.042$ & $26.2 \pm 0.7$ & $6.914 \pm 0.044$ \\
\hline HD2074-g2-L6 & 5 & 3.8 & 18 & 6.89 & 380 & 1.2 & 2,800 & $1.620 \pm 0.023$ & $6.375 \pm 0.036$ & $30.7 \pm 0.5$ & $6.862 \pm 0.037$ \\
\hline HD2074-g2-L7 & 5 & 3.8 & 18 & 7.99 & 450 & 0.8 & 5,000 & $1.593 \pm 0.055$ & $6.362 \pm 0.034$ & $30.2 \pm 1.2$ & $6.840 \pm 0.039$ \\
\hline HD2074-g2-L8 & 5 & 3.8 & 18 & 9.37 & 530 & 0.6 & 10,200 & $1.908 \pm 0.071$ & $6.347 \pm 0.039$ & $37.1 \pm 1.6$ & $6.938 \pm 0.047$ \\
\hline
\end{tabular}

Source: DTN: GS021208315215.009 [DIRS 164750].

a All subsamples are from station 30+51 in the Yucca Mountain Exploratory Studies Facility, at a depth of $270 \mathrm{~m}$ below land surface.

${ }^{b}$ Weights and concentrations for whole-hemisphere digestions are measured directly. Thicknesses, weights, and concentrations for in situ digestions are estimated by methods explained in the text.

${ }^{c}$ Isotope ratios are corrected for contributions from spike and blank and for mass fractionation. ${ }^{230} \mathrm{Th} /{ }^{238} \mathrm{U}$ and ${ }^{234} \mathrm{U} /{ }^{238} \mathrm{U}$ ratios are also corrected for contributions from a secular equilibrium detrital component with activity ratios of ${ }^{232} \mathrm{Th} /{ }^{238} \mathrm{U}=1.9 \pm 0.95,{ }^{230} \mathrm{Th} /{ }^{238} \mathrm{U}=1.0 \pm 0.5$, and ${ }^{234} \mathrm{U} /{ }^{238} \mathrm{U}=1.0 \pm 0.2$. Uncertainties are given

${ }^{\text {d }}{ }^{230} \mathrm{Th} / \mathrm{U}$ date and initial ${ }^{234} \mathrm{U} /{ }^{238} \mathrm{U}$ calculated from ${ }^{232} \mathrm{Th}$-corrected isotope ratios with uncertainties given at the $95 \%$ confidence level.

n.a. $\quad=$ Not applicable.

n.d. = Not determined

$\mathrm{AR}=$ activity ratio

Values for ${ }^{230} \mathrm{Th} / \mathrm{U}$ dates are taken directly from Paces et al. (2001 [DIRS 156507]). Ages are estimated using an approach similar to ${ }^{234} \mathrm{U} /{ }^{238} \mathrm{U}$ ages described in Appendix Section A4.2. 
Initial microdigestion results yielded much younger ${ }^{230} \mathrm{Th} / \mathrm{U}$ dates $(4.0 \pm 1.9$ to $11.6 \pm 0.6 \mathrm{ka}$; Table 6-44) and higher initial ${ }^{234} \mathrm{U} /{ }^{238} \mathrm{U}$ AR values (6.80 to 8.6) than those obtained for whole-hemisphere digestions. A second set of experiments involving sequential microdigestions from a single opal hemisphere yielded ages ranging from $6.3 \pm 0.1$ to $61.4 \pm 2.5 \mathrm{ka}$, with initial ${ }^{234} \mathrm{U} /{ }^{238} \mathrm{U}$ ARs from 6.0 to 6.7 . A third set of microdigestions was conducted on one of the same opal hemispheres used for IMP analysis (subsample HD2074-g2). The remaining hemisphere was extracted from the microprobe mount and glued onto a glass slide, so that the outer surface was oriented upwards. In this series of sequential microdigestions, repeated measurements of surface elevation were made to yield surface profiles after each step. Dates for the subsample HD2074-g2 sequential microdigestions range from $7.3 \pm 0.7$ to $37.1 \pm 1.6 \mathrm{ka}$, and initial ${ }^{234} \mathrm{U} /{ }^{238} \mathrm{U}$ ARs vary from 6.69 to 6.94 . The resulting ${ }^{230} \mathrm{Th} / \mathrm{U}$ dates form a smooth pattern of increasing age when plotted against depth from the outermost surface (Figure 6-203), with a possible inflection point at approximately $25 \mathrm{ka}$. The four subsample-HD2074-g2 microdigestion analyses with dates younger than $25 \mathrm{ka}$ yield a regression with a shallower slope $(0.35 \pm 0.23 \mu \mathrm{m} / \mathrm{ka})$, whereas the five microdigestion analyses with dates older than $20 \mathrm{ka}$ yield a regression with a steeper slope $(1.16 \pm 0.35 \mu \mathrm{m} / \mathrm{ka})$. All data from microdigestions of subsample HD2074-g2 yield a combined regression slope of $0.68 \pm 0.22 \mu \mathrm{m} / \mathrm{ka}$.

Discussion: Uranium-series dates and growth rates are determined at much finer scales of spatial resolution by IMP and microdigestion TIMS analyses than by earlier whole-hemisphere TIMS methods. IMP spots integrate material deposited over a thickness of approximately $35 \mu \mathrm{m}$, whereas microdigestion TIMS analyses integrate opal deposited over thicknesses of less than $5 \mu \mathrm{m}$. Outermost IMP spots have ${ }^{230} \mathrm{Th} / \mathrm{U}$ dates that cluster at approximately $50 \mathrm{ka}$, whereas microdigestion TIMS analyses indicate that this same interval consists of layers deposited more recently. Conversely, IMP ${ }^{234} \mathrm{U} /{ }^{238} \mathrm{U}$ model dates for deeper layers show that material in the interior of the hemispheres is more than 1 million years old.

Data collected at higher spatial resolutions are consistent with the previously hypothesized model of long-term "continuous" deposition for Yucca Mountain secondary minerals, in the sense that secondary minerals formed slowly over extended periods of time. However, the microdigestion data imply that growth rates were not necessarily constant and that it is possible that no deposits occur during periods of low infiltration. These aspects were anticipated previously (Neymark and Paces 2000 [DIRS 127012], p. 158; and Paces et al. 2001 [DIRS 156507], p. 55), but the high spatial resolution of IMP and microdigestion TIMS techniques was required to confirm the temporal scale and variability of mineral deposition.

The available data suggest that Pleistocene growth rates were slower than those during the Miocene were. Compared with the long-term average growth rates of 1 to $5 \mathrm{~mm} / \mathrm{Ma}$ for Miocene-to-Pleistocene deposits (Neymark et al. 2002 [DIRS 158673]), the average Pleistocene growth rate determined for the sample HD2074 opal $(0.68 \mathrm{~mm} / \mathrm{Ma})$ is almost 10 times lower than the Miocene-Pleistocene rate. Reduced Pleistocene growth rates may reflect a shift to increased aridity in the region over the last 2 million years (Axelrod 1979 [DIRS 161531]; Winograd et al. 1985 [DIRS 109187]; and Thompson 1991 [DIRS 109175]). Previous studies (Paces et al. 2001 [DIRS 156507]) did not identify these small differences because of the averaging effects of the milligram-sized, rather than microgram-sized, samples. 


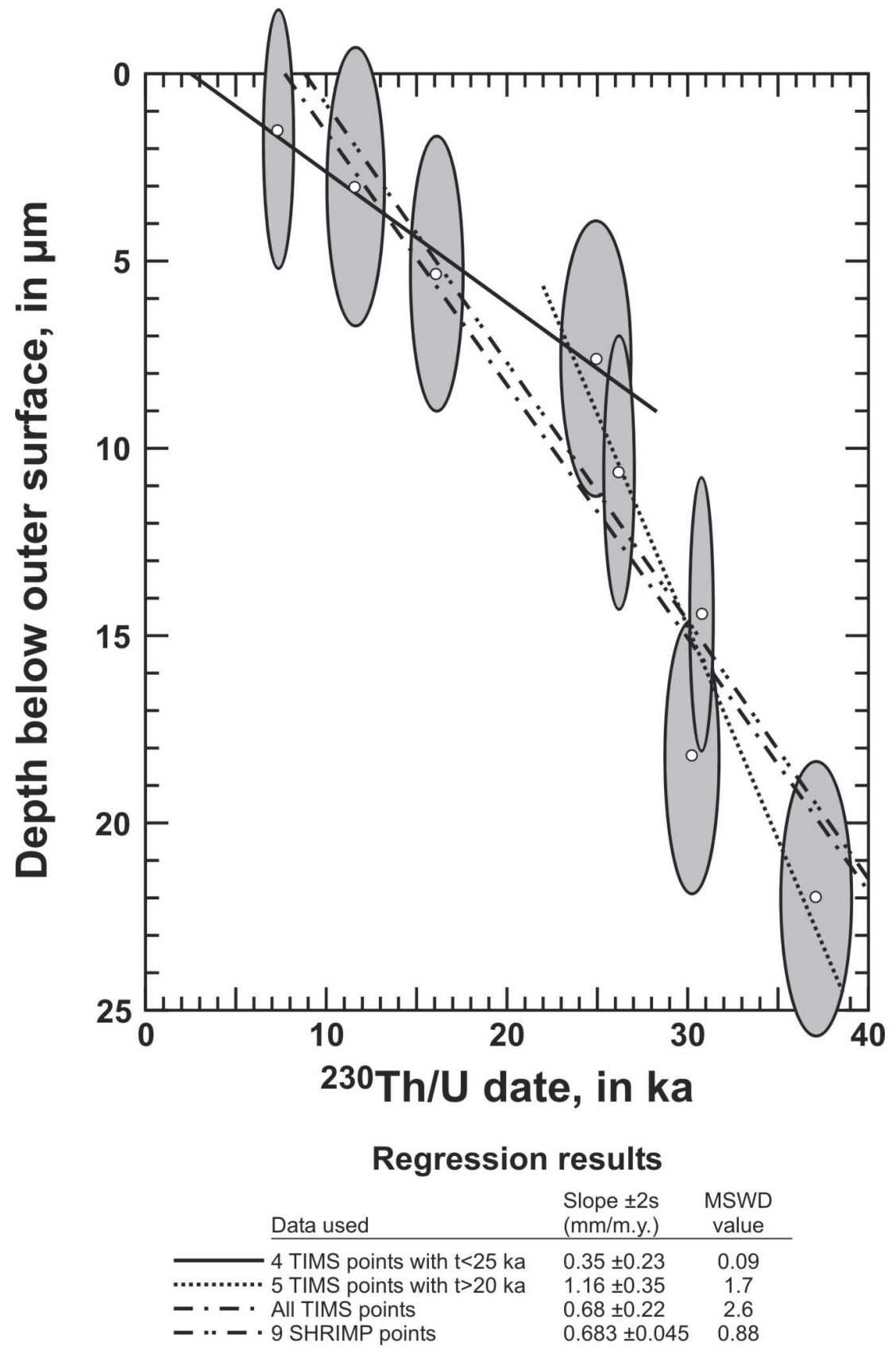

Source: DTN: GS021208315215.009 [DIRS 164750].

NOTES: Two-sigma error ellipses are shown, along with various regressions using $2 \sigma$ age uncertainties from Table 6-44 and a constant 3- $\mu \mathrm{m}$ depth uncertainty. Also shown is the regression curve extrapolated from data older than $48 \mathrm{ka}$, which were determined by ion microprobe for the same hemisphere (Figure 6-202). Values for ${ }^{230} \mathrm{Th} / \mathrm{U}$ dates are taken directly from Paces et al. (2001 [DIRS 156507]). Ages are estimated from an approach similar to ${ }^{234} \mathrm{U} /{ }^{238} \mathrm{U}$ ages described in Appendix Section 14.2.

MSWD=mean square weighted deviant; SHRIMP=Sensitive High Resolution lon Microprobe; TIMS= Thermal-Ionization Mass Spectrometry.

Figure 6-203. Depth-Age Relations for Sequential Microdigestions of Opal Hemisphere Subsample HD2074-g2 
The microdigestion TIMS data represent the first evidence that mineral growth rates in the Yucca Mountain UZ may have varied during the late Pleistocene. Age-depth relations imply faster growth rates under pluvial/glacial climate conditions between 20 and $40 \mathrm{ka}$, and slower growth rates during transitional and interpluvial climate conditions after that. The absence of reasonably precise dates for outermost layers younger than $6.34 \pm 0.12$ to $7.3 \pm 0.7 \mathrm{ka}$, plus the non-zero age intercept between 3 and $9 \mathrm{ka}$ for depth-age regressions, imply that no opal has been added in the last several thousand years.

The correlation of growth rates with variable Pleistocene climates indicates that mineral growth is correlated with percolation flux. Infiltration and UZ percolation are likely to be greatest during episodes of greatest mean annual precipitation and coolest mean annual temperature when evaporation/evapotranspiration is minimized. Full pluvial/glacial climate conditions at Yucca Mountain resulted in greater surface water and groundwater fluxes up to approximately 15 to $20 \mathrm{ka}$ (Spaulding 1985 [DIRS 106883]; Paces et al. 1993 [DIRS 106474]; Lundstrom et al. 1996 [DIRS 136523]; Forester et al. 1999 [DIRS 109425]; and Paces and Whelan 2001 [DIRS 154724]). Greater UZ fluxes during this time resulted in a higher mineral growth rate $(1.16 \mathrm{~mm} / \mathrm{Ma})$ compared to the rates $(0.35 \mathrm{~mm} / \mathrm{Ma})$ associated with glacial transition conditions between approximately 10 and $20 \mathrm{ka}$. The possible absence of mineral growth over the last several-thousand years implies that fracture flow supplying solute to the sample-HD2074 depositional site may have ceased during the driest interglacial periods. Time lags (between climate variability and percolation deep within Yucca Mountain) of up to thousands of years may also complicate the relations between surface and UZ hydrology; however, these initial results are encouraging evidence of a climate-percolation relation.

Two methods of uranium-series dating were applied to finely laminated opal hemispheres formed within unsaturated felsic tuffs at Yucca Mountain. The first method used an ion microprobe to determine isotope compositions of $45-\mu \mathrm{m}$-diameter spots on transects across two opal hemispheres approximately $1 \mathrm{~mm}$ in size; the second used in situ microdigestions to sequentially remove 2- to 5 - $\mu$ m-thick layers of outermost material. Both methods substantially improved spatial resolution of the analyses relative to the millimeter-scale subsamples analyzed previously by standard total digestion techniques. As a result, the opal growth histories can be reconstructed in more detail.

\subsubsection{Uranium-series Delineation of UZ Flow Zones}

Rock samples from two areas in the underground workings at Yucca Mountain (Figure 6-204) were selected for analysis of ${ }^{234} \mathrm{U}_{-}{ }^{230} \mathrm{Th}-{ }^{238} \mathrm{U}$ by TIMS. Details are described in the data package DTN: GS021208312272.008 [DIRS 164609] and by Paces and Neymark (2003 [DIRS 162900]). Three Topopah Spring Tuff (TSw) tuff samples were collected from two sites in the ECRB Cross-Drift within the repository block 220 to $300 \mathrm{~m}$ below land surface and 120 to $200 \mathrm{~m}$ below the base of the Paintbrush nonwelded (PTn) (samples HD2423 to HD2425 in Figure 6-204). In addition, 11 samples of Tiva Canyon Tuff (TCw) tuff and post-TCw nonwelded tuff were collected along a profile across the Bow Ridge fault zone in the ESF tunnel only 20 to $30 \mathrm{~m}$ below land surface (samples HD2426 to HD2436 in Figure 6-204). The two different sample localities were selected to represent areas of lower percolation flux in the ECRB Cross-Drift below the Paintbrush nonwelded (PTn) and higher flux in the near-surface ESF environment that may be further channeled along the Bow Ridge fault zone. In addition, samples were collected to represent hydrologically "active" sites (i.e., those containing fractures clearly associated with visible secondary hydrogenic mineral deposits) and "inactive" sites (unfractured material or fractured rock lacking secondary minerals). 
Table 6-45. Uranium and Thorium Concentrations and ${ }^{234} \mathrm{U}^{230} \mathrm{Th}^{238} \mathrm{U}-{ }^{232} \mathrm{Th}$ Isotopic Compositions for Whole Rock-Samples from the ECRB Cross-Drift and ESF

\begin{tabular}{|c|c|c|c|c|c|c|c|c|c|c|c|c|c|c|c|}
\hline \multirow[b]{2}{*}{$\begin{array}{c}\text { Subsample } \\
\text { Name }\end{array}$} & \multirow[b]{2}{*}{ Location } & \multirow[b]{2}{*}{$\begin{array}{l}\text { Distance } \\
\text { from } \\
\text { start of } \\
\text { tunnel or } \\
\text { alcove } \\
\text { (m) }\end{array}$} & \multirow[b]{2}{*}{ 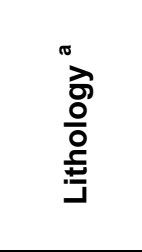 } & \multirow[b]{2}{*}{$\begin{array}{c}\text { Distance } \\
\text { from } \\
\text { fracture } \\
\text { surface } \\
(\mathrm{mm})\end{array}$} & \multicolumn{4}{|c|}{ Concentrations, in $\mu \mathrm{g} / \mathrm{g}^{\mathrm{b}}$} & \multirow[b]{2}{*}{ 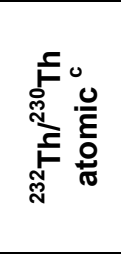 } & \multicolumn{6}{|c|}{ Activity Ratios $^{c, d}$} \\
\hline & & & & & $\mathbf{U}$ & $2 \sigma$ & Th & $2 \sigma$ & & 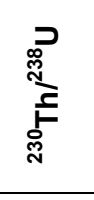 & $2 \sigma$ & 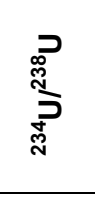 & $2 \sigma$ & 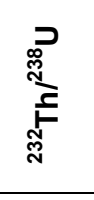 & $2 \sigma$ \\
\hline HD2423-U1 & ECRB Cross-Drift & 1640.8 & Tptpll & 0.2 & 4.316 & 0.019 & 24.05 & 0.15 & 334,800 & 1.016 & 0.022 & 1.002 & 0.005 & 1.837 & 0.012 \\
\hline HD2423-U2 & ECRB Cross-Drift & 1640.8 & Tptpll & 0.5 & 4.341 & 0.025 & 22.7 & 1.1 & 321,700 & 0.991 & 0.024 & 0.989 & 0.006 & 1.722 & 0.083 \\
\hline HD2423-U3 & ECRB Cross-Drift & 1640.8 & Tptpll & 3 & 4.447 & 0.015 & 22.22 & 0.11 & 321,800 & 0.947 & 0.010 & 0.989 & 0.007 & 1.647 & 0.009 \\
\hline HD2423-U4 & ECRB Cross-Drift & 1640.8 & Tptpll & 10 & 4.530 & 0.016 & 21.96 & 0.11 & 315,100 & 0.939 & 0.010 & 0.987 & 0.005 & 1.598 & 0.009 \\
\hline HD2424-U1 & ECRB Cross-Drift & 1641.1 & Tptpll & 0.5 & 4.513 & 0.019 & 25.74 & 0.21 & 362,700 & 0.959 & 0.023 & 0.973 & 0.006 & 1.879 & 0.016 \\
\hline HD2424-U2 & ECRB Cross-Drift & 1641.1 & Tptpll & 5 & 4.564 & 0.017 & 24.35 & 0.14 & 330,000 & 0.986 & 0.011 & 0.973 & 0.004 & 1.759 & 0.011 \\
\hline HD2424-U3 & ECRB Cross-Drift & 1641.1 & Tptpll & 20 & 4.471 & 0.018 & 22.57 & 0.12 & 332,700 & 0.926 & 0.009 & 0.960 & 0.005 & 1.664 & 0.010 \\
\hline HD2425-U1 & ECRB Alcove \#8 & 1.2 & Tptpul & 0.5 & 4.453 & 0.019 & 29.62 & 0.16 & 434,300 & 0.934 & 0.010 & 0.948 & 0.005 & 2.193 & 0.013 \\
\hline HD2425-U2 & ECRB Alcove \#8 & 1.2 & Tptpul & 2 & 4.466 & 0.018 & 25.20 & 0.14 & 349,700 & 0.985 & 0.010 & 0.961 & 0.005 & 1.860 & 0.011 \\
\hline HD2425-U3 & ECRB Alcove \#8 & 1.2 & Tptpul & 19 & 4.377 & 0.017 & 23.71 & 0.14 & 338,000 & 0.978 & 0.014 & 0.963 & 0.005 & 1.786 & 0.011 \\
\hline HD2426-U1 & ESF North Ramp & 183.4 & Tpcpll & 3 & 4.794 & 0.018 & 24.41 & 0.13 & 321,800 & 0.965 & 0.009 & 0.961 & 0.005 & 1.678 & 0.010 \\
\hline HD2426-U2 & ESF North Ramp & 183.4 & Tpcpll & 16 & 4.891 & 0.018 & 25.74 & 0.15 & 343,100 & 0.936 & 0.008 & 0.964 & 0.005 & 1.735 & 0.011 \\
\hline HD2427-U1 & ESF North Ramp & 187.1 & Tpcpll & 3 & 4.820 & 0.019 & 25.37 & 0.24 & 333,000 & 0.965 & 0.021 & 0.986 & 0.005 & 1.735 & 0.017 \\
\hline HD2427-U2 & ESF North Ramp & 187.1 & Tpcpll & 22 & 5.081 & 0.022 & 24.23 & 0.15 & 307,100 & 0.947 & 0.008 & 0.991 & 0.006 & 1.572 & 0.010 \\
\hline HD2428-U1 & ESF North Ramp & 197.0 & Tpcpll & 3 & 5.085 & 0.023 & 25.43 & 0.14 & 335,800 & 0.909 & 0.008 & 0.940 & 0.007 & 1.649 & 0.010 \\
\hline HD2428-U2 & ESF North Ramp & 197.0 & Tpcpll & 25 & 4.972 & 0.020 & 24.66 & 0.14 & 337,400 & 0.897 & 0.008 & 0.949 & 0.007 & 1.635 & 0.010 \\
\hline HD2429-U1 & ESF North Ramp & 198.3 & Tpcpll & 2 & 4.890 & 0.020 & 22.77 & 0.13 & 318,400 & 0.892 & 0.014 & 0.968 & 0.007 & 1.535 & 0.010 \\
\hline HD2429-U2 & ESF North Ramp & 198.3 & Tpcpll & 15 & 4.788 & 0.021 & 23.78 & 0.14 & 339,500 & 0.892 & 0.012 & 0.966 & 0.006 & 1.637 & 0.010 \\
\hline HD2430-U1 & ESF North Ramp & 199.8 & Tpcpll & 0.25 & 4.468 & 0.018 & 26.56 & 0.17 & 322,800 & 1.123 & 0.015 & 0.986 & 0.006 & 1.959 & 0.013 \\
\hline HD2430-U2 & ESF North Ramp & 199.8 & Tpcpll & 3 & 4.425 & 0.017 & 24.11 & 0.13 & 320,200 & 1.038 & 0.009 & 0.971 & 0.005 & 1.796 & 0.011 \\
\hline HD2430-U5 & ESF North Ramp & 199.8 & Tpcpll & 13.5 & 4.660 & 0.017 & 28.87 & 0.19 & 326,700 & 1.157 & 0.023 & 0.951 & 0.004 & 2.042 & 0.015 \\
\hline HD2431-U1 & ESF North Ramp & 199.9 & fault rock & $\mathrm{N} / \mathrm{A}$ & 4.169 & 0.018 & 22.31 & 0.18 & 354,400 & 0.921 & 0.006 & 0.944 & 0.004 & 1.764 & 0.014 \\
\hline HD2431-U2 & ESF North Ramp & 199.9 & fault rock & $\mathrm{N} / \mathrm{A}$ & 4.377 & 0.018 & 24.51 & 0.12 & 333,500 & 1.024 & 0.011 & 0.955 & 0.006 & 1.846 & 0.010 \\
\hline HD2432-U1 & ESF North Ramp & 200.6 & fault rock & $N / A$ & 4.755 & 0.019 & 25.73 & 0.15 & 372,800 & 0.886 & 0.008 & 0.892 & 0.004 & 1.783 & 0.011 \\
\hline
\end{tabular}


Table 6-45. Uranium and Thorium Concentrations and ${ }^{234} \mathrm{U}-{ }^{230} \mathrm{Th}^{238} \mathrm{U}-{ }^{232} \mathrm{Th}$ Isotopic Compositions for Whole-RockSamples from the ECRB Cross-Drift and ESF (Continued)

\begin{tabular}{|c|c|c|c|c|c|c|c|c|c|c|c|c|c|c|c|}
\hline \multirow[b]{2}{*}{$\begin{array}{c}\text { Subsample } \\
\text { Name }\end{array}$} & \multirow[b]{2}{*}{ Location } & \multirow{2}{*}{$\begin{array}{l}\text { Distance } \\
\text { from } \\
\text { start of } \\
\text { tunnel or } \\
\text { alcove } \\
\text { (m) }\end{array}$} & \multirow[b]{2}{*}{$\begin{array}{l}\text { Lith- } \\
\text { ology }{ }^{a}\end{array}$} & \multirow[b]{2}{*}{$\begin{array}{l}\text { Distance } \\
\text { from } \\
\text { fracture } \\
\text { surface } \\
(\mathrm{mm})\end{array}$} & \multicolumn{4}{|c|}{ Concentrations, in $\mu \mathrm{g} / \mathrm{g}^{\mathrm{b}}$} & \multirow{2}{*}{ 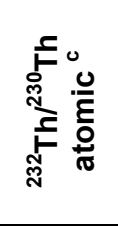 } & \multicolumn{6}{|c|}{ Activity Ratios ${ }^{c, d}$} \\
\hline & & & & & $\mathbf{U}$ & $2 \sigma$ & Th & $2 \sigma$ & & 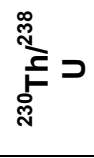 & $2 \sigma$ & 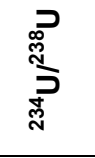 & $2 \sigma$ & 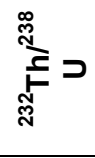 & $2 \sigma$ \\
\hline HD2433-U1 & \begin{tabular}{|l|} 
ESF North Ramp \\
\end{tabular} & 200.5 & fault rock & $\mathrm{N} / \mathrm{A}$ & 4.369 & 0.017 & 23.28 & 0.18 & 352,500 & 0.922 & 0.008 & 0.945 & 0.004 & 1.756 & 0.014 \\
\hline HD2434-U1 & ESF North Ramp & 203.3 & post-TCw & $\mathrm{N} / \mathrm{A}$ & 2.800 & 0.012 & 20.56 & 0.11 & 545,400 & 0.821 & 0.010 & 0.764 & 0.008 & 2.420 & 0.015 \\
\hline HD2435-U1 & ESF North Ramp & 213.0 & post-TCw & $\mathrm{N} / \mathrm{A}$ & 5.436 & 0.021 & 19.48 & 0.11 & 227,400 & 0.962 & 0.008 & 0.962 & 0.006 & 1.181 & 0.008 \\
\hline HD2436-U1 & ESF North Ramp & 215.7 & post-TCw & $\mathrm{N} / \mathrm{A}$ & 4.903 & 0.018 & 21.94 & 0.11 & 280,300 & 0.974 & 0.010 & 0.973 & 0.006 & 1.475 & 0.009 \\
\hline
\end{tabular}

${ }^{a}$ Lithostratigraphic unit designations from Buesch et al. (1996 [DIRS 100106]) include Tptpll (Topopah Spring Tuff lower lithophysal unit) and Tptpul (Topopah

Spring Tuff upper lithophysal unit) in the Topopah Spring Tuff (TSw), and Tpcpll (Tiva Canyon Tuff lower lithophysal unit) in the Tiva Canyon Tuff (TCw).

${ }^{b}$ Concentrations determined by isotope dilution using known amounts of a mixed ${ }^{236} \mathrm{U}-{ }^{229} \mathrm{Th}$ tracer solution.

${ }^{c}$ Corrected for mass fractionation and contributions from spike and blank.

${ }^{d}$ Activity ratios calculated using decay constants $\lambda_{230}=9.158 \times 10^{-6} \mathrm{yr}^{-1}, \lambda_{234}=2.8262 \times 10^{-6} \mathrm{yr}^{-1}$ (Cheng et al. $\left.2000[\mathrm{DIRS} 153475]\right), \lambda_{238}=1.55125 \times 10^{-10} \mathrm{yr}^{-1}$ ["Precision Measurement of Half-Lives and Specific Activities of ${ }^{235} \mathrm{U}$ and ${ }^{238} \mathrm{U}$ " (Jaffey et al. 1971 [DIRS 164637]), and $\lambda_{232}=4.9475 \times 10^{-11} \mathrm{yr}{ }^{-1}(\mathrm{Steiger}$ and ذ) Jäger 1977 [DIRS 133377]). DTN: GS021208312272.008 [DIRS 164609]. 
A.

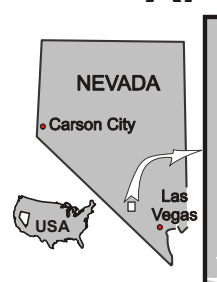

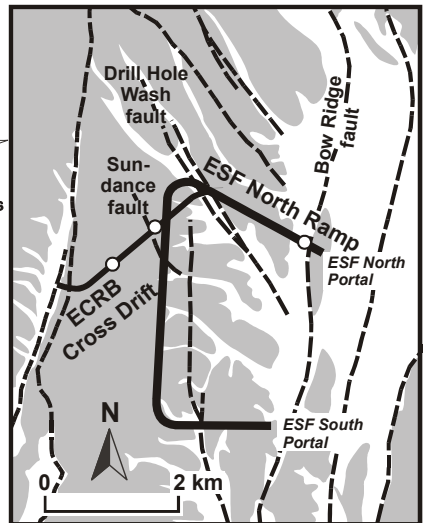

$\square$ Quaternary deposits

$\square$ Miocene volcanic bedrock

- Selected faults

- Exploratory Studies Facility (ESF)

- Enhanced Characterization of the Repository Block (ECRB) Cross O Drift

$\because$ post-Tiva Canyon nonwelded tuff Tiva Canyon welded units

$\square$ Paintbrush nonwelded units

$\mathbb{M}$ Topopah Spring welded units Tptpul = crystal-poor upper lithophysal Tptpmn = crystal-poor middle nonlithophysal Tptpll = crystal-poor lower lithophysal Tptpln = crystal-poor lower nonlithophysal

Calico Hills nonwelded tuff and older volcanic rocks
B. ESF North Ramp
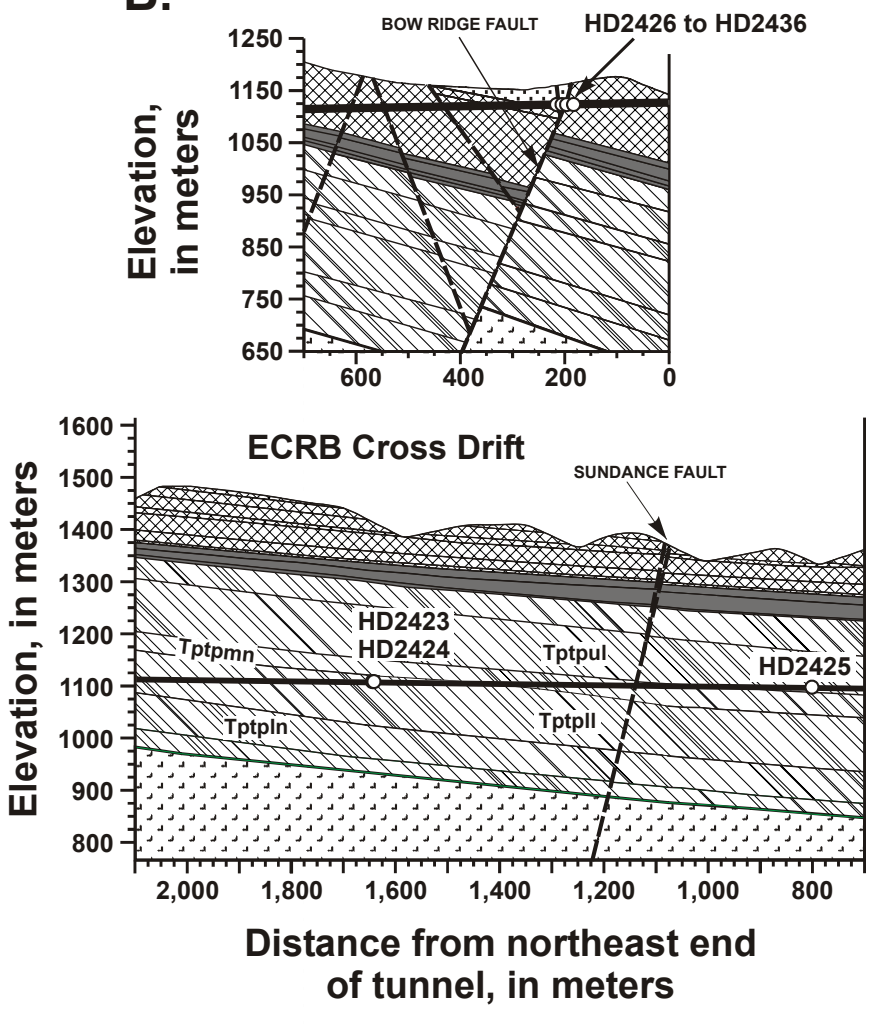

Source: DTNs: GS030808315215.001 [DIRS 165426]; GS021208312272.008 [DIRS 164609]; GS971108314224.020 [DIRS 105561]; GS971108314224.021 [DIRS 106007]; GS990408314224.001 [DIRS 108396]; GS990408314224.002 [DIRS 105625].

NOTES: Panel $A=$ Generalized geologic map of Yucca Mountain showing sample locations.

Panel $B=$ Cross sections along the ESF north ramp tunnel alignment (upper section) and the ECRB Cross-Drift tunnel alignment (lower section) showing sample locations.

"HD" numbers are identification numbers of samples (e.g., HD2423 refers to sample HD2423).

Figure 6-204. Sample Locations and Details of Yucca Mountain, the ESF, and the ECRB

\subsection{Uranium-series "Variations in Fracture Versus Matrix Samples}

Both matrix and fracture flow may contribute to water/rock interactions and consequent uranium-series disequilibrium. To test for increased uranium mobility and ${ }^{234} \mathrm{U} /{ }^{238} \mathrm{U}$ fractionation on fracture surfaces relative to interiors of welded tuff fragments, investigators collected multiple subsamples at varying distances $(0.2$ to $25 \mathrm{~mm})$ from discrete fracture surfaces. Distance profiles show constant or depleted uranium concentrations near fracture surfaces, whereas thorium concentrations are commonly greatest for the subsamples closest to fracture surfaces (Table 6-45, Panel A of Figure 6-205). Given the very low solubility of thorium in low-temperature aqueous solutions (Kaufman 1969 [DIRS 164722]; and Langmuir and Herman 1980 [DIRS 147527]) and the near absence of ${ }^{232} \mathrm{Th}$ in Yucca Mountain UZ secondary calcite and silica deposits (Paces et al. 2001 [DIRS 156507]), the higher concentrations of thorium on fracture surfaces are probably caused either by the removal of uranium and more soluble cations while thorium remained immobile, or by inclusion of small 
amounts of secondary manganese oxides, which preferentially concentrate thorium (Neymark and Amelin 2002 [DIRS 164725]). At the same time, the ${ }^{234} \mathrm{U} /{ }^{238} \mathrm{U}$ AR remains constant across depth profiles whereas the ${ }^{230} \mathrm{Th} /{ }^{238} \mathrm{U}$ AR shows greater but nonsystematic variations (Panel B of Figure 6-205). Based on the small number of available analyses that pertain to these subsamples, systematic differences in either the ${ }^{234} \mathrm{U} /{ }^{238} \mathrm{U}$ or ${ }^{230} \mathrm{Th} /{ }^{238} \mathrm{U}$ disequilibrium are not apparent in comparisons between subsamples representing fracture surfaces, and those obtained from the interiors of the same tuff fragments.

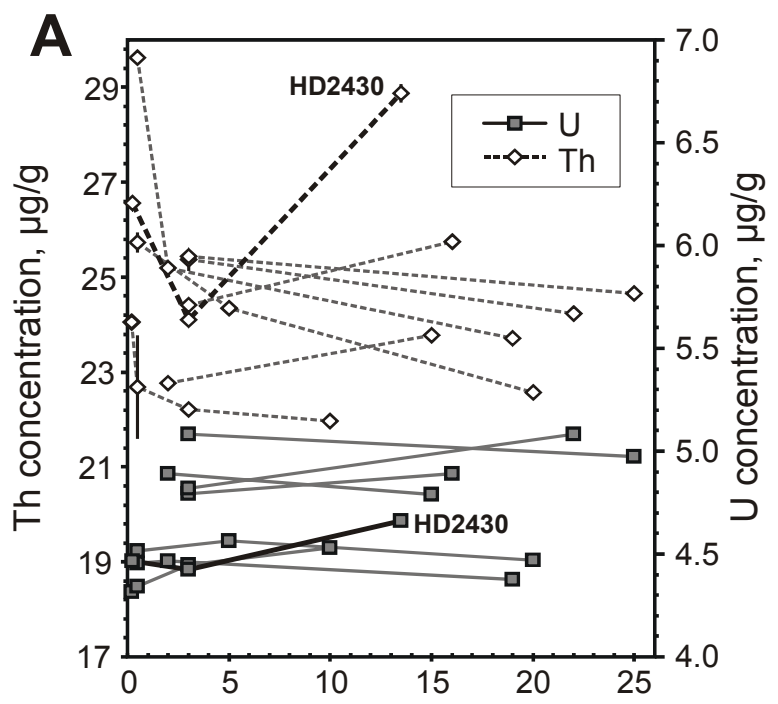

Distance from fracture surface, $\mathrm{mm}$

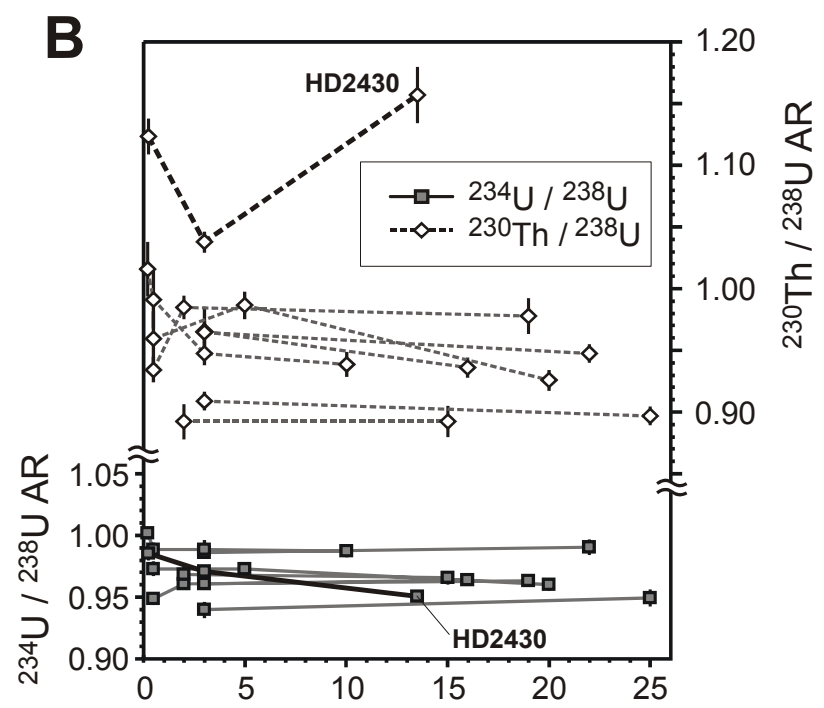

Distance from fracture surface, $\mathrm{mm}$

Source: DTN: GS021208312272.008 [DIRS 164609].

NOTES: Panel $A=$ Thorium and uranium concentration. Panel $\mathrm{B}={ }^{234} \mathrm{U} /{ }^{238} \mathrm{U}$ and ${ }^{230} \mathrm{Th} /{ }^{238} \mathrm{U}$.

Figure 6-205. Variations in Activity Ratios in Yucca Mountain Whole-Rock Subsamples Plotted against Distance from the Fracture Surface

A notable exception (to the observation of general consistency of both concentration and isotopic composition between fracture surfaces and interiors of individual tuff fragments) was obtained for multiple subsamples of sample HD2430. This welded tuff sample was collected from the footwall surface of the Bow Ridge fault (see Section 6.14.3.2.3). It shows not only the largest ${ }^{230} \mathrm{Th} /{ }^{238} \mathrm{U}$ AR values of all of the samples analyzed in this study, but also a large and erratic variation of both thorium concentration and ${ }^{230} \mathrm{Th} /{ }^{238} \mathrm{U}$ AR with distance (Figure 6-205). In contrast, the ${ }^{234} \mathrm{U} /{ }^{238} \mathrm{U}$ AR (Table 6-45) shows a small but consistent decrease from the subsample representing the fracture surface $(0.986 \pm 0.006)$ to the innermost subsample $(0.951 \pm$ $0.004)$ at a distance of approximately $13.5 \mathrm{~mm}$.

\subsection{Uranium-series Variations in Deep UZ Samples}

Whole-rock ${ }^{234} \mathrm{U} /{ }^{238} \mathrm{U}$ and ${ }^{230} \mathrm{Th} /{ }^{238} \mathrm{U}$ ARs show small but significant variations at depth within the Topopah Spring Tuff (TSw) (Table 6-45 and Figure 6-206). Nearly all subsamples have a ${ }^{234} \mathrm{U} /{ }^{238} \mathrm{U}$ AR between approximately 1.0 and 0.95 ; in most cases, values are statistically distinguishable from the secular equilibrium value of 1.0 that is expected for rocks undisturbed 
by water-rock interactions. The ${ }^{230} \mathrm{Th} /{ }^{238} \mathrm{U}$ AR values are also lower than the secular equilibrium value of 1.0; however, most analyses plot near the ${ }^{234} \mathrm{U} /{ }^{230} \mathrm{Th}$ "equiline" (equal ${ }^{234} \mathrm{U}$ and ${ }^{230} \mathrm{Th}$ activities), indicating that the observed ${ }^{230} \mathrm{Th}$ is in radioactive equilibrium with its immediate parent isotope, ${ }^{234} \mathrm{U}$, present in the sample.

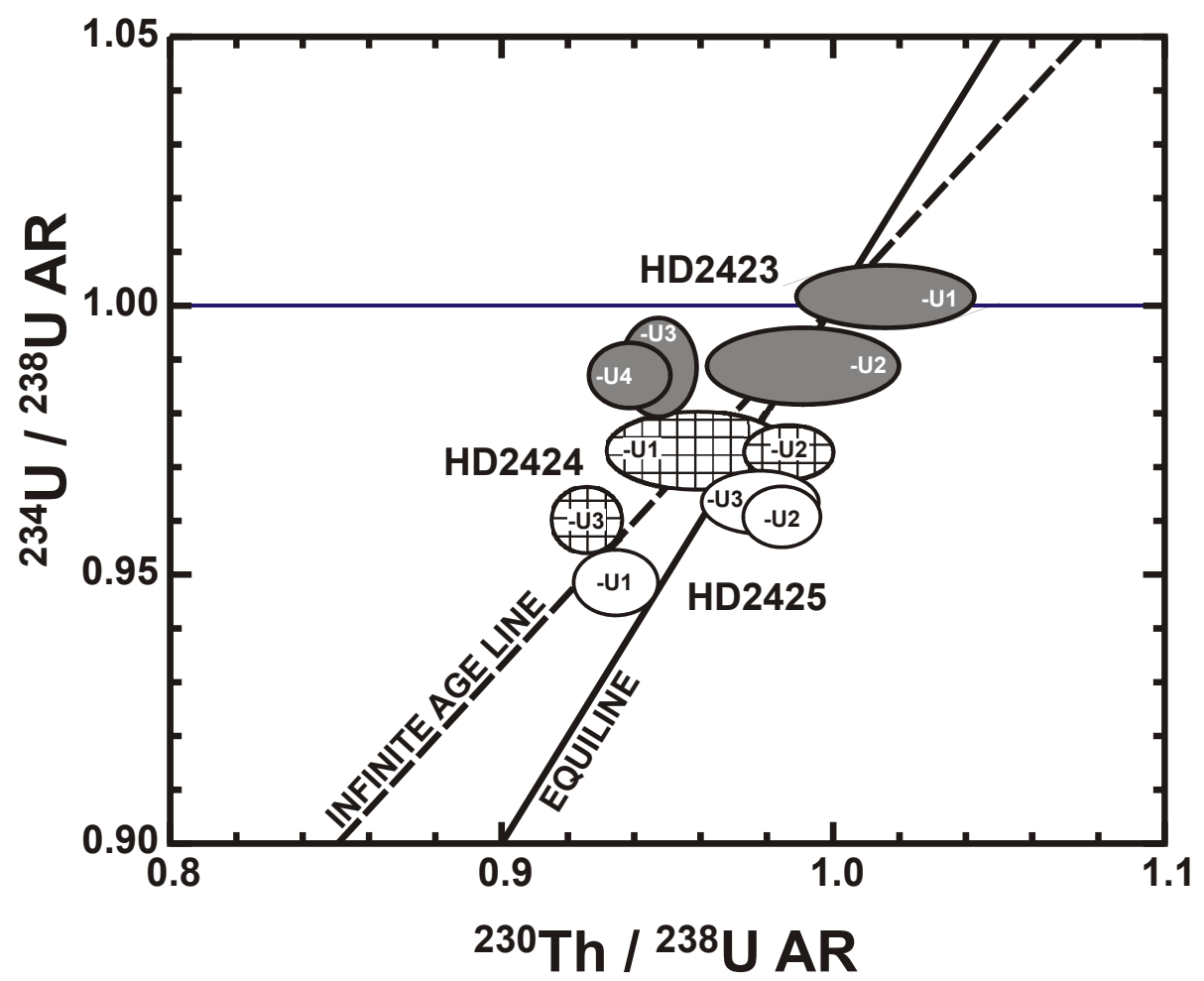

Source: DTN: GS021208312272.008 [DIRS 164609].

NOTES: Data are shown as $2 \sigma$ error ellipses. Sample HD2423 (approximately $300 \mathrm{~m}$ below land surface; shaded ellipses) shows no macroscopic evidence for fracture flow, whereas samples HD2424 (approximately $300 \mathrm{~m}$ below land surface; cross-hatched ellipses) and HD2425 (approximately $220 \mathrm{~m}$ below land surface; open ellipses) are closely associated with hydrogenic calcite deposits indicating past fracture flow and seepage. The ${ }^{230} \mathrm{Th} /{ }^{234} \mathrm{U}$ equiline connects isotopic compositions with equal ${ }^{230} \mathrm{Th}$ and ${ }^{234} \mathrm{U}$ activities. The infinite-age line represents the loci of points for the maximum ${ }^{230} \mathrm{Th} /{ }^{238} \mathrm{U}$ AR possible for a given ${ }^{234} \mathrm{U} /{ }^{238} \mathrm{U}$ AR under conditions of closed isotopic evolution.

Figure 6-206. Relations between ${ }^{230} \mathrm{Th} /{ }^{238} \mathrm{U}$ and ${ }^{234} \mathrm{U} /{ }^{238} \mathrm{U}$ Activity Ratios (ARs) for Three Samples from the ECRB Cross-Drift

Differences in the degree of radioactive disequilibrium between samples associated with sites supporting past fracture flow (as indicated by closely related secondary hydrogenic mineral deposits) also were compared with results from a sampling site lacking obvious evidence of fracture flow. Of the three Topopah Spring Tuff (TSw) samples from the ECRB Cross-Drift, sample HD2423 (at a distance of $1640.8 \mathrm{~m}$ from the northeast end of the ECRB Cross-Drift) is not associated with any visible secondary hydrogenic minerals, whereas samples HD2424 (at $1641.1 \mathrm{~m}$ ) and HD2425 (at $800 \mathrm{~m}$ ) are both from sites with closely associated secondary calcite deposits. Resulting ${ }^{234} \mathrm{U} /{ }^{238} \mathrm{U}$ AR values (Table 6-45) for the "inactive" fracture (sample HD2423, shaded pattern in Figure 6-206) are closer to the secular equilibrium value of 1 compared to samples associated with "active" fracture flow (sample HD2424 (cross-hatched 
pattern), and sample HD2425 (open pattern), in Figure 6-206), which have ${ }^{234} \mathrm{U} /{ }^{238} \mathrm{U}$ AR values in greater disequilibrium. In addition, sample HD2425, which was taken from a stratigraphically higher subunit of the Topopah Spring Tuff (TSw) (crystal-poor upper lithophysal), yields slightly greater ${ }^{234} \mathrm{U}^{238} \mathrm{U}$ disequilibrium than sample HD2424, which was taken from a stratigraphically lower subunit of the Topopah Spring Tuff (TSw) (crystal-poor lower lithophysal). These limited data support the expectation that water/rock interaction is greatest in areas that are associated with fracture flow and at shallower depths within the Topopah Spring Tuff (TSw).

\subsection{Uranium-series Variations in Shallow UZ Samples}

Samples from the ESF near the Bow Ridge fault zone consist of Tiva Canyon Tuff (TCw) in the footwall block, post-TCw nonwelded tuff in the hanging-wall block, and a mixture of the two lithologies in the 2-m-wide fault zone (Figure 6-207). The sampling line across the fault zone was intended to evaluate differences between normal fracture or matrix flow and focused flow within the highly brecciated fault zone within $30 \mathrm{~m}$ of the land surface.

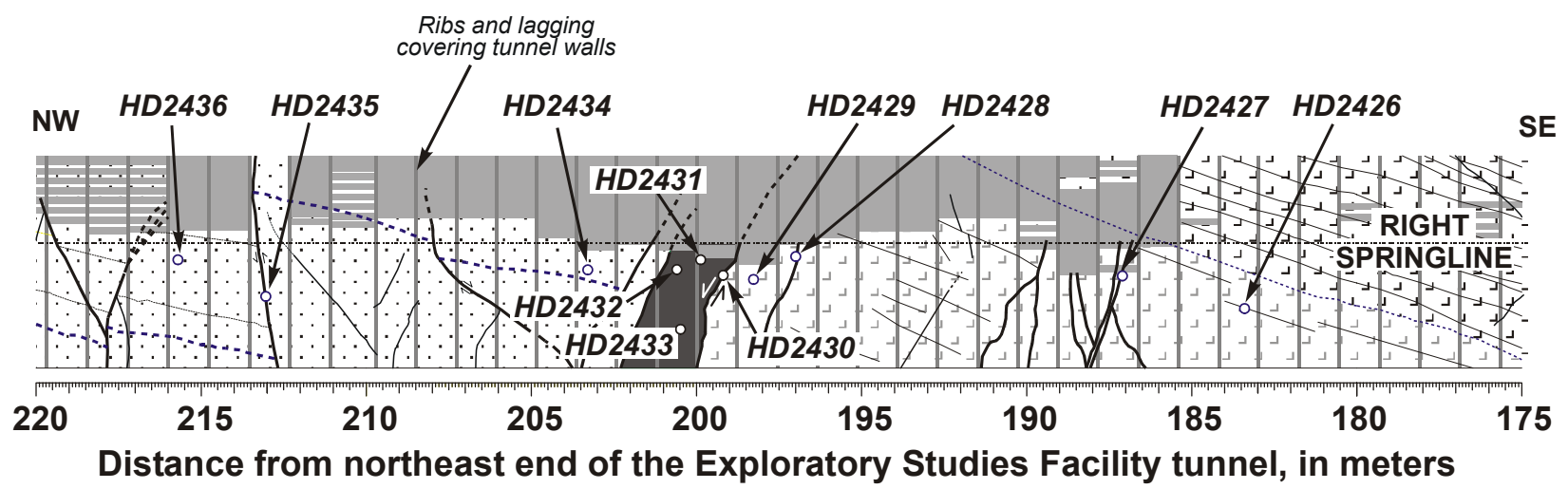

Lithologic units

$\because$ post-Tiva Canyon nonwelded tuff

Tiva Canyon tuff - welded

Middle nonlithophysal subunit

Lower lithophysal subunit

Bow Ridge fault zone breccia

Source: DTNs: GS950508314224.003 [DIRS 107488]; GS021208312272.008 [DIRS 164609].

NOTE: Map modified from Beason et al. (1996 [DIRS 101191], pp. 175-220).

Figure 6-207. Map of the Right Rib of the Exploratory Studies Facility Tunnel Showing Uranium-Series Sample Locations

In ESF samples from the Bow Ridge fault zone, both ${ }^{234} \mathrm{U} /{ }^{238} \mathrm{U}$ and ${ }^{230} \mathrm{Th} /{ }^{238} \mathrm{U}$ ARs span a wider range of values than they do in samples from analyses of the deeper Topopah Spring Tuff (TSw) samples (Table 6-45). Eleven samples across the Bow Ridge fault zone have ${ }^{234} \mathrm{U} /{ }^{238} \mathrm{U}$ AR values less than 1.0 (0.99 to 0.76$)$, but ${ }^{230} \mathrm{Th} /{ }^{238} \mathrm{U}$ AR values that are above and below $1.0(0.82$ to 1.16; Figure 6-208). Samples from within the fault zone show the greatest degree of 
${ }^{230} \mathrm{Th} /{ }^{238} \mathrm{U}$ disequilibrium with activity ratios between 1.04 and 1.16 for Tiva Canyon Tuff (TCw) sample HD2430 from the footwall surface. The surface of a Tiva Canyon Tuff (TCw) clast (approximately $1 \mathrm{~cm}$ in size) within the fault zone (subsample HD2431-U2) also had higher ${ }^{230} \mathrm{Th} /{ }^{238} \mathrm{U}$ ARs $(1.024 \pm 0.011)$ than the ARs for bulk samples of the nonwelded matrix from within the fault zone (0.886 to 0.922) (subsamples HD2431-U1, HD2432-U1, and HD2433-U1). The same samples that have the highest ${ }^{230} \mathrm{Th} /{ }^{238} \mathrm{U}$ ARs have relatively small amounts of ${ }^{234} \mathrm{U}$ depletion (a ${ }^{234} \mathrm{U} /{ }^{238} \mathrm{U}$ AR of 0.951 to 0.986$)$ that are comparable to other whole-rock samples from both the ESF main drift and ECRB Cross-Drift.

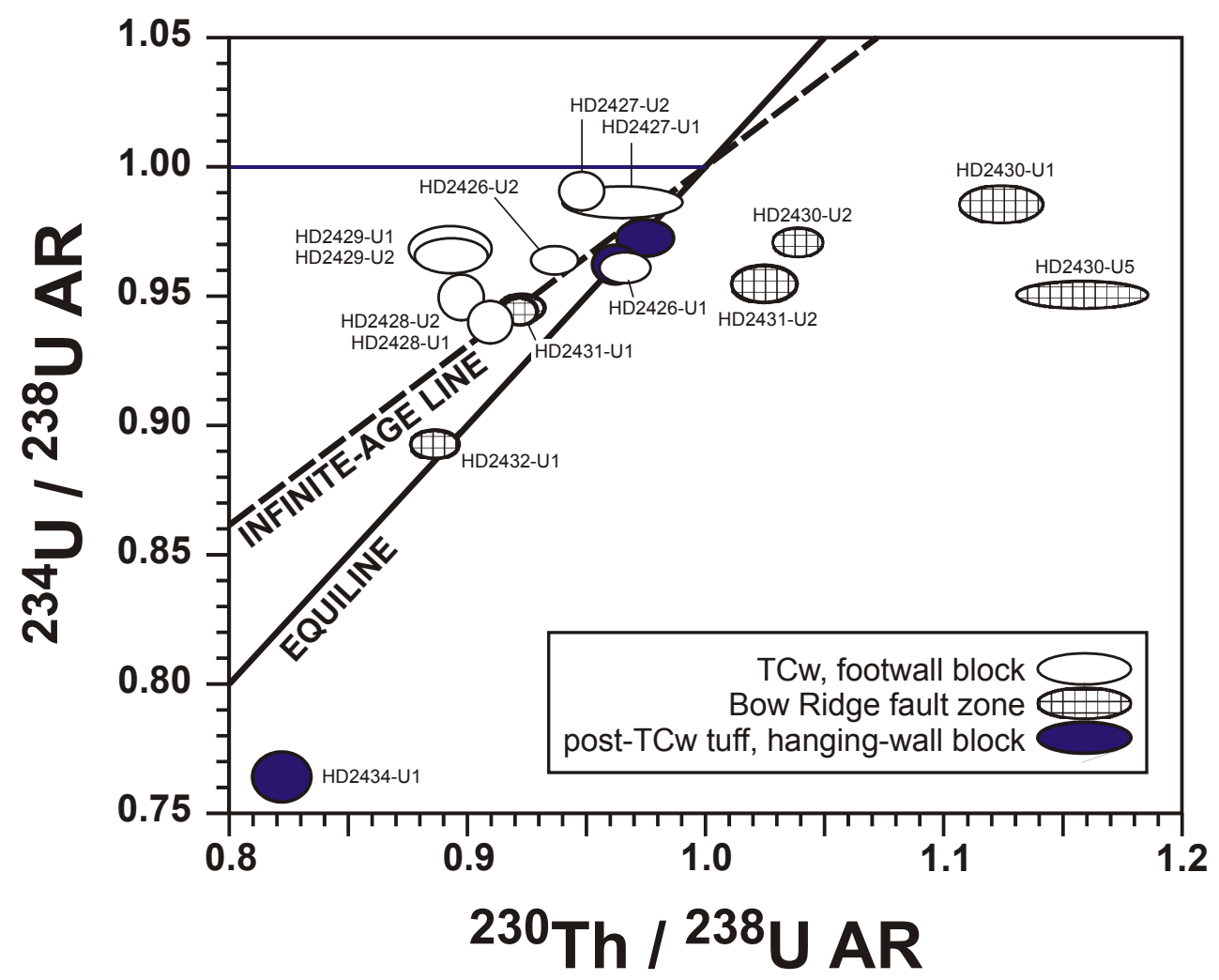

Source: DTN: GS021208312272.008 [DIRS 164609].

NOTE: All samples were taken 20 to $30 \mathrm{~m}$ below land surface. ${ }^{230} \mathrm{Th} /{ }^{234} \mathrm{U}$ equiline and infinite-age line as in Figure 6-206.

Figure 6-208. Uranium-series Isotopic Compositions (2 $\sigma$ Error Ellipses) for Samples from the Exploratory Studies Facility near the Bow Ridge Fault Zone

Two of three samples of post-TCw (post-Tiva Canyon Tuff) nonwelded tuff from the hanging-wall block have ${ }^{234} \mathrm{U} /{ }^{238} \mathrm{U}$ and ${ }^{230} \mathrm{Th} /{ }^{238} \mathrm{U}$ ARs that plot along the equiline with only small amounts of ${ }^{234} \mathrm{U}$ depletion $\left({ }^{234} \mathrm{U} /{ }^{238} \mathrm{U}\right.$ ARs of 0.962 and 0.973$)$. It is worth noting that both analyses show overlapping compositions, because sample HD2435 is a sample of wall rock taken from a section adjoining a 5- to 10-cm-thick, near-vertical fracture filled with calcrete and tan pedogenic opal. In contrast, subsample HD2434-U1, from 1 to $2 \mathrm{~m}$ west of the Bow Ridge fault zone, shows the greatest amount of ${ }^{234} \mathrm{U}$ depletion with a ${ }^{234} \mathrm{U} /{ }^{238} \mathrm{U}$ AR of 0.764 and a ${ }^{230} \mathrm{Th} /{ }^{238} \mathrm{U}$ AR offset somewhat from the equiline toward higher ${ }^{230 \mathrm{Th}}$ ARs. 


\subsection{Comparisons of Water-rock Environments}

Preliminary results suggest that rates of ${ }^{238} \mathrm{U}$ loss are low in Yucca Mountain tuffs compared to crystalline rocks in other areas. The median value for the ${ }^{238} \mathrm{U}$ leach constant $\left(\mathrm{c}_{8}\right)$ is $1.3 \times 10^{-7} /$ year for Topopah Spring Tuff (TSw) samples and $6.2 \times 10^{-7} /$ year for Tiva Canyon Tuff (TCw) samples (Paces and Neymark 2003 [DIRS 162900], pp. 27-39). The leach constant for ${ }^{234} \mathrm{U}$ is denoted by $\mathrm{c}_{4}$. Calculated median $\mathrm{c}_{4} / \mathrm{c}_{8}$ values are 1.6 for Topopah Spring Tuff (TSw) samples and 1.2 for Tiva Canyon Tuff (TCw) samples. These values support general geochemical arguments that the degree of fractionation between ${ }^{234} U$ and ${ }^{238} U$ is inversely proportional to the rate of uranium removal. In a study of uranium and thorium in crystalline rocks from California, Wyoming, Colorado, and Illinois, Rosholt (1983 [DIRS 164723]) found a wide range of uranium-series compositions. Median values of $c_{8}$ and $c_{4} / c_{8}$ calculated for these rocks using the same equations are $6.0 \times 10^{-7}$ year and 1.05, respectively (Paces and Neymark 2003 [DIRS 162900], pp. 27-39). Higher values for $\mathrm{c}_{8}$ were also calculated for Eye-Dashwa granite samples ( 1 to $2 \times 10^{-6} /$ year (Gascoyne and Schwarcz 1986 [DIRS 164720], pp. 75-85)). Comparisons of these data sets are complicated by differences in analytical methods (TIMS versus alpha-decay counting) and the variety of sample types, including both surface and drill-core samples. In contrast to compositions of crystalline rock, fine-grained fluvial sediments exposed to extensive water/rock interactions have $\mathrm{c}_{8}$ values ranging from 3 to $80 \times 10^{-6} /$ year (Vigier et al. 2001 [DIRS 164719], pp. 549-563).

\subsubsection{FRACTURE MINERAL DISTRIBUTION AND MINERALOGY}

Secondary (low-temperature) mineral deposits consist of approximately 1-mm- to approximately 40-mm-thick irregular coatings of predominantly calcite interlayered with lesser amounts of silica phases, including opal, chalcedony, and quartz. Other phases may also be present in minor amounts, including fluorite, clay minerals, zeolites, and manganese oxides; however, these phases are mostly present in older parts of the coatings (Paces et al. 2001 [DIRS 156507], p. 8). Textural details of secondary minerals vary widely in both space and time (Paces et al. 2001 [DIRS 156507], pp. 11-17; and Whelan et al. 2002 [DIRS 160442], p. 738). Calcite typically forms equant, blocky prisms on high-angle fracture surfaces, and unusually delicately bladed crystals in lithophysal cavities and in low-angle fractures. Opal typically forms water-clear solid-hemispheres, botryoidal masses, or thin sheets coating calcite substrates. Opal commonly occurs at the tops of calcite blades. Both opal and calcite are finely layered (micron to submicron) and commonly are intimately intergrown. Outermost surfaces of both minerals show little evidence of dissolution, although scattered patches of basal porous zones may be related to dissolution of early-formed calcite.

Most of the secondary mineralization within the UZ occurs as patchy coatings on the footwalls of fracture cavities or as irregular to hummocky accumulations on the floors of lithophysal cavities (Paces et al. 2001 [DIRS 156507], p. 8; and Whelan et al. 2002 [DIRS 160442], p. 737). Hanging-wall surfaces and cavity ceilings are almost invariably devoid of calcite/silica deposits (Paces et al. 2001 [DIRS 156507], pp. 10-11; and Whelan, et al., 2002 [DIRS 160442], p. 737). Although some small-aperture fractures may be completely filled with calcite, most secondary minerals are present in fractures and lithophysal cavities with substantial open space. Calcite/silica deposits are present in only a small percentage of all fractures or lithophysal cavities (Paces et al. 2001 [DIRS 156507], p. 11); more than 90 percent of the fractures and 
cavities exposed in the underground workings do not contain secondary minerals (Whelan et al. 2002 [DIRS 160442], p. 738). This observation is considered strong evidence that secondary mineral deposits are related to fracture flow and seepage rather than to percolation through the matrix of the welded tuffs. Locations of secondary calcite/silica deposits within underground workings at Yucca Mountain are consistent with formation under hydrologically unsaturated conditions and are inconsistent with formation, even under locally saturated conditions (Paces et al. 2001 [DIRS 156507], p. 66; and Whelan et al. 2002 [DIRS 160442]).

The distribution of secondary minerals within the repository block has been estimated by two different methods. Mineral line-surveys based on visual observation were conducted along tunnel walls in both the ESF main drift and ECRB Cross-Drift. The method involves visually estimating the physical dimensions of secondary mineral deposits within a 60 -cm-wide band of tunnel wall centered on a $30-\mathrm{m}$ tape measure stretched 1.2 to $1.7 \mathrm{~m}$ above the concrete invert (floor) in the ESF, or between the conveyor belt and the right rib spring line in the ECRB Cross-Drift. Thickness, length, and orientation of the mineral deposits were measured within the survey band, and cross-sectional areas of hydrogenic minerals were determined from these measurements. Sums of these areas are divided by the total surveyed area $\left(30 \times 0.6 \mathrm{~m}^{2}\right.$ less areas covered by ribs, lagging, or muck) to obtain mineral abundances in percent. Local irregularities of the tunnel walls, the complex geometry of the mineral coatings, and the accumulation of rock dust obscuring mineral occurrences are sources of measurement error. Within the ESF, surveys typically were conducted on 100-m centers, resulting in 81 determinations for 78 stations. Within the shorter ECRB Cross-Drift, surveys were conducted continuously from $750 \mathrm{~m}$ to $2100 \mathrm{~m}$ in the drift. These surveys were partitioned into 38 separate $25-\mathrm{m}$ or $30-\mathrm{m}$ sections for comparison with the ESF surveys.

The second method of determining mineral abundances relied on the amount of $\mathrm{CO}_{2}$ gas generated by acid treatment of cuttings produced during dry-drilling of two surface-based boreholes, Borehole USW WT-24 and Borehole USW SD-6. Cuttings were collected for each 5 feet of borehole advance, and representative splits were pulverized for $\mathrm{CO}_{2}$ determination by gas chromatography (White et al. 1999 [DIRS 151450]) and calcium determinations by X-ray fluorescence. Calcite abundances were calculated from measured $\mathrm{CO}_{2}$ concentrations and compared to calcium contents from the same intervals. Concentrations of calcium and $\mathrm{CO}_{2}$-derived calcite concentrations are highly correlated (with a correlation coefficient $\mathrm{R}^{2}$ greater than 0.95 ) for compositionally uniform high-silica rhyolite in both the Tiva Canyon and Topopah Spring Tuff units, and have slopes that are consistent with the addition of stoichiometric calcite (dashed lines in Figure 6-209). In addition, calcite-free y-intercept calcium concentrations are similar to bulk-rock values of calcium reported for the Tiva Canyon high-silica rhyolite (average value of $1800 \mu \mathrm{g} / \mathrm{g}$ calcium (Peterman and Futa 1996 [DIRS 106494])) and Topopah Spring high-silica rhyolite (average value of $3600 \mu \mathrm{g} / \mathrm{g}$ calcium (Peterman and Cloke 2002 [DIRS 162576])). 


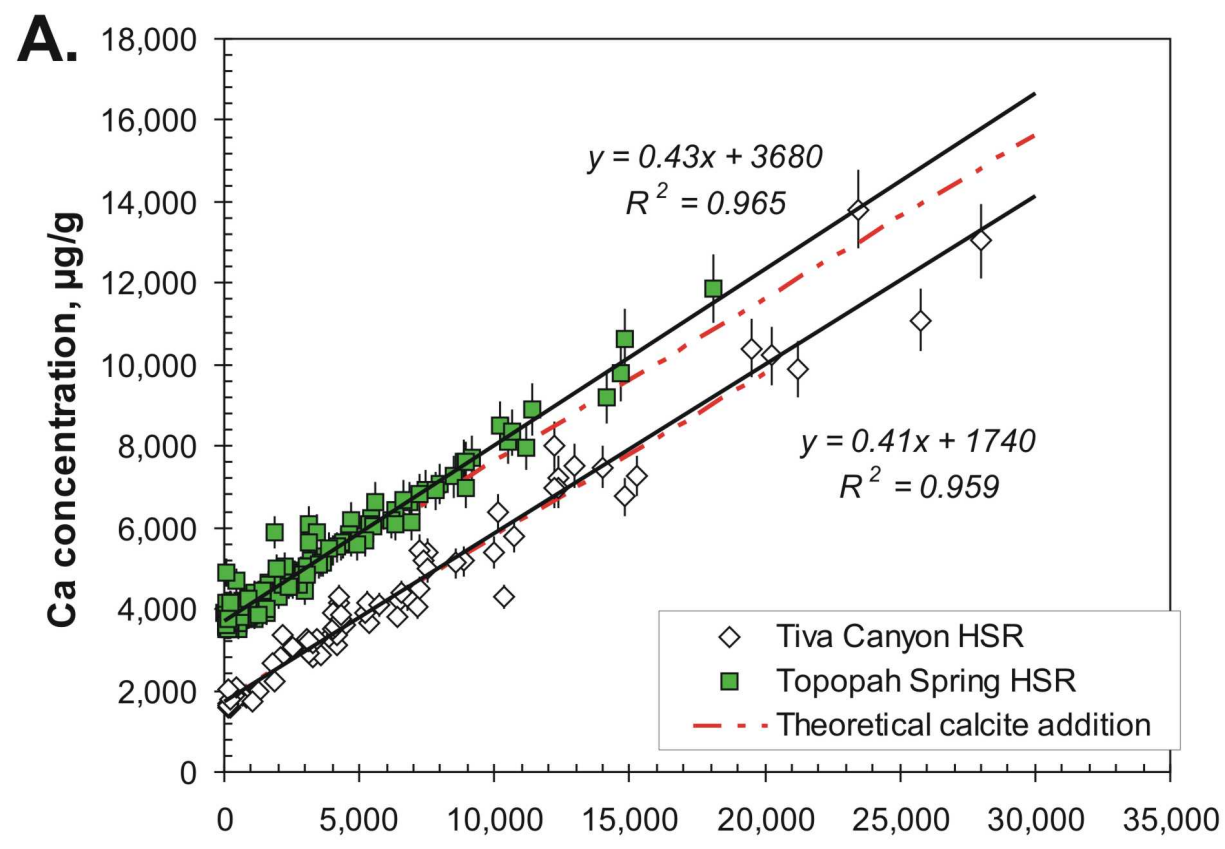

\section{$\mathrm{CO}_{2}$-derived calcite concentration, in $\mu \mathrm{g} / \mathrm{g}$}

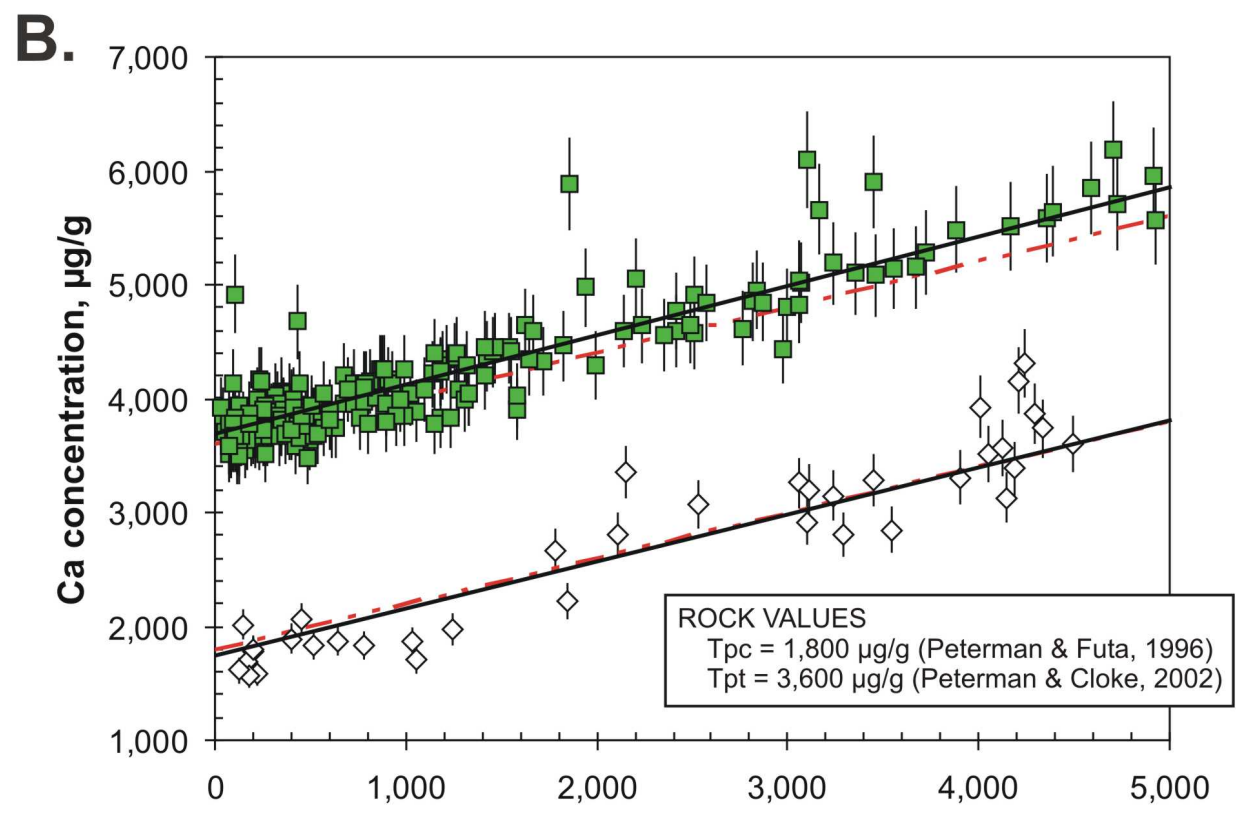

$\mathrm{CO}_{2}$-derived calcite concentration, in $\mu \mathrm{g} / \mathrm{g}$

Source: DTNs: GS030908315215.002 [DIRS 166097]; GS020608315215.002 [DIRS 162126];

GS021008315215.007 [DIRS 162127]; see also Peterman and Futa (1996 [DIRS 106494]) and Peterman and Cloke (2002 [DIRS 162576]).

Figure 6-209. Relations between Calcium Concentration Determined by X-ray Fluorescence and Calcite Concentration Determined by $\mathrm{CO}_{2}$ Evolution for Cuttings of Tiva Canyon and Topopah Spring High-Silica Rhyolite from Boreholes USW SD-6 and USW WT-24 


\subsubsection{Results}

\subsection{ESF Line-Survey Results}

Mineral abundances in the 78 ESF line-survey intervals ranged from no observed hydrogenic minerals to an interval that had 36 deposits yielding a total hydrogenic mineral abundance of 0.65 percent (Figure 6-210 and Figure 6-211). In general, nonwelded tuffs (of the Paintbrush nonwelded (PTn)) with large matrix permeability and few open fractures or cavities have small hydrogenic mineral abundances compared to the welded tuffs (Tiva Canyon Tuff (TCw) and Topopah Spring Tuff (TSw)). Abundance data for all intervals in welded tuffs (71 surveys) have an arithmetic mean of 0.084 percent; however, the frequency distribution is strongly skewed (Panel A of Figure 6-212). Logarithms of the mineral percentages are more symmetrically distributed around a mean value of 0.034 percent (Panel B of Figure 6-218), indicating that mineral populations averaged over $30-\mathrm{m}$ intervals are better represented by lognormal distributions. In the following discussion, log means are used to represent the average mineral abundances when values for multiple survey intervals are given. See Appendix Section I1 and Appendix Section 2 for calculation details.

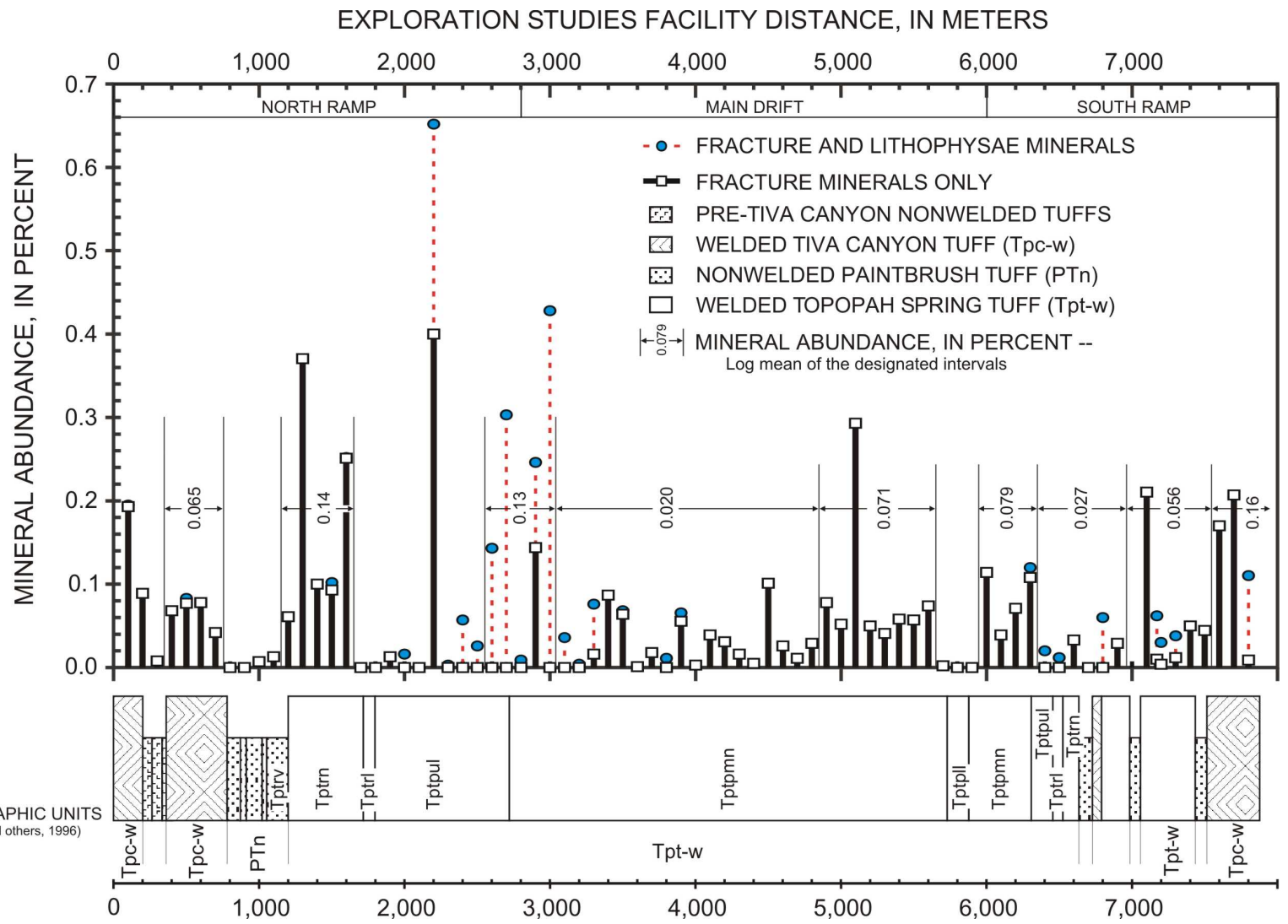

Source: DTN: GS980308315215.008 [DIRS 107355].

NOTE: Mineral abundances (log means in volume percent) are shown for selected intervals.

Figure 6-210. Hydrogenic Mineral Abundances for 30-m Surveys in the Exploratory Studies Facility Plotted against Distance from the ESF North Portal 


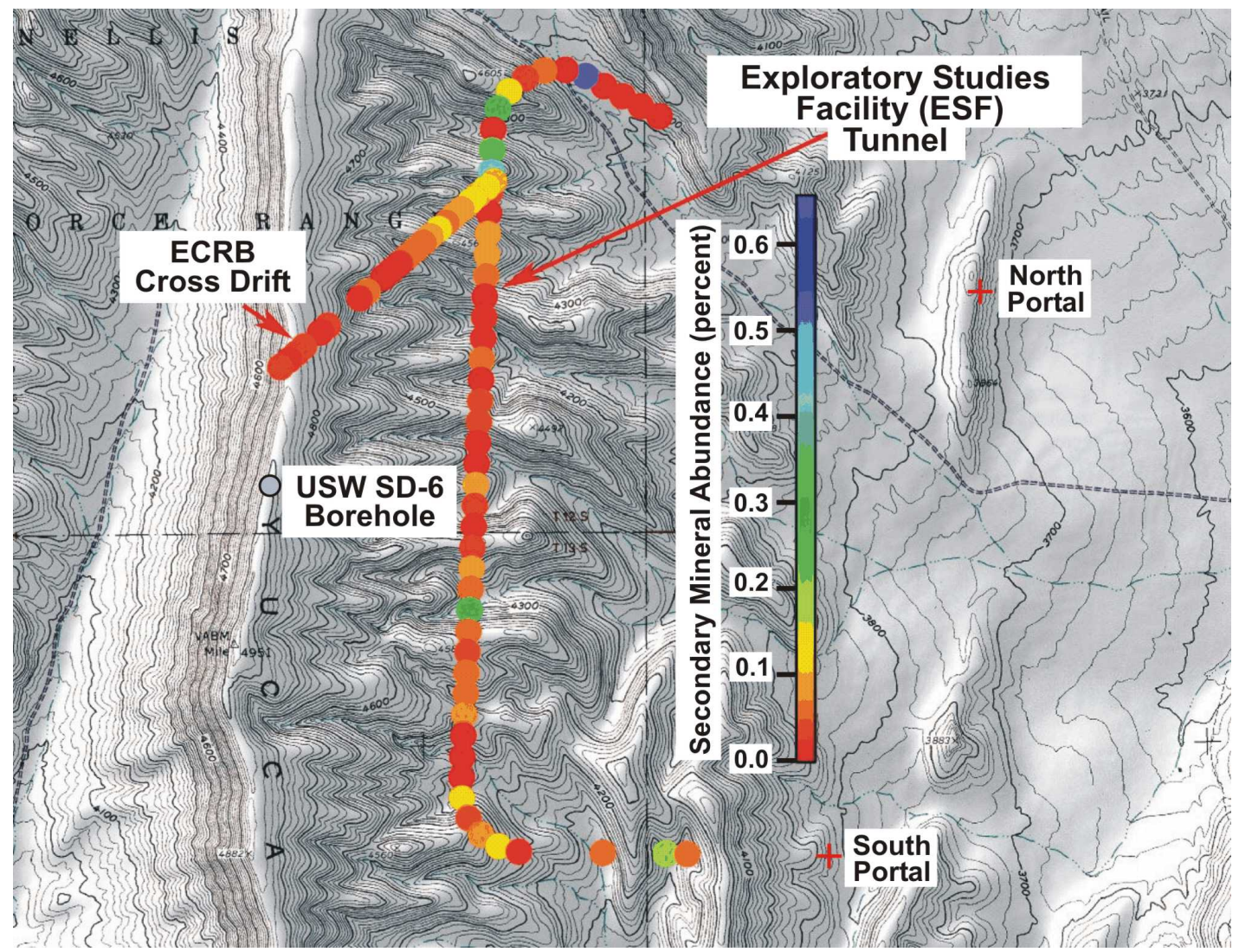

Source: DTNs: GS980308315215.008 [DIRS 107355]; GS030808315215.001 [DIRS 165426].

NOTES: Calcite abundances (volume percent) estimated from line surveys in the Topopah Spring Tuff (TSw) are shown by circles colored according to value. Base map is USGS Busted Butte quadrangle (7.5-minute series), contour interval is $20 \mathrm{ft}(6.1 \mathrm{~m})$; the Drill Hole Wash is illustrated as a dashed line.

Figure 6-211. Calcite Abundances in a Shaded Topographic Map of the Area Overlying the Underground Workings at the Repository Site

Several different factors may control the distribution of hydrogenic minerals in the subsurface, including topography, infiltration, fracture density, fault and shear frequency, and depth. None of these factors appears to have a high degree of correlation with the measured mineral abundances, although the survey with the largest abundance is directly underneath Drill Hole Wash (illustrated as a dashed line), the largest drainage overlying the underground workings (Figure 6-211). Models of infiltration generally predict greater infiltration over bedrock areas compared to alluvium-floored valleys (Flint et al. 2001 [DIRS 156351]), resulting in the highest infiltration expected in the ESF main drift between 3000 and $6000 \mathrm{~m}$. This ESF interval, however, generally contains low average mineral abundances (Panel C of Figure 6-213). Simulated infiltration values compared directly with the mineral-survey data (Marshall et al. 1998 [DIRS 107415], Figure 1) suggest a possible correlation in the Tiva Canyon Tuff (TCw) (the correlation coefficient, $\mathrm{R}^{2}$, for linear regression is 0.43$)$ based on a limited number $(\mathrm{N}=7)$ of survey intervals; however, no correlation between simulated infiltration and mineral abundance is present in the Topopah Spring Tuff (TSw) $\left(\mathrm{R}^{2}=0.009 ; \mathrm{N}=50\right)$. These observations are interpreted to mean that other factors besides infiltration control the distribution of mineral abundances beneath the Paintbrush nonwelded (PTn). 

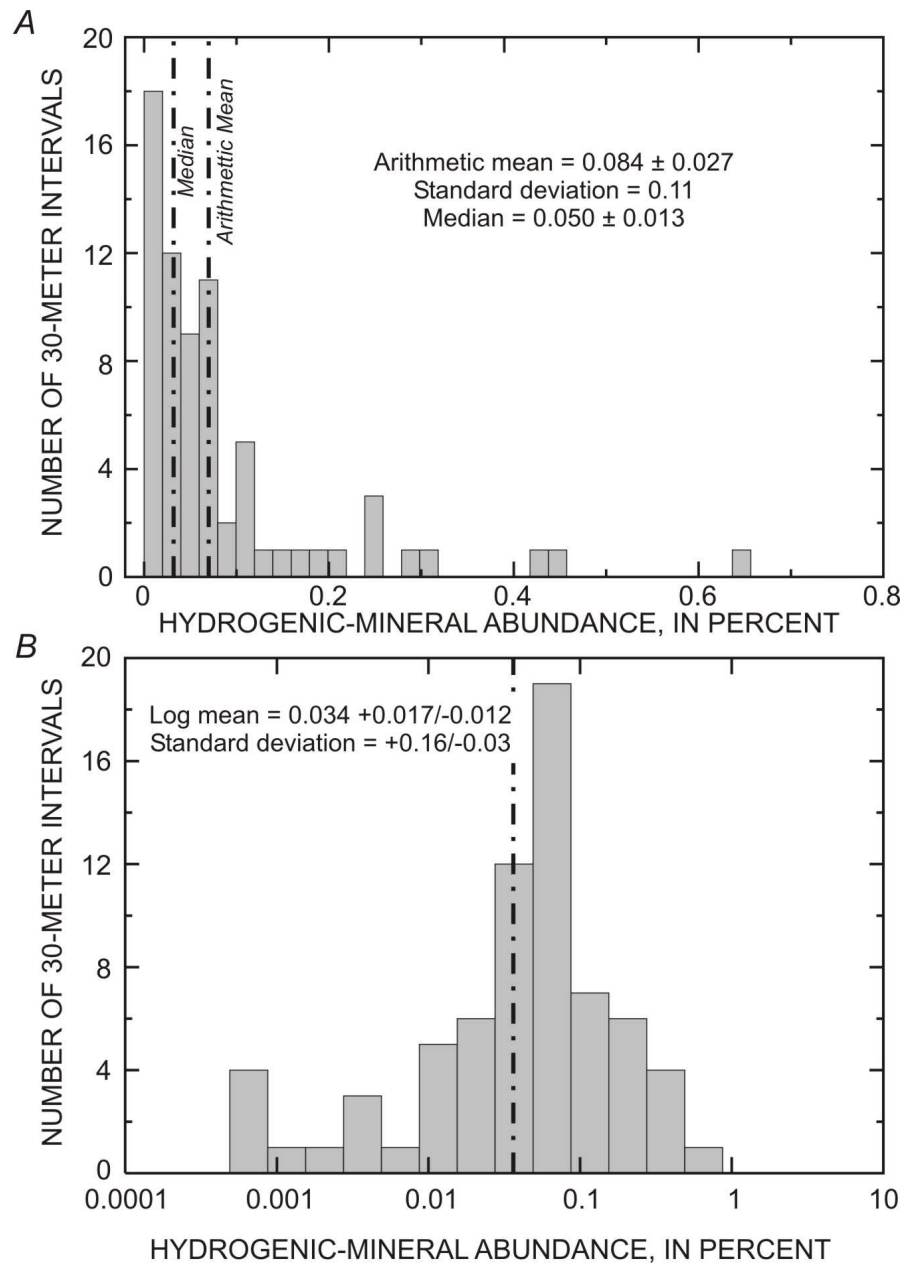

Source: DTN: GS980308315215.008 [DIRS 107355].

NOTES: A total of 71 intervals are plotted, and uncertainties for mean and median estimates are given at the 95-percent confidence level (Appendix Section 15).

Panel $\mathrm{A}=$ Linear scale.

Panel $B=$ Log scale.

Figure 6-212. Histograms Showing Hydrogenic Mineral Abundances in Welded Tuffs in the Exploratory Studies Facility

Mineral abundances also can be compared to structural features mapped in the ESF. The number of fractures per meter is generally low in the ESF north ramp, and increases substantially in the ESF main drift in the Topopah Spring Tuff (TSw) middle nonlithophysal zone (Panel A of Figure 6-213). Many of these fractures are strata-bound features formed during cooling of the volcanic rock and, consequently, are unlikely to have long-range continuity that would facilitate UZ flow. Results of comparisons between data shown in Panel A and Panel C of Figure 6-213 imply that mineral abundances are not correlated to fracture frequency. 


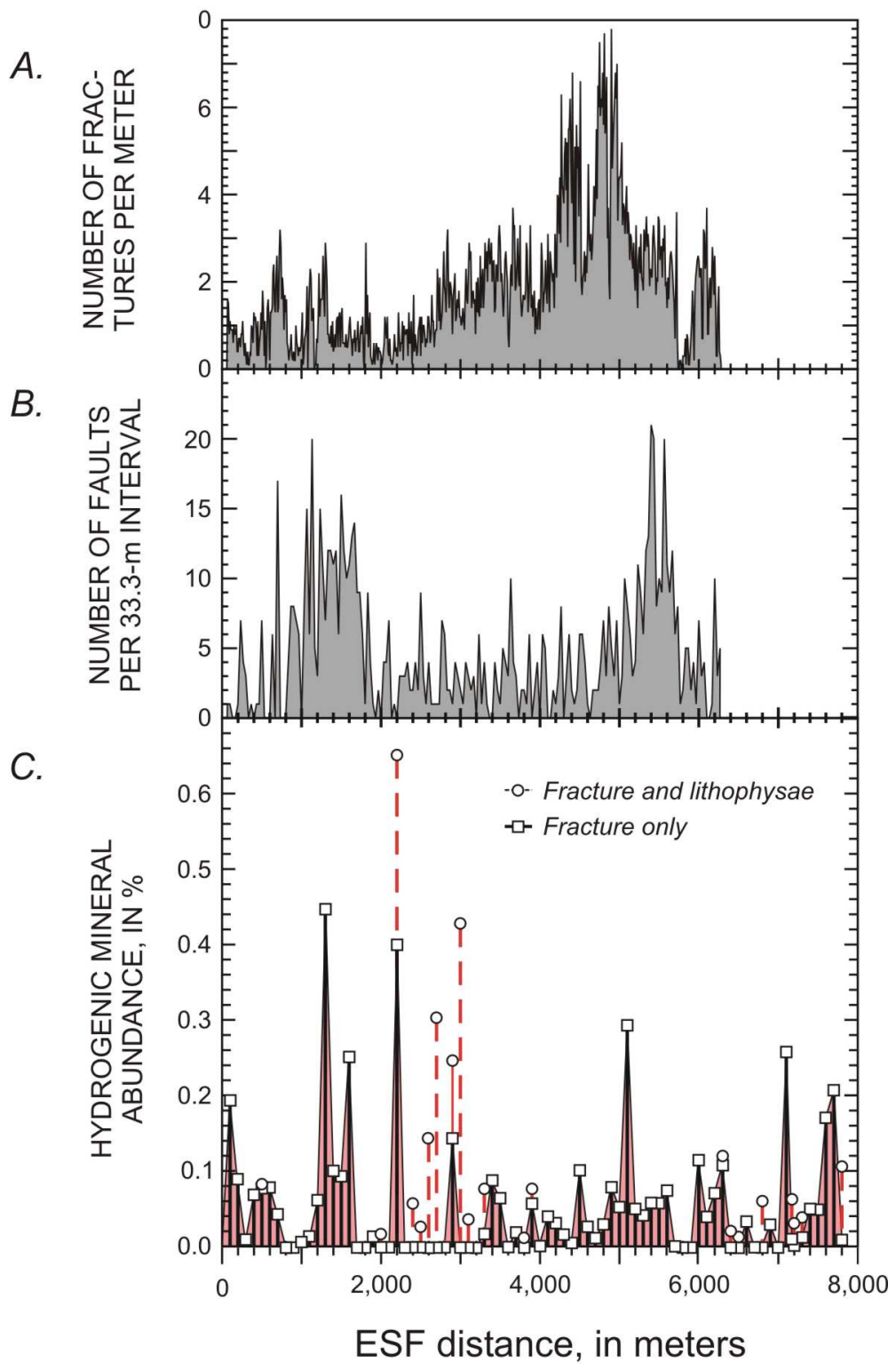

Source: DTNs: GS960908314224.014 [DIRS 106033]; GS970208314224.003 [DIRS 106048]; GS971108314224.020 [DIRS 105561]; GS971108314224.021 [DIRS 106007]; GS971108314224.022 [DIRS 106009]; GS971108314224.023 [DIRS 106010]; GS971108314224.024 [DIRS 106023]; GS971108314224.025 [DIRS 106025]; GS971108314224.026 [DIRS 106032]; GS971108314224.028 [DIRS 106047]; GS980308315215.008 [DIRS 107355].

NOTES: Panel $A=$ Fracture density.

Panel $\mathrm{B}=$ Fault and shear density.

Panel $\mathrm{C}=$ Hydrogenic mineral abundance.

Figure 6-213. Variations with Distance in the Exploratory Studies Facility from the ESF North Portal 
In contrast to fractures, faults and shears may provide long-range connectivity for percolation. Distributions of these structures in the first $6200 \mathrm{~m}$ of the ESF cluster in two areas, the first between approximately 1000 and $1800 \mathrm{~m}$, and the second between approximately 4900 and $5800 \mathrm{~m}$ (Panel B of Figure 6-213). These areas also have mineral abundances that are generally greater than the mean value for the ESF (Figure 6-210 and Panel C of Figure 6-213). Although some major faults are interpreted to be generally responsible for greater mineral abundances in adjacent areas (the western splay of the Drill Hole Wash fault and associated ESF survey at $2200 \mathrm{~m}$ are the most notable examples), other major faults have no closely related hydrogenic minerals. In spite of the qualitative observations, no correlation exists when mineral abundance data from the welded units of the Topopah Spring Tuff are plotted against the number of faults and shears in the corresponding ESF intervals (Figure 6-214). Correlation between these parameters may be lacking, in part, because some of the faults may not effectively transmit water. If faults do act as percolation conduits, they may lack the open space necessary for hydrogenic mineral deposition. Mineral deposits associated with faulting also may be offset from mapped fault planes. For example, large mineral abundances were observed in the ESF between 2200 and $2230 \mathrm{~m}$, although the western splay of the fault intersects the ESF at approximately $2270 \mathrm{~m}$. This being the case, a relation (albeit a complex one) may exist between faulting, percolation, and mineral deposition.

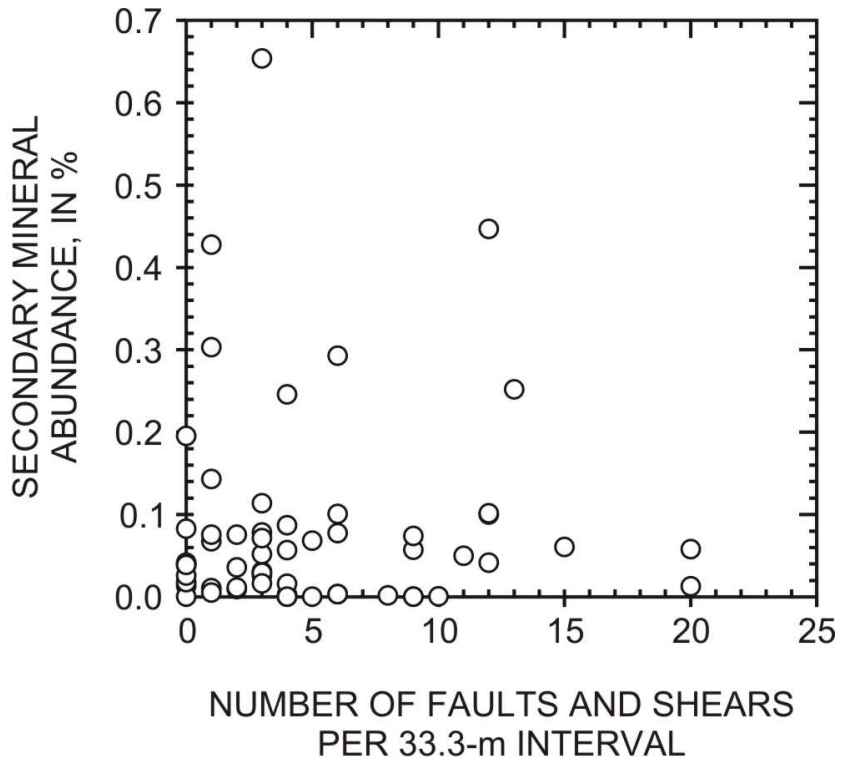

Source: DTNs: GS960708314224.008 [DIRS 105617], GS960708314224.010 [DIRS 106031], GS000608314224.004 [DIRS 152573], GS960908314224.014 [DIRS 106033], GS970208314224.003 [DIRS 106048], GS971108314224.020 [DIRS 105561], GS971108314224.021 [DIRS 106007], GS971108314224.022 [DIRS 106009], GS971108314224.023 [DIRS 106010], GS971108314224.024 [DIRS 106023], GS971108314224.025 [DIRS 106025], GS971108314224.026 [DIRS 106032], GS971108314224.028 [DIRS 106047].

Figure 6-214. Relation between Hydrogenic Mineral Abundance in Welded Units of the Topopah Spring Tuff and the Number of Faults and Shears Measured in the Corresponding Intervals in the Exploratory Studies Facility 
Lithostratigraphic depth also may control the abundance of hydrogenic minerals. To evaluate this possibility, 30-m survey intervals were grouped by host lithology and their location (i.e., along the ESF north ramp, ESF south ramp, and ESF main drift). Lithostratigraphic zones of the Tiva Canyon Tuff (TCw) have log means of the hydrogenic mineral abundances that range from 0.053 to 0.16 percent. The small number of observations, and the lack of large variation between percentages in the north and south ramps, justify calculating an overall Tiva Canyon Tuff (TCw) $\log$ mean of 0.094 percent $(\mathrm{N}=9)$. Welded zones in the TSw generally have mineral-abundance percentages that are lower than the Tiva Canyon Tuff (TCw) mean, although the Topopah Spring Tuff (TSw) crystal-rich nonlithophysal unit in the ESF north ramp area has a log mean of 0.14 $(\mathrm{N}=5)$. The same zone in the ESF south ramp has a lower percentage of $0.028(\mathrm{~N}=4)$. The Topopah Spring Tuff (TSw) upper lithophysal zone exposed in the ESF north ramp has a small value of 0.014 percent $(\mathrm{N}=11)$ with a large uncertainty because of the scatter of individual surveys. If the values for surveys under Drill Hole Wash (1800 to $2300 \mathrm{~m})$ are excluded, the log-mean increases to 0.090 percent $(\mathrm{N}=4)$. The same zone exposed in the ESF south ramp has a value of 0.047 percent $(\mathrm{N}=6)$, and the log mean value for both areas (excluding surveys under Drill Hole Wash) is 0.060 percent $(\mathrm{N}=10)$. This latter value is preferred, in part, because a similar value is obtained if the lithophysal-rich parts of the underlying middle nonlithophysal zone are combined with the ESF north ramp upper lithophysal data (2400 to $3300 \mathrm{~m}$ ). Mineral abundances for the Topopah Spring Tuff (TSw) middle nonlithophysal zone in the ESF main drift are based on the largest number of surveys and have a log-mean value of 0.030 percent $(\mathrm{N}=30)$, although this value varies from 0.020 percent toward the north to 0.071 percent toward the south (Figure 6-210). The Topopah Spring Tuff (TSw) lower lithophysal zone was exposed only in one survey $(5700 \mathrm{~m})$ and lacked macroscopic calcite or opal. Preferred estimates of mineral abundances grouped by stratigraphic position (filled symbols, Figure 6-215) suggest that values decrease with depth in the UZ, although substantial overlap exists in uncertainties among the groups.

\subsection{Borehole Cutting Results}

In addition to other supporting data, stratigraphic controls on mineral distributions are supported by data from USW WT-24 and USW SD-6 cuttings (Figure 6-216). In both cases, calcite concentrations are highest near the surface in the Tiva Canyon Tuff (TCW). Concentrations decrease with increasing depth in the Tiva Canyon Tuff ( $\mathrm{TCw}$ ) and into the nonwelded tuffs of the Paintbrush nonwelded (PTn). At WT-24, calcite concentrations are very low within the thick Paintbrush nonwelded (PTn) (median value of $46 \mu \mathrm{g} / \mathrm{g}$ ) and remain low in the Topopah Spring Tuff (TSw) until near the base of the upper lithophysal unit (Tptpul; median value $=270 \mu \mathrm{g} / \mathrm{g}$ ). Concentrations increase dramatically in the Topopah Spring Tuff (TSw) middle nonlithophysal unit (Tptpmn; median value $=2700 \mu \mathrm{g} / \mathrm{g}$ ) and gradually decrease with depth in the lower lithophysal (Tptpll; median value $=1200 \mu \mathrm{g} / \mathrm{g}$ ) and lower nonlithophysal (Tptpln; median value $=162 \mu \mathrm{g} / \mathrm{g}$ ) units. At SD-6, a similar increase in calcite concentration is observed within the Tptpul (median value $=1700 \mu \mathrm{g} / \mathrm{g}$ ); however, concentrations quickly decrease in the underlying welded units $($ Tptpmn median $=1100 \mu \mathrm{g} / \mathrm{g}$; Tptpll median $=518 \mu \mathrm{g} / \mathrm{g}$; Tptpln $=598 \mu \mathrm{g} / \mathrm{g})$. 


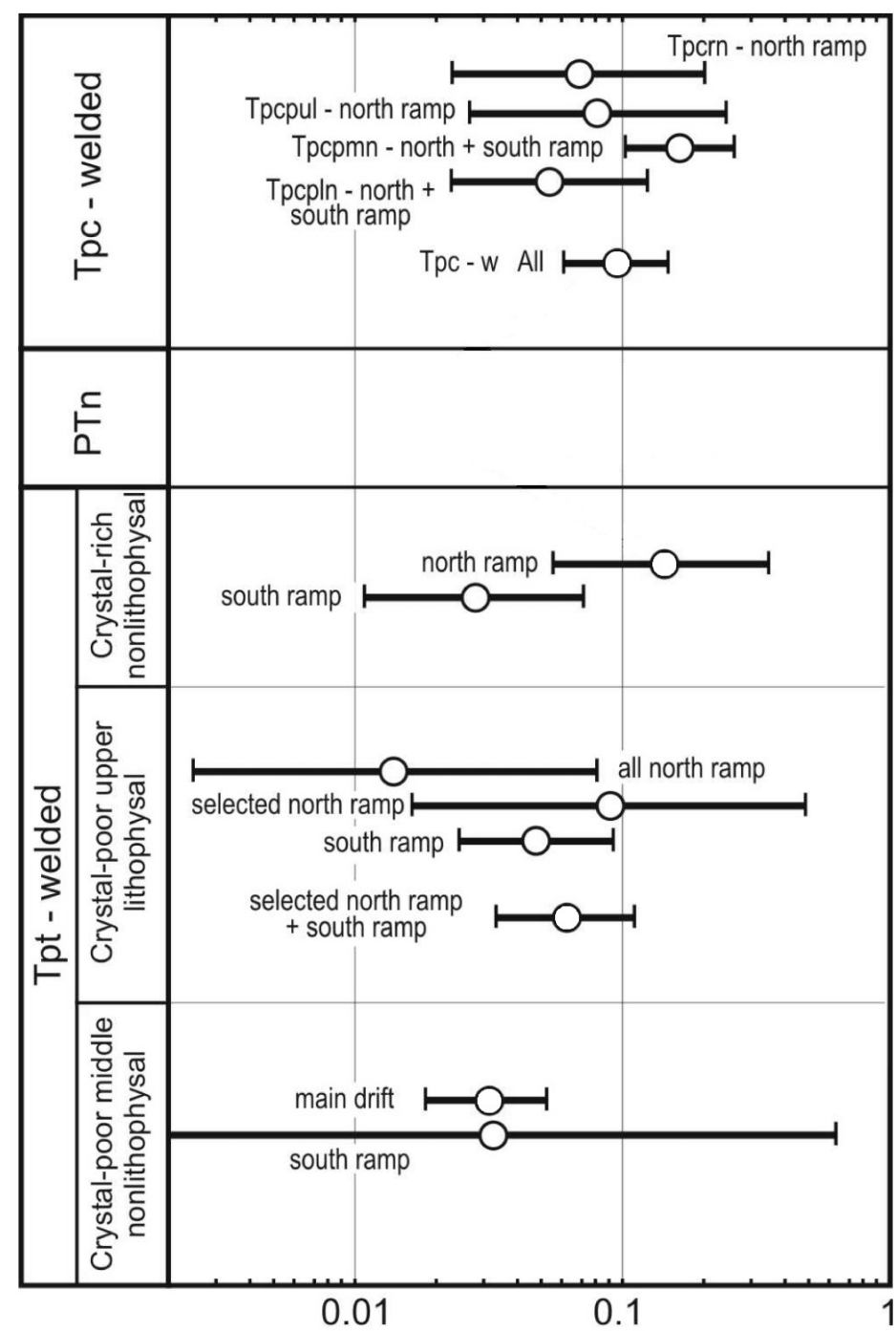

\section{HYDROGENIC-MINERAL ABUNDANCE, IN LOG MEAN PERCENT}

Sources: Stratigraphic units from Buesch et al. (1996 [DIRS 100106]).

DTNs: GS980308315215.008 [DIRS 107355].

Figure 6-215. Summary of Hydrogenic-Mineral Abundances in Welded Tuffs in the Exploratory Studies Facility 


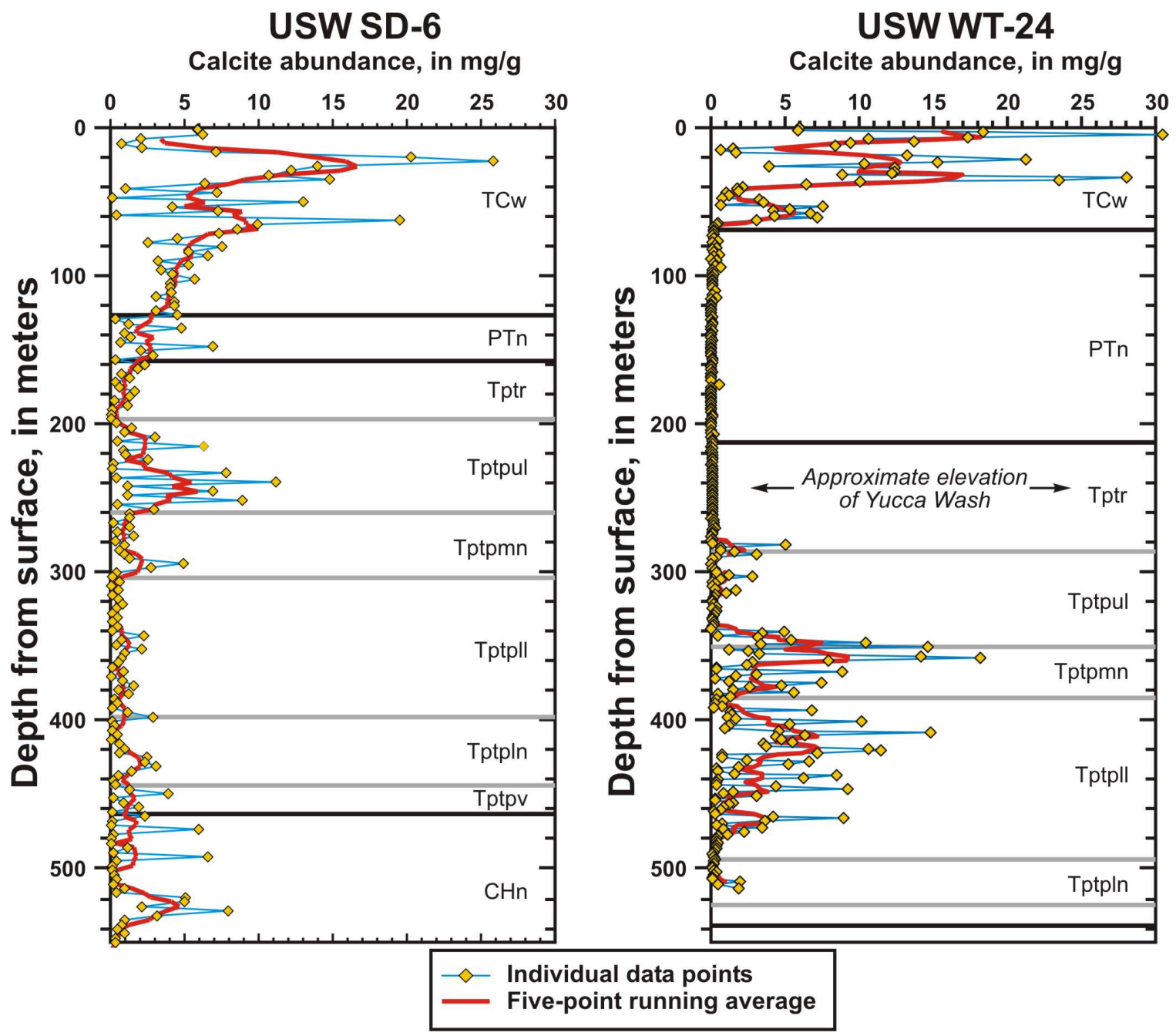

Source: DTNs: GS030908315215.002 [DIRS 166097]; GS020608315215.002 [DIRS 162126];

GS021008315215.007 [DIRS 162127].

Figure 6-216. Profiles of Calcite Abundance Calculated from $\mathrm{CO}_{2}$ Determinations on Cuttings from Boreholes USW SD-6 and USW WT-24

\subsection{Interpretation of Results}

These data show clear evidence for stratigraphic control on calcite concentration. The general trend of large decreases in calcite concentration through the Tiva Canyon Tuff (TCw) are pronounced in both boreholes and most likely reflect larger amounts of gas flow and consequent rates of evaporation in the shallow, fractured tuffs. Variations in oxygen-isotope compositions of late-stage calcite were also used as evidence for greater evaporative effects in the Tiva Canyon Tuff (TCw) relative to the Topopah Spring Tuff (TSw) (Whelan et al. 2002 [DIRS 160442], Figure 8). Reduced gas fluxes within the Paintbrush nonwelded (PTn) are a likely cause for lower calcite concentrations. Conceptual models of calcite deposition rely on interactions between independently migrating gas and liquid phases as a primary cause for both calcite and opal deposition (Paces et al. 2001 [DIRS 156507]; and Whelan et al. 2002 [DIRS 160442]). 
Decreased amounts of gas flow beneath the Paintbrush nonwelded (PTn) are a likely cause for the overall lower calcite abundances in the Topopah Spring Tuff (TSw) compared to the Tiva Canyon Tuff (TCw). Variations in oxygen isotopes in Topopah Spring Tuff (TSw) calcite are interpreted as evidence of greater influence from geothermal effects than evaporative effects (Szabo and Kyzer 1990 [DIRS 109172]; Whelan et al. 1994 [DIRS 100091]; and Whelan et al. 2002 [DIRS 160442], p. 743). However, the causes for large observed variations in calcite concentration within Topopah Spring Tuff (TSw) units are not obvious. Variations within the Topopah Spring Tuff (TSw) are similar in both boreholes. Both profiles show marked increases in concentration far below the Paintbrush nonwelded (PTn)/ Topopah Spring Tuff (TSw) boundary within the Tptpul or Tptpmn units. Both profiles also show distinct decreases in calcite concentrations below this peak, although overall abundances of calcite are much greater in the deeper Topopah Spring Tuff (TSw) units in Borehole USW WT-24. Additional factors may affect UZ flow at this site, including the possibility of dispersal of UZ flow associated with overland recharge in Yucca Wash less than $1 \mathrm{~km}$ to the northeast. Anomalously large calcite abundances have also been observed in drill core from nearby Borehole USW G-2. Because of this complication, the calcite concentration profile from Borehole USW SD-6 may better represent calcite distributions within the repository footprint.

Line surveys completed in the ECRB Cross-Drift provide additional support for the interpretations above, specifically that surface infiltration has little effect on seepage in the Topopah Spring Tuff (TSw) and that there is an overall decrease in seepage with stratigraphic depth within the Topopah Spring Tuff (TSw). If the calcite abundance measurements from the ECRB Cross-Drift and from USW SD-6 are divided into lithostratigraphic zones (Figure 6-217), it is apparent that both sets of data reveal similar decreases in calcite abundance with depth, implying decreasing percolation with depth. The cross-drift data clearly do not show any increase in abundance under the crest of Yucca Mountain (Figure 6-211), and this is another indication of the lack of correlation with simulated infiltration differences due to topographic effects.

In addition to variations in gas flux through the Topopah Spring Tuff (TSw), changes in percolation flux with depth may also influence calcite deposition. Increases in calcite concentrations in the Tptpul and upper parts of the Tptpmn may reflect fracture water that seeps into lithophysal cavities and is dispersed over very large surface areas exposed to open space. Interactions with an upward-migrating gas phase passing through these cavities causes slow growth of calcite and opal. Consequently, less fracture water may be available for subsequent percolation to greater depths. The much lower calcite concentrations observed in the underlying Tptpll may reflect lower total fracture-water fluxes and reduced percolation. 


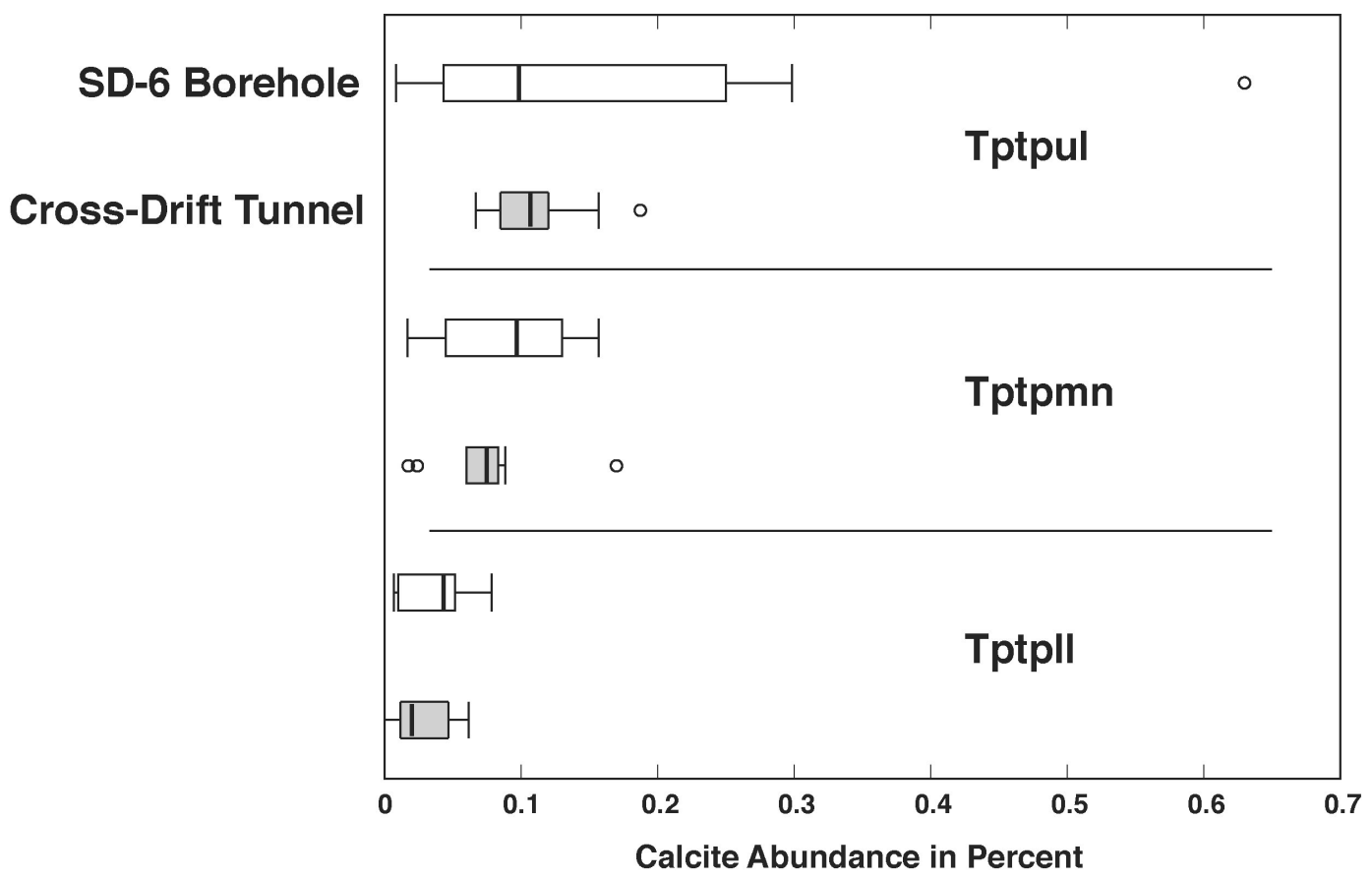

Source: DTNs: GS030908315215.002 [DIRS 166097]; GS030808315215.001 [DIRS 165426]; GS020608315215.002 [DIRS 162126].

NOTES: Note that two different methods were used to estimate calcite abundance as discussed in the text; borehole abundances are weight percent, and cross-drift abundances are volume percent. Both sets of data clearly show a decrease in abundance with depth, especially in the lower lithophysal zone (Tptpll). See Appendix Section 14 for details of box and whisker plots.

The black vertical lines indicate the mean value; the boxes indicate 2 times the standard deviation; the outer lines (also known as "whiskers") indicate the total range of data values, and individual points indicate outlier data. Open boxes describe data from Borehole SD-6; filled boxes describe data from the ECRB Cross-Drift.

Figure 6-217. Box and Whisker Plots for Distributions of Calcite Abundance Measurements in Borehole USW SD-6 and the ECRB Cross-Drift (gray boxes) for Three Lithostratigraphic Zones

\subsection{Estimates of Past Percolation Volumes}

Using calculated volumes of calcite at each surveyed site in the underground workings within the Topopah Spring Tuff (TSw), it is possible to estimate the volumes of water required to deposit the calcite. By scaling the individual volumes up to the volume that would correspond to a 5-m-long waste package, estimates of past water percolation may be made on a per-wastepackage basis (Marshall et al. 2003 [DIRS 162891]). The data required to make these estimations includes the statistical distribution of coating thicknesses and cavity widths (Figure 6-218). The details of the estimations are presented in Marshall et al. (2003 [DIRS 162891]). 
A

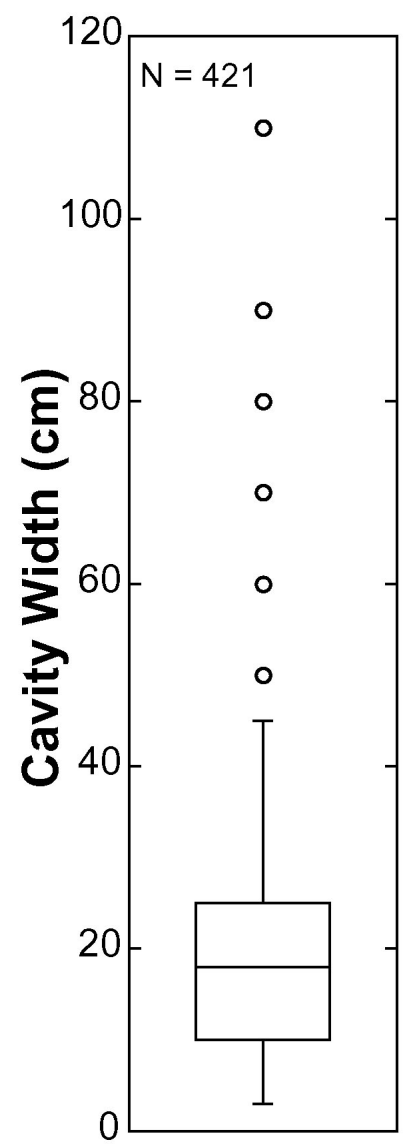

B

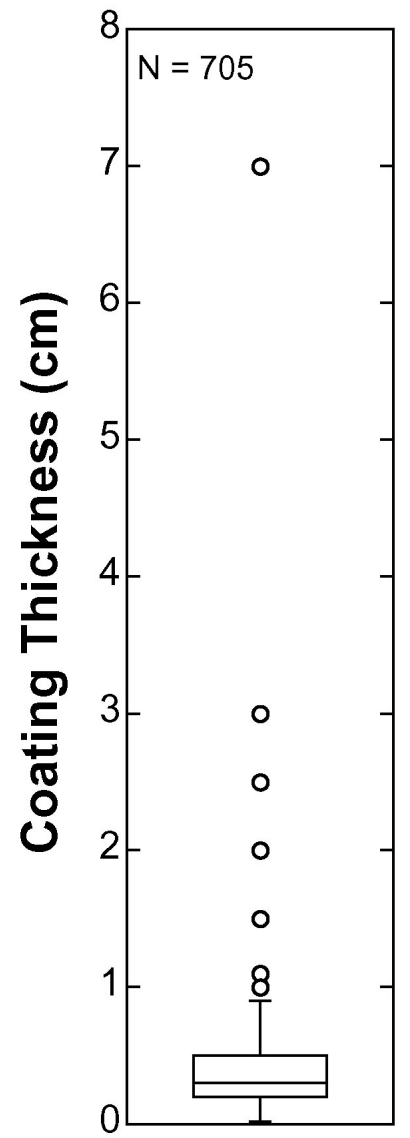

Source: DTNs: GS030808315215.001 [DIRS 165426]; GS980308315215.008 [DIRS 107355].

NOTES: The upper and lower limits of the box are the 75th and 25th percentiles of the data, the horizontal line dividing the box is the median, the outer lines (also known as "whiskers") indicate the total range of the data as calculated from the box range, and outliers are shown by circles. $\mathrm{N}$ is the number of measurements (Appendix Section 14).

Panel A = Box and whisker plots for distributions of lithophysal cavity widths in the Topopah Spring Tuff (TSw).

Panel B = Coating Thicknesses for Both Cavities and Fractures in the Topopah Spring Tuff (TSw).

Figure 6-218. Topopah Spring Tuff Details 


\section{CONCLUSIONS}

Since the inception of the ambient field testing program in 1995 (during the excavation of the ESF), progress has been made on:

- drift seepage studies in niches and the ECRB Cross-Drift,

- air-permeability testing,

- fracture/fault flow tests in alcoves,

- wetting-front and moisture monitoring along ESF drifts,

- drift-scale infiltration and tracer testing,

- tracer transport testing at Busted Butte, and

- geochemical evaluations.

This report focuses on in situ field-testing of processes. The technical summary and conclusions for analyses in Section 6.1 through Section 6.14 are provided in Section 7.1 through Section 7.14, respectively. In brief, the key findings for each technical area include:

\section{Seepage Studies}

Key findings from Section 6.2 (on seepage tests in niches):

- The presence of a seepage threshold was well established by seepage tests in three niches along the ESF main drift in the middle nonlithophysal zone (Tptpmn) of the Topopah Spring Tuff (TSw) (Table 6-8, Section 6.2.2.1). Long-term seepage tests behind sealed bulkheads at Niche 4 (Niche 4788) confirmed the seepage results of early short-term transient tests at Niche 2 (Niche 3650).

- ECRB Cross-Drift Niche 5 (Niche CD 1620), located in the lower lithophysal zone (Tptpll) of the Topopah Spring Tuff (TSw), has large permeability and strong capillarity, as indicated by air-permeability tests and flow-path patterns observed during niche excavation (Table 6-6, Figure 6-24, Section 6.2.1.2).

- The presence of a seepage threshold was confirmed in the lower lithophysal niche testing, with seepage reduced to zero as the liquid release rate decreased (Figure 6-44, Section 6.2.1.3.5.3).

- Water flowing along niche sidewalls was observed in Niche 5 (Niche CD 1620) (Figure 6-46, Section 6.2.1.3.5.4), and in Niche 4 (Niche 4788).

Key findings from field observations and test results from Niche 5 (Niche CD 1620):

- The borehole conditions in the lower lithophysal tuff (Tptpll) are, in general, much worse than the borehole conditions in the middle nonlithophysal zone (Tptpmn), with loose rock blocking several boreholes. This is also true of slots constructed in the Tptpll (Table 6-7, Figure 6-36, Section 6.2.1.3.5.2). 
- The mass balance tests at Niche 5 (Niche CD 1620) did not achieve the objective of determining the amount of water diverted by the drift. Safety concerns prevented proper installation of the water collection system within the slot space (Section 6.2.1.3.5.4).

Key findings from additional seepage tests in Section 6.11 (on systematic hydrologic characterization):

- Liquid release tests have been conducted in intervals along four slanted boreholes, covering a drift segment more than $100 \mathrm{~m}$ long, along the lower lithophysal zone (Tptpll). In some tests, seepage diversion (of injected water around the drift) was nearly 100-percent effective; in other tests it was less than 10-percent effective (Figure 6-148, Section 6.11.3.6).

- Systematic hydrologic characterization along the ECRB Cross-Drift through the lower lithophysal (Tptpll) zone of the Topopah Spring Tuff (TSw) quantified the ventilation effects on measured seepage in this heterogeneous unit (examples found in Figure 6-141, Section 6.11.2.7, Figure 6.142, Section 6.11.2.8; summary provided in Figure 6-148, Section 6.11.3.6).

Key findings from Section 6.3 (on tracer migration evaluation after niche seepage tests):

- Dyes and nonreactive tracers were confined locally (within a $1.0-\mathrm{m}-\mathrm{by}-1.6-\mathrm{m}$ area for the last test in Niche 2 (Niche 3650)), near the liquid-release points above the niche ceiling (Section 6.3.1.2), as were tracers released from multiple sequences of short-term seepage tests (Section 6.3.2.2).

\section{Air-Permeability Testing}

Key findings from Section 6.1 (on air-permeability characterization of heterogeneous fracture networks), and from Section 6.5 (on pneumatic flow path connections):

- Heterogeneity was systematically evaluated with air-injection tests. The variations in borehole-scale and drift-scale permeability values, and the variations in permeability enhancements induced by excavation effects, are orders of magnitude larger than the site-to-site variations of average values along the ESF main drift (Section 6.1.2.4). In addition to mechanical effects due to excavation, some of the increase in permeability is probably caused by the creation of new connections (of previously dead-ended fractures) to the open drift boundary.

- Pneumatic flow paths through fractures were spatially heterogeneous and discrete in the Topopah Spring Tuff (TSw) (Figure 6-67, Figure 6-69, Section 6.5.1).

- Fault zone flow paths and nonwelded tuff layers contributed to the complexity of pneumatic responses in the Paintbrush nonwelded (PTn) zone, with an argillic layer effectively dampening the pneumatic responses (Figure 6-73, Section 6.5.2). 


\section{Fracture/Fault Flow Tests in Alcoves}

Key findings from Section 6.6 (on welded tuff fracture-matrix interaction tests), and from Section 6.7 (on nonwelded tuff fault and matrix tests):

- Liquid flow paths through fractures were spatially heterogeneous and discrete in the Topopah Spring Tuff (TSw) (Figure 6-80, Section 6.6.2.3).

- Flow in fractures in the Topopah Spring Tuff (TSw) was intermittent in nature, even when the flow boundary conditions were stable (Panel b of Figure 6-79, Section 6.6.2.3).

- The Paintbrush nonwelded (PTn) zone (both fault and matrix) has a large capacity to dampen infiltration pulses. During releases in boreholes above the slot, no seepage water was detected in the slot (see Section 6.7.1.2 on slot observation, Section 6.7.2.1.2 on water transport times in fault, and Section 6.7.2.2.2 on water transport times in the matrix).

\section{Wetting-Front and Moisture Monitoring}

Key findings from Section 6.8 (on water-potential measurements), from Section 6.9 (on construction water migration), and from Section 6.10 (on moisture monitoring and water analysis in underground drifts):

- Rock dryout zones were shown to extend approximately $3 \mathrm{~m}$ into the wall of a ventilated drift section (Figure 6-95, Section 6.8.2.3, Panel c of Figure 6-109, Section 6.10.2.1.1).

- In actively ventilated sections, large changes in relative humidity conditions could be related to moisture removal by ventilation (Section 6.10.1.2.1).

- The last one-third of the ECRB Cross-Drift was sealed intermittently for days to months over a total period of several years. Nevertheless, based on water-potential measurements in the boreholes (Figure 6-109, Section 6.10.2.1.1), rocks that had partially dried out as a result of ventilation were not completely rewetted.

- The occurrence of temperature and relative humidity differences necessary for condensation and moisture redistribution were established by variations in the in-drift moisture sensors (Section 6.10.2.1).

- Wet areas and droplets were observed, and liquid samples of condensate were collected, during entries into sealed sections of the ECRB Cross-Drift (Section 10.2.2). Based on limited chemical analyses of the relatively clean water collected, the presence of water was attributed to condensation (Section 6.10.3.1).

- Construction water was detected more than $10 \mathrm{~m}$ below the invert at the starter tunnel of the ECRB Cross-Drift (Section 6.9.2.1), and more than $30 \mathrm{~m}$ below the invert at a location in the highly fractured zone (Figure 6-105, Section 6.10.1.3). 


\section{Drift-Scale Infiltration and Tracer Testing}

Key findings from Section 6.12 (on drift-to-drift infiltration and seepage tests), and from Section 6.1 (on air-permeability measurements):

- Infiltration, wetting-front detection, and seepage collection data for faults were collected at the drift-to-drift test site, located between Alcove 8 in the ECRB Cross-Drift and Niche 3 (Niche 3107) in the ESF main drift (Section 6.12.2). The location of the Tptpul-Tptpmn interface between two tuff units that comprise the test site has been confirmed by baseline geophysical tomographies (Section 6.12.3).

- The air-permeability data measured in the slanted boreholes below Alcove 8 had large variability associated with the transition from the upper lithophysal zone to the middle nonlithophysal zone across the Tptpul-Tptpmn tuff interface (Section 6.1.2.2.2).

- Breakthrough curves of two tracers in the fault test clearly indicated that the molecular size of tracers had a considerable effect on transport: the larger tracer had a faster transport, and the smaller tracer was delayed by effective matrix diffusion into tuff blocks next to the fractures (Figure 6-159, Section 6.12.2.4).

\section{Tracer Transport Testing at Busted Butte}

Key findings from Section 6.13 (on Busted Butte transport tests):

- The Unsaturated Zone Transport Test (UZTT) at Busted Butte provided field-scale data on transport properties of the vitric Calico Hills hydrogeological unit and the basal vitrophyre at the tuff interface between Topopah Spring and Calico Hills units (Section 6.13.1.2).

- Capillarity was shown to be strong in the vitric Calico Hills (Figure 6-173, Section 6.13.2.1).

- Spatial heterogeneity was shown to affect transport through the vitrophyre (Section 6.13.2.2).

- It was shown that sorbing tracers did not move significantly (Section 6.13.3). The plume migration was evaluated by mine-back sample analyses (Section 6.13.3.4), and by periodic ground penetrating radar (GPR) tomography (Section 6.13.4).

- Neutron moisture data and laboratory radionuclide transport data corroborated the findings that were based on tracer pad analyses and mine-out images from the UZTT (Section 6.13.5). 


\section{Geochemical Evaluations}

Key findings from Section 6.14 (on geochemical and isotopic measurements):

- Along the ECRB Cross-Drift, pore-water chemistry exhibits greater variability than the heterogeneity in rock mineral distribution (Section 6.14.1).

- The bomb-pulse ${ }^{36} \mathrm{Cl} / \mathrm{Cl}$ signals in fault/feature locations might exist along the ESF north ramp and ESF main drift (Figure 6-195, Section 6.14.2.1.1). Samples with high tritium-activity levels (indicating young water) were found at multiple locations, especially along the south ramp of the ESF and in sections of the ECRB Cross-Drift (Section 6.14.2.2).

- Uranium isotope data illustrate the sensitivity of redistribution and transport to percolation flux magnitude (Section 6.14.3).

- Fracture calcite/opal data support the understanding that only a small percentage of fracture surfaces are coated primarily on the footwalls, that lithophysal cavities have secondary precipitates only at the bottom, that growth rates are low, and that the inferred percolation and seepage rates are small (Section 6.14.4).

The following UZ model reports contain information on the status of field testing and monitoring activities at different sites in the ESF (information and findings relevant to modeling are also listed):

- Extensive pneumatic air-permeability tests were conducted in borehole clusters before and after niche excavation, and in alcove test beds before liquid releases (Section 6.1). The test results are inputs to Seepage Calibration Model and Seepage Testing Data (BSC 2004 [DIRS 171764]; Seepage Model for PA Including Drift Collapse (BSC 2004 [DIRS 167652]; and Abstraction of Drift Seepage (BSC 2004 [DIRS 169131]).

- Immediately after excavation of Niche 1 (Niche 3566), which is located in the vicinity of the Sundance fault, an elongated, damp feature was visible at the back wall of the niche (Section 6.1.2.2.1, Figure 6-24 in Section 6.2.1.2). The feature disappeared most likely due to evaporation. The niche was then sealed and kept closed for more than two years in order to reduce evaporation effects. However, the damp feature did not reappear.

- Niche 2 (Niche 3650), located in a fractured setting away from faults, was the site of 40 liquid-release tests that were conducted to quantify seepage thresholds (Section 6.2.1.3.1). The core samples from the last of these tests were analyzed for tracer distribution (Section 6.3, Section 6.4).

- Niche 3 (Niche 3107), located in a relatively uniform rock mass below the crossover point between the ESF main drift and the ECRB Cross-Drift, was the site of the drift-todrift fault tests and the large plot tests for matrix diffusion and active fracture model calibration and validation (Section 6.3.1.3.2, Section 6.12). 
- Niche 4 (Niche 4788), located in a highly fractured zone, was the site of pre- and post-excavation characterization, and several long-term seepage testing sequences (Section 6.2.1.3.3).

- Niche 5 (Niche CD 1620), located near the center of the repository in the lower lithophysal zone, was the site of a series of consecutive seepage tests. The data from these tests were used as inputs to the report Seepage Calibration Model and Seepage Testing Data (BSC 2004 [DIRS 171764]). Evaporation losses were quantified and used to improve the seepage calibration model (Section 6.2.1.3.5).

- Systematic hydrologic characterization along the ECRB Cross-Drift (Section 6.11):

1. Provided data from the lower lithophysal zone (Tptpll) of the Topopah Spring Tuff (TSw) used as part of the calibration and validation of the seepage calibration model (BSC 2004 [DIRS 171764]),

2. Provided observations on the heterogeneity of fractures and lithophysal cavities, and

3. Quantified ventilation effects along the open drift.

- Alcove 1, located $30 \mathrm{~m}$ below the ground surface near the ESF North Portal in the Tiva Canyon welded tuff $(\mathrm{TCw})$ unit, was the site of a large-scale infiltration study. The test results from two series of flow and tracer tests were analyzed in Liu et al. (2003 [DIRS 162470]). Matrix diffusion was shown to be important in the dilution of the tracer concentration, and in the reduction of the tracer breakthrough at the Alcove 1 test site (Section 6.12.5).

- Alcove 4, located in a layered zone with a fault bounded by the porous Paintbrush nonwelded tuff (PTn) unit, was the site of a series of tests that were undertaken to evaluate the migration of injected water (Section 6.7). The effectiveness of dampening liquid pulses was found to be consistent with the relatively uniform and steady flow distribution in the Paintbrush nonwelded tuff (PTn) unit described in UZ Flow Models and Submodels (BSC 2004 [DIRS 169861]).

- Alcove 6, located in a fractured zone that included relatively competent matrix blocks, was the site of a series of tests, in which water dripping into a slot below the test bed was collected and measured (Section 6.6). The large fracture flow (outflow into the slot below the test bed) percentage was consistent with the percentage predicted by UZ Flow Models and Submodels (BSC 2004 [DIRS 169861]).

- The Alcove-8/Niche-3 (Niche 3107) data (liquid release rate, seepage rate, tracer breakthroughs in Section 6.12) as part of the validation of the UZ flow model (BSC 2004 [DIRS 169861]) and the UZ radionuclide transport model (BSC 2004 [DIRS 164500]). 
- Water potentials have been measured with heat dissipation probes, psychrometers, and tensiometers in ESF boreholes at alcoves, at niches, and along the ECRB Cross-Drift (Section 6.6, Section 6.7, Section 6.8, Section 6.9, Section 6.10, and Section 6.12). The results of water-potential data from the ECRB were used as part of the validation of the UZ flow model (BSC 2004 [DIRS 169861]). The dryout-zone data were also considered in the design of the repository and of ground-support systems, and were used to quantify vapor flux into the drift for evaluation of in-drift conditions.

- Construction-water migration was monitored at the starter tunnel of the ECRB Cross-Drift, and below the crossover point (Section 6.9). Data on the distributions of lithium-bromide tracers from boreholes drilled into the drift floor (invert) (Section 6.10.1.3) were inputs to the Yucca Mountain site description document.

- Moisture monitoring stations continued to collect data to evaluate the impact of tunnel ventilation on moisture removal (Section 6.10.1.2).

- Condensation observed in the sealed sections of the ECRB Cross-Drift provided additional insights regarding in-drift redistribution of moisture under thermal and relative humidity variations (Section 6.10.2).

- Busted Butte transport test data (plume configuration, tracer distributions, and breakthrough, in Section 6.13) from Phase 1A, Phase 1B, and Phase 2 were used as part of the validation of the UZ radionuclide transport model (BSC 2004 [DIRS 164500]).

- The chloride data and data pertaining to several geochemistry and transport properties (Section 6.14) were used as part of the validation of the UZ flow model (BSC 2004 [DIRS 169861]) and the UZ radionuclide transport model (BSC 2004 [DIRS 164500]).

The ambient testing program has evolved from its initial focus on the middle nonlithophysal zone (Tptpmn) of the Topopah Spring Tuff (TSw), to a focus on the lower lithophysal unit (Tptpll) of the Topopah Spring Tuff (TSw), to a focus on both the Paintbrush nonwelded (PTn) above the repository horizon and the Calico Hills nonwelded $(\mathrm{CHn})$ below the repository horizon. The tests were used as direct input for the calibration of UZ process models, as indirect input for their validation, and as corroborative evidence to support or refute existing and alternate conceptual models for seepage into drifts, fracture flow, fracture-matrix interaction, and drainage and migration below the repository.

Because most of the repository horizon is in the lower lithophysal unit (Tptpll) of the Topopah Spring Tuff (TSw), it is important to characterize this unit, to determine whether the presence of lithophysal cavities and friable tuff media has significant effects on the seepage distributions and percolation characteristics. The seepage-threshold quantification was confirmed with long-term tests. The long-term tests also addressed the concerns regarding the capillary barrier concept under steady-state conditions, the effects of evaporation, and the effects of moisture storage and flow-diversion capacities. Quantification of spatial distribution of fast flow paths, and assessment of temporal variations of episodic percolation events, have been advanced by testing and monitoring refinements for in situ conditions. 
The emphasis of this report is on active-flow testing in niches and alcoves. These activities, together with many other laboratory and field activities analyzed in other analysis and model reports, provide data for inputs to other model reports for process evaluation, calibration, and validation. Sections 7.1 to 7.14 present summaries of data analyses found in Sections 6.1 to 6.14, respectively. Credible interpretations can be achieved with close interactions between testing and modeling, as documented in the model reports and scientific analysis reports cited, and on an activity-by-activity basis.

This report may be affected by technical product input that requires confirmation. The status of the technical product input data quality can be confirmed by review of the DIRS database.

Technical product outputs have been generated to document and summarize the results from analyses of some sets of DTNs. In some cases, the technical product outputs are directly used by downstream models. In other cases, the technical product output has been generated with suggestions for potential uses. For cases in which technical product output DTNs were issued, the use of each technical product output is summarized, and discussions of associated uncertainties and limitations of data are included. The DTNs generated as product output from this report are summarized in Table 7-1 (see also discussions in Sections 7.1, 7.2.1, and 7.11).

Two Yucca Mountain Review Plan (YMRP) acceptance criteria for this report are listed in Section 4.2:

1. data sufficiency for model justification, and

2. data uncertainty characterization for propagation through models.

These criteria are addressed in this report by:

- reporting the statistics of parameter distributions (for cases of field measurements and laboratory experiments with sufficient data),

- by describing the challenges and chronologies of data collection issues during the test and measurement periods, and

- by comparing different techniques, where available, for quantification of similar parameters for the same unsaturated processes, over different scales.

The measured results are analyzed and reported in this report for use as inputs to other UZ and coupled-process models. The process models form the basis for additional abstractions, through use of the ranges of measured parameters and other sources of information. Summaries of various activities (for data sufficiency and uncertainty evaluations) are presented in Sections 7.1 through 7.14. 
Table 7-1. Output DTNs from This Report

\begin{tabular}{|l|l|}
\hline \multicolumn{1}{|c|}{ Data Tracking Number } & \multicolumn{1}{c|}{ Title } \\
\hline LB0110LIQR0015.001 & Developed Data for Liquid Release/Seepage Tests and Systematic Testing \\
\hline LB0110NICH4LIQ.001 & Niche 4788 Ceiling - Wetting Front Data \\
\hline LB0110SYST0015.001 & Developed Data for Systematic Testing \\
\hline LB0310AIRK0015.001 & Developed Data for Air-K Tests \\
\hline
\end{tabular}

\subsection{SUMMARY AND CONCLUSIONS OF AIR-PERMEABILITY DISTRIBUTION AND EXCAVATION-INDUCED ENHANCEMENT IN NICHES}

The pneumatic packer system (that included automated controls and automated data acquisition) was used to conduct systematic and extensive air-permeability tests in borehole clusters at five niches and other test beds. Single-hole permeability data were used to detect changes in permeability (and boundary conditions) as a result of nearby excavation, and to characterize sites. Pre- and post-excavation permeability profiles (with a $0.3-\mathrm{m}$ spatial resolution) for boreholes used for drift-seepage and liquid-release tests are presented in this report.

Air-permeability distributions were used as inputs to the report Seepage Calibration Model and Seepage Testing Data (BSC 2004 [DIRS 171764]), to assess the capillary-barrier and seepage-threshold mechanisms. (Fractures immediately above the niches are important to the evaluation of seepage into drifts.)

The approach summarized in Cook (2000 [DIRS 165411]), and in Wang and Ellsworth (1999 [DIRS 104366]), is used to collect the air-permeability distribution data described in Section 6.1. The main results from air-permeability profile and distribution analyses are:

- The excavation-induced permeability enhancements in borehole intervals are large, with an average borehole enhancement of one to two orders of magnitude.

- Borehole-scale and drift-scale distributions, and excavation-induced enhancements of permeability variations, are orders of magnitude larger than the site-to-site variations of average values along the ESF main drift (Section 6.1.2.4).

Because spatial variability at the drift scale controls local flow path and seepage, it is important to characterize the permeability distribution in fractured tuff. The relatively small difference in mean permeability values for different niches reduced uncertainties associated with site-scale spatial heterogeneity. The liquid-seepage tests in locally distinct niches resulted in seepage-threshold values within a relatively narrow range. The uncertainties for seepage into drifts were well established for the middle nonlithophysal zone (Tptpmn) of the Topopah Spring Tuff (TSw), where four existing niches were located. The seepage evaluation with nearly continuous releases was carried out for the lower lithophysal tuff unit (Tptpll) of the Topopah Spring Tuff (TSw), to acquire the necessary data for the majority of the repository horizon.

Output DTN: LB0310AIRK0015.001 (for computed ratios of post-excavation air-permeability data over pre-excavation air-permeability data) is the technical product output from the analysis presented in Section 6.1 of this report. 
The permeability ratios in this DTN are presented in Section 6.1.2.3. As shown in Figures 6-19 through Figure 6-23, the correlation coefficient $\mathrm{R}^{2}$ of the ratio as a function of initial permeability has low values (from approximately 0.11 to approximately 0.17 ), representing a poor fit. These results, together with permeability profiles in Section 6.1.1 and statistical analyses summarized in Tables 6-2 through 6-6, provide the basis for understanding the permeability-stress coupling, and the measure of natural variability of the fractures of the tuff units. Heterogeneity quantification is important for other hydrologic processes. Downstream users of the air-permeability data must recognize the natural variability and spatial heterogeneity, and must quantify the hydrologic effects in a manner that is consistent with the air-permeability measures.

\subsection{SUMMARY AND CONCLUSIONS OF LIQUID-RELEASE AND SEEPAGE TESTS IN NICHES}

Liquid releases and seepage tests (Trautz and Wang 2002 [DIRS 160335]; 2001 [DIRS 165419]; and Wang et al. 1999 [DIRS 106146]) were used to collect seepage data, as described in Section 6.2 and summarized in Sections 7.2.1 through 7.2.3.

\subsubsection{Pre-Excavation Liquid-Release Testing and Niche Excavation Activities}

Numerous liquid-release tests were conducted prior to the excavation of each niche, to evaluate how far a finite pulse of water would be transported through relatively undisturbed fractures located in the middle nonlithophysal zone of the Topopah Spring Tuff (TSw). Similar tests were conducted in the lower lithophysal zone of the Topopah Spring Tuff (TSw), to identify the main difference (in effective capillary strengths) between these two major repository host rocks.

The maximum depth of the wetting front increased as the mass of injected fluid increased. Based on the results, it appears that maximum-depth data cannot discriminate the type of flow (i.e., high-angle fracture flow versus network flow) observed during the test. Lateral spreading and the aspect ratio (i.e., ratio of depth to lateral spreading) may be stronger measures of the type of flow that predominates. Increased lateral spreading of the wetting front is related to well-connected fracture networks that contain both high- and low-angle fractures; large aspect ratios are related to flow in individual vertical fractures. Some additional details are as follows:

- Flow in the middle nonlithophysal zone (Tptpmn) is dominated by gravity, with large aspect ratios observed in most flow paths.

- The lower lithophysal zone (Tptpll) has some flow paths with symmetric patterns, indicating relatively strong capillarity capable of spreading the plumes.

DTN LB0110LIQR0015.001 (for liquid-release test analyses and computed seepage rates) and DTN LB0110NICH4LIQ.001 (for wetting front characterization in the ceiling of Niche 4 [Niche 4788]) are technical product outputs from the analyses presented in Section 6.2.1 of this report.

DTN LB0110LIQR0015.001 was used in the development of the water retention curves for fractures (illustrated in Figure 6-49 and summarized in Table 6-10 and Table 6-11). Various data sets were used to generate the water retention curves; seepage threshold fluxes were determined 
through use of the test data that had relatively high correlation coefficients in Table 6-8. Although the data for the seepage thresholds have high certainty, the analyses that used analytic solutions had uncertainties associated with the approximations of medium uniformity. Downstream models, such as the seepage calibration model (BSC 2004 [DIRS 171764]), recognized this limitation, and formulated the heterogeneous numerical models, and took into consideration air-permeability distributions.

DTN LB0110NICH4LIQ.001 was used in the analyses of wetting-front movements observed on a niche ceiling, as illustrated in Figure 6-30. The relatively uniform patterns at early times, and the interferences by fractures at later times, are presented to facilitate a better understanding of the seepage and diversion mechanisms. The DTN was generated for use by models with fractures explicitly taken into account. To use such an approach, additional data (of fracture characteristics for each discrete fracture) is needed.

\subsubsection{Post-Excavation Seepage Tests at Niche 2 (Niche 3650), Niche 4 (Niche 4788), and Niche 5 (Niche CD 1620)}

The focus of the seepage tests at Niche 2 (Niche 3650) was to investigate the amount of water that would drip into a mined opening from transient liquid-release events of short duration. The tests can be summarized as follows:

- Forty post-excavation liquid-release tests were conducted on 16 different test intervals located above Niche 2 (Niche 3650) within the middle nonlithophysal zone of the Topopah Spring Tuff unit.

- Of the 16 zones tested, water seeped into the capture system from 10 zones; water appeared at the niche ceiling, but did not drip, in three zones; and, in three zones, no water appeared.

- The seepage percentage (defined as the amount of water captured in the niche, divided by the amount of water released into the rock) values ranged from 0 to 56.2.

During the early stages of testing, the memory effect, or wetting history, was determined to have a profound impact on seepage. If the liquid-release tests were performed too close together in time, it was found (as expected) that the seepage percentage increased dramatically. This is because the fractures contained residual moisture, and their unsaturated conductivity was higher during subsequent tests. The test with a 56.2-percent seepage result (the third test in a series of four tests in the same interval) was conducted within 2 hours of the second test, which had 23.2 percent seepage. By comparison, the first test, which was conducted 20 days before the second test, had a fairly consistent result of 22.6 percent seepage. Some additional details are as follows:

- The seepage-threshold flux (defined as the flux of water that, when introduced into the injection borehole, results in zero seepage) was evaluated for the 10 zones that seeped that are noted in Section 6.2.2.1 (Table 6-8 lists the 10 tests in Niche 2 (Niche 3650), and includes seepage threshold determinations). 
- The seepage-threshold fluxes measured at Niche 2 (Niche 3650) varied from $6.35 \times 10^{-9}$ to $4.31 \times 10^{-6} \mathrm{~m} / \mathrm{s}$ (equivalent to 200 to $136000 \mathrm{~mm} /$ year).

- Analytical techniques specific to a homogenous, unsaturated porous medium, derived by Philip et al. (1989 [DIRS 105743]), were used to evaluate and interpret the seepage-threshold data.

Two types of flow paths were observed in the field during the mining operation, as described in Section 6.2.1.2. Estimates of the volumetric water content were produced in Section 6.2.2.3, using wetting-front arrival times recorded during the seepage tests. The $\alpha$-values resulting from the analyses performed in Section 6.2.2.2 were used to estimate the water potentials of the fractures reported in Section 6.2.2.4. Water-potential estimates and the corresponding volumetric water contents were used to construct the fracture-water retention curves presented in Section 6.2.2.5. Examination of these plots indicates that:

- Fractures appear to drain very quickly (Figure 6-49).

- Saturated water content may be as high as 5 percent (Table 6-10).

The approach of using short-term tests at Niche 2 (Niche 3650) in ventilated conditions was replaced by long-term tests at both Niche 3 (Niche 3107) and Niche 4 (Niche 4788) under controlled high-humidity conditions. The series of Niche 4 (Niche 4788) tests was more complete (see Table 6-8 on seepage threshold analyses, with three test intervals in Niche 4 (Niche 4788) versus one test interval in Niche 3 (Niche 3107)) and was used in the seepage calibration model (BSC 2004 [DIRS 171764]) to calibrate and validate the model. The analytic solution approach presented in this report indicated that:

- The seepage thresholds determined by the long-term tests are comparable to the seepage thresholds determined by short-term tests (Table 6-8, Section 6.2.2.1 on comparison; Section 6.2.1.3 on test durations).

For Niche 5 (Niche CD 1620) in the lower lithophysal tuff, Test \#2 demonstrated that:

- Seepage thresholds exist even with the series of tests conducted consecutively, with essentially no waiting periods between tests at different rates (see example in Figure 6-44, Section 6.2.1.3.5.3).

- The slot did not effectively capture lateral movement of water around the niche (Section 6.2.1.3.5.2).

The lack of evidence that seepage occurred into the slot implies that the supplemental objectives of the test, stated in Section 6.2.1.3.5.1, were not met in this study. However, both at Niche 4 (Niche 4788) and Niche 5 (Niche CD 1620), photographic evidence showed that when water was introduced into boreholes above the niche:

- A wetted area spread across the ceiling and down the terminal face and sidewall of Niche 4 (Niche 4788) in the middle nonlithophysal zone (Tptpmn) (Trautz and Wang 2002 [DIRS 160335]). 
- A wetted area spread down the sidewall of Niche 5 (Niche CD 1620) in the lower lithophysal tuff Tptpll (Figure 6-46).

\subsubsection{Constraints and Limitations of the Niche Seepage Test Results}

The seepage test results at Niche 2 (Niche 3650), including the determinations of the seepage thresholds, were based on multiple liquid-release tests of short duration and with small amounts of water released (on the order of one liter). Injection rates in some of the test were high enough to induce seepage. The relative humidity in the open niche was affected by the ventilation in the ESF main drift and was thus low, leading to evaporation and water removal from the rock through the vapor phase. These evaporation effects may have reduced the liquid seepage flux used to determine the seepage threshold. An additional source of uncertainty is the unknown storage capacity of the formation between the injection point and the niche ceiling. These uncertainties were addressed by:

1. Controlling and/or monitoring evaporation conditions in the niches,

2. Performing long-term liquid-release tests to reduce storage effects, and/or

3. Analyzing the seepage-rate data through use of a numerical model that accounts for evaporation and storage effects.

The liquid-release tests at Niche 3 (Niche 3107) and at Niche 4 (Niche 4788) were conducted over periods significantly longer than the tests conducted in Niche 2 (Niche 3650), with some at lower release rates and under better control of ventilation and humidity effects.

Within a finite testing period, long-duration water releases may not have been followed by sufficiently long recovery periods before the next test, with a different rate, was initiated. The same long-duration approaches have been used in tests at the lower lithophysal unit (Tptpll) at Niche 5 (Niche CD 1620), where some tests were conducted with essentially no recovery periods between tests with different rates.

The constraints and limitations of the seepage test results in the middle nonlithophysal zone (Tptpmn) of the Topopah Spring Tuff (TSw) with recovery periods, and in the lower lithophysal zone (Tptpll) of the Topopah Spring Tuff (TSw) with minimal recovery periods, should be carefully evaluated to assess their applicability. The intended use of niche test data is for seepage process evaluation. 


\subsection{SUMMARY AND CONCLUSIONS OF TRACER-MIGRATION DELINEATION AT NICHE 2 (NICHE 3650)}

Tracer distribution in cores after a liquid-release event at Niche 2 (Niche 3650) is analyzed in Section 6.3. Niche 2 (Niche 3650) was the first of three niches (Niche 2 [Niche 3650], Niche 3 [Niche 3107], and Niche 4 [Niche 4788]) in which a series of seepage tests was conducted in the middle nonlithophysal zone of the Topopah Spring Tuff (TSw). The results of multiple sequences of short-term seepage tests showed that:

- Spatial distributions of tracers that resulted from early liquid-release tests conducted in Niche 2 (Niche 3650) consistently pointed to localized flow with limited lateral spreading.

- Tracer migration from the last short-term test was localized and possibly confined within the $1.0-\mathrm{m}-\mathrm{by}-1.6-\mathrm{m}$ area directly below the liquid-release interval, with a vertical scale of approximately $0.7 \mathrm{~m}$. This conclusion was based mainly on analyses of iodine as a conservative tracer.

Liquid-release tests reported in Section 6.2 indicated that post-excavation seepage water was captured, in most cases, directly beneath the test zone or in capture cells adjoining the interval. Flow-path observations during niche excavations generally showed that the dyes did not spread laterally to great extents (also see preliminary results of Niche 1 (Niche 3566) and Niche 2 (Niche 3650) reported in Wang et al. (1999 [DIRS 106146], pp. 329-332)). Gravity-driven flow was the primary flow mechanism in fracture systems, either through individual fractures and/or through the fracture network connected to the release intervals. In Section 6.4 of this report, results of additional laboratory tests of tracer sorption and fracture-matrix interactions are presented.

The absence of nonreactive tracers, especially iodine (introduced only at the last pulse release), together with the localized spatial distributions of dyes long after the liquid releases, suggests that the gravity-driven component is strong. Capillary imbibition and capillary barrier effects could promote lateral spreading. Note that dye is sorbing (i.e., the observed dye pattern represents the minimum extent of water migration), which makes the related interpretation uncertain.

The results provide a data set for flow path distribution from multiple liquid releases that use different tracers. The data set can be used to quantify natural variability and uncertainties of flow and transport on the scale of a few meters. Because the tracer distributions are based on cores recovered from a cluster of boreholes, uncertainties exist that are associated with flow and transport out the domain between the boreholes. Ventilation drying may also contribute to the uncertainties in the test interpretation. These considerations should be taken into account in using the data set for detailed calculations of the flow and transport processes in this spatial scale of a few meters. 


\subsection{SUMMARY AND CONCLUSIONS ON TRACER PENETRATION AND WATER IMBIBITION INTO WELDED TUFF MATRIX}

Field and laboratory tracer experiments have been conducted to investigate the flow partitioning between fracture flow and matrix imbibition under unsaturated conditions. During niche excavation, dye-stained rock samples were collected for laboratory analyses. Additional tuff samples collected from the repository horizon were machined as rock cores for laboratory studies of tracer penetration into the rock matrix, with two different initial water saturations. In the drift seepage tests that used dye tracers, seepage-water samples were collected. A rock-drilling and sampling technique was developed to profile the tracer concentration in the rock matrix, as discussed in Section 6.4 and in $\mathrm{Hu}$ et al. (2002 [DIRS 165412]). The samples were collected in Niche 2 (Niche 3650). The laboratory evaluation complements the evaluation documented in Section 6.3 for the site in the middle nonlithophysal zone (Tptpmn) of the Topopah Spring Tuff (TSw). Some additional details are as follows:

- For rock samples, the sorbing dye-tracer penetration depths were on the order of several millimeters from the fractures that permitted flow.

- In well-controlled laboratory tracer-imbibition tests under both high and low initial water saturations, the concentration profiles of sorbing dyes lag behind the nonreactive bromide front, with the dye transport distance of a few millimeters over the contact time (approximately 18 hours).

- If the initial water saturation is relatively high (75.8 percent), the bromide front lags significantly behind the moisture front. However, if the initial water saturation is relatively low (12.5 percent), the bromide front is comparable to the moisture front.

- Retardation of sorbing tracers increased with a decrease in saturation, as measured in the dry core and in the wet core. This verified the functional relationship between retardation and water content.

- Core measurements can be used to measure retardation factors in in situ conditions, to check the results of batch experiments that used crushed tuff in saturated conditions.

Data presented in Section 6.4 revealed subtle processes (especially at the interface boundary region between the core bottom and the water reservoir) that simulated the contact of flow-permitting fractures with the adjoining tuff matrix. Data of flow partitioning, front separation, and tracer retardation can be used for validation of fracture-matrix interaction and fracture flow models.

The uncertainties of the laboratory measurements are associated with the spatial resolution limitations of drilling and sampling techniques (see Figure 6-62, Section 6.4.1.4) and analytic accuracy (see Appendix E for additional evaluations). Compared to field-testing conditions, these measurement uncertainties are small. The laboratory measurements provided improved process understanding and alternate approaches for block rock characterization, complementing the measurements from crushed rock samples. 


\subsection{SUMMARY AND CONCLUSIONS OF SINGLE-HOLE PERMEABILITY DISTRIBUTIONS AND CROSSHOLE CONNECTIVITY ANALYSES}

Crosshole analyses of pneumatic air-permeability test data are presented for Niche 4 (Niche 4788), Alcove 6, and Alcove 4 in Section 6.5. Crosshole connectivity analyses for Niche 4 (Niche 4788) are used in the seepage tests in this highly fractured zone. The pneumatic air-permeability test results were used for interval selection and test interpretation in the series of tests conducted for fracture flows and fracture-matrix interactions in the Topopah Spring Tuff (TSw) at Alcove 6, and for fault and matrix flows in Paintbrush nonwelded (PTn) in Alcove 4. Niche 4 (Niche 4788) and Alcove 6 are in the fractured middle nonlithophysal zone (Tptpmn) of the Topopah Spring Tuff (TSw). Alcove 4 is in porous Paintbrush nonwelded (PTn) tuff.

The main results from permeability distribution and crosshole analyses are:

- Welded-tuff test sites had distinct flow paths that were clearly identified by crosshole analyses from isolated injection intervals to observation intervals (Section 6.5.1).

- The fracture flow connections were predominately unidirectional (an injection interval induced a response in an observation interval, but the interval did not necessarily detect injection into the original observation interval) (Section 6.5.1).

- The Paintbrush nonwelded (PTn) test bed in Alcove 4 had many more pneumatic flow connections than the corresponding Topopah Spring Tuff (TSw) sites in niches and in Alcove 6. Weaker connections were trimmed out to reveal the stronger connections (Figure 6-72, Figure 6-73).

- Using crosshole analyses, the argillic layer in the test bed was shown to be a nearly impermeable barrier (Figure 6-73, Section 6.5.2).

- Stronger flow connections were associated with a fault in the test bed at Alcove 4. A high-permeability zone near the end of the test block was identified by the air-permeability results and crosshole analyses (Figure 6-73, Section 6.5.2).

The crosshole air-injection tests presented visually (see Section 6.5) primarily support the selection of liquid injection intervals. The uncertainty in measured air-injection rates and induced pressure buildup are expected to be small compared to the variability in formation properties and the conceptual model uncertainties. The uncertainties associated with permeability testing (Section 6.1.2.4) also apply to the evaluation of the crosshole responses. The crosshole analysis results can be used for heterogeneous model evaluation over the spatial domain covered by the borehole clusters. Discrete fracture network models can use the crosshole analysis for inputs for the heterogeneity field.

\subsection{SUMMARY AND CONCLUSIONS OF FRACTURE FLOW IN THE FRACTURE-MATRIX TEST BED AT ALCOVE 6}

Fracture flow data were collected in a slotted test bed located at Alcove 6 of the ESF within the Topopah Spring Tuff (TSw). The existence of a slot below the injection zones made it possible 
to quantify both the inflow into the system, and the outflow at the lower boundary, and to better evaluate the flow field in underground test conditions, as described in Section 6.6, and in Salve et al. (2002 [DIRS 161318]), and in Hu et al. (2001 [DIRS 165413]).

In this field study, techniques developed to investigate flow in fractured welded tuffs were evaluated. Results from field tests suggest that certain fundamental flow parameters (such as transport times, percolation, and seepage rates) can be characterized in situ. Alcove 6 is in the middle nonlithophysal zone (Tptpmn) of the Topopah Spring Tuff (TSw), with a well-defined fracture network through competent welded tuff rock.

The test results revealed aspects of flow in unsaturated, fractured systems, and provided insight into the conceptualization of flow through unsaturated and fractured rock formations. The Alcove 6 test was the first test (on unsaturated fractured tuff conducted in the ESF) that attempted to take water mass conservation explicitly into account. In field tests, controlling the boundaries is frequently difficult, and liquid can flow to unknown domains. Transient data collected at Alcove 6 also contribute to the evaluation of unsaturated flow in fractured tuffs.

Several sets of liquid-release tests were conducted through use of localized injections of liquid into a low-permeability zone (LPZ) and into a high-permeability zone (HPZ) along a borehole. The major test results were:

- For all injections into both LPZ and HPZ, changes in electrical resistance and psychrometer readings were detected in two monitoring boreholes approximately $0.6 \mathrm{~m}$ below the point of injection.

- For the LPZ tests, water did not seep into the slot located $1.65 \mathrm{~m}$ below the point of injection.

- The liquid-release rate into the LPZ was observed to steadily decrease by two orders of magnitude (from greater than $30 \mathrm{~mL} /$ minute to less than $0.1 \mathrm{~mL} /$ minute) over a 24 -hour period.

- In the HPZ, liquid-release rates under constant-head conditions were significantly higher (approximately $100 \mathrm{~mL} /$ minute), with intermittent changes observed in the intake rate.

- For injection tests in the HPZ, water was observed to drip into the slot in 3 to 7 minutes at high injection rates (rates of approximately 28 to approximately $100 \mathrm{~mL} / \mathrm{min}$.); in 1 hour at the low injection rate of $14 \mathrm{~mL} / \mathrm{min}$; and in 5 hours at the lowest rate of $5 \mathrm{~mL} / \mathrm{min}$.

- During the course of each test, seepage rates measured in the slot showed intermittent responses despite constant-head or constant-rate conditions imposed at the input boundary (Panel b of Figure 6-79, Section 6.6.2.3).

- The percentage of the cumulative volume of water that was recovered in the slot was observed to increase with time in most tests, and approached steady-state values after approximately $10 \mathrm{~L}$ of water had been injected (Section 6.6.2.1). 
- The highest injected-water recovery rate for high-rate injection tests was 80 percent (Figure 6-79, Section 6.6.2.3).

- The minimum volumes of fracture flow paths were estimated, for each test, from measurements of fluid volume before wetting front arrivals, and from measurements of drainage volume into the slot after termination of injection. The cumulative flow path volumes were found to vary from approximately $0.5 \mathrm{~L}$ to approximately $1.3 \mathrm{~L}$ after termination of liquid injection (Figure 6-81, Section 6.6.2.3).

- Plug-flow processes were observed with tracer analyses. "New" water replaced "old" water from the previous test, with some backdiffusion effects occurring, as indicated by rebounding (Figure 6-82, Section 6.6.2.4).

The stepped and intermittent changes could be associated with heterogeneous distribution of storage volumes in the connected fracture flow paths, in the dead-end fractures, and in the rock matrix blocks. The test results from Alcove 6 could be used to evaluate fracture flows and fracture-matrix interactions.

Significant uncertainties were associated with a series of tests that were conducted that used relatively short durations in comparison with the duration of seepage tests in niches. Nevertheless, the qualitative understanding gained from Alcove 6 testing could be used for the design of other tests, such as the Alcove-8/Niche-3 (Niche 3107) tests described in Section 6.12.

\subsection{SUMMARY AND CONCLUSIONS OF FLOW THROUGH THE FAULT AND MATRIX IN THE TEST BED AT ALCOVE 4}

Fault and matrix flow data were collected in a test bed located in the Paintbrush nonwelded (PTn) unit at Alcove 4 in the ESF. Using a series of horizontal boreholes, the intake rates and plume transport times in various locations within the test bed were determined, as described in Section 6.7, and in Salve et al. (2003 [DIRS 164470]), and in Salve and Oldenburg (2001 [DIRS 157316]).

These test results revealed aspects of flow in a fault located within the nonwelded tuffs, and provided insights into the flow properties of the Paintbrush nonwelded (PTn) tuff. With the exception of a well-defined fault trace, no visible fracture traces were evident in the bulk of the Paintbrush nonwelded (PTn) tuff test bed. A series of localized liquid-release tests helped determine that:

- Intake rates within a fault located in the Paintbrush nonwelded (PTn) decreased as more water was introduced into the release zone (i.e., from an initial value of approximately $200 \mathrm{~mL} / \mathrm{min}$. to approximately $50 \mathrm{~mL} / \mathrm{min}$. after $193 \mathrm{~L}$ of water entered the injection zone).

- The transport time of the wetting front that resulted from water released in the fault decreased when the fault was wet (i.e., in closely timed tests, the plume was transported more quickly in subsequent releases). 
- Over time, the hydrologic properties of the fault appeared to change (water was transported along the fault at significantly slower rates).

- The matrix adjoining the fault imbibed water that was introduced into the fault. Changes in saturation were seen at distances greater than $1.0 \mathrm{~m}$ from the point of release.

- The intake rates and wetting-front transport times in the matrix were significantly slower than they were in the fault. Water released into the matrix was observed to be transported $0.45 \mathrm{~m}$ in 14 days.

Significant uncertainties were associated with a series of tests that were conducted that used relatively short durations in comparison with the duration of seepage tests in niches. Furthermore, the volume of water that was injected (to induce seepage and water collection in the slot below) was insufficient. Nevertheless, the tests provided a qualitative understanding of the flow through the nonwelded tuff unit, and showed that the unit had large dampening capacities for modulating infiltrating pulses.

\subsection{SUMMARY AND CONCLUSIONS OF WATER-POTENTIAL MEASUREMENTS CONDUCTED IN THREE NICHES WITHIN THE ESF MAIN DRIFT}

Psychrometer measurements in the ESF suggested significant variability in water potentials between and within Niche 1 (Niche 3566), Niche 2 (Niche 3650), and Niche 3 (Niche 3107). All three niches were in the middle nonlithophysal zone (Tptpmn) of the Topopah Spring Tuff (TSw). The main observations were:

- The effects of ventilation might have penetrated the rock to depths in excess of $3 \mathrm{~m}$.

- Two possible zones were observed to have significantly higher water potentials in Niche 1 (Niche 3566). The first was observed at the end of the middle borehole. The second was detected $6.25 \mathrm{~m}$ into Borehole A in Niche 1 (Niche 3566). Borehole A was drilled from the niche, toward the Sundance fault.

- Large variability in water potential $(-15$ and $-84 \mathrm{~m})$ existed in the short $0.9-\mathrm{m}$ distance between two boreholes at Niche 3 (Niche 3107).

- At 10-m depths (i.e. in the zone unaffected by drift ventilation), Niche 1 (Niche 3566, with potential 0.4 to $-13 \mathrm{~m}$ ) appeared to be wetter than Niche 2 (Niche 3650, with potential -1 to $-39 \mathrm{~m})$.

These potential measurements were taken before the bulkhead closed in Niche 1 (Niche 3566), and before seepage measurements in Niche 2 (Niche 3650) and in Niche 3 (Niche 3107) were taken. The data are presented in this report for future comparisons with potential measurements elsewhere in the ESF, including the ECRB Cross-Drift.

Psychrometer measurements are sensitive to testing conditions, as discussed in Appendix G. The measurement uncertainties associated with water potential in the field are relatively large (see Appendix G) in comparison with other hydrologic measurements, such as saturation from core 
measurements. The data from measurements taken before bulkhead closure were also greatly influenced by ventilation drying. The results indicate that wet conditions existed in the vicinity of the Sundance fault. The absolute magnitude of the water potential should only be used when the measurement uncertainties and test site ventilating conditions are taken into account.

\subsection{SUMMARY AND CONCLUSIONS OF MONITORING CONSTRUCTION-WATER MIGRATION}

The sensors in a borehole below the starter tunnel of the ECRB Cross-Drift detected conditions associated with wetting-front migration. Yet no seepage was observed at the crossover point along the ESF main drift below the ECRB Cross-Drift.

The ECRB Cross-Drift starter tunnel is located in the upper lithophysal zone (Tptpul) of the Topopah Spring Tuff (TSw). The crossover point in the ESF main drift is located in the middle nonlithophysal zone (Tptpmn) of the Topopah Spring Tuff (TSw).

The specific observations were:

- A ponding event that occurred on March 8, 1998, increased water-potential values up to a depth of $8.65 \mathrm{~m}$ (17.3 $\mathrm{m}$ along the borehole).

- Along the borehole, the impact of changes in water-potential values occurred at different locations, and at different times, during the monitoring period. Early in March 1998, the large impact was restricted to close to the borehole collar. By early April 1998, this impact was more pronounced at a depth of between 4.7 and $5.7 \mathrm{~m}$ (between 9.4 and $11.4 \mathrm{~m}$ along the borehole).

- One concern related to the use of a slanting borehole to measure wetting-front migration is the possibility of the bore cavity short-circuiting flow paths. Such a short-circuiting does not appear to have happened, as indicated by the analysis of recovery responses observed at the depth of $5.2 \mathrm{~m}$. At that depth, the response to a wetting event was negligible when compared with other psychrometers close to (above and below) this location, suggesting that this zone was well-isolated (hydraulically) from the adjacent zones, and the wetting front did not reach it.

- The performance of the ERPs, when compared with the performance of psychrometers, suggests that the probes (without any change to their design) could be effectively used as a qualitative tool to detect the arrival (or departure) of wetting fronts. Unlike psychrometers, the probes were relatively inexpensive, easy to maintain, and had a low failure rate. Such advantages made them particularly useful for extensive downhole monitoring applications in fractured-rock environments, such as found at Yucca Mountain.

- At the crossover point, no seepage was observed, nor were wetting-front signals detected at the crossover point when the ECRB Cross-Drift tunnel boring machine (TBM) passed above the ESF main drift. The TBM apparently did not use enough water to induce dripping into the ESF main drift, located $17.5 \mathrm{~m}$ below it. 
In the repository at Yucca Mountain, performance-confirmation drifts are to be located above (or below) the waste emplacement drifts, to monitor the waste-induced impacts. It is therefore important to evaluate drift-to-drift migration and drift seepage, and to detect wetting fronts. The experience gained in the integrated monitoring station at the crossover point (with seepage collection trays, water-potential and wetting-front sensors, and thermal/visual imaging devices) can be applied to future testing and monitoring tasks.

These observations of wetting front migrations associated with construction water usage are of a qualitative nature because of limited sensor sensitivities, and uncertainties in the total amount and rates of water used for the excavation. Nevertheless, the findings provided order-ofmagnitude estimates on the migration below drifts.

\subsection{SUMMARY AND CONCLUSIONS OF ANALYSES OF CONSTRUCTION EFFECTS}

Some observations of ESF moisture conditions are presented in Sections 6.10.1. The ESF main drift is in the middle nonlithophysal zone (Tptpmn) of the Topopah Spring Tuff (TSw). Sections of the ECRB Cross-Drift were sealed off by bulkheads; such sections are in the lower lithophysal (Tptpll) and lower nonlithophysal (Tptpln) zones of the Topopah Spring Tuff (TSw), and the Solitario Canyon fault.

The observations can be summarized as follows:

- Shortly after drift excavation, high humidity conditions were detected near the TBM.

- In the month after the excavation, the relative humidity gradient near the end of the ESF tunnel was greater than the gradient close to the entrance.

- Construction water migration results are presented in Section 6.10.1.3 and in Finsterle et al. (2002 [DIRS 165415]).

- The construction water reached a minimum depth of $30 \mathrm{~m}$ at a borehole outside Alcove 7 (Figure 6-105).

In the ongoing moisture study of bulkheaded sections in the ECRB Cross-Drift, observations were as follows:

- Water-potential measurements in boreholes suggest that the tuff matrix is still relatively dry to a depth of 0.5 to $1.0 \mathrm{~m}$.

- Moisture conditions (relative humidity and temperature) respond (relatively) quickly to bulkhead entries and TBM power fluctuations.

- Wet spots were observed and liquid water was collected in sections and, based on chemical analyses of the clean water collected, the presence of water can likely be attributed to condensation. Isotopic signatures indicated that the collected water underwent an evaporation shift. 
Qualitative observations, moisture evolution data, drying profiles into the rocks, and chemical analyses of collected water were used to address questions regarding the origin of water (i.e., whether it resulted from seepage or condensation). Limitations and uncertainties in the supporting information prevent a conclusive determination of the origin of the observed water. Nevertheless, there are strong indications that the water resulted from condensation processes.

\subsection{SUMMARY AND CONCLUSIONS OF SYSTEMATIC HYDROLOGIC CHARACTERIZATION ALONG THE ECRB CROSS-DRIFT}

Hydrologic characterization of the lower lithophysal zone of the Topopah Spring welded tuff zone (Tptpll) was initiated in the ECRB Cross-Drift, using the systematic approach of testing at regular intervals as described in Section 6.11 and in Cook et al. (2003 [DIRS 165424]). Analyses of data from several sets of tests were performed in 10 zones, using four low-angle boreholes. The results indicated that:

- Small fractures (less than $1 \mathrm{~m}$ in length) were well connected, giving rise to air-permeability values on the order of $10^{-11} \mathrm{~m}^{2}$. The connected fractures probably constituted the main contribution to fast paths for liquid flow.

- In the transient process of establishing the fast paths between the water release (at a vertical distance of between 1 and $5 \mathrm{~m}$ above the drift) and the drift ceiling, some water imbibed into the rock matrix, and some water seeped into the lithophysal cavities. Out of the available storage porosity of 0.125 of the lithophysal cavities, approximately 20 to 50 percent participated in taking in water introduced when the rate of injection was tens of milliliters per minute. When the water-release rate was an order of magnitude higher, water flow primarily occured in the fractures, with little participation from the matrix or lithophysal cavities during the time required to intersect the drift.

- Under steady-state conditions, water introduced from one to several meters above the drift flowed down toward the drift in preferential paths, not in a plume. A fraction of the water missed the drift because of nonuniform flow from fracture heterogeneity, and a fraction of the water was diverted around the drift because of capillary effects. The former component of nonintersecting flow was controlled by geometry, and was likely independent of the water-release rate.

- An injection-rate estimate was made (from a borehole of a given area at a given distance above the drift), below which there was no seepage into the drift. Based on the information discussed in Section 6.11.3.3 (for Borehole LA\#1), a value of $15 \mathrm{~mL} / \mathrm{min}$ was obtained, for a projected borehole area of $0.13 \mathrm{~m}^{2}$, at an average height of $1.3 \mathrm{~m}$ above the drift.

- Because of the low humidity inside the ECRB Cross-Drift, and because of the drift ventilation system, effects of evaporation must be considered when interpreting seepage data from systematic testing. After the completion of the first set of tests (when the significance of evaporation was first noted), relative humidity measurements and open-pan evaporation measurements were incorporated into the systematic-testing equipment system. 
- Systematic testing in Boreholes LA\#2 and LA\#1 revealed an effective porosity of 0.028 for one-time fill cavities, 0.027 for drainable cavities, and 0.013 for fractures.

- Systematic testing in Boreholes LA\#3 and LA\#4 revealed very heterogeneous responses, ranging from tight zones with low capacities to take up water injected into the borehole intervals, to a high-permeability zone in which nearly 100 percent of all injected water was diverted around the drift.

DTN LB0110SYST0015.001 (computed comparisons from systematic testing) is technical product output from the analysis presented in Section 6.11 of this report.

DTN LB0110SYST0015.001 was generated in 2001 for systematic testing results from raw data for the first two slanted boreholes drilled into the crown of the ECRB Cross-Drift, as illustrated in Figures 6-130 through 6-139. Later data sets include data processing, and eliminate the need to generate this type of technical product output.

From the perspective of the objectives of this report, the strength of systematic testing was its potential to provide insight regarding how spatial heterogeneity impacts seepage, flow, and transport processes. Uncertainties associated with ventilation effects were a significant component of the testing conditions in the periodically ventilated ECRB Cross-Drift (and can be accounted for using pan-evaporation data).

The systematic-testing data set was the first set available in 2001 for seepage evaluation in the lower lithophysal zone, and the data set was used in a later revision of the seepage calibration model (BSC 2004 [DIRS 171764]).

\subsection{SUMMARY AND CONCLUSIONS OF DRIFT-TO-DRIFT TESTS BETWEEN ALCOVE 8 AND NICHE 3 (NICHE 3107)}

Alcove 8 is located in the upper lithophysal tuff (Tptpul) of the Topopah Spring Tuff (TSw), approximately $20 \mathrm{~m}$ directly above Niche 3 (Niche 3107) in the middle nonlithophysal zone (Tptpmn) of the Topopah Spring Tuff (TSw). Data obtained during Alcove-8/Niche-3 (Niche 3107) testing characterizes the response of the system to releases of water under constant-head conditions. Specifically:

- Infiltration rates along the fault reached quasi-steady-state conditions approximately 45 days after water was introduced to the infiltration zones, and the infiltration rates varied at different locations along the fault.

- Observations of saturation changes within the fault indicated the velocity of the wetting front (vertically along the fault) was approximately $0.65 \mathrm{~m} / \mathrm{s}$.

- Seepage observations indicated that quasi-steady-state conditions may have been reached two months after the initial releases into the fault.

- Radar data collected in support of the Alcove-8/Niche-3 (Niche 3107) infiltration experiment suggested that this method was appropriate for investigating subsurface anomalies that may have been related to moisture migration. 
- Experimental results indicated that matrix diffusion had an important effect on solute transport.

- An observed low seepage recovery rate from the fault implied good communication between the fault and the surrounding fracture networks.

- Similar tracer arrival times (corresponding to the peak concentration values) for most flow paths suggests that macrodispersion may not be important for solute transport in unsaturated fractured rock.

- The observation of the first seepage spot in Niche 3 (Niche 3107), 21 days after water was introduced along the nonfaulted section of Alcove 8, suggests that wetting-front velocity was approximately $1.0 \mathrm{~m}$ /day below the large plot test bed.

The relatively long flow distance of approximately $20 \mathrm{~m}$ between the injection plot in Alcove 8 and the ceiling of Niche 3107 (Niche 3) provides possibilities for water to be diverted through discrete geological features (such as fractures or the contact between the upper lithophysal and middle nonlithophysal zones), thus bypassing the collection system in the niche. The fact that only a portion of the released water can be accounted for leads to confidence that the physical processes that were expected to impact seepage are indeed effective. However, uncertainties arise in the detailed interpretations, because of the lack of mass balance.

\subsection{SUMMARY AND CONCLUSIONS OF THE BUSTED BUTTE UNSATURATED ZONE TRANSPORT TEST}

The UZTT at Busted Butte was designed to address uncertainties associated with flow and transport in the UZ, particularly in the Calico Hills unit. The UZTT was comprised of three tightly integrated efforts: the field test, a parallel laboratory program, and assessment and validation of computational models. Section 6.13 and Appendix H present the results of the field test and associated laboratory analyses. The model assessment and validation are reported in Radionuclide Transport Models Under Ambient Conditions (BSC 2004 [DIRS 164500]). The tracer sorption to vitric tuffs of Busted Butte is also described in Turin et al. 2002 [DIRS 164633].

The design of the UZTT began in 1997. Injection of tracers for Phase 1 began in April 1998, and Phase 2 injection was completed in October 2000. The mineback excavation of Phase 2 continued in 2001. The results provide important information regarding the UZ transport performance of the Calico Hills hydrologic units, and include the following main conclusions:

- Flow and transport in the Calico Hills hydrologic units (Tac and Tptpv1) were strongly capillary dominated, as observed from fluorescein distributions in the Phase 1A test.

- Fractures in the Tptpv1 and Tac zones at Busted Butte did not act as fast flow paths, as observed in Phase 1A; they appeared to play a role as a barrier or permeability contrast boundary.

- Heterogeneity appears to have had a significant effect on flow, as observed in Phase 1A for layer contacts and in Phase 2 for faults. 
- Breakthrough times of nonreactive bromide were approximately linear with transport distance.

- Sorption can delay chemical transport, as shown from the breakthrough curves of lithium.

- Neutron moisture data corroborate plume and breakthrough data pertaining to moisture changes associated with injections into the test block.

- Laboratory measurements with radionuclides were taken, to complement measurements taken during field tracer testing; technetium (as the pertechneate anion) moved slightly faster than tritiated water in a small $1-\mathrm{ft}^{3}$ block, and at approximately the same velocity in a $1-\mathrm{m}^{3}$ block (both blocks were from the Busted Butte site).

Uncertainties exist in the degree of sorption. Note that the delay of chemical transport across the complex interface between the injection point in the vitrophyre and the detection point in the Calico Hills nonwelded (CHn) can potentially be attributed to sorption. The interface may introduce flow and transport processes that divert water and tracer in an unpredictable fashion. Some interference of grout residue in the formation may also contribute to uncertainty in the interpretation of fluid movement.

\subsection{SUMMARY AND CONCLUSIONS FOR GEOCHEMICAL AND ISOTOPIC OBSERVATIONS AND ANALYSIS OF THE UNSATURATED ZONE}

Section 6.14 and references therein describe the geochemical and isotopic observations and analyses of samples collected primarily along the underground drifts in the UZ of the ESF. The summaries are presented in the following sections:

- Section 7.14.1 (for Section 6.14.1) addresses pore water and rock geochemistry.

- Section 7.14.2 (for Section 6.14.2) addresses isotopic examination of ${ }^{36} \mathrm{Cl}$ and tritium for potential fast flow signals, and fluid-inclusion temperature signals for thermal history, at Yucca Mountain.

- Section 7.14.3 (for Section 6.14.3) addresses uranium isotopic studies of past climate records, and delineation of UZ flow zones.

- Section 7.14.4 (for Section 6.14.4) addresses fracture mineral distributions and implications. Some model interpretations and detailed analyses are documented in cited references. 


\subsubsection{Pore Water and Bulk Repository Rock Unit Geochemistry}

An analysis and an interpretation of pore-water data are found in Section 6.14.1.1. Rock chemistry in the ECRB Cross-Drift is compiled in Section 6.14.1.2. In the Topopah Spring Tuff (TSw), the results indicate:

- The dissolved ion composition of pore water shows considerable stratigraphic and lateral variability (Table 6-37, Section 6.14.1.1).

- The variability in major and trace elements, and in mineral contents of the rocks, is exceedingly small (Table 6-38, Table 6-39, Table 6-40, Section 6.14.1.2).

The existence of pore-water variability in the repository deep underground testifies to the inefficiency of advective or diffusional mixing in the downward percolation of pore water.

The rock samples from the ECRB Cross-Drift represent both lithophysal and nonlithophysal zones. The analyses indicate the chemical homogeneity of the phenocryst-poor rhyolite unit (Topopah Spring Tuff (TSw)), excluding localized deposits of vapor-phase minerals and low-temperature calcite and opal in fractures, cavities, and faults (Peterman and Cloke 2002 [DIRS 162576]).

\subsubsection{Isotope Geochemical Studies}

Fast-flow paths and the thermal history at Yucca Mountain have been evaluated in Section 6.14.2.

\subsubsection{Isotope Geochemical Studies of ${ }^{36} \mathrm{Cl} / \mathrm{Cl}$ Signatures}

The ${ }^{36} \mathrm{Cl}$ validation study results are briefly presented in Section 6.14.2.

\subsubsection{Tritium in Pore Water}

The analyses of tritium in pore water from several locations within the ESF main drift and ECRB Cross-Drift indicate that substantial amounts of young pore water exist:

- In the Bow Ridge fault above the Paintbrush nonwelded (PTn) unit.

- In the south ramp of the ESF, where the Paintbrush nonwelded (PTn) unit is faulted and offset.

- In the ECRB (from 750 to $950 \mathrm{~m}$ along the ECRB Cross-Drift), in the upper lithophysal zone of the Topopah Spring welded tuff (Tptpul).

The occurrences of young pore water in the Bow Ridge fault and in the south ramp of the ESF are clearly linked to the absence of the Paintbrush nonwelded (PTn) subunits or the inability of such subunits to impede downward percolation of young water at those locations. In the ECRB Cross-Drift, what features may provide the pathways for the percolation of young water is unclear. 
The distribution of young percolation water in the ESF main drift and ECRB Cross-Drift does not generally agree with that determined from chlorine isotopes (Fabryka-Martin et al. 1998 [DIRS 162737]):

- Analyses of chlorine-36 indicate significant percolation of young water at the Drill Hole Wash fault and Sundance fault. Only a fraction of 52 samples contained tritium-activity levels in excess of the 1-TU threshold that indicates the presence of young water (Section 6.14.2.2.2).

- Analyses of chlorine-36 in the ESF south ramp did not identify the presence of young water. The majority of 23 samples contained tritium-activity levels in excess of the 1-TU threshold (Section 6.14.2.2.2).

It is possible that, in the Drill Hole Wash fault and Sundance fault, the pore water near the fractures that provided the fast pathways evaporated, due to the barometric pumping of relatively dry air. If this did occur, the evaporated water could leave behind chloride salts containing post-weapons-testing isotope ratios, although the tritium evidence would evaporate with the water. In the ESF south ramp, where numerous samples contained post-weapons-testing levels of tritium, it is possible that large amounts of old chloride were dissolved during percolation of the young water, such that any post-weapons-testing chlorine-36 ratios would be unrecognizable. Measurement uncertainties are discussed in Section 6.14.

\subsubsection{Thermal Regime}

- The sequence of thermal history at Yucca Mountain was reconstructed from depositional temperatures inferred from fluid inclusions, oxygen isotope evaluations, and uranium-thorium geochronologic studies.

- Depositional temperatures of secondary mineral deposits in the UZ at Yucca Mountain, estimated from the fluid-inclusion $\mathrm{T}_{\mathrm{h}}$, and calculated from calcite $\delta^{18} \mathrm{O}$ values, range from present-day ambient to as high as $93^{\circ} \mathrm{C}$.

- Coupled with depositional ages interpolated or extrapolated from uranium-lead geochronologic studies of associated chalcedony or opal, these temperature estimates demonstrate a thermal history that is generally consistent with regional heating from the deep magmatic sources responsible for the silicic volcanism 15 to 11 million years ago.

- Maximum temperatures in the UZ occurred more than 10 million years ago, followed by slow cooling to near-modern ambient temperatures between 2 and 4 millions years ago.

- The UZ appears to have been at or near present-day ambient temperatures for the past 2 to 4 million years.

- Several deposits in the ESF north ramp, however, appear to have formed at temperatures too high to reflect conductive heating from a magmatic heat source. These deposits are associated with fractures present since early cooling of the Tiva Canyon Tuff, and may record fumarolic activity during posteruptive cooling of the tuffs 12.7 million years ago. 
The implications are as follows:

- None of the thermal data requires, or is consistent with, deposition from upwelling hydrothermal fluids.

- The sparse and scattered distribution of the secondary mineral deposits, and their restriction to fracture footwalls and cavity floors, is incompatible with deposition from upwelling of hydrothermal fluids. Upwelling would cause local flooding of the open spaces, and result in a pervasive deposition of secondary minerals that is not observed.

- The distribution and morphology, as well as the geochemical characteristics of the deposits, are fully consistent with deposition from meteoric waters infiltrating at the surface and percolating through the UZ, but at temperatures greater than modern ambient temperatures in the period before 4 to 2 million years ago.

\subsubsection{Uranium Studies}

Uranium isotope ratios are used to indicate past climate conditions and flow paths in the UZ in Section 6.14.3.

\subsubsection{Uranium-Series Dating}

Two methods of uranium-series dating were applied to finely laminated opal hemispheres formed within unsaturated felsic tuffs at Yucca Mountain:

1. An ion microprobe was used to determine isotope compositions of $45-\mu \mathrm{m}$-diameter spots on transects across two millimeter-sized opal hemispheres.

2. In situ microdigestions were used to sequentially remove 2 - to 5 - $\mu$ m-thick layers of surface material.

Both methods substantially improved spatial resolution of the analyses relative to the millimeter-scale subsamples analyzed previously by standard total-digestion techniques. As a result, the opal growth histories can be reconstructed in more detail.

Ion-microprobe ${ }^{230} \mathrm{Th} / \mathrm{U}$ and model ${ }^{234} \mathrm{U} /{ }^{238} \mathrm{U}$ dates from traverses across two opal hemispheres indicate that:

- Age increases progressively with microstratigraphic depth. Spots near the base of the hemispheres have ages of more than one million years.

- The age-depth relations define average opal growth rates of 0.56 and $0.683 \mathrm{~mm} / \mathrm{Ma}$ for two separate hemispheres. In situ microdigestions resulted in even finer spatial resolution ( 2 to $5 \mu \mathrm{m}$ per analysis), and the youngest dates.

- Reliable ${ }^{230} \mathrm{Th} / \mathrm{U}$ dates for the outermost layers of several hemispheres range from $6.34 \pm 0.12$ to $11.6 \pm 1.4 \mathrm{ka}$. 
Sequential microdigestions from the outer $22 \mu \mathrm{m}$ of one hemisphere yielded:

- Dates of approximately $37.1 \pm 1.6 \mathrm{ka}$, resulting in an average growth rate of $0.68 \mathrm{~mm} / \mathrm{Ma}$.

- Opal growth rates that appear to have been faster between approximately 25 and 40 ka $(1.16 \mathrm{~mm} / \mathrm{Ma})$, and slower between approximately 5 and $25 \mathrm{ka}(0.35 \mathrm{~mm} / \mathrm{Ma})$.

- A lack of outermost opal dates younger than approximately $6 \mathrm{ka}$, and age-depth intercepts of 3 to $10 \mathrm{ka}$, both of which imply that opal was not deposited in the last several-thousand years.

Although dates determined by these two methods do not represent the highest levels of precision, they are considered reliable because of the overall consistency of both ages and initial ${ }^{234} U /{ }^{238} U$ ratios in both data sets, and because of the identical average growth rates calculated for the two different scales of sample resolution. Collectively, these data:

- Confirm the previously hypothesized conceptual model of "continuous" deposition for Yucca Mountain UZ secondary minerals (Neymark and Paces 2000 [DIRS 127012]; Neymark et al. 2000 [DIRS 162710]; and Paces et al. 2001 [DIRS 156507]).

- Demonstrate that material is added at very slow rates from solutions seeping into air-filled cavities, and that these rates are likely correlated with climate-controlled percolation flux.

- Imply (based on the absence of mineral growth over the last several-thousand years) that seepage may cease completely during the most arid parts of Pleistocene climate cycles.

The data do not provide conclusive evidence that the growth patterns observed in opal hemispheres (taken from sample HD2074) are correlated with other UZ mineral deposits, and do not provide conclusive evidence regarding whether these patterns can be correlated more reliably with other climate signals.

\subsubsection{Uranium-series Flow Paths in the UZ}

TIMS analyses of ${ }^{234} \mathrm{U}^{238} \mathrm{U}-{ }^{230} \mathrm{Th}-{ }^{232} \mathrm{Th}$ in whole-rock samples confirmed earlier indications of ${ }^{234} \mathrm{U}-{ }^{230} \mathrm{Th}-{ }^{238} \mathrm{U}$ disequilibria in the Yucca Mountain UZ tuffs:

- Results indicated that radioactive disequilibria were present as a result of both matrix and fracture flow, and that the degree of disequilibrium between these two environments is similar.

- Results also showed systematic differences in ${ }^{234} \mathrm{U} /{ }^{238} \mathrm{U}$ and ${ }^{230} \mathrm{Th} /{ }^{238} \mathrm{U}$ ratios that are consistent with sample location within the UZ, and with hydrologic concepts of higher percolation fluxes in the shallow Bow Ridge fault zone (20 to $30 \mathrm{~m}$ depth) and lower fluxes at the repository horizon (220 to $300 \mathrm{~m}$ depth). 
Data from most samples of welded tuff at the repository horizon experienced lesser rates of ${ }^{238} \mathrm{U}$ removal and greater loss of ${ }^{234} \mathrm{U}$ relative to ${ }^{238} \mathrm{U}$. In contrast, samples from the shallow Bow Ridge fault zone show a higher degree of ${ }^{238} \mathrm{U}$ loss and smaller preferential ${ }^{234} \mathrm{U}$ loss, indicating isotopic evolution in an environment with greater amounts of water/rock interaction. Samples in the footwall block of the Bow Ridge fault zone show some evidence for uranium-gain that may be coupled to water/rock interactions within the fault zone.

The amount of water/rock interaction estimated from these uranium-series data may be lower for rocks in the repository horizon at Yucca Mountain than they appear to be in other crystalline rock environments.

Results from these samples suggest that uranium-series data may provide a tool for identifying zones of lesser and greater percolation flux within the Yucca Mountain UZ. These types of data may therefore offer a means of independently testing numerical models of flow and transport.

\subsubsection{Fracture Mineralogy}

Low-temperature deposits of calcite and opal are present in open cavities and fractures within the volcanic rocks at Yucca Mountain. The abundances of these minerals have been estimated in Section 6.14 .4 by surveying underground tunnels and by direct measurement of carbonate in borehole cuttings. Some additional details are as follows:

- The abundances are log-normally distributed about a mean value of 0.03 percent of the rock volume, based on ESF line survey data.

- The abundance of calcite and opal is generally not correlated with faults, fracture density, or topography, although one line survey with a large abundance is located beneath Drill Hole Wash, and is possibly associated with a nearby fault.

- Both line survey data collected in the ECRB Cross-Drift, and estimates of calcite abundance from the nearby Borehole USW SD-6, show a decrease in calcite with stratigraphic depth. This is interpreted as indicating a decrease in seepage with depth (Marshall et al. 2003 [DIRS 162891]).

Although little uncertainty is associated with the statistical information on mineral abundances and analytical techniques (see Section 6.14), correlating these abundances with percolation or seepage flux requires the use of additional data and supporting assumptions (see Marshall et al. 2003 [DIRS 162891]); the resulting interpretations are thus uncertain and remain qualitative.

\subsection{HOW THE ACCEPTANCE CRITERIA ARE ADDRESSED}

The following information describes how this report addresses the acceptance criteria in the Yucca Mountain Review Plan, Final Report (NRC 2003 [DIRS 163274], Sections 2.2.1.3.3.3, 2.2.1.3.6.3, and 2.2.1.3.7.3):

- Only those acceptance criteria that are applicable to this report (see Section 4.2) are discussed. 
- In most cases, the applicable acceptance criteria are not addressed solely by this report; rather, the acceptance criteria are fully addressed when this report is considered in conjunction with other analysis and model reports that describe flow and transport in the UZ.

- Where a subcriterion includes several components, only the applicable components are addressed.

How these components are addressed is summarized in the remainder of this section.

Acceptance Criteria from Section 2.2.1.3.3, Quantity and Chemistry of Water Contacting Engineered Barriers and Waste Forms.

\section{Acceptance Criterion 2, Data Are Sufficient for Model Justification.}

Subcriterion (1): Data used in defining the waste emplacement environment were collected, described, interpreted, and synthesized as described in Sections 4, 6, and 7. Hydrologic and geological data contained in this report are adequately described and justified herein and in conjunction with the data source, in the analysis and interpretation of the data, and through interpretation of the conclusions based on the data analysis. Sections 4.1.1 through 4.1.14 describe the sources of the data. Detailed information in Sections 6.1 through 6.14 adequately describes the analysis and interpretation of these data. Sections 7.1 through 7.14 describe, in detail, the results and conclusions derived from the testing and data analysis.

Acceptance Criterion 3, Data Uncertainty Is Characterized and Propagated through Model Abstraction.

Subcriterion (2): The parameter values and distributions are developed based on Yucca Mountain data from field measurements and laboratory experiments. As discussed in detail in Sections 4.1.1 through 4.1.14 and Sections 6.1 through 6.14, the data are derived from direct studies of geological units of concern to Yucca Mountain, are developed and documented using appropriate scientific techniques, and are compiled by application of QA (quality assurance) methodologies. These data are, therefore, reasonable and technically defensible.

\section{Acceptance Criteria from Section 2.2.1.3.6, Flow Paths in the Unsaturated Zone}

\section{Acceptance Criterion 2, Data Are Sufficient for Model Justification.}

Subcriterion (1): Sections 6.1 through 6.14 and the summaries in Sections 7.1 through 7.14 present the hydrologic information gathered to describe the ambient flow of water in the drift vicinity. These sections adequately justify the choice and use of the data, and provide fully adequate, detailed descriptions of how the data were or can be used, interpreted and synthesized into parameters relating to ambient drift flow and seepage.

Subcriterion (2): As discussed in detail in Sections 4.1.1 through 4.1.14 and Sections 6.1 through 6.14, the data were developed using acceptable scientific techniques, and were compiled utilizing QA methodology. The QA program (Section 2) ensures the quality of the data used in 
this report. Approved QA procedures identified in the TWP (BSC 2004 [DIRS 169654], Section 4) have been used to conduct and document the activities described in this report.

Subcriterion (5): The analyses described in Sections 6.1 through 6.14 were performed to assess data sufficiency and the possible need for additional data. This is exemplified in the use of the understanding gained from relatively short-duration Alcove 6 testing to design other tests, such as the Alcove-8/Niche-3 (Niche 3107) tests described in Section 6.12. The later tests have much longer durations over larger scales.

\section{Acceptance Criterion 3, Data Uncertainty Is Characterized and Propagated through Model Abstraction:}

(Note that this report does not discuss conceptual models, process models, or abstraction models. The criteria discussed below thus address only a small aspect of the related issues. See relevant model reports for a more detailed discussion of how data uncertainty is propagated through model abstraction.)

Subcriterion (5): This report documents the data and subsequent analyses from ambient field-testing activities performed in underground drifts through UZ tuff rock units. Coupled processes (such as pore-water chemical changes and fracture flow-diffusion interactions) are incorporated into the data through the experimental results.

Subcriterion (6): Uncertainties in the characteristics of the natural system are considered in the detailed evaluations included in this report. The summaries of measurement results and uncertainties are discussed in Sections 6.1 through 6.14. The results of this report (summarized in Sections 7.1 through 7.14) provide data for, and analyze uncertainties that could propagate through, UZ process and abstraction models (see Section 7 for a listing of model reports and abstractions that use this data).

\section{Acceptance Criteria from Section 2.2.1.3.7, Radionuclide Transport in the Unsaturated Zone}

\section{Acceptance Criterion 2, Data Are Sufficient for Model Justification:}

Subcriterion (1): Data used in defining the waste emplacement environment are collected, described, interpreted, and synthesized as described in Sections 4, 6, and 7. Hydrologic and geological data described in this report are adequately described and justified in defining the data source, in the analysis and interpretation of the data, and through interpretation of the conclusions based on the data analysis. Sections 4.1.1 through 4.1.14 describe the sources of the data. Detailed information in Sections 6.1 through 6.14 adequately describes the analysis and interpretation of these data. Sections 7.1 through 7.14 describe, in detail, the results and conclusions derived from the testing and data analysis.

Subcriterion (3): The parameter values and distributions are developed based on Yucca Mountain data from field measurements, laboratory experiments, and natural analogue research (Sections 6.1 through 6.14). As discussed in detail in Sections 4.1.1 through 4.1 .14 and Sections 6.1 through 6.14, the data reflect the characteristics of Yucca Mountain structural features, fracture distributions, fracture properties, and stratigraphy; are developed using appropriate scientific techniques; and are compiled utilizing QA methodology. Summaries are 
presented in Sections 7.1 through 7.14 for various activities for data sufficiency, and are carried out as discussed in Sections 6.1 through 6.14.

\section{Acceptance Criterion 3, Data Uncertainty Is Characterized and Propagated through Model Abstraction:}

(Note that this report does not discuss conceptual models, process models, or abstraction models. The criteria discussed below thus address only a small aspect of the related issues. See relevant model reports for a more detailed discussion of how data uncertainty is propagated through model abstraction.)

Subcriterion (2): Estimated flow and transport parameter values and distributions are developed based on Yucca Mountain data from field measurements (including air-injection tests, moisture monitoring, and liquid-release tests (Sections 6.1 through 6.13)), laboratory experiments (experiments on core borings and laboratory radionuclide transport data), and test data at analogue sites (data from the test block at Busted Butte (Section 6.13.6) and isotopic observations and analysis (Section 6.14)). As discussed in detail in Sections 4.1.1 through 4.1.14 and Sections 6.1 through 6.14, the data reflect the characteristics of Yucca Mountain UZ structural features, fracture distributions, fracture properties, and stratigraphy; are developed using appropriate scientific techniques; and are compiled utilizing QA methodology. The parameters developed in this report are, therefore, appropriate and valid for the UZ at Yucca Mountain.

Subcriterion (4): Parameters developed in this report have been adequately analyzed for uncertainties pertaining to sampling or measurement errors, analytical uncertainties, scaling uncertainties, and uncertainties in laboratory measurements. These analyses are noted in the detailed discussions in Sections 6.1 through 6.14, and in the summaries presented in Sections 7.1 through 7.14 . 


\section{INTENTIONALLY LEFT BLANK}




\section{INPUTS AND REFERENCES}

The following is a list of the references cited in this document. Column 2 represents the unique six-digit numerical identifier (the Document Input Reference System [DIRS] number), which is placed in the text following the reference callout (e.g., BSC 2004 [DIRS 167969]). The purpose of these numbers is to assist the reader in locating a specific reference. Within the reference list, multiple sources by the same author (e.g., BSC 2004) are sorted alphabetically by title.

\subsection{DOCUMENTS CITED}

Andreini, M.S. and Steenhuis, T.S. 1990. "Preferential Paths of Flow Under 106071

Conventional and Conservation Tillage." Geoderma, 46, 85-102. Amsterdam, The Netherlands: Elsevier. TIC: 245381.

Axelrod, D.I. 1979. "Age and Origin of Sonoran Desert Vegetation.” Occasional

Papers of the California Academy of Sciences. Number 132. San Francisco,

California: California Academy of Sciences. TIC: 218991.

Barr, D.L.; Moyer, T.C.; Singleton, W.L.; Albin, A.L.; Lung, R.C.; Lee, A.C.; Beason,

100029 S.C.; and Eatman, G.L.W. 1996. Geology of the North Ramp - Stations 4+00 to 28+00, Exploratory Studies Facility, Yucca Mountain Project, Yucca Mountain, Nevada. Denver, Colorado: U.S. Geological Survey. ACC: MOL.19970106.0496.

Bear, J. 1972. Dynamics of Fluids in Porous Media. Environmental Science Series. Biswas, A.K., ed. New York, New York: Elsevier. TIC: 217356.

Beason, S.C.; Turlington, G.A.; Lung, R.C.; Eatman, G.L.W.; Ryter, D.; and Barr, D.L. 1996. Geology of the North Ramp - Station 0+60 to 4+00, Exploratory Studies

Facility, Yucca Mountain Project, Yucca Mountain, Nevada. Denver, Colorado: U.S. Geological Survey. ACC: MOL.19970106.0449.

Benson, L. and Klieforth, H. 1989. "Stable Isotopes in Precipitation and Ground Water in the Yucca Mountain Region, Southern Nevada: Paleoclimatic Implications." 104370 Aspects of Climate Variability in the Pacific and the Western Americas. Peterson, D.H., ed.. Geophysical Monograph 55. Pages 41-59. Washington, D.C.: American Geophysical Union. TIC: 224413.

Bish, D.L. and Vaniman, D.T. 1985. Mineralogic Summary of Yucca Mountain, 101196 Nevada. LA-10543-MS. Los Alamos, New Mexico: Los Alamos National Laboratory. ACC: MOL.19950412.0041.

Bodvarsson, G.S. and Bandurraga, T.M., eds. 1996. Development and Calibration of 100102 the Three-Dimensional Site-Scale Unsaturated Zone Model of Yucca Mountain, Nevada. LBNL-39315. Berkeley, California: Lawrence Berkeley National Laboratory. ACC: MOL.19970701.0692. 
Bouwer, H. 1966. "Rapid Field Measurement of Air Entry Value and Hydraulic 155682 Conductivity of Soil as Significant Parameters in Flow System Analysis." Water Resources Research, 2, (4), 729-738. Washington, D.C.: American Geophysical Union. TIC: 225260.

Braester, C. 1973. "Moisture Variation at the Soil Surface and the Advance of the 106088 Wetting Front During Infiltration at Constant Flux." Water Resources Research, 9, (3), 687-694. Washington, D.C.: American Geophysical Union. TIC: 242383.

Broxton, D.E.; Chipera, S.J.; Byers, F.M., Jr.; and Rautman, C.A. 1993. Geologic 107386 Evaluation of Six Nonwelded Tuff Sites in the Vicinity of Yucca Mountain, Nevada for a Surface-Based Test Facility for the Yucca Mountain Project. LA-12542-MS. Los Alamos, New Mexico: Los Alamos National Laboratory. ACC: NNA.19940224.0128.

Broxton, D.E.; Warren, R.G.; Byers, F.M.; and Scott, R.B. 1989. "Chemical and 100024 Mineralogic Trends Within the Timber Mountain-Oasis Valley Caldera Complex, Nevada: Evidence for Multiple Cycles of Chemical Evolution in a Long-Lived Silicic Magma System." Journal of Geophysical Research, 94, (B5), 5961-5985.

Washington, D.C.: American Geophysical Union. TIC: 225928.

BSC (Bechtel SAIC Company) 2001. Test Plan for: Moisture Monitoring in the ECRB Bulkheaded Cross Drift. SITP-02-UZ-001 REV 00. Las Vegas, Nevada: Bechtel SAIC Company. ACC: MOL.20011018.0011.

BSC 2001. Test Plan for: Niche 5 Seepage Testing. SITP-02-UZ-002 REV 00. Las Vegas, Nevada: Bechtel SAIC Company. ACC: MOL.20020117.0200.

BSC 2001. Test Plan for: Systematic Hydrological Testing in the ECRB Cross Drift. SITP-02-UZ-004 REV 00. Las Vegas, Nevada: Bechtel SAIC Company. ACC: MOL.20020128.0432.

BSC 2002. Guidelines for Developing and Documenting Alternative Conceptual Models, Model Abstractions, and Parameter Uncertainty in the Total System Performance Assessment for the License Application. TDR-WIS-PA-000008 REV 00 ICN 01. Las Vegas, Nevada: Bechtel SAIC Company. ACC: MOL.20020904.0002.

BSC 2002. Test Plan for the Unsaturated Zone Transport Test at Busted Butte, Nevada. SITP-02-UZ-006 REV 00. Las Vegas, Nevada: Bechtel SAIC Company. ACC: MOL.20020509.0352.

BSC 2002. Test Plan for: Alcove 8 Flow \& Seepage Testing. SITP-02-UZ-003 SITP-02-UZ-010 REV 00. Las Vegas, Nevada: Bechtel SAIC Company. ACC: MOL.20020117.0199. 
BSC 2002. Total System Performance Assessment-License Application Methods and 160146 Approach. TDR-WIS-PA-000006 REV 00. Las Vegas, Nevada: Bechtel SAIC Company. ACC: MOL.20020923.0175.

BSC 2004. Abstraction of Drift Seepage. MDL-NBS-HS-000019 REV 01. Las Vegas, 169131 Nevada: Bechtel SAIC Company. ACC: DOC.20041103.0003.

BSC 2004. Analysis of Hydrologic Properties Data. ANL-NBS-HS-000042 REV 00.170038 Las Vegas, Nevada: Bechtel SAIC Company. ACC: DOC.20041005.0004.

BSC 2004. D\&E / PA/C IED Emplacement Drift Configuration and Environment. 800-IED-MGR0-00201-000-00B. Las Vegas, Nevada: Bechtel SAIC Company. ACC: ENG.20040326.0001.

BSC 2004. Features, Events, and Processes in UZ Flow and Transport. 170012 ANL-NBS-MD-000001, Rev. 03. Las Vegas, Nevada: Bechtel SAIC Company.

BSC 2004. Geologic Framework Model (GFM2000). MDL-NBS-GS-000002 REV 170029 02. Las Vegas, Nevada: Bechtel SAIC Company. ACC: DOC.20040827.0008.

BSC 2004. Mineralogic Model (MM3.0) Report. MDL-NBS-GS-000003 REV 01. Las Vegas, Nevada: Bechtel SAIC Company. ACC: DOC.20040908.0006.

BSC 2004. Q-List. 000-30R-MGR0-00500-000-000 REV 00. Las Vegas, Nevada: Bechtel SAIC Company. ACC: ENG.20040721.0007.

BSC 2004. Radionuclide Transport Models Under Ambient Conditions. MDL-NBSHS-000008 REV 02. Las Vegas, Nevada: Bechtel SAIC Company. ACC:

DOC.20041101.0002.

BSC 2004. Seepage Calibration Model and Seepage Testing Data. 171764 MDL-NBS-HS-000004 REV 03. Las Vegas, Nevada: Bechtel SAIC Company. ACC: DOC.20040922.0003.

BSC 2004. Seepage Model for PA Including Drift Collapse. MDL-NBS-HS-000002 REV 03. Las Vegas, Nevada: Bechtel SAIC Company. ACC: DOC.20040922.0008.

BSC 2004. Technical Work Plan for: Performance Assessment Unsaturated Zone. 170031 TWP-NBS-HS-000003 REV 02 Errata 001. Las Vegas, Nevada: Bechtel SAIC Company. ACC: MOL.20030102.0108; DOC.20040121.0001.

BSC 2004. Technical Work Plan for: Regulatory Integration Evaluation of Analysis and Model Reports Supporting the TSPA-LA. TWP-MGR-PA-000014 REV 00 ICN 01. Las Vegas, Nevada: Bechtel SAIC Company. ACC: DOC.20040603.0001. 
BSC 2004. Technical Work Plan for: Unsaturated Zone Flow Analysis and Model

SAIC Company. ACC: DOC.20040701.0005.

BSC 2004. UZ Flow Models and Submodels. MDL-NBS-HS-000006 REV 02. Las

Vegas, Nevada: Bechtel SAIC Company. ACC: DOC.20041101.0004.

BSC 2004. Yucca Mountain Site Description. TDR-CRW-GS-000001 REV 02 ICN

DOC.20040504.0008.

Buesch, D.C. and Spengler, R.W. 1998. "Character of the Middle Nonlithophysal Zone of the Topopah Spring Tuff at Yucca Mountain." High-Level Radioactive Waste Management, Proceedings of the Eighth International Conference, Las Vegas, Nevada, May 11-14, 1998. Pages 16-23. La Grange Park, Illinois: American Nuclear Society. TIC: 237082.

Buesch, D.C.; Spengler, R.W.; Moyer, T.C.; and Geslin, J.K. 1996. Proposed 100106 Stratigraphic Nomenclature and Macroscopic Identification of Lithostratigraphic Units of the Paintbrush Group Exposed at Yucca Mountain, Nevada. Open-File Report 94-469. Denver, Colorado: U.S. Geological Survey. ACC: MOL.19970205.0061.

Bussod, G. 1999. Busted Butte On-Site Logbook \#2, UZ Transport Field Test 146978 (LA-EES-5-NBK-98-020). Scientific Notebook SN-LANL-SCI-039-V1. ACC: MOL.20000307.0380.

Bussod, G. 2001. LA-EES-1-NBK-98-005, UZ Transport Test Notebook 2. Scientific 165281 Notebook SN-LANL-SCI-038-V1. ACC: MOL.20010830.0382.

Bussod, G. and Turin, H.J. 2000. LA-CST-NBK-98-017, Busted Butte Project 165300 IC/ICPAES Notebook. Scientific Notebook SN-LANL-SCI-127-V1. ACC: MOL.20001219.0010.

Bussod, G. and Wolfsberg, L. 2000. LA-CST-NBK-98-002, Busted Butte Project \#1. Scientific Notebook SN-LANL-SCI-159-V1. ACC: MOL.20001219.0004.

Bussod, G. and Wolfsberg, L. 2000. LA-CST-NBK-98-009, Busted Butte Project 165312 Fluorimetry Notebook. Scientific Notebook SN-LANL-SCI-169-V1.

ACC: MOL.20000926.0186.

Bussod, G. and Wolfsberg, L. 2000. LA-CST-NBK-98-012, Busted Butte Project 165308 Notebook \# 2. Scientific Notebook SN-LANL-SCI-160-V1. ACC: MOL.20001219.0008. 
Bussod, G. and Wolfsberg, L. 2000. LA-CST-NBK-98-015, Busted Butte Pad 165310 Processing Notebook \# 1. Scientific Notebook SN-LANL-SCI-161-V1.

ACC: MOL.20001219.0002.

Bussod, G. and Wolfsberg, L. 2000. LA-CST-NBK-98-016, Busted Butte Project 165311 Sample Tracking Forms. Scientific Notebook SN-LANL-SCI-163-V1.

ACC: MOL.20000926.0192.

Bussod, G. and Wolfsberg, L. 2000. LA-CST-NBK-98-017, Busted Butte Project 165303 IC/ICPAES Notebook. Scientific Notebook SN-LANL-SCI-136-V1.

ACC: MOL.20001023.0241.

Bussod, G. and Wolfsberg, L. 2000. LA-CST-NBK-98-018, Busted Butte Project 165301 Microscopy Notebook. Scientific Notebook SN-LANL-SCI-133-V1.

ACC: MOL.20000926.0199.

Bussod, G. and Wolfsberg, L. 2000. LA-CST-NBK-99-003, Busted Butte ICPMS. Scientific Notebook SN-LANL-SCI-192-V1. ACC: MOL.20000926.0201.

Bussod, G.; Turin, H.J.; and Wolfsberg, L. 2000. Busted Butte Tracer Preparation Notebook \#1. Scientific Notebook SN-LANL-SCI-145-V1. ACC: MOL.20000710.0325; MOL.19991109.0060.

Bussod, G.; Turin, H.J.; and Wolfsberg, L. 2000. LA-CST-NBK-99-004; YMP Busted Butte Sorption. Scientific Notebook SN-LANL-SCI-191-V1.

ACC: MOL.20001219.0012.

Bussod, G.Y. 1998. Busted Butte On-Site Logbook \#1, UZ Transport Field Test (LA-EES-5-NBK-98-010). Scientific Notebook SN-LANL-SCI-040-V1.

ACC: MOL.20000321.0288.

Bussod, G.Y. and Stockton, J. 1999. J. Stockton SEA-YMP Notebook \#1. Scientific 165324 Notebook SN-LANL-SCI-043-V1. ACC: MOL.19990719.0103;

MOL.19991109.0114.

Bussod, G.Y. and Turin, H.J. 2001. LA-CST-NBK-98-004, Busted Butte Collection 165321 Pad Notebook. Scientific Notebook SN-LANL-SCI-199-V1.

ACC: MOL.20010718.0258.

Bussod, G.Y. and Wolfsberg, L. 2000. LA-EES-5-NBK-98-019, UZTT Cylinder 165364 Volume Notebook - Phase 1. Scientific Notebook SN-LANL-SCI-228-V1. ACC: MOL.20000926.0182; MOL.20001219.0023.

Bussod, G.Y.; Coen, K.; and Eckhardt, R.C. 1998. LA Testing Status Report: Busted Butte Unsaturated Zone Transport Test FY 98. SPU85M4. Los Alamos, New Mexico: Los Alamos National Laboratory. TIC: 246363. 
Bussod, G.Y.; Turin, H.J.; and Lowry, W.E. 1999. Busted Butte Unsaturated Zone

Transport Test: Fiscal Year 1998 Status Report. LA-13670-SR. Los Alamos, New Mexico: Los Alamos National Laboratory. TIC: 250657.

Canori, G.F. and Leitner, M.M. 2003. Project Requirements Document.

166275

TER-MGR-MD-000001 REV 02. Las Vegas, Nevada: Bechtel SAIC Company.

ACC: DOC.20031222.0006.

Carlos, B.A.; Chipera, S.J.; Bish, D.L.; and Craven, S.J. 1993. "Fracture-Lining Manganese Oxide Minerals in Silicic Tuff, Yucca Mountain, Nevada, U.S.A.” Chemical Geology, 107, 47-69. Amsterdam, The Netherlands: Elsevier.

TIC: 208629.

Cheng, H.; Edwards, R.L.; Hoff, J.; Gallup, C.D.; Richards, D.A.; and Asmerom, Y. 2000. "The Half-Lives of Uranium-234 and Thorium-230." Chemical Geology, 169, 17-33. Amsterdam, The Netherlands: Elsevier. TIC: 249205.

Chipera, S.J.; Vaniman, D.T.; and Bish, D.L. 1996. Zeolite Abundances and the Vitric-to-Zeolitic Transition in Drill Holes USW SD-7, 9, and 12, Yucca Mountain, Nevada. LA-EES-1-TIP-96-005. Los Alamos, New Mexico: Los Alamos National Laboratory. ACC: MOL.19970407.0339.

Clark, I.D. and Fritz, P. 1997. Environmental Isotopes in Hydrogeology. Boca Raton, 105738 Florida: Lewis Publishers. TIC: 233503.

Cook, P. 2000. "In Situ Pneumatic Testing at Yucca Mountain.” International Journal of Rock Mechanics and Mining Sciences, 37, (1-2), 357-367. New York, New York: Pergamon. TIC: 254967.

Cook, P. 2001. Drift Scale Seepage Test. Scientific Notebook YMP-LBNL-JSW-PJC-6.2. ACC: MOL.20011105.0080.

Cook, P.J.; Salve, R.; Freifeld, B.M.; and Tsang, Y.T. 2003. "Measurement System 165424 for Systematic Hydrological Characterization of Unsaturated Fractured Welded Tuff in a Mined Underground Tunnel." Ground Water, 41, (4), 449-457. Westerville, Ohio: National Ground Water Association. TIC: 211670.

Coplen, T.B.; Hopple, J.A.; Böhlke, J.K.; Peiser, H.S.; Rieder, S.E.; Krouse, H.R.; Rosman, K.J.R.; Ding, T.; Vocke, R.D., Jr.; Révész, K.M.; Lamberty, A.; Taylor, P.; and De Bièvre, P. 2003. Compilation of Minimum and Maximum Isotope Ratios of Selected Elements in Naturally Occurring Terrestrial Materials and Reagents. Water-Resources Investigations Report 01-4222. Reston, Virginia: U.S. Geological Survey. TIC: 255203. 
CRWMS (Civilian Radioactive Waste Management System) M\&O (Management and 156876 Operating Contractor) 1999. Exploratory Studies Facility, Cross Drift Alcove \#8 Plan and Sections. BABEAF000-01717-2100-40312 REV 00. Las Vegas, Nevada:

CRWMS M\&O. ACC: MOL.19990608.0041.

CRWMS M\&O 2001. Unsaturated Zone and Saturated Zone Transport Properties 154024 (U0100). ANL-NBS-HS-000019 REV 00 ICN 1. Las Vegas, Nevada: CRWMS M\&O. ACC: MOL.20010201.0026.

Daily, B. and Buettner, M. 2002. Electrical Resistance Tomography at the Unsaturated Zone Transport Test at Busted Butte. Scientific Notebook SN-LLNL-SCI-421-V1. ACC: MOL.20010522.0183; MOL.20020418.0126.

Descour, J.M.; Hanna, K.; Conover, D.; and Hoekstra, B. 2001. Seismic Tomography 156869 Technology for the Water Infiltration Experiment. TDR-EBS-MD-000017 REV 00. Las Vegas, Nevada: Bechtel SAIC Company. ACC: MOL.20010508.0194.

DOE (U.S. Department of Energy) 1998. Total System Performance Assessment. 100550 Volume 3 of Viability Assessment of a Repository at Yucca Mountain. DOE/RW-0508. Washington, D.C.: U.S. Department of Energy, Office of Civilian Radioactive Waste Management. ACC: MOL.19981007.0030.

Drew, D. 2002. AECL Busted Butte Experiment General Laboratory Notebook - 3. Scientific Notebook SN-LANL-SCI-208-V3. ACC: MOL.20021023.0183.

Drew, D. 2002. AECL Busted Butte Saturated Experiment Laboratory Notebook - 6. Scientific Notebook SN-LANL-SCI-206-V6. ACC: MOL.20021104.0186.

Drew, D. 2002. AECL Busted Butte Saturated Experiment Laboratory Notebook-5. 165330 Scientific Notebook SN-LANL-SCI-206-V5. ACC：MOL.20020827.0022.

Drew, D. 2002. AECL Busted Butte Unsaturated Experiment Laboratory Notebook 10. Scientific Notebook SN-LANL-SCI-207-V10. ACC: MOL.20020827.0025.

Drew, D. 2002. AECL Busted Butte Unsaturated Experiment Laboratory Notebook 11. Scientific Notebook SN-LANL-SCI-207-V11. ACC: MOL.20021023.0178.

Drew, D. 2002. AECL Busted Butte Unsaturated Experiment Laboratory Notebook 12. Scientific Notebook SN-LANL-SCI-207-V12. ACC: MOL.20030313.0074.

Drew, D. 2003. AECL Busted Butte Saturated Experiment Laboratory Notebook - 7. Scientific Notebook SN-LANL-SCI-206-V7. ACC: MOL.20030717.0441.

Drew, D. 2003. AECL Busted Butte Unsaturated Experiment Laboratory ACC: MOL.20030904.0343. 
Drew, D.J. 2001. AECL Busted Butte Experiment General Notebook - 1. Scientific Notebook SN-LANL-SCI-208-V1. ACC: MOL.20010830.0390.

165360

Drew, D.J. 2001. AECL Busted Butte Experiment General Notebook - 2. Scientific 165361 Notebook SN-LANL-SCI-208-V2. ACC: MOL.20011219.0336.

Drew, D.J. 2001. AECL Busted Butte Field Notebook - 1. Scientific Notebook 166105 SN-LANL-SCI-205-V1. ACC: MOL.20010716.0243.

Drew, D.J. 2001. AECL Busted Butte Saturated Experiment Laboratory Notebook - 1. 165323 Scientific Notebook SN-LANL-SCI-206-V1. ACC：MOL.20010830.0375.

Drew, D.J. 2001. AECL Busted Butte Saturated Experiment Laboratory Notebook -2. Scientific Notebook SN-LANL-SCI-206-V2. ACC: MOL.20011219.0343.

Drew, D.J. 2001. AECL Busted Butte Unsaturated Experiment Laboratory 165336 Notebook - 1. Scientific Notebook SN-LANL-SCI-207-V1. ACC: MOL.20010830.0387.

Drew, D.J. 2001. AECL Busted Butte Unsaturated Experiment Laboratory Notebook - 165348 2. Scientific Notebook SN-LANL-SCI-207-V2. ACC: MOL.20010830.0378.

Drew, D.J. 2001. AECL Busted Butte Unsaturated Experiment Laboratory Notebook 165349

3. Scientific Notebook SN-LANL-SCI-207-V3. ACC: MOL.20010830.0380.

Drew, D.J. 2001. AECL Busted Butte Unsaturated Experiment Laboratory Notebook - 165350 4. Scientific Notebook SN-LANL-SCI-207-V4. ACC: MOL.20010910.0212.

Drew, D.J. 2001. AECL Busted Butte Unsaturated Experiment Laboratory Notebook - 165351 5. Scientific Notebook SN-LANL-SCI-207-V5. ACC: MOL.20010910.0214.

Drew, D.J. 2001. AECL Busted Butte Unsaturated Experiment Laboratory Notebook 165352

6. Scientific Notebook SN-LANL-SCI-207-V6. ACC: MOL.20011219.0346.

Drew, D.J. 2001. AECL Busted Butte Unsaturated Experiment Laboratory Notebook - 165354 7. Scientific Notebook SN-LANL-SCI-207-V7. ACC: MOL.20020417.0399.

Drew, D.J. 2002. AECL Busted Butte Saturated Experiment Laboratory Notebook - 4. 165328 Scientific Notebook SN-LANL-SCI-206-V4. ACC: MOL.20020628.0360.

Drew, D.J. 2002. AECL Busted Butte Saturated Experiment Laboratory Notebook -3. 165326 Scientific Notebook SN-LANL-SCI-206-V3. ACC：MOL.20020625.0175.

Drew, D.J. 2002. AECL Busted Butte Unsaturated Experiment Laboratory Notebook - 165356 8. Scientific Notebook SN-LANL-SCI-207-V8. ACC: MOL.20020625.0181.

Drew, D.J. 2002. AECL Busted Butte Unsaturated Experiment Laboratory Notebook - 165358 9. Scientific Notebook SN-LANL-SCI-207-V9. ACC: MOL.20020625.0178. 
Dublyansky, Y.; Ford, D.; and Reutski, V. 2001. "Traces of Epigenetic Hydrothermal 161543 Activity at Yucca Mountain, Nevada: Preliminary Data on the Fluid Inclusion and Stable Isotope Evidence." Chemical Geology, 173, (1-3), 125-149. New York, New York: Elsevier. TIC: 253849.

Dublyansky, Y.; Reutsky, V.; and Shugurova, N. 1996. "Fluid Inclusions in Calcite 109204 from the Yucca Mountain Exploratory Tunnel." Sixth Biennial Pan American Conference on Research in Fluid Inclusions, May 30 - June 1, 1996. Brown, P.E. and Hagemann, S.G., eds. Madison, Wisconsin: Department of Geology, University of Wisconsin. TIC: 237704.

Dunn, S. 2001. LA-EES-5-NBK-98-012: SEA: S. Salvit-Dunn, 03/23/98, SEA-YMP 165297 Lab Notebook \#1. Scientific Notebook SN-LANL-SCI-042-V1. ACC: MOL.19991109.0078; MOL.20011119.0378; MOL.20011119.0379; MOL.20011119.0380.

Fabryka-Martin, J.; Wolfsberg, A.V.; Dixon, P.R.; Levy, S.; Musgrave, J.; and Turin, 144839 H.J. 1996. Summary Report of Chlorine-36 Studies: Sampling, Analysis and Simulation of Chlorine-36 in the Exploratory Studies Facility. Milestone 3783M. Los Alamos, New Mexico: Los Alamos National Laboratory. ACC: MOL.19970103.0047.

Fabryka-Martin, J.T.; Turin, H.J.; Wolfsberg, A.V.; Brenner, D.L.; Dixon, P.R.; and 162737 Musgrave, J.A. 1998. Summary Report of Chlorine-36 Studies as of August 1996. LA-13458-MS. Los Alamos, New Mexico: Los Alamos National Laboratory. ACC: MOL.20031119.0395.

Fabryka-Martin, J.T.; Wolfsberg, A.V.; Dixon, P.R.; Levy, S.S.; Musgrave, J.A.; and Turin, H.J. 1997. Summary Report of Chlorine-36 Studies: Sampling, Analysis, and Simulation of Chlorine-36 in the Exploratory Studies Facility. LA-13352-MS.

Los Alamos, New Mexico: Los Alamos National Laboratory.

ACC: MOL.19980812.0254.

Farnham, I.M.; Meigs, L.C.; Dominguez, M.E.; Lindley, K.; Daniels, J.M.; and Stetzenbach, K.J. 2000. "Evaluation of Tracers Used for the WIPP Tracer Tests." Appendix H of Interpretations of Tracer Tests Performed in the Culebra Dolomite at the Waste Isolation Pilot Plant Site. Meigs, L.C.; Beauheim, R.L.; and Jones, T.L., eds. SAND97-3109. Albuquerque, New Mexico: Sandia National Laboratories. TIC: 255153.

Faure, G. 1986. Principles of Isotope Geology. 2nd Edition. New York, New York: 105559 John Wiley \& Sons. TIC: 237212.

Finsterle, S.; Fabryka-Martin, J.T.; and Wang, J.S.Y. 2002. "Migration of a Water 165415 Pulse Through Fractured Porous Media." Journal of Contaminant Hydrology, 54, (1-2), 37-57. New York, New York: Elsevier. TIC: 254968. 
Flint, A.L.; Flint, L.E.; Bodvarsson, G.S.; Kwicklis, E.M.; and Fabryka-Martin, J.

2001. "Evolution of the Conceptual Model of Unsaturated Zone Hydrology at Yucca

Mountain, Nevada." Journal of Hydrology, 247, (1-2), 1-30. New York, New York:

Elsevier. TIC: 250932.

Flint, A.L.; Flint, L.E.; Kwicklis, E.M.; Bodvarsson, G.S.; and Fabryka-Martin, J.M.

2001. "Hydrology of Yucca Mountain, Nevada." Reviews of Geophysics, 39, (4),

447-470. Washington, D.C.: American Geophysical Union. TIC: 254964.

Flint, A.L.; Hevesi, J.A.; and Flint, L.E. 1996. Conceptual and Numerical Model of

Infiltration for the Yucca Mountain Area, Nevada. Milestone 3GUI623M. Denver,

Colorado: U.S. Geological Survey. ACC: MOL.19970409.0087.

Flint, L. 2001. Busted Butte Hydrologic Properties. Scientific Notebook

165381

SN-USGS-SCI-117-V1. ACC: MOL.20020214.0398.

Flint, L. 2001. Busted Butte Hydrologic Properties. Scientific Notebook

SN-USGS-SCI-117-V2. ACC: MOL.20020214.0399.

Flint, L.; Hudson, D.; and Kostalek, T. 2002. Busted Butte Hydrologic Properties.

165383

Scientific Notebook SN-USGS-SCI-117-V3. ACC: MOL.20020926.0130.

Flint, L.E. 1998. Characterization of Hydrogeologic Units Using Matrix Properties,

Yucca Mountain, Nevada. Water-Resources Investigations Report 97-4243. Denver,

Colorado: U.S. Geological Survey. ACC: MOL.19980429.0512.

Flood, T.P.; Vogel, T.A.; and Schuraytz, B.C. 1989. "Chemical Evolution of a

164636

Magmatic System: The Paintbrush Tuff, Southwest Nevada Volcanic Field." Journal of Geophysical Research, 94, (B5), 5943-5960. Washington, D.C.: American

Geophysical Union. TIC: 235505.

Forester, R.M.; Bradbury, J.P.; Carter, C.; Elvidge-Tuma, A.B.; Hemphill, M.L.;

109425

Lundstrom, S.C.; Mahan, S.A.; Marshall, B.D.; Neymark, L.A.; Paces, J.B.; Sharpe, S.E.; Whelan, J.F.; and Wigand, P.E. 1999. The Climatic and Hydrologic History of Southern Nevada During the Late Quaternary. Open-File Report 98-635. Denver, Colorado: U.S. Geological Survey. TIC: 245717.

Freeze, R.A. and Cherry, J.A. 1979. Groundwater. Englewood Cliffs, New Jersey:

101173 Prentice-Hall. TIC: 217571.

Gascoyne, M. 2003. "Soluble Salts in the Yucca Mountain Tuff and their Significance." Proceedings of the 10th International High-Level Radioactive Waste Management Conference (IHLRWM), March 30-April 2, 2003, Las Vegas, Nevada. Pages 340-347. La Grange Park, Illinois: American Nuclear Society. TIC: 254202.

162716 
Gascoyne, M. and Schwarcz, H.P. 1986. "Radionuclide Migration over Recent 164720 Geologic Time in a Granitic Pluton." Chemical Geology, 59, 75-85. New York, New York: Elsevier. TIC: 254779.

Gascoyne, M.; Miller, N.H.; and Neymark, L.A. 2002. "Uranium-Series 154800

Disequilibrium in Tuffs from Yucca Mountain, Nevada, as Evidence of Pore-Fluid Flow Over the Last Million Years.” Applied Geochemistry, 17, (6), 781-792.

New York, New York: Elsevier. TIC: 251901.

Geldon, A.L.; Umari, A.M.A.; Fahy, M.F.; Earle, J.D.; Gemmell, J.M.; and Darnell, J. 100397 1997. Results of Hydraulic and Conservative Tracer Tests in Miocene Tuffaceous Rocks at the C-Hole Complex, 1995 to 1997, Yucca Mountain, Nye County, Nevada. Milestone SP23PM3. Las Vegas, Nevada: U.S. Geological Survey.

ACC: MOL.19980122.0412.

Ghuman, B.S. and Prihar, S.S. 1980. "Chloride Displacement by Water in 106099 Homogeneous Columns of Three Soils." Soil Science Society of America Journal, 44, (1), 17-21. Madison, Wisconsin: Soil Science Society of America. TIC: 246698.

Grim, R.E. 1968. “Clay-Water System.” Clay Mineralogy. 2nd Edition. Pages 234-277. New York, New York: McGraw Hill. TIC: 247447.

GSA (Geological Society of America) 1995. Rock Color Chart with Genuine Munsell ${ }^{\circledR}$ Color Chips. Boulder, Colorado: Geological Society of America.

TIC: 242285.

Guertal, W. 2001. Seepage into Alcove 1. Scientific Notebook 164070 SN-USGS-SCI-108-V1. ACC: MOL.20011219.0325.

Guertal, W. and Flint, A. 2000. ESF Niche Studies. Scientific Notebook 165384 SN-USGS-SCI-110-V1. ACC: MOL.20000512.0035.

Haga, M. 2001. Marc Haga Busted Butte Personal Laboratory Notebook. Scientific Notebook SN-LANL-SCI-253-V1. ACC: MOL.20020128.0171.

Hillel, D. 1998. Environmental Soil Physics. San Diego, California: Academic Press. TIC: 254422.

Hillel, D. 1980. Fundamentals of Soil Physics. New York, New York: Academic Press. TIC: 215655.

Hinds, J. 2000. Percolation and Seepage. Scientific Notebook YMP-LBNL-JSW-JJH-1. ACC: MOL.20000307.0066; MOL.20000419.0645. 
Hu, M.Q. 1999. Characterization of Yucca Mountain Percolation in the Unsaturated

ACC: MOL.20000107.0345.

Hu, M.Q. 1999. Characterization of Yucca Mountain Percolation in the Unsaturated

156541

Zone-ESF Study. Scientific Notebook YMP-LBNL-JSW-QH-1B.

ACC: MOL.20000107.0346.

Hu, M.Q. 1999. Characterization of Yucca Mountain Percolation in the Unsaturated Zone-ESF Study. Scientific Notebook YMP-LBNL-JSW-QH-1C.

ACC: MOL.19991210.0212.

Hu, M.Q. 1999. Characterization of Yucca Mountain Percolation in the Unsaturated

Zone-ESF Study. Scientific Notebook YMP-LBNL-JSW-QH-1D.

ACC: MOL.19991013.0467.

Hu, M.Q. 2000. Characterization of Yucca Mountain Percolation in the Unsaturated Zone-ESF Study. Scientific Notebook YMP-LBNL-JSW-QH-1E.

ACC: MOL.19991013.0468; MOL.20010201.0419.

Hu, Q.; Kneafsey, T.J.; Trautz, R.C.; and Wang, J.S.Y. 2002. "Tracer Penetration into

165412

Welded Tuff Matrix from Flowing Fractures." Vadose Zone Journal, 1, (1), 102-112.

Madison, Wisconsin: Soil Science Society of America. TIC: 254966.

Hu, Q.; Salve, S.; Stringfellow, W.T.; and Wang, J.S.Y. 2001. "Field

165413

Tracer-Transport Tests in Unsaturated Fractured Tuff." Journal of Contaminant

Hydrology, 51, (1-2), 1-12. New York, New York: Elsevier. TIC: 254969.

Hudson, D. 2002. Crossover Alcove - Seepage into Niche 3 and Tracer Testing.

Scientific Notebook SN-USGS-SCI-120-V1. ACC: MOL.20020513.0380.

Hudson, D. 2002. Crossover Alcove - Seepage into Niche 3 and Tracer Testing.

Scientific Notebook SN-USGS-SCI-120-V2. ACC: MOL.20020513.0381.

Hudson, D. 2002. Crossover Alcove - Seepage into Niche 3 and Tracer Testing.

Scientific Notebook SN-USGS-SCI-120-V3. ACC: MOL.20020513.0382.

Hudson, D. 2002. Crossover Alcove - Seepage into Niche 3 and Tracer Testing. Scientific Notebook SN-USGS-SCI-120-V5. ACC: MOL.20020920.0307.

Hudson, D. 2002. Crossover Alcove - Seepage into Niche 3 and Tracer Testing. Scientific Notebook SN-USGS-SCI-120-V6. ACC: MOL.20030106.0357.

Hudson, D. 2003. Crossover Alcove - Seepage into Niche 3 and Tracer Testing. 156473 156542 
Hudson, D. and Guertal, W. 2002. Crossover Alcove - Seepage into Niche 3 and 165388 Tracer Testing. Scientific Notebook SN-USGS-SCI-120-V4.

ACC: MOL.20020513.0383.

Hudson, D.B. 2002. Bulkhead Moisture Monitoring in the Cross Drift. Scientific

163398 Notebook SN-USGS-SCI-133-V1. ACC: MOL.20021125.0122.

Hudson, D.B. 2002. Moisture Monitoring in the Exploratory Studies Facility (ESF) 165391 and Cross Drift. Scientific Notebook SN-USGS-SCI-128-V1.

ACC: MOL.20020520.0349.

Hudson, D.B. 2002. Moisture Monitoring in the Exploratory Studies Facility (ESF) and Cross Drift. Scientific Notebook SN-USGS-SCI-128-V2.

ACC: MOL.20021125.0124.

Hudson, D.B. 2003. Bulkhead Moisture Monitoring in the Cross Drift. Scientific Notebook SN-USGS-SCI-133-V2. ACC: MOL.20030711.0158.

Hudson, D.B. 2003. Moisture Monitoring in the Exploratory Studies Facility (ESF) 165273 and Cross Drift. Scientific Notebook SN-USGS-SCI-128-V3.

ACC: MOL.20030821.0214.

Jaffey, A.H.; Flynn, K.F.; Glendenin, L.E.; Bentley, W.C.; and Essling, A.M. 1971. "Precision Measurement of Half-Lives and Specific Activities of ${ }^{235} \mathrm{U}$ and ${ }^{238} \mathrm{U}$." Physical Review C, 4, (5), 1889-1906. Ridge, New York: American Institute of Physics. TIC: 254712.

Kasnavia, T.; Vu, D.; and Sabatini, D.A. 1999. "Fluorescent Dye and Media 164629 Properties Affecting Sorption and Tracer Selection.” Ground Water, 37, (3), 376-381. Westerville, Ohio: Association of Ground Water Scientists \& Engineers.

TIC: 254708.

Kaufman, A. 1969. "The $\mathrm{Th}^{232}$ Concentration of Surface Ocean Water." Geochimica 164722 et Cosmochimica Acta, 33, (6), 717-724. New York, New York: Pergamon. TIC: 254837.

Kearney, M.L.; Wolfsberg, L.E.; Groffman, A.R.; Jones, C.L.; and Turin, H.J. 2000. 165255 "Solubility of Rare Earth Elements and Transition Metals as a Function of Increasing pH During Unsaturated-Zone Transport Tests at Busted Butte, Nevada." Abstracts with Programs - Geological Society of America, 32, (7), A-209. Boulder, Colorado: Geological Society of America. TIC: 249113.

Klinkenberg, L.J. 1942. "The Permeability of Porous Media to Liquids and Gases." 106105 Drilling and Production Practice 1941. New York, New York: American Petroleum Institute. TIC: 217454. 
Kurzmack, M.; LeCain, G.D.; and Hudson, D. 2002. "Relative Humidity, Pressure, and Temperature Values from the Ghost Dance Fault Alcove 7, Yucca Mountain, Nevada." Abstracts with Programs - Geological Society of America, 34, (6), 59. Boulder, Colorado: Geological Society of America. TIC: 254868.

LeCain, G.D. 1995. Pneumatic Testing in 45-Degree-Inclined Boreholes in Ash-Flow 101700 Tuff Near Superior, Arizona. Water-Resources Investigations Report 95-4073.

Denver, Colorado: U.S. Geological Survey. ACC: MOL.19960715.0083.

LeCain, G.D. 1998. Results from Air-Injection and Tracer Testing in the Upper Tiva Canyon, Bow Ridge Fault, and Upper Paintbrush Contact Alcoves of the Exploratory Studies Facility, August 1994 through July 1996, Yucca Mountain, Nevada. Water-Resources Investigations Report 98-4058. Denver, Colorado: U.S. Geological Survey. ACC: MOL.19980625.0344.

LeCain, G.D.; Lu, N.; and Kurzmack, M. 2002. Use of Temperature, Pressure, and Water Potential Data to Estimate Infiltration and Monitor Percolation in Pagany Wash Associated with the Winter of 1997-98 El Niño Precipitation, Yucca Mountain, Nevada. Water Resources Investigations Report 02-4035. Denver, Colorado: U.S. Geological Survey. TIC: 252641.

Levy, S.; Chipera, S.; WoldeGabriel, G.; Fabryka-Martin, J.; Roach, J.; and Sweetkind, D. 1999. "Flow-Path Textures and Mineralogy in Tuffs of the Unsaturated Zone."

Faults and Subsurface Fluid Flow in the Shallow Crust. Geophysical Monograph 113. 159-183. Washington, D.C.: American Geophysical Union. TIC: 254128.

Levy, S.S. 2001. LA-EES-1-NBK-94-002, Mineralogic/Petrologic/Structural Studies in Support of Unsaturated Zone Flow and Transport Test. Scientific Notebook SN-LANL-SCI-220-V1. ACC: MOL.20010705.0124.

Levy, S.S. 2002. Busted Butte Applicability Studies. Scientific Notebook 100052 SN-LANL-SCI-256-V1. ACC: MOL.20021104.0185.

Lipman, P.W. and McKay, E.J. 1965. Geologic Map of the Topopah Spring SW Quadrangle, Nye County, Nevada. Geologic Quadrangle Map GQ-439. Denver, Colorado: U.S. Geological Survey. TIC: 212352.

Lipman, P.W.; Christiansen, R.L.; and O'Connor, J.T. 1966. A Compositionally 165363 Zoned Ash-Flow Sheet in Southern Nevada. Professional Paper 524-F. Washington, D.C.: U.S. Geological Survey. TIC: 219972.

Liu, H-H.; Haukwa, C.B.; Ahlers, C.F.; Bodvarsson, G.S.; Flint, A.L.; and Guertal, W.B. 2003. "Modeling Flow and Transport in Unsaturated Fractured Rock: An Evaluation of the Continuum Approach." Journal of Contaminant Hydrology, 62-63, 173-188. New York, New York: Elsevier. TIC: 254205. 
Lowry, W. 2001. LA-EES-5-NBK-98-016; SEA: W.Lowry, 03/23/98, SEA-YMP, 164632 Lab Notebook \#1. Scientific Notebook SN-LANL-SCI-046-V1.

ACC: MOL.20011212.0024.

Lundstrom, S.C.; Paces, J.B.; and Mahan, S.M. 1996. "Late Quaternary History of 136523 Fortymile Wash, Southern Nevada: A Record of Geomorphic Response to Climate Change in the Yucca Mountain Region." Abstracts with Programs - Geological Society of America, 28, (7), A-552. Boulder, Colorado: Geological Society of America. TIC: 247474.

Marshall, B.D. and Futa, K. 2003. "Strontium in Pore Water from the Topopah Spring Tuff, Yucca Mountain, Nevada." Proceedings of the 10th International High-Level Radioactive Waste Management Conference (IHLRWM), March 30-April 2, 2003, Las Vegas, Nevada. Pages 373-376. La Grange Park, Illinois: American Nuclear Society. TIC: 254204.

Marshall, B.D. and Whelan, J.F. 2000. "Isotope Geochemistry of Calcite Coatings and 154415 the Thermal History of the Unsaturated Zone at Yucca Mountain, Nevada." Abstracts with Programs - Geological Society of America, 32, (7), A-259. Boulder, Colorado: Geological Society of America. TIC: 249113.

Marshall, B.D. and Whelan, J.F. 2001. "Simulating the Thermal History of the Unsaturated Zone at Yucca Mountain, Nevada." Abstracts with Programs - Geological Society of America, 33, (6), A-375. Boulder, Colorado: Geological Society of America. TIC: 252701.

Marshall, B.D.; Neymark, L.A.; and Peterman, Z.E. 2003. "Estimation of Past Seepage Volumes from Calcite Distribution in the Topopah Spring Tuff, Yucca Mountain, Nevada." Journal of Contaminant Hydrology, 62-63, 237-247. New York, New York: Elsevier. TIC: 254210.

Marshall, B.D.; Neymark, L.A.; Paces, J.B.; Peterman, Z.E.; and Whelan, J.F. 2000. "Seepage Flux Conceptualized from Secondary Calcite in Lithophysal Cavities in the Topopah Spring Tuff, Yucca Mountain, Nevada." SME Annual Meeting, February 28March 1, 2000, Salt Lake City, Utah. Preprint 00-12. Littleton, Colorado: Society for Mining, Metallurgy, and Exploration. TIC: 248608.

Marshall, B.D.; Paces, J.B.; Neymark, L.A.; Whelan, J.F.; and Peterman, Z.E. 1998. "Secondary Minerals Record Past Percolation Flux at Yucca Mountain, Nevada." High-Level Radioactive Waste Management, Proceedings of the Eighth International Conference, Las Vegas, Nevada, May 11-14, 1998. Pages 127-129. La Grange Park, Illinois: American Nuclear Society. TIC: 237082.

Mongano, G.S.; Singleton, W.L.; Moyer, T.C.; Beason, S.C.; Eatman, G.L.W.; Albin, 149850 A.L.; and Lung, R.C. 1999. Geology of the ECRB Cross Drift - Exploratory Studies Facility, Yucca Mountain Project, Yucca Mountain, Nevada. Deliverable SPG42GM3. Denver, Colorado: U.S. Geological Survey. ACC: MOL.20000324.0614. 
Moyer, T.C. and Geslin, J.K. 1995. Lithostratigraphy of the Calico Hills Formation and Prow Pass Tuff (Crater Flat Group) at Yucca Mountain, Nevada. Open-File Report 94-460. Denver, Colorado: U.S. Geological Survey. ACC: MOL.19941208.0003.

Moyer, T.C.; Geslin, J.K.; and Flint, L.E. 1996. Stratigraphic Relations and Hydrologic Properties of the Paintbrush Tuff Nonwelded (PTn) Hydrologic Unit, Yucca Mountain, Nevada. Open-File Report 95-397. Denver, Colorado: U.S. Geological Survey. ACC: MOL.19970204.0216.

Muskat, M. 1982. The Flow of Homogeneous Fluids through Porous Media. Boston, 134132 Massachusetts: International Human Resources Development Corporation.

TIC: 208295.

Neymark, L.A. and Amelin, Y. 2002. "Extreme U-Th-Pb Fractionation Among 164725 Hydrogenic Fracture-Coating Minerals in Felsic Tuffs at Yucca Mountain, Nevada, USA: Implications for Geochronology." Geochimica et Cosmochimica Acta, 66, (15A), Page A552. New York, New York: Pergamon. TIC: 254805.

Neymark, L.A. and Paces, J.B. 2000. "Consequences of Slow Growth for ${ }^{230} \mathrm{Th} / \mathrm{U}$ 127012 Dating of Quaternary Opals, Yucca Mountain, NV, USA.” Chemical Geology, 164, (1-2), 143-160. Amsterdam, The Netherlands: Elsevier. TIC: 246316.

Neymark, L.A.; Amelin, Y.; Paces, J.B.; and Peterman, Z.E. 2002. "U-Pb Ages of 158673 Secondary Silica at Yucca Mountain, Nevada: Implications for the Paleohydrology of the Unsaturated Zone." Applied Geochemistry, 17, (6), 709-734. New York, New York: Elsevier. TIC: 252598.

Neymark, L.A.; Amelin, Y.V.; and Paces, J.B. 2000 . ${ }^{\text {‘206 }} \mathrm{Pb}^{-230}{ }^{23 h}-{ }^{234} \mathrm{U}-{ }^{238} \mathrm{U}$ and ${ }^{207} \mathrm{~Pb}-{ }^{235} \mathrm{U}$ Geochronology of Quaternary Opal, Yucca Mountain, Nevada." Geochimica et Cosmochimica Acta, 64, (17), 2913-2928. New York, New York: Pergamon. TIC: 253360.

Neymark, L.A.; Amelin, Y.V.; Paces, J.B.; and Peterman, Z.E. 1998. "U-Pb Age Evidence for Long-Term Stability of the Unsaturated Zone at Yucca Mountain." High-Level Radioactive Waste Management, Proceedings of the Eighth International Conference, Las Vegas, Nevada, May 11-14, 1998. Pages 85-87. La Grange Park, Illinois: American Nuclear Society. TIC: 237082.

NRC (U.S. Nuclear Regulatory Commission) 2003. Yucca Mountain Review Plan, Final Report. NUREG-1804, Rev. 2. Washington, D.C.: U.S. Nuclear Regulatory Commission, Office of Nuclear Material Safety and Safeguards. TIC: 254568.

Oldenburg, C. 2000. Percolation and Seepage. Scientific Notebook YMP-LBNL-JSW-CMO-1. ACC: MOL.20000922.0075. 
Ostlund, H.G. 1987. "Tritium." Volume 7 of GEOSECS Atlantic, Pacific, and Indian 163335 Ocean Expeditions. Shorebased Data and Graphics. Pages 7-10. Washington, D.C.: National Science Foundation. TIC: 254317.

Paces, J.B. and Neymark, L.A. 2003. "U-Series Disequilibrium as a Test for 162900 Unsaturated-Zone Hydrologic Models at Yucca Mountain, Nevada." Proceedings of the 10th International High-Level Radioactive Waste Management Conference (IHLRWM), March 30-April 2, 2003, Las Vegas, Nevada. Pages 27-38. La Grange Park, Illinois: American Nuclear Society. TIC: 254201.

Paces, J.B. and Whelan, J.F. 2001. "Water-Table Fluctuations in the Amargosa Desert, Nye County, Nevada." "Back to the Future - Managing the Back End of the Nuclear Fuel Cycle to Create a More Secure Energy Future," Proceedings of the 9th International High-Level Radioactive Waste Management Conference (IHLRWM), Las Vegas, Nevada, April 29-May 3, 2001. La Grange Park, Illinois: American Nuclear Society. TIC: 247873.

Paces, J.B.; Neymark, L.A.; Marshall, B.D.; Whelan, J.F.; and Peterman, Z.E. 1998. 107408 "Inferences for Yucca Mountain Unsaturated-Zone Hydrology from Secondary Minerals." High-Level Radioactive Waste Management, Proceedings of the Eighth International Conference, Las Vegas, Nevada, May 11-14, 1998. Pages 36-39. La Grange Park, Illinois: American Nuclear Society. TIC: 237082.

Paces, J.B.; Neymark, L.A.; Marshall, B.D.; Whelan, J.F.; and Peterman, Z.E. 2001. Ages and Origins of Calcite and Opal in the Exploratory Studies Facility Tunnel, Yucca Mountain, Nevada. Water-Resources Investigations Report 01-4049. Denver, Colorado: U.S. Geological Survey. TIC: 251284.

Paces, J.B.; Peterman, Z.E.; Neymark, L.A.; Nimz, G.J.; Gascoyne, M.; and Marshall, 162738 B.D. 2003. "Summary of Chlorine-36 Validation Studies at Yucca Mountain, Nevada." Proceedings of the 10th International High-Level Radioactive Waste Management Conference (IHLRWM), March 30-April 2, 2003, Las Vegas, Nevada. Pages 348-356. La Grange Park, Illinois: American Nuclear Society. TIC: 254253.

Paces, J.B.; Taylor, E.M.; and Bush, C. 1993. "Late Quaternary History and Uranium 106474 Isotopic Compositions of Ground Water Discharge Deposits, Crater Flat, Nevada." High Level Radioactive Waste Management, Proceedings of the Fourth Annual International Conference, Las Vegas, Nevada, April 26-30, 1993. 2, 1573-1580. La Grange Park, Illinois: American Nuclear Society. TIC: 208542.

Peterman, Z.E. and Cloke, P.L. 2001. "Geochemical Homogeneity of Tuffs at the 155696 Potential Repository Level, Yucca Mountain, Nevada." "Back to the Future Managing the Back End of the Nuclear Fuel Cycle to Create a More Secure Energy Future, " Proceedings of the 9th International High-Level Radioactive Waste Management Conference (IHLRWM), Las Vegas, Nevada, April 29-May 3, 2001. La Grange Park, Illinois: American Nuclear Society. TIC: 247873. 
Peterman, Z.E. and Cloke, P.L. 2002. "Geochemistry of Rock Units at the Potential 162576 Repository Level, Yucca Mountain, Nevada (includes Erratum).” Applied Geochemistry, 17, (6,7), 683-698, 955-958. New York, New York: Pergamon. TIC: $252516 ; 252517$.

Peterman, Z.E. and Futa, K. 1996. Geochemistry of Core Samples of the Tiva Canyon 106494 Tuff from Drill Hole UE-25 NRG\#3, Yucca Mountain, Nevada. Open-File Report 95-325. Denver, Colorado: U.S. Geological Survey. ACC: MOL.19961118.0132.

Peterman, Z.E. and Marshall, B.D. 2002. "Geochemistry of Pore Water from Densely Welded Topopah Spring Tuff at Yucca Mountain, Nevada.” GSA Abstracts with Programs, 34, (6), 308. Boulder, Colorado: Geological Society of America. TIC: 254868.

Peterman, Z.E.; Spengler, R.W.; Singer, F.R.; and Dickerson, R.P. 1993. "Isotopic 106498 and Trace Element Variability in Altered and Unaltered Tuffs at Yucca Mountain, Nevada." High Level Radioactive Waste Management, Proceedings of the Fourth Annual International Conference, Las Vegas, Nevada, April 26-30, 1993. 2, 1940-1947. La Grange Park, Illinois: American Nuclear Society. TIC: 208542.

Peterson, J. 2002. Busted Butte (YMP-LBNL-ELM-JP-1). Scientific Notebook SN-LBNL-SCI-193-V1. ACC: MOL.20030115.0004.

Philip, J.R. 1986. "Linearized Unsteady Multidimensional Infiltration." Water Resources Research, 22, (12), 1717-1727. Washington, D.C.: American Geophysical Union. TIC: 239826.

Philip, J.R. 1989. "The Scattering Analog for Infiltration in Porous Media." Reviews of Geophysics, 27, (4), 431-448. Washington, D.C.: American Geophysical Union. TIC: 251332.

Philip, J.R.; Knight, J.H.; and Waechter, R.T. 1989. "Unsaturated Seepage and Subterranean Holes: Conspectus, and Exclusion Problem for Circular Cylindrical Cavities." Water Resources Research, 25, (1), 16-28. Washington, D.C.: American Geophysical Union. TIC: 239117.

Porro, I. and Wierenga, P.J. 1993. "Transient and Steady-State Transport through a Large Unsaturated Soil Column." Ground Water, 31, (2), 193-200. Dublin, Ohio: National Ground Water Association. TIC: 246899.

Pruess, K. 1999. “A Mechanistic Model for Water Seepage Through Thick 165379 106133 Unsaturated Zones in Fractured Rocks of Low Matrix Permeability." Water Resources Research, 35, (4), 1039-1051. Washington, D.C.: American Geophysical Union. TIC: 244913. 
Pullan, A.J. 1990. "The Quasilinear Approximation for Unsaturated Porous Media

Raats, P.A.C. and Gardner, W.R. 1971. "Comparison of Empirical Relationships Between Pressure Head and Hydraulic Conductivity and Some Observations on Radially Symmetric Flow." Water Resources Research, 7, (4), 921-928. Washington, D.C.: American Geophysical Union. TIC: 239815.

Rautman, C.A. and Engstrom, D.A. 1996. Geology of the USW SD-12 Drill Hole 100642 Yucca Mountain, Nevada. SAND96-1368. Albuquerque, New Mexico: Sandia National Laboratories. ACC: MOL.19970613.0101.

Rautman, C.A. and Engstrom, D.A. 1996. Geology of the USW SD-7 Drill Hole Yucca 101008 Mountain, Nevada. SAND96-1474. Albuquerque, New Mexico: Sandia National Laboratories. ACC: MOL.19971218.0442.

Reimus, P.W.; Adams, A.; Haga, M.J.; Humphrey, A.; Callahan, T.; Anghel, I.; and 126243 Counce, D. 1999. Results and Interpretation of Hydraulic and Tracer Testing in the Prow Pass Tuff at the C-Holes. Milestone SP32E7M4. Los Alamos, New Mexico: Los Alamos National Laboratory. TIC: 246377.

Rosholt, J.N. 1983. "Isotopic Composition of Uranium and Thorium in Crystalline Rocks." Journal of Geophysical Research, 88, (B9), 7315-7330. Washington, D.C.: American Geophysical Union. TIC: 254838.

Russo, R.E.; Mao, X.; Borisov, O.V.; and Liu, H. 2000. "Laser Ablation in Atomic Spectroscopy." Encyclopedia of Analytical Chemistry. Meyers, R.A., ed. Pages 9485-9506. Chichester, England: John Wiley \& Sons. TIC: 250479.

Sabatini, D.A. and Austin, T.A. 1991. "Characteristics of Rhodamine WT and 164630 Fluorescein as Adsorbing Ground-Water Tracers." Ground Water, 29, (3), 341-349. Westerville, Ohio: Association of Ground Water Scientists \& Engineers. TIC: 254709.

Salve, R. 1999. Fracture Flow, Fracture-Matrix Interaction. Scientific Notebook YMP-LBNL-JSW-RS-1. ACC: MOL.19991013.0470.

Salve, R. 1999. Fracture Flow, Fracture-Matrix Interaction. Scientific Notebook YMP-LBNL-JSW-RS-1A. ACC: MOL.19991013.0471.

Salve, R. 1999. Measurements of Moisture Potential in P Tunnel Calico Hills using Tensiometers and Psychrometers. Scientific Notebook YMP-LBNL-JW-1.2A. ACC: MOL.19991013.0473. 
Salve, R. 1999. Measurements of Moisture Potential in P Tunnel/Calico Hills using Tensiometers and Psychrometers. Scientific Notebook YMP-LBNL-JW-1.2.

ACC: MOL.20000215.0229.

Salve, R. 2000. Percolation and Seepage. Scientific Notebook

156548

YMP-LBNL-JSW-RS-2. ACC: MOL.20000908.0236.

Salve, R. 2002. YMP-LBNL-JSW-RS-4 UZ Investigations-ESF/Drift-FY00.

165378

Scientific Notebook SN-LBNL-SCI-182-V1. ACC：MOL.20020708.0384.

Salve, R. 2003. Moisture Monitoring in the ESF, YMP-LBNL-JSW-RS-5-UZ Investigations-ESF/XDrift. Scientific Notebook SN-LBNL-SCI-181-V1.

ACC: MOL.20030430.0281.

Salve, R. and Oldenburg, C.M. 2001. "Water Flow Within a Fault in Altered

Nonwelded Tuff." Water Resources Research, 37, (12), 3043-3056. Washington,

D.C.: American Geophysical Union. TIC: 251485.

Salve, R.; Oldenburg, C.M.; and Wang, J.S.Y. 2003. "Fault-Matrix Interactions in

164470

Nonwelded Tuff of the Paintbrush Group at Yucca Mountain." Journal of

Contaminant Hydrology, 62-63, 269-286. New York, New York: Elsevier.

TIC: 254205.

Salve, R.; Wang, J.S.Y.; and Doughty, C. 2002. "Liquid-Release Tests in Unsaturated

161318

Fractured Welded Tuffs: I. Field Investigations." Journal of Hydrology, 256, (1-2),

60-79. New York, New York: Elsevier. TIC: 253774.

Sass, J.H.; Dudley, W.W., Jr.; and Lachenbruch, A.H. 1995. "Regional Thermal 101288

Setting." Chapter 8 of Major Results of Geophysical Investigations at Yucca Mountain and Vicinity, Southern Nevada. Oliver, H.W.; Ponce, D.A.; and Hunter, W.C., eds. Open-File Report 95-74. Menlo Park, California: U.S. Geological Survey.

ACC: MOL.19980305.0122.

Sass, J.H.; Lachenbruch, A.H.; Dudley, W.W., Jr.; Priest, S.S.; and Munroe, R.J. 1988. 100644 Temperature, Thermal Conductivity, and Heat Flow Near Yucca Mountain, Nevada: Some Tectonic and Hydrologic Implications. Open-File Report 87-649. Denver, Colorado: U.S. Geological Survey. TIC: 203195.

Sawyer, D.A.; Fleck, R.J.; Lanphere, M.A.; Warren, R.G.; Broxton, D.E.; and Hudson, 100075 M.R. 1994. "Episodic Caldera Volcanism in the Miocene Southwestern Nevada Volcanic Field: Revised Stratigraphic Framework, ${ }^{40} \mathrm{Ar} /{ }^{39} \mathrm{Ar}$ Geochronology, and Implications for Magmatism and Extension." Geological Society of America Bulletin, 106, (10), 1304-1318. Boulder, Colorado: Geological Society of America.

TIC: 222523. 
Scanlon, B.R. 2000. "Uncertainties in Estimating Water Fluxes and Residence Times

171740 Using Environmental Tracers in an Arid Unsaturated Zone." Water Resources Research, 36, (2), 395-409. Washington, D.C.: American Geophysical Union. TIC: 256442.

Schuraytz, B.C.; Vogel, T.A.; and Younker, L.W. 1989. "Evidence for Dynamic 107248 Withdrawal from a Layered Magma Body: The Topopah Spring Tuff, Southwestern Nevada." Journal of Geophysical Research, 94, (B5), 5925-5942. Washington, D.C.: American Geophysical Union. TIC: 225936.

Scott, R.B. and Bonk, J. 1984. Preliminary Geologic Map of Yucca Mountain, Nye 104181 County, Nevada, with Geologic Sections. Open-File Report 84-494. Denver, Colorado: U.S. Geological Survey. ACC: HQS.19880517.1443.

Scott, R.B. and Castellanos, M. 1984. Stratigraphic and Structural Relations of Volcanic Rocks in Drill Holes USW GU-3 and USW G-3, Yucca Mountain, Nye County, Nevada. Open-File Report 84-491. Denver, Colorado: U.S. Geological Survey. ACC: NNA.19870519.0095.

Selby, S.M., ed. 1975. CRC Standard Mathematical Tables. 23rd Edition. Cleveland, 106143 Ohio: CRC Press. TIC: 247118.

Soll, W. 2001. Busted Butte UZTT Phase 2A Tracer Level Records. Scientific Notebook SN-LANL-SCI-257-V1. ACC: MOL.20010605.0371.

Soll, W. and Aldrich, M.J. 2002. Mineralogic/Petrologic/Structural Studies in Support of Busted Butte Unsaturated Zone Flow and Transport Test. Scientific Notebook SN-LANL-SCI-261-V1. ACC: MOL.20020517.0132.

Soll, W. and Bussod, G.Y. 2001. LA-EES-5-NBK-99-003 Busted Butte On-Site Logbook \#3, UZ Transport Field Test. Scientific Notebook SN-LANL-SCI-106-V1. ACC: MOL.20010531.0104.

Soll, W. and Wolfsberg, L. 2000. Busted Butte Project IC/ICP-AES Notebook \#2. Notebook SN-LANL-SCI-232-V1. ACC: MOL.20001219.0006.

Soll, W. and Wolfsberg, L. 2000. Pad Concentration and Loading Calculations. Scientific Notebook SN-LANL-SCI-193-V1. ACC: MOL.20000926.0190.

Soll, W. and Wolfsberg, L. 2000. The Busted Butte Project Sample Tracking Forms \# 165313

2. Scientific Notebook SN-LANL-SCI-184-V1. ACC: MOL.20000926.0188. 
Soll, W. and Wolfsberg, L. 2002. Busted Butte Research and Development Notebook 165367 for Chemical Analyses. Scientific Notebook SN-LANL-SCI-241-V1.

ACC: MOL.20021104.0176.

Soll, W.; Bussod, G.; and Mason, N.G. 2001. LA-EES-5-NBK-98-011, Sensor Design

165296

/ N. Mason SEA-YMP Notebook \#1. Scientific Notebook SN-LANL-SCI-041-V1.

ACC: MOL.20011212.0020.

Soll, W.; Turin, H.J.; and Wolfsberg, L. 2002. Busted Butte Master Notebook for 165366 Chemical Analyses. Scientific Notebook SN-LANL-SCI-239-V1.

ACC: MOL.20030121.0082.

Spaulding, W.G. 1985. Vegetation and Climates of the Last 45,000 Years in the Vicinity of the Nevada Test Site, South-Central Nevada. Professional Paper 1329. Washington, D.C.: U.S. Geological Survey. TIC: 203210.

Steiger, R.H. and Jager, E. 1977. "Subcommission on Geochronology: Convention on the Use of Decay Constants in Geo- and Cosmochronology." Earth and Planetary Science Letters, 36, 359-362. Amsterdam, The Netherlands: Elsevier. TIC: 236817.

Stepek, J. 2000. Characterization of Yucca Mountain Percolation in the Unsaturated Zone - ESF Study. Scientific Notebook YMP-LBNL-JSW-JS-1.

ACC: MOL.19991013.0476; MOL.20010724.0086.

SubTerra. 1998. Final Report, TRW Environmental Safety Systems, Inc., Busted Butte Test Facility. Project: 97-35. Kirkland, Washington: SubTerra. TIC: 247628.

Szabo, B.J. and Kyser, T.K. 1990. "Ages and Stable-Isotope Compositions of 106883 Secondary Calcite and Opal in Drill Cores from Tertiary Volcanic Rocks of the Yucca Mountain Area, Nevada." Geological Society of America Bulletin, 102, 1714-1719. Boulder, Colorado: Geological Society of America. TIC: 221927.

Thompson, R.S. 1991. "Pliocene Environments and Climates in the Western United States." Quaternary Science Reviews, 10, 115-132. Oxford, United Kingdom: Pergamon Press. TIC: 234260.

Thorstenson, D.C.; Weeks, E.P.; Haas, H.; Busenberg, E.; Plummer, L.N.; and Peters, 126827 C.A. 1998. "Chemistry of Unsaturated Zone Gases Sampled in Open Boreholes at the Crest of Yucca Mountain, Nevada: Data and Basic Concepts of Chemical and Physical Processes in the Mountain." Water Resources Research, 34, (6), 1507-1529.

Washington, D.C.: American Geophysical Union. TIC: 246315.

Tokunaga, T.K. and Wan, J. 1997. "Water Film Flow Along Fracture Surfaces of Porous Rock." Water Resources Research, 33, (6), 1287-1295. Washington, D.C.: American Geophysical Union. TIC: 242739. 
Trautz, R. 2003. YMP-LBNL-RCT-5 Moisture Monitoring in the ESF (Phase 2)/Drift 166248 Seepage Test. SN-LBNL-SCI-221-V1. ACC: MOL.20011029.0234;

MOL.20020923.0235; MOL.20030929.0011.

Trautz, R.C. 1999. Moisture Monitoring in the ESF (Phase 2)/Drift Seepage Test.

156563

Scientific Notebook YMP-LBNL-RCT-1. ACC: MOL.20000306.0470;

MOL.20001121.0084.

Trautz, R.C. 2001. Moisture Monitoring in the ESF (Phase 2)/Drift Seepage Test.

Scientific Notebook YMP-LBNL-RCT-2. ACC: MOL.20011030.0706.

Trautz, R.C. 2001. Moisture Monitoring in the ESF (Phase 2)/Drift Seepage Test.

Scientific Notebook YMP-LBNL-RCT-4. ACC: MOL.20020508.0272.

Trautz, R.C. 2001. Niche Excavation; Liquid Flow Testing; Borehole Drilling and

Pneumatic Testing; Drift Seepage Testing. Scientific Notebook YMP-LBNL-RCT-3.

ACC: MOL.20011116.0083.

Trautz, R.C. and Wang, J.S.Y. 2001. "Evaluation of Seepage into an Underground Opening Using Small-Scale Field Experiments, Yucca Mountain, Nevada." Mining Engineering, 53, (12), 41-44. Littleton, Colorado: Society for Mining, Metallurgy and Exploration. TIC: 253862.

Trautz, R.C. and Wang, J.S.Y. 2002. "Seepage into an Underground Opening Constructed in Unsaturated Fractured Rock Under Evaporative Conditions." Water Resources Research, 38, (10), 6-1 through 6-14. Washington, D.C.: American Geophysical Union. TIC: 253348.

Tsang, Y. and Wang, J. 2000. ECRB Systematic Hydrological Testing. Scientific Notebook SN-LBNL-SCI-179-V1. ACC: MOL.20001016.0017.

Tseng, P-H. and Bussod, G.Y. 2001. "Evaluation of the Filter Paper Technique for In Situ Sampling of Solute Transport in Unsaturated Soils and Tuffs." Water Resources Research, 37, (7), 1913-1928. Washington, D.C.: American Geophysical Union. TIC: 255448.

Turin, H.J. 2001. Busted Butte Phase II Overcore and Mineback Activities. Scientific 165368 Notebook SN-LANL-SCI-252-V1. ACC: MOL.20020204.0180.

Turin, H.J.; Groffman, A.R.; Wolfsberg, L.E.; Roach, J.L.; and Strietelmeier, B.A. 2002. "Tracer and Radionuclide Sorption to Vitric Tuffs of Busted Butte, Nevada." Applied Geochemistry, 17, (6), 825-836. New York, New York: Pergamon.

TIC: 254046.

USGS (U.S. Geological Survey) 2001. Simulation of Net Infiltration for Modern and Potential Future Climates. ANL-NBS-HS-000032 REV 00 ICN 02. Denver, Colorado: U.S. Geological Survey. ACC: MOL.20011119.0334. 
USGS 2002. Test Plan for: Chlorine-36 Validation. SITP-02-UZ-005 REV 00.

Denver, Colorado: U.S. Geological Survey. ACC: MOL.20020213.0179.

USGS 2002. Test Plan for: UZ Hydrochemistry Investigations. SITP-02-UZ-007

158194

REV 00. Denver, Colorado: U.S. Geological Survey. ACC: MOL.20020204.0146.

Vandergraaf, T.T.; Drew, D.J.; and Ticknor, K.V. 2002. Busted Butte Report on

165099

Laboratory Radionuclide Migration Experiments in Non-Welded Tuff Under

Unsaturated Conditions. AECL-12170. Pinawa, Manitoba, Canada: Atomic Energy

of Canada Limited. ACC: MOL.20030919.0118.

Vandergraaf, T.T.; Drew, D.J.; Ticknor, K.V.; and Seddon, W.A. 2002. "Radionuclide

165133

Migration Experiments at a Scale of up to 1 Metre in Tuff Blocks Under Unsaturated

Conditions." Abstracts with Programs - Geological Society of America, 34, (6), 237.

Boulder, Colorado: Geological Society of America. TIC: 254868.

Vaniman, D.T.; Chipera, S.J.; Bish, D.L.; Carey, J.W.; and Levy, S.S. 2001.

157427

"Quantification of Unsaturated-Zone Alteration and Cation Exchange in Zeolitized

Tuffs at Yucca Mountain, Nevada, USA." Geochimica et Cosmochimica Acta, 65,

(20), 3409-3433. New York, New York: Elsevier. TIC: 251574.

Vigier, N.; Bourdon, B.; Turner, S.; and Allègre, C.J. 2001. "Erosion Timescales

Derived from U-Decay Series Measurements in Rivers." Earth and Planetary Science

Letters, 193, (3-4), 549-563. New York, New York: Elsevier. TIC: 254755.

Wang, J. 1997. Characterization of Yucca Mountain Percolation in the Unsaturated

156530

Zone - ESF Study. Scientific Notebook YMP-LBNL-JSW-6.

ACC: MOL.19991013.0459.

Wang, J. 1997. Characterization of Yucca Mountain Percolation in the Unsaturated Zone - ESF Study. Scientific Notebook YMP-LBNL-JSW-6A.

ACC: MOL.19991013.0460.

Wang, J. 1999. Characterization of Yucca Mountain Percolation in the Unsaturated

Zone - ESF Study. Scientific Notebook YMP-LBNL-JSW-6B.

ACC: MOL.19991013.0461.

Wang, J. 1999. Characterization of Yucca Mountain Percolation in the Unsaturated Zone - ESF Study. Scientific Notebook YMP-LBNL-JSW-6C.

ACC: MOL.19991013.0462.

Wang, J. 2000. Characterization of Yucca Mountain Percolation in the Unsaturated Zone - Exploratory Shaft Facility Study. Scientific Notebook YMP-LBNL-JSW-4.3. ACC: MOL.19991018.0187; MOL.20000808.0010. 
Wang, J.S. 2003. "Scientific Notebooks Referenced in Scientific Analysis Report 165376 U0015, In-Situ Field Testing Processes, ANL-NBS-HS-000005 REV 02."

Memorandum from J.S. Wang (BSC) to File, December 2, 2003, with attachments. ACC: MOL.20031202.0097.

Wang, J.S.Y. and Elsworth, D. 1999. "Permeability Changes Induced by Excavation 104366 in Fractured Tuff." Rock Mechanics for Industry, Proceedings of the 37th U.S. Rock Mechanics Symposium, Vail, Colorado, USA, 6-9 June 1999. Amadei, B.; Kranz, R.L.; Scott, G.A.; and Smeallie, P.H., eds. 2, 751-757. Brookfield, Vermont: A.A. Balkema. TIC: 245246.

Wang, J.S.Y. and Narasimhan, T.N. 1993. "Unsaturated Flow in Fractured Porous 106793 Media." Chapter 7 of Flow and Contaminant Transport in Fractured Rock. Bear, J.; Tsang, C-F.; and de Marsily, G., eds. San Diego, California: Academic Press. TIC: 235461.

Wang, J.S.Y.; Flint, A.L.; Nitao, J.J.; Chesnut, D.A.; Cook, P.; Cook, N.G.W.; 101309 Birkholzer, J.; Freifeld, B.; Flint, L.E.; Ellet, K.; Mitchell, A.J.; Homuth, E.F.; Griego, G.J.; Cerny, J.A.; and Johnson, C.L. 1996. Evaluation of Moisture Evolution in the Exploratory Studies Facility. Milestone TR31K6M. Berkeley, California: Lawrence Berkeley National Laboratory. ACC: MOL.19961231.0089.

Wang, J.S.Y.; Trautz, R.C.; Cook, P.J.; Finsterle, S.; James, A.L.; and Birkholzer, J. 1999. "Field Tests and Model Analyses of Seepage into Drift." Journal of Contaminant Hydrology, 38, (1-3), 323-347. New York, New York: Elsevier. TIC: 244160 .

Warrick, A.W.; Biggar, J.W.; and Nielsen, D.R. 1971. "Simultaneous Solute and 106150 Water Transfer for an Unsaturated Soil." Water Resources Research, 7, (5), 1216-1225. Washington, D.C.: American Geophysical Union. TIC: 245674.

Whelan, J.F. and Moscati, R.J. 1998. "9 M.Y. Record of Southern Nevada Climate from Yucca Mountain Secondary Minerals." High-Level Radioactive Waste Management, Proceedings of the Eighth International Conference, Las Vegas, Nevada, May 11-14, 1998. Pages 12-15. La Grange Park, Illinois: American Nuclear Society. TIC: 237082.

Whelan, J.F.; Moscati, R.J.; Allerton, S.B.M.; and Marshall, B.D. 1998. Applications of Isotope Geochemistry to the Reconstruction of Yucca Mountain, Nevada, Paleohydrology-Status of Investigations: June 1996. Open-File Report 98-83. Denver, Colorado: U.S. Geological Survey. ACC: MOL.19981012.0740.

Whelan, J.F.; Neymark, L.A.; Roedder, E.; and Moscati, R.J. 2003.

"Thermochronology of Secondary Minerals from the Yucca Mountain Unsaturated Zone." Proceedings of the 10th International High-Level Radioactive Waste Management Conference (IHLRWM), March 30-April 2, 2003, Las Vegas, Nevada. Pages 357-366. La Grange Park, Illinois: American Nuclear Society. TIC: 254368. 
Whelan, J.F.; Paces, J.B.; and Peterman, Z.E. 2002. "Physical and Stable-Isotope 160442 Evidence for Formation of Secondary Calcite and Silica in the Unsaturated Zone, Yucca Mountain, Nevada." Applied Geochemistry, 17, (6), 735-750. New York, New York: Elsevier. TIC: 253462.

Whelan, J.F.; Roedder, E.; and Paces, J.B. 2001. "Evidence for an Unsaturated-Zone 154773 Origin of Secondary Minerals in Yucca Mountain, Nevada." "Back to the Future Managing the Back End of the Nuclear Fuel Cycle to Create a More Secure Energy Future, "Proceedings of the 9th International High-Level Radioactive Waste Management Conference (IHLRWM), Las Vegas, Nevada, April 29-May 3, 2001. La Grange Park, Illinois: American Nuclear Society. TIC: 247873.

Whelan, J.F.; Vaniman, D.T.; Stuckless, J.S.; and Moscati, R.J. 1994. "Paleoclimatic 100091 and Paleohydrologic Records from Secondary Calcite: Yucca Mountain, Nevada." High Level Radioactive Waste Management, Proceedings of the Fifth Annual International Conference, Las Vegas, Nevada, May 22-26, 1994. 4, 2738-2745. La Grange Park, Illinois: American Nuclear Society. TIC: 210984.

White, A.F.; Bullen, T.D.; Vivit, D.V.; Schulz, M.S.; and Clow, D.W. 1999. "The Role of Disseminated Calcite in the Chemical Weathering of Granitoid Rocks." Geochimica et Cosmochimica Acta, 63, (13/14), 1939-1953. New York, New York: Pergamon Press. TIC: 248634.

White, I. and Sully, M.J. 1987. "Macroscopic and Microscopic Capillary Length and 106152 Time Scales from Field Infiltration." Water Resources Research, 23, (8), 1514-1522. Washington, D.C.: American Geophysical Union. TIC: 239821.

Williams, K. 2000. Busted Butte. Scientific Notebook SN-LBNL-SCI-119-V1. ACC: MOL.20001011.0059.

Williams, K. 2002. YMP-LBNL-ELM-KHW-2 UZ Busted Butte. Scientific 165374 Notebook SN-LBNL-SCI-119-V2. ACC: MOL.20021126.0232.

Wilson, N.S.F.; Cline, J.S.; and Lundberg, S.A.W. 2000. "Paragenesis and Chemical 154279 Composition of Secondary Mineralization at Yucca Mountain, Nevada." Abstracts with Programs - Geological Society of America, 32, (7), A-260. Boulder, Colorado: Geological Society of America. TIC: 249113.

Wilson, N.S.F.; Cline, J.S.; Rotert, J.; and Amelin, Y.V. 2000. "Timing and 151450 Temperature of Fluid Movement at Yucca Mountain, NV: Fluid Inclusion Analyses and U-Pb and U-Series Dating." Abstracts with Programs - Geological Society of America, 32, (7), A-260. Boulder, Colorado: Geological Society of America. TIC: 249113. 
Wilson, S.F. and Cline, J.S. 2001. "Paragenesis, Temperature and Timing of Secondary Minerals at Yucca Mountain." "Back to the Future - Managing the Back End of the Nuclear Fuel Cycle to Create a More Secure Energy Future," Proceedings of the 9th International High-Level Radioactive Waste Management Conference (IHLRWM), Las Vegas, Nevada, April 29-May 3, 2001. La Grange Park, Illinois: American Nuclear Society. TIC: 247873.

Winograd, I.J.; Szabo, B.J.; Coplen, T.B.; Riggs, A.C.; and Kolesar, P.T. 1985. "TwoMillion-Year Record of Deuterium Depletion in Great Basin Ground Waters." Science, 227, 519-522. Washington, D.C.: American Association for the Advancement of Science. TIC: 216799.

Wu, Y.S.; Liu, H.H.; Bodvarsson, G.S.; and Zellmer, K.E. 2001. A Triple-Continuum Approach for Modeling Flow and Transport Processes in Fractured Rock.

LBNL-48875. Berkeley, California: Lawrence Berkeley National Laboratory. TIC: 251297.

Wyckoff, D. 1999. Unsaturated Zone Transport Test (LA-EES-5-NBK-98-014).

Scientific Notebook SN-LANL-SCI-044-V1. ACC：MOL.20001023.0116.

Yang, I.C. 2002. "Percolation Flux and Transport Velocity in the Unsaturated Zone, Yucca Mountain, Nevada." Applied Geochemistry, 17, (6), 807-817. New York, New York: Elsevier. TIC: 253605.

Yang, I.C.; Peterman, Z.E.; and Scofield, K.M. 2003. "Chemical Analyses of Pore Water from Boreholes USW SD-6 and USW WT-24, Yucca Mountain, Nevada." Journal of Contaminant Hydrology, 62-63, 361-380. New York, New York: Elsevier. TIC: 254205.

Yang, I.C.; Rattray, G.W.; and Yu, P. 1996. Interpretation of Chemical and Isotopic Data from Boreholes in the Unsaturated Zone at Yucca Mountain, Nevada. Water-Resources Investigations Report 96-4058. Denver, Colorado: U.S. Geological Survey. ACC: MOL.19980528.0216.

Yang, I.C.; Yu, P.; Rattray, G.W.; Ferarese, J.S.; and Ryan, J.N. 1998. Hydrochemical Investigations in Characterizing the Unsaturated Zone at Yucca Mountain, Nevada. Water-Resources Investigations Report 98-4132. Denver, Colorado: U.S. Geological Survey. ACC: MOL.19981012.0790.

YMP (Yucca Mountain Site Characterization Project) 2000. Field Test Data Office. ACC: MOL.20010122.0092. 
YMP 2002. Moisture Studies in the ESF. FWP-ESF-96-004, Rev. 8. Washington,

Youden, W.J. 1951. Statistical Methods for Chemists. New York, New York: John

153339

Wiley \& Sons. TIC: 248814.

\subsection{CODES, STANDARDS, REGULATIONS, AND PROCEDURES}

10 CFR 63. Energy: Disposal of High-Level Radioactive Wastes in a Geologic

Repository at Yucca Mountain, Nevada. Readily available.

AP-2.22Q, Rev. 1, ICN 1. Classification Analyses and Maintenance of the Q-List.

Washington, D.C.: U.S. Department of Energy, Office of Civilian Radioactive Waste Management. ACC: DOC.20040714.0002.

AP-16.1Q, Rev. 8, ICN 2. Condition Reporting and Resolution. Washington, D.C.: U.S. Department of Energy, Office of Civilian Radioactive Waste Management. ACC: DOC.20040812.0002.

AP-12.1Q, Rev. 0, ICN 2. Control of Measuring and Test Equipment and Calibration Standards. Washington, D.C.: U.S. Department of Energy, Office of Civilian Radioactive Waste Management. ACC: DOC.20040429.0006.

AP-SIII.9Q, Rev. 1, ICN 7. Scientific Analysis. Washington, D.C.: U.S. Department of Energy, Office of Civilian Radioactive Waste Management.

ACC: DOC.20040920.0001

LP-SI.11Q-BSC, Rev. 0, ICN 1. Software Management. Washington, D.C.: U.S. Department of Energy, Office of Civilian Radioactive Waste Management. ACC: DOC.20041005.0008.

YMP-LBNL-TIP/GP 5.0, Rev. 0 Mod. 0. Ground Penetrating Radar Data Acquisition. Berkeley, California: Lawrence Berkeley National Laboratory. ACC: MOL.19990205.0129.

\subsection{SOURCE DATA, LISTED BY DATA TRACKING NUMBER}

GS000308312242.002. Phase 1 of Water Collection in Alcove 1 from 05/05/98 to 08/27/98. Submittal date: 03/01/2000.

GS000308313211.001. Geochemistry of Repository Block.

Submittal date: $03 / 27 / 2000$.

GS000399991221.003. Preliminary Alcove 1 Infiltration Experiment Data. Submittal 147024 date: $03 / 10 / 2000$. 
GS000608314224.004. Provisional Results: Geotechnical Data for Station 35+00 to

152573 Station 40+00, Main Drift of the ESF. Submittal date: 06/20/2000.

GS000808312242.006. Pulse Flow Meter Data for the Alcove 1 Infiltration

162980 Experiment from 02/19/99 to 06/20/00. Submittal date: 09/07/2000.

GS001108312242.009. Tracker Data for the Alcove 1 Infiltration Experiment, Phase II 165202 05/09/99 to 07/05/00. Submittal date: $11 / 07 / 2000$.

GS010608312242.002. Small Plot Infiltration in Alcove 8 Using a Box Permeameter 165543 from August 28, 2000 to December 14, 2000. Submittal date: 06/27/2001.

GS010608312242.004. Crossover Alcove/Seepage into Niche 3; Small Plot Infiltration 165542 Using a Cylinder Permeameter from August 9, 2000 to August 21, 2000. Submittal date: $06 / 28 / 2001$.

GS010808315215.003. Fluid Inclusion Homogenization Temperatures from the ESF, ECRB, and EWCD, 12/99 to 4/01. Submittal date: 09/04/2001.

GS010808315215.004. Uranium and Lead Concentrations, Lead Isotopic 164850 Compositions, and U-Pb Isotope Ages for the ESF Secondary Minerals Determined at the Royal Ontario Museum between April 20, 2000 and April 19, 2001. Submittal date: $08 / 29 / 2001$.

GS020408312272.002. Tritium Abundance Data from Pore-Water in Core Samples 162342 from Yucca Mountain ESF Boreholes for the Period of April 30, 1998 through March 21, 2001. Submittal date: 05/08/2002.

GS020408312272.003. Collection and Analysis of Pore Water Samples for the Period from April 2001 to February 2002. Submittal date: 04/24/2002.

GS020508312242.001. Trench Fault Infiltration in Alcove 8 Using Permeameters from March 5, 2001 to June 1, 2001. Submittal date: 05/22/2002.

GS020608315215.002. Carbon Dioxide Abundances, Carbon Dioxide Concentrations, 162126 and Normative Calcite Concentrations for Cuttings from Borehole USW SD-6, USW WT-24, and ECRB Cross Drift Boreholes, Determined by Carbon Dioxide Evolution, May 25, 2000 and September 8, 2000. Submittal date: 06/26/2002.

GS020908312242.002. Trenched Fault Infiltration in Alcove 8 Using Permeameters from June 1, 2001 to March 26, 2002. Submittal date: 09/17/2002. and ECRB, 10/01 to 5/02. Submittal date: 09/26/2001. 
GS020908315215.004. Stable Carbon and Oxygen Isotope Analyses of ESF/ECRB

Calcite and USW SD-6 and USW WT-24 Whole Rock; 1/1999-6/2002.

Submittal date: 10/16/2002.

GS021008312242.003. Moisture Monitoring in ESF, Alcoves 3 and 4, from April 1,

162178

2000 through March 31, 2002. Submittal date: 01/15/2003.

GS021008315215.005. Uranium, Thorium, and Lead Concentrations, Lead Isotopic

164848

Compositions, U-Pb Isotope Ages and 234U/238U and 230TH/238U Activity Ratios for the ESF and ECRB Secondary Minerals Determined at the Royal Ontario Museum between 11/16/01 and 4/7/02. Submittal date: 10/21/2002.

GS021008315215.007. Carbon Dioxide and Normative Calcite Concentrations in Powdered Cuttings from Borehole USW WT-24 Determined by CO2 Evolution between July 1998 and August 1999. Submittal date: 11/07/2002.

GS021208312272.005. Tritium Abundance Data from Pore-Water in Core Samples 162934 from Yucca Mountain ESF ECRB. Submittal date: 12/19/2002.

GS021208312272.008. Uranium and Thorium Concentrations and 234U-230TH164609 238U-232TH Isotopic Compositions from Whole Rock Samples from the ECRB Cross-Drift and ESF Analyzed between February and June, 2002. Submittal date: 01/28/2003.

GS021208315215.008. 238U-234U-230TH-232TH Isotope Ratios and Calculated 164851 Ages for Opal Hemispheres from Sample HD2074 (SPC00506577) at Station 30+51 in the Exploratory Studies Facility Determined Using Ion-Probe Mass Spectrometry. Submittal date: $12 / 19 / 2002$.

GS021208315215.009. U Abundances, 238U-234U-230TH-232TH Activity Ratios, 164750 and Calculated 230TH/U Ages, and Initial 234U/238U Activity Ratios Determined for Sequential In-Situ Microdigestions of Opal Hemispheres from the ESF by Thermal Ionization Mass Spectrometry. Submittal date: 12/19/2002.

GS030208312242.003. Trenched Fault Infiltration in Alcove 8 Using Permeameters 165544 from March 26, 2002 to August 20, 2002. Submittal date: 03/10/2003.

GS030208312272.001. Gas and Water Vapor Chemistry Data in Yucca Mountain ESF 162935 ECRB Bulkheads. Submittal date: 03/11/2003.

GS030408312272.002. Analysis of Water-Quality Samples for the Period from July 165226 2002 to November 2002. Submittal date: 05/07/2003.

GS030508312242.004. Photographs from Niche 3 of the Alcove 8/Niche 3 Seepage 165545 Experiment During Construction Showing Construction Water in Niche 3, March 6, 2000. Submittal date: 06/03/2003. 
GS030608312231.002. Digital Image Data from the Moisture Monitoring Tests in the

ECRB Bulkheaded Cross Drift from January 22, 2001 to February 3, 2003.

Submittal date: 07/09/2003.

GS030608312242.005. Surface Infiltration in a Large Plot in Alcove 8 Using

166200

Permeameters from November 19, 2002 to March 24, 2003.

Submittal date: 06/24/2003.

GS030808315215.001. Line Survey Information from the East-West Cross-Drift

Obtained to Estimate Secondary Mineral Abundance. Submittal date: 09/23/2003.

GS030908315215.002. X-Ray Fluorescence Elemental Compositions Determined on

166097

Cuttings from USW SD-6 and USW WT-24 Analyzed from May 20, 1998 to March 13,

2001. Submittal date: 10/20/2003.

GS031008312242.007. Surface Infiltration in a Large Plot in Alcove 8 Using

Permeameters from August 20, 2002 to November 19, 2002.

Submittal date: 10/31/2003.

GS031208312232.002. Deep UZ Surface-Based Borehole Instrumentation Program

Data from Boreholes USW NRG-7A, UE-25 UZ\#4, USW NRG-6, UE-25 UZ\#5, USW

UZ-7A and USW SD-12 for the Time Period 4/1/98 through 9/30/98. Submittal date:

$07 / 15 / 2004$.

GS950508314224.003. Provisional Results: Geotechnical Data - Full Periphery Map

107488

Data from North Ramp of the Exploratory Studies Facility, Stations 0+60 to 4+00.

Submittal date: 05/24/1995.

GS951108312231.009. Physical Properties, Water Content, and Water Potential for Borehole USW SD-7. Submittal date: 09/26/1995.

GS951208312272.002. Tritium Analyses of Porewater from USW UZ-14, USW

NRG-6, USW NRG-7A and UE-25 UZ\#16 and of Perched Water from USW SD-7, USW SD-9, USW UZ-14 and USW NRG-7A from 12/09/92 to 5/15/95.

Submittal date: $12 / 15 / 1995$.

GS960708314224.008. Provisional Results: Geotechnical Data for Station $30+00$ to Station $35+00$, Main Drift of the ESF. Submittal date: 08/05/1996.

105617

GS960708314224.010. Provisional Results: Geotechnical Data for Station 40+00 to 106031 Station 45+00, Main Drift of the ESF. Submittal date: 08/05/1996.

GS960808312231.004. Physical Properties, Water Content and Water Potential for 108985 Samples from Lower Depths in Boreholes USW SD- 7 and USW SD-12. Submittal date: $08 / 30 / 1996$. 
GS960808312231.005. Water Permeability and Relative Humidity Calculated Porosity

108995 for Samples from Boreholes USW SD-7, USW SD-9, USW SD-12 and USW UZ-14.

Submittal date: 08/30/1996.

GS960908314224.014. Provisional Results - ESF Main Drift, Station 50+00 to Station

106033 55+00. Submittal date: 09/09/1996.

GS960908314224.020. Analysis Report: Geology of the North Ramp - Stations 4+00 106059 to 28+00 and Data: Detailed Line Survey and Full-Periphery Geotechnical Map Alcoves 3 (UPCA) and 4 (LPCA), and Comparative Geologic Cross Section - Stations 0+60 to 28+00. Submittal date: 09/09/1996.

GS970208312242.001. Moisture Monitoring in the ESF, Oct. 1, 1996 through Jan. 31, 1997. Submittal date: 02/19/1997.

GS970208314224.003. Geotechnical Data for Station 60+00 to Station 65+00, South Ramp of the ESF. Submittal date: 02/12/1997.

GS970208315215.005. Carbon and Oxygen Stable Isotope Kiel Analyses of Calcite 107351 from the ESF and USW G-1, G-2 and G-4, UE-25 A\#1, USW NRG-6 and NRG-7/7A, and UE-25 UZ\#16, April 1996 - January 1997. Submittal date: 02/27/1997.

GS970708312242.002. Moisture Monitoring in the ESF, Feb. 1, 1997 through July 31, 1997. Submittal date: 07/18/1997.

GS970808312232.005. Deep Unsaturated Zone Surface-Based Borehole Instrumentation Program Data from Boreholes USW NRG-7A, UE-25 UZ\#4, UE-25 UZ\#5, USW UZ-7A and USW SD-12 for the Time Period 1/1/97 - 6/30/97. Submittal date: $08 / 28 / 1997$.

GS970808315215.010. Carbon and Oxygen Stable Isotope Analyses of Calcite from the ESF and USW G-1, G-2, and G-3/GU-3, from 01/16/97 to 07/18/97. Submittal date: $08 / 18 / 1997$.

GS971108312232.007. Deep Unsaturated Zone Surface-Based Borehole Instrumentation Program Data from Boreholes USW NRG-7A, UE-25 UZ \#4, UE-25 UZ \#5, USW UZ-7A and USW SD-12 for the Time Period 7/1/97 - 9/30/97. Submittal date: $11 / 18 / 1997$.

GS971108314224.020. Revision 1 of Detailed Line Survey Data, Station 0+60 to 105561 Station 4+00, North Ramp Starter Tunnel, Exploratory Studies Facility. Submittal date: $12 / 03 / 1997$.

GS971108314224.021. Revision 1 of Detailed Line Survey Data, Station 4+00 to 106007 Station 8+00, North Ramp, Exploratory Studies Facility. Submittal date: 12/03/1997. 
GS971108314224.022. Revision 1 of Detailed Line Survey Data, Station 8+00 to

106009

Station 10+00, North Ramp, Exploratory Studies Facility. Submittal date: 12/03/1997.

GS971108314224.023. Revision 1 of Detailed Line Survey Data, Station $10+00$ to

106010

Station $18+00$, North Ramp, Exploratory Studies Facility.

Submittal date: 12/03/1997.

GS971108314224.024. Revision 1 of Detailed Line Survey Data, Station $18+00$ to

106023

Station 26+00, North Ramp, Exploratory Studies Facility. Submittal date: 12/03/1997.

GS971108314224.025. Revision 1 of Detailed Line Survey Data, Station 26+00 to

106025

Station 30+00, North Ramp and Main Drift, Exploratory Studies Facility. Submittal date: $12 / 03 / 1997$.

GS971108314224.026. Revision 1 of Detailed Line Survey Data, Station $45+00$ to

106032

Station 50+00, Main Drift, Exploratory Studies Facility. Submittal date: 12/03/1997.

GS971108314224.028. Revision 1 of Detailed Line Survey Data, Station 55+00 to

Station 60+00, Main Drift and South Ramp, Exploratory Studies Facility. Submittal date: $12 / 03 / 1997$.

GS980308312242.001. Time Domain Reflectometry Measurements in the South Ramp

135181

of the ESF, August 1, 1997 to January 4, 1998. Submittal date: 03/04/1998.

GS980308312242.002. Heat Dissipation Probe Measurements in the South Ramp of the ESF, August 1, 1997 to January 31, 1998. Submittal date: 03/09/1998.

GS980308312242.003. Physical Properties of Borehole Samples from the ESF South Ramp (ESF Station 59+65M to ESF Station 76+33M). Submittal date: 03/16/1998.

GS980308312242.004. Water Potential Measurements Using the Filter Paper

Technique for Borehole Samples from the ESF North Ramp (ESF Station 7+27 M to ESF Station 10+70 M) and the ESF South Ramp (ESF Station 59+65 M to 76+33 M). Submittal date: 03/19/1998.

GS980308312242.005. Physical Properties of Lexan-Sealed Borehole Samples from the PIN Exposure in the ESF North Ramp (ESF Station 7+27 M to ESF Station 10+70 M). Submittal date: 03/11/1998.

GS980308315215.008. Line Survey Information from the Exploratory Studies Facility Obtained to Estimate Secondary Mineral Abundance. Submittal date: 03/24/1998.

107355

GS980408312232.001. Deep Unsaturated Zone Surface-Based Borehole 105982 Instrumentation Program Data from Boreholes USW NRG-7A, UE-25 UZ \#4, USW NRG-6, UE-25 UZ \#5, USW UZ-7A and USW SD-12 for the Time Period 10/01/97 03/31/98. Submittal date: 04/16/1998. 
GS980908312242.018. Physical Properties of Borehole Core Samples from

ESF-MD-NICHE3566\#1, ESF-MD-NICHE3566\#2, ESF-MD-NICHE3566\#3A,

ESF-MD-NICHE3566LT\#1, ESF-MD-NICHE3566LT\#2, ESF-MD-NICHE3566LT\#3,

ESF-MD-NICHE3566LT\#4, ESF-MD-NICHE3566LT\#5, and

ESF-MD-NICHE3566LT\#6. Submittal date: 09/03/1998.

GS980908312242.020. Physical Properties of Borehole Core Samples from

135172

ESF-MD-NICHE3650\#1, ESF-MD-NICHE3650\#2, ESF-MD-NICHE3650\#3,

ESF-MD-NICHE3650\#4, ESF-MD-NICHE3650\#5, ESF-MD-NICHE3650\#6, and

ESF-MD-NICHE3650\#7. Submittal date: 09/05/1998.

GS980908312242.022. Water Potentials Measured with Heat Dissipation Probes in

135157

Twenty-One Drill Holes in Niche 1 (ESF-NICHE3566) from 11/04/97 to 07/31/98.

Submittal date: 09/11/1998.

GS980908312242.024. Moisture Monitoring in the ESF, August 1, 1997 to July 31,

135132 1998. Submittal date: $09 / 15 / 1998$.

GS980908312242.028. Physical and Hydrologic Properties of Borehole Core Samples

135176 from ESF-SAD-GTB\#1. Submittal date: 09/16/1998.

GS980908312242.029. Physical and Hydrologic Properties of Borehole Core Samples

135175 from ESF-NDR-MF\#1, ESF-NDR-MF\#2, and ESF-NDR-MF\#4 in Alcove 6 of the ESF. Submittal date: 09/17/1998.

GS980908312242.030. Physical Properties of Borehole Core Samples from ESF-ECRB-SLANT\#2. Submittal date: 09/17/1998.

GS980908312242.032. Physical and Hydrologic Properties of Borehole Core Samples and Water Potential Measurements Using the Filter Paper Technique for Borehole Samples from ESF-LPCA-PTN\#1 and ESF-LPCA-PTN\#2 in Alcove 4. Submittal date: 09/17/1998.

GS980908312242.033. Physical and Hydrologic Properties of Borehole Core Samples and Water Potential Measurements Using the Filter Paper Technique for Borehole Samples from ESF-UPCA-PTN\#1 in Alcove 3 of the ESF. Submittal date: 09/17/1998.

GS980908312242.035. Moisture Monitoring in the ECRB, 04/08/98 to 07/31/98.

Submittal date: 09/24/1998.

GS980908312242.036. Water Potentials Measured with Heat Dissipation Probes in

ECRB Holes from 4/23/98 to 7/31/98. Submittal date: 09/22/1998.

GS980908315213.002. Carbon and Oxygen Stable Isotopic Compositions of Exploratory Studies Facility Secondary Calcite Occurrences, 10/01/97 to 08/15/98. Submittal date: 09/16/1998. 
GS990108312242.005. Temperature, Relative Humidity and Barometric Pressure Data 166000 for Alcove 7 of the ESF from 12/08/97 to 12/12/98. Submittal date: 01/28/1999.

GS990108312242.006. Pulse Flow Meter Data for the Alcove 1 Infiltration 162979 Experiment from 03/08/98 to 12/04/98. Submittal date: 01/29/1999.

GS990183122410.001. Tritium Data from Pore Water from ESF Borehole Cores, 1997146125 Analyses by USES. Submittal date: 01/06/1999.

GS990183122410.004. Tritium Data from Pore Water from ESF Borehole Cores, 1998 Analyses by University of Miami. Submittal date: 10/14/1999.

GS990308312242.007. Laboratory and Centrifuge Measurements of Physical and 107185 Hydraulic Properties of Core Samples from Busted Butte Boreholes UZTT-BB-INJ-1, UZTT-BB-INJ-3, UZTT-BB-INJ-4, UZTT-BB-INJ-6, UZTT-BB-COL-5 and UZTT-BB-COL-8. Submittal date: 03/22/1999.

GS990408314224.001. Detailed Line Survey Data for Stations 00+00.89 to 14+95.18, 108396 ECRB Cross-Drift. Submittal date: 09/09/1999.

GS990408314224.002. Detailed Line Survey Data for Stations $15+00.85$ to $26+63.85$, ECRB Cross Drift. Submittal date: 09/09/1999.

GS990408314224.006. Full-Periphery Geologic Maps for Station 20+00 to 26+81, ECRB Cross Drift. Submittal date: 09/09/1999.

GS990708312242.008. Physical and Hydraulic Properties of Core Samples from Busted Butte Boreholes. Submittal date: 07/01/1999.

GS990708314224.007. Detailed Line Survey Data for Busted Butte Access Drift and Busted Butte Cross Drift. Submittal date: 11/02/1999.

GS990908314224.010. Geology of the ECRB Cross Drift: Graphical Data. Submittal date: $09 / 14 / 1999$.

GS990908315213.001. Stable Carbon and Oxygen Isotope Data for Calcite from the ESF and Analyzed 2/96 - 5/99. Submittal date: 10/28/1999.

LA0002JF12213U.001. Chemistry Data for Porewater Extracted from Drillcore from 154760 Surface-Based Boreholes USW NRG-6, USW NRG-7A, USW UZ-7A, USW UZ-14, UE-25 UZ\#16, USW UZ-N55, USW SD-6, USW SD-7, USW SD-9, USW SD-12, and USW WT-24. Submittal date: 02/15/2000.

LA0002JF12213U.002. Chemistry Data for Porewater Extracted from ESF, Cross 156281 Drift and Busted Butte Drill Core. Submittal date: 02/15/2000. 
LA0008WS831372.001. Calculated Daily Injection Rates for the Busted Butte

156582

Unsaturated Zone Transport Tests. Submittal date: 08/23/2000.

LA0108TV12213U.001. Static Batch Sorption Coefficients and Retardation

161525

Coefficients. Submittal date: 08/14/2001.

LA0112WS831372.001. Busted Butte UZ Transport Test: Phase II Collection Pad

157100

Tracer Loading. Submittal date: 12/06/2001.

LA0112WS831372.002. Busted Butte UZ Transport Test: Phase II Collection Pad

157115

Tracer Concentrations. Submittal date: 12/06/2001.

LA0112WS831372.003. Busted Butte UZ Transport Test: Phase II Normalized

157106

Collection Pad Tracer Concentrations. Submittal date: 12/06/2001.

LA0201WS831372.004. Calculated Moisture Content for the Busted Butte Site Phase

165422

II Collection Boreholes. Submittal date: 01/03/2002.

LA0204SL831372.001. Mineralogy of the Busted Butte Phase 2 Test Block.

164749

Submittal date: 04/17/2002.

LA0207SL831372.001. Lithostratigraphic Classification of Hydrologic-Property

160824

Core-Sampling Depths, Busted Butte Phase 2 Test Block. Submittal date: 07/16/2002.

LA0302WS831372.001. Fluorescein Plume Images from the Phase 1A Mineback at

162765

Busted Butte. Submittal date: 02/26/2003.

LA0305RR831222.001. Chlorine-36 and Cl in Salts Leached from Rock Samples for the Chlorine-36 Validation Study. Submittal date: 05/22/2003.

163422

LA0307RR831222.001. Chloride, Bromide, Sulfate, and Chlorine-36 Analyses of Salts Leached from Cross Drift Rock Samples in FY99 and FY00. Submittal date:

07/09/2003.

LA0307RR831222.002. Chloride, Bromide, Sulfate, and Chlorine-36 Analyses of Salts Leached from ESF 36Cl Validation Drillcore Samples in FY99.

Submittal date: 07/09/2003.

LA0311SD831372.001. In-Situ Air Permeability Measurements at Busted Butte.

166197

Submittal date: $11 / 19 / 2003$.

LA9909JF831222.012. Chloride, Bromide, and Sulfate Analyses of Porewater

122736

Extracted from ESF Niche 3566 (Niche \#1) and ESF 3650 (Niche \#2) Drillcore.

Submittal date: 09/29/1999.

LA9909WS831372.001. Busted Butte UZ Transport Test: Faze I Collection Pad

122739

Extract Concentrations. Submittal date: 09/29/1999. 
LA9909WS831372.002. Busted Butte UZ Transport Test: Phase I Collection Pad 122741 Tracer Loading and Tracer Concentrations. Submittal date: 09/30/1999.

LA9909WS831372.015. ICPAES Porewater Analysis for Rock Samples from Busted Butte, NV. Submittal date: 10/01/1999.

LA9909WS831372.016. ION Chromatography Porewater Analysis for Rock Samples from Busted Butte, NV. Submittal date: 09/30/1999.

LA9909WS831372.017. pH of Porewater of Rock Samples from Busted Butte, NV. Submittal date: 09/30/1999.

LA9909WS831372.018. Gravimetric Moisture Content of Rock Samples from Busted Butte, NV. Submittal date: 09/30/1999.

LA9910WS831372.008. Busted Butte UZ Transport Test: Gravimetric Moisture 147156 Content and Bromide Concentration in Selected Phase 1A Rock Samples. Submittal date: $11 / 03 / 1999$.

LAJF831222AQ98.004. Chloride, Bromide, Sulfate, and Chlorine-36 Analyses of 107364 Salts Leached from ESF Rock Samples. Submittal date: 09/10/1998.

LAJF831222AQ98.007. Chloride, Bromide, and Sulfate Analyses of Salts Leached 122730 from ECRB-CWAT\#1, \#2, and \#3 Drill Core. Submittal date: 09/09/1998.

LAJF831222AQ98.009. Chlorine-36 Analyses of Salts Leached from ESF Niche 3566 (Niche \#1) Drillcore. Submittal date: 09/09/1998.

LAJF831222AQ98.011. Chloride, Bromide, Sulfate and Chlorine-36 Analyses of 145402 Springs, Groundwater, Porewater, Perched Water and Surface Runoff. Submittal date: 09/10/1998.

Langmuir, D. and Herman, J.S. 1980. "The Mobility of Thorium in Natural Waters at 147527 Low Temperatures." Geochimica et Cosmochimica Acta, 44, 1753-1766. New York, New York: Pergamon Press. TIC: 237029.

LB00032412213U.001. Busted Butte Ground Penetrating Radar Data Collected June 149214 1998 through February 2000 at the Unsaturated Zone Transport Test (UZTT): GPR Velocity Data. Submittal date: 03/24/2000.

LB00090012213U.001. Air K Testing in Borehole SYBT-ERCB-LA\#2 at CS 17+26 in 153141 Cross Drift. Submittal date: 11/03/2000.

LB00090012213U.002. Liquid Release Tests from Borehole SYBT-ECRB-LA\#2 at CS 17+26 in Cross Drift. Submittal date: 11/09/2000.

LB0010NICH3LIQ.001. Niche 3107 Seepage Test. Submittal date: 11/02/2000. 
LB0010NICH4LIQ.001. Niche 4788 Seepage Test. Submittal date: 11/02/2000.

LB0011AIRKTEST.001. Air Permeability Testing in Niches 3566 and 3650.

153155

Submittal date: $11 / 08 / 2000$.

LB0011CO2DST08.001. Isotope Data for CO2 from Gas Samples Collected from

153460

Hydrology Holes in Drift-Scale Test. Submittal date: 12/09/2000.

LB0012AIRKTEST.001. Niche 5 Air K Testing 3/23/00-4/3/00.

154586

Submittal date: $12 / 21 / 2000$.

LB002181233124.001. Air Permeability and Pneumatic Pressure Data Collected 146878 Between October 27, 1999 through November 7, 1999 from Niche 5 (ECRB Niche 1620) of the ESF. Submittal date: $02 / 18 / 2000$.

LB0102NICH5LIQ.001. Niche 5 Seepage Tests - Pre Excavation.

155681

Submittal date: $02 / 28 / 2001$.

LB0108CO2DST05.001. Concentration and Isotope Data for CO2 and H2O from Gas 156888 Samples Collected from Hydrology Holes in Drift-Scale Test - May and August 1999, April 2000, January and April 2001. Submittal date: 08/27/2001.

LB0110A8N3GPRB.001. Alcove 8/Niche 3 GPR Baseline Data. Submittal date:

156912 $11 / 12 / 2001$.

LB0110A8N3LIQR.001. Preliminary Observations from the Fault Test at 157001 Alcove8/Niche3. Submittal date: 11/12/2001.

LB0110AK23POST.001. AK2 and AK3 Post-Excavation Air-K. Submittal date: 156905 $11 / 12 / 2001$.

LB0110AKN5POST.001. Niche 5 (1620 in ECRB) Post-Excavation Air-K. Submittal 156904 date: $11 / 12 / 2001$.

LB0110BSTBTGPR.001. Busted Butte GPR Data. Submittal date: 11/12/2001.

LB0110COREPROP.001. Lab Measurements of 14 Matrix Cores.

Submittal date: $11 / 12 / 2001$.

LB0110ECRBH2OA.001. ECRB Water Analyses. Submittal date: 11/12/2001.

156886

LB0110ECRBH2OI.001. Isotope Data for Water Samples Collected from the ECRB.

156887

Submittal date: $11 / 12 / 2001$.

LB0110ECRBH2OP.001. Water Potential Data from Three Locations in the ECRB.

Submittal date: $11 / 12 / 2001$.

156883 
LB0110ECRBLIQR.001. Systematic Testing in ECRB-SYBT-LA\#1, 12/20/2000. 156878 Submittal date: $11 / 12 / 2001$.

LB0110ECRBLIQR.002. Systematic Testing in ECRB-SYBT-LA\#1, 2/28/2001.

156879

Submittal date: 11/12/2001.

LB0110ECRBLIQR.003. Systematic Testing in ECRB-SYBT-LA\#2, 10/23/2000.

156877

Submittal date: $11 / 12 / 2001$.

LB0110TUFTRACR.001. Using Laser Ablation to Study Tracer Movement in Tuff.

156979

Submittal date: $11 / 12 / 2001$.

LB0203ECRBLIQR.001. Systematic Testing in ECRB-SYBT-LA\#3(May-July 2001). 158462

Submittal date: 03/20/2002.

LB0204NICH3TRC.001. Fault Infiltration Test Tracer Sampling Apr 2001-Mar 2002. 158478 Submittal date: 04/30/2002.

LB0207NICH5LIQ.001. Niche 5 Seepage Tests (CD 1620). Submittal date: 07/09/2002.

LB0208NICH5LIQ.001. Niche 5 Seepage Tests (CD 1620), July-August 2002.

161210

Submittal date: 08/22/2002.

LB0209A8N3LIQR.001. Resistance Measurements from Borehole 10 in Niche3

165461

(5/23/2001 - 9/3/2002). Submittal date: 09/11/2002.

LB0209NICH5LIQ.001. Niche 5 Seepage Tests (CD 1620), June-August 2002.

Submittal date: 09/11/2002.

LB0210NICH5LIQ.001. Niche 5 Seepage Tests (CD 1620), August-October 2002.

161211

Submittal date: $10 / 25 / 2002$.

LB0211NICH5LIQ.001. Niche 5 Seepage Tests (CD 1620), August-October 2002.

160792

Submittal date: 11/14/2002.

LB0301ECRBRHTB.001. Moisture Monitoring at Four Locations in the ECRB.

164605

Submittal date: 01/31/2003.

LB0301SYTSTLA4.001. Systematic Testing in ECRB-SYBT-LA\#4. Submittal date:

165227

01/31/2003.

LB0302ALC8AIRK.001. Alcove 8 Air Permeability Testing. Submittal date:

164748 $02 / 28 / 2003$.

LB0303A8N3LIQR.001. Alcove 8 - Niche 3 Seepage Data Compilation. Submittal 162570 date: $03 / 19 / 2003$. 
LB0306A8N3LIQR.001. Fault Infiltration Test from Alcoves to Niche3

(9/18/2002 - 10/16/2002). Submittal date: 06/19/2003.

LB0307ECRBRHTB.001. Moisture Monitoring at Four Locations in the ECRB.

164843

Submittal date: 07/30/2003.

LB0308A8N3SEEP.001. Niche 3 Seepage (10/16/2002-04/02/2003). Submittal date:

166090 08/29/2003.

LB0406ESFNH2OP.001. Water Potential Measurements in Niches 3566, 3650, and 3107 of the ESF. Submittal date: 06/21/2004.

LB960800831224.001. Relative Humidity, Temperature, and Pressure in ESF

105793

Monitoring Stations. Submittal date: 08/23/1996.

LB970300831224.001. Moisture Data Report from October 1996 to January, 1997.

105794

Submittal date: 03/13/1997.

LB970801233124.001. Moisture Monitoring Data Collected at ESF Sensor Stations.

105796 Submittal date: 08/27/1997.

LB970901233124.002. Moisture Monitoring Data Collected at Stationary Moisture

105798 Stations. Submittal date: 09/30/1997.

LB980001233124.004. Liquid Release Test Data from Niche 3566 and Niche 3650 of 136583 the ESF in Milestone Report, "Drift Seepage Test and Niche Moisture Study: Phase 1 Report on Flux Threshold Determination, Air Permeability Distribution, and Water Potential Measurement. Submittal date: 11/23/1999.

LB980901233124.003. Liquid Release and Tracer Tests in Niches 3566, 3650, 3107, 105592 and 4788 in the ESF. Submittal date: 09/14/1998.

LB980901233124.004. Pneumatic Pressure and Air Permeability Data from Alcove 6 105855 in the ESF. Submittal date: 09/14/1998.

LB980901233124.009. Pneumatic Pressure and Air Permeability Data from Alcove 4 105856 in the ESF. Submittal date: 09/14/1998.

LB980901233124.014. Borehole Monitoring at the Single Borehole in the ECRB and 105858 ECRB Crossover Point in the ESF. Submittal date: 09/14/1998.

LB980901233124.101. Pneumatic Pressure and Air Permeability Data from Niche 136593 3107 and Niche 4788 in the ESF from Chapter 2 of Report SP33PBM4: Fracture Flow and Seepage Testing in the ESF, FY98. Submittal date: 11/23/1999.

LB980912332245.001. Air Injection Data from Niche 3107 of the ESF. Submittal 110828 date: 09/30/1998. 
LB980912332245.002. Gas Tracer Data from Niche 3107 of the ESF. Submittal date: 105593 09/30/1998.

LB990601233124.001. Seepage Data Feed to UZ Drift-Scale Flow Model for 105888 TSPA-SR. Submittal date: 06/18/1999.

LB990601233124.003. Seepage Data Feed to UZ Drift-Scale Flow Model for 106051 TSPA-SR. Submittal date: 06/18/1999.

LB990901233124.001. Alcove 6 Tracer Tests for AMR U0015, “In Situ Field Testing of Processes." Submittal date: 11/01/1999.

LB990901233124.002. Alcove 6 Flow Data for AMR U0015, "In Situ Field Testing of Processes". Submittal date: 11/01/1999.

LB990901233124.003. Tracer Lab Analyses of Dye Penetration in Niches 3650 and 155690 4788 of the ESF for AMR U0015, "In Situ Field Testing of Processes." Submittal date: 11/01/1999.

LB990901233124.004. Air Permeability Cross-Hole Connectivity in Alcove 6, Alcove 4, and Niche 4 of the ESF for AMR U0015, "In Situ Testing of Field Processes".

Submittal date: 11/01/1999.

LB990901233124.005. Alcove 4 Flow Data for AMR U0015, "In Situ Field Testing of Processes". Submittal date: 11/01/1999.

LB990901233124.006. Moisture Data from the ECRB Cross Drift for AMR U0015, "In Situ Testing of Field Processes". Submittal date: 11/01/1999.

LL030408023121.027. Cl Abundance and Cl Ratios of Leachates from ESF Core Samples. Submittal date: 04/17/2003.

LL031200223121.036. Cl Abundance and Cl Ratio of Leachates from ESF Core Samples. Submittal date: 12/03/2003.

LL990612704244.098. ERT Data for Busted Butte. Submittal date: 06/21/1999.

MO0004GSC00167.000. As-Built Coordinate of Boreholes in the Test Alcove and 150300 Running Drift, Busted Butte Test Facility (BBTF). Submittal date: 04/20/2000.

MO0006J13WTRCM.000. Recommended Mean Values of Major Constituents in J-13 151029 Well Water. Submittal date: 06/07/2000.

MO0008GSC00269.000. As-Built ECRB Alcove 8, Construction Observation Alcove 166198 (COA) - Boreholes (\#1 through 7). Submittal date: 08/01/2000.

MO0012MWDGFM02.002. Geologic Framework Model (GFM2000). Submittal date: 153777 $12 / 18 / 2000$. 
MO0107GSC01061.000. As-Built Profile of Bat-Wing Excavation, Niche \#5 ECRB. 155369 Submittal date: 07/03/2001.

MO0107GSC01069.000. ESF Niche \#4 (Niche 4788) Borehole As-Built Information. 156941 Submittal date: 07/19/2001.

MO0312GSC03176.000. ECRB - Niche \#5 (Niche 1620) Borehole As-Built Information. Submittal date: 12/01/2003.

MO0407SEPFEPLA.000. LA FOP List. Submittal date: 07/20/2004.

MO9901MWDGFM31.000. Geologic Framework Model. Submittal date: 01/06/1999.

\subsection{OUTPUT DATA, LISTED BY DATA TRACKING NUMBER}

LB0110LIQR0015.001. Developed Data for Liquid Release/Seepage Tests and Systematic Testing. Submittal date: 11/12/2001.

LB0110NICH4LIQ.001. Niche 4788 Ceiling - Wetting Front Data. Submittal date: $11 / 12 / 2001$.

LB0110SYST0015.001. Developed Data for Systematic Testing. Submittal date: 12/06/2001.

LB0310AIRK0015.001. Developed Data for Air-K Tests. Submittal date: 10/07/2003.

\subsection{SOFTWARE CODES}

CRWMS M\&O 1999. Software Routine: ECRB-XYZ. V.03. PC. 30093-V.03. 147402

LBNL (Lawrence Berkeley National Laboratory) 1998. Software Code:

152835

EARTHVISION. V4.0. SGI, IRIX 6.4. 30035-2 V4.0. 
APPENDIX A

AUTOMATED AIR-INJECTION SYSTEM 


\section{A1. AUTOMATIC PNEUMATIC INJECTION PACKERS}

The pneumatic-testing equipment is a specially designed packer system fabricated to consider specific testing needs. For site-to-site and borehole-to-borehole comparisons to be meaningful, it must be possible for many boreholes, at numerous sites, to be tested in a controlled manner. For determination of connectivity between boreholes, all permutations of injection and response zones at a site must be examined, so the boreholes must be instrumented for simultaneous measurements. In heterogeneous rock, such as that at the ESF, compensating for variations in results caused by different test configurations (such as test interval length or test scale) is difficult. Therefore, only one parameter (in this case, the location of the test zone) is varied at a time, to keep the testing as consistent as possible. To ensure that the air permeability of unaltered rock would be measured, boreholes were drilled dry and at low speed, a process that minimizes damage to the formation and thereby allows the packer systems to be placed along the entire length of each borehole.

In light of the need for consistency, the same packer design is used for injection and observation. This approach is amenable to the automation and remote control necessary for establishing consistent testing regimens, and accommodating the large number of tests. Inflatable rubber sealing bladders on a packer string can be manipulated independently, and divide a borehole into 14 different zones over the length of the string. Zone resolution is $0.3 \mathrm{~m}$, and the bladders cover the entire length of the string. This configuration allows $4.8 \mathrm{~m}$ of borehole to be covered by one string. One 3.2-mm-diameter port (for pressure measurement) and one 6.4-mm-diameter port (for air-injection service) is assigned to each zone. Up to seven boreholes can be instrumented at one time (for a discussion of borehole limitations, see Section 6.2). All packer inflation and air-injection lines can be controlled automatically. A modular design allows partial dismantling of the packer strings in the field, for repair or work in tight quarters. Figure A-1 shows a diagram of a portion of a packer assembly.

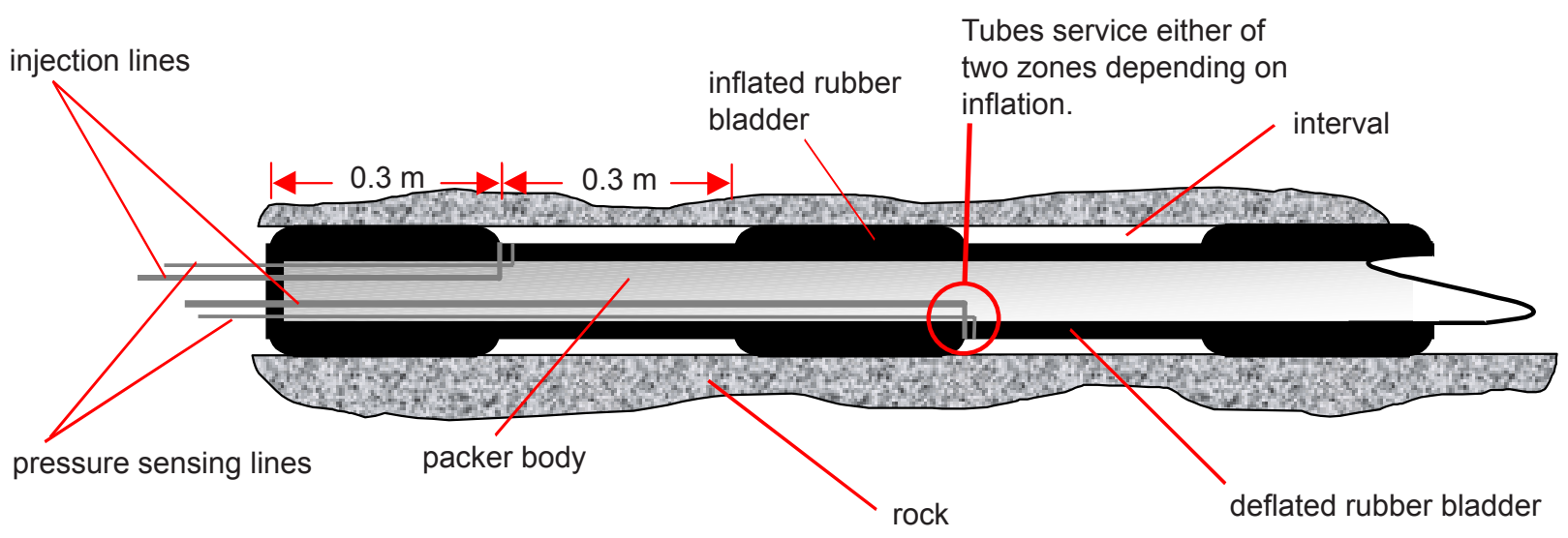

Figure A-1. Schematic of Automatic Packer Design

If all bladders are inflated at the same time, the packer string seals the entire section of borehole that is occupied by the string. However, by inflating only every other bladder (and leaving the remaining bladders deflated), an alternating sequence of open and closed (sealed) intervals is produced. Depending on the setting of the injection control valves, an open interval becomes either an observation zone used to monitor pressure, or an injection zone where air is introduced 
(under pressure) during a test. Once tests have been performed in these open zones, the inflated bladders are deflated and the deflated bladders are inflated (causing those zones that were once closed to become open and those that were originally open to become closed). In this manner, almost the entire length of the packer string is usable for testing every $0.3 \mathrm{~m}$, and does not require the string to be moved. By changing the zones on the injection packer independently from those on the observation packers, four possible zone configurations are available during a given packer installation. All permutations of these injection and observation positions are used to ensure that all positions within each observation borehole are allowed a chance to respond to a given injection zone. Figure A-2 shows schematically how this process is implemented. The observation packer zones are usually changed in unison because the amount of perturbation caused (to the flow field) by the observation-zone locations is considered insignificant. Permutations between them would cause only second-order effects in the response system.

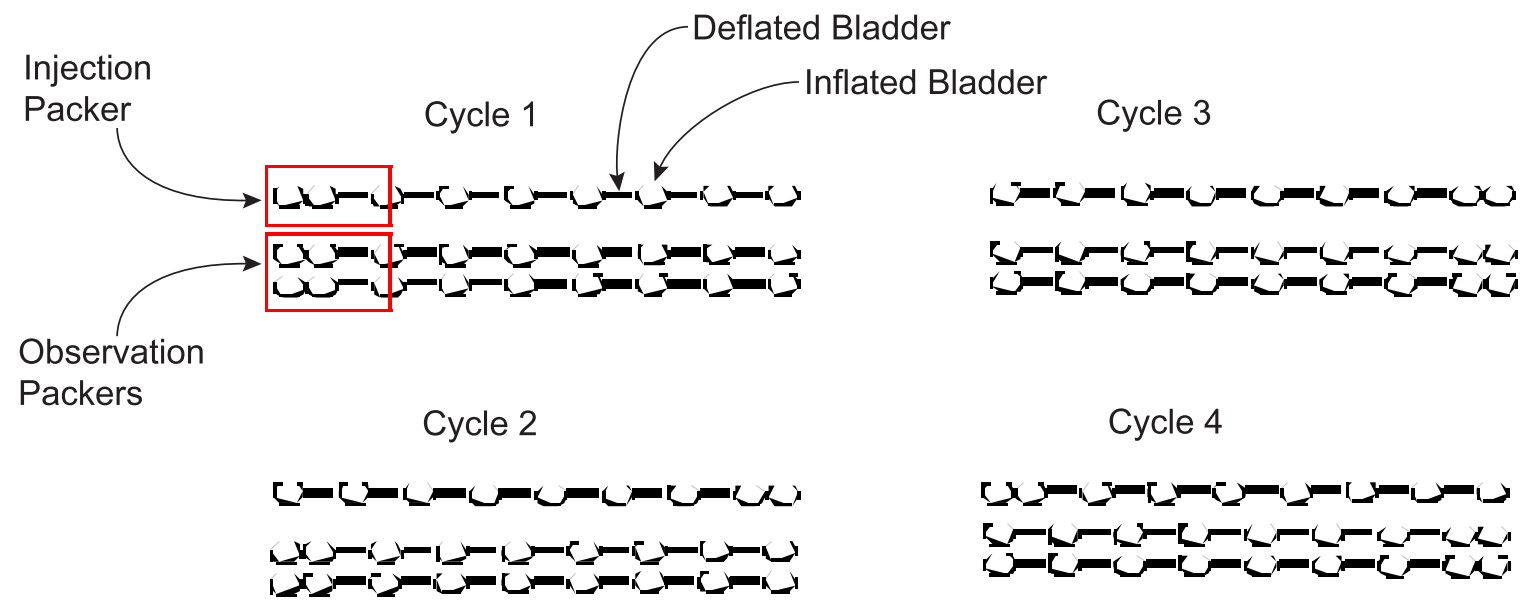

Figure A-2. Schematic of the Permutation Scheme for Automatic Packers

\section{A2. AIR-INJECTION FLOW INSTRUMENTATION}

Pressure monitoring for each zone was accomplished using pressure transducers that were accurate to a resolution of 0.3 kilopascals $(\mathrm{kPa})$. Mass flow controllers (MFCs) with voltage control and output were used to inject a constant mass-flow rate of air during each permeability test. The MFCs measure and control gas flow rates within a maximum error of 10 percent of full scale; four sizes of MFCs, ranging from 1 to 500 standard liters per minute (SLPM) full scale, were used, to span the anticipated flow-rate ranges. The pressure transducer and MFC outputs were continually monitored and digitally recorded throughout testing, using a 27-bit voltmeter and an computer. Time resolution for the data from all sources was set nominally at five seconds.

\section{A3. INITIAL SETUP IN TESTING REGIMEN}

Initially, by performing some manually operated tests for a given site, the operator determined under what conditions steady state was reached, and at what injection pressure packer leak-by could occur. (Leak-by is the condition of injected air forcing its way past the packer and breaking the packer-rock seal.) When leak-by occurs, a distinct and sudden pressure response occurs in the guard zone, as the packer seal with the borehole is broken. 
The information from these initial tests was used to plan the design of the automatic controls. The operator determined packer leak-by pressure by observing the pressure response in the observation zones axially adjacent to the injection zone. The packer inflation pressure was set at roughly $240 \mathrm{kPa}$ above the ambient pressure, to ensure adequate contact with the borehole without risk of damage to the rubber bladders. At this inflation, and depending on rock conditions, the leak-by pressure was usually approximately $138 \mathrm{kPa}$ above the ambient pressure, and the limit for any injection pressure was typically set to $80 \mathrm{kPa}$ above the ambient pressure.

\section{A4. AUTOMATION AND MULTI-RATE APPROACH}

Utilization of the automatic controls ensured that the tests would reach steady state, and be completed in minimal time. In addition, automation enabled testing to be continuous ( 24 hours per day). The automation scheme allotted a minimum time to every injection test. The allotted time was adequate to collect a sufficient number of data points to determine the slope of the injection pressure response. Steady state was defined in the automation routine as the condition that exists when the slope of pressure-change over time is less than a certain set point. If, after the minimum time, the criterion of steady state had not been met, the test was allowed to continue until it had been met. Pauses between tests provided time to monitor recovery pressure. Any excess pressure was bled off from all intervals for sufficient time, so that the residual pressure in the formation can reach ambient conditions before further testing is initiated.

The automation routine allowed multiple flow rates at each test interval, and also ensured that injection pressure did not exceed the packer leak-by pressure. The test would be shut off if the injection pressure came within approximately 60 percent of the packer leak-by pressure, and the data would automatically be annotated (to chronicle that steady state had not been attained). To save time, injections at higher rates were not attempted in a zone that was under this condition. Conversely, if pressure in an injection zone did not rise above a certain threshold value after a short time, testing at that particular flow rate was stopped, and a higher-flow-rate test was attempted. The multirate strategy ensured that, by using higher flow rates, highly permeable injection intervals would more be more likely to have sufficient pressure to generate a measurable response in the observation intervals. It also ensured that, by using low flow rates, the very tight intervals could be measured without the possible interference of packer leak-by.

Theoretically, for a given interval location, the same permeability value should result, regardless of the flow rate that is used. However, small differences in permeability might occur at different flow rates and between repeat tests, possibly as a result of movement of residual water within the fractures. In the case of water redistribution, as testing progresses, permeability will increase slightly for higher rates, as injection pressures overcome the capillary forces that hold the water in the formation. As the flow rate increases, a small decrease in apparent permeability can be observed in drier areas, because of turbulence at higher air injection rates.

Any large discrepancy between permeabilities at different flow rates, and any large discrepancy between repeat tests for a given zone, can be attributed to compromised packer sealing.

The maximum flow rate that did not cause the zone pressure to exceed the packer leak-by pressure during a test was chosen for single-hole permeability calculations, and was also used to detect crosshole responses. 


\section{INTENTIONALLY LEFT BLANK}




\section{APPENDIX B}

COMPUTATION TABLES FOR NICHE STUDIES 
Table B-1 presents aspect ratios on flow paths observed during niche excavation (which is referred to in Section 6.2.1.2). Table B-2 presents borehole-to-niche-ceiling distances for seepage tests (referred to in Section 6.2.1.3). Table B-3a through Table B-4e present liquid-release fluxes on seepage threshold determinations (referred to in Section 6.2.2.1). Table B-5 (on alpha values) is the computation summarized in Table 6-9. Table B-4 and Table B-6 are referred to in Figure 6-48 (on seepage threshold). Table B-7 and Table B-8 are referred to in Figure 6-49 and Figure 6-50 (on water retention curves).

Table B-1. Computation of Aspect Ratio (Depth to Lateral Distance)

\begin{tabular}{|c|c|c|c|c|c|c|}
\hline A & B & C & D & $\mathbf{E}$ & $\mathbf{F}$ & G \\
\hline $\begin{array}{c}\text { Observed Dye } \\
\text { Observed }\end{array}$ & $\begin{array}{c}\text { Injection } \\
\text { Borehole } \\
\text { Name }\end{array}$ & $\begin{array}{l}\text { Injection } \\
\text { Interval } \\
\text { (m) }\end{array}$ & $\begin{array}{c}\text { Mass } \\
\text { Injected } \\
(\mathrm{g})\end{array}$ & $\begin{array}{c}\text { (Input) } \\
\text { Maximum } \\
\text { Lateral } \\
\text { Distance } \\
\text { (m) }\end{array}$ & $\begin{array}{l}\text { (Input) } \\
\text { Maximum } \\
\text { Penetration } \\
\text { Depth } \\
\text { (m) }\end{array}$ & $\begin{array}{c}\text { (Output) } \\
\text { Ratio of } \\
\text { Depth to } \\
\text { Lateral } \\
\text { Distance }\end{array}$ \\
\hline \multicolumn{7}{|c|}{ Niche 1 (Niche 3566 in Tptpmn) } \\
\hline FD\&C Red No. 40 & M & $2.13-2.44$ & 941.7 & 0.73 & 1.52 & 2.08 \\
\hline Acid Yellow 7 & $\mathrm{M}$ & $2.77-3.05$ & 120.3 & 0.16 & 0.30 & 1.90 \\
\hline FD\&C Blue No. 1 & $\mathrm{M}$ & $4.57-4.88$ & 474.0 & 0.30 & 1.30 & 4.33 \\
\hline \multicolumn{7}{|c|}{ Niche 2 (Niche 3650 in Tptpmn) } \\
\hline FD\&C Red No. 40 & UL & $7.01-7.31$ & 694.5 & 0.99 & 1.42 & 1.43 \\
\hline FD\&C Blue No. 1 & UM & $4.27-4.57$ & 675.8 & 0.58 & 1.68 & 2.90 \\
\hline FD\&C Red No. 40 & UM & $4.88-5.18$ & 937.4 & 0.28 & 0.86 & 3.07 \\
\hline FD\&C Blue No. 1 & UM & $6.70-7.01$ & 438.7 & 1.05 & 1.82 & 1.74 \\
\hline FD\&C Red No. 40 & UR & $1.52-1.82$ & 369.9 & 0.76 & 1.41 & 1.86 \\
\hline FD\&C Blue No. 1 & UR & $2.13-2.43$ & 999.8 & 0.32 & 2.57 & 8.03 \\
\hline Sulpho Rhodamine B & ML & $4.88-5.18$ & 151.6 & 0.08 & 0.02 & 0.25 \\
\hline Sulpho Rhodamine B & ML & $6.70-7.01$ & 170.9 & 0.25 & 1.02 & 4.06 \\
\hline \multicolumn{7}{|c|}{ Niche 3 (Niche 3107 in Tptpmn) } \\
\hline Green & B1.5 & $3.35-3.66$ & 391.3 & 0.54 & 0.87 & 1.61 \\
\hline FD\&C Blue No. 1 & UM & $4.88-5.18$ & 111.7 & 0.27 & 1.19 & 4.41 \\
\hline \multicolumn{7}{|c|}{ Niche 4 (Niche 4788 in Tptpmn) } \\
\hline FD\&C Red No. 40 & UM & $4.27-4.57$ & 151.1 & 0.31 & 0.96 & 3.08 \\
\hline Green & UM & $4.88-5.18$ & 401.8 & 0.51 & 1.79 & 3.50 \\
\hline FD\&C Blue No. 1 & UM & $6.40-6.70$ & 1019.7 & 0.78 & 1.25 & 1.61 \\
\hline
\end{tabular}


Table B-1. Computation of Aspect Ratio (Depth to Lateral Distance) (Continued)

\begin{tabular}{|c|c|c|c|c|c|c|}
\hline A & B & C & D & $E$ & $\mathbf{F}$ & G \\
\hline $\begin{array}{c}\text { Observed Dye } \\
\text { Observed }\end{array}$ & $\begin{array}{c}\text { Injection } \\
\text { Borehole } \\
\text { Name } \\
\end{array}$ & $\begin{array}{l}\text { Injection } \\
\text { Interval } \\
(\mathrm{m})\end{array}$ & $\begin{array}{c}\text { Mass } \\
\text { Injected } \\
(\mathbf{g})\end{array}$ & $\begin{array}{c}\text { (Input) } \\
\text { Maximum } \\
\text { Lateral } \\
\text { Distance } \\
(\mathrm{m}) \\
\end{array}$ & $\begin{array}{l}\text { (Input) } \\
\text { Maximum } \\
\text { Penetration } \\
\text { Depth } \\
(\mathrm{m}) \\
\end{array}$ & $\begin{array}{c}\text { (Output) } \\
\text { Ratio of } \\
\text { Depth to } \\
\text { Lateral } \\
\text { Distance }\end{array}$ \\
\hline \multicolumn{7}{|c|}{ Niche 5 (Niche 1620 in Tptpll) } \\
\hline Green & $\# 1$ & $1.48-1.78$ & 1184.7 & 0.76 & 1.25 & 1.64 \\
\hline Rhodamine & $\# 1$ & $2.54-2.84$ & 1342.8 & 0.22 & 1.37 & 6.23 \\
\hline Green & $\# 1$ & $3.31-3.61$ & 804.7 & 0.21 & 0.28 & 1.33 \\
\hline Rhodamine & $\# 1$ & $4.54-4.84$ & 826.9 & 0.15 & 0.19 & 1.27 \\
\hline FD\&C Blue No. 1 & $\# 1$ & $5.44-5.74$ & 1001.8 & 0.33 & 0.18 & 0.55 \\
\hline Rhodamine & $\# 1$ & $6.54-6.84$ & 1041.3 & 0.16 & 0.07 & 0.44 \\
\hline FD\&C Blue No. 1 & $\# 1$ & $7.58-7.88$ & 1555.9 & 0.17 & 0.18 & 1.06 \\
\hline Rhodamine & $\# 1$ & $8.54-8.84$ & 1142.2 & 0.26 & 0.15 & 0.58 \\
\hline
\end{tabular}

Source: Columns A through E from DTN: LB980001233124.004 [DIRS 136583] for Niche 1 (Niche 3566) and Niche 2 (Niche 3650). A through E from DTN: LB980901233124.003 [DIRS 105592] for Niche 3 (Niche 3107) and Niche 4 (Niche 4788). A through E from DTN: LB0102NICH5LIQ.001 [DIRS 155681] for Niche 3 (Niche 3107) and Niche 4 (Niche 4788).

NOTES: D for Niche 5 (Niche 1620) are reported in $\mathrm{kg}$ and converted to $\mathrm{g}$ in table by multiplying by $1000 \mathrm{~g} / \mathrm{kg}$. $G=F / E$.

Avg. Tptpmn and Avg. Tptpll computed using Microsoft Excel 2000 arithmetic average (AVERAGE) function.

FD\&C = Federal Food, Drug, and Cosmetic Act; $\mathrm{M}=$ middle; $\mathrm{ML}=$ middle left; $\mathrm{UL}=$ upper left; $\mathrm{UM}=$ upper middle; UR = upper right. 
Table B-2. Computation of Distance from Borehole to Niche Ceiling at Niche 4 (Niche 4788) Based on Niche-Study Data

\begin{tabular}{|c|c|c|c|c|c|c|c|c|c|c|c|c|}
\hline A & B & C & D & $E$ & $\mathbf{F}$ & G & $\mathbf{H}$ & I & J & $\mathbf{K}$ & $\mathbf{L}$ & $\mathbf{M}$ \\
\hline Niche & $\begin{array}{l}\text { Borehole } \\
\text { Name and } \\
\text { Depth } \\
\text { (m) }\end{array}$ & \begin{tabular}{|c|} 
(Input) \\
Vertical \\
Distance \\
From \\
Horizontal \\
Scanline To \\
Borehole UM \\
Collar \\
(m)
\end{tabular} & $\begin{array}{c}\text { (Input) } \\
\text { Elevation } \\
\text { of } \\
\text { Borehole } \\
\text { UM at } \\
\text { Collar } \\
\text { (m) } \\
\end{array}$ & \begin{tabular}{|} 
(Input) \\
Elevation \\
of \\
Borehole \\
Collar \\
(m) \\
\end{tabular} & $\begin{array}{c}\text { (Output) } \\
\text { Difference } \\
\text { in } \\
\text { Elevation } \\
\text { between } \\
\text { Columns D } \\
\text { and E } \\
\text { (m) }\end{array}$ & $\begin{array}{l}\text { (Output) } \\
\text { Elevation of } \\
\text { Borehole } \\
\text { Collar above } \\
\text { Horizontal } \\
\text { Scanline } \\
\text { (m) }\end{array}$ & $\begin{array}{c}\text { (Input) } \\
\text { Borehole } \\
\text { Inclination } \\
\text { (minutes } \\
\text { component) }\end{array}$ & $\begin{array}{c}\text { (Input) } \\
\text { Borehole } \\
\text { Inclination } \\
\text { (seconds } \\
\text { component) }\end{array}$ & $\begin{array}{c}\text { (Output) } \\
\text { Borehole } \\
\text { Inclination } \\
\text { (radians) }\end{array}$ & $\begin{array}{c}\text { (Output) } \\
\text { Sine of } \\
\text { Borehole } \\
\text { Inclination }\end{array}$ & $\begin{array}{l}\text { (Output) } \\
\text { Cosine of } \\
\text { Borehole } \\
\text { Inclination }\end{array}$ & $\begin{array}{l}\text { (Input) } \\
\text { Local } \\
\text { Horizontal } \\
\text { Coordinate } \\
\text { for Borehole } \\
\text { Collar } \\
\text { (m) }\end{array}$ \\
\hline \multirow[t]{3}{*}{4} & $\begin{array}{c}\text { UL } 7.62- \\
7.93\end{array}$ & 1.505 & 1096.57 & 1096.58 & 0.01 & 1.515 & -41 & -13 & -0.0120 & -0.0120 & 0.9999 & 4.17 \\
\hline & $\begin{array}{c}\text { UM } 6.10- \\
6.40\end{array}$ & 1.505 & 1096.57 & 1096.57 & 0.00 & 1.505 & -41 & -23 & -0.0120 & -0.0120 & 0.9999 & 4.87 \\
\hline & $\begin{array}{c}\text { UR } 5.18- \\
5.48\end{array}$ & 1.505 & 1096.57 & 1096.57 & 0.00 & 1.505 & -10 & -26 & -0.0030 & -0.0030 & 1.0000 & 5.82 \\
\hline
\end{tabular}

Source: Columns D and E from survey data DTN: MO0107GSC01069.000 [DIRS 156941].

Columns $\mathrm{H}$ and I from survey data DTN: M00107GSC01069.000 [DIRS 156941].

Column M from survey data DTN: MO0107GSC01069.000 [DIRS 156941], local coordinate system see note for T and U.

NOTES: Column $\mathrm{C}$ is a horizontal scanline or datum measured along the centerline of the niche was used to relate known survey stations to the boreholes and a local coordinate system setup inside the niche. Nodes on a regular $0.6 \times 0.6 \mathrm{~m}$ grid were marked on the niche ceiling using the frame holding the seepage capture trays as the basis for the grid (see Trautz (2001 [DIRS 156903], p. 36) for details).

$\mathrm{F}=\mathrm{E}-\mathrm{D}$.

$\mathrm{G}=\mathrm{C}+\mathrm{F}$.

$\mathrm{K}=\sin (\mathrm{J})$.

$\mathrm{L}=\cos (\mathrm{J})$.

$J=(I / 360+H / 60) \times \pi / 360$. 
Table B-2. Computation of Distance from Borehole to Niche Ceiling at Niche 4 (Niche 4788) Based on Niche-Study Data (Continued)

\begin{tabular}{|c|c|c|c|c|c|c|c|c|c|c|c|c|}
\hline & $\mathbf{N}$ & 0 & $\mathbf{P}$ & $\mathbf{Q}$ & $\mathbf{R}$ & S & $\mathbf{T}$ & $\mathbf{U}$ & V & $\mathbf{W}$ & $x$ & $\mathbf{Y}$ \\
\hline Niche & $\begin{array}{c}\text { (Input) } \\
\text { Distance } \\
\text { along } \\
\text { Inclined } \\
\text { Borehole } \\
\text { from Collar } \\
\text { to Start of } \\
\text { Test Interval } \\
\text { (m) }\end{array}$ & $\begin{array}{c}\text { (Input) } \\
\text { Distance } \\
\text { along } \\
\text { Inclined } \\
\text { Borehole } \\
\text { from Collar } \\
\text { to End of } \\
\text { Test Interval } \\
\text { (m) }\end{array}$ & $\begin{array}{l}\text { (Output) } \\
\text { Distance } \\
\text { along } \\
\text { Inclined } \\
\text { Borehole } \\
\text { from } \\
\text { Collar to } \\
\text { Center of } \\
\text { Test } \\
\text { Interval } \\
\text { (m) }\end{array}$ & $\begin{array}{l}\text { (Output) } \\
\text { Vertical } \\
\text { Distance } \\
\text { from } \\
\text { Borehole } \\
\text { Collar to } \\
\text { Center of } \\
\text { Test } \\
\text { Interval } \\
\text { (m) }\end{array}$ & $\begin{array}{l}\text { (Output) } \\
\text { Vertical } \\
\text { Distance } \\
\text { from } \\
\text { Horizontal } \\
\text { Scanline to } \\
\text { Center of } \\
\text { Test } \\
\text { Interval } \\
\text { (m) }\end{array}$ & $\begin{array}{c}\text { (Output) } \\
\text { Local } \\
\text { Horizontal } \\
\text { Coordinate } \\
\text { for Center of } \\
\text { Test Interval } \\
\text { (m) }\end{array}$ & $\begin{array}{c}\text { (Input) } \\
\text { Local } \\
\text { Horizontal } \\
\text { Coordinate } \\
\text { for Start of } \\
\text { Capture } \\
\text { Node } \\
\text { (m) }\end{array}$ & $\begin{array}{l}\text { (Input) } \\
\text { Local } \\
\text { Horizontal } \\
\text { Coordinate } \\
\text { for End of } \\
\text { Capture } \\
\text { Node } \\
\text { (m) }\end{array}$ & $\begin{array}{c}\text { (Input) } \\
\text { Vertical } \\
\text { Distance } \\
\text { from } \\
\text { Horizontal } \\
\text { Scanline } \\
\text { to Ceiling } \\
\text { above } \\
\text { Start Node } \\
\text { (m) } \\
\end{array}$ & $\begin{array}{c}\text { (Input) } \\
\text { Vertical } \\
\text { Distance } \\
\text { from } \\
\text { Horizontal } \\
\text { Scanline } \\
\text { to Ceiling } \\
\text { above } \\
\text { End Node } \\
\text { (m) }\end{array}$ & $\begin{array}{l}\text { (Output) } \\
\text { Interpolated } \\
\text { Vertical } \\
\text { Distance from } \\
\text { Horizontal } \\
\text { Scanline to } \\
\text { the Ceiling } \\
\text { below the } \\
\text { Center of the } \\
\text { Test Interval } \\
(m)\end{array}$ & $\begin{array}{l}\text { (Output) } \\
\text { Distance } \\
\text { from } \\
\text { Borehole } \\
\text { Bottom to } \\
\text { Ceiling } \\
\text { (m) }\end{array}$ \\
\hline \multirow[b]{3}{*}{4} & 7.62 & 7.93 & 7.775 & -0.09 & 1.42 & 11.944 & 11.905 & 11.905 & 0.81 & 0.84 & 0.820 & 0.60 \\
\hline & 6.10 & 6.40 & 6.25 & -0.08 & 1.43 & 11.12 & 10.955 & 11.26 & 0.84 & 0.855 & 0.848 & 0.58 \\
\hline & 5.18 & 5.48 & 5.33 & -0.02 & 1.49 & 11.15 & 10.615 & 11.905 & 0.76 & 0.73 & 0.748 & 0.74 \\
\hline
\end{tabular}

Source: Columns N and O from DTN: LB0010NICH4LIQ.001 [DIRS 153145].

NOTES: $\quad P=N+(O-N) / 2$.

$Q=K \times P$.

$\mathrm{R}=\mathrm{G}+\mathrm{Q}$.

$S=M+(P \times L)$.

Columns T and U represent local coordinates. They are horizontal distances from the ESF centerline taken parallel to the niche axis to the starting node and ending node of the capture system, respectively, that bracket the center of the overlying test interval, $\mathrm{S}$. Note that the center of the interval lies between two nodes at the same horizontal coordinate, $11.905 \mathrm{~m}$, for UL 7.62 to 7.93 . Values from Scientific Notebook by Trautz (2001 [DIRS 156903 ], p. 36).

Columns $\mathrm{V}$ and $\mathrm{W}$ are the vertical distances from the horizontal scanline plane to the ceiling of the niche at the start and end node at the horizontal coordinate T and U, respectively. Values from Scientific Notebook by Trautz (2001 [DIRS 156903], pp. 36, 38, 40, 41).

Column $X$ is the interpolated distance to ceiling determined using $V$ and $W . X=V+(W-V) \times(S-T) /(U-T)$ except for UL 7.62 to 7.93 where $\mathrm{X}=\mathrm{V}+(\mathrm{W}-\mathrm{V}) \times(0.3-0.2) / 0.3$ and 0.3 is the distance between nodes $(2,12)$ and $(3,12)$.

$\mathrm{Y}=\mathrm{R}-\mathrm{X}$. 
Table B-3a. Computation of Liquid Release Flux for Post-Excavation Seepage Tests at Niche 3 (Niche 3107) Based on Niche-Study Data

\begin{tabular}{|c|c|c|c|c|c|c|c|}
\hline A & B & C & D & $\mathbf{E}$ & $\mathbf{F}$ & G & $\mathbf{H}$ \\
\hline $\begin{array}{c}\text { Borehole } \\
\text { Name }\end{array}$ & $\begin{array}{c}\text { Depth } \\
\text { (m) }\end{array}$ & Test Name & $\begin{array}{l}\text { (Input) } \\
\text { Liquid- } \\
\text { Release } \\
\text { Rate Qs } \\
\text { (kg/s) }\end{array}$ & $\begin{array}{c}\text { Seepage } \\
\text { Percentage } \\
\left(y^{\prime}\right)(\%)\end{array}$ & \begin{tabular}{|c|} 
Computed \\
Cross- \\
Sectional Area \\
A \\
$\left(\mathrm{m}^{2}\right)$ \\
\end{tabular} & $\begin{array}{c}\text { (Output) } \\
\text { Liquid- } \\
\text { Release Flux } \\
\left(q_{s}\right) \\
(\mathrm{m} / \mathrm{s}) \\
\end{array}$ & $\begin{array}{l}\text { (Output) } \\
\text { Liquid- } \\
\text { Release } \\
\text { Flux (qs) } \\
\text { (mm/yr) }\end{array}$ \\
\hline \multirow[t]{9}{*}{ UM } & \multirow{9}{*}{$\begin{array}{c}4.88- \\
5.18\end{array}$} & Test \#1 3/4/99 & 1.4266E-05 & 0 & 0.053 & 2.67E-07 & 8420 \\
\hline & & Test \#1 4/7/99 & $9.7304 \mathrm{E}-05$ & $\mathrm{~N} / \mathrm{A}$ & 0.053 & $1.82 \mathrm{E}-06$ & 57430 \\
\hline & & Test \#1 4-27-99 & 3.9897E-05 & 5.465 & 0.053 & 7.47E-07 & 23548 \\
\hline & & Test \#1 4-30-99 & 1.4113E-05 & 0 & 0.053 & 2.64E-07 & 8330 \\
\hline & & Test \#1 5/6/99 & 9.0739E-05 & 47.271 & 0.053 & 1.70E-06 & 53555 \\
\hline & & Test \#1 9-21-99 & 8.39647E-05 & 42.975 & 0.053 & $1.57 \mathrm{E}-06$ & 49557 \\
\hline & & Test \#1 9-23-99 & 8.7576E-05 & 46.08 & 0.053 & 1.64E-06 & 51689 \\
\hline & & Test \#1 9-27-99 & 9.0044E-05 & 59.5915 & 0.053 & 1.69E-06 & 53145 \\
\hline & & Test \#1 10-11-99 & $9.03981 \mathrm{E}-05$ & 70.0857 & 0.053 & 1.69E-06 & 53354 \\
\hline
\end{tabular}

Source: Columns A through E from DTN: LB0010NICH3LIQ.001 [DIRS 153144].

NOTES: Columns $\mathrm{F}$ through $\mathrm{H}$ computed in Microsoft Excel 2000 spreadsheet using formulae below:

$F=$ wetted area of borehole up to return port of packers $=[2 \pi-(2 \operatorname{Arccosine}(\mathrm{d} / \mathrm{r}))] \mathrm{hr}$,

where

$\mathrm{d}=$ nominal vertical distance from center of borehole to return port on packer system $=2.54 \mathrm{~cm}$.

$r=$ nominal radius of borehole $=3.81 \mathrm{~cm}=0.0381 \mathrm{~m}$.

$\mathrm{h}=$ nominal test interval length $=1$ foot $=0.3048 \mathrm{~m}$.

$\mathrm{G}=\mathrm{D} \times(1000 \mathrm{~g} / \mathrm{kg}) /\left(1000000 \mathrm{~g} / \mathrm{m}^{3} \times \mathrm{F}\right)=\mathrm{D} /(1000 \times \mathrm{F})$,

where

density of water is assumed to be equal to $1000000 \mathrm{~g} / \mathrm{m}^{3}$.

$\mathrm{H}=\mathrm{G} \times(1000 \mathrm{~mm} / \mathrm{m}) \times(86400 \mathrm{~s} /$ day $) \times(365$ days/year $)$.

$\mathrm{UM}=$ upper middle. 
Table B-3b. Computation of Liquid Release Flux for Post-Excavation Seepage Tests at Niche 4 (Niche 4788) Based on Niche-Study Data

\begin{tabular}{|c|c|c|c|c|c|c|c|}
\hline $\mathbf{A}$ & B & C & D & $\mathbf{E}$ & $\mathbf{F}$ & G & $\mathbf{H}$ \\
\hline $\begin{array}{c}\text { Borehole } \\
\text { Name }\end{array}$ & $\begin{array}{c}\text { Depth } \\
(\mathrm{m})\end{array}$ & Test Name & $\begin{array}{c}\text { (Input) } \\
\text { Liquid-release } \\
\text { Rate } \\
\left(Q_{\mathbf{s}}\right) \\
(\mathbf{k g} / \mathbf{s})\end{array}$ & $\begin{array}{c}\text { Seepage } \\
\text { Percentage } \\
\left(\mathbf{y}^{\prime}\right) \\
(\%) \\
\end{array}$ & $\begin{array}{c}\text { Computed } \\
\text { Cross-sectional } \\
\text { Area A } \\
\left(\mathrm{m}^{2}\right)\end{array}$ & $\begin{array}{c}\text { (Output) } \\
\text { Liquid-release } \\
\text { Flux } \\
\left(\mathrm{q}_{\mathrm{s}}\right) \\
(\mathrm{m} / \mathrm{s})\end{array}$ & $\begin{array}{c}\text { (Output) } \\
\text { Liquid-release } \\
\text { Flux } \\
\left(\mathrm{q}_{\mathrm{s}}\right) \\
(\mathrm{mm} / \mathrm{yr})\end{array}$ \\
\hline \multirow[t]{4}{*}{ UL } & \multirow[t]{4}{*}{$7.62-7.93$} & Test \#1 11/3/99 & 8.8095E-05 & 24.159 & 0.053 & 1.65E-06 & 51995 \\
\hline & & Test \#1 11-30-99 Niche 4788 & 4.9246E-05 & 17.964 & 0.053 & $9.22 \mathrm{E}-07$ & 29066 \\
\hline & & Test \#1 01-24-00 & 7.81146E-06 & 0.0 & 0.053 & $1.46 \mathrm{E}-07$ & 4610 \\
\hline & & Test \#1 6-26-2000 & 1.91662E-05 & 14.4488 & 0.053 & 3.59E-07 & 11312 \\
\hline \multirow[t]{6}{*}{ UM } & \multirow[t]{6}{*}{$6.10-6.40$} & Test \#1 Niche 4788 11/16/99 & 9.16384E-05 & 35.383 & 0.053 & $1.72 \mathrm{E}-06$ & 54086 \\
\hline & & Test \#1 Niche 4788 12-10-99 & 3.91451E-05 & 23.405 & 0.053 & 7.33E-07 & 23104 \\
\hline & & Test \#1 02-09-2000 & 8.819E-06 & 0.0 & 0.053 & $1.65 \mathrm{E}-07$ & 5205 \\
\hline & & Test \#1 3-10-2000 & $9.681 \mathrm{E}-06$ & 0.0 & 0.053 & $1.81 \mathrm{E}-07$ & 5714 \\
\hline & & Test \#1 3-14-2000 & 8.8479E-06 & 0.0 & 0.053 & $1.66 \mathrm{E}-07$ & 5222 \\
\hline & & Test \#1 06-08-2000 & 2.0489E-05 & 8.5381 & 0.053 & 3.83E-07 & 12093 \\
\hline \multirow[t]{3}{*}{ UR } & \multirow[t]{3}{*}{$5.18-5.48$} & Test \#1 Niche 4788 12/7/99 & $9.00855 E-05$ & 68.6623 & 0.053 & 1.69E-06 & 53170 \\
\hline & & Test \#1 1/5/2000 & 3.79689E-05 & 56.4895 & 0.053 & 7.11E-07 & 22410 \\
\hline & & Test \#1 02-14-2000 & 8.80016E-06 & 11.092 & 0.053 & 1.65E-07 & 5194 \\
\hline
\end{tabular}

Source: A through E from DTN: LB0010NICH4LIQ.001 [DIRS 153145].

NOTES: $\mathrm{F}$ through $\mathrm{H}$ computed in Excel 2000 spreadsheet using formulae below:

$F=$ wetted area of borehole up to return port of packers $=[2 \pi-(2 \operatorname{Arccosine}(\mathrm{d} / \mathrm{r}))] \mathrm{hr}$ where:

$\mathrm{d}=$ nominal vertical distance from center of borehole to return port on packer system $=2.54 \mathrm{~cm}$

$r=$ nominal radius of borehole $=3.81 \mathrm{~cm}=0.0381 \mathrm{~m}$.

$\mathrm{h}=$ nominal test interval length $=1 \mathrm{foot}=0.3048 \mathrm{~m}$.

$\mathrm{G}=\mathrm{D} \times(1000 \mathrm{~g} / \mathrm{kg}) /\left(1000000 \mathrm{~g} / \mathrm{m}^{3} \times \mathrm{F}\right)=\mathrm{D} /(1000 \times \mathrm{F})$, where density of water is assumed $=1000000 \mathrm{~g} / \mathrm{m}^{3}$.

$\mathrm{H}=\mathrm{G} \times(1000 \mathrm{~mm} / \mathrm{m}) \times(86400 \mathrm{~s} /$ day $) \times(365$ days/year $)$.

$\mathrm{UL}=$ upper left; $\mathrm{UM}=$ upper middle; UR = upper right. 
Table B-4. Summary of Regression Equations and Computation of Seepage Threshold Fluxes $\left(\mathrm{K}_{0}^{*}\right)$ and Saturated Hydraulic Conductivities $\left(\mathrm{K}_{\mathrm{l}}\right)$ Based on Niche-Study Data

\begin{tabular}{|c|c|c|c|c|c|c|c|c|c|c|}
\hline A & B & C & D & $\mathbf{E}$ & $\mathbf{F}$ & G & $\mathbf{H}$ & I & $\mathbf{J}$ & $\mathbf{K}$ \\
\hline Niche & $\begin{array}{c}\text { Borehole } \\
\text { Name and } \\
\text { Depth } \\
(\mathrm{m})\end{array}$ & $\begin{array}{c}\text { Output Linear Regression } \\
\text { Equation }\end{array}$ & $\begin{array}{c}\text { (Input) } \\
\text { Data } \\
\text { Points } \\
\end{array}$ & $\begin{array}{c}\text { (Output) } \\
\text { Correlation } \\
\text { Coefficient } \\
\left(\mathbf{R}^{2}\right) \\
\end{array}$ & $\begin{array}{l}\text { (Input) } \\
\text { Slope }\end{array}$ & $\begin{array}{c}\text { (Input) } \\
\text { Intercep } \\
t\end{array}$ & \begin{tabular}{|} 
(Output/Input) \\
Seepage \\
Threshold \\
Flux \\
$\left(\mathrm{K}_{\circ}^{*}\right)$ \\
$(\mathrm{m} / \mathrm{s})$ \\
\end{tabular} & $\begin{array}{c}\text { (Output) } \\
\text { Seepage } \\
\text { Threshold } \\
\text { Flux } \\
\left(\mathrm{K}_{\circ}^{*}\right) \\
(\mathrm{mm} / \mathrm{yr}) \\
\end{array}$ & $\begin{array}{c}\text { (Input) } \\
\text { Air } \\
\text { Permeability } \\
(\mathbf{k}) \\
\left(\mathrm{m}^{2}\right) \\
\end{array}$ & $\begin{array}{c}\text { (Output) } \\
\text { Saturated } \\
\text { Hydraulic } \\
\text { Conductivity } \\
\left(\mathrm{K}_{\mathrm{I}}\right) \\
(\mathrm{m} / \mathrm{s}) \\
\end{array}$ \\
\hline \multirow[t]{10}{*}{2} & UL 7.01-7.32 & $y=0.6833 \operatorname{Ln}\left(K_{\circ}\right)+8.5742$ & 2 & NR & $\mathrm{NC}$ & NC & $3.55 \mathrm{E}-06$ & $1.12 \mathrm{E}+05$ & $\mathrm{NC}$ & 8.98E-05 \\
\hline & UL 7.62-7.92 & $y=5.7394 \operatorname{Ln}\left(K_{o}\right)+92.627$ & 3 & 0.979 & $\mathrm{NC}$ & $\mathrm{NC}$ & 9.80E-08 & $3.09 \mathrm{E}+03$ & $\mathrm{NC}$ & $1.51 \mathrm{E}-04$ \\
\hline & UM 4.27-4.57 & $y=5.2757 \operatorname{Ln}\left(K_{0}\right)+79.443$ & 4 & 0.921 & $\mathrm{NC}$ & $\mathrm{NC}$ & 2.89E-07 & $9.11 \mathrm{E}+03$ & $\mathrm{NC}$ & 2.62E-05 \\
\hline & UM 4.88-5.18 & $y=2.304 \operatorname{Ln}\left(K_{o}\right)+31.767$ & 3 & 0.975 & $\mathrm{NC}$ & $\mathrm{NC}$ & 1.03E-06 & $3.25 \mathrm{E}+04$ & $\mathrm{NC}$ & $2.52 \mathrm{E}-03$ \\
\hline & UM 5.49-5.79 & $y=5.8876 \operatorname{Ln}\left(K_{0}\right)+87.528$ & 4 & 0.963 & $\mathrm{NC}$ & $\mathrm{NC}$ & $3.50 \mathrm{E}-07$ & $1.10 \mathrm{E}+04$ & $\mathrm{NC}$ & $2.16 \mathrm{E}-05$ \\
\hline & UR 4.27-4.57 & $y=0.314 \operatorname{Ln}\left(K_{0}\right)+4.3283$ & 2 & NR & $\mathrm{NC}$ & $\mathrm{NC}$ & 1.03E-06 & $3.25 \mathrm{E}+04$ & $\mathrm{NC}$ & 4.08E-05 \\
\hline & UR 4.88-5.18 & $y=0.3165 \operatorname{Ln}\left(K_{o}\right)+4.3751$ & 2 & NR & $\mathrm{NC}$ & $\mathrm{NC}$ & 9.92E-07 & $3.13 \mathrm{E}+04$ & $\mathrm{NC}$ & 9.87E-05 \\
\hline & UR 5.49-5.79 & $y=28.419 \operatorname{Ln}\left(K_{0}\right)+351.09$ & 2 & NR & $\mathrm{NC}$ & $\mathrm{NC}$ & 4.31E-06 & $1.36 \mathrm{E}+05$ & $\mathrm{NC}$ & 1.71E-05 \\
\hline & UR $6.10-6.40$ & $y=4.2169 \operatorname{Ln}\left(K_{0}\right)+79.596$ & 2 & NR & $\mathrm{NC}$ & $\mathrm{NC}$ & 6.35E-09 & $2.00 \mathrm{E}+02$ & $\mathrm{NC}$ & 3.01E-05 \\
\hline & UR 6.71-7.01 & $y=10.574 \operatorname{Ln}\left(K_{\circ}\right)+165.28$ & 3 & 0.974 & $\mathrm{NC}$ & $\mathrm{NC}$ & 1.63E-07 & $5.14 \mathrm{E}+03$ & $\mathrm{NC}$ & $2.28 \mathrm{E}-04$ \\
\hline 3 & UM 4.88-5.18 & $\mathrm{y}=30.440 \mathrm{Ln}\left(\mathrm{K}_{\mathrm{o}}\right)+456.085$ & 8 & 0.820 & 30.440 & 456.085 & $3.11 \mathrm{E}-07$ & $9.81 \mathrm{E}+03$ & NA & NA \\
\hline \multirow[t]{3}{*}{4} & UL 7.62-7.93 & $y=9.273 \operatorname{Ln}\left(K_{0}\right)+148.119$ & 4 & 0.929 & 9.273 & 148.119 & 1.16E-07 & $3.65 \mathrm{E}+03$ & $2.51 \mathrm{E}-12$ & $2.46 \mathrm{E}-05$ \\
\hline & UM 6.10-6.40 & $\mathrm{y}=15.697 \mathrm{Ln}\left(\mathrm{K}_{\mathrm{o}}\right)+243.611$ & 4 & 0.980 & 15.697 & 243.611 & $1.82 \mathrm{E}-07$ & $5.74 \mathrm{E}+03$ & $2.50 \mathrm{E}-11$ & $2.45 \mathrm{E}-04$ \\
\hline & UR 5.18-5.48 & $y=25.415 \operatorname{Ln}\left(K_{o}\right)+410.285$ & 3 & 0.970 & 25.415 & 410.285 & 9.75E-08 & $3.07 \mathrm{E}+03$ & $4.00 \mathrm{E}-13$ & 3.92E-06 \\
\hline
\end{tabular}

Source: $\quad$ Column C for Niche 2 (Niche 3650) from DTN LB980001233124.004 [DIRS 136583]; Column E for Niche 2 (Niche 3650) from

DTN: LB980001233124.004 [DIRS 136583]. Column H for Niche 2 (Niche 3650) from DTN: LB980901233124.003 [DIRS 105592]; Column J for Niche 3

(Niche 3107) and Niche 4 (Niche 4788) from DTN LB990601233124.001 [DIRS 105888]; Column K for Niche 2 (Niche 3650 ) from DTN: LB980901233124.003 [DIRS 105592].

NOTES: Column C for Niche 3 (Niche 3107) and Niche 4 (Niche 4788) computed using equations below using Microsoft Excel 2000 built-in Regression Analysis Tool pack (see Tables B-4b to B-4e). $y=$ predicted seepage percentage (\%). Derived from measured seepage percentages $\left(y^{\prime}\right)$ in Table B-4a (E). $\mathrm{K}_{\mathrm{o}}=$ net downward liquid-release flux $(\mathrm{m} / \mathrm{s})$ from regression model. Derived from computed liquid-release fluxes (In[q $\left.\mathrm{q}_{\mathrm{s}}\right]$ ) in Table $\mathrm{B}-4 \mathrm{a}(\mathrm{G})$.

$\mathrm{D}=$ number of data points used in linear regression.

E for Niche 3 (Niche 3107) and Niche 4 (Niche 4788) = correlation coefficient from Microsoft Excel 2000 built-in Regression Analysis Tool pack (see Tables B-4b to B 4e)

$\mathrm{F}=$ slope of regression line $\mathrm{C}$.

$\mathrm{G}=$ intercept of regression line $\mathrm{C}$.

$\mathrm{H}$ for Niche 3 (Niche 3107 ) and Niche 4 (Niche 4788) are computed by setting $y=0$ in $C$ and solving $K_{0}(0)=K_{0}{ }^{*}=\exp (-G / F)$.

$\mathrm{I}=\mathrm{H} \times 1000 \mathrm{~mm} / \mathrm{m} \times 86400 \mathrm{~s} /$ day $\times 365$ days/year for all the niches.

$\mathrm{K}=\mathrm{J} \times\left(100 \times 100 \mathrm{~cm}^{2} / \mathrm{m}^{2}\right) \times 980 \mathrm{~m} / \mathrm{s} / \mathrm{cm}^{2}$; the conversion factor 980 is from Freeze and Cherry (1979 [DIRS 101173]).

$\mathrm{NA}=$ Not available. The test could not be completed as planned because of rock properties outside the measurable range of the equipment

$N R=$ Not reported because two data points result in perfect correlation $\left(R^{2}=1.0\right)$, therefore, correlation coefficient is meaningless

$\mathrm{NC}=$ Intermediate computations not performed for Niche 2 (Niche 3650) because they were performed in earlier technical products using the same formulae and methods. Output shown in Table for Niche 2 (Niche 3650) was obtained directly from TDMS except where noted. 
Table B-4a. Data Used in Linear Regression Analysis (y' vs. In $\mathrm{q}_{\mathrm{s}}$ )

\begin{tabular}{|c|c|c|c|c|c|c|}
\hline A & B & C & D & $\mathbf{E}$ & $\mathbf{F}$ & G \\
\hline Niche & \begin{tabular}{|c|c}
$\begin{array}{c}\text { Borehole } \\
\text { Name }\end{array}$ \\
\end{tabular} & $\begin{array}{c}\text { Depth } \\
(\mathrm{m})\end{array}$ & Test Name & $\begin{array}{c}\text { (Input) } \\
\text { Seepage } \\
\text { Percentages } \\
\left(y^{\prime}\right) \\
(\%) \\
\end{array}$ & $\begin{array}{c}\text { (Input) } \\
\text { Liquid-Release } \\
\text { Flux } \\
\left(q_{s}\right) \\
(\mathrm{m} / \mathrm{s}) \\
\end{array}$ & $\begin{array}{c}\text { (Output) } \\
\text { Natural Log of } \\
\text { Liquid-Release } \\
\text { Flux } \\
\left(\ln \left(q_{s}\right)\right)\end{array}$ \\
\hline \multirow[t]{8}{*}{3} & \multirow[t]{8}{*}{ UM } & \multirow[t]{8}{*}{$4.88-5.18$} & Test \#1 3/4/99 & 0.0 & 2.67E-07 & -15.136 \\
\hline & & & Test \#1 4-27-99 & 5.5 & 7.47E-07 & -14.108 \\
\hline & & & Test \#1 4-30-99 & 0.0 & 2.64E-07 & -15.147 \\
\hline & & & Test \#1 5/6/99 & 47.3 & 1.70E-06 & -13.286 \\
\hline & & & Test \#1 9-21-99 & 43.0 & 1.57E-06 & -13.364 \\
\hline & & & Test \#1 9-23-99 & 46.1 & 1.64E-06 & -13.321 \\
\hline & & & Test \#1 9-27-99 & 59.6 & 1.69E-06 & -13.294 \\
\hline & & & Test \#1 10-11-99 & 70.1 & 1.69E-06 & -13.290 \\
\hline \multirow[t]{11}{*}{4} & \multirow[t]{4}{*}{ UL } & \multirow[t]{4}{*}{ 7.62-7.93 } & Test \#1 11/3/99 & 24.2 & 1.65E-06 & -13.315 \\
\hline & & & Test \#1 11-30-99 Niche 4788 & 18.0 & $9.22 \mathrm{E}-07$ & -13.897 \\
\hline & & & Test \#1 01-24-00 & 0.0 & $1.46 \mathrm{E}-07$ & -15.738 \\
\hline & & & Test \#1 6-26-2000 & 14.4 & 3.59E-07 & -14.841 \\
\hline & \multirow[t]{4}{*}{ UM } & \multirow[t]{4}{*}{$6.10-6.40$} & Test \#1 Niche 4788 11/16/99 & 35.4 & $1.72 \mathrm{E}-06$ & -13.276 \\
\hline & & & Test \#1 Niche 4788 12-10-99 & 23.4 & 7.33E-07 & -14.127 \\
\hline & & & Test \#1 3-14-2000 & 0.0 & 1.66E-07 & -15.614 \\
\hline & & & Test \#1 06-08-2000 & 8.5 & 3.83E-07 & -14.774 \\
\hline & \multirow[t]{3}{*}{ UR } & \multirow[t]{3}{*}{ 5.18-5.48 } & Test \#1 Niche 4788 12/7/99 & 68.7 & 1.69E-06 & -13.293 \\
\hline & & & Test \#1 1/5/2000 & 56.5 & 7.11E-07 & -14.157 \\
\hline & & & Test \#1 02-14-2000 & 11.1 & $1.65 \mathrm{E}-07$ & -15.619 \\
\hline
\end{tabular}

Source: Columns A through F from Table B-3a and Table B-3b.

NOTE: $G=\ln (F)$ 
Table B-4b. Linear Regression Summary (Output) for Niche 3 (Niche 3107) UM 4.88-5.18

\begin{tabular}{|c|c|c|c|c|c|c|c|c|}
\hline ANOVA & $d f$ & ss & MS & $F$ & Significance $F$ & & & \\
\hline Regression & 1 & 4500.737 & 4500.737 & 27.411 & 0.002 & & & \\
\hline Residual & 6 & 985.173 & 164.195 & & & & & \\
\hline Total & 7 & 5485.910 & & & & & & \\
\hline & Coefficients & Standard Error & $t$ Stat & P-value & Lower $95 \%$ & Upper 95\% & Lower $95.0 \%$ & Upper $95.0 \%$ \\
\hline $\begin{array}{l}y \text {-intercept of linear } \\
\text { regression equation }\end{array}$ & 456.085 & 80.759 & 5.647 & 0.001 & 258.474 & 653.695 & 258.474 & 653.695 \\
\hline $\begin{array}{l}\text { slope of linear regression } \\
\text { equation }\end{array}$ & 30.440 & 5.814 & 5.236 & 0.002 & 16.214 & 44.667 & 16.214 & 44.667 \\
\hline
\end{tabular}

All output shown in this table was obtained using Microsoft Excel 2000 built-in Tools/Data analysis/Regression package.

Data used in regression analysis are from Table B-4a, where the " $y$ " data are the input seepage percentiles, and the " $x$ " data are the $\ln \left(\mathrm{q}_{\mathrm{s}}\right)$

Regression Statistics: $\mathrm{R}$ Square $=0.820 ;$ Number of Observations $=8$.

Table B-4c. Linear Regression Summary (Output) for Niche 4 (Niche 4788) UL 7.62-7.93

\begin{tabular}{|c|c|c|c|c|c|c|c|c|}
\hline ANOVA & $d f$ & ss & MS & $F$ & Significance $F$ & & & \\
\hline Regression & 1 & 292.815 & 292.815 & 26.353 & 0.036 & & & \\
\hline Residual & 2 & 22.223 & 11.111 & & & & & \\
\hline Total & 3 & 315.038 & & & & & & \\
\hline & Coefficients & Standard Error & $t$ Stat & $P$-value & Lower 95\% & Upper 95\% & Lower $95.0 \%$ & Upper $95.0 \%$ \\
\hline $\begin{array}{l}\text { y-intercept of linear } \\
\text { regression equation }\end{array}$ & 148.119 & 26.152 & 5.664 & 0.030 & 35.597 & 260.640 & 35.597 & 260.640 \\
\hline $\begin{array}{l}\text { Slope of linear } \\
\text { regression equation }\end{array}$ & 9.273 & 1.806 & 5.133 & 0.036 & 1.501 & 17.045 & 1.501 & 17.045 \\
\hline
\end{tabular}

NOTES: All output shown in this table was obtained using Microsoft Excel 2000 built-in Tools/Data analysis/Regression package.

Data used in regression analysis are from Table B-4a, where the " $y$ " data are the input seepage percentiles, and the " $x$ " are the $\ln \left(q_{s}\right)$

Regression Statistics: $\mathrm{R}$ Square $=0.929 ;$ Number of Observations $=4$. 
Table B-4d. Linear Regression Summary (Output) for Niche 4 (Niche 4788) UM 6.10-6.40

\begin{tabular}{|c|c|c|c|c|c|c|c|c|}
\hline ANOVA & $d f$ & ss & MS & $F$ & Significance $F$ & & & \\
\hline Regression & 1 & 724.849 & 724.849 & 99.295 & 0.010 & & & \\
\hline Residual & 2 & 14.600 & 7.300 & & & & & \\
\hline \multirow[t]{2}{*}{ Total } & 3 & 739.449 & & & & & & \\
\hline & Coefficients & Standard Error & $t$ Stat & P-value & Lower $95 \%$ & Upper 95\% & Lower $95.0 \%$ & Upper $95.0 \%$ \\
\hline $\begin{array}{l}y \text {-intercept of linear } \\
\text { regression equation }\end{array}$ & 243.611 & 22.798 & 10.685 & 0.009 & 145.517 & 341.704 & 145.517 & 341.704 \\
\hline $\begin{array}{l}\text { Slope of linear } \\
\text { regression equation }\end{array}$ & 15.697 & 1.575 & 9.965 & 0.010 & 8.919 & 22.474 & 8.919 & 22.474 \\
\hline
\end{tabular}

regression equation

NOTES: All output shown in this table was obtained using Microsoft Excel 2000 built-in Tools/Data analysis/Regression package.

Data used in regression analysis are from Table B-4a, where the " $y$ " data are the input seepage percentiles, and the " $x$ " data are the In( $\left.q_{s}\right)$.

Regression Statistics: R Square $=0.980$; Number of Observations $=4$.

Table B-4e. Linear Regression Summary (Output) for Niche 4 (Niche 4788) UR 5.18-5.48

\begin{tabular}{|c|c|c|c|c|c|c|c|c|}
\hline ANOVA & $d f$ & ss & MS & $\boldsymbol{F}$ & Significance $\boldsymbol{F}$ & & & \\
\hline Regression & 1 & 1785.798 & 1785.798 & 32.263 & 0.111 & & & \\
\hline Residual & 1 & 55.352 & 55.352 & & & & & \\
\hline \multirow[t]{2}{*}{ Total } & 2 & 1841.150 & & & & & & \\
\hline & Coefficients & Standard Error & $t$ Stat & $P$-value & Lower $95 \%$ & Upper 95\% & Lower $95.0 \%$ & Upper $95.0 \%$ \\
\hline $\begin{array}{l}y \text {-intercept of linear } \\
\text { regression equation }\end{array}$ & 410.285 & 64.381 & 6.373 & 0.099 & -407.747 & 1228.317 & -407.747 & 1228.317 \\
\hline $\begin{array}{l}\text { Slope of linear } \\
\text { regression equation }\end{array}$ & 25.415 & 4.474 & 5.680 & 0.111 & -31.438 & 82.268 & -31.438 & 82.268 \\
\hline
\end{tabular}

NOTES: All output shown in this table was obtained using Microsoft Excel 2000 built-in Tools/Data analysis/Regression package.

Data used in regression analysis are from Table B-4a, where the " $y$ " data are the input seepage percentiles, and the " $x$ " data are the In( $\left.q_{s}\right)$.

Regression Statistics: R Square $=0.970$; Number of Observations $=3$. 
Table B-5. Computation of $\alpha$-Values Based on Niche-Study Data

\begin{tabular}{|c|c|c|c|c|c|c|c|c|}
\hline A & B & C & D & E & $\mathbf{F}$ & G & H & $\mathbf{I}$ \\
\hline Niche & $\begin{array}{c}\text { Borehole } \\
\text { Name and } \\
\text { Depth } \\
(\mathrm{m})\end{array}$ & $\begin{array}{c}\text { (Input) } \\
\text { Seepage } \\
\text { Threshold } \\
\text { Flux } \\
\left(\mathrm{K}_{0}^{*}\right) \\
(\mathrm{m} / \mathrm{s}) \\
\end{array}$ & \begin{tabular}{|c|} 
(Input) \\
Saturated \\
Hydraulic \\
conductivity \\
$\left(\mathrm{K}_{\mathbf{l}}\right)$ \\
$(\mathrm{m} / \mathrm{s})$ \\
\end{tabular} & \begin{tabular}{|c} 
(Intermediate \\
Output) \\
(Kot / K $\left.\mathbf{K}_{\mathbf{l}}\right)$ \\
(dimensionless) \\
\end{tabular} & $\begin{array}{c}\text { (Intermediate } \\
\text { Output) } \\
\text { Inverse of } \\
\text { Dimensionless } \\
\text { Potentials } \\
\left(\left[\vartheta_{\max }(\mathbf{s})\right]^{-1}\right) \\
\end{array}$ & $\begin{array}{c}\text { (Output) } \\
\text { Sorptive } \\
\text { Number } \\
(\alpha) \\
\left(\mathrm{m}^{-1}\right) \\
\end{array}$ & $\begin{array}{l}\text { (Output) } \\
\text { Capillary } \\
\text { Strength } \\
\left(\alpha^{-1}\right) \\
(\mathrm{m}) \\
\end{array}$ & $\begin{array}{c}\text { (Output) } \\
\text { Error } \\
(\%)\end{array}$ \\
\hline \multirow[t]{10}{*}{2} & UL 7.01-7.32 & 3.55E-06 & 8.98E-05 & $\mathrm{NC}$ & $\mathrm{NC}$ & 11.7 & 0.0855 & $\mathrm{NC}$ \\
\hline & UL 7.62-7.92 & $9.80 \mathrm{E}-08$ & $1.51 \mathrm{E}-04$ & $\mathrm{NC}$ & $\mathrm{NC}$ & 771.9 & 0.0013 & $\mathrm{NC}$ \\
\hline & UM 4.27-4.57 & $2.89 \mathrm{E}-07$ & 2.62E-05 & $\mathrm{NC}$ & $\mathrm{NC}$ & 44.4 & 0.0225 & $\mathrm{NC}$ \\
\hline & UM 4.88-5.18 & 1.03E-06 & 2.52E-03 & $\mathrm{NC}$ & $\mathrm{NC}$ & 1225.5 & 0.0008 & $\mathrm{NC}$ \\
\hline & UM 5.49-5.79 & 3.50E-07 & 2.16E-05 & $\mathrm{NC}$ & $\mathrm{NC}$ & 29.9 & 0.0334 & $\mathrm{NC}$ \\
\hline & UR 4.27-4.57 & 1.03E-06 & 4.08E-05 & $\mathrm{NC}$ & $\mathrm{NC}$ & 18.8 & 0.0532 & $\mathrm{NC}$ \\
\hline & UR 4.88-5.18 & 9.92E-07 & 9.87E-05 & $\mathrm{NC}$ & $\mathrm{NC}$ & 48.8 & 0.0205 & $\mathrm{NC}$ \\
\hline & UR 5.49-5.79 & 4.31E-06 & $1.71 \mathrm{E}-05$ & $\mathrm{NC}$ & $\mathrm{NC}$ & 1.4 & 0.71 & $\mathrm{NC}$ \\
\hline & UR $6.10-6.40$ & $6.35 \mathrm{E}-09$ & 3.01E-05 & $\mathrm{NC}$ & $\mathrm{NC}$ & 2373.7 & 0.0004 & $\mathrm{NC}$ \\
\hline & UR 6.71-7.01 & $1.63 \mathrm{E}-07$ & $2.28 \mathrm{E}-04$ & $\mathrm{NC}$ & $\mathrm{NC}$ & 699.2 & 0.0014 & $\mathrm{NC}$ \\
\hline \multirow[t]{3}{*}{4} & UL 7.62-7.93 & 1.16E-07 & $2.46 \mathrm{E}-05$ & $4.70 \mathrm{E}-03$ & 4.70E-03 & 105.4 & 0.0095 & $-3.66 \mathrm{E}-04$ \\
\hline & UM 6.10-6.40 & $1.82 \mathrm{E}-07$ & $2.45 \mathrm{E}-04$ & $7.43 E-04$ & 7.43E-04 & 672.3 & 0.0015 & $-1.80 \mathrm{E}-04$ \\
\hline & UR 5.18-5.48 & $9.75 \mathrm{E}-08$ & $3.92 \mathrm{E}-06$ & $2.49 \mathrm{E}-02$ & $2.49 \mathrm{E}-02$ & 19.1 & 0.0523 & $-9.41 \mathrm{E}-05$ \\
\hline \multicolumn{6}{|c|}{ Theoretical limit } & 521.7 & 0.0019 & NA \\
\hline
\end{tabular}

Source: G for Niche 2 (Niche 3650) from DTN: LB980901233124.003 [DIRS 105592].

NOTE(S): Intermediate computations not performed for Niche 2 (Niche 3650) because they were performed in other technical products using the same formulae shown below. Output shown in table for Niche 2

(Niche 3650) was obtained directly from TDMS except where noted.

Source of Column C values: Column H of Table B-4.

Source of Column D values: Column K of Table B-4.

$\mathrm{E}=\mathrm{C} / \mathrm{D}$.

$F=1 /(2 \times G+2-(1 / G))=\left[\vartheta_{\max }(s)\right]^{-1}$,

where $\vartheta_{\max }$ and $s$ are defined by Equations (84) and (14) in Philip et al. 1989 [DIRS 105743].

In this case, $s=0.5 \times \alpha \times r=0.5 \times \alpha \times 2=\alpha$, since the nominal radius of the niche $(r)$ is

approximately $2 \mathrm{~m}$.

$\mathrm{G}=\alpha$, sorptive number,

where $\alpha$ is selected such that absolute value of Error (i.e., column I) is $<1 \mathrm{E}-03 \%$.

(Theoretical limit) $=\alpha=$ maximum sorptive number $=\left(2^{*} \rho \times \mathrm{g} / \gamma\right)^{1 / 2}$,

where $\rho=$ density of water assumed equal to $1000 \mathrm{~kg} / \mathrm{m}^{3}$,

$\mathrm{g}=$ acceleration of gravity $9.8 \mathrm{~m} / \mathrm{s}^{2}$, and

$\gamma=$ surface tension of water assumed equal to $0.072 \mathrm{~kg} / \mathrm{s}^{2}$.

Equation $\mathrm{G}$ (theoretical limit) can be derived by substituting the maximum aperture $\left(\beta_{\max }\right)$ that can sustain a fluid meniscus because of capillary forces $\left(\beta_{\max }=(2 \gamma / \rho \mathrm{g})^{1 / 2}\right)$ into the capillary height of rise equation $2 \alpha^{-1}=2 \gamma /\left(\rho g \beta_{\max }\right)$.

Expression for $\beta_{\max }$ from Wang and Narasimhan 1993 [DIRS 106793]. Expression for capillary height of rise equation from Philip 1989 [DIRS 156974].

$H=1 / G=\alpha^{-1}$, capillary strength of the porous medium computed for all niches.

$\mathrm{I}=100 \times(\mathrm{E}-\mathrm{F}) / \mathrm{E}$. Note that $\mathrm{K}_{\mathrm{o}}^{*} / \mathrm{K}_{\mathrm{I}}=\left[\vartheta_{\max }(\mathrm{s})\right]^{-1}$ as noted in Section 3.4 of Philip et al. 1989

[DIRS 105743].

$\mathrm{NA}=$ Not applicable

$\mathrm{NC}=$ Intermediate computations not performed for Niche 2 (Niche 3650) because they were performed in earlier technical products using the same formulae and methods. Output shown in Table for Niche 2 (Niche 3650) was obtained directly from TDMS except where noted. 
Table B-6. Computed Values of Seepage Threshold Values

\begin{tabular}{|c|c|c|c|c|c|c|c|}
\hline A & B & C & D & E & $\mathbf{F}$ & G & H \\
\hline $\begin{array}{c}\text { (Output) } \\
\mathrm{K}_{l} \\
\text { (mm/yr) }\end{array}$ & $\begin{array}{c}\text { (Input) } \\
\mathrm{K}_{l} \\
(\mathrm{~m} / \mathrm{s})\end{array}$ & $\begin{array}{c}\text { (Input) } \\
\mathbf{s} \\
\text { (dimensionless) }\end{array}$ & $\begin{array}{c}\text { (Input) } \\
2 \mathrm{~s} \\
\text { (dimensionless) }\end{array}$ & $\begin{array}{c}\text { (Intermediate } \\
\text { Output) } \\
\vartheta_{\max } \\
\text { (dimensionless) }\end{array}$ & $\begin{array}{c}\text { (Output) } \\
{\left[\vartheta_{\max }\right]^{-1}} \\
\text { (dimensionless) }^{\text {(dims }}\end{array}$ & \begin{tabular}{|c|} 
(Interme \\
-diate \\
Output) \\
$\mathrm{K}_{0}^{\star}$ \\
$(\mathrm{m} / \mathrm{s})$ \\
\end{tabular} & \begin{tabular}{|c|} 
(Output) \\
$\mathrm{K}_{\mathrm{o}}^{*}$ \\
$(\mathrm{~mm} / \mathrm{yr})$
\end{tabular} \\
\hline $3.154 \mathrm{E}+01$ & 1.000E-09 & 521.7 & 1043.5 & 1045.50 & $9.56 \mathrm{E}-04$ & $9.56 \mathrm{E}-13$ & 3.02E-02 \\
\hline $4.730 \mathrm{E}+01$ & 1.500E-09 & 521.7 & 1043.5 & 1045.50 & 9.56E-04 & 1.43E-12 & 4.52E-02 \\
\hline $6.307 \mathrm{E}+01$ & 2.000E-09 & 521.7 & 1043.5 & 1045.50 & 9.56E-04 & $1.91 \mathrm{E}-12$ & $6.03 \mathrm{E}-02$ \\
\hline $9.461 \mathrm{E}+01$ & 3.000E-09 & 521.7 & 1043.5 & 1045.50 & 9.56E-04 & 2.87E-12 & $9.05 \mathrm{E}-02$ \\
\hline $1.261 \mathrm{E}+02$ & 4.000E-09 & 521.7 & 1043.5 & 1045.50 & 9.56E-04 & $3.83 \mathrm{E}-12$ & $1.21 \mathrm{E}-01$ \\
\hline $1.577 \mathrm{E}+02$ & 5.000E-09 & 521.7 & 1043.5 & 1045.50 & $9.56 \mathrm{E}-04$ & $4.78 \mathrm{E}-12$ & $1.51 \mathrm{E}-01$ \\
\hline $1.892 \mathrm{E}+02$ & 6.000E-09 & 521.7 & 1043.5 & 1045.50 & $9.56 \mathrm{E}-04$ & $5.74 \mathrm{E}-12$ & $1.81 \mathrm{E}-01$ \\
\hline $2.208 \mathrm{E}+02$ & 7.000E-09 & 521.7 & 1043.5 & 1045.50 & 9.56E-04 & 6.70E-12 & $2.11 \mathrm{E}-01$ \\
\hline $2.523 E+02$ & 8.000E-09 & 521.7 & 1043.5 & 1045.50 & 9.56E-04 & 7.65E-12 & $2.41 \mathrm{E}-01$ \\
\hline $2.838 \mathrm{E}+02$ & 9.000E-09 & 521.7 & 1043.5 & 1045.50 & 9.56E-04 & $8.61 \mathrm{E}-12$ & 2.71E-01 \\
\hline $3.154 \mathrm{E}+02$ & $1.000 \mathrm{E}-08$ & 521.7 & 1043.5 & 1045.50 & 9.56E-04 & $9.56 \mathrm{E}-12$ & 3.02E-01 \\
\hline $4.730 \mathrm{E}+02$ & 1.500E-08 & 521.7 & 1043.5 & 1045.50 & $9.56 \mathrm{E}-04$ & 1.43E-11 & 4.52E-01 \\
\hline $6.307 \mathrm{E}+02$ & 2.000E-08 & 521.7 & 1043.5 & 1045.50 & $9.56 \mathrm{E}-04$ & $1.91 \mathrm{E}-11$ & 6.03E-01 \\
\hline $9.461 \mathrm{E}+02$ & 3.000E-08 & 521.7 & 1043.5 & 1045.50 & 9.56E-04 & 2.87E-11 & 9.05E-01 \\
\hline $1.261 \mathrm{E}+03$ & 4.000E-08 & 521.7 & 1043.5 & 1045.50 & 9.56E-04 & 3.83E-11 & $1.21 \mathrm{E}+00$ \\
\hline $1.577 \mathrm{E}+03$ & 5.000E-08 & 521.7 & 1043.5 & 1045.50 & 9.56E-04 & $4.78 \mathrm{E}-11$ & $1.51 \mathrm{E}+00$ \\
\hline $1.892 \mathrm{E}+03$ & 6.000E-08 & 521.7 & 1043.5 & 1045.50 & $9.56 \mathrm{E}-04$ & $5.74 \mathrm{E}-11$ & $1.81 E+00$ \\
\hline $2.208 \mathrm{E}+03$ & 7.000E-08 & 521.7 & 1043.5 & 1045.50 & 9.56E-04 & $6.70 \mathrm{E}-11$ & $2.11 \mathrm{E}+00$ \\
\hline $2.523 E+03$ & $8.000 \mathrm{E}-08$ & 521.7 & 1043.5 & 1045.50 & 9.56E-04 & $7.65 \mathrm{E}-11$ & $2.41 \mathrm{E}+00$ \\
\hline $2.838 \mathrm{E}+03$ & $9.000 \mathrm{E}-08$ & 521.7 & 1043.5 & 1045.50 & $9.56 \mathrm{E}-04$ & 8.61E-11 & $2.71 \mathrm{E}+00$ \\
\hline $3.154 \mathrm{E}+03$ & $1.000 \mathrm{E}-07$ & 521.7 & 1043.5 & 1045.50 & 9.56E-04 & $9.56 \mathrm{E}-11$ & $3.02 E+00$ \\
\hline $4.730 \mathrm{E}+03$ & $1.500 \mathrm{E}-07$ & 521.7 & 1043.5 & 1045.50 & $9.56 \mathrm{E}-04$ & $1.43 \mathrm{E}-10$ & $4.52 E+00$ \\
\hline $6.307 \mathrm{E}+03$ & $2.000 \mathrm{E}-07$ & 521.7 & 1043.5 & 1045.50 & 9.56E-04 & $1.91 \mathrm{E}-10$ & $6.03 E+00$ \\
\hline $9.461 \mathrm{E}+03$ & 3.000E-07 & 521.7 & 1043.5 & 1045.50 & $9.56 \mathrm{E}-04$ & 2.87E-10 & $9.05 E+00$ \\
\hline $1.261 \mathrm{E}+04$ & 4.000E-07 & 521.7 & 1043.5 & 1045.50 & $9.56 \mathrm{E}-04$ & 3.83E-10 & $1.21 \mathrm{E}+01$ \\
\hline $1.577 \mathrm{E}+04$ & 5.000E-07 & 521.7 & 1043.5 & 1045.50 & 9.56E-04 & $4.78 \mathrm{E}-10$ & $1.51 \mathrm{E}+01$ \\
\hline $1.892 \mathrm{E}+04$ & 6.000E-07 & 521.7 & 1043.5 & 1045.50 & 9.56E-04 & $5.74 \mathrm{E}-10$ & $1.81 \mathrm{E}+01$ \\
\hline $2.208 \mathrm{E}+04$ & 7.000E-07 & 521.7 & 1043.5 & 1045.50 & 9.56E-04 & $6.70 \mathrm{E}-10$ & $2.11 \mathrm{E}+01$ \\
\hline $2.523 E+04$ & $8.000 \mathrm{E}-07$ & 521.7 & 1043.5 & 1045.50 & 9.56E-04 & 7.65E-10 & $2.41 \mathrm{E}+01$ \\
\hline $2.838 \mathrm{E}+04$ & $9.000 \mathrm{E}-07$ & 521.7 & 1043.5 & 1045.50 & $9.56 \mathrm{E}-04$ & $8.61 \mathrm{E}-10$ & $2.71 \mathrm{E}+01$ \\
\hline $3.154 \mathrm{E}+04$ & $1.000 \mathrm{E}-06$ & 521.7 & 1043.5 & 1045.50 & 9.56E-04 & $9.56 \mathrm{E}-10$ & $3.02 E+01$ \\
\hline $4.730 \mathrm{E}+04$ & 1.500E-06 & 521.7 & 1043.5 & 1045.50 & $9.56 \mathrm{E}-04$ & 1.43E-09 & $4.52 \mathrm{E}+01$ \\
\hline $6.307 \mathrm{E}+04$ & $2.000 \mathrm{E}-06$ & 521.7 & 1043.5 & 1045.50 & $9.56 \mathrm{E}-04$ & $1.91 \mathrm{E}-09$ & $6.03 E+01$ \\
\hline $9.461 \mathrm{E}+04$ & 3.000E-06 & 521.7 & 1043.5 & 1045.50 & 9.56E-04 & 2.87E-09 & $9.05 E+01$ \\
\hline $1.261 \mathrm{E}+05$ & 4.000E-06 & 521.7 & 1043.5 & 1045.50 & $9.56 \mathrm{E}-04$ & 3.83E-09 & $1.21 \mathrm{E}+02$ \\
\hline 1.577E+05 & 5.000E-06 & 521.7 & 1043.5 & 1045.50 & 9.56E-04 & 4.78E-09 & $1.51 \mathrm{E}+02$ \\
\hline $1.892 \mathrm{E}+05$ & 6.000E-06 & 521.7 & 1043.5 & 1045.50 & $9.56 \mathrm{E}-04$ & 5.74E-09 & $1.81 \mathrm{E}+02$ \\
\hline $2.208 \mathrm{E}+05$ & 7.000E-06 & 521.7 & 1043.5 & 1045.50 & 9.56E-04 & 6.70E-09 & $2.11 \mathrm{E}+02$ \\
\hline $2.523 E+05$ & 8.000E-06 & 521.7 & 1043.5 & 1045.50 & 9.56E-04 & 7.65E-09 & $2.41 \mathrm{E}+02$ \\
\hline $2.838 \mathrm{E}+05$ & $9.000 \mathrm{E}-06$ & 521.7 & 1043.5 & 1045.50 & $9.56 \mathrm{E}-04$ & 8.61E-09 & $2.71 E+02$ \\
\hline
\end{tabular}


Table B-6. Computed Values of Seepage Threshold Values (Continued)

\begin{tabular}{|c|c|c|c|c|c|c|c|}
\hline $\begin{array}{c}\text { (Output) } \\
\mathrm{K}_{l} \\
(\mathrm{~mm} / \mathrm{yr})\end{array}$ & $\begin{array}{c}\text { (Input) } \\
\mathrm{K}_{I} \\
(\mathrm{~m} / \mathrm{s})\end{array}$ & $\begin{array}{c}\text { (Input) } \\
\mathbf{s} \\
\text { (dimensionless) }\end{array}$ & $\begin{array}{c}\text { (Input) } \\
2 \mathrm{~s} \\
\text { (dimensionless) }\end{array}$ & \begin{tabular}{|c} 
(Intermediate \\
Output) \\
$\vartheta_{\max }$ \\
(dimensionless)
\end{tabular} & $\begin{array}{c}\text { (Output) } \\
{\left[\vartheta_{\max }\right]^{-1}} \\
\text { (dimensionless) }\end{array}$ & \begin{tabular}{|c|} 
(Interme \\
-diate \\
Output) \\
$\mathrm{K}_{\mathrm{*}}$ \\
$(\mathrm{m} / \mathrm{s})$ \\
\end{tabular} & $\begin{array}{c}\text { (Output) } \\
\mathrm{K}_{0}^{*} \\
(\mathrm{~mm} / \mathrm{yr})\end{array}$ \\
\hline $3.154 \mathrm{E}+05$ & $1.000 \mathrm{E}-05$ & 521.7 & 1043.5 & 1045.50 & 9.56E-04 & 9.56E-09 & $3.02 E+02$ \\
\hline $4.730 \mathrm{E}+05$ & $1.500 \mathrm{E}-05$ & 521.7 & 1043.5 & 1045.50 & 9.56E-04 & $1.43 \mathrm{E}-08$ & $4.52 E+02$ \\
\hline $6.307 \mathrm{E}+05$ & $2.000 \mathrm{E}-05$ & 521.7 & 1043.5 & 1045.50 & $9.56 \mathrm{E}-04$ & 1.91E-08 & $6.03 E+02$ \\
\hline $9.461 \mathrm{E}+05$ & $3.000 \mathrm{E}-05$ & 521.7 & 1043.5 & 1045.50 & $9.56 \mathrm{E}-04$ & \begin{tabular}{|l|}
$2.87 \mathrm{E}-08$ \\
\end{tabular} & $9.05 \mathrm{E}+02$ \\
\hline $1.261 \mathrm{E}+06$ & 4.000E-05 & 521.7 & 1043.5 & 1045.50 & $9.56 \mathrm{E}-04$ & 3.83E-08 & 1.21E+03 \\
\hline $1.577 \mathrm{E}+06$ & $5.000 \mathrm{E}-05$ & 521.7 & 1043.5 & 1045.50 & 9.56E-04 & 4.78E-08 & $1.51 \mathrm{E}+03$ \\
\hline $1.892 \mathrm{E}+06$ & $6.000 \mathrm{E}-05$ & 521.7 & 1043.5 & 1045.50 & 9.56E-04 & 5.74E-08 & $1.81 E+03$ \\
\hline $2.208 \mathrm{E}+06$ & $7.000 \mathrm{E}-05$ & 521.7 & 1043.5 & 1045.50 & 9.56E-04 & 6.70E-08 & $2.11 \mathrm{E}+03$ \\
\hline $2.523 \mathrm{E}+06$ & $8.000 \mathrm{E}-05$ & 521.7 & 1043.5 & 1045.50 & 9.56E-04 & 7.65E-08 & $2.41 E+03$ \\
\hline $2.838 \mathrm{E}+06$ & $9.000 \mathrm{E}-05$ & 521.7 & 1043.5 & 1045.50 & 9.56E-04 & 8.61E-08 & $2.71 \mathrm{E}+03$ \\
\hline $3.154 \mathrm{E}+06$ & $1.000 \mathrm{E}-04$ & 521.7 & 1043.5 & 1045.50 & 9.56E-04 & 9.56E-08 & $3.02 E+03$ \\
\hline $4.730 \mathrm{E}+06$ & $1.500 \mathrm{E}-04$ & 521.7 & 1043.5 & 1045.50 & $9.56 \mathrm{E}-04$ & 1.43E-07 & $4.52 \mathrm{E}+03$ \\
\hline $6.307 \mathrm{E}+06$ & $2.000 \mathrm{E}-04$ & 521.7 & 1043.5 & 1045.50 & $9.56 \mathrm{E}-04$ & 1.91E-07 & $6.03 E+03$ \\
\hline $9.461 \mathrm{E}+06$ & $3.000 \mathrm{E}-04$ & 521.7 & 1043.5 & 1045.50 & 9.56E-04 & 2.87E-07 & $9.05 E+03$ \\
\hline $1.261 \mathrm{E}+07$ & $4.000 \mathrm{E}-04$ & 521.7 & 1043.5 & 1045.50 & 9.56E-04 & 3.83E-07 & $1.21 \mathrm{E}+04$ \\
\hline $1.577 \mathrm{E}+07$ & $5.000 \mathrm{E}-04$ & 521.7 & 1043.5 & 1045.50 & $9.56 \mathrm{E}-04$ & 4.78E- 07 & $1.51 \mathrm{E}+04$ \\
\hline $1.892 \mathrm{E}+07$ & $6.000 \mathrm{E}-04$ & 521.7 & 1043.5 & 1045.50 & $9.56 \mathrm{E}-04$ & 5.74E- 07 & $1.81 \mathrm{E}+04$ \\
\hline $2.208 \mathrm{E}+07$ & 7.000E-04 & 521.7 & 1043.5 & 1045.50 & 9.56E-04 & 6.70E-07 & $2.11 E+04$ \\
\hline $2.523 \mathrm{E}+07$ & $8.000 \mathrm{E}-04$ & 521.7 & 1043.5 & 1045.50 & $9.56 \mathrm{E}-04$ & 7.65E-07 & $2.41 \mathrm{E}+04$ \\
\hline $2.838 \mathrm{E}+07$ & $9.000 \mathrm{E}-04$ & 521.7 & 1043.5 & 1045.50 & 9.56E-04 & 8.61E-07 & $2.71 \mathrm{E}+04$ \\
\hline $3.154 \mathrm{E}+07$ & $1.000 \mathrm{E}-03$ & 521.7 & 1043.5 & 1045.50 & 9.56E-04 & $9.56 \mathrm{E}-07$ & $3.02 E+04$ \\
\hline $4.730 \mathrm{E}+07$ & $1.500 \mathrm{E}-03$ & 521.7 & 1043.5 & 1045.50 & 9.56E-04 & $1.43 \mathrm{E}-06$ & $4.52 E+04$ \\
\hline $6.307 \mathrm{E}+07$ & $2.000 \mathrm{E}-03$ & 521.7 & 1043.5 & 1045.50 & 9.56E-04 & 1.91E-06 & $6.03 E+04$ \\
\hline $9.461 \mathrm{E}+07$ & $3.000 \mathrm{E}-03$ & 521.7 & 1043.5 & 1045.50 & 9.56E-04 & 2.87E-06 & $9.05 E+04$ \\
\hline $1.261 \mathrm{E}+08$ & 4.000E-03 & 521.7 & 1043.5 & 1045.50 & $9.56 \mathrm{E}-04$ & 3.83E-06 & $1.21 \mathrm{E}+05$ \\
\hline $1.577 \mathrm{E}+08$ & $5.000 \mathrm{E}-03$ & 521.7 & 1043.5 & 1045.50 & 9.56E-04 & $4.78 \mathrm{E}-06$ & $1.51 \mathrm{E}+05$ \\
\hline $1.892 \mathrm{E}+08$ & $6.000 \mathrm{E}-03$ & 521.7 & 1043.5 & 1045.50 & 9.56E-04 & 5.74E-06 & $1.81 \mathrm{E}+05$ \\
\hline $2.208 \mathrm{E}+08$ & $7.000 \mathrm{E}-03$ & 521.7 & 1043.5 & 1045.50 & $9.56 \mathrm{E}-04$ & $6.70 \mathrm{E}-06$ & $2.11 \mathrm{E}+05$ \\
\hline $2.523 \mathrm{E}+08$ & $8.000 \mathrm{E}-03$ & 521.7 & 1043.5 & 1045.50 & $9.56 \mathrm{E}-04$ & 7.65E-06 & $2.41 \mathrm{E}+05$ \\
\hline $2.838 \mathrm{E}+08$ & $9.000 \mathrm{E}-03$ & 521.7 & 1043.5 & 1045.50 & 9.56E-04 & 8.61E-06 & $2.71 \mathrm{E}+05$ \\
\hline $3.154 \mathrm{E}+08$ & $1.000 \mathrm{E}-02$ & 521.7 & 1043.5 & 1045.50 & 9.56E-04 & $9.56 \mathrm{E}-06$ & $3.02 E+05$ \\
\hline
\end{tabular}

NOTE(S): Refer to Philip et al. (1989 [DIRS 105743]) for an explanation of nomenclature.

$A=B \times 1000 \mathrm{~mm} / \mathrm{m} \times 86400 \mathrm{~s} /$ day $\times 365$ days/year.

$B=$ saturated hydraulic conductivity whose values are arbitrarily set in this column to span the range of values measured during air $k$ tests performed at Niche 2 (Niche 3650) and Niche 4 (Niche 4788).

$\mathrm{C}=$ (Theoretical limit) from bottom of Table B-5, column $\mathrm{G}$.

$\mathrm{D}=2 \times \mathrm{C}$

$E=2 s+2-1 / s$.

$F=1 / E$.

$\mathrm{G}=\mathrm{B} \times \mathrm{F}$.

$\mathrm{H}=\mathrm{G} \times 1000 \mathrm{~mm} / \mathrm{m} \times 86400 \mathrm{~s} /$ day $\times 365$ days/year. 
Table B-7. Computation of Estimated Water Potentials Based on Niche-Study Data

\begin{tabular}{|c|c|c|c|c|c|c|}
\hline $\mathbf{A}$ & B & C & D & $\mathbf{E}$ & $\mathbf{F}$ & G \\
\hline Niche & $\begin{array}{l}\text { Borehole } \\
\text { Name and } \\
\text { Depth } \\
(\mathrm{m})\end{array}$ & Test Name & $\begin{array}{l}\text { (Input) } \\
\text { Liquid- } \\
\text { Release } \\
\text { Flux } \\
\left(q_{s}\right) \\
(\mathrm{m} / \mathrm{s})\end{array}$ & $\begin{array}{c}\text { (Input) } \\
\text { Saturated } \\
\text { Hydraulic } \\
\text { Conductivity } \\
\left(\mathrm{K}_{\mathbf{l}}\right) \\
(\mathrm{m} / \mathrm{s})\end{array}$ & $\begin{array}{c}\text { (Input) } \\
\text { Alpha } \\
\text { Value } \\
(\alpha) \\
\left(\mathrm{m}^{-1}\right)\end{array}$ & 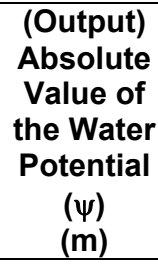 \\
\hline \multirow[t]{20}{*}{2} & UL 7.62-7.92 & Test \#2 1-6-98 & $9.49 \mathrm{E}-06$ & $1.51 \mathrm{E}-04$ & 771.9 & 3.59E-03 \\
\hline & UL 7.62-7.92 & Test \#1 2-12-98 & 1.89E-06 & $1.51 \mathrm{E}-04$ & 771.9 & 5.68E-03 \\
\hline & UL 7.62-7.92 & Test \#1 3-4-98 & 2.33E-07 & $1.51 \mathrm{E}-04$ & 771.9 & 8.39E-03 \\
\hline & UM 4.27-4.57 & $\begin{array}{l}\text { Test } 5 \text { Niche } 3650 \\
(11-13-97)\end{array}$ & 3.78E-05 & 2.62E-05 & 44.4 & 8.26E-03 \\
\hline & UM 4.27-4.57 & Test \#1 12-3-97 & $9.42 \mathrm{E}-06$ & 2.62E-05 & 44.4 & 2.30E-02 \\
\hline & UM 4.27-4.57 & Test \#2 12-3-97 & 9.47E-06 & 2.62E-05 & 44.4 & 2.29E-02 \\
\hline & UM 4.27-4.57 & Test \#1 1-7-98 & 8.82E-07 & 2.62E-05 & 44.4 & 7.64E-02 \\
\hline & UM 4.27-4.57 & Test \#2 2-10-98 & 3.09E-07 & 2.62E-05 & 44.4 & 1.00E-01 \\
\hline & UM 4.88-5.18 & $\begin{array}{l}\text { Test } 1 \text { Niche } 3650 \\
(11-12-97) \\
\end{array}$ & 5.41E-05 & $2.52 \mathrm{E}-03$ & 1225.5 & $3.13 \mathrm{E}-03$ \\
\hline & UM 4.88-5.18 & Test \#1 12-4-97 & 9.49E-06 & $2.52 \mathrm{E}-03$ & 1225.5 & 4.56E-03 \\
\hline & UM 4.88-5.18 & Test \#2 12-5-97 & 2.70E-06 & $2.52 \mathrm{E}-03$ & 1225.5 & $5.58 \mathrm{E}-03$ \\
\hline & UM 4.88-5.18 & Test \#1 1-8-98 & 8.75E-07 & $2.52 \mathrm{E}-03$ & 1225.5 & $6.50 \mathrm{E}-03$ \\
\hline & UM 4.88-5.18 & Test \#1 3-6-98 & 2.48E-07 & $2.52 \mathrm{E}-03$ & 1225.5 & 7.53E-03 \\
\hline & UM 5.49-5.79 & $\begin{array}{l}\text { Test } 4 \text { Niche } 3650 \\
(11-13-97) \\
\end{array}$ & 3.87E-05 & 2.16E-05 & 29.9 & $1.95 \mathrm{E}-02$ \\
\hline & UM 5.49-5.79 & Test \#2 12-4-97 & $9.43 \mathrm{E}-06$ & 2.16E-05 & 29.9 & $2.77 \mathrm{E}-02$ \\
\hline & UM 5.49-5.79 & Test \#1 1-9-98 & $1.08 \mathrm{E}-06$ & 2.16E-05 & 29.9 & 1.00E-01 \\
\hline & UM 5.49-5.79 & Test \#1 2-11-98 & $2.55 \mathrm{E}-07$ & 2.16E-05 & 29.9 & $1.48 \mathrm{E}-01$ \\
\hline & UR 6.71-7.01 & Test \#1 1-13-98 & $3.68 \mathrm{E}-06$ & 2.28E-04 & 699.2 & 5.90E-03 \\
\hline & UR 6.71-7.01 & Test \#1 2-3-98 & $1.91 \mathrm{E}-06$ & $2.28 \mathrm{E}-04$ & 699.2 & $6.84 \mathrm{E}-03$ \\
\hline & UR 6.71-7.01 & Test \#1 3-5-98 & 2.48E-07 & $2.28 \mathrm{E}-04$ & 699.2 & 9.76E-03 \\
\hline \multirow[t]{11}{*}{4} & UL 7.62-7.93 & Test \#1 11/3/99 & 1.65E-06 & 2.46E-05 & 105.4 & 2.56E-02 \\
\hline & UL 7.62-7.93 & $\begin{array}{l}\text { Test \#1 11-30-99 } \\
\text { Niche 4788 } \\
\end{array}$ & $9.22 \mathrm{E}-07$ & 2.46E-05 & 105.4 & $3.12 \mathrm{E}-02$ \\
\hline & UL 7.62-7.93 & Test \#1 6-26-2000 & $3.59 \mathrm{E}-07$ & $2.46 \mathrm{E}-05$ & 105.4 & 4.01E-02 \\
\hline & UL 7.62-7.93 & Test \#1 01-24-00 & 1.46E-07 & $2.46 \mathrm{E}-05$ & 105.4 & 4.86E-02 \\
\hline & UM 6.10-6.40 & $\begin{array}{l}\text { Test \#1 Niche } 4788 \\
11 / 16 / 99 \\
\end{array}$ & $1.72 \mathrm{E}-06$ & $2.45 \mathrm{E}-04$ & 672.3 & 7.38E-03 \\
\hline & UM 6.10-6.40 & $\begin{array}{l}\text { Test \#1 Niche } 4788 \\
\text { 12-10-99 } \\
\end{array}$ & 7.33E-07 & $2.45 \mathrm{E}-04$ & 672.3 & 8.65E-03 \\
\hline & UM 6.10-6.40 & Test \#1 06-08-2000 & $3.83 \mathrm{E}-07$ & $2.45 \mathrm{E}-04$ & 672.3 & $9.61 \mathrm{E}-03$ \\
\hline & UM 6.10-6.40 & Test \#1 3-14-2000 & $1.66 \mathrm{E}-07$ & $2.45 \mathrm{E}-04$ & 672.3 & 1.09E-02 \\
\hline & UR 5.18-5.48 & $\begin{array}{l}\text { Test \#1 Niche } 4788 \\
\text { 12/7/99 }\end{array}$ & $1.69 \mathrm{E}-06$ & $3.92 \mathrm{E}-06$ & 19.1 & 4.41E-02 \\
\hline & UR 5.18-5.48 & Test \#1 1/5/2000 & 7.11E-07 & $3.92 \mathrm{E}-06$ & 19.1 & 8.93E-02 \\
\hline & UR 5.18-5.48 & Test \#1 02-14-2000 & 1.65E-07 & 3.92E-06 & 19.1 & 1.66E-01 \\
\hline
\end{tabular}

NOTES: $\quad$ D for Niche 2 (Niche 3650) from DTN: LB980901233124.003 [DIRS 105592]; D for Niche 4 (Niche 4788) computed in Table B-3b (G), respectively.

E from Table B-4 (K).

F from Table B-5 $(\mathrm{G})$.

$G=\ln (D / E) / F ; G$ for Niche 2 (Niche 3650) from DTN: LB980901233124.003 [DIRS 105592] using same formula. 
Table B-8. Computation of Estimated Water Content Change Based on Niche-Study Data

\begin{tabular}{|c|c|c|c|c|c|c|}
\hline A & B & C & D & $E$ & $\mathbf{F}$ & G \\
\hline Niche & $\begin{array}{l}\text { Borehole } \\
\text { Name and } \\
\text { Depth } \\
\text { (m) }\end{array}$ & Test Name & $\begin{array}{c}\text { (Input) } \\
\text { Liquid-Release } \\
\text { Flux } \\
\left(\mathbf{q}_{\mathrm{s}}\right) \\
(\mathrm{m} / \mathrm{s}) \\
\end{array}$ & $\begin{array}{l}\text { (Input) } \\
\text { Arrival Time } \\
\text { of Wetting } \\
\text { Front at } \\
\text { Ceiling } \\
\text { (t) } \\
\text { (s) }\end{array}$ & $\begin{array}{c}\text { (Input) } \\
\text { Distance } \\
\text { to Ceiling } \\
\left(z_{p}\right) \\
(m) \\
\end{array}$ & $\begin{array}{c}\text { (Output) } \\
\text { Average Water } \\
\text { Content } \\
\text { Change } \\
\left(\theta_{\text {ave }}-\theta_{\mathrm{n}}\right) \\
\left(\mathrm{m}^{3} / \mathrm{m}^{3}\right) \\
\end{array}$ \\
\hline \multirow[t]{20}{*}{2} & UL 7.62-7.92 & Test \#2 1-6-98 & $9.49 \mathrm{E}-06$ & 690 & 0.65 & 0.0101 \\
\hline & UL 7.62-7.92 & Test \#1 2-12-98 & $1.89 \mathrm{E}-06$ & 570 & 0.65 & 0.0017 \\
\hline & UL 7.62-7.92 & Test \#1 3-4-98 & 2.33E-07 & 2610 & 0.65 & 0.0009 \\
\hline & UM 4.27-4.57 & Test 5 Niche 3650 (11-13-97) & 3.78E-05 & 416 & 0.65 & 0.0242 \\
\hline & UM 4.27-4.57 & Test \#1 12-3-97 & $9.42 \mathrm{E}-06$ & 1008 & 0.65 & 0.0146 \\
\hline & UM 4.27-4.57 & Test \#2 12-3-97 & 9.47E-06 & 514 & 0.65 & 0.0075 \\
\hline & UM 4.27-4.57 & Test \#1 1-7-98 & $8.82 \mathrm{E}-07$ & 8811 & 0.65 & 0.0120 \\
\hline & UM 4.27-4.57 & Test \#2 2-10-98 & 3.09E-07 & 13375 & 0.65 & 0.0063 \\
\hline & UM 4.88-5.18 & Test 1 Niche 3650 (11-12-97) & $5.41 \mathrm{E}-05$ & 180 & 0.65 & 0.0150 \\
\hline & UM 4.88-5.18 & Test \#1 12-4-97 & $9.49 \mathrm{E}-06$ & 298 & 0.65 & 0.0043 \\
\hline & UM 4.88-5.18 & Test \#2 12-5-97 & $2.70 \mathrm{E}-06$ & 952 & 0.65 & 0.0040 \\
\hline & UM 4.88-5.18 & Test \#1 1-8-98 & 8.75E-07 & 6060 & 0.65 & 0.0082 \\
\hline & UM 4.88-5.18 & Test \#1 3-6-98 & $2.48 \mathrm{E}-07$ & 21690 & 0.65 & 0.0083 \\
\hline & UM 5.49-5.79 & Test 4 Niche 3650 (11-13-97) & 3.87E-05 & 208 & 0.65 & 0.0124 \\
\hline & UM 5.49-5.79 & Test \#2 12-4-97 & $9.43 \mathrm{E}-06$ & 420 & 0.65 & 0.0061 \\
\hline & UM 5.49-5.79 & Test \#1 1-9-98 & $1.08 \mathrm{E}-06$ & 2750 & 0.65 & 0.0046 \\
\hline & UM 5.49-5.79 & Test \#1 2-11-98 & $2.55 \mathrm{E}-07$ & 10130 & 0.65 & 0.0040 \\
\hline & UR 6.71-7.01 & Test \#1 1-13-98 & 3.68E-06 & 416 & 0.65 & 0.0024 \\
\hline & UR 6.71-7.01 & Test \#1 2-3-98 & 1.91E-06 & 626 & 0.65 & 0.0018 \\
\hline & UR 6.71-7.01 & Test \#1 3-5-98 & $2.48 \mathrm{E}-07$ & 4457 & 0.65 & 0.0017 \\
\hline \multirow[t]{11}{*}{4} & UL 7.62-7.93 & Test \#1 11/3/99 & 1.65E-06 & 7057 & 0.60 & 0.0193 \\
\hline & UL 7.62-7.93 & Test \#1 11-30-99 Niche 4788 & $9.22 \mathrm{E}-07$ & 3602 & 0.60 & 0.0055 \\
\hline & UL 7.62-7.93 & Test \#1 6-26-2000 & 3.59E-07 & 16445 & 0.60 & 0.0098 \\
\hline & UL 7.62-7.93 & Test \#1 01-24-00 & 1.46E-07 & 45697 & 0.60 & 0.0111 \\
\hline & UM 6.10-6.40 & Test \#1 Niche 4788 11/16/99 & 1.72E-06 & 16572 & 0.58 & 0.0489 \\
\hline & UM 6.10-6.40 & Test \#1 Niche 4788 12-10-99 & 7.33E-07 & 39938 & 0.58 & 0.0503 \\
\hline & UM 6.10-6.40 & Test \#1 06-08-2000 & 3.83E-07 & 50190 & 0.58 & 0.0331 \\
\hline & UM 6.10-6.40 & Test \#1 3-14-2000 & $1.66 \mathrm{E}-07$ & 124800 & 0.58 & 0.0355 \\
\hline & UR 5.18-5.48 & Test \#1 Niche 4788 12/7/99 & 1.69E-06 & 4034 & 0.74 & 0.0092 \\
\hline & UR 5.18-5.48 & Test \#1 1/5/2000 & 7.11E-07 & 5707 & 0.74 & 0.0055 \\
\hline & UR 5.18-5.48 & Test \#1 02-14-2000 & 1.65E-07 & 24900 & 0.74 & 0.0055 \\
\hline
\end{tabular}

Source: D for Niche 2 (Niche 3650) from DTN: LB980901233124.003 [DIRS 105592].

NOTES: $\quad D$ for Niche 4 (Niche 4788) computed in Table B-3b (G).

E in hour:minute:second format for Niche 4 (Niche 4788) from DTN: LB0010NICH4LIQ.001 [DIRS 153145].

E conversion from hour:minute:second format to seconds $=($ hours $\times 3600)+($ minutes $\times 60)+($ seconds in table).

E in seconds for Niche 2 (Niche 3650) from DTN: LB980901233124.003 [DIRS 105592] using same conversion.

$F$ for Niche 2 (Niche 3650) from Wang (1999 [DIRS 153449], p. 84).

$\mathrm{F}$ for Niche 4 (Niche 4788) from Table B-2.

$\mathrm{G}=\mathrm{D} \times \mathrm{E} / \mathrm{F}$ for Niche 4 (Niche 4788).

G for Niche 2 (Niche 3650) from DTN: LB980901233124.003 [DIRS 105592] using same formula. 


\section{INTENTIONALLY LEFT BLANK}


APPENDIX C

SUPPLEMENTAL SOURCE OF DATA ON SEEPAGE TESTS AT NICHE 5 (NICHE 1620) 


\section{C1. SURVEY DATA}

Figure C-1 contains as-built slot profiles to supplement Figure 6-36.

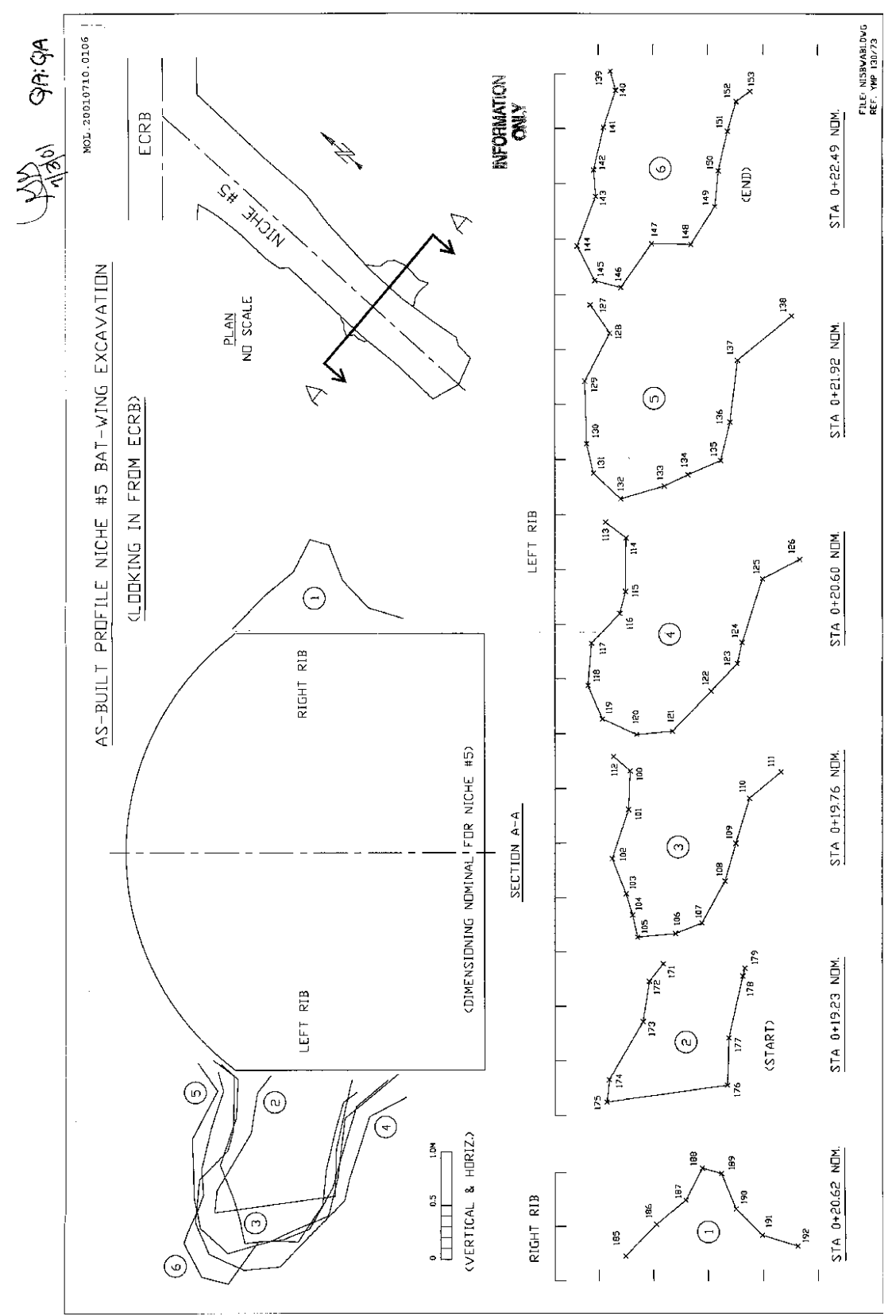

Source: DTN: MO0107GSC01061.000 [DIRS 155369].

Figure C-1. As-Built Profile Niche \#5 Bat-Wing Excavation (Looking in from ECRB) 


\section{C2. TEST OPERATION AND CONTROL EQUIPMENT}

Appendix Section C2 contains details of test operation on control equipment. The test operation and control equipment can be categorized into three general functional groups, as follows:

1. Valves and pumps that allow the user to control the direction, speed, and duration of fluid (air and water) movement through the manifolds, transmission lines, and straddle packers. Two pumps were used to control the release rate into the test interval, and valves were used to fill the release reservoir with more water once it was depleted. High-capacity pumps were periodically used to empty the capture reservoirs and return reservoirs, where seepage and return waters, respectively, accumulated during an experiment.

2. Instruments and sensors (including electronic balances, pressure transducers, and water-level sensors) provide system feedback. The operator used feedback from these sensors to manipulate control variables by manually or programmatically changing corresponding process variables. Automated equipment-control software (described in Appendix Section C3) was also used to continually poll these sensors and automatically change process variables (e.g., to start and stop a pump) to effect a change to a corresponding control variable (e.g., the release rate). Once a test was started, it could run for long periods of time without an operator, through use of the automated control routines.

3. The FieldPoint (FP) modular distributed input/output system by National Instruments was used to monitor and control process variables. Several FP modules were used as controllers; such modules allowed the user to open and close valves, start and stop pumps, etc., by means of the Graphical User Interface (GUI) "front panel" controls of the software described in Appendix Section C3.

Detailed process control diagrams associated with the test equipment are provided in Figure C-2 (for the injection and return manifolds) and in Figure C-3 (for the capture manifold).

The primary components of the test operation and control equipment are Aro solenoid valves, Nupro pneumatic valves, Richway air pinch valves, straddle packers, pumps, Kavlico pressure transducers, Gems water level sensors, and Mettler Toledo balances.

Solenoid valves are used to control the flow of compressed air to the pneumatic and pinch valves, and the straddle packers (see Figure C-2 and Figure C-3). An FP control module is used to send a voltage signal to the input terminal of a solenoid valve, which causes the pneumatic or pinch valve to open, and allows compressed air to pass through the pneumatic or pinch valve body. If the solenoid valve is opened while connected to a pneumatic or pinch valve, the air pressure will open or close these valves, depending upon their initial state (i.e., normally open or normally closed). Solenoid valves are also used to directly control the air pressure needed to inflate the rubber glands of the straddle packer (see Figure C-2).

Pneumatic and pinch valves are used to control the movement of water through the injection manifold. Water is pumped from the release reservoir (that rests on a Model SG 16001 Mettler Toledo balance (capacity $16.1 \mathrm{~kg}$ )), through the release manifold and straddle packers (via 
tubing), to the test interval. A change in the pump speed results in a change in the rate at which water is released into the test zone. Two pumps having different pumping speeds (high and low) are used for this purpose: a MASTERFLEX ${ }^{\circledR} \mathrm{L} / \mathrm{S}{ }^{\circledR}$ variable-speed digital peristaltic pump ( 0.1 to $340 \mathrm{~g} / \mathrm{min})$, and a Scilog piston pump (0.02 to $11 \mathrm{~g} / \mathrm{min})$. An FP control module is used to send a 3.5 to $20 \mathrm{mAmp}$ electrical signal to one of the pumps. Depending upon the amperage, the pump speed changes (from 0 percent) to up to 100 percent of the pump's full-scale output. The balance is used to monitor the rate at which water is pumped into the borehole. When, based on its mass, the release reservoir has been depleted a pneumatic valve is opened on the water supply line to replenish the release reservoir. The release reservoir can be replenished manually, or automatically using equipment-control software. A Gems float switch is used (as a high-water-level indicator in the release reservoir) to close the water supply valve, and to turn off the release pumps (in the event the release reservoir accidentally overfills).

The return port and return line connect the test interval, through the straddle packer, to the return manifold and the return reservoir that rests upon another balance (Figure C-2 and Figure C-3). If the pumping rate exceeds the infiltration capacity of the rock, then water will pond in the borehole, and will eventually flow out, through the return line, to the return reservoir that rests upon a second Model SG16001 Mettler Toledo balance. Pneumatic and pinch valves are used to control the movement of liquid through the return manifold and transmission lines. The balance is used to monitor the rate at which water returns, by gravity, to the return reservoir. Once the return reservoir is full (as determined by its mass), a high capacity $(0.12-17.0 \mathrm{~kg} / \mathrm{min}$.) MASTERFLEX ${ }^{\circledR} \mathrm{I} / \mathrm{P}{ }^{\circledR}$ variable speed peristaltic pump is used to remove the water from the return reservoir. An FP control module is used to actuate the pump, either manually or automatically (through use of the software listed in Appendix Section C3).

Water introduced into the test interval is expected to move from the borehole, through the rock, to the niche ceiling, where it drips into the niche (Figure C-2 and Figure C-3). A capture system (consisting of 0.30 -m-wide, 1.20 -m-long trays constructed of transparent Lexan ${ }^{\circledR}$ plastic hung from an aluminum frame) was used to collect the water that dripped from the niche ceiling (Figure 6-40). Each plastic tray was approximately $0.2 \mathrm{~m}$ deep, and had four separate 0.30-m-by-0.30-m compartments. Each compartment drained (from the bottom, through a pinch valve and associated tubing) to a capture reservoir that rested upon a Model SG16001 Mettler Toledo balance (a third balance, not one of the aforementioned ones).

The pinch valve could be opened or closed by closing or opening, respectively, its corresponding solenoid valve. The spatial distribution of seepage was determined by sequentially opening and closing the various pinch valves, and using the capture balance to measure the cumulative water mass collected in a given compartment. Once the capture reservoir was full (as determined by its mass), a second MASTERFLEX ${ }^{\circledR} I / P ®$ variable speed peristaltic pump was used to remove the water from the capture reservoir. An FP control module was then used to actuate the pump, either manually, or automatically (through use of the software described in Appendix Section C3). 


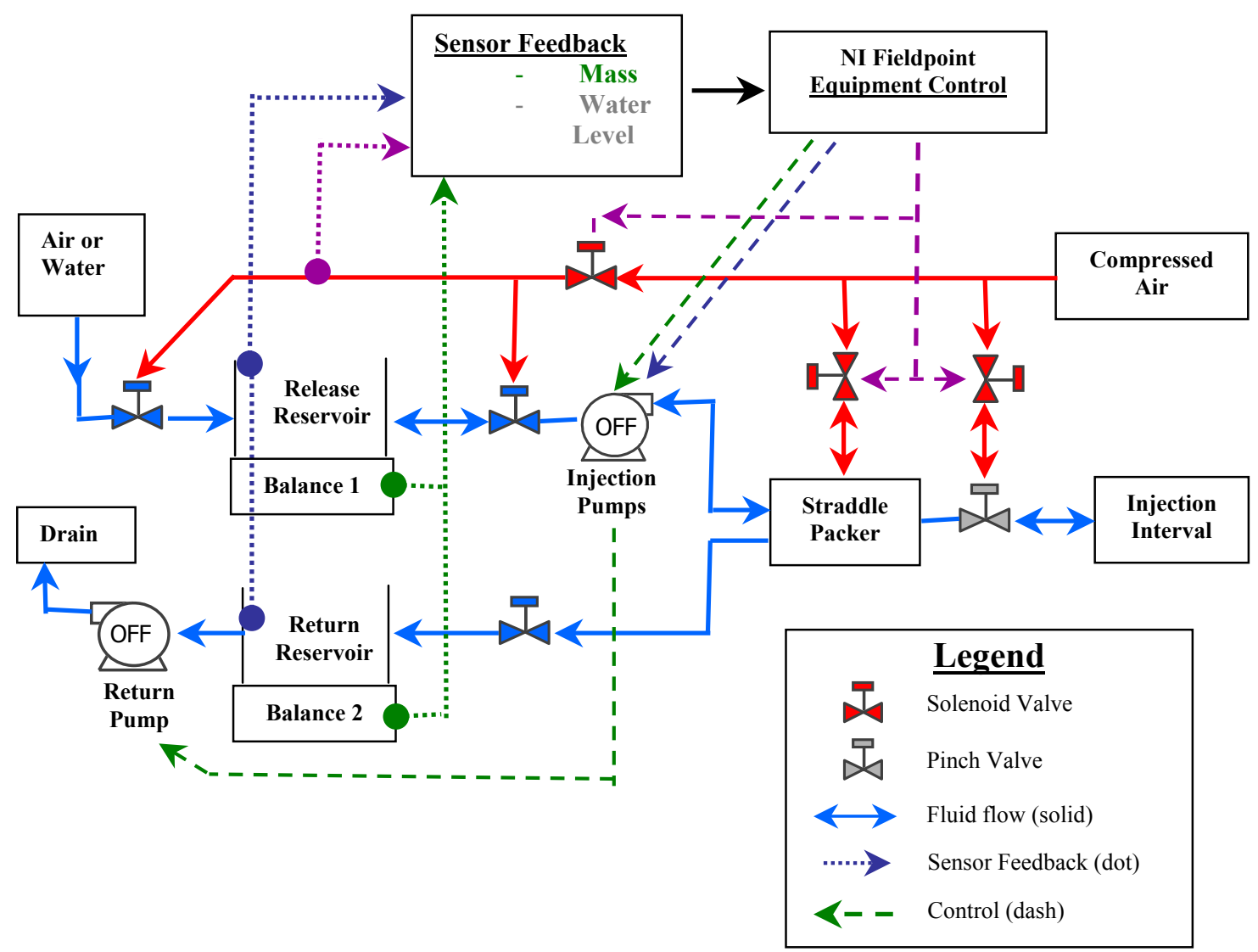

Figure C-2. Process Diagram for the Release and Return Manifolds Used to Control Water Flow to and from the Test Interval 


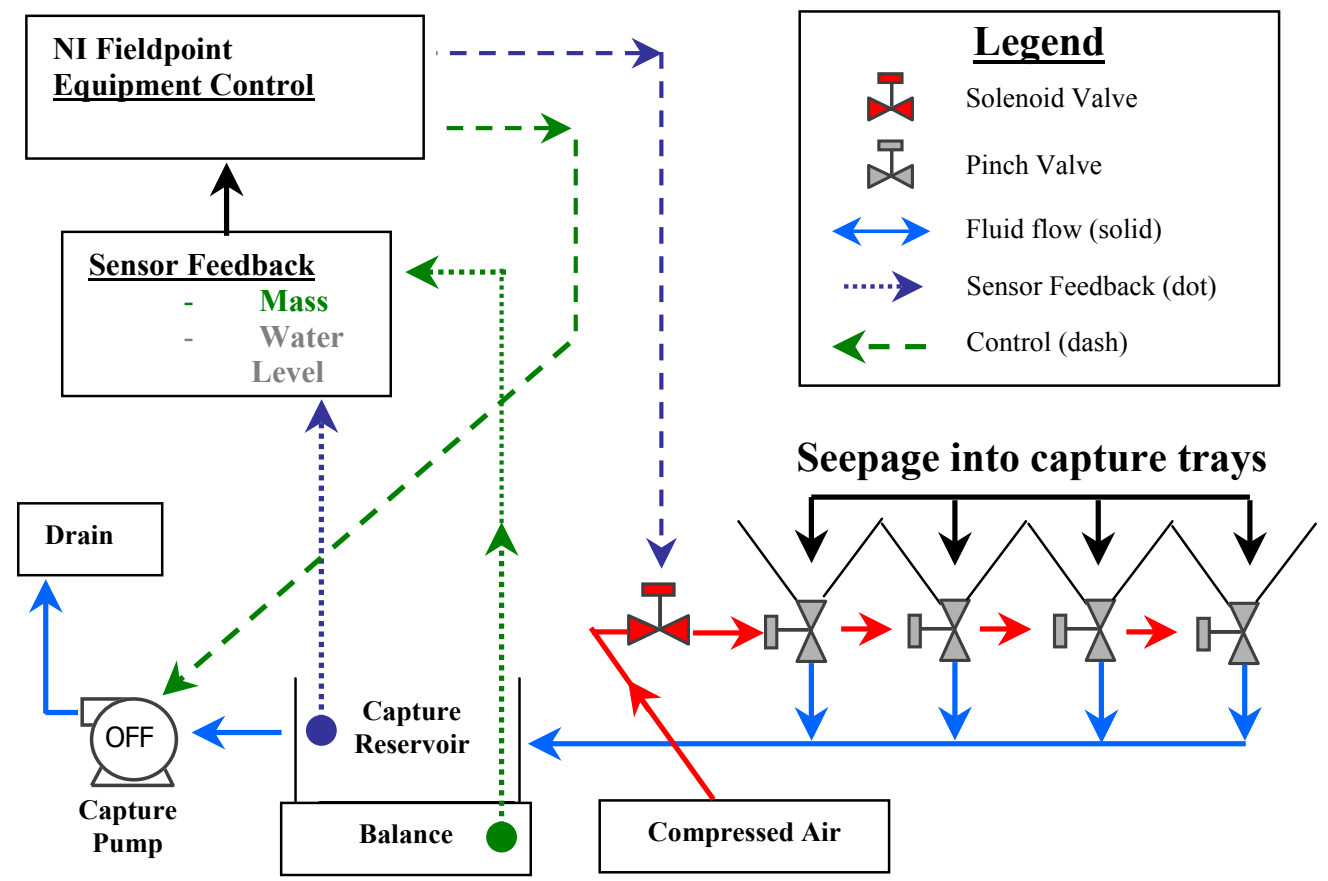

Figure C-3. Process Diagram for the Capture Manifold Used to Measure and Control Seepage Collected inside the Niche 


\section{C3. EQUIPMENT CONTROL AND DATA ACQUISITION}

Appendix Section C3 describes software of measuring and testing equipment. The custom-designed test operation was developed for PCs through use of the National Instruments LabVIEW graphical development environment (to control the seepage test equipment), which permitted both manual and automated manipulation (and control) of the test equipment and parameters described in Section C2. LabVIEW V.6 provided a useful equipment and sensor interface. The control (e.g., valve icon of GUI) and indicator (e.g., graph) functions provided in LabVIEW V.6 permitted the user to build custom "virtual instruments" that could be viewed and operated from a PC. The operator interfaces with the equipment either by clicking on GUI icons (that represent the valves, buttons, knobs, etc., that control processes) to generate pop-up windows containing relevant information, or by viewing GUI indicators that display data (through use of such devices as graphs, gauges, and tanks) on the PC. Figure C-4 shows a portion of the front-panel display for "Combined system box.vi," a virtual instrument used to control valves and monitor test equipment.

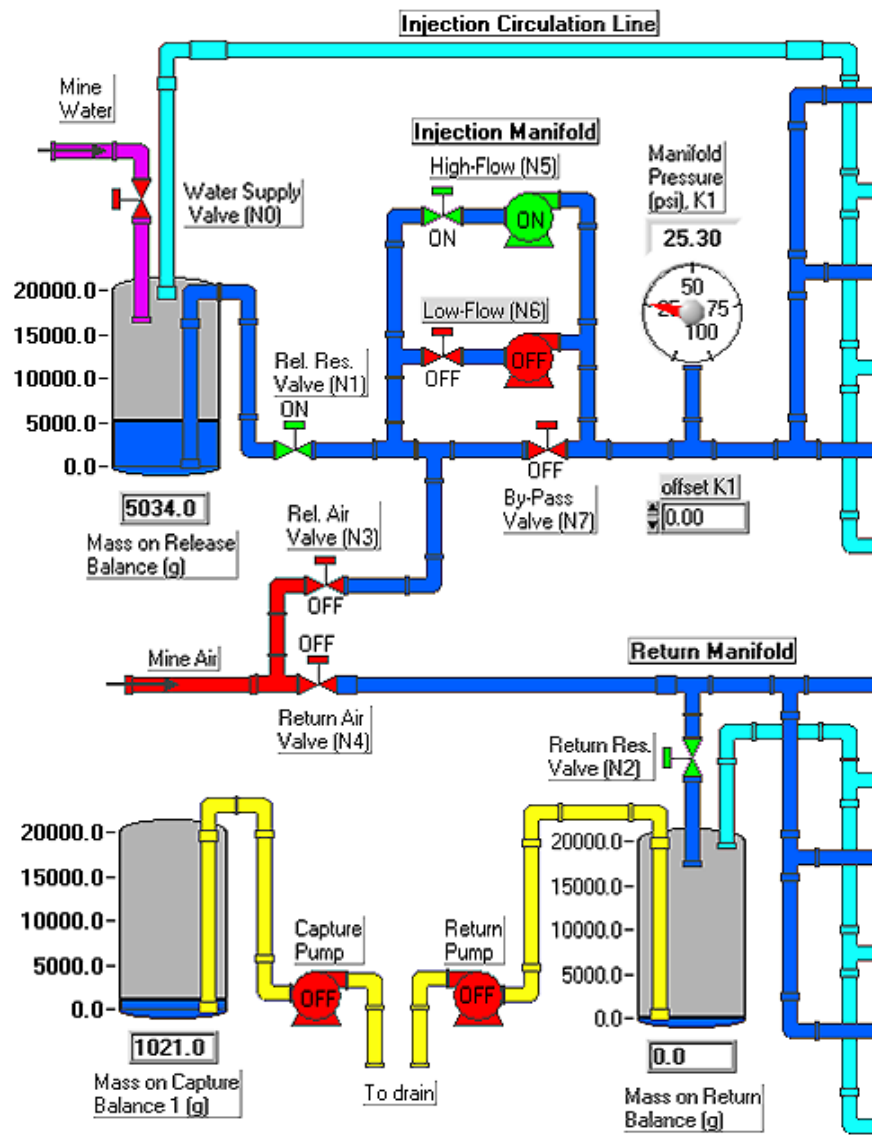

Figure C-4. Front Panel Display for LabVIEW V.6 Virtual Instrument Showing Example of Equipment Control Parameters

Unattended operation and remote access to the automated equipment (both possible because of software functionality) were critical to the success of the seepage tests, because the long duration of the experiments, and the limited access to the equipment during routine (e.g., weekend and holidays) and unexpected (e.g., power failures) closures of the ESF made less-automated methods unfeasible. 


\section{C4. NICHE 5 (NICHE CD 1620) DATA FILES AND SCIENTIFIC NOTEBOOKS}

Appendix Section C4 describes the test sequence and provides a list of scientific notebooks. Five sets of data were submitted to the Technical Database Management System (TDMS). Three of the data sets (DTNs: LB0207NICH5LIQ.001 [DIRS 160408], LB0209NICH5LIQ.001 [DIRS 160796], and LB0211NICH5LIQ.001 [DIRS 160792]) contain data files (in comma-delimited ASCII format) and are summarized in Table C-1. The remaining data sets, DTN: LB0208NICH5LIQ.001 [DIRS 161210] and DTN: LB0210NICH5LIQ.001 [DIRS 161211]), contained preliminary data, and were subsequently superseded by LB0209NICH5LIQ.001 [DIRS 160796] and LB0211NICH5LIQ.001 [DIRS 160792], respectively. Table C-1 also identifies the scientific notebook pages pertinent to each test; the pages provide test-specific details (including the serial number and location of instruments and sensors used during the experiment, test operating conditions, etc.).

The names of the electronic files that contain the test data (that were generated through use of the data acquisition equipment and software) are listed in Table C-1. Test data files consist of four types.

The three data-file types that include "(seep)," "(smass)," or "(srate)" in their filename contain the seepage-percentage, seep-mass, or seepage-rate data, respectively, from individual capture compartments that fed seepage water to the capture balance(s) during the test (Figure C-2 and Figure C-3). All other test files contain the cumulative mass and rate of water released (Balance 1) and returned (Balance 2), and the total seepage captured (Balance 3 and/or Balance 4), as these were measured by the Mettler Toledo balances that were used during the experiments.

As noted in Appendix Section C3, after July 15, 2002, only one balance was used to measure seepage into the niche (i.e., Balance 3), and Balance 4 was used to measure evaporation. 
Table C-1. Source of Data for Post-Excavation Seepage Tests at Niche 5 (Niche CD 1620)

\begin{tabular}{|c|c|c|c|c|c|c|}
\hline \multirow{2}{*}{$\begin{array}{l}\text { Borehole or Data } \\
\text { Description }\end{array}$} & \multirow[b]{2}{*}{ Depth (m) } & \multirow[b]{2}{*}{ Test Name } & \multirow[b]{2}{*}{ Start Date } & \multirow[b]{2}{*}{ End Date } & \multicolumn{2}{|c|}{ Source of Data } \\
\hline & & & & & Scientific Notebook & Filename \\
\hline$\# 2$ & $6.40-6.70$ & Test \#1 5-6-02 & $5 / 6 / 2002$ & $5 / 10 / 2002$ & $\begin{array}{l}\text { Trautz } 2003 \text { ([DIRS 166248], } \\
\text { pp. 154-160, 162-167, 169-171,178-190, } \\
\text { 193-196, 199, 201-202, 220, 226-229, and } \\
\text { 233) }\end{array}$ & Test\#1_BH\#2_21-22_ft_5-6-02.csv \\
\hline \#2 & $6.10-6.40$ & Test \#2 5-17-02 & $5 / 17 / 2002$ & $5 / 17 / 2002$ & $\begin{array}{l}\text { Trautz } 2003 \text { ([DIRS 166248], } \\
\text { pp. 154-160, 162-167, 169-171, } \\
\text { 178-190, 201-203, 205-208, } 220 \\
\text { 226-229, and 233) }\end{array}$ & $\begin{array}{l}\text { Test\#2_BH\#2_20-21_ft_5-17-02.csv } \\
\text { Test\#2_BH\#2_20-21_ft_5-17-02 (seep)_\#1.csv } \\
\text { Test\#2_BH\#2_20-21_ft_5-17-02 (smass)_\#1.csv } \\
\text { Test\#2_BH\#2_20-21_ft_5-17-02 (srate)_\#1.csv }\end{array}$ \\
\hline$\# 5$ & $8.53-8.83$ & Test \#1 5-3-02 & $5 / 3 / 2002$ & $5 / 14 / 2002$ & $\begin{array}{l}\text { Trautz } 2003 \text { ([DIRS 166248], } \\
\text { pp. 154-160, 162-166, 168-178, } \\
\text { 184-192, 195-202, 220, and 229-233) }\end{array}$ & $\begin{array}{l}\text { Test\#1_b5_28-29_ft_5-3-02_\#1.csv } \\
\text { Test\#1_b5_28-29_ft_5-3-02_\#2.csv } \\
\text { Test\#1_b5_28-29_ft_5-3-02_\#3.csv } \\
\text { Test\#1_b5_28-29_ft_5-3-02_\#4.csv } \\
\text { Test\#1_b5_28-29_ft_5-3-02_(seep).csv } \\
\text { Test\#1_b5_28-29_ft_5-3-02_(smass).csv } \\
\text { Test\#1_b5_28-29_ft_5-3-02_(srate).csv }\end{array}$ \\
\hline$\# 5$ & $8.53-8.83$ & Test \#2 5-16-02 & $5 / 16 / 2000$ & $5 / 31 / 2002$ & $\begin{array}{l}\text { Trautz } 2003 \text { ([DIRS 166248], } \\
\text { pp. 154-160, 162-166, 168-178, } \\
\text { 184-190, 201-222, and 226-234) }\end{array}$ & $\begin{array}{l}\text { Tes\#2_b5_28-29_ft_5-16-02.csv } \\
\text { Tes\#2_b5_28-29_ft_5-16-02_(seep)_\#1.csv } \\
\text { Tes\#2_b5_28-29_ft_5-16-02_(seep)_\#2.csv } \\
\text { Tes\#2_b5_28-29_ft_5-16-02_(seep)_\#3.csv } \\
\text { Tes\#2_b5_28-29_ft_5-16-02_(seep)_\#4.csv } \\
\text { Test\#2_b5_28-29_ft_5-16-02_(smass)_\#1.csv } \\
\text { Tes\#2_b5_28-29_ft_5-16-02_(smass)_\#2.csv } \\
\text { Test\#2_b5_28-29_ft_5-16-02_(smass)_\#3.csv } \\
\text { Test\#2_b5_28-29_ft_5-16-02_(smass)_\#4.csv } \\
\text { Tes\#2_b5_28-29_ft_5-16-02_(srate)_\#1.csv } \\
\text { Test22_b5_28-29_ft_5-16-02_(srate)_\#2.csv } \\
\text { Test\#2_b5_28-29_ft_5-16-02_(srate)_\#3.csv } \\
\text { Test\#2_b5_28-29_ft_5-16-02_(srate)_\#4.csv } \\
\text { Test\#2_BH\#2_20-21_ft_5-17-02.csv } \\
\text { Test\#2_BH\#2_20-21_ft_5-17-02 (seep)_\#1.csv } \\
\text { Test\#2_BH\#2_20-21_ft_5-17-02 (seep)_\#2.csv }\end{array}$ \\
\hline
\end{tabular}


Table C-1. Source of Data for Post-Excavation Seepage Tests at Niche 5 (Niche CD 1620) (Continued)

\begin{tabular}{|c|c|c|c|c|c|c|}
\hline \multirow{2}{*}{$\begin{array}{c}\text { Borehole or } \\
\text { Data Description }\end{array}$} & \multirow[b]{2}{*}{ Depth (m) } & \multirow[b]{2}{*}{ Test Name } & \multirow[b]{2}{*}{ Start Date } & \multirow[b]{2}{*}{ End Date } & \multicolumn{2}{|c|}{ Source of Data } \\
\hline & & & & & Scientific Notebook & Filename \\
\hline$\# 5$ & $8.53-8.83$ & Test \#2 5-16-02 & $5 / 16 / 2000$ & $5 / 31 / 2002$ & $\begin{array}{l}\text { Trautz } 2003 \text { ([DIRS 166248], } \\
\text { pp. 154-160, 162-166, 168-178, } \\
\text { 184-190, 201-222, and 226-234) }\end{array}$ & $\begin{array}{l}\text { Test\#2_BH\#2_20-21_ft_5-17-02 (seep)_\#3.csv } \\
\text { Test\#2_BH\#2_20-21_ft_5-17-02 (smass)_\#1.csv } \\
\text { Test\#2_BH\#2_20-21_ft_5-17-02 (smass)_\#2.csv } \\
\text { Test\#2_BH\#2_20-21_ft_5-17-02 (smass)_\#3.csv } \\
\text { Test\#2_BH\#2_20-21_ft_5-17-02 (srate)_\#1.csv } \\
\text { Test\#2_BH\#2_20-21_ft_5-17-02 (srate)_\#2.csv } \\
\text { Test\#2_BH\#2_20-21_ft_5-17-02 (srate)_\#3.csv }\end{array}$ \\
\hline \multicolumn{2}{|c|}{ Evaporation pan data } & (Pre-tests.) & $\begin{array}{l}12 / 7 / 2000 \\
2 / 7 / 2001 \\
2 / 21 / 2001 \\
4 / 2 / 2001 \\
7 / 12 / 2001\end{array}$ & $\begin{array}{c}12 / 12 / 2000 \\
2 / 8 / 2001 \\
4 / 2 / 2001 \\
4 / 3 / 2001 \\
8 / 25 / 2001\end{array}$ & $\begin{array}{l}\text { Trautz } 2001 \text { ([DIRS 161208], } \\
\text { pp. 90-91, 116-117, 120, 130-131, } \\
\text { 156-157, 195, and 298-299) }\end{array}$ & $\begin{array}{l}\text { Evap Niche CD1620 12-7-00.csv } \\
\text { Evap Niche CD1620 start2-07-01.csv } \\
\text { Evap Niche CD1620 start 2-21-01.csv } \\
\text { Evap Niche CD1620 start 4-02-01.csv } \\
\text { Evap Niche CD1620 start 7-12-01.csv }\end{array}$ \\
\hline \multicolumn{2}{|c|}{ Evaporation pan data } & (All tests.) & $\begin{array}{c}5 / 2 / 2002 \\
5 / 6 / 2002 \\
5 / 10 / 2002 \\
5 / 2 / 2002 \\
5 / 6 / 2002\end{array}$ & $\begin{array}{c}5 / 3 / 2002 \\
5 / 10 / 2002 \\
6 / 13 / 2002 \\
5 / 3 / 2002 \\
6 / 13 / 2002\end{array}$ & $\begin{array}{l}\text { Trautz } 2003 \text { ([DIRS 166248], } \\
\text { pp. 187, 192, 193, 198, 199, 203, } \\
220,223,226-230, \text { and 233) }\end{array}$ & $\begin{array}{l}\text { N5 Evap inside start 5-2-02.csv } \\
\text { N5 Evap inside start 5-6-02.csv } \\
\text { N5_Evap_inside_start_5-10-02.csv } \\
\text { N5 Evap out start 5-2-02.csv } \\
\text { N5_Evap_out_start 5-6-02.csv }\end{array}$ \\
\hline \multicolumn{2}{|c|}{$\begin{array}{l}\text { Relative humidity and } \\
\text { temperature inside niche }\end{array}$} & (Pre-tests.) & $\begin{array}{l}12 / 7 / 2000 \\
1 / 23 / 2001 \\
2 / 26 / 2001 \\
3 / 21 / 2001 \\
3 / 22 / 2001 \\
7 / 12 / 2001 \\
7 / 24 / 2001 \\
8 / 25 / 2001\end{array}$ & \begin{tabular}{c|}
$12 / 21 / 2000$ \\
$2 / 26 / 2001$ \\
$3 / 21 / 2001$ \\
$3 / 22 / 2001$ \\
$4 / 3 / 2001$ \\
$7 / 24 / 2001$ \\
$8 / 25 / 2001$ \\
$9 / 12 / 2001$
\end{tabular} & $\begin{array}{l}\text { Trautz } 2001 \text { ([DIRS 156903], } \\
\text { p. 47.) } \\
\text { and } \\
\text { Trautz } 2001 \text { ([DIRS 161208], } \\
\text { pp. 90-91, 116, 134-135, 143, 158, } \\
\text { 190-195, 219-221, and 298-299) }\end{array}$ & $\begin{array}{l}\text { N51-23.csv } \\
\text { N52-26.csv } \\
\text { N53-21.csv } \\
\text { N54-3-01.csv } \\
\text { N54-3.csv } \\
\text { N57-24.csv } \\
\text { N58-25.csv } \\
\text { N59-12.csv }\end{array}$ \\
\hline \multicolumn{2}{|c|}{$\begin{array}{l}\text { Relative humidity and } \\
\text { temperature inside and outside } \\
\text { niche, and liquid } \\
\text { pressure in release lines } \\
\end{array}$} & (All tests.) & $\begin{array}{l}5 / 2 / 2002 \\
5 / 2 / 2002 \\
5 / 2 / 2002 \\
5 / 2 / 2002 \\
\end{array}$ & $\begin{array}{c}5 / 6 / 2002 \\
5 / 9 / 2002 \\
5 / 22 / 2002 \\
6 / 3 / 2002 \\
\end{array}$ & $\begin{array}{l}\text { Trautz } 2003 \text { ([DIRS 166248], } \\
\text { pp. 162-164, 170-171, 186, 188-190, } \\
\text { 192, 197, 210, 220-222, 226-230, } \\
\text { and 233) }\end{array}$ & $\begin{array}{l}\text { N5_RH-T-P_5-6-02.csV } \\
\text { N5_RH-T-p_5-9-02.csv } \\
\text { N5_RH-T-p_5-22-02.csV } \\
\text { N5_RH-T-p_6-3-02.csV }\end{array}$ \\
\hline$\# 3$ & $6.40-6.70$ & Test\#1 7-16-02 & $7 / 16 / 2002$ & $8 / 14 / 2002$ & $\begin{array}{l}\text { Trautz } 2003 \text { ([DIRS 166248], } \\
\text { pp. 154-159, 162-164, 170-183, 201, } \\
239-258,262-273, \text { and 297-301) }\end{array}$ & $\begin{array}{l}\text { Test\#1_BH\#3_21-22_ft_7-16-02_\#1.csv } \\
\text { Test\#1_BH\#3_21-22_ft_7-16-02_\#1 (seep).csv } \\
\text { Test\#1_BH\#3_21-22_ft_7-16-02_\#1 (smass).csv } \\
\text { Test\#1_BH\#3_21-22_ft_7-16-02_\#1 (srate).csv }\end{array}$ \\
\hline
\end{tabular}


Table C-1. Source of Data for Post-Excavation Seepage Tests at Niche 5 (Niche CD 1620) (Continued)

\begin{tabular}{|c|c|c|c|c|c|c|}
\hline \multirow{2}{*}{$\begin{array}{c}\text { Borehole or } \\
\text { Data Description } \\
\end{array}$} & \multirow[b]{2}{*}{ Depth (m) } & \multirow[b]{2}{*}{ Test Name } & \multirow[b]{2}{*}{ Start Date } & \multirow[b]{2}{*}{ End Date } & \multicolumn{2}{|c|}{ Source of Data } \\
\hline & & & & & Scientific Notebook & Filename \\
\hline$\# 3$ & $6.40-6.70$ & Test \#1 8-14-02 & $8 / 14 / 2002$ & $8 / 26 / 2002$ & $\begin{array}{l}\text { Trautz } 2003 \text { ([DIRS 166248], } \\
\text { pp. 154-159, 162-164, 170-183, 201, } \\
239-258,273-285, \text { and } 297-301)\end{array}$ & $\begin{array}{l}\text { Tes\#1_BH\#3_21-22_ft_8-14-02_\#1.csv } \\
\text { Test\#1_BH\#3_21-22_ft_8-14-02_\#1 (seep).csv } \\
\text { Test\#1_BH\#3_21-22_ft_8-14-02_\#1 (smass).csv } \\
\text { Test\#1_BH\#3_21-22_ft_8-14-02_\#1 (srate).csv } \\
\text { Test\#1_BH\#3_21-22_ft_8-14-02_\#2.csv } \\
\text { Test\#1_BH\#3_21-22_ft_8-14-02_\#2 (seep).csv } \\
\text { Test\#1_BH\#3_21-22_ft_8-14-02_\#2 (smass).csv } \\
\text { Test\#1_BH\#3_21-22_ft_8-14-02_\#2 (srate).csv }\end{array}$ \\
\hline$\# 5$ & $8.53-8.83$ & Test \#1 7-15-02 & $7 / 15 / 2002$ & $8 / 26 / 2002$ & $\begin{array}{l}\text { Trautz } 2003 \text { ([DIRS 166248], } \\
\text { pp.154-159, 162-164, 170-183, 201, } \\
\text { 239-262, 267-273, 275-285. } \\
\text { and 297-301) }\end{array}$ & \begin{tabular}{|l} 
Test\#1_b5_28-29_ft_7-15-02_\#1.csv \\
Test\#1_b5_28-29_ft_7-15-02_\#1_(seep).csv \\
Test\#1_b5_28-29_ft_7-15-02_\#1_(smass).csv \\
Test\#1_b5_28-29_ft_7-15-02_\#1_(srate).csv \\
Test\#1_b5_28-29_ft_7-15-02_\#2.csv \\
Test\#1_b5_28-29_ft_7-15-02_\#2 (seep).csv \\
Test\#1_b5_28-29_ft_7-15-02_\#2 (smass).csv \\
Test\#1_b5_28-29_ft_7-15-02_\#2 (srate).csv
\end{tabular} \\
\hline \multicolumn{2}{|c|}{$\begin{array}{l}\text { Evaporation pan } \\
\text { data inside and outside } \\
\text { Niche } 5 \text { (Niche CD 1620) }\end{array}$} & (Pre-tests.) & $\begin{array}{c}7 / 2 / 2002 \\
7 / 3 / 2002 \\
6 / 27 / 2002 \\
7 / 3 / 2002\end{array}$ & $\begin{array}{c}7 / 3 / 2002 \\
7 / 15 / 2002 \\
7 / 3 / 2002 \\
7 / 16 / 2002\end{array}$ & $\begin{array}{l}\text { Trautz } 2003 \text { ([DIRS 166248], } \\
\text { pp. 242, 244-246, 260, 263, } \\
\text { and 272-273) }\end{array}$ & $\begin{array}{l}\text { N5_Evap_inside_start_7-2-02.csv } \\
\text { N5_Evap_inside_start_7-3-02.csv } \\
\text { N5_Evap_out_start 6-27-02.csv } \\
\text { N5_Evap_out_start_7-3-02.csv }\end{array}$ \\
\hline \multicolumn{2}{|c|}{$\begin{array}{l}\text { Evaporation pan } \\
\text { data inside and outside } \\
\text { Niche } 5 \text { (Niche CD 1620) }\end{array}$} & (During tests.) & $\begin{array}{l}7 / 15 / 2002 \\
7 / 15 / 2002 \\
7 / 16 / 2002 \\
8 / 13 / 2002 \\
8 / 14 / 2002 \\
8 / 23 / 2002 \\
\end{array}$ & $\begin{array}{l}7 / 15 / 2002 \\
8 / 26 / 2002 \\
8 / 12 / 2002 \\
8 / 14 / 2002 \\
8 / 22 / 2002 \\
8 / 26 / 2002 \\
\end{array}$ & $\begin{array}{l}\text { Trautz } 2003 \text { ([DIRS 166248], } \\
\text { pp. 240-241, 247-250, 258, 260, 263, } \\
265,272-274,281-282 \text {, and 283-285) }\end{array}$ & $\begin{array}{l}\text { Test\#1_b5_28-29_ft_7-15-02_\#1.csv } \\
\text { Test\#1_b5_28-29_ft_7-15-02_\#2.csv } \\
\text { Test\#1_BH\#3_21-22_ft_7-16-02_\#1.csv } \\
\text { Test\#1_BH\#3_21-22_ft_8-13-02_\#1.csv } \\
\text { Test\#1_BH\#3_21-22_ft_8-14-02_\#1.csv } \\
\text { Test\#1_BH\#3_21-22_ft_8-14-02_\#2.csv }\end{array}$ \\
\hline \multicolumn{2}{|c|}{$\begin{array}{l}\text { Relative humidity and } \\
\text { temperature inside and } \\
\text { outside niche, and liquid } \\
\text { pressure in release lines }\end{array}$} & (All tests.) & $7 / 3 / 2002$ & $8 / 19 / 2002$ & $\begin{array}{l}\text { Trautz } 2003 \text { ([DIRS 166248], } \\
\text { pp. 162-164, 170-171, 186, 188-190, } \\
\text { 220-222, 224-226, 239-243, 245, } \\
278,280-281, \text { and 297-299) }\end{array}$ & N5_RH-T-p_8-19-02.csv \\
\hline
\end{tabular}


Table C-1. Source of Data for Post-Excavation Seepage Tests at Niche 5 (Niche CD 1620) (Continued)

\begin{tabular}{|c|c|c|c|c|c|c|}
\hline \multirow{2}{*}{$\begin{array}{c}\text { Borehole or Data } \\
\text { Description }\end{array}$} & \multirow[b]{2}{*}{ Depth (m) } & \multirow[b]{2}{*}{ Test Name } & \multirow[b]{2}{*}{ Start Date } & \multirow[b]{2}{*}{ End Date } & \multicolumn{2}{|c|}{ Source of Data } \\
\hline & & & & & Scientific Notebook & Filename \\
\hline$\# 4$ & $6.40-6.70$ & Test\#1 9-17-02 & 9/17/2002 & $10 / 1 / 2002$ & $\begin{array}{l}\text { Trautz } 2003 \text { ([DIRS 166248], } \\
\text { pp.154-159, 162-163, 165, 170-183, } \\
\text { 243-245, 284, and 287) } \\
\text { and } \\
\text { Trautz 2001 ([DIRS 161208], } \\
\text { pp. 14-15, 18-41, 54-56, 61-62, and 65) }\end{array}$ & $\begin{array}{l}\text { Test\#1_BH\#4_10-11_ft_9-17-02_\#1.csv } \\
\text { Test\#1_BH\#4_10-11_ft_9-17-02_\#1a_(seep).csv } \\
\text { Test\#1_BH\#4_10-11_ft_9-17-02_\#1a_(smass).csv } \\
\text { Test\#1_BH\#4_10-11_ft_9-17-02_\#1a_(srate).csv } \\
\text { Test\#1_BH\#4_10-11_ft_9-17-02_\#2_(seep).csv } \\
\text { Test\#1_BH\#4_10-11_ft_9-17-02_\#2_(smass).csv } \\
\text { Test\#1_BH\#4_10-11_ft_9-17-02_\#2_(srate).csv }\end{array}$ \\
\hline$\# 4$ & $6.40-6.70$ & Test \#1 10-1-02 & $10 / 1 / 2002$ & $10 / 28 / 2002$ & $\begin{array}{l}\text { Trautz } 2003 \text { [DIRS 166248], } \\
\text { pp.154-159, 162-163, 165, 170-183, } \\
\text { 243-245, 284, and 287. } \\
\text { Trautz } 2001 \text { [DIRS 161208], } \\
\text { pp. 14-15, 18-40, 42-60, 63-66. }\end{array}$ & Test\#1_BH\#4_10-11_ft_9-17-02_\#1.csv \\
\hline$\# 5$ & $8.53-8.83$ & Test \#2 9-17-02 & $9 / 17 / 2002$ & $10 / 28 / 2002$ & $\begin{array}{l}\text { Trautz } 2003 \text { [DIRS 166248], } \\
\text { pp.154-159, 162-163, 165, 170-183, } \\
243-245,284,286-287 . \\
\text { and } \\
\text { Trautz } 2001 \text { ([DIRS 161208], } \\
\text { pp. 14-17, 20-41, 43-47, 49-53, 55-62, } \\
65, \text { and 67) }\end{array}$ & $\begin{array}{l}\text { Test\#2_b5_20-21_ft_9-17-02_\#2 (seep).csv } \\
\text { Test\#2_b5_20-21_ft_9-17-02_\#2 (smass).csv } \\
\text { Test\#2_b5_20-21_ft_9-17-02_\#2 (srate).csv } \\
\text { Test\#2_b5_20-21_ft_9-17-02_\#1.csv } \\
\text { Test\#2_b5_20-21_ft_9-17-02_\#1a (seep).csv } \\
\text { Test\#2_b5_20-21_ft_9-17-02_\#1a (smass).csv } \\
\text { Test\#2_b5_20-21_ft_9-17-02_\#1a (srate).csv }\end{array}$ \\
\hline \multicolumn{2}{|c|}{$\begin{array}{l}\text { Evaporation pan } \\
\text { data inside and outside } \\
\text { Niche } 5 \text { (Niche CD 1620) }\end{array}$} & (All tests.) & $9 / 17 / 2002$ & $10 / 28 / 2002$ & $\begin{array}{l}\text { Trautz } 2003 \text { ([DIRS 166248], } \\
\text { pp. 240-241, 247-250, 260, 263, 265, } \\
\text { 272-274, 281-282, and 283-285) } \\
\text { Trautz 2001 ([DIRS 161208], } \\
\text { pp. 14-19, 28, 41-42, 45-46, 55-56, and 59) }\end{array}$ & \begin{tabular}{|l} 
Test\#1_BH\#4_10-11_ft_9-17-02_\#1.csv \\
Test\#2_b5_20-21_ft_9-17-02_\#1.csv
\end{tabular} \\
\hline \multicolumn{2}{|c|}{$\begin{array}{l}\text { Relative humidity and } \\
\text { temperature inside and } \\
\text { outside niche, and liquid } \\
\text { pressure in release lines }\end{array}$} & (All tests.) & $\begin{array}{c}8 / 20 / 2002 \\
9 / 18 / 2002 \\
10 / 18 / 2002\end{array}$ & $\begin{array}{c}9 / 18 / 2002 \\
10 / 18 / 2002 \\
10 / 29 / 2002\end{array}$ & $\begin{array}{l}\text { Trautz } 2003 \text { [DIRS 166248], } \\
\text { pp. 162-164, 170-171, 186, 188-190, 221- } \\
\text { 222, 224-225, 239-243, 245, 280-281. } \\
\text { Trautz } 2001 \text { ([DIRS 161208], } \\
\text { pp. 16, 18,20, 52, and 54-56) }\end{array}$ & $\begin{array}{l}\text { N5_RH-T-p_9-18-02.csv } \\
\text { N5_RH-T-p_10-18-02.csv } \\
\text { N5_RH-T-p_10-29-02.csv }\end{array}$ \\
\hline
\end{tabular}

Source: DTN: LB0207NICH5LIQ.001 [DIRS 160408], native data file Niche CD1620 data sources: rev 8-9-02.x/s.

DTN: LB0209NICH5LIQ.001 [DIRS 160796], native data file Niche CD1620 data sources: rev 9-13-02 \#2.x/s.

DTN: LB0211NICH5LIQ.001 [DIRS 160792], native data file Niche CD1620 data sources: rev 11-15-02.x/s.

NOTE: csv file extension = comma delimited ASCII formatted file. 


\section{INTENTIONALLY LEFT BLANK}


APPENDIX D

SEEPAGE PARAMETER EVALUATION 


\section{D1. APPROACH TO EVALUATION SEEPAGE PARAMETERS}

Appendix Section D1 describes the approach used to determine seepage parameters. In liquid-release tests for seepage quantification, the saturated conductivities are estimated from air permeability values, the fracture capillarities are estimated from the seepage threshold fluxes, and the water potentials are estimated for the flow paths from the liquid-release interval to the niche ceiling. The following paragraphs discuss the approach used to derive the seepage parameters.

Permeability is an intrinsic parameter that characterizes the resistance (to flow) of the rock medium. Where laboratory test conditions include a well-defined unidirectional flow path through a core specimen, the permeability value is independent of the liquid used in the measurement. In the field conditions associated with localized injections, the flow path followed by the air is different from the flow path followed by the liquid. The following approximations, together with the detailed evaluation in Appendix Section D2, describe the relationship between air permeability and liquid permeability in the niche seepage tests: For locally saturated conditions (such as those found in the immediate vicinity of a liquid-filled borehole interval), the saturated permeability to liquid flow is approximately equal to the permeability measured in air-injection tests; the saturated liquid flux is estimated from the measured air-permeability value and the wetted area of the borehole, as described in Appendix Section D2.

The estimations of saturated liquid permeability are evaluated in Appendix Section D2 through use of available data collected in the niche studies. The evaluation compares the estimated flux values with measured flux values from cases that included evidence that the tested borehole intervals were saturated (as determined by return flow during injection). Where liquid flow occurs primarily through fractures below the borehole interval (as a result of pressure-gradient-driven gravity drainage and air flow into fractures around the borehole interval), the liquid permeability and air permeability represent the effective values of different fracture flow paths. The evaluation of the difference between liquid permeability and air permeability is documented in Appendix Section D2, where it is shown that the saturated liquid permeability is within one order of magnitude of the air permeability.

Gravity-driven flow is considered the primary flow mechanism in fractures with weak capillarity, and liquid fracture flow is described by Darcy's law. Under unsaturated conditions, capillary forces and gravity are the driving mechanisms for flow. Because fracture apertures are much larger than tuff matrix pores, capillarity has much less of an effect on liquid fracture flow than does the effect of gravity. This difference in effects justifies the neglect of fracture capillarity, and the use of gravity gradient, to estimate flux. The small fracture capillarity is evaluated in Section 6.2.2.2.

Philip et al. (1989 [DIRS 105743]) developed an analytical solution that describes the conditions under which water flows from an unsaturated porous medium into a buried cylindrical cavity. The solution is used in Section 6.2.2.2 to compute the sorptive number, $\alpha$, a hydraulic parameter that is related to the strength of the capillary forces exerted by the porous medium. In the approach taken by Philip et al. (1989 [DIRS 105743], pp. 16-18), the approximation of steady downward flow of water through a homogeneous, isotropic, unsaturated porous medium is used. Far from the cavity, the flow velocity is spatially uniform. The flow region is considered infinite 
in extent. These conditions underlie the derivation of Philip's capillary barrier solution. Furthermore, Philip et al. (1989 [DIRS 105743], Section 1.5, p. 17) note that the requirement for homogeneity is relatively weak. Analytic solutions are generally derived, in most cases, with simplified descriptions and approximations regarding the flow domain in the surrounding medium. Results derived from an analytic solution represent effective values. The description, evaluation, and justification of Philip's capillary barrier solution are presented in Section 6.2.2.2.

Braester (1973 [DIRS 106088]) derived a time-dependent solution for the average volumetric-water-content distribution in a porous medium, where water is released from a surface source of constant flux. This solution is described, and used to estimate the volumetric water content of the fractures, in Section 6.2.2.3. The following simplifications were used by Braester (1973 [DIRS 106088]) to derive the solution; a one-dimensional (1-D) formulation of Richards' equation, which includes both gravity- and capillary-driven components of flow, is used to describe flow through an unsaturated porous medium:

The 1-D flow approximation can be evaluated and justified by:

1. the weak fracture capillarity values described in Section 6.2.2.2,

2. the roughly 1-D flow paths observed during niche excavation described in Section 6.2.1.2, and

3. the limited spatial spread of seepage fluxes observed during post-excavation seepage tests described in Section 6.2.1.3.1.

The downward translation of a wetted profile is at constant velocity. The average value of the water content at the infiltrating surface over time is considered by Braester (1973 [DIRS 106088], p. 688) to be equal to the average value of water content over the wetted depth. This approximation becomes valid if the solution of water content takes the form of a downward translation of the entire wetted profile at constant velocity. In general, this would occur after the capillary forces near the source have diminished, and the volumetric water content at the soil surface reaches its steady-state limit, with the gravity gradient driving the liquid flux. The times required to reach steady state, and the evaluations of this requirement( of downward translation of wetted profiles at constant velocity), are also discussed in Appendix Section D3.

\section{D2. COMPARISON OF LIQUID AND AIR-DERIVED SATURATED HYDRAULIC CONDUCTIVITIES}

Appendix Section D2 discusses estimation of saturated hydraulic conductivity using air-permeability (referred to in Section 6.2.2.1, in discussion of seepage thresholds). The liquid-release rate, $Q_{s}[\mathrm{~kg} / \mathrm{s}]$ measured during each test (Section 6.2.1.3.1) was converted to a liquid-release flux, $q_{s}[\mathrm{~m} / \mathrm{s}]$, using the following equation:

$$
q_{s}=\frac{Q_{s}}{A \rho_{w}}
$$


where $A\left[\mathrm{~m}^{2}\right]$ is the cross-sectional area of flow, and $\rho_{w}\left[\mathrm{~kg} / \mathrm{m}^{3}\right]$ is the density of water (set at $1000 \mathrm{~kg} / \mathrm{m}^{3}$ ). The $q_{s}$ data are tabulated in DTN: LB980001233124.004 [DIRS 136583] for the seepage tests conducted at Niche 2 (Niche 3650).

The cross-sectional area was derived from the water level that could rise to a maximum elevation of $0.0635 \mathrm{~m}$ in the borehole (an elevation equivalent to the maximum ponding depth within the borehole). The ponding depth is controlled by the elevation of the liquid-return line, which prevents the buildup of excess pressure in the test interval by allowing water to flow from the test interval to the surface. If water rises to the level of the return line, then wetted area $A$ is less than the surface area of the entire test interval, and equal to that portion of the curved surface area of a right circular cylinder lying below the water line as follows (Selby 1975 [DIRS 106143], pp. 12, 16):

$$
A=[2 \pi-(2 \operatorname{Arccosine}(d / r))] h r
$$

where

$$
\begin{aligned}
& d=\text { the vertical distance from the center of the cylinder to the water line }(0.0254 \mathrm{~m}) . \\
& r=\text { the radius of the borehole }(0.0381 \mathrm{~m}) . \\
& h=\text { the test interval length }(0.3048 \mathrm{~m}) .
\end{aligned}
$$

With these parameters, the cross-sectional area of flow $A$ is equal to $5.343 \times 10^{-2} \mathrm{~m}^{2}$.

With the approach described in Appendix Section D1, estimates of the saturated hydraulic conductivity for liquid flow through the fractured porous medium were obtained by equating the air permeability $(k)$ (derived from the air-injection tests) with the water permeability $\left(k_{l}\right)$ of the porous medium. In turn, $k_{l}$ is related to the saturated hydraulic conductivity $\left(K_{l}\right)$ of a porous medium through the functional relation defined by Darcy's law (Freeze and Cherry 1979 [DIRS 101173], p. 27, Equation (2.28)):

$$
K_{l}=\frac{k_{l} \rho_{w} g}{\mu}
$$

where $g\left[\mathrm{~m} / \mathrm{s}^{2}\right]$ is the acceleration of gravity and $\mu[\mathrm{Pa} \cdot \mathrm{s}]$ is the viscosity of water. Air-permeability values reported in DTN: LB980001233124.004 [DIRS 136583] were converted to the equivalent saturated hydraulic conductivity values $\left(K_{l} \approx K_{\text {air-sat }}\right)$ reported in DTN: LB980901233124.003 [DIRS 105592] as shown in the Scientific Notebook by Wang (1999 [DIRS 153449], p. 38). This conversion permitted a comparison of the $K_{\text {air-sat }}$ values to the $q_{s}$ values, which are also summarized in DTN: LB980901233124.003 [DIRS 105592]. The $q_{s}$ values were computed using Equation D-1 and:

1. the liquid-release rates $\left(Q_{s}\right)$ from the pre-excavation tests performed at Niche 1 (Niche 3566) and Niche 2 (Niche 3650) (DTN: LB980001233124.004 [DIRS 136583]), 
2. the pre-excavation tests performed at Niche 3 (Niche 3107) and Niche 4 (Niche 4788) (DTN: LB980901233124.003 [DIRS 105592]), and

3. the post-excavation seepage tests from Niche 2 (Niche 3650) (DTN: LB980001233124.004 [DIRS 136583]). ${ }^{1}$

Under slightly ponded conditions in the borehole (i.e., saturated conditions), $q_{s}$ may initially exceed the saturated hydraulic conductivity of the test interval during the early stages of the test. During the later stages of the test, gravity-driven flow will dominate, a unit hydraulic gradient will be established near the borehole wall in the porous material, and $q_{s}$ will approach $K_{l}$ for the interval. Based on the approach described in Appendix Section D1, gravity-driven flow is considered the primary flow mechanism in the fracture systems tested at Niche 2 (Niche 3650). Therefore, it is expected that capillary effects are short-lived and, for all practical purposes, the $q_{s}$ for a given interval can be considered equal to $K_{l}$. Theoretically, $q_{s}$ can exceed $K_{l}$ if water ponds to a significant depth or is injected under high pressure, creating a steep hydraulic gradient within the porous material near the borehole wall. However, the packer system used in the seepage tests was designed so that water could not pond more than $0.0635 \mathrm{~m}$, to prevent return flow to the surface from occurring.

Return flow provided direct evidence that the liquid pumping rate exceeded the infiltration capacity of the test interval, implying that $q_{s}=K_{l}$, which in turn should equal $K_{\text {air } \text { sat }}$ (using the approximation that $K_{\text {air-sat }}$ is a reasonable estimate of $K_{l}$ ). The $K_{\text {air-sat }}$ and $q_{s}$ values (from DTN: LB980901233124.003 [DIRS 105592]) of those tests that exhibited return flow are plotted in Figure C-1, which also includes a solid line that represents the relation $K_{\text {air-sat }}=K_{l}=q_{s}$. A data point located above the solid line indicates that $K_{\text {air-sat }}$ can have a value that is greater than $K_{l}$, and a data point below the solid line indicates that $K_{\text {air-sat }}$ can have a value that is less than $K_{l}$.

The data values are expected to fall on the $K_{\text {air-sat }}=q_{s}$ line if air-permeability and liquid-release tests are directly correlated.

Figure D-1 indicates that the data points are equally distributed above and below the $K_{\text {air sat }}=q_{s}$ line, and that the majority of points fall within a factor of 10 of $K_{\text {air-sat }}=q_{s}$. Therefore, the equivalent saturated hydraulic conductivity derived from the air-injection tests appears to approximately characterize the saturated hydraulic conductivity represented by $q_{s}$. The scattering of the individual data points around the line is a measure of estimations, approximations, and experimental uncertainties that have been simplified during the process of relating airflow processes to liquid-flow processes.

${ }^{1}$ The entire cross-sectional area of the borehole was used to compute the air-permeability values reported in DTN: LB980001233124.002 [DIRS 136583] because gravitational effects on air are negligible and, thus, the entire cross-sectional area of the borehole is typically available for airflow. A smaller wetted area, as calculated by Equation D-2, was used to compute the liquid-release flux values. 


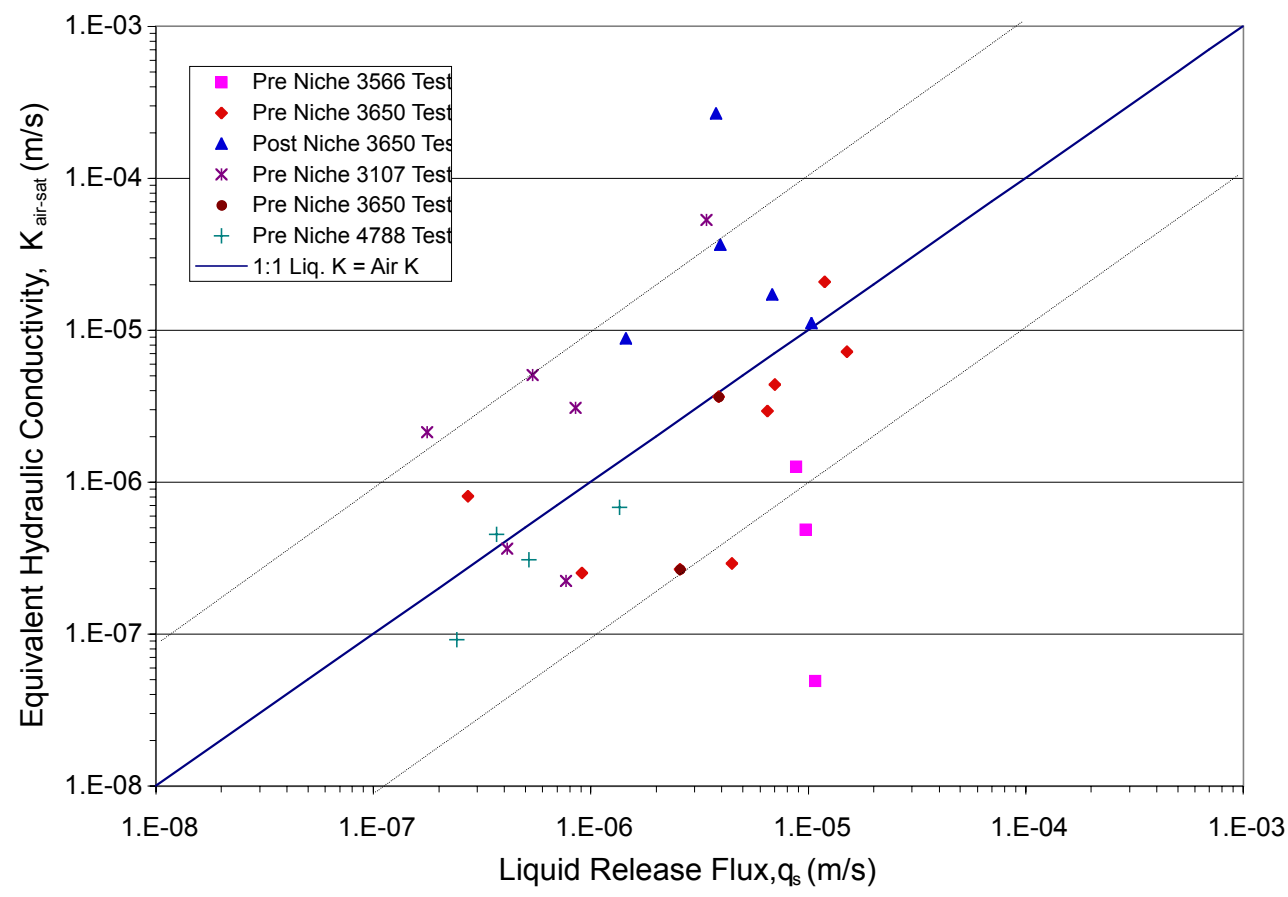

Source: DTN: LB980901233124.003 [DIRS 105592].

NOTE: The thin lines indicate one order of magnitude above and below the line indicating equivalence between liquid and air conductivity.

Figure D-1. Comparison of Liquid and Air-Derived Saturated Hydraulic Conductivities

\section{D3. WATER-CONTENT PROFILE EVALUATION}

\section{D3.1 EVALUATION OF APPROXIMATION OF ONE-DIMENSIONAL (1-D) FLOW}

Appendix Section D3 describes water-content-profile evaluation (referred to in Section 6.2.2.3, in discussion on use of water-content information to estimate water-retention curves in fractures). Large $\alpha$-values calculated in Section 6.2.2.2 indicate that gravity-driven flow predominates in the fractures tested at Niche 2 (Niche 3650). Although the large $\alpha$-values alone do not collectively imply that flow is strictly $1-\mathrm{D}$, they do imply limited lateral spreading of the wetting front in the fractures, because capillary forces will probably be negligible during the early stages of liquid release. Once the wetting front arrives at the niche ceiling, however, capillary forces become very important as water saturations begin to increase because of the capillary barrier, resulting in water being diverted laterally around the cavity. Therefore, flow will change from 1-D to 2-D or 3-D once the wetting front arrives at the ceiling. This implies that the $\theta_{\text {ave }}$ values calculated using Braester's model are no longer valid after the wetting front arrives at the niche ceiling.

Field observations made during the pre-excavation liquid release and post-excavation seepage tests provide evidence that flow is roughly 1-D. Figure 6-25 shows that the average aspect ratio (i.e., the ratio of depth to lateral distance traveled by the wetting front) is slightly less than 2 for the tests that represent fracture networks, and approximately 4.5 for the high-angle fracture data. This implies that, for a $0.65-\mathrm{m}$ travel distance, lateral spreading is expected to be, on average, 
within $0.32 \mathrm{~m}$ of the borehole in the fractured network case, and within $0.15 \mathrm{~m}$ in the near-vertical fracture case. An average angle of wetting-front migration from the vertical can be defined as $\operatorname{Arctan}(0.32 / 0.65)=26^{\circ}$. This analysis is further supported by two field observations made during the post-excavation seepage tests as described in Section 6.2.1.3.1:

1. the majority of water was typically captured in only one or two $0.305-\mathrm{m}-\mathrm{by}-0.305-\mathrm{m}$ cells located directly beneath the test interval, and

2. the wetting front typically arrived at the niche ceiling directly below the test zone.

\section{D3.2 EVALUATION OF APPROXIMATION OF DOWNWARD TRANSLATION OF THE WETTED PROFILE AT CONSTANT VELOCITY}

During infiltration tests, the liquid-release rate approaches an asymptotic value equal to the hydraulic conductivity as time progresses. Moreover, steady moisture conditions are established rather rapidly in the vicinity of the source, typically with a geometric mean of 1.7 hours when water is introduced at a water potential equal to or greater than zero (White and Sully 1987 [DIRS 106152], pp. 1514, 1521). In the liquid-release tests considered here, water was often introduced at a flux that was much lower than the saturated hydraulic conductivity, which led to conditions that were significantly different from those underlying the previous conclusion. Consequently, the solution for unsteady multidimensional infiltration developed by Philip (1986 [DIRS 106133], p. 1725) and summarized by White and Sully (1987 [DIRS 106152], p. 1521) is used to determine the time to steady moisture conditions (which checks the validity of the approach presented in Appendix Section D1, on downward translation of a wetting profile at constant velocity, and determines whether the volumetric water contents presented in Section 6.2.2.3 were derived through use of an appropriate model).

Philip (1986 [DIRS 106133]) developed an analytical solution for unsteady 2-D unsaturated flow from a buried horizontal cylinder into an infinitely porous medium of uniform initial water content $\theta_{n}$. This solution is also assumed to be valid for flow through unsaturated, fractured media. Richards' equation was linearized through the introduction of a diffusivity constant, $D$ (Philip 1986 [DIRS 106133], Equation (1)), and an exponential relation between hydraulic conductivity and water potential (see Equation 6-4 in Section 6.2.2.2). Philip (1986 [DIRS 106133], p. 1719) found that, regardless of the cavity shape and dimensionality of the flow field, the solution for dimensionless potential $(\vartheta)$ is approximately reducible to the product of the steady solution $\left(\vartheta_{\infty}\right)$ and G (the degree of approach to the steady moisture condition, $\vartheta_{\infty}$ ). Initially, G is zero everywhere (Philip 1986 [DIRS 106133], Figure 1); it approaches a value of 1 rapidly near the source, and slowly far from the source and at very large dimensionless times. The unsteady solution approaches the steady solution as G approaches a value of 1 everywhere.

Using the same approach that Philip used for a spherical source (Philip 1986 [DIRS 106133], Section 8 , p. 1725), the time required $\left(t_{D} 95 \%\right)$ to obtain 95 percent of the steady-state moisture conditions (that is, $\mathrm{G}=0.95$ ) for flow from a buried horizontal cylinder was computed. This time was calculated for a point slightly outside the borehole $\left(r_{D}=1.1\right)$, and for a point on the niche ceiling $\left(r_{D}=17.1=0.65 \mathrm{~m} / 0.0381 \mathrm{~m}\right)$. The details of the analysis can be found in Scientific Notebook YMP-LBNL-JSW-6c (Wang 1999 [DIRS 153449], pp. 85-91) and the $t_{D} 95 \%$ 
values are tabulated in DTN: LB980901233124.003 [DIRS 105592] for each group of tests where seepage was observed.

The dimensional time $\left(t_{95 \%}\right)$ at which the moisture profile reaches 95 percent of its steady value can be calculated using $t_{D} 95 \%$ (Philip 1986 [DIRS 106133], p. 1718, Equation (15)). The details of the analysis can be found in the Scientific Notebook by Wang (1999 [DIRS 153449], pp. 91-92) and the $t_{95 \%}$ values are tabulated in Table D-1 and DTN: LB980901233124.003 [DIRS 105592], along with the arrival time of the wetting front at the niche ceiling.

Examination of the $t_{95} \%$ values in Table D-1 indicates that, for all the tests, near-steady-state moisture conditions (i.e., constant $\theta$ ) are reached near the borehole wall within 6 minutes (344 s) of the start of the test, and before pumping ceased (pumping times are tabulated in DTN: LB980001233124.004 [DIRS 136583]). In addition, for all tests of individual fractures or small groups of vertical fractures, the observed time to the arrival of the wetting front was similar to the calculated $t_{95 \%}$ for $\mathrm{r}_{\mathrm{D}}=17.1$; and, for all tests (except Test $\# 2$ in borehole UR), the observed time to the arrival of the wetting front was between 59 percent and 71 percent of the calculated $t_{95 \%}$ for $\mathrm{r}_{\mathrm{D}}=17.1$.

This similarity between the observed and estimated wetting-front travel times supports the approximation (used in Section 6.2.2.3) that downward translation of the wetting profile is at constant velocity. That is, $q_{s}$ approached the saturated hydraulic conductivity of the fractured media, which resulted in the downward migration of the wetted profile at a constant velocity within the time limit of each test. In addition, in all cases, steady-state moisture conditions are obtained near the borehole prior to the arrival of the wetting front. After the wetting front has arrived at the ceiling, the moisture conditions again begin to change near the release borehole, as the water saturation increases because of the capillary barrier.

Based on this analysis, the use of Equation 6-9 in Section 6.2.2.3 (to estimate the change of volumetric water contents) appears to be reasonable.

Table D-1. Time to Steady-State Moisture Conditions

\begin{tabular}{|c|c|c|c|c|c|c|}
\hline \multirow[b]{2}{*}{ Borehole } & \multirow[b]{2}{*}{ Test Name } & \multirow[b]{2}{*}{ Test Date } & \multirow[b]{2}{*}{$\begin{array}{l}\text { Test Interval } \\
\text { (m) }\end{array}$} & \multicolumn{2}{|c|}{ Time to Steady State ${ }^{1}$} & \multirow{2}{*}{$\begin{array}{l}\text { Wetting Front }{ }^{2} \\
\text { Arrival Time } \\
\text { (hr) }\end{array}$} \\
\hline & & & & $\begin{array}{c}r_{D}=1.1 \\
(h r)\end{array}$ & $\begin{array}{c}r_{D}=17.1 \\
(h r)\end{array}$ & \\
\hline \multicolumn{7}{|c|}{ Fracture Networks } \\
\hline \multirow[t]{2}{*}{ UR } & Test \#1 1-15-98 & $1 / 15 / 98$ & $4.88-5.18$ & 0.0129 & 0.691 & 0.497 \\
\hline & Test \#1 2-6-98 & $2 / 6 / 98$ & $4.88-5.18$ & 0.0317 & 1.696 & 1.221 \\
\hline \multirow[t]{2}{*}{ UL } & Test \#1 12-10-97 & $12 / 10 / 97$ & $7.01-7.32$ & 0.0012 & 0.127 & 0.067 \\
\hline & Test \#1 1-6-98 & $1 / 6 / 98$ & $7.01-7.32$ & 0.0160 & 1.740 & 0.914 \\
\hline \multirow[t]{2}{*}{ UR } & Test \#1 1-14-98 & $1 / 14 / 98$ & $4.27-4.57$ & 0.0200 & 1.580 & 0.936 \\
\hline & Test \#1 2-5-98 & $2 / 5 / 98$ & $4.27-4.57$ & 0.0590 & 4.650 & 2.753 \\
\hline
\end{tabular}


Table D-1. Time to Steady-State Moisture Conditions (Continued)

\begin{tabular}{|c|c|c|c|c|c|c|}
\hline \multirow[b]{2}{*}{ Borehole } & \multirow[b]{2}{*}{ Test Name } & \multirow[b]{2}{*}{ Test Date } & \multirow[b]{2}{*}{$\begin{array}{l}\text { Test Interval } \\
\text { (m) }\end{array}$} & \multicolumn{2}{|c|}{ Time to Steady State ${ }^{1}$} & \multirow{2}{*}{$\begin{array}{l}\text { Wetting Front }{ }^{2} \\
\text { Arrival Time } \\
\text { (hr) }\end{array}$} \\
\hline & & & & $\begin{array}{c}r_{D}=1.1 \\
(h r)\end{array}$ & $\begin{array}{c}r_{D}=17.1 \\
(h r)\end{array}$ & \\
\hline \multicolumn{7}{|c|}{ Fracture Networks (Continued) } \\
\hline \multirow[t]{5}{*}{ UM } & Test 5 Niche 3650 & $11 / 13 / 97$ & $4.27-4.57$ & 0.0030 & 0.163 & 0.116 \\
\hline & Test 5 Niche 3650 & $12 / 3 / 97$ & $4.27-4.57$ & 0.0072 & 0.396 & 0.280 \\
\hline & Test \#2 12-3-97 & $12 / 3 / 97$ & $4.27-4.57$ & 0.0037 & 0.202 & 0.143 \\
\hline & Test \#1 1-7-98 & $1 / 7 / 98$ & $4.27-4.57$ & 0.0630 & 3.458 & 2.448 \\
\hline & Test \#2 2-10-98 & $2 / 10 / 98$ & $4.27-4.57$ & 0.0957 & 5.249 & 3.700 \\
\hline \multirow[t]{4}{*}{ UM } & Test 4 Niche 3650 & $11 / 13 / 97$ & $5.49-5.79$ & 0.0014 & 0.088 & 0.058 \\
\hline & Test \#2 12-4-97 & $12 / 4 / 97$ & $5.49-5.79$ & 0.0028 & 0.178 & 0.117 \\
\hline & Test \#1 1-9-98 & $1 / 9 / 98$ & $5.49-5.79$ & 0.0186 & 1.164 & 0.764 \\
\hline & Test \#1 2-11-98 & $2 / 11 / 98$ & $5.49-5.79$ & 0.0684 & 4.289 & 2.800 \\
\hline \multirow[t]{2}{*}{ UR } & Test \#2 1-13-98 & $1 / 13 / 98$ & $5.49-5.79$ & 0.0005 & 0.527 & 0.150 \\
\hline & Test \#2 2-10-98 & $2 / 10 / 98$ & $5.49-5.79$ & 0.0002 & 0.224 & 0.064 \\
\hline \multicolumn{7}{|c|}{ Individual or Small Groups of Vertical Fractures } \\
\hline \multirow[t]{5}{*}{ UM } & Test 1 Niche 3650 & $11 / 12 / 97$ & $4.88-5.18$ & 0.0007 & 0.051 & 0.050 \\
\hline & Test \#1 12-4-97 & $12 / 4 / 97$ & $4.88-5.18$ & 0.0011 & 0.085 & 0.083 \\
\hline & Test \#2 12-5-97 & $12 / 5 / 97$ & $4.88-5.18$ & 0.0035 & 0.272 & 0.264 \\
\hline & Test \#1 1-8-98 & $1 / 8 / 98$ & $4.88-5.18$ & 0.0225 & 1.729 & 1.683 \\
\hline & Test \#1 3-6-98 & $3 / 6 / 98$ & $4.88-5.18$ & 0.0807 & 6.189 & 6.025 \\
\hline \multirow[t]{3}{*}{ UR } & Test \#1 1-13-98 & $1 / 13 / 98$ & $6.71-7.01$ & 0.0018 & 0.122 & 0.116 \\
\hline & Test \#1 2-3-98 & $2 / 3 / 98$ & $6.71-7.01$ & 0.0027 & 0.184 & 0.174 \\
\hline & Test \#1 3-5-98 & $3 / 5 / 98$ & $6.71-7.01$ & 0.0195 & 1.307 & 1.238 \\
\hline \multirow[t]{3}{*}{ UL } & Test \#2 1-6-98 & $1 / 6 / 98$ & $7.62-7.92$ & 0.0029 & 0.201 & 0.192 \\
\hline & Test \#1 2-12-98 & $2 / 12 / 98$ & $7.62-7.92$ & 0.0024 & 0.166 & 0.158 \\
\hline & Test \#1 3-4-98 & $3 / 4 / 98$ & $7.62-7.92$ & 0.0111 & 0.761 & 0.725 \\
\hline \multirow[t]{2}{*}{ UR } & Test \#2 1-14-98 & $1 / 14 / 98$ & $6.10-6.40$ & 0.0030 & 0.267 & 0.267 \\
\hline & Test \#1 2-4-98 & 2/4/98 & $6.10-6.40$ & 0.0116 & 1.046 & 1.043 \\
\hline
\end{tabular}

NOTES: ${ }^{1}$ Source: DTN: LB980901233124.003 [DIRS 105592].

2 Source: DTN: LB980001233124.004 [DIRS 136583]. 
APPENDIX E

LABORATORY MEASUREMENTS OF RETARDATION AND FRONT SEPARATION 


\section{E1. WATER IMBIBITION LABORATORY TESTS}

Laboratory analyses described in this appendix pertain to dyed samples collected from the niches, and core samples for tracer retardation and front separation measurements. Rock cores $5.08 \mathrm{~cm}$ in diameter and $2.0 \mathrm{~cm}$ in length were used for the imbibition experiments, to examine tracer penetration into the unsaturated rock matrix. Cores were cut and machined from a clean sample block that was taken from the same stratigraphic unit as the niche locations in which tracer release tests were conducted. Porosity, bulk-density, and particle-density measurements were based on the core dry weight (dried at $\left.60^{\circ} \mathrm{C}\right)$.

Partial saturation of cores was achieved by equilibrating cores within relative humidity chambers controlled by various saturated brines and/or water, until they reached constant weights. Cores with two different levels of initial water saturation $\left(\mathrm{S}_{\mathrm{w}}\right)$ (approximately 15 percent and 80 percent) were used to investigate and compare tracer penetration behavior with respect to saturation levels.

The core was hung inside a humidity-controlled chamber, with the core bottom submerged (to a depth of approximately $1 \mathrm{~mm}$ ) in a water reservoir containing tracers. The core weight gain was continuously recorded by a data acquisition system. The water contained approximately $10 \mathrm{~g} / \mathrm{L} \mathrm{LiBr}, 1 \mathrm{~g} / \mathrm{L}$ FD\&C Blue No. 1, and $1 \mathrm{~g} / \mathrm{L}$ Sulpho Rhodamine B. These tracers were selected to compare the behavior of nonreactive bromide to the behavior of the dyes used in the field tracer work. The study was designed to simulate the imbibition and penetration of tracers into the matrix from a continuously flowing fracture. After a predetermined period of time (approximately 16 to 20 hours), the core was lifted out of the reservoir, and the moisture front was examined. Rock sampling was immediately conducted as described In Section E2.

\section{E2. ROCK SAMPLING AND TRACER EXTRACTION}

The cuttings obtained by drilling into tracer-stained rock samples to a specified depth were collected and eluted, and the supernatant was analyzed to profile tracer location and concentration. A mill (Bridgeport Series II) (Hu 1999 [DIRS 156540], pp. 37-38) was used for drilling. The rock sample was immobilized on the working platform, and, except for the area to be drilled, the rock surface was covered with tape. A series of drill bits of different sizes (with flat-bottom, carbide-end mill cutters) were used to sample different depths of the same area of the sample. The largest drill bit was used for the rock-surface drilling, and the bit size gradually decreased with increased drilling depth, to minimize carry-over powder contamination from previous depths. A tube was placed around the carbide-end mill cutter to reduce powder loss and to maximize sample recovery. The drilling was carried out slowly and steadily, in 1-mm increments; a Mitutoyo digital caliper (precision $0.01 \mathrm{~mm}$ ) was used to measure the increments.

A stainless steel needle (attached to a stainless steel filter holder, connected to a vacuum source) was used to collect drill cuttings at each 1-mm increment. The vacuum intensity was tested and adjusted before samples were collected. Two pieces of cellulose nitrate membrane (with a membrane pore size of $0.45 \mu \mathrm{m}$ ) were used inside the filter holder, to trap the sample powder. (The powder was suctioned and trapped into the collection device by pointing the needle at the drilled hole, and applying the vacuum.) Collected cuttings were transferred to an amber-glass vial before tracer extraction occurred. Before drilling the next interval, the drilled hole was 
cleaned using an air stream just strong enough to remove any powder that might be left from the collection, and the cutter was cleaned with premoistened wipes and dried with a gentle air stream.

Laboratory samples, and three dye-stained field-sample rocks that had a flat face, were selected for rock drilling (the flat surfaces with dye stains were approximated to be fracture surfaces of active flow paths induced by dye-water releases). No visible fracture coatings were observed on the three field samples.

For the laboratory studies, samples of cylinder-shaped machined cores were taken from both the top and bottom of the core. Samples were taken first from the top, which was the cleaner side (i.e., it was the core side that was not in physical contact with liquid), to $16 \mathrm{~mm}$. Samples were then taken from the bottom, to $10 \mathrm{~mm}$. This sampling scheme allowed a comparison and evaluation of powder contamination of the drilling method. Drilling from the two sides was conducted so that the drill holes did not intersect each other.

Dye tracers were extracted from the drill cuttings into the aqueous phase by mixing (nominally for 15 seconds) $5 \mathrm{~mL}$ Nanopure water with $0.1 \mathrm{~g}$ of powder sample, at the speed of 1,400 rpm. The mixture was then filtered, and the concentration of the tracer in the clear aqueous phase was measured. Either a Gelman Supor ${ }^{\circledR}$ hydrophilic polyethersulfone membrane filter or a Whatman cellulose nitrate membrane was used for the filtration. Testing showed negligible mass loss to both membranes for FD\&C Blue No. 1 and Sulpho Rhodamine B.

Extraction efficiency was evaluated by spiking a known amount of tracers into the rock powder (less than $104 \mu \mathrm{m}$ fraction) for one day. The results showed an extraction efficiency of:

- $98.0 \pm 4.6$ percent (average plus and minus standard deviation, 5 replicates) for bromide.

- $94.1 \pm 3.8$ percent for FD\&C Blue No. 1 (6 replicates).

- $55.2 \pm 0.7$ percent for Sulpho Rhodamine B (7 replicates).

The extraction procedure was not designed to be exhaustive for the maximum mass extraction. Relative comparisons with identical procedures were used in this study.

\section{E3. MEASUREMENT OF AQUEOUS TRACER CONCENTRATION}

The aqueous concentration of FD\&C Blue No. 1 dye was measured using a UV/vis Spectrophotometer (Hitachi, Model U-2001) at the characteristic wavelength of $630 \mathrm{~nm}$. Sulpho Rhodamine B concentration was measured using a Spectrofluorophotometer (Shimadzu, Model RF-1501) at the excitation wavelength of $565 \mathrm{~nm}$ and emission wavelength of $590 \mathrm{~nm}$. Depending upon the tracer concentration present in the samples, samples were diluted appropriately until the final solution measurement fell into the linear range of the calibration curve.

Bromide concentration was measured by Ion Specific Electrode (Orion, Ionplus design) with the addition of an ion strength adjuster that had a volume ratio of 50:1. Background levels for all tracers were measured through use of powder from clean tuff samples. The clean powder was obtained from a clean rock sample that was crushed for size reduction to pass through a $104 \mu \mathrm{m}$ 
opening sieve, similar to the powder size of the drill cuttings. Refer to the associated scientific notebook pages (Hu 1999 ([DIRS 156540], pp. 20-22, 37-48, 54, 68-82, 86-99, and 103-126); $\mathrm{Hu} 1999$ ([DIRS 156541], pp. 9, 27, 42, 77, 118, 123-140, and 149); and $\mathrm{Hu} 1999$ ([DIRS 156542], pp. 13, 17-25, 39-41, 51-102, and 105-112)) for detailed entries about instrument calibration and tracer measurements.

\section{E4. EVALUATION OF DRILLING TECHNIQUE}

Tracer cross-contamination during drilling was evaluated by drilling for machined cores from both the top and bottom of the selected rock samples. For both drilling directions, measured tracer concentrations were compared over distance, as noted in Figure E-1 (for Core D with lower initial water saturation $\mathrm{S}_{\mathrm{w}}$ ) and Figure E-2 (for Core $\mathrm{H}$ with high initial $\mathrm{S}_{\mathrm{w}}$ ). Note that the core bottom was the core side in physical contact with the tracer solution. For the lower $\mathrm{S}_{\mathrm{w}}$ case, the tracer concentration was comparable for both drilling directions, and showed no significant powder carryover (Panels a and b of Figure E-1). A slight difference at the 4-to-5-mm interval is observed in Panel b of Figure E-1 for Sulpho Rhodamine B. This difference could be real, because the fluorometer that was used for measurement had a low detection limit of approximately $0.021 \mathrm{mg} / \mathrm{kg}$. Overall, the drilling technique yielded reliable concentration profile results.

For the case with the higher initial $S_{w}$, the difference in concentration between the two drilling directions is measurable (Panel a of Figure E-2). After the tracer-rock contact and experiments were completed, the drilling was conducted from the core top (cleaner side) first, and was then conducted from the bottom after the core was inverted. Drilling and sample collection for 10 depth intervals was completed in approximately one hour. The difference in concentrations shown in Panel a of Figure E-2 for the two drilling directions may have resulted from any one or a combination of:

- Gravitational flow during the second drilling phase,

- Heterogeneity,

- Flow resulting from exposure to the atmosphere,

- Evaporation loss resulting from heating caused by drilling.

The spreading of the tracer front at the high initial $S_{w}$ made the flow redistribution effects more pronounced than was the case with the sharp tracer front at the low initial $\mathrm{S}_{\mathrm{w}}$. For Sulpho Rhodamine B, the difference was less evident (Panel b of Figure E-2). In the data evaluation, results from the core top were used if the necessary data were available. 

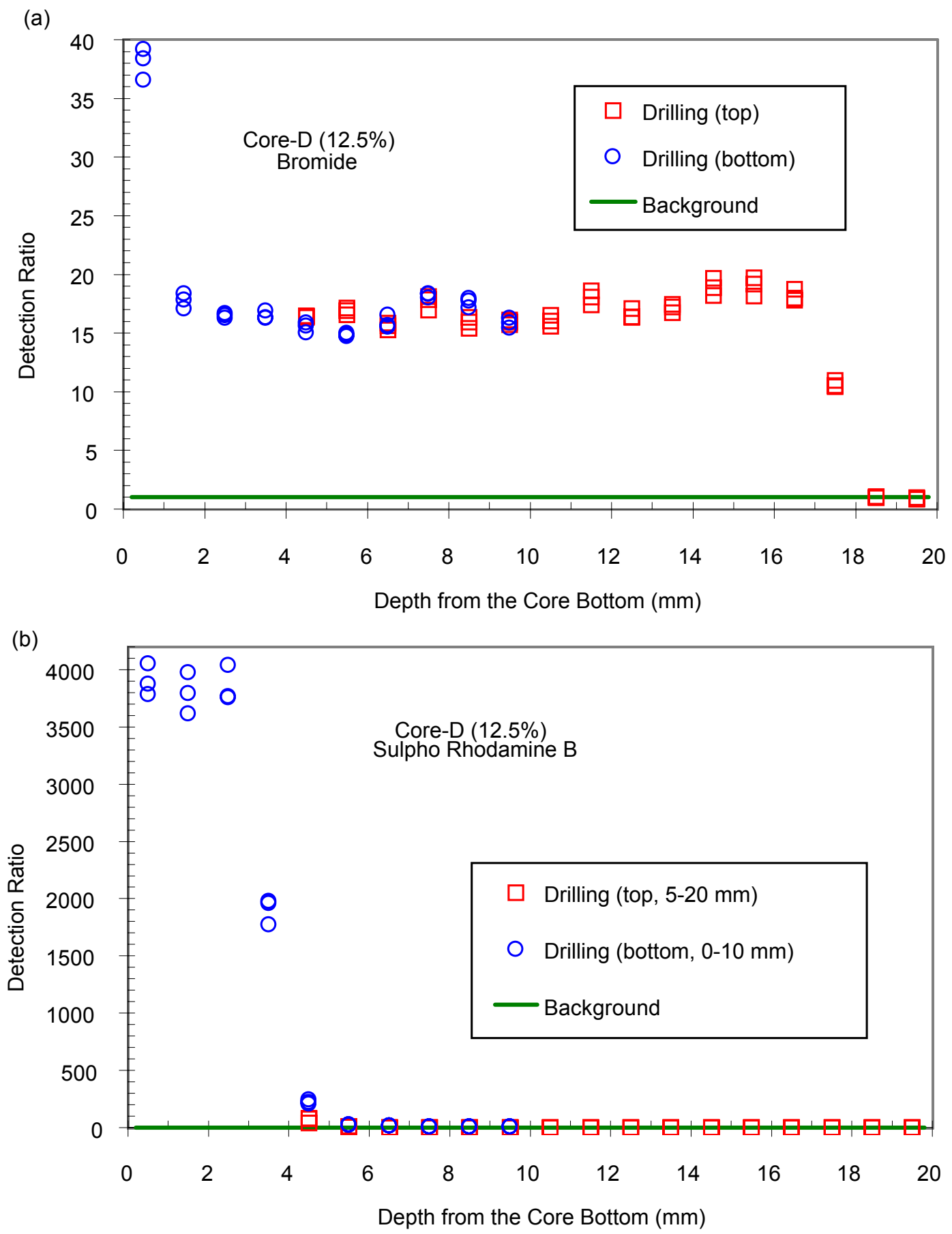

Source: DTN: LB990901233124.003 [DIRS 155690].

NOTES: The core ID and the initial core saturation (in parentheses) are presented in the panels of the figure. Panel $a=$ Bromide.

Panel $b=$ Sulpho Rhodamine B.

Figure E-1. Comparison of Measured Detection Ratio from the Opposite Drilling Directions for Core D with Lower Initial $\mathrm{S}_{\mathrm{w}}$ 
(a)

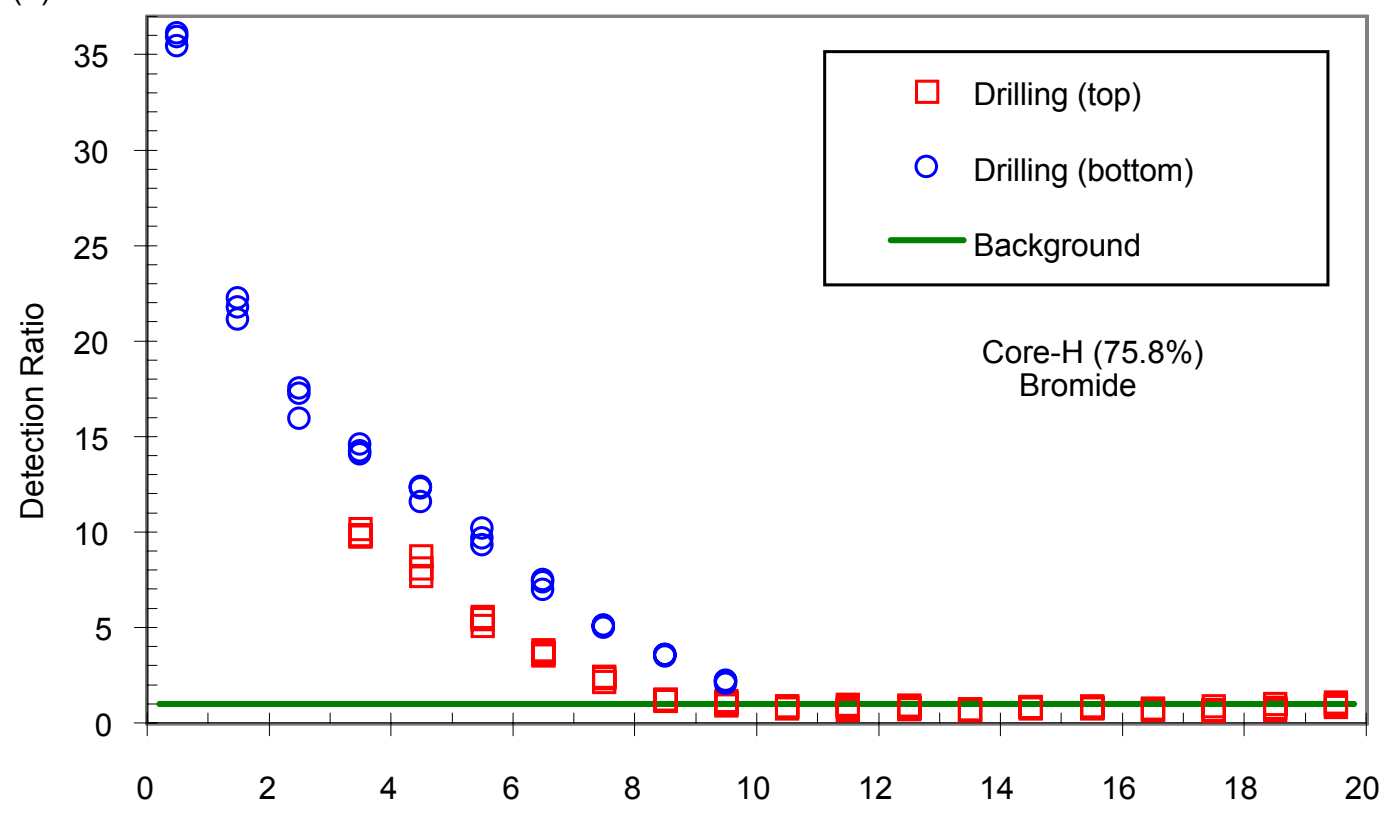

(b)

Depth from the Core Bottom $(\mathrm{mm})$

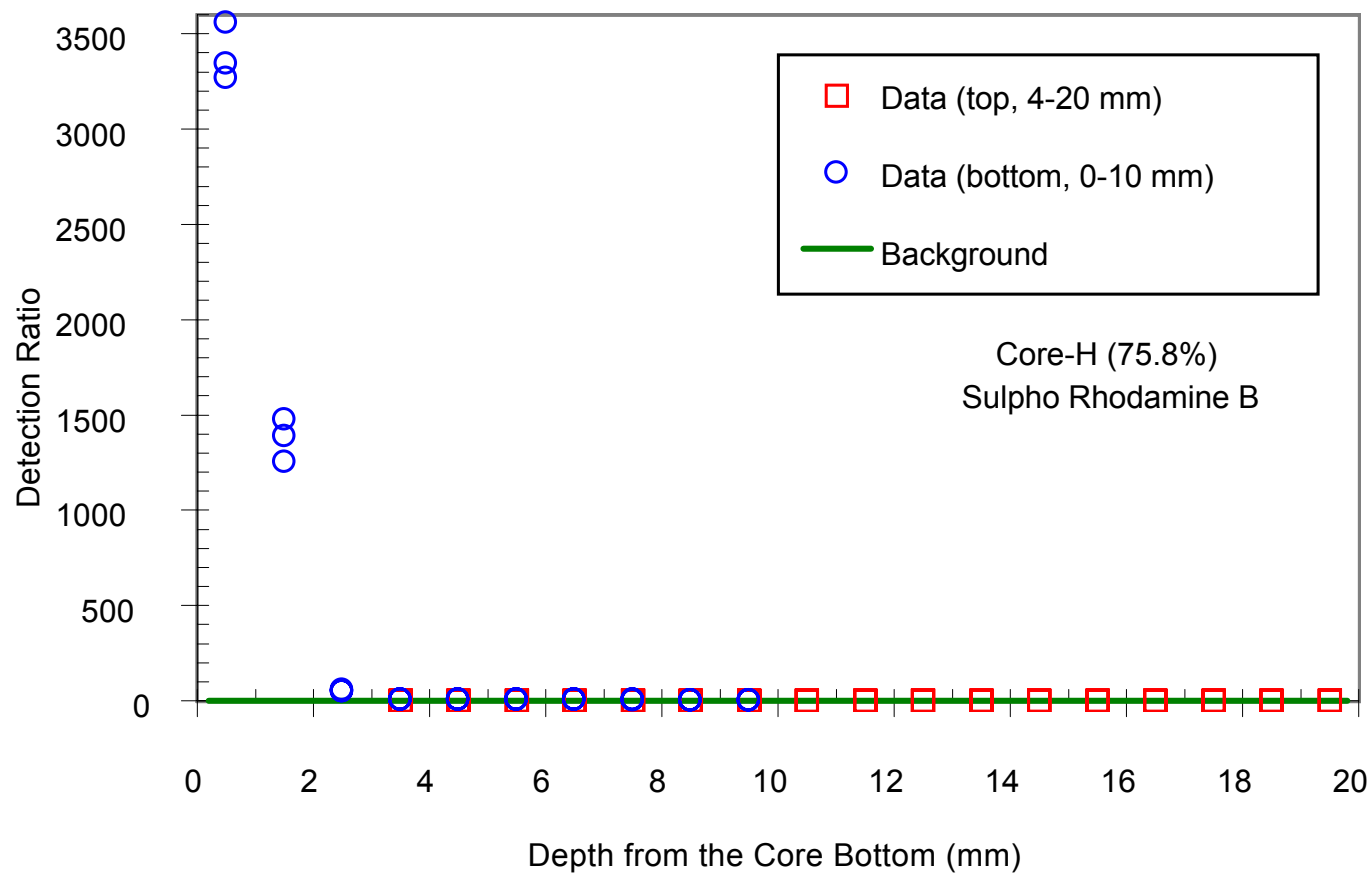

Source: DTN: LB990901233124.003 [DIRS 155690].

NOTES: The core ID and the initial core saturation (in parentheses) are presented in the panels of the figure.

Panel $\mathrm{a}=$ Bromide.

Panel $b=$ Sulpho Rhodamine B.

Figure E-2. Comparison of Measured Detection Ratio from the Opposite Drilling Directions for Core $\mathrm{H}$ with Higher Initial $\mathrm{S}_{\mathrm{w}}$ 
INTENTIONALLY LEFT BLANK 


\section{APPENDIX F}

FIELD EQUIPMENT FOR CONTROLLED WATER RELEASE, WETTING-FRONT DETECTION, AND SEEPAGE COLLECTION 


\section{F1. FLUID INJECTION}

Appendix F1 describes equipment for controlled release of water into isolated zones.

Five sets of data were submitted to the Technical Database Management System (TDMS). Three of the data sets (DTNs: LB0207NICH5LIQ.001 [DIRS 160408], LB0209NICH5LIQ.001 [DIRS 160796], and LB0211NICH5LIQ.001 [DIRS 160792]) contained data files (in comma-delimited ASCII format). The remaining data sets (DTNs: LB0208NICH5LIQ.001 [DIRS 161210] and LB0210NICH5LIQ.001 [DIRS 161211]) contained preliminary data and were subsequently superseded by LB0209NICH5LIQ.001 [DIRS 160796] and LB0211NICH5LIQ.001 [DIRS 160792], respectively.

Test data files consist of four types. Three of these types include the "(seep)," "(smass)," and "(srate)" in their filename. These files contain the seepage percentage, seep mass, and seepage rate data, respectively, from individual capture compartments that drain seepage water to the capture balance(s). The fourth type of test data file does not have such suffixes in their filename (e.g., Test\#1_BH\#2_21-22_ft_5-6-02.csv); these files contain data on the cumulative mass and rate of water released (Balance 1), water returned (Balance 2), and the total seepage captured (Balance 3 and/or 4), as measured by the Mettler Toledo balances used during the experiments. As noted in Section 6.2.1.3.5.3, after July 15, 2002, only one balance was used to measure seepage into the niche (i.e., Balance 3 ), and Balance 4 was used to measure evaporation.

The liquid-release experiments required water to be injected into the formation over a $0.3-\mathrm{m}$ zone in the borehole, under constant-head or constant-rate conditions. The constant-head tests were conducted first to determine the maximum rates at which the zone could take in water. The subsequent set of tests required that water be released to the formation at predetermined rates that ranged from approximately $5 \mathrm{~mL} / \mathrm{min}$ to approximately $100 \mathrm{~mL} / \mathrm{min}$. The fluid-release apparatus was capable of delivering either the constant-head method of injection or the constant-rate method of injection. The main components of the fluid-release apparatus included an inflatable packer system for isolating the injection zone, a pump for delivering water, and a reservoir for providing a continuous supply of water (Panel a of Figure F-1).

The inflation packer system consisted of two rubber packers, each $0.60 \mathrm{~m}$ long, connected to an inflation line (Panel b of Figure F-1). Two stainless tubes (inside diameter: $0.95 \mathrm{~cm}$ and $0.31 \mathrm{~cm}$ ) passed through one of the packers to provide fluid (air and water) access into the injection zone. The $0.95-\mathrm{cm}$ tube was used to deliver fluid into the injection zone; the $0.31-\mathrm{cm}$ tube was used, as a siphon, to remove excess water from the injection zone. Before liquid was released into the formation, the packer system was located to straddle the zone of interest (determined based on air-permeability measurements), and was then inflated to a pressure of approximately $200 \mathrm{kPa}$. The 0.95 - $\mathrm{cm}$-inside-diameter stainless steel tube was then connected to a water supply line from a constant-head or a constant-rate system. Pressure in the inflation packers was continuously monitored during the entire period of injection, to ensure that the injection zone remained isolated from adjacent zones of the borehole.

To capture the temporal variability in vertical flux of water from the injection zone, an automated liquid-release system was developed. This system allowed for continuous measurement of local liquid-release rates. The unit included of a storage tank (approximately 
4.5 L) for water supply to a clear-acrylic, constant-head chamber. The chamber, which had a $0.15-\mathrm{m}$ inside-diameter and was $0.30 \mathrm{~m}$ tall, served to maintain a constant head of water above the liquid-release surface within the injection zone (Panel c of Figure F-1). Constant head was maintained by a level switch that activated the pump when the water level dropped below the control level. The control level was nominally set at or slightly above the elevation of the horizontal injection borehole. Two pressure transducers continuously recorded the height of water in each tank. A pulse damper was installed between the pump and tank, to reduce any pump-generated pulsating effects (which could migrate to the storage tank and influence the pressure readings).

The constant-rate injection system included all the components used in the constant-head system except the constant-head chamber. To allow for easy regulation of flow rates in the field, the pump was calibrated before field deployment to relate flow rates with displayed numbers on a 10-turn speed control. In the field, the speed control was set at the desired flow rate before the pump was activated. The actual flow rate was determined from the change in pressure measured by transducers located at the bottom of the water reservoir. A data acquisition system was used to record changes in head of water (water level) in the reservoir.
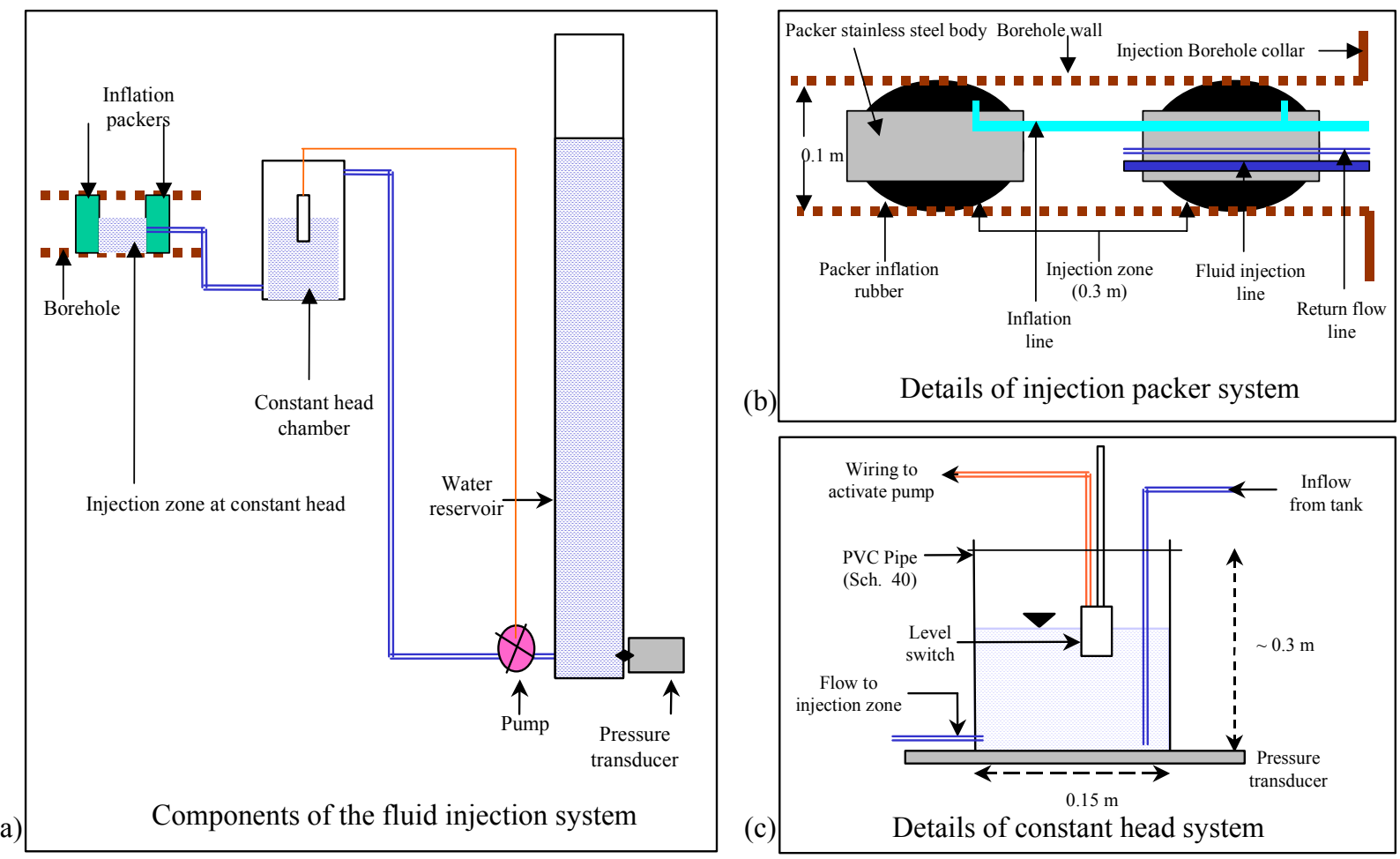

NOTE: Figure is not to scale.

Figure F-1. Schematic Illustration of Liquid Release System for Constant-Head and Constant-Rate Injections 


\section{F2. BOREHOLE MONITORING}

Appendix F2 describes borehole monitoring performed to detect changes in saturation and water potential.

In three monitoring boreholes (Boreholes B, C, and D in Figure 6-74), changes in saturation and water potential were measured continuously during the entire field investigation. Changes in saturation were measured with electrical resistivity probes (ERPs) located at $0.15-\mathrm{m}$ intervals along the $6.0-\mathrm{m}$ length of each borehole. These ERPs consisted of two electrical leads sandwiched between pieces of filter paper. Water-potential measurements were made with psychrometers. With the multiplexing capabilities of the data logger (model CR7, Campbell Scientific Inc.), hourly measurements of up to 80 psychrometers (model PST-55, Wescor Inc.) were automated. The chromel-constantan junction in the psychrometer was cooled with an electric current to a temperature below dew point to first induce condensation, followed by evaporation without electric current. Temperature depression resulting from evaporation was recorded and used to determine water potentials in the vicinity of the psychrometers.

The psychrometers and ERP were housed in borehole sensor trays (BSTs), installed along the length of each monitoring borehole (Panel a of Figure F-2). The BSTs were fabricated from 0.10-m outside diameter (OD) PVC pipes; each section was $3.0 \mathrm{~m}$ long. Each pipe section was cut lengthwise to produce a $0.075-\mathrm{m}$-wide curved tray (Panel b of Figure F-2). On each tray, psychrometers were installed at $0.5-\mathrm{m}$ intervals along the borehole, and ERPs were located at 0.25-m intervals (Panels b and c of Figure F-2). BST housing permitted immediate contact between ERPs and the borehole wall. The psychrometers were installed inside small cavities ( $0.005 \mathrm{~m}$ in diameter) perforated through the BST wall to measure water potentials of the rock. A 3.0-m-long steel spoon, with the same layout as the trays, was used to guide each BST to the assigned location along the borehole. Two BSTs were located along each section of borehole, one in contact with the top of the borehole and the other in contact with the bottom of the borehole. Each pair of BSTs was separated by a wedge that tightly pressed the BSTs against the borehole wall. The double BST configuration improved the contacts between ERPs and the borehole wall, and allowed two sensors (one on the upper BST and one on the lower BST) to detect wetting-front advances at each location along the borehole. 
(a)
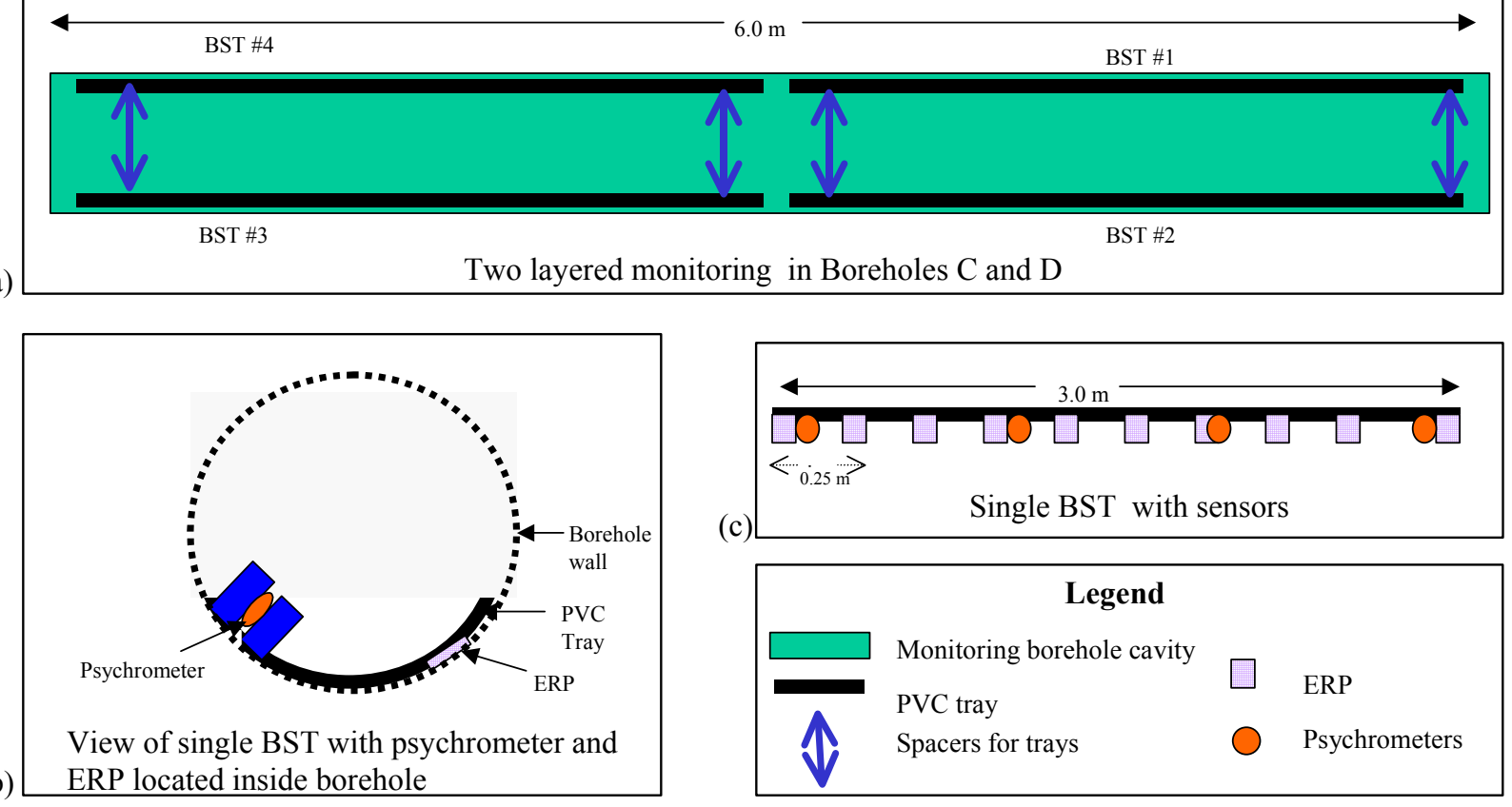

Figure F-2. Schematic Illustration of Borehole Monitoring System

\section{F3. SEEPAGE COLLECTION}

Appendix F3 describes the collection of seepage in an excavated slot. To measure water seeping into the slot after liquid release into the injection borehole, a water collection system was designed to capture seepage from the slot ceiling (Figure F-3). Design of this system was dictated by the slot geometry and the locations of 'I' beam supports. A row of stainless steel trays was fabricated for each of the four accessible compartments between the I-beams. Each tray consisted of a funnel-shaped water collector $0.46 \mathrm{~m}$ long and $0.40 \mathrm{~m}$ wide, tapered to a single point $0.20 \mathrm{~m}$ from the top. For each compartment, seven trays were assembled along a single steel frame, which facilitated installation inside the slot. Water captured in the stainless steel trays was transferred into clear PVC collection bottles $(0.076-\mathrm{m}$ inside diameter, $0.45 \mathrm{~m}$ tall). Water falling into the trays was drained to the collection bottles through Teflon ${ }^{\circledR}$ tubes $(0.635-\mathrm{cm} \mathrm{OD})$. An intermittent vacuum was applied to the collection bottles such that water stored on the trays or in Teflon tubes could be sucked into the collection bottles. The amounts of seepage water in the collection bottles were recorded at a frequency that was determined in the field, and which was based upon observed accumulation rates. 


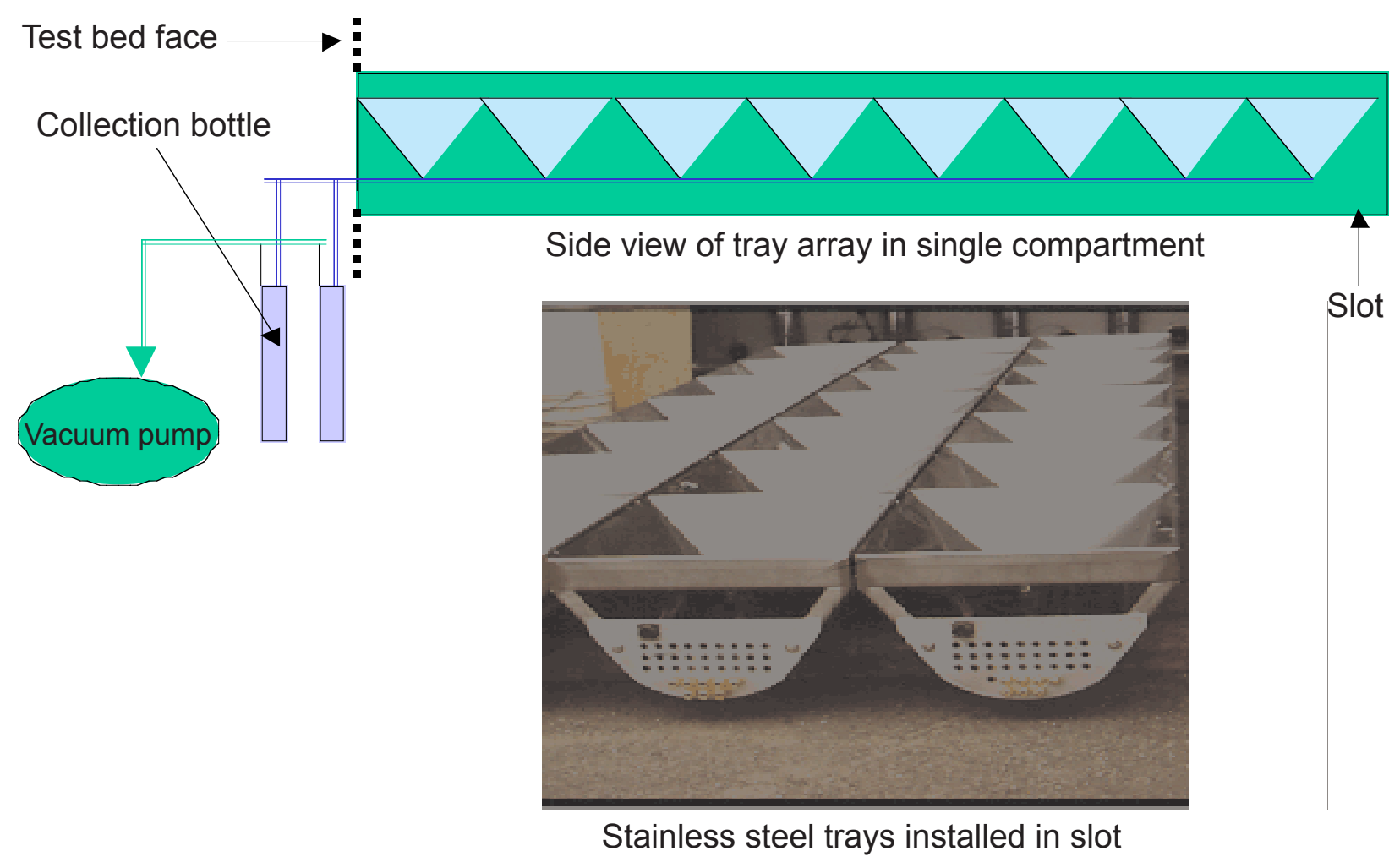

Figure F-3. Schematic Illustration of Water Collection System Installed in Slot 
INTENTIONALLY LEFT BLANK 
APPENDIX G

MEASUREMENT OF WATER POTENTIAL USING PSYCHROMETERS 
Prior to field use, all psychrometers were calibrated in the laboratory, using potassium chloride solutions (0.1-1.0 molal or mole of solute per 1000 grams of solvent). If feasible and practical, a second calibration was done in the laboratory, after psychrometers had been used for field measurements.

During the calibration procedure, psychrometers were isolated in an insulated box, to minimize temperature fluctuations. Automated measurements were then made using the multiplexing capabilities of the Campbell CR7 data logger. When the psychrometers were observed to have reached equilibrium, they were removed from the calibration solution, washed in distilled water, air-dried, and immersed in the next solution. After calibrations were completed, all psychrometers were washed and air-dried before installation in the field.

During laboratory calibrations and preliminary field measurements, the shape of the psychrometer output curve was significantly influenced by the cooling voltage and cooling duration for a given water potential (Figure G-1). The shape of the output curve also changed dramatically when the psychrometers became contaminated with dust particles (Figure G-2). Given the high rate of failure of psychrometers in the field, optimizing both the cooling voltage and duration for a given water potential was important to help identify psychrometers that were contaminated or otherwise malfunctioning. Optimization was accomplished by increasing the cooling voltage and/or increasing the time over which the cooling voltage was applied until a well-defined plateau resulted for the psychrometer output. Data from contaminated or malfunctioning psychrometers were not suitable for interpretation use, and were labeled accordingly (Salve 1999 [DIRS 156552], pp. 103-152).

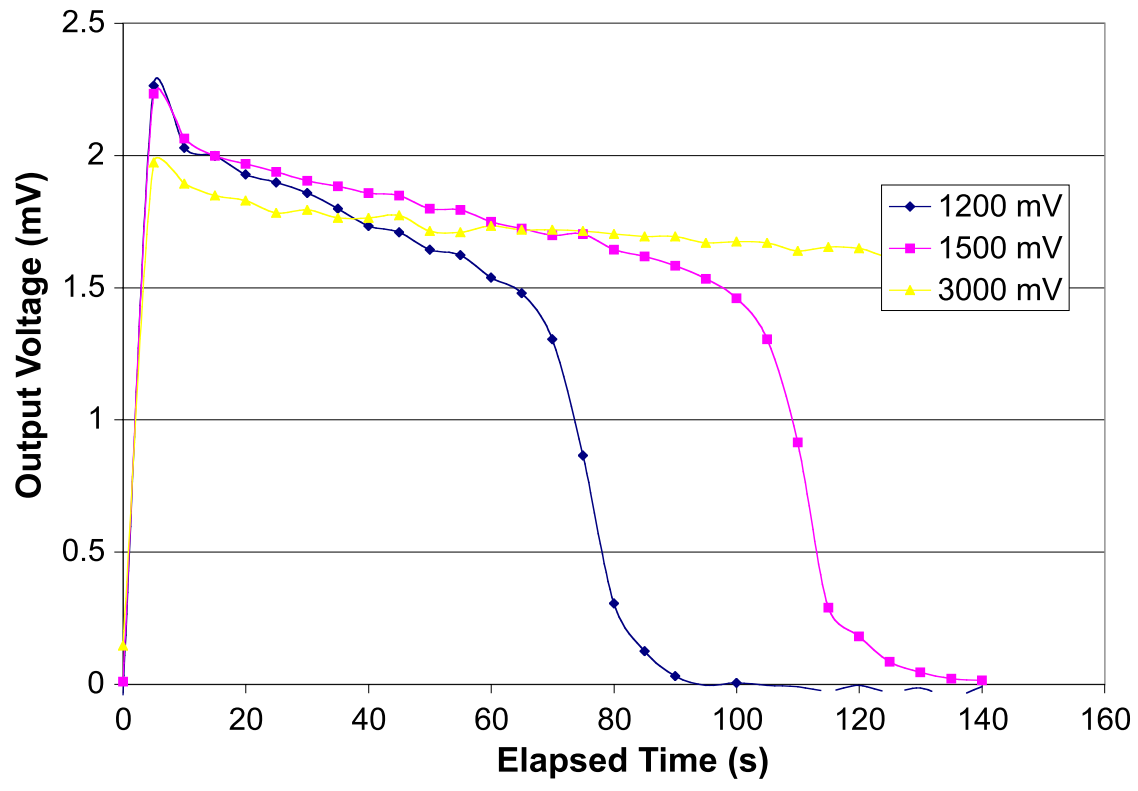

Source: DTN: LB90406ESFNH2OP.001 [DIRS 171588].

Figure G-1. Effect of Cooling Current on Psychrometer Output Curve (PSY-732) 


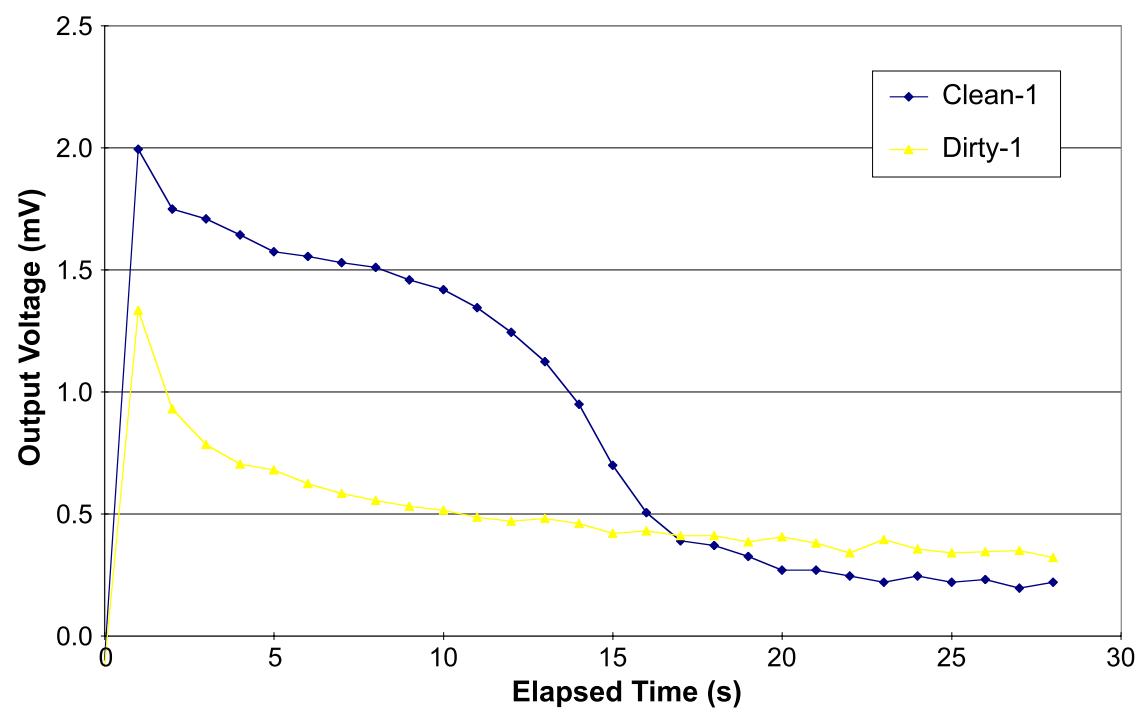

Source: DTN: LB90406ESFNH2OP.001 [DIRS 171588].

Figure G-2. Effect of Dust Coating on Psychrometer Output Curve (PSY-731) 


\section{APPENDIX H \\ GEOLOGY, MINERALOGY, AND HYDROLOGY-BUSTED BUTTE APPLICABILITY}




\section{H1. GEOLOGY OF THE BUSTED BUTTE TEST FACILITY}

The selection of southeastern Busted Butte, $8 \mathrm{~km}$ southeast of the repository area at Yucca Mountain, as a field test facility was based on a presumption that the test results could be appropriately used in numerical studies of flow and transport in the Calico Hills Formation at Yucca Mountain (Bussod et al. 1999 [DIRS 155695], p. 2). The presumption of applicability relies upon the hydrologic similarity of stratigraphic units at Busted Butte and Yucca Mountain.

The Calico Hills section of southeastern Busted Butte, a thin distal residue of deposits, cannot completely represent the variability of the Calico Hills formation below the nuclear waste repository. Because the Busted Butte section is so thin, it was important to more precisely determine which portion of the Calico Hills section occurs at the Busted Butte test facility. Data are examined to document the extent of lithostratigraphic correspondence between the Busted Butte and Yucca Mountain sections; the examination focuses on the portion of the Busted Butte section in which tracer tests were conducted.

Busted Butte is a small $(2.5 \mathrm{~km}$ by $1 \mathrm{~km})$ north-trending mountain block primarily made up of thick, ignimbrite deposits of the Paintbrush Group. This fault-block uplift is bound by northeast--and north-trending normal faults, and it is split by a north-trending down-to-the-west normal fault that gives Busted Butte its distinctive appearance. The test facility is located within a small (300 to $350 \mathrm{~m}$ wide) horst on the southeast side of Busted Butte. Geological units exposed in the vicinity of the test facility include, in ascending stratigraphic order: the Wahmonie Formation, the Calico Hills Formation, and the Topopah Spring Tuff (Figure H-1). The test facility is constructed in the Topopah Spring Tuff and the Calico Hills Formation. The Wahmonie Formation, which is not present below the repository, is also absent from the UZTT test block itself. 


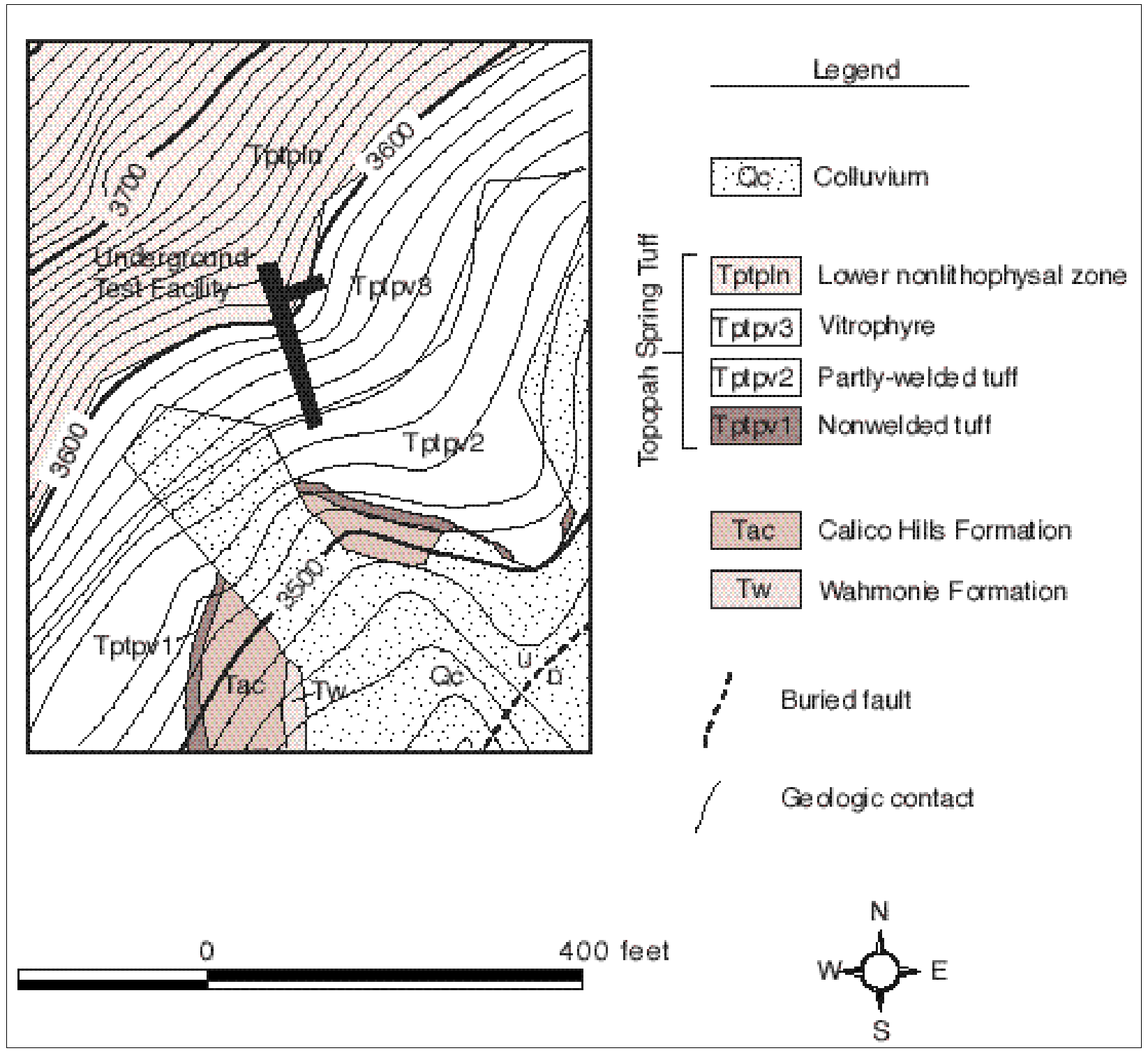

Source: CRWMS M\&O 2001 [DIRS 154024], Figure 44.

NOTES: No DTN is provided for this figure because it is not applicable; this figure is provided for illustration purposes only.

The plot is a geologic map of the area around the underground test facility in the southeastern part of Busted Butte.

The contour interval is $10 \mathrm{ft}$.

The tunnel entrance is at the southern end of the facility.

Figure H-1. Busted Butte Geologic Map 


\section{H2. STRATIGRAPHIC SETTING OF BUSTED BUTTE}

The stratigraphic succession at Busted Butte was originally mapped in Lipman and McKay (1965 [DIRS 104158]), which recognized the widespread principal units of the Paintbrush Group and small local exposures of underlying nonwelded tuffs not attributed to specific formations (undivided tuffs (Tt) according to their nomenclature). Broxton et al. (1993 [DIRS 107386], pp. 6,9) assigned the nonwelded tuffs to the Calico Hills Formation, the Wahmonie Formation, and the Prow Pass Tuff in order of increasing age and depth. This report follows the stratigraphic assignments of Broxton et al. (1993 [DIRS 107386]), but all of the stratigraphic nomenclature has been updated from the original sources to reflect the usage in Sawyer et al. (1994 [DIRS 100075], Table 1)].

The Calico Hills, Wahmonie, and Prow Pass tuffs were derived from different volcanic centers (Sawyer et al. 1994 [DIRS 100075], Table 1). The pattern of decreasing unit thickness from north to south along Yucca Mountain (Moyer and Geslin 1995 [DIRS 101269], Figure 3) is consistent with derivation of the Calico Hills pyroclastic material from an eruptive center north of the mountain (Sawyer et al. 1994 [DIRS 100075], p. 1307). Thickness of the Calico Hills tuff decreases over a distance of approximately $13 \mathrm{~km}$, from more than $289 \mathrm{~m}$ at the northern end of Yucca Mountain (Moyer and Geslin 1995 [DIRS 101269], Figure 3) to approximately $6.4 \mathrm{~m}$ at the southeastern Busted Butte outcrop near the flow-and-transport test facility (Broxton et al. 1993 [DIRS 107386], p. 9). At Raven Canyon, approximately 15 km southwest of Busted Butte, the Calico Hills Formation is absent and the Paintbrush Tuff rests on the Wahmonie Formation (Peterman et al. 1993 [DIRS 106498], Figure 2).

\section{H3. LITHOLOGY OF THE CALICO HILLS FORMATION}

The predominant rock types of the Calico Hills Formation in the Yucca Mountain area are an upper section of ash-flow and air-fall tuffs and a lower section of bedded tuffs and sandstones (Moyer and Geslin 1995 [DIRS 101269], p. 5). All of these rocks originally consisted predominantly of glassy pyroclasts (volcanic ash, shards, and pumice clasts that formed as the lava was erupted and fragmented). The rocks also contained smaller amounts of phenocrysts (crystals from the lava) and lithic inclusions (crystalline or glassy rock fragments).

In the northeastern portion of the Yucca Mountain region, the glassy constituents of the Calico Hills tuffs have been altered to a mixture of zeolites (mostly clinoptilolite), smectite clay, and secondary silica. The Calico Hills Formation in the southeastern and southwestern Yucca Mountain region (including Busted Butte) remains mostly glassy, although some intervals contain appreciable amounts of smectite, clinoptilolite, and other secondary minerals. The areal distribution of zeolitic Calico Hills tuff is depicted in Mineralogic Model (MM3.0) Report (2004 [DIRS 170031], Figures 6-12 to 6-16). Areas of low zeolite content in the cited figures generally show where the tuff is vitric.

\section{H4. CRITERIA OF UNIT IDENTIFICATION}

Moyer and Geslin (1995 [DIRS 101269], Figure 2) divides the Calico Hills formation (from bottom to top) into the basal sandstone unit, the bedded tuff unit, and five pyroclastic units, of which Unit 1 is the deepest. Positive recognition of the units depends heavily upon observing 
the entire stratigraphic sequence in drill core or outcrop, and identifying the distinctive contacts (boundaries) between adjacent units (Moyer and Geslin 1995 [DIRS 101269], pp. 50-51). Moyer and Geslin (1995 [DIRS 101269], pp. 5-8) also defines typical values for color and for phenocryst content, lithic grains, and pumice clasts associated with each unit; and summaries of chemical and mineralogic/petrographic data show that the data for some of these parameters, taken alone, are sufficient only to distinguish the upper ash-flow/air-fall tuff section from the lower bedded tuff and sandstone. Within the ash-flow/air-fall section, however, the phenocryst data do not reliably make distinctions between units 3, 4, and 5 because of the large overlaps in parameter-value populations (Moyer and Geslin 1995 [DIRS 101269], Figures 4 and 5).

Drill hole USW GU-3 is the fully cored hole closest to Busted Butte. It is also the source of the only drill core studied by Moyer and Geslin (1995 [DIRS 101269]) that showed that the Calico Hills section is vitric, like the section at Busted Butte. Unit identification in this hole was considered very ambiguous by Moyer and Geslin (1995 [DIRS 101269], pp. 8-9), due to poor core recovery of the vitric Calico Hills interval. The main problem with making unit identifications in the Calico Hills section of drill core USW GU-3 is that contacts are missing because of incomplete core recovery. Moyer and Geslin (1995 [DIRS 101269], pp. 8-9) tentatively recognizes Unit 3 and underlying bedded tuffs in this core, but does not rule out the presence of additional units. The absence of well-supported unit correlations in USW GU-3, along with a paucity of data from other drill sites in which the Calico Hills Formation is vitric, increases the difficulty of comparison between Busted Butte and Yucca Mountain based solely on existing data.

The identification of lithostratigraphic units at southeastern Busted Butte is based on a combination of characteristics common to other locations in which the units are exposed. Moyer and Geslin (1995 [DIRS 101269], pp. 8, 10) notes lithologic similarities between the Calico Hills section exposed at Busted Butte and the USW GU-3 section, especially the presence of black, perlitic-glass lithic clasts (glass chunks with distinctive rounded surfaces) described in Moyer and Geslin (1995 [DIRS 101269], p. 8) as "black obsidian" or "obsidian lithic clasts". The restricted occurrence of these clasts was considered a basis for identification and intersite correlation of Unit 3 in Moyer and Geslin (1995 [DIRS 101269], p. 8), which did not have much data to support this interpretation because such data could only come from locations in which the perlite clasts escaped zeolitic alteration. At the time the report (Moyer and Geslin 1995 [DIRS 101269]) was produced, the USW GU-3 and USW UZ-14 cores were the only sources of data for the vitric or partly vitric Calico Hills Formation.

As a follow-up to the observations and interpretations of Moyer and Geslin (1995 [DIRS 101269]), new petrographic data on rock color, lithic-clast content, and black perlitic-clast content were collected for a vertical suite of samples from the Busted Butte test facility. Comparable data were collected for drill-hole samples from USW GU-3, USW H-5, and USW SD-12 (all holes with predominantly vitric Calico Hills sections). These data are used to document the comparison of Calico Hills sections between Busted Butte and Yucca Mountain.

\section{H5. EVALUATION OF PETROGRAPHIC PARAMETERS}

Because Moyer and Geslin (1995 [DIRS 101269], pp. 8, 10) suggests that the Busted Butte section represents Unit 3, efforts reported in this appendix concentrate on collection and 
evaluation of data that are most useful to distinguishing Unit 3 from other units of the Calico Hills Formation, particularly the adjacent Units 2 and 4. Given that the Busted Butte section appears to contain only one pyroclastic-flow unit, the identification of that unit must be based on observable petrographic parameters without recourse to examination of the contacts of a multi-unit sequence. The parameters deemed to have the most characteristic values for Unit 3 are:

- total lithic-clast content, and

- presence of black perlitic lithic clasts.

Moyer and Geslin (1995 [DIRS 101269], pp. 6 to 7) found that the lithic-clast content of Unit 3 is in the range of 5 to 10 percent (excluding localized zones of higher concentration), which is higher than the ranges of 1 to 5 percent in Units 2 and 4. Data on lithic-clast content in vitric Calico Hills tuff is presented in Table H-2. In keeping with the presumed usage of Moyer and Geslin (1995 [DIRS 101269], p. 8), the lithic-clast abundances determined for this study include both crystalline and vitric lithic clasts. Such usage differs from some published data (Broxton et al. 1993 [DIRS 107386], p. 43) that include only crystalline clasts in the lithic-abundance determination.

Moyer and Geslin (1995 [DIRS 101269], p. 8) believed that the black perlitic lithic clasts might be unique to Unit 3, but had few data to support that assumption. For this assumption to be used with confidence at Busted Butte, it must be supported by data from additional sites. Table H-2 summarizes new observations of black perlitic clast distribution in vitric Calico Hills tuff, taken from available samples. The table also contains matrix-color data (applicable to vitric samples only). Moyer and Geslin (1995 [DIRS 101269], pp. 5, 6, 8, 51) considers color to be a useful characteristic for distinguishing units; most color observations included therein pertain to zeolitized tuffs that may differ in color from unaltered tuffs of equivalent stratigraphic position. The following criteria are used to identify Unit 3 within a vertical sequence of samples:

- Lithic clast content: Lithic-clast content is perhaps the most consistently useful discriminant for the identification of Unit 3 within a vertical sequence of samples in which more than one unit is present. The data suite for USW SD-12 defines an interval in the middle of the Calico Hills Formation that has a lithic-clast content of 5 to 10 percent.

- Black, perlitic clast content: The distribution of black perlitic clasts in USW SD-12 is reasonably, but not perfectly, congruent with the interval containing 5 to 10 percent total lithic clasts. Data for the smaller sample suites from drill holes USW GU-3 and USW H-5 also suggest a correspondence between black perlite occurrences and the total lithic-clast content that is characteristic of Unit 3. The existence of samples without black perlite clasts (bedded tuff below the perlite interval in USW GU-3 and USW SD-12, and the tuff section above the perlite interval in USW SD-12) confirms that black perlite content can be used to discriminate between units.

- Color: The color data for predominantly vitric Calico Hills samples show some similarities to the colors of zeolitic tuff in Unit 3, although the zeolitic tuff is more likely to have yellow or orange tints (Moyer and Geslin 1995 [DIRS 101269], p. 51). The data 
also indicate that color alone is not a useful interunit discriminant in every case. For example, the data for USW SD-12 show little difference between the Unit 3 samples and samples inferred to be from overlying Unit 4. In contrast, the USW GU-3 suite shows a reliable color difference between the orange pink of Unit 3 and the yellowish brown of the underlying bedded tuff.

The 2-m section of uppermost Calico Hills tuff located in the Busted Butte test facility shares the two most characteristic lithologic attributes of Unit 3: lithic-clast content in the 5 to 10 percent range and the presence of black perlitic clasts. Note that the observations for drill-hole samples, intended to confirm the applicability of the Moyer and Geslin unit-discrimination criteria to vitric tuff (Moyer and Geslin 1995 [DIRS 101269]), were derived from small suites of discrete samples. To achieve greater certainty of unit identification, a direct examination of the entire vitric Calico Hills section (complete with contacts) in drill core USW SD-12 should be made.

\section{H6. STRATIGRAPHY AND MINERALOGY OF THE BUSTED BUTTE TEST FACILITY}

Busted Butte is a small $(2.5 \mathrm{~km}$ by $1 \mathrm{~km})$ mountain block primarily made up of ignimbrite deposits of the Paintbrush Group. This fault-block uplift is bounded by northeast- and north-trending normal faults, and it is split by a north-trending down-to-the-west normal fault that gives Busted Butte its distinctive appearance. Tuff units generally have dips of less than 10 degrees, except where affected by drag near large faults. Small exposures of older volcanic units, including the Calico Hills Formation, Wahmonie Formation, and Prow Pass Tuff, occur near the base of the butte on the north and southeast sides (Broxton et al. 1993 [DIRS 107386], pp. 5-10).

The test facility is located within a small horst on the southeast side of Busted Butte. The horst is 300 to $350 \mathrm{~m}$ wide and is bounded by a down-to-the-west Paintbrush Canyon fault on the west and by a down-to-the-east splay of the Busted Butte fault on the east (Scott and Bonk 1984 [DIRS 104181]). Geologic units exposed in the vicinity of the test facility include, in order of ascending position and decreasing age, the Wahmonie Formation, the Calico Hills Formation, and the Topopah Spring Tuff. The test facility is constructed in the Topopah Spring Tuff and the Calico Hills Formation.

Brief descriptions of the formal and informal lithologic units in the underground test facility, with emphasis on the Phase 2 test block, are provided in this appendix. A representative stratigraphic and lithologic section is shown in Figure H-2. Characterization of the lithologic units was accomplished by examining and sampling the walls of the test block, by examination of drill core collected before and during the test, and by studying and sampling the mineback faces excavated into the test block after completion of the test. All color descriptions are based on the Munsell system, Rock Color Chart with Genuine Munsell ${ }^{\circledR}$ Color Chips (Geological Society of America 1995 [DIRS 105787]).

The descriptions and nomenclature of subunits within the Calico Hills Formation that are found in this appendix are informal and can only be used as indirect input.

This appendix follows the criteria of Buesch et al. (1996 [DIRS 100106]) for definition and recognition of lithologic zones within the Topopah Spring Tuff. Because lithologic zones were 
used to define numerical model units, replacement of the gradational transitions between the zones with no-thickness boundaries was necessary. The rationale and consequences of this substitution are discussed in this appendix.

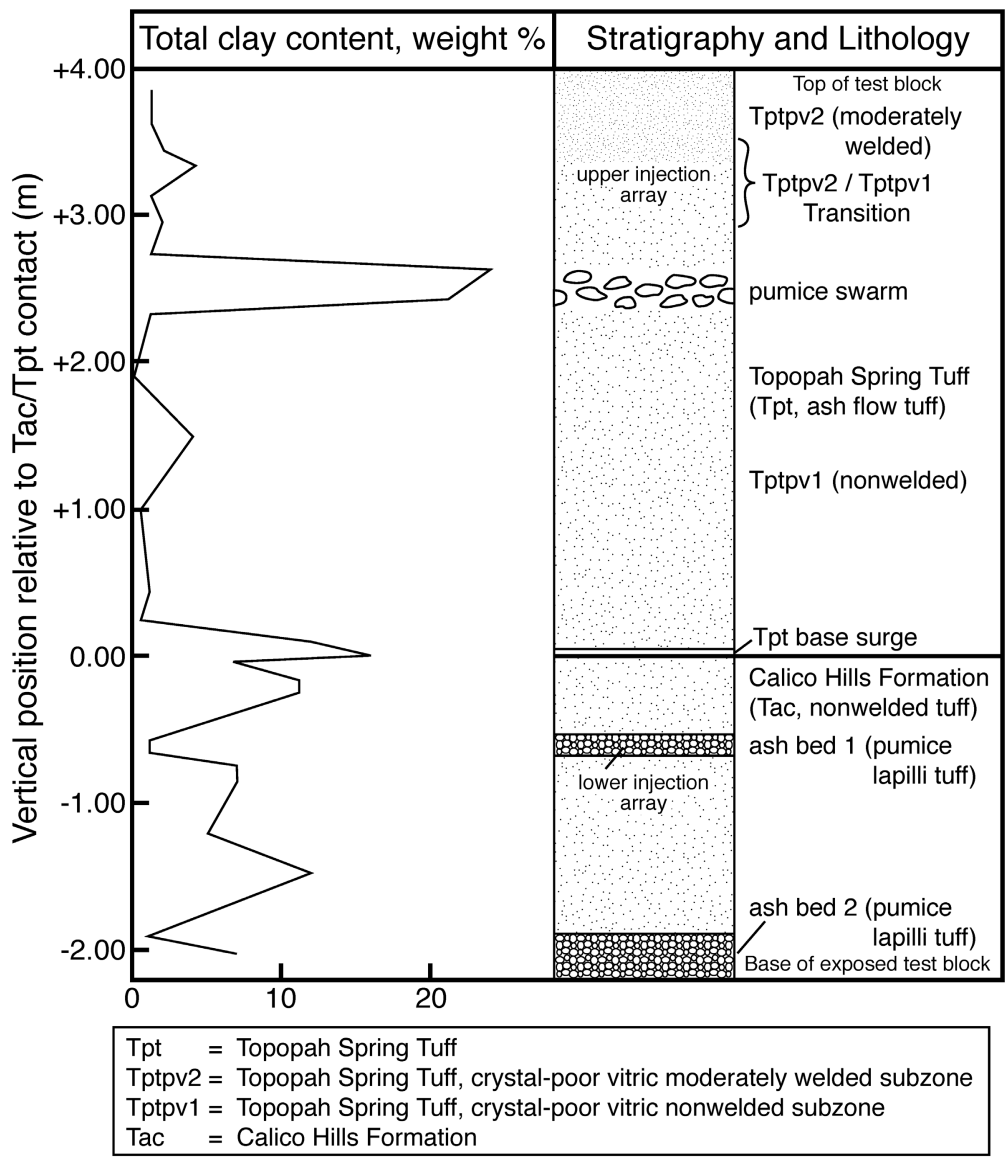

Source: DTN: LA0204SL831372.001 [DIRS 164749].

Figure H-2. Stratigraphy and Clay Content of the Phase 2 Test Block

\section{$\underline{\text { Calico Hills Formation }}$}

A little more than $2 \mathrm{~m}$ of Calico Hills Formation (Tac) is exposed in the test area of the facility in the lower walls of both the main adit and the test alcove. The exposed unit consists predominantly of light brown (5YR 6/4), nonwelded vitric tuffs. Fine ash (particles less than one millimeter in diameter) is the principal constituent of the tuffs. Other constituents include varicolored crystalline lithic grains and glass chunks (5 to 25 percent by volume), feldspar, quartz, biotite phenocrysts (5 to 10 percent), and pumice lapilli of centimeter size or less (less than or equal to 5 percent). The tuff is uncemented, but variable cohesion is provided by the clay alteration described in this appendix.

Interspersed with the light brown tuffs are two Beds of pumice-lapilli tuff, each approximately $20 \mathrm{~cm}$ thick. The upper layer is known informally as "Ash Bed 1," "Ash Layer 1," or "Ash 1," and the lower layer is known as "Ash Bed 2," "Ash Layer 2," or "Ash 2." Neither bed is composed principally of ash, but the names have gained sufficient currency within the field-test 
project that they are retained and used in this appendix. Ash Bed 1 is pinkish gray (5YR 8/1), nonwelded, and vitric. Amorphous opal cement comprises approximately 5 percent of the tuff, and contributes to its resistant, cohesive character.

\section{$\underline{\text { Topopah Spring Tuff }}$}

Buesch et al. (1996 [DIRS 100106], pp. 43-44) defined the crystal-poor vitric zone (Tptpv) in the lowermost Topopah Spring Tuff (Tpt), and subdivided it into three subzones distinguished by a progressively decreasing degree of welding (compaction through viscous flow of the glassy components as the tuff cooled). The two lower subzones are present in the Phase 2 test block. The moderately welded subzone (Tptpv2), as described by Buesch et al. (1996 [DIRS 100106], p. 44), has moderately to strongly deformed pumice clasts in a moderately welded matrix. Near-vertical fractures are present. The nonwelded subzone below (Tptpv1) is characterized by partially deformed to nondeformed pumice clasts in a partially welded to nonwelded matrix.

At Busted Butte, no bedded tuff between the base of the Topopah Spring Tuff and the underlying Calico Hills Formation compares to the 2-m-thick unit observed in drill core by Scott and Castellanos (1984 [DIRS 101291], p. 101). The lowermost part of the Topopah Spring Tuff, included within Tptpv1, is a base surge deposit that is, at its maximum, approximately seven centimeters thick, and rests directly on the Tac. The base surge is finely laminated on a millimeter scale, and contains well-aligned pumice lapilli (less than or equal to $2 \mathrm{~cm}$ across, elongations less than or equal to 4:1) and black glass chunks in a matrix of vitric ash.

The Tptpv1 contains many texturally distinctive layers, although none is so well defined as the beds in the underlying Tac. Layers may be defined by concentrations or sizes of pumice lapilli, by the presence of abundant vitric shards, or similar characteristics. A mixed pumice population, indicated by variations in color, size, flattening, and alteration, is present in the upper portion of the Tptpv1 and in the Tptpv2. Heterogeneity of layering is absent from the Tptpv2 in the test block.

\section{Defining the Tptpv1/Tptpv2 Boundary}

The boundary between the two subzones can be gradational across a 0.5 -m-to-2-m-thick vertical interval (Buesch et al. 1996 [DIRS 100106], p. 44). Note that subzones are defined on the basis of a syngenetic property (the degree of welding) rather than on depositional criteria. Within the context of the Busted Butte flow and transport test, the Tptpv1/Tptpv2 boundary is important to distinguish between the lithologic subzones, as they serve as a marker separating two hydrogeologic units used in modeling. The boundary must therefore be defined as a discrete surface suitable for numerical modeling, rather than as a gradational transition. The challenge is to determine whether consistent and significant hydrogeologic differences exist between the two subzones, and to then correlate the location of the hydrogeologic change with well-defined, mappable lithologic changes. This iterative process was satisfactorily accomplished for test purposes, but it did not resolve the geological uncertainties.

Lithologic criteria for distinguishing Tptpv2 and Tptpv1 subzones could not be applied uniformly throughout the test block. For example, one criterion was the presence of vertical cooling joints in the Tptpv2 that terminated at the boundary with Tptpv1. This was a useful 
criterion for mapping the boundary within the Phase 2 test alcove, but the first mineback faces were devoid of similar fractures in what was otherwise recognizable as Tptpv2. In the last two-mineback faces, joints were present, but the joint terminations had been extended downward due to tectonic modification.

The chief recognition criterion for the Tptpv1/Tptpv2 boundary in the Phase 2 mineback was the uppermost occurrence of undeformed, subequant, vitric pumice lapilli up to approximately $10 \mathrm{~cm}$ across. For the first seven-mineback faces, the boundary defined on this basis was at essentially the same elevation as the boundary mapped on the test alcove injection face. Between Face 7 and Face 8 , the boundary rises approximately $0.6 \mathrm{~m}$ in a westerly direction, whereas the boundary mapped on the injection face remains level. No attempt has been made to investigate the differences, and both sets of data have been accepted for modeling purposes.

The ambiguities described in this appendix have led to minor inconsistencies in boundary definition for modeling purposes, and in sample selection for properties characterization. The modeled boundary surface is slightly more irregular because of the inconsistencies. Three samples designated as Tptpv1/Tptpv2 in Table $\mathrm{H}-1$ span an approximately $40-\mathrm{cm}$ vertical range of identified boundary locations, based on the various criteria for defining the boundary. This range may be taken as an estimate of the uncertainty in boundary location due to differing criteria at any particular location within the Phase 2 block. 


\begin{tabular}{|c|c|c|c|c|c|c|c|c|c|c|c|c|c|}
\hline $\begin{array}{c}\text { LANL } \\
\text { Number }\end{array}$ & $\begin{array}{c}\text { SPC } \\
\text { Number }\end{array}$ & $\begin{array}{c}\text { Vertical } \\
\text { Position } \\
\text { Relative to } \\
\text { Tpt/Tac } \\
\text { Contact }(\mathrm{m}) \\
\end{array}$ & $\begin{array}{c}\text { Stratigraphic/ } \\
\text { Lithologic } \\
\text { Designation }\end{array}$ & Smectite & Kaolinite & Quartz & Cristobalite & Feldspar & Hematite & Amorphous & Mica & Cryptomelane & Total \\
\hline $3692, \mathrm{p} 1$ & 575100 & +3.86 & Tptpv2 & n.d. & $1(1)$ & n.d. & n.d. & $2(1)$ & n.d. & $97(1)$ & n.d. & n.d. & $100(1)$ \\
\hline $3693, \mathrm{p} 1$ & 575101 & +3.64 & Tptpv2 & trace & $1(1)$ & $1(1)$ & n.d. & $1(1)$ & n.d. & $97(2)$ & n.d. & n.d. & $100(2)$ \\
\hline $3693, p 2$ & 575101 & +3.44 & Tptpv2 & trace & $2(1)$ & trace & n.d. & $2(1)$ & n.d. & $96(1)$ & n.d. & n.d. & $100(1)$ \\
\hline $3594, \mathrm{p} 1$ & 525159 & +3.40 & Tptpv2 & $3(1)$ & $1(1)$ & trace & n.d. & $1(1)$ & n.d. & $95(2)$ & trace & n.d. & $100(2)$ \\
\hline $3695, \mathrm{p} 1$ & 575103 & +3.15 & Tptpv1/Tptpv2 & n.d. & $1(1)$ & n.d. & trace? & $1(1)$ & n.d. & $98(1)$ & n.d. & n.d. & $100(1)$ \\
\hline $3593, \mathrm{p} 2$ & 525158 & +3.00 & Tptpv1/Tptpv2 & trace & $2(1)$ & trace & n.d. & $2(1)$ & trace & $96(1)$ & trace & n.d. & $100(1)$ \\
\hline $3593, \mathrm{p} 1$ & 525158 & +2.80 & Tptpv1/Tptpv2 & trace & $1(1)$ & n.d. & n.d. & $2(1)$ & n.d. & $97(1)$ & trace & n.d. & $100(1)$ \\
\hline $3698, \mathrm{p} 1$ & 575106 & +2.65 & Tptpv1 & 11(3) & $13(3)$ & $1(1)$ & n.d. & $5(1)$ & trace & $70(4)$ & n.d. & n.d. & $100(4)$ \\
\hline $3699, \mathrm{p} 1$ & 575107 & +2.44 & Tptpv1 & $13(4)$ & $8(2)$ & trace & n.d. & $4(1)$ & trace & $75(5)$ & n.d. & n.d. & $100(5)$ \\
\hline $3699, p 2$ & 575107 & +2.36 & Tptpv1 & n.d. & $1(1)$ & n.d. & n.d. & $3(1)$ & trace & $96(1)$ & trace & n.d. & $100(1)$ \\
\hline $3702, p 1$ & 575110 & +1.92 & Tptpv1 & n.d. & n.d. & trace & trace & $1(1)$ & trace & $99(1)$ & trace & n.d. & $100(1)$ \\
\hline $3591, \mathrm{p} 1$ & 525156 & +1.65 & Tptpv1 & $2(1)$ & $1(1)$ & trace & n.d. & $2(1)$ & trace & $95(2)$ & trace & n.d. & $100(2)$ \\
\hline $3589, \mathrm{p} 1$ & 525154 & +1.55 & Tptpv1 & $3(1)$ & $1(1)$ & trace & n.d. & $2(1)$ & n.d. & $94(2)$ & trace & n.d. & $100(2)$ \\
\hline $3707, \mathrm{p} 1$ & 575115 & +1.00 & Tptpv1 & trace & n.d. & trace & trace & $2(1)$ & trace & $98(1)$ & trace & n.d. & $100(1)$ \\
\hline $3582, \mathrm{p} 1$ & 525147 & +0.45 & Tptpv1 & $1(1)$ & n.d. & trace & n.d. & $1(1)$ & trace & $98(1)$ & trace & n.d. & $100(1)$ \\
\hline $3583, \mathrm{p} 1$ & 525148 & +0.25 & Tptpv1 & trace & n.d. & trace & trace & $2(1)$ & trace & $98(1)$ & trace & n.d. & $100(1)$ \\
\hline $3583, \mathrm{p} 2$ & 525148 & +0.10 & Tptpv1 & $12(4)$ & n.d. & trace & trace & $3(1)$ & trace & $85(4)$ & trace & n.d. & $100(4)$ \\
\hline $3583, p 3$ & 525148 & +0.01 & $\begin{array}{l}\text { Tpt, base } \\
\text { surge }\end{array}$ & $16(5)$ & n.d. & $3(1)$ & $1(1)$ & $6(1)$ & trace & $74(5)$ & trace & n.d. & $100(5)$ \\
\hline $3584, \mathrm{p} 1$ & 525149 & -0.01 & Tac & $7(2)$ & n.d. & $3(1)$ & $1(1)$ & $9(1)$ & trace & $80(3)$ & trace & n.d. & $100(3)$ \\
\hline $3584, \mathrm{p} 2$ & 525149 & -0.15 & Tac & $11(3)$ & n.d. & $3(1)$ & $1(1)$ & $8(1)$ & $1(1)$ & $76(4)$ & trace & n.d. & $100(4)$ \\
\hline $3587, \mathrm{p} 1$ & 525152 & -0.25 & Tac & $11(3)$ & n.d. & $4(1)$ & $1(1)$ & $8(1)$ & trace & $76(3)$ & trace & n.d. & $100(3)$ \\
\hline $3585, \mathrm{p} 1$ & 525150 & -0.57 & Tac, ash bed 1 & $1(1)$ & n.d. & $6(1)$ & trace & $11(2)$ & trace & $82(2)$ & trace & n.d. & $100(2)$ \\
\hline $3585, \mathrm{p} 2$ & 525150 & -0.65 & Tac, ash bed 1 & $1(1)$ & n.d. & $4(1)$ & $1(1)$ & $13(2)$ & trace & $81(3)$ & trace & n.d. & $100(3)$ \\
\hline $3585, \mathrm{p} 3$ & 525150 & -0.72 & Tac & $7(2)$ & n.d. & $4(1)$ & $1(1)$ & $11(2)$ & trace & $77(3)$ & trace & n.d. & $100(3)$ \\
\hline $3586, \mathrm{p} 1$ & 525151 & -0.83 & Tac & $7(2)$ & n.d. & $5(1)$ & $1(1)$ & $11(2)$ & trace & $76(3)$ & trace & n.d. & $100(3)$ \\
\hline $3598, \mathrm{p} 1$ & 527826 & -1.20 & Tac & $5(2)$ & n.d. & $4(1)$ & $1(1)$ & $10(1)$ & trace & $80(3)$ & trace & n.d. & $100(3)$ \\
\hline
\end{tabular}




\begin{tabular}{|c|c|c|c|c|c|c|c|c|c|c|c|c|c|}
\hline $\begin{array}{c}\text { LANL } \\
\text { Number }\end{array}$ & $\begin{array}{c}\text { SPC } \\
\text { Number }\end{array}$ & $\begin{array}{c}\text { Vertical } \\
\text { Position } \\
\text { Relative to } \\
\text { Tpt/Tac } \\
\text { Contact (m) }\end{array}$ & \begin{tabular}{|c} 
Stratigraphic/ \\
Lithologic \\
Designation
\end{tabular} & Smectite & Kaolinite & Quartz & Cristobalite & Feldspar & Hematite & Amorphous & Mica & Cryptomelane & Total \\
\hline 3598,p2 & 527826 & -1.45 & Tac & $12(4)$ & n.d. & $5(1)$ & $1(1)$ & $11(2)$ & trace & $71(5)$ & trace & n.d. & $100(5)$ \\
\hline $3596, \mathrm{p} 1$ & 527827 & -1.87 & Tac, ash bed 2 & $1(1)$ & n.d. & $5(1)$ & $1(1)$ & $9(1)$ & n.d. & $84(2)$ & trace & $5^{a}$ & $100(2)$ \\
\hline $3596, p 2$ & 527827 & -2.07 & Tac, ash bed 2 & $7(2)$ & n.d. & $6(1)$ & $1(1)$ & $10(1)$ & n.d. & $76(3)$ & trace & n.d. & $100(3)$ \\
\hline
\end{tabular}

Source: DTN: LA0204SL831372.001 [DIRS 164749].

NOTE(S): Estimated 2-sigma errors are in parentheses.

Los Alamos National Laboratory number is an internal tracking number assigned to mineralogy-petrology samples.

SPC number is the number used by the Sample Management Facility to identify and track samples.

Tptpv1 = Topopah Spring Tuff crystal-poor vitric zone, nonwelded subzone.

Tptpv2 = Topopah Spring Tuff crystal-poor vitric zone, moderately welded subzone

Tpt $=$ Topopah Spring Tuff.

Tac $=$ Calico Hills Formation. Ash beds 1 and 2, also known as ash layers 1 and 2, are informally designated layers of pumice-lapilli tuff

Cristobalite diffraction peaks, where detected, are broad, indicating the presence of poorly crystalline cristobalite or opal-C.

"Amorphous" principally denotes volcanic glass, but small amounts of opal-A also may be present. Opal-A is most abundant in Tac ash beds 1 and 2 , where it is estimated to comprise a few weight percent.

trace = less than 0.5 weight percent, queried ("?") where presence of phase is uncertain.

n.d. = not detected.

a This sample also contains a possible trace amount of lithiophorite. No error is given for the cryptomelane abundance because no standard reference intensity was used, and the value is an estimate. Because the value is an estimate, it is not included in the total. 


\section{$\underline{\text { Faults }}$}

Test objectives included investigating the influence of faults on fluid movement. However, the distribution of faults within the Phase 2 test block was largely unknown at the time the test facility was constructed. The location and orientation of the test block were driven by the need to penetrate as much of the Calico Hills Formation as possible; locating the test block to optimize fault-transport studies was a lower priority. The test block, as sited, contained two faults that were exposed on the collection face in the main adit. The injection face in the test alcove included no identifiable faults (DTN: GS990708314224.007 [DIRS 164604]). At the beginning of the test, nothing more was known about the presence of faults within the test block.

The two unnamed normal faults exposed in the collection face are both near-vertical and dip away from each other, defining a narrow horst block oriented diagonally across the rectangular test block. One of the faults was projected to extend slightly into the rock volumes below the upper and lower injection arrays within the boundaries of the test block. The other fault was located a least several meters laterally beyond either injection array and was, therefore, less likely to encounter fluid injected during the test.

The mineback through the Phase 2 test block revealed that the fault below the injection arrays extends approximately $6 \mathrm{~m}$ into the block, as far back as the fifth mineback face. The fault includes at least two branches, and the amount of offset decreases inward from the collection face. It does not intersect any of the injection boreholes. A fault (or faults) of similar orientation and "sense of offset" was (were) observed on mineback faces 2, 3, and 4, and intersect(s) injection holes UZTT-BB-INJ-9 (Borehole 26) and -10 (Borehole 27).

Directly visible effects of faults on tracer movement are minor. No concentrations of fluorescent tracer were observed along fault traces exposed in the mineback, except within clay-rich pumice lapilli cut by the fault. The same effect was observed in lapilli away from the fault. The other fault effect was observed in damp zones above and below ash bed 1. The damp zones, visible in newly completed mineback faces, are parallel to bedding and have fairly uniform and flat upper and lower margins. Where the damp zones are crossed by faults, the upper margins of the zones extend upward along the fault trace or have a mounded appearance centered on the fault trace. This is particularly noticeable in the damp zone above ash bed 1 .

\section{Mineralogic Variability of the Phase 2 Test Block}

Mineralogic data were collected to help verify stratigraphic-unit assignments and to identify potential effects of mineralogy on the flow-and-transport test results. The mineralogy of a composite vertical section through the southwestern portion of the test block is presented in Table H-1, with all abundances in weight percent. The analyzed aliquots were taken from block samples of intact rock, rather than from drill core, to provide better representation and vertical coverage of the lithologic subunits present in the test block. The use of block samples also avoided potential problems with disturbed core. 


\section{Primary-Phase Mineralogic Variation}

Volcanic glass (shards, ash, and pumice clasts), plus quartz and feldspar in phenocrysts and xenoliths, are the primary pyroclastic constituents of the

- Tptpv1 (crystal-poor vitric nonwelded subzone of the Topopah Spring Tuff),

- Tptpv2 (crystal-poor vitric moderately welded subzone of the Topopah Spring Tuff), and

- Tac (Calico Hills Formation).

All Tpt subzones contain 1 percent (or less) quartz and 2 percent (or less) feldspar, with the exception of two intervals that have higher abundances of crystalline pyroclasts. The pumice swarm is characterized by feldspar contents of 4 to 5 percent, although it contains no more quartz than the bulk of the Tptpv1 and Tptpv2. The base surge directly above the Tac contains 3 percent quartz and 6 percent feldspar.

The Tac contains more crystalline pyroclasts than the overlying Tpt subzones, with 3 to 6 percent quartz and 8 to 13 percent feldspar. From ash layer 1 downward, the crystalline pyroclast content is slightly higher (13 to 19 percent quartz + feldspar) than it is in the uppermost Tac above ash layer 1 (11-13 percent).

\section{$\underline{\text { Secondary Alteration }}$}

As noted in this appendix, volcanic glass is the most abundant constituent of the partially welded to nonwelded tuffs located in the Busted Butte test facility. Glass is relatively susceptible to alteration by groundwater and is rarely preserved wherever the tuffs have been below the water table. The glassy rocks of Busted Butte are mostly unaltered, typical of nonwelded tuffs in the unsaturated zone of the Yucca Mountain region. Smectite and kaolinite clays are the principal alteration products of volcanic glass in the test facility. Figure H-2 highlights the vertical variability of clay content, and associations of clay content with specific stratigraphic/lithologic features.

Clay content of the Topopah Spring Tuff in the test block is 4 percent or less, except in two layers within the Tptpv1. One of the two layers is a primary depositional feature informally called the pumice swarm, pumice layer, or pumice zone. The pumice layer contains 30 to 50 percent (Levy 2001 [DIRS 165363], p. 31) large (approximately $10 \mathrm{~cm}$ long; Bussod 1999 [DIRS 146978], p. 85), elongate pumice clasts aligned with the flow fabric of the ash flow. This layer is present throughout the Busted Butte test facility, but the layer thickness and the abundance of pumice clasts within the layer are variable. Alteration of the pumice clasts (and perhaps the matrix, as well) has produced bulk smectite + kaolinite contents as high as 24 percent.

A smectite clay content of 12 to 16 percent was documented within and just above the base surge deposit of the Topopah Spring Tuff. This is a higher-clay content than is present in either the overlying Tptpv1 tuff or the immediately underlying Calico Hills tuff. The localization of stronger alteration above the contact may have resulted from perching of downward-percolating water due to a permeability contrast at the contact. 
Clay content is generally higher in the Tac than in the overlying Tpt subzones. Smectite is the only clay mineral present. Except in the ash layers, the total smectite content of Tac samples is between 5 and 12 percent. Smectite content of the ash layers is between 1 and 7 percent. The lower clay content of the ash layers (actually pumice-lapilli tuffs) may be a consequence of early opal-A (amorphous silica) deposition that filled pores and cemented the pumice clasts. The cementation restricted fluid access to the volcanic glass of which the pumice clasts are composed, and protected it from the alteration that affected adjacent uncemented tuff.

\section{Effects of Mineralogy on Test Results}

The influence of clay content on the movement of introduced moisture is expected to be the predominant observable mineralogic effect on test performance. All of the tuff in the test block contains at least some smectite clay, a mineral with a strong affinity for water that is held in a partially ordered condition between the clay tetrahedral lattice layers. The ambient water content of the tuff probably is less than the capacity of the smectite to hold water. Smectite-rich stratigraphic layers that are close to an injection array, such as the pumice swarm in the upper Tptpv1, may capture and concentrate the tracer fluid. Kaolinite is less effective than smectite in attracting water (Grim 1968 [DIRS 164642], pp. 251-254, 264-266)], but it also contributes to the overall effect in the pumice swarm in which it is abundant. The combined smectite+kaolinite content of the bulk rock within the pumice swarm is 21 to 24 percent, and the pumice swarm is within approximately $1 \mathrm{~m}$ below the Phase 2 upper injection array. This fluid-imbibition effect may be detectable in neutron logs of collection boreholes that traverse the pumice swarm, and in auger samples collected during the mineback.

A thinner, relatively smectite-rich interval in and above the Tpt base surge may behave like the pumice swarm with respect to tracer fluid. This interval is approximately $0.1 \mathrm{~m}$ thick, and contains 12 to 16 percent smectite. The base surge is located approximately $70 \mathrm{~cm}$ above the Phase 2 lower injection array. In this position, a thin smectitic interval may have less of an effect on moisture retention than the pumice swarm does. Data from the collection borehole designated Borehole UZTT-BB-COL-2, centered on the base surge, may document any moisture effects of the clay-rich rock.

\section{H7. APPLICABILITY OF BUSTED BUTTE HYDROLOGIC DATA TO YUCCA MOUNTAIN}

The Busted Butte UZTT included both field tests of aqueous tracer transport and laboratory measurements of hydrologic, tracer-sorption, and matrix-diffusion properties of rock samples from the field-test facility (Bussod et al. 1999 DIRS 155695]). The selection of southeastern Busted Butte, $8 \mathrm{~km}$ southeast of the repository area at Yucca Mountain, to site a field test facility was based on a presumption that the test results could be appropriately used in numerical studies of flow and transport in the Calico Hills Formation (Tac) at Yucca Mountain (Bussod et al., 1999 [DIRS 155695], p. 2). Equivalence of stratigraphic units at Busted Butte and Yucca Mountain is the fundamental criterion for a presumption of applicability. Moreover, criteria for applicability are similarities of lithology and mineralogy, particularly mineralogic changes due to alteration. Additional criteria are similarities of measured hydrologic properties between the Calico Hills Formation at Busted Butte and Yucca Mountain Calico Hills sections of corresponding stratigraphy, lithology, and mineralogy. 
The Calico Hills section at southeastern Busted Butte, a thin distal residue of deposits with an aggregate thickness of one hundred to several hundred feet at Yucca Mountain, cannot completely represent the variability of the Calico Hills Formation below the nuclear waste repository. Because the Busted Butte section is so thin, it is important to more precisely determine which portion of the Calico Hills section occurs at the Busted Butte test facility.

\section{$\underline{\text { Lithostratigraphic Correspondence }}$}

An informal internal lithostratigraphy of the Calico Hills Formation devised by Moyer and Geslin (1995 [DIRS 101269], pp. 5-9) provides a useful basis for comparing the Busted Butte and Yucca Mountain rock sections. The Calico Hills Formation is divided into five ash-flow/air-fall tuff units, plus a bedded tuff and volcaniclastic sandstone at the base of the formation. The majority of units (other than bedded tuff/sandstones) are laterally discontinuous, but pyroclastic Unit 3 is present in most, and perhaps all, of the drill cores examined in Moyer and Geslin (1995 [DIRS 101269], pp. 6, 8-9). Moyer and Geslin (1995 [DIRS 101269], pp. 8, 10) notes lithologic similarities between the Calico Hills section exposed at Busted Butte and the USW GU-3 drill core section, especially the presence of black, perlitic-glass lithic clasts (glass chunks with distinctive rounded surfaces, described in Moyer and Geslin (1995 [DIRS 101269], p. 8) as "black obsidian" or "obsidian lithic clasts"). The restricted occurrence of these clasts, in addition to a lithic-inclusion content of five to ten volume percent (Moyer and Geslin 1995 [DIRS 101269], Table 3; also reproduced here as Table H-2), was considered a basis for identification and intersite correlation of Unit 3 by Moyer and Geslin (1995 [DIRS 101269], p. 8).

The nominally 2-m-thick section of uppermost Calico Hills Formation in the Busted Butte Phase 2 test block shares the two most characteristic lithologic attributes of Unit 3: lithic-clast content in the 5 to 10 percent range, and the presence of black perlitic clasts (Table H2). Hydrologic-properties samples were collected from this section. Data from Yucca Mountain vitric Tac sections from Boreholes USW SD-7 and SD-12, used for comparison with the Busted Butte Tac data, have been identified as parts of Unit 3 (Rautman and Engstrom 1996 [DIRS 101008]; Rautman and Engstrom 1996 [DIRS 100642]).

Table H-2. Calico Hills Formation Lithostratigraphy

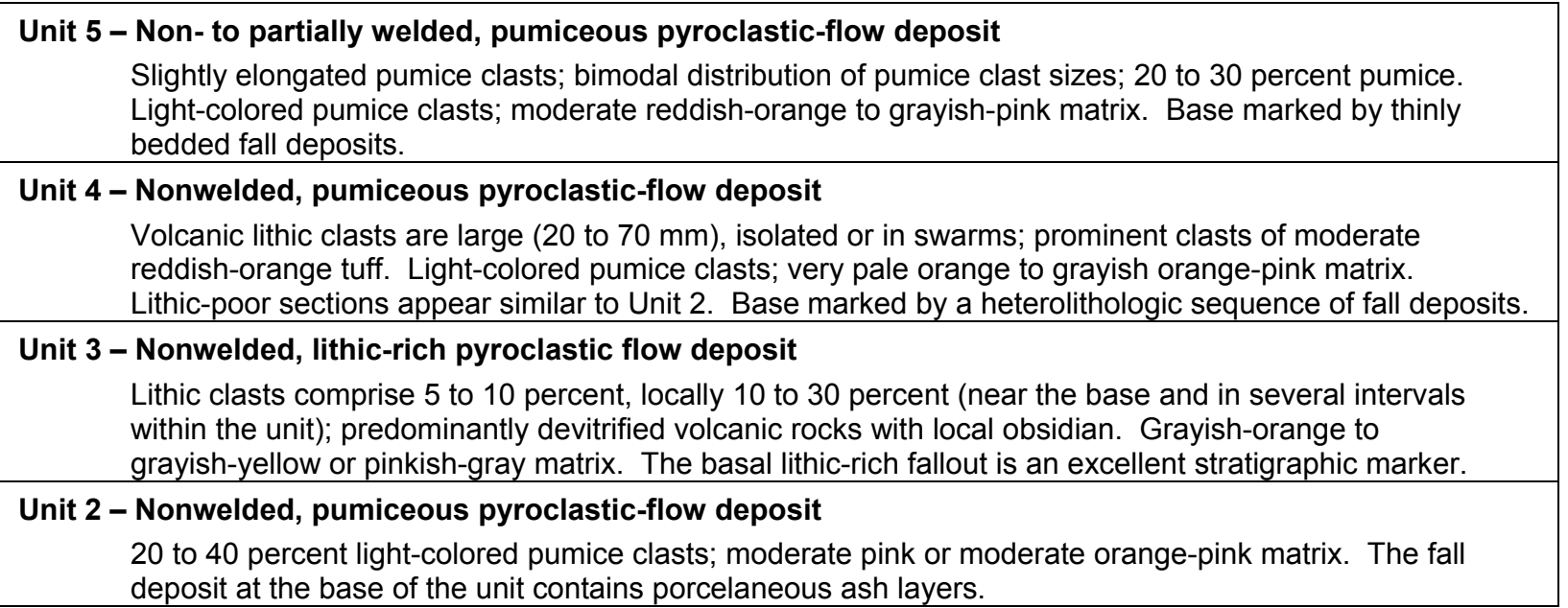


Table H-2. Calico Hills Formation Lithostratigraphy (Continued)

Unit 1 - Nonwelded, lithic-rich pyroclastic-flow deposit
15 to 20 percent devitrified volcanic lithic clasts near the base; lithic clasts decrease upward to 3 to
7 percent. Light-colored pumice clasts; grayish orange-pink to light greenish-gray matrix; 7 to 12 percent
phenocrysts.
Bedded tuff unit
Interbedded coarse-grained fallout deposits, pyroclastic-flow deposits (many reworked or with paleosols),
and thinly bedded porcelaneous ash-fall deposits. Pyroclastic-flow deposits have 13 to 25 percent
phenocrysts.
Basal sandstone unit
Massive to laminated, immature volcaniclastic sandstone; very pale orange to moderate red; medium to
coarse grained; accumulations of argillic pumice clasts and rare sedimentary structures including load
casts, pinch-and-swell structures, and flame structures. Locally interbedded with reworked
pyroclastic-flow deposits.

\section{Mineralogic Correspondence}

For hydrologic purposes, the Calico Hills Formation at Yucca Mountain is categorized as either vitric or zeolitic (containing clinoptilolite). The downward change from vitric to zeolitic Tac is defined (based on hydrologic criteria) as a five-percent reduction in the porosity (Flint 1998 [DIRS 100033], p. 29). Zeolitization reduces the saturated hydraulic conductivity by several orders of magnitude relative to the conductivity of less-altered vitric tuff (Flint 1998 [DIRS 100033], p. 35). The Busted Butte section of the Tac is predominantly vitric, and its hydrologic properties should therefore most resemble those of vitric Tac in the southern and western parts of Yucca Mountain.

In Tac sections at Yucca Mountain that are mostly vitric, exemplified by the section in drill hole USW SD-12 (Chipera et al. 1996 [DIRS 101331], Table 3), smectite clay comprises as much as two-weight percent in tuffs that contain 1 to 10 percent clinoptilolite. The vitric Tac section in the Busted Butte test facility contains two lithologic varieties, both of which are nonwelded: pyroclastic-flow tuff and pumice-lapilli (air-fall) tuff. Neither lithology is zeolitic, but the pyroclastic-flow tuff contains 7 to 12 percent smectite clay and the pumice air-fall tuff contains 1 to 7 percent smectite (DTN: LA0204SL831372.001 [DIRS 164749]). Thus, the ranges of secondary hydrous-mineral contents in the predominantly vitric Tac of Busted Butte and USW SD-12 are very similar. It has not been investigated whether it is significant that the Busted Butte secondary mineralogy is smectite, whereas the Yucca Mountain secondary mineralogy is dominated by zeolite.

Borehole USW SD-7 is the only other source of qualified vitric Tac core. Four samples (from the uppermost vitric portion of the Tac section of this core) each contain a maximum of one percent of smectite and a maximum of one percent of zeolite (Chipera et al. 1996 [DIRS 101331], Table 1). In this respect, they differ from the more-altered Busted Butte and USW SD-12 vitric Tac.

\section{$\underline{\text { Within-Site Variability of Hydrologic Properties }}$}

Within the nominal 2-m thickness of the Tac in the Phase 2 test block, pyroclastic-flow tuff comprises approximately 80 percent of the section and pumice air-fall tuff accounts for 
approximately 20 percent in two beds. The data set of 37 Tac hydrologic-properties samples contained 16 samples of pyroclastic-flow tuff and 21 samples from a single bed of pumice air-fall tuff. The subset of samples for which saturated hydraulic conductivity has been measured includes five pyroclastic-flow tuff samples and 19 pumice air-fall samples. This means that the permeability data set is heavily skewed toward a less common lithology, with approximately 80 percent of the measurements representing approximately 20 percent of the Tac section in the test block.

The potential effect of this uneven sample coverage may be assessed from the data in Table H-3. The mean porosities and standard deviations of the two lithologies are the same. Geometric mean saturated hydraulic conductivity of the pumice air-fall is a factor of two higher than the comparable value for the pyroclastic-flow tuff.

This finding raises questions about whether this difference reflects consistent and characteristic attributes of the two lithologies at Busted Butte and Yucca Mountain, and whether a difference of this magnitude is meaningful for modeling purposes. If the representation error is a problem, this under-representation is even more strongly pronounced.

Table H-3. Hydrologic Properties of Calico Hills Formation, Busted Butte

\begin{tabular}{|c|c|c|c|c|}
\hline $\begin{array}{l}\text { Borehole } \\
\text { (UZTT-BB-) }\end{array}$ & $\begin{array}{l}\text { Sampling } \\
\text { Depth } \\
\text { (ft) }\end{array}$ & Stratigraphic Category & $\begin{array}{l}\text { RH Oven Porosity } \\
\left(\mathrm{cm}^{3} / \mathrm{cm}^{3}\right)\end{array}$ & $\begin{array}{c}\text { Saturated Hydraulic } \\
\text { Conductivity } \\
(\mathrm{m} / \mathrm{s})\end{array}$ \\
\hline COL-1 & 10.5 & Tac pyroclastic flow & 0.34 & $\mathrm{~N} / \mathrm{A}$ \\
\hline COL-1 & 16.8 & Tac pyroclastic flow & 0.33 & $\mathrm{~N} / \mathrm{A}$ \\
\hline COL-2 & 6.5 & Tac pyroclastic flow & 0.34 & $7.2 \mathrm{E}-05$ \\
\hline COL-2 & 7.6 & Tac pyroclastic flow & 0.34 & $4.6 \mathrm{E}-05$ \\
\hline COL-10 & 6.7 & Tac pyroclastic flow & 0.31 & N/A \\
\hline COL-10 & 10.6 & Tac pyroclastic flow & 0.32 & $\mathrm{~N} / \mathrm{A}$ \\
\hline COL-10 & 21.5 & Tac pyroclastic flow & 0.49 & $\mathrm{~N} / \mathrm{A}$ \\
\hline COL-10 & 25.5 & Tac pyroclastic flow & 0.34 & N/A \\
\hline COL-11 & 20.9 & Tac pyroclastic flow & 0.32 & N/A \\
\hline COL-11 & 30.5 & Tac pyroclastic flow & 0.36 & $\mathrm{~N} / \mathrm{A}$ \\
\hline COL-12 & 7.5 & Tac pyroclastic flow & 0.34 & $1.9 \mathrm{E}-05$ \\
\hline COL-12 & 9.5 & Tac pyroclastic flow & 0.32 & $3.7 \mathrm{E}-05$ \\
\hline COL-12 & 11.0 & Tac pyroclastic flow & 0.31 & $\mathrm{~N} / \mathrm{A}$ \\
\hline COL-12 & 22.2 & Tac pyroclastic flow & 0.32 & N/A \\
\hline COL-12 & 23.5 & Tac pyroclastic flow & 0.33 & $\mathrm{~N} / \mathrm{A}$ \\
\hline COL-12 & 25.8 & Tac pyroclastic flow & 0.32 & $1.5 \mathrm{E}-05$ \\
\hline \multicolumn{3}{|c|}{ Arithmetic mean Tac pyroclastic flow porosity } & 0.34 & \\
\hline Standard d & iation Tac $p$ & clastic flow porosity & 0.04 & \\
\hline \multicolumn{4}{|c|}{ Geometric mean Tac pyroclastic flow saturated hydraulic conductivity } & $3.2 \mathrm{E}-05$ \\
\hline INJ-7 & 11.9 & Tac pumice air-fall & 0.37 & $4.3 \mathrm{E}-05$ \\
\hline INJ-7 & 14.7 & Tac pumice & 0.34 & $2.1 \mathrm{E}-05$ \\
\hline INJ-7 & 18.7 & Tac pumice & 0.31 & $4.5 \mathrm{E}-05$ \\
\hline INJ-7 & 20.3 & Tac pumice & 0.32 & $1.1 \mathrm{E}-05$ \\
\hline INJ-8 & 8.6 & Tac pumice & 0.33 & $1.0 \mathrm{E}-05$ \\
\hline INJ-8 & 11.6 & Tac pumice & 0.32 & $3.1 \mathrm{E}-05$ \\
\hline INJ-8 & 14.1 & Tac pumice & 0.32 & $8.4 \mathrm{E}-06$ \\
\hline INJ-8 & 19.4 & Tac pumice & 0.33 & $8.3 \mathrm{E}-06$ \\
\hline INJ-8 & 25.0 & Tac pumice & 0.46 & $5.1 \mathrm{E}-07$ \\
\hline INJ-9 & 6.0 & Tac pumice & 0.31 & $\mathrm{~N} / \mathrm{A}$ \\
\hline INJ-9 & 10.5 & Tac pumice & 0.35 & $5.5 \mathrm{E}-05$ \\
\hline INJ-9 & 12.3 & Tac pumice & 0.34 & $2.4 \mathrm{E}-05$ \\
\hline INJ-9 & 18.6 & Tac pumice & 0.31 & $3.1 \mathrm{E}-06$ \\
\hline
\end{tabular}


Table H-3. Hydrologic Properties of Calico Hills Formation, Busted Butte (Continued)

\begin{tabular}{|c|c|c|c|c|}
\hline $\begin{array}{l}\text { Borehole } \\
\text { (UZTT-BB-) }\end{array}$ & $\begin{array}{l}\text { Sampling } \\
\text { Depth } \\
\text { (ft) }\end{array}$ & Stratigraphic Category & $\begin{array}{l}\text { RH Oven Porosity } \\
\left(\mathrm{cm}^{3} / \mathrm{cm}^{3}\right)\end{array}$ & $\begin{array}{c}\text { Saturated Hydraulic } \\
\text { Conductivity } \\
(\mathrm{m} / \mathrm{s})\end{array}$ \\
\hline INJ-9 & 19.7 & Tac pumice & 0.27 & $2.0 \mathrm{E}-06$ \\
\hline INJ-9 & 21.5 & Tac pumice & 0.35 & $8.8 \mathrm{E}-06$ \\
\hline INJ-10 & 8.7 & Tac pumice & 0.36 & $8.8 \mathrm{E}-06$ \\
\hline INJ-10 & 11.8 & Tac pumice & 0.33 & $\mathrm{~N} / \mathrm{A}$ \\
\hline INJ-10 & 15.7 & Tac pumice & 0.31 & $4.2 \mathrm{E}-05$ \\
\hline INJ-10 & 17.4 & Tac pumice & 0.36 & $4.2 \mathrm{E}-05$ \\
\hline INJ-10 & 20.6 & Tac pumice & 0.33 & 4.2E-05 \\
\hline INJ-10 & 22.8 & Tac pumice & 0.33 & 4.3E-05 \\
\hline \multicolumn{3}{|c|}{ Arithmetic mean Tac pumice flow porosity } & 0.34 & \\
\hline \multicolumn{3}{|c|}{ Standard deviation Tac pumice flow porosity } & 0.04 & \\
\hline \multicolumn{4}{|c|}{ Geometric mean Tac pumice flow saturated hydraulic conductivity } & 1.4E-05 \\
\hline
\end{tabular}

Source: DTNs: GS990708312242.008 [DIRS 109822] (hydrologic properties), LA0207SL831372.001 [DIRS 160824] (stratigraphic category).

\section{Comparison of Busted Butte and Yucca Mountain Hydrologic Properties}

Table H-4 contains porosity data for a portion of the Tac section in Borehole USW SD-12 at Yucca Mountain. This portion shares petrologic characteristics used to identify the Busted Butte Tac section as Unit 3 in the Moyer and Geslin classification (1995 [DIRS 101269]). The depth interval identified here as Unit 3 in USW SD-12 differs from the interval designated as Unit 3 in Rautman and Engstrom (1996 [DIRS 100642], p. 51), but the difference is not considered important for the purpose of this analysis.

The comparison of hydrologic properties is limited to porosity data, because saturated hydraulic conductivity data are not available for the USW SD-12 Tac section. The mean porosity of the USW SD-12 section is slightly lower than that of the Busted Butte section, including both pyroclastic-flow and pumice air-fall lithologies. The standard deviations are the same for USW SD-12 and for both Busted Butte lithologies. This is an indication that the very restricted provenance of the Busted Butte samples may not have seriously biased the variability of that data set.

Table H-4. Porosity Data for the Calico Hills Formation in USW SD-12

\begin{tabular}{|c|c|c|c|}
\hline Borehole & $\begin{array}{c}\text { Sample Depth } \\
\text { (ft) }\end{array}$ & Stratigraphic Category & $\begin{array}{c}\text { RH Oven Porosity } \\
\left(\mathbf{c m}^{\mathbf{3}} / \mathbf{c m}^{\mathbf{3}}\right)\end{array}$ \\
\hline USW SD-12 & 1500.6 & Tac Unit 3, Busted Butte equivalent & 0.295 \\
\hline USW SD-12 & 1504.0 & Tac Unit 3, Busted Butte equivalent & 0.361 \\
\hline USW SD-12 & 1507.0 & Tac Unit 3, Busted Butte equivalent & 0.336 \\
\hline USW SD-12 & 1509.8 & Tac Unit 3, Busted Butte equivalent & 0.333 \\
\hline USW SD-12 & 1513.0 & Tac Unit 3, Busted Butte equivalent & 0.335 \\
\hline USW SD-12 & 1515.7 & Tac Unit 3, Busted Butte equivalent & 0.324 \\
\hline USW SD-12 & 1519.1 & Tac Unit 3, Busted Butte equivalent & 0.304 \\
\hline USW SD-12 & 1522.2 & Tac Unit 3, Busted Butte equivalent & 0.308 \\
\hline USW SD-12 & 1524.5 & Tac Unit 3, Busted Butte equivalent & 0.260 \\
\hline
\end{tabular}


Table H-4. Porosity Data for the Calico Hills Formation in USW SD-12 (Continued)

\begin{tabular}{|c|c|c|c|}
\hline Borehole & $\begin{array}{c}\text { Sample Depth } \\
\text { (ft) }\end{array}$ & Stratigraphic Category & $\begin{array}{c}\text { RH Oven Porosity } \\
\mathbf{( c m}^{\mathbf{3}} / \mathbf{c m}^{\mathbf{3}} \mathbf{)}\end{array}$ \\
\hline USW SD-12 & 1528.2 & Tac Unit 3, Busted Butte equivalent & 0.308 \\
\hline USW SD-12 & 1531.0 & Tac Unit 3, Busted Butte equivalent & 0.340 \\
\hline USW SD-12 & 1534.4 & Tac Unit 3, Busted Butte equivalent & 0.309 \\
\hline USW SD-12 & 1537.2 & Tac Unit 3, Busted Butte equivalent & 0.333 \\
\hline USW SD-12 & 1539.8 & Tac Unit 3, Busted Butte equivalent & 0.318 \\
\hline USW SD-12 & 1542.5 & Tac Unit 3, Busted Butte equivalent & 0.312 \\
\hline USW SD-12 & 1546.0 & Tac Unit 3, Busted Butte equivalent & 0.327 \\
\hline USW SD-12 & 1549.0 & Tac Unit 3, Busted Butte equivalent & 0.280 \\
\hline USW SD-12 & 1557.1 & Tac Unit 3, Busted Butte equivalent & 0.321 \\
\hline USW SD-12 & 1558.1 & Tac Unit 3, Busted Butte equivalent & 0.304 \\
\hline USW SD-12 & 1560.4 & Tac Unit 3, Busted Butte equivalent & 0.310 \\
\hline USW SD-12 & 1563.5 & Tac Unit 3, Busted Butte equivalent & 0.272 \\
\hline USW SD-12 & 1567.0 & Tac Unit 3, Busted Butte equivalent & 0.257 \\
\hline USW SD-12 & 1570.0 & Tac Unit 3, Busted Butte equivalent & 0.260 \\
\hline USW SD-12 & 1573.2 & Tac Unit 3, Busted Butte equivalent & 0.313 \\
\hline USW SD-12 & 1575.2 & Tac Unit 3, Busted Butte equivalent & 0.307 \\
\hline USW SD-12 & 1578.8 & Tac Unit 3, Busted Butte equivalent & 0.330 \\
\hline USW SD-12 & 1581.6 & Tac Unit 3, Busted Butte equivalent & 0.318 \\
\hline Arithmetic mean & & Tac Unit 3, Busted Butte equivalent & 0.31 \\
\hline Standard deviation & & Tac Unit 3, Busted Butte equivalent & 0.04 \\
\hline
\end{tabular}

Source: DTN: GS960808312231.004 [DIRS 108985].

The mineralogic differences between the relatively unaltered upper Tac section in USW SD-7 and the somewhat more altered Busted Butte and USW SD-12 vitric Tac sections have been noted elsewhere in this appendix. Hydrologic-properties data for four samples in Table H5 also are distinctive. All porosity values are below the mean porosity values for Busted Butte and USW SD-12. Similarly, the saturated hydraulic conductivity values are all below the mean value of $1.7 \times 10^{-5}$ for all Busted Butte test facility Tac. The combination of lower porosity and hydraulic conductivity in a minimally altered tuff may reflect an increased degree of compaction relative to the two other sites. Alternatively, the differences may be a function of what is recoverable in the coring (a known problem). An additional potential difference might result if the Tac is non-uniform and has different transverse and longitudinal properties. The reported difference might then partially result from measurement of properties from vertically extracted core versus horizontally extracted core. 
Table H-5. Porosity and Permeability Data for the Calico Hills Formation in USW SD-7

\begin{tabular}{|c|c|c|c|c|}
\hline Borehole & $\begin{array}{c}\text { Sample Depth, } \\
(\mathrm{ft})^{\mathrm{a}}\end{array}$ & Stratigraphic Category $^{\mathrm{b}}$ & $\begin{array}{l}\text { RH Oven Porosity } \\
\left(\mathrm{cm}^{3} / \mathrm{cm}^{3}\right)\end{array}$ & $\begin{array}{c}\text { Saturated Hydraulic } \\
\text { Conductivity } \\
(\mathrm{m} / \mathrm{s})\end{array}$ \\
\hline USW SD-7 & $1396.4 / 1396.0$ & Tac Unit 3 & 0.298 & 1.60E-05 \\
\hline USW SD-7 & $1410.3 / 1410.7$ & Tac Unit 3 & 0.272 & 3.30E-06 \\
\hline USW SD-7 & $1422.0 / 1422.2$ & Tac Unit 3 & 0.308 & 7.10E-06 \\
\hline USW SD-7 & $1428.0 / 1428.0$ & Tac Unit 3 & 0.221 & $2.80 \mathrm{E}-09$ \\
\hline
\end{tabular}

Source: DTNs: GS951108312231.009 [DIRS 108984] (porosity), GS960808312231.005 [DIRS 108995]

(saturated hydraulic conductivity).

a The first depth is the porosity sample; the second depth is the saturated hydraulic conductivity sample.

${ }^{b}$ Based on Rautman and Engstrom (1996 [DIRS 101008], p. 12). The 1,396-ft samples are above the Tac, according to this reference.

Samples of the Calico Hills Formation and Topopah Spring Tuff exposed in Busted Butte outcrops were used to determine the hydrologic properties of the formations in the test block. Table H-6 presents the mean and standard deviation for porosity, saturated conductivity, and van Genuchten parameters for samples taken from the three units at Busted Butte.

Table H-6. Hydrogeologic Properties of Busted Butte Units

\begin{tabular}{|l|c|c|c|c|c|c|}
\hline \multicolumn{1}{|c|}{ Unit } & $\begin{array}{c}\text { Number of } \\
\text { Samples }\end{array}$ & $\begin{array}{c}\text { Porosity } \\
\text { Mean }\end{array}$ & $\begin{array}{c}\text { Porosity } \\
\text { Std. Dev. }\end{array}$ & $\begin{array}{c}\boldsymbol{K}_{\text {sat }}[\mathbf{m} / \mathbf{s}] \\
\text { Arith. Mean }\end{array}$ & $\begin{array}{c}\boldsymbol{K}_{\text {sat }}[\mathrm{m} / \mathbf{s}] \\
\text { Std. Dev. }\end{array}$ & $\begin{array}{c}\boldsymbol{K}_{\text {sat }}[\mathrm{m} / \mathbf{s}] \\
\mathbf{G e o m} . \text { Mean }\end{array}$ \\
\hline Tac & 35 & 0.354 & 0.042 & $2.363 \mathrm{E}-05$ & $1.720 \mathrm{E}-05$ & $1.523 \mathrm{E}-05$ \\
\hline Tptpv1 & 25 & 0.420 & 0.040 & $1.073 \mathrm{E}-05$ & $1.853 \mathrm{E}-05$ & $3.372 \mathrm{E}-06$ \\
\hline Tptpv2 & 19 & 0.387 & 0.032 & $4.397 \mathrm{E}-06$ & $4.387 \mathrm{E}-06$ & $2.651 \mathrm{E}-06$ \\
\hline
\end{tabular}

\begin{tabular}{|l|c|c|c|c|c|}
\hline Unit & $\begin{array}{c}\text { Number of } \\
\text { Samples }\end{array}$ & $\begin{array}{c}\text { van Genuchten } \\
\text { alpha [1/m] } \\
\text { Mean }\end{array}$ & $\begin{array}{c}\text { van Genuchten } \\
\text { alpha [1/m] } \\
\text { Std. Dev. }\end{array}$ & $\begin{array}{c}\text { van Genuchten } \boldsymbol{n} \\
\text { Mean }\end{array}$ & $\begin{array}{c}\text { van Genuchten } \boldsymbol{n} \\
\text { Std. Dev. }\end{array}$ \\
\hline Tac & 35 & 3.014 & 2.632 & 1.279 & 0.205 \\
\hline Tptpv1 & 25 & 0.685 & 0.365 & 1.385 & 0.278 \\
\hline Tptpv2 & 19 & 0.633 & 0.015 & 1.309 & 0.109 \\
\hline
\end{tabular}

Source: Mean and standard deviation of values calculated from the following DTNs: GS990308312242.007 [DIRS 107185]; GS990708312242.008 [DIRS 109822].

\section{Conclusions}

The amount of existing hydrologic-properties data for the vitric Tac at Yucca Mountain is insufficient to make a quantitative assessment of vitric Tac data from Busted Butte relative to Yucca Mountain data. The use of Busted Butte vitric Tac hydrologic properties to model hydrologic processes at Yucca Mountain is based on an assumption that no additional data from Yucca Mountain proper will be available. An examination of existing data suggests that property values at Busted Butte probably lie within the range of Yucca Mountain values, but the variation of Yucca Mountain values is almost certainly greater than that of Busted Butte, because the scale of the Busted Butte site is considerably smaller than that of the corresponding 
hydrogeologic units at Yucca Mountain. Values of Busted Butte hydrologic properties (such as porosity and saturated hydraulic conductivity) may be near the high end of the range for these property values at Yucca Mountain. If this is correct, one possible explanation may be that the Tac tends to be slightly more compacted at Yucca Mountain than at Busted Butte, because it has a thinner overburden. Another possible explanation is that recovery in the Yucca Mountain cores was limited to rock that was more intact and thus had smaller values of hydrologic properties. The smectitic alteration at Busted Butte differs from zeolitic alteration at Yucca Mountain, but the data are insufficient to test for a relationship between alteration mineralogy and variations in hydrologic properties. 
INTENTIONALLY LEFT BLANK 


\section{APPENDIX I}

CALCULATIONS PERFORMED USING EXCEL SPREADSHEETS AND FUNCTIONS 


\section{I1. MEAN: GEOMETRIC AND ARITHMETIC}

The difference between arithmetic and geometric means is in the underlying statistical distribution used in mean calculation. The arithmetic mean gives equal weight to all data and uses the normal (bell-shaped) distribution. Unless specifically called out in the text (as in Section 6.1.2) the average or mean values presented in this report are calculated using the arithmetic mean. In all cases, the DTN listed in the text of the section (or included as a note to a table or figure) contains the input values, and the output values are produced using the following functions:

If the following function is typed into Excel:

$$
=\text { AVERAGE }(A 1: \text { A34) }
$$

then the arithmetic mean, or average value, of the data in cells A1 through A34 will be returned.

If the following function is typed into Excel:

$$
=\text { GEOMEAN(A1: A34) }
$$

then the geometric mean value of the data in cells A1 through A34 will be returned.

The term log mean (as used in Section 6.14.4) is the same as the geometric mean.

\section{I2. MEDIAN, MODE, AND STANDARD DEVIATION}

Data in some of the sections (e.g., Section 6.1 and Section 6.14) have been used to calculate median, mode, and standard deviation summary statistics. The median is the middle point of the probability distribution, where 50 percent of the observations lie on one side of the median, and 50 percent lie on the other side of the median. The mode is the portion of the distribution with the greatest frequency of occurrence. In a normal distribution, the mean, median, and mode should be equivalent. The standard deviation $(\sigma)$, also referred to as error and variability in this report, is a measure of the spread of the probability distribution around the arithmetic mean. In Excel, these values were calculated for this report using the following functions:

$$
=\text { MEDIAN(A1: A34), }
$$

which returns the median value for the data in cells A1 through A34,

$$
=\operatorname{MODE}(\mathrm{A} 1: \mathrm{A} 34) \text {, }
$$

which returns the mode for the data in cells A1 through A34,

$$
=\mathrm{STDEV}(\mathrm{A} 1: \mathrm{A} 34) \text {, }
$$

which returns the standard deviation of the data in cells A1 through A34, and

$$
=\operatorname{VAR}(\mathrm{A} 1: \mathrm{A} 34) \text {, }
$$

which returns the variance of the data in cells A1 through A34. 


\section{I3. SPREADSHEET CALCULATIONS}

Using the preset functions in Excel, equations may be entered and calculated. Section 6.1 (which contains Equation 6-1), Section 6.2 (which contains Equation 6-3 to Equation 6-10), Section 6.4 (which contains Equation 6-11), and Section 6.10 (which contains Equations 6-12 and 6-13) contain equations that were calculated using data for analyses in the respective sections. For example, Equation I-7 (see also Equation 6-1) was used to calculate air-permeability from pressure differences during steady-state air injection using the following modified Hvorslev's formula (LeCain 1995 [DIRS 101700], p. 10, Equation 15):

$$
k=\frac{P_{s c} Q_{s c} \mu \ln \left(\frac{L}{r_{w}}\right) T_{f}}{\pi L\left(P_{2}^{2}-P_{1}^{2}\right) T_{s c}}
$$

where

$$
\begin{array}{ll}
k & =\text { permeability, } \mathrm{m}^{2} \\
P_{s c} & =\text { standard pressure, } \mathrm{Pa} \\
Q_{s c} & =\text { flow-rate at standard conditions, } \mathrm{m}^{3} / \mathrm{s} \\
\mu & =\text { dynamic viscosity of air, } \mathrm{Pa} \cdot \mathrm{s} \\
L & =\text { length of zone, } \mathrm{m} \\
r_{w} & =\text { radius of bore, } \mathrm{m} \\
T_{f} & =\text { temperature of formation, } \mathrm{K} \\
P_{2} & \text { = injection zone pressure at steady-state, } \mathrm{Pa} \\
P_{1} & =\text { ambient pressure, } \mathrm{Pa} \\
T_{s c} & =\text { standard temperature, } \mathrm{K} \\
\ln & =\text { natural log }
\end{array}
$$

In Excel, the input data used in the calculations for this example (DTN: LB0011AIRKTEST.001 [DIRS 153155]) (the first 9 entries shown) would appear as seen in Table I-1.

The input DTN in this case contains $P_{2}$ injection zone pressure at steady state, (in $\mathrm{Pa}$ ), $P_{1}$ ambient pressure (in $\mathrm{Pa}$ ), and $Q_{s c}$ flow-rate at standard conditions (in $\mathrm{m}^{3} / \mathrm{s}$ ). The remaining values in the calculations are standard constants obtained from reference books or site-specific values (e.g., borehole radius and length), all of which have been documented in the scientific notebooks referenced for the section. The output for this equation is the permeability values $(\mathrm{k})$ in column J.

Other calculations have been performed in a similar manner using equations presented in Section 6.1, Section 6.2, and Section 6.4. Details on the calculations in Section 6.2 are listed as notes to the tables in Appendix B. (See Appendix B for details: only the general practices related to calculations in Excel are discussed here.) 
Table I-1. Calculation Spreadsheet for Permeability (Output) from Input in DTN: LB0011AIRKTEST.001

\begin{tabular}{|l|c|c|c|c|c|c|c|c|c|c|}
\hline & A & B & C & D & E & F & G & H & I & J \\
\hline $\mathbf{1}$ & $\mathbf{P 1}$ & $\mathbf{P 2}$ & $\mathbf{L}$ & $\mathbf{Q s c}$ & $\mathbf{U}$ & $\mathbf{~ w}$ & $\mathbf{T f}$ & Tsc & Psc & k -permeability \\
\hline $\mathbf{2}$ & 89515.40 & 215482.27 & 0.3048 & $8.30 \mathrm{E}-04$ & $1.78 \mathrm{E}-05$ & 0.0381 & 288.1 & 288.1 & 101352.9 & $8.46 \mathrm{E}-14$ \\
\hline $\mathbf{3}$ & 92174.57 & 146320.52 & 0.3048 & $1.69 \mathrm{E}-05$ & $1.78 \mathrm{E}-05$ & 0.0381 & 288.1 & 288.1 & 101352.9 & $5.12 \mathrm{E}-15$ \\
\hline $\mathbf{4}$ & 89023.91 & 124321.86 & 0.3048 & $1.69 \mathrm{E}-05$ & $1.78 \mathrm{E}-05$ & 0.0381 & 288.1 & 288.1 & 101352.9 & $8.78 \mathrm{E}-15$ \\
\hline $\mathbf{5}$ & 90593.25 & 129981.18 & 0.3048 & $1.69 \mathrm{E}-05$ & $1.78 \mathrm{E}-05$ & 0.0381 & 288.1 & 288.1 & 101352.9 & $7.61 \mathrm{E}-15$ \\
\hline $\mathbf{6}$ & 88695.51 & 165094.52 & 0.3048 & $8.37 \mathrm{E}-05$ & $1.78 \mathrm{E}-05$ & 0.0381 & 288.1 & 288.1 & 101352.9 & $1.69 \mathrm{E}-14$ \\
\hline $\mathbf{7}$ & 89190.80 & 118626.97 & 0.3048 & $1.69 \mathrm{E}-05$ & $1.78 \mathrm{E}-05$ & 0.0381 & 288.1 & 288.1 & 101352.9 & $1.08 \mathrm{E}-14$ \\
\hline $\mathbf{8}$ & 89843.76 & 107377.01 & 0.3048 & $8.36 \mathrm{E}-05$ & $1.78 \mathrm{E}-05$ & 0.0381 & 288.1 & 288.1 & 101352.9 & $9.47 \mathrm{E}-14$ \\
\hline $\mathbf{9}$ & 89755.15 & 115576.75 & 0.3048 & $8.29 \mathrm{E}-04$ & $1.78 \mathrm{E}-05$ & 0.0381 & 288.1 & 288.1 & 101352.9 & $6.12 \mathrm{E}-13$ \\
\hline
\end{tabular}

Source: DTN: LB0011AIRKTEST.001 [DIRS 153155]

In cell: Equation for permeability (Equation 6-1):

$\mathrm{J} 2 \quad\left(\mathrm{I} 2^{*} \mathrm{D} 2^{*} \mathrm{E} 2^{*} \mathrm{LN}(\mathrm{C} 2 / \mathrm{F} 2)^{*} \mathrm{G} 2\right) /\left(3.14^{*} \mathrm{C} 2^{*}\left(\left(\mathrm{~B} 2^{\wedge} 2\right)-\left(\mathrm{A} 2^{\wedge} 2\right)\right)^{*} \mathrm{H} 2\right)$

J3 $\left(I 3^{*} \mathrm{D} 3^{*} \mathrm{E} 3^{*} \mathrm{LN}(\mathrm{C} 3 / \mathrm{F} 3)^{*} \mathrm{G} 3\right) /\left(3.14^{*} \mathrm{C} 3^{*}\left(\left(\mathrm{~B} 3^{\wedge} 2\right)-\left(\mathrm{A} 3^{\wedge} 2\right)\right)^{*} \mathrm{H} 3\right)$

$\mathrm{J} 4 \quad\left(14^{*} \mathrm{D} 4{ }^{*} \mathrm{E} 4^{*} \mathrm{LN}(\mathrm{C} 4 / \mathrm{F} 4)^{*} \mathrm{G} 4\right) /\left(3.14^{*} \mathrm{C} 4^{*}\left(\left(\mathrm{~B} 4^{\wedge} 2\right)-\left(\mathrm{A} 4^{\wedge} 2\right)\right)^{*} \mathrm{H} 4\right)$

J5 $\quad\left(15^{*} \mathrm{D} 5^{*} \mathrm{E} 5^{*} \mathrm{LN}(\mathrm{C} 5 / \mathrm{F} 5)^{*} \mathrm{G} 5\right) /\left(3.14^{*} \mathrm{C} 5^{\star}\left(\left(\mathrm{B} 5^{\wedge} 2\right)-\left(\mathrm{A} 5^{\wedge} 2\right)\right)^{*} \mathrm{H} 5\right)$

$\mathrm{J} 6 \quad\left(\mathrm{I} 6^{*} \mathrm{D} 6{ }^{*} \mathrm{E} 6{ }^{*} \mathrm{LN}(\mathrm{C} 6 / \mathrm{F} 6)^{*} \mathrm{G} 6\right) /\left(3.14^{*} \mathrm{C} 6^{*}\left(\left(\mathrm{~B} 6^{\wedge} 2\right)-\left(\mathrm{A} 6^{\wedge} 2\right)\right)^{*} \mathrm{H} 6\right)$

J7 $\quad\left(17^{*} \mathrm{D} 7^{*} \mathrm{E} 7^{*} \mathrm{LN}(\mathrm{C} 7 / \mathrm{F} 7)^{*} \mathrm{G} 7\right) /\left(3.14^{*} \mathrm{C} 7^{*}\left(\left(\mathrm{~B} 7^{\wedge} 2\right)-\left(\mathrm{A} 7^{\wedge} 2\right)\right)^{*} \mathrm{H} 7\right)$

J8 $\quad\left(18^{*} \mathrm{D} 8^{*} \mathrm{E} 8^{*} \mathrm{LN}(\mathrm{C} 8 / \mathrm{F} 8)^{*} \mathrm{G} 8\right) /\left(3.14^{*} \mathrm{C} 8^{*}\left(\left(\mathrm{~B} 8{ }^{\wedge} 2\right)-\left(\mathrm{A} 8^{\wedge} 2\right)\right)^{*} \mathrm{H} 8\right)$

J9 $\left(19^{*} \mathrm{D} 9{ }^{*} \mathrm{E} 9{ }^{*} \mathrm{LN}(\mathrm{C} 9 / \mathrm{F} 9)^{*} \mathrm{G} 9\right) /\left(3.14^{*} \mathrm{C} 9^{*}\left(\left(\mathrm{~B} 9^{\wedge} 2\right)-\left(\mathrm{A} 9^{\wedge} 2\right)\right)^{*} \mathrm{H} 9\right)$

Data have been truncated, and are presented here as an example calculation only.

\section{I4. PLOTTING AND TREND-LINES}

Microsoft Excel can also be used to plot data organized into columns and rows. This is performed by highlighting the data columns to be plotted (e.g., sample date column and seepage volume column) and then going to the INSERT pull-down menu and selecting the CHART option. The Excel Chart Wizard will then appear on screen and guide the user through the options to format the plot as desired. The following is provided as an example, with data from Section 6.10.2, and using input corroborating data from Fundamentals of Soil Physics (Hillel 1980 [DIRS 101134], p. 39).

Once a chart exists and is selected (activated), a CHART file appears as a pull-down menu and can be used to adjust chart format. From the CHART pull-down menu, ADD TRENDLINE may be selected to have Excel add a line to the data, based upon a least-squares best-fit technique. This means that a line is added that minimizes the sum of the squared differences between the line and the actual data. This feature of Excel has been used in this report in Figures 6-19 through Figure 6-23, Figure 6-122, Figure 6-141, Figure 6-142, and Figure 6-145. It is a calculation (based upon data) similar to the others performed in Excel. Excel was also used to display box plots of data (Figure 6-217 and Figure 6-218), which are boxes on a graph with a line through the mean value and the upper and lower boundaries of the box at 2 times the standard deviation level. The outer lines (known as whiskers) of the box plot indicate the total range of data values, and individual points indicate outlier data. 


\begin{tabular}{|c|c|}
\hline $\begin{array}{c}\text { Temperature } \\
\left({ }^{\circ} \mathbf{C}\right)\end{array}$ & $\begin{array}{c}\text { Vapor Density } \\
\left(\mathbf{k g} / \mathbf{m}^{3}\right)\end{array}$ \\
\hline 0 & 0.00485 \\
\hline 5 & 0.0068 \\
\hline 10 & 0.0094 \\
\hline 15 & 0.01285 \\
\hline 20 & 0.0173 \\
\hline 25 & 0.02305 \\
\hline 30 & 0.03038 \\
\hline 35 & 0.03963 \\
\hline
\end{tabular}

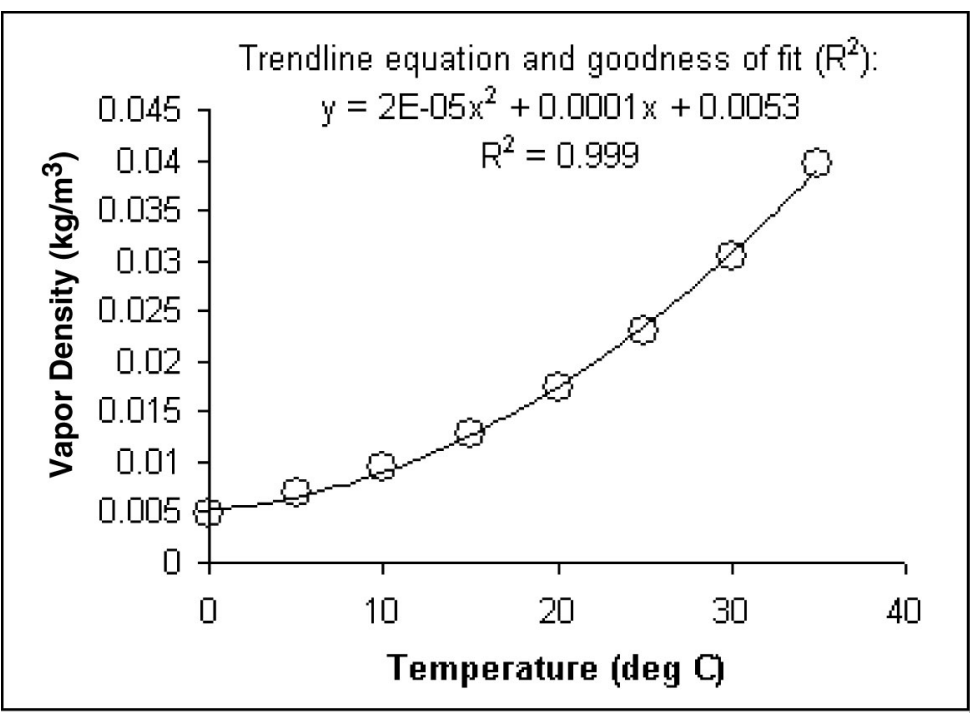

Figure I-1. Example of Plotting and Trendline Addition in Excel Based on Figure 6-122

\section{I4.1 EXCEL SMOOTHING FUNCTION}

Some of the plotted data figures displayed in this report are presented using smoothed lines to connect data points (see Figures 6-76, 6-79, 6-80, 6-191, 6-192, 6-193, and 6-194 for examples). Display of data in this manner may be appropriate for various reasons, including that the continuity of the processes under observation is better characterized. The following discussion summarizes the smoothing function calculation in Excel.

In Excel, plots of data may be smoothed, which means that the lines between data points are made nonlinear to round the edges of sharp peaks in the data. The data itself remains unchanged, but the lines between the data are calculated using an exponential smoothing formula included in the Excel program as part of the Analysis ToolPak. This formula is designed to predict a value based on the forecast for the prior period (data point). The tool uses the smoothing constant $a$, the magnitude of which determines how strongly forecasts respond to errors in the prior forecast. The function estimates the plotted result $F$, from each time step $F_{t}$, for the following time step $F_{t+1}$. The function is:

$$
F_{t+1}=F_{t}+a^{*}\left(A_{t}-F_{t}\right)=F_{t}+(1-\text { dampFact })^{*}\left(A_{t}-F_{t}\right)
$$

where $A_{t}$ are the actual data points used to constrain the function. The damping factor (dampFact) is a corrective factor that minimizes the instability of data collected across a population. Larger constants yield a faster response, but can produce erratic projections. Smaller constants can result in long lags for forecast values. The default damping factor is 0.3 .

\section{I4.2 CALCULATION OF ESTIMATED ${ }^{234} \mathrm{U} /{ }^{238} \mathrm{U}$ AGES}

The following calculation is performed in an Excel spreadsheet as described elsewhere in this appendix, and is used in Section 6.14.3 to estimate the ages of opal mineral deposits from uranium isotope ratios. This ratiometric calculation is a standard approach in geochemical analyses. The activity of ${ }^{234} \mathrm{U}$ at any time in a closed mineral system consists of the ${ }^{234} \mathrm{U}$ activity 
generated in place by decay of ${ }^{238} \mathrm{U}$ in the sample, and the amount of excess ${ }^{234} \mathrm{U}$ activity remaining from the ${ }^{234} \mathrm{U}$ incorporated into the mineral at the time of formation. The mathematical expression for this relation is given by Faure (1986 [DIRS 105559], p. 369, Equation 21.22). Rearranging to solve for the age of the system, $t$ :

$$
t=\frac{\ln \left(\frac{\left(\frac{{ }^{234} U}{{ }^{238} U}\right)_{\text {measured }}-1}{\left(\frac{{ }^{234} U}{{ }^{238} U}\right)_{\text {initial }}-1}\right)}{-\lambda_{234}}
$$

where $\lambda_{234}$ is the radioactive decay constant for ${ }^{234} \mathrm{U}$ of $2.8262 \times 10^{-6}$ /year (Cheng et al. 2000 [DIRS 153475]). Therefore, estimated ${ }^{234} \mathrm{U} /{ }^{238} \mathrm{U}$ ages are calculated from measured ${ }^{234} \mathrm{U} /{ }^{238} \mathrm{U}$ ratios, and an assumed initial ${ }^{234} \mathrm{U} /{ }^{238} \mathrm{U}$, estimated, in the present case, using the average of initial ${ }^{234} \mathrm{U} /{ }^{238} \mathrm{U}$ activity ratios calculated using ${ }^{238} \mathrm{U}_{-}{ }^{234} \mathrm{U}_{-}{ }^{230} \mathrm{Th}$ data for SHRIMP (the ion microprobe technique) spots younger than $200 \mathrm{ka}$. The resulting estimated ${ }^{234} \mathrm{U} /{ }^{238} \mathrm{U}$ ages are presented in Table 6-43 and Figures 6-206, 6-207, and 6-208.

\section{I5. OTHER STATISTICS}

Statistical analyses can be performed using functions in Microsoft Excel. These include Student t-tests, normality tests, correlations tests, coefficient of variation calculations, F-tests, and linear regression. These statistical functions can be calculated for arrays of data (in rows and columns) using the INSERT pull-down menu and FUNCTION command.

In Section 6.14.1.2, a Fisher (F) test is performed to examine intersample variability. The analysis was performed as described by Youden, (1951 [DIRS 153339]) and Peterman and Cloke (2002 [DIRS 162576] p. 692):

$$
\mathrm{F}=\left[\Sigma\left(\mathrm{x}_{\mathrm{m}}-\mu\right)^{2} /\left(\mathrm{n}_{\mathrm{m}}-1\right)\right] /\left[\Sigma\left(\mathrm{x}_{\mathrm{a}}-\mathrm{x}_{\mathrm{b}}\right)^{2} / \mathrm{n}\right]
$$

where

$$
\begin{array}{ll}
\mathrm{x}_{\mathrm{m}}= & \text { means of duplicate analyses } \\
\mu= & \text { overall mean of the analyses } \\
\mathrm{n}_{\mathrm{m}}= & \text { number of samples }(20) \\
\mathrm{x}_{\mathrm{a}} \text { and } \mathrm{x}_{\mathrm{b}} & \text { are the duplicate analyses } \\
\mathrm{n}_{\mathrm{m}}= & \text { number of duplicate analyses } \\
\mathrm{n}= & \text { total number of analyses }
\end{array}
$$

A critical F-value is defined by Youden (1951 [DIRS 153339]) for a given level of probability (in this case, 95 percent). In Section 6.14.3, a discussion on the slopes of a regression line is provided for input DTN: GS021208315215.009 [DIRS 164750]. In this regression, the isotope ratios for data ${ }^{230} \mathrm{Th} / \mathrm{U}$ are analyzed in a linear regression, using Excel. This is done by plotting the data (in this case, ${ }^{230} \mathrm{Th} / \mathrm{U}$ ratio (column F) ) as a function of the distance from the surface of the sample. By then adding a TRENDLINE as discussed in Section I4, the slope of the regression may be obtained from the equation as displayed in Figure I-1. 
Table I-2. Calculation Excel Spreadsheet for Output in Table 6-44 and Figure 6-209

\begin{tabular}{|c|c|c|c|c|c|c|c|c|}
\hline A & B & C & D & E & $\mathbf{F}$ & G & H & I \\
\hline Row & $\begin{array}{c}\text { Sample } \\
\text { Designation }\end{array}$ & $\begin{array}{c}\text { Elapsed } \\
\text { Time } \\
\text { (min.) }\end{array}$ & $\begin{array}{c}\text { Uranium } \\
\text { Abundance } \\
\text { (ng) }\end{array}$ & $\begin{array}{c}{ }^{230} \text { Thorium/ } \\
\text { 232Thorium } \\
\text { Radioactivity } \\
\text { Ratio } \\
\end{array}$ & $\begin{array}{l}{ }^{230} \text { Thorium/ } \\
\text { 238Uranium } \\
\text { Isotopic Ratio }\end{array}$ & $\begin{array}{c}{ }^{234} \text { Uranium/ } \\
\text { 238Uranium } \\
\text { Radioactivity } \\
\text { Ratio } \\
\end{array}$ & $\begin{array}{c}\text { Mineral Age } \\
\text { (ka) }\end{array}$ & $\begin{array}{c}\text { Initial } \\
\text { 234Uranium/ } \\
{ }^{238} \text { Uranium } \\
\text { Radioactivity } \\
\text { Ratio }\end{array}$ \\
\hline 1 & HD2074-T1a & $1-2$ & 12.6 & $1,250 \pm 400$ & $0.3436 \pm 0.0045$ & $6.043 \pm 0.082$ & $6.34 \pm 0.12$ & $6.134 \pm 0.082$ \\
\hline 2 & HD2074-T1b & 3 & 0.744 & $134 \pm 32$ & $0.901 \pm 0.069$ & $6.421 \pm 0.058$ & $16.2 \pm 1.3$ & $6.674 \pm 0.061$ \\
\hline 3 & HD2074-T1C & 12 & 1.64 & $720 \pm 220$ & $1.490 \pm 0.056$ & $6.089 \pm 0.054$ & $29.5 \pm 1.3$ & $6.531 \pm 0.058$ \\
\hline 4 & HD2074-T1d & 12 & 1.22 & $1,400 \pm 4,200$ & $2.393 \pm 0.076$ & $5.213 \pm 0.049$ & $61.4 \pm 2.5$ & $6.011 \pm 0.059$ \\
\hline 5 & HD2074-g2-L1 & 2 & 2.21 & $550 \pm 340$ & $0.430 \pm 0.038$ & $6.574 \pm 0.089$ & $7.3 \pm 0.7$ & $6.691 \pm 0.090$ \\
\hline 6 & HD2074-g2-L2 & 2 & 3.13 & $580 \pm 180$ & $0.671 \pm 0.074$ & $6.561 \pm 0.058$ & $11.6 \pm 1.3$ & $6.747 \pm 0.062$ \\
\hline 7 & HD2074-g2-L3 & 3 & 4.81 & $940 \pm 220$ & $0.932 \pm 0.064$ & $6.649 \pm 0.084$ & $16.1 \pm 1.2$ & $6.913 \pm 0.086$ \\
\hline 8 & HD2074-g2-L4 & 3 & 4.5 & $3,300 \pm 1,900$ & $1.350 \pm 0.077$ & $6.435 \pm 0.041$ & $24.9 \pm 1.6$ & $6.831 \pm 0.048$ \\
\hline 9 & HD2074-g2-L5 & 4 & 5.1 & $5,700 \pm 4,700$ & $1.427 \pm 0.034$ & $6.492 \pm 0.042$ & $26.2 \pm 0.7$ & $6.914 \pm 0.044$ \\
\hline 10 & HD2074-g2-L6 & 5 & 6.89 & $2,770 \pm 720$ & $1.620 \pm 0.023$ & $6.375 \pm 0.036$ & $30.7 \pm 0.5$ & $6.862 \pm 0.037$ \\
\hline
\end{tabular}

Source: DTN: GS021208315215.009 [DIRS 164750].

NOTE: Data have been truncated, and are presented here as an example calculation only.

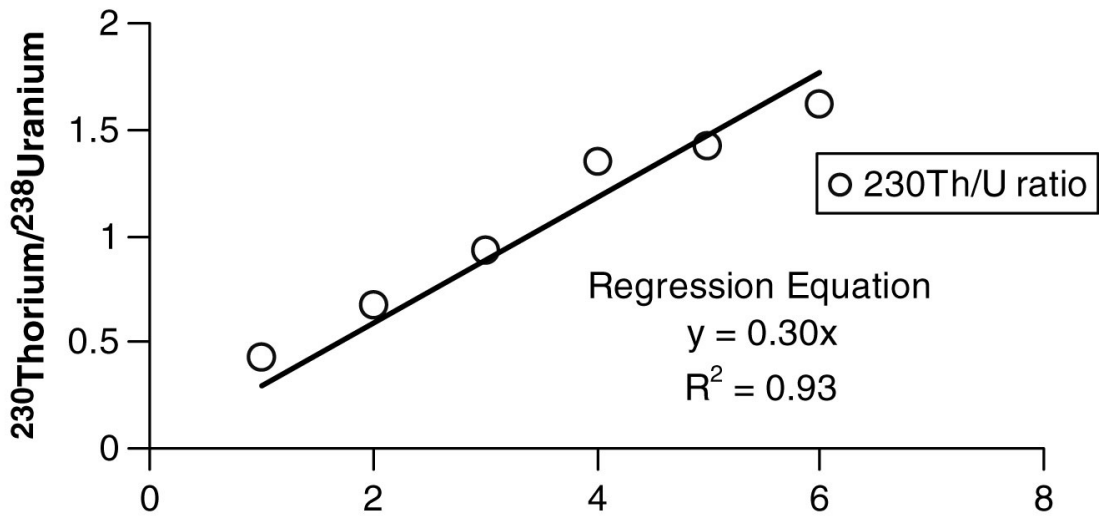

Distance from outer surface

Source: DTN: GS021208315215.009 [DIRS 164750].

NOTE: The results are discussed in section 6.14.3 and are related to Table 6-44 and Figure 6-209.

Figure I-2. Example of Linear Regression in Excel with the $y=m x$ Equation, Where $m$ is the Regression-Slope

The resulting slope (0.30) in Figure I-2 is not the same as the 0.35 slope reported in Section 6.14.3, because only rows 5 through 10 were used for demonstration purposes in this appendix. In this appendix, the distance is indicated by the last digit in the sample designation. 


\section{I6. CALCULATIONS FOR SPECIFIC FIGURES}

The following subsections document specific calculations used to create figures that require more detail than provided in Appendix Section I4.

\section{I6.1 DESCRIPTORS FOR EVAPORATION-PAN DATA IN FIGURE 6-42 (DTN：LB0211NICH5LIQ.001)}

Evaporation-pan data were measured using a single balance loaded with a container filled with water. A "Mettler Single Scale 8-31-01.vi V2.0" referred to as Balance 4, was used to record the evaporation rate after 7-15-02. Figure 6-42 shows the evaporation rate inside and outside the niche during Test \#2 9-17-02. The plot indicates that the average evaporation flux outside of the niche is approximately a factor of 20 greater than the average evaporation flux inside the niche. The input evaporation data (DTN: LB0211NICH5LIQ.001 [DIRS 160792]) collected during the study, and contained in the original data files, give the evaporation rates $(\mathrm{g} / \mathrm{s})$. These data rates were converted to output evaporation fluxes $\left(\mathrm{g} / \mathrm{s}-\mathrm{m}^{2}\right)$ shown in Column I of Table I-3. These outputs were obtained by dividing the evaporation rate (measured water-mass loss over time, in Column $\mathrm{G}$ ) by the surface area of the evaporation pan (i.e., $\pi r^{2}$, where $r$ is the radius of the pan, in Column H). The radius of the evaporation pan inside the niche was $0.075 \mathrm{~m}$ (Trautz 2003 [DIRS 166248], p. 187).

Table I-3. Calculation Excel Spreadsheet for Output in Figure 6-42

\begin{tabular}{|c|c|c|c|c|c|c|c|c|}
\hline A & B & C & D & $E$ & $\mathbf{F}$ & G & $\mathrm{H}$ & I \\
\hline $\begin{array}{c}\text { Date and } \\
\text { Date }\end{array}$ & Time & $\begin{array}{c}\text { Elapsed } \\
\text { Time } \\
\text { (s) }\end{array}$ & Weight & Units & Status & $\begin{array}{c}\text { Mass Rate } \\
(\mathbf{g} / \mathbf{s})\end{array}$ & $\begin{array}{c}\text { Area, } \pi r^{2} \\
\left(m^{2}\right)\end{array}$ & $\begin{array}{c}\text { Evaporation } \\
\left(\mathrm{g} / \mathrm{s}-\mathrm{m}^{2}\right)\end{array}$ \\
\hline $9 / 17 / 2002$ & 2:01:01 PM & 0 & 2163.3 & $g$ & SD & 0 & 0.01767146 & 0 \\
\hline $9 / 17 / 2002$ & 2:01:04 PM & 3.695 & 2163.5 & $g$ & SD & 0.054127 & 0.01767146 & 3.062961637 \\
\hline $9 / 17 / 2002$ & 2:01:21 PM & 20.029 & 2162.2 & $g$ & SD & -0.079589 & 0.01767146 & -4.503816094 \\
\hline 9/17/2002 & 2:01:37 PM & 36.362 & 2163.3 & g & S D & 0.067348 & 0.01767146 & 3.811117194 \\
\hline $9 / 17 / 2002$ & 2:01:54 PM & 52.746 & 2162.9 & $g$ & SD & -0.024414 & 0.01767146 & -1.381549789 \\
\hline 9/17/2002 & 2:02:10 PM & 69.079 & 2163.3 & $g$ & SD & 0.02449 & 0.01767146 & 1.385850509 \\
\hline $9 / 17 / 2002$ & 2:02:27 PM & 86.134 & 2163.2 & $g$ & SD & -0.005863 & 0.01767146 & -0.331777931 \\
\hline 9/17/2002 & 2:02:43 PM & 102.467 & 2163.5 & $g$ & SD & 0.018368 & 0.01767146 & 1.039416176 \\
\hline $9 / 17 / 2002$ & 2:03:00 PM & 118.791 & 2163.4 & $\mathrm{~g}$ & SD & -0.006126 & 0.01767146 & -0.346660687 \\
\hline $9 / 17 / 2002$ & 2:03:16 PM & 135.124 & 2162.9 & $g$ & SD & -0.030613 & 0.01767146 & -1.73234143 \\
\hline 9/17/2002 & 2:03:32 PM & 151.457 & 2163.5 & $\mathrm{~g}$ & SD & 0.036735 & 0.01767146 & 2.078775763 \\
\hline
\end{tabular}

Source: DTN: LB0211NICH5LIQ.001 [DIRS 160792].

NOTE: Data are from Balance 4; they have been truncated, and are presented here as an example calculation only.

\section{I6.2 DESCRIPTOR FOR DATA IN FIGURE 6-131(B) (DTN： LB0110ECRBLIQR.002)}

In Table I-4 the rate data for plotting is computed as follows: cumulative volume from columns B and D, which are taken from LB0110ECRBLIQR.002 [DIRS 156879], and have already been divided by 1,000 (to convert milligrams to liters), and written to Columns $\mathrm{C}$ and $\mathrm{E}$, respectively, of the plotting worksheet. Injection rate data are written to Column $\mathrm{F}$ in this 
worksheet by taking the difference of sequential-row data in Column $\mathrm{C}$ and dividing this difference by sequential-row data from Column A (time stamp data), and then multiplying by appropriate conversion factors.

Similarly, seepage rate data are written to Column $\mathrm{H}$ by taking the difference of sequential-row data in Column E, and dividing this difference by sequential-row data from Column A (time stamp data), and then multiplying by appropriate conversion factors. The rate data are smoothed for plotting by taking a 20-point moving average (using the Excel "AVERAGE" function, see Equation I-1), and writing the result to the row corresponding to the time stamp of the first data point of the 20-point averaging series. The averaging results are performed in this fashion on the rate data from Columns $\mathrm{F}$ and $\mathrm{H}$, and written to Output Columns $\mathrm{G}$ and I for plotting against Column A.

Table I-4. Calculation Excel Spreadsheet for Output in Figure 6-131(b)

\begin{tabular}{|c|c|c|c|c|c|c|c|c|}
\hline$A$ & B & C & D & $E$ & $\mathbf{F}$ & G & $\mathrm{H}$ & 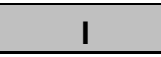 \\
\hline Date and Time & $\begin{array}{c}\text { Injection } \\
\text { (g) }\end{array}$ & $\begin{array}{c}\text { Injection } \\
\text { (L) }\end{array}$ & \begin{tabular}{|c|} 
Seepage \\
(g)
\end{tabular} & \begin{tabular}{|c} 
Seepage \\
(L)
\end{tabular} & \begin{tabular}{|c} 
Injection \\
Rate \\
(mL/min.)
\end{tabular} & $\begin{array}{l}\text { 20-point } \\
\text { Moving- } \\
\text { average } \\
\text { Injection } \\
\text { Rate } \\
\text { (mL/min.) }\end{array}$ & $\begin{array}{c}\text { Seepage } \\
\text { Rate } \\
\text { (mL/min.) }\end{array}$ & $\begin{array}{c}\text { 20-point } \\
\text { Moving- } \\
\text { average } \\
\text { Seepage } \\
\text { Rate } \\
\text { (mL/min.) }\end{array}$ \\
\hline 2/28/2001 13:59 & 376.4733 & 0.376473 & 8.269747 & 0.00827 & 9.50 & 9.54 & 0.00 & -0.07 \\
\hline $2 / 28 / 200114: 19$ & 566.9406 & 0.566941 & 8.269747 & 0.00827 & 12.83 & 9.64 & 0.00 & -0.07 \\
\hline $2 / 28 / 200114: 39$ & \begin{tabular}{|l|}
823.9857 \\
\end{tabular} & 0.823986 & 8.269747 & 0.00827 & 11.57 & 9.57 & -0.07 & -0.07 \\
\hline 2/28/2001 14:59 & 1055.978 & 1.055978 & 6.891456 & 0.006891 & 10.13 & 9.42 & -0.07 & -0.06 \\
\hline $2 / 28 / 2001$ 15:19 & 1259.144 & 1.259144 & 5.513165 & 0.005513 & 10.31 & 9.51 & 0.00 & -0.06 \\
\hline 2/28/2001 15:39 & 1465.741 & 1.465741 & 5.513165 & 0.005513 & 9.94 & 9.55 & -0.03 & -0.06 \\
\hline $2 / 28 / 2001$ 15:59 & \begin{tabular}{|l|}
1665.131 \\
\end{tabular} & 1.665131 & 4.824019 & \begin{tabular}{|l|}
0.004824 \\
\end{tabular} & 8.04 & 9.64 & -0.10 & -0.06 \\
\hline $2 / 28 / 2001$ 16:19 & \begin{tabular}{|l|}
1826.771 \\
\end{tabular} & 1.826771 & 2.756582 & \begin{tabular}{|l|}
0.002757 \\
\end{tabular} & 1.52 & 9.86 & -0.31 & -0.05 \\
\hline $2 / 28 / 200116: 39$ & \begin{tabular}{|l|}
1857.314 \\
\end{tabular} & 1.857314 & -3.44573 & -0.00345 & -4.18 & 10.45 & -0.45 & -0.03 \\
\hline $2 / 28 / 200116: 59$ & \begin{tabular}{|l|}
1773.577 \\
\end{tabular} & 1.773577 & -12.4046 & -0.0124 & 3.73 & 11.28 & 0.00 & -0.01 \\
\hline $2 / 28 / 2001$ 17:20 & \begin{tabular}{|l|}
1848.391 \\
\end{tabular} & 1.848391 & -12.4046 & -0.0124 & 14.22 & 11.72 & 0.00 & -0.01 \\
\hline 2/28/2001 17:40 & \begin{tabular}{|l|}
2133.234 \\
\end{tabular} & 2.133234 & -12.4046 & -0.0124 & 14.05 & 11.60 & 0.00 & -0.01 \\
\hline 2/28/2001 18:00 & 2414.989 & 2.414989 & -12.4046 & -0.0124 & 14.25 & 11.38 & -0.03 & -0.01 \\
\hline
\end{tabular}

Source: DTN: LB0110ECRBLIQR.002 [DIRS 156879].

NOTE: Data have been truncated, and are presented here as an example calculation only.

\section{I6.3 DESCRIPTOR FOR DATA IN FIGURES 6-141 THROUGH 6-143 (DTN: LB0203ECRBLIQR.001)}

Columns B, C, and D of Table I-5 contain the injection, return, and seepage volume data, respectively, from LB0203ECRBLIQR.001 [DIRS 158462] for LA\#3 Zone 1, and have already been divided by $1000 \mathrm{~g} / \mathrm{L}$ to convert grams to liters. Rates in Columns $\mathrm{E}$ and $\mathrm{G}$ were calculated through use of Columns B and D, respectively, in combination with time data from Column A. Rate data are calculated by taking the difference of sequential-row data in a column, and dividing 
this difference by sequential-row data from column A (time stamp data), and multiplying this by conversion factors $[1000(\mathrm{~g} / \mathrm{L}) / 1440(\mathrm{~min} /$ day $)]$ to get $\mathrm{mL} / \mathrm{min}$.

Columns $\mathrm{F}$ and $\mathrm{H}$ have a 17-point moving average (using Equation I-1), calculated from data in Columns $\mathrm{E}$ and $\mathrm{G}$, respectively. The output is written to the row corresponding to the first row of the series for each average. Return data are not plotted (the measured values indicate that there was no return).

Table I-5. Calculation Excel Spreadsheet for Output in Figure 6-141

\begin{tabular}{|c|c|c|c|c|c|c|c|}
\hline A & $\mathbf{B}$ & $\mathbf{C}$ & $\mathbf{D}$ & $\mathbf{E}$ & $\mathbf{F}$ & $\mathbf{G}$ & $\mathbf{H}$ \\
\hline Date and Time & $\begin{array}{c}\text { Injection } \\
\text { Volume } \\
\mathbf{( L )}\end{array}$ & $\begin{array}{c}\text { Return } \\
\text { Volume } \\
(\mathbf{L})\end{array}$ & $\begin{array}{c}\text { Seepage } \\
\text { Volume } \\
\mathbf{( L )}\end{array}$ & $\begin{array}{c}\text { Injection } \\
\text { Rate } \\
\text { (mL/min.) }\end{array}$ & $\begin{array}{c}\text { 17-point } \\
\text { Moving-average } \\
\text { Injection Rate } \\
\text { (mL/min.) }\end{array}$ & $\begin{array}{c}\text { Seepage } \\
\text { Rate } \\
\text { (mL/min.) }\end{array}$ & $\begin{array}{c}\text { Moving-average } \\
\text { Seepage Rate } \\
\text { (mL/min.) }\end{array}$ \\
\hline $5 / 17 / 200115: 33$ & 0.42967 & -0.00892 & -0.00276 & 34.5923 & 36.25259193 & -0.06874 & 0.040454465 \\
\hline $5 / 17 / 200115: 53$ & 1.12324 & -0.0151 & -0.00413 & 32.5041 & 36.41670827 & -0.05156 & 0.040454465 \\
\hline $5 / 17 / 200116: 13$ & 1.77495 & -0.01922 & -0.00517 & 35.13798 & 36.65835198 & -0.05143 & 0.041465388 \\
\hline $5 / 17 / 200116: 33$ & 2.48122 & -0.02196 & -0.0062 & 39.05319 & 36.76620501 & -0.0342 & 0.040446921 \\
\hline $5 / 17 / 200116: 54$ & 3.26815 & -0.02951 & -0.00689 & 35.45289 & 36.63771063 & 0.034343 & 0.040436887 \\
\hline $5 / 17 / 200117: 14$ & 3.97957 & -0.03775 & -0.0062 & 36.69389 & 36.77217985 & 0.1376 & 0.036393193 \\
\hline $5 / 17 / 200117: 34$ & 4.71467 & -0.03432 & -0.00345 & 36.56069 & 36.73816646 & 0.618684 & 0.02829909 \\
\hline $5 / 17 / 200117: 54$ & 5.44771 & -0.01853 & 0.00896 & 37.87866 & 36.84489242 & 0.274971 & -0.008094107 \\
\hline $5 / 17 / 200118: 14$ & 6.20718 & -0.01441 & 0.01447 & 34.57519 & 36.79052259 & -0.03437 & -0.024268861 \\
\hline $5 / 17 / 200118: 34$ & 6.90041 & -0.01441 & 0.01378 & 33.18211 & 36.9455773 & -0.0344 & -0.022247016 \\
\hline $5 / 17 / 200118: 54$ & 7.56516 & -0.01682 & 0.01309 & 26.39353 & 37.19951427 & 0.017186 & -0.020223488 \\
\hline
\end{tabular}

Source: DTN: LB0203ECRBLIQR.001 [DIRS 158462].

NOTE: Data have been truncated, and are presented here as an example calculation only.

Columns J, K, and L of Table I-6 contain the injection, return and seepage volume data, respectively, from LB0203ECRBLIQR.001 [DIRS 158462] for LA\#3 Zone 2, and have already been divided by $1000 \mathrm{~g} / \mathrm{L}$ to convert from grams to liters. Rates in Columns $\mathrm{M}$ and $\mathrm{O}$ were calculated through use of Columns $J$ and $L$, respectively, in combination with time data from Column I. Rate data are calculated by taking the difference of sequential-row data in a column, and dividing this difference by sequential-row data from Column A (time stamp data), and multiplying this by conversion factors $[1000(\mathrm{~g} / \mathrm{L}) / 1440(\mathrm{~min} /$ day $)]$ to get $\mathrm{mL} / \mathrm{min}$.

Columns $\mathrm{N}$ and $\mathrm{P}$ have a 17-point moving average (using Equation I-1), calculated from data in Columns $\mathrm{M}$ and $\mathrm{O}$, respectively. The data from this calculation are written to the row corresponding to the first row of the series for each average. Return data are not plotted (the measured values indicate that there was no return). 
Table I-6. Calculation Excel Spreadsheet for Output in Figure 6-142

\begin{tabular}{|c|c|c|c|c|c|c|c|}
\hline I & J & K & $\mathbf{L}$ & M & $\mathbf{N}$ & 0 & $\mathbf{P}$ \\
\hline Date and Time & $\begin{array}{c}\text { Injection } \\
\text { Volume } \\
\text { (L) }\end{array}$ & $\begin{array}{c}\text { Return } \\
\text { Volume } \\
(\mathrm{L})\end{array}$ & $\begin{array}{c}\text { Seepage } \\
\text { Volume } \\
\text { (L) }\end{array}$ & $\begin{array}{l}\text { Injection Rate } \\
\text { (mL/min.) }\end{array}$ & $\begin{array}{c}\text { 17-point } \\
\text { Moving- } \\
\text { average } \\
\text { Injection Rate } \\
\text { (mL/min.) }\end{array}$ & $\begin{array}{c}\text { Seepage } \\
\text { Rate } \\
\text { (mL/min.) }\end{array}$ & $\begin{array}{c}\text { 17-point } \\
\text { Moving- } \\
\text { average } \\
\text { Seepage Rate } \\
\text { (mL/min.) }\end{array}$ \\
\hline 5/17/2001 15:33 & 0.26597 & -0.00069 & -0.00069 & 73.03580223 & 70.10880015 & -0.03437 & 0.034428271 \\
\hline 5/17/2001 15:53 & 1.73034 & -0.01167 & -0.00138 & 66.30904562 & 70.10880014 & -0.03437 & .032406423 \\
\hline 5/17/2001 16:13 & 3.05983 & 0.01922 & -0.00207 & 69.11494788 & 70.49140268 & -0.06857 & 0.028362738 \\
\hline 5/17/2001 16:33 & 4.44904 & -0.02471 & -0.00345 & 57.02140797 & 70.69082885 & -0.1368 & 0.030374522 \\
\hline 5/17/2001 16:54 & 5.59802 & -0.035 & -0.0062 & 58.62638488 & 71.58049591 & -0.06869 & 0.036399916 \\
\hline $5 / 17 / 200117: 14$ & 6.77446 & -0.03844 & -0.00758 & 67.83744879 & 72.36819868 & 0.1032 & 0.040440248 \\
\hline $5 / 17 / 200117: 34$ & 8.13347 & -0.03569 & -0.00551 & 70.02331071 & 72.60853901 & 0.171857 & 0.036391514 \\
\hline $5 / 17 / 200117: 54$ & 9.53744 & -0.03226 & -0.00207 & 68.51706506 & 72.7384225 & 0.206228 & 0.026282293 \\
\hline 5/17/2001 18:14 & 10.9112 & -0.035 & 0.00207 & 72.45384363 & 72.9861073 & 0.481199 & 0.014151227 \\
\hline $5 / 17 / 2001$ 18:34 & 12.3639 & -0.03741 & 0.01172 & 73.88457489 & 73.51470289 & 0.0688 & -0.014154591 \\
\hline
\end{tabular}

Source: DTN: LB0203ECRBLIQR.001 [DIRS 158462].

NOTE: Data have been truncated, and are presented here as an example calculation only.

The linear curve fit for evaporation uses the Excel trendline (see Section I4) option for fitting a curve to an existing plot. The slope is from the equation generated by Excel for the fit.

Columns R, S, and T of Table I-7 contain the injection, return and seepage volume data, respectively, from DTN: LB0203ECRBLIQR.001 [DIRS 158462] for LA\#3 Zone 3, and have already been divided by $1000 \mathrm{~g} / \mathrm{L}$, to convert grams to liters. The rates in Columns $\mathrm{U}$ and $\mathrm{W}$ were calculated through use of Columns $\mathrm{R}$ and $\mathrm{S}$ (not $\mathrm{T}$ ), respectively, in combination with time data from Column Q. Rate data are calculated by taking the difference of sequential-row data in a column, and dividing this difference by sequential-row data from Column A (time stamp data), and multiplying this by conversion factors $[1000(\mathrm{~g} / \mathrm{L}) / 1440(\mathrm{~min} /$ day $)]$ to get $\mathrm{mL} / \mathrm{min}$.

Columns $\mathrm{V}$ and $\mathrm{X}$ have a 17-point moving average (using Equation I-1), calculated from data in Columns $\mathrm{U}$ and $\mathrm{W}$, respectively. The data from this calculation are written to the row corresponding to the first row of the series for each average. Rows in column $\mathrm{Y}$ equal $\mathrm{V}$ minus X. Seepage data are not plotted (the measured values indicate that there was no seepage). 
Table I-7. Calculation Excel Spreadsheet for Output in Figure 6-143

\begin{tabular}{|c|c|c|c|c|c|c|c|c|}
\hline $\mathbf{Q}$ & $\mathbf{R}$ & s & $T$ & U & V & W & $x$ & Y \\
\hline Date and Time & $\begin{array}{c}\begin{array}{c}\text { Injection } \\
\text { Volume } \\
\text { (L) }\end{array} \\
\end{array}$ & $\begin{array}{c}\text { Return } \\
\text { Volume } \\
\text { (L) }\end{array}$ & $\begin{array}{c}\text { Seepage } \\
\text { Volume } \\
\text { (L) }\end{array}$ & $\begin{array}{c}\text { Injection } \\
\text { Rate } \\
\text { (mL/min.) }\end{array}$ & $\begin{array}{l}\text { Moving- } \\
\text { average } \\
\text { Injection } \\
\text { Rate } \\
\text { (mL/min.) }\end{array}$ & \begin{tabular}{|c} 
Return \\
Rate \\
(mL/min.)
\end{tabular} & $\begin{array}{c}\text { 17-point } \\
\text { Moving- } \\
\text { average } \\
\text { Return Rate } \\
\text { (mL/min.) }\end{array}$ & \\
\hline 5/17/2001 15:33 & 0.12492 & -0.00275 & 1.40724 & 96.84475 & 102.1661207 & 7.223133 & 75.80776078 & 26.35835987 \\
\hline 5/17/2001 15:53 & 2.06666 & & & 38 & 102 & 28. & 446 & 21. \\
\hline 5/17/2001 16:13 & 40132 & 121 & 1.43 & 53 & 103 & 33.7 & 3995 & 16.7 \\
\hline 5/17/2001 16:34 & 5.98136 & & & 98.9 & & 41.31827 & 90.16232341 & 13.18006459 \\
\hline 5/17/2001 16:54 & 7.97595 & 2.21628 & 1.43825 & 42 & 3166 & 39.7 & 93.70043656 & 9.980880038 \\
\hline 5/17/2001 17:14 & 9.96093 & 3.01247 & 1.40103 & 98.75831 & 104.0469133 & 35.87162 & 68893 & 6.633224337 \\
\hline 5/17/2001 17:34 & 11.9394 & 3.7311 & 1.40276 & 56 & 104.3823991 & 135.0315 & 101.25 & 3.131349904 \\
\hline $5 / 17 / 2 C$ & 13.81 & & & & & 90. & 4615 & 5.689752607 \\
\hline 5/17/2001 18:14 & 15.8963 & 8.40424 & 1.42929 & \begin{tabular}{|l|}
104.2733 \\
\end{tabular} & 105.0831659 & 97.37536 & 99.56860494 & 5.51456092 \\
\hline $5 / 17 / 2001$ 18:34 & 17.987 & 10.3566 & 1.42171 & 105.011 & 105.0539672 & 94.11589 & 99.85555683 & 5.198410416 \\
\hline
\end{tabular}

Source: DTN: LB0203ECRBLIQR.001 [DIRS 158462].

NOTE: Data have been truncated, and are presented here as an example calculation only.

\section{$\begin{array}{llllllll}\text { I6.4 DESCRIPTOR } & \text { FOR } & \text { DATA } & \text { IN } & \text { FIGURES 6-144 } & \text { THROUGH } & \text { 6-146 }\end{array}$ (DTN: LB0301SYTSTLA4.001)}

Columns B, C, and D of Table I-8 contain the injection, return, and seepage (seepage is for Zone 2 as per the TDMS notes) volume data, respectively, from Zone 1 of Borehole LA\#4, and have already been divided by $1000 \mathrm{~g} / \mathrm{L}$ to convert grams to liters. The rates in Columns $\mathrm{E}$ and $\mathrm{G}$ were calculated through use of Columns B and C, respectively, in combination with time data from Column A. Rate data are calculated by taking the difference of sequential-row data in a column, and dividing this difference by the difference in sequential-row data from Column A (time stamp data), and multiplying this by conversion factors $[1000(\mathrm{~g} / \mathrm{L}) / 1440(\mathrm{~min} / \mathrm{day})]$ to get $\mathrm{mL} / \mathrm{min}$.

Columns $\mathrm{F}$ and $\mathrm{H}$ have a 17-point moving average (using Equation I-1), calculated from data in Columns E and G, respectively. The data from this calculation are written to the row corresponding to the first row of the series for each average. Column I equals Column $\mathrm{F}$ minus Column H. Seepage data are not plotted (the measured values indicate that there was no seepage for Zone 1). 
Table I-8. Calculation Excel Spreadsheet for Output in Figure 6-144

\begin{tabular}{|c|c|c|c|c|c|c|c|c|}
\hline A & $\mathbf{B}$ & $\mathbf{C}$ & $\mathbf{D}$ & $\mathbf{E}$ & $\mathbf{F}$ & $\mathbf{G}$ & $\mathbf{H}$ & $\mathbf{I}$ \\
\hline Date and Time & $\begin{array}{c}\text { Zone 1 } \\
\text { Injection } \\
\text { Volume } \\
\mathbf{( L )}\end{array}$ & $\begin{array}{c}\text { Zone 1 } \\
\text { Return } \\
\text { Volume } \\
\mathbf{( L )}\end{array}$ & $\begin{array}{c}\text { Zone 2 } \\
\text { Seepage } \\
\text { Volume } \\
\mathbf{( L )}\end{array}$ & $\begin{array}{c}\text { 20-point } \\
\text { Moving- } \\
\text { Injection } \\
\text { Rate } \\
\text { average } \\
\text { Injection. } \\
\text { Rate } \\
\text { (mL/min.) }\end{array}$ & $\begin{array}{c}\text { Return } \\
\text { Rate } \\
\text { (mL/min. }\end{array}$ & $\begin{array}{c}\text { 20-point } \\
\text { Moving- } \\
\text { average } \\
\text { Return Rate } \\
\text { (mL/min.) }\end{array}$ & $\begin{array}{c}\text { Net Inflow } \\
\text { Rate } \\
\text { (mL/min.) }\end{array}$ \\
\hline $2 / 6 / 200214: 26$ & 0.82193 & 0.01785 & 0.0062 & 35.12291 & 6.149953688 & 0.171164 & 1.539103191 & 4.610850497 \\
\hline 2/6/2002 14:46 & 1.52614 & 0.02128 & 0.0062 & 35.99585 & 4.057721964 & 3.252121 & 1.527021005 & 2.530700959 \\
\hline 2/6/2002 15:06 & 2.24786 & 0.08648 & 0.00551 & 30.71529 & 1.918149921 & 9.353345 & 1.329673623 & 0.588476297 \\
\hline $2 / 6 / 200215: 26$ & 2.86319 & 0.27386 & 0.00345 & 19.78659 & 0.0267929 & 9.379803 & 0.77343575 & -0.74664285 \\
\hline $2 / 6 / 200215: 46$ & 3.25991 & 0.46193 & 0.00276 & -0.822272 & -1.0827092 & 4.316929 & 0.228736438 & -1.311445637 \\
\hline $2 / 6 / 200216: 06$ & 3.24344 & 0.54841 & 0.00207 & -2.516115 & -1.00713272 & 0.71889 & -0.025200537 & -0.981932188 \\
\hline $2 / 6 / 200216: 26$ & 3.19299 & 0.56282 & 0.00276 & -2.398294 & -0.84100268 & 0.034261 & -0.068495033 & -0.772507647 \\
\hline $2 / 6 / 200216: 46$ & 3.14494 & 0.56351 & 0.00276 & -4.039477 & -0.69488815 & 0 & -0.070510406 & -0.624377742 \\
\hline $2 / 6 / 200217: 06$ & 3.06395 & 0.56351 & 0.00345 & -0.907925 & -0.48143621 & -0.13705 & -0.074537802 & -0.406898408 \\
\hline $2 / 6 / 200217: 26$ & 3.04576 & 0.56076 & 0.00345 & -0.633308 & -0.55902806 & -0.13693 & -0.078568549 & -0.480459515 \\
\hline
\end{tabular}

Source: DTN: LB0301SYTSTLA4.001 [DIRS 165227].

NOTE: Data have been truncated, and are presented here as an example calculation only.

Columns B, C, and M of Table I-9 contain the injection, return, and seepage volume data, respectively, from DTN: LB0301SYTSTLA4.001 [DIRS 165227] for LA\#4 Zone 2, and have already been divided by $1000 \mathrm{~g} / \mathrm{L}$ to convert grams to liters. Note that Column $\mathrm{A}$ has the traditional time stamp corresponding to Zone 2 injection and return $(\mathrm{B}, \mathrm{C})$, but that Column I has times corresponding to seepage data in Column M. This is because the injection and seepage data come from different files, with slightly different time stamps, as per the notes from the TDMS. The rates in Columns $\mathrm{E}$ and $\mathrm{P}$ were calculated through use of Columns $\mathrm{B}$ and $\mathrm{M}$, respectively, in combination with time data from Columns A and I, respectively. Rate data are calculated by taking the difference of sequential-row data in a column, and dividing this difference by the difference in sequential-row data from Column A (time stamp data), or Column I in the case of seepage data in Column $\mathrm{M}$, and multiplying this by conversion factors $[1000(\mathrm{~g} / \mathrm{L}) / 1440(\mathrm{~min} /$ day $)]$ to get $\mathrm{mL} / \mathrm{min}$.

Columns F and Q have a 17-point moving average (using Equation I-1), calculated from data in Columns $\mathrm{E}$ and $\mathrm{P}$, respectively. The data from this calculation are written to the row corresponding to the first row of the series for each average. Column J equals $\mathrm{F}$ minus Q. Return data are not plotted (the measured values indicate that there was no return). Zone 1 data (in columns $\mathrm{D}, \mathrm{K}, \mathrm{J}, \mathrm{N}, \mathrm{O}$ ) are not plotted in this figure. 
Table I-9. Calculation Excel Spreadsheet for Output in Figure 6-145

\begin{tabular}{|c|c|c|c|c|c|c|}
\hline A & B & C & D & $E$ & $\mathbf{F}$ & I \\
\hline Date and Time & $\begin{array}{c}\text { Zone } 2 \\
\text { Injection } \\
\text { Volume } \\
\text { (L) }\end{array}$ & $\begin{array}{c}\text { Zone } 2 \\
\text { Return } \\
\text { Volume } \\
\text { (L) }\end{array}$ & $\begin{array}{c}\text { Zone } 1 \\
\text { Seepage } \\
\text { Volume } \\
\text { (L) }\end{array}$ & $\begin{array}{c}\text { Zone 2 } \\
\text { Injection } \\
\text { Rate } \\
\text { (mL/min.) }\end{array}$ & $\begin{array}{c}\text { Zone 2 } \\
\text { 17-point Moving- } \\
\text { Average } \\
\text { Injection Rate } \\
\text { (mL/min.) }\end{array}$ & Date and Time \\
\hline 10/20/2002 09:02 & 435.465 & -2.18094 & -0.00138 & 46.2318 & 43.26999709 & 10/20/2002 09:04 \\
\hline \begin{tabular}{|l|}
$10 / 20 / 2002 ~ 09: 23$ \\
\end{tabular} & 436.395 & -2.18403 & -0.00138 & 45.82622 & 43.09739301 & 10/20/2002 09:24 \\
\hline 10/20/2002 09:43 & 437.316 & -2.18403 & -0.00207 & 45.87355 & 42.96269607 & 10/20/2002 09:45 \\
\hline 10/20/2002 10:03 & 438.239 & -2.18265 & -0.00138 & 45.78825 & 42.84528516 & 10/20/2002 10:05 \\
\hline $10 / 20 / 2002$ 10:23 & 439.16 & -2.17236 & -0.00138 & 45.97591 & 42.66257286 & $10 / 20 / 200210: 25$ \\
\hline 10/20/2002 10:43 & 440.085 & -2.15829 & -0.00138 & 45.70295 & 42.48394771 & 10/20/2002 10:45 \\
\hline 10/20/2002 11:03 & 441.004 & -2.1449 & -0.00138 & 46.56039 & 42.33743495 & 10/20/2002 11:05 \\
\hline 10/20/2002 11:23 & 441.94 & -2.13049 & -0.00069 & 46.55594 & 42.16545265 & \\
\hline 10/20/2002 11:43 & 442.877 & -2.12534 & -0.00069 & 30.01583 & 41.98482048 & \\
\hline
\end{tabular}

\begin{tabular}{|c|c|c|c|c|c|c|c|}
\hline $\mathbf{J}$ & $\mathbf{K}$ & $\mathbf{L}$ & $\mathbf{M}$ & $\mathbf{N}$ & $\mathbf{0}$ & $\mathbf{P}$ & $\mathbf{Q}$ \\
\hline $\begin{array}{c}\text { Net Loss Rate } \\
\text { (mL/min) }\end{array}$ & $\begin{array}{c}\text { Zone 1 } \\
\text { Injection } \\
\text { Volume } \\
\mathbf{( L )}\end{array}$ & $\begin{array}{c}\text { Zone 1 } \\
\text { Return } \\
\text { Volume } \\
(\mathbf{L})\end{array}$ & $\begin{array}{c}\text { Zone 2 } \\
\text { Seepage } \\
\text { Volume } \\
\mathbf{( L )}\end{array}$ & $\begin{array}{c}\text { Zone 1 } \\
\text { Injection } \\
\text { Rate } \\
\mathbf{( L )}\end{array}$ & $\begin{array}{c}\text { Zone 1 } \\
\text { 17-point } \\
\text { Moving-average } \\
\text { Injection Rate } \\
\text { (mL/min.) }\end{array}$ & $\begin{array}{c}\text { Zone 2 } \\
\text { Seepage } \\
\text { Rate } \\
\text { (mL/min.) }\end{array}$ & $\begin{array}{c}\text { Moving-point } \\
\text { Zone 2 } \\
\text { Seepage Rate } \\
\text { (mL/min.) }\end{array}$ \\
\hline 40.79148803 & -0.0048 & 0.00137 & 0.04893 & -0.170597 & -0.24282589 & 2.500793 & 2.478509058 \\
\hline 40.62380401 & -0.00824 & 0.00275 & 0.09924 & -0.170597 & -0.24082552 & 2.517922 & 2.473588999 \\
\hline 40.49829032 & -0.01167 & 0.00343 & 0.14989 & -0.068239 & -0.24081722 & 2.466536 & 2.464405749 \\
\hline 40.38893998 & -0.01304 & 0.00412 & 0.19951 & -0.204886 & -0.24683829 & 2.605725 & 2.456345175 \\
\hline 40.22762295 & -0.01716 & 0.0048 & 0.25188 & -0.204716 & -0.24080225 & 2.483665 & 2.434949909 \\
\hline 40.06008109 & -0.02128 & 0.00618 & 0.30185 & -0.170597 & -0.24080225 & 2.483665 & 2.423866617 \\
\hline 39.91457591 & -0.02471 & 0.00755 & 0.35181 & -0.204716 & -0.24080225 & 2.500793 & 2.422859045 \\
\hline
\end{tabular}

Source: DTN: LB0301SYTSTLA4.001 [DIRS 165227].

NOTE: Data have been truncated, and are presented here as an example calculation only.

The linear curve fit for evaporation (Figure 6-145) uses the Excel trendline option for putting a curve fit onto an existing plot. Slope is from the equation generated by Excel for the fit.

For example, rate calculations for Figure 6-146 are as follows: Columns S, T, and U of Table I-10 contain the injection, return, and seepage volume data, respectively, from DTN: LB0301SYTSTLA4.001 [DIRS 165227] for LA4 Zone 3, and have already been divided by 1,000 to convert milliliters to liters. The rates in Columns $\mathrm{V}$ and $\mathrm{X}$ were calculated through use of Columns $\mathrm{S}$ and $\mathrm{T}$ (not $\mathrm{U}$ ), respectively, in combination with time data from Column $\mathrm{R}$. Rate data are calculated by taking the difference of sequential-row data in a column, and dividing this by the difference of sequential-row data from Column $\mathrm{R}$ (time stamp data), and multiplying this by conversion factors $[1000(\mathrm{~g} / \mathrm{L}) / 1440(\mathrm{~min} /$ day $)]$ to get $\mathrm{mL} / \mathrm{min}$. 
Columns W and Y have a 17-point moving average (using Equation I-1), calculated from data in Columns $U$ and $\mathrm{W}$, respectively. The data from this calculation are written to the row corresponding to the first row of the series for each average. Data in Column $Z$ are the difference between the average injection rate and the average return rate (that is, $\mathrm{Zn}=\mathrm{W} n-\mathrm{Y} n$ ), where $n$ is the row number. Seepage data are not plotted (the measured values indicate that there was no seepage).

Table I-10. Calculation Excel Spreadsheet for Output in Figure 6-146

\begin{tabular}{|c|c|c|c|c|c|c|c|c|}
\hline $\mathbf{R}$ & $\mathbf{S}$ & $\mathbf{T}$ & $\mathbf{U}$ & $\mathbf{V}$ & $\mathbf{W}$ & $\mathbf{X}$ & $\mathbf{Y}$ & $\mathbf{Z}$ \\
\hline & $\begin{array}{c}\text { Zone 3 } \\
\text { Injection } \\
\text { Volume } \\
\text { Date and Time }\end{array}$ & $\begin{array}{c}\text { Zone 3 } \\
\text { Return } \\
\text { Volume } \\
(\mathbf{L})\end{array}$ & $\begin{array}{c}\text { Zone 3 } \\
\text { Seepage } \\
\text { Volume } \\
(\mathbf{L})\end{array}$ & $\begin{array}{c}\text { Zone 3 } \\
\text { Injection } \\
\text { Rate } \\
\text { (mL/min.) }\end{array}$ & $\begin{array}{c}\text { Zone 3 } \\
\text { 20-point } \\
\text { Moving- } \\
\text { average } \\
\text { Injection } \\
\text { Rate } \\
(\mathbf{m L / m i n . )}\end{array}$ & $\begin{array}{c}\text { Zone 3 } \\
\text { Return } \\
\text { Rate } \\
\text { (mL/min.) }\end{array}$ & $\begin{array}{c}\text { Zone 3 } \\
\text { 20-point } \\
\text { Moving- } \\
\text { average } \\
\text { Return Rate } \\
\text { (mL/min.) }\end{array}$ & $\begin{array}{c}\text { Zone 3 } \\
\text { Net Inflow } \\
\text { (mL/min.) }\end{array}$ \\
\hline 2/6/2002 14:27 & 0.32671 & 0.00549 & -0.00034 & 3.237696 & 0.522815012 & -0.29122 & -0.128931088 & 0.6517461 \\
\hline $2 / 6 / 200214: 48$ & 0.39157 & -0.00034 & -0.00207 & 2.276485 & 0.337400713 & -0.59907 & -0.112808103 & 0.450208816 \\
\hline $2 / 6 / 200215: 08$ & 0.43722 & -0.01235 & -0.00551 & 0.788011 & 0.211551322 & 0.034261 & -0.080591458 & 0.29214278 \\
\hline $2 / 6 / 200215: 28$ & 0.453 & -0.01167 & -0.01447 & 0.222514 & 0.17123884 & 0 & -0.084620527 & 0.255859367 \\
\hline $2 / 6 / 200215: 48$ & 0.45746 & -0.01167 & -0.01792 & 0.25696 & 0.152103686 & -0.17131 & -0.076559036 & 0.228662722 \\
\hline $2 / 6 / 200216: 08$ & 0.46261 & -0.0151 & -0.01999 & 0.205397 & 0.141015786 & -0.13693 & -0.06849587 & 0.209511657 \\
\hline $2 / 6 / 200216: 28$ & 0.46673 & -0.01785 & -0.02067 & 0.017131 & 0.132964347 & 0.068523 & -0.062456454 & 0.195420802 \\
\hline $2 / 6 / 200216: 48$ & 0.46707 & -0.01647 & -0.02067 & 0.119815 & 0.131956662 & 0.034233 & -0.066487201 & 0.198443863 \\
\hline
\end{tabular}

Source: DTN: LB0301SYTSTLA4.001 [DIRS 165227].

NOTE: Data have been truncated, and are presented here as an example calculation only.

\section{I6.5 WETTING-FRONT VELOCITY CALCULATION IN FIGURE 6-155 OBSERVED IN BOREHOLES 1, 9, AND 10 IN NICHE 3 (NICHE 3107)}

The data used for this calculation are from DTNs: LB0110A8N3LIQR.001 [DIRS 157001] and LB0209A8N3LIQR.001 [DIRS 165461]. Each of these files includes the resistance measurements taken in the boreholes after the application of water along the fault. The decreasing resistance measured by ERPs located along the wall of each of these boreholes indicates increased wetting of the borehole walls.

The arrival time of the wetting front was determined to be the time when the resistance in a sensor first began to decrease after the application of water in the fault in early March 2001. For each of the boreholes, the date of the first observed decrease in resistance is noted for each of the measurement locations in Boreholes 1, 9, and 10 in Niche 3 (Niche 3107) (Table I-11a to Table I-11c). The time to first response is calculated by subtracting the date 03/06/2001 from the date of first response, and formatting the result as a number. The values in Table I-11 are used as input. 
Table I-11a. Date of First Response in Borehole 1

\begin{tabular}{|c|c|c|}
\hline Borehole & First Response & $\begin{array}{l}\text { Time (days) to } \\
\text { First Response } \\
\text { (from 03/06/01) }\end{array}$ \\
\hline BH\#1-0.40 & $8 / 6 / 01$ & 153 \\
\hline BH\#1-0.65 & $2 / 17 / 01$ & $N / A^{a}$ \\
\hline BH\#1-0.90 & $6 / 9 / 01$ & 95 \\
\hline BH\#1-1.15 & $7 / 8 / 01$ & 124 \\
\hline BH\#1-1.40 & $6 / 22 / 01$ & 108 \\
\hline $\mathrm{BH \# 1-1.65}$ & $5 / 25 / 01$ & 80 \\
\hline BH\#1-1.90 & $7 / 19 / 01$ & 135 \\
\hline $\mathrm{BH \# 1-2.15}$ & $7 / 8 / 01$ & 124 \\
\hline $\mathrm{BH \# 1-2.40}$ & $7 / 9 / 01$ & 125 \\
\hline $\mathrm{BH \# 1-2.65}$ & $9 / 25 / 01$ & 203 \\
\hline $\mathrm{BH \# 1-2.90}$ & $7 / 4 / 01$ & 120 \\
\hline BH\#1-3.15 & $7 / 6 / 01$ & 122 \\
\hline $\mathrm{BH \# 1-3.40}$ & $5 / 23 / 01$ & 78 \\
\hline BH\#1-3.65 & $8 / 11 / 01$ & 158 \\
\hline BH\#1-3.90 & $7 / 26 / 01$ & 142 \\
\hline $\mathrm{BH} \# 1-4.15$ & $4 / 10 / 01$ & 35 \\
\hline $\mathrm{BH \# 1-4.40}$ & $9 / 23 / 01$ & 201 \\
\hline $\mathrm{BH \# 1-4.65}$ & $7 / 18 / 01$ & 134 \\
\hline BH\#1-4.90 & $6 / 9 / 01$ & 95 \\
\hline $\mathrm{BH \# 1-5.15}$ & $8 / 22 / 01$ & 169 \\
\hline $\mathrm{BH \# 1-5.40}$ & $5 / 7 / 01$ & 62 \\
\hline $\mathrm{BH \# 1-5.65}$ & $3 / 23 / 01$ & 17 \\
\hline $\mathrm{BH \# 1-5.90}$ & $8 / 23 / 01$ & 170 \\
\hline
\end{tabular}

Source: DTN: LB0110A8N3LIQR.001 [DIRS 157001].

a The decrease in electrical resistance observed at a date prior to liquid release is obviously not related to the wetting front arrival. 
Table I-11b. Date of First Response in Borehole 9

\begin{tabular}{|c|c|c|}
\hline Borehole & First Response & $\begin{array}{l}\text { Time (days) to } \\
\text { First Response } \\
\text { (from 03/06/01) }\end{array}$ \\
\hline BH\#9-0.15 & $5 / 30 / 01$ & 85 \\
\hline $\mathrm{BH} \# 9-0.40$ & $5 / 18 / 01$ & 73 \\
\hline BH\#9-0.65 & $5 / 18 / 01$ & 73 \\
\hline $\mathrm{BH} \# 9-0.90$ & $4 / 19 / 01$ & 44 \\
\hline ВН\#9-1.15 & $4 / 13 / 01$ & 38 \\
\hline BH\#9-1.40 & $4 / 6 / 01$ & 31 \\
\hline BH\#9-1.65 & $4 / 6 / 01$ & 31 \\
\hline BH\#9-1.90 & $4 / 6 / 01$ & 31 \\
\hline BH\#9-2.15 & $4 / 9 / 01$ & 34 \\
\hline $\mathrm{BH} \# 9-2.40$ & $4 / 9 / 01$ & 34 \\
\hline $\mathrm{BH} \# 9-2.65$ & $4 / 12 / 01$ & 37 \\
\hline $\mathrm{BH \# 9-2.90}$ & $4 / 21 / 01$ & 46 \\
\hline BH\#9-3.15 & $4 / 22 / 01$ & 47 \\
\hline $\mathrm{BH \# 9-3.40}$ & $5 / 2 / 01$ & 57 \\
\hline BH\#9-3.65 & $4 / 22 / 01$ & 47 \\
\hline BH\#9-3.90 & $5 / 13 / 01$ & 68 \\
\hline $\mathrm{BH \# 9-4.15}$ & $6 / 15 / 01$ & 101 \\
\hline $\mathrm{BH} \# 9-4.40$ & $6 / 19 / 01$ & 105 \\
\hline $\mathrm{BH} \# 9-4.65$ & $5 / 23 / 01$ & 78 \\
\hline BH\#9-4.90 & $6 / 26 / 01$ & 112 \\
\hline BH\#9-5.15 & $6 / 23 / 01$ & 109 \\
\hline $\mathrm{BH \# 9-5.40}$ & $5 / 13 / 01$ & 68 \\
\hline BH\#9-5.65 & $5 / 30 / 01$ & 85 \\
\hline $\mathrm{BH} \# 9-5.90$ & $6 / 24 / 01$ & 110 \\
\hline $\mathrm{BH} \# 9-6.15$ & Not Known & $\mathrm{N} / \mathrm{A}$ \\
\hline BH\#9-6.40 & Not Known & $\mathrm{N} / \mathrm{A}$ \\
\hline $\mathrm{BH} \# 9-6.65$ & Not Known & $\mathrm{N} / \mathrm{A}$ \\
\hline BH\#9-6.90 & Not Known & $\mathrm{N} / \mathrm{A}$ \\
\hline BH\#9-7.15 & Not Known & $\mathrm{N} / \mathrm{A}$ \\
\hline BH\#9-7.40 & Not Known & $\mathrm{N} / \mathrm{A}$ \\
\hline $\mathrm{BH} \# 9-7.65$ & Not Known & $\mathrm{N} / \mathrm{A}$ \\
\hline BH\#9-7.90 & Not Known & $\mathrm{N} / \mathrm{A}$ \\
\hline BH\#9-8.15 & Not Known & $\mathrm{N} / \mathrm{A}$ \\
\hline BH\#9-8.40 & Not Known & $\mathrm{N} / \mathrm{A}$ \\
\hline BH\#9-8.65 & Not Known & $\mathrm{N} / \mathrm{A}$ \\
\hline BH\#9-8.90 & Not Known & $\mathrm{N} / \mathrm{A}$ \\
\hline
\end{tabular}

Source: DTN: LB0110A8N3LIQR.001 [DIRS 157001]. 
Table I-11c. Date of First Response in Borehole 10

\begin{tabular}{|c|c|c|}
\hline Borehole & First Response & $\begin{array}{l}\text { Time (days) to } \\
\text { First Response } \\
\text { (from 03/06/01) }\end{array}$ \\
\hline $\mathrm{BH \# 10-0.15}$ & $7 / 3 / 01$ & 119 \\
\hline $\mathrm{BH \# 10-0.40}$ & $7 / 8 / 01$ & 124 \\
\hline $\mathrm{BH \# 10-0.65}$ & $5 / 25 / 01$ & 80 \\
\hline $\mathrm{BH \# 10-0.90}$ & $5 / 24 / 01$ & 79 \\
\hline $\mathrm{BH \# 10-1.15}$ & $5 / 7 / 01$ & 62 \\
\hline $\mathrm{BH \# 10-1.40}$ & $4 / 21 / 01$ & 46 \\
\hline BH\#10-1.65 & $4 / 9 / 01$ & 34 \\
\hline BH\#10-1.90 & $4 / 9 / 01$ & 34 \\
\hline BH\#10-2.15 & $4 / 9 / 01$ & 34 \\
\hline $\mathrm{BH \# 10-2.40}$ & $4 / 9 / 01$ & 34 \\
\hline BH\#10-2.65 & $4 / 10 / 01$ & 35 \\
\hline $\mathrm{BH \# 10-2.90}$ & $4 / 18 / 01$ & 43 \\
\hline $\mathrm{BH \# 10-3.15}$ & $4 / 19 / 01$ & 44 \\
\hline BH\#10-3.40 & $4 / 18 / 01$ & 43 \\
\hline $\mathrm{BH \# 10-3.65}$ & $5 / 1 / 01$ & 56 \\
\hline $\mathrm{BH \# 10-3.90}$ & $5 / 2 / 01$ & 57 \\
\hline $\mathrm{BH \# 10-4.15}$ & $6 / 7 / 01$ & 93 \\
\hline $\mathrm{BH \# 10-4.40}$ & $5 / 13 / 01$ & 68 \\
\hline $\mathrm{BH \# 10-4.65}$ & $5 / 2 / 01$ & 57 \\
\hline BH\#10-4.90 & $6 / 23 / 01$ & 109 \\
\hline $\mathrm{BH \# 10-5.15}$ & $7 / 2 / 01$ & 118 \\
\hline $\mathrm{BH \# 10-5.40}$ & $6 / 23 / 01$ & 109 \\
\hline $\mathrm{BH \# 10-5.65}$ & $5 / 29 / 01$ & 84 \\
\hline $\mathrm{BH \# 10-5.90}$ & $6 / 30 / 01$ & 116 \\
\hline $\mathrm{BH \# 10-6.15}$ & $5 / 29 / 01$ & 84 \\
\hline $\mathrm{BH \# 10-6.40}$ & $6 / 25 / 01$ & 111 \\
\hline BH\#10-6.65 & $7 / 6 / 01$ & 122 \\
\hline BH\#10-6.90 & $6 / 22 / 01$ & 108 \\
\hline BH\#10-7.15 & $8 / 12 / 01$ & 159 \\
\hline $\mathrm{BH \# 10-7.40}$ & No wetting & $\mathrm{N} / \mathrm{A}$ \\
\hline $\mathrm{BH \# 10-7.65}$ & No wetting & $\mathrm{N} / \mathrm{A}$ \\
\hline BH\#10-7.90 & No wetting & $\mathrm{N} / \mathrm{A}$ \\
\hline BH\#10-8.15 & No wetting & $\mathrm{N} / \mathrm{A}$ \\
\hline $\mathrm{BH \# 10-8.40}$ & No wetting & $\mathrm{N} / \mathrm{A}$ \\
\hline BH\#10-8.65 & No wetting & $\mathrm{N} / \mathrm{A}$ \\
\hline BH\#10-8.90 & No wetting & $\mathrm{N} / \mathrm{A}$ \\
\hline
\end{tabular}

Source: DTN: LB0209A8N3LIQR.001 [DIRS 165461]. 
The horizontal plane along which Borehole 1 lies is approximately $21 \mathrm{~m}$ below the water release zone in Alcove 8, and the horizontal plane along which Boreholes 9 and 10 lie is approximately $19 \mathrm{~m}$ below the injection zone in Alcove 8. The wetting-front velocities (m/day) in Table I-12 are calculated by dividing these travel distances by the transport times (days) for the wetting front to reach the sensor location along the borehole.

Using Table I-12, Figure I-3 is a plot of the velocity data determined from Boreholes 1, 9 and 10 (Figure I-3). This is similar to Figure 6-155, presented in Section 6.12.

Table I-12. Wetting-Front Velocity Calculated for Locations along Boreholes 1, 9, and 10

\begin{tabular}{|c|c|c|c|c|c|c|c|}
\hline \multirow[b]{2}{*}{ Distance from collar } & \multicolumn{3}{|c|}{$\begin{array}{l}\text { Travel time in days since start of liquid } \\
\text { release on } 03 / 06 / 01\end{array}$} & \multicolumn{4}{|c|}{ Velocity of Wetting Front (meters/day) } \\
\hline & Borehole 1 & Borehole 9 & Borehole 10 & Distance from collar & Borehole 1 & Borehole 9 & Borehole 10 \\
\hline 0.15 & & 85 & 119 & 0.15 & & 0.2 & 0.2 \\
\hline 0.40 & 153 & 73 & 124 & 0.40 & 0.1 & 0.3 & 0.2 \\
\hline 0.65 & -17 & 73 & 80 & 0.65 & & 0.3 & 0.2 \\
\hline 0.90 & 95 & 44 & 79 & 0.90 & 0.2 & 0.4 & 0.2 \\
\hline 1.15 & 124 & 38 & 62 & 1.15 & 0.2 & 0.5 & 0.3 \\
\hline 1.40 & 108 & 31 & 46 & 1.40 & 0.2 & 0.6 & 0.4 \\
\hline 1.65 & 80 & 31 & 34 & 1.65 & 0.3 & 0.6 & 0.6 \\
\hline 1.90 & 135 & 31 & 34 & 1.90 & 0.2 & 0.6 & 0.6 \\
\hline 2.15 & 124 & 34 & 34 & 2.15 & 0.2 & 0.6 & 0.6 \\
\hline 2.40 & 125 & 34 & 34 & 2.40 & 0.2 & 0.6 & 0.6 \\
\hline 2.65 & 203 & 37 & 35 & 2.65 & 0.1 & 0.5 & 0.5 \\
\hline 2.90 & 120 & 46 & 43 & 2.90 & 0.2 & 0.4 & 0.4 \\
\hline 3.15 & 122 & 47 & 44 & 3.15 & 0.2 & 0.4 & 0.4 \\
\hline 3.40 & 78 & 57 & 43 & 3.40 & 0.3 & 0.3 & 0.4 \\
\hline 3.65 & 158 & 47 & 56 & 3.65 & 0.1 & 0.4 & 0.3 \\
\hline 3.90 & 142 & 68 & 57 & 3.90 & 0.1 & 0.3 & 0.3 \\
\hline 4.15 & 35 & 101 & 93 & 4.15 & 0.6 & 0.2 & 0.2 \\
\hline 4.40 & 201 & 105 & 68 & 4.40 & 0.1 & 0.2 & 0.3 \\
\hline 4.65 & 134 & 78 & 57 & 4.65 & 0.2 & 0.2 & 0.3 \\
\hline 4.90 & 95 & 112 & 109 & 4.90 & 0.2 & 0.2 & 0.2 \\
\hline 5.15 & 169 & 109 & 118 & 5.15 & 0.1 & 0.2 & 0.2 \\
\hline 5.40 & 62 & 68 & 109 & 5.40 & 0.3 & 0.3 & 0.2 \\
\hline 5.65 & 17 & 85 & 84 & 5.65 & 1.2 & 0.2 & 0.2 \\
\hline 5.90 & 170 & 110 & 116 & 5.90 & 0.1 & 0.2 & 0.2 \\
\hline 6.15 & & & 84 & 6.15 & & & 0.2 \\
\hline 6.40 & & & 111 & 6.40 & & & 0.2 \\
\hline 6.65 & & & 122 & 6.65 & & & 0.2 \\
\hline 6.90 & & & 108 & 6.90 & & & 0.2 \\
\hline 7.15 & & & 159 & 7.15 & & & 0.1 \\
\hline 7.40 & & & & 7.40 & & & \\
\hline 7.65 & & & & 7.65 & & & \\
\hline 7.90 & & & & 7.90 & & & \\
\hline 8.15 & & & & 8.15 & & & \\
\hline 8.40 & & & & 8.40 & & & \\
\hline 8.65 & & & & 8.65 & & & \\
\hline 8.90 & & & & 8.90 & & & \\
\hline
\end{tabular}

Source: DTNs: LB0110A8N3LIQR.001 [DIRS 157001], LB0209A8N3LIQR.001 [DIRS 165461]. 


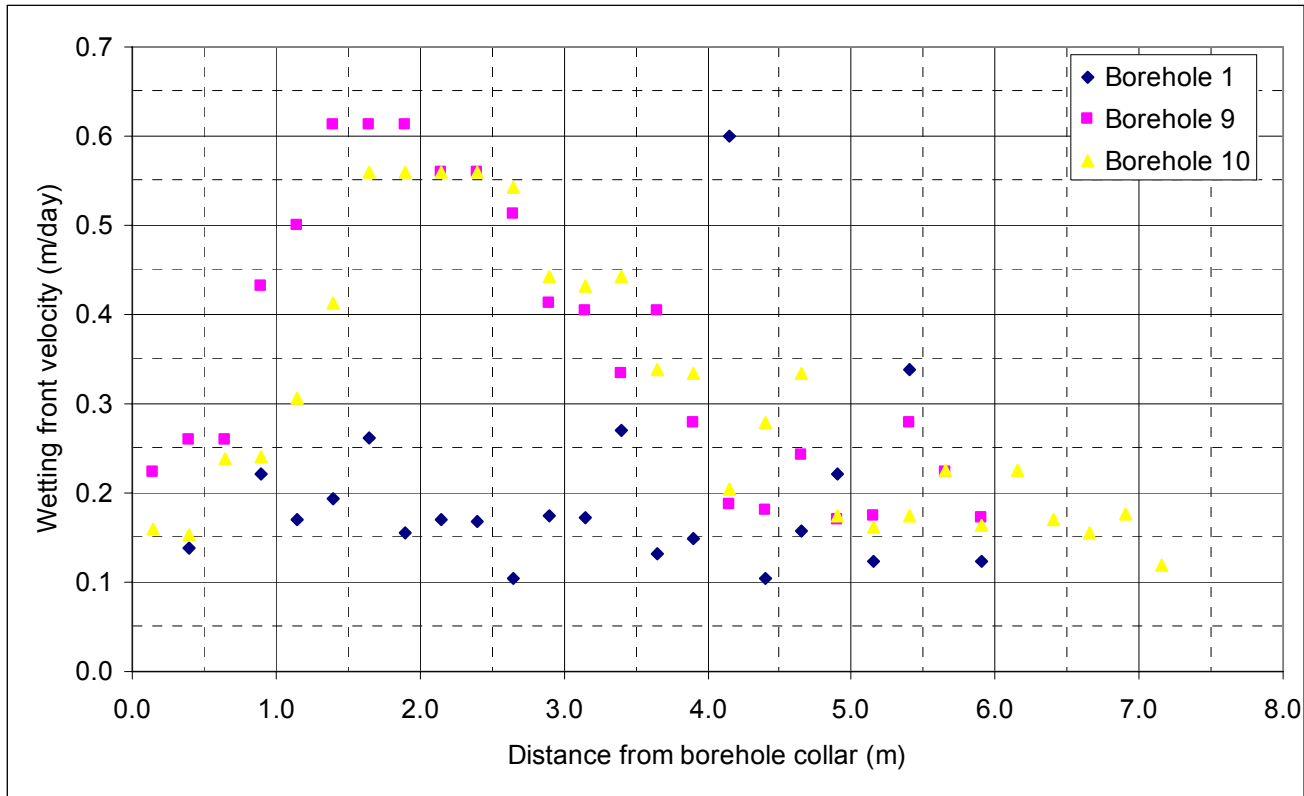

Source: DTNs: LB0110A8N3LIQR.001 [DIRS 157001], LB0209A8N3LIQR.001 [DIRS 165461], LB0303A8N3LIQR.001 [DIRS 162570].

Figure I-3. Wetting-Front Velocities for Boreholes 1, 9, and 10 as Presented in Figure 6-155

\section{I6.6 ROCK COMPOSITION CALCULATION IN TABLE 6-38 OF TOPOPAH SPRING TUFF IN THE CROSS DRIFT}

Duplicate rock samples were collected along the ECRB Cross Drift at 20 locations, from Station $10+00$ to Station $25+00$. The measured rock compositions of all 40 samples are documented in DTN: GS000308313211.001 [DIRS 162015]. The mean values and standard deviation $(\sigma)$ were calculated by treating all 40 samples in the same manner. In the analyses presented in Table 6-38, the mean of each pair was calculated before statistical calculations of $\sigma$ and the standard deviation of the mean (SDOM). SDOM was calculated by dividing $\sigma$ by $\sqrt{ } 20$. Then the ranges were represented by calculating the mean value plus or minus 2 times SDOM. Table I-13 compares the $\sigma$ calculated by these two different analyses from the same data set. The data of the most abundant oxide, $\mathrm{SiO}_{2}$, are shown, as an example, in the first two data columns.

A second example in the table pertains to converting trace element measurements expressed in ppm to weight percent of the oxide form (Zirconium $\mathrm{Zr}$ to $\mathrm{ZrO}_{2}$, with molecular weights 91.2 and 123.2, respectively, and a ratio equal to $123.2 / 91.2$, which is equal to 1.351 ).

The third example pertains to the treatment of the carbonate group, with low measured values that were sometimes below the detection limit.

These three examples cover the range of analyses needed to present the results in Table 6-38. 
Table I-13. Rock Composition Analyses of Duplicated Measurements and Trace Element Conversion

\begin{tabular}{|c|c|c|c|c|c|c|c|c|}
\hline Sample & Unit & $\begin{array}{c}\mathrm{SiO}_{2} \\
\text { Measured } \\
\text { Weight } \\
(\%)\end{array}$ & $\begin{array}{c}\mathrm{SiO}_{2} \text { Means } \\
\text { of } \\
\text { Duplicates }\end{array}$ & $\begin{array}{c}\mathrm{Zr} \\
\text { Trace } \\
\text { Element } \\
(p p m)\end{array}$ & $\begin{array}{c}\mathrm{ZrO}_{2} \\
\text { Calculated } \\
\text { Weight } \\
(\%)\end{array}$ & $\begin{array}{c}\mathrm{CO}_{2} \\
\text { Measured } \\
\text { Weight } \\
(\%)\end{array}$ & $\begin{array}{c}\mathrm{CO}_{2} \text { Means } \\
\text { of } \\
\text { Duplicates }\end{array}$ & $\begin{array}{l}\text { Sample } \\
\text { Number }\end{array}$ \\
\hline CS1000a & Tptpul & 76.2 & \multirow{2}{*}{76.35} & 113 & 0.015 & 0.01 & \multirow{2}{*}{0.01} & 1 \\
\hline CS1000b & Tptpul & 76.5 & & $\mathrm{~N} / \mathrm{A}$ & $\mathrm{N} / \mathrm{A}$ & 0.01 & & 2 \\
\hline CS1050a & Tptpmn & 76.5 & \multirow{2}{*}{76.35} & 111 & 0.015 & 0.01 & \multirow{2}{*}{0.01} & 3 \\
\hline CS1050b & Tptpmn & 76.2 & & $\mathrm{~N} / \mathrm{A}$ & $\mathrm{N} / \mathrm{A}$ & $<0.01$ & & 4 \\
\hline CS1150a & Tptpmn & 76.5 & \multirow{2}{*}{76.55} & 116 & 0.016 & $<0.01$ & \multirow{2}{*}{0.01} & 5 \\
\hline CS1150b & Tptpmn & 76.6 & & $\mathrm{~N} / \mathrm{A}$ & $\mathrm{N} / \mathrm{A}$ & 0.01 & & 6 \\
\hline CS1200a & Tptpmn & 76.7 & \multirow{2}{*}{76.70} & 113 & 0.015 & $<0.01$ & \multirow{2}{*}{$\mathrm{N} / \mathrm{A}$} & 7 \\
\hline CS1200b & Tptpmn & 76.7 & & $\mathrm{~N} / \mathrm{A}$ & $\mathrm{N} / \mathrm{A}$ & $<0.01$ & & 8 \\
\hline CS1300a & Tptpmn & 76.3 & \multirow{2}{*}{76.35} & 119 & 0.016 & 0.01 & \multirow{2}{*}{0.01} & 9 \\
\hline CS1300b & Tptpmn & 76.4 & & $\mathrm{~N} / \mathrm{A}$ & N/A & 0.01 & & 10 \\
\hline CS1350a & Tptpmn & 76.2 & \multirow{2}{*}{76.15} & 112 & 0.015 & 0.02 & \multirow{2}{*}{0.02} & 11 \\
\hline CS1350b & Tptpmn & 76.1 & & $\mathrm{~N} / \mathrm{A}$ & $\mathrm{N} / \mathrm{A}$ & $<0.01$ & & 12 \\
\hline CS1400a & Tptpmn & 76.0 & \multirow{2}{*}{76.25} & 117 & 0.016 & 0.01 & \multirow{2}{*}{0.01} & 13 \\
\hline CS1400b & Tptpmn & 76.5 & & $\mathrm{~N} / \mathrm{A}$ & $\mathrm{N} / \mathrm{A}$ & 0.01 & & 14 \\
\hline CS1450a & Tptpll & 76.3 & \multirow{2}{*}{76.10} & 120 & 0.016 & 0.01 & \multirow{2}{*}{0.01} & 15 \\
\hline CS1450b & Tptpll & 75.9 & & $\mathrm{~N} / \mathrm{A}$ & $\mathrm{N} / \mathrm{A}$ & $<0.01$ & & 16 \\
\hline CS1500a & Tptpll & 76.5 & \multirow{2}{*}{76.55} & 110 & 0.015 & 0.01 & \multirow{2}{*}{0.01} & 17 \\
\hline CS1500b & Tptpll & 76.6 & & $\mathrm{~N} / \mathrm{A}$ & $\mathrm{N} / \mathrm{A}$ & 0.01 & & 18 \\
\hline CS1750a & Tptpll & 76.4 & \multirow{2}{*}{76.55} & 116 & 0.016 & 0.01 & \multirow{2}{*}{0.01} & 19 \\
\hline CS1750b & Tptpll & 76.7 & & N/A & N/A & 0.01 & & 20 \\
\hline CS1800a & Tptpll & 75.8 & \multirow{2}{*}{75.80} & 120 & 0.016 & 0.01 & \multirow{2}{*}{0.01} & 21 \\
\hline CS1800b & Tptpll & 75.8 & & N/A & $\mathrm{N} / \mathrm{A}$ & 0.01 & & 22 \\
\hline CS1950a & Tptpll & 76.3 & 7640 & 115 & 0.016 & $<0.01$ & 01 & 23 \\
\hline CS1950b & Tptpll & 76.5 & 16.40 & $\mathrm{~N} / \mathrm{A}$ & $\mathrm{N} / \mathrm{A}$ & 0.01 & 0.01 & 24 \\
\hline CS2000a & Tptpll & 76.4 & & 119 & 0.016 & 0.02 & & 25 \\
\hline CS2000b & Tptpll & 77.1 & 6.15 & $\mathrm{~N} / \mathrm{A}$ & N/A & 0.02 & 0.02 & 26 \\
\hline CS2100a & Tptpll & 75.4 & & 116 & 0.016 & $<0.01$ & & 27 \\
\hline CS2100b & Tptpll & 75.5 & 15.45 & $\mathrm{~N} / \mathrm{A}$ & $\mathrm{N} / \mathrm{A}$ & 0.01 & 0.01 & 28 \\
\hline CS2150a & Tptpll & 76.1 & 7625 & 116 & 0.016 & 0.01 & & 29 \\
\hline CS2150b & Tptpll & 76.4 & 16.25 & $\mathrm{~N} / \mathrm{A}$ & $\mathrm{N} / \mathrm{A}$ & $<0.01$ & 0.01 & 30 \\
\hline CS2250a & Tptpll & 75.7 & & 118 & 0.016 & $<0.01$ & & 31 \\
\hline CS2250b & Tptpll & 76.3 & 76.00 & N/A & N/A & $<0.01$ & N/A & 32 \\
\hline CS2350a & Tptpln & 75.9 & 625 & 118 & 0.016 & $<0.01$ & 01 & 33 \\
\hline CS2350b & Tptpln & 76.6 & 0.25 & $\mathrm{~N} / \mathrm{A}$ & $\mathrm{N} / \mathrm{A}$ & 0.01 & 0.01 & 34 \\
\hline CS2400a & Tptpln & 76.5 & & 121 & 0.016 & $<0.01$ & & 35 \\
\hline CS2400b & Tptpln & 76.0 & 6.25 & $\mathrm{~N} / \mathrm{A}$ & $\mathrm{N} / \mathrm{A}$ & $<0.01$ & N/A & 36 \\
\hline CS2450a & Tptpln & 75.8 & & 126 & 0.017 & $<0.01$ & & 37 \\
\hline CS2450b & Tptpln & 76.3 & 0.05 & $\mathrm{~N} / \mathrm{A}$ & N/A & 0.01 & 0.01 & 38 \\
\hline CS2500a & Tptpln & 76.6 & & 114 & 0.015 & $<0.01$ & N & 39 \\
\hline CS2500b & Tptpln & 76.8 & 16.10 & $\mathrm{~N} / \mathrm{A}$ & N/A & $<0.01$ & N/A & 40 \\
\hline Mean & & 76.29 & 76.29 & 116 & 0.016 & 0.01 & 0.011 & \\
\hline Sigma & & 0.37 & 0.32 & 3.8 & 0.001 & 0.003 & 0.003 & \\
\hline SDOM & & & 0.07 & & 0.000 & & 0.001 & \\
\hline Min & & & 76.15 & & 0.015 & & 0.010 & \\
\hline Max & & & 76.43 & & 0.016 & & 0.013 & \\
\hline
\end{tabular}

NOTE(S): $\mathrm{SiO}_{2}$ means were calculated by averaging of two samples (a and b) from the same location. $\mathrm{ZrO}_{2}$ values were calculated by the $\mathrm{Zr}$ trace element values in ppm to weight\% by multiplying the ppm data by $1.351 / 10,000$, where the molecular weight ratio $=132.2 / 91.2=1.351$.

$\mathrm{CO}_{2}$ mean values were calculated by averaging or by setting to the measured value if the duplicate value is below the detection limit. 